\title{
Phase I Hydrologic Data for the Groundwater Flow and Contaminant Transport Model of Corrective Action Unit 97: Yucca Flat/Climax Mine, Nevada Test Site, Nye County, Nevada
}

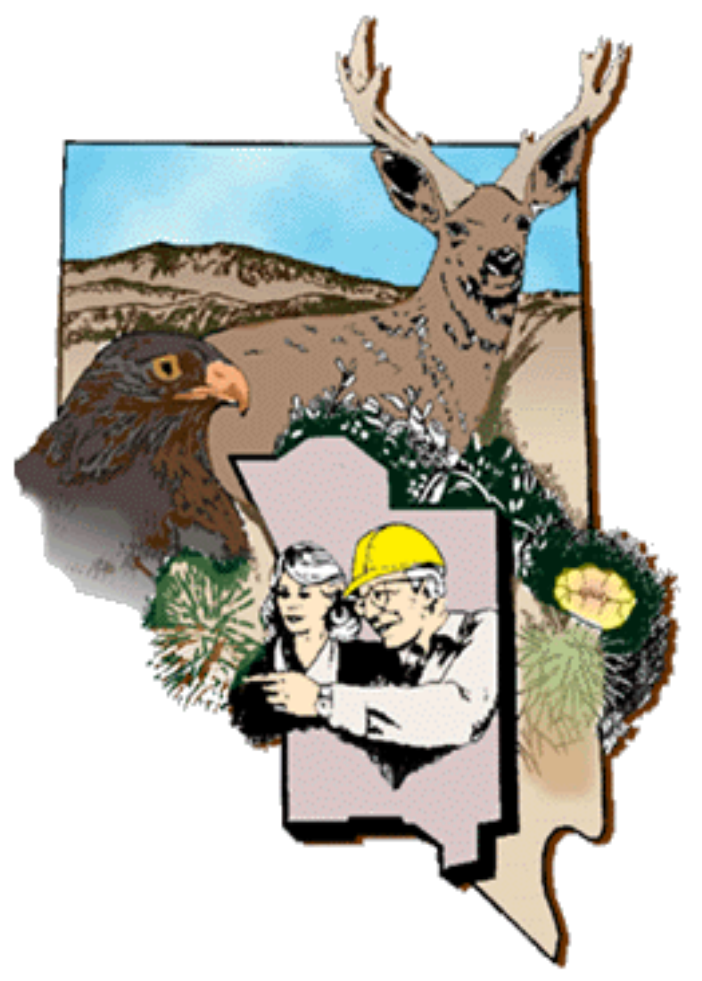

Revision No.: 0

June 2006

Prepared for U.S. Department of Energy under Contract No. DE-AC52-03NA99205. 
Available for public sale, in paper, from:

U.S. Department of Commerce

National Technical Information Service

5285 Port Royal Road

Springfield, VA 22161

Phone: 800.553 .6847

Fax: 703.605.6900

Email: orders@ntis.gov

Online ordering: http://www.ntis.gov/ordering.htm

Available electronically at http://www.osti.gov/bridge

Available for a processing fee to U.S. Department of Energy and its contractors, in paper, from:

\author{
U.S. Department of Energy \\ Office of Scientific and Technical Information \\ P.O. Box 62 \\ Oak Ridge, TN 37831-0062 \\ Phone: 865.576.8401 \\ Fax: 865.576.5728 \\ Email: reports@adonis.osti.gov
}

Reference herein to any specific commercial product, process, or service by trade name, trademark, manufacturer, or otherwise, does not necessarily constitute or imply its endorsement, recommendation, or favoring by the United States Government or any agency thereof or its contractors or subcontractors. 


\section{PHASE I HYDROLOGIC DATA FOR THE GROUNDWATER FLOW AND CONTAMINANT TRANSPORT MODEL OF CORRECTIVE ACTION UNIT 97: YUCCA FLAT/CLIMAX MINE, NEVADA TEST SITE, NYE COUNTY, NEVADA}

Contributors:

Stoller-Navarro Joint Venture

John McCord

Greg Ruskauff

Irene Farnham

William Fryer

Perry Montazer

John Pickens

Keely Brooks

Nathan Bryant

Christie Miller

Janice Rose

Jeff Sanchez

Revision No.: 0

June 2006

Stoller-Navarro Joint Venture

$7710 \mathrm{~W}$. Cheyenne, Building 3

Las Vegas, NV 89129
Bechtel Nevada

Sigmund L. Drellack 
PHASE I HYDROLOGIC DATA FOR THE GROUNDWATER FLOW AND CONTAMINANT TRANSPORT MODEL OF CORRECTIVE ACTION UNIT 97: YUCCA FLAT/CLIMAX MINE, NEVADA TEST SITE, NYE COUNTY, NEVADA

Approved by: APPROVED SIGNATURE

Date: 6/15/2006

John McCord, UGTA Project Manager

Stoller-Navarro Joint Venture 


\section{TABLE OF CONTENTS}

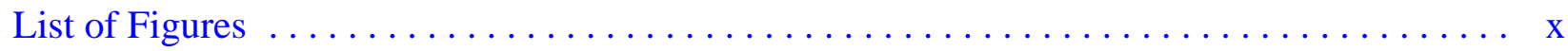

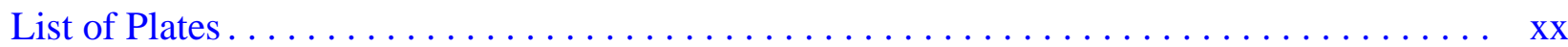

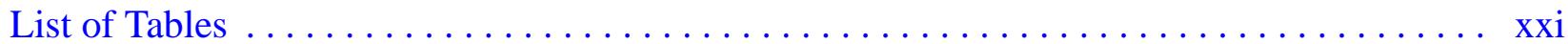

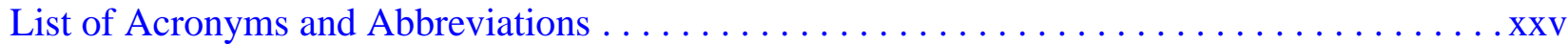

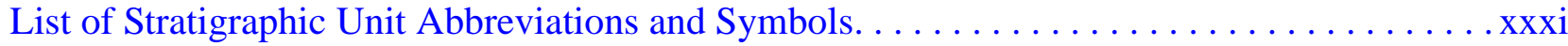

$1.0 \quad$ Introduction. . . . . . . . . . . . . . . . . . . . . . .

1.1 Purpose, Objectives, and Scope . . . . . . . . . . . . . . . . 1-2

1.2 Yucca Flat/Climax Mine Background . . . . . . . . . . . . . . . 1-3

1.2.1 Underground Nuclear Testing in Yucca Flat . . . . . . . . . . . . . 1-3

1.3 Yucca Flat/Climax Mine CAU Investigation Boundaries . . . . . . . . . . 1-5

1.4 Project Participants . . . . . . . . . . . . . . . . . . . . 10

1.5 Summary of the Federal Facility Agreement and Consent Order . . . . . . . 1-10

1.5.1 Summary of the UGTA Corrective Action Strategy . . . . . . . . . . 1-11

1.6 Documents Supporting Yucca Flat/Climax Mine Data Analysis . . . . . . . . . . 1-14

$1.7 \quad$ Phase I Data Collection Activities . . . . . . . . . . . . . . . . . . . . . . . 1-17

1.8 Report Organization . . . . . . . . . . . . . . . . . . . 17

2.0 Geologic and Hydrologic Setting . . . . . . . . . . . . . . . . . . . 2-1

$2.1 \quad$ Physiographic Setting . . . . . . . . . . . . . . . . . . . 2-1

2.2 Geologic Setting . . . . . . . . . . . . . . . . . . . . . . 2

2.2.1 Structural Framework. . . . . . . . . . . . . . . . 2-4

2.3 Hydrogeologic Framework. . . . . . . . . . . . . . . . . 2-5

2.3.1 Yucca Flat Hydrogeologic Units . . . . . . . . . . . . . . . . . 2-6

2.3.2 Yucca Flat /Climax Mine Hydrostratigraphic Units . . . . . . . . . 2-6

2.4 Hydrologic Setting . . . . . . . . . . . . . . . . . . . . . . . . .

2.4.1 Climate ............................... 2-12

2.4.2 Surface Water. . . . . . . . . . . . . . . . . . . . . . 2-12

2.4 .3 Groundwater Sub-Basins . . . . . . . . . . . . . . . . . 2-12

2.4.4 Groundwater Recharge and Discharge............... 2-14

2.4.5 Regional-Scale Groundwater Flow . . . . . . . . . . . . . . . . 2-14

2.4.6 Groundwater Flow in Yucca Flat. . . . . . . . . . . . . . . . . 2-15

2.4.7 Groundwater Elevations in the Yucca Flat Area . . . . . . . . . . . . 2-16

2.5 Death Valley Regional Flow System Model . . . . . . . . . . . . . . . . 2-18

3.0 Corrective Action Unit Modeling Approach . . . . . . . . . . . . . . . . 3-1

3.1 Overview of the CAU Modeling Approach . . . . . . . . . . . . . . . . 3-1

3.1.1 Integrated Three-Dimensional Model Development . . . . . . . . . . 3-1

3.1 .2 Total System Model . . . . . . . . . . . . . . . . . . . 3-2

3.1.3 Corrective Action Unit Model Validation . . . . . . . . . . . . . . . . . 3-3

3.2 Groundwater Flow Modeling Approach. . . . . . . . . . . . . . . . . . . 3-3

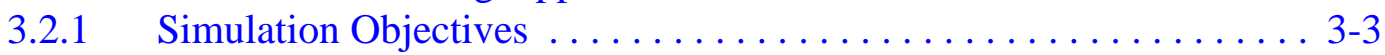

3.2.2 Geologic Model . . . . . . . . . . . . . . . . . . . . . . 3-4 


\section{TABLE OF CONTENTS (CONTINUED)}

3.2.3 Model Parameters............................. 3-4

3.2.4 Corrective Action Unit Model Boundaries and Boundary

Conditions. ............................ 3-4

3.2.5 Select Computer Code . . . . . . . . . . . . . . . . . . . 3

3.2.6 Grid Generation .......................... 3-6

3.2.7 Flow Model Calibration ...................... 3-7

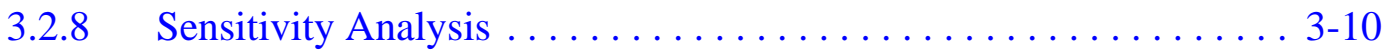

3.2.9 Model Verification .......................... 3-11

3.2.10 Model Documentation .............................. 3-11

3.3 Data Requirements . . . . . . . . . . . . . . . . . . . . . . . . 3

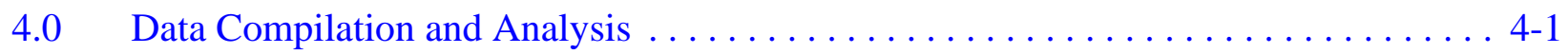

$4.1 \quad$ Data Sources ................................. 4-1

4.1.1 Yucca Flat/Climax Mine-Specific Data ................ 4-2

4.1.2 Nevada Test Site Investigation Area Data ................. 4-2

4.1.3 Yucca Mountain Project Data ................... 4-2

4.1.4 Other Data ............................. 4-3

4.2 Description of Yucca Flat/Climax Mine CAU Data and Information ...... . 4 4-3

4.2.1 Hydrostratigraphic Framework ..................... 4-3

4.2.2 Hydraulic Properties............................ 4-4

4.2.3 Recharge from Precipitation. .................. 4-5

4.2.4 Groundwater Discharge .......................... 4-6

4.2.5 Lateral Boundary Fluxes $\ldots \ldots \ldots \ldots \ldots \ldots \ldots \ldots \ldots \ldots .4 .7$

4.2 .6 Hydraulic Head. . . . . . . . . . . . . . . . . . . . . . 4-8

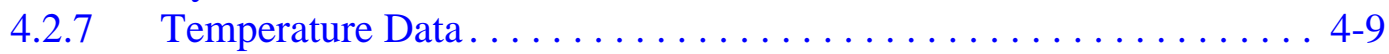

4.2.8 Groundwater Chemistry . . . . . . . . . . . . . . . . . . . 4

4.3 Approach to Data Compilation and Analysis . . . . . . . . . . . . . . . 4-11

4.3.1 Data Compilation ............................ 4-11

4.3.2 Data Transfer ........................... 4-11

4.3.2.1 Data Transfer Methodology . . . . . . . . . . . . . . 4 4-12

4.3.2.2 Similarity Criteria $\ldots \ldots \ldots \ldots \ldots \ldots \ldots \ldots \ldots .4 .12$

4.3.2.2.1 Geologic History . . . . . . . . . . . . . 4-12

4.3.2.2.2 Lithology ................... 4-13

4.3.2.2.3 Alteration .................. 4-13

4.3.2.2.4 Stress History $\ldots \ldots \ldots \ldots \ldots . . .4 .4 .13$

4.3.2.2.5 Groundwater Chemistry ........... 4-13

4.3.2.3 Yucca Mountain Project Data Transfer ........... . 4-14

4.3.3 Quality Assurance of Data and Data Documentation........... 4-14

4.3.3.1 Data Documentation Evaluation .............. 4-14

4.3.3.2 Data Quality Evaluation ................. 4-15

4.3.4 Data Analysis Limitations . . . . . . . . . . . . . . . . .

5.0 Yucca Flat/Climax Mine CAU Hydrostratigraphic Framework. . . . . . . . . . . . . 5 5-1

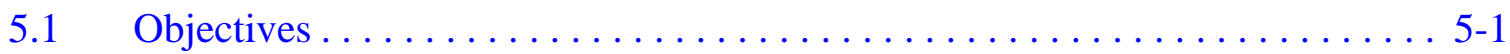




\section{TABle of Contents (Continued)}

5.2 Hydrostratigraphic Model Development Methodology . . . . . . . . . . . . . 5-1

$5.3 \quad$ Structural Model . . . . . . . . . . . . . . . . . . . . . . . 5-5

$5.3 .1 \quad$ Structural Overview . . . . . . . . . . . . . . . . . 5-5

5.3 .2 Structural Elements . . . . . . . . . . . . . . . . . . 5-6

$5.3 .3 \quad$ Hydrogeologic Insights $\ldots \ldots \ldots \ldots \ldots \ldots \ldots \ldots \ldots \ldots$. . . . . . . . . . . . .

$5.4 \quad$ Hydrostratigraphy . . . . . . . . . . . . . . . . . . . . 5-11

5.4.1 Hydrogeologic Units of the Yucca Flat Model Area . . . . . . . . . . 5-11

5.4.2 Hydrostratigraphic Units of the Yucca Flat/Climax Mine

CAU Model . . . . . . . . . . . . . . . . . . . . . . . . . . . . . . 5-12

5.5 Hydrostratigraphic Unit Alternative Scenarios. . . . . . . . . . . . . . . 5-22

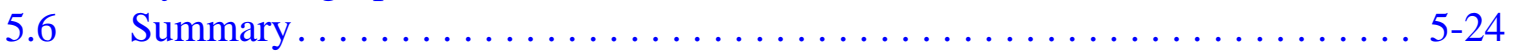

6.0 Saturated Media Hydraulic Properties $\ldots \ldots \ldots \ldots \ldots \ldots \ldots \ldots \ldots \ldots \ldots . \ldots \ldots$

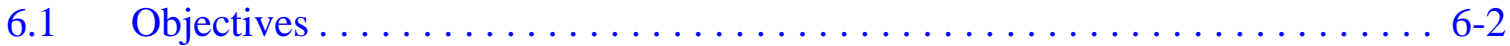

6.2 Data Types and Prioritization .................... 6-3

6.3 Data Compilation and Evaluation. . . . . . . . . . . . . . . . . . . . . . . .

6.3 .1 Data Sources............................. 6-4

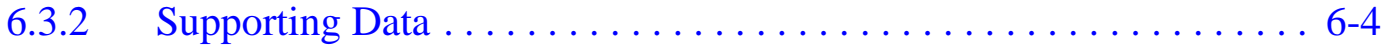

6.3 .3 Data Quality Assurance ........................ 6-5

6.3 .4 Data Transferability . . . . . . . . . . . . . . . . . . 6-6

$6.4 \quad$ Hydraulic Parameters . . . . . . . . . . . . . . . . . . . . . 6-7

6.4.1 Scales of Test Data and Applicability ................. 6-8

6.4.2 Test Analyses and Associated Uncertainties . . . . . . . . . . . . . 6-10

6.4.3 Handling of Multiple Test Results for One Well . . . . . . . . . . . . 6-10

6.5 Analysis of Hydraulic Conductivity Data. . . . . . . . . . . . . . . 6-11

6.5.1 Methodology........................... 6-12

6.5.2 Kolmogorov-Smirnov Test for $\log$ Normality . . . . . . . . . . . . . 6-14

6.5.3 Spatial Distribution of Data ................... 6-15

$6.6 \quad$ Analysis Results . . . . . . . . . . . . . . . . . . . 6 6-18

6.6.1 Hydraulic Conductivity Analysis . . . . . . . . . . . . . . . . 6-18

6.6.2 Depth Dependence of Hydraulic Conductivity . . . . . . . . . . . . . 6 6-24

6.6 .3 Depth-Decay Formulation . . . . . . . . . . . . . . . 6-24

6.6.4 Analysis of NTS Datasets for Depth Decay . . . . . . . . . . . . 6-27

6.7 Hydrogeologic Unit-Specific Hydraulic Conductivity Analyses . . . . . . . . . 6-32

6.7.1 Alluvial Aquifer Hydrogeologic Unit . . . . . . . . . . . . . . . 6 6-33

6.7.2 Volcanic Aquifer Hydrogeologic Unit . . . . . . . . . . . . . . . . 6-36

6.7.3 Lava Flow Aquifer Hydrogeologic Unit . . . . . . . . . . . . . . . 6-39

6.7.4 Tuff Confining Unit Hydrogeologic Unit. . . . . . . . . . . . . . . . . . . 6-41

6.7.5 Lower Carbonate Aquifer Hydrogeologic Unit . . . . . . . . . . . . . . . 6-43

6.7.6 Test-Scale and Spatial Variability . . . . . . . . . . . . . . . . 6- 6-46

6.8 Aquifer Unit Versus Confining Unit Results . . . . . . . . . . . . . . . . . 6 6-49

6.9 Aquifer Storage Properties . . . . . . . . . . . . . . . . . . . . . . . . . 6-49

6.10 Conversion of Hydraulic Conductivity to Permeability . . . . . . . . . . 6-51 


\section{TABLE OF CONTENTS (CONTINUED)}

6.10.1 Uncertainty of Permeability Due to Temperature ........... 6-53

6.10.2 Affect of Temperature Change on Test Response Measurement. . . 6 6-55

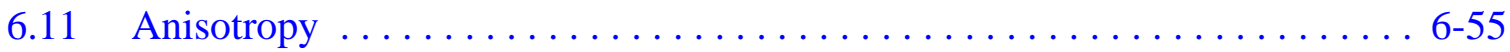

6.11 .1 Horizontal Anisotropy ........................ 6-55

6.11 .2 Vertical Anisotropy ........................... 6-56

6.12 ER-6-1 Multiple-Well Aquifer Test ...................... 6-57

6.12.1 Groundwater Production and Hydraulic Response Data . . . . . . . 6-57

6.12.2 Summary of Test Results and Analysis . . . . . . . . . . . . . . 6-58

6.12 .3 Limitations .............................. 6-60

6.13 High-Pressure Zone Studies . . . . . . . . . . . . . . . . . . . . 6-60

6.13.1 U.S. Geological Survey Tuff Pile Study ............... 6-61

6.13.2 Los Alamos National Laboratory "Tuff-Pile" Study. . . . . . . . . 6-62

6.14 Limitations . . . . . . . . . . . . . . . . . . . . . . . . . . . . 6-62

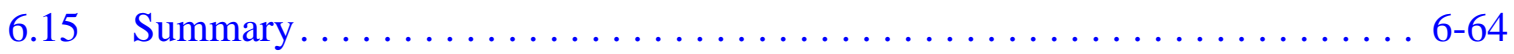

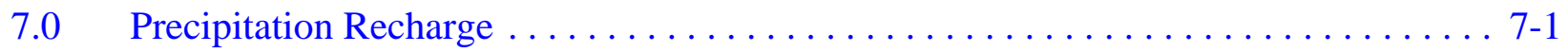

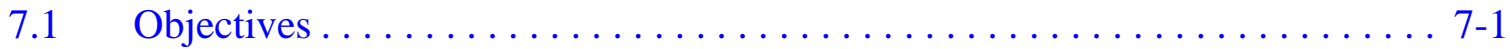

$7.2 \quad$ Approach....................................... $7-1$

7.3 Data Types and Prioritization $\ldots \ldots \ldots \ldots \ldots \ldots \ldots \ldots \ldots \ldots \ldots \ldots \ldots \ldots \ldots \ldots \ldots \ldots .2$

$7.4 \quad$ Recharge Model Descriptions...................... $7-2$

7.4.1 Underground Test Area Original Recharge Model ............ 7-3

7.4.1.1 Overview Description of the Maxey and Eakin Method ... 7-3

7.4.1.2 Modified Maxey-Eakin Method Used in the UGTA

Original Regional Groundwater Flow Model ........ 7-5

7.4.1.2.1 Methodology .................. 7-6

7.4.1.2.2 Construction of the Digital Precipitation Map and Grid File ................. 7-6

7.4.1.2.3 UGTA Original Recharge Model

Precipitation Distribution ............ 7-8

7.4.1.2.4 Recharge .................. 7-12

7.4.1.2.5 Preliminary Recharge Distribution ....... 7-13

7.4.1.2.6 Recharge Allocation ............... 7-13

7.4.2 Revised UGTA Recharge Model ................... 7-17

7.4.3 U.S. Geological Survey Recharge Models................. 7-20

7.4.3.1 Recharge Models Based on the USGS Death Valley

Region Distributed Parameter Watershed Model ..... 7-20

7.4.3.2 U.S. Geological Survey Calibrated Recharge Model . . . 7-35

7.4.4 Desert Research Institute Recharge Models................ . . 7-35

7.4.4.1 Methodology .......................... 7-39

7.4.4.2 Results ........................ 7-45

7.4.4.3 Upscaling To Extend the Results from Russell and

Minor To Encompass the UGTA Regional Model Area . . 7-46

$7.5 \quad$ Factors Influencing Recharge in Yucca Flat. . . . . . . . . . . . . 7-48 


\section{TABle of Contents (Continued)}

7.5.1 Potential for No Recharge in Interfluve Areas . . . . . . . . . . . . 7-52

7.5.2 Potential for Enhanced Local Recharge in Subsidence

Craters and Playa Crack . . . . . . . . . . . . . . . 7-52

7.5.3 Alternative Conceptual Model for Recharge in Yucca Flat . . . . . . 7-54

7.6 Summary of Alternative Recharge Models . . . . . . . . . . . . . . . 7 7-55

7.7 Limitations . . . . . . . . . . . . . . . . . . . . . . . . . . . 7-58

8.0 Groundwater Discharge $\ldots \ldots \ldots \ldots \ldots \ldots \ldots \ldots \ldots \ldots \ldots \ldots \ldots \ldots \ldots$

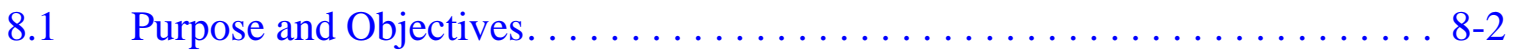

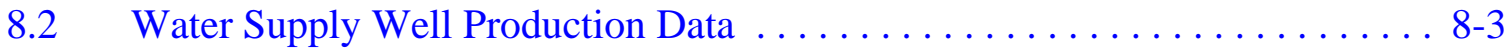

8.2.1 Description of Available Data . . . . . . . . . . . . . 8 8-5

8.2 .2 Data Evaluation .......................... 8-6

8.2.2.1 Data Documentation Evaluation . ... . . . . . . 8-7

8.2.2.2 Data Quality Evaluation . . . . . . . . . . . . . 8-7

8.2.3 Groundwater Production Data . . . . . . . . . . . . . . . . . 8-7

8.2.4 Summary of Water Supply Well Discharge Data. . . . . . . . . . 8 8-16

8.2.5 Limitations . . . . . . . . . . . . . . . . . . . 8 8-17

8.3 Environmental Restoration Well Testing Program. . . . . . . . . . . . 8-17

$8.3 .1 \quad$ ER Well Tests. . . . . . . . . . . . . . . . . . . . 8-18

8.3.2 Description of Available Data . . . . . . . . . . . . . 8-18

8.3.3 Data Evaluation ....................... 8-18

8.3.3.1 Data Documentation Evaluation ............. 8-18

8.3.3.2 Data Quality Evaluation ................. 8-18

8.3.4 Groundwater Production Data . . . . . . . . . . . . . . 8-21

8.3.5 Summary of Production Data ................. 8-21

8.3.6 Limitations . . . . . . . . . . . . . . . . . . . . . . . . . . 8-21

$8.4 \quad$ Spring Discharges . . . . . . . . . . . . . . . . . . . . . . 8-21

8.4.1 Description of Available Data . . . . . . . . . . . . 8-22

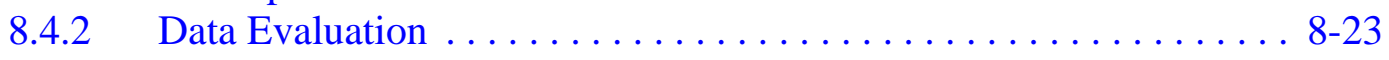

8.4.2.1 Data Documentation Evaluation ............ 8-23

8.4.2.2 Data Quality Evaluation ................. 8-23

8.4.3 Spring Discharge Data .................... 8-23

8.4.4 Summary of Spring Discharge Data. . . . . . . . . . . . . . 8-26

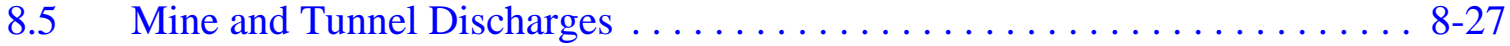

8.5.1 Description of Available Data . . . . . . . . . . . . . . . . . . 8-29

8.5 .2 Data Evaluation ....................... 8-30

8.5.2.1 Data Documentation Evaluation ............ 8-30

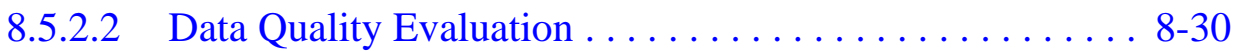

8.5.3 Tunnel Discharge Data . . . . . . . . . . . . . . . . 8-30

8.5.4 Summary of Tunnel Discharge Data . . . . . . . . . . . . . . 8-30

8.5.5 Limitations ....................... 8-31

$9.0 \quad$ Lateral Boundary Fluxes. . . . . . . . . . . . . . . . . . . . . . . 9-1

9.1 Objectives .......................... 


\section{TABLE OF CONTENTS (CONTINUED)}

$9.2 \quad$ Approach.................................... 9-2

$9.3 \quad$ Analysis Results . . . . . . . . . . . . . . . . . . . . . . . . .

9.4 Discussion of Results . . . . . . . . . . . . . . . . . . . . . . . . . . . . 9-7

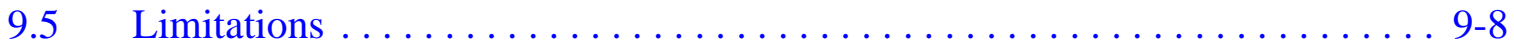

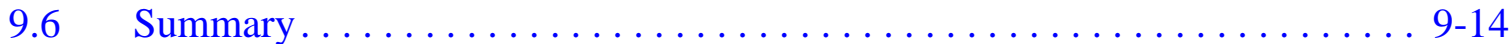

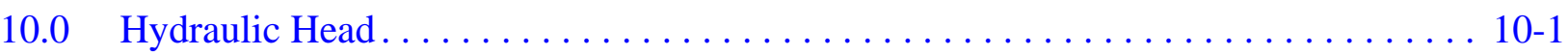

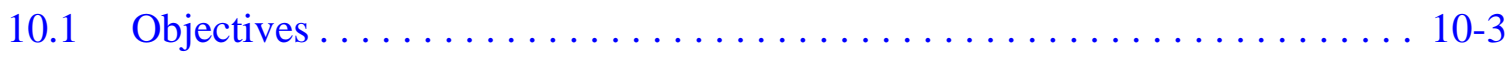

10.2 Context for Hydraulic Head Analysis. . . . . . . . . . . . . . . . . . . 10-5

10.2.1 Calibration Target Heads . . . . . . . . . . . . . . . . . . . . . . 10 10

10.2.2 Potentiometric Maps. . . . . . . . . . . . . . . . . . . . . 10-7

10.3 Methodology . . . . . . . . . . . . . . . . . . . . . . . . . . 10-9

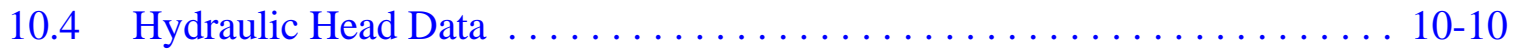

10.4.1 Data Types................................. 10-10

10.4.2 Data Sources ............................ 10-12

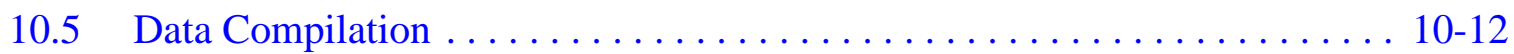

10.5.1 Depth-to-Water Data......................... 10-12

10.5.2 General Site Information ..................... 10-13

10.5.2.1 Land-Surface Elevation ................... 10-13

10.5.2.2 Formation Access Interval . . . . . . . . . . . . . . . 10-14

10.5.2.3 Hydrostratigraphic Units in the Formation Access

Interval ................................ . 10-15

10.6 Hydraulic Head Uncertainties. . . . . . . . . . . . . . . . . . . . . . 10-15

10.6.1 Measurement Method Uncertainty . . . . . . . . . . . . . 10-16

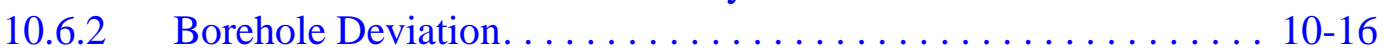

10.6.3 Barometric Pressure Variation and Earth Tides . . . . . . . . . . . 10-16

10.6.4 Temperature Variation and Temperature Gradients. . . . . . . . . 10-17

10.7 Steady-State Head Determination. . . . . . . . . . . . . . . . . . 10-18

10.7.1 Calibration Target Head Values................... 10-20

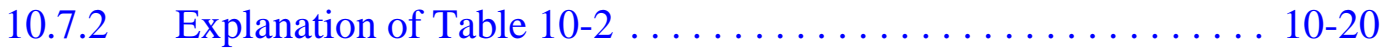

10.7.3 Additional Representative Head Values. . . . . . . . . . . . . 10-26

10.7.4 Variations in Steady-State Head Record Periods . . . . . . . . . . 10-26

10.8 Potentiometric Horizon Maps . . . . . . . . . . . . . . . . . . . . . . . . 10-29

10.9 Water Table Potentiometric Horizon. . . . . . . . . . . . . . . . . . . . 10-30

10.10 Lower Carbonate Aquifer Potentiometric Horizon . . . . . . . . . . . . . . 10-31

10.11 Vertical Head Differences . . . . . . . . . . . . . . . . . . . . . . 10-31

10.12 Fiscal Year 2005 Rainier Mesa Wells . . . . . . . . . . . . . . . . . 10-32

10.13 High-Pressure Zone . . . . . . . . . . . . . . . . . . . . . . . 10-33

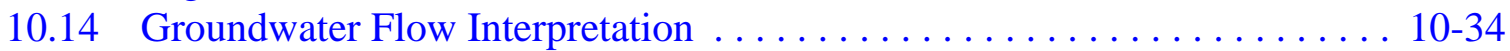

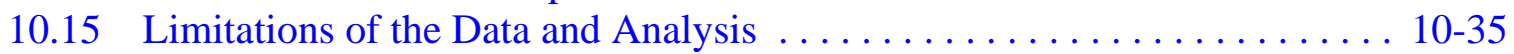

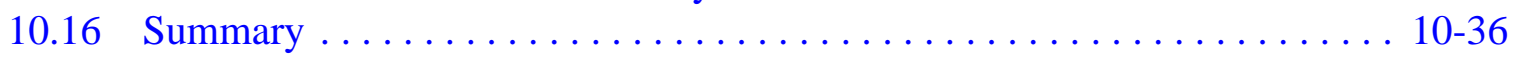

11.0 Subsurface Temperature Data. . . . . . . . . . . . . . . . . . . . . . . . . . . . . . 11-1

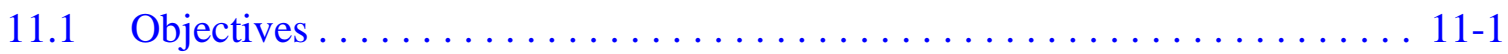




\section{TABle of Contents (Continued)}

11.2 Temperature Data and Information Relevant to the Yucca Flat/Climax Mine Hydrostratigraphic Framework Model Area . . . . . . . . . . . . . . 11-2

11.2.1 Basic Temperature Data Types . . . . . . . . . . . . . . 11-3

11.3 Thermal Conductivity Data and Information . . . . . . . . . . . 11-3

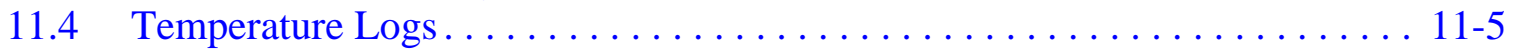

11.4.1 Temperature Log Data Summary . . . . . . . . . . . . . . . . 11-6

11.5 Evaluation of Temperature Profiles to Identify Potential

Advective Heat Transport . . . . . . . . . . . . . . . . . . . . 11-6

11.5.1 Background. . . . . . . . . . . . . . . . . . . . 11-11

11.5.2 Evaluation of Yucca Flat Temperature Profiles . . . . . . . . . . . 11-14

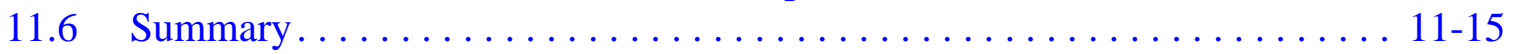

11.7 Other Yucca Flat Temperature Data. . . . . . . . . . . . . . 11-15

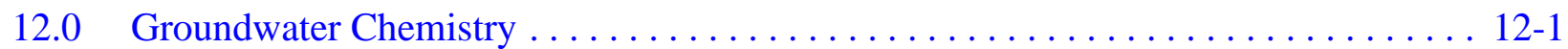

12.1 Objectives . . . . . . . . . . .

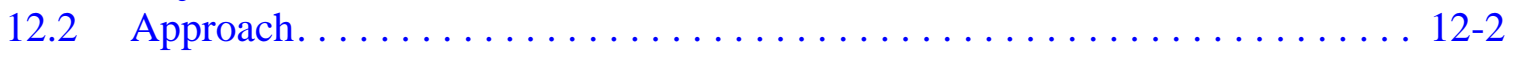

12.3 Data Description . . . . . . . . . . . . . . . . . . . . . . . 12-5

12.4 Data Evaluation. . . . . . . . . . . . . . . . . . . . . 12-11

12.4.1 Data Documentation Evaluation. . . . . . . . . . . . . . . 12-11

12.4.2 Data Quality Evaluation . . . . . . . . . . . . . . . . . . 12-11

12.5 Analysis Process and Results . . . . . . . . . . . . . . . . . . 12-12

12.5.1 Major-Ion Chemistry . . . . . . . . . . . . . . . . . . 12-12

12.5.2 Stable and Radioactive Environmental Isotopes . . . . . . . . . . 12-16

12.5.2.1 Hydrogen and Oxygen Isotopes . . . . . . . . . . . 12-17

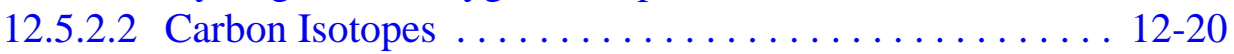

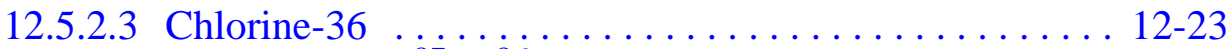

12.5.2.4 Strontium and ${ }^{87} \mathrm{Sr} /{ }^{86} \mathrm{Sr}$ Values . . . . . . . . . . 12-25

12.5.2.5 Uranium and ${ }^{234} \mathrm{U} /{ }^{238} \mathrm{U}$ Activity Ratio . . . . . . . . . 12-28

12.6 Groundwater Flow Path Evaluations . . . . . . . . . . . . . . . . . 12-29

12.6.1 Geochemical Modeling Methodology . . . . . . . . . . . . . . . 12-31

12.6.1.1 Conservative Tracers . . . . . . . . . . . . . . . 12-32

12.6.1.2 Strontium and Strontium Isotopes $\left({ }^{87} \mathrm{Sr} /{ }^{86} \mathrm{Sr}\right) \ldots \ldots$ 12-32

12.6.1.3 Geochemical Modeling with NETPATH

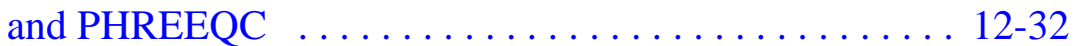

12.6.1.3.1 NETPATH ... . . . . . . . . . . . 12-33

12.6.1.3.2 PHREEQC Modeling . . . . . . . . . 12-34

12.6.2 Geochemical Modeling Results . . . . . . . . . . . . . . . 12-36

12.6.2.1 Northern Flow Path . . . . . . . . . . . . . . 12-36

12.6.2.2 Eastern Flow Paths . . . . . . . . . . . . . . . . 12-38

12.6.2.3 Western Flow Paths . . . . . . . . . . . . . . . 12-40

12.6.2.4 Southeastern Flow Path . . . . . . . . . . . . . . 12-42

12.6.2.5 West Central Flow Path . . . . . . . . . . . . . 12-43

12.7 Limitations . . . . . . . . . . . . . . . . . . . . . . . . . 12-44 


\section{TABLE OF CONTENTS (CONTINUED)}

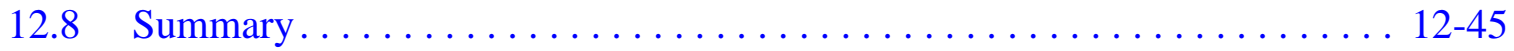

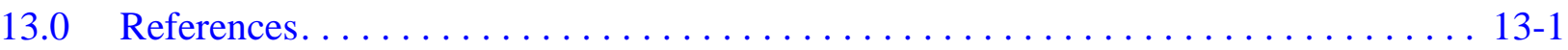

Appendix A - Nuclear Tests in the Yucca Flat/Climax Mine Corrective Action Unit

A.1.0 Nuclear Tests in the Yucca Flat/Climax Mine Corrective Action Unit . . . . . . . . . . A-1

A.2.0 References.................................... A-27

\section{Appendix B - Data Collection Activities}

B.1.0 Summary of Data Collection for the Yucca Flat/Climax Mine

Corrective Action Unit . . . . . . . . . . . . . . . . . . . .

B.2.0 Yucca Flat/Climax Mine CAU-Specific Well Drilling and Testing. . . . . . . . . . . B-2

B.3.0 Yucca Flat/Climax Mine CAIP-Identified

Characterization Activities . . . . . . . . . . . . . . . . . . . . . . . B-6

B.3.1 Tuff Confining Unit Mineralogical Studies. . . . . . . . . . . . . . B-6

B.3.2 Geophysical Interpretation of the Paleozoic Framework . . . . . . . . . . B-8

B.3.2.1 Natural-Source Magnetotelluric Survey . . . . . . . . . . . . . . B-8

B.3.2.2 Gravity and Aeromagnetic Data Interpretation . . . . . . . . . . . B-8

B.3.2.3 Analysis of Existing Seismic Data . . . . . . . . . . . . . B-9

B.3.3 Hydrologic Investigation of Wells ER-6-1 and ER-6-2 . . . . . . . . B-9

B.3.4 Isotope/Geochemistry Mass-Balance Study . . . . . . . . . . . . . . . . B-10

B.3.5 Analysis of Existing Tracer Test Data. . . . . . . . . . . . . . . . . B-10

B.3.6 Laboratory Radionuclide Transport Studies . . . . . . . . . . . . . B-11

B.3.7 Rainier Mesa Colloid Transport Studies . . . . . . . . . . . . . . B-11

B.3.8 Analysis of Data for Phenomenological Models . . . . . . . . . . . . . . B-12

B.4.0 Other Studies. . . . . . . . . . . . . . . . . . . . . . . . . . . . B-13

B.5.0 References.................................... B-15

\section{Appendix C - Hydraulic Head Supplementary Information}

C.1.0 Hydraulic Head Supplementary Information $\ldots \ldots \ldots \ldots \ldots \ldots \ldots \ldots \ldots \ldots$ C-1

C.1.1 Well Formation Access Interval and Hydrograph Report . . . . . . . . . . . C-1

C.1.1.1 Hydraulic Head Formation Access Interval and Hydrograph

Report Field Descriptions. . . . . . . . . . . . . . . C-1

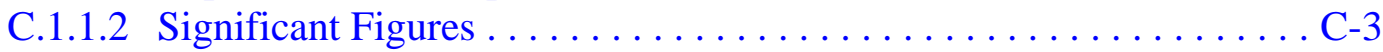

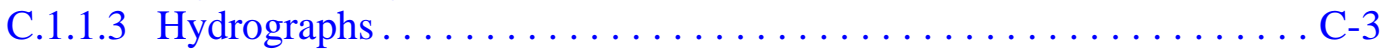

C.1.2 Assignment of Formation Access Intervals to Potentiometric Horizons . . . . . C-3

C.1.2.1 Conceptual Model and Considerations. . . . . . . . . . . . . . C-4

C.1.2.2 Qualification Scheme ....................... C-4

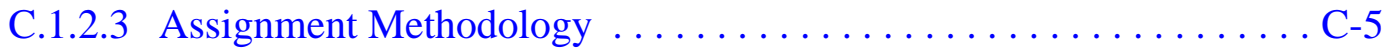




\section{TABle of Contents (Continued)}

C.2.0 References.......................................... C-10

\section{Appendix D - Alternative Hydrostratigraphic Framework Models}

D.1.0 Alternative Hydrostratigraphic

Framework Models. . . . . . . . . . . . . . . . . . . . . .

D.1.1 Alternative 1 - CP Thrust . . . . . . . . . . . . . . . . . .

D.1.2 Alternative 2 - Hydrologic Barrier in Northern Yucca Flat . . . . . . . . . . . . D-2

D.1.3 Alternative 3 - Contiguous UCCU in Southwestern Yucca Flat . . . . . . . . . D-2

D.1.4 Alternative 4 - Fault Juxtaposition . . . . . . . . . . . . . . . . . D-3

D.1.5 Alternative 5 - Partial Zeolitization .................... D-3

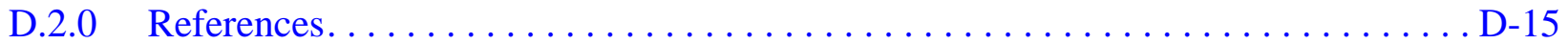

\section{Appendix E - Literature Review and Technical Basis for Permeability Depth-Decay}

E.1.0 Literature Review and Technical Basis for Permeability Depth-Decay. . . . . . . . . . E-1

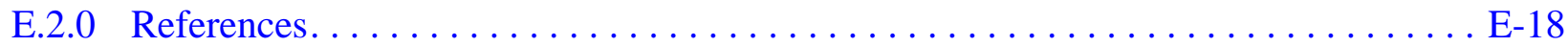

\section{Appendix F - Boundary Flux Calculations}

F.1.0 Boundary Flux Calculations $\ldots \ldots \ldots \ldots \ldots \ldots \ldots \ldots \ldots \ldots \ldots \ldots \ldots \ldots$

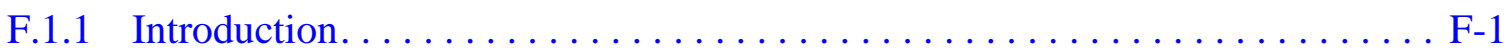

F.1.2 Recharge ............................. . .

F.1.2.1 Preparation of Recharge Data for Lateral Boundary Flux

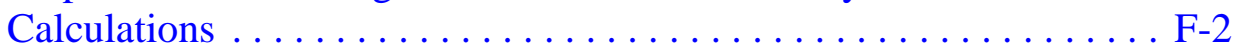

F.1.3 Lateral Boundary Flux Evaluation and Analysis................. F-2

F.1.4 Application of Recharge Models . . . . . . . . . . . . . . . . . F-4

F.1.5 Procedures for Simulations and Calibrations. . . . . . . . . . . . . F-4

F.1.6 Forward Simulations with Fixed (Unperturbed) Hydraulic Parameters . . . . . F-6

F.2.0 References.................................. F-15

\section{Appendix G - Temperature Profile Data}

G.1.0 Yucca Flat/Climax Mine Area temperature Data . . . . . . . . . . . . . . . . . G-1

G.1.1 Temperature Data From Gillespie $(2005) \ldots \ldots \ldots \ldots \ldots \ldots \ldots$. . . . . . . . . . . . . . . . . . . .

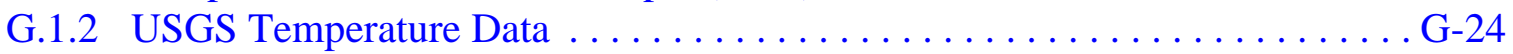

G.2.0 References................................... G-62

\section{Appendix H - Groundwater Chemistry Data}

H.1.0 Groundwater Chemistry $\ldots \ldots \ldots \ldots \ldots \ldots \ldots \ldots \ldots \ldots \ldots \ldots \ldots \ldots \ldots \ldots \ldots \ldots$ 


\section{LIST OF FIGURES}

NUMBER

TITLE

PAGE

1-1 Location of the Yucca Flat/Climax Mine CAU . . . . . . . . . . . . . . . . . 1-4

1-2 Regional-Scale Boundaries $\ldots \ldots \ldots \ldots \ldots \ldots \ldots \ldots \ldots \ldots \ldots \ldots \ldots \ldots \ldots \ldots$

1-3 Nevada Test Site-Scale Boundaries . . . . . . . . . . . . . . . . . . . 1-8

1-4 Yucca Flat/Climax Mine CAU-Scale Boundaries . . . . . . . . . . . . . . . . . . . 1-9

1-5 Process Flow Diagram for the Underground Test Area Corrective Action Units . . . . 1-12

2-1 Generalized Surface Geologic Map of the NTS Area $\ldots \ldots \ldots \ldots \ldots \ldots \ldots \ldots \ldots$

2-2 Regional Groundwater Flow Pattern . . . . . . . . . . . . . . . . 2-13

2-3 Yucca Flat Groundwater Flow Pattern . . . . . . . . . . . . . . . . . . . . 2-17

3-1 Data Types and Utilization in the Groundwater Flow Model . . . . . . . . . . . . . 3-13

5-1 Satellite Image of the Yucca Flat/Climax Mine Area Showing Physiographic Features and Locations of Underground Nuclear Tests . . . . . . . . . . . . . . . 5-4

5-2 Pre-Tertiary Structure of the Yucca Flat/Climax Mine HFM Area . . . . . . . . . . . . . 5-9

5-3 Correlation of Stratigraphic and HSUs of the Yucca Flat/Climax Mine HFM Area. . .5-13

5-4 Block Model View Showing HSUs at the Surface within theYucca Flat/Climax Mine CAU HFM Area . . . . . . . . . . . . . . . . . . . . . . . . . .

5-5 Block Model View Showing Extent of the PCUT, the BLFA, and Intermediate AA2 and AA1 within the Yucca Flat/Climax Mine HFM Area (AA3 removed) . . . . 5-16

5-6 Block Model View Showing Distribution of HSUs within the Yucca Flat/Climax Mine HFM Area with the Alluvium Removed. . . . . . . . . . . . . . . . . . . . . . . 5-17

5-7 Block Model View Showing Distribution of Volcanic Confining HSUs (alluvial and volcanic aquifer units removed) within the Yucca Flat/Climax Mine HFM Area . . . . . . . . . . . . . . . . . . . . . . . . . 5-18

5-8 Block Model View Showing Distribution of Pre-Tertiary HSUs within the Yucca Flat/Climax Mine HFM Area (alluvial and volcanic units removed) . . . . . . . 5-19

6-1 NTS Investigation Area Locations of Hydraulic Conductivity Data . . . . . . . . . . 6-16 


\section{LIST OF FIGURES (CONTINUED)}

NUMBER

TITLE

PAGE

6-2 Yucca Flat/Climax Mine Hydraulic Property Data Location. . . . . . . . . . . . . . . . 6-17

6-3 Relationship of HGU Hydraulic Conductivity Distributions . . . . . . . . . . . . . 6-23

6-4 Overlay of NTS Investigation Area HGU Hydraulic Conductivity Distributions . . . . 6-23

6-5 Hydraulic Conductivity Versus Depth for the Yucca Flat/Climax Mine Dataset . . . . 6-31

6-6 Hydraulic Conductivity Versus Depth for the NTS Investigation Area Dataset . . . . 6-31

6-7 Alluvial Aquifer Pumping-Scale Hydraulic Conductivity Probability

Distribution for the Yucca Flat/Climax Mine Dataset . . . . . . . . . . . . . . . . . . 6-34

6-8 Alluvial Aquifer Pumping-Scale Hydraulic Conductivity Versus Depth for the

Yucca Flat/Climax Mine Dataset . . . . . . . . . . . . . . . . . . . . . 6-34

6-9 Alluvial Aquifer Pumping-Scale Hydraulic Conductivity Probability

Distribution for the NTS Investigation Area Dataset.

6-10 Alluvial Aquifer Pumping-Scale Hydraulic Conductivity Versus

Depth for the NTS Investigation Area Dataset. . . . . . . . . . . . . . . . . . . . . 6-35

6-11 Volcanic Aquifer Pumping-Scale Hydraulic Conductivity Values Probability

Distribution for the Yucca Flat/Climax Mine Dataset

6-12 Volcanic Aquifer Pumping-Scale Hydraulic Conductivity Versus Depth for the

Yucca Flat/Climax Mine Dataset . . . . . . . . . . . . . . . . . . . . 6-37

6-13 Volcanic Aquifer Pumping-Scale Hydraulic Conductivity Probability

Distribution for the NTS Investigation Area Dataset.

6-14 Volcanic Aquifer Pumping-Scale Hydraulic Conductivity Versus Depth for the NTS Investigation Area Dataset. . . . . . . . . . . . . . . . . . . . . . . . 6-38

6-15 Lava Flow Aquifer Pumping-Scale Hydraulic Conductivity Values Probability Distribution for the NTS Investigation Area Dataset. . . . . . . . . . . . . . . . . . . 6-40

6-16 Lava Flow Aquifer Pumping-Scale Hydraulic Conductivity Versus Depth for the NTS Investigation Area Dataset. . . . . . . . . . . . . . . . . . . . 6-40

6-17 Tuff Confining Unit Pumping-Scale Hydraulic Conductivity Probability Distribution for the NTS Investigation Area Dataset . . . . . . . . . . . . . . 6-42 


\section{LIST OF FIGURES (CONTINUED)}

NUMBER

TITLE

PAGE

6-18 Tuff Confining Unit Pumping-Scale Hydraulic Conductivity Versus Depth the NTS Investigation Area Dataset. . . . . . . . . . . . . . . . . . . . .

6-19 Lower Carbonate Aquifer Pumping-Scale Hydraulic Conductivity Probability Distribution for the Yucca Flat/Climax Mine Dataset . . . . . . . . . . . . . . . . . 6-44

6-20 Lower Carbonate Aquifer Pumping-Scale Hydraulic Conductivity Versus Depth for the Yucca Flat/Climax Mine Dataset. . . . . . . . . . . . . . . . . . 6-44

6-21 Lower Carbonate Aquifer Pumping-Scale Hydraulic Conductivity Probability Distribution for the NTS Investigation Area Dataset . . . . . . . . . . . . . 6-45

6-22 Lower Carbonate Aquifer Pumping-Scale Hydraulic Conductivity Versus Depth for the NTS Investigation Area Dataset . . . . . . . . . . . . . . . . . . .

6-23 Specific Storage Data for the Yucca Flat/Climax Mine Dataset . . . . . . . . . . . 6-52

6-24 Specific Storage Data for the NTS Investigation Area Dataset . . . . . . . . . . . . 6-52

6-25 Fracture Specific Storage Data for the NTS Investigation Area Dataset . . . . . . . . 6 6-53

6-26 Location of Wells Monitored for the ER-6-1 MWAT . . . . . . . . . . . . . . . . 6-59

7-1 Precipitation Map for the NTS Region Used for the UGTA Original Recharge Model . . . . . . . . . . . . . . . . . . . . . . . 7-9

7-2 Potential Recharge Redistribution Areas in the NTS Region $\ldots \ldots \ldots \ldots \ldots \ldots .7-15$

7-3 NTS Region with the UGTA Original Recharge Model Inserted into the USGS DVRFS Model (Belcher et al., 2004) . . . . . . . . . . . . . . . 7-18

7-4 Updated Precipitation Map for the Nevada Test Site Region (UGTA Revised

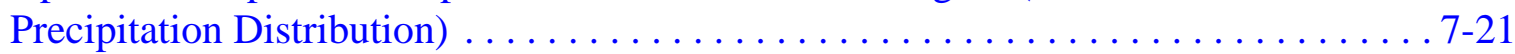

7-5 NTS Region with the UGTA Revised Recharge Model Inserted into the DVRFS Model (Belcher et al., 2004) . . . . . . . . . . . . . . . . . . . . 7-22

7-6 NTS Region with the USGS Recharge Distribution Model 1 which Includes Run-on Infiltration Component in Recharge Inserted into the USGS DVRFS Model (Belcher et al., 2004). . . . . . . . . . . . . . . . . . . . . . . 7-36 


\section{LIST OF FIGURES (CONTINUED)}

NUMBER

TITLE

PAGE

7-7 NTS Region with the USGS Distribution Recharge Model 2 which Does Not Include Run-on Infiltration Component in Recharge Inserted into the USGS

DVRFS Model (Belcher et al., 2004) . . . . . . . . . . . . . . . . . . 7-37

7-8 USGS Recharge Distribution Model 3 Calibrated for the Steady-State Version of the USGS DVRFS Model (Belcher et al., 2004) . . . . . . . . . . . . . . 7-38

7-9 Relationship Between UGTA Revised ME Recharge Rate and DRI Models . . . . . . 7-47

7-10 NTS Region with the DRI Recharge Distribution with Alluvial Mask (Russell and Minor, 2002) Inserted into the USGS DVRFS Model

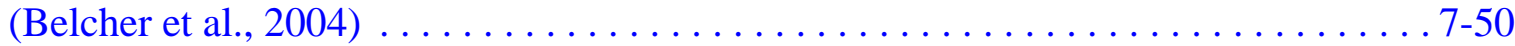

7-11 NTS Region with the DRI Recharge Distribution with Alluvial and Elevation Mask (Russell and Minor, 2002) Inserted into the USGS DVRFS Model

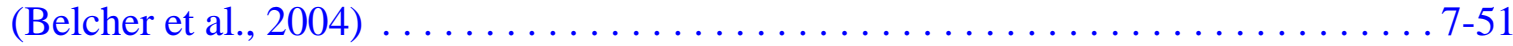

7-12 Recharge Rate for All Recharge Models and All Hydrographic Areas . . . . . . . . . . 7-57

8-1 Location of Groundwater Pumping Wells in the Yucca Flat/Climax Mine Area . . . . 8-4

8-2 Total Annual Production of Water Supply Wells in the Yucca Flat/Climax Mine Area. . . . . . . . . . . . . . . . . . . . . . . . . . . . . . . . 8 8 12

8-3 Production History for Yucca Flat/Climax Mine Groundwater Pumping Wells . . . . . 8-13

8-4 Location of ER Well Hydraulic Tests in the Yucca Flat/Climax Mine Area. . . . . . . 8-20

8-5 Location of Springs in the Yucca Flat/Climax Mine Area. . . . . . . . . . . . . . . . . . 8-24

8-6 Location of Tunnels in the Yucca Flat/Climax Mine Area . . . . . . . . . . . . . . 8-28

9-1 Yucca Flat/Climax Mine CAU Area Showing Lines of Cross-Sections . . . . . . . . . 9-10

9-2 Cross Section A-A' through Yucca Flat/Climax Mine HFM Area . . . . . . . . . . . 9-11

9-3 Cross Section B-B' through Yucca Flat/Climax Mine HFM Area . . . . . . . . . . . 9-12

9-4 Cross Section C-C' through Yucca Flat/Climax Mine HFM Area . . . . . . . . . . . . 9-13

11-1 Wells in the Yucca Flat/Climax Mine Area with Temperature Logs Evaluated . . . . . 11-8

11-2 Estimated Heat Flow from Wells in the Yucca Flat/Climax Mine Area . . . . . . . . 11-10 


\section{LIST OF FIGURES (CONTINUED)}

NUMBER

TITLE

PAGE

11-3 Simulated (a) Temperature and (b) Heat Flux Profiles in Homogenous Rock and Simulated (c) Temperature and (d) Heat Flux Profiles in Layered Rock . . . . . . 11-12

11-4 Temperature Profile for Well UE-1L . . . . . . . . . . . . . . . . . 11-17

11-5 Temperature Profile for Well UE-2ce $\ldots \ldots \ldots \ldots \ldots \ldots \ldots \ldots \ldots \ldots \ldots \ldots \ldots \ldots$

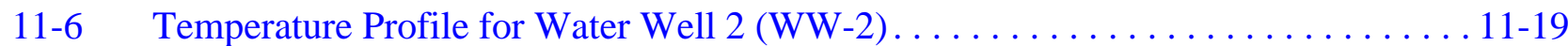

11-7 Temperature Profile for Well UE-6d . . . . . . . . . . . . . . . . . 11-20

11-8 Temperature Profile for Well UE-10j. . . . . . . . . . . . . . . . 11-21

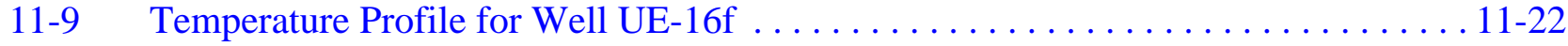

11-10 Temperature Profile for Well UE-4t-1 . . . . . . . . . . . . . . . . . 11-23

12-1 Yucca Flat/Climax Mine Geochemistry Study Area . . . . . . . . . . . . . . . . 12-3

12-2 Wells and Springs in the Yucca Flat/Climax Mine Geochemical Investigation Area With Geochemical and/or Isotopic Data . . . . . . . . . . . . . . . . 12-4

12-3 Piper Diagram for Groundwater of Alluvial Aquifer and Clastic Confining Units . . 12-14

12-4 Piper Diagram for Groundwater of Volcanic Aquifers and Confining Units . . . . 12-15

12-5 Piper Diagram for Groundwater of the Lower Carbonate Aquifer . . . . . . . . . 12-16

12-6 Plot of $\delta \mathrm{D}$ Versus $\delta^{18} \mathrm{O}$ Values for Regional and Perched Groundwater Samples in Northern Yucca Flat and Surrounding Areas . . . . . . . . . . . . . . . . . . 12-19

12-7 Plot of $\delta \mathrm{D}$ Versus $\delta^{18} \mathrm{O}$ Values for Groundwater Samples in the Yucca Flat/Climax Mine Study Area . . . . . . . . . . . . . . . . . . . . . . . . . 12-21

12-8 Plot of $\delta^{13} \mathrm{C}$ Versus ${ }^{14} \mathrm{C}$ Values for Springs and Wells Within the Yucca Flat/Climax Mine Study Area . . . . . . . . . . . . . . . . . . . . 12-22

12-9 Plot of ${ }^{36} \mathrm{Cl} / \mathrm{Cl}$ Ratios Versus Inverse $\mathrm{Cl}$ Values for Wells Within the Yucca Flat/Climax Mine Study Area . . . . . . . . . . . . . . . . . . . . 12-24

12-10 ${ }^{87} \mathrm{Sr} /{ }^{86} \mathrm{Sr}$ Versus Sr Concentration for Springs and Wells Within the Yucca Flat/Climax Mine Study Area . . . . . . . . . . . . . . . . . . . . 12-27 


\section{LIST OF FIGURES (CONTINUED)}

NUMBER

TITLE

PAGE

12-11 ${ }^{234} \mathrm{U} /{ }^{238} \mathrm{U}$ Activity Ratio Versus Uranium Concentration for Springs and Wells Within the Yucca Flat/Climax Mine Study Area . . . . . . . . . . . . . . . . . . . . 12-29

12-12 Conceptual Flow Paths Evaluated in the Yucca Flat/Climax Mine Geochemical

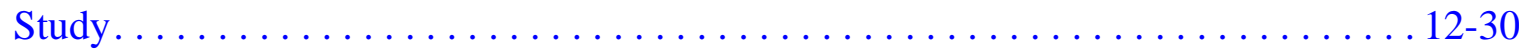

B.2-1 Yucca Flat/Climax Mine CAU-Specific Investigation and Recompletion Well Locations . . . . . . . . . . . . . . . . . . . . . . . . . . . . . . . . B-5

D.1-1 Comparison of the UCCU Extent and CP Thrust Location in the Base Model

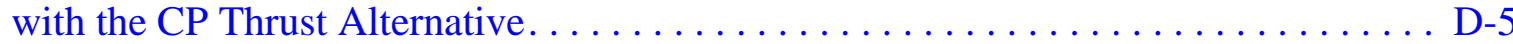

D.1-2 West-East Profiles through Northern Yucca Flat Comparing the UCCU Extent and CP Thrust Location in the Base Model with the CP Thrust Alternative . . . . . . D -6

D.1-3 Comparison of the LCA3 Extent and CP Thrust Location in the Base Model with the $\mathrm{CP}$ Thrust Alternative. . . . . . . . . . . . . . . . . . . . . . . D-7

D.1-4 West-East Profiles through Northern Yucca Flat Comparing the LCA3 Extent and CP Thrust Location in the Base Model with the CP Thrust Alternative . . . . . . . D-8

D.1-5 Comparison of the LCCU Geometry in the Base Model with the Hydrologic

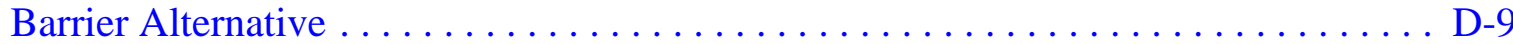

D.1-6 West-East Profiles through Climax Stock Comparing the Base Model with the Hydrologic Barrier Alternative. . . . . . . . . . . . . . . . . . . . . . . D-10

D.1-7 Comparison of the UCCU Extent in the Base Model with the Contiguous UCCU Alternative . . . . . . . . . . . . . . . . . . . . . . . . . . . D 11

D.1-8 West-East Profile through the Southwestern Corner of the Yucca Flat Model Comparing the Base Model with the Contiguous UCCU Alternative . . . . . . . . . D-12

D.1-9 West-East Profiles through Central Yucca Flat Comparing the Base Model with the Fault Juxtaposition Alternative. . . . . . . . . . . . . . . . . D-13

D.1-10 View of the Yucca Flat Base Model Showing Area Affected in the Partial Zeolitization Alternative. ............................. D-14

F.1-1 Observation Points and Calibration Targets Used for the Original and Modified (merged) Calibrations in the Vicinity of the Yucca Flat/Climax Mine HFM . . . . . . . F-7 


\section{LIST OF FIGURES (CONTINUED)}

NUMBER

TITLE

PAGE

F.1-2 Residual Heads (Observed-Simulated) Distribution for Simulation Case Using the Original DVRFS Steady-State Calibrated Recharge Model and the Original DVRFS HFM . . . . . . . . . . . . . . . . . . . . . . . .

F.1-3 Residual Heads (Observed-Simulated) Distribution for Simulation Case Using the USGS DVRFS Recharge Model and the Yucca Flat/Climax Mine Base HFM (merged).

F.1-4 Residual Heads (Observed-Simulated) Distribution for Simulation Case Using the Original DVRFS Steady-State Calibrated Recharge Model and the Yucca Flat/ClimaxMine Partial Zeolitization HFM (merged).

F.1-5 Residual Heads (Observed-Simulated) Distribution for Simulation Case Using theOriginal DVRFS Steady-State Calibrated Recharge Model and the Yucca Flat/Climax Mine Control Point Thrust HFM (merged).

F.1-6 Residual Heads (Observed-Simulated) Distribution for Simulation Case Using the Original DVRFS Steady-State Calibrated Recharge Model and the Yucca Flat/Climax Mine Hydrologic Barrier HFM (merged).

F.1-7 Residual Heads (Observed-Simulated) Distribution for Simulation Case Using theOriginal DVRFS Steady-State Calibrated Recharge Model and the Yucca Flat/Climax Mine Contiguous UCCU HFM (merged).

F.1-8 Residual Heads (Observed-Simulated) Distribution for Simulation Case Using the Original DVRFS Steady-State Calibrated Recharge Model and the Yucca Flat/Climax Mine Fault Juxtaposition HFM (merged).

G.1-1 Location of Wells in the Yucca Flat/Climax Mine Area with Temperature Log Profiles ... . . . . . . . . . . . . . . . . . . . . . . . . . . . G-3

G.1-2 Temperature Profile for Yucca Flat Well UE-1q . . . . . . . . . . . . G-5

G.1-3 Temperature Profile for Yucca Flat Well UE-1L. . . . . . . . . . . . . . G-6

G.1-4 Temperature Profile for Yucca Flat Well UE-2ce . . . . . . . . . . . . . G-7

G.1-5 Temperature Profile for Yucca Flat Well WW-2 . . . . . . . . . . . G-8

G.1-6 Temperature Profile for Yucca Flat Well ER-3-1-2. . . . . . . . . . . . . G-9

G.1-7 Temperature Profile for Yucca Flat Well ER-3-2-2 . . . . . . . . . . . . . . G-10 


\section{LIST OF FIGURES (CONTINUED)}

NUMBER

TITLE

PAGE

G.1-8 Temperature Profile for Yucca Flat Well UE-3e\#4-1 . . . . . . . . . . . . . G-11

G.1-9 Temperature Profile for Yucca Flat Well TW-7 . . . . . . . . . . . . . . G-12

G.1-10 Temperature Profile for Yucca Flat Well TW-D . . . . . . . . . . . . . . . G-13

G.1-11 Temperature Profile for Yucca Flat Well ER-6-1 . . . . . . . . . . . . . . G-14

G.1-12 Temperature Profile for Yucca Flat Well UE-6d . . . . . . . . . . . . . . . . . . . G-15

G.1-13 Temperature Profile for Yucca Flat Well UE-10j . ................. G-16

G.1-14 Temperature Profile for Yucca Flat Well ER-12-2 . . . . . . . . . . . . . . . . . G-17

G.1-15 Temperature Profile for Yucca Flat Well UE-14b ................... G-18

G.1-16 Temperature Profile for Yucca Flat Well U-15k . . . . . . . . . . . . . . . . . . . . G-19

G.1-17 Temperature Profile for Yucca Flat Well UE-16f ................... G-20

G.1-18 Temperature Profile for Yucca Flat Well UE-17a . . . . . . . . . . . . . . . G-21

G.1-19 Temperature Profile for Yucca Flat Well UE-4t-1.................. G-22

G.1-20 Temperature Profile for Yucca Flat Well ER-2-1 . . . . . . . . . . . . . . . . . G-23

G.1-21 Location of Wells in the Yucca Flat/Climax Mine Area with USGS Temperature

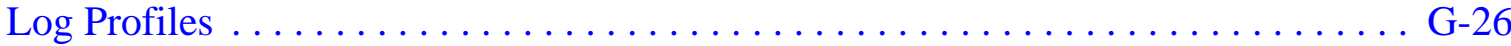

G.1-22 Location of Wells in the Yucca Flat/Climax Mine Area with USGS Temperature Measurements in the Upper Part of the Water Column (5 and 55 feet below

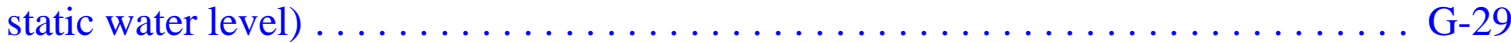

G.1-23 USGS Temperature Profile for Yucca Flat Well ER- 2-1 main (shallow). . . . . . . G-31

G.1-24 USGS Temperature Profile for Yucca Flat Well ER- 2-1 piezometer (deep) . . . . . . G-32

G.1-25 USGS Temperature Profile for Yucca Flat Well ER- 3-2-2 (middle) . . . . . . . . . . G-33

G.1-26 USGS Temperature Profile for Yucca Flat Well ER- 6-1 main (3206 ft) . . . . . . . . G-34

G.1-27 USGS Temperature Profile for Yucca Flat Well ER- 6-1-1............. G-35 


\section{LIST OF FIGURES (CONTINUED)}

NUMBER

TITLE

PAGE

G.1-28 USGS Temperature Profile for Yucca Flat Well ER- 6-1-2 main . . . . . . . . . . G G-36

G.1-29 USGS Temperature Profile for Yucca Flat Well ER- 6-1-2 piezometer . . . . . . . . . G-37

G.1-30 USGS Temperature Profile for Yucca Flat Well ER- 6-2 . . . . . . . . . . . . G-38

G.1-31 USGS Temperature Profile for Yucca Flat Well ER-12-1 (1641-1846 ft) . . . . . . G-39

G.1-32 USGS Temperature Profile for Yucca Flat Well ER-12-2 main (lower zone). . . . . G G-40

G.1-33 USGS Temperature Profile for Yucca Flat Well ER-12-2 main (upper zone). . . . . . G-41

G.1-34 USGS Temperature Profile for Yucca Flat Well ER-12-2 piezometer . . . . . . . . . G-42

G.1-35 USGS Temperature Profile for Yucca Flat Well TW- $7 \ldots \ldots \ldots \ldots \ldots \ldots \ldots$. . . . . . .

G.1-36 USGS Temperature Profile for Yucca Flat Well TW- B . . . . . . . . . . . . . . . G-44

G.1-37 USGS Temperature Profile for Yucca Flat Well TW- D . . . . . . . . . . . . . G-45

G.1-38 USGS Temperature Profile for Yucca Flat Well U - 3cn $5 \ldots \ldots \ldots \ldots \ldots \ldots$. . . G-46

G.1-39 USGS Temperature Profile for Yucca Flat Well U - 3mi . . . . . . . . . . . G-47

G.1-40 USGS Temperature Profile for Yucca Flat Well U -15k Test Hole. . . . . . . . . . . G-48

G.1-41 USGS Temperature Profile for Yucca Flat Well UE- 1 h. . . . . . . . . . . . . . . G-49

G.1-42 USGS Temperature Profile for Yucca Flat Well UE- 1q $(2600 \mathrm{ft}) \ldots \ldots \ldots$. . . . . G-50

G.1-43 USGS Temperature Profile for Yucca Flat Well UE- 3e 4-2 (1919 ft) . . . . . . . . G-51

G.1-44 USGS Temperature Profile for Yucca Flat Well UE- 4t 1 (1906-2010 ft) . . . . . . G-52

G.1-45 USGS Temperature Profile for Yucca Flat Well UE- 4t 2 (1564-1754 ft) . . . . . . G-53

G.1-46 USGS Temperature Profile for Yucca Flat Well UE- 6d . . . . . . . . . . . . G-54

G.1-47 USGS Temperature Profile for Yucca Flat Well UE- 6e (2090-2230 ft). . . . . . . . G-55

G.1-48 USGS Temperature Profile for Yucca Flat Well UE-10j (2232-2297 ft) . . . . . . . G-56

G.1-49 USGS Temperature Profile for Yucca Flat Well UE-14b . . . . . . . . . . . G-57 


\section{LIST OF FIGURES (CONTINUED)}

NUMBER

G.1-50 USGS Temperature Profile for Yucca Flat Well UE-16f $(1479 \mathrm{ft}) \ldots \ldots \ldots \ldots$. . . . G-58

G.1-51 USGS Temperature Profile for Yucca Flat Well UE-17a . . . . . . . . . . . . . G-59

G.1-52 USGS Temperature Profile for Yucca Flat Well WW- $2(3422 \mathrm{ft}) \ldots . . . \ldots$. . . . . G-60

G.1-53 USGS Temperature Profile for Yucca Flat Well WW- $3(1800 \mathrm{ft}) \ldots \ldots \ldots$. . . . G G-61 


\section{LIST OF PLATES}

NUMBER

TITLE

1 Geologic Map of the Yucca Flat/Climax Mine Model Area . . . . . . . . . . . . . . Pocket

2 Drill Holes in the Yucca Flat/Climax Mine Model Area. . . . . . . . . . . . . . Pocket

3 Distribution of Hydrostratigraphic Units at the Surface

for the Yucca Flat/Climax Mine Model Area . . . . . . . . . . . . . . . . . Pocket

4 Distribution of Hydrostratigraphic Units at the Water Table

for the Yucca Flat/Climax Mine Model Area . . . . . . . . . . . . . . . . . Pocket

$5 \quad$ Select Profiles of Hydrostratigraphic Units

for the Yucca Flat/Climax Mine Model Area . . . . . . . . . . . . . . . . . . . Pocket

6 Yucca Flat/Climax Mine Data Compilation Area Hydraulic Heads . . . . . . . . . . . Pocket

$7 \quad$ Yucca Flat/Climax Mine Water Table and LCA Potentiometric

Horizon Hydraulic Head Wells . . . . . . . . . . . . . . . . . . Pocket

A.1.1 Map of Yucca Flat/Climax Mine Showing UGTA Corrective Action Sites,

UGTA Well Locations, Test Related Surface Effects, and Selected

Basin-Forming Faults . . . . . . . . . . . . . . . . . . . . . . 


\section{LIST OF TABLES}

NUMBER

TITLE

PAGE

1-1 Yucca Flat/Climax Mine CAU Corrective Action Investigation

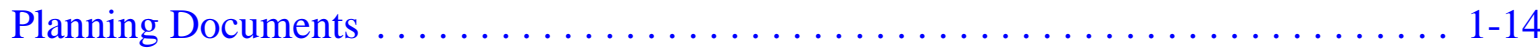

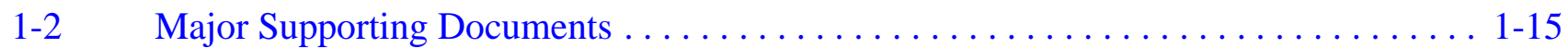

2-1 Hydrogeologic Units of the Yucca Flat/Climax Mine Geologic Model . . . . . . . . . . 2-7

2-2 HSUs of the Yucca Flat/Climax Mine HFM . . . . . . . . . . . . . . . . . . 2-8

2-3 HGUs for the Death Valley Regional Ground-Water Flow System Hydrogeologic

Framework Model . . . . . . . . . . . . . . . . . . . . . . . . . . . . . . . 2-20

5-1 Correlation of Hydrostratigraphic Units of the Yucca Flat/Climax Mine

CAU Model and Earlier Models . . . . . . . . . . . . . . . . . . . 5-20

6-1 Summary of Yucca Flat/Climax Mine-Specific Hydraulic Conductivity Analysis ... . 6-19

6-2 Summary of NTS Investigation Area Hydraulic Conductivity Analysis . . . . . . . . 6-20

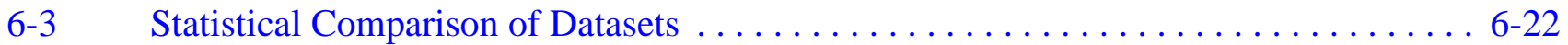

6-4 Investigations Addressing Depth Dependence of Permeability or Hydraulic

Conductivity. .............................. 6-26

6-5 Summary of Depth-Decay Analysis . . . . . . . . . . . . . . . . . . . . . 6 6-29

6-6 Variation of the Mean and SD of Hydraulic Conductivity Data by Scale of

Measurements, by HSU . . . . . . . . . . . . . . . . . . . . . . . 6-48

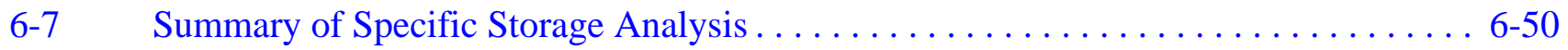

6-8 Variation of Water Properties With Temperature . . . . . . . . . . . . . . . 6-54

6-9 Production Well and Observation Well Information . . . . . . . . . . . . . . 6-60

6-10 Best-fit Parameter Estimates for Individual Observation Well Response Simulation . . 6-61

6-11 USGS Tuff Pile Study Parameter Estimates . . . . . . . . . . . . . . . . . 6-62

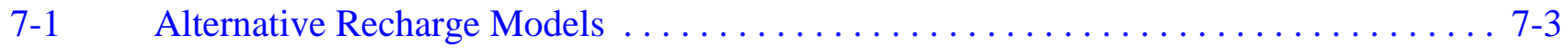

7-2 Precipitation Station Data Used for UGTA Original Recharge Model . . . . . . . . . . 7-7 


\section{LIST OF TABLES (CONTINUED)}

NUMBER

TITLE

PAGE

7-3 Comparison of Average Daily Precipitation to Published Values by

Hydrographic Area . . . . . . . . . . . . . . . . . . . . . . . . .

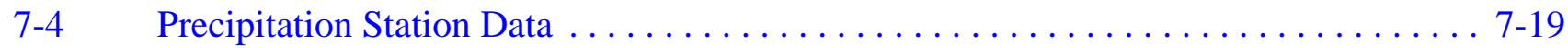

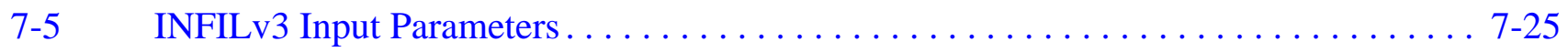

7-6 Model Coefficients Used To Simulate Stream Flow and Net Infiltration in INFLv3

Models 1-4 of the Death Valley Region, Nevada and California . . . . . . . . . . 7-31

7-7 Simulated Net-Infiltration Rates and Volumes Using INFLv3 Models 1 and 2 for

HAs and Subareas in the Death Valley Region, Nevada and California, 1950-1999 . . 7-33

7-8 Scaled DRI Recharge Rates Using UGTA Revised Maxey and Eakin Model . . . . . . 7-49

7-9 Recharge Rates for HAs for All Recharge Models . . . . . . . . . . . . . 7-56

8-1 Summary of Pumping Data for Wells in Yucca Flat $\ldots \ldots \ldots \ldots \ldots \ldots \ldots$

8-2 Site Information for Water Supply Wells Located in the Yucca Flat/Climax Mine

Data Compilation Area $\ldots \ldots \ldots \ldots \ldots \ldots \ldots \ldots \ldots \ldots . \ldots . \ldots . \ldots$

8-3 Yucca Flat/Climax Mine Area Water Supply Well Production . . . . . . . . . . . 8-10

8-4 Environmental Restoration Well Tests . . . . . . . . . . . . . . . . . . . . . . 8-19

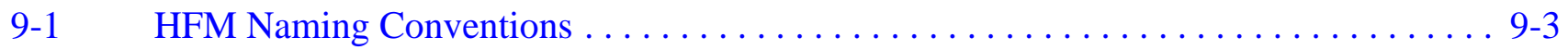

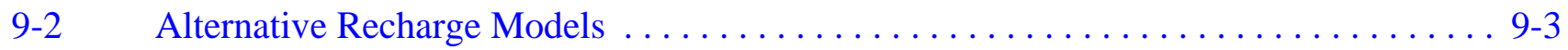

9-3 Total Water Balance for the Alternative Regional Flow Models at the

Yucca Flat/Climax Mine HFM . . . . . . . . . . . . . . . . . . . . 9-6

9-4 Statistics for Yucca Flat/Climax Mine Lateral Boundary Flow Rates . . . . . . . . . 9-9

9-5 Summary of Net Boundary Flux Ranges for Yucca Flat/Climax Mine HFM

Boundaries . . . . . . . . . . . . . . . . . . . . . . . . . . . . 9-14

10-1 U.S. Geological Survey Water Level Attributes of Interest . . . . . . . . . . . . . . . 10-19

10-2 Yucca Flat/Climax Mine Calibration Target Data. . . . . . . . . . . . . . . . 10-21

10-3 Additional Water Level Information . . . . . . . . . . . . . . . . . . 10-27 


\section{LIST OF TABLES (CONTINUED)}

NUMBER

11-1 Key Reports Providing Temperature Data and Information for the NTS Area. . . . . . 11-2

11-2 Saturated Thermal Conductivity Values for Major Volcanic Rock Units and Dolomite at the NTS . . . . . . . . . . . . . . . . . . . . . . . . . . 11-4

11-3 Typical Rock Thermal Conductivity Values . . . . . . . . . . . . . . . . 11-5

11-4 Saturated Thermal Conductivity for the HGUs Included in the Yucca Flat/Climax Mine Hydrogeologic Framework Model . . . . . . . . . . . . . . . . . . 11-6

11-5 Wells with Temperature Logs in the Yucca Flat/Climax Mine Area . . . . . . . . . 11-7

11-6 Temperature and Heat Flow for Wells in the Yucca Flat/Climax Mine Area. . . . . . . 11-9

11-7 Yucca Flat Wells with Temperature Profiles that Suggest the Potential for Advective Heat Transport . . . . . . . . . . . . . . . . . . . . . . . . . . . . 11-14

12-1 Summary of Sampling Events for Groundwater Quality Data Parameters From Wells and Springs in the Yucca Flat/Climax Mine Geochemistry Study Area. . . . . . 12-6

12-2 Dissolved Organic Carbon Calculated Groundwater Ages . . . . . . . . . . . . . . 12-23

A.1-1 Shaft and Tunnel Nuclear Detonations in the Yucca Flat/Climax Mine Corrective Action Unit. . . . . . . . . . . . . . . . . . . . . . . . A-3

B.2-1 Yucca Flat/Climax Mine Phase I Well Drilling and Testing . . . . . . . . . . . B-3

B.3-1 Yucca Flat/Climax Mine Phase I Well Recompletions and Testing . . . . . . . . . . B-7

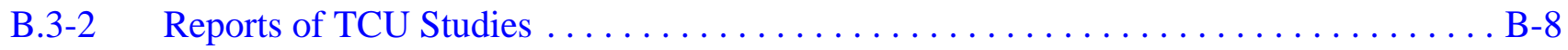

B.3-3 Reports of Gravity and Aeromagnetic Studies . . . . . . . . . . . . . . . B-9

B.4-1 Reports of Other Studies Conducted for the Yucca Flat/Climax Mine Phase I

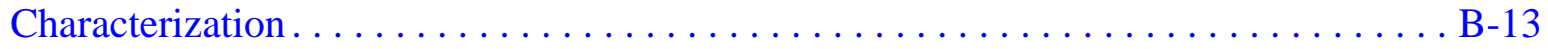

C.1-1 Qualification Levels. . . . . . . . . . . . . . . . . .

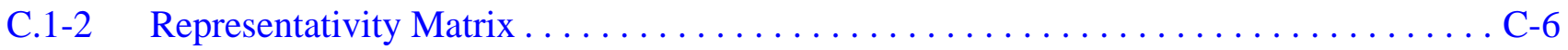

C.1-3 Formation Access Interval Assignment to Potentiometric Horizons. . . . . . . . . . . C-7 


\section{LIST OF TABLES (CONTINUED)}

NUMBER

TITLE

PAGE

E.1-1 Investigations Addressing Depth Dependence of Permeability or Hydraulic Conductivity . . . . . . . . . . . . . .

F.1-1 Alternative Hydrologic Framework Models . . . . . . . . . . . . . . . . . F F-3

F.1-2 Alternative Recharge Models $\ldots \ldots \ldots \ldots \ldots \ldots \ldots \ldots \ldots \ldots \ldots \ldots \ldots$

F.1-3 Simulation Cases Presented in this Report $\ldots \ldots \ldots \ldots \ldots \ldots \ldots \ldots \ldots \ldots \ldots$

F.1-4 Calibrated Horizontal Hydraulic Conductivity (in $\mathrm{m} / \mathrm{d}) \ldots \ldots \ldots \ldots \ldots \ldots \ldots \ldots$

G.1-1 Wells with Temperature Logs from Gillespie (2005) in the Yucca Flat/Climax Mine Area. . . . . . . . . . . . . . . . . . . . . . G-2

G.1-2 List of Temperature Profile Figures from Gillespie (2005) for the Yucca Flat/Climax Mine Area. . . . . . . . . . . . . . . . . . . . . . . . . G-4

G.1-3 Wells with USGS Temperature Logs in the Yucca Flat/Climax Mine Area. . . . . . . . G-25

G.1-4 Yucca Flat/Climax Mine Area Wells with USGS Temperature Measurements made at 5 and 55 feet below the Static Water Level . . . . . . . . . . . . . . . G-27

G.1-5 List of USGS Temperature Profile Figures for the Yucca Flat/Climax Mine Area ... . G-30

H.1-1 Major-Ion Data for Yucca Flat/Climax Mine Geochemical Evaluation . . . . . . . . . . . H-2

H.1-2 Isotope Data for Yucca Flat/Climax Mine Geochemical Evaluation . . . . . . . . . . . H-7

H.1-3 Field Measurement Data for Yucca Flat/Climax Mine Geochemical Evaluation. . . . . H-12

H.1-4 Strontium and Uranium Data for Yucca Flat/Climax Mine Geochemical Evaluation . . H-17

H.1-5 Select Trace and Minor Element Data for Yucca Flat/Climax Mine Geochemical Evaluation . . . . . . . . . . . . . . . . . . . . . . . . . 22 


\section{LIST OF ACRONYMS AND ABBREVIATIONS}

AAE Average estimation error

amsl Above mean sea level

ASTM American Society for Testing and Materials

bgs Below ground surface

BI Borehole Index

BN Bechtel Nevada

${ }^{\circ} \mathrm{C} \quad$ Degrees Celsius

${ }^{\circ} \mathrm{C} / \mathrm{m} \quad$ Degrees Celsius per meter

CADD Corrective Action Decision Document

CAI Corrective Action Investigation

CAIP Corrective Action Investigation Plan

CAP Corrective Action Plan

CAS Corrective Action Site

CAU Corrective Action Unit

CDF Cumulative density function

$\mathrm{cm} \quad$ Centimeter

$\mathrm{cm}^{3} \quad$ Cubic centimeters

$\mathrm{cm} / \mathrm{yr} \quad$ Centimeters per year

$\mathrm{CP} \quad$ Control Point

CR Closure Report

CV Coefficient of variability

DDE_F Data documentation evaluation flag

DEM Digital elevation map

DOE U.S. Department of Energy

DRI Desert Research Institute 


\section{List of ACRONyms AND ABbreViations (Continued)}

DQE_F Data quality evaluation flag

DTRA Defense Threat Reduction Agency

DVRFS Death Valley Regional Ground-Water Flow System

ECDF Empirical distribution function

EPA U.S. Environmental Protection Agency

ER Environmental Restoration

ERP Environmental Restoration Program

ESRI Enivronmental Systems Research Institute

$\mathrm{EV}^{\circledR} \quad$ EarthVision $^{\circledR}$

ET Evapotranspiration

${ }^{\circ} \mathrm{F} \quad$ Degrees Fahrenheit

FAI Formation access interval

FEHM Finite Element Heat-Mass Transfer Code

FFACO Federal Facility Agreement and Consent Order

ft Feet

$\mathrm{ft} / \mathrm{d} \quad$ Feet per day

$\mathrm{ft} / \mathrm{y} \quad$ Feet per year

$\mathrm{ft}^{3} / \mathrm{d} \quad$ Cubic feet per day

FY Fiscal year

gal Gallon

GCP Groundwater Characerization Project

GIS Geographic Information System

GMWL Global Meteoric Water Line

gpm Gallons per minute

GPS Global Positioning System 


\section{LIST OF ACRONYMS AND ABBREVIATIONS (CONTINUED)}

HA Hydrographic area

HFM Hydrostratigraphic Framework Model

HGU Hydrogeologic Unit

HSU Hydrostratigraphic Unit

HRMP Hydrologic Resource Management Program

ID Identification

in. inches

in./yr Inches per year

K Hydraulic conductivity

$\mathrm{k} \quad$ Intrinsic permeability

$\mathrm{K}_{\mathrm{d}} \quad$ Distribution coefficient

K-S Kolmogorov-Smirnov

kg Kilogram

$\mathrm{kg} / \mathrm{s} \quad$ Kilograms per second

$\mathrm{K}_{\mathrm{H}} \quad$ Hydraulic conductivity horizontal

km Kilometer

$\mathrm{km}^{2} \quad$ Square kilometer

$\mathrm{k}_{0} \quad$ Reference permeability

kt Kiloton

$\mathrm{L} / \mathrm{m}^{2} / \mathrm{y} \quad$ Liters per square meter per year

L/yr Liters per year

LaGriT Los Alamos Grid Toolbox

LANL Los Alamos National Laboratory

LLNL Lawrence Livermore National Laboratory

Lpm Liters per minute 


\section{List of ACRONyms AND ABbreViations (Continued)}

LMWL Local Meteoric Water Line

m Meter

m/d Meters per day

$\mathrm{m} / \mathrm{yr} \quad$ Meters per year

$\mathrm{m}^{2} \quad$ Square meter

$\mathrm{m}^{3} \quad$ Cubic meter

$\mathrm{m}^{3} / \mathrm{d} \quad$ Cubic meters per day

$\mathrm{m}^{3} / \mathrm{yr} \quad$ Cubic meters per year

$\mathrm{M} \& \mathrm{O} \quad$ Management and operating

Ma Million years ago

ME Maxey-Eaton

$\mathrm{mg} / \mathrm{kg} \quad$ Milligrams per kilogram

$\mathrm{mg} / \mathrm{L} \quad$ Milligrams per liter

mi Mile

$\mathrm{mi}^{2} \quad$ Square mile

$\mathrm{m}^{3} / \mathrm{d} \quad$ Cubic meters per day

mrem/yr Millirem per year

mm Millimeters

$\mathrm{mm} / \mathrm{yr} \quad$ Millimeters per year

MT Magnetollurgic

MWAT Multiple Well Aquifer Test

MWAT-TT Multiple-well aquifer test-tracer test

$\mathrm{mW} / \mathrm{m}^{2} \quad$ Milliwatts per square meter

N/A Not applicable

NA Not available 


\section{LIST OF ACRONYMS AND ABBREVIATIONS (CONTINUED)}

NAD North American Datum

NCDC National Climatic Data Center

NDEP Nevada Division of Environmental Protection

NNSA/NSO U.S. Department of Energy, National Nuclear Security Administration Nevada Site Office

NOAA National Oceanic and Atmospheric Administration

NTS Nevada Test Site

NWIS National Water Information System

PDB Pee Dee Belemnite

pdf Probability density function

PEST Parameter Estimation Software

QA Quality Assurance

QAPP Quality Assurance Program Plan

$\mathrm{R}^{2} \quad$ Correlation coefficient

RREMP Routine Radiological Environmental Monitoring Program

S Storage coefficient

SD Standard Deviation

SDWA Safe Drinking Water Act

SMSE Standardized mean-square error

SNJV Stoller-Navarro Joint Venture

SWIP Survey Waste Injection Program

SWNVF Southwestern Nevada Volcanic Field

TBD Technical basis document

TW Test Well

TWG Technical Working Group

UGTA Underground Test Area 


\section{List OF ACRONYMS AND ABBREVIATIONS (CONTINUED)}

$\begin{array}{ll}\text { USGS } & \text { U.S. Geological Survey } \\ \text { UTM } & \text { Universal Transverse Mercator } \\ \text { VOIA } & \text { Value of Information Analysis } \\ \text { VSMOW } & \text { Vienna Standard Mean Ocean Water } \\ \text { W/m }{ }^{\circ} \mathrm{C} & \text { Watts per meter degrees Celsius } \\ \text { WW } & \text { Water Well } \\ \text { YMP } & \text { Yucca Mountain Project } \\ \text { 1-D } & \text { One-dimensional } \\ \text { 2-D } & \text { Two-dimensional } \\ \text { 3-D } & \text { Three-dimensional } \\ \text { Mg/L } & \text { Micrograms per liter }\end{array}$




\section{LIST OF StRATIGRAPHIC UNIT ABBREVIATIONS AND SYMBOLS}

AA

ATCU

BLFA

BRA

BRCU

CA

CCU

GCU

LCA

LCA3

LCCU

LFA

LTCU

LVTA

MGCU

OAA

OAA1

OSBCU

PCU

PCU1U

PCUT

PRETBG

PRETBG1

TCU

TM
Alluvial Aquifer

Argillic Tuff Confining Unit

Basalt Lava-Flow Aquifer

Belted Range Aquifer

Belted Range Confining Unit

Carbonate Aquifer

Clastic Confining Unit

Granite Confining Unit

Lower Carbonate Aquifer

Lower Carbonate Aquifer - Yucca Flat Upper Plate

Lower Clastic Confining Unit

Lava-Flow Aquifer

Lower Tuff Confining Unit

Lower Vitric Tuff Aquifer

Mesozoic Granite Confining Unit

Older Alluvial Aquifer

Older Alluvial Aquifer 1

Oak Spring Butte Confining Unit

Playa Confining Unit

Playa Confining Unit, Upper

Playa Confining Unit (the $\mathrm{EV}^{\circledR}$ equivalent to the PCU)

Pre-Grouse Canyon Tuff Lava-Flow Aquifer

Pre-Grouse Canyon Tuff Lava-Flow Aquifer 1

Tuff Confining Unit

Timber Mountain 


\section{List of StRatigraphic UNIT AbBREVIations aNd Symbols (Continued)}

TM-LVTA Timber Mountain Lower Vitric-Tuff Aquifer

TM-UVTA Timber Mountain Upper Vitric-Tuff Aquifer

TM-WTA Timber Mountain Welded-Tuff Aquifer

TSA Topopah Spring Aquifer

TUBA Tub Spring Aquifer

UCA Upper Carbonate Aquifer

UCCU Upper Clastic Confining Unit

UTCU Upper Tuff Confining Unit

VA Volcanic Aquifer

VCU Volcaniclastic Confining Unit

VTA Vitric-Tuff Aquifer

WTA Welded-Tuff Aquifer 


\subsection{InTRODUCTION}

The U.S. Department of Energy (DOE), National Nuclear Security Administration Nevada Site Office (NNSA/NSO) initiated the Underground Test Area (UGTA) Project to assess and evaluate the effects of the underground nuclear weapons tests on groundwater beneath the Nevada Test Site (NTS) and vicinity. The framework for this evaluation is provided in Appendix VI, Revision No. 1 (December 7, 2000) of the Federal Facility Agreement and Consent Order (FFACO, 1996). Section 3.0 of Appendix VI "Corrective Action Strategy" of the FFACO describes the process that will be used to complete corrective actions specifically for the UGTA Project. The objective of the UGTA corrective action strategy is to define contaminant boundaries for each UGTA corrective action unit (CAU) where groundwater may have become contaminated from the underground nuclear weapons tests. The contaminant boundaries are determined based on modeling of groundwater flow and contaminant transport. A summary of the FFACO corrective action process and the UGTA corrective action strategy is provided in Section 1.5.

The FFACO (1996) corrective action process for the Yucca Flat/Climax Mine CAU 97 was initiated with the Corrective Action Investigation Plan (CAIP) (DOE/NV, 2000a). The CAIP included a review of existing data on the CAU and proposed a set of data collection activities to collect additional characterization data. These recommendations were based on a value of information analysis (VOIA) (IT, 1999), which evaluated the value of different possible data collection activities, with respect to reduction in uncertainty of the contaminant boundary, through simplified transport modeling.

The Yucca Flat/Climax Mine CAIP identifies a three-step model development process to evaluate the impact of underground nuclear testing on groundwater to determine a contaminant boundary (DOE/NV, 2000a). The three steps are as follows:

1. Data compilation and analysis that provides the necessary modeling data that is completed in two parts: the first addressing the groundwater flow model, and the second the transport model. 
2. Development of a groundwater flow model.

3. Development of a groundwater transport model.

This report presents the results of the first part of the first step, documenting the data compilation, evaluation, and analysis for the groundwater flow model. The second part, documentation of transport model data will be the subject of a separate report.

\subsection{Purpose, Objectives, and Scope}

The purpose of this document is to present the compilation and evaluation of the available hydrologic data and information relevant to the development of the Yucca Flat/Climax Mine CAU groundwater flow model, which is a fundamental tool in the prediction of the extent of contaminant migration. Where appropriate, data and information documented elsewhere are summarized with reference to the complete documentation.

The specific task objectives for hydrologic data documentation are as follows:

- Identify and compile available hydrologic data and supporting information required to develop and validate the groundwater flow model for the Yucca Flat/Climax Mine CAU.

- Assess the quality of the data and associated documentation, and assign qualifiers to denote levels of quality.

- Analyze the data to derive expected values or spatial distributions and estimates of the associated uncertainty and variability.

The scope of this document includes documentation of the data compilation and assessment and information required to model groundwater flow for the Yucca Flat/Climax Mine CAU and presentation of the data analysis. Data types include hydrogeology, hydraulic properties, precipitation recharge, groundwater discharge, lateral boundary fluxes, hydraulic head, temperature data, and groundwater chemistry. Hydrogeology is addressed with an overview of the Yucca Flat/Climax Mine Hydrostratigraphic Framework Model (HFM). The HFM is fully documented in a separate report prepared by Bechtel Nevada ([BN], 2006) and is summarized in Section 5.0 of this report. Lateral boundary fluxes at the Yucca Flat/Climax Mine HFM boundaries are derived from the U.S. Geological Survey (USGS) Death Valley Regional Ground-Water Flow System (DVRFS) 
groundwater flow model (Belcher et al., 2004). An overview of the DVRFS model is provided in Section 2.5.

\subsection{Yucca Flat/Climax Mine Background}

The Yucca Flat/Climax Mine CAU area is a large (approximately 19 kilometers [km] east-west by $35 \mathrm{~km}$ north-south [11 by 21 miles (mi)]) structural valley located in the northeastern corner of the NTS. The area is formed by perimeter mountain ranges and interior down-dropping due to extensional north-south oriented faulting. The Yucca Flat/Climax Mine CAU constitutes the largest of several geographic areas within the NTS previously used for underground nuclear testing. This CAU includes NTS Areas 1 through 4, 6 through 12, and 15; only small portions of Areas 11 and 12 are included (Figure 1-1).

\subsubsection{Underground Nuclear Testing in Yucca Flat}

Between 1957 and 1992, a total of 747 underground nuclear detonations were conducted in shafts and tunnels in this CAU. These tests included 744 detonations in Yucca Flat proper and three detonations in the Climax Mine tunnel complex (DOE/NV, 2000b). The tests comprise 720 Corrective Action Sites (CASs); the reduced number of CASs is the result of multiple detonations for some tests. Underground nuclear tests are designated (either individually or as groups) as CASs in the FFACO (1996). Appendix A contains a complete list of the underground nuclear tests and related test information. The location of the CASs and UGTA wells in the Yucca Flat/Climax Mine CAU, along with test related surface effects are shown in Plate A.1-1. As shown in Plate A.1-1, no underground nuclear tests were detonated in Areas 11 and 12 of the Yucca Flat/Climax Mine CAU.

Announced test yields for the Yucca Flat/Climax Mine CAU range from zero to 500 kilotons (kt), and the depth of burial ranges from 58 to 780 meters (m) below ground surface (bgs). Nuclear devices were emplaced in one of four types of geologic media in Yucca Flat and Climax Mine: alluvial deposits, Tertiary volcanics, carbonates, or intrusives (DOE/NV, 2000a). Approximately 23 percent of these detonations were conducted near or below the water table; with potential for groundwater contamination in the vicinity and possibly downgradient of the underground test locations. Transport in groundwater is the primary long-term mechanism for subsurface migration of contamination from underground nuclear tests. 


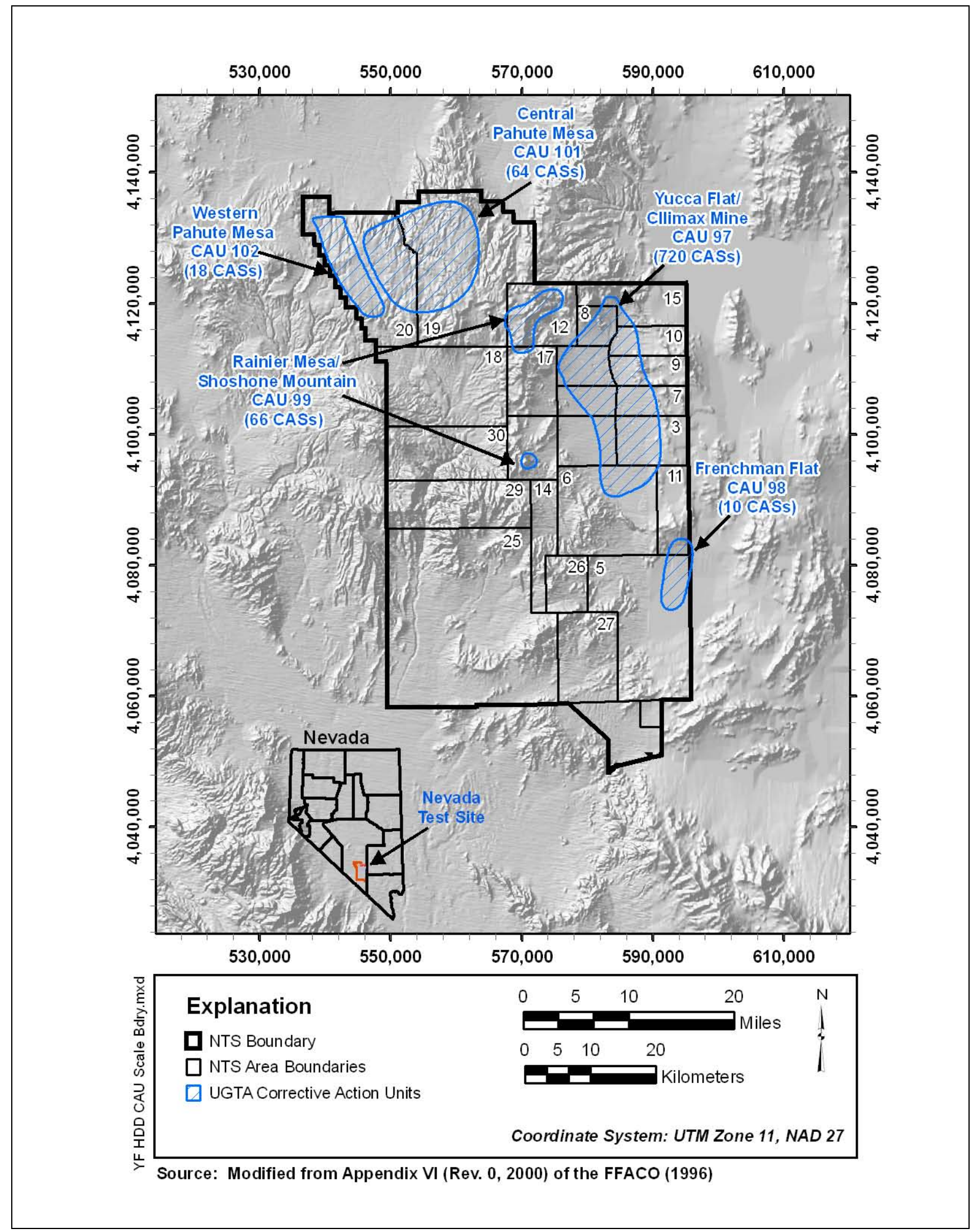

Figure 1-1

\section{Location of the Yucca Flat/Climax Mine CAU}




\subsection{Yucca Flat/Climax Mine CAU Investigation Boundaries}

Figure 1-1 shows the location of the Yucca Flat/Climax Mine CAU on the NTS. Information has been characterized at a variety of different scales, corresponding to different areal boundaries, depending upon the objectives of the characterization activity. This section introduces the defining boundaries for the major characterization activities and data sources. Figure 1-2 shows the location of the NTS within the larger boundaries of the DVRFS model (Belcher et al., 2004). Also shown is the boundary of the UGTA regional model (DOE/NV, 1997b), formerly used by UGTA for regional-scale characterization, and the original DVRFS (D'Agnese et al., 1997) boundary. The NTS Investigation Area had been previously defined for UGTA regional-scale modeling to identify the area in which specific information may be appropriately generalized for application to NTS-specific uses. This boundary has been used in previous UGTA hydrologic data compilation tasks including the UGTA regional model (DOE/NV, 1997b), the Pahute Mesa hydrologic data document (SNJV, 2004c), and the Frenchman Flat hydrologic data document (SNJV, 2004e).

The Yucca Flat/Climax Mine Investigation Area was defined in the Yucca Flat/Climax Mine CAIP to denote the areal extent over which data and information should be compiled and evaluated for potential use in Yucca Flat/Climax Mine CAU-specific modeling (DOE/NV, 2000a). Data compilation and evaluation for this entire area will be accomplished at several scales appropriate to the focus and localization required to support flow modeling. The immediate focus for Phase I groundwater flow modeling is the Yucca Flat/Climax Mine area, the modeling strategy for which is discussed in Section 3.0. This involves a CAU-scale groundwater flow model embedded within a regional-scale model. The data compilation area for the Yucca Flat/Climax Mine CAU-scale model is addressed in the following paragraph and Figure 1-3. Data compilation and evaluation for areas distant from the Yucca Flat/Climax Mine CAU are addressed in other documents. Both the UGTA regional model documentation (DOE/NV, 1997b) and the documentation for the DVRFS model (Belcher et al., 2004) provide data compilation and evaluation for the entire area of the Yucca Flat/Climax Mine Investigation Area at scales appropriate to regional modeling. The area immediately downgradient of the Yucca Flat/Climax Mine CAU is addressed within the Frenchman Flat hydrologic data document (SNJV, 2004e), and the Pahute Mesa hydrologic data compilation (SNJV, 2004c) covers the area to the west. These provide a level of data compilation and evaluation similar to the Yucca Flat/Climax Mine data documentation. The Rainier Mesa/Shoshone Mountain 
hydrologic data documentation will provide detailed data compilation and evaluation for the immediately adjacent area west of the Yucca Flat/Climax Mine CAU. Coordinated use of the CAU-specific data compilations will help ensure consistency of the CAU-specific flow models.

Figure 1-3 shows boundaries at the NTS-scale including the Yucca Flat/Climax Mine CAIP Investigation Area, the NTS UGTA CAUs and their corresponding HFM boundaries, and the boundary used for hydrologic data compilation for the Yucca Flat/Climax Mine CAU. The latter boundary, encompassing the Yucca Flat/Climax Mine CAU and the Yucca Flat/Climax Mine HFM boundary, was defined for compilation and analysis of data requiring continuity and consistency beyond the CAU boundary. This includes such data as hydraulic head, hydraulic properties, precipitation recharge data, and also applies to lateral boundary flux determination and geochemistry evaluation. The Yucca Flat/Climax Mine HFM boundaries shown include the original model area (DOE/NV, 1997b) and the northern and eastern extensions that were added in fiscal year (FY) 1999 and FY 2004, respectively (BN, 2005). This larger area was selected to better define the groundwater flow system boundaries for Yucca Flat and Climax Mine. The different CAU HFM boundaries overlap, and the separate models are consistent across the overlap areas. Figure 1-4 shows a detailed view of the CAU within the Yucca Flat/Climax Mine data compilation area.

The application of these different boundaries for characterization is discussed in detail in the relevant sections of this document. The larger area shown as the Yucca Flat/Climax Mine CAIP Investigation Area is addressed by data compilation and evaluation at different scales of data compilation and evaluation appropriate to the requirements for modeling at those scales. This document is focused on the Yucca Flat/Climax Mine CAU and adjacent areas (Yucca Flat/Climax Mine data compilation area) required for the Yucca Flat/Climax Mine CAU-scale groundwater flow model. Data and information for the immediate areas adjacent to the Yucca Flat/Climax Mine CAU data compilation area are available in the applicable hydrologic data documents. The Pahute Mesa hydrologic data compilation (SNJV, 2004c) covers the immediate area west of the Yucca Flat/Climax Mine CAU, and the Frenchman Flat hydrologic data compilation (SNJV, 2004e) covers the immediate area south of CAU 97. Further downgradient from the Yucca Flat/Climax Mine CAU, information is available from the USGS DVRFS model (Belcher et al., 2004), the UGTA regional model documentation (DOE/NV, 1997b), and the Yucca Mountain Project (YMP) documentation (DOE/OCRWM, 2002). 


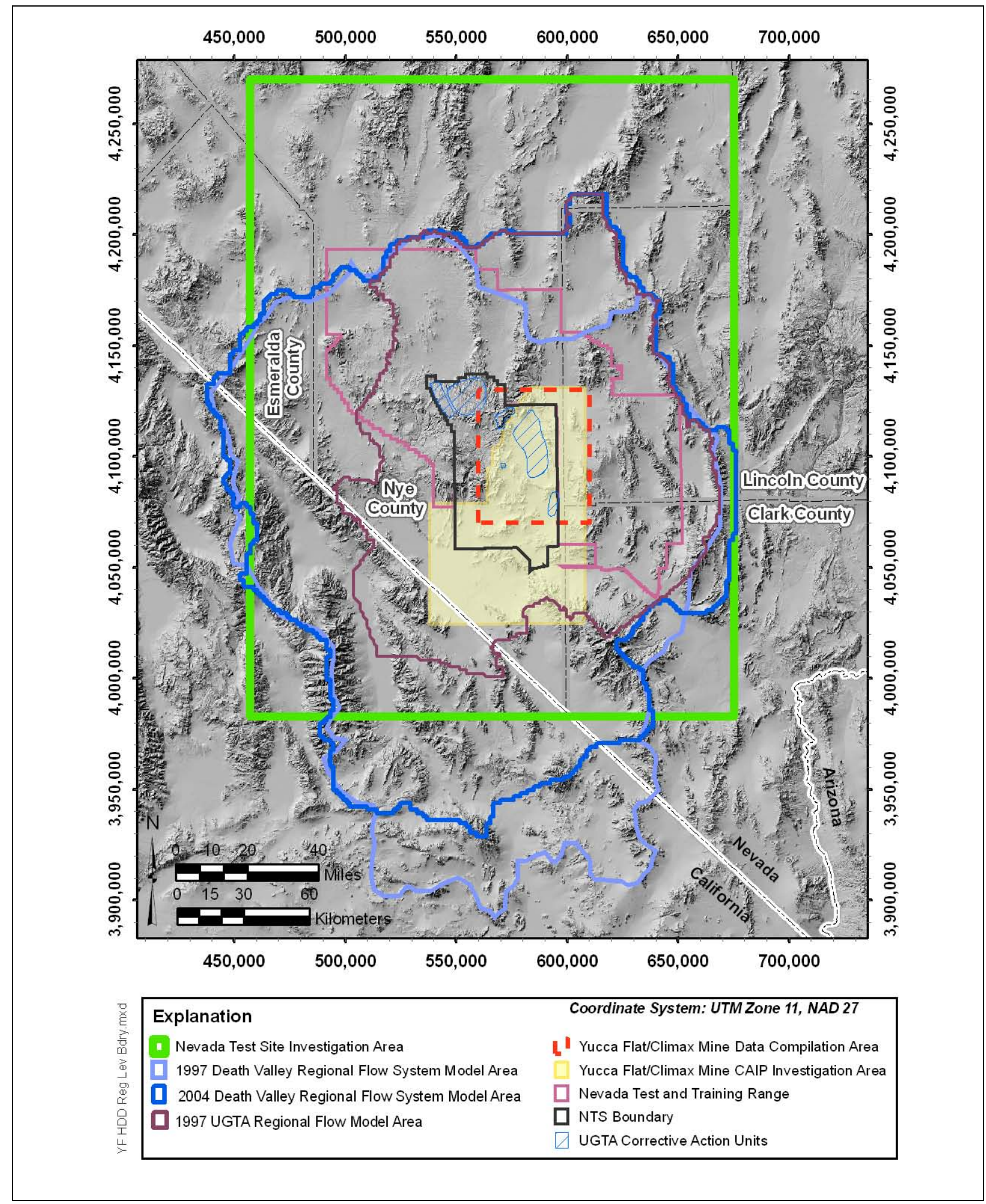

Figure 1-2

Regional-Scale Boundaries 


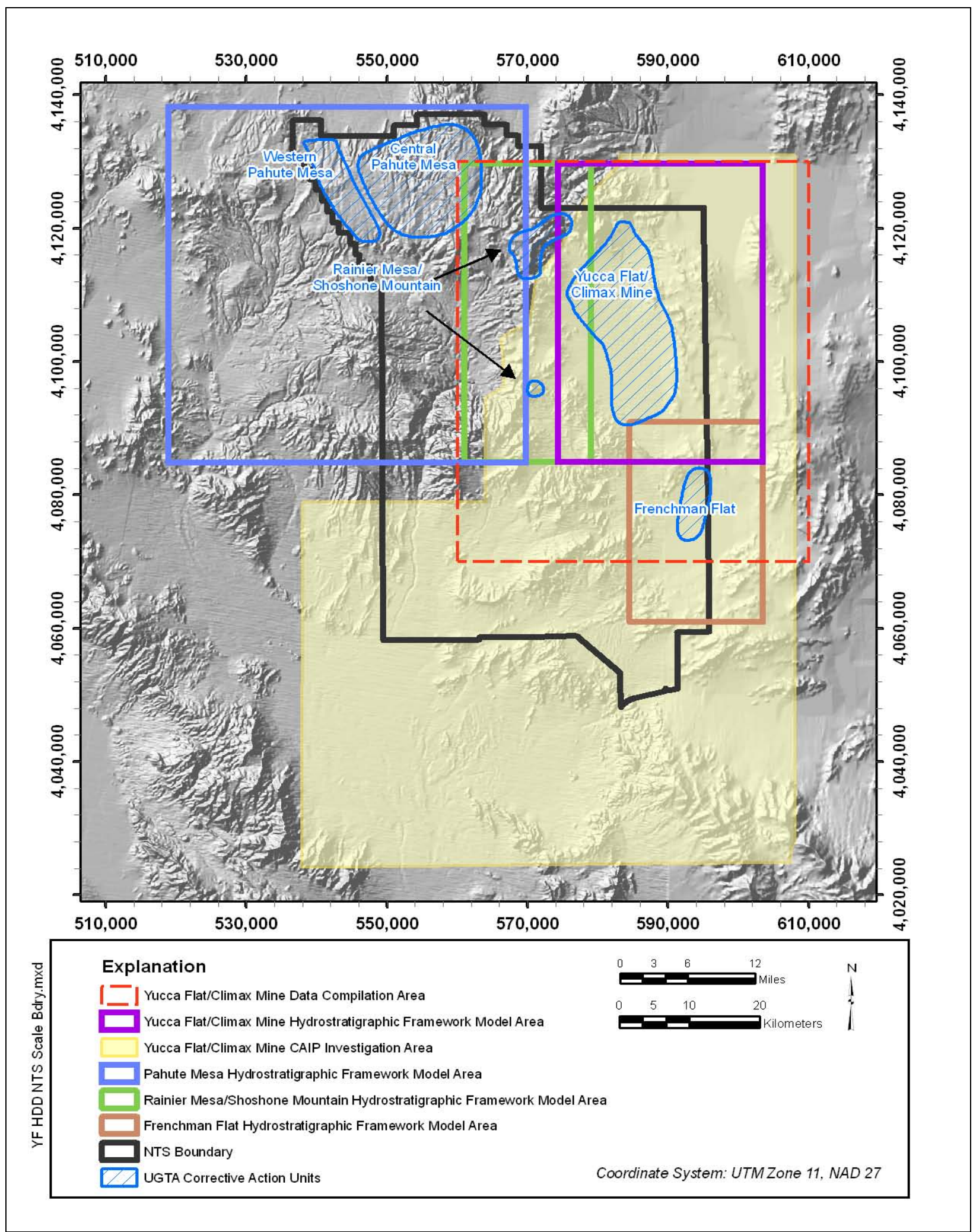

Figure 1-3

Nevada Test Site-Scale Boundaries 


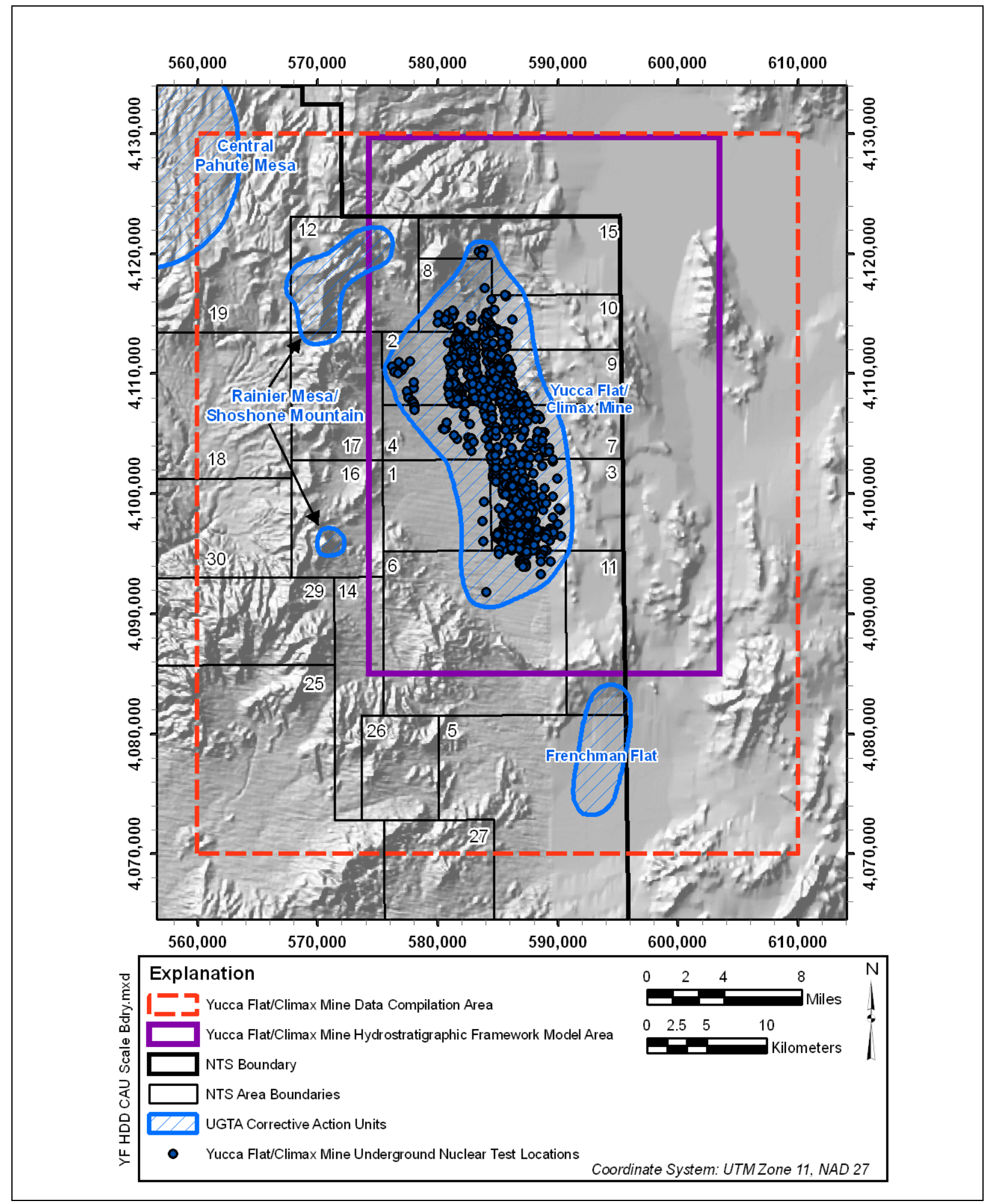

Figure 1-4

Yucca Flat/Climax Mine CAU-Scale Boundaries 


\subsection{Project Participants}

The UGTA Project is a component of NNSA/NSO Environmental Restoration Program (ERP). The UGTA Project corrective action investigations (CAIs) are managed by the NNSA/NSO UGTA Project Manager. A Technical Working Group (TWG) has been established to assist the NNSA/NSO UGTA Project Manager with technical management issues. Tasks assigned to the TWG include providing expert technical support to plan, guide, and monitor UGTA technical work, and to serve as internal peer reviewers of UGTA products. The TWG consists of representatives from the following organizations: BN, Desert Research Institute (DRI), GeoTrans, Inc., Lawrence Livermore National Laboratory (LLNL), Los Alamos National Laboratory (LANL), Stoller-Navarro Joint Venture (SNJV), and the USGS.

\subsection{Summary of the Federal Facility Agreement and Consent Order}

Since 1996, the Nevada Division of Environmental Protection (NDEP) has regulated NNSA/NSO corrective actions through the FFACO (1996). The individual locations covered by the agreement are known as CASs and are grouped into CAUs. The UGTA CAUs are Frenchman Flat, Central Pahute Mesa, Western Pahute Mesa, Yucca Flat/Climax Mine, and Rainier Mesa/Shoshone Mountain (Figure 1-1). Yucca Flat and Climax Mine (originally two separate CAUs) were later combined into the Yucca Flat/Climax Mine CAU 97 and are addressed together because of their adjacent location and the superposition of projected groundwater flow paths from Climax Mine onto the Yucca Flat CAU.

Section 3.0 of Appendix VI, Revision No. 1 (December 7, 2000) of the FFACO (1996) provides the current regulatory guidance on the UGTA corrective action strategy and is incorporated into this document.

The CAU-specific corrective action process includes six major components: CAIP, CAI, Corrective Action Decision Document (CADD), Corrective Action Plan (CAP), Closure Report (CR), and long-term monitoring. The purpose or contents of these documents are summarized as follows:

- The CAI planning is documented in the CAIP, an FFACO-required document that provides or references all specific information for planning investigation activities associated with CAUs or sites. 
- The CAI includes the collection of new data, the evaluation of new and existing data, and the development and use of CAU-specific groundwater flow and transport model(s).

- The CADD is an FFACO-required report that documents the CAI. It describes the results of the CAI, the corrective action alternatives considered, the results of their comparative evaluation, the selected corrective action, and the rationale for its selection.

- The CAP is a FFACO-required document describing how the selected remedial alternative shall be implemented. The CAP will contain the engineering design and all necessary specifications to implement the selected remedial alternative.

- The UGTA strategy has provisions for CAU closure only if the long-term monitoring alternative is selected. Closure activities include the preparation of a $\mathrm{CR}$, a review of the $\mathrm{CR}$ by NDEP, and long-term closure monitoring by the NNSA/NSO.

- Long-term closure monitoring is intended to ensure that the hydrologic conditions incorporated into determination of the compliance boundary do not change beyond the anticipated uncertainty (FFACO, 1996).

Figure 1-5 illustrates the decision process that will be used to achieve the FFACO corrective action strategy. The uppermost CAIP-level components (shaded) denote the steps so far completed in the regulatory framework for the Yucca Flat/Climax Mine CAU. The CAI-level, shaded component "Collect New Data" has been accomplished for Phase I, and the component "Evaluate Existing/New Data" identifies the data compilation and analysis activities that are initiated with this task, leading to the groundwater flow and transport model.

\subsubsection{Summary of the UGTA Corrective Action Strategy}

The focus of the UGTA corrective action strategy is to determine contaminant boundaries for each CAU in compliance with future monitoring requirements. The contaminant boundary is defined to encompass the predicted aggregate maximum extent of radionuclide contamination from underground testing exceeding the Safe Drinking Water Act (SDWA) standards. As such, it will be composed of both a perimeter boundary and a lower hydrostratigraphic unit (HSU) boundary.

Groundwater flow and contaminant transport models will be used to predict the location of this boundary during a future period of 1,000 years at a 95-percent level of confidence. Monitoring of the contaminant boundaries will determine long-term compliance. 


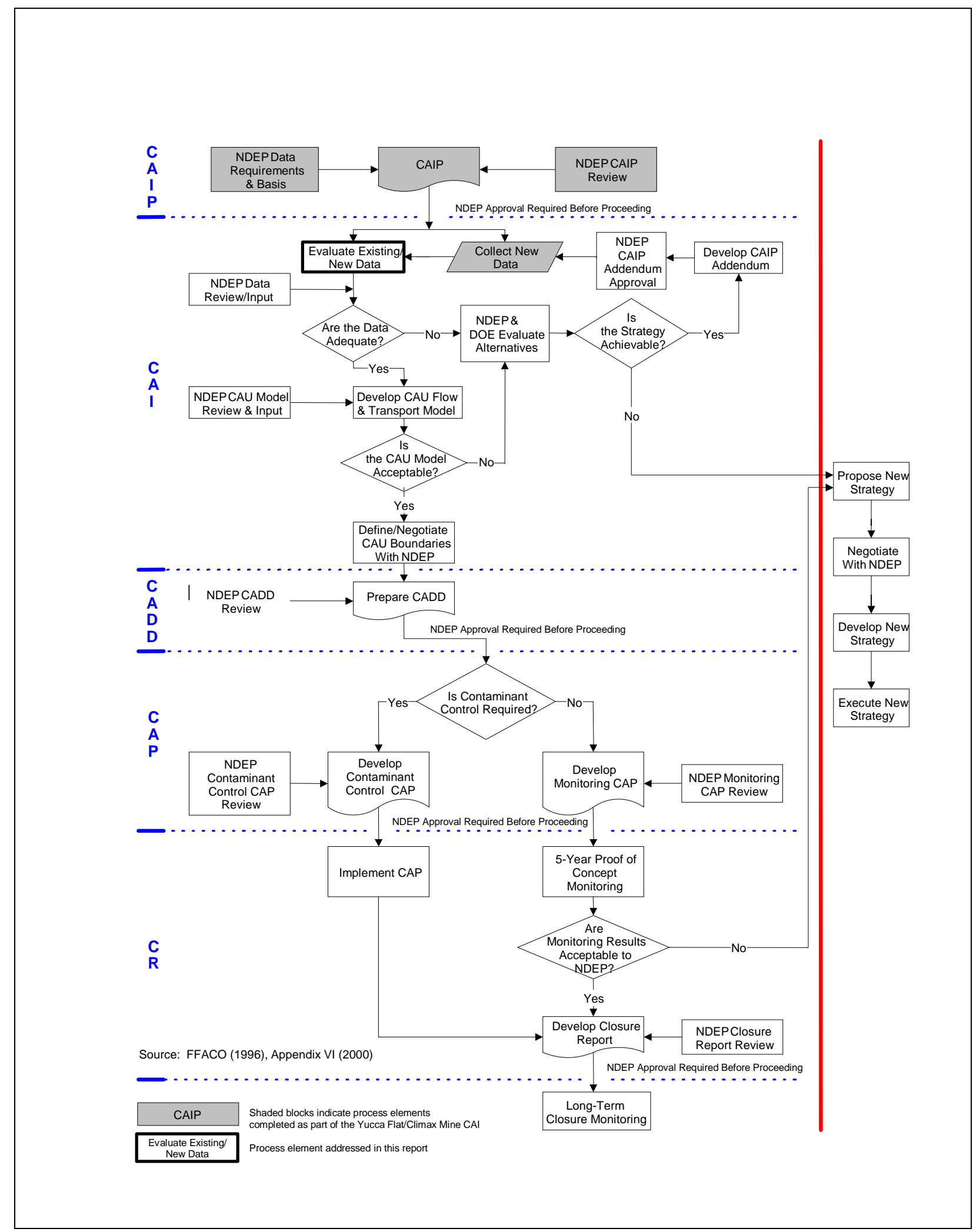

Figure 1-5

Process Flow Diagram for the Underground Test Area Corrective Action Units 
The UGTA corrective action strategy is implemented in two major phases: development of a regional flow model for use in evaluation, and coordination for all the UGTA CAUs, and a corrective action process for each of the CAUs. A model of regional flow encompassing the NTS and the groundwater flow systems extending to downgradient discharge was completed and documented in the Regional Groundwater Flow and Tritium Transport Modeling and Risk Assessment of the Underground Test Area, Nevada Test Site, Nevada (DOE/NV, 1997b). Regional flow modeling is a cross-cutting activity, supporting the entire UGTA program, providing the initial basis for assessing flow paths from CAUs, determining potential receptors, evaluating isolation or interaction of CAUs, and creating a consistent hydrogeologic framework across CAUs. Transport modeling of selected representative sources for each CAU provided the initial basis for determining the magnitude of risk from the source to potential receptors and for scaling individual CAU work (FFACO, 1996). With the recent release of the DVRFS transient model (Belcher et al., 2004), this new model has been adopted for use in the UGTA program where regional flow model information is required.

The second phase of the CAI process focuses on developing more detailed CAU-specific models that are based on CAU-specific data. The CAU-specific modeling objectives are to determine boundaries that encompass the extent of contamination, as defined in the FFACO (1996). Thus, this second phase is the basis for the analysis of relevant CAU-specific hydrologic data.

Table 1-1 lists the Yucca Flat/Climax Mine CAI planning documents. First completed was the Yucca Flat/Climax Mine VOIA (IT, 1999). The VOIA provided the basis for identifying the data collection activities specified in the Yucca Flat/Climax Mine CAIP (DOE/NV, 2000a), which was then developed and approved. Following approval, the strategy for development of the groundwater flow model was presented in the Yucca Flat/Climax Mine modeling strategy report (Shaw, 2003), which specifies data requirements for the modeling.

This report documents the next step in the CAIP process, data compilation, and analysis. It surveys available data, presents a compilation and summarization of relevant data, and provides analyses of these data in support of groundwater flow model development. Included in the report are overviews of the geologic model developed for the Yucca Flat/Climax Mine CAU and the regional flow system model used to determine lateral boundary fluxes. Additional information that may be used in support of model development is also presented and evaluated. 
Table 1-1

Yucca Flat/Climax Mine CAU Corrective Action Investigation Planning Documents

\begin{tabular}{||c|l||}
\hline \multicolumn{1}{|c|}{ Document Title } & \multicolumn{1}{c|}{ Description of Document } \\
\hline \hline $\begin{array}{c}\text { Value of Information Analysis for } \\
\text { Corrective Action Unit 97: Yucca Flat, } \\
\text { Nevada Test Site, Nevada (IT, 1999) }\end{array}$ & $\begin{array}{l}\text { Describes the evaluation of the sufficiency of existing information to } \\
\text { support the CAl, and identifies the major problems anticipated in } \\
\text { developing the geologic, flow and transport models. Potential data } \\
\text { collection activities to improve characterization data are evaluated for } \\
\text { potential benefit and prioritization. }\end{array}$ \\
$\begin{array}{c}\text { Corrective Action Investigation Plan for } \\
\text { Corrective Action Unit 97: Yucca } \\
\text { Flat/Climax Mine, Nevada Test Site, } \\
\text { Nevada (DOE/NV, 2000a) }\end{array}$ & $\begin{array}{l}\text { An FFACO (1996) requirement that summarizes the historical data for } \\
\text { the Yucca Flat/Climax Mine CAU and describes the characterization } \\
\text { activities that will be implemented to evaluate the extent of contamination } \\
\text { in groundwater due to underground nuclear testing, and the development } \\
\text { of a groundwater flow and transport model to predict the contaminant } \\
\text { boundary. }\end{array}$ \\
$\begin{array}{c}\text { Modeling Approach/Strategy for } \\
\text { Corrective Action Unit 97, Yucca Flat and } \\
\text { Climax Mine (Shaw, 2003) }\end{array}$ & $\begin{array}{l}\text { Describes approaches to modeling flow and transport through the } \\
\text { hydrogeologic system, including the underground test cavities, over time. } \\
\text { One approach is the development of numerical process models to } \\
\text { represent the processes that control flow and transport. The other } \\
\text { approach uses simplified representations of the process models to } \\
\text { assess the interactions between model and parameter uncertainty. }\end{array}$ \\
\hline
\end{tabular}

\subsection{Documents Supporting Yucca Flat/Climax Mine Data Analysis}

The Yucca Flat/Climax Mine CAU hydrologic data documentation is supported by key reports addressing regional-scale data analysis that is incorporated into Yucca Flat/Climax Mine-specific information. Table 1-2 lists these major reports and identifies their contribution to Yucca Flat/Climax Mine data compilation. 
Table 1-2

Major Supporting Documents

(Page 1 of 2)

\begin{tabular}{|c|c|c|}
\hline Report & Report Synopsis & $\begin{array}{l}\text { Contribution to Data } \\
\text { Compilation/Analysis }\end{array}$ \\
\hline $\begin{array}{l}\text { Hydrogeologic and Hydrochemical } \\
\text { Framework, South-Central Great Basin, } \\
\text { Nevada-California, with Special Reference } \\
\text { to the Nevada Test Site, Professional Paper } \\
\text { 712-C. (Winograd and Thordarson, 1975) }\end{array}$ & $\begin{array}{l}\text { The first report published on the regional groundwater flow system in } \\
\text { southern Nevada, specifically focused on the NTS area. It provides } \\
\text { comprehensive background information describing data and information } \\
\text { on the regional flow system as well as detailed information on the NTS. }\end{array}$ & $\begin{array}{l}\text { - Basic geologic and hydrologic } \\
\text { information on the NTS Area } \\
\text { - Conceptual model of regional } \\
\text { groundwater flow }\end{array}$ \\
\hline $\begin{array}{l}\text { Summary of Hydrogeologic Controls on } \\
\text { Ground-Water Flow at the Nevada Test Site, } \\
\text { Nye County, Nevada (Laczniak et al., 1996) }\end{array}$ & $\begin{array}{l}\text { Summarizes what was known and inferred about groundwater flow } \\
\text { throughout the UGTA region. As such, major controls on groundwater } \\
\text { flow are identified, some uncertainties about groundwater flow are } \\
\text { highlighted, and technical needs are prioritized and identified relative to } \\
\text { the ERP. }\end{array}$ & $\begin{array}{l}\text { - Conceptual model of regional } \\
\text { groundwater flow } \\
\text { - Overview discussion of NTS } \\
\text { hydrology }\end{array}$ \\
\hline $\begin{array}{c}\text { Underground Test Area Subproject Phase } 1 \\
\text { Data Analysis Task, Volumes I - IV, Data } \\
\text { Documentation Package (IT, 1996b, c, d, e) }\end{array}$ & $\begin{array}{l}\text { This data documentation package was developed to support the } \\
\text { development of the UGTA regional groundwater flow and tritium transport } \\
\text { model (DOE/NV, 1997b). Four volumes from this document are relevant } \\
\text { to the Yucca Flat/Climax Mine CAI. Volume I: Geologic Model } \\
\text { Documentation Package provides geologic data and analysis to define } \\
\text { the hydrogeologic framework for the groundwater flow system beneath } \\
\text { and near the NTS. Volume II: Potentiometric Data Documentation } \\
\text { Package is a compilation of a water-level dataset and ancillary data for } \\
\text { the groundwater flow system beneath and near the NTS. Volume III: } \\
\text { Groundwater Recharge and Discharge Data Documentation Package is } \\
\text { a compilation of recharge data and information and estimates of } \\
\text { recharge distribution; estimates of subsurface inflow and outflow relative } \\
\text { to the UGTA regional groundwater flow model boundary; and compilation } \\
\text { and analysis of natural discharge (springs and evapotranspiration [ET]) } \\
\text { and well discharge from the UGTA regional groundwater flow system. } \\
\text { Volume IV: Hydrologic Parameter Data Documentation Package is a } \\
\text { compilation and analysis of hydraulic parameters for rocks found within } \\
\text { the UGTA regional groundwater flow system. }\end{array}$ & $\begin{array}{l}\text { - Geologic data compilation and } \\
\text { analysis relative to the NTS region } \\
\text { - Water-level data and analysis } \\
\text { relative to the NTS region } \\
\text { - Recharge, discharge and } \\
\text { subsurface inflow/outflow data } \\
\text { compilation and analysis relative to } \\
\text { the NTS region } \\
\text { - Hydraulic parameter data } \\
\text { compilation and analysis relative to } \\
\text { the NTS region. }\end{array}$ \\
\hline
\end{tabular}


Table 1-2

\section{Major Supporting Documents}

(Page 2 of 2)

\begin{tabular}{|c|c|c|}
\hline Report & Report Synopsis & $\begin{array}{l}\text { Contribution to Data } \\
\text { Compilation/Analysis }\end{array}$ \\
\hline $\begin{array}{l}\text { Regional Groundwater Flow and Tritium } \\
\text { Transport Modeling and Risk Assessment of } \\
\text { the Underground Test Area, Nevada Test } \\
\text { Site, Nevada (DOE/NV, 1997b) }\end{array}$ & $\begin{array}{l}\text { This evaluation includes data analysis, model development, and model } \\
\text { predictions. Results of the regional evaluation of groundwater flow, } \\
\text { tritium migration, and risk assessment performed for the underground } \\
\text { test areas are presented in this report. This evaluation was used during } \\
\text { the planning of the Yucca Flat CAI and is the basis for development of } \\
\text { the CAU conceptual model. }\end{array}$ & $\begin{array}{l}\text { - Regional HFM } \\
\text { - Regional hydrologic data } \\
\text { compilation and analysis } \\
\text { - Quantitative model of regional } \\
\text { groundwater flow }\end{array}$ \\
\hline $\begin{array}{c}\text { Reconnaissance Estimates of Recharge } \\
\text { Based on an Elevation-dependent Chloride } \\
\text { Mass-balance Approach } \\
\text { (Russell and Minor, 2002) }\end{array}$ & $\begin{array}{l}\text { Describes the DRI evaluation of net infiltration and determination of } \\
\text { recharge via the development of recharge models derived from data } \\
\text { gathered from seventeen springs located in the Sheep Range, Spring } \\
\text { Mountains, and the NTS. The objective was to improve an existing } \\
\text { aquifer-response method based on the chloride mass-balance approach. } \\
\text { Results of the recharge estimates are reported. }\end{array}$ & - Recharge models \\
\hline $\begin{array}{c}\text { Simulation of Net Infiltration and Potential } \\
\text { Recharge Using a Distributed Parameter } \\
\text { Watershed Model for the Death Valley } \\
\text { Region, Nevada and California } \\
\text { (Hevesi et al., 2003) }\end{array}$ & $\begin{array}{l}\text { Reports the development and application of a distributed parameter } \\
\text { watershed model to estimate the temporal and spatial distribution of net } \\
\text { infiltration for the Death Valley region. }\end{array}$ & - Recharge models \\
\hline $\begin{array}{c}\text { Death Valley Regional Ground-Water Flow } \\
\text { System, Nevada and California - } \\
\text { Hydrogeologic Framework and Transient } \\
\text { Ground-Water Flow Model } \\
\text { (Belcher et al., 2004) }\end{array}$ & $\begin{array}{l}\text { Presents an updated regional flow model that was developed by the } \\
\text { USGS in collaboration with the YMP and the UGTA project. }\end{array}$ & $\begin{array}{l}\text { - Updated regional flow model } \\
\text { - Determination of lateral boundary } \\
\text { fluxes for CAU-specific modeling } \\
\text { - Recharge model }\end{array}$ \\
\hline $\begin{array}{l}\text { A Hydrostratigraphic Model and Alternatives } \\
\text { for the Groundwater Flow and Contaminant } \\
\text { Transport Model of Corrective Action Unit } \\
\text { 97: Yucca Flat-Climax Mine, Lincoln and } \\
\text { Nye Counties, Nevada (BN, 2006) }\end{array}$ & $\begin{array}{l}\text { Presents the hydrostratigraphic framework model for the Yucca } \\
\text { Flat/Climax Mine CAU that will be used for Phase I groundwater flow and } \\
\text { contaminant transport modeling. }\end{array}$ & $\begin{array}{l}\text { - Yucca Flat/Climax Mine } \\
\text { CAU-specific HFM base model and } \\
\text { alternatives }\end{array}$ \\
\hline
\end{tabular}




\subsection{Phase I Data Collection Activities}

A large variety of data collection activities have been conducted to supply information for Phase I data analysis and modeling, including activities specifically directed to address studies named in the Yucca Flat/Climax Mine CAIP (DOE/NV, 2000a). Appendix B contains an overview of the major Yucca Flat-specific data collection activities and studies that have been conducted since the advent of NTS environmental remediation characterization programs, and lists the major reports produced.

\subsection{Report Organization}

This report is organized into the following sections:

Section 1.0 introduces the document, defines the scope and objectives, provides background information on the FFACO (1996) corrective action strategy and the Yucca Flat/Climax Mine CAIP, and explains the document structure.

Section 2.0 presents an overview of the regional hydrogeologic setting, which covers basic physiographic, climatic, hydrographic, and geologic information. The DVRFS model (Belcher et al., 2004) is discussed regarding regional-scale characterization.

Section 3.0 summarizes the CAU modeling strategy and includes a discussion of the modeling approach for the Yucca Flat/Climax Mine CAU.

Section 4.0 discusses the approach to data compilation. Discussions include: data types, data sources, data compilation and analysis objectives, and data transferability. Yucca Flat/Climax Mine CAU data collection activities conducted for Phase I data analysis, and other major data analysis activities that have been conducted for the Yucca Flat/Climax Mine CAU, are listed and discussed.

Section 5.0 presents an overview of the Yucca Flat/Climax Mine CAU HFM.

Section 6.0 discusses available hydraulic property data and presents analyses of hydraulic property distributions and depth-decay organized by hydrogeologic unit (HGU). Factors affecting hydraulic properties, such as depth and temperature, are discussed. An overview of other hydraulic property information and analyses is presented. 
Section 7.0 discusses precipitation recharge models and presents the determination of precipitation recharge to be used for the Yucca Flat/Climax Mine CAU flow model.

Section 8.0 discusses groundwater discharges and available data, and presents tabulations and graphs of available discharge data to be used in the Yucca Flat/Climax Mine CAU flow model.

Section 9.0 presents the determination of lateral boundary fluxes in/out of the Yucca Flat/Climax Mine CAU based on the DVRFS model.

Section 10.0 discusses available hydraulic head data and the evaluation of the data with respect to the vertical interval to which the data apply (formation access of the well), the steady-state condition, and uncertainty. The determination of representative heads for each steady-state water level record, for use as target heads for calibration of the flow model is discussed, and a table of representative heads is presented. The areal distribution of head within the Yucca Flat/Climax Mine data compilation area and head differences with respect to potentiometric horizons is also evaluated.

Section 11.0 discusses available temperature data, presents tabulations and plots of temperature data by well, and identifies representative temperature distribution.

Section 12.0 discusses the geochemistry of groundwater in the Yucca Flat/Climax Mine CAU, and presents an overview of the evaluation of groundwater flow paths and travel times, based on geochemical mixing models and stable isotope data.

Section 13.0 provides citations for referenced material.

Appendix A contains a listing of underground nuclear tests in the Yucca Flat/Climax Mine CAU with general information on each test including name, location, depth and yield; as well as a test location map.

Appendix B presents an overview of the Yucca Flat/Climax Mine CAIP data collection activities that have been accomplished for the Yucca Flat/Climax Mine CAU during Phase I. 
Appendix $\mathrm{C}$ contains a report of formation access information, and hydrographs of the water-level data for each well. Also discussed is the scheme used to classify the representativeness of heads to potentiometric horizons relating to the characteristics of the formation access interval.

Appendix D presents an overview of alternative HFMs developed for the Yucca Flat/Climax Mine CAU and a summary of their salient features.

Appendix E presents a literature review and discussion of the technical basis for depth-decay of hydraulic conductivity.

Appendix F presents supporting data and discussion on the calculation of lateral boundary fluxes.

Appendix G contains tables of temperature measurements and logs.

Appendix $\mathrm{H}$ presents the dataset compiled for the Yucca Flat/Climax Mine geochemical investigation. 


\subsection{Geologic and Hydrologic Setting}

Section 2.0 presents basic, descriptive information on the geology and hydrology of the Yucca Flat/Climax Mine area within the context of the UGTA regional-scale setting. All CAU-specific information and data required for construction of the Yucca Flat/Climax Mine CAU-specific groundwater flow model is presented in detail in subsequent sections of this report.

The regional-scale hydrogeologic framework for the UGTA project was formerly embodied in the UGTA regional model (DOE/NV, 1997b). With the advent of Yucca Flat Phase I modeling activities, starting with this document, the USGS DVRFS model (Belcher, et al., 2004) has been adopted to replace the UGTA regional model. A brief discussion of this model is provided in Section 2.5.

The material in this section is based closely on material previously published in the following documents:

- Hydrogeologic and Hydrochemical Framework, South-Central Great Basin, Nevada-California, with Special Reference to the Nevada Test Site (Winograd and Thordarson, 1975)

- Summary of Hydrogeologic Controls on Ground-Water Flow at the Nevada Test Site, Nye County, Nevada (Laczniak et al., 1996)

- Yucca Flat Hydrogeologic Investigation Wells Drilling and Completion Criteria (IT, 2002)

- A Hydrostratigraphic Model and Alternatives for the Groundwater Flow and Contaminant Transport Model of Corrective Action Unit 97: Yucca Flat-Climax Mine, Lincoln and Nye Counties, Nevada (BN, 2006).

\subsection{Physiographic Setting}

The NTS is located in the high desert of the southern Great Basin in the northern-most subprovince of the basin and range physiographic province. The basin and range province is characterized by generally north-trending, linear mountain ranges occupying about 25 percent of the area; separated by 
broad intermontane basins filled with sediment and interbedded volcanic deposits (Peterson, 1981). A broad volcanic plateau occupies the central part of the region. Mountain ranges of the Great Basin are mostly tilted, fault-bounded blocks. These features are modified locally by the Las Vegas shear zone in the southern part of the NTS and by calderas of the Southwestern Nevada Volcanic Field (SWNVF) located in the western part of the NTS.

Yucca Flat is a topographically closed basin with a playa at its southern end. Faulted and tilted blocks of Tertiary-age volcanic rocks and underlying Paleozoic and Precambrian sedimentary rocks form low mountain ranges surrounding the basin. Recent alluvial deposits cover the volcanic rocks filling the basin.

Ground elevation in the Yucca Flat area ranges from about 1,195 m above mean sea level (amsl) at Yucca Lake (playa) in the southern portion to about 1,463 m amsl in the northern portion of the valley. The highest portions of the surrounding mountains and hills range from less than 1,500 $\mathrm{m}$ amsl in the south to over 2,316 m amsl on Rainier Mesa in the northwest corner of the study area. Yucca Flat is bounded by the Halfpint Range to the east; by Rainier Mesa and the Belted Range to the north; by the Eleana Range and Mine Mountain to the west; and by the Control Point (CP) Hills, and Massachusetts Mountain to the south. Figure 2-1 shows the basic physiographic features of the NTS.

\subsection{Geologic Setting}

Surficial geology in the NTS area is dominated by Tertiary volcanic rocks that were erupted from various vents in the SWNVF located on and adjacent to the western part of the NTS. At least six major calderas have been identified that were formed by the voluminous eruption of zoned ignimbrites between 16 and 7.5 million years ago (Sawyer et al., 1994). The volcanic rocks are covered in localized areas by late Tertiary and Quaternary surficial deposits such as alluvium, colluvium, eolian deposits, spring deposits, basalt lavas, lacustrine, and playa deposits which may aggregate up to several thousand feet in overall thickness.

Underlying the Tertiary volcanic rocks are Paleozoic and Proterozoic sedimentary and metasedimentary rocks including dolomite, limestone, quartzite, and argillite. During Precambrian and Paleozoic time, as much as 10,000 m of marine sediments were deposited in the NTS region (Cole, 1997). Mesozoic-age granitic intrusive masses are located north of Rainier Mesa and at the 

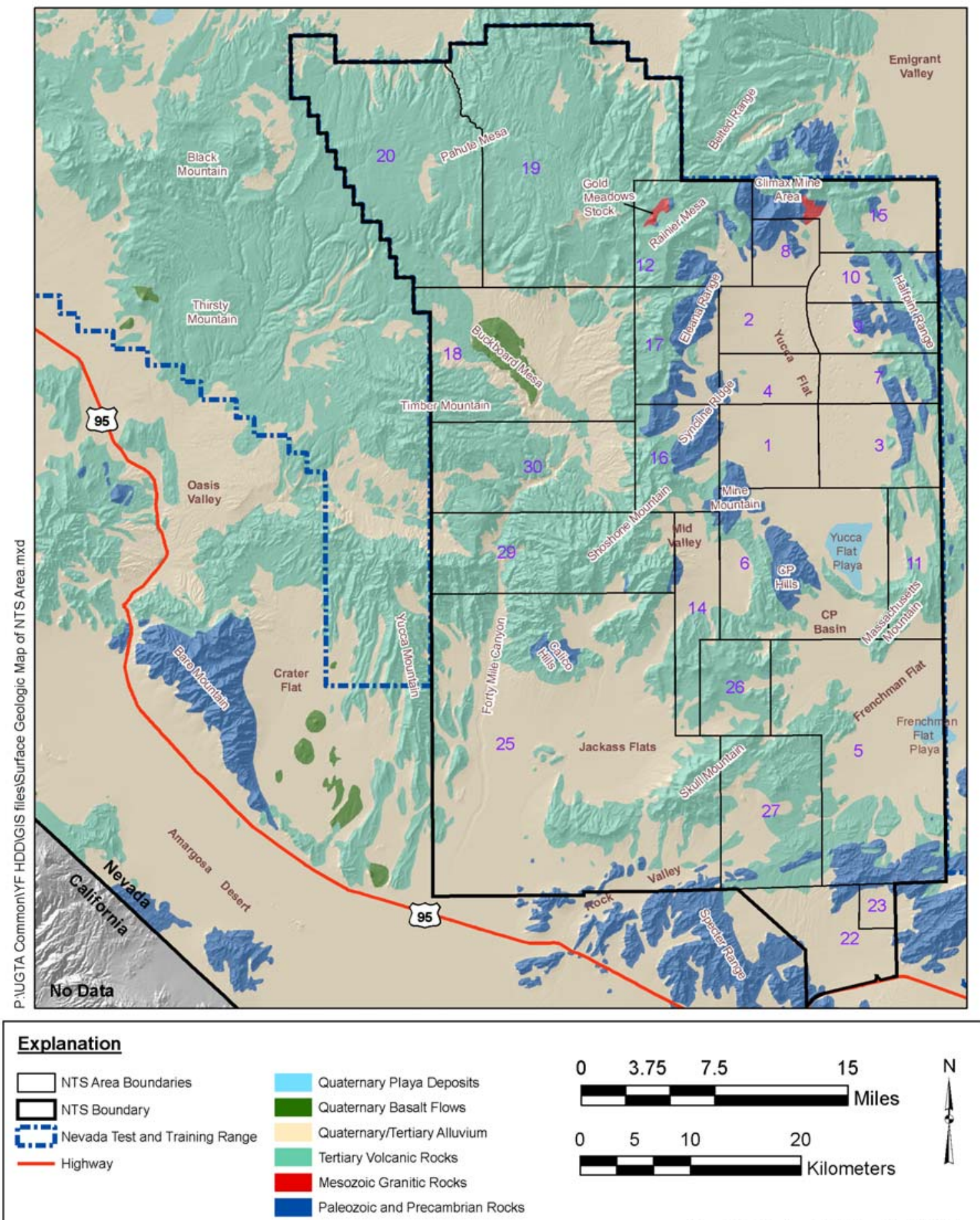

Coordinate System: UTM Zone 11, NAD 27

Source: Modified from Nevada Bureau of Mines and Geology, 1996

Figure 2-1

Generalized Surface Geologic Map of the NTS Area 
north end of Yucca Flat (Snyder, 1977; Gibbons et al., 1963). The only surface exposures of these rocks in the area are the Gold Meadows and Climax stocks. Geologic units exposed at the surface in the NTS area can be categorized as approximately 40 percent alluvium-filled basins, 20 percent Paleozoic and upper-Precambrian sedimentary rocks, and the remainder primarily Tertiary-age volcanic rocks, with a few small areas of exposed intrusives (Orkild et al., 1983; Slate et al., 1999).

Yucca Flat is a Cenozoic-age basin formed in response to basin-and-range extension. Major rock exposures in the highlands around the margins of Yucca Flat include Paleozoic sedimentary and siliciclastic rocks, Mesozoic intrusive rocks, and Cenozoic volcanics and tuffaceous sediments. Paleozoic sedimentary rocks exposed along the margins of Yucca Flat consist mostly of carbonate rocks ranging in age from Cambrian to Mississippian. Paleozoic siliciclastic rocks consist of Mississipian argillite and quatrzite. The Paleozoic rocks show compressional deformation mostly related to generally west-directed thrusting during the Mesozoic (e.g., CP thrust fault) as well as east-directed thrust faulting just west of Yucca Flat (e.g., Belted Range thrust fault). However, compressional deformation has been overprinted by extensive extensional deformation related to basin-and-range extension during the late Cenozoic (Caskey and Schweickert, 1992; Cole and Cashman, 1999). During the middle Late Cretaceous, granitic bodies (including the Climax Stock in northern Yucca Flat) intruded these deformed rocks (Maldondo, 1977; Houser and Poole, 1960).

\subsubsection{Structural Framework}

The NTS area is geologically complex and is characterized by several Tertiary-age calderas, relatively young basin-and-range-style normal faults, Mesozoic-age thrust faults, and intrusive bodies superimposed on a basement complex of highly deformed Paleozoic and Proterozoic sedimentary, and metasedimentary rocks. Yucca Flat is typical of many valleys in the basin and range province. Faulted and tilted blocks of Tertiary-age volcanic rocks and underlying Precambrian and Paleozoic sedimentary rocks form low ranges around the structural basin. The latter rocks compose the "basement" of the basin.

The thick section of Precambrian and Paleozoic rocks of the NTS area consists of carbonate and silicic clastic rocks. During Mesozoic time, compressional movements resulted in the formation of folds and thrust faults (e.g., Belted Range and CP thrust faults). During the middle-late Cretaceous, granitic bodies (such as the Climax stock in northern Yucca Flat) intruded these deformed rocks 
(Maldonado, 1977; Houser and Poole, 1960). During Cenozoic time, the sedimentary and intrusive rocks were buried in many places by thick sections of volcanic material deposited in several eruptive cycles from source areas in the SWNVF. The volcanic rocks include primarily ash-flow tuffs, ash-fall tuffs, and reworked tuffs, whose thicknesses and extent vary in the Yucca Flat area.

Large-scale, normal faulting began in the Yucca Flat area in response to regional extension near the end of this period of volcanism. This faulting formed the Yucca Flat basin, and as fault movement continued, blocks between faults were down-dropped and tilted, creating sub-basins within the Yucca Flat basin. Over the last several million years, gradual erosion of the highlands that surround Yucca Flat has deposited a thick blanket of alluvium over the tuff section. The thickness of the alluvium in the Yucca Flat basin varies as a function of the topography of the underlying deposits and continuing movement along faults during alluvium deposition.

More recent large-scale extensional faulting in the Yucca Flat area is significant. As such, the faults may profoundly affect the hydrogeology of the Tertiary volcanic units by controlling to a large extent, their position in the hydrostratigraphy. In addition, the faults may facilitate flow of groundwater from sources in younger rocks to the underlying regional aquifers. The major basin-forming faults generally strike in a northerly direction, and relative offset is typically downward to the east (e.g., Yucca, Topgallant, and Carpetbag faults). The structural model for the Yucca Flat/Climax Mine area is discussed in detail in Section 5.3.

\subsection{Hydrogeologic Framework}

The hydrogeologic framework for Yucca Flat and vicinity established by Winograd and Thordarson (1975) provides the foundation for most subsequent hydrogeologic studies in the area. The rocks of the NTS have been classified using a two-level classification scheme: hydrogeologic units (HGUs) and hydrostratigraphic units (HSUs) (IT, 1996a, e; BN, 2002). The HGUs categorize lithologic types according to their ability to transmit groundwater, which is a function of their primary lithologic properties, degree of fracturing, and secondary mineral alteration. Hydrostratigraphic units are groupings of contiguous stratigraphic units that have a particular hydrogeologic character, such as an aquifer or confining unit. An HSU may include units of several HGU types, but is defined so that a single type of HGU dominates. The HFM is constructed of HSUs, which provide the basis for incorporating geologic structure as well as hydrogeologic character. The HFM serves as input to the 
UGTA groundwater models. Note that the designations of aquifer or confining unit are based on the character of the hydraulic formations without regard to whether the unit is completely saturated.

\subsubsection{Yucca Flat Hydrogeologic Units}

Table 2-1 lists the HGU rock classifications for Yucca Flat, identifying the different types of rock units. The schema is adapted from Winograd and Thordarson (1975) and has been refined by both Laczniak et al. (1996) and BN (2006). This table is presented as an introduction to the general hydrogeologic distinctions between the various types of rocks on the NTS and in Yucca Flat in particular. The HGUs for the Yucca Flat/Climax Mine area are discussed in detail in Section 5.4.1.

\subsubsection{Yucca Flat /Climax Mine Hydrostratigraphic Units}

Table 2-2 presents the HSUs defined for the Yucca Flat/Climax Mine HFM. The HSUs are discussed in greater detail in Section 5.4.2.

\subsection{Hydrologic Setting}

The NTS is located within the Great Basin hydrographic province, which is characterized by internal drainage and consists of numerous closed hydrographic basins, including Yucca Flat. The NTS is totally within the DVRFS, which encompasses an area of about 15,800 square miles $\left(\mathrm{mi}^{2}\right)(40,900$ square kilometers $\left[\mathrm{km}^{2}\right]$ ) of the southern Great Basin (see Figure 1-2). This flow system is recharged in the high mountains of central Nevada and ultimately discharges in Death Valley (Harrill et al., 1988). Sub-basins of the groundwater flow system may discharge locally as springs or to playas and wetlands. However, the greatest part of groundwater flow moves through the system between sub-basins within a thick sequence of Paleozoic carbonate rocks that extends throughout the subsurface of much of central and southeastern Nevada (Dettinger, 1989). This carbonate aquifer (LCA HSU, Table 2-2) extends beneath much of Yucca Flat, although the regional connection of the aquifer to the west, north, and northeast of Yucca Flat is limited by the geologic structure. 
Table 2-1

Hydrogeologic Units of the Yucca Flat/Climax Mine Geologic Model

\begin{tabular}{|c|c|c|}
\hline Hydrogeologic Unit & Typical Lithologies & Hydrologic Significance \\
\hline $\begin{array}{l}\text { Playa Confining Unit } \\
\text { (PCU) }\end{array}$ & Clayey-silt, sandy-silt & $\begin{array}{l}\text { Surface/near-surface confining unit at Yucca Lake. May } \\
\text { limit or redirect recharge where present at surface. }\end{array}$ \\
\hline Alluvial aquifer (AA) & $\begin{array}{l}\text { Unconsolidated to partially } \\
\text { consolidated gravelly sand, } \\
\text { eolian sand, and colluvium; }\end{array}$ & $\begin{array}{l}\text { Can be highly permeable aquifer, but less so where } \\
\text { lenses of clay-rich paleocolluvium, zeolitic alteration, or } \\
\text { playa deposits are present. }\end{array}$ \\
\hline Welded-tuff aquifer (WTA) & $\begin{array}{l}\text { Welded ash-flow tuff; vitric } \\
\text { to devitrified }\end{array}$ & $\begin{array}{l}\text { Degree of welding greatly affects interstitial porosity } \\
\text { (porosity decreases as degree of welding increases) and } \\
\text { permeability (fracture permeability increases as degree } \\
\text { of welding increases). }\end{array}$ \\
\hline Vitric-tuff aquifer (VTA) & $\begin{array}{l}\text { Bedded tuff; ash-fall and } \\
\text { reworked tuff; vitric }\end{array}$ & $\begin{array}{l}\text { Volumetrically minor HGU. Generally does not extend } \\
\text { far below the static water level due to tendency of tuffs to } \\
\text { become zeolitized under saturated conditions, drastically } \\
\text { reducing permeability. Significant interstitial porosity } \\
\text { (i.e., } 20 \text { to } 40 \text { percent). Generally insignificant fracture } \\
\text { permeability. }\end{array}$ \\
\hline Lava-flow aquifer (LFA) & $\begin{array}{l}\text { Rhyolite, basalt and dacite } \\
\text { lava flows; includes } \\
\text { flow breccias } \\
\text { (commonly at base) }\end{array}$ & $\begin{array}{l}\text { Generally moderately thick (rhyolite) to thin (basalt) local } \\
\text { flows. Hydrologically complex; wide range of } \\
\text { transmissive character; fracture density and interstitial } \\
\text { porosity vary with lithologic variations. }\end{array}$ \\
\hline Tuff confining unit (TCU) & $\begin{array}{l}\text { Zeolitic bedded tuff with } \\
\text { interbedded, but less } \\
\text { significant, zeolitic, } \\
\text { nonwelded to partially } \\
\text { welded ash-flow tuff }\end{array}$ & $\begin{array}{l}\text { Where saturated, measured permeability is very low. } \\
\text { Perched and/or semi-perched water may occur in } \\
\text { overlying units. }\end{array}$ \\
\hline $\begin{array}{l}\text { Granite Confining Unit } \\
\text { (GCU) }\end{array}$ & $\begin{array}{l}\text { Granodiorite, quartz } \\
\text { monzonite }\end{array}$ & $\begin{array}{l}\text { Saturated at depth. Considered a confining unit due to } \\
\text { low intergranular porosity and permeability, and the lack } \\
\text { of interconnecting fractures. }\end{array}$ \\
\hline Clastic confining unit (CCU) & Argillite, siltstone, quartzite & $\begin{array}{l}\text { Relatively impermeable siliclastic rocks. } \\
\text { Coarser-grained rocks are fractured, but fracture porosity } \\
\text { is generally filled by secondary mineralization. }\end{array}$ \\
\hline Carbonate aquifer (CA) & Dolomite, limestone & $\begin{array}{l}\text { Transmissive character varies greatly depending on } \\
\text { fracture frequency. }\end{array}$ \\
\hline
\end{tabular}

Source: BN, 2006 (Adapted from Winograd and Thordarson, 1975; IT, 1996e; and Laczniak et al., 1996) 
Table 2-2

HSUs of the Yucca Flat/Climax Mine HFM

(Page 1 of 4)

\begin{tabular}{|c|c|c|c|}
\hline $\begin{array}{c}\text { Hydrostratigraphic } \\
\text { Unit }\end{array}$ & $\begin{array}{l}\text { Dominant } \\
\text { Hydrogeologic } \\
\text { Units }^{\mathrm{a}}\end{array}$ & Typical Lithologies & Hydrologic Significance \\
\hline Alluvial Aquifer (AA) & AA & $\begin{array}{l}\text { Alluvium: gravelly } \\
\text { sand; includes one or } \\
\text { more thin basalt flows } \\
\text { and eolian sands }\end{array}$ & $\begin{array}{l}\text { Generally unsaturated except in deepest } \\
\text { basins. }\end{array}$ \\
\hline $\begin{array}{l}\text { Playa Confining Unit } \\
\text { (PCU) }\end{array}$ & PCU & $\begin{array}{l}\text { Clayey silt and } \\
\text { sandy silt }\end{array}$ & $\begin{array}{l}\text { Playa units occur well above local water } \\
\text { table, but can impede recharge or } \\
\text { concentrate local recharge through large } \\
\text { surface cracks. Surface and near-surface } \\
\text { playas are found at Yucca Lake, Papoose } \\
\text { Lake, and southern West Emigrant Valley. }\end{array}$ \\
\hline $\begin{array}{l}\text { Basalt Lava-Flow } \\
\text { Aquifer (BLFA) }\end{array}$ & LFA & $\begin{array}{l}\text { Basalt lava flows, minor } \\
\text { sills and associated } \\
\text { dikes }\end{array}$ & $\begin{array}{l}\text { Several (possibly dissected) basalt flows } \\
\text { recognized in the middle of the alluvial } \\
\text { section of southwestern Yucca Flat, at the } \\
\text { surface as dikes and sills in the Halfpint } \\
\text { Range, and as a dike in the subsurface of } \\
\text { eastern Yucca Flat at drill hole UE-7h. } \\
\text { Generally unsaturated but deep feeder dikes, } \\
\text { if present, could affect groundwater flow. }\end{array}$ \\
\hline $\begin{array}{l}\text { Timber Mountain } \\
\text { Upper Vitric-Tuff } \\
\text { Aquifer (TM-UVTA) }\end{array}$ & $\begin{array}{l}\text { VTA, } \\
\text { minor WTA }\end{array}$ & $\begin{array}{c}\text { Includes vitric } \\
\text { nonwelded to partially } \\
\text { welded ash-flow and } \\
\text { bedded tuff }\end{array}$ & $\begin{array}{l}\text { Typically saturated only in the deepest } \\
\text { structural basins, comprises only the } \\
\text { Ammonia Tanks Tuff, which stratigraphically } \\
\text { overlies the TM-WTA. }\end{array}$ \\
\hline $\begin{array}{c}\text { Timber Mountain } \\
\text { Welded-Tuff Aquifer } \\
\text { (TM-WTA) }\end{array}$ & $\begin{array}{l}\text { WTA, } \\
\text { minor VTA }\end{array}$ & $\begin{array}{l}\text { Partially to densely } \\
\text { welded ash-flow tuff; } \\
\text { vitric to devitrified }\end{array}$ & $\begin{array}{l}\text { Typically saturated only in deep structural } \\
\text { basins. Strongly welded zones typically } \\
\text { found between less-welded zones. Prolific } \\
\text { aquifer where saturated. }\end{array}$ \\
\hline $\begin{array}{l}\text { Timber Mountain } \\
\text { Lower Vitric-Tuff } \\
\text { Aquifer (TM-LVTA) }\end{array}$ & VTA & $\begin{array}{l}\text { Nonwelded ash-flow } \\
\text { and bedded tuff; vitric }\end{array}$ & $\begin{array}{l}\text { Typically includes the nonzeolitized, } \\
\text { nonwelded lower portion of the Rainier Mesa } \\
\text { Tuff. However, this HSU can encompass all } \\
\text { nonzeolitized, nonwelded and bedded units } \\
\text { below the welded Rainier Mesa Tuff and } \\
\text { above the upper level of pervasive } \\
\text { zeolitization. Unaltered nonwelded and } \\
\text { ash-fall tuffs generally not found at depths } \\
\text { much below the static water level due to } \\
\text { tendency to become zeolitized (which } \\
\text { drastically reduces permeability) under } \\
\text { saturated conditions. }\end{array}$ \\
\hline
\end{tabular}


Table 2-2

HSUs of the Yucca Flat/Climax Mine HFM

(Page 2 of 4 )

\begin{tabular}{|c|c|c|c|}
\hline $\begin{array}{l}\text { Hydrostratigraphic } \\
\text { Unit }\end{array}$ & $\begin{array}{l}\text { Dominant } \\
\text { Hydrogeologic } \\
\text { Units }^{\mathrm{a}}\end{array}$ & Typical Lithologies & Hydrologic Significance \\
\hline $\begin{array}{c}\text { Upper Tuff } \\
\text { Confining Unit (UTCU) }\end{array}$ & TCU & Zeolitized bedded tuff & $\begin{array}{l}\text { Defined to encompass the zeolitized bedded } \\
\text { tuffs which stratigraphically overlie the } \\
\text { Topopah Spring Aquifer. Although some } \\
\text { geologic units of the UTCU are laterally } \\
\text { continuous with those of the LTCU, the UTCU } \\
\text { is limited aerially to extreme southern Yucca } \\
\text { Flat where the welded Topopah Spring Tuff is } \\
\text { an important aquifer present between the } \\
\text { UTCU and the LTCU. }\end{array}$ \\
\hline $\begin{array}{l}\text { Topopah Spring } \\
\text { Aquifer (TSA) }\end{array}$ & WTA, minor VTA & Welded ash-flow tuff & $\begin{array}{l}\text { Distribution in Yucca Flat is limited to extreme } \\
\text { southern portion. Hydrogeologic properties } \\
\text { are similar to those of the TM-WTA. Prolific } \\
\text { aquifer where saturated. }\end{array}$ \\
\hline $\begin{array}{l}\text { Lower Vitric Tuff } \\
\text { Aquifer (LVTA) }\end{array}$ & VTA & $\begin{array}{l}\text { Nonwelded and bedded } \\
\text { ash-flow tuff; vitric }\end{array}$ & $\begin{array}{l}\text { Relatively thin VTA unit below the TSA. } \\
\text { Grouped with the TM-LVTA where the TSA is } \\
\text { not present. }\end{array}$ \\
\hline $\begin{array}{l}\text { Belted Range Aquifer } \\
\text { (BRA) }\end{array}$ & WTA & Welded ash-flow tuff & $\begin{array}{l}\text { Typically saturated (perched water) only in } \\
\text { the Rainier Mesa area. This HSU includes } \\
\text { only welded Grouse Canyon Tuff and is } \\
\text { limited to the northern Yucca Flat model area. }\end{array}$ \\
\hline $\begin{array}{c}\text { Belted Range } \\
\text { Confining Unit (BRCU) }\end{array}$ & TCU & Zeolitized bedded tuffs & $\begin{array}{l}\text { Generally includes all zeolitized tuffs between } \\
\text { the (welded) Grouse Canyon Tuff and the } \\
\text { (welded) Tub Spring Tuff. Limited to the } \\
\text { northern Yucca Flat model area. }\end{array}$ \\
\hline $\begin{array}{l}\text { Pre-Grouse Canyon } \\
\text { Tuff Lava-Flow Aquifer } \\
\text { (PRETBG) }\end{array}$ & LFA & Lava flow & $\begin{array}{l}\text { Defined to include all the comendite lava } \\
\text { flows emplaced before the Grouse Canyon } \\
\text { Tuff but after the older Tunnel beds. Limited } \\
\text { to the northern Yucca Flat model area. }\end{array}$ \\
\hline $\begin{array}{l}\text { Tub Spring Aquifer } \\
\text { (TUBA) }\end{array}$ & WTA & Welded ash-flow tuff & $\begin{array}{l}\text { Comprises only the welded Tub Spring Tuff } \\
\text { and is limited to the northern Yucca Flat } \\
\text { model area. }\end{array}$ \\
\hline $\begin{array}{l}\text { Pre-Grouse Canyon } \\
\text { Tuff Lava-Flow } \\
\text { Aquifer } 1 \text { (PRETBG1) }\end{array}$ & LFA & Lava flow & $\begin{array}{l}\text { Defined to include all the comendite } \\
\text { lava-flows emplaced before the Tub Spring } \\
\text { Tuff but after the older Tunnel beds. Limited } \\
\text { to northern Yucca Flat. Hydrogeologically } \\
\text { equivalent to the PRETBG. }\end{array}$ \\
\hline
\end{tabular}


Table 2-2

HSUs of the Yucca Flat/Climax Mine HFM

(Page 3 of 4)

\begin{tabular}{|c|c|c|c|}
\hline $\begin{array}{c}\text { Hydrostratigraphic } \\
\text { Unit }\end{array}$ & $\begin{array}{l}\text { Dominant } \\
\text { Hydrogeologic } \\
\text { Units }^{\mathrm{a}}\end{array}$ & Typical Lithologies & Hydrologic Significance \\
\hline $\begin{array}{l}\text { Lower Tuff Confining } \\
\text { Unit (LTCU) }\end{array}$ & TCU & $\begin{array}{l}\text { Zeolitized bedded tuffs } \\
\text { with interbedded but } \\
\text { less significant } \\
\text { zeolitized, nonwelded to } \\
\text { partially welded } \\
\text { ash-flow tuffs }\end{array}$ & $\begin{array}{l}\text { Generally includes all zeolitized tuffs in the } \\
\text { Yucca Flat area. Stratigraphically the LTCU } \\
\text { may include all units from the base of the } \\
\text { Rainier Mesa Tuff to the top of the Paleozoic } \\
\text { rocks. The strongly argillized older tuffs and } \\
\text { paleocolluvium that immediately overlie } \\
\text { pre-Tertiary rocks may also be included. The } \\
\text { uppermost zeolitized bedded tuffs overlying } \\
\text { the TSA in southern Yucca Flat form a } \\
\text { separate HSU (the UTCU). }\end{array}$ \\
\hline $\begin{array}{l}\text { Oak Spring Butte } \\
\text { Confining Unit } \\
\text { (OSBCU) }\end{array}$ & TCU & $\begin{array}{l}\text { Devitrified to zeolitic } \\
\text { non- to partially-welded } \\
\text { tuffs and intervening } \\
\text { bedded tuffs }\end{array}$ & $\begin{array}{l}\text { Includes altered older ash-flow tuff units and } \\
\text { Tunnel Bed } 1 \text { and } 2 \text {. Welding in the older ash } \\
\text { flow units may increase overall hydraulic } \\
\text { conductivity. Devitrification of the ash flow } \\
\text { units may have limited zeolitization. } \\
\text { Differentiated in the Yucca Flat basin. }\end{array}$ \\
\hline $\begin{array}{c}\text { Argillic Tuff Confining } \\
\text { Unit (ATCU) }\end{array}$ & TCU & $\begin{array}{l}\text { Argillic bedded tuffs, } \\
\text { minor paleocolluvium }\end{array}$ & $\begin{array}{l}\text { Includes the argillic, lowermost Tertiary } \\
\text { volcanic units and paleocolluvium that } \\
\text { immediately overlie the pre-Tertiary rocks. }\end{array}$ \\
\hline $\begin{array}{c}\text { Volcaniclastic } \\
\text { Confining Unit (VCU) }\end{array}$ & $\begin{array}{l}80 \% \text { AA and } \\
20 \% \text { TCU }\end{array}$ & $\begin{array}{l}\text { Sandy gravels, } \\
\text { siltstone, and } \\
\text { tuffaceous sandstones }\end{array}$ & $\begin{array}{l}\text { Older Tertiary-age sedimentary rocks of } \\
\text { variable lithologies. Present in the } \\
\text { southeastern corner of the Yucca Flat model } \\
\text { area. Similar to AA, but differentiated for } \\
\text { compatibility with adjoining Frenchman Flat } \\
\text { model. }\end{array}$ \\
\hline $\begin{array}{l}\text { Mesozoic Granite } \\
\text { Confining Unit } \\
\text { (MGCU) }\end{array}$ & $\mathrm{GCU}$ & $\begin{array}{l}\text { Granodiorite and } \\
\text { quartz monzonite }\end{array}$ & $\begin{array}{l}\text { Includes two intrusives: Climax and Gold } \\
\text { Meadows. Based on observations at the } \\
\text { Climax Mine, the granite has very low } \\
\text { permeability and is considered to be a } \\
\text { confining unit. Locally may have perched } \\
\text { water contained within fractures. The two } \\
\text { stocks may be connected at depth and are } \\
\text { suspected to constitute the hydrologic barrier } \\
\text { at the north end of Yucca Flat. }\end{array}$ \\
\hline $\begin{array}{l}\text { Lower Carbonate } \\
\text { Aquifer - Yucca Flat } \\
\text { upper plate (LCA3) }\end{array}$ & $\mathrm{CA}$ & Limestone and dolomite & $\begin{array}{l}\text { Typically includes Cambrian through } \\
\text { Ordovician units that have been thrust over } \\
\text { the Eleana Formation and the Chainman } \\
\text { Shale. }\end{array}$ \\
\hline $\begin{array}{l}\text { Lower Clastic } \\
\text { Confining Unit - Yucca } \\
\text { Flat upper plate } \\
\text { (LCCU1 and 2) }\end{array}$ & $\mathrm{CCU}$ & Quartzite and siltstone & $\begin{array}{l}\text { Includes Proterozoic through lower Cambrian } \\
\text { units that have been thrust over younger } \\
\text { units. }\end{array}$ \\
\hline
\end{tabular}


Table 2-2

HSUs of the Yucca Flat/Climax Mine HFM

(Page 4 of 4 )

\begin{tabular}{||c|c|c|l||}
\hline $\begin{array}{c}\text { Hydrostratigraphic } \\
\text { Unit }\end{array}$ & $\begin{array}{c}\text { Dominant } \\
\text { Hydrogeologic } \\
\text { Units }\end{array}$ & Typical Lithologies & Hydrologic Significance \\
\hline \hline $\begin{array}{c}\text { Upper Carbonate } \\
\text { Aquifer (UCA) }\end{array}$ & CA & Limestone & $\begin{array}{l}\text { Includes the Tippipah Limestone (correlative } \\
\text { with the Bird Spring Formation) which } \\
\text { stratigraphically overlies the Chainman Shale } \\
\text { at Syncline Ridge and may contain perched } \\
\text { water. }\end{array}$ \\
\hline $\begin{array}{c}\text { Upper Clastic } \\
\text { Confining Unit (UCCU) }\end{array}$ & CCU & Argillite and quartzite & $\begin{array}{l}\text { As much as 2,745-m thick. Typically forms } \\
\text { foot walls of Mesozoic thrust faults in NTS } \\
\text { region. Limited areal extent; western Yucca } \\
\text { Flat and portions of CP Basin. }\end{array}$ \\
\hline $\begin{array}{c}\text { Lower Carbonate } \\
\text { Aquifer (LCA) }\end{array}$ & CA & Dolomite and limestone & $\begin{array}{l}\text { Important regional aquifer underlying most of } \\
\text { southern Nevada. Composite thickness up to } \\
\text { 4,430 m. Transmissive character varies } \\
\text { greatly depending on fracture and fault } \\
\text { frequency. }\end{array}$ \\
\hline $\begin{array}{c}\text { Lower Clastic } \\
\text { Confining Unit (LCCU) }\end{array}$ & CCU & Quartzite and siltstone & $\begin{array}{l}\text { Significant regional confining unit. Composite } \\
\text { thickness about 2,870 m. May present barrier } \\
\text { to deep regional groundwater flow where } \\
\text { structurally high (e.g., northeastern Yucca } \\
\text { Flat). }\end{array}$ \\
\hline \hline
\end{tabular}

a Table 2-1 for HGU definitions.

Source: Modified from BN, 2006 


\subsubsection{Climate}

Annual precipitation totals on the NTS average approximately 10 centimeters $(\mathrm{cm})$ in the lower valleys to $25 \mathrm{~cm}$ in the higher mountain ranges (DOE/NV, 1998). Precipitation in the area is usually sporadic, falling as small amounts of rain or snow during isolated, short duration winter and summer storms. Severe weather can occur in the region, usually in the form of summer thunderstorms. Daily temperatures vary with elevation, with extremes ranging from -15 to 45 degrees Celsius $\left({ }^{\circ} \mathrm{C}\right)$ (DOE/NV, 1998).

\subsubsection{Surface Water}

Yucca Flat is a topographically closed basin with no surface streams entering or leaving the basin. Internal drainage is ephemeral with surface water flowing only in response to precipitation events or snowmelt. Surface water runoff is conveyed through normally dry washes toward the lowest areas of the basin and may collect on the playa (seasonally dry lake) named Yucca Lake, located in southern Yucca Flat. While water may stand on the playa for a few weeks before evaporating, the playa is dry most of the year. A deep fissure, approximately one mile long, opened in the alluvium along the east side of the south end of Yucca Lake in 1969, which may be the result of movement on faults as well as dessication of playa deposits (Doty and Rush, 1985). Large flows of surface runoff into the fissure during and after storm events have been observed, which may locally recharge to the groundwater system. It is not known to what depth the fissure penetrates.

Springs that emanate from the local perched groundwater systems are the only natural sources of perennial surface water in the region. There are twenty-four known springs, or seeps, on the NTS (Hansen et al., 1997), some of which are located in the Yucca Flat data compilation area.

\subsubsection{Groundwater Sub-Basins}

Groundwater flow through the NTS area is conveyed through several DVRFS sub-basins that discharge south of the NTS. Three principal groundwater sub-basins, named for their down-gradient discharge areas, are identified and their boundaries shown in Figure 2-2. Yucca Flat is within the Ash Meadows groundwater sub-basin. The division shown between the Ash Meadows and Alkali Flats-Furnace Creek sub-basins is approximate based on the water level contours, especially where contours are sparse. 


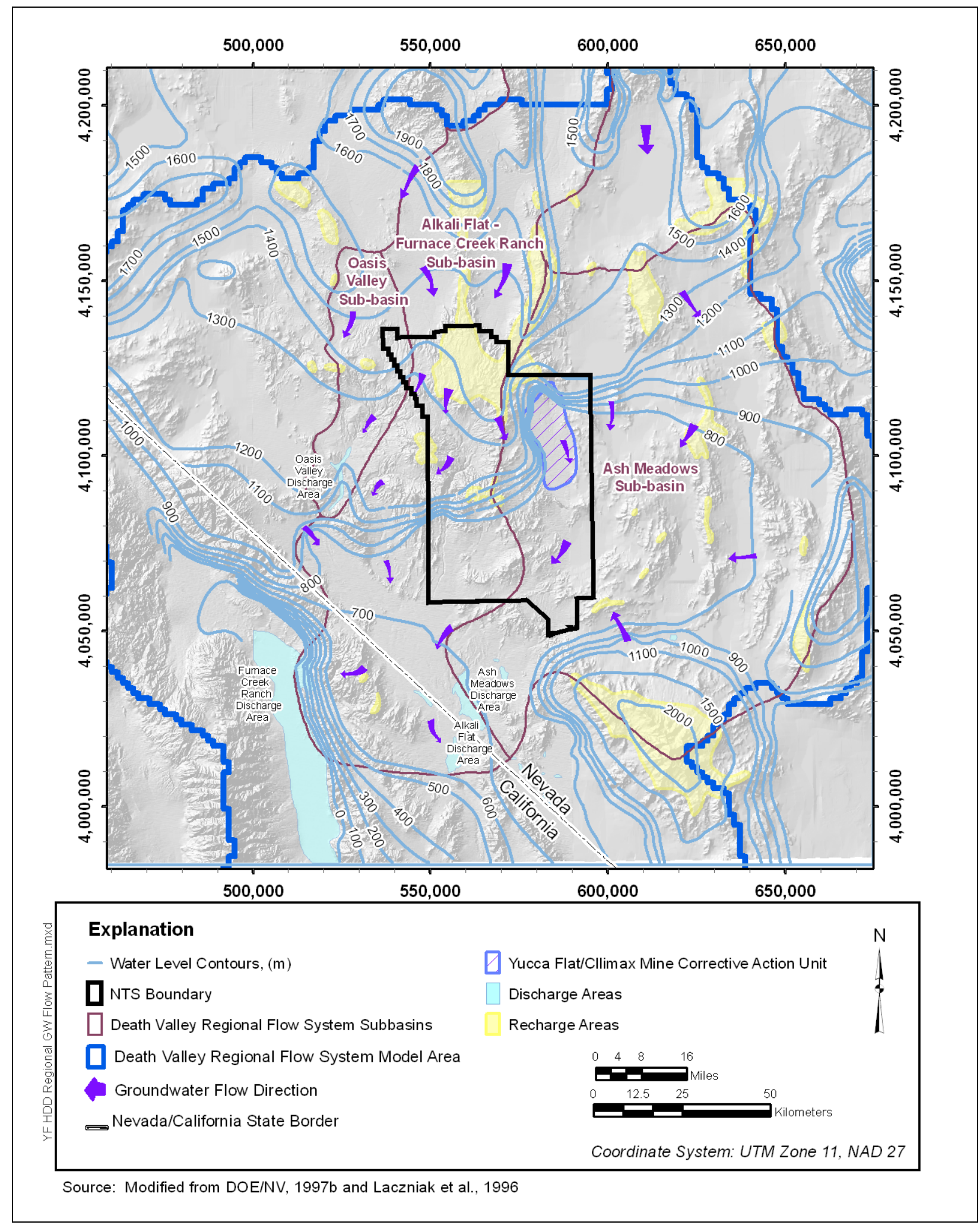

Figure 2-2

Regional Groundwater Flow Pattern 


\subsubsection{Groundwater Recharge and Discharge}

Recharge to a groundwater flow system occurs as areal recharge from precipitation and from subsurface inflow from adjacent groundwater flow systems. Areal recharge from precipitation is input to the groundwater flow model in the form of spatially distributed areal rates. The areal recharge distribution and rates cannot be directly and accurately measured for large areas. However, they may be estimated using other types of data and accepted scientific techniques. Specific variables needed to estimate natural areal recharge are precipitation rates and distribution, land surface elevation distribution and location, and extent of potential valley-floor recharge areas such as stream courses and playas.

Natural groundwater discharge occurs primarily from ET, spring discharge, and subsurface underflow to adjacent groundwater flow systems located downgradient. Major areas of natural groundwater discharge in the NTS region include Oasis Valley, Ash Meadows, Alkali Flat, Death Valley, and Penoyer Valley. There are no natural groundwater discharges from the Yucca Flat/Climax Mine CAU (see Section 8.0) except groundwater outflow.

Within the NTS region, artificial discharge occurs as groundwater pumpage from drinking water supply wells (public and domestic), agricultural wells, and industrial wells. Potable and industrial water supply wells for the NTS produce water from the carbonate, volcanic, and valley-fill aquifers. South of the NTS, private and public water-supply wells are completed in the valley-fill aquifer. Groundwater pumpage records are used to estimate artificial discharge.

\subsubsection{Regional-Scale Groundwater Flow}

Groundwater flow is controlled by structural and geologic conditions, and the distribution of recharge and discharge locations. Regional groundwater flow occurs through both volcanic formations and the regional carbonate aquifer (LCA). The direction of groundwater flow locally is most influenced by structural and geologic conditions that affect the distribution and thickness of the LCA, through which the greater part of groundwater flow between the groundwater sub-basins occurs.

Figure 2-2 shows water level elevation contours that were developed for the UGTA regional model (DOE/NV 1997b), which are similar to the groundwater contours shown in Laczniak et al. (1996). These are contours of the head potential for the regional groundwater flow system, based on water 
levels measured in wells completed in different geologic formations at varying depths. These contours were developed specifically for evaluation of regional groundwater flow in the NTS area, and are not as generalized as contours for the USGS DVRFS model (Belcher et al., 2004). Consequently, they provide greater local detail of groundwater flow in the Yucca Flat area, and are presented here to support evaluation of Yucca Flat-specific groundwater contours.

The general direction of groundwater flow in the NTS area is from north to south, leaving the NTS to the southwest as indicated by the arrows denoting inferred groundwater flow directions. Groundwater ultimately discharges at Alkali Flat, Ash Meadows and Amargosa Valley areas to the south, and Death Valley to the southwest. Horizontal hydraulic gradients are generally very low to the east and west of the NTS. In other areas, the prevailing flow direction and hydraulic gradients may locally be influenced by the structural position of geologic units with significantly lower permeability than that of the LCA. If the units of low permeability have structural orientations that are perpendicular to flow, large hydraulic gradients may be observed across the units. If their structural orientation is parallel to the prevailing flow direction, the effect may be insignificant. Structural uplifts of the basement rocks and the distribution of confining units cause many of the observed steep gradients within the flow system. Low-permeability sediments along the Funeral Mountains, such as the Tertiary Death Valley section sediments, also cause a steep hydraulic gradient between Amargosa Desert and Death Valley.

\subsubsection{Groundwater Flow in Yucca Flat}

Groundwater flow through the Yucca Flat area, inferred from regional groundwater elevation contours, is generally north to south (Figure 2-2). However, the regional groundwater elevation contours curve around the west, north, and northeast sides of Yucca Flat, indicating the presence of hydrogeologic controls on the inflow to the Yucca Flat basin. The pattern of steep contours around the northern end of Yucca Flat reflects reduced transmissivity within the regional flow system, resulting in reduced flow through this border. The greatest transmissivity is within the LCA, which provides transmissive continuity with adjoining groundwater basins. However, LCA transmissivity and connectivity to the regional flow system is reduced around the west, north, and northeast sides of Yucca Flat. The thickness of the LCA to the north, overlying the MGCU and the LCCU, is greatly reduced due to the structurally high position of those HSUs. The LCA pinches out along the 
northeast border where the LCCU rises above the water table. To the west of Yucca Flat, the LCA is located below a thick section of UCCU, and is absent within the nested calderas area of Timber Mountain and Pahute Mesa. These structural features, which reduce the transmissivity of the regional connection of Yucca Flat, are referred to as "hydrologic barriers." Locally, the regional flow pattern around and through Yucca Flat is distorted by these hydrologic barriers. South of Yucca Flat, the regional flow pattern is re-established.

The local pattern of groundwater flow within Yucca Flat in the LCA can be inferred from the pre-development LCA groundwater elevation contours shown in Figure 2-3. These contours were developed for the UGTA regional model (DOE/NV 1997b), which are specific contours for the LCA in Yucca Flat developed to evaluate flow in the LCA beneath Yucca Flat, and further discussed in Section 10.8. The two different sets of groundwater contours shown on this map were developed at different scales and are not perfectly coordinated (generalized groundwater elevation versus LCA-specific head), but show the relationship of regional groundwater flow with the local pattern. The LCA groundwater elevation contours within the Yucca Flat basin form a "trough" with the axis running approximately north-south along the center of the basin and opening to the south. This configuration is consistent with the steep regional water-level contours around the northern part Yucca Flat, also shown on Figure 2-3, and southerly flow from Yucca Flat back into the regional flow pattern. The LCA groundwater elevation contours indicate lateral flow toward the center of the basin and drainage south from the central basin. The trough alignment is similar to the alignment of the dominant faulting, and is consistent with the interpretation of faults as high-conductivity paths for groundwater flow.

\subsubsection{Groundwater Elevations in the Yucca Flat Area}

The water table is within volcanic formations throughout most of central Yucca Flat, but is locally in alluvium in south central Yucca Flat where the thickness of the alluvium is greater. The water table is within carbonates and other "basement" rocks around the perimeter of the basin. Water-table elevations greater than 1,300 m amsl are found immediately north, northeast, and west of Yucca Flat compared to elevations less than $740 \mathrm{~m}$ amsl within Yucca Flat proper, which reflects the steep gradients previously noted (Figure 2-3). These steep gradients reflect water levels measured in wells completed in formations overlying the UCCU and MGCU, which are much higher than in the 


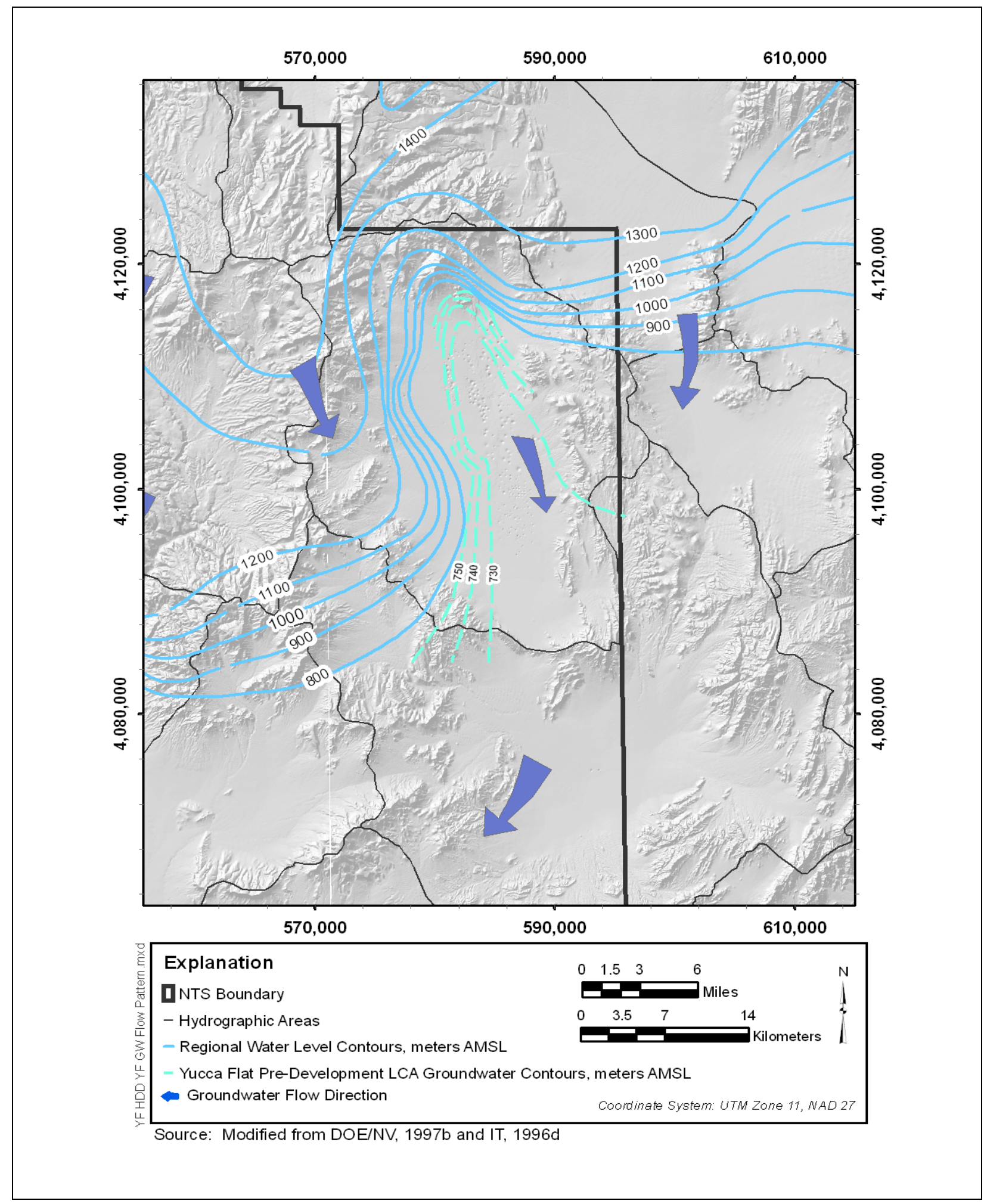

Figure 2-3

Yucca Flat Groundwater Flow Pattern 
underlying LCA. Within Yucca Flat, LCA head elevations vary from approximately $738 \mathrm{~m}$ amsl at the northern end (UE-10j) to approximately $726 \mathrm{~m}$ amsl at the southern end (Water Well-C [WW-C]).

The water table in the Yucca Flat basin is relatively deep; ranging from about $153 \mathrm{~m}$ bgs (elevation 1,199 m amsl) in extreme western Yucca Flat to more than $580 \mathrm{~m} \mathrm{bgs}$ (elevation $734 \mathrm{~m}$ amsl) in north-central Yucca Flat. Throughout much of Yucca Flat, the water table is located within the lower part of the volcanic section in various TCUs. Within the deeper Yucca Flat structural sub-basins, the water table is within volcanic aquifer units or the alluvium in localized areas of western Yucca Flat. Anomalously high water levels in parts of central Yucca Flat (e.g., within Areas $3,4,7$, and 8) are thought to be the result of over-pressurization of the saturated zeolitized tuffs (Hawkins et al., 1989; Hale et al., 1995) caused by the underground nuclear tests that were conducted in this area.

Water levels measured in wells completed in the AA and volcanic units in the eastern two-thirds of Yucca Flat are typically about $20 \mathrm{~m}$ higher than in wells completed in the LCA (Winograd and Thordarson, 1975; IT, 1996d). The hydrogeology of the HSU structure suggests that the higher elevation of the water table is the result of low-permeability zeolitized TCUs overlying the LCA restricting downward flow to the LCA. The semi-perched water within the alluvium and volcanic aquifers may also move downward to the LCA along one or more of the basin-forming faults in the central portion of the valley.

Beneath the hills surrounding Yucca Flat to the west, north, and northeast, the water table is generally within Paleozoic units. In Mid Valley, southwest of Yucca Flat, depth-to-water is approximately $508 \mathrm{~m}$ at UE-14b (elevation approximately $819 \mathrm{~m}$ amsl) within volcanic tuffs. Immediately south of Yucca Flat, in CP Basin, depth-to-water at WW-4a is approximately $257 \mathrm{~m}$ (elevation approximately $842 \mathrm{~m}$ ) within the upper volcanic aquifers. To the north, in west Emigrant Valley, the water table is relatively shallow, within the alluvium at a depth of approximately $35 \mathrm{~m}$ (elevation approximately $1,320 \mathrm{~m}$ amsl) at Watertown 4.

\subsection{Death Valley Regional Flow System Model}

The DVRFS model (Belcher et al., 2004) was developed to support NNSA/NSO investigations at the NTS and the YMP. The DVRFS model incorporates newly available data and modeling tools, and 
integrates the results from two previous regional-scale models to provide the most current regional-scale groundwater flow model for the Death Valley region. The two previous models were the UGTA regional model (DOE/NV, 1997b), which was developed to evaluate radionuclide transport from underground nuclear weapons test sites on the NTS, and the YMP/Hydrologic Resource Management Program (HRMP) model (D’Agnese et al., 1997), which was developed to characterize the regional groundwater flow system relative to the potential radionuclide releases from the proposed geologic, high-level radioactive waste repository at Yucca Mountain.

The DVRFS integrates a three-dimensional (3-D) hydrogeologic framework model and a 3-D groundwater flow model (Belcher et al., 2004). The hydrogeologic framework model incorporates regional geologic data and information (stratigraphy and structure) that captures the spatial geologic complexities in a regional sense within the model boundary. There are 27 HGUs defined and incorporated into this model that are summarized in Table 2-3. Section 5.4, Table 5-1, provides a cross-walk between these HGUs and the Yucca Flat/Climax Mine HFM HSUs (BN, 2006). The DVRFS groundwater flow model uses MODFLOW-2000 (Harbaugh et al., 2000), a 3-D, finite-difference modular modeling code that incorporates a nonlinear, least-squares regression technique to estimate model parameters. The DVRFS groundwater flow model has 16 layers of defined thickness, a finite-difference grid with 194 rows and 160 columns, and uniform cells 1,500 m on each side (Belcher et al., 2004).

This document describes the procedures for estimating lateral boundary fluxes (groundwater inflow and outflow) along the Yucca Flat/Climax Mine HFM (BN, 2006) boundaries (see Section 9.0) using the DVRFS model (Belcher et al., 2004). In addition, the calibrated regional recharge distribution from the DVRFS model provides an alternative recharge distribution model for the Yucca Flat/Climax Mine area (see Section 7.0). 
Table 2-3

HGUs for the Death Valley Regional Ground-Water Flow System Hydrogeologic Framework Model

(Page 1 of 2)

\begin{tabular}{|c|c|c|}
\hline $\begin{array}{l}\text { HGU } \\
\text { Abbreviation }\end{array}$ & $\begin{array}{l}\text { HGU } \\
\text { Name }\end{array}$ & Description \\
\hline YAA & Younger Alluvial Aquifer & Pliocene to Holocene coarse-grained basin-fill deposits \\
\hline YACU & $\begin{array}{l}\text { Younger Alluvial Confining } \\
\text { Unit }\end{array}$ & Pliocene to Holocene playa and fine-grained basin-fill deposits \\
\hline OAA & Older Alluvial Aquifer & Pliocene to Holocene coarse-grained basin-fill deposits \\
\hline OACU & Older Alluvial Confining Unit & Pliocene to Holocene playa and fine-grained basin-fill deposits \\
\hline LA & Limestone Aquifer & Cenozoic limestone, undivided \\
\hline LFU & Lava-Flow Unit & $\begin{array}{l}\text { Cenozoic basalt cones and flows and surface outcrops of } \\
\text { rhyolite-lava flows }\end{array}$ \\
\hline YVU & Younger Volcanic Unit & Cenozoic volcanic rocks that overlie the Thirsty Canyon Group \\
\hline Upper VSU & $\begin{array}{l}\text { Volcanic and } \\
\text { Sedimentary Unit }\end{array}$ & $\begin{array}{l}\text { Cenozoic volcanic and sedimentary rocks, undivided, that } \\
\text { overlie volcanic rocks of SWNVF }\end{array}$ \\
\hline TMVA & $\begin{array}{l}\text { Thirsty Canyon-Timber } \\
\text { Mountain Volcanic Aquifer }\end{array}$ & $\begin{array}{l}\text { Miocene Thirsty Canyon and Timber Mountain Groups, plus } \\
\text { Stonewall Mountain tuff, undivided }\end{array}$ \\
\hline PVA & Paintbrush Volcanic Aquifer & Miocene Paintbrush Group \\
\hline $\mathrm{CHVU}$ & Calico Hills Volcanic Unit & Miocene Calico Hills Formation \\
\hline WVU & Wahmonie Volcanic Unit & Miocene Wahmonie and Salyer Formations \\
\hline CFPPA & $\begin{array}{l}\text { Crater Flat-Prow Pass } \\
\text { Aquifer }\end{array}$ & Miocene Crater Flat Group, Prow Pass Tuff \\
\hline CFBCU & $\begin{array}{l}\text { Crater Flat-Bullfrog } \\
\text { Confining Unit }\end{array}$ & Miocene Crater Flat Group, Bullfrog Tuff \\
\hline CFTA & Crater Flat-Tram Aquifer & Miocene Crater Flat Group, Tram Tuff \\
\hline BRU & Belted Range Unit & Miocene Belted Range Group \\
\hline OVU & Older Volcanic Unit & $\begin{array}{l}\text { Oligocene to Miocene; near the NTS consists of all volcanic } \\
\text { rocks older than the Belted Range Group. Elsewhere, consists } \\
\text { of all tuffs that originated outside of the SWNVF }\end{array}$ \\
\hline Lower VSU & $\begin{array}{l}\text { Volcanic and } \\
\text { Sedimentary Unit }\end{array}$ & $\begin{array}{l}\text { Cenozoic volcanic and sedimentary rocks, undivided; where } \\
\text { named Cenozoic volcanic rocks exist, lower VSU } \\
\text { underlies them }\end{array}$ \\
\hline SCU & Sedimentary Confining Unit & Paleozoic and Mesozoic sedimentary and volcanic rocks \\
\hline UCA & Upper Carbonate Aquifer & $\begin{array}{l}\text { Paleozoic carbonate rocks (UCA only used where UCCU exists, } \\
\text { otherwise UCA is lumped with LCA) }\end{array}$ \\
\hline UCCU & $\begin{array}{l}\text { Upper Clastic } \\
\text { Confining Unit }\end{array}$ & $\begin{array}{l}\text { Upper Devonian to Mississippian Eleana Formation and } \\
\text { Chainman Shale }\end{array}$ \\
\hline LCA_T1 & $\begin{array}{l}\text { Lower Carbonate Aquifer } \\
\text { (thrusted) }\end{array}$ & $\begin{array}{l}\text { Cambrian through Devonian predominantly carbonate rocks, } \\
\text { thrusted }\end{array}$ \\
\hline
\end{tabular}


Table 2-3

HGUs for the Death Valley Regional Ground-Water Flow System Hydrogeologic Framework Model

(Page 2 of 2)

\begin{tabular}{|c|c|l||}
\hline $\begin{array}{c}\text { HGU } \\
\text { Abbreviation }\end{array}$ & $\begin{array}{c}\text { HGU } \\
\text { Name }\end{array}$ & \multicolumn{1}{c|}{ Description } \\
\hline \hline LCCU_T1 & $\begin{array}{c}\text { Lower Clastic } \\
\text { Confining Unit } \\
\text { (thrusted) }\end{array}$ & $\begin{array}{l}\text { Late Proterozoic through Lower Cambrian primarily siliciclastic } \\
\text { rocks (including the Pahrump Group and Noonday dolomite), } \\
\text { thrusted }\end{array}$ \\
\hline LCA & Lower Carbonate Aquifer & Cambrian through Devonian predominantly carbonate rocks \\
\hline LCCU & $\begin{array}{l}\text { Lower Clastic } \\
\text { Confining Unit }\end{array}$ & $\begin{array}{l}\text { Late Proterozoic through Lower Cambrian primarily siliciclastic } \\
\text { rocks (including the Pahrump Group and Noonday dolomite) }\end{array}$ \\
\hline $\mathrm{XCU}$ & Crystalline Confining Unit & Middle Proterozoic metamorphic and igneous rocks \\
\hline ICU & Intrusive Confining Unit & All intrusive rocks, regardless of age \\
\hline
\end{tabular}

Source: Belcher et al., 2004 


\subsection{Corrective Action Unit Modeling ApProach}

The process for achieving the UGTA corrective action strategy includes modeling to define the maximum extent of contaminant transport within a specified time frame. The use of groundwater flow and transport models to achieve the objectives of the corrective action strategy is specified in Appendix VI, Revision No. 1 (December 7, 2000) of the FFACO (1996). This section presents an overview of the CAU groundwater flow and transport modeling approach, descriptions of the groundwater flow models, and data requirements. Additional discussion of the modeling approach for the Yucca Flat/Climax Mine CAU is included in Shaw (2003).

\subsection{Overview of the CAU Modeling Approach}

In areas of underground nuclear testing on the NTS, groundwater flow occurs through diverse and structurally complex rocks (Laczniak et al., 1996). Given the complexity of the hydrogeologic system, sources, and processes controlling transport, computer models will be required to meet the objectives of the FFACO (1996) corrective action strategy. The modeling approach used to develop an integrated 3-D model for flow and transport begins with characterization of the system, development of conceptual models based on evaluations and assumptions of system processes, and mathematical representation of these processes. Mathematical models representing the system are then implemented with a computer.

\subsubsection{Integrated Three-Dimensional Model Development}

The CAU flow and transport models will consist of an integrated set of models. Some of these models focus on a small-scale (relative to the $\mathrm{CAU}$ ) process such as radionuclide release from source regions. Others simplify CAU-scale processes such as reactive transport in fractures to an abstraction for system sensitivity analysis. Combined, the models (referred to as component models) constitute the CAU predictive model. Essential aspects of the processes described by the detailed mechanistic 
models must be accurately represented in the CAU model. This representation must include the uncertainty associated with the process or parameters.

The integrating numerical model will be a 3-D, finite-element flow and transport simulator that captures the complex geologic structure including units of variable thickness, faults, and offsets, as well as complex transport processes associated with reactive solutes and fractured rock. The CAU groundwater flow model component requires two other component models: a DVRFS groundwater flow model (Belcher et al., 2004) and the precipitation recharge model(s). The CAU contaminant transport model component requires the CAU groundwater flow model and the hydrologic source term model.

\subsubsection{Total System Model}

The detailed process models are computationally intensive and a comprehensive uncertainty analysis may not be feasible. Therefore, to complement the detailed process models including the integrated 3-D numerical CAU model, a total system modeling approach for dynamic, probabilistic simulations may be used to develop simplified abstraction models (Shaw, 2003). Simplified abstraction models reduce the description of more detailed process models to capture dominant processes and behaviors in one-dimensional (1-D) transport models. These abstraction models facilitate a more thorough uncertainty analysis of the governing parameters and processes.

To use the total system model, it must be first demonstrated that simplified formulations capture the same general phenomena as the more complex CAU and process models. Then the total system model could be used to efficiently conduct additional sensitivity and uncertainty analyses not feasible with the complex CAU model. A more detailed discussion of the total system modeling approach is provided in Shaw (2003).

As computer technology advances, it may become feasible, in some situations, to use only the CAU process models in the uncertainty analyses. However, considering the geologic complexity and the number of underground nuclear tests conducted in Yucca Flat, the use of a total system model may be necessary to meet sensitivity and uncertainty analysis needs. 


\subsubsection{Corrective Action Unit Model Validation}

The process of model validation, as it applied to the CAU model, involves following a modeling protocol—a series of steps that, when followed, build support to demonstrate that a given site-specific model is capable of producing meaningful results. This increases confidence in the model predictions. To ensure fidelity of the CAU model to the physical system, a ten-step protocol will be utilized. These ten steps are: (1) establishment of model purpose, (2) development of conceptual model, (3) selection of a computer code and verification of the code, (4) model design, (5) model calibration, (6) sensitivity and uncertainty analyses, (7) model verification, (8) predictive simulations, (9) presentation of model results, and (10) postaudit (Shaw, 2003).

\subsection{Groundwater Flow Modeling Approach}

This section describes the approach used for development of the CAU groundwater flow model and the associated data requirements. The CAU transport modeling approach are documented in a separate report (Shaw, 2003).

The steps for developing the CAU groundwater flow model include:

- Identify simulation objectives

- Define CAU geologic model

- Define parameter distributions for model inputs

- Define CAU flow model boundaries

- Select computer code

- Generate CAU model grid

- Calibrate CAU flow model

- Perform parameter sensitivity analysis

- Perform model verification

- Prepare model documentation

\subsubsection{Simulation Objectives}

Simulation objectives are defined in Appendix VI, Revision No. 1 (December 7, 2000) of the FFACO (1996). A calibrated groundwater flow model for each CAU will be constructed to simulate local 3-D flow, evaluate the range of flow conditions in the CAU that may be important in determining maximum extent of transport, and provide boundary conditions for transport to predict contaminant migration from source locations. 


\subsubsection{Geologic Model}

The geologic boundaries were chosen such that: they coincide with perceived geologic and hydrologic domains, include important faults that may impact flow within Yucca Flat, and the contaminant source areas and perceived migration pathways were included. A base model and five alternative geologic models have been developed (BN, 2006) for the Yucca Flat/Climax Mine CAU (see Section 5.5). The Yucca Flat/Climax Mine CAU flow and transport models will be developed within the boundaries of the geologic model.

\subsubsection{Model Parameters}

Specific data types needed to support groundwater flow modeling include hydraulic properties, groundwater discharge systems, precipitation recharge, discharge, lateral boundary fluxes, and hydraulic heads. Parameter distributions were developed based on review and analysis of available data and information.

\subsubsection{Corrective Action Unit Model Boundaries and Boundary Conditions}

The next step of the process is identification of the model boundaries and boundary conditions for the CAU-scale model. When selecting boundaries for a flow and transport model, features of the aquifer system such as precipitation recharge and discharge zones, low-permeability rock layers (at base of model), or aquifer connections with surface water bodies are preferred because they provide easily described hydraulic boundary information. The characteristics of the Yucca Flat/Climax Mine CAU are such that natural physical boundaries are too distant to be used for the lateral boundaries of the flow and transport model. The boundaries of the CAU flow and transport model will be selected to incorporate all relevant sources, important hydrogeologic features, and wells providing hydrologic and geologic information. These boundaries will be similar to the geologic model boundaries, but not extending beyond them. Lateral boundary (see Section 9.0) conditions will be obtained from the DVRFS groundwater flow model (Belcher et al., 2004). The precipitation recharge models (see Section 7.0) will provide fluxes for the upper model surface. The bottom of the model will not be deeper than the estimated contact between the LCA and the underlying LCCU because the LCCU hydraulic conductivity $(\mathrm{K})$ is conceptualized as an impermeable boundary for modeling purposes. 


\subsubsection{Select Computer Code}

The Finite Element Heat-Mass Transfer (FEHM) code (Zyvoloski et al., 1997b), developed by LANL, was chosen for the Pahute Mesa CAU-scale flow and transport model (DOE/NV, 1999), and Frenchman Flat CAU-scale flow (DOE/NV, 2001) and transport model, and has demonstrated to be suitable for development of these calibrated groundwater flow models. The processes of interest for the Yucca Flat/Climax Mine CAU are the same as those of the Pahute Mesa and Frenchman Flat CAUs. Therefore, FEHM has been selected for development of the Yucca Flat CAU/Climax Mine model (Shaw, 2003).

The FEHM code simulates 3-D, time-dependent, multiphase, nonisothermal flow; and multicomponent, reactive, and equilibrium transport through porous and fractured media. The finite-element formulation of the FEHM code provides an accurate representation of complex 3-D geologic media and structures and their effects on subsurface and transport flow. Specific capabilities include:

- Three-dimensionality

- Flow of air, water, and heat

- Multiple chemically reactive and sorbing tracers

- Colloid transport

- Finite-element/finite-volume formulation

- Coupled stress module

- Saturated and unsaturated media

- Preconditioned conjugate gradient solution of coupled nonlinear equations

- Porous media equivalent model

- Double-porosity/double-permeability capabilities

- Complex geometries with unstructured grids

- Two different reactive, double-porosity, particle-tracking modules

- Coupled to parameter estimation (PEST) software

- Linked with Los Alamos Grid Toolbox (LaGriT) grid generation software (George, 1997)

- Supported on a variety of computer systems

Documentation includes: a description of the mathematical models and numerical methods used by FEHM (Zyvoloski et al., 1997a), the FEHM User's Manual (Zyvoloski et al., 1997b), documentation of the functional and performance requirements for FEHM, description of FEHM software, and verification and validation reports (Dash et al., 1997; Dash, 2000 and 2001). Further, the software is maintained in configuration management at LANL. With each new release, the software is subjected 
to a rigorous verification test to ensure accuracy and functionality. Los Alamos Grid Toolbox (George, 1997) is an auxiliary code to the FEHM code, developed by LANL to generate finite-element meshes for FEHM models.

Assumptions for the flow and energy transport models in FEHM include fluid flow governed by Darcy's Law, thermal equilibrium between fluid and rock, immovable rock phase, and negligible viscous heating. Zyvoloski et al. (1997a) discusses specific assumptions. Inputs to the flow model include the finite-element grid, initial conditions, lateral boundary conditions, recharge, and material properties for HSUs and faults. For application to isothermal groundwater flow, the calibrated FEHM model produces values of hydraulic head or pressure for each node in the grid.

The PEST software developed by Watermark Computing (2004) provides a nonlinear parameter estimation routine that may be used to automatically calibrate a flow model. The PEST code may be used with any existing modeling computer code for model calibration without making any changes to that code. However, FEHM was modified to efficiently provide data needed by PEST with no additional post-processing.

The three codes (FEHM [Zyvoloski et al., 1997a], PEST [Watermark Computing, 2004], and LaGriT [George, 1997]) have been used in the YMP modeling activities. Their usage in the development of the YMP saturated zone flow model is documented in Saturated Zone Site-Scale Flow Model (DOE/OCRWM, 2004). The YMP models are developed under the YMP Quality Assurance Program.

\subsubsection{Grid Generation}

Simulations of flow and transport, including particle tracking, in 3-D domains representing the complex hydrostratigraphy described in the hydrogeologic models will be conducted on finite-element grids. The grids are discrete interconnected tetrahedra that, when connected together, capture the structure of the hydrostratigraphy. The flexibility of finite elements allows for the resolution of the grid to vary spatially to capture source areas and complex structures, such as faults with higher resolution than other areas where coarser discretization is sufficient. 
The method developed for the flow of information from hydrogeologic interpretation through grid generation has several steps. The process begins with incorporation of a given hydrostratigraphic digital model using EarthVision ${ }^{\circledR}\left(\mathrm{EV}^{\circledR}\right)$ (Version 7.5 by Dynamic Graphics, 2002). EarthVision ${ }^{\circledR}$ is a suite of software applications used for geospatial analyses. Elevations describing the surface of each $\mathrm{HSU}$, and traces of each fault, are extracted from the $\mathrm{EV}^{\circledR}$ model (Version 7.5 by Dynamic Graphics, 2002) and become inputs to the grid generation software, LaGriT (George, 1997). This code is composed of a suite of grid generation tools and provides an integrated system for all grid generation steps.

Unique properties can be assigned to each HSU and fault in the grid. Grid generation will require decisions on the location of high-resolution areas. Possible candidates for high resolution include fault zones, thin HSUs, and testing areas. A process for transferring hydrogeologic framework model information from an $\mathrm{EV}^{\circledR}$ model (Version 7.5 by Dynamic Graphics, 2002) to inputs required by LaGriT (George, 1997) has been developed, tested, and applied to development of the Pahute Mesa and Frenchman Flat CAU models. Keeping the flow model grids coarse, then adding higher resolution to source regions and plume pathways for the transport simulations, can increase calibration efficiency, and is another approach that may be considered.

\subsubsection{Flow Model Calibration}

Calibration consists of determining model parameter values such that simulated heads and fluxes are consistent with observed or target values as well as consistency with the characterization data. The input parameters for the CAU flow model will include the permeabilities of the HSUs and faults in the model domain (see Section 6.0) and fluxes, through the top of the model, estimated as precipitation recharge (seeSection 7.0). Specified observations for the CAU model will include fluxes through lateral model boundaries calculated using the DVRFS groundwater flow model (Belcher et al., 2004) (see Section 9.0) and predevelopment hydraulic heads measured in wells within the model domain (see Section 10.0). Local estimates of flow, along with uncertainty, will be provided for use in the CAU model. These data provide "targets" for the steady-state calibration process. Data required for calibration includes information from hydrologic data analysis including well locations, locations of open intervals, HSUs represented by open intervals, lateral boundary 
fluxes from the regional flow model, and fluxes into the water table from the precipitation recharge model.

The PEST code is used in conjunction with FEHM to calculate the weighted sum of squared differences between model-generated heads and observed heads, and between simulated flux values and regional model fluxes at the model boundary. This sum is referred to as the objective function. The PEST code then repeatedly runs the flow model to guide the adjustment of parameters until the objective function is minimized. The advantage of using PEST is that it automates tedious parameter adjustments allowing the analyst to focus more on the problem than data manipulations, and provides statistical analyses that are useful in understanding model behavior and goodness. Due to random and systematic errors, there will always be some discrepancy between modeled versus measured values. The PEST code attempts to minimize this discrepancy and provides estimates of uncertainty in the results. Because the flow model must run many times during calibration, this part of the process requires heavy usage of computing resources, and the UGTA Project currently maintains a 40-node Linux cluster for this purpose. A flow model calibration will be specific to a geologic model, specific precipitation recharge, and the lateral boundary fluxes and hydraulic heads used as calibration targets. Alternative geologic models, alternative precipitation recharge models, or changes in calibration targets will require additional calibrations.

The PEST optimization process produces calibrated values, estimated 95-percent confidence limits, and a measure of sensitivity for HSU and fault hydraulic properties used as parameters. However, it is recognized that the PEST uncertainty results, based on the typical linear assumptions, will not be appropriate for full uncertainty and sensitivity analysis. Rather, expert judgment, the degree to which characterization data and model parameters agree; and supplemental techniques, such as perturbation analyses, will also be used.

After steady-state calibration, it may be possible to perform additional transient calibration to further build confidence in the model. The issue of tuff pile overpressuring in NTS Areas 4 and 6 is currently under investigation by LANL. When completed and documented, this investigation will provide an assessment of transient effects related to testing that may have value for transient calibration. In addition, the Yucca Flat/Climax Mine CAIP (DOE/NV, 2000a) suggests that it may be possible to use the effects of water well pumping as a transient calibration dataset (see Section 10.0 for an 
assessment). Another potential dataset for transient calibration in the LCA is available from the ER-6-1 multiple-well aquifer test (MWAT) (SNJV, 2004g).

The calibration for complex models is expected to be nonunique. That is, more than one set of parameter values provided to the flow model could result in the observed hydraulic heads and fluxes. It may be possible to use geochemistry to provide independent lines of evidence leading to the prediction of groundwater flow paths and travel times for comparison (see Section 12.0).

The groundwater temperature field is nonisothermal (seeSection 11.0), and thermal effects may need to be considered. Sources of heat include flow of heat from deeper layers toward the surface evidenced by the geothermal gradient (Gillespie, 2005) and residual thermal pulses from underground nuclear tests. Gillespie (2005) analyzed well temperature profiles from the NTS and found no obvious heat advection in the volcanic and carbonate rocks, although the estimated thermal properties of the LCA are somewhat low, and may suggest ubiquitous, lateral groundwater flow. The small-scale phenomenon of underground nuclear tests will be handled in the hydrologic source term. The saturated $\mathrm{K}$ is dependent on both rock and water properties. The FEHM code uses intrinsic permeability, which is independent of temperature. Finite Element Heat-Mass Transfer Code can account for thermal variation effects without having to simulate heat flow explicitly.

The goal of model calibration (also called "parameter estimation," "solving the inverse problem," and "inversion") is to make the model agree with reality by adjusting model parameters within their ranges of variation. A variety of numeric and graphical tools can be used to investigate flow model calibration, which include summary statistical measures such as the mean error (or residual), standard deviation (SD) of error, and sum of weighted square error. Statistical measures are useful for summarizing model behavior, but do not readily give a sense of the spatial distribution of error. To address this issue, the following graphical analyses also will be considered:

- The scattergram (or cross-plot) shows the observed data versus computed results plotted against each other is useful for identifying overall goodness and bias.

- Post-plots of head residuals in plan view show the distribution of errors in the model.

- Flow residuals are examined using bar charts, although they also can be visualized with a scattergram. 
Calibration of the CAU model is an iterative process of assessing model error and adjusting parameters (whether or not an automated procedure is used). First, a simplified sensitivity/uncertainty analysis will be performed to bound ranges of flux into the model. The range of boundary fluxes will come from uncertainty in the DVRFS groundwater flow model (Belcher et al., 2004). The hydraulic characteristics of each HSU will be treated in a deterministic fashion. Anisotropy and reduction in $\mathrm{K}$ with depth will be investigated for appropriate geologic units. The steady-state CAU model will be calibrated to observed water levels and to the range of the fluxes on the boundaries.

Calibration of the Yucca Flat/Climax Mine CAU groundwater flow model will use an approach that will base calibration on evaluation of the weight of evidence. Evidence to be considered includes:

- Appropriateness of geologic representation

- Goodness of fit of head and boundary flux

- Agreement with site characterization data

- Agreement with overall conceptual model

- Agreement with water-balance information

- Flow direction information based on streamline particle tracking

The groundwater flow model for the Yucca Flat area will be calibrated using American Society for Testing and Materials (ASTM) standard guidance for calibrating groundwater models. The Standard Guide for Calibrating a Ground-Water Flow Model Application (ASTM, 2002f) is a guide for calibrating porous medium (continuum) groundwater flow models. The method can be adjusted to use on other types of groundwater models such as multiphase models, noncontinuum (karst or fracture flow) models, or mass transport models. The ASTM standard procedures that will be used to implement the guidance cover the use of site-specific information (ASTM, 2002a), applying modeling to site-specific problems (ASTM, 1993), defining boundary (ASTM, 2002b) and initial conditions (ASTM, 2002c), performing sensitivity analyses (ASTM, 2002d), and documenting groundwater flow model applications (ASTM, 2002e).

\subsubsection{Sensitivity Analysis}

Sensitivity analysis is a systematic process of varying the magnitude of model inputs such as K, precipitation recharge, and boundary conditions and determining the effect on model outputs such as hydraulic head and flux. Sensitivity analyses are conducted in conjunction with calibration of the 
flow model. Sensitivity analyses conducted during model calibration help identify parameters that can be estimated. Formal sensitivity analyses conducted after model calibration help identify parameters that affect the model results.

\subsubsection{Model Verification}

As part of the validation process, flow model verification will be attempted if data exists that can reasonably be used for such a purpose. The Yucca Flat/Climax Mine CAIP (DOE/NV, 2000a) suggests transient hydraulic head from pumping could be used, and the Yucca Flat modeling strategy (Shaw, 2003) suggests that geochemistry could be used. Such transient head verification using water well effects also was proposed for Pahute Mesa (DOE/NV, 1999), but while the effects of pumping were identified, the data was not of sufficient density and quality to be used for verification (SNJV, 2004c). Section 10.0 presents the hydraulic head data and a recommendation as to whether such data is of sufficient quality and quantity for such a verification exercise.

The dataset for model verification will be chosen once supporting analyses are completed and during flow model development and calibration phase. If a suitable dataset is not available, additional data may be collected for purposes of model verification. However, until the CAU modeling is complete, it is not possible to identify what type of data should be collected.

\subsubsection{Model Documentation}

Documentation for the Yucca Flat/Climax Mine CAU model will include:

- Identification of all components, inputs, and assumptions of the analysis

- Justification of assumptions, simplifications, and parameter ranges and distributions used

- Description of all uncertainties

- Identification of the results of sensitivity analysis

- Description of major alternative model formulations and uncertainty of results to alternatives

- Documentation of final model sufficiently detailed to allow replication of modeling and calculations 
- Identification of all significant limitations of the model

- Description of all significant conclusions, limitations, and insights

\subsection{Data Requirements}

Specific data types necessary to simulate groundwater flow shown in Figure 3-1are geologic,

hydraulic head, precipitation and recharge estimates, groundwater discharge estimates, $\mathrm{k}$ (or intrinsic permeability), temperature, and groundwater chemistry. Geologic data are described in Section 5.0. Hydraulic head data serve as targets to which the flow model is calibrated. Recharge refers to either lateral flow across the CAU-model boundary into the model or recharge that enters from the land surface and reaches the groundwater flow system. Discharge is the lateral flow across the CAU-model boundaries out of the model, natural discharge to the surface (e.g., ET, springs, seeps), or flow from wells. There is no natural surface discharge from the groundwater flow system in the Yucca Flat basin. An understanding of the natural geochemical system may provide constraints on the flow model for the Yucca Flat/Climax Mine CAU.

Figure 3-1 presents data types and their utilization in the groundwater-flow model (SNJV, 2004e). The various data types are described in Section 4.2. The summary and discussion of data for K and storage properties, precipitation and recharge estimates, groundwater discharge, lateral boundary flux, hydraulic heads, temperature, and groundwater geochemistry are presented in Sections 6.0 through 12.0, respectively. 


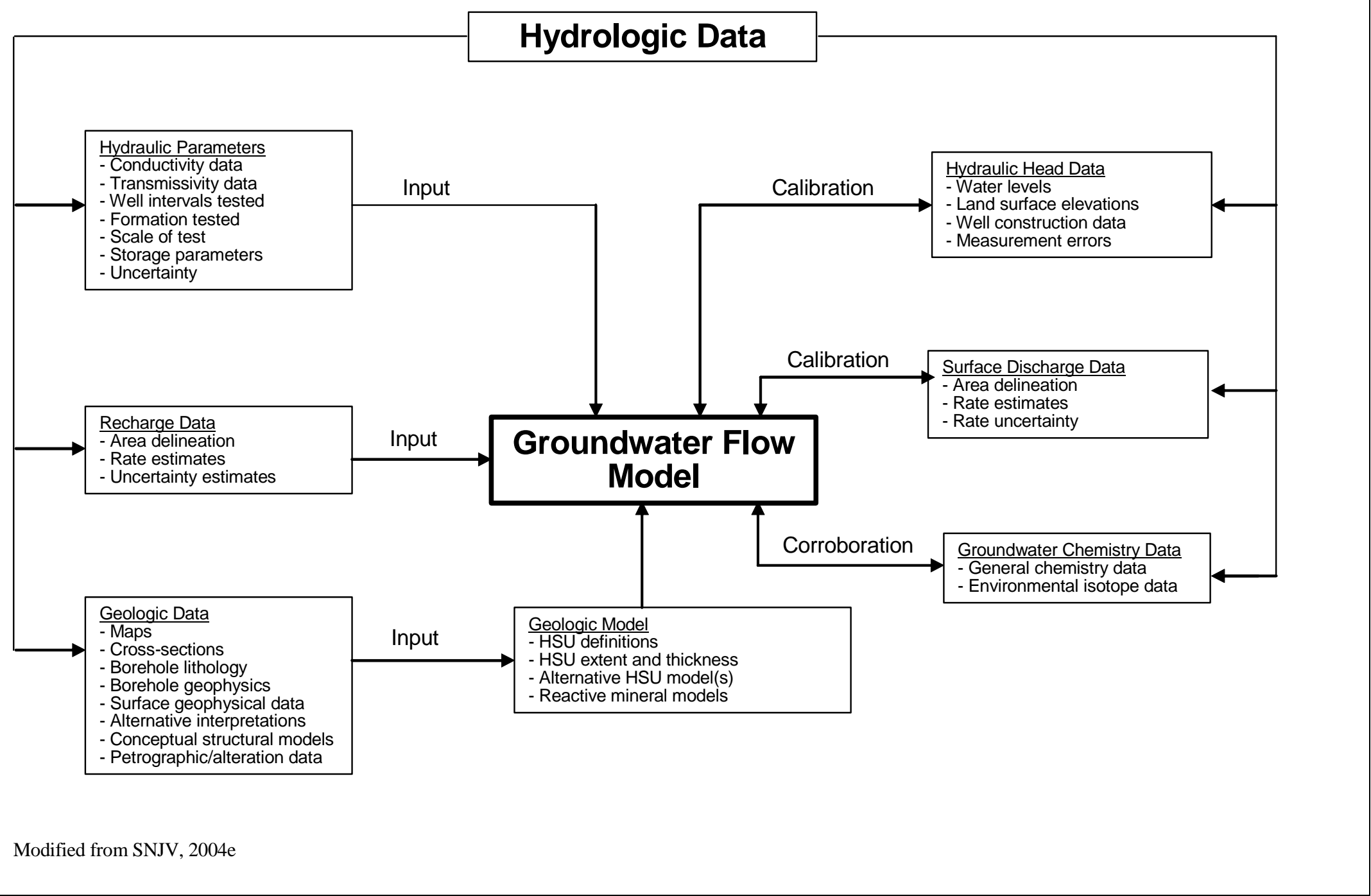

Figure 3-1

Data Types and Utilization in the Groundwater Flow Model 


\subsection{Data Compilation and analysis}

As described in Section 3.3, specific data types needed to support a groundwater flow model include geologic, hydraulic parameters, precipitation recharge (including lateral flow across the CAU model boundary), groundwater discharge, and hydraulic heads. In addition, two other data types will be used to supplement the evaluation of the Yucca Flat/Climax Mine CAU groundwater flow model. These supplementary data types include geochemistry and temperature. In this section, the requirements and approach for compilation and analyses of these data for the Yucca Flat/Climax Mine CAU is discussed.

\subsection{Data Sources}

Since the establishment of the NTS, many data sources for the Yucca Flat/Climax Mine CAU have been developed from various scientific and engineering studies conducted by a number of organizations. Most of these data sources have been identified and, where applicable, are referenced in this document. Additional, unpublished data have also been identified in the project files of many organizations. Much of the data has been incorporated into databases developed as part of the UGTA regional groundwater flow and transport modeling document (DOE/NV, 1997b). These databases have been supplemented with new data collected through UGTA field investigations conducted according to the Yucca Flat/Climax Mine CAIP (DOE/NV, 2000a). Appendix B provides an overview of the major Yucca Flat/Climax Mine CAU-specific activities specified in the CAIP.

Data from the NTS and Yucca Flat, in general, have been gathered by several organizations, which include: BN, LLNL, LANL, DRI, USGS, SNJV, and the University of Nevada, Las Vegas-Harry Reid Center for Environmental Studies. A large amount of historic data had also been gathered under the auspices of previous NTS management and operating $(\mathrm{M} \& \mathrm{O})$ contractors Reynolds Electrical \& Engineering Co., Inc., Fenix \& Scisson, Architect and Engineer Contractors, Raytheon Services Nevada, and Environmental Restoration contractors (IT Corporation and Shaw Environmental, Inc.). 


\subsubsection{Yucca Flat/Climax Mine-Specific Data}

Data collected from within the Yucca Flat/Climax Mine data compilation area (see Figure 1-2) are classified as Yucca Flat/Climax Mine-specific data. These data are directly applicable to the Yucca Flat/Climax Mine CAU. Data from within the larger Yucca Flat/Climax Mine CAIP Investigation Area are also compiled for use in the Yucca Flat/Climax Mine CAU to support modeling that may extend further downgradient from this CAU.

\subsubsection{Nevada Test Site Investigation Area Data}

Nevada Test Site Investigation Area data have been compiled and analyzed where applicable to provide additional input to reduce parameter uncertainty. Data transferability is discussed in Section 4.3.2, and specific uses of transferred data are discussed and justified where necessary. This larger investigation area includes other CAUs and adjacent areas in the vicinity of the NTS where the geology and data documentation meet the criteria for data transfer.

CAU-specific hydrologic data compilations have been conducted previously for Frenchman Flat (Phase I and Phase II) and Pahute Mesa (Phase I). These compilations provide datasets that may be readily transferable or data that may be re-evaluated for transfer. There are other data compilations such as for the HRMP, the NTS weapons testing program, and ongoing environmental monitoring by the $\mathrm{M} \& \mathrm{O}$ contractor and other affiliated organizations that may also provide appropriate data.

\subsubsection{Yucca Mountain Project Data}

The YMP is the proposed geologic storage location for commercial high-level radioactive waste in the United States. High-quality data have been collected and analyzed during investigations of the Yucca Mountain site, including several parameters relevant to Yucca Flat/Climax Mine CAU modeling. Yucca Mountain is located adjacent to the southeastern corner of the NTS, within the NTS Investigation Area. The volcanic geology in the YMP area is similar to the volcanic geology in nearby UGTA CAUs. A process was developed specifically to assess the transferability of YMP data (SNJV, 2004f). The data were then incorporated in the regional HSU analysis, which can be applied to the Yucca Flat/Climax Mine CAU through a crosswalk, based on similar HSU characteristics. 


\subsubsection{Other Data}

Data from other distant locations may be incorporated in the analysis for select purposes. The use of such data is explained and justified in the discussion of data analysis for the particular data type.

\subsection{Description of Yucca Flat/Climax Mine CAU Data and Information}

This section provides summary descriptions of the Yucca Flat/Climax Mine CAU data and information. These summary descriptions address objectives, data sources, and approach to data analyses for each individual data type, and provide a road map to the more detailed analyses documented in this report.

\subsubsection{Hydrostratigraphic Framework}

Hydrostratigraphic framework models provide the hydrogeologic foundation for discretization of UGTA CAU-specific groundwater flow and transport models. These HFMs are developed by compiling relevant stratigraphic (including lithologic and alteration information) and structural geologic information within the model area. This information is used to group contiguous stratigraphic units with relatively similar hydraulic characteristics, such as hydraulic conductivity, fracturing, and porosity into HSUs, which are then used to construct 3-D HFMs. Stratigraphic units may vary in their hydrogeologic characteristics throughout their occurrence and be placed into different HSUs in different locations. Because of the complex hydrogeology and sparse sampling frequency of subsurface geologic data, there is uncertainty in interpolation and extrapolation of this information within the model area. To capture these uncertainties, selected alternative HFMs are developed that are consistent with the geologic data. The criteria for the selection of alternative HFMs for use in groundwater flow and transport models is the potential for the alternative HFM to significantly impact groundwater flow and transport model results.

For the Yucca Flat/Climax Mine CAU, five alternative HFMs were constructed using the $\mathrm{EV}^{\circledR}$ (Version 7.5 by Dynamic Graphics, 2002) geologic modeling platform. Data sources used as input for the $\mathrm{EV}^{\circledR} \mathrm{HFMs}$ include: existing geological and geophysical maps, new and existing drill hole data, other regional and CAU-specific HFMs, detailed Yucca Flat/Climax Mine geologic cross-sections, surface effects from underground nuclear tests, hydrogeologic studies at Climax Stock, studies of alluvial materials in the NTS area, and mineralogic studies of the volcanic rocks in 
the NTS area. The data sources and the development of the Yucca Flat/Climax Mine CAU HFMs are described in A Hydrostratigraphic Model and Alternatives for the Groundwater Flow and Contaminant Transport Model of Corrective Action Unit 97: Yucca Flat-Climax Mine, Lincoln and Nye Counties, Nevada (BN, 2006). Section 5.0 and Appendix D provide summary discussions of the Yucca Flat/Climax Mine HFMs.

\subsubsection{Hydraulic Properties}

Groundwater flow models require a clear understanding of the nature of groundwater flow within the modeled geologic formations and the assignment of appropriate hydraulic property parameter values to the modeled geology. Hydraulic conductivity is the primary hydraulic property for a steady-state groundwater flow model. Another hydraulic property, specific storage, is also required for potential transient groundwater flow modeling. The objective of data analysis is to determine representative hydraulic property parameter values for the scale over which the model is discretized.

In UGTA CAU-scale groundwater flow and transport models, the hydrogeologic structure is captured within a HFM based on HSUs that are defined by both hydraulic characteristics and stratigraphic continuity. Hydraulic property data are analyzed within the context of the HFM. The modeled area is large and hydraulic properties can be expected to vary across the extent of the model domain. Consequently, no single parameter value is representative. Because there is insufficient data to explicitly define the spatial distribution of parameter values, probability distributions are specified to characterize the variability of the parameter value. The distributions provide a reference range for parameter values during model calibration. Qualitative characterization, that is, evaluation of parameter value variability with respect to factors that are not quantitatively characterized, provides guidance for adjustment of parameters within the reference range. Uncertainties in the determination of representative parameter value distributions must also be considered.

Hydraulic parameter values are analyzed by HSU and scale of testing. Hydraulic parameter values are generally determined from analyses of hydraulic tests conducted insitu using a well completed in the formation of interest or from laboratory tests on samples of the formation. These two different data sources provide very different scales of information and may produce very different results. The insitu tests provide more appropriate scale information for use in modeling but are much more dependent on interpretation of test conditions for the analysis. Statistics are determined to 
characterize each dataset. Where there are sufficient data, the data are tested for conformance to the assumption of log-normal distribution, and probability distributions are derived.

Analysis is conducted at two levels of specificity: CAU-specific information and generalized information for the NTS Investigation Area. There are limited CAU-specific data available for Yucca Flat/Climax Mine; insufficient in most cases to support statistical analysis. This situation is approached in two ways. First, the data for similar HSUs within Yucca Flat may be aggregated to provide a generalized characterization for a type of HSU. Second, Yucca Flat/Climax Mine HSUs can be correlated to regional HSUs to allow use of data from outside Yucca Flat for a more general characterization of a type of HSU. Regional HSU data are available for the NTS Investigation Area and a larger area surrounding the NTS, which was identified for the UGTA regional model in which formations with similar hydrostratigraphic character were assigned to regional HSUs. The greater amount of data resulting from generalization of the HSUs allows statistical evaluation of parameter values for the generalized HSU, which captures the variability of such formations but loses specificity.

Data compilation includes recent results from tests conducted by the UGTA program, results from historical tests conducted by different organizations for various programs and purposes on the NTS and YMP, and results of other tests conducted near the NTS, if they are determined relevant. The source material varies considerably in quality regarding the test data collection and documentation, justification of assumptions and interpretations made during analysis, and data fit to the theoretical model used. Professional judgment must be used to evaluate the quality and representativeness of test analyses, and the applicability of the data evaluation.

Section 6.0 presents a detailed discussion of the analysis of hydraulic properties for the Yucca Flat/Climax Mine CAU model area.

\subsubsection{Recharge from Precipitation}

The groundwater flow system of the Yucca Flat/Climax Mine CAU model area is replenished by areal recharge from precipitation and by inflow from adjacent groundwater basins through lateral boundaries. Both of these contributors to the groundwater flow system require that regional precipitation data be evaluated by using recharge models to quantify the amount of water that 
recharges the saturated zone. At the regional scale, recharge models provide a component of flow to the regional groundwater flow system that is factored into the quantification of the inflow across lateral boundaries into a CAU-specific model area. At the CAU model area scale, recharge models quantify the amount of water that directly recharges the saturated zone underlying the model area.

Subsidiary considerations for recharge distribution concern discharge from springs and tunnels located within the Yucca Flat hydrographic basin. In both cases, recharge from precipitation is intercepted above the water table, representing collection from an undefined area, and localized for surface discharge. The discharge may re-enter the groundwater system, at somewhat reduced volume, due to losses to ET. These situations may locally affect recharge to the groundwater flow system, but the effects are not anticipated to be significant.

For the NTS region and previous UGTA CAU groundwater flow models (Frenchman Flat and Pahute Mesa), six alternative recharge models were utilized to capture the uncertainty in the precipitation recharge for the both the NTS region and the CAU-specific model areas. These recharge models are also used to evaluate recharge for the Yucca Flat/Climax Mine CAU HFM area. In addition to these six alternative recharge models, one additional recharge model is incorporated into the recharge evaluation for the Yucca Flat/Climax Mine CAU model area. Section 7.0 presents a detailed discussion of the seven recharge models, and an analysis of the alternative recharge models for the Yucca Flat/Climax Mine CAU HFM area.

\subsubsection{Groundwater Discharge}

Groundwater discharge information for the Yucca Flat/Climax Mine CAU flow system is required for the water budget of the groundwater flow model. Groundwater discharge can be natural or man-made. Natural discharge from the groundwater system to the ground surface can occur through spring flow and ET. However, all spring flow discharge and ET losses in the Yucca Flat/Climax Mine CAU originate from perched groundwater zones above the main groundwater flow system of the basin and do not directly affect the groundwater flow model. Tunnels and mines in Rainier Mesa, which is within the Yucca Flat hydrographic basin, also collect groundwater from the unsaturated zone above the water table and discharge to the surface. A large percentage of the spring and tunnel/mine discharges are lost to ET. The contribution to recharge from reinfiltration from these discharges is not expected to be significant in terms of the Yucca Flat/Climax Mine CAU 
groundwater flow model. However, spring and tunnel discharge data are compiled and presented, herein, for completeness. Natural groundwater discharge also occurs as underflow, which is considered during analysis of lateral boundary flux.

Man-made discharge occurs through the pumping of wells. Long-term, high-rate pumping can remove significant volumes of water from the groundwater flow system and could have substantial effects on hydraulic heads. There has been a long history of water production for potable and construction use in Yucca Flat, and the production from such wells is tabulated. Water-supply well production is tabulated and maintained by the USGS from records supplied by the NTS M\&O contractor. The records are in the form of monthly or yearly production as total volume for the nominal time increment, and there may be gaps in the historical records. In addition, there also has been short-term production from various wells in the Yucca Flat/Climax Mine CAU for the purposes of well development and testing. The objective of the data compilation and analysis of well discharges is to provide complete and accurate records of the rates and durations of production.

Section 8.0 presents a detailed discussion of the analysis of groundwater discharge for the Yucca Flat/Climax Mine CAU.

\subsubsection{Lateral Boundary Fluxes}

Inflow and outflow through the lateral boundaries of the Yucca Flat/Climax Mine CAU-scale groundwater flow model will constitute an important portion of the water budget of the modeled system. Because Yucca Flat/Climax Mine is a closed hydrographic basin and there are no significant natural discharge areas within the Yucca Flat/Climax Mine CAU HFM boundaries, the important components of the water budget consist of the lateral fluxes and areal recharge. There are no significant practical means of directly measuring groundwater fluxes at the scale and spatial frequency needed to represent the conditions at the CAU flow-model boundary. Therefore, the approach taken for UGTA CAU groundwater flow modeling is to estimate the lateral boundary fluxes (both model area inflow and outflow) indirectly through the use of a regional-scale flow model. The regional-scale, groundwater flow model used for this evaluation is the DVRFS model (Belcher et al., 2004). 
To quantify uncertainty related to lateral boundary flux estimates, a series of alternative regional-scale, groundwater flow models were developed. These alternative regional-scale, groundwater flow models represent alternative representations of the DVRFS model (Belcher et al., 2004) that incorporate the alternative Yucca Flat/Climax Mine HFMs and recharge distribution models. A total of 13 alternative regional-scale flow models were calibrated using MODFLOW 2000 (Harbaugh et al., 2000). The net fluxes into and out of each of the Yucca Flat/Climax Mine CAU-scale model boundaries were then calculated for each calibrated model using the MODFLOW utility package ZONEBUDGET (Harbaugh, 1990). The boundary fluxes derived from the alternative regional-scale flow models are intended to constrain boundary fluxes related to the Yucca Flat/Climax Mine CAU-scale model area. Specifically, the fluxes into and out of the CAU-scale model area should remain within the range of values derived from the alternative regional-scale flow models. In addition, the hydraulic heads from the alternative regional-scale flow models can be used to augment the boundary conditions for the CAU model. The use of 13 regional-scale flow models allows for boundary-flux calculations that encompass the uncertainty associated with the plausible alternative HFMs (see Section 5.5) and the alternative recharge models (see Section 7.0).

Section 9.0 presents a detailed discussion of the lateral boundary analyses for the Yucca Flat/Climax Mine CAU model area.

\subsubsection{Hydraulic Head}

The hydraulic head distribution data reflects the hydraulic potential that drives groundwater flow, and provides one of the fundamental bases for calibration of the groundwater flow model. The calibration of the steady-state flow model is presumed to be the predevelopment head distribution (see Section 3.2.7). Hydraulic head data are available throughout the history of NTS activity, although the spatial density of such data is low in the early years and greater with development.

Hydraulic head data are used to determine calibration targets for the groundwater flow model and potentially for definition of some boundary conditions. The data are used to determine average, representative head values (predevelopment and contemporary) for a select group of wells and to develop head distribution maps for HSUs for qualitative evaluation. An assessment of measurement uncertainty is included in the analysis. 
The primary source of the data are from the USGS National Water Information System (NWIS) which are summarized for Yucca Flat in Fenelon (2005). Additional data pertinent to the Yucca Flat/Climax Mine CAU were obtained from multiple NTS reports and depth-to-water measurements from the UGTA Project records. These data were compiled for various analyses including:

- Statistical analyses of well-specific hydraulic head data to describe data uncertainty.

- Identification of a subset of well-specific hydraulic heads (and their uncertainty) representative of predevelopment, steady-state conditions for the Yucca Flat/Climax Mine CAU area for use as calibration targets for groundwater flow modeling.

- Development of potentiometric surface maps using the predevelopment, steady-state hydraulic head datasets for the Yucca Flat/Climax Mine CAU.

- Evaluation of well-specific hydrographs to identify temporal trends in hydraulic head.

- Identification and evaluation of transient responses to groundwater pumping using well-specific hydrographs.

- Evaluation of vertical gradients between HSUs.

Section 10.0 presents a detailed discussion of the hydraulic head data compilation and analyses for the Yucca Flat/Climax Mine CAU.

\subsubsection{Temperature Data}

Information on the spatial variation of subsurface temperature is useful for a variety of purposes. Temperature is used for the calculation of hydraulic conductivity within the selected groundwater flow model code, which uses intrinsic permeability. Intrinsic permeability is related to hydraulic conductivity as:

$$
\text { Intrinsic Permeability = Hydraulic Conductivity } \mathrm{x} \text { (viscosity/density) }
$$

Both the viscosity and density of water are temperature dependent. Temperature information provides the basis for determination of the intrinsic permeability from hydraulic conductivity, which accounts for the effect of temperature variation. 
In addition, temperature is a potential field affecting groundwater flow that may be used for nonisothermal modeling. Moreover, hydraulic head information used in isothermal simulations may require correction for temperature for use in flow model calibration.

The sources for temperature data are temperature logs that record temperature variation with depth. Temperature logs have been acquired by various NTS investigators as part of geophysical logging associated with well drilling and subsequent temperature logging of completed wells. Temperature $\log$ s are available for many wells in the Yucca Flat/Climax Mine area. Thus, these temperature data and various reports on the analyses have been compiled and evaluated.

Section 11.0 presents a detailed discussion of the temperature data for the Yucca Flat/Climax Mine CAU.

\subsubsection{Groundwater Chemistry}

Groundwater chemistry data are not directly used as input in the flow model; rather, interpretations of groundwater chemistry data are used to evaluate and verify calibration of the groundwater flow and transport models. These interpretations provide independent information on potential groundwater flow paths and travel times that may be used in developing and calibrating the groundwater flow model for the Yucca Flat/Climax Mine CAU. Groundwater chemistry data for the Yucca Flat/Climax Mine CAU are summarized from a geochemistry-based investigation of Yucca Flat/Climax Mine groundwater flow (SNJV, 2006a). This investigation addressed the proportion of groundwater inflow to the Yucca Flat/Climax Mine area from outlying areas versus local recharge from the surrounding highlands and investigates potential CAU-scale flow paths within the LCA. Three conceptual groundwater flow paths within the LCA were evaluated: (1) flow from north to south along the eastern side of the Yucca Flat basin, (2) flow from north to south along the western side of the basin, and (3) flow entering Yucca Flat along the southeastern basin margin moving through southern Yucca Flat to Frenchman Flat. Finally, the nature of groundwater geochemistry in the west-central Yucca Flat/Climax Mine LCA is evaluated in terms of potential vertical flow from overlying HSUs into the LCA.

Section 12.0 presents a detailed discussion of the groundwater geochemistry data and evaluations for the Yucca Flat/Climax Mine CAU. 


\subsection{Approach to Data Compilation and Analysis}

Data analysis is the process of compiling, assessing, and interpreting available data in preparation for CAU groundwater flow modeling. The data needed for CAU modeling include a wide variety of types, from a wide variety of sources, and represent a wide variety of measurements and scales of measurement. The process of analyzing the data can be summarized in the following seven steps: (1) compilation of existing data for the Yucca Flat/Climax Mine Data Compilation Area, (2) transfer of applicable data from outside the Yucca Flat/Climax Mine CAU, (3) assignment of data quality indicators, (4) assessment of data representativeness and appropriateness for use in CAU modeling, (5) data reduction and analysis, (6) graphical and tabular presentation of results, and (7) discussion of data limitations and the possible impacts to the model. This document presents data analysis and results used to support the development of a CAU-scale groundwater flow model.

\subsubsection{Data Compilation}

Data compilation efforts were focused on obtaining all hydrologic data relevant to the Yucca Flat/Climax Mine CAU. Significant effort was placed on assuring that the datasets used for the analysis tasks were complete and represent all newly acquired data from the Yucca Flat/Climax Mine Phase I data collection activities along with all relevant historical data for this CAU. In some cases, the analyses were supplemented with data collected within the larger Yucca Flat/Climax Mine CAIP Investigation Area. Much of these data have been compiled into databases that are subsequently used for the analysis tasks. These databases are either working databases that are used solely within the UGTA project (e.g., SNJV groundwater database) or published databases (e.g., GEOCHEM05.mdb [SNJV, 2005b] and the USGS Water-level Database [Fenelon, 2005]) that are publicly available.

\subsubsection{Data Transfer}

Use of data from sites outside the Yucca Flat/ Climax Mine CAU may be appropriate to reduce parameter uncertainty when developing models in a sparse data environment (Freeze et al., 1990). This approach incorporates parameter data for similar environments in determination of parameters to be used in modeling the study area. For the data types addressed in this document, data transfer is only applicable to hydraulic properties and geochemical properties. Nearby sites considered for 
additional data sources for the Yucca Flat/Climax Mine CAU are adjacent CAUs and sites associated with the YMP.

A technical basis document (TBD) for data transferability (SNJV, 2004f) provides a comprehensive discussion of requirements and methodology for data transfer, which were considered for the analyses in this document. The data transfer methodology for the parameters of interest is based on rock genesis and evolution factors, especially similar lithologies, alteration, mineralogy, and structural setting. Section 4.3.2.2 contains a summary of the primary criteria listed in the TBD. However, alternate approaches for incorporation of the transferred data are presented in the individual datatype sections for dealing with competing objectives and specific situations.

\subsubsection{Data Transfer Methodology}

The use of hydraulic property and geochemistry data from other, nearby study areas to develop certain parameter distributions for use in groundwater flow modeling of the Yucca Flat/Climax Mine CAU can be justified by examining the specific relevant similarities between the HSUs of Yucca Flat/Climax Mine HFMs and the other areas. If sufficient data are available for the primary study area, a statistical comparison can be made between the study area data and the total dataset, including transferred data, to determine if the two datasets are comparable. If it can be shown that the two datasets have comparable distributions, it would provide further justification for the incorporation of the data into the existing dataset. Qualitative evaluation of transferability is required otherwise.

\subsubsection{Similarity Criteria}

This section focuses on rock genesis and evolution factors that influence rock characteristics and, therefore, flow and geochemical parameters. These factors include the geologic history of the area, lithology, alteration, stress history, and groundwater chemistry.

\subsection{Geologic History}

The geologic history of an area is an indicator of processes that can have a significant effect on the hydraulic properties of rock formations as well as groundwater geochemistry. For example, the depositional environment of a rock can influence things such as the primary porosity of sedimentary rocks or the texture of volcanic rocks. Subsequent structural episodes may produce fracturing that 
could increase the hydraulic conductivity of the formation and the nature of flow through the formation.

\subsection{Lithology}

The specific rock type has an important impact on rock characteristics that affect groundwater flow and geochemistry. For example, alluvial materials ranging in texture from fine sand to coarse gravels that are well sorted would obviously have different hydraulic properties than an indurated, nonfractured carbonate rock, as well as different mineralogy affecting the geochemistry.

\subsection{Alteration}

Alteration of the rock can have a great effect on the hydraulic properties of the rock and the alteration process is necessarily interactive with the groundwater geochemistry. For example, the formation of zeolitic material in volcanic tuffs can greatly decrease the permeability of a given formation by directly affecting the porosity structure of the formation and fracture aperature.

\subsection{Stress History}

The stress history of a given area has a large impact on rock characteristics that affect the flow of groundwater and groundwater geochemistry. The state of stress can influence a variety of things such as fracture orientation, connectivity, and aperture as well as mineralogic changes. For example, regions of extensional stress tend to form fractures that are open and would increase hydraulic conductivity.

\subsection{Groundwater Chemistry}

Groundwater chemistry plays an important role in the evolution of rock characteristics affecting groundwater flow. The specific chemistry controls mineral dissolution and precipitation reactions, which in turn can affect fracture geometry, due to filling fractures with minerals, or result in an enhancement of permeability, due to dissolution of flow channels. 


\subsubsection{Yucca Mountain Project Data Transfer}

The YMP site characterization program is one of the largest geologic and hydrologic characterization studies of volcanic rocks ever conducted. The proximity and similar hydrogeologic environment of the Yucca Mountain site to Yucca Flat make it particularly relevant as a data source for hydraulic properties for similar Yucca Flat/Climax Mine CAU HSUs. A detailed rationale for the transfer of data from the YMP is provided in Appendix B of the hydrologic data documentation package for Pahute Mesa (SNJV, 2004c). A brief summary for the justification of data transfer from the YMP to Yucca Flat/Climax Mine includes:

- Located in the SWNVF

- Volcanic rocks are the result of similar depositional processes

- Similar lithologic units and some lithologic units have the same source

- Similar types of alteration including devitrification and zeolitization

- Similar regional tectonic stresses that resulted in similar fracture orientations

- Similar groundwater chemistry

\subsubsection{Quality Assurance of Data and Data Documentation}

During evaluation of data usage, the quality of the documentation for the data source and the quality (suitability) of the data for use are evaluated. These subjects are discussed in detail in the Underground Test Area Quality Assurance Project Plan, Nevada Test Site, Nevada (NNSA/NSO, 2003), and the approach used in this document is summarized below.

\subsubsection{Data Documentation Evaluation}

Data documentation flags provide information on the traceability (or pedigree) of the data. Typically, data collected in the recent past has much better documentation than data collected and reported many years ago. Qualification of the documentation of the data makes it easier to investigate and evaluate the quality of the data used in modeling.

Each data record for a given dataset is assigned a data documentation evaluation flag (DDE_F) value to indicate the level of documentation available for that data record. The process of data qualification ensures that the pedigree of the data is retained for database users. However, it is important to note that the data documentation quality does not neccessarily indicate the quality or the usefulness of the data for Yucca Flat/Climax Mine CAU modeling. Historic data may not meet current standards for 
documentation but are often of high quality and can be extremely useful in the CAU investigations. In some cases, historic data are invaluable, and new data cannot be acquired to serve the purpose.

The five levels of data documentation evaluation flags are as follows:

Level 1. Data are collected in accordance with NNSA/NSO ERP Quality Assurance Program Plans (QAPPs), approved State of Nevada procedures, and/or participant-specific procedures. This ranking indicates that all supporting data documentation is on file and available to data users for review.

Level 2. Data are collected in accordance with approved plans and procedures as required for Level 1 , with the exception that one or more documentation requirements may be deficient in some way. Examples of data documentation deficiencies may include lost or destroyed field data collection forms or data acquired using interim or draft procedures.

Level 3. Data are collected using accepted scientific methodology (e.g., ASTM, U.S. Environmental Protection Agency [EPA] methods, USGS procedures) and accompanied by supporting and corroborative documentation such as testing apparatus diagrams, field or laboratory notes, and procedures.

Level 4. Data are collected by a participating NNSA/NSO ERP, organization or another organization not associated with the NNSA/NSO ERP, before the issuance and implementation of project-approved standard policies, procedures, or practices governing data acquisition and qualification. The methods of data collection are documented and traceable; however, the validity of data use or compliance with reference procedures is indeterminate. Supporting documentation may or may not exist.

Level 5. Data are obtained under unknown, undesirable, or uncertain conditions. When data documentation is unknown, any available supporting or helpful descriptions of the intended use and conditions of data capture should be described.

\subsubsection{Data Quality Evaluation}

The data qualification process varies depending on the type of parameter. The criteria used to evaluate the quality of different types of data are dependent on the data type and the intended use. 
Thus, various criteria are used to assess data quality. The general procedure includes assigning one or more data quality evaluation flags (DQE_F) to each record, or group of records compiled in the dataset, indicating the data quality or suitability of the individual data record for the intended usage. The DQE_F and their definitions depend on the data type. Specific quality evaluation procedures are described in the different sections of this document for each data type.

\subsubsection{Data Analysis Limitations}

Data limitations need to be identified. These limitations may be related to the level of data documentation, the data collection method, the data analysis method, or other factors that may limit the confidence in the values. Within the discussion of each dataset, data limitations will be noted. 


\subsection{Yucca Flat/Climax Mine CAU HYDROSTRATIGRAPHIC FRAMEWORK}

A 3-D HFM and alternatives for the Yucca Flat/Climax Mine CAU were completed in 2005 and are fully documented in the report: A Hydrostratigraphic Framework Model and Alternatives for the Groundwater Flow and Contaminant Transport Model of Corrective Action Unit 97: Yucca Flat/Climax Mine, Lincoln and Nye Counties, Nevada (BN, 2006). This section provides an overview of how the Yucca Flat/Climax Mine CAU-specific hydrostratigraphic framework was developed and presents brief summaries of the hydrostratigraphic system, structural model, and alternative models. The regional-scale setting is described in Section 2.0.

\subsection{Objectives}

The primary objective of the Phase I Yucca Flat/Climax Mine hydrostratigraphic modeling effort was to produce a 3-D HFM that depicts the geometric relationships of HSUs and structural features in the Yucca Flat/Climax Mine CAU model area. This also included development of alternative HSU models for some of the non-unique interpretations. The Yucca Flat/Climax Mine HFM and alternative scenarios will be used to model groundwater flow and contaminant transport for the Yucca Flat/Climax Mine CAU.

\subsection{Hydrostratigraphic Model Development Methodology}

Models are being developed by the UGTA Project of the NNSA/NSO ERP to predict groundwater flow and contaminant transport from the source areas to groundwater discharge areas. The hydrologic and contaminant-transport models require a hydrostratigraphic framework that addresses the character and extent of geologic units in 3-D. The approach followed to develop the base HFM and alternative models is described in this section.

The hydrogeology of the NTS, including Yucca Flat and Climax Mine is complex (see Plate 1, a surficial geology map of the Yucca Flat/Climax Mine model area). The thick sections of alluvium 
and volcanic rocks comprise a wide variety of lithologies that can range in hydraulic character from aquifer to aquitard. Basin-and-range faulting has acted to further complicate the area, placing the various lithologic units in juxtaposition, and blocking or enhancing the flow of groundwater in a variety of ways.

The general hydrogeologic framework for the NTS and vicinity, established by USGS geoscientists in the early 1970s, has provided the foundation for most subsequent hydrogeologic studies at the NTS, including the Yucca Flat/Climax Mine HFM. The hydrostratigraphic framework for the Yucca Flat/Climax Mine area documented in BN (2006) was also enhanced by many field and analytical studies supported by the UGTA Project and conducted over several years. As a result of these studies and the contributions of many experts and organizations associated with the NTS, the hydrogeologic understanding of the model area has become increasingly detailed and refined.

The Yucca Flat/Climax Mine HFM is based largely on the hydrologic framework described by Winograd and Thordarson (1975) for the NTS area. This early work was further developed by Laczniak et al. (1996), the UGTA Phase I hydrostratigraphic regional modeling team (IT, 1996a, b, c), and UGTA CAU-scale modeling teams (BN, 2002, 2005, 2006).

The Yucca Flat/Climax Mine HFM(s) were constructed using EV ${ }^{\circledR}$ (Version 7.5, by Dynamic Graphics, 2002), a 3-D geologic model building and visualization software package. Inputs included drill-hole data, geophysical surveys (e.g., MT, seismic, magnetic and gravity data), digital elevation model data, outcrop and fault data from surface geologic maps, and post-shot surface effects maps (Grasso, 2001 and 2003). Interpretive data includes cross-sections and subsurface maps (isopach, structure-contour, and unit-extent maps). Where deemed necessary, the data were supplemented with interpretations in the form of "pseudo drill holes." A "pseudo drill hole" is a fictitious data point used to facilitate the automated contouring of data. The data for the "pseudo drill holes" are obtained from surficial geology maps, geophysical data, and/or geologist's interpretations.

Prior to the actual construction of the digital 3-D framework model, two important tasks had to be completed. First, a structural model of the area was developed that included the locations and orientations of all the relevant faults in the model area. The structure of the base HFM is founded on the conceptual model developed over the years for the weapons testing program at the NTS and refined by the UGTA Project (BN, 2006). Bechtel Nevada developed a detailed structural model by 
integrating this conceptual model and 2-D reflection seismic, gravity, magnetic (both aerial and surface surveys), magnetotelluric (MT) survey data, post-shot surface effects, surface geology, and drill hole data. The base HFM includes 180 structural elements, most of which are normal faults (basin-and-range type faults). Several older thrust faults (the CP and Belted Range thrusts and related imbricate thrust faults) are also included. Fault information was imported into the $\mathrm{EV}^{\circledR}$ (Version 7.5, by Dynamic Graphics, 2002) modeling software to form a fault-tree model that depicts all the model faults in 3-D space. The fault-tree model formed the framework on which the HFM was built. Only faults that were considered to be significant were included in the model. These include faults with apparent displacement typically greater than about $60 \mathrm{~m}$ and those that are thought to form significant structural boundaries. A more detailed discussion of the structural model is provided in Section 5.3.

Although the structural framework of the Yucca Flat/Climax Mine HFM is the fault-tree, the foundation of the model is the hydrostratigraphic classification system. The second important step was to develop a hydrostratigraphic system through a rigorous analysis of stratigraphic and lithologic data in and around Yucca Flat. The drill-hole database (Drellack and Thompson, 1990; Wagoner and Richardson, 1986; Warren et al., 2003) was then integrated to a hydrostratigraphic database based on this hydrostratigraphic system. This database, along with the enhanced conceptual structural model, provided the basis for constructing cross-sections, unit-extent maps, and structure contour maps for each HSU. Three-dimensional surfaces were derived from these maps using the $\mathrm{EV}^{\circledR}$ (Version 7.5, by Dynamic Graphics, 2002) modeling software. The 3-D volumes defined by these surfaces will serve as inputs for the UGTA groundwater-modeling process. The Yucca Flat/Climax Mine hydrostratigraphic system consists of 25 HSUs that form volumes in the model. A description of the hydrostratigraphic classification system developed for the Yucca Flat/Climax HFM is provided in Section 5.4.

Data are fairly prevalent and adequately distributed within the Yucca Flat basin as defined by the former underground nuclear testing areas (Figure 5-1). Data available for this portion of the model area consist of hundreds of drill holes (Plate 2), numerous geophysical studies including $225 \mathrm{~km}$ of 2-D seismic lines, thousands of gravity measurements, and other surveys. Collectively, this dataset allows for excellent characterization of the subsurface. Within the former testing areas, HSU geometry, fault locations, and fault displacements are fairly well constrained by the dataset. Hydrologic properties can be extrapolated from a limited number of well tests and inferred from 


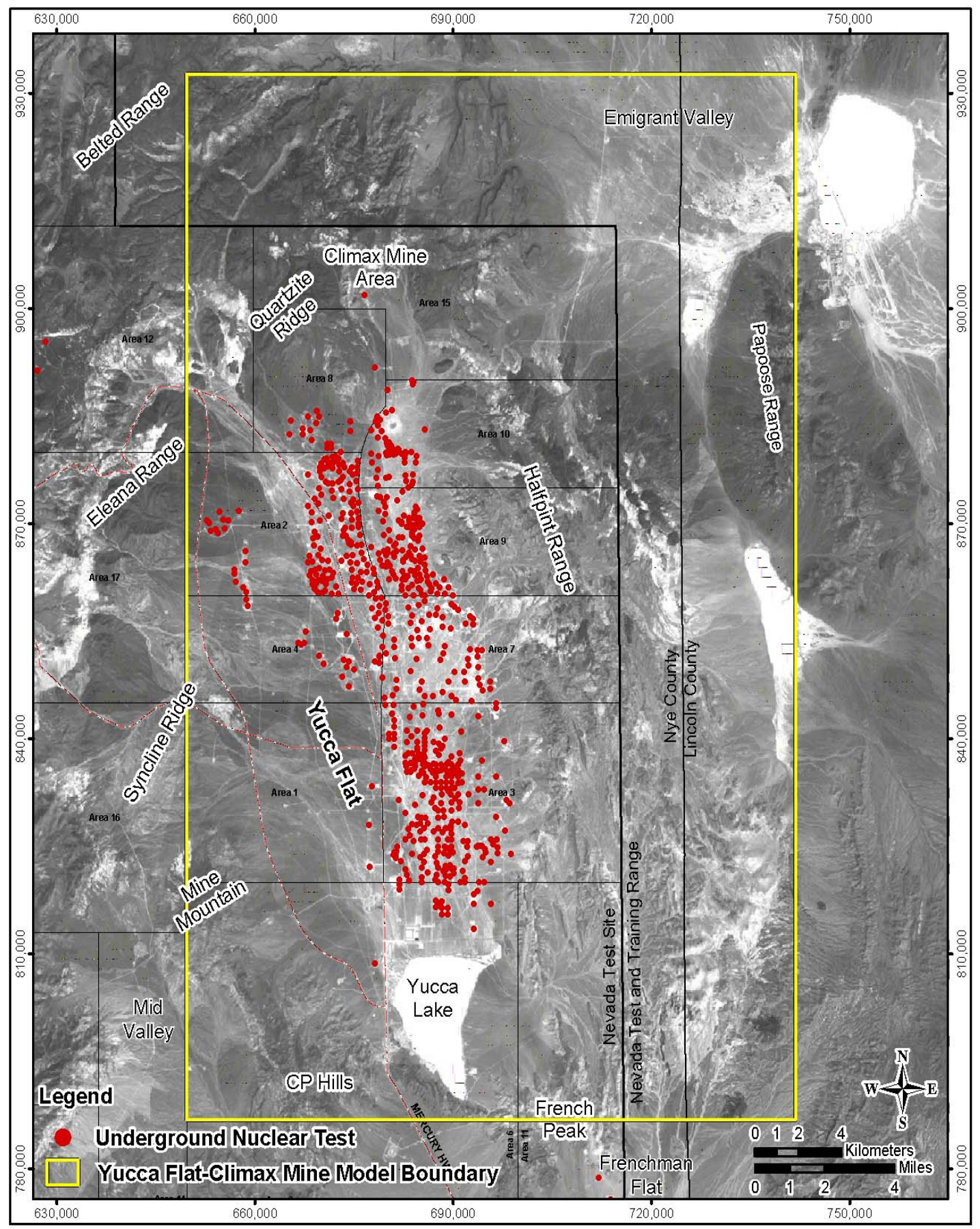

Figure 5-1

Satellite Image of the Yucca Flat/Climax Mine Area Showing Physiographic Features and Locations of Underground Nuclear Tests 
outcrop properties, geophysical logs, and/or laboratory analyses of core samples. Outside the former testing areas, data are more sparse and, consequently, uncertainty increases. The UGTA Project supplemented the available data with data acquisition initiatives including drilling programs (IT, 2002) and geophysical surveys (i.e., MT and gravity). Areas of lower confidence include some of the alluvial filled/covered valleys east of Yucca Flat, the deeper subsurface in extreme southern Yucca Flat, and peripheral areas such as Emigrant Valley in the northeast corner and Mid Valley in the southwest corner of the model.

To capture the uncertainty associated with the HSU framework, a number of alternative interpretations were considered in addition to the base HFM (Section 5.5). Construction of the alternative models generally followed the same process as used for construction of the base model.

\subsection{Structural Model}

Structures define the geometric configuration of the Yucca Flat/Climax Mine CAU model area by controlling the distribution, thickness, and orientation of units, and thus are an important part of the hydrogeologic regime of the area. Basin-forming structures had a strong influence on depositional patterns of alluvial deposits and the extent, thickness, and structural elevation of volcanic deposits. Some faults place units with different hydrologic properties in juxtaposition, which may have significant hydrogeologic consequences. Also, the structures may act as either conduits of groundwater flow, if characterized by open fractures, or barriers to flow, if associated with fine-grained gouge, or increased alteration of nearby rocks. This section provides a brief overview of the structural setting of the model and describes the structural elements of the model area.

\subsubsection{Structural Overview}

The interpretation of the structural geology in the Yucca Flat vicinity is challenging because complex pre-Tertiary contractional deformation was overprinted by more recent extensional deformation. In addition, most of the major structural features are buried by thick deposits of volcanic rocks and alluvium. Fortunately, a large and robust dataset is available for Yucca Flat that includes surface geologic exposures (outcrop and post-shot surface effect data), drill-hole data, and a variety of geophysical data. Recently acquired data from deep-drilling and geophysical surveys, specifically an MT survey, proved valuable in better constraining the structural model of the basin. 
The structural history of the NTS area began with east- to southeast-directed thrusting along the Belted Range thrust fault between 280 and 100 million years ago (Ma) and resulted in complex contractional deformation within pre-Tertiary rocks along the present western margin of Yucca Flat. Proterozoic to Cambrian siliciclastic rocks were placed over Devonian carbonate and Mississippian siliciclastic rocks along the Belted Range thrust fault northwest of Yucca Flat. Imbricate thrusting in front of the advancing Belted Range thrust sheet created a complex stack of thrust slices of footwall rocks that involve Devonian carbonate rocks and Mississippian siliciclastic rocks. Shortly after the initiation of Belted Range thrusting, a west-vergent thrust fault (CP thrust fault) formed foreland (east) of the Belted Range thrust system along what is believed to be an east-dipping high-angle ramp structure in what is now the central portion of Yucca Flat. The CP thrust placed Cambrian and Ordovician carbonate rocks over Mississippian siliciclastic and Devonian carbonate rocks. Between approximately 15 and $10 \mathrm{Ma}$ in the NTS region, generally east-west directed extension resulted in the formation of basins such as Frenchman Flat, Emigrant Valley, and Kawich Valley by displacement along west-dipping high-angle normal faults located along the eastern margins of the developing basins. This also resulted in an eastward tilt to stratigraphic units. In Yucca Flat, however, reactivation of the east-dipping high-angle ramp structure of the $\mathrm{CP}$ thrust fault resulted in the formation of the east-dipping Carpetbag-Topgallant fault system near the center of the present Yucca Flat topographic basin, and the formation of the west-tilted Yucca Flat structural basin (BN, 2006).

\subsubsection{Structural Elements}

The primary structural elements within the Yucca Flat/Climax Mine HFM are high-angle normal faults, thrust faults, and folds. Each of these structural elements is described below.

\section{Thrust Faults}

Although the Belted Range thrust fault does not extend within the boundaries of the Yucca Flat/Climax Mine HFM, a foreland imbricate thrust fault related to the main thrust fault is present in the northwest corner of the model area. This fault places Devonian and Silurian carbonate rocks over Mississippian siliciclastic rocks (Gibbons et al., 1963; Cole and Cashman, 1999) and was included in the HFM. Other related imbricate thrusts are recognized but generally place Mississippian siliciclastic rocks over rocks of similar age and composition. Because these thrust faults likely juxtapose rocks of similar hydrogeologic character, they were not included in the model. In addition, 
data from ER-12-2, which was drilled east of the Eleana Range in northwestern Yucca Flat, provide evidence that no major structural disruption occurs between the Mississippian rocks of the Eleana Range and those penetrated in ER-12-2 (Prothro, 2005).

The west-vergent CP thrust fault is likely the most hydrologically significant pre-Tertiary structure within the model area, and thus is included in the HFM. The thrust fault is located in the western portion of the model area, where it places carbonate rocks over siliciclastic rocks. The sinuous trace of the $\mathrm{CP}$ thrust fault indicates that it is a relatively low-angle fault beneath the western portion of Yucca Flat, where it cuts through the less competent and highly bedded Mississippian siliciclastic rocks of the Chainman Shale and Eleana Formation. The fault plane, however, appears to steepen rapidly eastward beneath central Yucca Flat, based on MT data (Asch et al., 2005), and thus forms a ramp structure beneath the central portion of the basin (Profile 2 in Appendix D of BN, 2006). As discussed in Section 5.3.1, the location of the CP thrust ramp appears to be coincident with the location of the east-dipping Carpetbag-Topgallant normal fault system, a major basin-forming fault system which bounds the deep Yucca Flat structural basin on the west. Thus, the Carpetbag-Topgallant normal fault system may represent a reactivation of the pre-existing CP thrust ramp. Additional evidence for coupling of the $\mathrm{CP}$ thrust ramp and the Carpetbag-Topgallant fault system is that Mississippian rocks within the footwall of the $\mathrm{CP}$ thrust fault beneath the western portion of Yucca Flat are not observed in the MT data east of the Carpetbag-Topgallant fault system, nor do they crop out in the hills bordering Yucca Flat on the east. This suggests that Mississippian rocks within the hanging wall of the $\mathrm{CP}$ thrust fault were eroded off of the hanging wall as a result of being thrust upward along a high-angle ramp structure located beneath central Yucca Flat. In the Yucca Flat/Climax Mine HFM, the CP thrust fault is modeled as merging downward and eastward into the Carpetbag-Topgallant fault system.

\section{High-Angle Normal Faults}

The most common structural feature in the model are high-angle normal faults (having vertical [dip slip] displacement) related to basin-and-range extension and basin formation. Approximately 178 high-angle faults are included in the framework model (Plate 1). Faults are typically modeled with a 75-degree dip based on measured dips of faults exposed around Yucca Flat (which range from 50 to 85 degrees), and the stratal tilt (generally less than 15 degrees) of the Rainier Mesa and Ammonia Tanks Tuffs within and along the eastern margin of the basin (Barnes et al., 1965; Byers and Barnes, 
1967; Hinrichs and McKay, 1965). Most faults are modeled as single fault planes that extend to the base of the model. Some faults, however, terminate against other faults. Because the main basin-forming faults dip to the east in Yucca Flat, west-dipping faults in the model were typically terminated against east-dipping faults.

The locations of the high-angle faults were based on mapped surface traces, drill-hole data, mapped surface effects from underground nuclear tests, and geophysical evidence. The traces of surface faults were digitized from surface geology maps (USGS geologic quadrangle maps listed in Table 2-1 of BN, 2006, and Workman et al., 2002). Only the main surface faults were included in the framework model. These faults typically have apparent offsets greater than $61 \mathrm{~m}$ and appear to provide the main control on the structural fabric and outcrop patterns in the highlands bordering Yucca Flat.

\section{Folds}

Pre-Tertiary contractional deformation in the Yucca Flat vicinity resulted in the folding of pre-Tertiary rocks within the model area. Because of the scale of the HFM, only the larger folds are expressed in the model. These include the Halfpint Range anticline, the Syncline Ridge syncline, the Yucca Flat syncline, and the Quartzite Ridge anticline.

The pre-Tertiary rocks in the Halfpint Range generally dip moderately to the southwest and west toward Yucca Flat, forming the southwest limb of the broad northwest-trending Halfpint Range anticline, the axis of which crosses the northern portion of the range (Figure 5-2). Proterozoic siliciclastic rocks form the core of the Halfpint Range anticline, and pre-Tertiary rocks become progressively younger to the south within the range away from the anticline (Barnes et al., 1965; Hinrichs and McKay, 1965; Byers and Barnes, 1967).

Pre-Tertiary rocks within the Halfpint Range also form the northeast limb of the broad synclinal form beneath the eastern portion of Yucca Flat. This synclinal form is expressed by stratigraphic relationships of the pre-Tertiary subcrop surface beneath the eastern portion of Yucca Flat based on deep drill hole data (Cole et al., 1997). This synclinal form likely represents a hanging-wall syncline associated with the CP thrust fault. Designated the Yucca Flat syncline, it has been severely overprinted by later extensive normal faulting related to basin-and-range extension and basin formation. 


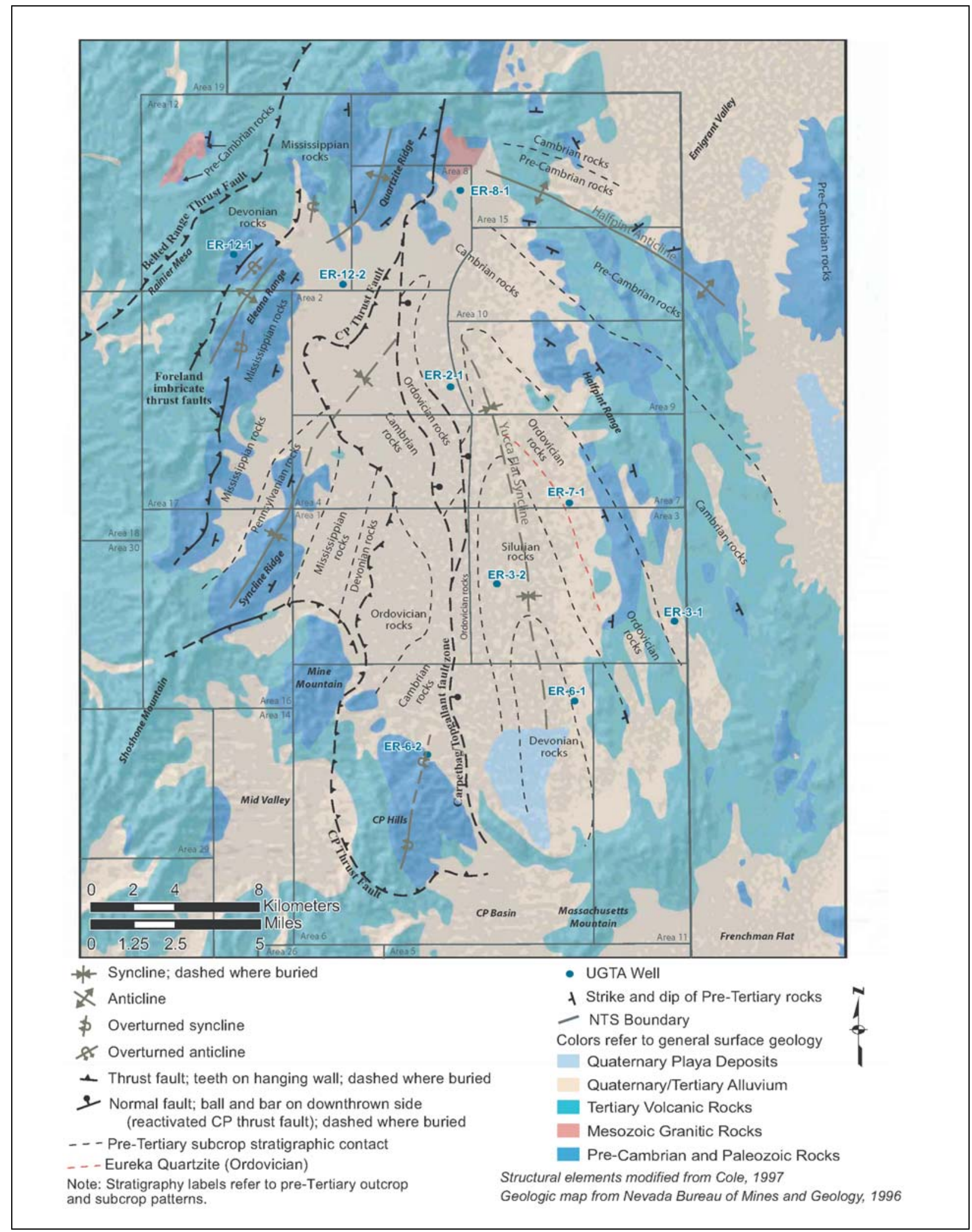

Figure 5-2

Pre-Tertiary Structure of the Yucca Flat/Climax Mine HFM Area 
Another syncline is present along the western edge of the model area. This structural feature is the northeast continuation of the Syncline Ridge syncline, which is exposed at Syncline Ridge just west of the model area. Syncline Ridge is composed of Pennsylvanian and Permian carbonate rocks that have been broadly folded into a northeast trending syncline. The Syncline Ridge syncline trends northeast beneath the northwest portion of Yucca Flat, where it composes the footwall of the $\mathrm{CP}$ thrust fault. It is overridden by and eventually terminates against the $\mathrm{CP}$ thrust fault beneath the northern portion of Yucca Flat.

The Mississippian siliciclastic rocks exposed on Quartzite Ridge in the northwestern portion of the model area have been folded into a north-northeast-trending anticline that appears to continue southwestward into the Eleana Range, located west of the model area. The Quartzite Ridge anticline and Syncline Ridge syncline are modeled as adjacent fold pairs within the footwall rocks between the converging Belted Range and CP thrust faults.

\subsubsection{Hydrogeologic Insights}

It is typical for rocks to be more fractured near faults, and thus rock properties tend to be different near and adjacent to faults. Enhanced conductivity may be a characteristic of the younger normal faults. However, thrust faulting (including the $\mathrm{CP}$ thrust) and associated fracturing are older than approximately 100 million years at the NTS. Therefore, fractures associated with thrusting are more likely to be healed or filled than fractures associated with more recent basin-and-range normal faulting, which began in the Yucca Flat area approximately $10 \mathrm{Ma}$, and probably continues today. Reactivation of the older thrust structures during basin-and-range extension, such as that described for the CP thrust fault and documented at Mine Mountain (Cole and Cashman, 1999), likely created new fractures and could have reopened preexisting fractures associated with the old thrust structures. However, it is difficult to predict if (and where) an older thrust fault may have undergone reactivation due to later structural activity, particularly if the thrust fault is buried or poorly exposed. Regarding the $\mathrm{CP}$ thrust fault and how it is modeled in the $\mathrm{EV}^{\circledR}$ (Version 7.5, by Dynamic Graphics, 2002) framework model, the steeper portion (i.e., ramp) that is coincident with the Carpetbag-Topgallant fault should be considered reactivated, resulting in a possible increase in transmissivity along and near the fault where it cuts through brittle rocks such as the LCA. 


\subsection{Hydrostratigraphy}

The hydrogeologic framework for the NTS region, including Yucca Flat and vicinity, established by Winograd and Thordarson (1975) provided the foundation for most subsequent hydrogeologic studies in the area (e.g. Laczniak et al., 1996; IT, 1996e; BN, 2006). As introduced in Section 2.3 and Section 5.2, the rocks of the NTS have been classified for hydrologic modeling using a two-level classification scheme in which HGUs are grouped to form HSUs (IT, 1996a; BN, 2002). New units and additional detail have been added to the basic framework definition, but the system developed by these early workers remains the best way to understand the hydrostratigraphy of the NTS region.

\subsubsection{Hydrogeologic Units of the Yucca Flat Model Area}

All the rocks of the Yucca Flat/Climax Mine model area are classified as one of the following nine HGUs: PCU, AA, WTA, VTA, LFA, TCU, GCU, CCU, and CA (see Table 2-1).

\section{Alluvial Hydrogeologic Units}

Two alluvial HGUs are present in the Yucca Flat/Climax Mine model area: the AA (also an HSU) and the PCU. The AA consists mainly of gravelly sand and sandy gravel eroded from the surrounding mountains during basin development, and deposited on alluvial fans by debris flow and sheetflood processes. Deposits of finer-grained eolian sand are intercalated within the coarser alluvial deposits. The PCU consists of fine-grained sand, silt, and clay deposited as playa lake sediments in the topographic low point of the basin.

\section{Volcanic Hydrogeologic Units}

The volcanic rocks within the model area are categorized into four HGUs based on primary lithologic properties, degree of fracturing, and secondary mineral alteration. In general, the altered volcanic rocks, which are typically zeolitized and support few fractures (Prothro, 1998), act as confining units, and the unaltered rocks form aquifers. The aquifer units are further divided into WTAs and VTAs, depending on degree of welding, and LFAs. Denser rocks, such as welded ash-flow tuff and lava flows, tend to fracture more readily, and therefore have relatively high permeability (Blankennagel and Weir, 1973; Winograd and Thordarson, 1975; Laczniak et al., 1996; IT, 1996e; Prothro and Drellack, 1997b). 


\section{Pre-Tertiary Hydrogeologic Units}

The hydrogeology of the pre-Tertiary sedimentary rocks at the NTS follows the framework developed by Winograd and Thordarson (1975), and used in the UGTA Phase I regional modeling effort (IT, 1996a, c, e) and subsequent CAU-scale models (BN, 2002, 2005, 2006; Gonzales et al., 1998).

Within the model area, pre-Tertiary rocks are categorized as aquifer or confining unit HGUs based on lithology. The siliciclastic rocks, such as quartzite, siltstone, and shale, are classified as CCUs. Carbonate rocks, such as limestone and dolomite, are classified as CAs (Winograd and Thordarson, 1975; Laczniak et al., 1996). The granitic intrusive rocks are classified as confining units (BN, 2002).

\subsubsection{Hydrostratigraphic Units of the Yucca Flat/Climax Mine CAU Model}

To develop the Yucca Flat/Climax Mine HFM, earlier hydrogeologic framework models were integrated with drill-hole data (stratigraphic, lithologic, and alteration data), data from several geophysical, geological, and hydrological studies, and a conceptual structural model, to formulate a hydrostratigraphic system. Applying this updated understanding of Yucca Flat/Climax Mine area hydrogeology, the geologic units in the study area are organized into 25 HSUs that include 13 aquifers and 12 confining units (see Table 2-2). The alluvial section was subdivided into 3 HSUs, including the AA, BLFA, and PCU. There are 13 Tertiary-age volcanic HSUs, including 8 aquifers and 5 confining units. The intrusive granitic rocks are classified as a confining unit. The underlying pre-Tertiary rocks were divided into 7 HSUs, including 3 aquifers and 4 confining units. These HSUs serve as 3-D bodies that are represented in the finite element mesh for the UGTA groundwater modeling process (IT, 1996c).

An important step in the development of the Yucca Flat hydrostratigraphic classification system was to group individual HGUs of similar character into larger HSUs to facilitate mapping and 3-D model construction. A critical component of this step was the careful integration of Yucca Flat stratigraphy. The integration of stratigraphic concepts is important to assure that individual HGUs grouped within HSUs, and the HSUs properly correlate within the model. The correlation of stratigraphic units and HSUs of the Yucca Flat/Climax Mine HFM area is depicted graphically in Figure 5-3.

Hydrostratigraphic units can be thought of as groupings of contiguous stratigraphic units that have a particular hydrogeologic character, such as aquifer or confining unit. For the Yucca Flat/Climax Mine model, most HSUs consist of a single HGU (e.g., the TM-LVTA essentially is 100 percent 


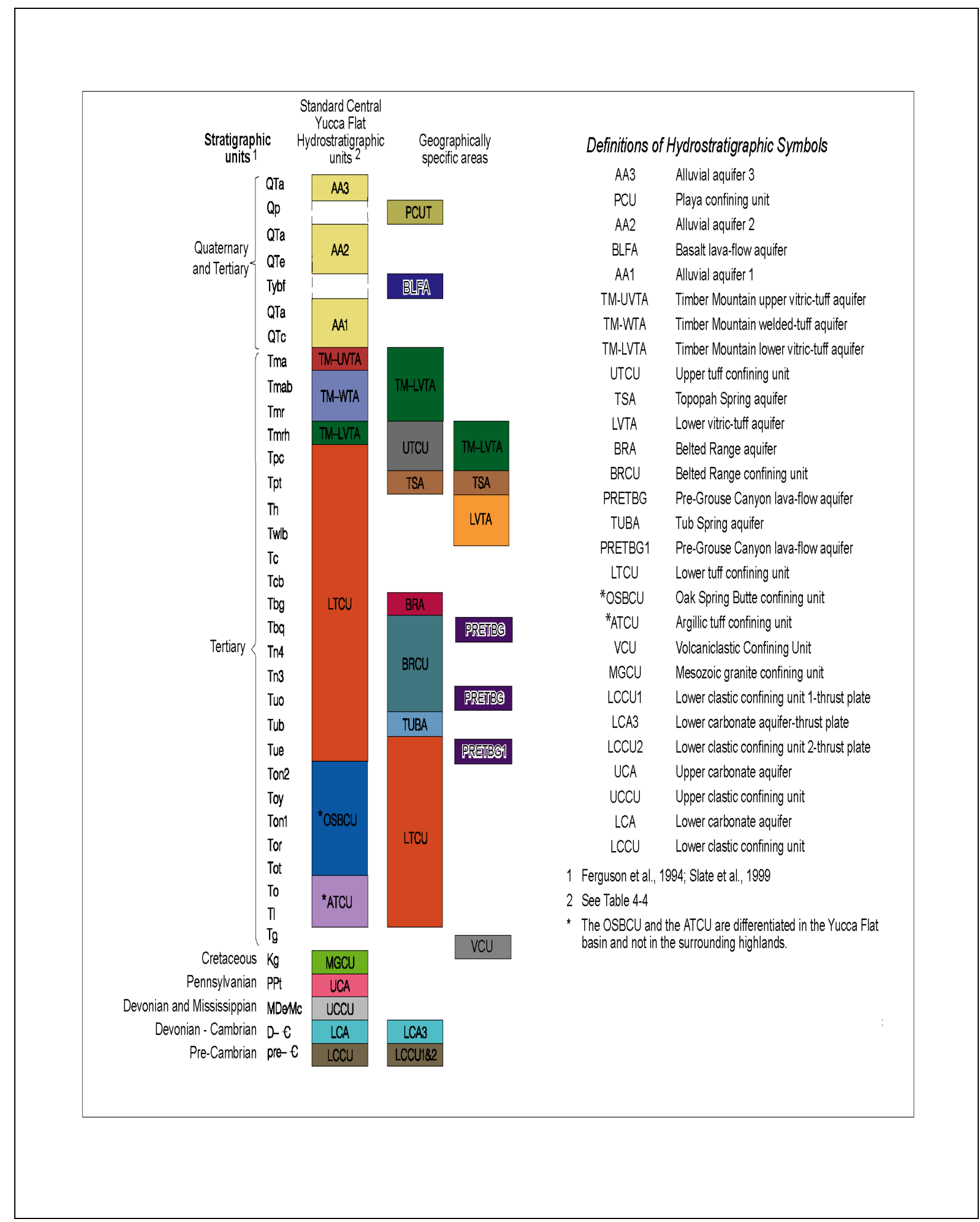

Figure 5-3

Correlation of Stratigraphic and HSUs of the Yucca Flat/Climax Mine HFM Area 
VTA). There are four exceptions (the TM-UVTA, TM-WTA, TSA, and VCU) that may consist of several HGUs, but are defined so that a single general type of HGU dominates (e.g., mostly WTA). These exceptions are noted in the "Dominant HGU" column of Table 2-2.

Brief descriptions of all the HSUs in the Yucca Flat/Climax Mine HFM are provided in Table 2-2. They are generally listed in descending order from the top of the model to the bottom, though some are laterally rather than vertically contiguous, and not all units are present in all parts of the model area. A more detailed description of each HSU can be found in BN (2006).

The geometric configuration of the HSUs as defined in the model is represented in 3-D perspective views and 2-D plan maps and profiles in various figures throughout this report. The distribution of HSUs at the surface within the Yucca Flat/Climax Mine HFM area is shown in a block model view in Figure 5-4 and in Plate 3. The distribution of HSUs at the water table is presented in Plate 4. Figure 5-5 is a block model view showing the extent of the PCUT (the EV ${ }^{\circledR}$ equivalent to the PCU), the BLFA, and intermediate alluvium (AA2 and AA1) within the Yucca Flat/Climax Mine HFM area (AA3 removed). The distribution of HSUs within the Yucca Flat/Climax Mine HFM area with the alluvium removed is shown in Figure 5-6. The distribution of volcanic confining HSUs (alluvial and upper volcanic aquifer units removed) within the Yucca Flat/Climax Mine HFM area is shown in Figure 5-7.

A block model view showing distribution of pre-Tertiary HSUs within the Yucca Flat/Climax Mine HFM area (alluvial and volcanic units removed) is presented in Figure 5-8.

A north-south hydrostratigraphic profile (along the general direction of groundwater flow) is provided in Plate 5 along with West-east hydrostratigraphic profiles C-C' and D-D' through central Yucca Flat. The profiles illustrate the relationships of the HSUs and structures in various vertical planes. The locations of these profile lines are shown on Plate 3 and Plate 4. These model profiles are from the Yucca Flat 3-D framework documentation package (BN, 2006), where additional cross sections and detailed information regarding this CAU-scale model can be found.

Table 5-1 shows the correlation of Yucca Flat/Climax Mine HSUs with HSUs of earlier and nearby hydrostratigraphic models for this region. As can be seen from the information presented in this 

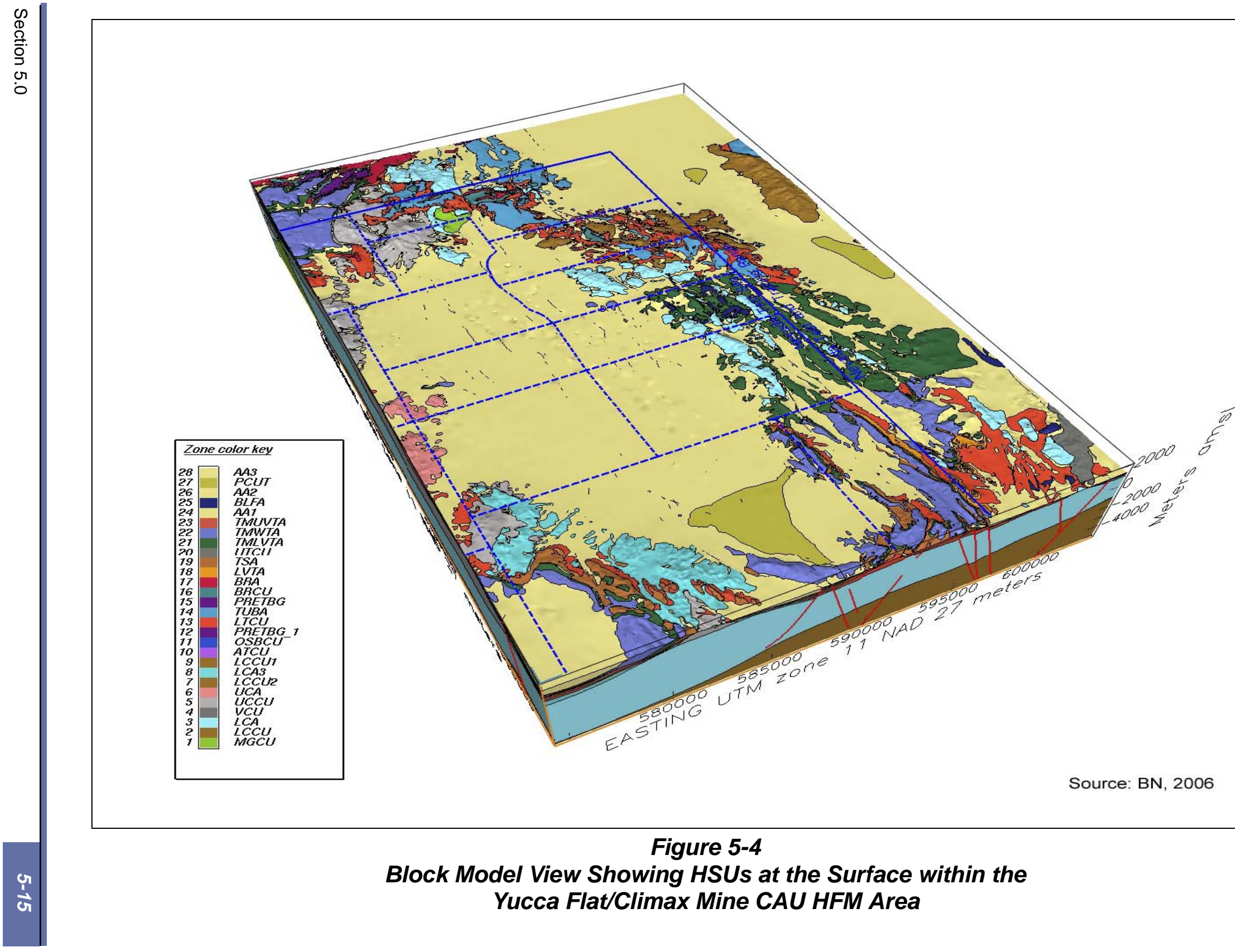

Source: BN, 2006

Figure 5-4

Block Model View Showing HSUs at the Surface within the Yucca Flat/Climax Mine CAU HFM Area 

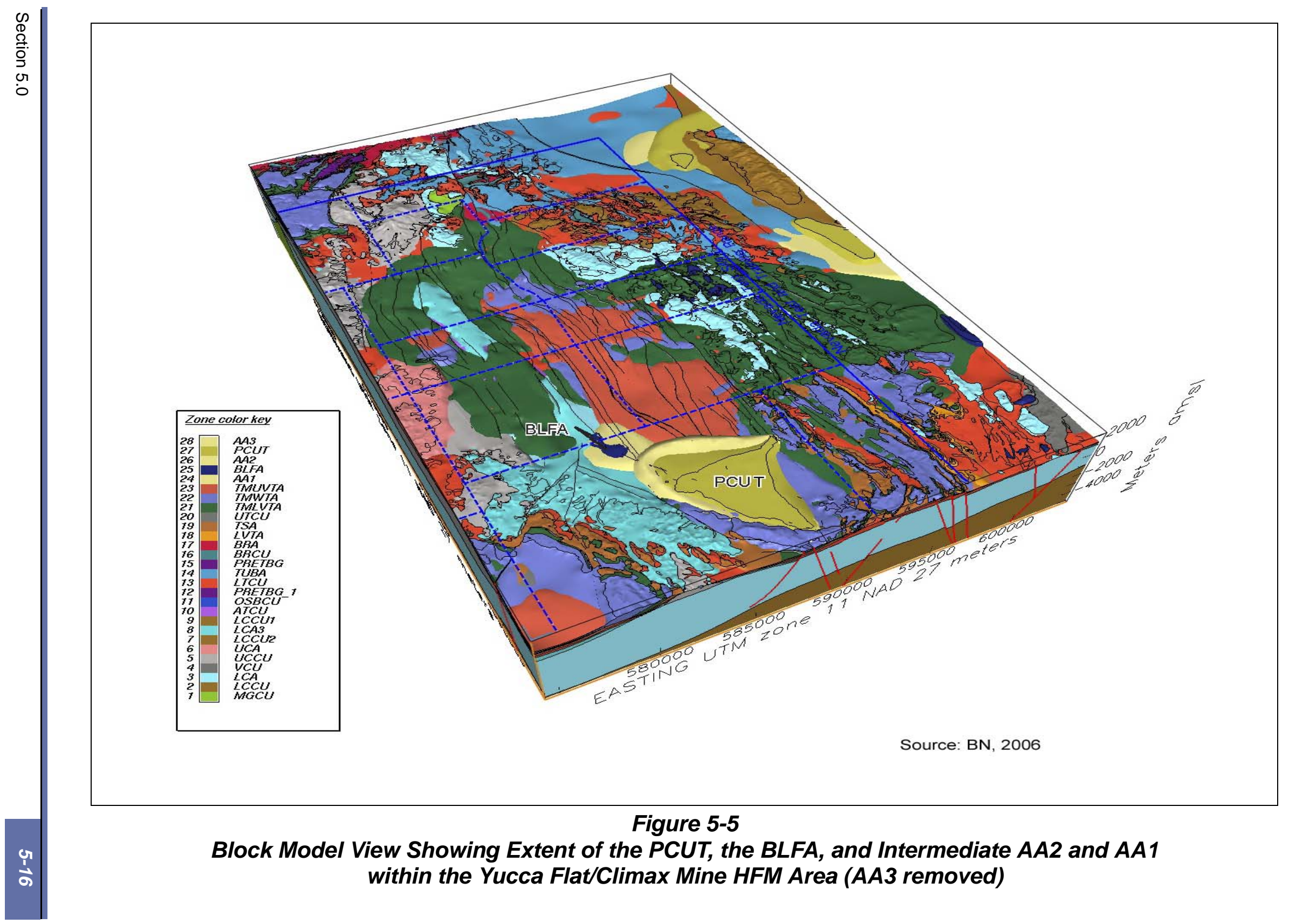

Figure 5-5

Block Model View Showing Extent of the PCUT, the BLFA, and Intermediate AA2 and AA1 within the Yucca Flat/Climax Mine HFM Area (AA3 removed) 

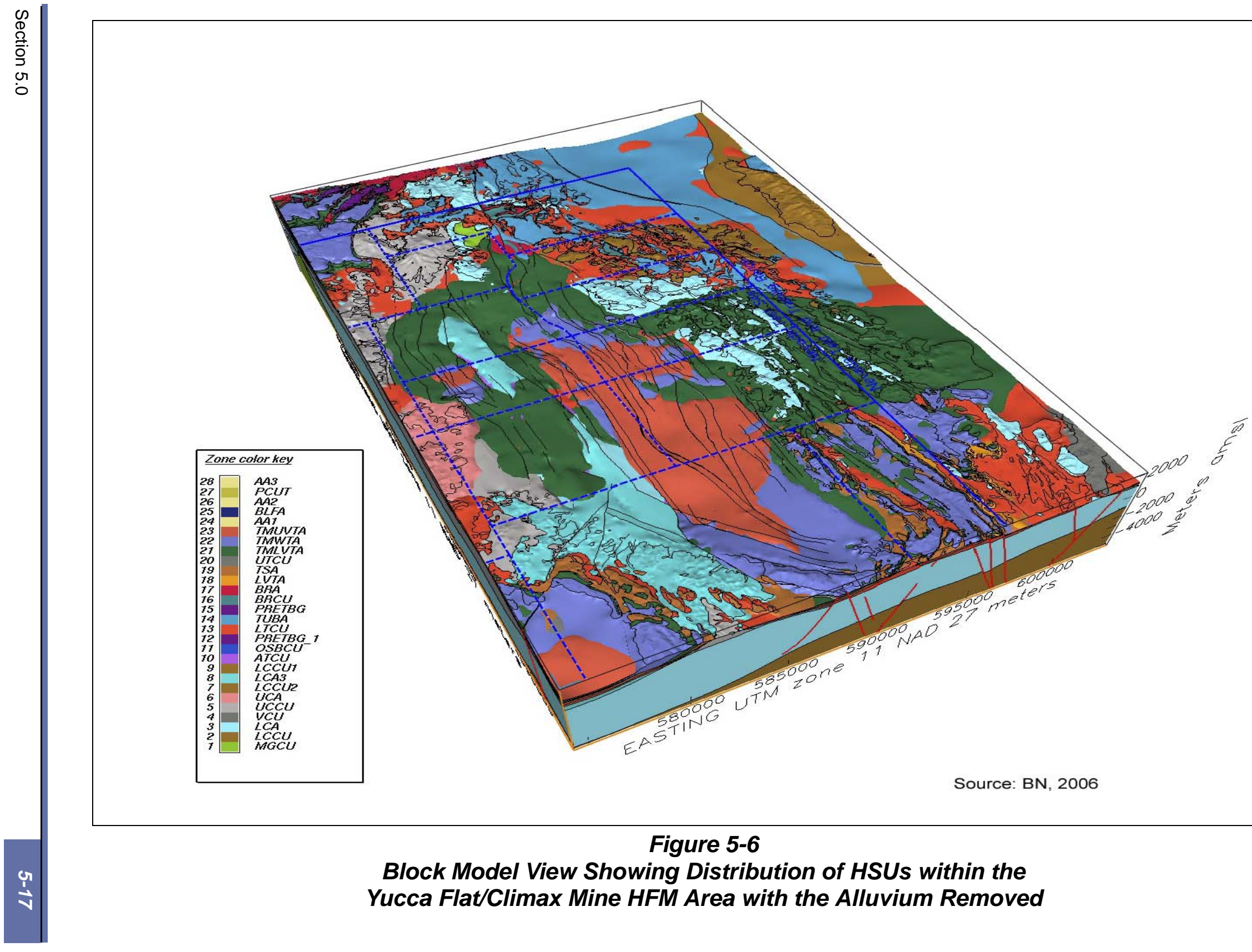

Figure 5-6

Block Model View Showing Distribution of HSUs within the Yucca Flat/Climax Mine HFM Area with the Alluvium Removed 


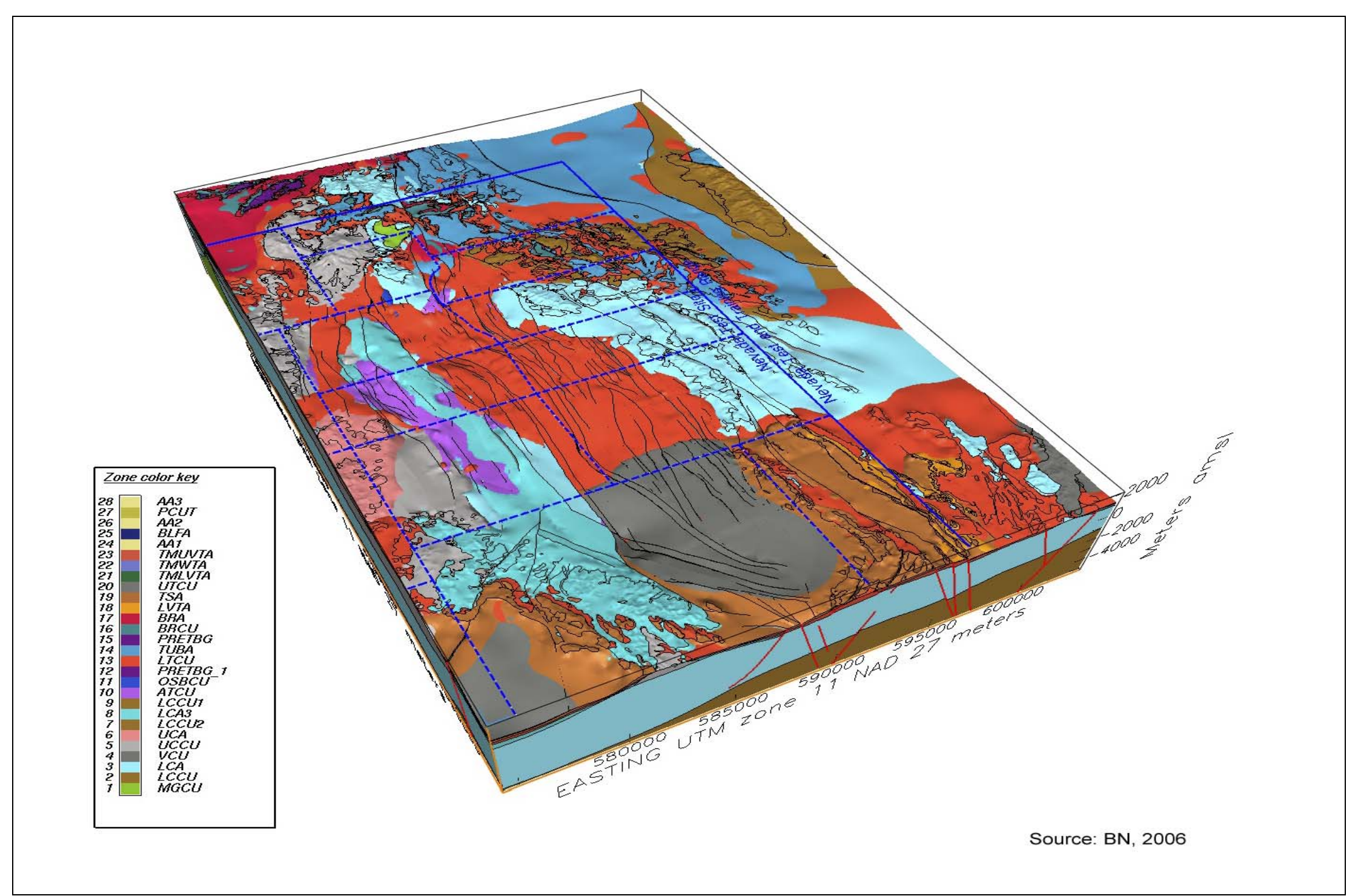

Figure 5-7

Block Model View Showing Distribution of Volcanic Confining HSUs (alluvial and volcanic aquifer units removed) within the Yucca Flat/Climax Mine HFM Area 

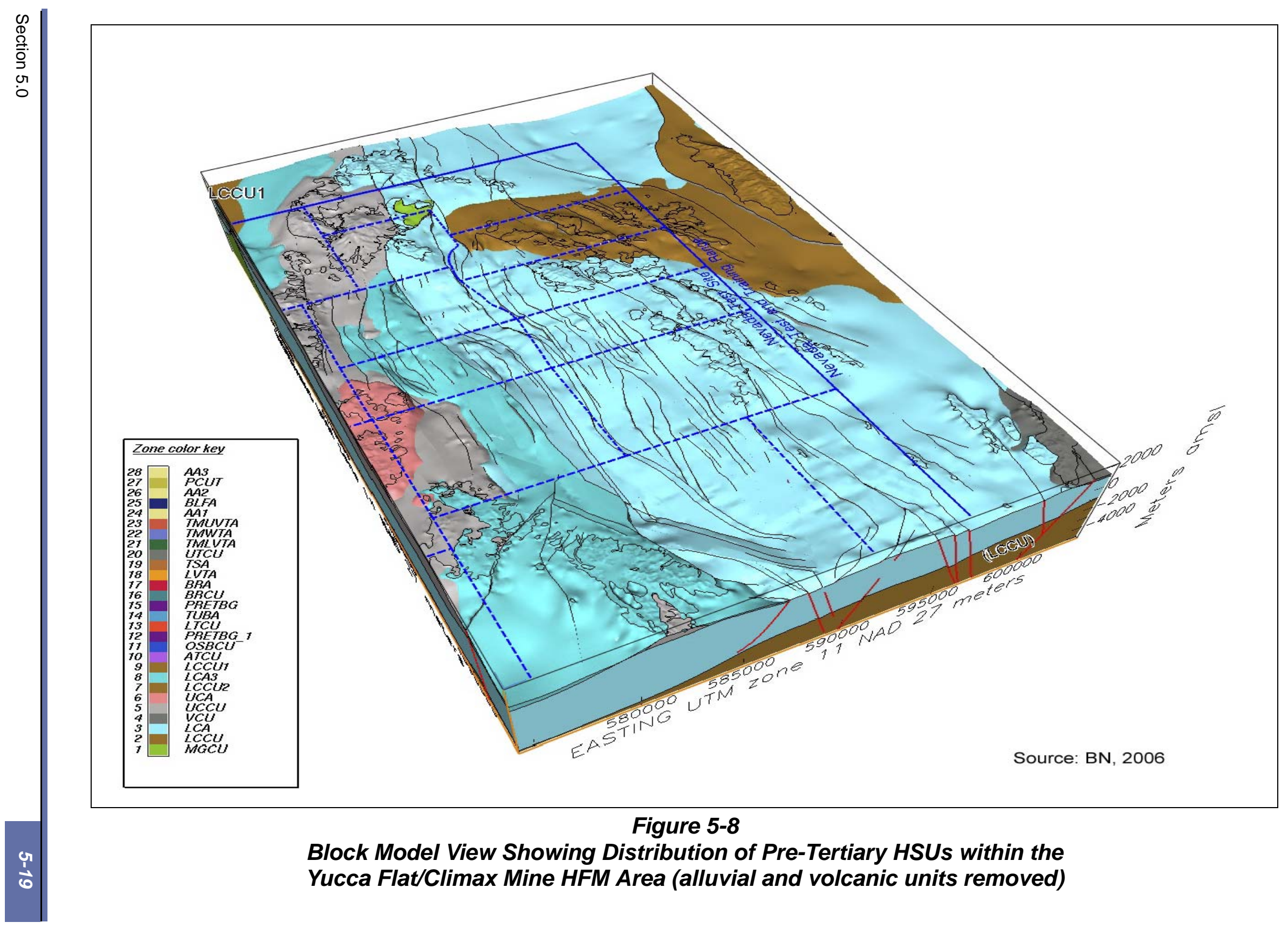

Figure 5-8

Block Model View Showing Distribution of Pre-Tertiary HSUs within the Yucca Flat/Climax Mine HFM Area (alluvial and volcanic units removed) 
Table 5-1

Correlation of Hydrostratigraphic Units of the Yucca Flat/Climax Mine CAU Model and Earlier Models (Page 1 of 2)

\begin{tabular}{|c|c|c|c|c|c|}
\hline Hydrostratigraphic Unit & $\begin{array}{l}\text { Symbol This } \\
\text { Report }\end{array}$ & $\begin{array}{c}\text { Correlation with } \\
\text { Phase II Frenchman } \\
\text { Flat Model } \mathbf{a , b}\end{array}$ & $\begin{array}{c}\text { Correlation with } \\
\text { Pahute Mesa/Oasis } \\
\text { Valley Modelc }\end{array}$ & $\begin{array}{l}\text { Correlation with } \\
\text { UGTA Phase } 1^{\mathrm{d}} \\
\text { Regional Model }\end{array}$ & $\begin{array}{l}\text { Correlation with } \\
\text { DVRFS Model }^{\text {e }}\end{array}$ \\
\hline Alluvial Aquifer & $\mathrm{AA} 3, \mathrm{AA} 2, \mathrm{AA}^{\mathrm{f}}$ & $\mathrm{AA} 3, \mathrm{AA} 2, \mathrm{AA}^{\mathrm{f}}$ & AA & \multirow{3}{*}{$A A^{g}$} & YAA \\
\hline Playa Confining Unit & PCUT & PCU2T, PCU1U, PCU1L & $N P^{h}$ & & YACU \\
\hline Basalt Lava-Flow Aquifer & BLFA & BLFA & YVCM & & LFU \\
\hline $\begin{array}{c}\text { Timber Mountain Upper Vitric-Tuff } \\
\text { Aquifer }\end{array}$ & TM-UVTA & $N P^{h}$ & \multirow{2}{*}{$\mathrm{TMA}^{\mathrm{g}}$} & \multirow{11}{*}{$\mathrm{VA}^{\mathrm{g}}, \mathrm{TC}^{\mathrm{g}}$} & \multirow{2}{*}{ TMVAg $^{g}$} \\
\hline $\begin{array}{c}\text { Timber Mountain Welded-Tuff } \\
\text { Aquifer }\end{array}$ & TM-WTA & TM-WTA & & & \\
\hline $\begin{array}{c}\text { Timber Mountain Lower Vitric-Tuff } \\
\text { Aquifer }\end{array}$ & TM-LVTA & TM-LVTA & PVTA & & TMVA, PVA \\
\hline Upper Tuff Confining Unit & UTCU & UTCU & UPCU, LPCU & & \multirow{2}{*}{$\mathrm{PVA}^{\mathrm{g}}$} \\
\hline Topopah Spring Aquifer & TSA & TSA & TSA & & \\
\hline Lower Vitric-Tuff Aquifer & LVTA & LVTA & PVTA & & $\mathrm{CHVU}$ \\
\hline Belted Range Aquifer & BRA & NP & BRA & & \\
\hline Belted Range Confining Unit & BRCU & NP (LTCU) & & & BRUg \\
\hline $\begin{array}{c}\text { Pre-grouse Canyon Tuff Lava-Flow } \\
\text { Aquifer }\end{array}$ & PRETBG & \multirow{3}{*}{$N P^{h}$} & $\left(\mathrm{PBRCM}^{\mathrm{g}}\right)$ & & \\
\hline Tub Spring Aquifer & TUBA & & $N P^{h}$ & & \multirow{5}{*}{ OVUg } \\
\hline $\begin{array}{c}\text { Pre-Grouse Canyon Tuff Lava Flow } \\
\text { Aquifer } 1\end{array}$ & PRETBG $1^{f}$ & & NP $\left(\mathrm{PBRCM}^{\mathrm{g}}\right)$ & & \\
\hline Lower Tuff Confining Unit & LTCU & \multirow{3}{*}{ LTCUg $^{g}$ LTCU1 $^{f}$} & CFCU, BFCU, PBRCM ${ }^{i}$ & \multirow{3}{*}{ VCU $g, B C U^{g}$} & \\
\hline Oak Spring Butte Confining Unit & OSBCU & & PPPCMf & & \\
\hline Argillic Tuff Confining Unit & ATCU & & PBRCIVI & & \\
\hline
\end{tabular}


Table 5-1

Correlation of Hydrostratigraphic Units of the Yucca Flat/Climax Mine CAU Model and Earlier Models

(Page 2 of 2)

\begin{tabular}{|c|c|c|c|c|c|}
\hline Hydrostratigraphic Unit & $\begin{array}{l}\text { Symbol This } \\
\text { Report }\end{array}$ & $\begin{array}{c}\text { Correlation with } \\
\text { Phase II Frenchman } \\
\text { Flat Model }^{a, b}\end{array}$ & $\begin{array}{c}\text { Correlation with } \\
\text { Pahute Mesa/Oasis } \\
\text { Valley Modelc }\end{array}$ & $\begin{array}{l}\text { Correlation with } \\
\text { UGTA Phase } 1^{\mathrm{d}} \\
\text { Regional Model }\end{array}$ & $\begin{array}{l}\text { Correlation with } \\
\text { DVRFS Model }^{\mathrm{e}}\end{array}$ \\
\hline Mesozoic Granite Confining Unit & MGCU & \multirow[b]{2}{*}{$N P^{h}$} & MGCU & 1 & ICU \\
\hline $\begin{array}{l}\text { Lower Clastic Confining Unit 1- } \\
\text { Thrust Plate }\end{array}$ & LCCU1 & & LCCU1 & LCCU1 & LCCU_T1 \\
\hline $\begin{array}{l}\text { Lower Carbonate Aquifer-Thrust } \\
\text { Plate }\end{array}$ & LCA3 & LCA3 & LCA3 & LCA3 & LCA_T1 \\
\hline $\begin{array}{c}\text { Lower Clastic Confining Unit } 2 \text { - } \\
\text { Thrust Plate }\end{array}$ & LCCU2 & \multirow[t]{2}{*}{$N P^{h}$} & \multirow[t]{2}{*}{$N P^{h}$} & $N P^{h}$ & LCCU_T1 \\
\hline Upper Carbonate Aquifer & UCA & & & LCA3 & UCA \\
\hline Upper Clastic Confining Unit & UCCU & UCCU & UCCU & UCCU & UCCU \\
\hline Lower Carbonate Aquifer & LCA & LCA & LCA & LCA & LCA \\
\hline Lower Clastic Confining Unit & LCCU & LCCU & LCCU & LCCU & LCCU \\
\hline
\end{tabular}

Source: BN, 2006

alf correlative to more than one HSU, all HSUs are listed.

bSee BN (2005) for explanation of Frenchman Flat HSU nomenclature.

'See BN (2002) for explanation of Pahute Mesa/Oasis Valley HSU nomenclature.

dSee IT (1996e) for explanation of the UGTA Phase I HSU nomenclature.

eSee Section 2.5 for explanation of the DVRFS nomenclature.

'Subdivisions, though hydrogeologically equivalent, are necessary to satisfy operational requirements of the $\mathrm{EV}^{\circledR}$ modeling software.

gNot subdivided.

not present.

PBRCM may included minor embedded ash-flow tuffs. 
section, the Yucca Flat/Climax Mine HFM includes considerable structural detail and stratigraphic enhancement over both of the preceding regional HFM models included in the UGTA regional model (DOE/NV, 1997b) and the DVRFS model (Belcher et al., 2004). The total number of HSUs increased from 10 in the UGTA regional model, and 17 in the DVRFS model to 25; most of the increase affected the Quaternary-Tertiary alluvial section and the Tertiary volcanic section. Except for geometry details, the pre-Tertiary HSUs remain as initially defined, with the addition of the UCA and the LCCU2 thrust sheet.

\subsection{Hydrostratigraphic Unit Alternative Scenarios}

The Yucca Flat/Climax Mine HFM area is geologically complex (a surface geologic map is provided as Plate 1). Many of the major features within the valley are buried, and subsurface data are scarce in some areas. Portions of the model are thus necessarily simplified and represent non-unique solutions to the 3-D distribution of HSUs.

To address non-unique aspects of different interpretations within the base model, alternative interpretations were developed for portions of the base model. Many of the ideas for alternative scenarios were conceived and evaluated during construction of the base model. These initial alternative ideas were presented to the UGTA TWG pre-emptive review committee for their consideration and evaluation, and to solicit additional alternative ideas. Each alternative idea was evaluated and categorized, for which the main criterion was whether the proposed change or alternative interpretation had the potential to significantly affect groundwater flow and contaminant transport. The geological probability and how well constrained each alternative idea is, was also considered.

The alternatives were grouped into four priority categories. Group A alternatives are ideas judged to be significant and viable enough to be included in the base model. Two alternatives were identified as Group A and incorporated directly into the base model. These two alternatives replaced base model interpretations that were subsequently developed as alternative models (see below).

Five alternative ideas were identified as Group B alternatives, and were judged to be significant enough to develop as separate models. Each alternative was inserted into a copy of the base model, resulting in five separate alternative models. 
Group $\mathrm{C}$ alternatives may be potentially significant. If judged to be significant during hydrologic modeling, Group C alternatives would be addressed by varying the assignment of model parameters within the base HFM to address the alternative feature(s) of interest. There is one Group C alternative identified for the Yucca Flat/Climax Mine HFM that is associated with removing the hydrologic effect of the north-south trending ridge of low permeability LCCU2 along the Carpetbag-Topgallant fault system that is incorporated into the base HFM. This alternative could be explored during hydrologic modeling by changing LCCU2 hydrologic properties to LCA properties (BN, 2006).

Group D alternatives were deemed not significant or viable enough to warrant development as alternative models. These alternative ideas will not be considered further.

Following this evaluation of the alternatives, the base HFM model was updated using the Group A alternatives, and the alternatives placed under Group B were developed further into $\mathrm{EV}^{\circledR}$ (Version 7.5 by Dynamic Graphics, 2002) HFMs. The alternative models were constructed after the base model was completed, generally using the same model construction techniques. Each alternative model is equally bound by all the data and interpretation methods used for development of the base model. However, each alternative scenario is of limited geographic extent, and thus affects only a portion of the base HFM. The alternative HFMs are fully functional replicas of the base model that can be used to test whether the alternative interpretations affect flow and transport.

Alternative scenarios that the TWG pre-emptive review committee deemed important enough to pursue (Group B) are listed below in descending order of inferred potential impact.

- Alternative \#1 - CP Thrust

- Alternative \#2 - Hydrologic barrier in northern Yucca Flat

- Alternative \#3 - Contiguous UCCU in southwestern Yucca Flat

- Alternative \#4 - Fault juxtaposition

- Alternative \#5 - Partial zeolitization

A summary description of the alternative HSU models is provided in Appendix D, Section D.1.0. For details, see the report entitled: A Hydrostratigraphic Model for the Groundwater Flow and Contaminant Transport Model of Corrective Action Unit 97: Yucca Flat, Lincoln and Nye Counties, Nevada (BN, 2006). 


\subsection{Summary}

A new 3-D HFM for the Yucca Flat/Climax Mine CAU was completed in 2005 and published in 2006 (BN, 2006). The model area includes Yucca Flat and Climax Mine, former underground nuclear testing areas at the NTS, and proximal areas. The model area is approximately $1,250 \mathrm{~km}^{2}$ in size and is geologically complex.

A diverse set of geological and geophysical data collected over the past 50 years was used to develop a structural model and hydrostratigraphic system for the basin. These were integrated using $\mathrm{EV}^{\circledR}$ (Version 7.5 by Dynamic Graphics, 2002) software to develop the 3-D HFM. Fifty-six stratigraphic units in the model area were grouped into 25 HSUs based on each unit's propensity toward aquifer or aquitard characteristics. The alluvial section is divided into 3 HSUs including 2 aquifers and 1 confining unit. The volcanic units in the model area are organized into 13 HSUs that include 8 aquifers and 5 confining units. The underlying pre-Tertiary rocks are divided into 7 HSUs, including 3 aquifers and 4 confining units. Other units include 1 Tertiary-age sedimentary confining unit and 1 Mesozoic-age granitic confining unit. The model depicts the thickness, extent, and geometric relationships of these HSUs ("layers" or volumes in the model) along with the major structural features (i.e., faults). The model incorporates 178 high-angle normal faults of Tertiary age and 2 low-angle thrust faults of Mesozoic age. 


\subsection{Saturated Media Hydraulic Properties}

Values used for the hydraulic properties of HSUs in the simulation of groundwater flow and transport should be consistent with available information to provide confidence in the simulation results. Specifically, hydraulic conductivity is a basic parameter for groundwater flow modeling that determines the volumetric flow rate and is sufficient for steady-state modeling. Representative hydraulic conductivities for the formations to be modeled, at the scale over which the model is discretized, are integral to producing defensible model predictions. Previous UGTA groundwater flow models, such as the UGTA regional model (DOE/NV, 1997b) and the Frenchman Flat Phase II groundwater flow model (SNJV, 2006b) have incorporated depth-decay of hydraulic conductivity, and the relationship of hydraulic conductivity to depth is analyzed and characterized for the datasets to support this modeling feature. Storage properties of the formations are also of interest as a basic hydraulic parameter needed for transient simulations of groundwater flow. There are many uncertainties in the determination of representative parameter values, which will be discussed in this section, and an uncertainty analysis accompanies the use of the available data.

The assessment and analysis of hydraulic parameter data presented in this section serves several project needs for Yucca Flat/Climax Mine CAU Phase I modeling. The analysis produced statistical estimates for the range of hydraulic conductivity, depth-decay of hydraulic conductivity, and storage parameter values for the major HSUs/HGUs in the Yucca Flat/Climax Mine CAU. The analysis was conducted at two scales: the first using all of the regional data (NTS Investigation Area) for equivalent regional HGUs, and second at the CAU-scale (Yucca Flat/Climax Mine Data Compilation Area). There is substantially less Yucca Flat/Climax Mine CAU-specific data, which does not provide specific data for all relevant HSUs/HGUs, or sufficient data to determine statistics for those HSUs/HGUs for which there were data. The Yucca Flat/Climax Mine HFM is complex and many types of HGUs are represented by multiple HSUs. Some HGUs are directly equivalent to HSUs while others generally represent a variety of HSUs of similar character. The data were aggregated by HGU to provide sufficient data for statistical analysis. The basis for transferability of hydraulic 
parameter data is discussed. The discussion also addresses the relationship of hydraulic properties to the scale-of-measurement, the spatial variation of hydraulic properties, and the variation with depth. Information on anisotropy of hydraulic conductivity and variation due to temperature are presented.

Several recent studies have been conducted that provide different kinds of information on hydraulic parameters for Yucca Flat/Climax Mine HSUs. In 2004, the large scale MWAT-TT (tracer test) conducted at the ER-6-1 well site in southeastern Yucca Flat/Climax Mine in the LCA included 90 days of high-rate pumping. Aquifer response was monitored in a large network of wells in the LCA and TCU up to a 2-km distance. Analysis of the aquifer responses provides very large scale information on hydraulic properties of the LCA that were interpreted with respect to the fault system in that part of Yucca Flat/Climax Mine. The USGS and LANL completed separate studies in 2005 and 2006, respectively, of the hydrogeology of specific areas in west central Yucca Flat/Climax Mine known as the high pressure zone, part of which is the LANL Tuff Pile containment area. Pore pressure in the TCUs in these areas were affected by underground nuclear testing, increasing head measured in wells in the area by up to several hundred feet. These studies provide estimates of the hydraulic conductivity of the confining unit formations based on calibration of models simulating the head increase and subsequent slow decline and three studies are discussed the end of this section.

Finally, the state of knowledge of the hydraulic parameters is assessed, and the limitations of the available data are considered.

\subsection{Objectives}

The specific objectives for the hydraulic parameter assessment include the following:

- Compile and evaluate available hydraulic parameter data for use in the Yucca Flat/Climax Mine CAU Phase I flow modeling.

- Determine appropriate ranges and distributions for hydraulic conductivity, hydraulic conductivity depth-decay, and specific storage for Yucca Flat/Climax Mine HSUs/HGUs.

- Assess the relationship of hydraulic conductivity with scale of measurement, spatial variation of hydraulic conductivity within the Yucca Flat/Climax Mine CAU, and the dependence of hydraulic conductivity on subsurface temperature. 


\subsection{Data Types and Prioritization}

Hydraulic conductivity, or intrinsic permeability (hereafter referred to as permeability) in the case of models that include temperature, is the primary hydraulic parameter used to simulate groundwater flow under steady-state conditions. Transmissivity, the product of hydraulic conductivity and transmissive thickness, is conceptually the property that varies at the scale of HSUs, and defines units of hydrostratigraphic character that have consistent hydraulic properties. Transmissivity within the groundwater flow model is determined by nodal hydraulic conductivity values and node spacing. The HSU thickness is determined from the HFM. Transmissivity is calibrated in the groundwater flow model through adjustment of the nodal hydraulic conductivities, because the thickness of the HSU is fixed by the HFM. As a result, the calibration parameter for the flow model is hydraulic conductivity. Hydraulic conductivity is the variable analyzed for variability and uncertainty. Hydraulic conductivity is obtained directly from either analytic or numeric analysis of the hydraulic response measurements (drawdown or recovery data) that incorporate an assumed transmissive thickness, or calculated by dividing the transmissivity obtained from analysis by the test interval or other transmissive thickness.

Storage information is secondary, because the transport model will be based on steady-state groundwater flow conditions. However, this information is needed to perform transient runs, which may be used for model verification.

\subsection{Data Compilation and Evaluation}

The SNJV maintains a working groundwater data compilation that contains a hydraulic properties table with information on hydraulic testing and analysis results for a large area of southern Nevada. This data compilation was originally developed to support regional flow modeling for the UGTA program and contains the transmissivity and/or hydraulic conductivity values compiled for interpretations of aquifer, packer, and slug tests, laboratory permeability, and grain size analyses. The data compilation includes supporting information such as well information for each test, test parameters, stratigraphy and lithology for the borehole, information on the analysis, and the data source. Storage parameter data were also compiled for MWATs, which are generally accepted as the only reliable basis for determining storage values. However, storage parameter data are less available, because MWATs are not commonly performed. There is a variety of storage data for the 
NTS Investigation Area but only a few values for the Yucca Flat/Climax Mine Data Compilation Area. The data compilation was updated for this analysis with additional data from recent Yucca Flat/Climax Mine Phase I data collection activities not included in the previous analyses for the Frenchman Flat Phase II hydrologic data document (SNJV, 2004e).

\subsubsection{Data Sources}

Hydraulic property data were obtained from published and unpublished sources. Published data were obtained from reports by the following organizations: DRI, IT Corporation, LANL, LLNL, Sandia National Laboratories, Shaw Environmental, Inc., SNJV, USGS, and a variety of other organizations. Publications providing hydraulic parameter values may or may not include the raw and/or reduced drawdown and/or recovery data and specifics for the interpretation. An effort was made to acquire full documentation for each test, and the extent of documentation acquired is reflected in the DDE_F qualifiers, discussed in Section 6.3.3. Specific references for data sources are listed in the data compilation. Evaluation of the actual drawdown or recovery data available was important for assessing the adequacy of the interpretation and for assigning the data confidence identifiers. Unpublished data and interpretations were obtained from DRI, the USGS, and the ER Contractor files as part of the ERP. Unpublished test interpretations are only preliminary interpretations. Copies of all data sources, including unpublished data and interpretations for entries in the data compilation, are filed in SNJV Central Files.

\subsubsection{Supporting Data}

Data necessary for the hydraulic parameter data analysis include site information, well construction, hydrostratigraphic information, and hydrologic test information and include the following data types:

\section{Site Information}

- Reporting name

- Site location

- Land-surface elevation

\section{Test Interval Information}

- Top and bottom elevations of the tested interval

- Stratigraphic unit for the test interval

- HSU designation 


\section{Hydraulic Test Information}

- Test start date

- Pumping rate

- Pumping duration

- Data availability

\section{Test Interpretation Information}

- Method of analysis

- Organization performing the analysis

- Hydraulic conductivity

- Transmissivity

- Storage coefficient

- Data documentation evaluation flag

- Data quality evaluation flag

Most of these categories are self-explanatory except for the data quality identifiers, which are described later in this section.

\subsubsection{Data Quality Assurance}

Data qualification for the hydraulic parameters analysis was based on the requirements described in Section 4.3.3 and are applied as described below.

\section{Data Documentation Evaluation}

Documentation of the data for the primary parameters of concern (i.e., hydraulic conductivity and storage) was evaluated, and values were assigned to the Flag DDE_F according to data documentation requirements in Section 4.3.3.1.

\section{Data Quality Evaluation}

Data quality relative to the use of the hydraulic parameter analysis results is a function of the representativeness of the derived parameter value statistics. It was decided that the most representative statistics would be determined using all data rather than only the highest quality data. In cases where there were many data values for an HSU/HGU, the statistical analysis is expected to preclude the undue influence of any particular data value. In cases where there were few HSU/HGU data, there is an insufficient basis to identify questionable data. Many historical test results actually may be high quality, but cannot be objectively identified as such from the available records. 
Consequently, DQE_Fs were not assigned as they had been in the regional model report. Data quality evaluation procedures have been re-evaluated in the data transferability TBD (SNJV, 2004f), and revised procedures will be considered for future analyses. For the Yucca Flat/Climax Mine Phase II data analysis, data quality evaluation was handled according to ranking the suitability of the data for use in CAU modeling.

\subsubsection{Data Transferability}

Data transferability (see Section 4.3.2 for a general discussion) pertains to the use of hydraulic property data from the NTS Investigation Area outside of the Yucca Flat/Climax Mine area to characterize HSUs for Yucca Flat/Climax Mine modeling. The HSUs of the Yucca Flat/Climax Mine HFM include those common throughout the region such as the AA, MGCU, UCCU, LCA, and LCCU and a multiplicity of volcanic HSUs specific to Yucca Flat/Climax Mine stratigraphy but similar to volcanic HGUs in hydrogeologic character on the regional scale. When categorized at the HGU level, formations in Yucca Flat/Climax Mine are directly equivalent to formations at the regional scale. The NTS Investigation Area was originally defined to support the UGTA regional model (DOE/NV 1997b) and includes data from a much larger area than the NTS. Analysis of the dataset for this larger area is included in CAU-specific data evaluation to fill out the distributions of data with information thought to be appropriate. The results for the two scales of data completion and analysis can be directly compared to evaluate the transferability.

All of the data from within the NTS Investigation Area were analyzed with respect to regional HGUs and the scale of the test. Data transfer of hydraulic property data from outside of the Yucca Flat/Climax Mine CAU was handled as a function of correlating the tested formation for each analysis to a breakdown of HGUs. The assignment for each analysis result was based on cross-referencing regional HSU/HGUs with Yucca Flat/Climax Mine HSU/HGUs according to the tables in Section 2.0, as well as evaluation of the stratigraphic and lithologic information specific for each well. The scale of the HFM (does not perfectly honor the specific geology of each well), as well as situations where tested intervals included multiple HSUs/HGUs of different character, required individual interpretation of HSU/HGU applicability. As mentioned previously, the analysis was conducted at both the regional- and CAU-specific scale. Comparisons of Yucca Flat/Climax Mine-specific distributions and the correlated regional HGU parameter distributions provides guidance to modelers in the use of the two distributions. 
A substantial amount of the data used in the NTS Investigation Area analysis was obtained from sites associated with Yucca Mountain, which is located southwest of the Yucca Flat/Climax Mine Data Compilation Area. Justification for the use of YMP data was provided in Section 4.3.2.3 and Appendix B of the Hydrologic Data for the Groundwater Flow and Contaminant Transport Model of Corrective Action Units 101 and 102: Central and Western Pahute Mesa, Nye County, Nevada (SNJV, 2004c).

\subsection{Hydraulic Parameters}

Two hydraulic parameters, hydraulic conductivity and specific storage, are characterized in this section. Hydraulic conductivity is the primary parameter of interest and is sufficient for steady-state modeling. The storage properties of the rock units are characterized in the form of specific storage, which would be used for transient modeling.

Hydraulic conductivity is a property that varies by location within a rock unit, and is necessarily averaged over a volume of rock in the process of testing. The value measured for hydraulic conductivity depends on the particular volume of rock tested (i.e., well location and radius of influence). Different test methods and specifications can produce different results at a location as a function of the scale of the test (i.e., the specific volume of rock tested). Characterization of hydraulic conductivity of an HSU can take several forms, and the appropriate form of the characterization depends on the intended use of the data. Conducting many tests at different locations or of different volumes within a particular rock unit (defined by HSUs for this analysis) produces a range of hydraulic conductivity values.

The data can be considered as location specific, pertaining to a specified volume of the rock unit for each test value. This characterizes the variability as a spatial property. However, when the subject rock unit (HSU across the area of interest) is very large, only a small percentage of the total volume of the subject unit is typically characterized, leaving much of the unit uncharacterized even when many tests are conducted. An alternate type of characterization is determination of a parametric probability model for the test parameter values, which can then be used to define a probability density function (PDF) for the data. The distribution fitted to the data provides information that can be used to constrain the fitting of generalized values for hydraulic conductivity to rock volumes that do not correspond to the original test volumes. Comparison of the parameter values used for HSUs in the 
calibrated model to the PDFs for the HSUs can provide confidence in the appropriateness of the calibrated value. This latter type of characterization is the primary approach used in this analysis.

In addition to the variability of the hydraulic conductivity values across the HSU, there are a variety of uncertainties inherent in the determination of the values that are embedded in the data. Uncertainty is related to the suitability of the test method, test measurement accuracy, appropriateness of the analysis method for the test, and assumptions made about the test and interval tested. The uncertainty in the analyses results is difficult to quantify and is not readily separable from the variability described by the parametric probability model. The total uncertainty resulting from these factors may be substantial and potentially increase the apparent variability. This is evident in cases where several different analyses of the same test, or analyses of different tests on the same well, produced very different results.

\subsubsection{Scales of Test Data and Applicability}

The scale of the test is recognized as an important factor for the representativeness of the test result for use in modeling (Rovey and Cherkauer, 1995). For the purpose of modeling groundwater flow on a large scale, parameter values representative of groundwater flow at larger scales are more appropriate than values representative of smaller scales of measurement. The larger-scale data better reflect the overall hydraulic character of formations, which are modeled as consistent at the HSU scale. Additionally in fractured rocks, the scales of the data are important to capture the effect of fracturing on the overall properties. The data were analyzed in separate groups for the three distinct scales of tests as follows:

- Pumping-scale tests are considered to provide the most appropriate information for use in large-scale modeling, because they provide results representative of the greatest aquifer volume and are more likely to reflect high hydraulic conductivity structure in tested formations. Multi-well pumping tests (with observation wells) provide better quality information but are less common.

- Slug test-scale tests (including packer tests) provide less representative information, test smaller volumes of formations (both vertical interval and radius), are more affected by local variability and effects related to drilling, construction, and test methods.

- Laboratory-scale tests may provide data somewhat applicable to unfractured and/or granular media formations but are not appropriate for characterizing large-scale formation properties 
for formations that are dominated by fractures. These data can provide hydraulic conductivity information on matrix properties of fractured formations.

The pumping-scale tests are conducted in situ on short to long test intervals (typically in the range of 30 to $305 \mathrm{~m}$ or more) moving relatively large volumes of water to induce pressure, and possibly dewatering responses in the test formation, over relatively long periods of time (typically 12 hours to 90 days). These methods test much larger volumes of rock extending relatively large distances from the borehole. The response in the pumping well may be substantially affected by near borehole conditions reflecting drilling damage, but responses measured in remote observation wells provide data unaffected by local formation damage. Tests with observation wells provide better quality information, because the observation well responses are not affected by well losses and near-borehole effects that are difficult to correct in the analysis of the test. Such tests can also provide directional property data. Depending on the length of the test, the test may reveal different aspects of the formation response that are related to time or distance from the well.

The slug- and packer-test scale tests are conducted in situ on fairly short test intervals (typically in the range of about 2 to $15 \mathrm{~m}$ ) using small volumes of water (from several to hundreds of gallons) to induce pressure pulses that equilibrate in a relatively short period (ranging from seconds to days). These methods test a relatively small volume of rock in the immediate area of the borehole. The results may be substantially influenced by near-borehole conditions that reflect drilling damage to the formation and effects from the well completion. In highly conductive formations, packer-test equipment may restrict flow and produce unrepresentative results. Slug-test results may also reflect test effects that substantially reduce the accuracy of test interpretation. The small volumetric stress on the rock unit associated with these methods do not produce good results in high-conductivity media.

The laboratory scale comprises measurements made on small samples (typically of about 1,000 to 2,000 cubic centimeters $\left[\mathrm{cm}^{3}\right]$ ) removed from the natural environment by various means and placed into a test apparatus in the laboratory. Samples may be chosen to be representative for the purpose, but the criteria used to determine representativeness are not always documented and are not necessarily consistent between different test sets. Rock/core samples tested are intact, and exclude features (such as fractures) that are not preserved in handling. Measurements are then made that generally represent the hydraulic conductivity of the intact matrix. Unconsolidated materials may be 
reasonably preserved in their natural state or repacked for testing. In some cases, the hydraulic conductivity for unconsolidated samples may be calculated from a grain size analysis.

\subsubsection{Test Analyses and Associated Uncertainties}

Larger-scale tests average hydraulic responses across larger volumes of rock, resulting from both longer vertical test intervals and greater radii, around the well contributing to the response. However, inhomogeneities that may be present within the larger test volume introduce uncertainties in the analyses of such tests. The uncertainties can result from undefined conditions or variability in the tested formation that are not accounted for in the test analyses, and the interaction of multiple conditions resulting in responses that do not strictly conform to one or another analysis model. For many tests, insufficient characterization data for the tested formation are available, and insufficient data are collected during testing to determine the components of the aquifer response that would eliminate uncertainties in analysis. Analyses generally used analytic models that represent one theoretical model for the response, and do not allow discrimination of multiple types of responses combined in the measured response. In many cases, it is difficult to determine which of several potentially appropriate conceptual models is correct for the response. Consequently, analysis results often reflect somewhat of an average of different additive responses, and a simplistic model to characterize the formation response. Data collection for many older tests was fairly limited regarding both the accuracy of equipment and the completeness of records, and the data does not support detailed analysis to identify, much less separate out, features of the overall response that may be attributed to operational conditions. Also, a significant weakness of much of the available data is that it is derived from analyses of single well tests. Such tests have added uncertainty because production losses, well losses, and near-borehole effects are combined with the formation response, and often are not or cannot be accounted for in the analysis of the test. Often there are large variations in property values determined for such tests depending upon the assumptions made for analysis of the test data.

\subsubsection{Handling of Multiple Test Results for One Well}

There are several situations that produce multiple test analysis results for one well. First, is the case in which there are multiple analyses of a single test. The multiple analyses can include analyses by different analysts, different analysis models applied to a test, or variations of assumptions made for a particular test analysis. Second, is the case with multiple, independent tests conducted in a well, 
usually with different test parameters. The third case is when there are multiple test intervals for a well resulting from changes in the well completion, temporary restrictions of the test interval for multiple tests, or different interpretations of the test interval based on various types of information.

The objective of this analysis was to identify independent measurements of hydraulic conductivity and to statistically characterize the variability of hydraulic conductivity, within the context of similar formation character (lithology, stratigraphy, hydraulic character), that could be translated to the HFM. Where there were multiple results for the same well and the same transmissive interval, multiple hydraulic conductivity values were averaged. This included multiple tests and multiple analysis models, assuming these represented testing and analysis uncertainty. However, variations in analysis assumptions that identified different tested intervals were treated as independent results, because the particular volume of formation tested embodied in the analysis was interpreted to be different.

\subsection{Analysis of Hydraulic Conductivity Data}

Analysis of the hydraulic conductivity data included separate evaluations of pumping-scale, slug test-scale, and laboratory-scale data to determine statistics for the hydraulic conductivity at each scale. A more detailed review of the pumping-scale data is presented, because these data are most relevant for use in large-scale modeling. The slug test-scale analysis results may be viewed as supporting the pumping-scale results but is not as relevant due to the smaller scale of the tests. The laboratory-scale data analysis is relevant to matrix properties of the formation, which may be useful for some purposes, but does not appropriately address the large-scale properties of the formation for flow modeling.

The data compilation for hydraulic property information includes data for a large area encompassing the NTS called the NTS Investigation Area (see Figure 1-2). This area was originally specified for the UGTA regional model (DOE/NV, 1997b) to determine hydraulic property values for that model. The geology within this area is relatively consistent with the NTS geology, and data for this area are considered to be generally relevant to formation hydraulic properties across the NTS and to Yucca Flat/Climax Mine in particular. Analysis was conducted for data from this area based on generalized classification of the tested formations by HSU/HGU. Analysis of data specific to the Yucca Flat/Climax Mine CAU was also conducted using data from the data compilation for an area defined as the Yucca Flat/Climax Mine CAU Data Compilation Area (see Figure 1-2). The spatial 
distribution of the hydraulic conductivity data is discussed first to show the extent to which the available data represent the Yucca Flat/Climax Mine CAU and the NTS Investigation Area overall.

The analysis was conducted specific to the Yucca Flat/Climax Mine HFM. However, the multiplicity of HSUs in the HFM resulted in relatively few data points for many of the individual volcanic HSUs. Also, there was no direct correlation of many of the Yucca Flat/Climax Mine HSUs to the regional HSUs. Consequently, the data were organized by HGUs on both the regional- and CAU-specific scales. The HGUs correspond to HSUs for the units of distinct character and provide broad categories for the volcanic units to which the Yucca Flat/Climax Mine HSUs can be correlated.

The analysis provides information on the available data including the number of independent data points, data range, minimum and maximum values, and statistics for log $\mathrm{K}$, including the mean and standard deviation, for each HSU at each test scale. For each CAU, an HSU-specific dataset having more than a few data points was evaluated for conformance to a log-normal distribution (Section 6.5.2). The 95-percent confidence interval was calculated for datasets for which a distribution was determined. Summary tables of the results are presented for CAU-specific data and all data within the NTS Investigation Area.

\subsubsection{Methodology}

This subsection summarizes the approach and methods used during the Phase I assessment of the hydraulic parameter dataset for the Yucca Flat/Climax Mine CAU. The following approach was used to define ranges for hydraulic conductivity and storage parameters for the HGUs in the Yucca Flat/Climax Mine CAU and for the NTS Investigation Area:

- Hydraulic parameter data have been compiled from published and unpublished sources into a data compilation. Information associated with each entry includes the location, test date, type of test, test parameters, tested interval, method of analysis, borehole lithology and stratigraphy, HSU(s) corresponding to the tested interval, analysis results, and a source reference for the information.

- The analysis was conducted on hydraulic conductivity and specific storage parameter values. Hydraulic conductivity is essentially a unit value for formation transmissivity and specific storage is a unit value for storativity. All hydraulic conductivity values are associated with a defined interval of the formation tested. Some test analysis methods return transmissivity values, which are scaled to hydraulic conductivity using the tested interval thickness, and 
others return hydraulic conductivity values based on the input interval thickness. In all cases, hydraulic conductivity values are based on interpretations of the tested interval thickness. The situation is similar for specific storage versus storativity. These normalized parameters allow evaluation of variations with depth (assigned to the midpoint of the tested interval) and location (assigned to the well location).

- The hydraulic parameter dataset included information for wells within a large area encompassing the NTS. Data analysis is conducted on two scales: CAU-specific data from wells located within the Yucca Flat/Climax Mine Data Compilation Area, and data within the NTS Investigation Area, which encompasses the NTS (see Section 1.2). The NTS Investigation Area dataset was first filtered from the data compilation. The Yucca Flat/Climax Mine-specific datasets were filtered from the NTS Investigation Area datasets after separation according to scale of the test and by HGU.

- The NTS Investigation Area dataset was separated into three datasets based on the scale of the test from which the parameter values were derived. The three scales were pumping-scale, slug-test scale, and laboratory-scale data.

- The data at each scale were then separated into HGU-specific datasets for the transmissive interval, which are more generalized than HSUs and apply at both analysis scales. The HGUs correspond closely to HSUs for formations of distinct character (e.g., AA, MGCU, UCCU, LCA/UCA/LCA3, and LCCU) and generally characterize the multiplicity of volcanic HSUs within the categories of volcanic aquifers (VAs), LFAs, and TCUs. In cases where multiple HGUs were present in the identified test interval, the test results were assigned to the HGU with the greater mean hydraulic conductivity unless other information indicated a more appropriate assignment.

- A nominal hydraulic conductivity was identified for each data entry using (in priority order) the average hydraulic conductivity, horizontal hydraulic conductivity, fracture hydraulic conductivity value, or transmissivity divided by the specified transmissive interval thickness. Where a transmissive interval thickness was not specified, the total length between the top and bottom of the transmissive interval was used. The mid-point depth of the test interval for each test result was also determined from the transmissive interval data.

- In fractured rocks, three types of hydraulic conductivities can be defined: bulk hydraulic conductivity, fracture hydraulic conductivity, and matrix hydraulic conductivity. A generalized measurement over a vertical interval is termed the bulk hydraulic conductivity. In cases where the formations are fractured, the hydraulic conductivity associated with the fracture system and associated with the matrix may be determined separately, depending upon the tests measurements and analysis methods. In general, the bulk hydraulic conductivity will be similar to the fracture-associated hydraulic conductivity, and matrix hydraulic conductivity will be significantly lower.

- In some cases, more than one test result or interpretation of a test for a test interval is available. Before further analysis, multiple results for a single test interval were 
arithmetically averaged. Results were not averaged for a well when different test intervals were specified or when different transmissive thicknesses were specified for the same test interval.

- The hydraulic conductivity data were then transformed to log base 10 values for analysis based on the assumption of log-normal distribution, to which hydraulic conductivity has been shown generally to conform, and which is verified in the later analysis.

- The resulting sets of unique location and depth-specific log base 10 hydraulic conductivity values were then statistically analyzed to determine the range, mean, SD, the correspondence to a log-normal probability distribution, and the 95-percent confidence interval where there were sufficient data. The results are presented in tables and displayed graphically.

- For datasets containing a large number of unique hydraulic conductivity values, the relationship of log base 10 hydraulic conductivity to transmissive interval midpoint depth were evaluated by performing regression of log base $10 \mathrm{~K}$ against midpoint depth of the test interval, to determine $\mathrm{K}_{0}$ (hydraulic conductivity surface intercept) and Lambda (regression slope). Also, 1 and 2 SDs for both parameters were calculated.

- The dataset for each HGU at the pumping-scale was screened for storage parameter values; general specific storage and fracture specific storage. Where storativity was reported, the data were normalized to specific storage by dividing storativity values by the transmissive interval thickness (as previously specified). The mean and SD for these data were calculated on an HGU basis. Probability distributions were calculated for specific storage and are displayed graphically by HGU.

\subsubsection{Kolmogorov-Smirnov Test for Log Normality}

Typically hydraulic conductivity variability has been found to be distributed according to a log-normal distribution. To the extent possible, it was desirable to determine whether the hydraulic conductivity values for each HSU conformed to such a distribution. Where there were sufficient data, the datasets for each HSU (at each scale) were tested for conformance with a log-normal distribution. A Kolmogorov-Smirnov (K-S) test (Benjamin and Cornell, 1970) was applied at the 5-percent level of significance to the empirical cumulative distribution function (ECDF) of the measured data. The test for $\log$ ECDF normality and an estimate of the range of uncertainty in the log-normal parameters is determined from the K-S statistic, D. The $\mathrm{D}$ is a measure of the maximum difference in cumulative probability between the data ECDF and the theoretical (log normal) cumulative density function (CDF). The difference is calculated for each measured datum(i); therefore, the data frequency is defined as $\mathrm{i} / \mathrm{n}$, where $\mathrm{n}$ is the total number of independent data points. This differs from a normal probability plot which is calculated using a frequency of $\mathrm{i} /(\mathrm{n}+1)$. A critical K-S statistic, $\mathrm{D}^{*}$, is then 
defined based on the number of data samples and the significance level (0.05). If the observed difference between the ECDF and CDF, D, is greater than the critical difference between distributions, $\mathrm{D}^{*}$, the null hypothesis (i.e., that the measured and theoretical distributions are statistically equal) is rejected.

For the figures illustrating the results of the K-S test, D is used to construct upper and lower bounding curves that define the smallest region of uncertainty for which the null hypothesis is not rejected. Similarly, $\mathrm{D}^{*}$ could be used to define the complete region of uncertainty for the measured data when the theoretical distribution and significance levels are specified. Within the K-S bounds, it is possible to observe the range of parameters describing the log-normal CDF. If the SD is held fixed (i.e., holding the slope constant), the mean can be shifted by some amount and remain within the bounds. Similarly, if the mean is held fixed but the slope of the CDF is varied, the SD could vary some amount. The two ranges cannot be varied simultaneously to their limits, or the model would no longer remain within the K-S bounds.

\subsubsection{Spatial Distribution of Data}

Figure 6-1 shows the locations of wells and boreholes for which hydraulic conductivity (or permeability) data are found in the data compilation. The locations are identified with three different symbols corresponding to the three scales of test information. In some cases, more than one scale of test is available at a single location. The data are not uniformly distributed throughout the NTS Investigation Area. Rather, the data are clustered in areas on the NTS where underground nuclear testing was performed, major construction facilities were located, or where ER drilling and testing activities have taken place. Off the NTS, data are generally located in areas of human settlement and activity or in areas of interest for resources. Note the cluster of data on the southwestern border of the NTS associated with the YMP.

Figure 6-2 shows the distribution of data within the Yucca Flat/Climax Mine CAU and the HSU to which the data pertains. As shown on the map, a relatively small number of locations with hydraulic property data are available for the Yucca Flat/Climax Mine CAU and most of what is available is for the LCA. 


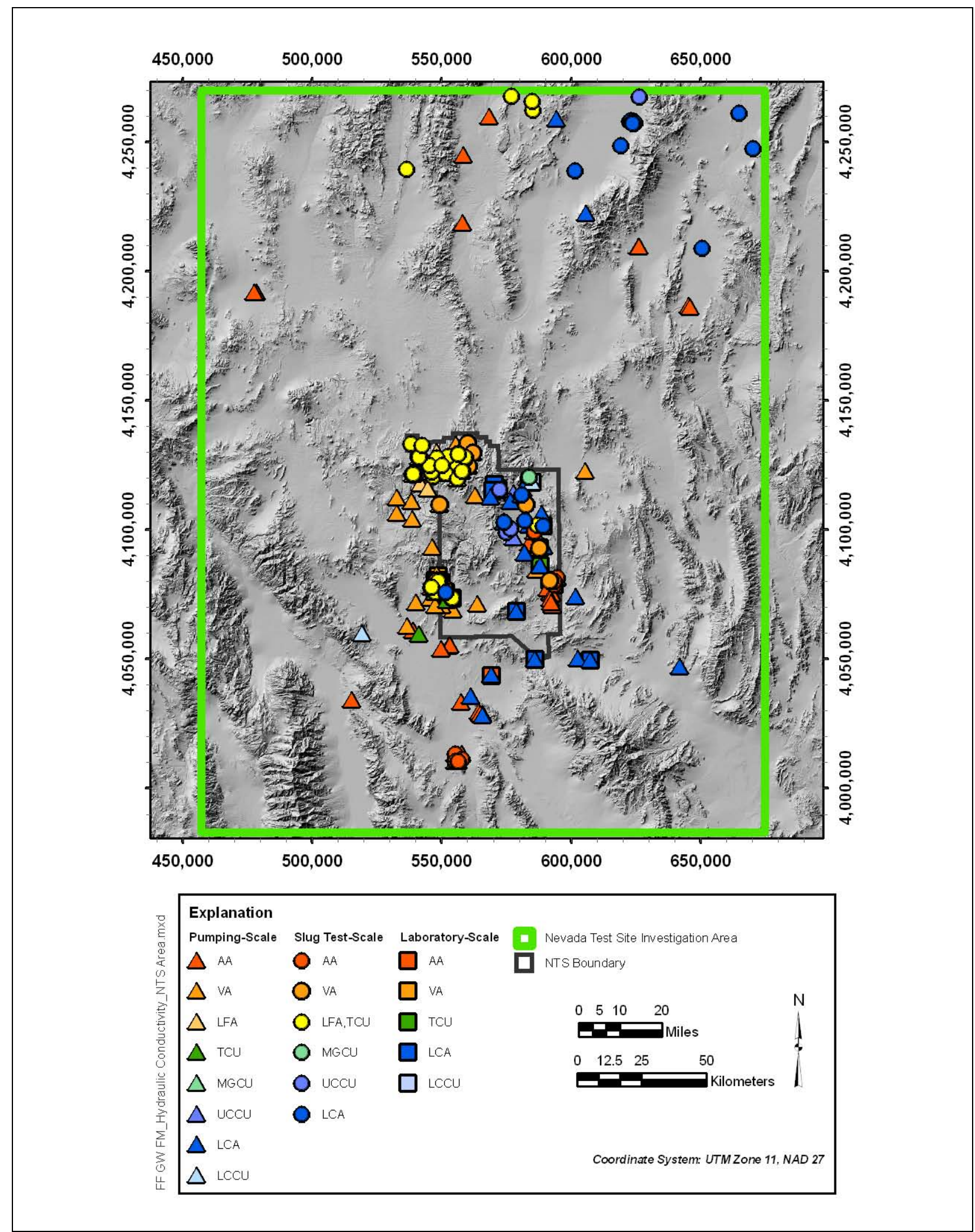

Figure 6-1

NTS Investigation Area Locations of Hydraulic Conductivity Data 


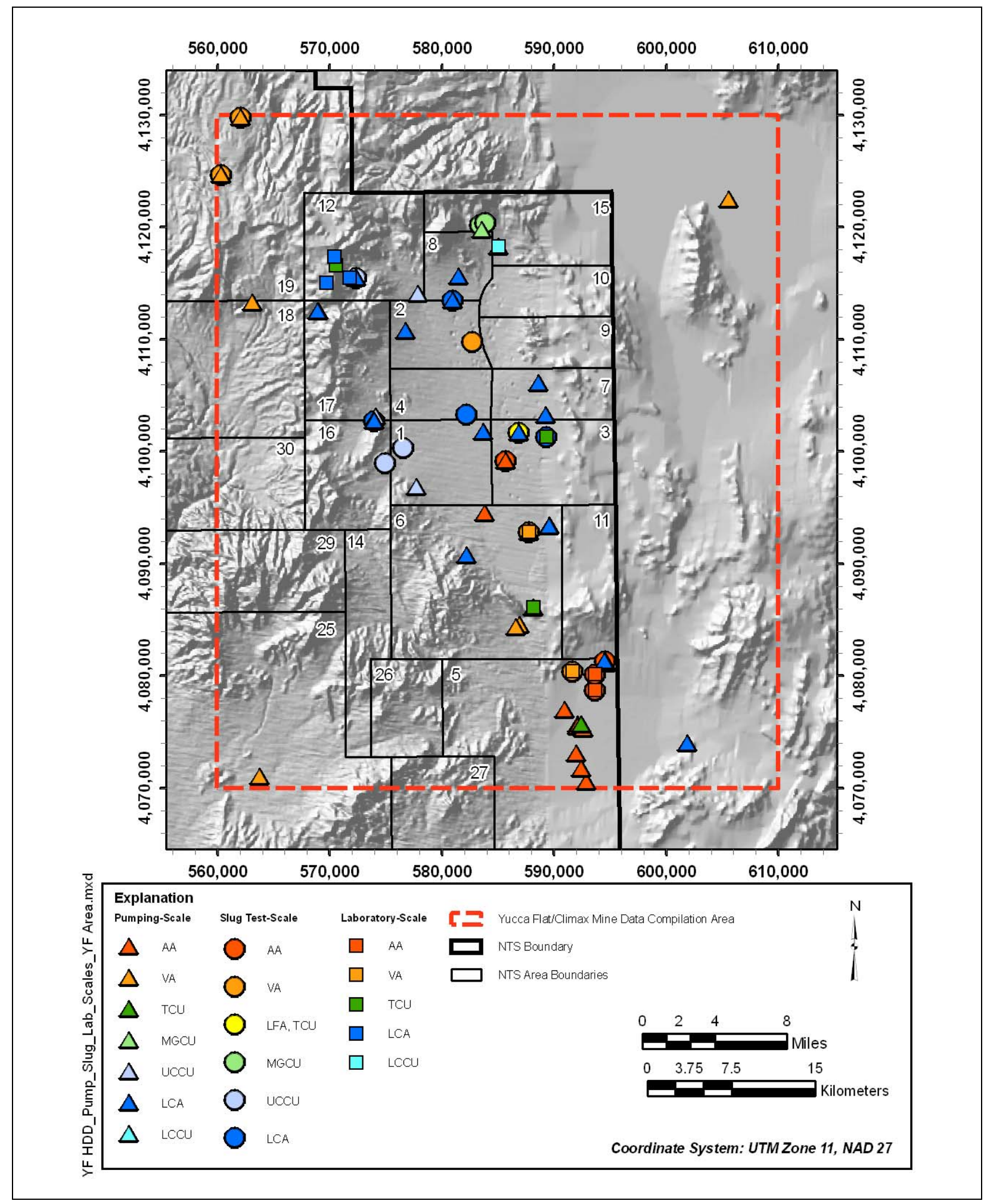

Figure 6-2

Yucca Flat/Climax Mine Hydraulic Property Data Location 
An analysis of spatial variability of hydraulic properties was not attempted due to the lack of sufficient data with appropriate spatial distribution and supporting information. Within most HGUs, the hydraulic conductivity is assumed to be primarily related to fracturing, and spatial variability would be related to proximity to structural features affecting fracturing. The hydraulic property data would have to be analyzed in conjunction with a structural model and fracturing characterization.

\subsection{Analysis Results}

This section provides summary tables and graphs of the results of the analyses. The following section provides detail on the individual HGU-specific analyses for both the CAU-specific data and the NTS Investigation Area data. Where available data supported testing for log-normal distributions, a graph of the K-S test result is shown.

\subsubsection{Hydraulic Conductivity Analysis}

Table 6-1 presents a summary of the analyses of Yucca Flat/Climax Mine-specific hydraulic conductivity data, and Table 6-2 presents a summary of the analyses of hydraulic conductivity data within the NTS Investigation Area. These tables show the results of the test by scale for each HGU (where data are available). The extent to which statistics could be developed for each dataset dependent upon the number of unique data values available. The ultimate aim was to determine the type of distribution for the property and define the distribution with confidence; however, this requires a substantial number of values in the dataset. The column "Count" in these tables indicates the number of unique data values for each analysis. In the last column, "Number of Entries" indicates the number of data compilation entries for the category that were aggregated to determine unique data values, and the "Number of Wells' indicates the number of different wells that these entries represent. The methodology used for determine unique entries was described in Section 6.5.1. The standard deviation of the mean of the population was estimated at the 95 per cent confidence level.

As can be seen in Table 6-1 and Table 6-2, extensive datasets were available for many of the HGUs at both areal scales and the three test scales. The HGU basis for analysis resulted in a substantial increase in the size of the category datasets compared to the HSU analysis in the Frenchman Flat hydrologic data document (SNJV, 2004e). The HGU assignments, based on multiple criteria, allowed assignment of many more data compilation entries as compared to HSUs assigned according 
Table 6-1

Summary of Yucca Flat/Climax Mine-Specific Hydraulic Conductivity Analysis

\begin{tabular}{|c|c|c|c|c|c|c|c|c|c|c|c|c|}
\hline \multirow{3}{*}{ HGU } & \multirow{2}{*}{ Mean } & \multicolumn{2}{|c|}{$\begin{array}{l}\text { Standard } \\
\text { Deviation }\end{array}$} & \multirow{3}{*}{ Count } & \multirow{2}{*}{ Minimum } & \multirow{3}{*}{ Maximum } & \multirow{3}{*}{$\begin{array}{c}\text { K-S } \\
\text { Critical } \\
\text { Statistic } \\
\text { D* }^{*}\end{array}$} & \multirow{3}{*}{$\begin{array}{c}\text { K-S } \\
\text { Statistic D } \\
\text { at } 95 \%\end{array}$} & \multirow{3}{*}{$\begin{array}{c}\text { Accept } \\
\text { Log-Normal } \\
\text { Hypothesis }\end{array}$} & \multicolumn{2}{|c|}{$\begin{array}{l}\text { 95\% Confidence } \\
\text { Interval Bounds }\end{array}$} & \multirow{3}{*}{$\begin{array}{c}\text { Number of } \\
\text { Entries/ } \\
\text { Number of } \\
\text { Wells }\end{array}$} \\
\hline & & Data & Population $^{a}$ & & & & & & & Lower & Upper & \\
\hline & \multicolumn{3}{|c|}{$\log 10$ K (m/day) } & & $\log 10$ K (m/day) & & & & & \multicolumn{2}{|c|}{$\log 10 \mathrm{~K}$ (m/day) } & \\
\hline \multicolumn{13}{|c|}{ Pumping-Scale } \\
\hline$\overline{\mathrm{AA}}$ & -0.13 & 0.93 & 0.41 & 22 & $\begin{array}{c}-1.47 \\
\end{array}$ & 2.39 & 0.17 & 0.29 & Yes & -1.96 & 1.70 & $70 / 12$ \\
\hline VA & 0.23 & 1.10 & 0.52 & 20 & -2.39 & 1.79 & 0.13 & 0.30 & Yes & -1.93 & 2.39 & $40 / 9$ \\
\hline$\overline{T C U}$ & -1.07 & & & 1 & & & & & & & & $1 / 1$ \\
\hline MGCU & -2.49 & & & 1 & & & & & & & & $1 / 1$ \\
\hline UCCU & -2.64 & 1.15 & 2.85 & 3 & -3.48 & -1.33 & & & & & & $3 / 3$ \\
\hline LCA & 0.03 & 1.31 & 0.44 & 36 & -2.85 & 2.10 & 0.12 & 0.23 & Yes & -2.53 & 2.58 & $175 / 20$ \\
\hline LCCU & -2.21 & & & 1 & & & & & & & & $1 / 1$ \\
\hline \multicolumn{13}{|c|}{ Slug Test-Scale } \\
\hline AA & -0.40 & 0.38 & 0.39 & 6 & -0.97 & 0.04 & 0.16 & 0.56 & Yes & -1.13 & 0.34 & $16 / 4$ \\
\hline VA & -1.98 & 0.84 & 0.45 & 16 & -2.94 & 0.09 & 0.16 & 0.34 & Yes & -3.64 & -0.33 & $35 / 5$ \\
\hline LFA, TCU & -2.38 & 0.56 & 0.40 & 10 & -3.28 & -1.36 & 0.09 & 0.43 & Yes & -3.47 & -1.28 & $10 / 3$ \\
\hline MGCU & -1.16 & 1.78 & 4.42 & 3 & -3.19 & 0.15 & & & & & & $3 / 3$ \\
\hline UCCU & -1.99 & 0.73 & 1.17 & 4 & -2.65 & -1.16 & & & & & & $4 / 4$ \\
\hline LCA & -1.03 & 0.46 & 0.35 & 9 & -1.54 & -0.32 & 0.18 & 0.45 & Yes & -1.92 & -0.13 & $11 / 4$ \\
\hline \multicolumn{13}{|c|}{ Laboratory-Scale } \\
\hline AA & -0.34 & 0.71 & 0.18 & 60 & -2.92 & 0.70 & 0.70 & 0.18 & No & -1.73 & 1.05 & $60 / 3$ \\
\hline VA & -2.09 & 0.81 & 0.67 & 8 & -3.09 & -1.09 & 0.22 & 0.48 & Yes & -3.67 & -0.51 & $8 / 3$ \\
\hline TCU & -3.57 & 1.14 & 0.40 & 34 & -6.00 & -1.55 & 0.10 & 0.23 & Yes & -5.81 & -1.34 & $34 / 3$ \\
\hline LCA & -5.21 & 0.40 & 0.63 & 4 & -5.52 & -4.70 & & & & & & $4 / 3$ \\
\hline LCCU & -6.56 & 0.66 & 0.25 & 30 & -7.54 & -4.69 & 0.16 & 0.25 & Yes & -7.86 & -5.26 & $30 / 1$ \\
\hline
\end{tabular}


Table 6-2

Summary of NTS Investigation Area Hydraulic Conductivity Analysis

\begin{tabular}{|c|c|c|c|c|c|c|c|c|c|c|c|c|}
\hline \multirow{3}{*}{ HGU } & \multirow{2}{*}{ Mean } & \multicolumn{2}{|c|}{$\begin{array}{l}\text { Standard } \\
\text { Deviation }\end{array}$} & \multirow{3}{*}{ Count } & \multirow{2}{*}{ Minimum } & \multirow{3}{*}{ Maximum } & \multirow{3}{*}{$\begin{array}{c}\text { K-S } \\
\text { Critical } \\
\text { Statistic } \\
\text { D* }\end{array}$} & \multirow{3}{*}{$\begin{array}{c}\text { K-S } \\
\text { Statistic } \\
\text { D at } 95 \%\end{array}$} & \multirow{3}{*}{$\begin{array}{c}\text { Accept } \\
\text { Log-Normal } \\
\text { Hypotheses }\end{array}$} & \multicolumn{2}{|c|}{$\begin{array}{l}\text { 95\% Confidence } \\
\text { Interval Bounds }\end{array}$} & \multirow{3}{*}{$\begin{array}{l}\text { Number of } \\
\text { Entriesl } \\
\text { Number of } \\
\text { Wells }\end{array}$} \\
\hline & & Data & Population $^{a}$ & & & & & & & Lower & Upper & \\
\hline & \multicolumn{3}{|c|}{$\log 10$ K (m/day) } & & $\log 10$ K (m/day) & & & & & \multicolumn{2}{|c|}{$\log 10 \mathrm{~K}$ (m/day) } & \\
\hline \multicolumn{13}{|c|}{ Pumping-Scale } \\
\hline$\overline{A A}$ & 0.45 & 0.93 & 0.26 & 51 & -1.47 & 2.54 & 0.06 & 0.19 & Yes & -1.37 & 2.27 & $107 / 40$ \\
\hline VA & -0.12 & 1.29 & 0.21 & 142 & -4.80 & 3.41 & 0.07 & 0.11 & Yes & -2.66 & 2.42 & $238 / 43$ \\
\hline LFA & -0.26 & 0.95 & 0.36 & 29 & -2.53 & 1.54 & 0.06 & 0.25 & Yes & -2.12 & 1.61 & $83 / 13$ \\
\hline TCU & -0.91 & 1.43 & 0.25 & 127 & -4.82 & 1.90 & 0.06 & 0.12 & Yes & -3.72 & 1.90 & $158 / 18$ \\
\hline MGCU & -2.49 & & & 1 & & & & & & & & $1 / 1$ \\
\hline UCCU & -2.64 & 1.15 & 2.85 & 3 & -3.48 & -1.33 & & & & & & $3 / 3$ \\
\hline LCA & 0.16 & 1.34 & 0.30 & 77 & -2.85 & 3.12 & 0.08 & 0.15 & Yes & -2.46 & 2.78 & $296 / 34$ \\
\hline LCCU & -0.78 & 2.02 & 18.16 & 2 & -2.21 & 0.65 & & & & & & $2 / 2$ \\
\hline \multicolumn{13}{|c|}{ Slug Test-Scale } \\
\hline$\overline{A A}$ & -0.70 & 1.17 & 0.68 & 14 & -3.60 & 0.53 & 0.15 & 0.36 & Yes & -3.01 & 1.60 & $25 / 12$ \\
\hline VA & -2.49 & 1.08 & 0.18 & 142 & -5.51 & 3.34 & 0.06 & 0.11 & Yes & -4.61 & -0.38 & $536 / 19$ \\
\hline LFA, TCU & -2.34 & 1.12 & 0.14 & 258 & -6.00 & 0.08 & 0.08 & 0.08 & Yes & -4.54 & -0.13 & $645 / 34$ \\
\hline MGCU & -1.16 & 1.78 & 4.42 & 3 & -3.19 & 0.15 & & & & & & $3 / 3$ \\
\hline UCCU & -2.35 & 0.79 & 0.73 & 7 & -3.58 & -1.16 & & & & & & $7 / 7$ \\
\hline LCA & -1.16 & 1.09 & 0.46 & 24 & -4.02 & 0.75 & 0.14 & 0.28 & Yes & -3.29 & 0.98 & $26 / 17$ \\
\hline \multicolumn{13}{|c|}{ Laboratory-Scale } \\
\hline$\overline{A A}$ & -0.76 & 1.56 & 0.36 & 73 & -6.54 & 0.84 & 0.20 & 0.16 & No & -3.81 & 2.29 & $73 / 5$ \\
\hline VA & -3.77 & 2.23 & 0.22 & 403 & -7.67 & 2.51 & 0.10 & 0.07 & No & -8.14 & 0.60 & $403 / 24$ \\
\hline TCU & -4.42 & 1.55 & 0.12 & 637 & -8.13 & 4.60 & 0.07 & 0.05 & No & -7.46 & -1.38 & $637 / 22$ \\
\hline LCA & -4.39 & 1.28 & 0.46 & 32 & -6.33 & -1.67 & 0.13 & 0.24 & Yes & -6.89 & -1.89 & $32 / 8$ \\
\hline LCCU & -6.56 & 0.66 & 0.25 & 30 & -7.54 & -4.69 & 0.16 & 0.25 & Yes & -7.86 & -5.26 & $30 / 1$ \\
\hline
\end{tabular}

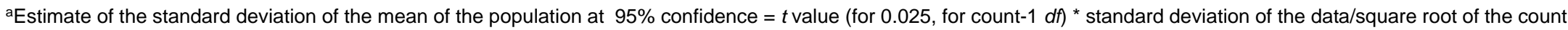


to the HFM. A major factor in this improvement is that many transmissive intervals span multiple HSUs and were not previously categorized within the HSU framework. However, the dominant HGU in the interval could be identified.

To indicate that the result of the K-S test (Section 6.5.2) did not reject the log-normality hypotheses, "Yes" is listed in the column "Accept Log-Normality Hypothesis." The log-normal hypothesis was not rejected for any datasets at the "Pumping-Scale" and "Slug-Test Scale." The log-normal hypothesis was rejected for several datasets at the "Laboratory-Scale." However, these datasets were probably not populated with random data points, but rather, data collected to characterize specific conditions or intervals in wells that could not be generally characterized by other methods. The 95-percent confidence interval bounds for log-normal distributions determined from the data analyses were calculated.

Table 6-3 presents statistical comparison of the two different areal-scale datasets for the three HGUs for which there were substantial datasets for both areal scales at the pumping test-scale. The K-S test for normality of the $\log _{10} \mathrm{~K}$ distributions found these distributions to conform. The F-Test: Two Sample for Variances, a test for the inequality of the variances, and the t-Test: Two Samples Assuming Equal or Unequal Variances (as appropriate based on the F test), testing the equality of the means of the two datasets, were conducted at the 0.05 significance level.

The results of the F-test were used to determine the correct version of the t-Test. The results of the $\mathrm{t}$-Test indicates that the mean of the population for the NTS Investigation Area AA dataset may not be equal to the mean of the population for the Yucca Flat/Climax Mine-specific dataset. Examination of the two datasets finds that most of the higher K values are in the NTS Investigation Area AA dataset and that all of the shallowest tests are from locations distant from the NTS, suggesting that the NTS Investigation Area AA dataset is not necessarily representative for the Yucca Flat/Climax Mine area. The t-Tests for the VA and LCA datasets indicate that the means of the populations for the NTS Investigation Area datasets may be equal to the means of the populations for the Yucca Flat/Climax Mine-specific datasets. Examination of the two areal-scale datasets for each HGU with respect to $\mathrm{K}$ values and to depth values finds that Yucca Flat/Climax Mine-specific data is distributed across the range of values in the NTS Investigation Area dataset. The NTS Investigation Area datasets may be representative for the Yucca Flat/Climax Mine area for these two HGUs. 
Table 6-3

Statistical Comparison of Datasets

\begin{tabular}{|c|c|c|c|c|c|c|}
\hline & \multicolumn{2}{|c|}{ AA Pumping-Scale Data } & \multicolumn{2}{|c|}{ VA Pumping-Scale Data } & \multicolumn{2}{|c|}{ LCA Pumping-Scale Data } \\
\hline & $\begin{array}{c}\text { YF Data } \\
\text { Compilation } \\
\text { Area }\end{array}$ & $\begin{array}{c}\text { NTS } \\
\text { Investigation } \\
\text { Area }\end{array}$ & $\begin{array}{c}\text { YF Data } \\
\text { Compilation } \\
\text { Area }\end{array}$ & $\begin{array}{c}\text { NTS } \\
\text { Investigation } \\
\text { Area }\end{array}$ & $\begin{array}{c}\text { YF Data } \\
\text { Compilation } \\
\text { Area }\end{array}$ & $\begin{array}{c}\text { NTS } \\
\text { Investigation } \\
\text { Area }\end{array}$ \\
\hline Parameter & \multicolumn{6}{|c|}{ F-Test Two-Sample for Variances } \\
\hline Mean & -0.13 & 0.45 & 0.23 & -0.12 & 0.03 & 0.16 \\
\hline Variance & 0.87 & 0.86 & 1.22 & 1.68 & 1.70 & 1.79 \\
\hline Observations & 22 & 51 & 20 & 142 & 36 & 77 \\
\hline Degrees of Freedom & 21 & 50 & 19 & 141 & 35 & 76 \\
\hline F Statistic & \multicolumn{2}{|r|}{$1.01\left(\right.$ Accept $\left.\mathrm{H}_{0}\right)$} & \multicolumn{2}{|r|}{$0.73\left(\right.$ Reject $\left.\mathrm{H}_{0}\right)$} & \multicolumn{2}{|r|}{$0.95\left(\right.$ Reject $\left.\mathrm{H}_{0}\right)$} \\
\hline$P(F<=f)$ one-tail & \multicolumn{2}{|c|}{0.47} & \multicolumn{2}{|c|}{0.21} & \multicolumn{2}{|c|}{0.45} \\
\hline F Critical one-tail & \multicolumn{2}{|c|}{1.77} & \multicolumn{2}{|c|}{0.52} & \multicolumn{2}{|c|}{0.60} \\
\hline Parameter & \multicolumn{2}{|c|}{$\begin{array}{l}\text { t-Test: Two-Sample } \\
\text { Assuming Equal Variances }\end{array}$} & \multicolumn{4}{|c|}{ t-Test: Two-Sample Assuming Unequal Variances } \\
\hline Mean & -0.13 & 0.45 & 0.23 & -0.12 & 0.03 & 0.16 \\
\hline Variance & 0.87 & 0.86 & 1.22 & 1.68 & 1.70 & 1.79 \\
\hline Observations & 22 & 51 & 20 & 142 & 36 & 77 \\
\hline Pooled Variance & \multicolumn{2}{|c|}{0.86} & \multicolumn{2}{|c|}{ NA } & \multicolumn{2}{|c|}{ NA } \\
\hline $\begin{array}{c}\text { Hypothesized } \\
\text { Difference of Means }\end{array}$ & \multicolumn{2}{|r|}{0} & \multicolumn{2}{|c|}{0} & \multicolumn{2}{|c|}{0} \\
\hline Degrees of Freedom & \multicolumn{2}{|c|}{71} & \multicolumn{2}{|c|}{27} & \multicolumn{2}{|c|}{70} \\
\hline t Statistic & \multicolumn{2}{|c|}{$-2.45\left(\right.$ Reject $\left.H_{0}\right)$} & \multicolumn{2}{|c|}{$1.29\left(\right.$ Accept $\left.H_{0}\right)$} & \multicolumn{2}{|c|}{$-0.51\left(\right.$ Accept $\left.\mathrm{H}_{0}\right)$} \\
\hline $\mathrm{P}(\mathrm{T}<=\mathrm{t})$ two-tail & \multicolumn{2}{|c|}{0.02} & \multicolumn{2}{|c|}{0.21} & \multicolumn{2}{|c|}{0.61} \\
\hline t Critical two-tail & \multicolumn{2}{|c|}{1.99} & \multicolumn{2}{|c|}{2.05} & \multicolumn{2}{|c|}{1.99} \\
\hline
\end{tabular}

Figure 6-3 illustrates the relationships of the hydraulic conductivity data distributions for the different HGU categories. The HGUs are shown in vertical order as they generally occur in the HFM. The results for both areal scales are shown. In particular, this diagram shows the relationship between the $\mathrm{K}$ distributions for aquifer unit and confining unit HGUs, and the vertical distribution of mean $\mathrm{K}$ in the HGUs. Figure 6-4 shows an overlay of the log-normal distributions for all of the HGUs for which distributions were determined for the NTS Investigation Area dataset. This diagram shows the relative width of the different HGU distributions as well the differences in $\mathrm{K}$. 


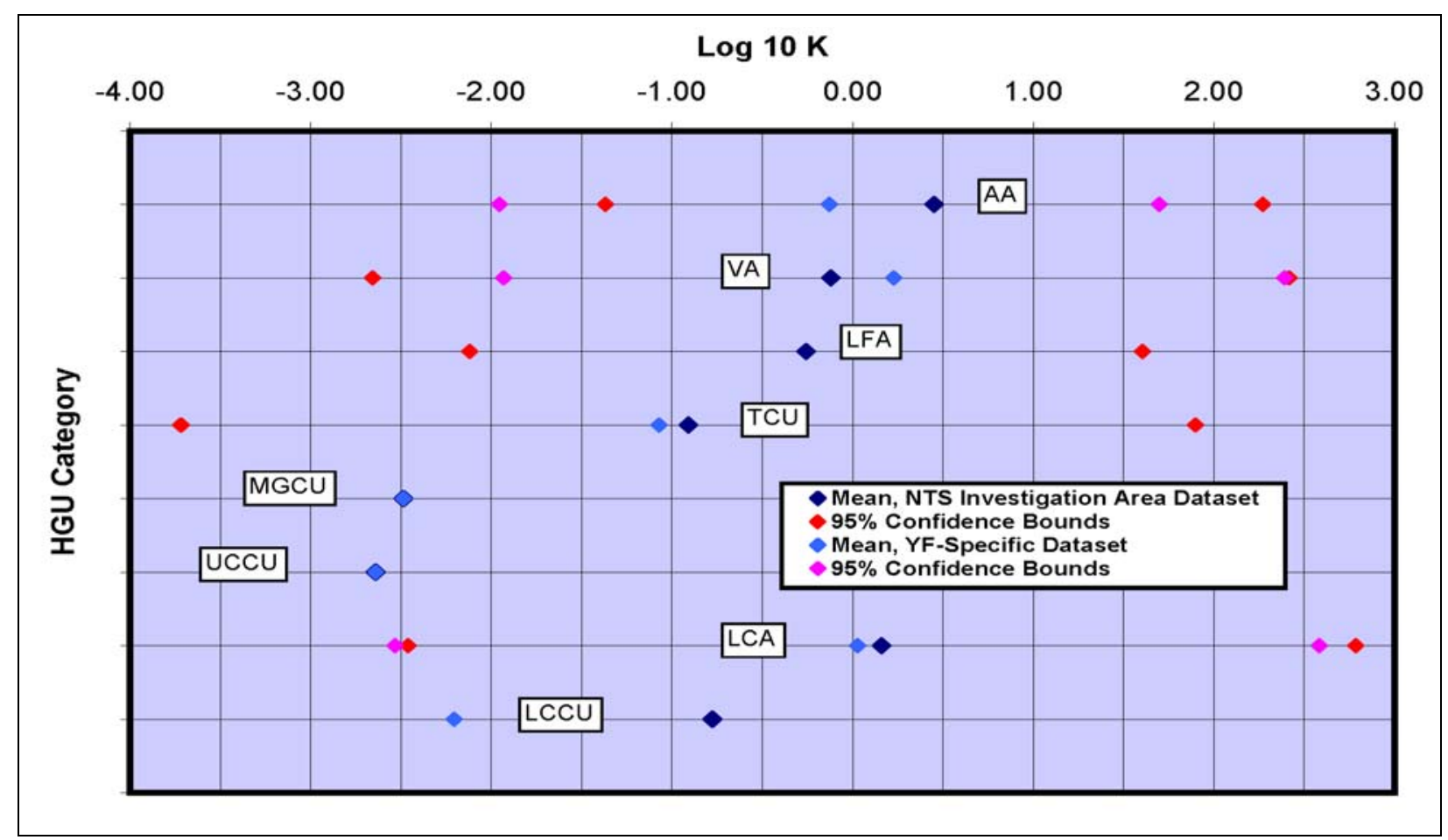

Figure 6-3

Relationship of HGU Hydraulic Conductivity Distributions

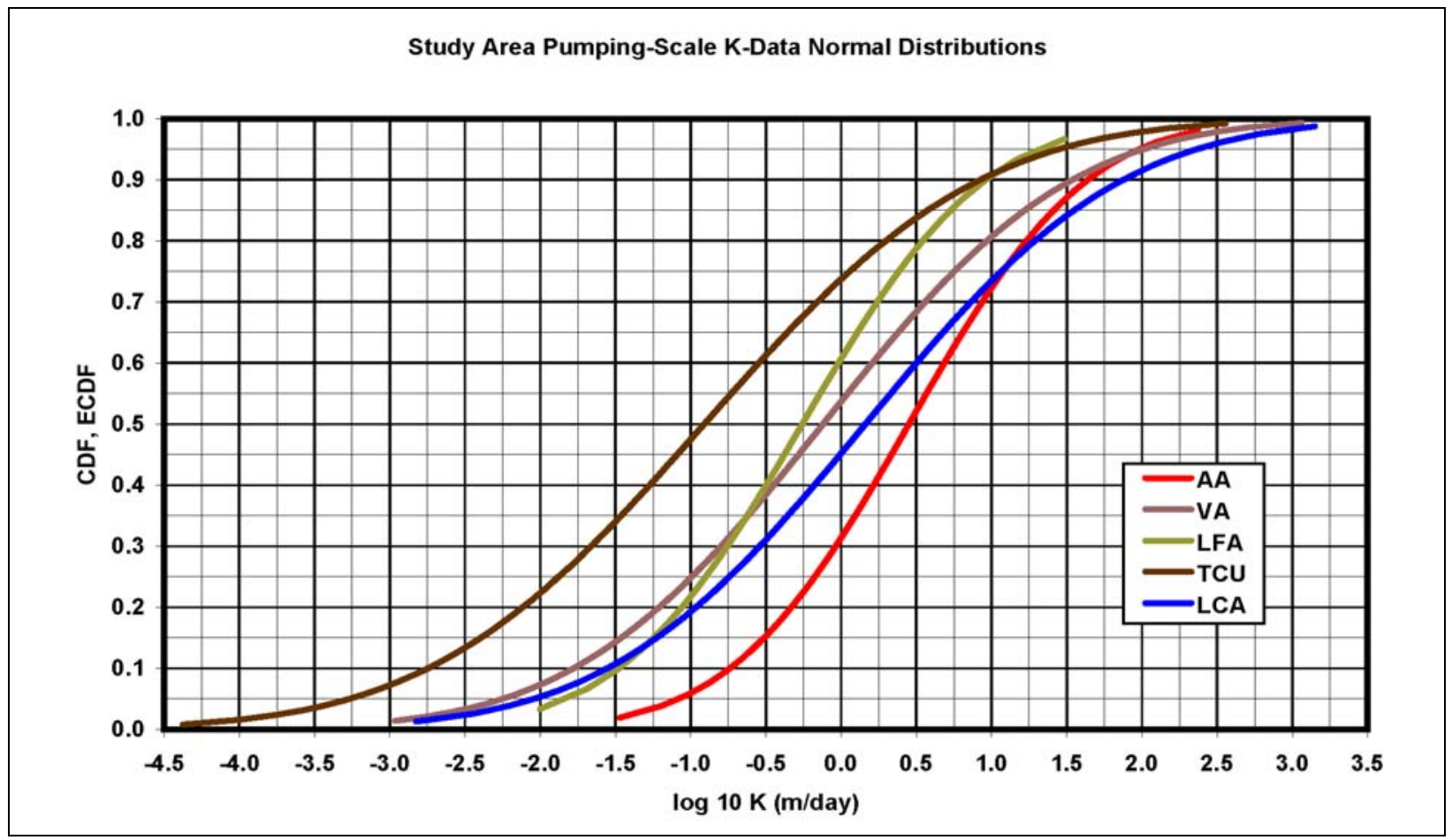

Figure 6-4

Overlay of NTS Investigation Area HGU Hydraulic Conductivity Distributions 


\subsubsection{Depth Dependence of Hydraulic Conductivity}

Depth-dependence for hydraulic conductivity has been used in previous UGTA flow models, which has proven useful in calibration of the models. The relationship of hydraulic conductivity to depth has been controversial, particularly because the data contain great scatter and the regression of the log of hydraulic conductivity against depth exhibits poor correlation. However, there is considerable support in the literature for the relationship, which is discussed in the following paragraphs. The data for hydraulic conductivity have been analyzed for the depth-dependence relationship, and the results are included in the analyses in this section. Use of the relationships developed is at the discretion of the modelers. As with the hydraulic conductivity analysis, the depth-dependence analyses provides guidance for modeling and does not purport to define the specific values that will be used during modeling. Confidence in model calibration values results when they are consistent with the data analyses. The analysis has been conducted in terms of hydraulic conductivity due to the lack of specific temperature information for all tests to support conversion of hydraulic conductivity to permeability. It is recognized that the general temperature increase with depth has an effect on this analysis which may be separated when hydraulic conductivity is converted to permeability. The potential uncertainty related to the variation in temperature is addressed in Section 6.10. The following theoretical discussion properly discusses the relationship of permeability to depth rather than hydraulic conductivity.

\subsubsection{Depth-Decay Formulation}

Since the 1970s, many authors have presented data and evaluations that identify and utilize a relationship that shows hydraulic conductivity or permeability decreasing with increasing depth in geologic and hydrogeologic investigations. This reduction in permeability with depth is discussed generally in the context of porosity reduction (and correlated permeability reduction) with depth as a consequence of compaction and/or geochemical processes for unfractured formations and as a consequence of fewer fractures present and fracture closure at higher in situ stresses for fractured formations. Review of the literature finds that permeability depth-decay has been recognized for decades by investigators in many geologic environments and has also been routinely adopted in groundwater modeling studies. Hydraulic conductivity depth-decay has also been incorporated as a standard capability in MODFLOW (the most-widely distributed and used groundwater flow model in the world) code versions in recent years. Examples of studies from the literature that address depth 
dependence of permeability or hydraulic conductivity are identified in Table 6-4. An extensive review of the literature is included in Appendix E.

This review of the literature illustrates that there is a solid foundation of scientific work that document reduction in permeability with depth as a reasonable approximation to represent hydraulic properties in groundwater flow models that extend to such depths that this factor is greater than the variability. It is a useful approach to assist in parameterizing models, because there is often limited data available to characterize the full depth and lateral extent of large regional groundwater flow models.

The relationship of hydraulic conductivity with depth, commonly termed depth-decay, is of interest for flow modeling to properly represent large-scale systematic hydraulic property variation in the vertical dimension. A decreasing linear trend is commonly observed in the logarithm of hydraulic conductivity with increasing depth, although the data commonly show great scatter. In spite of the data scatter, which indicates that there is great variability of hydraulic conductivity at different depths for many formations, the general conclusion in the literature is that hydraulic conductivity decreases with depth. Hydraulic conductivity as input into groundwater flow models represents an average value over the scale of the grid, and the depth decay trends as the generalization of the property.

Hydraulic conductivity decreases exponentially with depth, and the relationship is described by the equation:

$$
K_{\text {Depth }}=K_{0}\left(10^{-\lambda d}\right)
$$

Where:

$\mathrm{K}_{\text {Depth }}=$ Horizontal hydraulic conductivity at specified depth $(\mathrm{m} / \mathrm{d})$

$\mathrm{K}_{0}=$ Horizontal hydraulic conductivity at land surface $(\mathrm{m} / \mathrm{d})$

$\lambda=$ Decay coefficient (calculated from linear regression) $(1 / \mathrm{m})$

$\mathrm{d}=$ Depth from land surface $(\mathrm{m})$

The rate of decrease of hydraulic conductivity with depth is determined by the value of $\lambda$, the decay coefficient, and $\mathrm{K}_{0}$ provides the reference hydraulic conductivity at the ground surface, from which depth is measured. It is recognized that there may be depths such that K potentially may not decrease 
Table 6-4

Investigations Addressing Depth Dependence of Permeability or Hydraulic Conductivity (Page 1 of 2)

\begin{tabular}{|c|c|c|}
\hline Reference & $\begin{array}{l}\text { Permeability or } \\
\text { Hydraulic Conductivity } \\
\text { Depth-Dependence } \\
\text { Investigation }\end{array}$ & $\begin{array}{c}\text { Inclusion of Permeability } \\
\text { or Hydraulic } \\
\text { Conductivity } \\
\text { Depth-Dependence in } \\
\text { Groundwater Modeling }\end{array}$ \\
\hline Davis and Turk (1964) & $x$ & \\
\hline Davis and DeWiest (1966) & $x$ & \\
\hline Snow (1968) & $x$ & \\
\hline Carlsson and Olsson (1977) & $X^{\star}$ & \\
\hline Magara (1978) & $x$ & \\
\hline Gangi (1978) & $x$ & \\
\hline Freeze and Cherry (1979) & $x$ & \\
\hline Neglia (1979) & $X^{\star}$ & \\
\hline Rushton et al. (1982) & $x$ & $x$ \\
\hline de Marsily (1986) & $X^{*}$ & \\
\hline Rasmuson and Neretnieks (1986) & $x$ & \\
\hline Loucks et al. (1986) & $X^{\star}$ & \\
\hline Belitz and Bredehoeft (1988) & $x$ & $x$ \\
\hline Williams and Narasimhan (1989) & $x^{*}$ & $x$ \\
\hline Rushton et al. (1989) & $x$ & $x$ \\
\hline Lavenue et al. (1990) & $x$ & $x$ \\
\hline Domenico and Schwartz (1990) & $x$ & \\
\hline Prudic (1991) & $X^{*}$ & \\
\hline Whittemore et al. (1993) & $X^{\star}$ & $x$ \\
\hline Kuiper (1994) & $X^{\star}$ & $X^{\star}$ \\
\hline Mace and Dutton (1994) & $x$ & \\
\hline Lee et al. (1995) & $x$ & \\
\hline Stober (1996) & $x$ & \\
\hline DOE/NV (1997b) & $X^{\star}$ & $X^{\star}$ \\
\hline Haneberg et al. (1998) & $x$ & \\
\hline Mace (1998) & $x^{*}$ & \\
\hline
\end{tabular}


Table 6-4

Investigations Addressing Depth Dependence

of Permeability or Hydraulic Conductivity

(Page 2 of 2)

\begin{tabular}{|c|c|c|}
\hline Reference & $\begin{array}{l}\text { Permeability or } \\
\text { Hydraulic Conductivity } \\
\text { Depth-Dependence } \\
\text { Investigation }\end{array}$ & $\begin{array}{c}\text { Inclusion of Permeability } \\
\text { or Hydraulic } \\
\text { Conductivity } \\
\text { Depth-Dependence in } \\
\text { Groundwater Modeling }\end{array}$ \\
\hline Manning and Ingebritsen (1999) & $x$ & \\
\hline Ingebritsen and Manning (1999) & $x$ & \\
\hline Williamson and Grubb (2001) & $X^{*}$ & $X^{*}$ \\
\hline Budd (2001) & $X^{*}$ & \\
\hline Wilson et al. (2001) & $x$ & $x$ \\
\hline Belcher et al. (2001) & $X^{*}$ & \\
\hline Wilson (2003) & $x$ & $x$ \\
\hline Casadel et al. (2003) & $X^{*}$ & $X^{*}$ \\
\hline Anderman and Hill (2003) & $x^{*}$ & $X^{\star}$ \\
\hline Environment Agency (2003) & $x^{*}$ & $X^{*}$ \\
\hline Belcher et al. (2004) & $X^{*}$ & $X^{*}$ \\
\hline SNJV (2005e) & $X^{*}$ & $X^{*}$ \\
\hline
\end{tabular}

*Denotes investigations that use an exponential function to describe decreasing permeability or hydraulic conductivity with increasing depth.

further below some depth. For example, at greater depths either fracturing may be absent or porosity may reach a minimum value such that $\mathrm{K}$ does not decrease further with depth.

\subsubsection{Analysis of NTS Datasets for Depth Decay}

The depth dependence of hydraulic conductivity was analyzed for the complete pumping-scale datasets for both the CAU-specific and the NTS Investigation Area areal scales and for individual HGU datasets of the NTS Investigation Area. The "All-Data" analysis provides a generalized view of depth-dependence of hydraulic conductivity. Depth versus hydraulic conductivity trends may be specific to individual HGUs according to variations in physical properties affecting the hydraulic conductivity and the response to increasing effective stress with depth. Table 6-5 presents the results of correlation and regression analysis of the depth dependence of hydraulic conductivity for each 
dataset. These analyses were conducted using Excel ${ }^{\mathrm{R}} 2002$ Analysis Toolpak statistical calculation tools. Figure 6-5 is a graph of the Yucca Flat/Climax Mine-specific dataset and the regression trendline as well as two SDs for both $\mathrm{K}_{0}$ and $\lambda$. Figure 6-6 shows the regression for the NTS Investigation Area dataset. Graphs of the regression for individual HGUs are included in the HGU-specific sections.

The rightmost column in Table 6-5 indicates the correlation between the hydraulic conductivity data and the assigned depth, as expressed by the correlation coefficient (R). The correlation coefficient values indicate that there is significant correlation, and the negative sign indicates that hydraulic conductivity values decrease with increasing depth. The next two columns on the right present statistics on the regression of hydraulic conductivity against depth. The $\mathrm{R}^{2}$ value for the regression gives the proportion of the total variability in the hydraulic conductivity that can be accounted for by increasing depth. The NTS Investigation Area dataset, which is much larger than the Yucca Flat/Climax Mine-specific datset (Table 6-1 and Table 6-2), shows much greater correlation. These values reflect the data scatter, and are consistent with the understanding that other factors, such as heterogeniety and spatial variability, are also factors in the variability of hydraulic conductivity. The left columns in Table 6-5 provide statistics on the $\mathrm{K}_{0}$ and $\lambda$ parameter values for the best-fit linear regression line. The "p-Value" indicates that the probability for no relationship is very low. The $\mathrm{R}$ value under the Par heading indicates the correlation between the two parameters. 
Table 6-5

Summary of Depth-Decay Analysis

(Page 1 of 2)

\begin{tabular}{|c|c|c|c|c|c|c|c|c|c|c|c|c|c|}
\hline \multirow{2}{*}{$\begin{array}{c}\text { Data } \\
\text { Set }\end{array}$} & \multirow[b]{2}{*}{ Para } & \multirow[b]{2}{*}{ Value } & \multirow[b]{2}{*}{ SEb } & \multirow[b]{2}{*}{ t Stat ${ }^{c}$} & \multirow[b]{2}{*}{ P-value } & \multicolumn{4}{|c|}{ Confidence Bounds ${ }^{1}$} & \multirow{2}{*}{$\begin{array}{c}\text { Par } \\
\mathbf{R}^{\mathbf{e}}\end{array}$} & \multicolumn{2}{|c|}{ Regression } & \multirow{2}{*}{$\begin{array}{c}\text { Data } \\
\mathbf{R}^{\mathrm{f}}\end{array}$} \\
\hline & & & & & & $\begin{array}{c}\text { Lower } \\
95 \%\end{array}$ & $\begin{array}{c}\text { Upper } \\
95 \%\end{array}$ & $\begin{array}{l}\text { Lower } \\
68.27 \%\end{array}$ & $\begin{array}{c}\text { Upper } \\
68.27 \%\end{array}$ & & $\mathbf{R}^{\mathrm{e}, \mathrm{g}}$ & $\mathrm{SE}^{\mathrm{b}}$ & \\
\hline \multicolumn{14}{|c|}{ Yucca Flat/Climax Mine Data Compilation Area } \\
\hline \multirow{2}{*}{$\begin{array}{c}\text { All } \\
\text { Data }\end{array}$} & $\mathrm{K}_{0}^{\dagger}$ & 4.36E-01 & 2.94E-01 & 1.48 & $1.42 \mathrm{E}-01$ & $-1.49 \mathrm{E}-01$ & $1.02 \mathrm{E}+00$ & 1.40E-01 & 7.32E-01 & \multirow{2}{*}{-0.88} & \multirow{2}{*}{0.06} & \multirow{2}{*}{1.26} & \multirow{2}{*}{-0.24} \\
\hline & $\lambda$ & $-9.26 \mathrm{E}-04$ & 4.16E-04 & -2.23 & $2.88 \mathrm{E}-02$ & $-1.75 \mathrm{E}-03$ & $-9.83 E-05$ & $-1.35 \mathrm{E}-03$ & $-5.08 E-04$ & & & & \\
\hline \multirow{2}{*}{ AA } & $\mathrm{K}_{0}{ }^{\mathrm{f}}$ & 3.62E-01 & 4.63E-01 & 0.78 & 4.44E-01 & $-6.05 E-01$ & $1.33 \mathrm{E}+00$ & $-1.14 \mathrm{E}-01$ & 8.37E-01 & \multirow{2}{*}{-0.91} & \multirow{2}{*}{0.06} & \multirow{2}{*}{0.92} & \multirow{2}{*}{-0.25} \\
\hline & $\lambda$ & $-1.18 \mathrm{E}-03$ & $1.00 \mathrm{E}-03$ & -1.17 & $2.56 \mathrm{E}-01$ & $-3.27 \mathrm{E}-03$ & 9.19E-04 & $-2.21 E-03$ & $-1.45 E-04$ & & & & \\
\hline \multirow{2}{*}{ VA } & $\mathrm{K}_{0}{ }^{\mathrm{f}}$ & 8.56E-01 & $5.25 E-01$ & 1.63 & 1.21E-01 & $-2.52 \mathrm{E}-01$ & $1.96 \mathrm{E}+00$ & 3.15E-01 & $1.40 \mathrm{E}+00$ & \multirow{2}{*}{-0.88} & \multirow{2}{*}{0.11} & \multirow{2}{*}{1.09} & \multirow{2}{*}{-0.33} \\
\hline & $\lambda$ & $-1.07 \mathrm{E}-03$ & 7.52E-04 & -1.43 & 1.72E-01 & $-2.66 \mathrm{E}-03$ & 5.15E-04 & $-1.85 E-03$ & $-2.97 \mathrm{E}-04$ & & & & \\
\hline \multirow{2}{*}{ LCA } & $\mathrm{K}_{0}^{\dagger}$ & $1.44 \mathrm{E}+00$ & 6.22E-01 & 2.31 & 2.73E-02 & 1.71E-01 & $2.70 \mathrm{E}+00$ & 8.04E-01 & $2.07 \mathrm{E}+00$ & \multirow{2}{*}{-0.94} & \multirow{2}{*}{0.14} & \multirow{2}{*}{1.22} & \multirow{2}{*}{-0.38} \\
\hline & $\lambda$ & $-1.93 E-03$ & 8.04E-04 & -2.40 & $2.22 \mathrm{E}-02$ & -3.56E-03 & $-2.93 E-04$ & $-2.74 \mathrm{E}-03$ & $-1.11 E-03$ & & & & \\
\hline & & & & & & NTS Inv & igation Are & & & & & & \\
\hline All & $\mathrm{K}_{0}{ }^{\dagger}$ & 8.74E-01 & 1.13E-01 & 7.75 & $6.84 \mathrm{E}-14$ & 6.53E-01 & $1.10 \mathrm{E}+00$ & 7.61E-01 & 9.87E-01 & 096 & 026 & 110 & 051 \\
\hline Data & $\lambda$ & $-1.64 \mathrm{E}-03$ & 1.36E-04 & 12.0 & $9.11 E-29$ & $-1.91 \mathrm{E}-03$ & -1.37E-03 & $-1.78 \mathrm{E}-03$ & $-1.50 \mathrm{E}-03$ & -0.80 & $0 . \angle 0$ & 1.18 & -0.51 \\
\hline 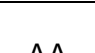 & $\mathrm{K}_{0}{ }^{\dagger}$ & 9.75E-01 & 1.82E-01 & 5.36 & 2.23E-06 & 6.10E-01 & $1.34 \mathrm{E}+00$ & 7.92E-01 & $1.16 \mathrm{E}+00$ & ר7 ח & ? 20 & $00 ?$ & 0 \\
\hline$A A$ & $\lambda$ & $-2.09 E-03$ & 5.59E-04 & -3.74 & 4.85E-04 & $-3.21 \mathrm{E}-03$ & $-9.67 E-04$ & $-2.65 E-03$ & -1.53E-03 & -0.11 & 0.22 & 0.83 & $-0.4 I$ \\
\hline VA & $\mathrm{K}_{0}{ }^{f}$ & $1.23 \mathrm{E}+00$ & 1.65E-01 & 7.46 & $9.40 \mathrm{E}-12$ & 9.05E-01 & $1.56 \mathrm{E}+00$ & $1.07 \mathrm{E}+00$ & $1.40 \mathrm{E}+00$ & 77 & 041 & 098 & -063 \\
\hline$V H$ & $\lambda$ & $-1.85 \mathrm{E}-03$ & 1.93E-04 & -9.60 & $6.02 \mathrm{E}-17$ & $-2.23 \mathrm{E}-03$ & $-1.47 \mathrm{E}-03$ & $-2.04 \mathrm{E}-03$ & -1.66E-03 & -0.11 & 0.41 & 0.90 & -0.03 \\
\hline 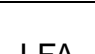 & $\mathrm{K}_{0}{ }^{\dagger}$ & 8.50E-01 & 3.33E-01 & 2.55 & 1.68E-02 & 1.66E-01 & $1.53 \mathrm{E}+00$ & 5.10E-01 & $1.19 \mathrm{E}+00$ & חQ ח & 031 & O & 050 \\
\hline LFA & $\lambda$ & $-1.20 \mathrm{E}-03$ & $3.24 \mathrm{E}-04$ & -3.70 & 9.70E-04 & -1.87E-03 & $-5.35 E-04$ & -1.53E-03 & -8.70E-04 & -0.90 & 0.34 & 0.19 & -0.58 \\
\hline TCU & $\mathrm{K}_{0}{ }^{\mathrm{f}}$ & $1.16 \mathrm{E}+00$ & 4.04E-01 & 2.87 & 4.82E-03 & 3.60E-01 & $1.96 \mathrm{E}+00$ & 7.53E-01 & $1.56 \mathrm{E}+00$ & 096 & 019 & 130 & 12 \\
\hline (100 & $\lambda$ & $-2.60 \mathrm{E}-03$ & 4.87E-04 & -5.35 & 4.12E-07 & $-3.57 \mathrm{E}-03$ & $-1.64 \mathrm{E}-03$ & $-3.09 E-03$ & $-2.12 \mathrm{E}-03$ & -0.90 & 0.19 & 1.30 & -0.43 \\
\hline
\end{tabular}


Table 6-5

Summary of Depth-Decay Analysis

(Page 2 of 2)

\begin{tabular}{|c|c|c|c|c|c|c|c|c|c|c|c|c|c|}
\hline \multirow{2}{*}{$\begin{array}{c}\text { Data } \\
\text { Set }\end{array}$} & \multirow[b]{2}{*}{ Para } & \multirow[b]{2}{*}{ Value } & \multirow[b]{2}{*}{ SE $^{b}$} & \multirow[b]{2}{*}{ t Stat ${ }^{c}$} & \multirow[b]{2}{*}{ P-value ${ }^{d}$} & \multicolumn{4}{|c|}{ Confidence Bounds ${ }^{1}$} & \multirow{2}{*}{$\begin{array}{c}\text { Par } \\
\mathbf{R}^{\mathbf{e}}\end{array}$} & \multicolumn{2}{|c|}{ Regression } & \multirow{2}{*}{$\begin{array}{c}\text { Data } \\
\mathbf{R}^{\mathbf{f}}\end{array}$} \\
\hline & & & & & & $\begin{array}{c}\text { Lower } \\
95 \%\end{array}$ & $\begin{array}{c}\text { Upper } \\
95 \%\end{array}$ & $\begin{array}{l}\text { Lower } \\
68.27 \%\end{array}$ & $\begin{array}{c}\text { Upper } \\
68.27 \%\end{array}$ & & $\mathbf{R}^{\mathbf{e}, \mathbf{g}}$ & $\mathrm{SE}^{b}$ & \\
\hline \multirow{2}{*}{ LCA } & $\mathrm{K}_{0}{ }^{f}$ & $1.06 \mathrm{E}+00$ & 2.39E-01 & 4.45 & $3.11 E-05$ & $5.86 \mathrm{E}-01$ & $1.54 \mathrm{E}+00$ & 8.21E-01 & $1.30 \mathrm{E}+00$ & \multirow{2}{*}{-0.84} & \multirow{2}{*}{0.25} & \multirow{2}{*}{1.12} & \multirow{2}{*}{-0.50} \\
\hline & $\lambda$ & $-1.28 \mathrm{E}-03$ & $2.58 E-04$ & -4.95 & 4.74E-06 & $-1.79 \mathrm{E}-03$ & $-7.62 \mathrm{E}-04$ & $-1.54 \mathrm{E}-03$ & $-1.02 \mathrm{E}-03$ & & & & \\
\hline
\end{tabular}

aPar = Parameter, referring to the two parameters in the depth-decay formulation

bStandard Error

ct-statistic

dLevel of significance

eCorrelation coefficient

${ }^{\mathrm{f}}$ Correlation coefficient squared

${ }^{g}$ As $\log K_{0}(m / d a y)$ 


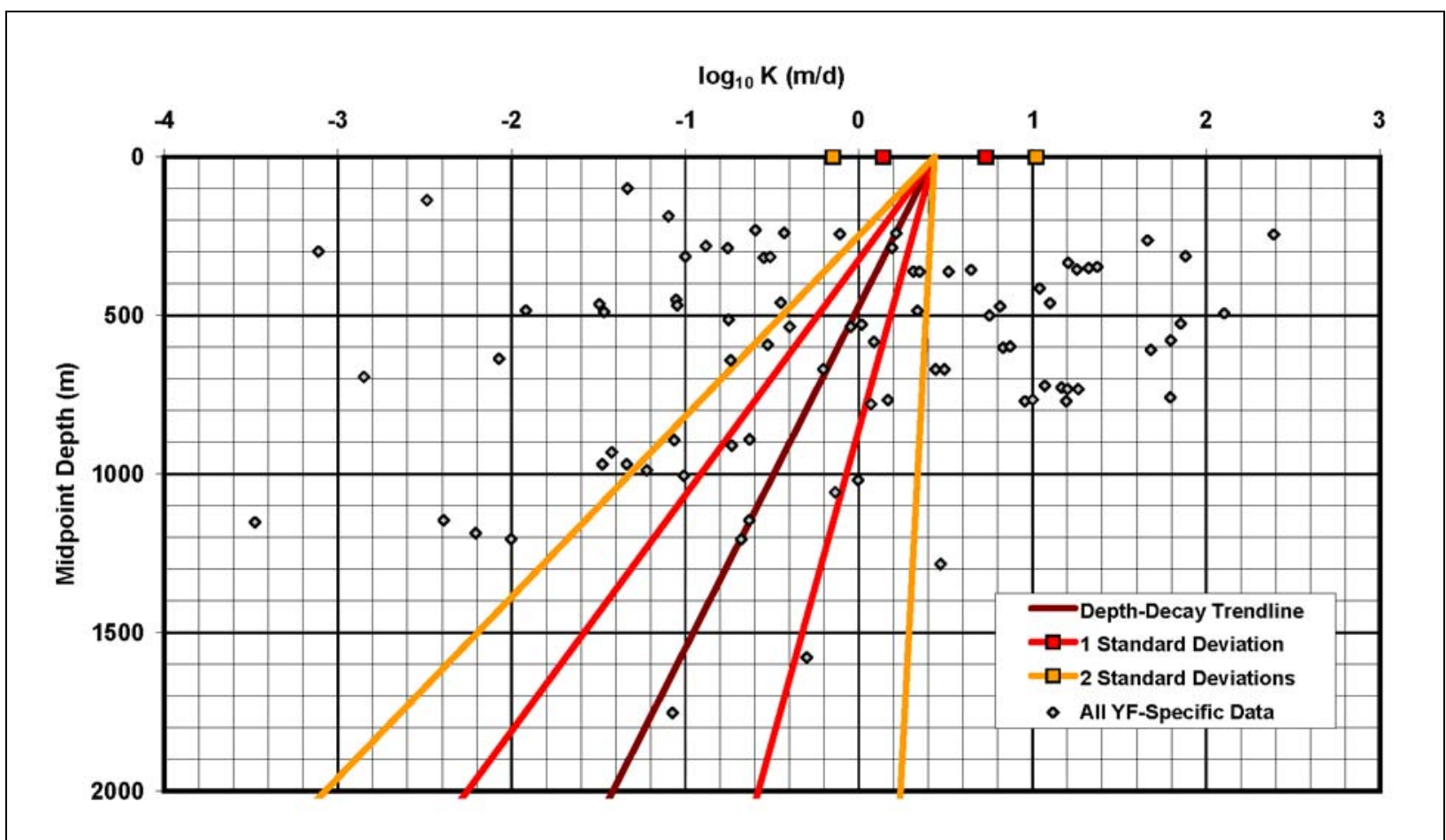

Figure 6-5

Hydraulic Conductivity Versus Depth for the Yucca Flat/Climax Mine Dataset

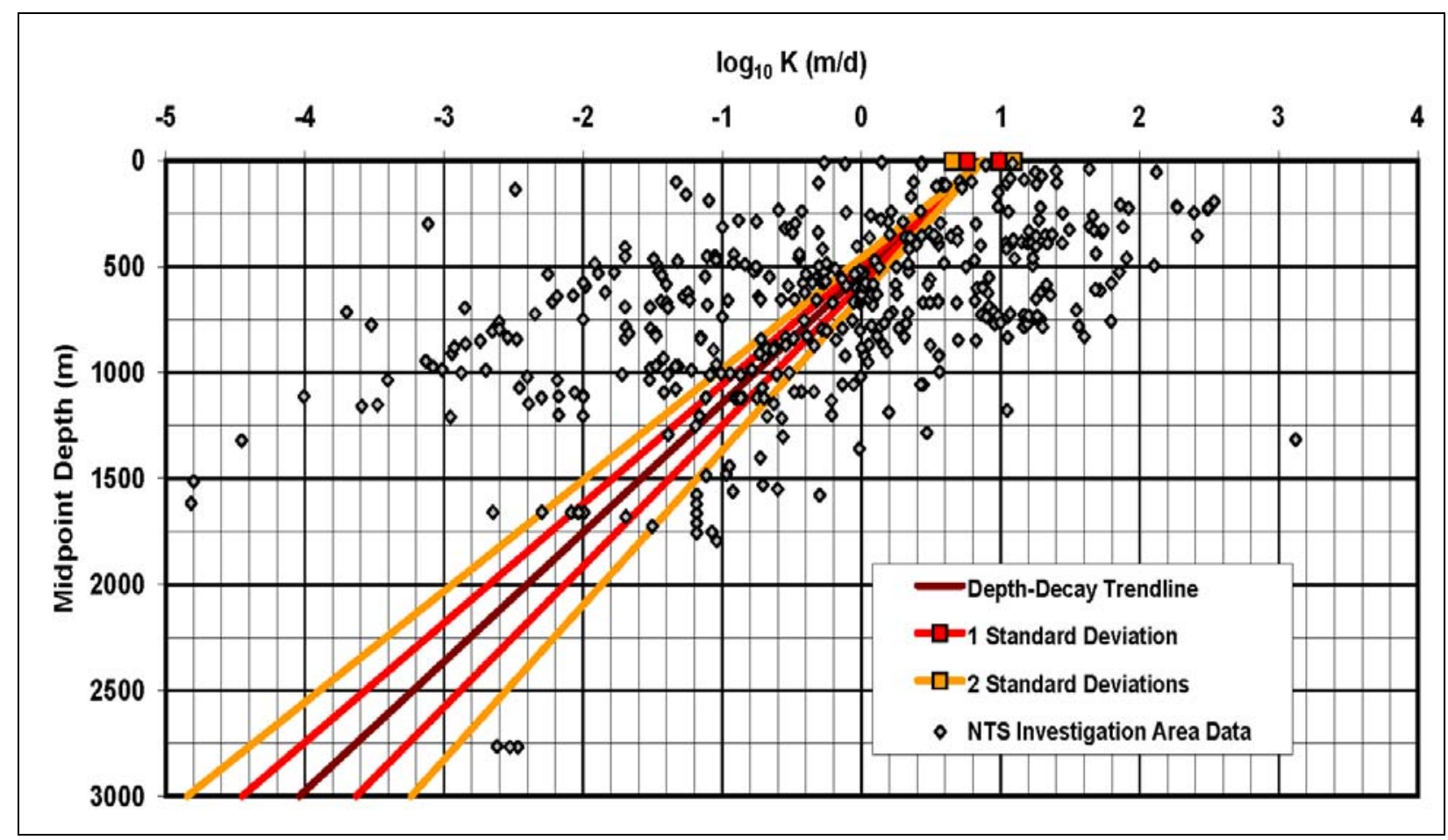

Figure 6-6

Hydraulic Conductivity Versus Depth for the NTS Investigation Area Dataset 
The plots of measured hydraulic conductivities versus depth that are reported in the literature show a relatively large amount of scatter, and thus a large amount of spread about any best-fit line representing the functional relationship of decreasing permeability or hydraulic conductivity versus increasing depth. The degree of data scatter shown for plots of hydraulic conductivity versus depth for Yucca Flat/Climax Mine and NTS Investigation Area data is consistent with the degree of scatter in other published studies in the literature (e.g., Rasmuson and Neretnieks, 1986; Loucks et al., 1986; Prudic, 1991; Kuiper, 1994; Mace and Dutton, 1994; Stober, 1996; Mace, 1998; Williamson and Grubb, 2001; and Budd, 2001). However, utilizing these depth-dependent relationships has been demonstrated as a useful approach to assist in parameterizing groundwater flow models, because often there are limited data available to characterize the full depth and lateral extent of all HSUs in large regional-scale groundwater flow models. The UGTA CAU-scale flow models are similar in scale to many "regional" models. Initial depth-decay relationships based on site-specific data are starting points for model parameterization that can then be modified during model calibration.

\subsection{Hydrogeologic Unit-Specific Hydraulic Conductivity Analyses}

The hydraulic conductivity data were sorted into HGU categories for analysis. The HGUs correspond closely to HSUs for formations of distinct character (e.g., AA, MGCU, UCCU, LCA/UCA/LCA3, and LCCU) and can be used to generally characterize the multiplicity of volcanic HSUs within the categories of VAs, LFAs, and TCUs. There were insufficient data for most of the individual HSUs within these latter categories to conduct meaningful statistical analyses. Also, the regional data could only be assigned to representative HGUs rather than to HSUs. Analyses were conducted at the HGU level for each scale of test. Data for wells located within the Yucca Flat/Climax Mine Data Compilation Area were filtered from the NTS Investigation Area individual datasets, for each scale of test, for each HGU. As seen in Tables 6-1 and 6-2, substantial datasets were available for many of the HGUs at all three scales. At the regional scale, there were pumping-scale data available for all of the HGUs represented in the Yucca Flat/Climax Mine HFM HSUs, although there were only single data points for two HGUs (MGCU and LCCU). These are the two least conductive HGUs, classified as confining units, in which pumping tests generally cannot be conducted. There are additional data at the slug test-scale and laboratory-scale for these HGUs. The following subsections discuss the HGU datasets for which there were data. 


\subsubsection{Alluvial Aquifer Hydrogeologic Unit}

The AA is most accessible, because it is the shallowest aquifer and has been fairly well investigated. Most of the pumping-scale hydraulic property data available for the Yucca Flat/Climax Mine CAU pertains to the HGUs used for water supply. The reported hydraulic conductivity values come from analyses of both single-well and multi-well tests (tests with observation wells). The results from single-well tests may be significantly different from multi-well tests because of difficulties in accounting for well losses and other production and local effects in single-well tests. Multi-well tests provide more accurate results and may also provide information on storage and anisotropy. However, the multi-well tests have generally not been interpreted with respect to anisotropy; rather, responses for multiple observation wells are commonly interpreted jointly to yield a single best-fit hydraulic conductivity. Figure 6-7 shows the results of the log-normality test for the Yucca Flat/Climax Mine Pumping-Scale AA data, and Figure 6-8 shows $\log _{10} \mathrm{~K}$ versus depth for this dataset. Figure 6-9 shows the results of the log-normality test for the NTS Investigation Area Pumping-Scale AA data, and Figure 6-10 shows $\log _{10} \mathrm{~K}$ versus depth for this dataset. Note in Table 6-1 and 6-2 that hydraulic conductivity distributions were also analyzed for the slug-test scale and the laboratory scale AA data, and both conformed to log-normal distribution. 
Phase I Hydrologic Data for CAU 97: Yucca Flat/Climax Mine, Nye County, Nevada Test Site, Nevada

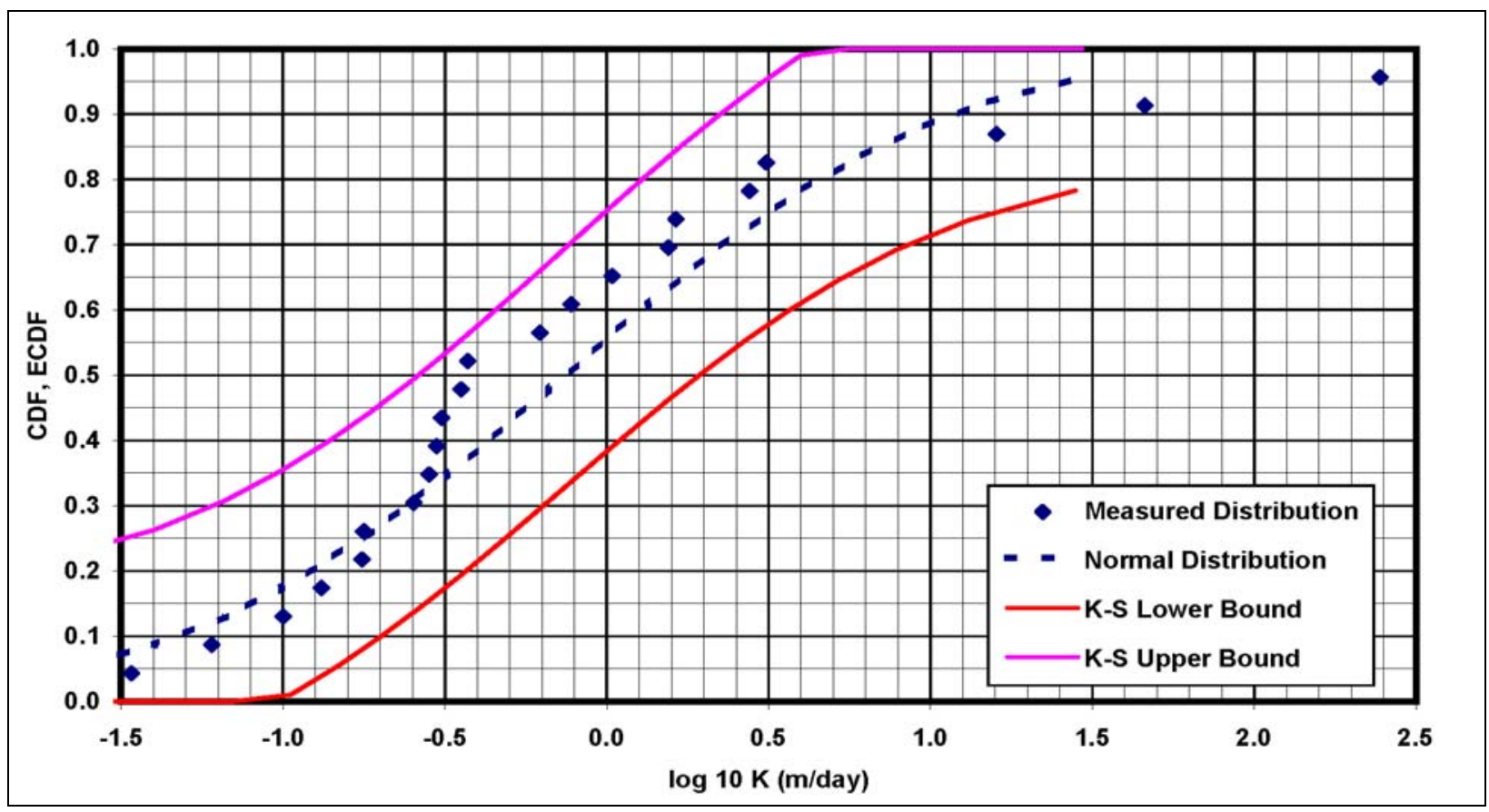

Figure 6-7

Alluvial Aquifer Pumping-Scale Hydraulic Conductivity Probability Distribution for the Yucca Flat/Climax Mine Dataset

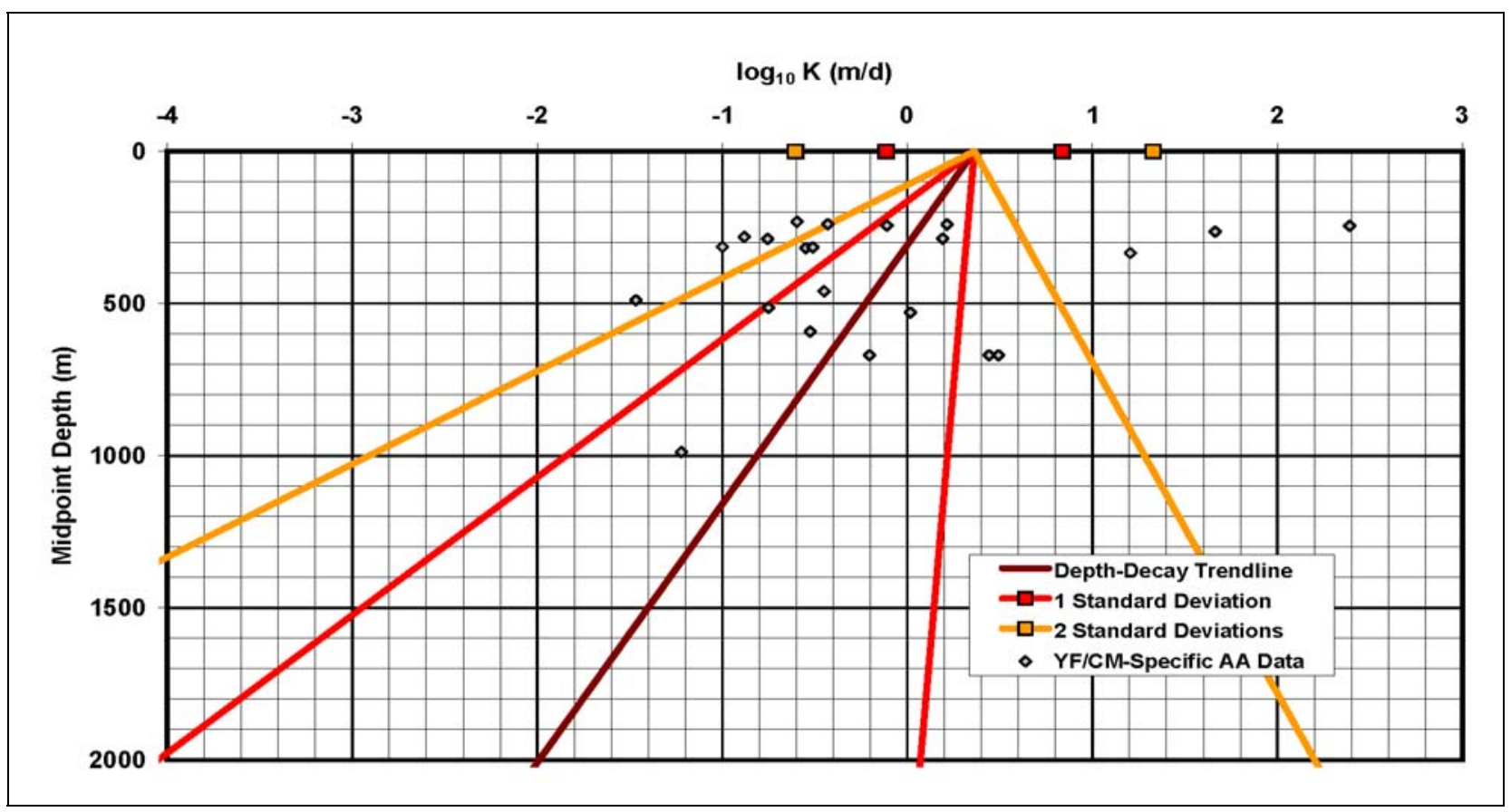

Figure 6-8

Alluvial Aquifer Pumping-Scale Hydraulic Conductivity Versus Depth for the Yucca Flat/Climax Mine Dataset 


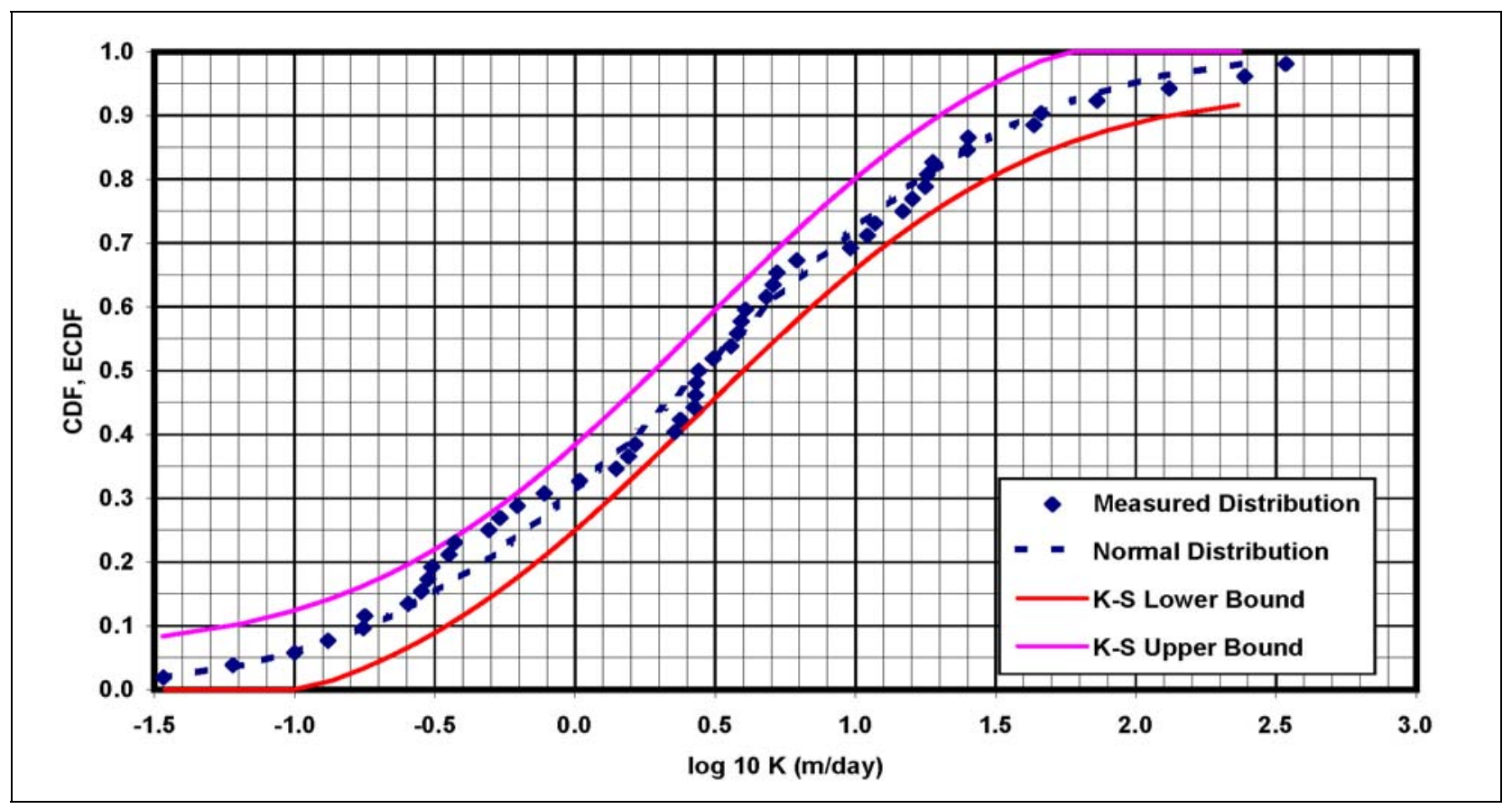

Figure 6-9

Alluvial Aquifer Pumping-Scale Hydraulic Conductivity Probability Distribution for the NTS Investigation Area Dataset

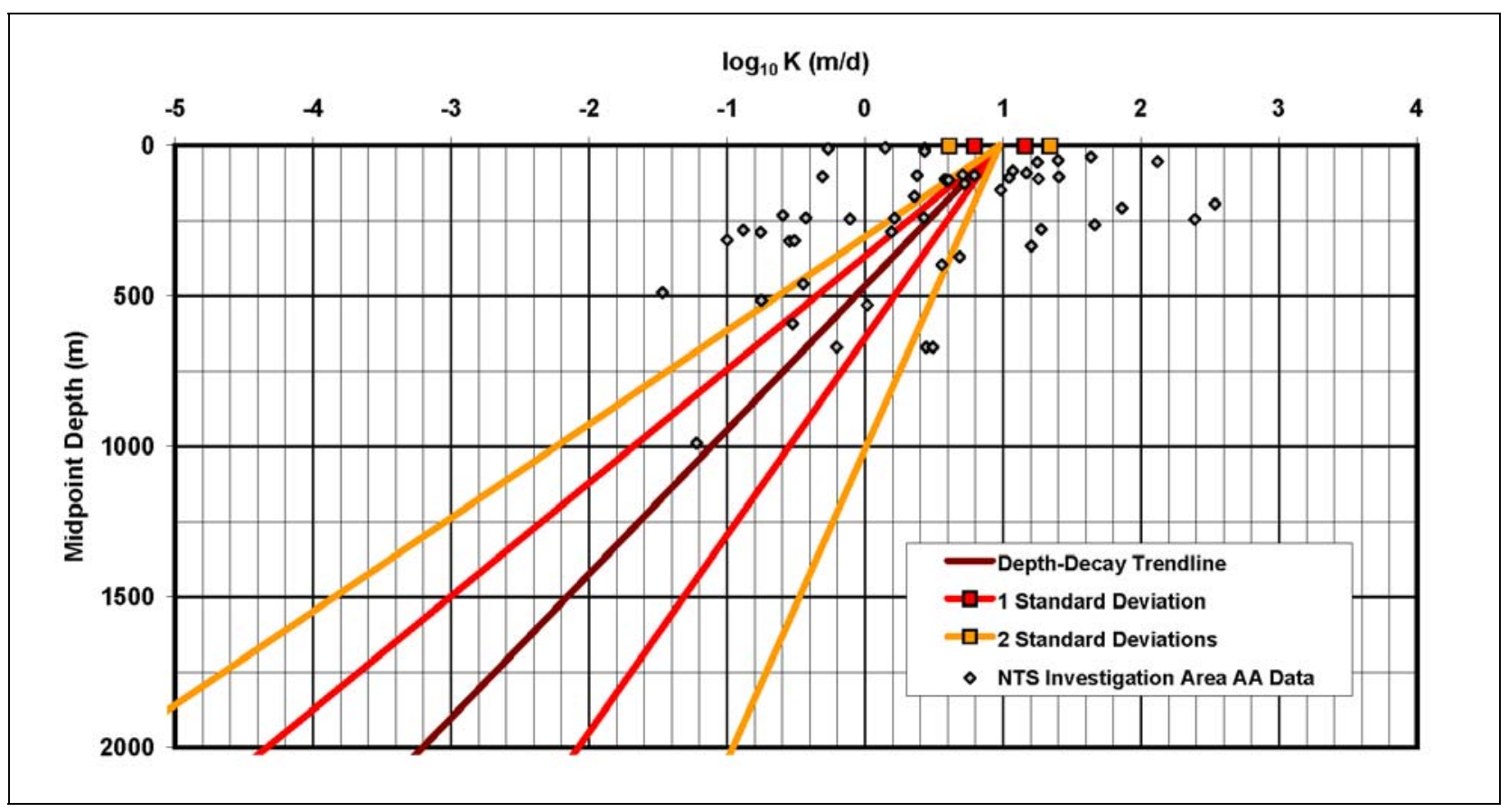

Figure 6-10

Alluvial Aquifer Pumping-Scale Hydraulic Conductivity Versus Depth for the NTS Investigation Area Dataset 


\subsubsection{Volcanic Aquifer Hydrogeologic Unit}

The VA HGUs are also used extensively for water supply, and there are a substantial number of data points in the Yucca Flat/Climax Mine CAU. Figure 6-11 shows the results of the log-normality test for the Yucca Flat/Climax Mine Pumping-Scale VA data, and Figure 6-12 shows $\log _{10} \mathrm{~K}$ versus depth for this dataset. Figure 6-13 shows the results of the log-normality test for the NTS Investigation Area Pumping-Scale VA data, and Figure 6-14 shows $\log _{10} \mathrm{~K}$ versus depth for this dataset. Note in Table 6-1 and 6-2 that hydraulic conductivity distributions were also analyzed for the slug-test scale and the laboratory-scale VA data, and both conformed to log-normal distribution. 


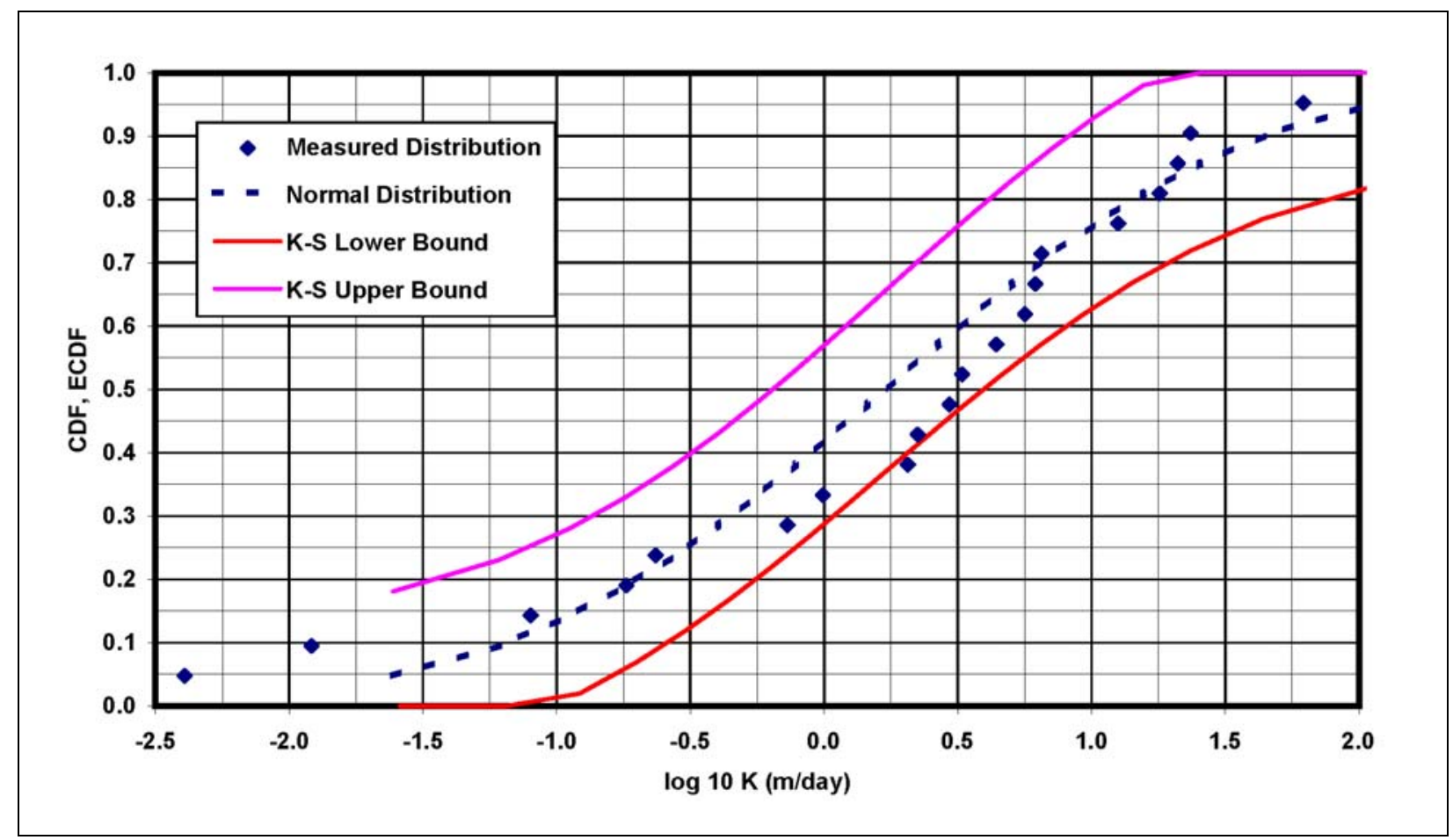

Figure 6-11

Volcanic Aquifer Pumping-Scale Hydraulic Conductivity Values Probability Distribution for the Yucca Flat/Climax Mine Dataset

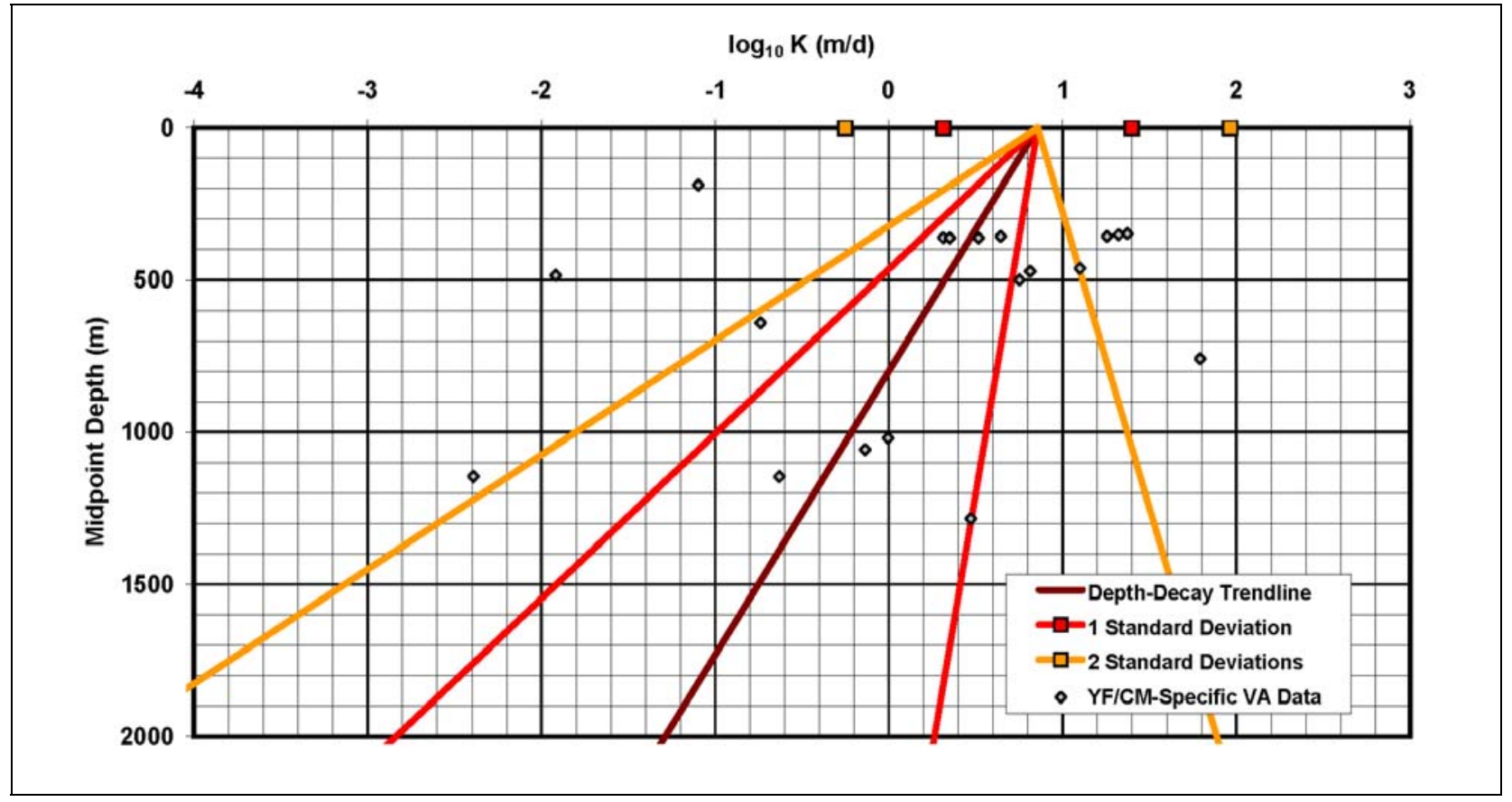

Figure 6-12

Volcanic Aquifer Pumping-Scale Hydraulic Conductivity Versus Depth for the Yucca Flat/Climax Mine Dataset 


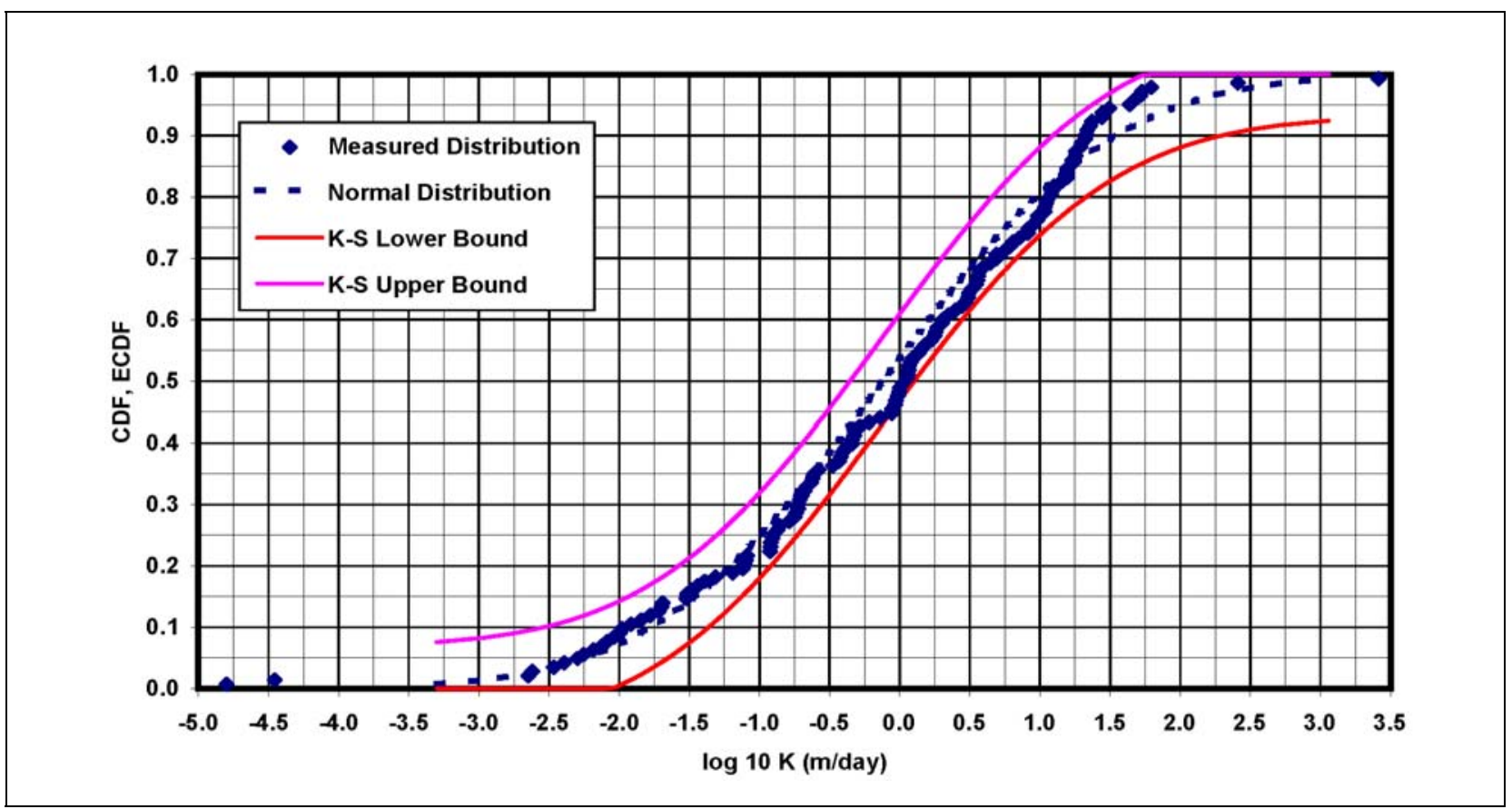

Figure 6-13

Volcanic Aquifer Pumping-Scale Hydraulic Conductivity Probability Distribution for the NTS Investigation Area Dataset

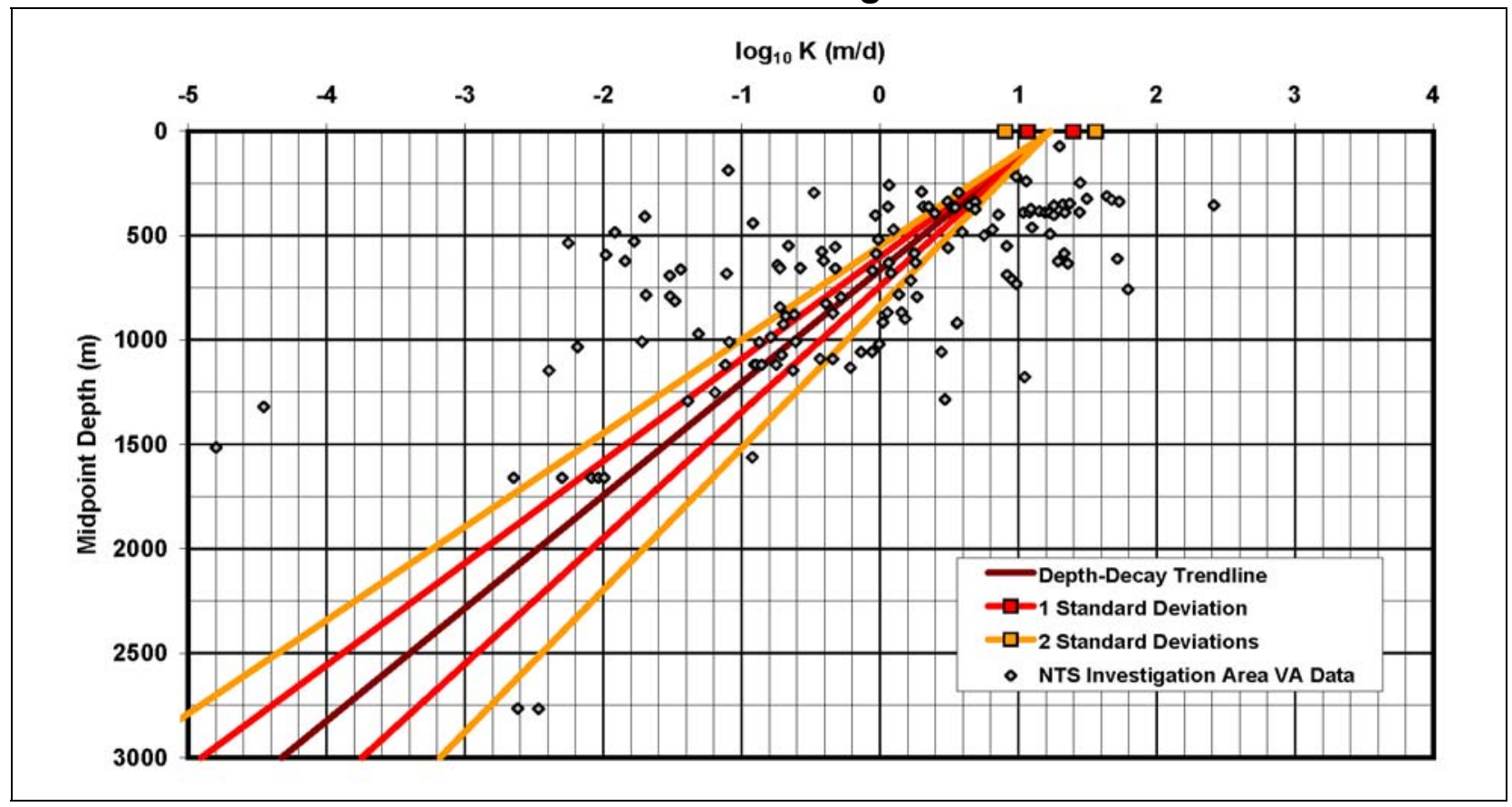

Figure 6-14

Volcanic Aquifer Pumping-Scale Hydraulic Conductivity Versus Depth for the NTS Investigation Area Dataset 


\subsubsection{Lava Flow Aquifer Hydrogeologic Unit}

The LFA HGU was also used extensively for water supply, and there are a substantial number of data points in the NTS Investigation Area dataset. Figure 6-15 shows the results of the log-normality test for the NTS Investigation Area Pumping-Scale LFA data, and Figure 6-16 shows $\log _{10} \mathrm{~K}$ versus depth for this dataset. There are no pumping-scale data for this HGU within the Yucca Flat/Climax Mine Data Compilation Area.

Note in Table 6-1 and 6-2 that hydraulic conductivity distributions were analyzed for the slug-test scale for a combined LFA and TCU dataset. The data for these two HGUs were combined at the slug test-scale, because the formation character (lithology, stratigraphy, and fracturing, as well as regional HSU distinctions) in the tested intervals was indistinguishable from the TCU HGU. That is, the test interval information indicated that the slug-tests were conducted in tuffs rather than lavas. It should be recognized that the Yucca Flat/Climax Mine geologic model HSUs, in this case LFAs, can include intervals of different formation character. This dataset is representative of the TCU and the low-permeability portions the LFA that are not highly fractured. 


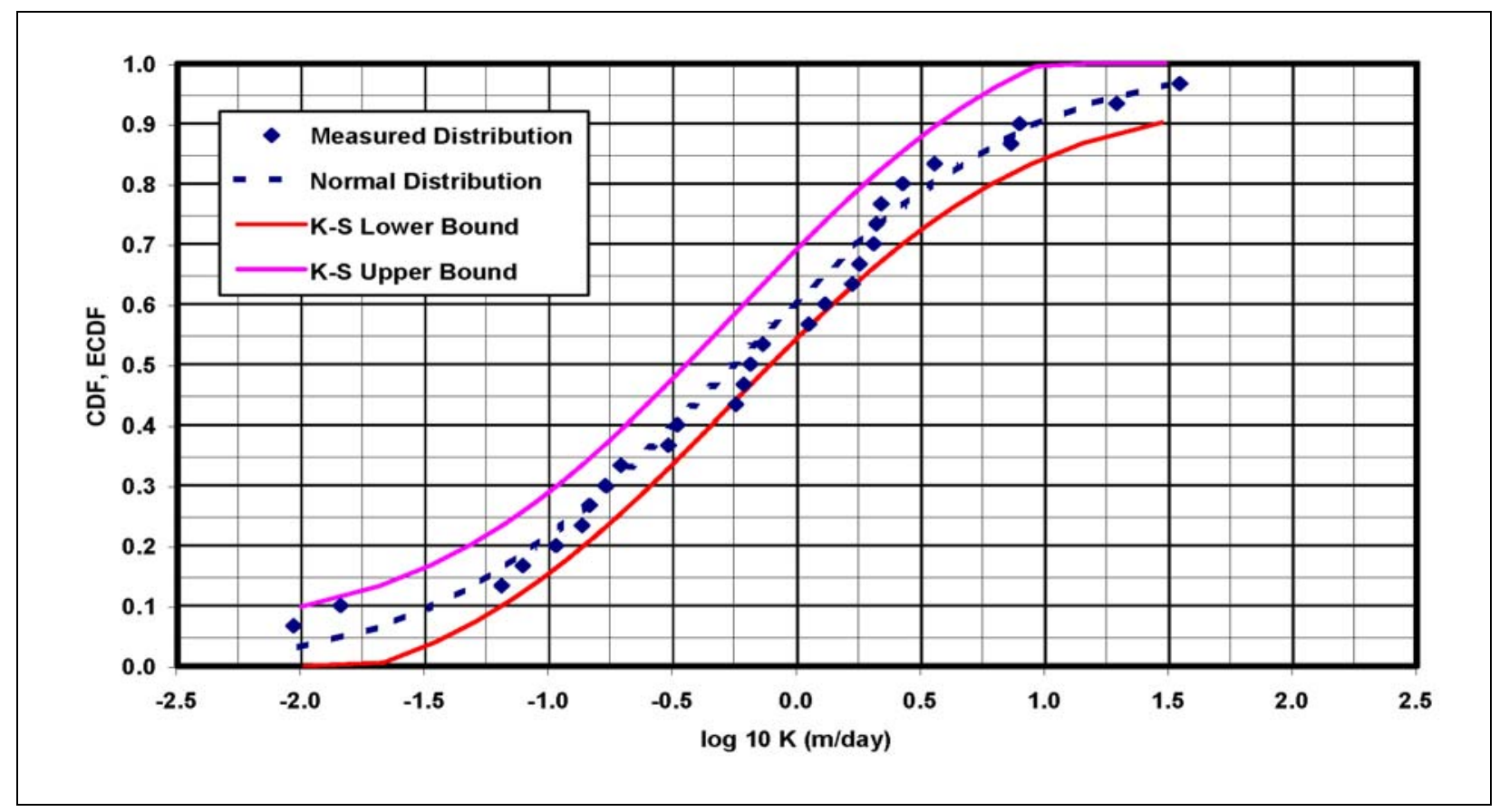

Figure 6-15

Lava Flow Aquifer Pumping-Scale Hydraulic Conductivity Values

Probability Distribution for the NTS Investigation Area Dataset

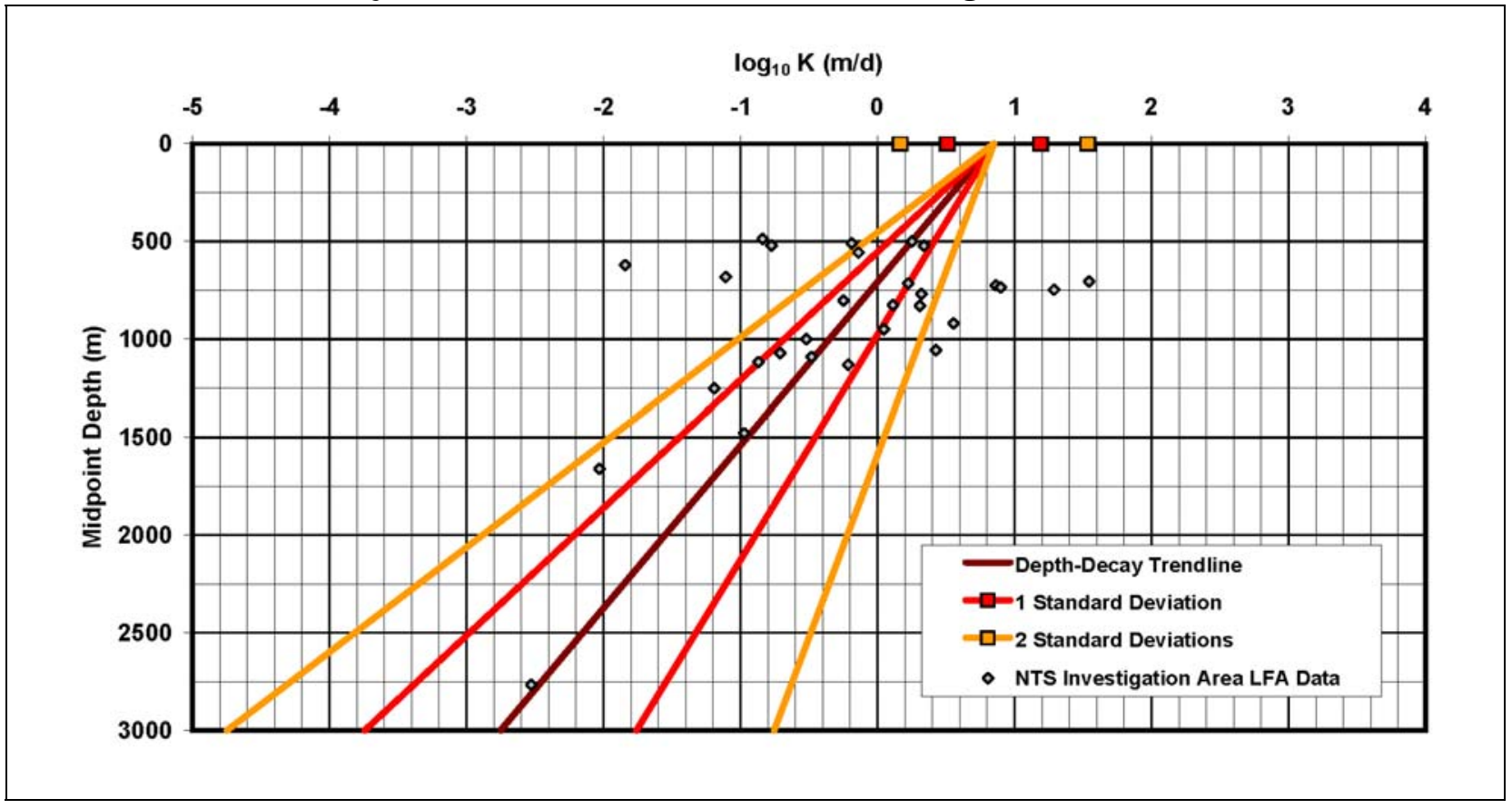

Figure 6-16

Lava Flow Aquifer Pumping-Scale Hydraulic Conductivity Versus Depth for the NTS Investigation Area Dataset 


\subsubsection{Tuff Confining Unit Hydrogeologic Unit}

There is only one pumping-scale data point for the TCU within the Yucca Flat/Climax Mine Data Compilation Area. Figure 6-17 shows the results of the log-normality test for the NTS Investigation Area Pumping-Scale TCU data, and Figure 6-18 shows $\log _{10} \mathrm{~K}$ versus depth for this dataset. As explained in Section 6.7.3, at the slug test-scale, the formation character (lithology, stratigraphy, and fracturing, as well as regional HSU distinctions) for the tested intervals for nominally LFA tests were indistinguishable from the TCU HGU, so the combined dataset LFA, TCU is generally representative of the TCU. Note in Table 6-1 and 6-2 that hydraulic conductivity distributions for the TCU data were also analyzed for the laboratory scale data and conformed to log-normal distribution. 


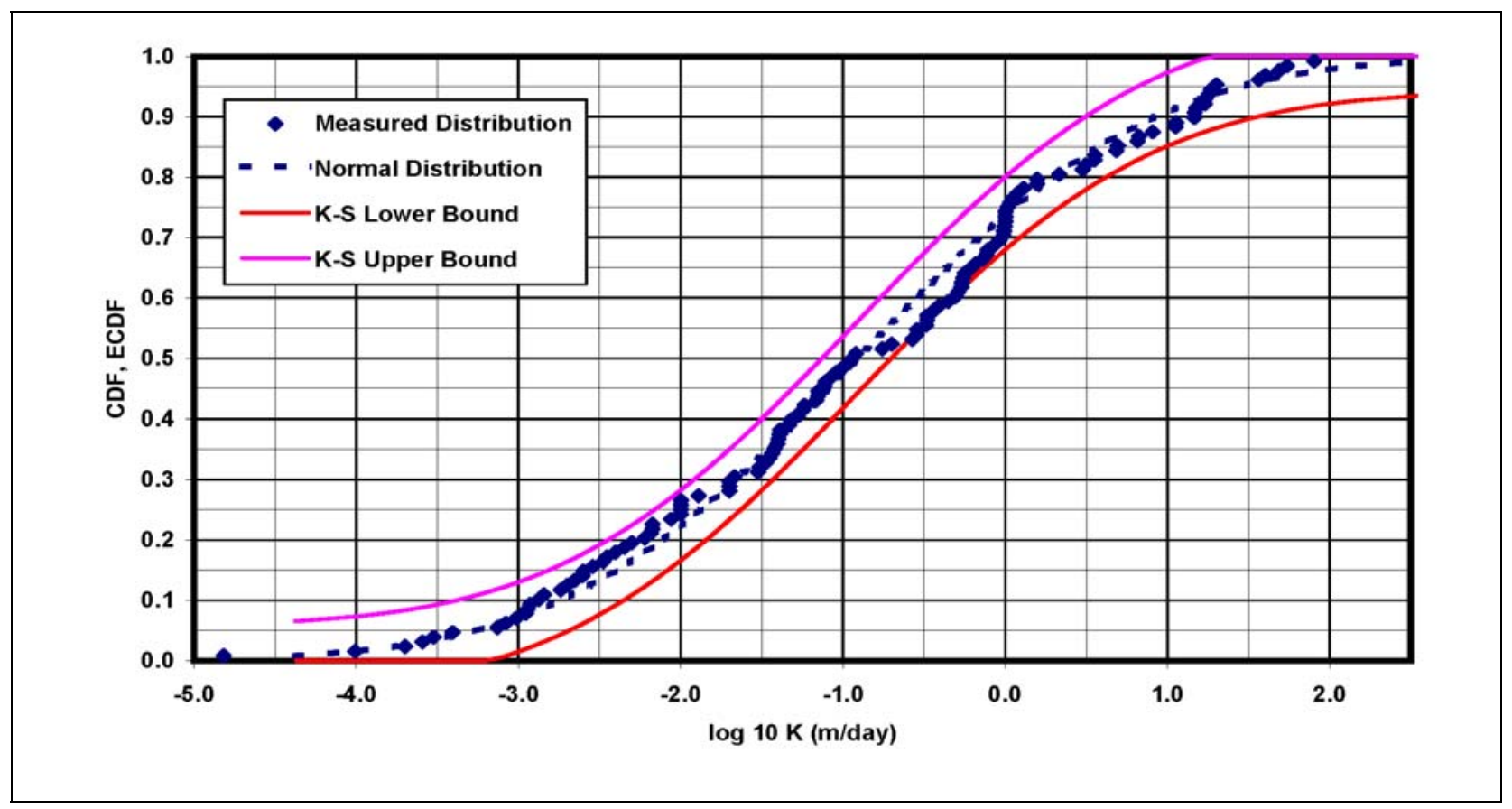

Figure 6-17

Tuff Confining Unit Pumping-Scale Hydraulic Conductivity Probability Distribution for the NTS Investigation Area Dataset

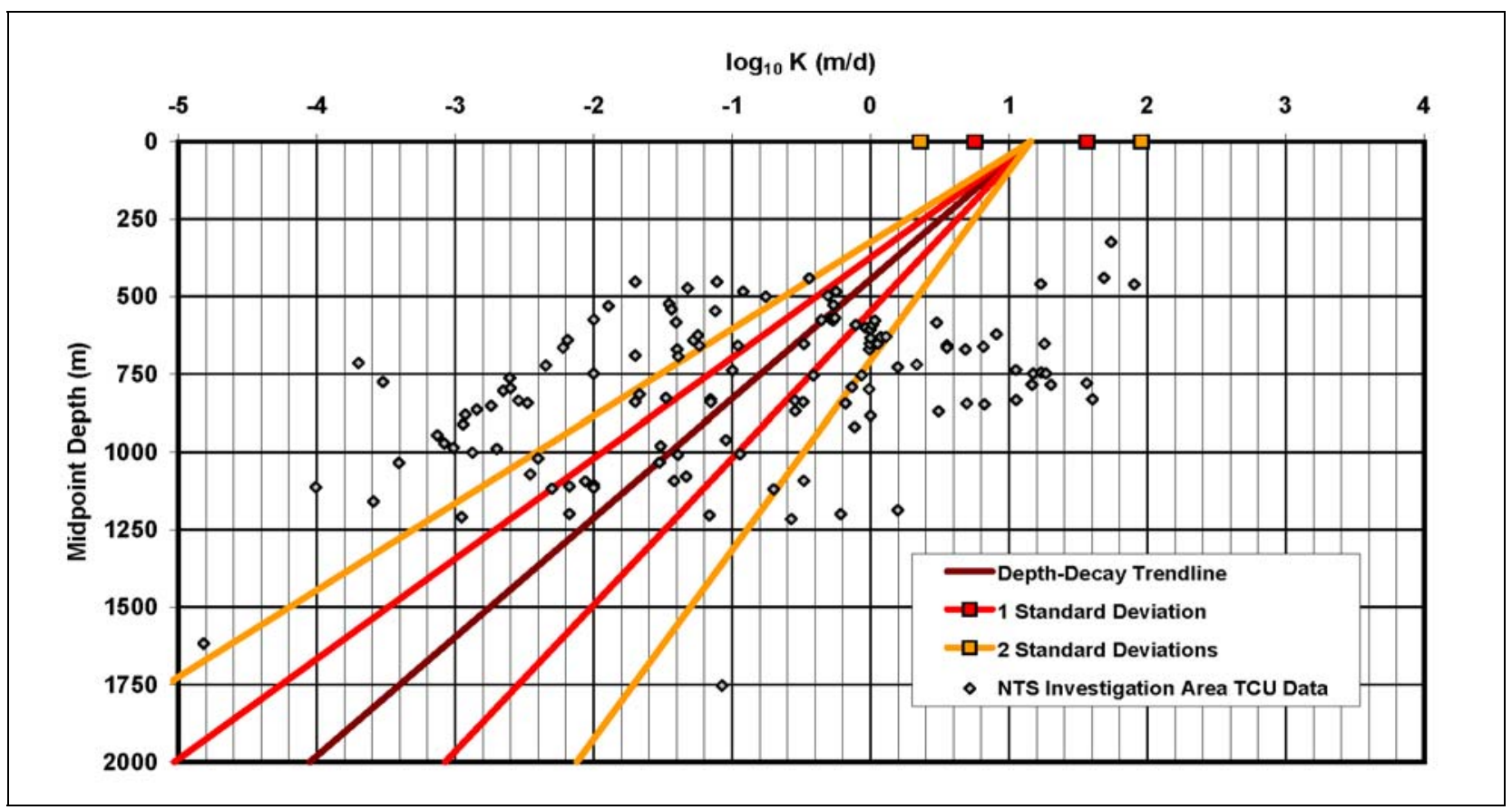

Figure 6-18

Tuff Confining Unit Pumping-Scale Hydraulic Conductivity Versus Depth the NTS Investigation Area Dataset 


\subsubsection{Lower Carbonate Aquifer Hydrogeologic Unit}

The LCA is another HGU used extensively for water supply, and there are a substantial number of data points in the NTS Investigation Area and specifically in the Yucca Flat/Climax Mine CAU. Figure 6-19 shows the results of the log-normality test for the Yucca Flat/Climax Mine Pumping-Scale LCA data, and Figure 6-20 shows $\log _{10} \mathrm{~K}$ versus depth for this dataset. Figure 6-21 shows the results of the log-normality test for the NTS Investigation Area Pumping-Scale LCA data, and Figure 6-22 shows $\log _{10} \mathrm{~K}$ versus depth for this dataset. Note in Table 6-1 and 6-2 that hydraulic conductivity distributions for LCA data were also analyzed for the slug-test scale and the laboratory scale data, and both conformed to log-normal distribution. 


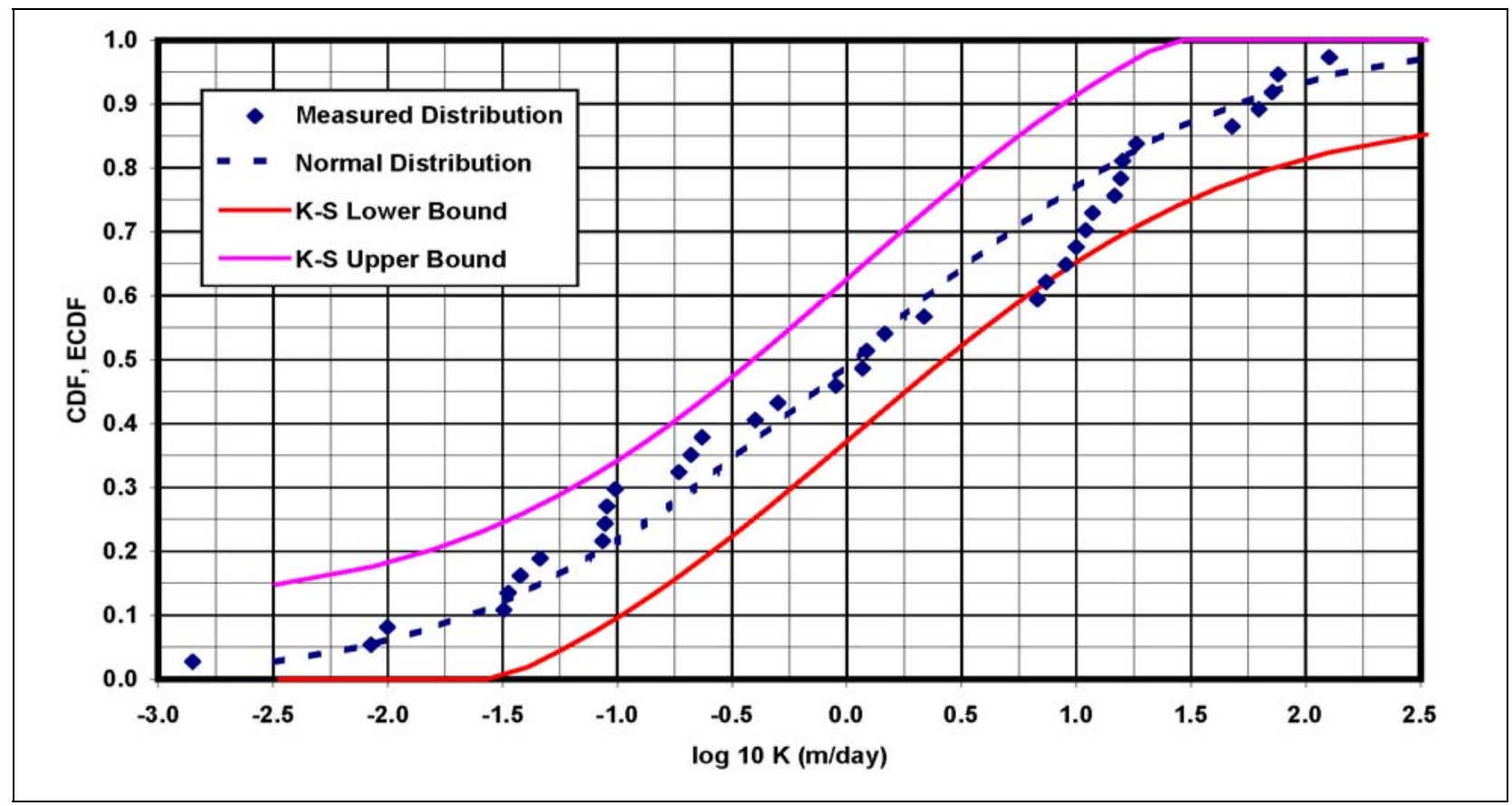

Figure 6-19

Lower Carbonate Aquifer Pumping-Scale Hydraulic Conductivity Probability Distribution for the Yucca Flat/Climax Mine Dataset

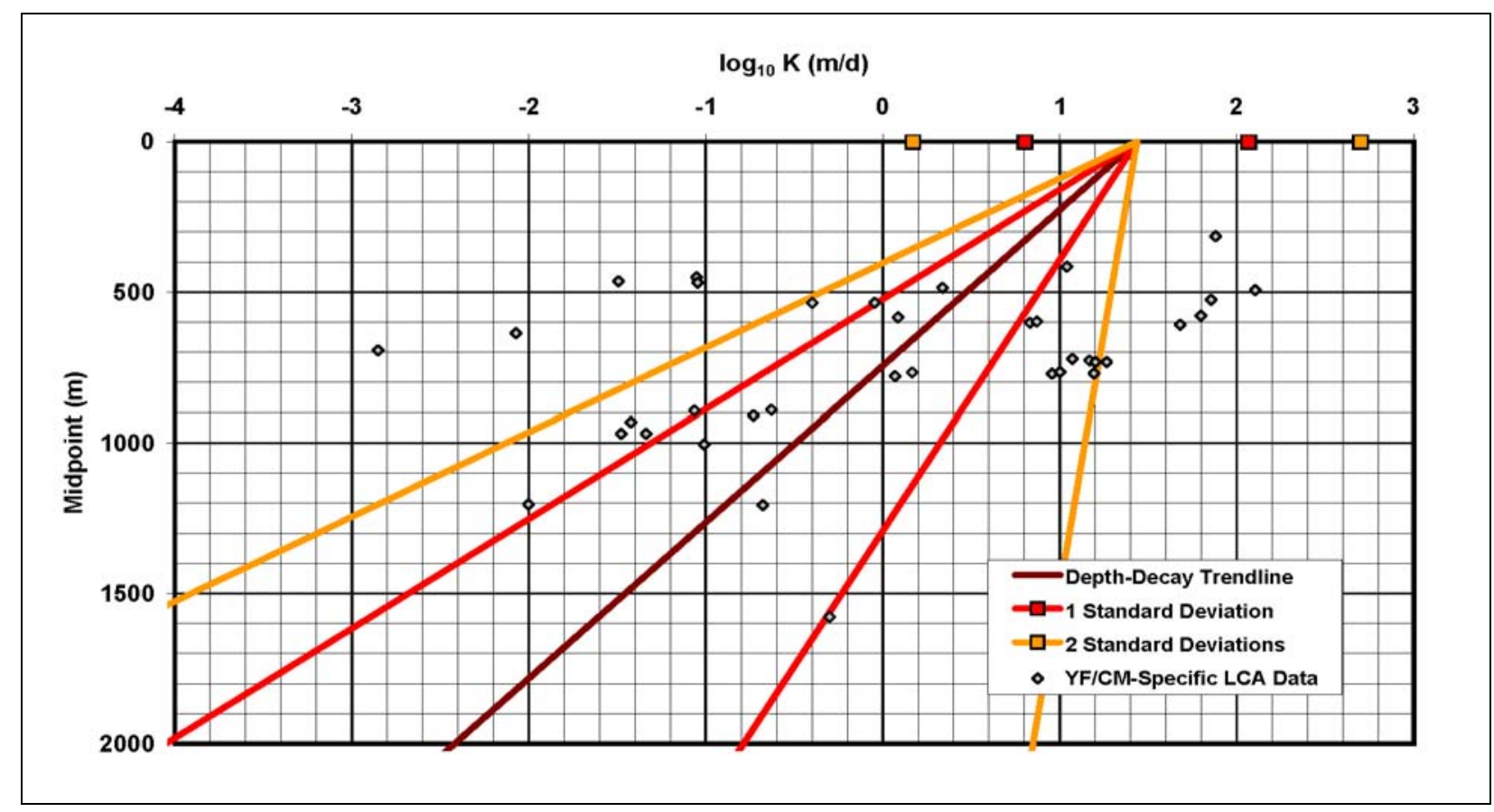

Figure 6-20

Lower Carbonate Aquifer Pumping-Scale Hydraulic Conductivity Versus Depth for the Yucca Flat/Climax Mine Dataset 


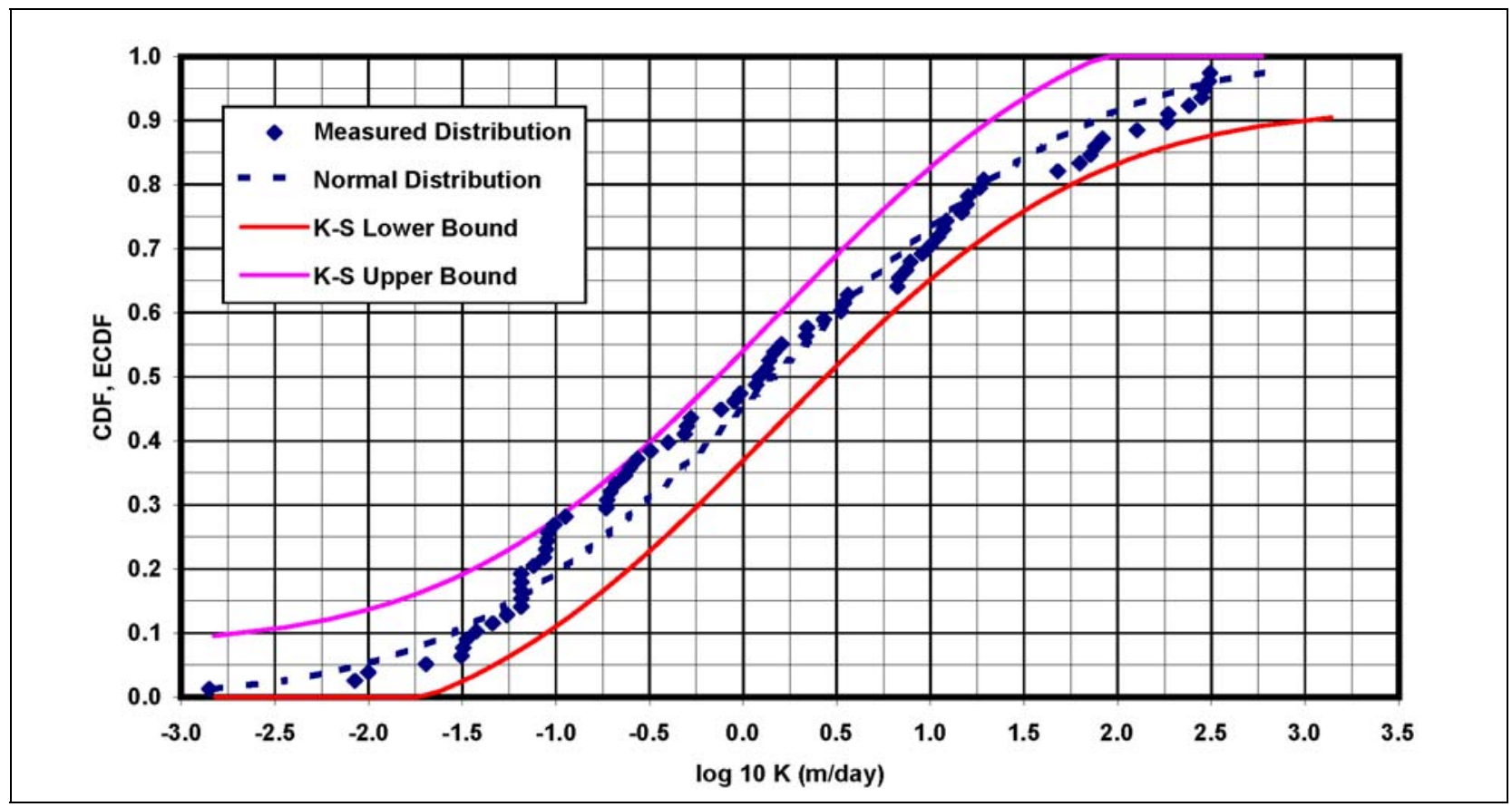

Figure 6-21

Lower Carbonate Aquifer Pumping-Scale Hydraulic Conductivity Probability Distribution for the NTS Investigation Area Dataset

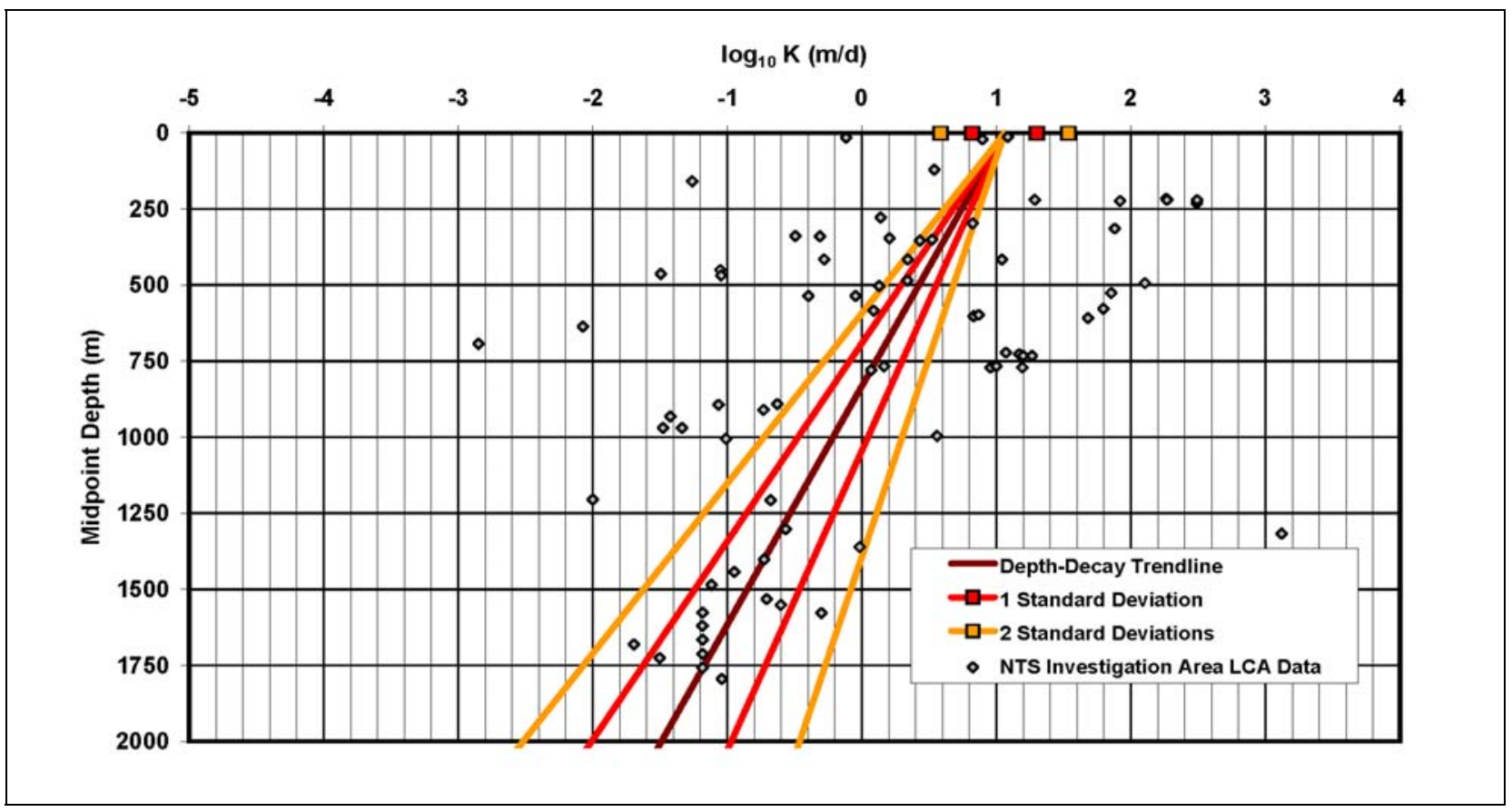

Figure 6-22

Lower Carbonate Aquifer Pumping-Scale Hydraulic Conductivity Versus Depth for the NTS Investigation Area Dataset 


\subsubsection{Test-Scale and Spatial Variability}

The hydraulic conductivity of natural geologic formations is known to be spatially variable. The data presented in this report support that observation. Not only is the hydraulic conductivity variable with depth, it varies laterally as demonstrated by distinctly different ranges of values of hydraulic conductivity at different well locations in the same HGU.

Vanmarcke (1983) has shown that as the scale of averaging increases, the variance of a random process decreases, and the correlation length increases. Rubin and Gomez-Hernandez (1990) present theoretical and numerical examples of the impact of scaling as a function of block size. As the block size increases relative to the correlation scale, the mean value of the block approaches the geometric mean, and the variance of the mean value is significantly reduced. In their examples, the variance was reduced by a factor of 10 when the block size was 6.5 times the correlation length. The difficulty with application of approaches such as Rubin and Gomez-Hernandez (1990) is that covariance information, especially correlation length, is needed. In reality, this covariance information is never available. However, several key observations from the theoretical studies can be made. First, the geometric mean is a reasonable estimate of the average hydraulic conductivity of a block. Second, the uncertainty in the hydraulic conductivity as characterized by the $\log _{10} \mathrm{SD}$ is larger than the uncertainty in the block-scale value, assuming that the available data represent the full range of variability in the formation. These scaling relationships are all based on the assumption of a constant mean and uniform statistical properties within an HSU. If these assumptions are incorrect, the conclusions of the theoretical studies may not apply.

Table 6-6 shows the variation of the mean and SD with the scale of measurement for each HSU. It can be seen that the mean value of $\log _{10}$ hydraulic conductivity generally increases from the laboratory scale to the pumping-scale for most of the HGUs. This is more true for the NTS Investigation Area datasets, which can have substantially larger counts (number of unique data points). The $\mathrm{SD}$ also is reduced between the laboratory scale and pumping scales for the datasets with large counts, the AA, VA, and TCU, and is almost the same for the LCA. There are substantial differences between the mean HGU Ks for the Yucca Flat/Climax Mine-specific pumping-scale dataset and the NTS Investigation Area pumping-scale dataset for the AA, VA, LCA, and LCCU, which may be related to the differences in the number of data points between the two datasets. Note that for the MGCU and UCCU, the datasets are the same and almost the same for the LCCU. The 
differences in the mean of the hydraulic conductivity data may be due to the sizes (and therefore, representativeness) of the datasets or actual spatial differences in hydraulic conductivity in the additional area covered by the larger dataset. The spatial location of data is shown in Figure 6-1.

Similar observations have been made in other studies reported in the literature. In contrast, Zlotnik et al. (2000) reviewed many of these other studies and conclude that there is little evidence for a scale effect in hydraulic conductivity. They conclude that large increases in mean hydraulic conductivity from laboratory- to field-scale measurements are most likely due to sampling bias, not true scale dependence. For the NTS data, this difference is probably mostly due to the greater sampling of the fracture system by larger-scale tests, which can be viewed both as a matter of scale dependence or sampling bias. They also point out the difficulty of quantifying the scale of measurement for field techniques such as pumping tests and slug tests. The analysis generalizes the field scale of measurement by pumping-scale and slug test-scale, but does not quantify the difference. In addition, Zlotnik et al. (2000) provide six general principles to apply to screening and comparing data. One of the principles is coverage to which they caution that comparison of data collected by two different techniques over two different subdomains is not possible. In other words, if the slug-test scale data were not collected in the same borehole and same depth interval as the pumping-scale data, the comparison of results is not meaningful. Most, if not all cases, generated under this analysis do not have overlapping domains. For the purposes of large-scale flow modeling, the pumping-scale data will be the primary choice and the slug test-scale data will be consulted only for secondary reference. Laboratory-scale data are not applicable to formations characterized by fracture flow, but may have limited usefulness in defining hydraulic conductivity in porous-media formations and in the matrix of the fractured formations. 
Table 6-6

Variation of the Mean and SD of Hydraulic Conductivity Data by Scale of Measurements, by HSU

\begin{tabular}{|c|c|c|c|c|c|c|c|c|c|c|}
\hline \multirow{2}{*}{ HSUs } & \multirow{2}{*}{ Data Source } & \multicolumn{3}{|c|}{$\begin{array}{l}\text { Pumping-Scale Data } \\
\log _{10} K(\mathrm{~m} / \mathrm{d})\end{array}$} & \multicolumn{3}{|c|}{$\begin{array}{c}\text { Slug-Test-Scale Data } \\
\log _{10} \mathrm{~K}(\mathrm{~m} / \mathrm{d})\end{array}$} & \multicolumn{3}{|c|}{$\begin{array}{l}\text { Laboratory-Scale Data } \\
\log _{10} K(\mathrm{~m} / \mathrm{d})\end{array}$} \\
\hline & & Mean & $\begin{array}{l}\text { Standard } \\
\text { Deviation }\end{array}$ & Count & Mean & $\begin{array}{l}\text { Standard } \\
\text { Deviation }\end{array}$ & Count & Mean & $\begin{array}{l}\text { Standard } \\
\text { Deviation }\end{array}$ & Count \\
\hline \multirow{2}{*}{ AA } & Yucca Flata & -0.13 & 0.93 & 22 & -0.40 & 0.38 & 6 & -0.34 & 0.71 & 60 \\
\hline & NTS Area ${ }^{b}$ & 0.45 & 0.93 & 51 & -0.70 & 1.17 & 14 & -0.76 & 1.56 & 73 \\
\hline \multirow{2}{*}{ VA } & Yucca Flat & 0.23 & 1.10 & 20 & -1.98 & 0.84 & 16 & -2.09 & 0.81 & 8 \\
\hline & NTS Area & -0.12 & 1.29 & 142 & -2.49 & 1.08 & 142 & -3.77 & 2.23 & 403 \\
\hline \multirow{2}{*}{ LFA } & Yucca Flat & NA & NA & NA & NA & NA & NA & NA & NA & NA \\
\hline & NTS Area & -0.26 & 0.95 & 29 & NA & NA & NA & NA & NA & NA \\
\hline \multirow{2}{*}{$\mathrm{TCU}$} & Yucca Flat & -1.07 & NA & 1 & -2.38 & 0.56 & 10 & -3.57 & 1.14 & 34 \\
\hline & NTS Area & -0.91 & 1.43 & 127 & -2.34 & 1.12 & 258 & -4.42 & 1.55 & 637 \\
\hline \multirow{2}{*}{ MGCU } & Yucca Flat & -2.49 & NA & 1 & -1.16 & 1.78 & 3 & NA & NA & NA \\
\hline & NTS Area & -2.49 & NA & 1 & -1.16 & 1.78 & 3 & NA & NA & NA \\
\hline \multirow{2}{*}{ UCCU } & Yucca Flat & -2.64 & 1.15 & 3 & -1.99 & 0.73 & 4 & NA & NA & NA \\
\hline & NTS Area & -2.64 & 1.15 & 3 & -2.35 & 0.79 & 7 & NA & NA & NA \\
\hline \multirow{2}{*}{ LCA } & Yucca Flat & 0.03 & 1.31 & 36 & -1.03 & 0.46 & 9 & -5.21 & 0.40 & 4 \\
\hline & NTS Area & 0.16 & 1.34 & 77 & -1.16 & 1.09 & 24 & -4.39 & 1.28 & 32 \\
\hline \multirow{2}{*}{ LCCU } & Yucca Flat & -2.21 & NA & 1 & NA & NA & NA & -6.56 & 0.66 & 30 \\
\hline & NTS Area & -0.78 & 2.02 & 2 & NA & NA & NA & -6.56 & 0.66 & 30 \\
\hline
\end{tabular}

aYucca Flat/Climax Mine Data Compilation Area

${ }^{b} N T S$ Investigation Area 


\subsection{Aquifer Unit Versus Confining Unit Results}

As shown in Figure 6-3, the pumping-scale data shows that the mean $\log _{10}$ hydraulic conductivity varies as would be expected with the unit designation, aquifer versus confining unit. This is true for all three scales of measurement as can be seen in Table 6-6. Also, the laboratory-scale data show that the matrix hydraulic conductivity of the volcanic and carbonate aquifer units are similar to the hydraulic conductivity of the confining units. This would bolster the interpretation that the large-scale hydraulic conductivity of those aquifer units is a function of the fracture system within those units.

\subsection{Aquifer Storage Properties}

The storage coefficient $(\mathrm{S})$ is defined as the volume of water that an aquifer releases from or takes into storage per unit surface area of the aquifer per unit change in head (Freeze and Cherry, 1979). It is a dimensionless variable that is generally smaller than 0.005 in confined aquifers. It is called the specific yield in unconfined aquifers and is a measure of the drainable porosity, typically less than 0.30. Specific storage $\left(\mathrm{S}_{\mathrm{s}}\right)$ is the amount of water that an aquifer releases from or takes into storage, per unit volume per unit decline in head, and is calculated by dividing the storage coefficient by the saturated thickness (b): $\mathrm{S}=\mathrm{S}_{\mathrm{s}}$ *b. Specific storage is used to assess storage parameter variability, because it removes the effects of unequal test interval lengths from the data.

Table 6-7 presents a summary of the analyses for "Specific Storage" and "Fracture Specific Storage" for both the Yucca Flat/Climax Mine and NTS Investigation Area datasets. These datasets contain all storage parameter values reported in analyses of pumping-scale tests, including results from both single- and multi-well tests. It is recognized that results from single-well tests are much less reliable than results from multi-well tests. However, few multi-well tests have been conducted, and there are consequently few storage values determined from such testing. Storage parameter values from those few multi-well tests will be considered during modeling, but this data compilation includes all available data. The general "Specific Storage" datasets, which includes all storage parameter values, generally had sufficient numbers of independent values to calculate statistics. There is much less data for "Fracture Specific Storage," which included only those storage parameter values specifically identified as fracture specific storage in data sources, resulting from analyses using models for dual-porosity. 
Table 6-7

Summary of Specific Storage Analysis

\begin{tabular}{|c|c|c|c|c|c|c|}
\hline \multicolumn{7}{|c|}{ Yucca Flat/Climax Mine-Specific Data } \\
\hline \multicolumn{7}{|c|}{ Specific Storage (1/m) } \\
\hline HGU & Mean & $\begin{array}{l}\text { Standard } \\
\text { Deviation }\end{array}$ & Count & Minimum & Maximum & $\begin{array}{l}\text { Number } \\
\text { of Entries }\end{array}$ \\
\hline$\overline{A A}$ & $1.22 \mathrm{E}-04$ & 1.60E-04 & 6 & $6.56 \mathrm{E}-06$ & 3.98E-04 & 11 \\
\hline VA & 1.21E-02 & 4.07E-02 & 12 & 8.51E-08 & $1.41 \mathrm{E}-01$ & 22 \\
\hline LCA & 5.21E-02 & $1.24 \mathrm{E}-01$ & 20 & 5.58E-09 & 4.69E-01 & 111 \\
\hline \multicolumn{7}{|c|}{ Fracture Specific Storage (1/m) } \\
\hline VA & 1.79E-06 & $\overline{\mathrm{N} / \mathrm{A}}$ & $\overline{1}$ & $\overline{\mathrm{N} / \mathrm{A}}$ & $\overline{\mathrm{N} / \mathrm{A}}$ & 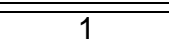 \\
\hline \multicolumn{7}{|c|}{ NTS Investigation Area } \\
\hline \multicolumn{7}{|c|}{ Specific Storage (1/m) } \\
\hline HGU & Mean & $\begin{array}{l}\text { Standard } \\
\text { Deviation }\end{array}$ & Count & Minimum & Maximum & $\begin{array}{l}\text { Number } \\
\text { of Entries }\end{array}$ \\
\hline$\overline{\mathrm{AA}}$ & 1.08E-04 & $2.00 \mathrm{E}-04$ & 22 & $1.40 \mathrm{E}-07$ & 7.90E-04 & 27 \\
\hline VA & 4.04E-03 & $2.32 \mathrm{E}-02$ & 37 & $3.71 \mathrm{E}-15$ & $1.41 \mathrm{E}-01$ & 72 \\
\hline LFA & 8.84E-04 & $3.14 \mathrm{E}-03$ & 13 & 1.49E-07 & $1.13 \mathrm{E}-02$ & 33 \\
\hline TCU & 7.02E-05 & $1.71 \mathrm{E}-04$ & 36 & 1.40E-07 & 8.44E-04 & 52 \\
\hline LCA & $3.58 \mathrm{E}-02$ & 9.97E-02 & 32 & $5.58 \mathrm{E}-09$ & 4.69E-01 & 162 \\
\hline \multicolumn{7}{|c|}{ Fracture Specific Storage (1/m) } \\
\hline VA & 1.79E-06 & N/A & 1 & N/A & N/A & 1 \\
\hline TCU & 5.43E-06 & 8.65E-06 & 7 & 5.91E-07 & $2.43 \mathrm{E}-05$ & 8 \\
\hline LCA & 1.01E-05 & 3.84E-06 & 5 & 8.33E-06 & 1.69E-05 & 9 \\
\hline
\end{tabular}

N/A = Not applicable 
Figure 6-23 and 6-24 show the distributions of the specific storage data for the Yucca Flat/Climax Mine and the NTS Investigation Area datasets, respectively, identified by HGU. The specific storage probability distribution for all data spans nine orders of magnitude. The specific storage values that are greater than $10^{-3}$ are suspect, because the associated storativities would require excessively high porosity. These very high storativity values are for the LCA from a location where the LCA is shallow and karstic and may have been dewatered during testing, in which case they actually represent specific yield. These data likely do not represent the conditions in the LCA for the Yucca Flat/Climax Mine CAU where it is deeply buried. Ignoring these values, the data span six orders of magnitude, centered on approximately $3.00 \times 10^{-6}$. The distributions for $\mathrm{S}_{\mathrm{s}}$ for the AA, VA, LFA, and TCU HSUs are similar. The distribution for the LCA would also be similar after removing those data above $1.00 \times 10^{-3}$.

Sanchez-Vila et al. (1999) show that in the presence of heterogeneity, which always occurs in reality, storativity estimates will often vary strongly as a function of the relative transmissivity of the flow path between the pumping and observation well. Thus, storativity estimates depend on the degree of transmissivity heterogeneity. Sanchez-Vila et al. (1999) also suggest that a good estimate of true storativity is rarely obtained in practice from pumping tests. It is possible that much of the apparent scatter in specific storage values is unrelated to the actual variability of storage properties. General survey information on storage properties of formations in southern Nevada can be found in Kilroy (1992).

Figure 6-25 shows the fracture specific storage probability distribution, which includes the VA, TCU, and LCA HGUs. The data for this parameter, which is generally not distinguished from the general specific storage parameter, is very limited. The LCA values shown in this plot reflect four identical values found in the data compilation for one test with four different hydraulic conductivity analyses. The fracture-specific storage values span about 1.5 orders of magnitude.

\subsection{Conversion of Hydraulic Conductivity to Permeability}

The hydraulic conductivity determined from testing is a function of the temperature of the water in the tested interval as well as the formation properties. The temperature of the water in formations on the NTS varies widely both spatially, in relation to geologic features, and with depth, in relation to the geothermal gradient. Section 11.0 addresses the temperature distribution across the 


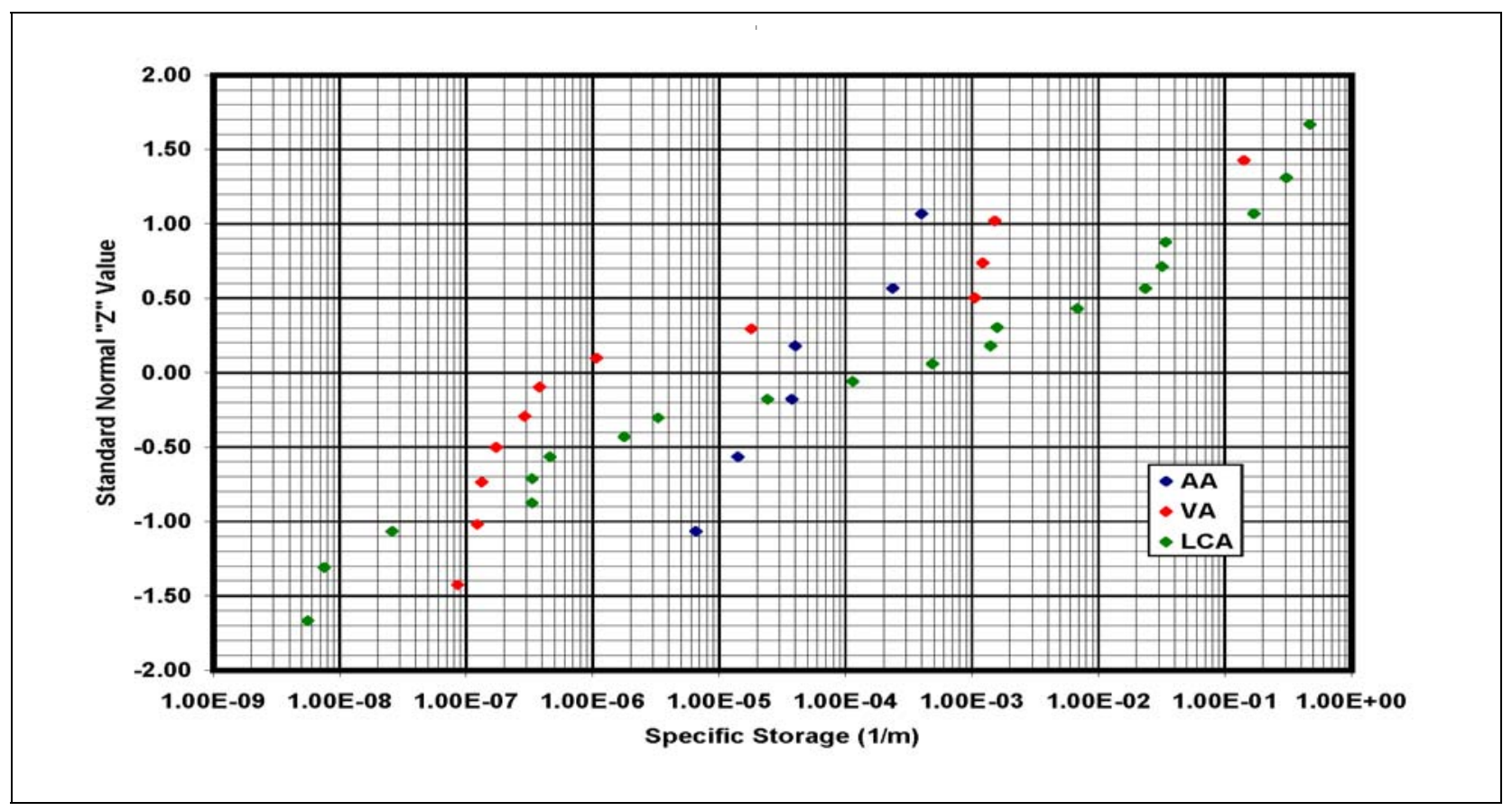

Figure 6-23

Specific Storage Data for the Yucca Flat/Climax Mine Dataset

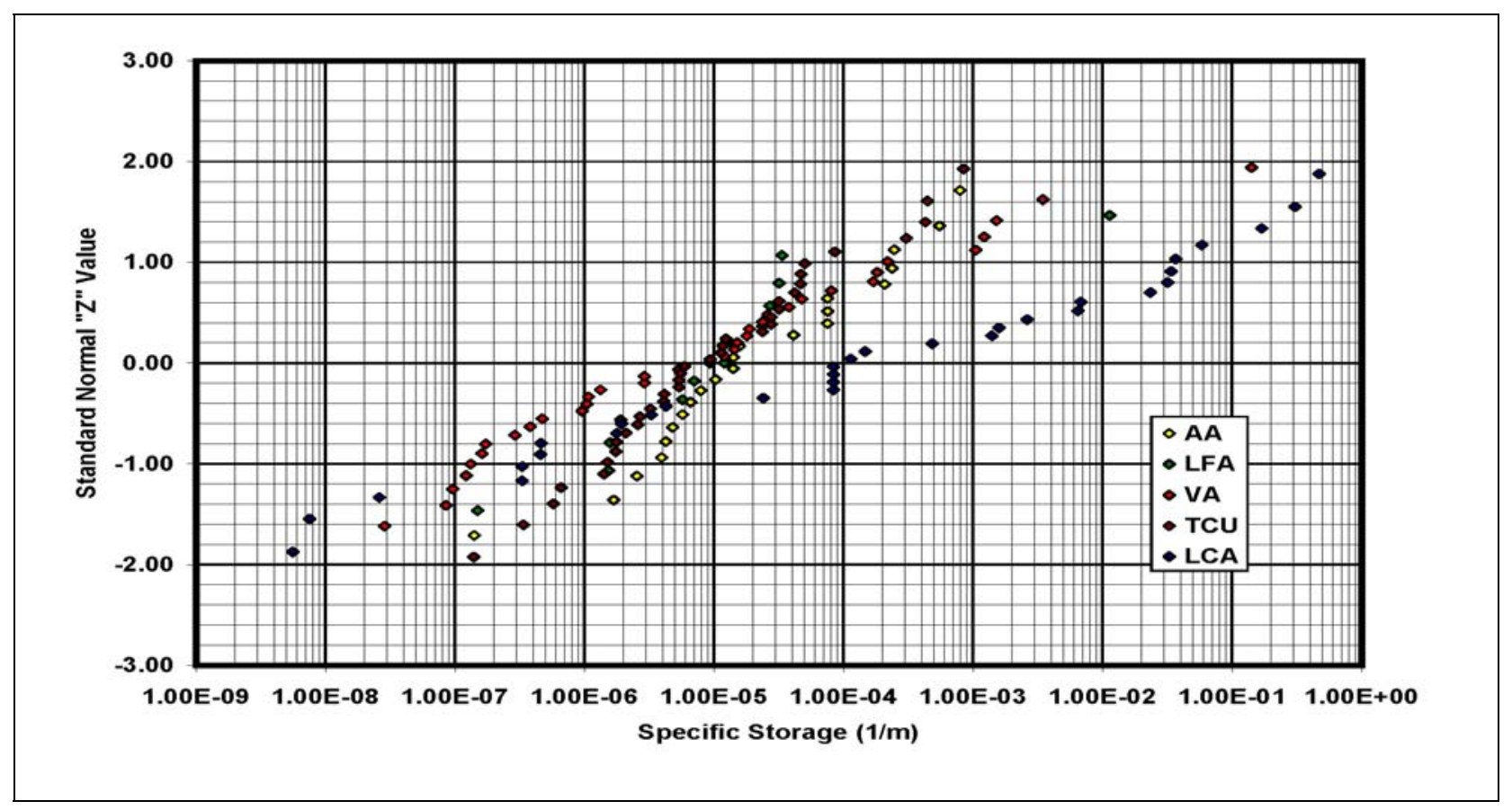

Figure 6-24

Specific Storage Data for the NTS Investigation Area Dataset 


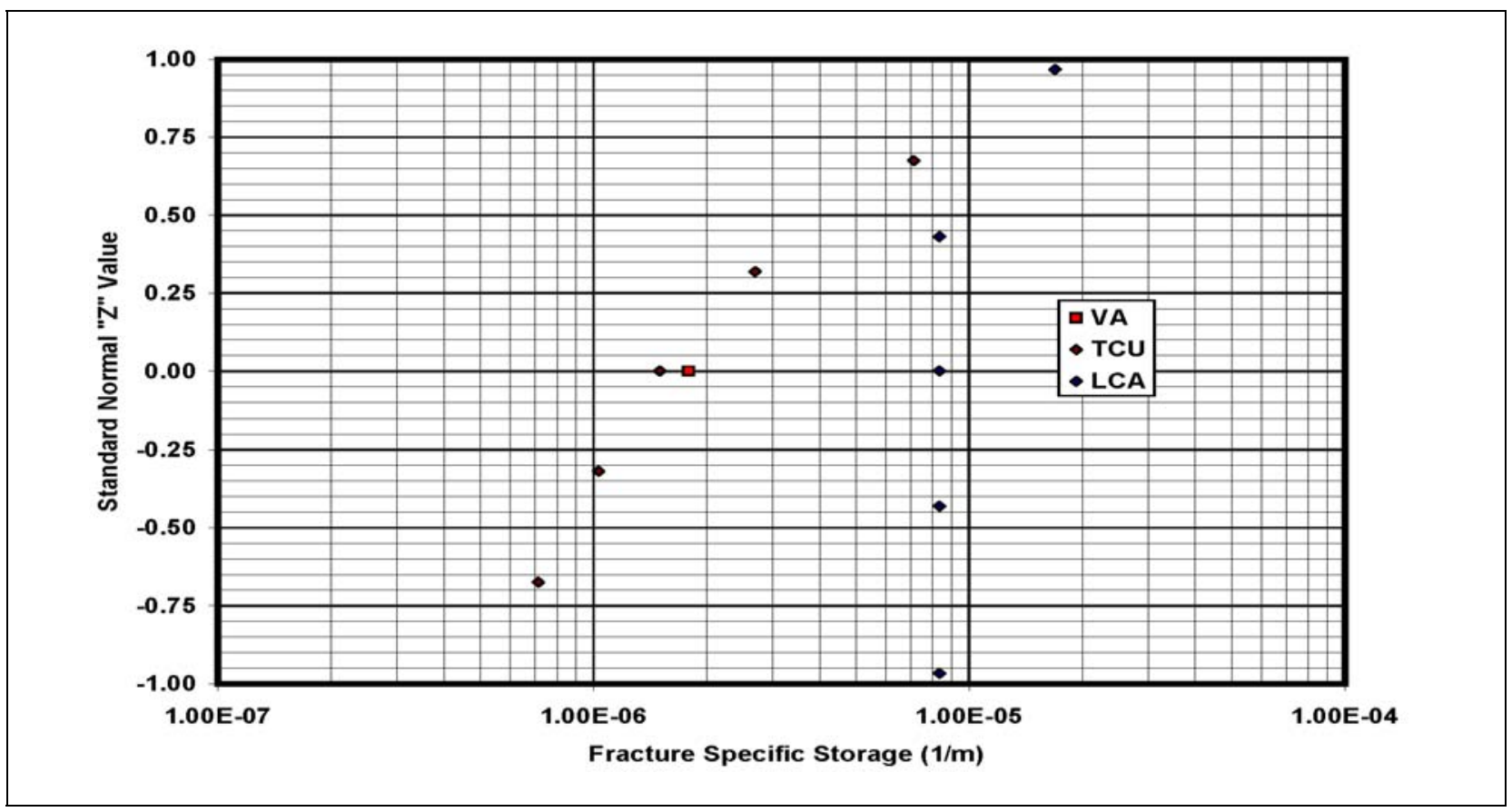

Figure 6-25

Fracture Specific Storage Data for the NTS Investigation Area Dataset

Yucca Flat/Climax Mine Data Compilation Area. Conversion from hydraulic conductivity to permeability removes the influence of fluid properties, specifically viscosity.

Intrinsic permeability $(\mathrm{k})$ can be calculated from the hydraulic conductivity $(\mathrm{K})$ if the temperature of the water produced from the formation is known. The relationship is $\mathrm{k}=\mathrm{K} \mu / \rho \mathrm{g}$, where $\mu$ is the dynamic viscosity of water, $\rho$ is the density of water, and $g$ is the force of gravity (Freeze and Cherry, 1979). Both $\mu$ and $\rho$ vary with the temperature of the water. Determining $\mathrm{k}$ for each hydraulic conductivity value would normalize the hydraulic conductivity data with respect to the variation in temperature.

\subsubsection{Uncertainty of Permeability Due to Temperature}

Specific temperature information is not available for many of the hydraulic tests, especially the older tests. The analysis of spatial temperature variation and temperature gradients for the Yucca Flat/Climax Mine CAU may be used as the basis for specifying the appropriate temperature for use in conversion of hydraulic conductivity values to permeability. Temperature data for Yucca Flat/Climax Mine wells is presented in Section 11.0. Subsurface temperature and temperature gradients can vary 
locally as well as large-scale trends, so the uncertainty of this approach would depend upon the nearby location of appropriate subsurface temperature data. Also, it has been observed that the water produced during testing does not always approximate the temperature at the production depth determined from non-pumping temperature logs. This situation could not be readily accounted for without well-specific pumping temperature data. Consequently, assumptions would have to be made about temperatures applicable to each test.

Table 6-8 shows the variation of $\mu$ and $\rho$ with temperature for pure water. Water in the formations beneath the NTS is generally considered fresh, and the variation of water properties shown here is thought to be representative. Specific data for NTS waters is not available. The fourth column in Table 6-8 shows the ratio of $\mu / \rho$, which is the factor of the conversion from hydraulic conductivity to permeability that would vary by temperature. The ratio of the values of this factor for the uncertainty in temperature reflects the uncertainty in the conversion due to temperature. The downhole temperatures shown in Table $11-6$ range from a minimum of $14.7^{\circ} \mathrm{C}$ to a maximum of $53.7^{\circ} \mathrm{C}$. The uncertainty due to unknown temperature of the groundwater during testing for this temperature range is a factor of up to 2.2, that is, the ratio of $\mathrm{k}$ determined for the endpoint of this range.

Table 6-8

Variation of Water Properties With Temperature

\begin{tabular}{|c|c|c||c|}
\hline $\begin{array}{c}\text { Temperature } \\
\left({ }^{\circ} \mathbf{C}\right)\end{array}$ & $\rho-$ Density gm/cm ${ }^{3}$ & $\begin{array}{c}\mu-\text { Dynamic Viscosity } \\
\mathbf{g m / c m ~ s e c ~ ( 1 0})\end{array}$ & $\begin{array}{c}\mu / \rho \\
\mathbf{c m}^{2} / \mathbf{s e c}\left(\mathbf{1 0}^{\mathbf{2}}\right)\end{array}$ \\
\hline \hline 0 & 0.99984 & 1.793 & 1.793 \\
\hline 10 & 0.99970 & 1.307 & 1.307 \\
\hline 20 & 0.99821 & 1.002 & 1.004 \\
\hline 30 & 0.99565 & 0.798 & 0.801 \\
\hline 40 & 0.99222 & 0.653 & 0.658 \\
\hline 50 & 0.98803 & 0.547 & 0.554 \\
\hline 60 & 0.98320 & 0.467 & 0.475 \\
\hline 70 & 0.97778 & 0.404 & 0.413 \\
\hline 80 & 0.97182 & 0.354 & 0.364 \\
\hline
\end{tabular}

Data from CRC Handbook of Chemistry and Physics, $73^{\text {rd }}$ Edition (CRC, 1992) $\mathrm{gm} / \mathrm{cm}^{3}=$ Grams per cubic centimeter $\mathrm{gm} / \mathrm{cm} \mathrm{sec}=$ Grams per centimeter second 


\subsubsection{Affect of Temperature Change on Test Response Measurement}

Water temperature change during testing affects the measurement of the formation response, and consequently represents an uncertainty in the determination of hydraulic conductivity. The hydraulic response during testing is typically observed by measuring the elevation change in the free-water surface in the well. The magnitude of the change is the basic measure used to determine the hydraulic conductivity, which can be substantially affected by the density of the water in the water column, which varies as a function of temperature. The conversion of hydraulic conductivity to permeability discussed previously does not deal with this effect. This correction would typically require fairly complete downhole temperature information during the test to calculate the effect of temperature change on the free water surface elevation. During more recent testing on the NTS, temperature information has been collected which allows approximate corrections for the effect on the head change measurements, and this is incorporated in the hydraulic conductivity values reported for those tests. However, the lack of specific temperature information for most of the tests precludes evaluation of the uncertainty related to this effect or correction of the measured test responses. This effect is generally small, but can be significant when large temperature changes and/or long water columns are involved. The effect on the derived hydraulic conductivity is related to the magnitude of the effect relative to the magnitude of the corrected drawdown.

\subsection{Anisotropy}

In the general case, hydraulic conductivity is not a scalar value, but a second rank tensor, where hydraulic conductivity at a point in space is a function of direction. Commonly, anisotropy within a formation is described as two distinct factors, horizontal anisotropy and vertical anisotropy, which are determined and applied separately.

\subsubsection{Horizontal Anisotropy}

The variation of hydraulic conductivity in the horizontal plane can be conceptualized as an ellipse defined by major and minor axes representing the maximum and minimum hydraulic conductivity values. Horizontal anisotropy is described as the ratio of the maximum to minimum hydraulic conductivity. Anisotropy in the horizontal plane can be a primary (depositional) or a secondary (structural) characteristic of the formation, depending upon the nature of the anisotropy. In either 
case, anisotropy is a function of preferential orientation of some feature that affects hydraulic conductivity. In fractured rock, typical of the NTS, this may be the orientation of large-scale fracturing and faults. In practice, the "horizontal" plane of anisotropy is usually closely aligned with the structural dip or bedding plane dip of the formation.

Horizontal anisotropy can be determined at a scale appropriate for use in modeling from pumping-scale tests. The determination of horizontal anisotropy requires data from multiple observation wells completed in the same depth interval as the pumping well during aquifer testing. As discussed previously, very few multi-well aquifer tests have been conducted on the NTS. Also, anisotropy related to structure is location specific and applicable data would be required from the area to be modeled, or extrapolated from an analysis that relates calibrated value(s) of anisotropy to the structural feature, which is known across the area of interest.

The only test within the Yucca Flat/Climax Mine area that was analyzed to provide anisotropy information was the ER-6-1 MWAT, which is discussed in Section 6.12. This provides some information for the LCA in the area of ER-6-1 and between ER-6-1 and ER-7-1.

\subsubsection{Vertical Anisotropy}

Vertical anisotropy is defined as the ratio of vertical hydraulic conductivity to horizontal hydraulic conductivity. The variability in hydraulic conductivity associated with vertical lithologic variations within a formation is likely to cause hydraulic conductivity parallel to bedding (or the depositional "horizontal" reference plane) to be higher than the hydraulic conductivity across the beds (Freeze and Cherry, 1979). However, this expected relationship becomes complicated by the variable dip of the units through the basin. Vertical anisotropy is defined within individual formations (HSUs) for application to modeling.

Vertical anisotropy can be determined from analysis of pumping tests with observation wells set at depths that differ from the pumped well. However, such analyses are difficult and uncertain, because the tests are affected by other factors that are poorly constrained. There are no analyses of pumping-scale tests in the Yucca Flat/Climax Mine area that provide vertical anisotropy information. There are some laboratory data on vertical to horizontal anisotropy, but laboratory results are generally not applicable to large-scale modeling. 


\subsection{ER-6-1 Multiple-Well Aquifer Test}

The ER-6-1 MWAT-TT is discussed individually, because it provides significant information for characterization of the LCA in Yucca flat not available from any other test or from the general analysis of all test data. This test was implemented according to the Underground Test Area Project, ER-6-1 Multi-Well Aquifer Test - Tracer Test Plan (SNJV, 2004g). The objective of the aquifer test was to determine hydraulic properties for the LCA through long-term constant-rate pumping at the well cluster with monitoring of the formation response in a large network of widely-spaced wells. This aquifer test was conducted in conjunction with a tracer transport test at the ER-6-1 Well Cluster. The MWAT-TT was conducted at a high pumping rate (524 gallons per minute [gpm] average) and long duration (90 days), which provided significantly better diagnostic information for hydraulic properties than those historically collected from shorter duration tests.

The data for these tests are compiled and documented in the report ER-6-1 Well Cluster Multi-Well Aquifer Test - Tracer Test Data Report, Volumes I, II, and III (SNJV, 2005d), which includes electronic data files for all production and hydraulic response data. This dataset may be useful for verification of the groundwater flow model in transient mode, because a specific hydraulic response is associated with specific water production across a large portion of the model area. The analysis of the data are reported in Analysis of Hydraulic Responses from the ER-6-1 Multiple-Well Aquifer Test, Yucca Flat FY 2004 Testing Program, Nevada Test Site, Nye County, Nevada (SNJV, 2005a). The hydraulic conductivity values that were determined for the various observation wells were included in the data compilation for the general analysis of hydraulic properties. However, specific review of the large-scale properties determined from this test may be particularly helpful in calibrating the Yucca Flat/Climax Mine CAU flow model, because the properties were interpreted with respect to flow dimension and can be correlated to orientation with respect to faults.

\subsubsection{Groundwater Production and Hydraulic Response Data}

Well Cluster ER-6-1 is located in Area 6 in southeastern Yucca Flat (Figure 6-26). The cluster consists of three wells that were utilized for the MWAT-TT: ER-6-1, ER-6-1 \#1, and ER-6-1 \#2. The three wells are positioned in approximate alignment with the dominant local fracture orientation so that tracer transport would be primary along fractures rather than across fractures, providing information more relevant to large scale groundwater flow and transport. Well ER-6-1 \#2 was 
utilized as the production well, and ER-6-1 and ER-6-1 \#1 were utilized as both observation and tracer-injection wells. Both ER-6-1 and ER-6-1 \#2 penetrate approximately $396 \mathrm{~m}$ of the LCA, excluding short segments of the top of the LCA. For the MWAT-TT, ER-6-1 was divided into two test intervals to provide information related to differences in fracturing with depth. Well ER-6-1 \#1 penetrates the top 91-m interval of the LCA. Continuous water-level responses were recorded in the on-site wells and also three wells distal to the well cluster: Wells UE-1h, ER-7-1, and ER-3-1 completed in the LCA. In addition, the USGS, as part of its periodic Yucca Flat monitoring, observed water level responses in wells UE-7nS and U-3cn \#5, both completed in the LCA. Monitoring was also conducted in the overlying volcanic formation at the ER-6-1 cluster (TCU) in the ER-6-1 and ER-6-1 \#2 piezometers, and in nearby Test Well-B (TW-B) completed in a higher overlying volcanic unit (TSA). Table 6-9 provides the geographic coordinates, well-to-well distances, and completion interval information for wells within the cluster.

\subsubsection{Summary of Test Results and Analysis}

The hydraulic test produced measured responses to groundwater production from ER-6-1 \#2 in all but one of the wells completed in the LCA, even at the greatest distance. Table 6-10 shows the results of the hydraulic analysis. An important feature of this analysis is the inclusion of flow dimension (Walker and Roberts, 2003) with respect to scale. The flow dimension indicates the dimensional nature of the flow response, and it can be seen to change with time, and consequently, scale. Flow dimension can vary from 1 (linear flow) to 2 (radial flow) to 3 (spherical flow).

Particularly notable were measured responses at great distance in ER-3-1 and ER-7-1. The response in ER-7-1, which is aligned with ER-6-1 \#2 (the production well) along the dominant fault orientation, was prompt and substantial, allowing determination of effective hydraulic conductivity over the great distance. The analysis indicates that the hydraulic structure is highly anisotropic. The flow response becomes linear at larger scales, suggesting that flow is primarily controlled by the highly anisotropic fracture/fault system. The response at ER-3-1, located transverse to the fault alignment, was delayed and smaller than at ER-7-1, although closer to ER-6-1 \#2. The well that did not show a response, UE-1h, was separated from the production well by several major faults with substantial offsets. 


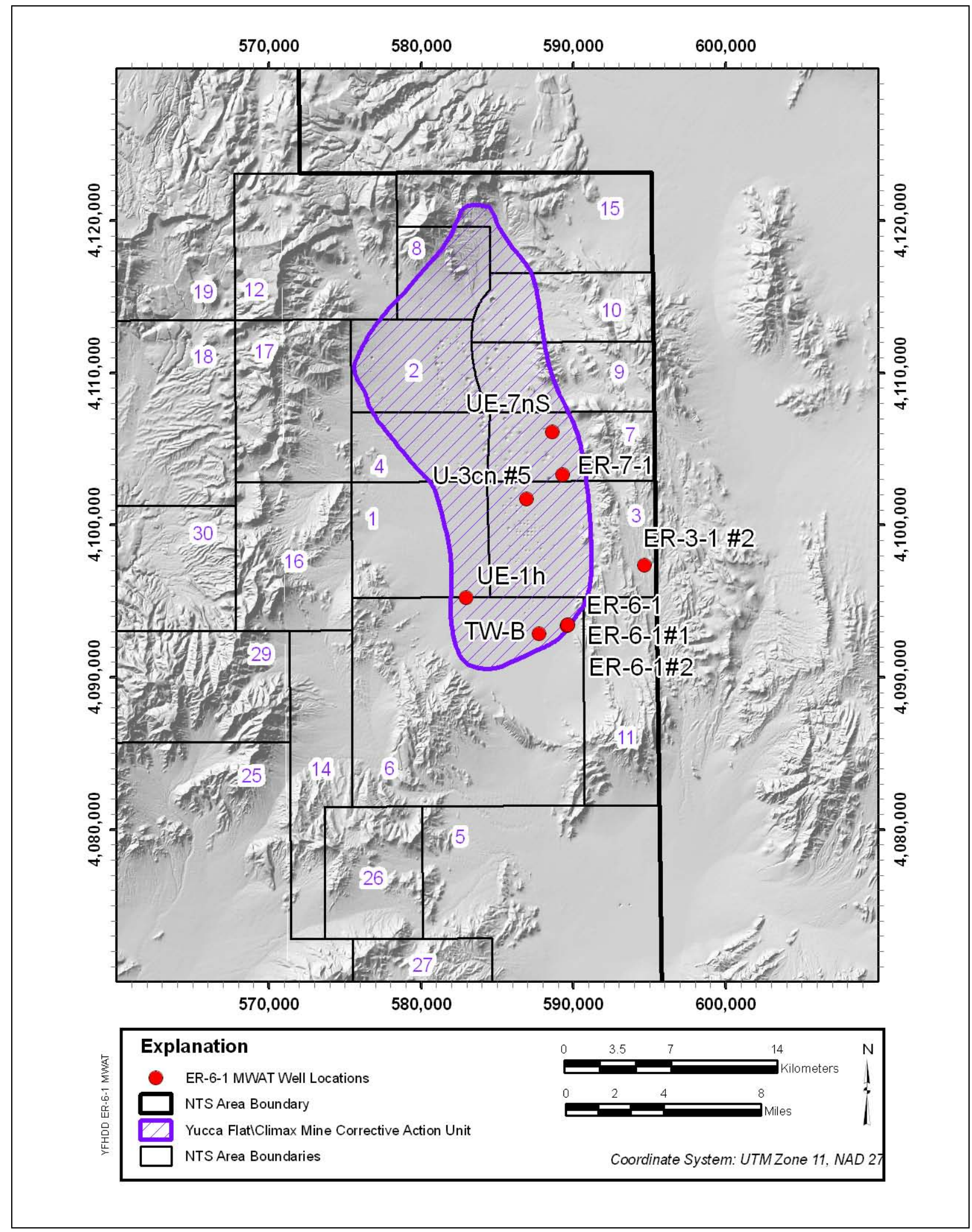

Figure 6-26

Location of Wells Monitored for the ER-6-1 MWAT 
Table 6-9

Production Well and Observation Well Information

\begin{tabular}{|c|c|c|c|c|}
\hline \multirow{2}{*}{ Well } & \multicolumn{2}{|c|}{$\begin{array}{l}\text { UTM Zone } 11 \\
\text { NAD } 27(\mathrm{~m})\end{array}$} & \multirow{2}{*}{$\begin{array}{c}\text { Distance from } \\
\text { ER-6-1 \#2/ER-6-1 } \\
\text { (ft) }\end{array}$} & \multirow{2}{*}{$\begin{array}{c}\text { Primary } \\
\text { Completion HSU }\end{array}$} \\
\hline & Northing & Easting & & \\
\hline \multicolumn{5}{|c|}{ MWAT-TT Production Well } \\
\hline ER-6-1 \#2 & $4,093,355.99$ & $589,616.51$ & $0 / 210.20$ & LCA \\
\hline \multicolumn{5}{|c|}{ Tracer Test Injection Wells, Aquifer Test Observation Wells } \\
\hline ER-6-1 \#1 & 4,093,402.96 & 589,635.92 & $166.69 / 50.13$ & LCA \\
\hline ER-6-1 Upper Zone & $4,093,417.93$ & $589,632.89$ & 210.20 & LCA \\
\hline ER-6-1 Lower Zone & $4,093,417.93$ & $589,632.89$ & 210.20 & LCA \\
\hline \multicolumn{5}{|c|}{ Aquifer Test Observation Wells } \\
\hline ER-6-1 \#2 piezometer & 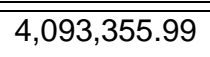 & $589,616.51$ & 0 & OSBCU \\
\hline ER-6-1 piezometer & $4,093,417.93$ & $589,632.89$ & 210.26 & OSBCU \\
\hline TW-B & $4,092,815.39$ & $587,780.39$ & $6,279.68$ & TSA \\
\hline ER-3-1 (\#2) & $4,097,338.98$ & $594,658.28$ & $21,080.18$ & LCA \\
\hline UE-1h & $4,095,223.52$ & $582,983.12$ & $22,609.13$ & LCA \\
\hline ER-7-1 & $4,103,274.60$ & $589,314.94$ & $32,556.41$ & LCA \\
\hline UE-7nS & $4,106,091.06$ & $588,644.04$ & 41,914 & LCA \\
\hline U3cn \#5 & $4,101,713.70$ & $586,921.84$ & 28,817 & LCA \\
\hline
\end{tabular}

\subsubsection{Limitations}

This dataset provides large-scale information on the hydraulic structure of the LCA in the southeastern part of Yucca Flat and may support verification of the groundwater flow model for the LCA in this area. Having observed the ability to characterize over a large scale with such a test, additional testing of the LCA with additional monitoring of wells in more directions and at greater distances, and testing in other locations could provide comprehensive evaluation of the hydraulic structure of the LCA in the Yucca Flat.

\subsection{High-Pressure Zone Studies}

High-pressure areas are found in the underground nuclear testing areas, primarily located in west central Yucca Flat in Areas 1, 2, 3, 4, 7, 8, and 9. These areas will be further discussed in Section 10.12 regarding head distribution. Pore pressures in the TCUs in these areas were affected by underground nuclear testing, increasing head measured in wells by up to several hundred feet. The 
USGS and LANL have completed separate studies of the hydraulics of specific areas in the high-pressure areas in 2005 and 2006, respectively. These studies provide detailed data compilation for the TCU structure and properties, and estimates of the effective hydraulic conductivity of the confining unit formations, based on calibration of models simulating the head increase and subsequent slow decline.

Table 6-10

Best-fit Parameter Estimates for Individual Observation Well Response Simulation

\begin{tabular}{|c|c|c|c|c|c|c|c|c|c|c|}
\hline \multirow{3}{*}{$\begin{array}{c}\begin{array}{c}\text { Observation } \\
\text { Well }\end{array} \\
\text { ER-6-1 Upper }\end{array}$} & \multirow{3}{*}{$\begin{array}{c}\begin{array}{c}\text { Hydraulic } \\
\text { Conductivity } \\
\text { (ft/d)(m/d) }\end{array} \\
234 / 71\end{array}$} & \multirow{3}{*}{$\begin{array}{c}\begin{array}{c}\text { Specific } \\
\text { Storage } \\
(1 / f t)(c / m)\end{array} \\
1.7 \mathrm{E}-09 \\
5.6 \mathrm{E}-09\end{array}$} & \multicolumn{8}{|c|}{$\begin{array}{l}\text { Radial Distance (ft) } \\
\text { from Pumping Well ER-6-1 \#2 (above); } \\
\text { Flow Dimension }{ }^{\mathrm{a}} \text { (below) }\end{array}$} \\
\hline & & & 30 & 60 & 100 & 200 & 1,000 & 5,000 & 10,000 & 20,000 \\
\hline & & & 1.9 & 2.2 & 2.4 & 2.2 & 2.0 & 2.2 & 1.4 & 1.1 \\
\hline \multirow{2}{*}{ ER-6-1 Lower } & \multirow{2}{*}{$249 / 76$} & \multirow{2}{*}{$\begin{array}{l}2.3 E-09 \\
7.6 E-09\end{array}$} & 30 & 60 & 100 & 200 & 1,000 & 5,000 & 10,000 & 20,000 \\
\hline & & & 2.0 & 2.4 & 2.3 & 2.1 & 2.0 & 1.6 & 1.0 & 1.2 \\
\hline \multirow{2}{*}{ ER-6-1 \#1 } & \multirow{2}{*}{$157 / 48$} & \multirow{2}{*}{$\begin{array}{l}5.4 \mathrm{E}-07 \\
1.8 \mathrm{E}-06\end{array}$} & 15 & 30 & 60 & 100 & 500 & 1,000 & 5,000 & 12,000 \\
\hline & & & 2.7 & 1.3 & 1.0 & 2.7 & 1.0 & 1.0 & 1.0 & 1.6 \\
\hline \multirow{2}{*}{ ER-7-1 } & \multirow{2}{*}{$4 / 1$} & \multirow{2}{*}{$\begin{array}{l}7.9 \mathrm{E}-09 \\
7.6 \mathrm{E}-08\end{array}$} & \multicolumn{3}{|c|}{500} & \multicolumn{2}{|c|}{2,500} & \multicolumn{3}{|c|}{20,000} \\
\hline & & & \multicolumn{3}{|c|}{2.4} & \multicolumn{2}{|c|}{1.0} & \multicolumn{3}{|c|}{1.6} \\
\hline ER-6-1 \#2 & $36 \mathrm{~b} / 11$ & $N A^{b}$ & \multicolumn{8}{|c|}{ NA } \\
\hline
\end{tabular}

${ }^{\mathrm{a}}$ Flow dimension is constant for each constant-distance step.

${ }^{\mathrm{b} C}$ Cooper-Jacob analyses, because of the radial flow assumption, result in hydraulic conductivity estimates that are one order of magnitude less than those derived in the nSights analysis, which incorporates the (bi)linear flow geometry indicated.

cSingle-well test analysis for well transmissivity does not permit storage estimate.

\subsubsection{U.S. Geological Survey Tuff Pile Study}

The USGS tuff pile study is published in Hydraulic Characterization of Overpressured Tuffs in Central Yucca Flat, Nevada Test Site, Nye County, Nevada (Halford et al., 2005). This study provides estimates for hydraulic properties of the overpressured volcanic tuffs (TCU HGU) in Area 4 derived from modeling the long-term subsidence of the ground surface as pore pressures decreased. Halford et al. (2005) state "hydraulic conductivity is characterized on the basis of slug-test analysis of drilling recovery data and by parameter estimation using two-dimensional (2-D) and 3-D groundwater flow models calibrated to measured water levels and InSAR-derived subsidence rates. Storage properties are estimated by the calibration of a 3-D groundwater flow model." Table 1 of Halford et al. (2005) provides the results of the slug-test analyses, Table 4 lists hydraulic property parameters estimated or 
evaluated by the cross-sectional model, and Table 5 lists hydraulic property parameters estimated or evaluated by the 3-D model. Table 6-11 lists the parameter estimates from these tables for the parameters of interest. These estimates models provide independent estimates of large-scale effective parameter values based on large-scale processes. In particular, these estimates apply to volumes of the volcanic tuffs that have been affected by underground nuclear testing and may not be appropriately represented by tests conducted in unaffected areas.

Table 6-11

USGS Tuff Pile Study Parameter Estimates

\begin{tabular}{|c|c|c|c|}
\hline Estimate Basis & $\begin{array}{c}\text { Hydraulic Conductivity } \\
\text { m/day }\end{array}$ & $\begin{array}{c}\text { Specific } \\
\text { Storage } \\
\mathbf{m}^{-1}\end{array}$ & $\begin{array}{c}\text { Specific } \\
\text { Yield }\end{array}$ \\
\hline \hline Slug-Test Analyses (from Areas 2,4,7,8) & $3 \mathrm{E}-7$ to $9 \mathrm{E}-4$ & $\mathrm{~N} / \mathrm{A}$ & N/A \\
\hline Two-Dimensional (Cross-Sectional) Model & $3 \mathrm{E}-6$ & $6 \mathrm{E}-6$ & 0.2 \\
\hline Three-Dimensional Model & $3 \mathrm{E}-6$ & $9 \mathrm{E}-6$ & 0.2 \\
\hline
\end{tabular}

\subsubsection{Los Alamos National Laboratory "Tuff-Pile" Study}

The LANL tuff pile study, still in progress, covers an area within Areas 3, 4, and 7, in the LANL Tuff Pile containment area. The study is focused on evaluation of the persistence of high pore pressures in very low hydraulic conductivity volcanic tuffs (TCU HGU) in close association with high hydraulic conductivity interbeds. This differs from the USGS study in that the volcanic tuffs are evaluated as 27 distinct stratigraphic units of differing hydraulic properties rather than as a single unit with a single property value. The evaluation of the range of properties of the 27 different units provides information on the variability of property values that are aggregated in the large scale. A report will be published following completion of the study.

\subsection{Limitations}

Overall, the data for hydraulic properties is of high quality, and provide hydraulic property information for the tested volumes of formation. However, there are significant limitations in applying the results of the analysis to the identification of representative hydraulic properties for the Yucca Flat/Climax Mine HSUs. As mentioned previously in this section, the amount of site specific data available to characterize hydraulic conductivity for Yucca Flat HSUs is not great. There are no 
data for many HSUs, especially from tests within Yucca Flat, which why the analysis was organized on an HGU basis. The HGUs allowed aggregation of large data sets to analyze for the statistical distribution. The distributions indicate the potential range of properties for the different formation types (HGUs) as defined by general character of hydrogeology. The character and relationship of the HGUs to the HSUs are described in Tables 2-1 and 2-2. However, many HSUs have their own distinct character, which may result in specific properties for the HSU that are not the same as the average for the HGU, but presumably would be within the 95-percent confidence range of the overall HGU. Following are specific limitations to consider when using the results of this hydraulic property analysis.

First, pumping-scale data is most appropriate for use in parameterization of CAU groundwater flow models. Yucca Flat/Climax Mine-specific data distributions were determined for five HGUs at the pumping scale: the AA, VA, LFA, TCU and LCA; four aquifer units and one confining unit. The TCU could be characterized with pumping-scale tests, because the hydraulic conductivity is sufficient due to fracturing to sustain pumping at moderate rates and drawdowns. Other confining units HGUs generally have hydraulic conductivity too low to easily conduct a pumping-scale test. The UGTA program has conducted several pumping-scale tests in such confining units, at very low pumping rates, with large drawdown, requiring specialized equipment. However, there have not been a sufficient number of these tests to evaluate statistics. Otherwise, the confining unit HGUs are characterized at the slug test-scale and the laboratory scale. However, these tests do not reflect the large-scale properties of the confining units very well, because the relevant large-scale properties are also related to fracturing. Because the fracturing in the low conductivity units may be widely spaced, short slug-test intervals may not encompass a representative sample of the fracturing, and laboratory-scale samples neccessarily do not include fractures.

Second, the available data for the Yucca Flat/Climax Mine CAU are very scattered throughout the investigation area and do not provide complete, comprehensive characterization across the extent of the Yucca Flat/Climax Mine HFM area. The aggregate area, presumed to have been tested by all of the tests for an HSU, only constitutes a small percentage of the total area of the HSU. The available data are not well distributed and cannot be shown to equally sample the range of properties that may be present or provide a sense of spatial variability. The NTS Investigation Area distributions are not specific to the Yucca Flat/Climax Mine CAU. 
Third, the data sampling (tested part of the formation) is biased, because many of the wells tested were drilled for water supply purposes and were specifically targeted for the most productive intervals of the formations penetrated. Tests in wells generally do not characterize the entire HSU (or a specific formation) in aggregate, but only shorter intervals selected during drilling or testing, usually because of the particular productivity of the interval. In general, the concept used for UGTA characterization drilling and well completion decisions has been that the more productive intervals are of primary interest under the assumption that transport of contaminants will preferentially occur in those intervals. This bias is particularly evident in cases of high hydraulic conductivity values for ostensible confining units when the formation is considered at the CAU scale. This is generally the result from a short test of a fractured interval within an otherwise low-conductivity formation.

The hydraulic properties of interest (that are characterized at the pumping scale) for many of these formations result from the fracturing within the formation. The individual tests provide information about the fracturing of the formation at a particular location, but there is no basis for assuming the fracturing is consistent across the extent of the HSU, vertically or laterally. In addition, tests of fractured formations provide information on the hydraulic properties of the fracture system, but these properties are not necessarily consistent with properties to be applied to an equivalent porous media flow model like the steady-state flow models constructed for the UGTA project.

\subsection{Summary}

The data presented in this summary come from a variety of sources and represent data measured at different scales. Pumping-scale measurements within the Yucca Flat/Climax Mine area have not been made in all Yucca Flat/Climax Mine HGUs, but the available data do include all three aquifer units, the AA, VA, and LCA, for which there were sufficient data to define hydraulic conductivity distributions. Single pumping-scale hydraulic conductivity measurements within the Yucca Flat/Climax Mine area are available for the LTCU, MGCU, and LCCU, but provide no information on the range of the hydraulic conductivity values. There were no pumping-scale tests in the TCU within the Yucca Flat/Climax Mine area. As mentioned previously, the confining unit HGUs generally have hydraulic conductivity too low to conduct pumping tests. Slug test-scale measurements provide a few additional values for the confining unit HGUs. The NTS Investigation 
Area data provides considerably more basis for determining representative distributions of hydraulic conductivity for Yucca Flat/Climax Mine HGUs.

In summary, the data available for hydraulic properties of the HSUs are not definitive for the HSUs in the Yucca Flat/Climax Mine area and do not necessarily provide specific characterization for the large-scale aggregate hydraulic properties of the HSUs. This section documents data compilation and analysis for the available data, which serves as a guide to determining appropriate hydraulic parameters. Data must be used with regard to these limitations and interpreted within the context of the difference between results from specific tests, and the aggregate, equivalent HSU properties appropriate for use in flow modeling.

The available data provide a large sample of hydraulic properties for the formations, the analysis defines the range of property values and statistics defining the distribution of property values. All of the pumping-scale analyses found data distributions that conformed to log normal distribution, as is generally identified in the literature. As was stated in the limitations, this does not identify the correct value for use in flow modeling. However, calibrated parameter values that are similar to the mean values would provide confidence that the model values are reasonable. 


\subsection{Precipitation Recharge}

The source of groundwater recharge in the DVRFS (including the NTS) is mainly from precipitation that falls on highlands and mountainous areas. Precipitation data are obtained from precipitation stations and interpolated to provide a regional precipitation map. The DVRFS report (Belcher et al., 2004) defines groundwater recharge as water that infiltrates downward through the unsaturated zone into the water table. Net infiltrated water is that portion of precipitation that infiltrates the ground surface and is not taken up by plants or lost to evaporation.

This section reviews seven alternative models to estimate precipitation recharge for the NTS region. These models use different methods for estimating precipitation recharge and include: an empirical mass-balance method and its derivatives, a deterministic distributed parameter watershed method, a model-calibration method, and a chloride mass-balance method. The alternative recharge models will be used to support the development of the CAU-scale groundwater flow model for the Yucca Flat/Climax Mine CAU.

\subsection{Objectives}

The objectives of these data analyses are to evaluate regional precipitation recharge rates/volumes and document alternative recharge models to estimate the bounds of uncertainty in recharge. The resulting alternative recharge distributions will be used to specify a range of recharge for use in both the Yucca Flat/Climax Mine CAU groundwater flow model to describe the upper boundary condition for this CAU-specific model, and in the DVRFS model (Belcher et al., 2004) to calculate lateral boundary fluxes for use in the Yucca Flat/Climax Mine CAU groundwater flow model (see Section 9.0).

\subsection{Approach}

Previous reports with precipitation recharge information for the NTS region were reviewed and recharge models were selected for evaluation. This approach yielded a range of recharge volumes 
and areal distributions for the recharge alternatives that can be used to provide reasonable bounds to precipitation recharge in the NTS area.

\subsection{Data Types and Prioritization}

The specific data types, their sources, and their prioritization for further evaluation are discussed in this section. Types of information needed for the creation of the steady-state flow model are:

- Previous recharge documents and datasets

- Precipitation station data

- Interpolated precipitation rate (inches/year [in./yr]) distribution

- Land surface elevation

- Methods of recharge estimation

Recharge information was compiled for the Yucca Flat/Climax Mine area of investigation and surrounding region. The main sources of information included DRI, USGS, and various reports cited herein. Information was obtained in the form of published and unpublished documents and datasets. Precipitation data were compiled from various federal, state, and local agencies. Land surfaceelevation data were obtained from the USGS or USGS topographic maps. All resulting recharge distribution maps for the different recharge models were normalized to account for different definitions of individual hydrographic areas (HAs) and differences in model gridding.

\subsection{Recharge Model Descriptions}

A total of seven alternative recharge models were selected to provide reasonable bounds to precipitation recharge in the NTS area. The following sections describe these alternative recharge models. The recharge models include: two UGTA models (UGTA Original and UGTA Revised) that utilize variations of the empirically based Maxey-Eakin (ME) method (Maxey and Eakin, 1949); two USGS models (Hevesi et al., 2003) that incorporate the physical processes that affect recharge (USGS Model 1-with run-on incorporated into recharge, USGS Model 2-without run-on incorporated into recharge); one USGS model based on the calibrated recharge from DVRFS model (USGS Model 3) (Belcher et al., 2004); and two DRI chloride mass balance models (DRI-alluvial mask and DRI-alluvial and elevation mask). These recharge models are summarized in Table 7-1. 
Table 7-1

Alternative Recharge Models

\begin{tabular}{|l|l|l||}
\hline \multicolumn{1}{|c|}{ Recharge Models } & \multicolumn{1}{|c||}{ Model Method } & \multicolumn{1}{c|}{ Reference } \\
\hline \hline UGTA Original & ME & DOE/NV, 1997b; IT, 1996b \\
\hline UGTA Revised & ME & SNJV, 2004e \\
\hline $\begin{array}{l}\text { USGS Model 1 - with run-on infiltration } \\
\text { included in recharge }\end{array}$ & Distributed parameter & Hevesi et al., 2003 \\
\hline $\begin{array}{l}\text { USGS Model 2 - without run-on } \\
\text { infiltration included in recharge }\end{array}$ & Distributed parameter & Hevesi et al., 2003 \\
\hline USGS Model 3 - calibrated recharge & Model calibration & Belcher et al., 2004 \\
\hline DRI - Alluvial Mask & Chloride mass balance & $\begin{array}{l}\text { Russell and Minor, 2002; Russell, } \\
\text { 2004; SNJV, 2004e }\end{array}$ \\
\hline DRI - Alluvial and Elevation Mask & Chloride mass balance & $\begin{array}{l}\text { Russell and Minor, 2002; Russell, } \\
\text { 2004; SNJV, 2004e }\end{array}$ \\
\hline
\end{tabular}

\subsubsection{Underground Test Area Original Recharge Model}

The UGTA Original recharge model was first developed during the regional model evaluation (DOE/NV, 1997b; IT, 1996b). This recharge model was derived using a modification to the Maxey-Eakin (ME) method (Maxey and Eakin, 1949) that involved reallocating recharge into canyons and washes. Descriptions of the ME method and the modification to the ME method presented in this section were obtained from the recharge-discharge documentation package (IT, 1996b). An updated version of the modified ME method was also developed to incorporate new precipitation data and correct errors and inconsistencies found in the UGTA Original recharge model (SNJV, 2004e). A description of this updated UGTA recharge model (hereafter referred to as UGTA Revised) is provided in Section 7.4.2.

\subsubsection{Overview Description of the Maxey and Eakin Method}

Maxey and Eakin (1949) first described a method of estimating recharge to groundwater from precipitation in a report on groundwater in White River Valley, Nevada. Maxey and Eakin (1949) employed a Nevada precipitation map containing HA designations developed by Hardman (1936). This approach estimates recharge by assuming that a relationship exists between a zone-specific percentage of precipitation and the recharge to groundwater. The ME coefficient is defined as the percentage of precipitation that recharges groundwater. 
Maxey and Eakin (1949) originally divided the recharge-precipitation ranges into zones and estimated a coefficient for each zone. These zones are: 0 percent recharge for precipitation of less than $8 \mathrm{in./yr}(20 \mathrm{~cm} / \mathrm{yr}) ; 3$ percent for 8 to $12 \mathrm{in./yr}(20$ to $30 \mathrm{~cm} / \mathrm{yr}$ ); 7 percent for 12 to $15 \mathrm{in} . / \mathrm{yr}$ (30 to $38 \mathrm{~cm} / \mathrm{yr}$ ); 15 percent for 15 to $20 \mathrm{in./yr}$ (38 to $51 \mathrm{~cm} / \mathrm{yr}$ ); and 25 percent for greater than 20 in./yr $(51 \mathrm{~cm} / \mathrm{yr})$.

The ME coefficients were developed by empirically comparing precipitation volumes with estimates of groundwater discharges for 13 groundwater basins in east-central Nevada. Maxey and Eakin (1949) were able to apply this method successfully to the White River Valley hydrologic basin, which is at an elevation greater than $1,670 \mathrm{~m}$.

The ME method may be described mathematically for a given HA by:

$$
\mathrm{R}=\Sigma \mathrm{r}_{\mathrm{i}} \mathrm{P}_{\mathrm{i}}
$$

Where:

$\mathrm{R}=$ Total ME recharge for a given HA

$\mathrm{r}_{\mathrm{i}}=\mathrm{ME}$ recharge coefficient for each delineated precipitation zone

$\mathrm{P}_{\mathrm{i}}=$ Precipitation for each delineated precipitation zone

Using consistent units, either recharge-volumetric rates or fluxes may be calculated using this equation. Customarily, using precipitation rates, recharge fluxes are calculated.

The ME method has been modified multiple times and used in numerous studies in Nevada to estimate recharge. Eakin et al. (1951) documents a study of groundwater in the Goshute-Antelope Valley, Elko County, Nevada using a modification of the ME method to account for both physiographic and topographic variability. To accomplish this, ME coefficients were assigned to ranges of altitudes, rather than to ranges or zones of precipitation. Recharge is assumed to occur where the mean annual precipitation is above $8 \mathrm{in./yr}(20 \mathrm{~cm})$ in the ME method or the land surface elevation is above 1,700 $\mathrm{m}$ in the Eakin et al. (1951) method. Recharge then increases with elevation according to the ME coefficients. Walker and Eakin (1963) used the Eakin et al. (1951) method in a groundwater study of the Amargosa Desert, Nevada and California. Malmberg (1967) used a modification of Eakin et al. (1951) in a groundwater study of the Pahrump Valley, Nevada and California. This modification increased the number of altitude zones. Rush (1970) used a 
modification of the Eakin et al. (1951) method to evaluate the regional groundwater systems in the vicinity of the NTS. This modification incorporated updated precipitation data and an area-specific elevation zonation based on 1,000 ft (304.8 m) elevation zones. Comparing these studies the ME coefficients for the 8 to $12 \mathrm{in./yr}$ (20 to $30 \mathrm{~cm} / \mathrm{yr}$ ) precipitation zone ranged from 3 percent (Maxey and Eakin, 1949; Malmberg, 1967; and Rush, 1970) to 1 percent (Walker and Eakin, 1963).

As mentioned above, the original ME coefficients were based on the Hardman (1936) precipitation map and calibrated to estimates of subsurface discharge from 13 groundwater basins in east-central Nevada (Maxey and Eakin, 1949). The application of these original ME coefficients, using modifications to the original precipitation data and/or the use of elevation zoning rather than precipitation zoning, introduces a degree of error to the original calibration of the ME coefficients that is typically not quantified.

A recent study by Epstein (2004) included an uncertainty analysis of the empirically derived ME method. This study used the bootstrap statistical technique (Efron and Tibshirani, 1998) to develop an independent predictive model to predict recharge for Nevada HAs. This model is currently used in on-going research to quantify the errors associated with recharge estimates for desert basins in Nevada. When published, the results of this research are expected to provide a measure of the uncertainty in ME coefficients.

\subsubsection{Modified Maxey-Eakin Method Used in the UGTA Original Regional Groundwater Flow Model}

The recharge distribution used in the UGTA regional model (DOE/NV, 1997b) was constructed using a modification of the ME method (Maxey and Eakin, 1949). The method used for this modification included the following procedures, as is described in this section:

- Construction and updating of a precipitation map using new and existing data.

- Calculation of recharge using ME coefficients.

- Calculation of total recharge volumes for individual HAs.

- Redistribution of a percentage of the total recharge within selected subareas to low-lying areas in wash or canyon reaches. 
- Multiplication of resulting recharge estimates for the entire model area by a coefficient calculated to make the estimated recharge value match the estimated discharge.

\subsection{Methodology}

A precipitation map of Nevada (Hardman, 1965) was used as a basis for construction of the digital precipitation map. The precipitation map was adapted by Hardman (1965) from an earlier version constructed by Hardman (1936). The map coverage includes the entire state of Nevada, but does not include the Death Valley portion of the UGTA regional groundwater flow system. To complete this portion of the digital precipitation map, the Death Valley section developed by James et al. (1993) was used. Additional data used in the construction of the digital precipitation map included the precipitation station data (Jacobson, 1996; French, 1996), the digital elevation map (DEM) from the USGS (1987), and a Nevada Test Site Image Region Map prepared by BN (1996). These data were used to validate the existing precipitation maps and changes to the existing maps during construction of the updated digital precipitation map. A modified ME approach was then applied to the digital precipitation map to calculate recharge.

\subsection{Construction of the Digital Precipitation Map and Grid File}

Two existing precipitation maps were combined to construct the digital precipitation map (IT, 1996b). First, precipitation contours from the existing precipitation maps of Hardman (1965) and James et al. (1993) were digitized and geographically registered. The resulting precipitation map was then updated using the most recently available precipitation station data and validated using satellite imagery and land surface-elevation data. Only those stations with greater than eight years of record were used based on the criteria developed during discussions with regional experts and providers of the data (Jacobson, 1996; French, 1996). The selected precipitation stations are listed in Table 7-2.

Precipitation contours in selected areas of the digital precipitation map were modified by reshaping the contours to incorporate the data from the selected precipitation stations. In most instances, the precipitation station data validated the existing precipitation contours and only minimal modifications were required. Contour lines were only modified where there were sufficient data to substantiate any changes. 
Table 7-2

Precipitation Station Data Used for UGTA Original Recharge Model

(Page 1 of 2)

\begin{tabular}{|c|c|c|c|c|c|c|}
\hline \multirow{2}{*}{$\begin{array}{l}\text { Station } \\
\text { Number }\end{array}$} & \multirow{2}{*}{ Station Name } & \multicolumn{2}{|c|}{$\begin{array}{l}\text { UTM Zone 11, } \\
\text { NAD } 27\end{array}$} & \multirow{2}{*}{$\begin{array}{c}\text { Land } \\
\text { Surface } \\
\text { Elevation } \\
\text { (m) }\end{array}$} & \multicolumn{2}{|c|}{$\begin{array}{l}\text { Average Annual } \\
\text { Precipitation }\end{array}$} \\
\hline & & $\begin{array}{l}\text { Easting } \\
\text { (m) }\end{array}$ & $\begin{array}{l}\text { Northing } \\
\text { (m) }\end{array}$ & & $\begin{array}{l}\text { Depth } \\
\text { cm/year } \\
\text { (in.lyr) }\end{array}$ & $\begin{array}{c}\text { Years } \\
\text { of } \\
\text { Record }\end{array}$ \\
\hline 11 & Tonopah Airport & 492,689 & $4,213,009$ & 1,655 & $16.3(6.42)$ & 29 \\
\hline 12 & Sarcobatus & 498,522 & $4,124,251$ & 1,225 & $9.0(3.54)$ & 14 \\
\hline 13 & Death Valley & 511,946 & $4,035,517$ & -52 & $6.9(2.72)$ & 18 \\
\hline 14 & Beatty & 525,210 & $4,094,706$ & 1,082 & $15.9(6.26)$ & 47 \\
\hline 27 & Lathrop Wells & 558,275 & $4,030,159$ & 664 & $8.5(3.35)$ & 21 \\
\hline 29 & Little Feller 2 & 560,698 & $4,106,882$ & 1,573 & $20.6(8.11)$ & 15 \\
\hline 34 & $40 \mathrm{MN}$ & 563,341 & $4,100,364$ & 1,469 & $20.8(8.19)$ & 33 \\
\hline 35 & $4 \mathrm{JA}$ & 563,445 & $4,071,032$ & 1,043 & $13.3(5.24)$ & 34 \\
\hline 36 & Shoshone Basin & 566,464 & $4,087,547$ & 1,725 & $21.6(8.50)$ & 13 \\
\hline 40 & Skull Mountain Pass & 568,500 & $4,065,887$ & 1,186 & $16.1(6.32)$ & 8 \\
\hline 41 & Area 12 Mesa & 569,624 & $4,116,171$ & 2,283 & $32.4(12.76)$ & 34 \\
\hline 43 & Stockade Pass & 570,759 & $4,113,178$ & 2,053 & $21.3(8.39)$ & 9 \\
\hline 46 & Tippipah Spring 2 & 571,887 & $4,100,851$ & 1,518 & $24.3(9.57)$ & 28 \\
\hline 47 & $\mathrm{RV}-1$ & 572,151 & $4,060,050$ & 1,036 & $15.9(6.26)$ & 28 \\
\hline 49 & Mid Valley & 573,701 & $4,091,914$ & 1,420 & $23.6(9.29)$ & 29 \\
\hline 53 & RV-Wash & 576,721 & $4,053,568$ & 866 & $10.0(3.92)$ & 8 \\
\hline 54 & Cane Springs & 579,583 & $4,074,185$ & 1,219 & $20.6(8.11)$ & 29 \\
\hline 56 & BJY & 584,209 & $4,102,022$ & 1,241 & $16.1(6.34)$ & 33 \\
\hline 57 & Yucca & 584,791 & $4,090,231$ & 1,195 & $17.0(6.69)$ & 34 \\
\hline 58 & PHS Farm & 585,301 & $4,118,280$ & 1,391 & $19.4(7.64)$ & 24 \\
\hline 59 & Desert Rock & 587,122 & $4,053,108$ & 1,005 & $15.2(5.98)$ & 30 \\
\hline 60 & Pahrump & 588,385 & $4,008,227$ & 823 & $12.6(4.96)$ & 20 \\
\hline 62 & Mercury & 589,740 & $4,057,169$ & 1,149 & $15.7(6.18)$ & 23 \\
\hline 63 & Well 5B & 592,263 & $4,073,193$ & 939 & $12.7(5.00)$ & 30 \\
\hline 66 & Trough Spring & 610,107 & $4,026,349$ & 2,512 & $45.0(17.70)$ & 9 \\
\hline 67 & Cold Creek & 613,563 & $4,030,708$ & 1,862 & $23.0(9.06)$ & 8 \\
\hline 68 & Indian Springs & 617,793 & $4,049,256$ & 951 & $11.6(4.57)$ & 25 \\
\hline 69 & Lee Canyon & 619,087 & $4,018,516$ & 2,594 & $53.4(21.02)$ & 9 \\
\hline 71 & Kyle Canyon & 623,466 & $4,012,260$ & 2,365 & $67.8(26.70)$ & 10 \\
\hline
\end{tabular}


Table 7-2

Precipitation Station Data Used for UGTA Original Recharge Model

(Page 2 of 2)

\begin{tabular}{|c|c|c|c|c|c|c|}
\hline \multirow{2}{*}{$\begin{array}{l}\text { Station } \\
\text { Number }\end{array}$} & \multirow[b]{2}{*}{ Station Name } & \multicolumn{2}{|c|}{$\begin{array}{l}\text { UTM Zone 11, } \\
\text { NAD } 27\end{array}$} & \multirow{2}{*}{$\begin{array}{c}\text { Land } \\
\text { Surface } \\
\text { Elevation } \\
\text { (m) }\end{array}$} & \multicolumn{2}{|c|}{$\begin{array}{l}\text { Average Annual } \\
\text { Precipitation }\end{array}$} \\
\hline & & $\begin{array}{l}\text { Easting } \\
\text { (m) }\end{array}$ & $\begin{array}{l}\text { Northing } \\
\text { (m) }\end{array}$ & & $\begin{array}{c}\text { Depth } \\
\text { cm/year } \\
\text { (in.lyr) }\end{array}$ & $\begin{array}{c}\text { Years } \\
\text { of } \\
\text { Record }\end{array}$ \\
\hline 72 & Adaven & 624,188 & $4,219,501$ & 1,905 & $32.1(12.64)$ & 47 \\
\hline 74 & Roberts Ranch & 627,418 & $4,003,163$ & 1,862 & $35.4(13.94)$ & 8 \\
\hline 75 & Red Rock Summit & 631,972 & $3,999,532$ & 1,984 & $27.0(10.63)$ & 8 \\
\hline 79 & Hayford Peak & 660,932 & $4,058,248$ & 2,999 & $42.4(16.70)$ & 9 \\
\hline 80 & Hidden Forest & 660,934 & $4,055,504$ & 2,304 & $32.0(12.60)$ & 9 \\
\hline 81 & Alamo & 662,347 & $4,136,921$ & 1,049 & $12.8(5.04)$ & 26 \\
\hline 82 & Las Vegas Airport & 665,072 & $3,994,546$ & 661 & $10.4(4.09)$ & 33 \\
\hline 83 & Sunrise Manor & 672,321 & $4,007,633$ & 555 & $10.6(4.17)$ & 32 \\
\hline
\end{tabular}

Source: IT, 1996b (Adapted from: Jacobson,1996; French, 1996)

The digital precipitation map was validated using the DEM and satellite imagery. The DEM grid was contoured according to the land-area model of Eakin et al. (1951) to show the 1,524 to 2,439-m contour lines. The precipitation map was validated by superposing the precipitation data (contours and station data) on the DEM. The accuracy of the DEM is $92 \mathrm{~m}$. The plot was used to ensure the contours were positioned correctly relative to elevation. In general, the contour shape coincides with the shape of the topographic features of the mountain ranges. Due to the poor quality of the copy and large scale of the Hardman map (1965), the validation process proved to be a very important step in constructing the digital precipitation map as error was introduced in tracing and scanning the maps developed by Hardman (1965) and James et al. (1993). The validated digital precipitation map was then used in the modified ME method to calculate the recharge distribution on a 1 by $1 \mathrm{~km}$ node spacing.

\subsection{UGTA Original Recharge Model Precipitation Distribution}

The precipitation distribution for the UGTA Original recharge model is presented in Figure 7-1

(IT, 1996b) with precipitation-depth contours and the precipitation station data, the UGTA groundwater flow system model boundary, and the DEM. The Spring Mountains in the south receive 


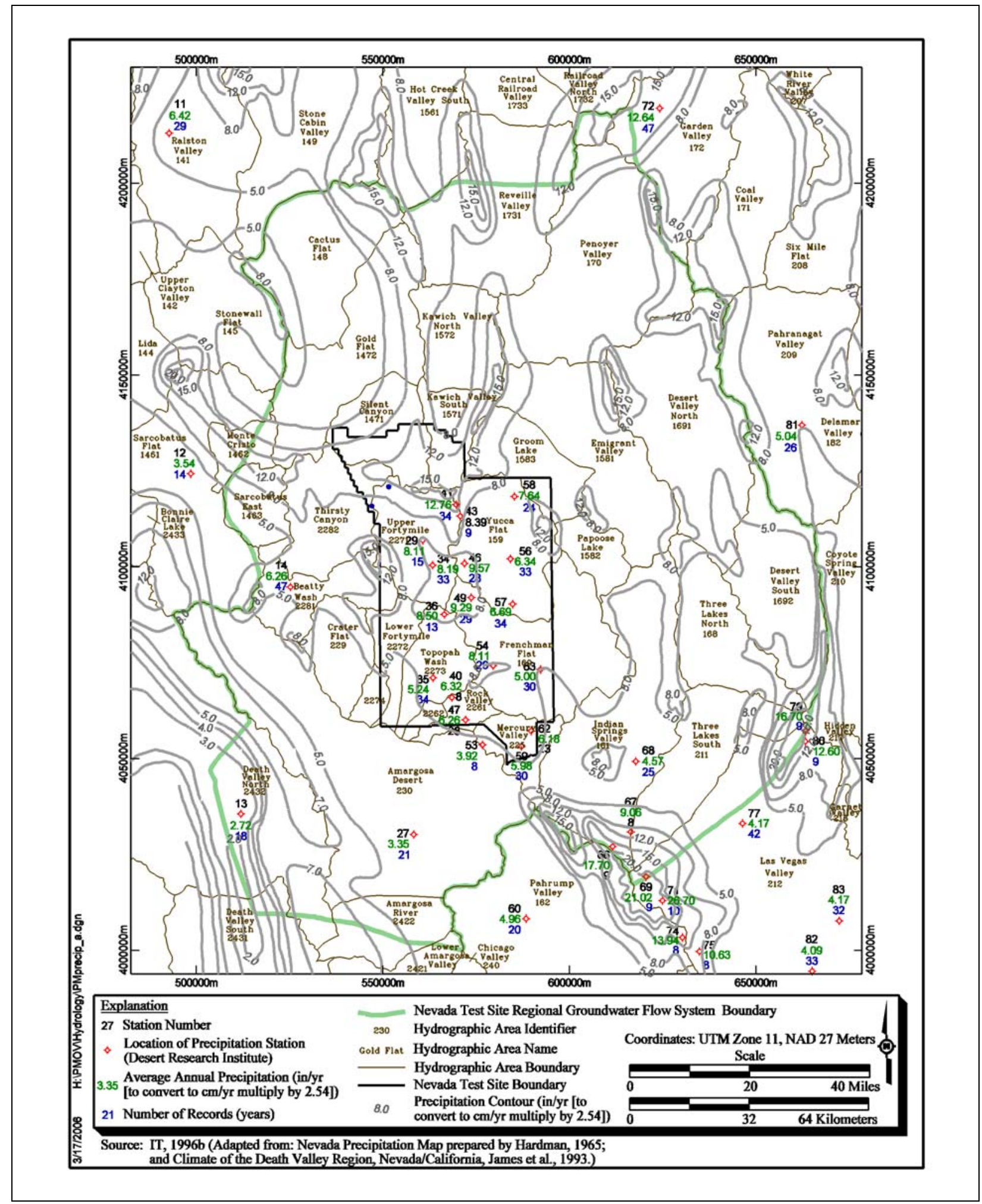

Figure 7-1

Precipitation Map for the NTS Region Used for the UGTA Original Recharge Model 
the highest amount of precipitation, 13.9 to $26.7 \mathrm{in.} / \mathrm{yr}(35.4$ to $67.8 \mathrm{~cm} / \mathrm{yr})$. This is followed by the Sheep Range to the east, 12.6 to 16.7 in./yr (32.0 to $42.4 \mathrm{~cm} / \mathrm{yr}$ ). Death Valley receives the least amount of precipitation with approximately $2.7 \mathrm{in.} / \mathrm{yr}(6.6 \mathrm{~cm} / \mathrm{yr})$.

Table 7-3 lists the average daily precipitation calculated from average annual precipitation for each HA. The average daily precipitation shown in column 3 only includes the precipitation within the UGTA groundwater flow system model boundary (DOE/NV, 1997b). Any precipitation outside the groundwater flow system model boundary (IT, 1996b) is not included in the total for the HA. Total average annual precipitation reported by Scott et al. (1971), converted to average daily precipitation, are included in columns 4 and 5 for comparison. The average daily precipitation reported for Scott et al. (1971) in Table 7-3 is prorated based on the area within the flow system model boundary (DOE/NV, 1997b) using the following equation:

$$
P_{p}=\frac{P_{t s} \times A_{f s}}{A_{h a}}
$$

Where:

$\mathrm{P}_{\mathrm{p}}=$ Prorated average daily precipitation

$\mathrm{P}_{\mathrm{ts}}=$ Average daily precipitation calculated from published average annual precipitation

$\mathrm{A}_{\mathrm{fs}}=$ Area within flow system model boundary (DOE/NV, 1997b)

$\mathrm{A}_{\mathrm{ha}}=$ Total area of HA

In general, the calculated total daily precipitation and total published precipitation from Scott et al. (1971) compare reasonably well. The difference between the two totals is about 118,000 cubic meters per day $\left(\mathrm{m}^{3} / \mathrm{d}\right)$. The maximum precipitation is found in the Tikaboo and Emigrant Valley HAs. The HAs with the largest discrepancy between totals are the Las Vegas Valley and Amargosa Desert. These HAs have very little, if any, recharge to the UGTA groundwater flow system and should not affect the modeling results.

Possible causes of discrepancies between the calculated precipitation and the published totals are:

- Error introduced during the tracing and scanning of the Hardman (1965) and James et al., (1993) maps.

- The use of different methods to construct the digital precipitation map. 
Table 7-3

Comparison of Average Daily Precipitation to Published Values by Hydrographic Area (Page 1 of 2)

\begin{tabular}{|c|c|c|c|c|}
\hline \multicolumn{2}{|r|}{ HA } & \multirow{2}{*}{$\begin{array}{l}\text { Average Daily } \\
\text { Precipitation } \\
\text { Calculated from } \\
\text { Average Annual } \\
\text { Precipitation } \\
\left(\mathrm{m}^{3} / \mathrm{d}\right)\end{array}$} & \multicolumn{2}{|c|}{$\begin{array}{l}\text { Published Precipitation Data } \\
\text { (Scott et al., 1971) }\end{array}$} \\
\hline Number & Name & & $\begin{array}{l}\text { Average Daily } \\
\text { Precipitation } \\
\text { Calculated from } \\
\text { Average Annual } \\
\text { Precipitation } \\
\left(\mathrm{m}^{3} / \mathrm{d}\right)\end{array}$ & $\begin{array}{c}\text { Total HA Average } \\
\text { Daily Precipitation } \\
\text { Calculated from } \\
\text { Average Annual } \\
\text { Precipitation } \\
\left(\mathrm{m}^{3} / \mathrm{d}\right)\end{array}$ \\
\hline 145 & Stonewall Flat & 2,546 & 4,878 & 371,737 \\
\hline 146 & Sarcobatus Flat & 202,290 & 311,556 & 642,091 \\
\hline 147 & Gold Flat & 889,195 & 844,856 & 844,856 \\
\hline 148 & Cactus Flat & 491,956 & 439,325 & 439,325 \\
\hline 149 & Stone Cabin Valley & 1,471 & 2,402 & $1,182,799$ \\
\hline 156 & Hot Creek Valley & 1,846 & 2,544 & $1,317,976$ \\
\hline 157 & Kawich Valley & 622,296 & 506,914 & 506,914 \\
\hline 158 & Emigrant Valley & $1,164,236$ & 959,757 & 959,757 \\
\hline 159 & Yucca Flat & 461,941 & 337,942 & 337,942 \\
\hline 160 & Frenchman Flat & 511,223 & 506,914 & 506,914 \\
\hline 161 & Indian Springs Valley & 728,691 & 912,445 & 912,445 \\
\hline 162 & Pahrump Valley & 1,531 & 5,397 & $1,419,358$ \\
\hline 168 & Three-Lakes Valley North & 276,120 & 371,737 & 371,737 \\
\hline 169 & Tikaboo Valley & $1,260,641$ & $1,284,181$ & $1,284,181$ \\
\hline 170 & Penoyer Valley & $1,127,129$ & 912,445 & 912,445 \\
\hline 171 & Coal Valley & 835 & 1,249 & 574,502 \\
\hline 172 & Garden Valley & 68,283 & 115,092 & 777,268 \\
\hline 173 & Railroad Valley South & 681,245 & 844,856 & 844,856 \\
\hline 209 & Pahranagat Valley & 1,446 & 3,564 & 912,445 \\
\hline 210 & Coyote Spring Valley & 13,005 & 18,106 & 743,473 \\
\hline 211 & Three-Lakes Valley South & 359,289 & 439,325 & 439,325 \\
\hline 212 & Las Vegas Valley & 248,265 & 613,223 & $2,230,420$ \\
\hline 225 & Mercury Valley & 104,576 & 128,418 & 128,418 \\
\hline 226 & Rock Valley & 85,759 & 87,865 & 87,865 \\
\hline 227 & Fortymile Canyon & 715,443 & 669,126 & 669,126 \\
\hline 228 & Oasis Valley & 660,013 & 506,914 & 506,914 \\
\hline 229 & Crater Flat & 153,895 & 206,145 & 206,145 \\
\hline
\end{tabular}


Table 7-3

Comparison of Average Daily Precipitation to Published Values by Hydrographic Area (Page 2 of 2)

\begin{tabular}{|c|c|c|c|c|}
\hline \multicolumn{2}{|r|}{ HA } & \multirow{2}{*}{$\begin{array}{l}\text { Average Daily } \\
\text { Precipitation } \\
\text { Calculated from } \\
\text { Average Annual } \\
\text { Precipitation } \\
\left(\mathrm{m}^{3} / \mathrm{d}\right)\end{array}$} & \multicolumn{2}{|c|}{$\begin{array}{l}\text { Published Precipitation Data } \\
\text { (Scott et al., 1971) }\end{array}$} \\
\hline Number & Name & & $\begin{array}{l}\text { Average Daily } \\
\text { Precipitation } \\
\text { Calculated from } \\
\text { Average Annual } \\
\text { Precipitation } \\
\left(\mathrm{m}^{3} / \mathrm{d}\right)\end{array}$ & $\begin{array}{c}\text { Total HA Average } \\
\text { Daily Precipitation } \\
\text { Calculated from } \\
\text { Average Annual } \\
\text { Precipitation } \\
\left(\mathrm{m}^{3} / \mathrm{d}\right)\end{array}$ \\
\hline 230 & Amargosa Desert & $1,131,415$ & 811,062 & 811,062 \\
\hline 242 & Amargosa River & 117,067 & $117,067^{\mathrm{b}}$ & NA \\
\hline 243 & Death Valley & 398,318 & $398,318^{b}$ & NA \\
\hline \multicolumn{2}{|c|}{ Total Average Daily Precipitation: } & $12,481,966$ & $12,363,623$ & NA \\
\hline
\end{tabular}

Source: SNJV, 2004e (Adapted from: IT, 1996b)

${ }^{a}$ Calculation only includes precipitation within the UGTA groundwater flow system boundary.

${ }^{b}$ Published precipitation data for HAs 242 and 243 not included in Scott et al. (1971).

- The use of different techniques to calculate the totals (i.e., summing individual grid nodes versus averaging contours within the HA).

- $\quad$ Rounding errors.

The most likely source of error is the use of different methods of calculations.

\subsection{Recharge}

In Nevada, the ME method has been used to calculate the total volume of recharge to groundwater in a given HA. Although the method indirectly correlates recharge magnitude to precipitation zones, the method does not take into account the specific locations where recharge actually occurs. It was assumed in DOE/NV (1997b) that the majority of the recharge occurs at higher elevations as assumed in the ME method. However, smaller portions of the recharge have been shown to occur at lower elevations, in washes and canyons. In a study of groundwater recharge in Fortymile Canyon, Savard (1994) reported that recharge does occur along the canyon after stream flow events, as indicated by rising water levels. Consequently, for the purpose of the UGTA regional model investigation, recharge was determined in two major steps: (1) generation of a preliminary recharge distribution, and (2) reallocation of a fraction of this recharge to canyons and washes. 


\subsection{Preliminary Recharge Distribution}

A preliminary recharge distribution was generated using the updated digital precipitation map and the ME coefficients. The area of the UGTA regional model was subdivided according to the boundaries of HAs as defined by Harrill et al. (1988). Thirty major HAs were identified within the model area. Recharge rates were calculated for each of the HAs using the 1- by 1-km precipitation grid and three sets of ME coefficients. The recharge rates were first calculated for each 1- by 1-km grid cell by multiplying the corresponding precipitation value by the ME coefficients. For the lower precipitation zone (20.3 to $30.5 \mathrm{~cm} / \mathrm{yr}$ ), the preliminary total recharge rate in $\mathrm{m}^{3} /$ day and recharge distribution were calculated using an ME coefficient of 2 percent. In addition, to evaluate the potential range in total recharge rates for the UGTA regional model ME coefficients of 1 percent and 3 percent for the lower precipitation zone were calculated.

Important recharge areas are located in the Belted, Groom, and Timpahute ranges in the north; in Pahranagat and Sheep ranges to the east; and the Spring Mountains on the southeastern boundary. The total recharge rate estimated for the UGTA regional model area for the ME coefficient of 2 percent for the lower precipitation zone is $233,447 \mathrm{~m}^{3} / \mathrm{d}$ (DOE/NV, 1997b). The recharge range derived from using the 1 and 3 percent ME coefficient for the lower precipitation zone is from $177,484 \mathrm{~m}^{3} / \mathrm{d}$ to $289,410 \mathrm{~m}^{3} / \mathrm{d}$ (DOE/NV, 1997b).

\subsection{Recharge Allocation}

A method was developed to calculate recharge rates for HAs where infiltration through canyons and washes contribute to recharge. In this method, types of recharge allocation zones which correspond to the canyons and washes are first identified. Then portions of the total HA recharge are allocated to these identified zones. A given HA may be subdivided into three types of recharge zones:

- Type A Zone: Upgradient recharge areas that receive greater than $20 \mathrm{~cm}$ (8 in.) of annual precipitation per year. This is where the majority of infiltration occurs.

- Type B Zone: Canyon-wash recharge areas that receive less than $20 \mathrm{~cm}$ (8 in.) of precipitation per year, but include alluvial fans and streams through which recharge may occur.

- Type C Zone: Areas of no recharge that receive less than $20 \mathrm{~cm}$ (8 in.) of precipitation per year, and contain no alluvial fans or stream reaches to facilitate infiltration. 
Recharge volumes were calculated for each subarea as outlined above. Ten HAs where Type B zones occur were identified on the NTS and vicinity. The HAs are Topopah Wash, Beatty Wash, Thirsty Canyon, Lower Fortymile Canyon, Upper Fortymile Canyon, Frenchman Flat, Yucca Flat, Silent Canyon, Kawich Valley South, and Groom Lake (Figure 7-2).

Each of these ten HAs were subdivided into Types A, B, and C. Type B zones were further subdivided into three types of recharge areas: B1, B2, and B3. Type B1 represents upland canyon and valley washes and stream reaches; Type B2 represents mountain front washes and stream reaches; and Type B3 represents valley bottom washes and stream reaches.

For each HA where Type B zones occur, a portion of the HA recharge volume was reallocated from Type A areas to Type B areas. It is important to emphasize that the total recharge rates calculated for each area was not modified; only the areal distribution was modified.

The following relations were used to proportion the volume of recharge to each zone:

$$
\begin{gathered}
\mathrm{V}_{\mathrm{A}}=\alpha \mathrm{V}_{\mathrm{T}} \\
\mathrm{V}_{\mathrm{B}}=(1-\alpha) \mathrm{V}_{\mathrm{T}}
\end{gathered}
$$

Where:

$\mathrm{V}_{\mathrm{T}}=$ The total recharge volume calculated using the ME method

$\mathrm{V}_{\mathrm{A}}=$ Recharge rate in Type $\mathrm{A}$ areas

$\mathrm{V}_{\mathrm{B}}=$ Recharge rate in Type $\mathrm{B}$ areas

$\alpha=$ Redistribution factor in fraction of the total recharge volume (0 to 1 )

As an example, if $\mathrm{V}_{\mathrm{T}}=100$ and $\alpha=0.30$, then $\mathrm{V}_{\mathrm{A}}=30$ and $\mathrm{V}_{\mathrm{B}}=70$.

The recharge volumes in Type B zones were further redistributed to each recharge subarea (B1, B2, and B3) using assigned fractions $\beta, \gamma$, and $\delta$, respectively. The following mass-balance equation was used for redistribution:

$$
\beta+\gamma+\delta=1
$$




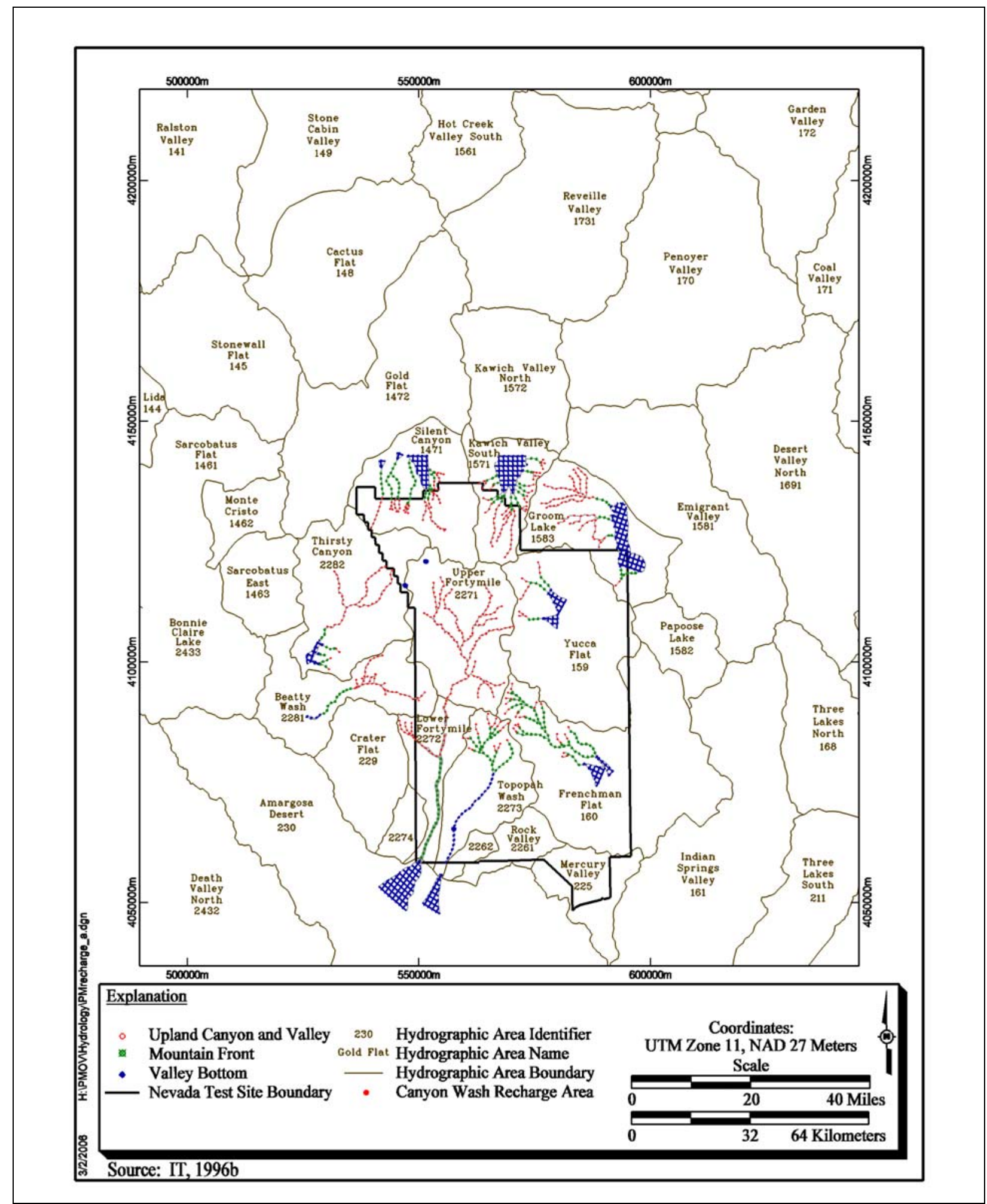

Figure 7-2

Potential Recharge Redistribution Areas in the NTS Region 
Where:

$\beta=$ Fraction of $V_{B}$ assigned to Type $B 1$ subareas

$\gamma=$ Fraction of $\mathrm{V}_{\mathrm{B}}$ assigned to Type $\mathrm{B} 2$ subareas

$\delta=$ Fraction of $V_{B}$ assigned to Type $B 3$ subareas

Within a given HA, each subarea of B1, B2, and B3 was subdivided into several wash or canyon reaches. Recharge volumes for each reach were then obtained by dividing the recharge volumes assigned to a given subarea type (B1, B2, or B3) by the number of reaches available within the given HA. This process of subdividing and reallocating recharge volumes to zones and subareas is referred to as the modified ME method.

A utility FORTRAN code was developed to implement the modified ME method. The code required the ME recharge distribution by HA, the spatial distribution of different types of recharge areas described above; and values for $\alpha, \beta, \gamma$, and $\delta$, based on estimates of recharge volumes for Type B zone and subtype areas. The code calculates a new recharge distribution for the upper cells of the UGTA regional model grid. This was an important feature that allowed adjusting the regional groundwater flow model recharge grid during the calibration process. The code listing and QA requirements are provided in the groundwater flow model documentation package (IT, 1996b).

The recharge reallocation coefficients $(\alpha, \beta, \gamma$, and $\delta$ ) were unknown because the recharge in Type B areas were unknown. Arbitrary initial values were assigned to these coefficients to generate an initial recharge grid. These values were adjusted during the groundwater flow model calibration process. The process and results are presented in the groundwater flow model documentation package (IT, 1996b).

The calibrated recharge flux for the UGTA regional model (DOE/NV, 1997b) was $204,080 \mathrm{~m}^{3} / \mathrm{d}$. This value is slightly different when compared to the preliminary recharge estimate. This difference is related to the approximation of the UGTA regional model boundary by the model grid boundary.

The UGTA Original recharge distribution developed during the calibration process of the UGTA regional model (DOE/NV, 1997b) was remapped for this document and is shown in Figure 7-3. This figure shows both the regional recharge distribution and the recharge distribution for the Yucca Flat/Climax Mine Investigation Area. Note that for this figure, the UGTA Original recharge 
distribution was inserted into the DVRFS model (Belcher et al., 2004). For the area outside of the UGTA regional model boundary (DOE/NV, 1997b), the steady-state recharge distribution from Belcher et al. (2004) is shown.

\subsubsection{Revised UGTA Recharge Model}

A revised recharge distribution model was developed subsequently by updating the UGTA Original recharge model. The development of this revised recharge distribution model is documented in the Phase II Frenchman Flat hydrologic data document (SNJV, 2004e). The update included: redigitalizing and recontouring the precipitation map, correcting errors in the digitization of the HAs, incorporating new precipitation station data, and recalculating the modified ME recharge distributions. The main precipitation map was redigitized to correct minor localized errors in the initial precipitation distribution. A different contouring program (EV ${ }^{\circledR}$ [Version 7.5 by Dynamic Graphics, 2002]) was used to grid the data. Following the update, a comparison to other recharge models was conducted to ensure no new errors were introduced during the redigitization.

The digitization of the original HA boundaries were found to be inaccurate. As a result, a grid cell would be included in the volumetric totals for a neighboring HA. In addition, because of the digitization inaccuracies, several HAs were inadvertently included in the NTS region, because one or two grid cells fell into the wrong peripheral HA. These inaccuracies were corrected by redigitizing the HA boundaries at a finer resolution.

Updated precipitation station data were also incorporated into the UGTA revised recharge model. These data are summarized in Table 7-4. The final digital precipitation map with updated precipitation information and revised contours is presented in Figure 7-4. The total recharge estimate was also uniformly increased by a factor of 1.0678 based on the recharge balance to discharge estimates reported in DOE/NV (1997b). This was deemed appropriate, because the modest change in total recharge was less than the uncertainty associated with many discharge estimates for the UGTA regional model area. All other aspects of the recharge calculations remained the same, including the redistribution.

The recharge distribution resulting from this revised UGTA recharge model was remapped for this document and is shown in Figure 7-5. This figure shows both the regional recharge distribution and 


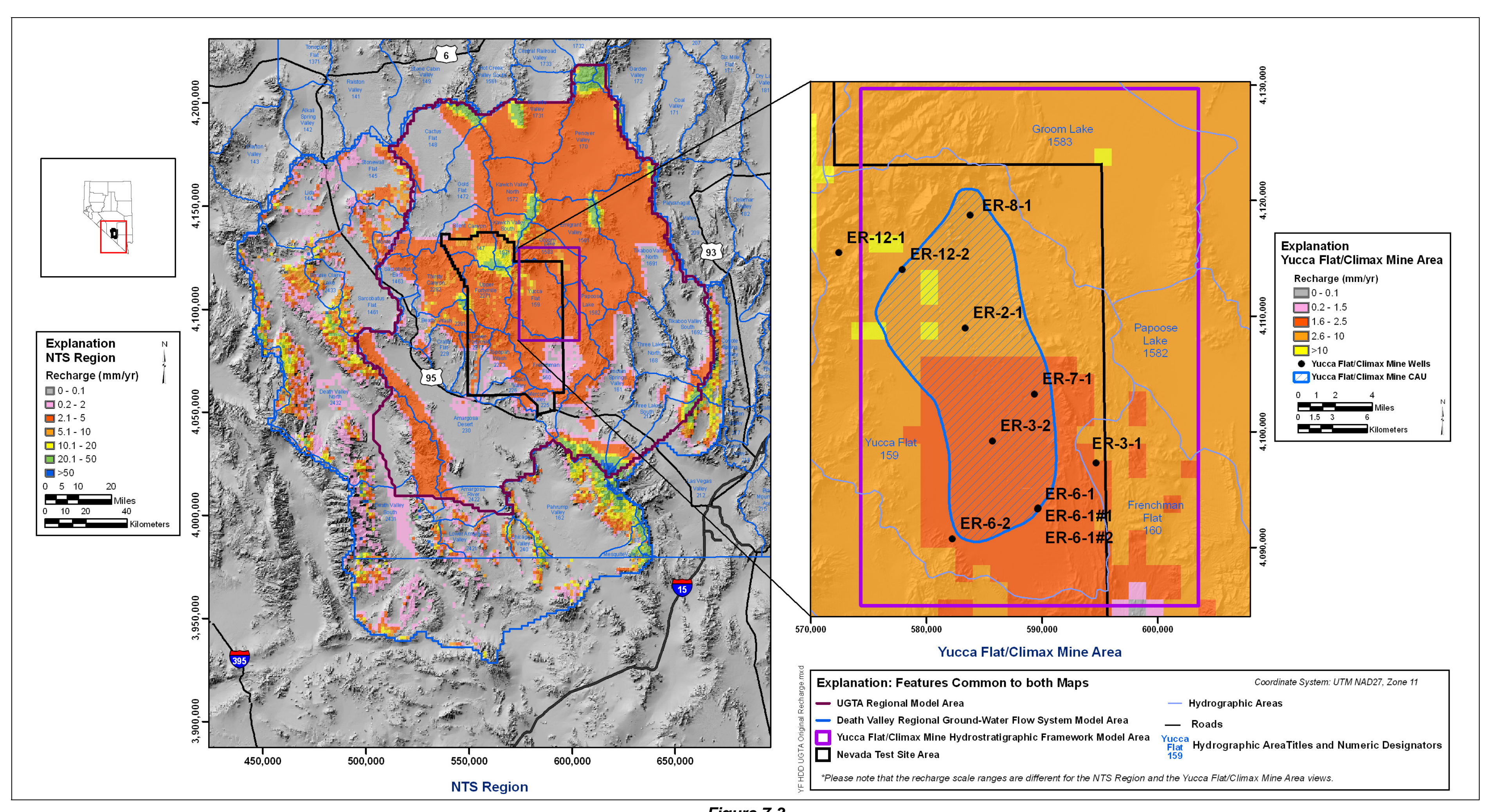

NTS Region with the UGTA Original Recharge Model Inserted into the USGS DVRFS Model (Belcher et al, 2004) (Note that the steady-state recharge distribution from the USGS DVRFS Model is used outside the UGTA Regional Model Boundary.) 
Table 7-4

Precipitation Station Data

(Page 1 of 2)

\begin{tabular}{|c|c|c|c|c|c|c|c|}
\hline \multirow{2}{*}{$\begin{array}{l}\text { Station } \\
\text { Number }\end{array}$} & \multirow{2}{*}{ Station Name } & \multicolumn{2}{|c|}{$\begin{array}{l}\text { UTM Zone 11, } \\
\text { NAD } 27\end{array}$} & \multirow{2}{*}{$\begin{array}{l}\text { Land } \\
\text { Surface } \\
\text { Elevation } \\
\text { (m) }\end{array}$} & \multicolumn{2}{|c|}{$\begin{array}{l}\text { Average Annual } \\
\text { Precipitation }\end{array}$} & \multirow{2}{*}{$\begin{array}{l}\text { Percent } \\
\text { Change }^{\mathrm{a}}\end{array}$} \\
\hline & & $\begin{array}{l}\text { Easting } \\
\text { (m) }\end{array}$ & $\begin{array}{l}\text { Northing } \\
\quad(\mathrm{m})\end{array}$ & & $\begin{array}{l}\text { Depth } \\
\text { cm/yr } \\
\text { (in./yr) }\end{array}$ & $\begin{array}{c}\text { Years } \\
\text { of } \\
\text { Record }\end{array}$ & \\
\hline 11 & Tonopah Airport & 492,689 & $4,213,009$ & 1,655 & $13.5(5.32)$ & 44 & -17.1 \\
\hline 12 & Sarcobatus & 498,522 & $4,124,251$ & 1,225 & $9.0(3.54)$ & 14 & $\mathrm{~N} / \mathrm{A}$ \\
\hline 13 & Death Valley & 511,946 & $4,035,517$ & -52 & $5.9(2.34)$ & 34 & -13.8 \\
\hline 14 & Beatty & 525,210 & $4,094,706$ & 1,082 & $15.9(6.26)$ & 47 & N/A \\
\hline 27 & Lathrop Wells & 558,275 & $4,030,159$ & 664 & $8.5(3.35)$ & 21 & $\mathrm{~N} / \mathrm{A}$ \\
\hline 29 & Little Feller 2 & 560,698 & $4,106,882$ & 1,573 & $20.1(7.93)$ & 27 & -2.3 \\
\hline 34 & $40 \mathrm{MN}$ & 563,341 & $4,100,364$ & 1,469 & $20.5(8.06)$ & 43 & -1.5 \\
\hline 35 & $4 \mathrm{JA}$ & 563,445 & $4,071,032$ & 1,043 & $14.1(5.56)$ & 46 & 6.2 \\
\hline 36 & Shoshone Basin & 566,464 & $4,087,547$ & 1,725 & $21.6(8.50)$ & 13 & N/A \\
\hline 40 & Skull Mountain Pass & 568,500 & $4,065,887$ & 1,186 & $16.1(6.32)$ & 8 & $\mathrm{~N} / \mathrm{A}$ \\
\hline 41 & Area 12 Mesa & 569,624 & $4,116,171$ & 2,283 & 31.5 (12.42) & 41 & -2.7 \\
\hline 43 & Stockade Pass & 570,759 & $4,113,178$ & 2,053 & $21.3(8.39)$ & 9 & N/A \\
\hline 46 & Tippipah Spring 2 & 571,887 & $4,100,851$ & 1,518 & $21.6(8.52)$ & 43 & -11.0 \\
\hline 47 & $\mathrm{RV}-1$ & 572,151 & $4,060,050$ & 1,036 & $15.8(6.22)$ & 40 & -0.7 \\
\hline 49 & Mid Valley & 573,701 & $4,091,914$ & 1,420 & $22.8(8.99)$ & 39 & -3.3 \\
\hline 53 & RV-Wash & 576,721 & $4,053,568$ & 866 & $10.0(3.92)$ & 8 & N/A \\
\hline 54 & Cane Springs & 579,583 & $4,074,185$ & 1,219 & $19.5(7.68)$ & 39 & -5.3 \\
\hline 56 & BJY & 584,209 & $4,102,022$ & 1,241 & $16.1(6.36)$ & 43 & 0.3 \\
\hline 57 & Yucca & 584,791 & $4,090,231$ & 1,195 & $16.8(6.62)$ & 45 & -1.0 \\
\hline 58 & PHS Farm & 585,301 & $4,118,280$ & 1,391 & $18.8(7.41)$ & 39 & -3.0 \\
\hline 59 & Desert Rock & 587,122 & $4,053,108$ & 1,005 & $14.5(5.72)$ & 40 & -4.4 \\
\hline 60 & Pahrump & 588,385 & $4,008,227$ & 823 & $11.6(4.58)$ & 30 & -7.7 \\
\hline 62 & Mercury & 589,740 & $4,057,169$ & 1,149 & $14.7(5.81)$ & 32 & -6.1 \\
\hline 63 & Well 5B & 592,263 & $4,073,193$ & 939 & $12.4(4.88)$ & 41 & -2.3 \\
\hline 66 & Trough Spring & 610,107 & $4,026,349$ & 2,512 & $45.0(17.70)$ & 9 & $\mathrm{~N} / \mathrm{A}$ \\
\hline 67 & Cold Creek & 613,563 & $4,030,708$ & 1,862 & $23.0(9.06)$ & 8 & N/A \\
\hline 68 & Indian Springs & 617,793 & $4,049,256$ & 951 & $11.6(4.57)$ & 25 & N/A \\
\hline 69 & Lee Canyon & 619,087 & $4,018,516$ & 2,594 & $53.4(21.02)$ & 9 & N/A \\
\hline 71 & Kyle Canyon & 623,466 & $4,012,260$ & 2,365 & $67.8(26.70)$ & 10 & N/A \\
\hline
\end{tabular}


Table 7-4

Precipitation Station Data

(Page 2 of 2)

\begin{tabular}{|c|c|c|c|c|c|c|c|}
\hline \multirow{2}{*}{$\begin{array}{l}\text { Station } \\
\text { Number }\end{array}$} & \multirow{2}{*}{ Station Name } & \multicolumn{2}{|c|}{$\begin{array}{l}\text { UTM Zone 11, } \\
\text { NAD } 27\end{array}$} & \multirow{2}{*}{$\begin{array}{c}\text { Land } \\
\text { Surface } \\
\text { Elevation } \\
\text { (m) }\end{array}$} & \multicolumn{2}{|c|}{$\begin{array}{l}\text { Average Annual } \\
\text { Precipitation }\end{array}$} & \multirow{2}{*}{$\begin{array}{l}\text { Percent } \\
\text { Change }^{\mathrm{a}}\end{array}$} \\
\hline & & $\begin{array}{l}\text { Easting } \\
\quad(\mathrm{m})\end{array}$ & $\begin{array}{l}\text { Northing } \\
\text { (m) }\end{array}$ & & $\begin{array}{l}\text { Depth } \\
\text { cm/yr } \\
\text { (in./yr) }\end{array}$ & $\begin{array}{c}\text { Years } \\
\text { of } \\
\text { Record }\end{array}$ & \\
\hline 72 & Adaven & 624,188 & $4,219,501$ & 1,905 & $32.1(12.64)$ & 47 & N/A \\
\hline 74 & Roberts Ranch & 627,418 & $4,003,163$ & 1,862 & $35.4(13.94)$ & 8 & N/A \\
\hline 75 & Red Rock Summit & 631,972 & $3,999,532$ & 1,984 & $27.0(10.63)$ & 8 & $\mathrm{~N} / \mathrm{A}$ \\
\hline 79 & Hayford Peak & 660,932 & $4,058,248$ & 2,999 & $42.4(16.70)$ & 9 & N/A \\
\hline 80 & Hidden Forest & 660,934 & $4,055,504$ & 2,304 & $32.0(12.60)$ & 9 & N/A \\
\hline 81 & Alamo & 662,347 & $4,136,921$ & 1,049 & $12.8(5.04)$ & 26 & N/A \\
\hline 82 & Las Vegas Airport & 665,072 & $3,994,546$ & 661 & $10.5(4.15)$ & 59 & 1.5 \\
\hline 83 & Sunrise Manor & 672,321 & $4,007,633$ & 555 & $10.6(4.17)$ & 32 & $\mathrm{~N} / \mathrm{A}$ \\
\hline
\end{tabular}

Source: SNJV 2004e (Adapted from: IT, 1996b; Jacobson, 1996; French, 1996; WRCC, 2004; ARL/SORD, 2004)

aPercent change in precipitation values with the inclusion of the new data for 2004.

the recharge distribution for the Yucca Flat/Climax Mine Investigation Area. Note that for this figure the UGTA revised recharge distribution was inserted into the DVRFS model (Belcher et al., 2004). For the area outside of the UGTA regional model boundary (DOE/NV, 1997b), the steady-state recharge distribution from Belcher et al. (2004) is shown.

\subsubsection{U.S. Geological Survey Recharge Models}

Three USGS recharge models have been identified as alternative recharge models for use in the Yucca Flat/Climax Mine CAU groundwater flow model. Two of these alternative recharge models are outputs from a distributed parameter watershed model (Hevesi et al., 2003). The third alternative recharge model is based on a modification to Model 1 from Hevesi et al. (2003) resulting from the calibration process of the updated DVRFS model (Belcher et al., 2004).

\subsubsection{Recharge Models Based on the USGS Death Valley Region Distributed Parameter Watershed Model}

The USGS (Hevesi et al., 2003), in support of a USGS saturated zone, groundwater flow model for the Death Valley region (D'Agnese et al., 1997), developed a deterministic distributed parameter 


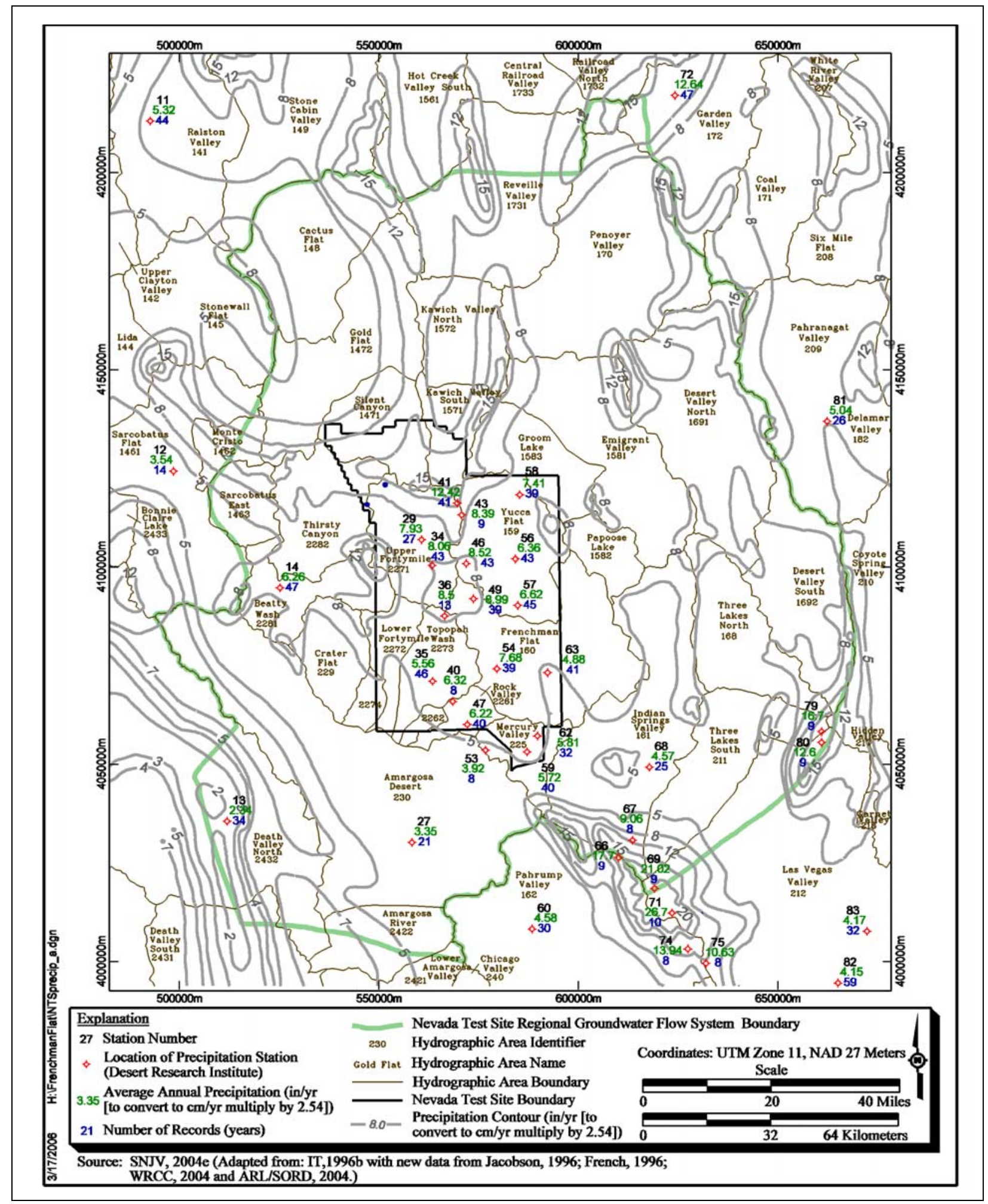

Figure 7-4

Updated Precipitation Map for the Nevada Test Site Region (UGTA Revised Precipitation Distribution) 


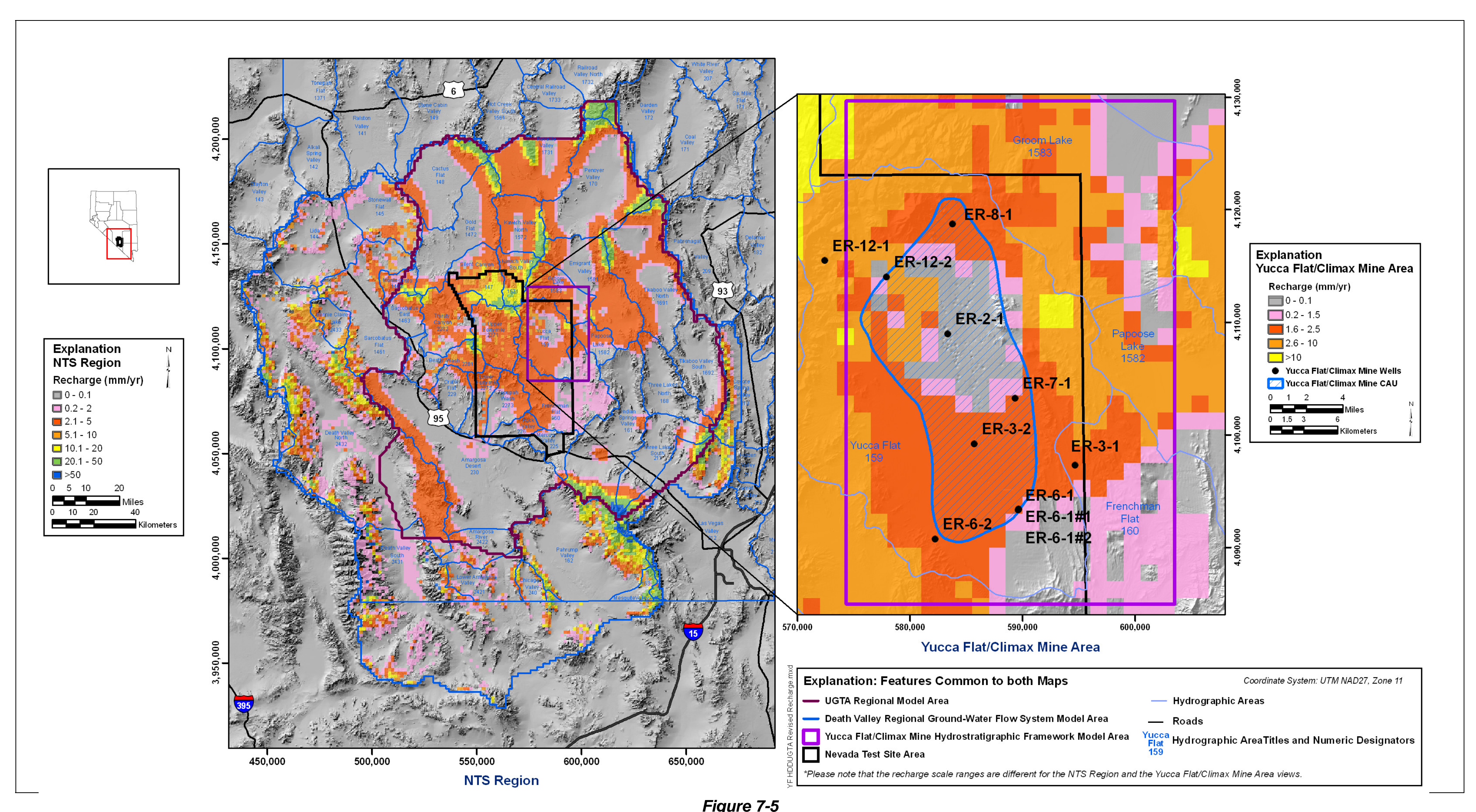

NTS Region with the UGTA Revised Recharge Model Inserted into the DVRFS Model (Belcher et al., 2004) (Note that the steady-state recharge distribution from the USGS DVRFS Model is used outside the UGTA Regional Model Boundary.) 
watershed model for estimating recharge in the Death Valley region. Of the alternative recharge models identified in this document for use in the Yucca Flat/Climax Mine CAU groundwater flow model, this is the only model that incorporates the physical processes that affect recharge. The model area included 42 HAs and subareas within or adjacent to the DVRFS.

The distributed parameter watershed model from Hevesi et al. (2003) used net-infiltration estimates to quantify the downward percolation of water across the lower boundary of the root zone and interpreted it as potential recharge under current climatic conditions. The purpose of the development of the distributed parameter watershed model was to define the upper boundary condition of the regional groundwater flow model (i.e., recharge).

The USGS Death Valley region distributed parameter watershed model (Hevesi et al., 2003) is based on a water-balance conceptual model of net infiltration for arid to semiarid environments. The major components of this conceptual model include:

- Precipitation

- Infiltration of rain, snowmelt, and surface water into soil or bedrock

- Surface-water runoff

- Surface-water run-on (overland flow and stream flow)

- Bare soil evaporation

- Transpiration from the root zone

- Redistribution of water content in the root zone

- Net infiltration across the lower boundary of the root zone

The FORTRAN computer code, INFILv3, was developed to simulate this conceptual model. Inputs to the INFILv3 computer code consist of:

- Climatic: Daily climate inputs, model coefficients for monthly climate models, and monthly atmospheric parameters.

- Digital Maps: A DEM and digitized maps of the spatial distribution of bedrock geology, soil types, and vegetation types. The DEM and digital map files were preprocessed to create a single watershed input file of spatially distributed drainage basin characteristics.

- Attribute Tables: Bedrock and deep alluvium, soil, and vegetation properties.

- Model Control Options: Simulation period, initial conditions, seasonal duration, stream channel characteristics, snowmelt and sublimation parameters, and input and output format options. 
Seven primary sources of data were used as either direct input or as input to preprocessing routines to develop parameter input files. The data sources included: (1) the DEM and topographic parameters developed using the DEM, (2) soil properties from a state-compiled geospatial database for soil properties, (3) bedrock and deep alluvium properties incorporated into the digitized map of HGUs, (4) vegetation and root-zone properties from the USGS/Biological Resources Division National Gap Analysis Program database, (5) daily climate inputs from National Oceanic and Atmospheric Administration/National Climatic Center Data Center (NOAA/NCDC) climate records, (6) monthly atmospheric parameters from the National Weather Service database, and (7) user defined model coefficients and simulation options. Table 7-5 (Hevesi et al., 2003) summarizes the input parameters including the source data, preprocessing (if any), input file, parameter name, description, use, and the units and estimated accuracy of the data.

The outputs from INFILv3 provide estimates of the temporal and spatial distribution of net infiltration and potential recharge in the Death Valley region and include:

- Time series results (annual, monthly, and daily) for simulated components of the water balance expressed as the mean simulation results for all grid cells and for specified grid locations.

- Spatially distributed simulation results for all components of the water balance.

- Summary statistics for model inputs and outputs, including the mean, maximum, and minimum values for all grid cells in the model domain.

Model calibration was accomplished using an iterative trial-and-error process of fitting simulated stream flow to measured stream-flow data. The INFILv3 model was calibrated to qualitative and quantitative comparisons of simulated stream flow, to historical stream-flow records in the Death Valley region, and comparison with previous estimates of basin-wide average recharge for the forty-two basin areas in the Death Valley region. Parameters that were adjusted to arrive at the qualitative calibration included bedrock saturated hydraulic conductivity, root density, storm duration, and parameters defining stream-channel characteristics (soil saturated hydraulic conductivity and wetted area). 
Table 7-5

INFILv3 Input Parameters

(Page 1 of 6$)$

\begin{tabular}{|c|c|c|c|c|c|c|c|}
\hline $\begin{array}{l}\text { Source } \\
\text { Data }\end{array}$ & Preprocessing & $\begin{array}{l}\text { Input } \\
\text { File }\end{array}$ & $\begin{array}{l}\text { Parameter } \\
\text { Name }\end{array}$ & $\begin{array}{l}\text { Parameter } \\
\text { Description }\end{array}$ & $\begin{array}{l}\text { Parameter } \\
\text { Use }\end{array}$ & Units & $\begin{array}{l}\text { Parameter } \\
\text { Accuracy }\end{array}$ \\
\hline \multicolumn{8}{|c|}{ DEM and Topographic Parameters Developed Using the DEM } \\
\hline \multirow[t]{12}{*}{ DEM } & \multirow{7}{*}{$\begin{array}{c}\text { GIS } \\
\text { Calculated }\end{array}$} & Watershed File & ElEV(rows,cols) & Land surface elevation & Potential ET, spatial interpolation models & $\mathrm{m}$ & High \\
\hline & & Watershed File & SLP(rows,cols) & Land surface slope & $\begin{array}{l}\text { Potential ET, } \\
\text { Streamflow routing }\end{array}$ & u & High \\
\hline & & Watershed File & ASP(rows,cols) & Land surface aspect & Potential ET & u & High \\
\hline & & Watershed File & EAST(rows,cols) & $\begin{array}{l}\text { DEM grid cell east-west } \\
\text { coordinate }\end{array}$ & $\begin{array}{l}\text { Grid cell location, spatial interpolation } \\
\text { models }\end{array}$ & $\mathrm{m}$ & High \\
\hline & & Watershed File & NORTH(r,c) & $\begin{array}{l}\text { DEM grid cell east-west } \\
\text { coordinate }\end{array}$ & $\begin{array}{l}\text { Grid cell location, spatial interpolation } \\
\text { models }\end{array}$ & $\mathrm{m}$ & High \\
\hline & & Watershed File & $\operatorname{LAT}(\mathrm{r}, \mathrm{c})$ & DEM grid cell latitude & Potential ET & dd & High \\
\hline & & Watershed File & $\operatorname{LON}(r, c)$ & DEM grid cell latitude & Potential ET & dd & High \\
\hline & \multirow{2}{*}{$\begin{array}{l}\text { SKYVIEW } \\
\text { Calculated }\end{array}$} & Watershed File & RIDGE $(r, c, 36)$ & 36 blocking ridge angles & Potential ET & d & Medium \\
\hline & & Watershed File & SKYVIEW(r,c) & Reduction in total skyview & Potential ET & u & Medium \\
\hline & \multirow{3}{*}{$\begin{array}{l}\text { GRDSORT01 } \\
\text { Calculated } \\
\text { ROUTER03 } \\
\text { Calculated }\end{array}$} & Watershed File & $\operatorname{LOCID}(r, c)$ & $\begin{array}{l}\text { Location identifier for upstream } \\
\text { cell }\end{array}$ & Streamflow routing & u & Medium \\
\hline & & Watershed File & IROUT(r,c) & $\begin{array}{l}\text { Location identifier for downstream } \\
\text { cell }\end{array}$ & Streamflow routing & u & Medium \\
\hline & & Watershed File & UPCELLs $(r, c)$ & Number of upstream cells & Streamflow routing & u & Medium \\
\hline \multicolumn{8}{|c|}{ Soil Properties Associated with the STATSGO Database } \\
\hline \multirow[t]{6}{*}{ STATSGO } & \multirow{6}{*}{$\begin{array}{c}\text { GIS } \\
\text { STATSGO34 }\end{array}$} & Watershed File & SOILTYPE(r,c) & Map code for STATSGO soil units & Spatial distribution of soil properties & u & Medium \\
\hline & & Watershed File & SOILTHCK $(r, c)$ & $\begin{array}{l}\text { Estimated soil thickness for } \\
\text { root-zone }\end{array}$ & Root-zone layer thickness & $\mathrm{m}$ & Low \\
\hline & & $\begin{array}{l}\text { Soil-Attribute } \\
\text { Table }\end{array}$ & SPOR(soiltype) & Soil porosity & Root-zone storage capacity & u & Medium \\
\hline & & $\begin{array}{l}\text { Soil-Attribute } \\
\text { Table }\end{array}$ & SWP(soiltype) & Soil wilting point & Root-zone storage capacity, ET model & u & Medium \\
\hline & & $\begin{array}{l}\text { Soil-Attribute } \\
\text { Table }\end{array}$ & SKS(soiltype) & $\begin{array}{l}\text { Soil saturated hydraulic } \\
\text { conductivity }\end{array}$ & $\begin{array}{l}\text { Root-zone infiltration and drainage } \\
\text { function }\end{array}$ & $\mathrm{mm} / \mathrm{day}$ & Medium \\
\hline & & $\begin{array}{l}\text { Soil-Attribute } \\
\text { Table }\end{array}$ & SOILB(soiltype) & Soil drainage function coefficient & $\begin{array}{l}\text { Root-zone infiltration and drainage } \\
\text { function }\end{array}$ & u & Medium \\
\hline
\end{tabular}


Table 7-5

INFILv3 Input Parameters

(Page 2 of 6)

\begin{tabular}{|c|c|c|c|c|c|c|c|}
\hline $\begin{array}{l}\text { Source } \\
\text { Data }\end{array}$ & Preprocessing & $\begin{array}{l}\text { Input } \\
\text { File }\end{array}$ & $\begin{array}{l}\text { Parameter } \\
\text { Name }\end{array}$ & $\begin{array}{l}\text { Parameter } \\
\text { Description }\end{array}$ & $\begin{array}{l}\text { Parameter } \\
\text { Use }\end{array}$ & Units & $\begin{array}{l}\text { Parameter } \\
\text { Accuracy }\end{array}$ \\
\hline \multicolumn{8}{|c|}{ Bedrock and Deep Alluvium Properties Associated with the Digital Map of Hydrogeologic Units } \\
\hline \multirow{4}{*}{$\begin{array}{c}\text { Faunt and } \\
\text { others (1997) } \\
\text { User defined }\end{array}$} & \multirow[t]{4}{*}{ GIS } & Watershed File & ROCKTYPE $(r, c)$ & Map code for hydrogeologic units & $\begin{array}{l}\text { Spatial distribution of bedrock and deep } \\
\text { properties }\end{array}$ & u & Medium \\
\hline & & $\begin{array}{c}\text { Bedrock } \\
\text { Attribute } \\
\text { Table }\end{array}$ & RPOR(rocktype) & $\begin{array}{l}\text { Effective root-zone porosity for } \\
\text { bedrock layer }\end{array}$ & $\begin{array}{l}\text { Defines storage capacity of root-zone in } \\
\text { bedrock layer }\end{array}$ & u & Low \\
\hline & & $\begin{array}{l}\text { Bedrock } \\
\text { Attribute } \\
\text { Table }\end{array}$ & $\begin{array}{c}\mathrm{RK}_{\mathrm{LO}} \\
\text { (rocktype) }\end{array}$ & $\begin{array}{l}\text { Effective unsaturated hydraulic } \\
\text { conductivity for hydrogeologic unit }\end{array}$ & $\begin{array}{l}\text { Defines lower bedrock hydraulic } \\
\text { conductivity }\end{array}$ & mm/day & Low \\
\hline & & $\begin{array}{c}\text { Bedrock } \\
\text { Attribute } \\
\text { Table }\end{array}$ & $\begin{array}{c}\mathrm{RK}_{\mathrm{HI}} \\
\text { (rocktype) }\end{array}$ & $\begin{array}{l}\text { Effective saturated hydraulic } \\
\text { conductivity for hydrogeologic unit }\end{array}$ & $\begin{array}{l}\text { Defines upper bedrock and deep alluvium } \\
\text { hydraulic conductivity }\end{array}$ & $\mathrm{mm} / \mathrm{day}$ & Low \\
\hline \multicolumn{8}{|c|}{ Vegetation and Root-Zone Properties Associated with the GAP Database } \\
\hline \multirow{4}{*}{ User defined } & \multirow{4}{*}{$\begin{array}{l}\text { GIS } \\
\text { None }\end{array}$} & Watershed File & VEGTYPE(r,c) & $\begin{array}{l}\text { Map code for GAP vegetation } \\
\text { units }\end{array}$ & $\begin{array}{l}\text { Spatial distribution of vegetation } \\
\text { properties, root zone layer properties }\end{array}$ & u & Medium \\
\hline & & Watershed File & VEGCOV $(r, c)$ & Vegetation cover & ET model & $\%$ & Medium \\
\hline & & $\begin{array}{l}\text { Vegetation } \\
\text { Attribute } \\
\text { Table }\end{array}$ & RZDEN(vegtype,I) & Root density for layer I & ET model & $\%$ & Low \\
\hline & & $\begin{array}{l}\text { Vegetation } \\
\text { Attribute } \\
\text { Table }\end{array}$ & RZDPTH(vegtype,I) & Root-zone layer thickness & ET model, root-zone drainage model & $\mathrm{m}$ & Low \\
\hline \multicolumn{8}{|c|}{ Snowmelt and Sublimation Parameters } \\
\hline \multirow[t]{4}{*}{$\begin{array}{l}\text { Maidment } \\
(1993)^{\star}\end{array}$} & \multirow[t]{7}{*}{ None } & Control File & SNODAY1 & Day number 1 for snowmelt model & $\begin{array}{l}\text { Define timing of early spring snowmelt } \\
\text { model }\end{array}$ & Day no. & Medium \\
\hline & & Control File & SNOPAR1 & Snowmelt parameter 1 & Degree-day snowmelt rate & $\mathrm{mm} / \mathrm{day}$ & Medium \\
\hline & & Control File & SNODAY2 & Day number 2 for snowmelt model & $\begin{array}{l}\text { Define timing of late spring snowmelt } \\
\text { model }\end{array}$ & Day no. & Medium \\
\hline & & Control File & SNOPAR2 & Snowmelt parameter 2 & Degree-day snowmelt rate & $\mathrm{mm} / \mathrm{day}$ & Medium \\
\hline \multirow[t]{3}{*}{ User defined } & & Control File & MELTIME & Duration of daily snowmelt & Controls intensity of snowmelt & Hours & Medium \\
\hline & & Control File & SUBPAR1 & Sublimation rate parameter \#1 & Sublimation & $\mathrm{u}$ & Low \\
\hline & & Control File & SUBPAR2 & Sublimation rate parameter \#2 & Sublimation & u & Low \\
\hline
\end{tabular}


Table 7-5

INFILv3 Input Parameters

(Page 3 of 6)

\begin{tabular}{|c|c|c|c|c|c|c|c|}
\hline $\begin{array}{l}\text { Source } \\
\text { Data }\end{array}$ & Preprocessing & $\begin{array}{l}\text { Input } \\
\text { File }\end{array}$ & $\begin{array}{l}\text { Parameter } \\
\text { Name }\end{array}$ & $\begin{array}{l}\text { Parameter } \\
\text { Description }\end{array}$ & $\begin{array}{l}\text { Parameter } \\
\text { Use }\end{array}$ & Units & $\begin{array}{l}\text { Parameter } \\
\text { Accuracy }\end{array}$ \\
\hline \multicolumn{8}{|c|}{ Simulation-Time Parameters } \\
\hline \multirow[t]{6}{*}{ User defined } & \multirow[t]{6}{*}{ None } & Control File & YRSTART & Simulation start year & Identifies simulation start date & $\mathrm{u}$ & $\mathrm{N} / \mathrm{A}$ \\
\hline & & Control File & MOSTART & Simulation start month & Identifies simulation start date & u & $\mathrm{N} / \mathrm{A}$ \\
\hline & & Control File & DYSTART & Simulation start day & Identifies simulation start date & $\mathrm{u}$ & $\mathrm{N} / \mathrm{A}$ \\
\hline & & Control File & YREND & Simulation end year & Identifies simulation end date & $\mathrm{u}$ & N/A \\
\hline & & Control File & MOEND & Simulation end month & Identifies simulation end date & u & $\mathrm{N} / \mathrm{A}$ \\
\hline & & Control File & DYEND & Simulation end day & Identifies simulation end date & u & $N / A$ \\
\hline \multicolumn{8}{|c|}{ Storm Duration Parameters } \\
\hline \multirow[t]{4}{*}{ User defined } & \multirow[t]{4}{*}{ None } & Control File & DYSUMBEG & $\begin{array}{l}\text { Start day number for summer } \\
\text { storms }\end{array}$ & $\begin{array}{l}\text { Defines beginning day number for } \\
\text { summer storm events }\end{array}$ & Day & Medium \\
\hline & & Control File & DYSUMEND & $\begin{array}{l}\text { End day number for summer } \\
\text { storms }\end{array}$ & $\begin{array}{l}\text { Defines ending day number for summer } \\
\text { storm events }\end{array}$ & Day & Medium \\
\hline & & Control File & STORMSUM & $\begin{array}{l}\text { Duration of summer precipitation } \\
\text { and streamflow }\end{array}$ & $\begin{array}{l}\text { Defines precipitation and streamflow } \\
\text { intensity for summer storms }\end{array}$ & Hours & Low \\
\hline & & Control File & STORMWIN & $\begin{array}{l}\text { Duration of winter precipitation } \\
\text { and streamflow }\end{array}$ & $\begin{array}{l}\text { Defines precipitation and streamflow } \\
\text { intensity for winter storms }\end{array}$ & Hours & Low \\
\hline \multicolumn{8}{|c|}{ ET Parameters } \\
\hline \multirow[t]{4}{*}{$\begin{array}{l}\text { Flint and } \\
\text { Childs (1987) }\end{array}$} & \multirow[t]{5}{*}{ None } & Control File & BSEA & $\begin{array}{l}\text { Priestley-Taylor model coefficient } \\
\# 1 \text { for bare soil evaporation }\end{array}$ & $\begin{array}{l}\text { ET model coefficient for modified } \\
\text { Priestley-Taylor equation, for bare-soil } \\
\text { evaporation }\end{array}$ & u & Medium \\
\hline & & Control File & BSEB & $\begin{array}{l}\text { Priestley-Taylor model coefficient } \\
\# 2 \text { for bare soil evaporation }\end{array}$ & $\begin{array}{l}\text { ET model coefficient for modified } \\
\text { Priestley-Taylor equation, for bare-soil } \\
\text { evaporation }\end{array}$ & u & Medium \\
\hline & & Control File & HSTEP & POTEVAP time step & $\begin{array}{l}\text { Define hourly time-step for potential ET } \\
\text { model }\end{array}$ & Hours & N/A \\
\hline & & Control File & ETA & $\begin{array}{l}\text { Priestley-Taylor model coefficient } \\
\# 1 \text { for transpiration }\end{array}$ & $\begin{array}{l}\text { ET model coefficient for modified } \\
\text { Priestley-Taylor equation, for transpiration }\end{array}$ & u & Medium \\
\hline User defined & & Control File & ETB & $\begin{array}{l}\text { Priestley-Taylor model coefficient } \\
\# 2 \text { for transpiration }\end{array}$ & $\begin{array}{l}\text { ET model coefficient for modified } \\
\text { Priestley-Taylor equation, for transpiration }\end{array}$ & u & Medium \\
\hline
\end{tabular}


Table 7-5

INFILv3 Input Parameters

(Page 4 of 6)

\begin{tabular}{|c|c|c|c|c|c|c|c|}
\hline $\begin{array}{l}\text { Source } \\
\text { Data }\end{array}$ & Preprocessing & $\begin{array}{l}\text { Input } \\
\text { File }\end{array}$ & $\begin{array}{l}\text { Parameter } \\
\text { Name }\end{array}$ & $\begin{array}{l}\text { Parameter } \\
\text { Description }\end{array}$ & $\begin{array}{l}\text { Parameter } \\
\text { Use }\end{array}$ & Units & $\begin{array}{l}\text { Paramete } \\
\text { Accuracy }\end{array}$ \\
\hline \multicolumn{8}{|c|}{ Stream-Channel Parameters } \\
\hline \multirow[t]{7}{*}{ User defined } & \multirow[t]{7}{*}{ None } & Control File & CHAN1 & $\begin{array}{l}\text { Surface-water minimum wetted } \\
\text { area factor }\end{array}$ & $\begin{array}{l}\text { Defines wetted area for stream-channel } \\
\text { grid cell }\end{array}$ & u & Low \\
\hline & & Control File & CHAN2 & $\begin{array}{l}\text { Surface-water wetted area model } \\
\text { coefficient }\end{array}$ & $\begin{array}{l}\text { Defines wetted area for stream-channel } \\
\text { grid cell }\end{array}$ & u & Low \\
\hline & & Control File & CHAN3 & $\begin{array}{l}\text { Surface-water headwater wetted } \\
\text { area factor }\end{array}$ & $\begin{array}{l}\text { Defines wetted area for stream-channel } \\
\text { grid cell }\end{array}$ & u & Low \\
\hline & & Control File & CHAN4 & $\begin{array}{l}\text { Surface-water maximum wetted } \\
\text { area factor }\end{array}$ & $\begin{array}{l}\text { Defines wetted area for stream-channel } \\
\text { grid cell }\end{array}$ & u & Low \\
\hline & & Control File & KSCHN1 & $\begin{array}{l}\text { Model coefficient for stream } \\
\text { channel characteristics }\end{array}$ & $\begin{array}{l}\text { Minimum number of upstream cells for } \\
\text { using KSCHN2 }\end{array}$ & u & Low \\
\hline & & Control File & $\mathrm{KSCHN} 2$ & $\begin{array}{l}\text { Model coefficient for stream } \\
\text { channel characteristics }\end{array}$ & $\begin{array}{l}\text { Scaler for adjusting soil saturated } \\
\text { hydraulic conductivity in channels }\end{array}$ & u & Low \\
\hline & & Control File & $\mathrm{KSCHN3}$ & $\begin{array}{l}\text { Soil saturated hydraulic } \\
\text { conductivity }\end{array}$ & $\begin{array}{l}\text { Maximum soil saturated hydraulic } \\
\text { conductivity in channels }\end{array}$ & u & Low \\
\hline \multicolumn{8}{|c|}{ Daily Climate Inputs Developed From NOAA/NCDC } \\
\hline \multirow[t]{5}{*}{$\begin{array}{l}\text { NOAAl } \\
\text { NCDC }\end{array}$} & \multirow[t]{5}{*}{ DAYINP14 } & Control File & INITOPT & Initial condition option & $\begin{array}{l}\text { Defines method for setting initial } \\
\text { conditions }\end{array}$ & u & N/A \\
\hline & & Control File & VWCFACT & $\begin{array}{l}\text { Scaler for setting initial water } \\
\text { content for root-zone }\end{array}$ & $\begin{array}{l}\text { Defines initial water content for soil layers } \\
\text { in root zone }\end{array}$ & u & Low \\
\hline & & Precip. File & PPT(day,st) & Daily precipitation & Daily precipitation input & $\mathrm{mm}$ & High \\
\hline & & $\begin{array}{l}\text { Maximum } \\
\text { Air Temp. } \\
\quad \text { File }\end{array}$ & TMAX(day,st) & Maximum daily air temperature & $\begin{array}{l}\text { Snowfall, snowmelt, sublimation, } \\
\text { potential ET }\end{array}$ & ${ }^{\circ} \mathrm{C}$ & High \\
\hline & & $\begin{array}{l}\text { Minimum } \\
\text { Air temp. } \\
\text { File }\end{array}$ & TMIN(day,st) & Minimum daily air temperature & $\begin{array}{l}\text { Snowfall, snowmelt, sublimation, } \\
\text { potential ET }\end{array}$ & ${ }^{\circ} \mathrm{C}$ & High \\
\hline User defined & EXCEL & $\begin{array}{l}\text { Monthly } \\
\text { Climate } \\
\text { Model }\end{array}$ & PPTMOD(month) & $\begin{array}{l}\text { Model type for monthly } \\
\text { precipitation-elevation regression } \\
\text { model }\end{array}$ & $\begin{array}{l}\text { Defines model type for daily precipitation } \\
\text { spatial interpolation model }\end{array}$ & u & Medium \\
\hline
\end{tabular}


Table 7-5

INFILv3 Input Parameters

(Page 5 of 6)

\begin{tabular}{|c|c|c|c|c|c|c|c|}
\hline $\begin{array}{l}\text { Source } \\
\text { Data }\end{array}$ & Preprocessing & $\begin{array}{l}\text { Input } \\
\text { File }\end{array}$ & $\begin{array}{l}\text { Parameter } \\
\text { Name }\end{array}$ & $\begin{array}{l}\text { Parameter } \\
\text { Description }\end{array}$ & $\begin{array}{l}\text { Parameter } \\
\text { Use }\end{array}$ & Units & $\begin{array}{l}\text { Parameter } \\
\text { Accuracy }\end{array}$ \\
\hline \multicolumn{8}{|c|}{ Daily Climate Inputs Developed From NOAA/NCDC - Continued } \\
\hline \multirow[t]{11}{*}{$\begin{array}{l}\text { User defined } \\
\quad \text { (cont.) }\end{array}$} & \multirow[t]{11}{*}{$\begin{array}{l}\text { EXCEL } \\
\text { (cont,) }\end{array}$} & $\begin{array}{l}\text { Monthly } \\
\text { Climate } \\
\text { Model }\end{array}$ & PPTA(month) & $\begin{array}{l}\text { Regression model coefficient for } \\
\text { precipitation-elevation regression } \\
\text { model }\end{array}$ & $\begin{array}{l}\text { Coefficient for daily precipitation spatial } \\
\text { interpolation model }\end{array}$ & u & Medium \\
\hline & & $\begin{array}{l}\text { Monthly } \\
\text { Climate } \\
\text { Model }\end{array}$ & PPTB(month) & $\begin{array}{l}\text { Regression model coefficient for } \\
\text { precipitation-elevation regression } \\
\text { model }\end{array}$ & $\begin{array}{l}\text { Coefficient for daily precipitation spatial } \\
\text { interpolation model }\end{array}$ & u & Medium \\
\hline & & $\begin{array}{l}\text { Monthly } \\
\text { Climate } \\
\text { Model }\end{array}$ & PPTC(month) & $\begin{array}{l}\text { Regression model coefficient for } \\
\text { precipitation-elevation regression } \\
\text { model }\end{array}$ & $\begin{array}{l}\text { Coefficient for daily precipitation spatial } \\
\text { interpolation model }\end{array}$ & u & Medium \\
\hline & & $\begin{array}{l}\text { Monthly } \\
\text { Climate } \\
\text { Model }\end{array}$ & TMAXMOD(month) & $\begin{array}{l}\text { Model type for monthly maximum } \\
\text { air temperature-elevation } \\
\text { regression model }\end{array}$ & $\begin{array}{l}\text { Defines model type for maximum daily air } \\
\text { temperature spatial interpolation model }\end{array}$ & u & High \\
\hline & & $\begin{array}{l}\text { Monthly } \\
\text { Climate } \\
\text { Model }\end{array}$ & TMAXA(month) & $\begin{array}{l}\text { Regression model coefficient for } \\
\text { maximum air } \\
\text { temperature-elevation model }\end{array}$ & $\begin{array}{l}\text { Coefficient for maximum daily air } \\
\text { temperature spatial interpolation model }\end{array}$ & u & High \\
\hline & & $\begin{array}{l}\text { Monthly } \\
\text { Climate } \\
\text { Model }\end{array}$ & TMAXB(month) & $\begin{array}{l}\text { Regression model coefficient for } \\
\text { maximum air } \\
\text { temperature-elevation model }\end{array}$ & $\begin{array}{l}\text { Coefficient for maximum daily air } \\
\text { temperature spatial interpolation model }\end{array}$ & u & High \\
\hline & & $\begin{array}{l}\text { Monthly } \\
\text { Climate } \\
\text { Model }\end{array}$ & TMAXC(month) & $\begin{array}{l}\text { Regression model coefficient for } \\
\text { maximum air } \\
\text { temperature-elevation model }\end{array}$ & $\begin{array}{l}\text { Coefficient for maximum daily air } \\
\text { temperature spatial interpolation model }\end{array}$ & u & High \\
\hline & & $\begin{array}{l}\text { Monthly } \\
\text { Climate } \\
\text { Model }\end{array}$ & TMINMOD(month) & $\begin{array}{l}\text { Model type for monthly } \\
\text { minimum air temperature- } \\
\text { elevation regression model }\end{array}$ & $\begin{array}{l}\text { Defines model type for minimum daily air } \\
\text { temperature spatial interpolation model }\end{array}$ & u & High \\
\hline & & $\begin{array}{l}\text { Monthly } \\
\text { Climate } \\
\text { Model }\end{array}$ & TMINA(month) & $\begin{array}{l}\text { Regression model coefficient for } \\
\text { minimum air } \\
\text { temperature-elevation model }\end{array}$ & $\begin{array}{l}\text { Coefficient for minimum daily air } \\
\text { temperature spatial interpolation model }\end{array}$ & u & High \\
\hline & & $\begin{array}{l}\text { Monthly } \\
\text { Climate } \\
\text { Model }\end{array}$ & TMINB(month) & $\begin{array}{l}\text { Regression model coefficient for } \\
\text { minimum air } \\
\text { temperature-elevation model }\end{array}$ & $\begin{array}{l}\text { Coefficient for minimum daily air } \\
\text { temperature spatial interpolation model }\end{array}$ & u & High \\
\hline & & $\begin{array}{l}\text { Monthly } \\
\text { Climate } \\
\text { Model }\end{array}$ & TMINC(month) & $\begin{array}{l}\text { Regression model coefficient for } \\
\text { minimum air } \\
\text { temperature-elevation model }\end{array}$ & $\begin{array}{l}\text { Coefficient for minimum daily air } \\
\text { temperature spatial interpolation model }\end{array}$ & $\mathrm{u}$ & High \\
\hline
\end{tabular}


Table 7-5

INFILv3 Input Parameters

(Page 6 of 6)

\begin{tabular}{|c|c|c|c|c|c|c|c|}
\hline $\begin{array}{l}\text { Source } \\
\text { Data }\end{array}$ & Preprocessing & $\begin{array}{l}\text { Input } \\
\text { File }\end{array}$ & $\begin{array}{l}\text { Parameter } \\
\text { Name }\end{array}$ & $\begin{array}{l}\text { Parameter } \\
\text { Description }\end{array}$ & $\begin{array}{l}\text { Parameter } \\
\text { Use }\end{array}$ & Units & $\begin{array}{l}\text { Paramete } \\
\text { Accuracy }\end{array}$ \\
\hline \multicolumn{8}{|c|}{ Monthly Atmospheric Parameters } \\
\hline \multirow[t]{5}{*}{ NWS } & \multirow[t]{5}{*}{ None } & $\begin{array}{c}\text { Monthly } \\
\text { Atmospheric } \\
\text { Parameter }\end{array}$ & OZONE(month) & Ozone layer thickness & $\begin{array}{l}\text { Potential ET model, incoming solar } \\
\text { radiation }\end{array}$ & $\mathrm{cm}$ & Medium \\
\hline & & $\begin{array}{c}\text { Monthly } \\
\text { Atmospheric } \\
\text { Parameter }\end{array}$ & WP(month) & Precipitable water in atmosphere & $\begin{array}{l}\text { Potential ET model, incoming solar } \\
\text { radiation }\end{array}$ & $\mathrm{cm}$ & Medium \\
\hline & & $\begin{array}{c}\text { Monthly } \\
\text { Atmospheric } \\
\text { Parameter }\end{array}$ & BETA(month) & Mean atmospheric turbidity & $\begin{array}{l}\text { Potential ET model, incoming solar } \\
\text { radiation, net radiation }\end{array}$ & u & Medium \\
\hline & & $\begin{array}{c}\text { Monthly } \\
\text { Atmospheric } \\
\text { Parameter }\end{array}$ & CSR(month) & Circumsolar radiation & $\begin{array}{l}\text { Potential ET model, incoming solar } \\
\text { radiation, net radiation }\end{array}$ & u & Medium \\
\hline & & $\begin{array}{c}\text { Monthly } \\
\text { Atmospheric } \\
\text { Parameter }\end{array}$ & PG(month) & Surface reflectivity & $\begin{array}{l}\text { Potential ET model, incoming solar } \\
\text { radiation, net radiation }\end{array}$ & u & Medium \\
\hline
\end{tabular}

Source: SNJV, 2004e (Adapted from: Hevesi et al., 2003)

$$
r=\text { Row }
$$

$\mathrm{c}=$ Column

$\%=$ Percentage

$\mathrm{u}=$ Unitless

$\mathrm{dd}=$ Decimal degrees

$d=$ Degrees

$\mathrm{mm} /$ day $=$ Millimeters per day

N/A = Not applicable

GIS = Geographic Information System

${ }^{\circ} \mathrm{C}=$ Degrees Celsius 
Four alternative calibrated models were selected by Hevesi et al. (2003) for model evaluation and the qualitative evaluation of model uncertainty. The differences in input parameters for the four selected models are summarized in Table 7-6 (Hevesi et al., 2003). With the exception of these different input parameters, all other INFILv3 inputs were the same for each alternative model.

Table 7-6

Model Coefficients Used To Simulate Stream Flow and Net Infiltration in INFLv3 Models 1-4 of the Death Valley Region, Nevada and California

\begin{tabular}{|c|c|c|c|c|c|}
\hline Parameter Description & $\begin{array}{l}\text { Parameter } \\
\text { Name }\end{array}$ & Model 1 & Model 2 & Model 3 & Model 4 \\
\hline Sublimation rate parameter 1 & SUBPAR1 & 0.4 & 0.4 & 0.35 & 04 \\
\hline Surface-water flow coupled to root zone & N/A & Yes & No & Yes & Yes \\
\hline Surface-water minimum wetted area factor & CHAN1 & .10 & .10 & .05 & .05 \\
\hline Surface-water wetted area model coefficient & CHAN2 & 10,000 & 10,000 & 10,000 & 5,000 \\
\hline Surface-water headwater wetted area factor & CHAN3 & .8 & .8 & .8 & .8 \\
\hline Surface-water maximum wetted area factor & CHAN4 & 2.0 & 2.0 & 1.0 & 1.0 \\
\hline Model coefficient for stream-channel characteristics & KSCHN1 & 20.0 & 20.0 & 20.0 & 2.0 \\
\hline Model coefficient for stream-channel characteristics & KSCHN3 & 2,000 & 2,000 & 2,000 & 4,000 \\
\hline Soil saturated hydraulic conductivity & KSCHN3 & 4.0 & 4.0 & 2.0 & 2.0 \\
\hline Potential ET time step (hours) & HSTEP & 2.0 & 2.0 & 2.0 & 1.0 \\
\hline $\begin{array}{l}\text { Duration of summer precipitation and stream flow } \\
\text { (hours) }\end{array}$ & STORMSUM & 2.0 & 2.0 & 1.0 & 2.0 \\
\hline Duration of winter precipitation and stream flow (hours) & STORMWIN & 12.0 & 12.0 & 8.0 & 12.0 \\
\hline Bedrock properties input file ${ }^{a}$ & $N / A$ & $A$ & A & $\mathrm{B}$ & $\mathrm{B}$ \\
\hline Root-zone parameters input file & $N / A$ & A & $A$ & A & $\mathrm{B}$ \\
\hline
\end{tabular}

Source: Modified from Hevesi et al., 2003

aRefer to Hevesi et al. (2003) Table 4 for description of bedrock properties input files A and B.

${ }^{\text {b}}$ Refer to Hevesi et al. (2003) Table 5 for description of root-zone parameters input file A and Hevesi et al. (2003) Table 6 for description of root-zone parameters input file B. 
Model 1 is considered the base-case model. Model 2 is identical to Model 1, except that stream flow is decoupled from the root zone model component and all surface water is discharged to playas or downstream drainage basins. The differences between these two models was used to evaluate the effect of stream flow on basin-wide net infiltration, and to determine the maximum simulated stream flow. As compared to Model 1, Model 3 includes reductions in several parameter values that, in general, increase the tendency to generate runoff, decrease the tendency for infiltration of surface water, and decrease the tendency for net infiltration. Model 4 is similar to Model 3 with adjustment to several parameters that strongly affect direct net-infiltration rates.

The INFILv3 model results for the four selected calibrated alternative models were evaluated using averages by comparing simulated basin-wide, net-infiltration rates and volumes with previous estimates of basin-wide recharge rates and volumes.

Model 1 provided the best overall calibration with simulation results indicating an average net infiltration of 2.8 millimeters per year $(\mathrm{mm} / \mathrm{yr})$, or a total potential recharge of $342,000 \mathrm{~m}^{3} / \mathrm{d}$ for the area of the DVRFS model area. The net-infiltration rate calculated is equivalent to 1.6 percent of the average precipitation rate $(171.3 \mathrm{~mm} / \mathrm{yr})$ for the period 1950 to 1999 simulated. This model also estimated an average runoff generation of $2.2 \mathrm{~mm} / \mathrm{yr}$ and an average run-on infiltration rate of $2.0 \mathrm{~mm} / \mathrm{yr}$. Average surface-water inflow to playa lake beds is simulated to be $0.2 \mathrm{~mm} / \mathrm{yr}$ (equivalent to $24,800 \mathrm{~m}^{3} / \mathrm{d}$ ), which is less than 10 percent of the runoff. The flow into the playas is assumed to evaporate.

Using the simulated output from the four alternative net infiltration models, three "goodness of fit" statistics were applied to the comparison of simulated results of net infiltration and previous estimates of recharge rates for the $42 \mathrm{HAs}$ in the model domain. These statistics included average estimation error (AEE), a standardized mean-square error (SMSE), and a correlation coefficient $\left(\mathrm{R}^{2}\right)$. Based on these statistics, Hevesi et al. (2003) found that the net infiltration rates simulated by INFILv3 Model 1 provide the best fit to the previous estimates of recharge rates. Model 2 was found to have the strongest correlation with estimated recharge, but the absolute values of AEE were higher for Model 2 than for Model 1. Finally, the simulated net infiltration for Models 3 and 4 did not compare well with basin-wide recharge estimates. The results of net infiltration simulations for Models 1 and 2 for the 42 HAs in the model domain are summarized in Table 7-7. 
Table 7-7

Simulated Net-Infiltration Rates and Volumes Using INFLv3 Models 1 and 2 for HAs and Subareas in the Death Valley Region, Nevada and California, 1950-1999

(Page 1 of 2)

\begin{tabular}{|c|c|c|c|c|c|}
\hline \multicolumn{2}{|l|}{ HA and Subarea } & \multicolumn{2}{|c|}{$\begin{array}{l}\text { Simulated Net Infiltration } \\
\qquad(\mathrm{mm} / \mathrm{yr})\end{array}$} & \multicolumn{2}{|c|}{$\begin{array}{l}\text { Simulated Net Infiltration } \\
\qquad\left(\mathrm{m}^{3} / \mathrm{d}\right)\end{array}$} \\
\hline Name & Identifier & Model 1 & Model 2 & Model 1 & Model 2 \\
\hline Alkali Spring Valley & 142 & 0.21 & 0.2 & 480 & 459 \\
\hline Amargosa Desert & 230 & 0.77 & 0.70 & 7,225 & 6,602 \\
\hline Cactus Flat & 148 & 1.70 & 1.37 & 4,761 & 3,840 \\
\hline California Valley & 241 & 2.75 & 1.78 & 2,617 & 1,689 \\
\hline Chicago Valley & 240 & 2.49 & 2.45 & 1,920 & 1,887 \\
\hline Clayton Valley & 143 & 0.90 & 0.72 & 3,549 & 2,842 \\
\hline Coal Valley & 171 & 3.47 & 2.82 & 11,219 & 9,100 \\
\hline Crater Flat & 229 & 0.70 & 0.66 & 904 & 860 \\
\hline Death Valley & 243 & 2.22 & 1.65 & 57,041 & 42,865 \\
\hline Emigrant Valley (Groom Lake) & $158 \mathrm{~A}$ & 4.14 & 2.74 & 19,382 & 12,810 \\
\hline Emigrant Valley (Papoose Lake) & $158 \mathrm{~B}$ & 1.61 & 1.23 & 1,243 & 954 \\
\hline Fortymile Canyon (Buckboard Mesa) & $227 \mathrm{~B}$ & 4.04 & 2.70 & 6,616 & 4,416 \\
\hline Fortymile Canyon (Jackass Flats) & $227 \mathrm{~A}$ & 2.67 & 1.55 & 5,347 & 3,114 \\
\hline Frenchman Flat & 160 & 1.98 & 1.85 & 6,426 & 5,998 \\
\hline Garden Valley & 172 & 3.50 & 2.80 & 11,223 & 8,969 \\
\hline Gold Flat & 147 & 2.94 & 2.26 & 14,201 & 10,922 \\
\hline Hidden Valley (south) & 166 & 0.33 & 0.33 & 78 & 77 \\
\hline Indian Springs Valley & 161 & 3.27 & 3.16 & 15,505 & 14,979 \\
\hline Ivanpah Valley (north) & $164 \mathrm{~A}$ & 2.73 & 2.69 & 4,723 & 4,659 \\
\hline Ivanpah Valley (south) & 164B & 1.47 & 0.81 & 5,299 & 2,909 \\
\hline Jean Lake Valley & 165 & 0.36 & 0.25 & 248 & 175 \\
\hline Kawich Valley & 157 & 4.89 & 3.31 & 12,454 & 8,428 \\
\hline Las Vegas Valley & 212 & 4.97 & 4.91 & 51,154 & 50,557 \\
\hline Lida Valley & 144 & 0.54 & 0.47 & 2,059 & 1,781 \\
\hline Lower Amargosa Valley & 242 & 0.79 & 0.75 & 2,591 & 2,470 \\
\hline Mercury Valley & 225 & 1.54 & 1.45 & 1,214 & 1,139 \\
\hline Mesquite Valley & 163 & 3.77 & 3.50 & 11,719 & 10,861 \\
\hline Oasis Valley & 228 & 2.55 & 2.01 & 7,459 & 6,689 \\
\hline Pahranagat Valley & 209 & 2.61 & 2.51 & 13,663 & 13,129 \\
\hline Pahrump Valley & 162 & 5.66 & 5.53 & 39,712 & 38,772 \\
\hline
\end{tabular}


Table 7-7

Simulated Net-Infiltration Rates and Volumes Using INFLv3 Models 1 and 2 for HAs and Subareas in the Death Valley Region, Nevada and California, 1950-1999 (Page 2 of 2)

\begin{tabular}{|c|c|c|c|c|c|}
\hline \multicolumn{2}{|l|}{ HA and Subarea } & \multicolumn{2}{|c|}{$\begin{array}{l}\text { Simulated Net Infiltration } \\
\qquad(\mathrm{mm} / \mathrm{yr})\end{array}$} & \multicolumn{2}{|c|}{$\begin{array}{l}\text { Simulated Net Infiltration } \\
\left(\mathrm{m}^{3} / \mathrm{d}\right)\end{array}$} \\
\hline Name & Identifier & Model 1 & Model 2 & Model 1 & Model 2 \\
\hline Penoyer Valley & 170 & 3.55 & 2.93 & 17,427 & 14,346 \\
\hline Railroad Valley (south) & $173 \mathrm{~A}$ & 3.32 & 2.66 & 13,964 & 11,181 \\
\hline Rock Valley & 226 & 2.00 & 1.94 & 1,189 & 1,157 \\
\hline Sacrobatus Flat & 146 & 1.44 & 1.18 & 8,329 & 6,866 \\
\hline Shadow Valley & 245 & 2.11 & 1.82 & 5,847 & 5,051 \\
\hline Stonewall Flat & 145 & 1.56 & 1.46 & 4,191 & 3,912 \\
\hline Three Lakes Valley (north) & 168 & 2.36 & 2.35 & 5,031 & 5,014 \\
\hline Three Lakes Valley (south) & 211 & 2.05 & 2.03 & 4,382 & 4,350 \\
\hline Tikapoo Valley (north) & $169 \mathrm{~A}$ & 3.07 & 2.84 & 13,410 & 12,400 \\
\hline Tikapoo Valley (south) & 169B & 2.96 & 2.95 & 7,751 & 7,743 \\
\hline Valjean Valley & 244 & 0.77 & 0.06 & 2,266 & 178 \\
\hline Yucca Flat & 159 & 2.48 & 1.91 & 5,257 & 4,051 \\
\hline \multicolumn{6}{|l|}{ Combined areas: } \\
\hline California and Chicago Valleys & 241 and 240 & 2.64 & 2.10 & 4,538 & 3,576 \\
\hline Emigrant Valley & 158 & 3.78 & 1.83 & 20,625 & 13,764 \\
\hline Fortymile Canyon & 227 & 3.28 & 2.05 & 11,963 & 7,530 \\
\hline Garden and Coal Valleys & 172 and 171 & 3.49 & 2.81 & 22,442 & 18,069 \\
\hline Mercury and Rock Valleys & 225 and 226 & 1.74 & 1.69 & 2,402 & 2,296 \\
\hline DVRFS model & $\mathrm{N} / \mathrm{A}$ & 2.77 & 2.36 & 342,098 & 293,121 \\
\hline Average estimation error $\left(\mathrm{m}^{3} / \mathrm{d}\right)$ & & -0.07 & -0.49 & -317 & $-2,954$ \\
\hline Standardized mean square error & & 0.61 & 0.64 & 0.18 & 0.12 \\
\hline Pearson correlation coefficient & 0 & 67 & 0.70 & 0.93 & 0.94 \\
\hline
\end{tabular}

Source: Modified from Hevesi et al., 2003, Tables 22 and 23 
The simulation results of the four alternative recharge models were used in a qualitative assessment of model uncertainty (Hevesi et al., 2003). Differences between Models 1 and 2 provide a qualitative measure of the uncertainty in net infiltration associated infiltrated run-on. This uncertainty is high because of the uncertainty in the channel characteristics and storm duration model components. These model components have a strong effect on simulated discharge. The comparison of Model 1 (includes run-on infiltration) and Model 2 (does not include run-on infiltration) indicates that the uncertainty in infiltrated run-on is approximately \pm 15 percent.

Models 1 and 2 documented in Hevesi et al. (2003) are selected to provide alternative recharge models for the Yucca Flat/Climax Mine CAU groundwater flow model. For this report, Model 1 is designated as "USGS Recharge Distribution Model 1—with run-on infiltration included in recharge" and Model 2 is designated "USGS Recharge Distribution Model 2-without run-on infiltration included in recharge." The recharge maps for these alternative recharge models are shown on Figures 7-6 and 7-7, respectively. These figures show both the regional-recharge distribution and the recharge distribution for the Yucca Flat/Climax Mine Investigation Area.

\subsubsection{U.S. Geological Survey Calibrated Recharge Model}

The updated USGS DVRFS model (Belcher et al., 2004) used the distributed parameter method of Hevesi et al. (2003) described above as the base recharge model estimate. However, the recharge rates from base recharge model (Model 1 from Hevesi et al., 2003) with a 278.5-m grid were resampled to the 1,500-m grid of the DVRFS model using a nearest-neighbor approach and adjusted during the DVRFS flow model calibration process to provide a better balance between recharge and discharge (Belcher et al., 2004). The recharge calibration targets include ET, spring discharge and hydraulic heads. For this report, this alternative recharge model is designated as "USGS Recharge Distribution Model 3-model calibration" Figure 7-8 shows the recharge distribution associated with this alternative recharge model.

\subsubsection{Desert Research Institute Recharge Models}

The DRI recharge models (Russell and Minor, 2002) used an elevation-dependent, chloride mass-balance approach to refine recharge estimates in the NTS region and provide information about the spatial variability of recharge within this region. This model combined methods similar to that of 


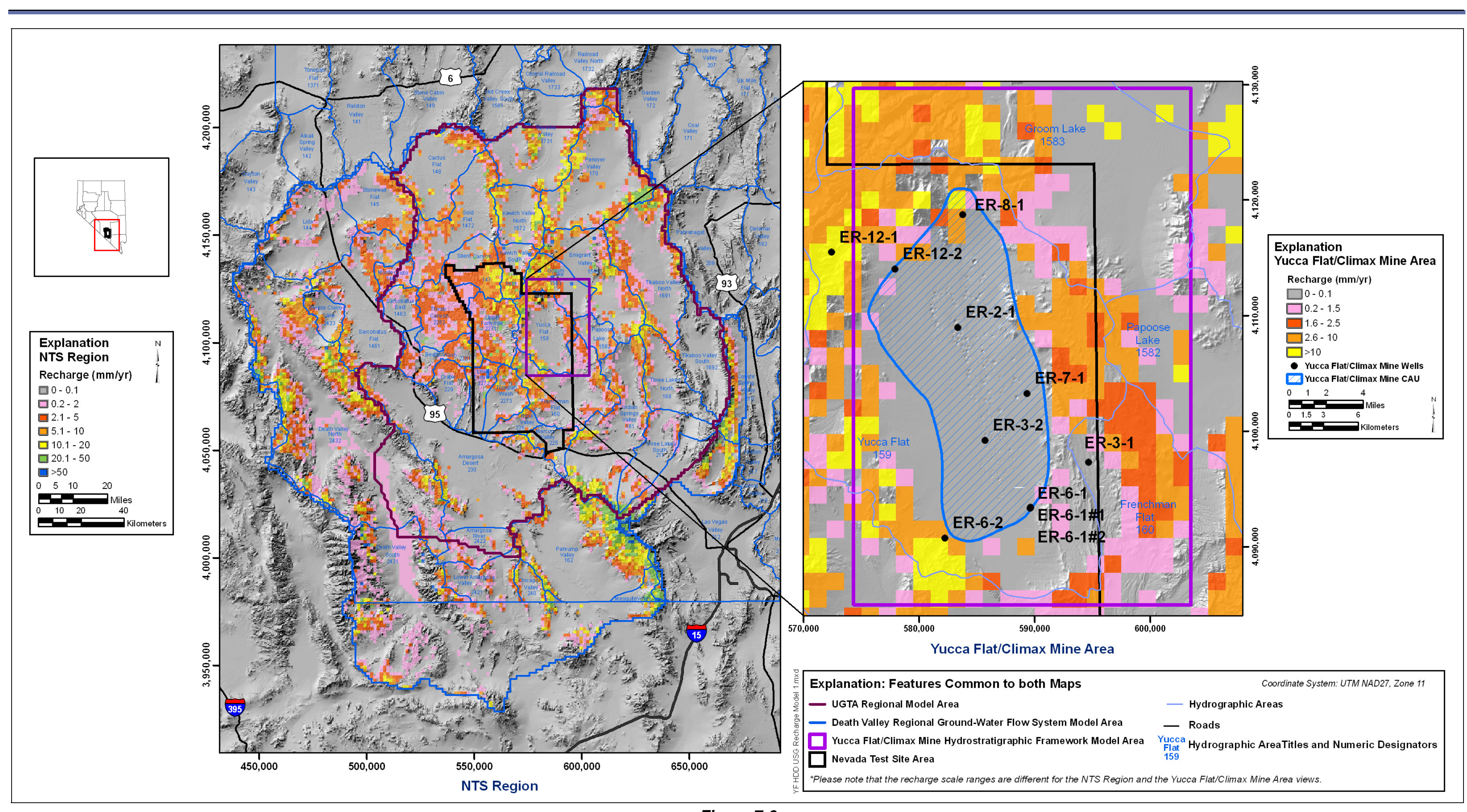

NTS Region with the USGS Recharge Distribution Model 1 which Includes Run-on Infiltration Component

in Recharge Inserted into the USGS DVRFS Model (Belcher et al., 2004)

(Note that the steady-state recharge distribution from the USGS DVRFS Model is used outside the UGTA Regional Model Boundary.) 


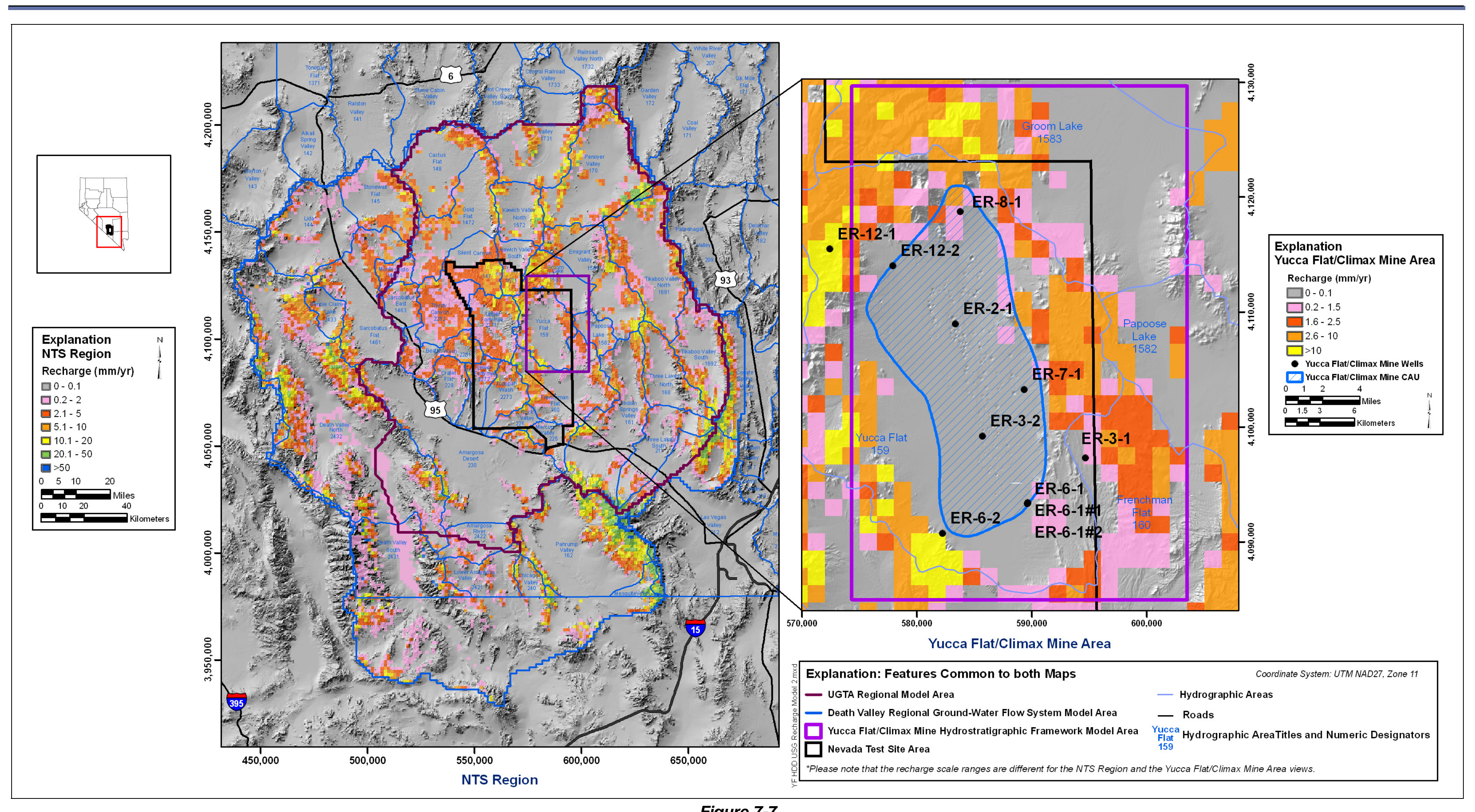

NTS Region with the USGS Distribution Recharge Model 2 which Does Not Include Run-on Infiltration Component in Recharge Inserted into the USGS DVRFS Model (Belcher et al., 2004)

(Note that the steady-state recharge distribution from the USGS DVRFS Model is used outside the UGTA Regional Model Boundary.) 


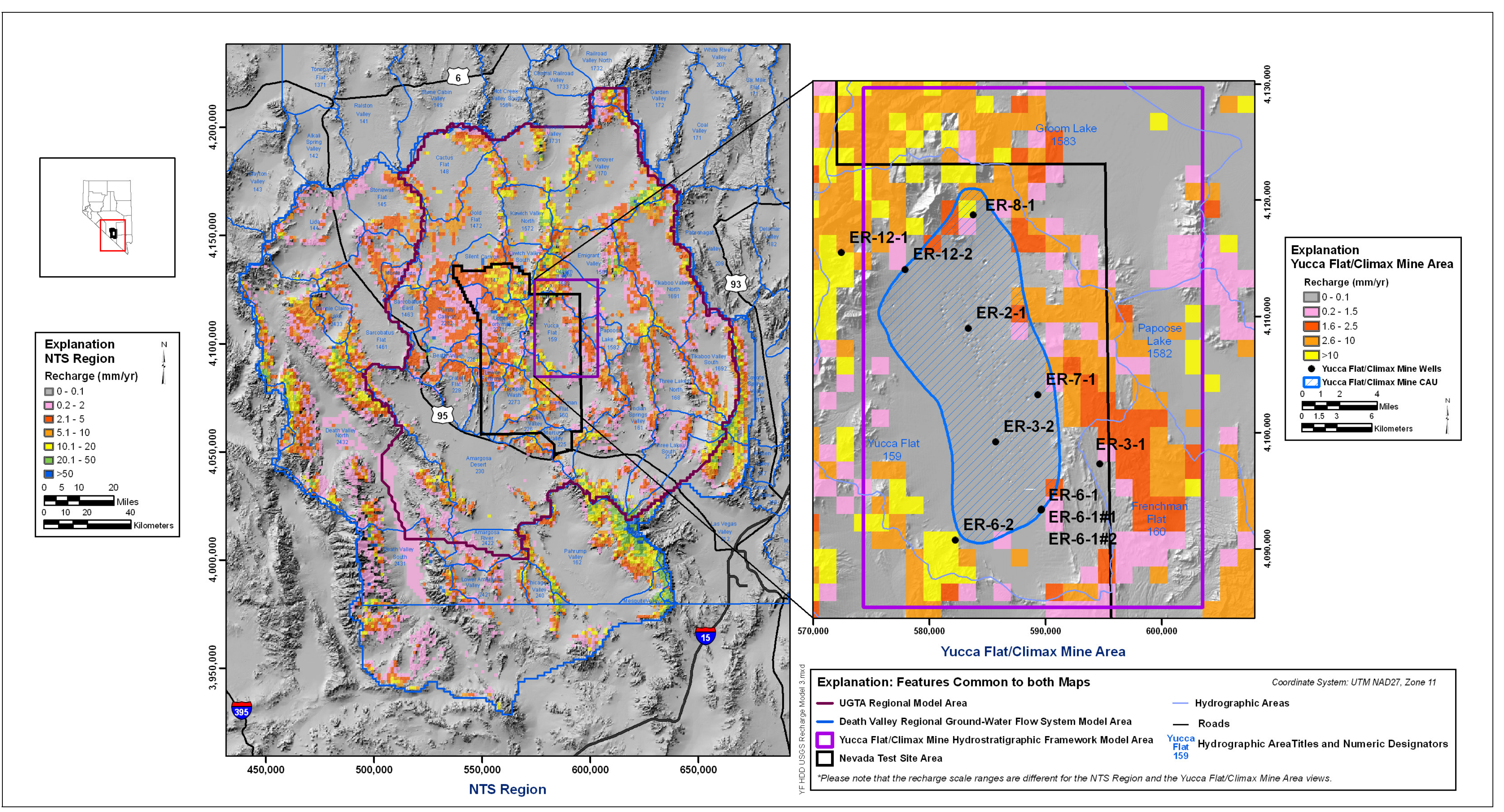

Figure 7-8
USGS Recharge Distribution Model 3 Calibrated for the Steady-State Version of the USGS DVRFS Model (Belcher et al., 2004) 
Maxey and Eakin (1949) and Dettinger (1989) to determine recharge rates from multiple spring watersheds in and around the NTS. The original area of investigation addressed by the DRI recharge models extended from 4040074 to 4140274 m northing and from 519753 to 599013 m easting UTM Zone 11, NAD 27, and included the NTS, Thirsty Canyon drainage, and Beatty in Nye County, Nevada (Russell and Minor, 2002). The results for this area of investigation were subsequently extended to incorporate the area encompassed by the UGTA regional model boundary (see Section 7.4.4.3).

\subsubsection{Methodology}

The methodology used by Russell and Minor (2002) included:

- Estimating precipitation for selected watershed areas.

- Estimating elevations for the selected springs and the ridgeline above the spring.

- Estimating the range in elevation of the watershed contributing to spring discharge.

- Quantifying discharge rates for selected springs.

- Analyzing spring water samples for chloride and bromide concentrations.

- Estimating atmospheric flux of chloride falling on the selected watersheds.

The datasets used in this investigation included: precipitation model outputs, elevation model outputs, geologic data, soil chloride concentration profile data, spring chloride concentration and discharge data, and atmospheric chloride concentration data. These data and estimates were used in a mass-balance approach. This approach relates spring discharge and spring chloride concentrations to precipitation rates and atmospheric chloride flux, to estimate recharge rates and the size of the spring watershed required to generate the observed spring discharge. Uncertainties in the data, and information related to key variables were quantified, and Monte Carlo methods were used to incorporate these parameter uncertainties into an uncertainty associated with the recharge rates.

The elevation-dependent, chloride mass-balance approach documented in Russell and Minor (2002) incorporated a similar assumption made by both Maxey and Eakin (1949) and Dettinger (1989) that there is a lower elevation below which recharge is negligible. In the case of their investigation, Russell and Minor (2002) defined this elevation as 1,237 m, which is the elevation of the outflow point of Cane Spring; the lowest-elevation spring known to exist on the NTS. In addition, Russell and Minor (2002) expanded the elevation-dependent recharge limit by evaluating the spatial distribution of alluvial formations that are assumed to be areas of negligible recharge. Based on these 
two assumptions, two versions of the DRI recharge model were developed. The first version assumed no recharge in the alluvial areas (DRI-alluvial mask). The second version assumed no recharge in the alluvial areas and the area below an elevation of 1,237 $\mathrm{m}$ (DRI—alluvial and elevation mask).

The precipitation models used by Russell and Minor (2002) included the PRISM model, the revised Hardman precipitation map (1965), and the Rush (1970) precipitation-elevation relationships. Precipitation data from 1961 to 1990 was used in the PRISM model at a grid resolution of $16 \mathrm{~km}^{2}$. The resolution was further refined to $4 \mathrm{~km}^{2}$ using kriging with a Gaussian distribution variogram. The Hardman map (1965) was revised by digitizing the original map and analyzing the revised map using Arcinfo to re-assess the precipitation amounts and distribution. The results were used in the ME method to estimate recharge rates for comparison. The Rush (1970) method was also re-assessed for comparison purposes using the revised precipitation map. These three independent precipitation models were used to provide a measure of the variability associated with estimated annual precipitation within the area of investigation.

Two USGS DEMs were used by Russell and Minor (2002) to define the watershed associated with the selected spring. The actual elevation range associated with a selected spring watershed was constrained between the elevation of the spring orifice and the elevation of the adjacent ridgeline or mountain top. These models included both a 30-m DEM to map the watershed area for each spring and estimate the watershed elevation, and a 100-m DEM to determine area-weighted mean elevations for $4 \mathrm{~km}^{2}$ areas that coincided with the centroid of the kriged $4 \mathrm{~km}^{2}$ resolution PRISM precipitation data. The resulting area-weighted mean elevation provides input into a regression equation to calculate mean annual recharge for that $4 \mathrm{~km}^{2}$ area.

Geologic input to delineate alluvial formation distributions in the original investigation area was primarily obtained from Wahl et al. (1997), with additional definition of the Sheep and Spring Ranges from Burchfiel et al. (1974) and Guth (1986). For the expanded investigation area, additional geologic information was obtained from the much larger scale statewide, geologic map of Stewart and Carlson (1978).

To support the argument that the areal distribution of alluvial sediments can be used to define a zone of negligible recharge, 40 boreholes were drilled in alluvial sediments. The vadose zone portion of the boreholes was sampled to develop chloride concentration versus depth profiles for locations in 
alluvial deposits. Results of analyses of the borehole-chloride profiles indicated that alluvial soils were incurring little or no recharge with the exception of those areas that experienced periodic impoundment.

The chloride ion is used as a tracer by investigators for evaluation of recharge because it is conservative when dissolved in water. As such, it does not enter oxidation or reduction reactions, form important solute complexes with other ions unless the chloride concentration is extremely high, form salts of low solubility; is unlikely to be sorbed on mineral surfaces, and plays few vital biogeochemical roles (Hem, 1985). Chloride occurs in the subsurface as part of the composition and mineralogy of soils and rocks. It is generally restricted to evaporites, incompletely leached marine sediments, or porous rocks that have been in contact with the ocean (Hem, 1985). However, volcanic rocks inherently have a substantial amount of chloride trapped within the interstitial structure that is not readily dissolved, except due to erosion and accelerated weathering processes. A significant source of chloride in areas where the aforementioned conditions are absent is atmospheric deposition. Chloride is present in rain and snow and originates at the surface of the ocean (Hem, 1985). Chloride is transported in the atmosphere and reaches land via precipitation (wet-fall) or as an aerosol (dry-fall). It is transported through subsurface material as precipitation infiltrates the ground. Some of the infiltrated water is lost to ET by plants, concentrating the chloride in the upper soil layers. The chloride concentration of the water that percolates below the zone of ET remains relatively constant and can be an indicator of recharge (Fouty, 1989; Eriksson and Khunakasem, 1969). Therefore, if the amount of precipitation and its chloride concentrations are known, the total rate of chloride infiltration may be calculated. Similarly, if the amount of spring, other surface discharges, and their concentrations are known, the amount of total chloride discharge can be calculated. A rigorous chloride mass-balance approach requires quantitative knowledge of all sources and sinks of the chloride ion. If the sole source of chloride is assumed to be the combined mass of wet-fall and dry-fall atmospheric deposition, expressed as concentration of chloride ion in precipitation $\left(\mathrm{C}_{\mathrm{p}}\right.$, milligrams per liter $[\mathrm{mg} / \mathrm{L}]$ ), then the quantity of recharge $\mathrm{R}$ (liters per year [L/yr]) is defined as (Maurer et al., 1996):

$$
\mathrm{R}=\left(\mathrm{C}_{\mathrm{p}} \mathrm{P}\right) /\left(\mathrm{C}_{\mathrm{r}}\right)-\left(\mathrm{C}_{\mathrm{SW}} \mathrm{S}_{\mathrm{W}}\right) /\left(\mathrm{C}_{\mathrm{r}}\right)
$$


Where:

$\mathrm{P}=$ Mean annual precipitation $(\mathrm{L} / \mathrm{yr})$

$\mathrm{C}_{\mathrm{SW}} \mathrm{S}_{\mathrm{W}}=$ Quantity of chloride $(\mathrm{mg} / \mathrm{L})$ and water $(\mathrm{L} / \mathrm{yr})$ that is removed due to surface-water runoff $\mathrm{C}_{\mathrm{r}}=$ Quantity of chloride in water that has recharged $(\mathrm{mg} / \mathrm{L})$

This equation assumes steady-state deposition of chloride and precipitation on an annual scale; no changes in the subsurface storage of either component; atmospheric wet-fall and dry-fall deposition of chloride as the only source of chloride in the system; and direct infiltration of precipitation as the only source of recharge. In addition, Russell and Minor (2002) assumed that for this investigation significant runoff from mountainous terraine was negligible. In their evaluation of these assumptions, Russell and Minor (2002) identified that while these assumptions are generally appropriate, by neglecting runoff that removes chloride availability for recharging waters, the quantity of recharge in mountainous areas tends to be overestimated.

Russell and Minor (2002) used the ${ }^{36} \mathrm{Cl} / \mathrm{Cl}$ method to determine the chloride flux to the land surface. This method involves determining the natural fallout of ${ }^{36} \mathrm{Cl}$ and dividing this estimate by the measured ${ }^{36} \mathrm{Cl} / \mathrm{Cl}$ ratio in water that has been recharged and the mean annual precipitation rate for the area of interest (Fabryka-Martin et al., 1993). The equation for calculating chloride flux to the land surface is:

$$
\mathrm{C}_{\mathrm{P}}=\frac{\text { atoms }{ }^{36} \mathrm{Cl}}{\mathrm{m}^{2} \mathrm{~s}} \cdot \frac{\mathrm{mole}}{6.022 \times 10^{23} \text { atoms }} \cdot \frac{35.5 \mathrm{~g} \mathrm{Cl}}{\mathrm{mole}} \cdot \frac{1000 \mathrm{mg}}{\mathrm{g}} \cdot \frac{3.1563 \times 10^{7} \mathrm{~s}}{\mathrm{yr}} \cdot \frac{\mathrm{Cl}}{{ }^{36} \mathrm{Cl}} \cdot \frac{1}{\mathrm{P}}
$$

Where:

$\mathrm{C}_{\mathrm{P}}=$ Effective concentration of chloride in precipitation $(\mathrm{mg} / \mathrm{L})$

atoms ${ }^{36} \mathrm{Cl} / \mathrm{m}^{2} \mathrm{~s}=\mathrm{Cosmogenic}$ production of ${ }^{36} \mathrm{Cl}$

${ }^{36} \mathrm{Cl} / \mathrm{Cl}=$ Measured ${ }^{36} \mathrm{Cl}$ to $\mathrm{Cl}$ ratio in the water of interest.

$\mathrm{P}=$ Area-weighted mean annual precipitation (liters per square meter per year $\left[\mathrm{L} / \mathrm{m}^{2} \mathrm{yr}\right]$ )

For their investigation, Russell and Minor (2002) used Equation (7-7) to evaluate the uncertainty associated with the effective chloride concentration in precipitation. Information on the cosmogenic production of ${ }^{36} \mathrm{Cl}$ for the investigation area was evaluated, and a lognormal distribution with a mean of 2.94 atoms ${ }^{36} \mathrm{Cl} / \mathrm{m}^{2}$ s and a SD of 0.0166 was established. Several regional, low-temperature springs that discharge adjacent to the investigation area and are thought to be the discharge point for recharge occurring in the eastern half of the investigation area were identified. Data on the ${ }^{36} \mathrm{Cl} / \mathrm{Cl}$ 
ratios for these springs (Amargosa Springs including Fairbanks Spring, Crystal Pool, and Big Spring) were evaluated, and a log-normal distribution with a mean of -28.51 and a SD of 0.0622 was established. As previously described, three precipitation models were used to estimate area-weighted annual precipitation across the study area. The evaluation of the output from these models resulted in identifying a normal distribution with a mean of $0.172959 \mathrm{~m}^{3} / \mathrm{m}^{2} / \mathrm{yr}$ and a SD of 0.02959 . The resulting statistical distributions for these three parameters were randomly sampled 1,000 times via Monte Carlo analysis to generate 1,000 sets of input parameters for use in Equation (7-7). The outputs using these 1,000 sets of input parameters were then used to determine an estimate of the effective chloride flux and associated uncertainty for the entire investigation area.

Many mountain ranges in Nevada contain springs. In most cases, these mountain springs originate from precipitation falling on the local mountain watershed. Based on this relationship, it is assumed that the spring chemistry is representative of recharge processes operating on the mountain range and that the degree of chloride enrichment within a spring's discharge is representative of all recharge processes within its watershed. Discharge rates, and chloride and bromide concentrations at 17 springs located in the Sheep Range, Spring Mountains, and within the NTS, were measured for the DRI recharge model (Russell and Minor, 2002). In addition, measured discharge and chloride concentrations from these springs were compared to estimates provided by previously published reports.

Extending this relationship, mountain spring chemistry can be related to watershed elevation. However, there is significant uncertainty in the spatial extent and thus the elevation of a mountain spring watershed. To address this uncertainty, Russell and Minor (2002) utilized precipitation maps, DEMs, measured spring discharge and chloride concentration, and a GIS to establish the area of a watershed necessary to support the spring measurements. This approach was based on constraining the quantity of precipitation that must fall on the watershed to sustain the discharge of that spring and its associated concentration of chloride. While this approach was able to define the watershed area, it did not address the areal distribution and elevation of the watershed. This was accomplished by assuming a hypothetical circular watershed with the calculated watershed area and using a GIS to optimize the location of that hypothetical circular watershed to: (1) a lowermost elevation defined the elevation of the spring orifice and (2) an uppermost elevation defined by the ridgeline or mountaintop 
above the spring. For these two hypothetical watershed locations, an area-weighted mean elevation was calculated to provide the range in potential elevation of a watershed.

Using this approach, Russell and Minor (2002) developed a relationship between the elevation of 17 spring watersheds and the rate of recharge using regression analysis. The statistical distributions describing the variability of the area-weighted mean elevation for each spring, and the 17 statistical distributions describing the uncertainty associated with the chloride concentration of each spring, were utilized in a 1,000-run Monte Carlo analysis. A selected simulation set for the 17 area-weighted mean elevations of springs in the study area was linked to 17 simulations of chloride concentrations within each spring. The randomly sampled chloride concentrations from all 17 springs were divided by a single estimate of effective chloride concentration in precipitation. The results consisted of a set of estimated area-weighted mean elevations of spring watersheds, and the ratio describing the relative enrichment of chloride in the precipitation water due to ET within each watershed. The resulting regression equation is:

$$
\left(\mathrm{C}_{\mathrm{r}} / \mathrm{C}_{\mathrm{p}}\right)=1.0+\mathrm{c} 1 * \mathrm{e}^{(\mathrm{c} 2 * \mathrm{elev})}
$$

Where:

$\mathrm{C}_{\mathrm{r}} / \mathrm{C}_{\mathrm{p}}=$ Ratio of recharge to precipitation chloride concentration $\mathrm{c} 1$ and $\mathrm{c} 2=$ Regression coefficients

elev $=$ Area-weighted mean elevation of the watershed of interest

The solved regression equation was incorporated into a Geographic Information System (GIS) and used with data layers incorporating the DEM, a modified version of the PRISM isohyetal map, and two models of the geology to determine the distribution of recharge across the study area. One model of the geology assumed no recharge in alluvial areas (alluvial mask), and the other assumed no recharge in alluvial areas nor in areas below an elevation of 1,237 m (alluvial and elevation mask). Modification of the PRISM dataset ensured consistency of precipitation estimates required to calculate recharge as a function of elevation.

To calculate recharge, Russell and Minor (2002) used the 100-m resolution DEM to calculate the area-weighted mean elevation of $4-\mathrm{km}^{2}$ grids that coincided with the spatial distribution for the 4- $\mathrm{km}^{2}$ resolution of the PRISM isohyetal map (Daley et al., 1994). Area-weighted mean elevation and mean precipitation for the $4-\mathrm{km}^{2}$ sample were used as input to Equation (7-8) to calculate $\mathrm{C}_{\mathrm{r}} / \mathrm{C}_{\mathrm{p}}$. The 
corresponding precipitation value for the $4-\mathrm{km}^{2}$ area was divided by $\mathrm{C}_{\mathrm{r}} / \mathrm{C}_{\mathrm{p}}$ to determine recharge for that area using Equation (7-6). Results were summed across the study area and then ranked. The 50th-percentile result was used to map the distribution of recharge across the study area. In addition, the results of the 5th, 50th, and 95th percentile were summarized by HAs for comparison to previously published results of recharge.

\subsubsection{Results}

Results of the Monte Carlo analysis yielded estimates of the mean and SD of volumetric recharge rates occurring within the study area for two sets of simulations using alternate definitions of the lower limit of recharge. The mean and SD were $28.168 \times 10^{6} \pm 7.008 \times 10^{6} \mathrm{~m}^{3} / \mathrm{yr}$ for the recharge model that assumed no recharge in the alluvial areas (alluvial mask) and $26.838 \times 10^{6} \pm 6.928$ $\mathrm{x} 10^{6} \mathrm{~m}^{3} / \mathrm{yr}$ for the recharge model that assumed no recharge in the alluvial areas and below an elevation of 1,237 $\mathrm{m}$ (alluvial and elevation mask).

Based on sensitivity analysis, Russell and Minor (2002) concluded that recharge estimates were most sensitive to variations in the chloride concentration of the spring discharge, and the model was found to be sensitive to variations in mean precipitation; the second most influential parameter affecting recharge rates within the study area. Validation of the results was performed semi-independently with an independent set of 13 springs in the Spring Mountains Range. Russell and Minor (2002) concluded that results were favorable and indeed validated the approach.

The elevation-dependent chloride mass balance method relies on changes in chloride concentration as a function of elevation to empirically estimate recharge and extrapolate the results. This method is affected by uncertainty in all parameters. This uncertainty was addressed through assessment of parametric uncertainty in the input parameters. Typically, the elevation-dependent chloride mass balance method will tend to underestimate recharge relative to other methods. However, in this study area, it is greater than most other estimates. The reason for this may be due to orographic affects impacting springs used to calibrate the method. 


\subsubsection{Upscaling To Extend the Results from Russell and Minor To Encompass the UGTA Regional Model Area}

The recharge models developed by Russell and Minor (2002) are for an area that immediately surrounds the NTS. This area is not entirely coincidental with the areas for which recharge estimates were developed by the USGS and the UGTA Project. In some instances, recharge estimates reported by Russell and Minor (2002) were only for portions of hydrographic basins. The DRI, in support of the UGTA Project, expanded the Russell and Minor (2002) study and estimated recharge for the entire area of the hydrographic basins that fell within the Russell and Minor (2002) original study area (Russell, 2004). However, the original recharge models still did not include all of the HAs in the UGTA regional model area. Therefore, another method was identified by the UGTA Project to estimate recharge rates using the Russell and Minor (2002) method for those HAs that were not included in their report (SNJV, 2004e). This methodology is described below.

Recharge volumes were calculated for a number of HAs using different methods and were compared to the results of the Russell and Minor (2002) method. A simple linear regression model was selected, because it provided the best fit with the fewest fitting parameters (Figure 7-9). The best correlation was between the recharge calculated by the UGTA Revised ME recharge model and the Russell and Minor (2002) alluvial and elevation mask recharge model for the 50th-percentile distribution $\left(\mathrm{R}^{2}=0.98\right)$. A good correlation was observed between the UGTA Revised ME recharge model and the results of Russell and Minor (2002) alluvial mask recharge model for the 50th-percentile distribution with a correlation coefficient of $\mathrm{R}^{2}=0.97$. Kawich Valley recharge was removed from the DRI dataset, because it was more than two SDs from the mean of the entire dataset, suggesting it was an outlier (Figure 7-9).

The regression formula was then applied to the remaining areas outside of the DRI dataset, but within the UGTA regional model area to calculate recharge for these HAs. Because linear correlations were used for both the alluvial and the elevation masks, all HAs had identical multipliers within one of the models; these multipliers were 1.36 and 1.34, respectively. Calculated HA-specific recharge rates are reported in Table 7-8 in the estimated 50th-percentile recharge columns. The DRI model results and the UGTA Revised ME recharge model results are reported for comparison. These estimated recharge rates were used in the regional model recharge distributions for those HAs not included in the Russell and Minor (2002) study area. It is noted that the recharge distribution for these HAs involved 

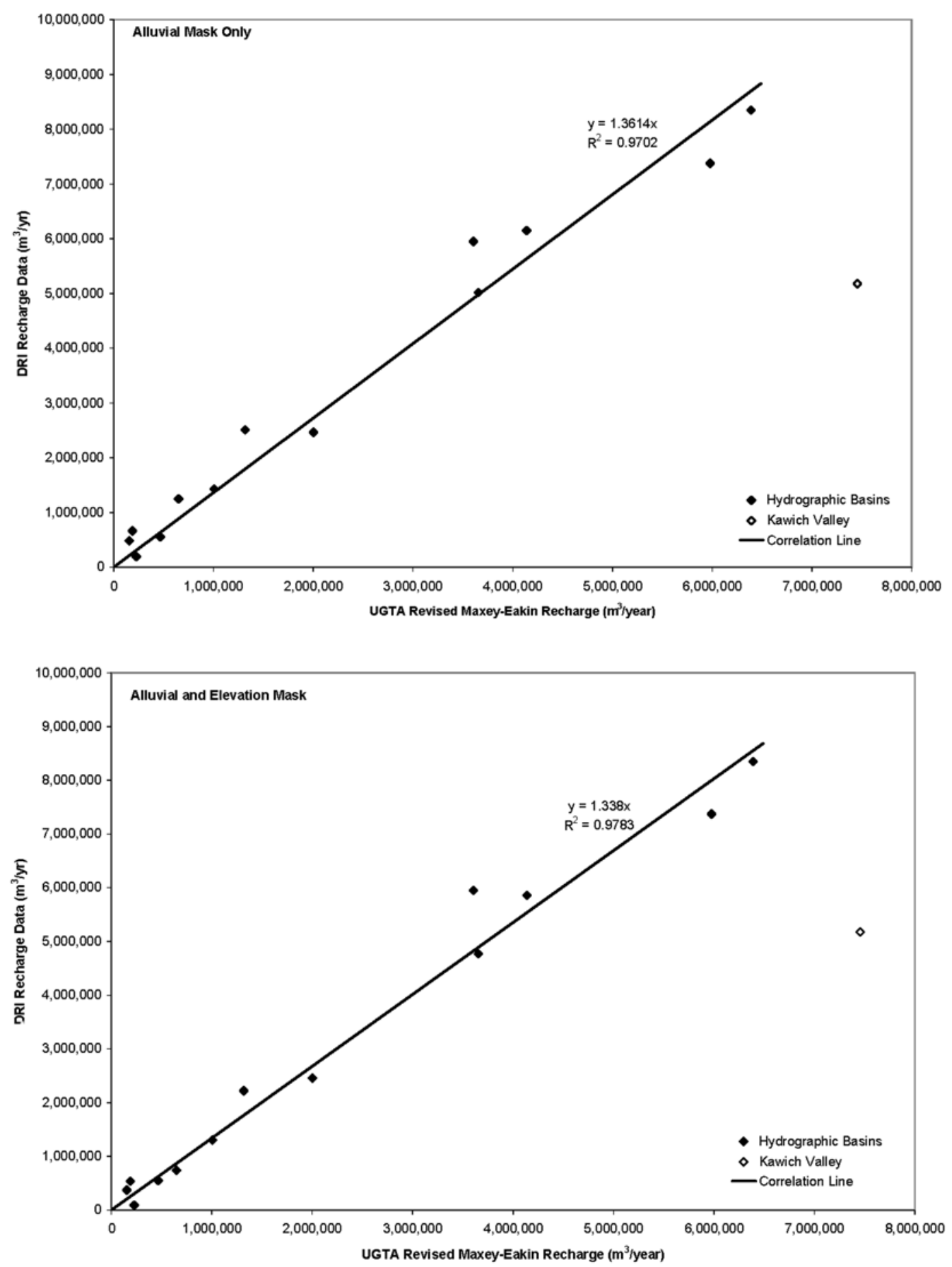

Source: SNJV, 2004e

Figure 7-9

Relationship Between UGTA Revised ME Recharge Rate and DRI Models 
extrapolation of the Russell and Minor (2002) results long distances away from the springs used to calibrate their model. This results in a greater degree of uncertainty associated with the extrapolated results.

The resultant recharge distribution for the entire UGTA regional model area for the alluvial mask 50th percentile are shown in Figure 7-10. The recharge distribution for the alluvial and elevation mask 50th-percentile distribution is shown in Figure 7-11.

Please note that for Figures 7-10 and 7-11, the recharge distributions were inserted into the DVRFS model (Belcher et al., 2004). For the area outside of the UGTA regional model boundary (DOE/NV 1997b), the steady-state recharge distribution from Belcher et al. (2004) is shown.

The values for some of the HAs presented in Table 7-8, and Figures 7-10 and 7-11 have been extrapolated from recharge data for areas that are quite distant from the UGTA regional model area. The farther the extrapolation distance, the less reliable the recharge estimates become. This is one reason why the value calculated for Kawich Valley is an outlier. Finally, there are few low- to mid-elevation springs on the NTS; thus, 10 of the 17 springs analyzed were located in the Spring Mountains or Sheep Range. The recharge processes at these springs may be impacted by orographic effects and, as a result, may be overestimating recharge in some of the hydrographic basins. Tabulated volumetric totals for these recharge distributions are presented in the Section 7.6.

The DRI is currently working to complete a northern Yucca Flat/Climax Mine sub-CAU-scale groundwater flow model. As part of this work DRI is updating its recharge model to correspond with the DVRFS model (Belcher et al., 2004). The final report documenting this work is scheduled to be completed in December 2006. When finalized, the updated DRI recharge model will be reviewed and, if appropriate, incorporated as an alternative recharge model during the development of the Yucca Flat/Climax Mine CAU groundwater flow model.

\subsection{Factors Influencing Recharge in Yucca Flat}

An inferred assumption in the application of the recharge models in regional and CAU model analyses is that, once water passes the bottom of the root zone, it is instantly available at the water table, though the water table may be hundreds of meters below. However, it is known that liquid and 
Table 7-8

Scaled DRI Recharge Rates Using UGTA Revised Maxey and Eakin Model

\begin{tabular}{|c|c|c|c|c|c|c|c|}
\hline \multirow[b]{2}{*}{$\begin{array}{c}\text { Sub-basin } \\
\text { Number }\end{array}$} & \multirow[b]{2}{*}{ Area Name } & \multirow[b]{2}{*}{ Secondary Name } & \multirow{2}{*}{$\begin{array}{c}\text { UGTA } \\
\begin{array}{c}\text { Revised } \\
\text { Maxey-Eakin Based } \\
\left(\mathrm{m}^{3} / \mathrm{yr}\right)\end{array}\end{array}$} & \multicolumn{2}{|c|}{ Alluvial Mask } & \multicolumn{2}{|c|}{ Alluvial and Elevation Mask } \\
\hline & & & & $\begin{array}{c}\text { DRI } \\
\text { 50th Percentile } \\
\left(\mathrm{m}^{3} / \mathrm{yr}\right)\end{array}$ & $\begin{array}{c}\text { Estimated 50th } \\
\text { Percentile } \\
\text { Recharge } \\
\left(\mathrm{m}^{3} / \mathrm{yr}\right)\end{array}$ & $\begin{array}{c}\text { DRI } \\
\text { 50th Percentile } \\
\left(\mathrm{m}^{3} / \mathrm{lyr}\right)\end{array}$ & $\begin{array}{l}\text { Estimated 50th } \\
\text { Percentile } \\
\text { Recharge } \\
\left(\mathrm{m}^{3} / \mathrm{yr}\right)\end{array}$ \\
\hline 1462 & Sarcobatus Flat-2 & Monte Cristo & 794,533 & & $1,081,677$ & & $1,063,085$ \\
\hline 1463 & Sarcobatus Flat-3 & Sarcobatus East & 568,889 & & 774,485 & & 761,173 \\
\hline 148 & Cactus Flat & & $3,304,088$ & & $4,498,185$ & & $4,420,869$ \\
\hline $1571 \& 1572$ & Kawich Valley & & $7,456,054$ & $5,176,836$ & $10,150,671$ & $5,176,836$ & $9,976,200$ \\
\hline 168 & Three Lakes Valley North & & 319,002 & & 434,289 & & 426,824 \\
\hline 1691 & Tikaboo Valley-1 & Tikaboo Valley North & $6,451,646$ & & $8,783,271$ & & $8,632,302$ \\
\hline 1692 & Tikaboo Valley-2 & Tikaboo Valley South & 760,360 & & $1,035,154$ & & $1,017,361$ \\
\hline 170 & Penoyer Valley & & $6,487,366$ & & $8,831,900$ & & $8,680,096$ \\
\hline 172 & Garden Valley & & $2,476,190$ & & $3,371,084$ & & $3,313,141$ \\
\hline 1731 & Railroad Valley South-1 & Reveille Valley & $5,464,048$ & & $7,438,755$ & & $7,310,896$ \\
\hline 1733 & Railroad Valley South-3 & Central Railroad Valley & $1,920,032$ & & $2,613,931$ & & $2,569,003$ \\
\hline 211 & Three Lakes Valley South & & $4,219,935$ & & $5,745,019$ & & $5,646,272$ \\
\hline 2121 & Las Vegas Valley-1 & & $5,015,045$ & & $6,827,482$ & & $6,710,130$ \\
\hline 2301 & Amargosa Desert & NV Portion & 648,360 & $1,250,517$ & 882,677 & 743,668 & 867,506 \\
\hline 2302 & Amargosa Desert & CA Portion & 807,342 & & $1,099,116$ & & $1,080,224$ \\
\hline 2421 & Amargosa River-1 & Lower Amargosa Valley & 0 & & 0 & & 0 \\
\hline 2422 & Amargosa River-2 & Amargosa River & 103,701 & & 141,179 & & 138,752 \\
\hline 2431 & Death Valley Central-1 & Death Valley South & 23,983 & & 32,651 & & 32,090 \\
\hline 2432 & Death Valley Central-2 & Death Valley North & $1,559,099$ & & $2,122,557$ & & $2,086,074$ \\
\hline $1471 \& 1472$ & Gold Flat & & $6,389,207$ & $8,349,933$ & $8,698,267$ & $8,349,933$ & $8,548,759$ \\
\hline 1582 & Emigrant Valley & & 466,868 & 552,945 & 635,594 & 552,945 & 624,669 \\
\hline $1581 \& 1583$ & Emigrant Valley & & $5,978,080$ & $7,376,521$ & $8,138,558$ & $7,376,521$ & $7,998,671$ \\
\hline 159 & Yucca Flat & & $2,001,386$ & $2,464,376$ & $2,724,686$ & $2,454,338$ & $2,677,854$ \\
\hline 160 & Frenchman Flat & & $1,319,064$ & $2,506,705$ & $1,795,773$ & $2,225,121$ & $1,764,907$ \\
\hline 161 & Indian Springs Valley & & $3,655,436$ & $5,014,868$ & $4,976,510$ & $4,773,754$ & $4,890,973$ \\
\hline 225 & Mercury Valley & & 154,914 & 480,655 & 210,900 & 370,761 & 207,275 \\
\hline 226 & Rock Valley & & 227,356 & 193,150 & 309,522 & 94,962 & 304,202 \\
\hline 2271 & Fortymile Canyon & & $3,606,419$ & $5,951,107$ & $4,909,779$ & $5,951,107$ & $4,825,389$ \\
\hline 2272,2273 & Fortymile Canyon & & $1,006,677$ & $1,426,551$ & $1,370,491$ & $1,302,880$ & $1,346,934$ \\
\hline $2281 \& 2282$ & Oasis Valley & & $4,138,337$ & $6,145,495$ & $5,633,931$ & $5,862,809$ & $5,537,094$ \\
\hline 229 & Crater Flat & & 187,843 & 661,209 & 255,729 & 540,229 & 251,333 \\
\hline
\end{tabular}

Source: SNJV, 2004e 


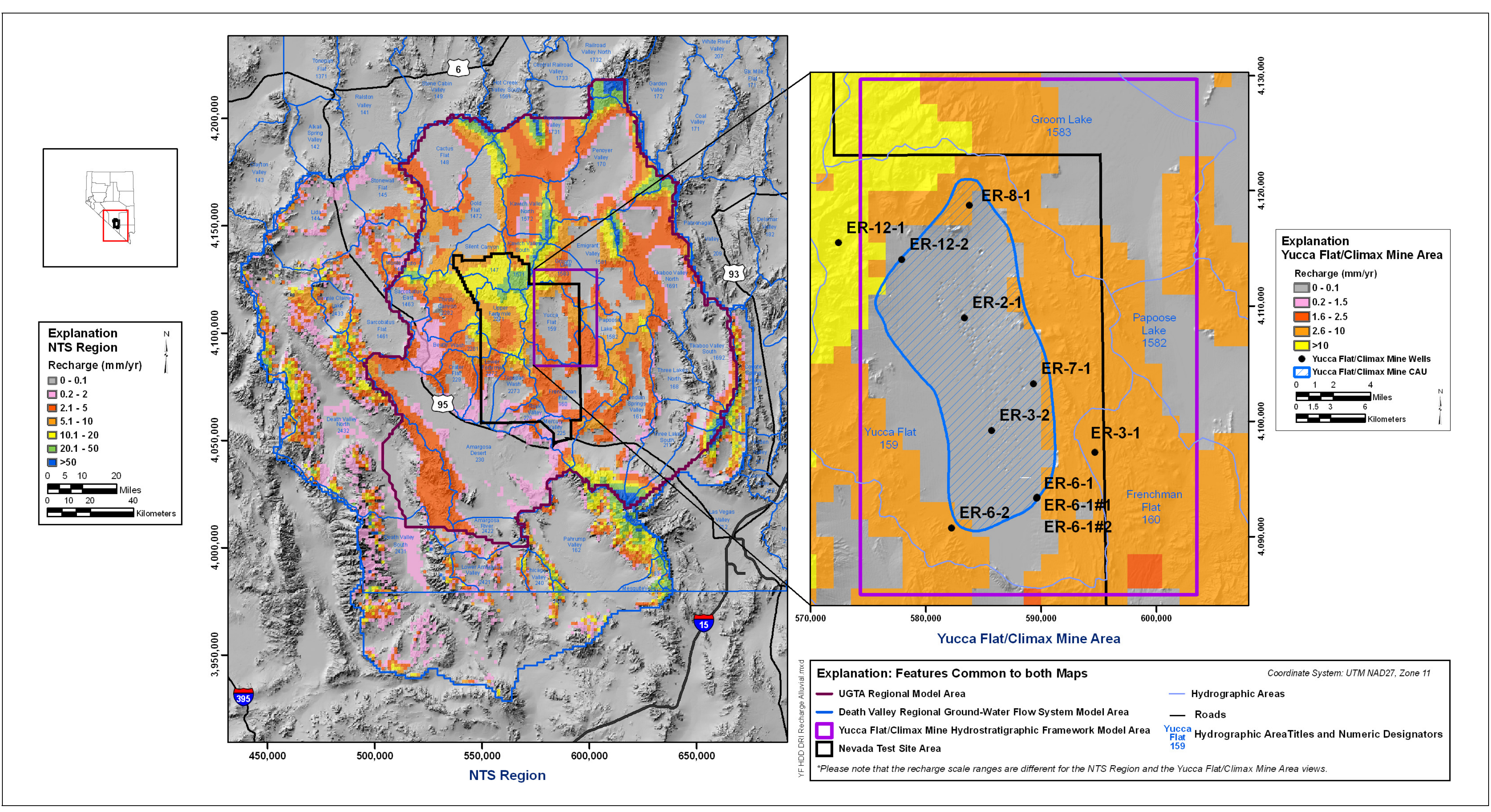

Figure 7-10
NTS Region with the DRI Recharge Distribution with Alluvial Mask (Russell and Minor, 2002)

Inserted into the USGS DVRFS Model (Belcher et al., 2004)

(Note that the steady-state recharge distribution from the USGS DVRFS Model is used outside the UGTA Regional Model Boundary.) 


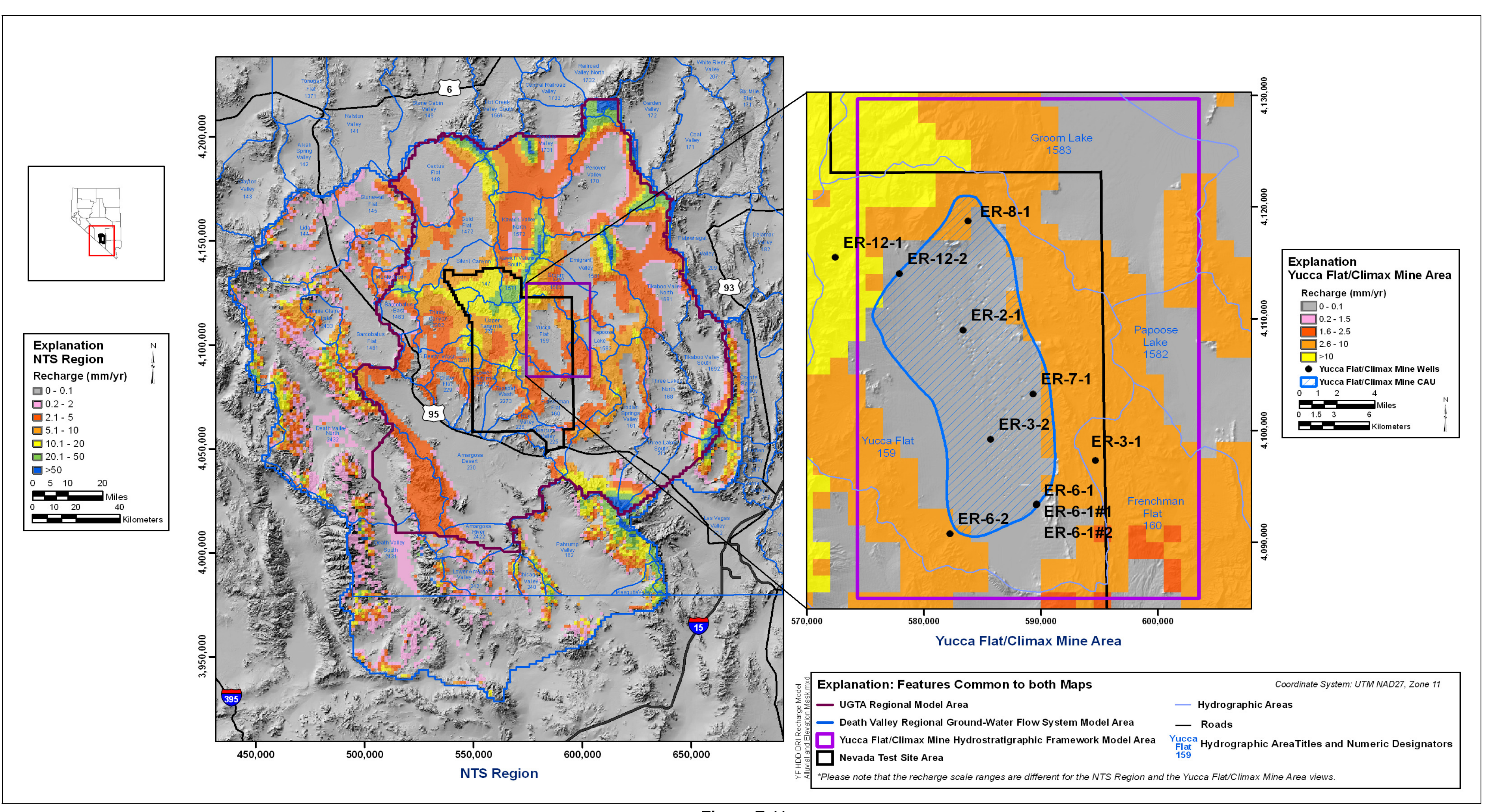

Figure 7-11

NTS Region with the DRI Recharge Distribution with Alluvial and Elevation Mask (Russell and Minor, 2002) Inserted into the USGS DVRFS Model (Belcher et al., 2004)

(Note that the steady-state recharge distribution from the USGS DVRFS Model is used outside the UGTA Regional Model Boundary.) 
vapor fluxes vary in the subsurface, and that water infiltrated below the root zone may not recharge a deep water table. In addition, surface effects of underground nuclear tests have resulted in subsidence craters in the playa basins on the NTS (Yucca Flat and Frenchman Flat). These subsidence craters have been shown to capture and focus runoff. The following discussion addresses these factors.

\subsubsection{Potential for No Recharge in Interfluve Areas}

Characterization studies from Area 5 (Tyler et al., 1996; BN, 1998a) suggest that under the weather conditions found in Yucca Flat, precipitation infiltration is removed via ET, and that recharge does not occur in the interfluve regions of Yucca Flat.

Recent research (Walvoord et al., 2002a and b) suggests that water flow below the root zone is upward, and that estimating liquid flux below the root zone and assuming that they are equivalent to groundwater recharge (as assumed in the previously documented alternative recharge models) may not be applicable. Research also suggests that transient effects from the climate change 12,000 to 15,000 years ago are still lingering in deep, arid basins such as Yucca Flat. To some extent, all the proposed recharge models show little recharge in Yucca Flat proper, but a limiting case may be no recharge in interfluves.

\subsubsection{Potential for Enhanced Local Recharge in Subsidence Craters and Playa Crack}

A striking feature of the topography of Yucca Flat is the large number of subsidence craters resulting from underground nuclear testing. The effects of these subsidence craters on enhancing local recharge in Yucca and Frenchman Flat has been studied by Tyler et al. (1986) and (1992), Hokett and Gillespie (1996), Hokett and French (1998), Wilson et al. (2000), and Hokett et al. (2000).

Hokett and Gillespie (1996), Hokett and French (1998), and Wilson et al. (2000) studied the potential for recharge near the U5a subsidence, which is near the location of the WISHBONE underground nuclear test in Frenchman Flat. The U5a crater was studied because extensive phreatophytic vegetation, large erosional gullies, and a playa near the collapse sink center suggested that this crater received substantial storm runoff. Following the data collection and preliminary evaluation of Hokett and Gillespie (1996) further analysis by Hokett and French (1998) suggested that water percolated to a depth of $129 \mathrm{~m}$ within 32 years, with a local recharge of $3.7 \mathrm{~m} / \mathrm{yr}$. Hokett and French (1998) also 
suggested that the fine-grained playa material appears to restrict infiltration to the surrounding annular region of coarser soils, which enhances recharge. Wilson et al. (2000) found that, under the subsidence crater playa, water content was greatly increased over a nearby undisturbed area. They also found that it was more likely that a single large ponding event occurred that introduced the water into the crater. Water from this event was estimated, but not proven, to have reached the water table within 32 years. Finally, detailed simulation analysis of alternative soil configurations showed that the deposition of fine material would prohibit future infiltration and suggested that the subsidence craters may be self-sealing.

Tyler et al. (1986) drilled two wells (one in the bottom of the U3fd subsidence crater and the other $207 \mathrm{~m}$ from the crater, which is near the location of the LAGUNA underground nuclear test in southern Yucca Flat) and collected soil moisture and other characterization data. The well in the subsidence crater bottom showed an enhanced moisture profile from ponding while the distal well did not. Estimated wetting front velocity from a conservative model ranged from 4.4 to $130 \mathrm{~m} / \mathrm{yr}$, giving the water table a transit time of 3 to 70 years assuming a depth-to-water of $300 \mathrm{~m}$. The distal well data suggested little or no infiltration. Estimated recharge rates ranged from 0.02 to $35 \mathrm{~m} / \mathrm{yr}$ using Darcy's Law and saturated soil hydraulic conductivity. Tyler et al. (1992) further supplemented the 1986 analysis by considering soil-moisture tritium profiles, which provided evidence of recent infiltration and downward movement of water. Thus, wetting front velocity was estimated at $5.3 \mathrm{~m} / \mathrm{yr}$ at a depth of $75 \mathrm{~m}$ (in 1985 when the wells were drilled), and with recharge between 0.55 and $0.70 \mathrm{~m} / \mathrm{yr}$. All data were collected at less than 50-m depth, with no apparent recent water (as indicated by tritium) below 44-m depth. As such, it was concluded that the combination of surface topography, coarse soils at the crater bottom, and periodic ponding events from the crater drainage basin allowed for deep infiltration and eventual recharge to the groundwater system.

Hokett et al. (2000) studied infiltration in northern Yucca Flat near the U10i subsidence crater formed by the underground nuclear test, BYE. They collected rain data and crater stage data for two years, and the largest rainfall event produced $2.4 \mathrm{~m}$ of ponding in the crater. Simulation analysis indicated that it took 84 days for the wetting front to reach a depth below the crater of $30 \mathrm{~m}$. No obvious preferential flow was observed, and it was suggested that such paths might be self-healing due to deposition of fine-grained material during runoff events. Soil analysis indicates that at least six significant ponding events have occurred in the crater since its formation. 
In addition to the presence of subsidence craters within Yucca Flat, there is one example of a large crack forming on the Yucca Lake playa. This crack opened in 1969 and was the subject of a three-year study by Doty and Rush (1985) to evaluate inflow into the crack and the potential to enhance localized recharge. As described by Doty and Rush (1985), vertical cracks in playas are not uncommon and could originate from either natural desiccation of the fine-grained playa deposits or tectonic processes. Playa cracks tend to evolve in a predictable way. When a crack first opens it will have a narrow width of less than an inch. Erosion from inflowing water will quickly extend this width up to several feet. As intermittent inflow continues, the crack exhibits a self-healing nature and eventually fills back to the land surface with water-transported sediment. Based on their evaluation of inflow into the Yucca Lake playa crack, Doty and Rush (1985) estimated that the potential recharge from the measured and assumed inflow into the crack ranged from 5 acre-ft to 20 acre-feet. This potential recharge is between 1 and 4 percent of the estimated average annual recharge to the Yucca Flat basin (Doty and Rush, 1985).

It is clear from the studies performed at three subsidence craters in Yucca Flat and Frenchman Flat, and the evaluation of the Yucca Lake playa crack, that enhanced local recharge can occur by capturing and focusing runoff. However, none of the data establishes that the enhanced infiltration actually reaches the often deep (greater than 300-m) water table. In addition, the interplay of local recharge, residual test heat, and mechanical rock damage is unknown. Finally, given the often large depth-to-water and self-healing nature of the craters and playa cracks, it is not obvious that it will always be the case where sufficient water infiltrates to the depth where radionuclides are present and carries them to the regional water table.

\subsubsection{Alternative Conceptual Model for Recharge in Yucca Flat}

By combining recent research related to recharge characteristics in deep, arid basins, and the potential for enhanced recharge in subsidence craters, an alternative conceptual model for recharge in Yucca Flat was developed. This model posits recharge is limited to areas along washes and in subsidence craters, where water is ponded or routed, and recharge is zero in interfluves and other undisturbed areas. 


\subsection{Summary of Alternative Recharge Models}

The recharge rates calculated by various methods are listed in Table 7-9 and graphed in Figure 7-12 for each HA or subarea with available data. Groundwater flow modeling of the Yucca Flat/Climax Mine CAU will consider recharge rates estimated by alternative models described in this section. These recharge models provide a range of recharge-rate estimates that will be used for uncertainty analysis and evaluation of alternative scenarios during the course of flow-model construction and calibration.

Three major methods of estimating recharge for the NTS region were used in the development of the alternative recharge model. These methods include: variations using the ME approach, variations using a deterministic-distributed parameter watershed model, and variations using an elevation-dependent chloride mass-balance approach.

The ME approach is an empirically-derived method, relating recharge to precipitation zones, from a base-precipitation map. Two modified versions of this approach were analyzed, including a model from the original UGTA regional groundwater flow modeling results (IT, 1996b; DOE/NV, 1997b), and a revised UGTA ME model using a revised and updated base precipitation map (SNJV, 2004e).

The USGS distributed parameter watershed model (Hevesi et al., 2003) demonstrates the processes that affect the net rate of infiltration past the root zone. These parameters include: precipitation, ET, soil type, percent and type of vegetative cover, bedrock type, and numerous other input parameters. The USGS approach is incorporated into three alternative recharge models. The first recharge model incorporates run-on infiltration into the recharge estimate (Model 1 from Hevesi et al., 2003). The second recharge model excludes run-on infiltration in the recharge estimate (Model 2 from Hevesi et al., 2003). The third recharge model results from adjusting the first USGS model (Model 1 from Hevesi et al., 2003) during the DVRFS model calibration process to provide a better balance between recharge and discharge (Belcher et al., 2004).

The DRI chloride mass-balance approach uses the precipitation to groundwater chloride ratios to estimate recharge (Russell and Minor, 2002). Higher chloride concentrations in groundwater discharged from springs result from ET of precipitation that contains low amounts of atmospheric chloride ion; thus providing a relative gauge for recharge. Chloride is considered a conservative 
Table 7-9

Recharge Rates for HAs for All Recharge Models

\begin{tabular}{|c|c|c|c|c|c|c|c|c|c|c|c|c|c|}
\hline \multirow{3}{*}{$\begin{array}{c}\text { Sub-Basin } \\
\text { Number }\end{array}$} & \multirow{3}{*}{ Area Name } & \multirow{3}{*}{ Secondary Name } & \multirow{3}{*}{\begin{tabular}{|c|c|c}
$\begin{array}{c}\text { UGTA } \\
\text { Oripinanal } \\
\text { modified ME }\end{array}$ \\
$\left(\mathrm{m}^{3} / \mathrm{yr}\right)$ \\
\end{tabular}} & \multirow{3}{*}{$\begin{array}{c}\begin{array}{c}\text { UGTA } \\
\text { Revised } \\
\text { modified ME }\end{array} \\
\left(\mathrm{m}^{3} / \mathrm{yr}\right)\end{array}$} & \multirow{3}{*}{$\begin{array}{r}\begin{array}{r}\text { USGS } \\
\text { Model } 1\end{array} \\
\left(\mathrm{~m}^{3} / \mathrm{yr}\right)\end{array}$} & \multirow{3}{*}{$\begin{array}{c}\begin{array}{c}\text { USGS } \\
\text { Model } 2\end{array} \\
\left(\mathrm{~m}^{3 / \mathrm{yr})}\right.\end{array}$} & \multirow{3}{*}{$\begin{array}{c}\begin{array}{c}\text { USGS } \\
\text { Model } 3\end{array} \\
\left(\mathrm{~m}^{3} / \mathrm{yr}\right)\end{array}$} & \multirow{2}{*}{\multicolumn{3}{|c|}{$\begin{array}{c}\text { DRI-Alluvial Mask Only } \\
\text { Percentile }\end{array}$}} & \multirow{2}{*}{\multicolumn{3}{|c|}{$\begin{array}{c}\begin{array}{c}\text { DRI-Alltuvial and } \\
\text { Elevation Mask }\end{array} \\
\text { Percentile }\end{array}$}} \\
\hline & & & & & & & & & & & & & \\
\hline & & & & & & & & $\begin{array}{c}5 \text { th } \\
\left(\mathrm{m}^{3} / \mathrm{yr}\right)\end{array}$ & $\begin{array}{l}50+\mathrm{th}^{\mathrm{a}} \\
\left(\mathrm{m}^{3} / \mathrm{yr}\right)\end{array}$ & $\begin{array}{c}95 \text { th } \\
\left(\mathrm{m}^{3 / y r}\right)\end{array}$ & $\begin{array}{c}5 \text { th } \\
\left(\mathrm{m}^{3} / \mathrm{yr}\right)\end{array}$ & $\begin{array}{l}50 \mathrm{th}^{\mathrm{a}} \\
\left(\mathrm{m}^{3} / \mathrm{yr}\right)\end{array}$ & $\begin{array}{c}95 \text { th } \\
\left(\mathrm{m}^{3} / \mathrm{yr}\right)\end{array}$ \\
\hline 1462 & Sarcobatus Flat-2 & Monte Cristo & 324,700 & 794,533 & 162,400 & 153,300 & \multirow{2}{*}{$3,092,009$} & & $1,082,000$ & & & $1,063,000$ & \\
\hline 1463 & Sarcobatus Flat-3 & Sarcobatus East & 420,300 & \begin{tabular}{|l|l|l|l|}
568,889 \\
\end{tabular} & 297,400 & 280,800 & & & 774,500 & & & 761,200 & \\
\hline 1471 & Gold Flat-1 \& 2 & Silent Canyon & $4,739,000$ & \begin{tabular}{|l|l|}
$3,726,785$ \\
\end{tabular} & $5,269,000$ & \begin{tabular}{|l|l|}
$4,052,000$ \\
\end{tabular} & $6,089,375$ & \begin{tabular}{|l|}
$3,902,375$ \\
\end{tabular} & $8,349,933$ & \begin{tabular}{|l|l|}
$12,806,618$ \\
\end{tabular} & $3,902,375$ & \begin{tabular}{|l|l|}
$8,349,933$ \\
\end{tabular} & \begin{tabular}{|l|l|}
$12,8006,618$ \\
\end{tabular} \\
\hline 148 & Cactus Flat & & $3,147,000$ & $3,304,088$ & $1,653,000$ & $1,326,000$ & $1,833,565$ & & $4,498,000$ & & & $4,421,000$ & \\
\hline 1571 & Kawich Valley-1 \& 2 & Kawich Valley South & $6,952,000$ & $4,068,436$ & $4,372,000$ & $2,923,000$ & $4,957,173$ & $2,074,601$ & $5,179,836$ & $8,317,501$ & $2,074,601$ & $5,179,836$ & $8,317,501$ \\
\hline 1582 & Emigrant Valley-2 & Papoose Lake & 887,800 & 466,868 & 412,600 & 305,300 & \begin{tabular}{|l|l|l}
751,4877 \\
\end{tabular} & 353,077 & 552,945 & 752,863 & \begin{tabular}{|l|l|}
353,077 \\
\end{tabular} & 552,945 & 752,863 \\
\hline 1581 & Emigrant Valley-1 \& 3 & Emigrant Valley & $7,891,000$ & $3,851,189$ & $6,897,000$ & $4,510,000$ & $6,031,775$ & $3,821,622$ & $7,376,521$ & $10,947,605$ & $3,821,622$ & $7,376,521$ & $10,947,605$ \\
\hline 159 & Yucca Flat & & $2,589,000$ & $2,001,386$ & 1,950,000 & $1,508,000$ & $\mid 1,987,241$ & $\mid \begin{array}{l}1,460,381 \\
\end{array}$ & $2,464,376$ & 3,462,957 & 1,458,825 & $2,454,338$ & $3,454,159$ \\
\hline 160 & $\begin{array}{l}\text { Frenchman Flat } \\
\text { int }\end{array}$ & & $2,542,000$ & $1,319,064$ & $2,344,000$ & $2,183,000$ & 2,303,408 & $1,563,499$ & $2,506,705$ & 3,451,927 & | 1,412,403 & $2,225,121$ & $3,043,080$ \\
\hline 161 & Indian Springs Valley & & $4,741,000$ & $3,655,436$ & $4,376,000$ & $4,210,000$ & $3,631,009$ & $2,836,248$ & $5,014,868$ & $7,189,613$ & $2,596,903$ & $4,773,754$ & 6,913,761 \\
\hline 168 & Three Lakes Valley North & & 300,600 & 319,002 & | $1,824,000$ & $1,819,000$ & | $1,436,828$ & & 434,300 & & & 426,800 & \\
\hline 1691 & Tikaboo Valley-1 & \begin{tabular}{|l} 
Tikaboo Valley North \\
\end{tabular} & $5,997,000$ & $6,451,646$ & $4,595,000$ & $4,241,000$ & $4,950,818$ & & $8,783,000$ & & & $8,632,000$ & \\
\hline 1692 & Tikaboo Valley-2 & Tikaboo Valley South & 606,700 & 760,360 & $2,401,000$ & $2,402,000$ & $2,289,789$ & & $1,035,000$ & & & $1,017,000$ & \\
\hline 170 & Penoyer Valley & & $8,382,000$ & $6,487,366$ & $6,289,000$ & $5,175,000$ & | $5,521,083$ & & $8,832,000$ & & & $8,680,000$ & \\
\hline 172 & Garden Valley & & $1,859,000$ & $2,476,190$ & 587,500 & 478,600 & 683,153 & & $3,371,000$ & & & $3,313,000$ & \\
\hline 1731 & Railroad Valley South-1 & Reveille Valley & $5,416,000$ & $5,464,048$ & $2,696,000$ & $2,266,000$ & $2,349,883$ & & $7,439,000$ & & & 7,311,000 & \\
\hline 1733 & Railroad Valley South-3 & Central Railroad Valley & \begin{tabular}{|l|l|}
$1,914,000$ \\
\end{tabular} & $1,920,032$ & 373,500 & 290,000 & 355,795 & & $2,614,000$ & & & $2,569,000$ & \\
\hline 211 & Three Lakes Valley South & & $4,221,000$ & 4,219,935 & $2,143,000$ & $2,117,000$ & $2,014,631$ & & $5,745,000$ & & & $5,646,000$ & \\
\hline 2121 & Las Vegas Valley-1 & & $5,063,000$ & $5,015,045$ & $2,412,000$ & $2,382,000$ & $7,733,000$ & & $6,827,000$ & & & $6,710,000$ & \\
\hline 225 & Mercury Valley & & 424,800 & 154,914 & 475,000 & 446,400 & 367,288 & 307,595 & 480,655 & 653,026 & 235,827 & 370,761 & 505,057 \\
\hline 226 & Rock Valley & & 176,700 & 227,356 & 385,200 & 374,600 & 392,512 & 103,387 & 193,150 & 282,715 & 58,471 & 94,962 & 131,371 \\
\hline 2271 & Fortymile Canyon-1 & Upper Fortymile & $3,477,000$ & $3,606,419$ & $2,545,000$ & $1,709,000$ & $2,165,209$ & $3,249,834$ & 5,951,107 & $8,648,052$ & $3,249,834$ & $5,951,107$ & $8,648,052$ \\
\hline 2272 & Fortymile Canyon- 2 \& 3 & Lower Fortymile & $1,129,300$ & 383,188 & $1,932,900$ & $1,146,300$ & $3,003,232$ & 918,752 & $1,426,551$ & $1,937,465$ & 832,277 & $1,302,880$ & $1,769,044$ \\
\hline 2281 & Oasis Valley-1 \& 2 & Beatty Wash & $4,022,000$ & $1,616,471$ & $3,041,000$ & $2,380,800$ & $3,144,653$ & $3,865,340$ & \begin{tabular}{|c|c|}
$6,45,495$ \\
\end{tabular} & $8,411,821$ & $3,638,233$ & $5,862,809$ & $8,069,781$ \\
\hline 229 & Crater Flat & & 179,800 & 187,843 & 347,500 & 327,500 & \begin{tabular}{|l|l|}
276,193 \\
\end{tabular} & 395,357 & \begin{tabular}{|l|l|}
661,209 \\
\end{tabular} & 926,301 & \begin{tabular}{|l|l|}
337,018 \\
\end{tabular} & 540,229 & \begin{tabular}{|l|l|l}
744,761 & \\
\end{tabular} \\
\hline $2301 \& 2302$ & Amargosa Desert & & $1,457,000$ & $1,455,702$ & $1,893,000$ & $1,730,000$ & $\mid 2,446,912$ & & $\mid$\begin{tabular}{|l|}
$1,981,700$ \\
\end{tabular} & & & $1,947,500$ & \\
\hline 2421 & Amargosa River-1 & $\begin{array}{l}\text { Lower Amargosa } \\
\text { Valley }\end{array}$ & 0 & 0 & 17,920 & 17,600 & \multirow{2}{*}{$1,189,042^{b}$} & & 0 & & & 0 & \\
\hline 2422 & Amargosa River-2 & Amargosa River & 105,000 & 103,701 & 279,900 & 257,300 & & & 1441,000 & & & 138,800 & \\
\hline 2431 & Death Valley Central-1 & Death Valley South & $\mid 15,870$ & 23,983 & 41,670 & 37,180 & \multirow{2}{*}{$15,562,937^{\mathrm{b}}$} & & 32,650 & & & 32,090 & \\
\hline 2432 & Death Valley Central-2 & Death Valley North & | $1,348,000$ & \begin{tabular}{|l|l|} 
& $1,559,099$ \\
\end{tabular} & $1,216,000$ & \begin{tabular}{|l|l|} 
& $1,195,000$ \\
\end{tabular} & & & $2,123,000$ & & & $2,086,000$ & \\
\hline
\end{tabular}

Source: Modified from SNJV, 2004e

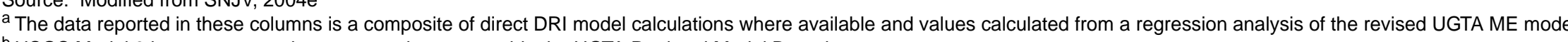

(he UGTA Regional Model Bound

Note: Bold text indicate calculated values as described in the text; based on extrapolated revised ME values. 


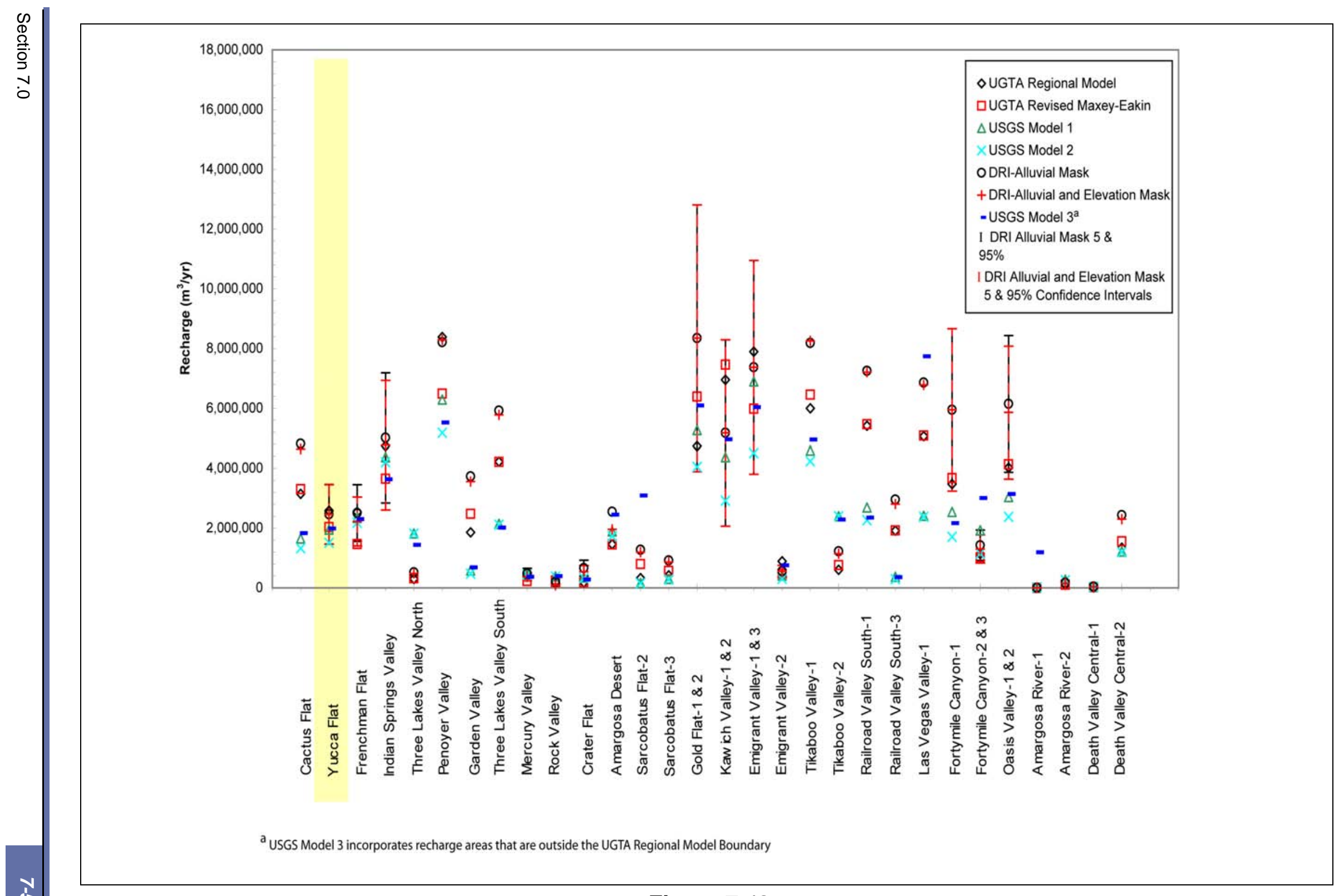

Figure 7-12

Recharge Rate for All Recharge Models and All Hydrographic Areas 
tracer in groundwater because it is assumed to be nonreactive with geologic material. This information, in conjunction with methods for: (1) estimating the elevation at which recharge is occurring for a given rate of chloride enrichment; and (2) assessing the lower limit of recharge, allowed DRI to estimate expected values of recharge rates and the uncertainty associated with these values within confidence intervals. Two recharge models were developed using this approach. The first recharge model assumes that no recharge occurs in alluvial deposits (alluvial mask). The second recharge model assumes no recharge occurs in alluvium and below an elevation of 1,237 $\mathrm{m}$ (alluvium and elevation mask). These recharge models were extended to encompass the entire UGTA regional model area (Russell, 2004; SNJV, 2004e).

\subsection{Limitations}

Numerous limitations and uncertainties are documented in the development of each reported recharge model. The reader is directed to those reports to obtain a complete description of each limitation, including how and at what point, in the application of the methodology it affects the resultant recharge estimate. However, there are several limitations that all report authors found to be in common. These limitations are discussed in this section.

All investigators referenced in this document agree that the greatest uncertainties are attributable to the sparsity of spatial and temporal distribution of precipitation data over the regional area of investigation. These recharge models are highly sensitive to distribution of precipitation; therefore, the sparsity of precipitation data, especially at higher elevations and in remote areas, greatly increases the uncertainty in the recharge model result. Furthermore, the short length of records and the uncertainty in the moisture content of the snowpack, introduces significant uncertainty in the results of the recharge estimates.

In addition to the sparsity of the precipitation data, limitations in the availability of other data types necessary to support some of the methods discussed in this section (e.g., chloride and bromide concentrations in the DRI method; Russell and Minor, 2002) introduce additional uncertainty. The regional scale of the models makes it very difficult and costly to collect sufficient detailed data to develop more than coarse estimates of recharge. Recharge models, with multiple uncertainty parameters, introduce more uncertainty in the recharge distribution. As such, variability in each parameter would potentially compound the overall uncertainty in the recharge distribution. 


\subsection{Groundwater Discharge}

Quantification of discharges from the groundwater flow system are required for the mass balance in groundwater flow modeling. Groundwater discharge may be natural (e.g., ET, spring discharge, etc.) or man made (e.g., well production). In Yucca Flat, man-made discharges are the only significant discharges, and the available data on man-made discharges are compiled in detail and presented in this section. These data may be required for modeling of the groundwater flow system to evaluate the effects of groundwater production on contemporary hydraulic-head distributions, as discussed in Section 10.0.

Man-made discharge from the groundwater flow system occurs primarily through the production of groundwater from wells. There are many wells within the Yucca Flat/Climax Mine CAU Data Compilation Area that have produced groundwater. These include water supply wells providing water for potable and industrial use, and boreholes and wells that have produced incidental volumes of groundwater during drilling, completion, and testing. Long-term groundwater production can remove significant volumes of water from the groundwater flow system, which can have substantial affects on the hydraulic head in the formation. The water supply wells which typically produced groundwater for periods of years to decades are of primary interest for this dataset. Production from water supply wells has been compiled and is presented in Section 8.2.

Most of the groundwater production from water supply wells was used for operations within Yucca Flat, particularly for drilling emplacement holes and associated test holes. Additional groundwater may be produced during drilling and development, but the additional production was generally at a relatively low rate and short in duration. Individual well production volumes are probably not of sufficient magnitude to warrant inclusion in the groundwater flow model. However, yearly aggregate volumes during peak drilling years may be of significance. Detailed records of water management for each site are not available, and estimates of production were not developed. Much of the groundwater production from water supply wells in Yucca Flat was lost back to the ground during 
drilling and other activities. However, this water generally was lost to a different part of the hydrologic system than from where it originated.

There has also been short-term production from various wells in the Yucca Flat/Climax Mine CAU for the purposes of hydraulic testing for hydrologic characterization. Hydraulic testing generally produced relatively low volumes of groundwater due to short test periods. However, the volumes are potentially significant when a number of tests were conducted during the course of one year. Such tests were conducted primarily under the UGTA Project, which began in 1992, and includes drilling and development of wells specifically for hydrologic characterization. These tests are addressed in Section 8.3.

Natural groundwater discharges can include underflow, ET, and spring flow. Underflow is considered in the analysis of lateral boundary flux in Section 9.0 and ET is included with the analysis of recharge in Section 7.0. In Yucca Flat, spring flows discharge from perched groundwater zones above the main groundwater flow system of the basin and do not directly affect the UGTA regional groundwater flow system. The spring collection areas intercept groundwater that is infiltrating to recharge, and discharge it to the ground surface. At the surface, some of the discharge is lost to ET, and the rest reinfiltrates into the ground to eventually recharge the groundwater flow system.

The tunnels and mines in Rainier Mesa/Aqueduct Mesa are mined into the same HSUs in which the springs occur, and function similar to the springs. The tunnels collect infiltrating groundwater from the unsaturated zone above the water table and discharge it to the surface, where some is lost to ET, and the rest continues to infiltrate. These discharges are not anticipated to significantly affect the Yucca Flat/Climax Mine groundwater flow system. Spring and tunnel discharge data were researched and evaluated in general, and are discussed in Sections 8.4 and 8.5, respectively. The nature of the data compilation and analysis for these sections is more qualitative than quantitative, because little quantitative data exists, and the qualitative data adequately characterizes the nature of discharges.

\subsection{Purpose and Objectives}

The purpose of this data analysis is to provide information on all discharges from the groundwater flow system within the Yucca Flat/Climax Mine Data Compilation Area required for groundwater 
flow modeling and other data analyses. The specific objectives for data compilation regarding groundwater discharge are to:

- Identify locations of groundwater discharge and associated producing formation(s).

- Summarize historical records of discharge rates, volumes, and discharge schedules.

- Assess and quantify uncertainties in groundwater discharge volumes.

\subsection{Water Supply Well Production Data}

There are nine water supply wells within Yucca Flat that have been used to produce groundwater for periods of years. The water supply wells are listed in Table 8-1, and their locations are shown on Figure 8-1, which covers the Yucca Flat/Climax Mine Data Compilation Area. Other wells may have been used for short periods to supply water for various uses, but regular records of such production were not maintained. Also within the Yucca Flat/Climax Mine Data Compilation Area are two production wells located in CP Basin, located just south of Yucca Flat, and six production wells in Frenchman Flat. The production records for these latter wells were compiled and summarized in the Phase II Hydrologic Data for the Groundwater Flow and Contaminant Transport Model of Corrective Action Unit 98: Frenchman Flat, Nye County, Nevada (SNJV, 2004e) and are not revisited in this document.

Table 8-1

Summary of Pumping Data for Wells in Yucca Flat

\begin{tabular}{|c|c|}
\hline Well Name & Period of Record \\
\hline \hline WW-A & $1961-1988$ \\
\hline WW-3 & $1952-1970$ \\
\hline WW-2 & $1962-1990$ \\
\hline WW-C & $1961-1995$ \\
\hline WW-C-1 & $1962-2004$ \\
\hline UE-1r WW & $1984-1988$ \\
\hline UE-2ce & $1977-1984$ \\
\hline UE-15d WW & $1962-1971$ \\
\hline UE-16d WW & $1981-2004$ \\
\hline
\end{tabular}

Source: Graves, 2005 


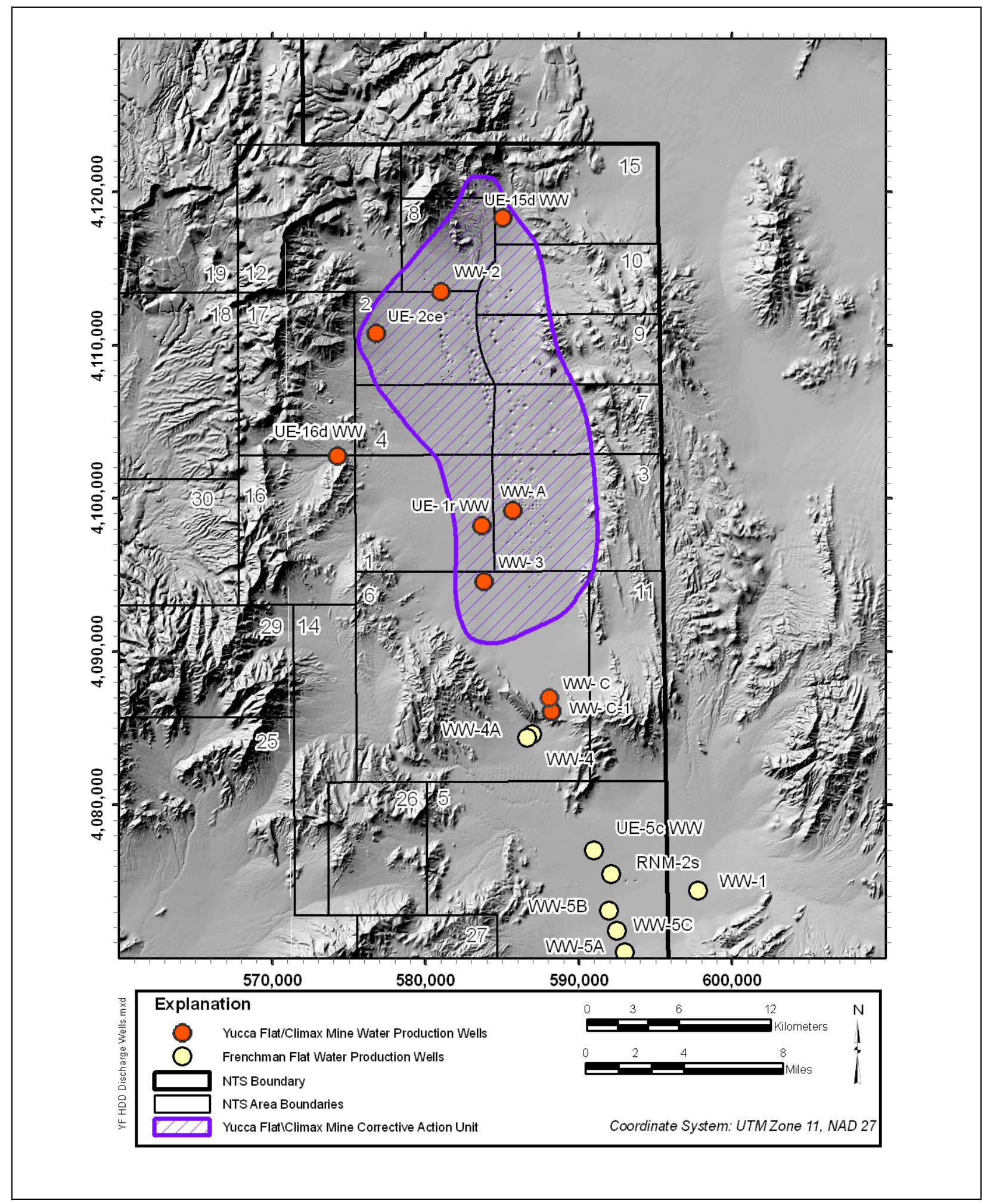

Figure 8-1

Location of Groundwater Pumping Wells in the Yucca Flat/Climax Mine Area 


\subsubsection{Description of Available Data}

The water supply well discharge data were supplied by the USGS as a table of monthly and yearly production. These data are available online at http://nevada.usgs.gov/doe_nv/water use and are continually updated. This data compilation includes production through the year 2004, which was selected as the end-of-data compilation period for all data that are date indexed. The data include: report year and month, withdrawal volumes, days reported, and sources of water use data. These data are compiled by the USGS from information supplied by the NTS M\&O contractor, for more recent pumpage, and from historical sources otherwise.

The data sources for all of the wells (except UE-2ce) were:

- Estimated annual average production data for 1952 through 1957 are from Claassen (1973).

- Annual production data for 1958 are from Claassen (1973). Monthly metered data for September through December are also available from the $M \& O$ water production reports.

- Monthly data for 1959 through 1964 are available from the M\&O water production reports. The annual data are the sum of the monthly data.

- In 1965, there were 329 days of metered data from the $\mathrm{M} \& \mathrm{O}$ water production reports. For the month of October, 4 days from September, and 1 day from November are missing in the monthly dataset. The annual values are from Claassen (1973).

- Some monthly data are available for 1966 and 1967 from the M\&O water production reports. The annual values are from Claassen (1973).

- Monthly data are not available for 1968 through 1971. Annual values are from Claassen (1973).

- Monthly data are not available for 1972 through 1982 . The annual values come from an estimate based on workforce population in Moreo et al. (2003).

- Monthly data are available for 1983, 1987 through 1989, and 1991 through 2004, from the $\mathrm{M} \& \mathrm{O}$ water production reports. The annual data are the sums of the monthly data.

- Monthly data are available for 1984 through 1986 , and 1990 from the M\&O water production reports. The annual data are the sum of the monthly data. A few of the monthly totals contain some estimated days. 
Well UE-15d WW was used to provide water for the EPA experimental farm in Area 15. The data sources for the well are as listed above with some exceptions. Claassen (1973) does not include an estimate for 1965, so the annual water production shown is the sum of the available monthly production from the $\mathrm{M} \& \mathrm{O}$ contractor. The well is not included in Moreo et al. (2003); therefore, no production estimates are available for 1972 through 1981. It is likely that there were some significant withdrawals from the period 1972 to 1981, especially near the beginning. By 1982, water use from this well was reported by the USGS as being insignificant.

The data source for UE-2ce is Radionuclide Migration Project 1984 Progress Report (Buddemeier and Isherwood, 1985). This report provides cumulative volume pumped, reported for nonuniform date intervals. The average pumping rate between these data points were calculated per month.

Much of the water pumped from the water supply wells is initially stored in nearby, unsealed ponds (Baugh, 2005) and then removed from the ponds. While resident in ponds, the water is subject to ET and may also infiltrate the vadose zone. The amount of produced water that is lost to infiltration is unknown, but potentially significant. Infiltration, in most cases, is to a different HSU than from where the water was produced. The net discharge of water from the Yucca Flat groundwater flow system will be somewhat less than the total metered production due to infiltration from these ponds. Some of the uses of water from these wells, such as the drilling of emplacement holes, also has the potential to re-emplace the produced water in the subsurface.

\subsubsection{Data Evaluation}

Evaluation of the data is based on the standards established for the UGTA Project, as defined in Sections 4.3.3.1 and 4.3.3.2. The primary criteria for data quality for well production data are completeness of records and accuracy of the recorded production volumes. The data compiled in this section are mostly from records of well production. Gaps in the historical records are noted in the individual data evaluations for each well. Estimates of usage during gaps in the records are provided, but the basis for those estimates were not researched and are not documented in this report. The USGS has independently verified the instrumentation used to measure production since 1998 (Fenelon, 2006). In general, the quality of documentation is greatest for more recent records and declines with age. 


\subsubsection{Data Documentation Evaluation}

The quality level of documentation, (DDE_F as defined in Section 4.3.3.1) for much of the well discharge data is 4 . Most of the data were collected by the NTS M\&O or the USGS using standard methods, but before issuance of project approved standards. The data are tabulated from compiled records of production volumes; however, original records were not reviewed. Methods of data collection are known, but supporting documentation for the data collection are often minimal or not available. The methods used for estimates of production are detailed in the specified source literature and are based on data sources of similar quality.

\subsubsection{Data Quality Evaluation}

The data (DQE_F as defined in Section 4.3.3.2) are considered to be high quality for periods where water production was measured directly. For periods where production is unrecorded, and estimates are used instead, the data are considered to be low quality and should be used with caution. In all cases, the data have been accepted from the specified data sources without research and confirmation of the values reported in the sources. For recent data, the quality control program of the compiling agency makes research and confirmation unnecessary. For historical data, unavailable primary documentation precludes such research and confirmation, and the data quality is considered lower.

\subsubsection{Groundwater Production Data}

Groundwater discharges from wells in the Yucca Flat/Climax Mine Data Compilation Area are discussed in this section. Data types necessary for assessment of well discharge are:

- Well identification number

- Well reporting name

- Well coordinates

- Effective open interval

- Schedule of water production

- Measured discharge rates

General information for the water supply wells, including the location, configuration, and the HSU from which each well produces, is summarized in Table 8-2. The locations provided are the most 
Table 8-2

Site Information for Water Supply Wells Located in the Yucca Flat/Climax Mine Data Compilation Area

\begin{tabular}{|c|c|c|c|c|c|c|c|c|}
\hline \multirow{2}{*}{$\begin{array}{c}\text { Well Reporting } \\
\text { Name }\end{array}$} & \multirow{2}{*}{$\begin{array}{l}\text { Well Borehole } \\
\text { Index Number }\end{array}$} & \multirow{2}{*}{$\begin{array}{c}\text { Well } \\
\text { Completion } \\
\text { Date }^{\mathrm{a}}\end{array}$} & \multirow{2}{*}{$\begin{array}{l}\text { UTM Easting } \\
(\mathrm{m})^{\mathrm{b}}\end{array}$} & \multirow{2}{*}{$\begin{array}{l}\text { UTM Northing } \\
(\mathbf{m})^{\mathrm{b}}\end{array}$} & \multicolumn{2}{|c|}{ Formation Access Interval } & \multirow{2}{*}{$\begin{array}{l}\text { Primary } \\
\text { HSUe }\end{array}$} & \multirow{2}{*}{$\begin{array}{c}\text { Secondary } \\
\text { HSUf }^{f}\end{array}$} \\
\hline & & & & & $\begin{array}{l}\text { Top Elevation } \\
(\mathrm{m} \text { amsl)c }\end{array}$ & $\begin{array}{l}\text { Bottom Elevation } \\
(m \text { amsl })^{d}\end{array}$ & & \\
\hline WW-A & 1745 & 9/5/1960 & $585,713.5$ & $4,099,194.2$ & 732.9 & 651.2 & AA & NA \\
\hline WW-3 & 1971 & $3 / 5 / 1952$ & $583,827.5$ & $4,094,554.7$ & 742.8 & 661.1 & $A A$ & NA \\
\hline WW-2 & 549 & $3 / 11 / 1962$ & $581,005.7$ & $4,113,499.6$ & 581.1 & 319.3 & LCA & NA \\
\hline WW-C & 1969 & $4 / 30 / 1967$ & $588,214.5$ & $4,086,124.7$ & 726.1 & 677.5 & LCA & NA \\
\hline WW-C-1 & 1970 & $6 / 9 / 1962$ & $588,235.5$ & $4,086,101.5$ & 726.8 & 693.0 & LCA & NA \\
\hline UE-1r WW & 23 & $1 / 16 / 1984$ & $583,674.1$ & $4,098,227.8$ & 525.1 & -42.7 & LCA & $\begin{array}{c}\text { TM-WTA, TM-LVTA, } \\
\text { LTCU, ATCU }\end{array}$ \\
\hline UE-2ce & $319 / 4020 / 4021$ & $1 / 23 / 1977$ & $576,804.1$ & $4,110,773.3$ & $1,011.1$ & 949.3 & LCA3 & TMLVTA \\
\hline UE-15d WW & 3186 & 4/17/1962 & $585,061.4$ & $4,118,300.8$ & 869.0 & -248.0 & $\mathrm{LCCU}$ & OSBCU \\
\hline UE-16d WW & 3235 & $3 / 5 / 1981$ & $574,293.0$ & $4,102,773.4$ & $1,198.2$ & 835.2 & UCA & UCCU \\
\hline
\end{tabular}

andicates date completed to the specified Formation Access Interval.

bUniversal Transverse Mercator Zone 11, North American Datum 1927 in m; source is the UGTA Borehole Index.

'Effective open interval top elevation in $\mathrm{m}$ amsl; calculated as land-surface elevation minus depth to top of effective open interval. Modified to the average water-level elevation when below the top of the physical Formation Access Interval.

dEffective open interval bottom elevation in $\mathrm{m}$ amsl; calculated as land-surface elevation minus depth to bottom of effective open interval.

ePrimary HSU = HSU that comprises the largest section of the well's open interval.

fSecondary HSU = HSU group within the report for evaluation and illustrative purposes. 
accurate locations available as listed in the SNJV internal Borehole tracking. The configuration information provided is the top and bottom elevation of the interval from which the well produces (the formation access interval). The HSUs in this interval were determined from the database compiled for the Yucca Flat/Climax Mine HFM. The Primary HSU designates the HSU from which the bulk of the water is produced. The Secondary HSU indicates other HSUs present in the completion interval, but not major sources of produced water.

Table 8-3 shows the annual production for each well, the total annual production for individual HSUs (AA, LCA, LCCU, UCA), and the total yearly production. Figure 8-2 is a graph of the total annual production for all water supply wells; specifically showing the production from the AA and LCA. Annual production data for each well is presented on individual graphs, Figure 8-3, accompanying the discussion for each well. A brief discussion of the discharge information for each well follows.

\section{WW-A}

Well WW-A is located in the eastern part of Area 3 in Yucca Flat. The well was active from October 1961 to October 1988 and the average annual production for 1961 to 1988 was 32.3 million gallons. Figure 8-3 shows yearly production. Monthly well production data are available for 1961 through 1964 and 1983 through 1988. The annual values reported for 1965 through 1971 are annual sums from Claassen (1973), and those for 1972 through 1982, are annual estimates based on workforce population from Moreo et al. (2003). Well WW-A is open from 651.2 to $732.9 \mathrm{~m}$ amsl within the AA.

\section{WW-3}

Well WW-3 is located in the northern part of Area 6 in Yucca Flat. The well was active from 1952 through 1970, and the annual average production for the well was 10.5 million gallons. Figure 8-3 shows yearly production. Monthly well production data are available for 1959 through 1964 from the $\mathrm{M} \& \mathrm{O}$ water production reports. The rest of the annual production data are estimates (1952 through 1957) and annual sums (1958 and 1965 through 1970) are from Claassen (1973).

Well WW-3 is open from 661.1 to $742.8 \mathrm{~m}$ amsl and produces from the AA. The completion interval includes alluvium, tuff, and clastic materials (Claassen,1973). 
Table 8-3

Yucca Flat/Climax Mine Area Water Supply Well Production

(Page 1 of 2)

\begin{tabular}{|c|c|c|c|c|c|c|c|c|c|c|c|c|}
\hline \multicolumn{13}{|c|}{ Annual Discharge (millions of gallons) } \\
\hline HSU & \multicolumn{2}{|c|}{ AA } & \multicolumn{4}{|c|}{ LCA } & \multirow{2}{*}{$\begin{array}{c}\text { LCA3 } \\
\text { UE-2ce }\end{array}$} & \multirow{2}{*}{\begin{tabular}{|c|} 
LCCU \\
UE-15d WW
\end{tabular}} & \multirow{2}{*}{\begin{tabular}{|c|} 
UCA \\
UE-16d WW
\end{tabular}} & \multirow{2}{*}{$\begin{array}{c}\text { AA } \\
\text { Production }\end{array}$} & \multirow{2}{*}{$\begin{array}{c}\text { LCA } \\
\text { Production }\end{array}$} & \multirow{2}{*}{$\begin{array}{c}\text { Yucca Flat } \\
\text { Total }\end{array}$} \\
\hline Year & WW-A & WW-3 & WW-2 & WW-C & WW-C-1 & UE-1r WW & & & & & & \\
\hline 1952 & N/A & 2.80 & $\mathrm{~N} / \mathrm{A}$ & N/A & N/A & N/A & N/A & $\mathrm{N} / \mathrm{A}$ & $\overline{\mathrm{N} / \mathrm{A}}$ & 2.80 & 0.00 & 2.80 \\
\hline 1953 & N/A & 2.80 & $\mathrm{~N} / \mathrm{A}$ & N/A & $\mathrm{N} / \mathrm{A}$ & N/A & $\mathrm{N} / \mathrm{A}$ & N/A & $\mathrm{N} / \mathrm{A}$ & 2.80 & 0.00 & 2.80 \\
\hline 1954 & $\mathrm{~N} / \mathrm{A}$ & 2.80 & $\mathrm{~N} / \mathrm{A}$ & $\mathrm{N} / \mathrm{A}$ & $\mathrm{N} / \mathrm{A}$ & $\mathrm{N} / \mathrm{A}$ & $\mathrm{N} / \mathrm{A}$ & $\mathrm{N} / \mathrm{A}$ & $\mathrm{N} / \mathrm{A}$ & 2.80 & 0.00 & 2.80 \\
\hline 1955 & $\mathrm{~N} / \mathrm{A}$ & 2.80 & $\mathrm{~N} / \mathrm{A}$ & $\mathrm{N} / \mathrm{A}$ & $\mathrm{N} / \mathrm{A}$ & $\mathrm{N} / \mathrm{A}$ & $\mathrm{N} / \mathrm{A}$ & $\mathrm{N} / \mathrm{A}$ & $\mathrm{N} / \mathrm{A}$ & 2.80 & 0.00 & 2.80 \\
\hline 1956 & $\mathrm{~N} / \mathrm{A}$ & 2.80 & $\mathrm{~N} / \mathrm{A}$ & $\mathrm{N} / \mathrm{A}$ & $\mathrm{N} / \mathrm{A}$ & $\mathrm{N} / \mathrm{A}$ & $\mathrm{N} / \mathrm{A}$ & $\mathrm{N} / \mathrm{A}$ & $\mathrm{N} / \mathrm{A}$ & 2.80 & 0.00 & 2.80 \\
\hline 1957 & $\mathrm{~N} / \mathrm{A}$ & 2.80 & $\mathrm{~N} / \mathrm{A}$ & $\mathrm{N} / \mathrm{A}$ & $\mathrm{N} / \mathrm{A}$ & $\mathrm{N} / \mathrm{A}$ & $\mathrm{N} / \mathrm{A}$ & $\mathrm{N} / \mathrm{A}$ & $\mathrm{N} / \mathrm{A}$ & 2.80 & 0.00 & 2.80 \\
\hline 1958 & $\mathrm{~N} / \mathrm{A}$ & 12.60 & $\mathrm{~N} / \mathrm{A}$ & $\mathrm{N} / \mathrm{A}$ & $\mathrm{N} / \mathrm{A}$ & N/A & $\mathrm{N} / \mathrm{A}$ & N/A & $\mathrm{N} / \mathrm{A}$ & 12.60 & 0.00 & 12.60 \\
\hline 1959 & $\mathrm{~N} / \mathrm{A}$ & 15.84 & $\mathrm{~N} / \mathrm{A}$ & $\mathrm{N} / \mathrm{A}$ & $\mathrm{N} / \mathrm{A}$ & $N / A$ & $\mathrm{~N} / \mathrm{A}$ & $\mathrm{N} / \mathrm{A}$ & $\mathrm{N} / \mathrm{A}$ & 15.84 & 0.00 & 15.84 \\
\hline 1960 & $\mathrm{~N} / \mathrm{A}$ & 11.25 & $\mathrm{~N} / \mathrm{A}$ & $\mathrm{N} / \mathrm{A}$ & $\mathrm{N} / \mathrm{A}$ & $\mathrm{N} / \mathrm{A}$ & $\mathrm{N} / \mathrm{A}$ & $\mathrm{N} / \mathrm{A}$ & $\mathrm{N} / \mathrm{A}$ & 11.25 & 0.00 & 11.25 \\
\hline 1961 & 13.45 & 13.00 & $\mathrm{~N} / \mathrm{A}$ & 4.90 & $\mathrm{~N} / \mathrm{A}$ & N/A & $\mathrm{N} / \mathrm{A}$ & $\mathrm{N} / \mathrm{A}$ & $\mathrm{N} / \mathrm{A}$ & 26.45 & 4.90 & 31.35 \\
\hline 1962 & 49.27 & 22.00 & 9.66 & 37.50 & 16.20 & $\mathrm{~N} / \mathrm{A}$ & $\mathrm{N} / \mathrm{A}$ & 0.29 & $\mathrm{~N} / \mathrm{A}$ & 71.27 & 63.36 & 134.92 \\
\hline 1963 & 32.83 & 22.40 & 23.87 & 45.10 & 33.95 & $\mathrm{~N} / \mathrm{A}$ & $\mathrm{N} / \mathrm{A}$ & 0.00 & $\mathrm{~N} / \mathrm{A}$ & 55.24 & 102.92 & 158.15 \\
\hline 1964 & 54.61 & 20.49 & 25.01 & 57.57 & 69.87 & $\mathrm{~N} / \mathrm{A}$ & $\mathrm{N} / \mathrm{A}$ & 0.00 & $\mathrm{~N} / \mathrm{A}$ & 75.10 & 152.44 & 227.55 \\
\hline 1965 & 46.10 & 16.10 & 35.00 & 30.90 & 39.10 & N/A & $\mathrm{N} / \mathrm{A}$ & 13.54 & $\mathrm{~N} / \mathrm{A}$ & 62.20 & 105.00 & 180.74 \\
\hline 1966 & 43.00 & 18.20 & 46.70 & 34.00 & 76.00 & $\mathrm{~N} / \mathrm{A}$ & $\mathrm{N} / \mathrm{A}$ & 17.10 & $\mathrm{~N} / \mathrm{A}$ & 61.20 & 156.70 & 235.00 \\
\hline 1967 & 26.90 & 14.90 & 51.40 & 28.90 & 34.00 & $\mathrm{~N} / \mathrm{A}$ & $\mathrm{N} / \mathrm{A}$ & 37.30 & $\mathrm{~N} / \mathrm{A}$ & 41.80 & 114.30 & 193.40 \\
\hline 1968 & 19.70 & 7.40 & 51.70 & 81.00 & 26.90 & $\mathrm{~N} / \mathrm{A}$ & $\mathrm{N} / \mathrm{A}$ & 40.30 & $\mathrm{~N} / \mathrm{A}$ & 27.10 & 159.60 & 227.00 \\
\hline 1969 & 31.60 & 6.80 & 70.70 & 95.60 & 36.40 & $\mathrm{~N} / \mathrm{A}$ & $\mathrm{N} / \mathrm{A}$ & 37.70 & $\mathrm{~N} / \mathrm{A}$ & 38.40 & 202.70 & 278.80 \\
\hline 1970 & 24.60 & 1.80 & 57.30 & 62.40 & 18.30 & $\mathrm{~N} / \mathrm{A}$ & $\mathrm{N} / \mathrm{A}$ & 37.40 & $\mathrm{~N} / \mathrm{A}$ & 26.40 & 138.00 & 201.80 \\
\hline 1971 & 31.40 & N/A & 36.50 & 83.40 & 20.40 & $\mathrm{~N} / \mathrm{A}$ & $\mathrm{N} / \mathrm{A}$ & 27.00 & $\mathrm{~N} / \mathrm{A}$ & 31.40 & 140.30 & 198.70 \\
\hline 1972 & 28.68 & $\mathrm{~N} / \mathrm{A}$ & 47.91 & 77.24 & 19.88 & $\mathrm{~N} / \mathrm{A}$ & $\mathrm{N} / \mathrm{A}$ & \multirow{12}{*}{$\begin{array}{l}\text { Unknown - } \\
\text { potentially } \\
\text { significant }\end{array}$} & $\mathrm{N} / \mathrm{A}$ & 28.68 & 145.03 & 173.70 \\
\hline 1973 & 24.77 & $\mathrm{~N} / \mathrm{A}$ & 39.76 & 61.60 & 17.27 & $\mathrm{~N} / \mathrm{A}$ & $\mathrm{N} / \mathrm{A}$ & & $\mathrm{N} / \mathrm{A}$ & 24.77 & 118.63 & 143.40 \\
\hline 1974 & 29.01 & $\mathrm{~N} / \mathrm{A}$ & 44.97 & 66.48 & 20.21 & $\mathrm{~N} / \mathrm{A}$ & $\mathrm{N} / \mathrm{A}$ & & $\mathrm{N} / \mathrm{A}$ & 29.01 & 131.66 & 160.67 \\
\hline 1975 & 29.98 & $\mathrm{~N} / \mathrm{A}$ & 44.65 & 63.22 & 21.18 & $\mathrm{~N} / \mathrm{A}$ & $\mathrm{N} / \mathrm{A}$ & & $\mathrm{N} / \mathrm{A}$ & 29.98 & 129.06 & 159.04 \\
\hline 1976 & 26.72 & $\mathrm{~N} / \mathrm{A}$ & 38.13 & 51.49 & 18.90 & $\mathrm{~N} / \mathrm{A}$ & $\mathrm{N} / \mathrm{A}$ & & $\mathrm{N} / \mathrm{A}$ & 26.72 & 108.52 & 135.25 \\
\hline 1977 & 25.09 & $\mathrm{~N} / \mathrm{A}$ & 34.55 & 43.67 & 17.92 & N/A & 0.99 & & $\mathrm{~N} / \mathrm{A}$ & 25.09 & 96.14 & 122.22 \\
\hline 1978 & 27.38 & $\mathrm{~N} / \mathrm{A}$ & 36.17 & 43.34 & 19.55 & $\mathrm{~N} / \mathrm{A}$ & 2.32 & & $\mathrm{~N} / \mathrm{A}$ & 27.38 & 99.07 & 128.77 \\
\hline 1979 & 24.77 & $\mathrm{~N} / \mathrm{A}$ & 31.61 & 35.20 & 17.92 & $\mathrm{~N} / \mathrm{A}$ & 0.00 & & $\mathrm{~N} / \mathrm{A}$ & 24.77 & 84.73 & 109.50 \\
\hline 1980 & 30.31 & $\mathrm{~N} / \mathrm{A}$ & 36.83 & 37.80 & 21.84 & N/A & 0.34 & & $\mathrm{~N} / \mathrm{A}$ & 30.31 & 96.47 & 127.11 \\
\hline 1981 & 35.52 & $\mathrm{~N} / \mathrm{A}$ & 41.39 & 38.78 & 25.75 & $\mathrm{~N} / \mathrm{A}$ & 1.25 & & 3.58 & 35.52 & 105.92 & 146.27 \\
\hline 1982 & 42.04 & $\mathrm{~N} / \mathrm{A}$ & 46.93 & 39.76 & 30.63 & $\mathrm{~N} / \mathrm{A}$ & 1.68 & & 4.24 & 42.04 & 117.32 & 165.28 \\
\hline 1983 & 44.52 & $\mathrm{~N} / \mathrm{A}$ & 43.45 & 27.72 & 37.63 & $\mathrm{~N} / \mathrm{A}$ & 3.99 & & 4.56 & 44.52 & 108.80 & 161.87 \\
\hline
\end{tabular}


Table 8-3

Yucca Flat/Climax Mine Area Water Supply Well Production

(Page 2 of 2)

\begin{tabular}{|c|c|c|c|c|c|c|c|c|c|c|c|c|}
\hline \multicolumn{13}{|c|}{ Annual Discharge (millions of gallons) } \\
\hline HSU & \multicolumn{2}{|c|}{ AA } & \multicolumn{4}{|c|}{ LCA } & \multirow{2}{*}{$\begin{array}{c}\text { LCA3 } \\
\text { UE-2ce }\end{array}$} & \multirow{2}{*}{$\frac{\text { LCCU }}{\text { UE-15d WW }}$} & \multirow{2}{*}{$\frac{\text { UCA }}{\text { UE-16d WW }}$} & \multirow{2}{*}{$\begin{array}{c}\text { AA } \\
\text { Production }\end{array}$} & \multirow{2}{*}{$\begin{array}{c}\text { LCA } \\
\text { Production }\end{array}$} & \multirow{2}{*}{$\begin{array}{c}\text { Yucca Flat } \\
\text { Total }\end{array}$} \\
\hline Year & WW-A & WW-3 & WW-2 & WW-C & WW-C-1 & UE-1r WW & & & & & & \\
\hline 1984 & 41.06 & $\mathrm{~N} / \mathrm{A}$ & 48.09 & 31.20 & 23.31 & 1.93 & 0.39 & \multirow{7}{*}{$\begin{array}{l}\text { Unknown - } \\
\text { probably minor }\end{array}$} & 8.10 & 441.06 & \begin{tabular}{|l|}
104.52 \\
\end{tabular} & 154.07 \\
\hline 1985 & 37.50 & N/A & 18.52 & 19.37 & 28.95 & 6.99 & $\mathrm{~N} / \mathrm{A}$ & & 25.37 & 37.50 & 73.83 & 136.70 \\
\hline 1986 & 31.35 & $\mathrm{~N} / \mathrm{A}$ & 19.45 & 17.26 & 30.05 & 4.41 & $\mathrm{~N} / \mathrm{A}$ & & 38.47 & 31.35 & 71.17 & 140.99 \\
\hline 1987 & 30.22 & $\mathrm{~N} / \mathrm{A}$ & 42.59 & 7.16 & 22.33 & 5.04 & $\mathrm{~N} / \mathrm{A}$ & & 34.03 & 30.22 & 77.12 & 141.37 \\
\hline 1988 & 20.65 & $\mathrm{~N} / \mathrm{A}$ & 24.15 & 17.40 & 24.83 & 4.74 & $\mathrm{~N} / \mathrm{A}$ & & 38.07 & 20.65 & 71.12 & 129.84 \\
\hline 1989 & $\mathrm{~N} / \mathrm{A}$ & $\mathrm{N} / \mathrm{A}$ & 19.45 & 31.60 & 28.07 & $\mathrm{~N} / \mathrm{A}$ & $\mathrm{N} / \mathrm{A}$ & & 26.01 & 0.00 & 79.12 & 105.13 \\
\hline 1990 & $\mathrm{~N} / \mathrm{A}$ & $\mathrm{N} / \mathrm{A}$ & 18.19 & 29.67 & 23.34 & $\mathrm{~N} / \mathrm{A}$ & $\mathrm{N} / \mathrm{A}$ & & 32.94 & 0.00 & 71.21 & 104.15 \\
\hline 1991 & $\mathrm{~N} / \mathrm{A}$ & $\mathrm{N} / \mathrm{A}$ & $\mathrm{N} / \mathrm{A}$ & 27.65 & 23.78 & $\mathrm{~N} / \mathrm{A}$ & $\mathrm{N} / \mathrm{A}$ & & 27.29 & 0.00 & 51.44 & 78.73 \\
\hline 1992 & $\mathrm{~N} / \mathrm{A}$ & $\mathrm{N} / \mathrm{A}$ & $\mathrm{N} / \mathrm{A}$ & 14.85 & 30.30 & $\mathrm{~N} / \mathrm{A}$ & $\mathrm{N} / \mathrm{A}$ & $\mathrm{N} / \mathrm{A}$ & 32.88 & 0.00 & 45.15 & 78.02 \\
\hline 1993 & $\mathrm{~N} / \mathrm{A}$ & $\mathrm{N} / \mathrm{A}$ & $\mathrm{N} / \mathrm{A}$ & 22.19 & 9.43 & $\mathrm{~N} / \mathrm{A}$ & $\mathrm{N} / \mathrm{A}$ & N/A & 47.89 & 0.00 & 31.62 & 79.51 \\
\hline 1994 & $\mathrm{~N} / \mathrm{A}$ & $\mathrm{N} / \mathrm{A}$ & $\mathrm{N} / \mathrm{A}$ & 16.54 & 6.10 & $\mathrm{~N} / \mathrm{A}$ & $\mathrm{N} / \mathrm{A}$ & $\mathrm{N} / \mathrm{A}$ & 51.66 & 0.00 & 22.64 & 74.30 \\
\hline 1995 & $\mathrm{~N} / \mathrm{A}$ & $\mathrm{N} / \mathrm{A}$ & $\mathrm{N} / \mathrm{A}$ & 4.22 & 13.89 & $\mathrm{~N} / \mathrm{A}$ & $\mathrm{N} / \mathrm{A}$ & $\mathrm{N} / \mathrm{A}$ & 35.52 & 0.00 & 18.12 & 53.64 \\
\hline 1996 & $\mathrm{~N} / \mathrm{A}$ & $\mathrm{N} / \mathrm{A}$ & $\mathrm{N} / \mathrm{A}$ & $\mathrm{N} / \mathrm{A}$ & 31.44 & $\mathrm{~N} / \mathrm{A}$ & $\mathrm{N} / \mathrm{A}$ & N/A & 38.42 & 0.00 & 31.44 & 69.86 \\
\hline 1997 & N/A & $\mathrm{N} / \mathrm{A}$ & $\mathrm{N} / \mathrm{A}$ & $\mathrm{N} / \mathrm{A}$ & 28.58 & $\mathrm{~N} / \mathrm{A}$ & $\mathrm{N} / \mathrm{A}$ & N/A & 41.45 & 0.00 & 28.58 & 70.04 \\
\hline 1998 & $\mathrm{~N} / \mathrm{A}$ & $\mathrm{N} / \mathrm{A}$ & $\mathrm{N} / \mathrm{A}$ & $\mathrm{N} / \mathrm{A}$ & 3.72 & $\mathrm{~N} / \mathrm{A}$ & $\mathrm{N} / \mathrm{A}$ & $\mathrm{N} / \mathrm{A}$ & 20.53 & 0.00 & 3.72 & 24.25 \\
\hline 1999 & $\mathrm{~N} / \mathrm{A}$ & $\mathrm{N} / \mathrm{A}$ & $\mathrm{N} / \mathrm{A}$ & $\mathrm{N} / \mathrm{A}$ & 18.49 & $\mathrm{~N} / \mathrm{A}$ & N/A & $\mathrm{N} / \mathrm{A}$ & 36.88 & 0.00 & 18.49 & 55.37 \\
\hline 2000 & $\mathrm{~N} / \mathrm{A}$ & $\mathrm{N} / \mathrm{A}$ & N/A & $\mathrm{N} / \mathrm{A}$ & 7.89 & $\mathrm{~N} / \mathrm{A}$ & $\mathrm{N} / \mathrm{A}$ & $\mathrm{N} / \mathrm{A}$ & 24.73 & 0.00 & 7.89 & 32.62 \\
\hline 2001 & N/A & $\mathrm{N} / \mathrm{A}$ & $\mathrm{N} / \mathrm{A}$ & $\mathrm{N} / \mathrm{A}$ & 16.07 & N/A & N/A & N/A & 43.87 & 0.00 & 16.07 & 59.94 \\
\hline 2002 & $\mathrm{~N} / \mathrm{A}$ & $\mathrm{N} / \mathrm{A}$ & $\mathrm{N} / \mathrm{A}$ & $\mathrm{N} / \mathrm{A}$ & 18.84 & $\mathrm{~N} / \mathrm{A}$ & N/A & $\mathrm{N} / \mathrm{A}$ & 30.48 & 0.00 & 18.84 & 49.32 \\
\hline 2003 & N/A & $\mathrm{N} / \mathrm{A}$ & $\mathrm{N} / \mathrm{A}$ & $\mathrm{N} / \mathrm{A}$ & 15.85 & $\mathrm{~N} / \mathrm{A}$ & $\mathrm{N} / \mathrm{A}$ & N/A & 30.49 & 0.00 & 15.85 & 46.34 \\
\hline 2004 & $\mathrm{~N} / \mathrm{A}$ & $\mathrm{N} / \mathrm{A}$ & $\mathrm{N} / \mathrm{A}$ & $\mathrm{N} / \mathrm{A}$ & 17.56 & $\mathrm{~N} / \mathrm{A}$ & $\mathrm{N} / \mathrm{A}$ & $\mathrm{N} / \mathrm{A}$ & 34.24 & 0.00 & 17.56 & 51.80 \\
\hline
\end{tabular}

Source: Graves, 2005

$\mathrm{N} / \mathrm{A}=$ Not applicable 


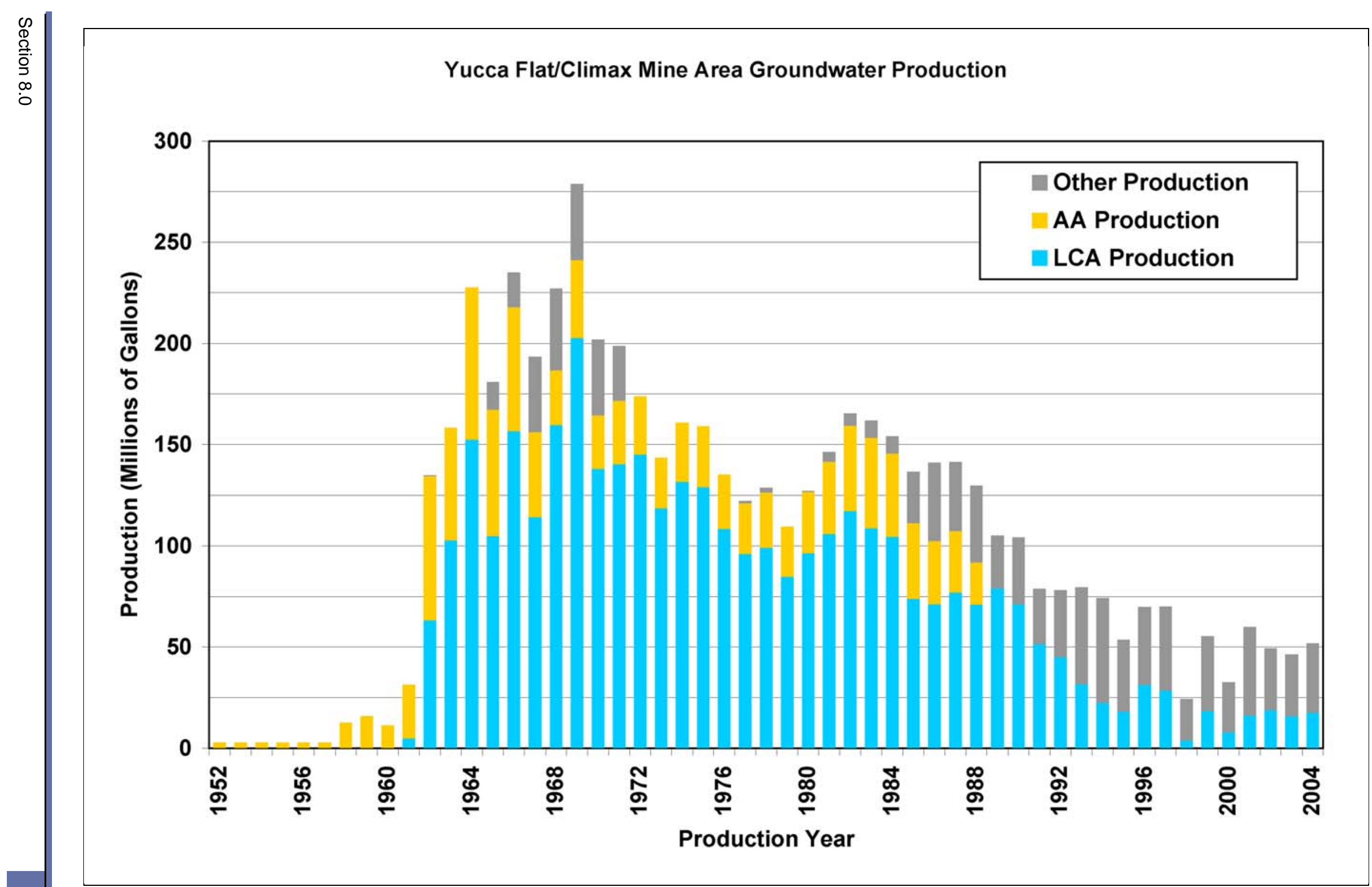

Figure 8-2

Total Annual Production of Water Supply Wells in the Yucca Flat/Climax Mine Area 

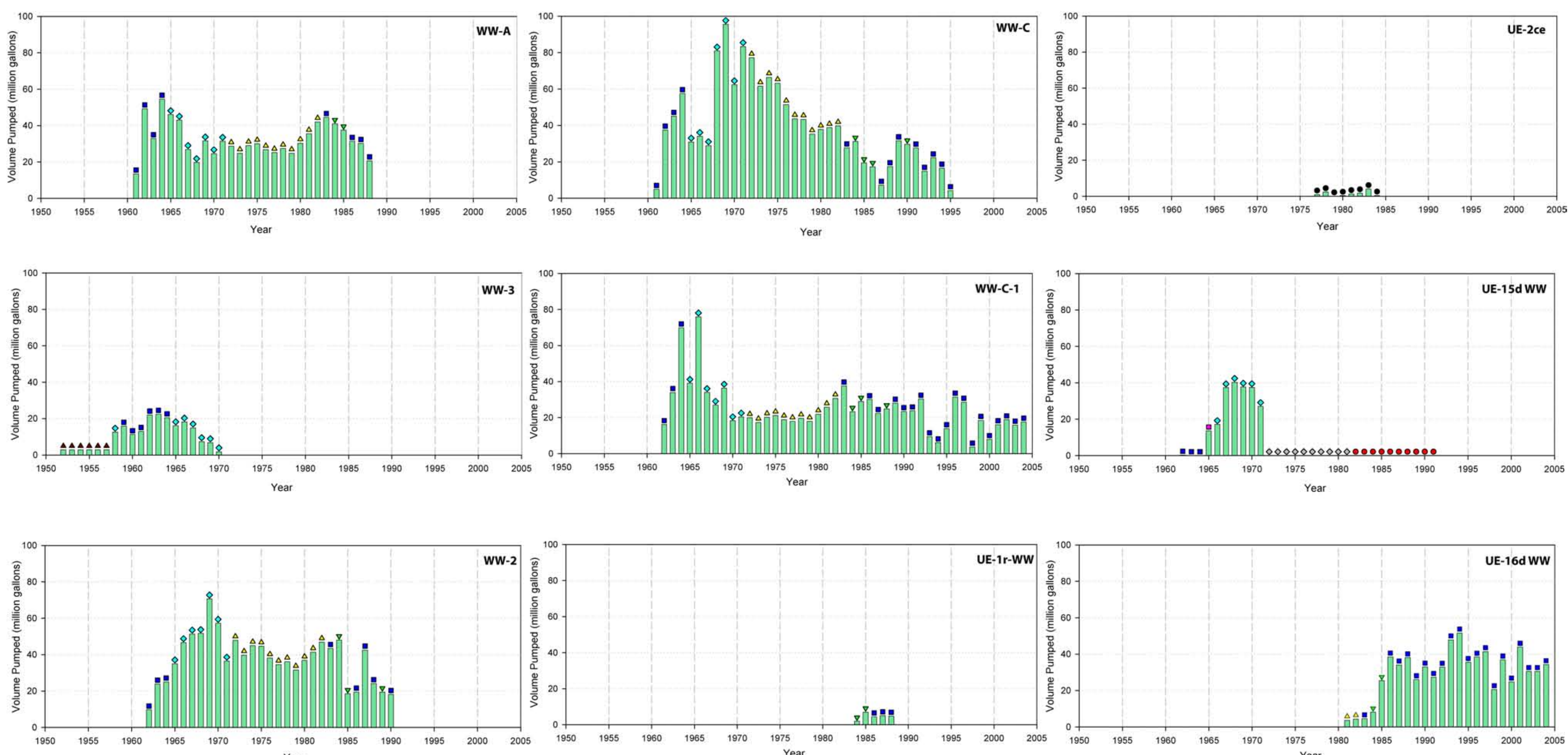

(n).
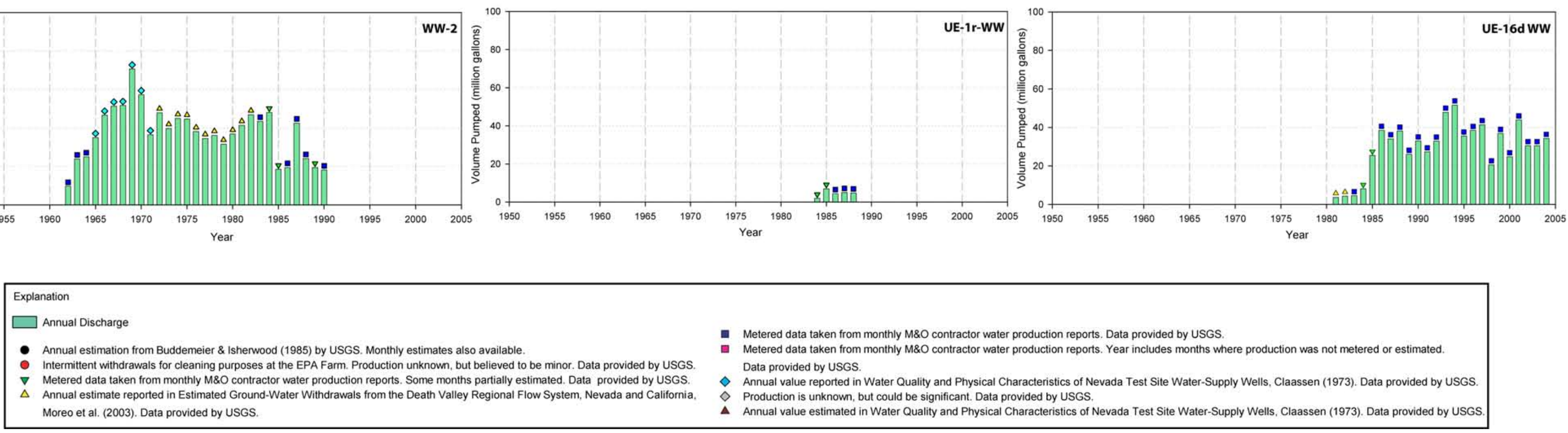

- Metered data taken from monthly M\&O contractor water production reports. Data provided by USGS

Data provided by USGS.

Annual value reported in Water Quality and Physical Characterisitics of Nevada Test Site Water-Supply Wells, Claassen (1973). Data provided by USGS

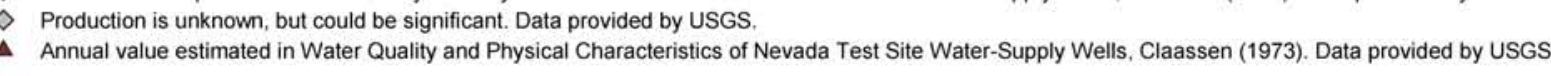




\section{$W W-2$}

Well WW-2 is located on the northern edge of Area 2 in Yucca Flat. The well was active from April 1962 through December 1990 and the average annual production was 37.4 million gallons.

Figure 8-3 shows yearly production. Monthly well-production data from the M\&O water production reports are available from 1962 through 1964 and 1983 through 1990. The annual values reported for 1965 through 1971 are annual sums from Claassen (1973) and those for 1972 through 1982 are annual estimates based on workforce population from Moreo et al. (2003). Well WW-2 is open from 319.3 to $581.1 \mathrm{~m}$ amsl within the LCA.

\section{$W W-C$}

Well WW-C is located in the southeastern part of Area 6 near the southern tip of Yucca Lake. The well was used from September 1961 to July 1995, with average annual production of 39.6 million gallons. Figure 8-3 shows yearly production. Monthly well production data are available for 1961 through 1964 and 1983 through 1995. The annual values reported for 1965 through 1971 are annual sums from Claassen (1973) and those for 1972 through 1982 are annual estimates based on workforce population from Moreo et al. (2003). Well WW-C is open from 677.5 to $726.1 \mathrm{~m}$ amsl within the LCA.

\section{WW-C-1}

Well WW-C-1 is located in the southeastern part of Area 6 near the southern tip of Yucca Lake, very close to WW-C. The well started production in June 1962 and is still in use. The average annual production for 1962 through 2004 was 24.7 million gallons. Figure 8-3 shows yearly production. Monthly well production data are available for 1962 through 1964 and 1983 through 2004. The annual values reported for 1965 through 1971 are annual sums from Claassen (1973) and those for 1972 through 1982 are annual estimates based on workforce population from Moreo et al. (2003). Well WW-C-1 is open from 693.0 to $726.8 \mathrm{~m}$ amsl within the LCA.

\section{UE-1r WW}

Well UE-1r WW is located on the eastern edge of Area 1 in Yucca Flat. The well was active from September 1984 to October 1988 and the average annual production was 6 million gallons.

Figure 8-3 shows yearly production. Monthly production data for the well are from the M\&O 
contractor water production reports. Well UE-1r WW is open from a depth of -42.7 to $525.1 \mathrm{~m}$ amsl, although a bridge in the hole was tagged at 3,145 ft $(958.6 \mathrm{~m})$ shortly after drilling. The well is open to the TM-WTA, TM-LVTA, and LTCU above the bridge and the ATCU and LCA below the bridge.

\section{UE-2ce}

Well UE-2ce is located in the western part of Area 2 in Yucca Flat and is $183 \mathrm{~m}$ from the site of the NASH test. The well was used from May 1977 to 1984 and the average annual production was 1.4 million gallons. Figure 8-3 shows yearly production. The well was drilled after the NASH test and water production from the well was used to monitor tritium in the groundwater. Production measurements for this well are from a status report for the Radionuclide Migration Project (Buddemeier and Isherwood, 1985). Well UE-2ce is open from 949.3 to 1,011.1 m amsl within the LCA3, which is separated from the LCA by a thick section of UCCU at this location. Production from this well ceased when the pump failed.

\section{UE-15d WW}

Well UE-15d WW is located in the southern part of Area 15 at the EPA Farm and was used to supply water for agricultural experiments. The well was used from 1962 through 1991, and production data are available for the years 1962 through 1965 from M\&O water production reports and annual sums are provided in Claassen (1973) for 1966 through 1971. There are no production estimates available from 1972 through 1991, but production for part of this period (1982 through 1991) is thought to be minor. The annual production for the remaining years is likely to be less than or equal to peak annual production (1967 through 1970). The average annual production for the years for which data is available was 21.1 million gallons. Figure 8-3 shows yearly production. Well UE-15d WW is open from -248.0 to $869.0 \mathrm{~m}$ amsl within the LCCU. This well produces substantially from a dolomite section (Claassen, 1973) within the LCCU but may also produce from fractures in the overlying quartzite and possibly a nearby fault. It is not known to what extent the fracturing may connect this well to the LCA, which is not present overlying the LCCU in this area, but is present some distance basinward. 


\section{UE-16d WW}

Well UE-16d WW is located in the northwest corner of Area 16 west of Yucca Flat. The well began production in March 1981 and is still in use. The average annual production for the well was 29.7 million gallons for 1981 through 2004. Figure 8-3 shows yearly production. Monthly well production data from M\&O water production reports are available from 1983 through 2004. Annual estimates for 1981 and 1982 are based on workforce population from Moreo et al. (2003). The well was originally completed to a total depth of $513.3 \mathrm{~m}$ amsl; however, the bottom of the hole is sealed off with a bridge plug near the bottom of the main casing, and the well is open from 835.2 to $1,198.2 \mathrm{~m}$ amsl. This producing interval is within the UCA, which is a carbonate section isolated from the LCA in this area.

\subsubsection{Summary of Water Supply Well Discharge Data}

The primary mechanism for groundwater discharge from the Yucca Flat groundwater flow system, other than underflow (Section 9.0), is production from water supply wells. Water has been pumped from nine water supply wells, two wells produced from the AA, five wells produced from the LCA, one well produced from the LCCU, and one well produced from the UCA.

The quality of the data compiled by the USGS from water production reports of the M\&O contractor is considered high. This constitutes an intermittent record from 1952 through 1991 and a continuous record since 1991 (see Section 8.2.1). Production was otherwise estimated by the USGS, as documented in the cited references, and all the estimated data are considered to be uncertain.

Groundwater withdrawals in Yucca Flat started in 1952 and were consistent at a low level (2.8 million gallons per year) until 1958. Production increased yearly starting in 1959, increasing rapidly in the early 1960s, and peaking in 1969 at 279 million gallons per year. Production varied between 122 and 202 million gallons per year through 1987 and declined thereafter to about 50 million gallons per year. Early production was from the AA, but the LCA became the major water supply source in the 1960s. Groundwater from the UCA was produced starting in the early 1980s and has been the dominant source since the early 1990s. Alluvial aquifer production ceased in the late 1980s.

Industrial water is generally pumped from the water supply wells to nearby ponds for storage, and removed from the ponds as needed. Surface water is also generally maintained in ponds for wildlife 
usage even when a well is no longer used for water supply. Pumpage for this purpose is incidental and not reported. Infiltration rates from these ponds to the groundwater system are not known.

\subsubsection{Limitations}

Limitations associated with the well discharge data are intermittent or missing production records for the water supply wells until 1991, after which records are continuous. There is also uncertainty about production for UE-15d WW for the years 1972 through 1981, during which anecdotal reference suggests there may have been substantial production. The same reference indicates there may also have been continuing but less substantial production in the following years. The production for UE-15d WW after 1971 is not estimated due to the lack of any quantitative basis for an estimate. Finally, the miscellaneous discharges from many wells in Yucca Flat that were produced for short periods, for a variety of purposes, are not known or estimated. In total, these discharges could be of substantial magnitude.

\subsection{Environmental Restoration Well Testing Program}

Since the inception of the Groundwater Characterization Program/UGTA program in 1992, the ER well-testing program has conducted 13 pumping tests in Yucca Flat. These tests commonly involve a development period of approximately 10 days, and a testing period of approximately 10 days, pumping at production rates from 160 to $550 \mathrm{gpm}$. A recent test at the ER-6-1 well cluster included a 90-day tracer test with an average production rate of $525 \mathrm{gpm}$. These testing programs constitute production of volumes of groundwater comparable to volumes produced by some of the water supply wells. The produced water is discharged to an on-site $\operatorname{sump}(\mathrm{s})$, an earthen basin either excavated into the ground or partially constructed with earthen berms. These basins are initially used for drilling and completion of the wells and are often lined to prevent fluid loss. However, the liners can be torn during drilling/completion operations or otherwise deteriorate and become leaky. In some cases, multiple basins are constructed, and only one is lined. Fluids may be routed to the lined basin until checked for contaminants, and then discharged to the unlined basin for infiltration. These wells are periodically pumped to purge the water in preparation for geochemical sampling. The volumes pumped for this purpose are generally relatively small and are not tabulated here. 


\subsubsection{ER Well Tests}

Table 8-4 lists the ER well hydraulic tests that involved substantial groundwater production.

Figure 8-4 shows the location of these wells. Several other wells were drilled by the ER program, but well development did not produce substantial volumes of groundwater, and testing was not conducted.

\subsubsection{Description of Available Data}

The available data for each well are summarized in Table 8-4. Water production was continuously monitored during these tests with electronic recording of flow rates from a flow meter or gauge and water distribution to the sumps was also monitored. These data are presented in the testing data reports for each well. The total produced volumes reported in Table 8-4 are taken from the regulatory reporting (Fluid Disposition form, filed in the SNJV Central Files for each well) for fluid management.

\subsubsection{Data Evaluation}

Evaluation of these data is based on the standards established for the UGTA project, as defined in Sections 4.3.3.1 and 4.3.3.2. The primary criteria for data quality for well production are completeness of records and accuracy of the recorded production volume.

\subsubsection{Data Documentation Evaluation}

The data for these tests were recorded and documented to the project standards at the time of the test and meet Level 1 data documentation criteria.

\subsubsection{Data Quality Evaluation}

The data for these tests were collected to a very high standard of accuracy and completeness, and the test was highly controlled regarding all factors known to be relevant. Therefore, the dataset quality is considered very high. 
Table 8-4

Environmental Restoration Well Tests

\begin{tabular}{|c|c|c|c|c|c|}
\hline Well Name & $\begin{array}{l}\text { Location } \\
\text { UTM, NAD 27, Zone } 11 \\
\text { Easting, Northing (m) }\end{array}$ & $\begin{array}{l}\text { Testing Date } \\
\text { Period }\end{array}$ & HSU Produced & $\begin{array}{l}\text { Total Volume } \\
\text { Produced } \\
\text { (gal) }\end{array}$ & Data Source \\
\hline UE-1q & $583,722.64,101,777.6$ & $5 / 1992-6 / 1992$ & LCA & 263,580 & Data Report, UE-1q Aquifer Test (DRI, 1992) \\
\hline UE-10j & $581,526.54,115,644.9$ & 4/1993 - 10/1993 & LCA & $1,952,569$ & $\begin{array}{c}\text { Pre-Completion Hydrologic Testing } \\
\text { Documentation Package for Well UE-10j } \\
\text { (IT, 1995) }\end{array}$ \\
\hline ER-2-1 & $583,334.64,108,978.3$ & $2 / 2003-9 / 2003$ & $\begin{array}{c}\text { TMWTA, TMLVTA, } \\
\text { LTCU }\end{array}$ & 27,632 & Fluid Disposition Form \\
\hline ER-3-1 & $594,658.34,097,339.0$ & $5 / 1994-10 / 1996$ & LCA & 348,883 & Fluid Disposition Form \\
\hline ER-6-1 & $589,632.7 \quad 4,093,417.9$ & 8/1992 - 10/1992 & LCA & 595,442 & Fluid Disposition Form \\
\hline ER-6-1 & $589,632.7 \quad 4,093,418.8$ & $12 / 2003-1 / 2004$ & LCA & $5,472,324$ & Fluid Disposition Form \\
\hline ER-6-1\#2 & $589,616.6 \quad 4,093,357.0$ & $10 / 2002-1 / 2003$ & LCA & $5,141,924$ & Fluid Disposition Form \\
\hline ER-6-1\#2 & $589,616.6 \quad 4,093,357.0$ & $2 / 2004-7 / 2004$ & LCA & $83,604,136$ & Fluid Disposition Form \\
\hline ER-6-2 & $582,235.8 \quad 4,090,744.9$ & 1/1993 - 8/1994 & LCA3 & 3,434 & Fluid Disposition Form \\
\hline ER-6-2 & $582,235.8 \quad 4,090,744.9$ & $7 / 2004-8 / 2004$ & LCA3 & $3,506,884$ & Fluid Disposition Form \\
\hline ER-7-1 & $589,315.0 \quad 4,103,275.3$ & 2/2003 - 7/2003 & LCA & $3,801,594$ & Fluid Disposition Form \\
\hline ER-12-1 & $572,411.5 \quad 4,115,492.8$ & 4/1992 & $\begin{array}{l}\text { UCCU (isolated } \\
\text { section of LCA3) }\end{array}$ & 213,050 & $\begin{array}{l}\text { ER-12-1 Completion Report } \\
\text { (Russell et al., 1996) }\end{array}$ \\
\hline ER-12-2 & $577,902.54,114,057.6$ & $11 / 2002-4 / 2003$ & UCCU & $1,567,623$ & Fluid Disposition Form \\
\hline
\end{tabular}




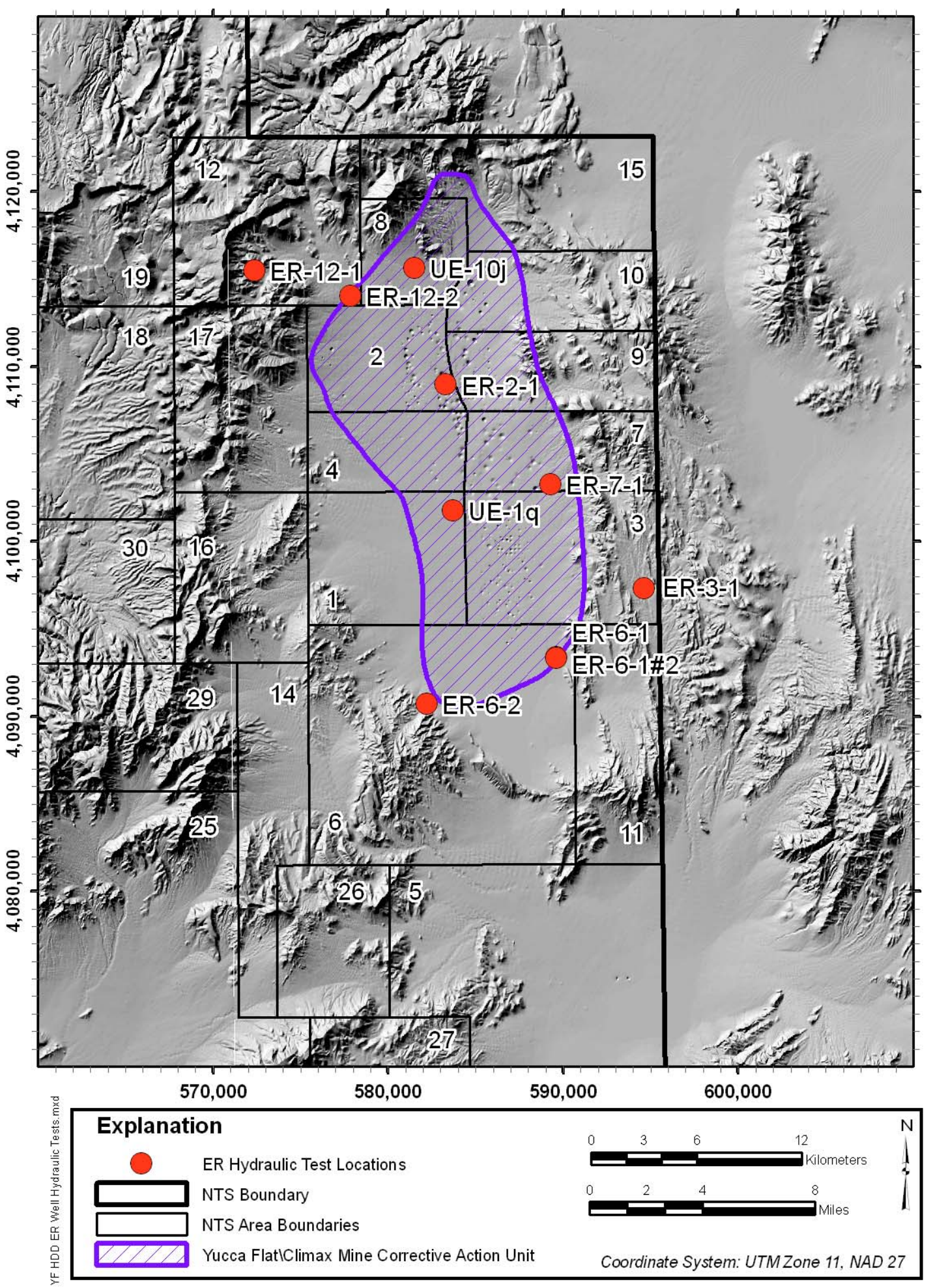

Figure 8-4

Location of ER Well Hydraulic Tests in the Yucca Flat/Climax Mine Area 


\subsubsection{Groundwater Production Data}

The total from each well for each production period, within a one-year time frame, was tabulated, including groundwater produced during drilling, development, and testing, less the volume of water that was imported for drilling, is listed in Table 8-4. Some of this water was discharged to lined sumps and other to infiltration areas. Tests were conducted twice for two wells, after modification of the well following the initial tests.

\subsubsection{Summary of Production Data}

The datasets provide complete information on the produced volumes of water for testing of the ER testing wells. However, the final disposition of the produced water placed in the sumps between infiltration and evaporation is not well known. That water placed in lined sumps may be contained for substantial periods, although most lined sumps eventually develop leaks. Water placed in unlined sumps and infiltration areas generally disappears in short time, presumably mostly to infiltration. In particular, note that the combined ER well testing production during the year 2003 may be significant relative to the production of the water supply wells that year. Also, in 2004, the production for ER-6-1 \#2 substantially exceeded the total production of the water supply wells.

\subsubsection{Limitations}

These datasets do not have any substantial limitations relative to the intended use.

\subsection{Spring Discharges}

Springs are groundwater discharges to the ground surface at locations where the ground surface locally intersects a level of saturation in the formation. There are a variety of different hydrologic situations that can create springs. The inclusion of spring discharge in groundwater flow modeling depends on the nature of the spring discharge within the hydrologic system. Springs that discharge directly from the groundwater flow system are treated as discharges in groundwater flow modeling, while springs that discharge from perched groundwater would modify groundwater recharge to the groundwater flow system. Therefore, it is necessary to have a basic understanding of the nature of each spring discharge as well as discharge data to characterize spring discharges. 
There are a several lines of evidence that the springs in the Yucca Flat/Climax Mine Data Compilation Area discharge from small, perched groundwater systems rather than the underlying regional aquifer as follows:

- Elevation differences between springs and the regional water table. For all of the springs included in this section, the elevations of the springs are significantly higher than the elevation of water levels in nearby wells. The interpreted water table throughout the Yucca Flat Data Compilation Area is substantially below the ground surface.

- Topographic and geologic locations of the springs. The springs are located at the bottom of Tertiary volcanic tuff stratigraphic sections near unconformity contacts with underlying Paleozoic rocks, causing perching of groundwater infiltration.

- Saturation data from Area 12 tunnels. Tunnels with discontinuous saturation are mined into Rainier Mesa in the same geologic units and in close proximity to some of the springs, which indicates locally perched groundwater.

- The discharge rate and water chemistry of the springs show significant correlation to precipitation events. The geochemical signature of the water indicates that the water is young.

In summary, the springs in the Yucca Flat/Climax Mine Data Compilation Area generally discharge from the bottom of largely zeolitized, Tertiary volcanic tuff units at unconformity contacts with underlying Paleozoic clastic and carbonate units. They occur where infiltrating recharge in the highlands becomes perched in the low permeability zeolitic units above the Paleozoic rocks and spreads laterally through fractures. Small wetland areas develop from the discharge surface flow, which does not extend far from the source during base-flow conditions. Some fraction of the discharge volume is lost to ET before reinfiltration of the water to eventually recharge the regional groundwater flow system. The significance of perched spring discharge is that the springs intercept potential recharge to the regional groundwater system and redistribute the reinfiltration component from the spring collection area to the surface discharge location. This locally modifies the areal distribution of recharge.

\subsubsection{Description of Available Data}

The springs for which data are compiled includes only those identified in the literature, with a surveyed location; all of the largest springs in the Yucca Flat/Climax Mine Data Compilation Area are included. A few smaller springs and seeps are referenced in the literature examined for this report; 
however, the flows for those springs are very small and are not considered significant with respect to the groundwater flow model. The available data for spring discharges are found in a variety of reports that are identified in the following spring-specific discussions. The most pertinent data from these reports are discussed.

\subsubsection{Data Evaluation}

Evaluation of the spring data is based on the standards established for the UGTA Project, as defined in Sections 4.3.3.1 and 4.3.3.2. The primary criteria for data quality for spring discharge data are completeness of records and accuracy of the recorded discharge volumes.

\subsubsection{Data Documentation Evaluation}

The quality level of documentation (DDE_F as defined in Section 4.3.3.1) for most of the spring discharge data is 3. Most of the data were collected by the USGS or other UGTA participating organizations using accepted scientific methodology, and the data collection is documented in the cited reports. Supporting documentation was not located and evaluated; the reports were accepted as presented.

\subsubsection{Data Quality Evaluation}

The data (DQE_F as defined in Section 4.3.3.2) are considered high quality for measurements made, but the completeness of discharge characterization is generally insufficient to determine a high quality estimate for the yearly spring discharge for the evaluation period 1952 to present. Only general estimates based on limited data are possible for quantification over this period.

\subsubsection{Spring Discharge Data}

The springs in the Yucca Flat area are located in the highlands that surround the basin (Figure 8-5). The largest spring discharges around 2.7 liters per minute (Lpm) (about 375,000 gallons per year) and the smallest discharge only intermittently after rainfall. Summaries of the information available in the literature are provided for each spring. However, the data are not comprehensively compiled or analyzed, because it has been determined that this data is not required for the groundwater flow modeling. For details, please refer to the cited literature sources. 

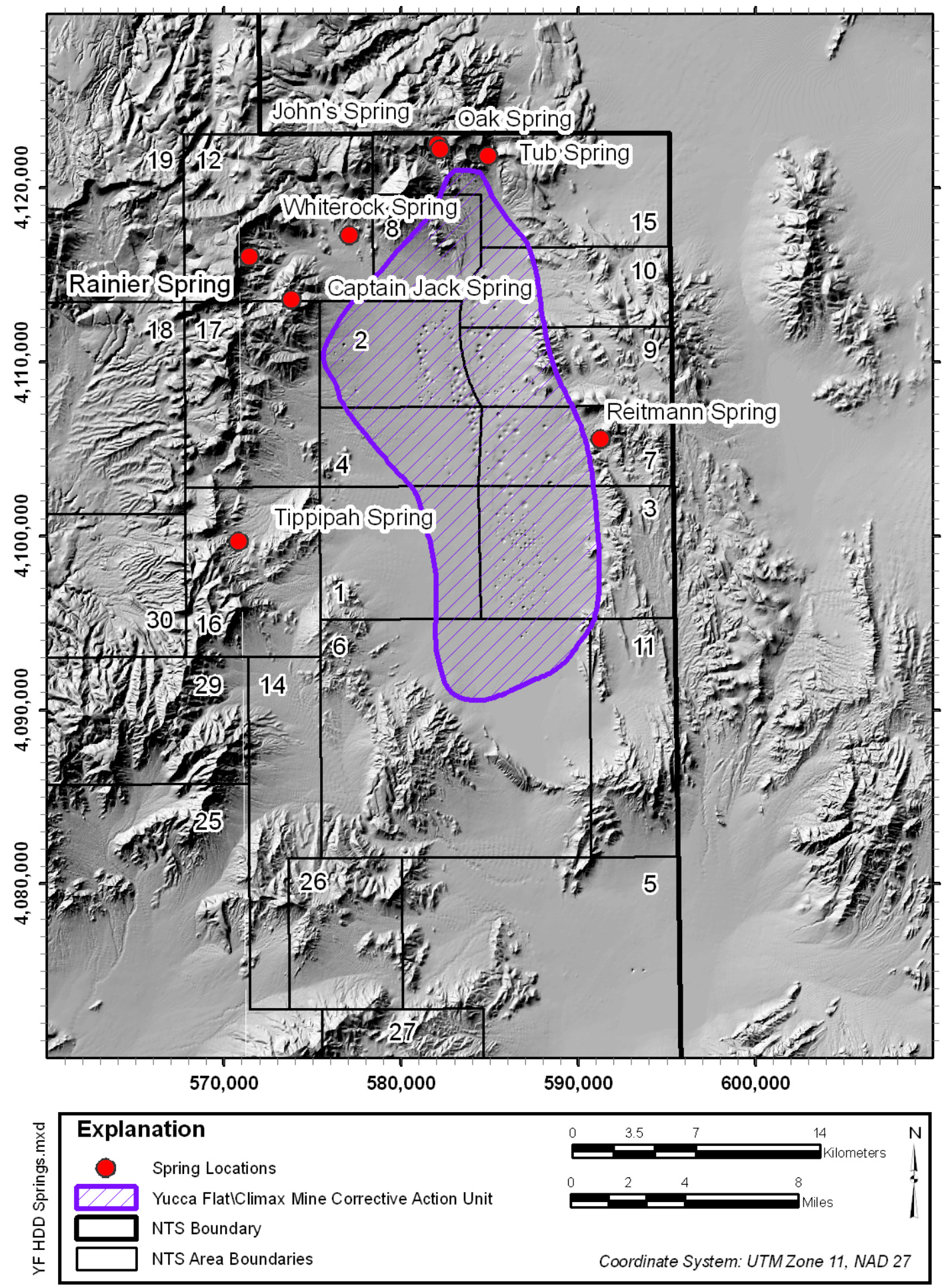

Figure 8-5

Location of Springs in the Yucca Flat/Climax Mine Area 


\section{Whiterock Spring}

Whiterock Spring is one of the largest and most extensively studied springs in the vicinity of Yucca

Flat and is located in the eastern part of Area 12. The spring discharges from two shallow adits in the zeolitized tuff of the Indian Trails Formation just above a contact with the Eleana Formation.

Lyles et al. (1990) measured the combined average discharge rate of the two adits at 2.23 Lpm (about 375,000 gallons per year). Based on spring flow and precipitation monitoring, carbon and oxygen isotope geochemistry, and ionic geochemistry data, Lyles et al. (1990) concludes that spring discharge peaks rapidly after major precipitation events, and the average age of water discharged from the spring is approximately two months. Ingraham et al. (1990) also examine isotopic chemistry data from Whiterock Spring and conclude that the water discharged is very young, and this reference contains additional observations on discharge.

\section{Rainier and Captain Jack Springs}

Rainier and Captain Jack Springs are located in Area 12 near the tunnels emplaced in Rainier Mesa. Rainier Spring is located within 350 m of the main entrance to the U12e Tunnel, and Captain Jack Spring is located on the east face of an adjacent ridge. Both springs are located in tuff units known as the Tunnel Beds. Observations of water discharging from Rainier Spring were made on September 18, 1957, October 4, 1957, and October 15, 1957. However, the spring was reported dry on November 10, 1960, December 18, 1996 and February 20, 1997 (Hansen et al., 1997). Moore (1961) reports that the flow at the Rainier Spring ranges from 0 to $0.5 \mathrm{Lpm}$. The discharge from Captain Jack Spring was measured at 0.9 Lpm on September 10, 1996 (Hansen et al., 1997).

The occurrence of water in the Tunnel Beds Formation was studied during mining of the tunnels in Area 12. Thordarson (1965) reports that a small number of open, dry fractures are interspersed with saturated fractures in the formation; the yield of water from fractures is highly variable, and most fractures drain completely, within a few weeks or months, after exposure in the tunnels.

Thordarson (1965) also reports that while the interstices of the zeolitic tuff are almost 100 percent saturated, the small amount of interstitial seepage indicates that the water is held in the rock by capillarity. 


\section{John’s Spring, Oak Spring, and Tub Spring}

John's Spring, Oak Spring, and Tub Spring are located in Area 15 just north of the Climax Mine. John's Spring and Oak Spring are located about $300 \mathrm{~m}$ from each other on the slope of a mesa in the Older Tunnel Bed unit. Tub Spring is located roughly $3 \mathrm{~km}$ east of these two springs in the Tuff of Twin Peaks. The springs appear to be located just above contacts with Devonian and Ordivician rocks mapped in the area (Slate et al., 1999). Discharges from the three springs in the Climax Mine area are all small. Hansen et al. (1997) report the discharge of John's Spring and Oak Spring at 0.4 Lpm each and Tub Spring at 0.1 Lpm, as measured in November and December of 1996.

\section{Reitmann Spring}

Reitmann Spring, also known as Reitmann Seep or Green Spring/Seep, is located just southwest of the Slanted Buttes, east of Yucca Flat at the bottom of a section of the Bullfrog Tuff near a contact with the Cambrian Nopah Formation. Hansen et al. (1997) report spring discharge of 0.03 Lpm, measured September, 1996, and 0.2 Lpm, measured November 1996.

\section{Tippipah Spring}

Tippipah Spring is located west of Yucca Flat, approximately $3.8 \mathrm{~km}$ north of Shoshone Mountain. The spring discharges from the Volcanics of Oak Spring Butte near the contact between tuff units and the underlying Eleana Formation (Lyles et al., 1990). Discharge from the spring was estimated to be approximately 2.7 Lpm on November 15, 1996 (Hansen et al., 1997). Lyles et al. (1990) evaluated water chemistry and water temperature data collected from July 1980 to April 1982, and concluded that the water is predominantly from local recharge and is relatively young.

\subsubsection{Summary of Spring Discharge Data}

There has been no continuous monitoring of discharges from the springs in the Yucca Flat/Climax Mine Data Compilation Area so the available discharge data for most of the springs in the Yucca Flat area cover only short periods of time. These data are not sufficient to develop accurate, long-term estimates of spring discharge. However, the data characterize the nature of spring flow and provide short-term data on discharge rates that could be used to develop rough estimates of long-term discharge. 
All of the springs in the Yucca Flat/Climax Mine area discharge from perched groundwater above the regional groundwater flow system and do not represent a direct discharge from the flow system. The effect of perched spring discharge is to intercept potential recharge to the regional groundwater system. Some portion of this intercepted recharge is lost to ET and the rest reinfiltrates and continues on to ultimately recharge the regional aquifer. This reinfiltration modifies the areal distribution of recharge. The amount of the discharge lost to ET before reinfiltration has not been thoroughly characterized; however, the discharges likely represent only a small percentage of the total average recharge in the upland areas, and the net effect on recharge is probably small.

\subsection{Mine and Tunnel Discharges}

Tunnel complexes were mined into both Rainier Mesa, located along the northwest border of Yucca Flat and Shoshone Mountain, located along the west central border, from 1957 to 1992, for underground nuclear tests. There are seven tunnel complexes in Rainier Mesa and one tunnel complex in Shoshone Mountain (Figure 8-6). These tunnel complexes are located above the regional water table, but groundwater is locally perched within the zeolitized tuff into which the tunnels were mined in the Rainier Mesa area. Three of the tunnel complexes in Rainier Mesa, E-, N-, and T-Tunnel sustained water inflows from perched groundwater through fractures/faults and silicified zones of sufficient volume to result in drainage from the tunnels. Water was also pumped into the tunnels for operational use, primarily for drilling, and then also drained from the tunnels. Groundwater from E-Tunnel inflows is currently permitted to flow to nearby surface ponds. The N-and T-Tunnels have been sealed with barriers built near their portals, and water has filled the open drifts behind the barriers. Only a few minor seeps of water were encountered in G-Tunnel, and the other tunnel complexes are also relatively dry. No substantial water inflows were encountered in the U-16a Tunnel at Shoshone Mountain, and there is no discharge. During mining of Climax Mine in a granitic stock located in the highlands just northeast of Yucca Flat (Figure 8-6), a small amount of groundwater may also have been discharged to a nearby pond.

The tunnel discharges present a situation similar to the spring discharges discussed in Section 8.3. The tunnels are located above the regional water table and encountered inflows from some fractures and faults only. The tunnels intercept potential recharge to the regional groundwater flow system. The intercepted infiltrating groundwater is then redistributed spatially, with some reduction in total 

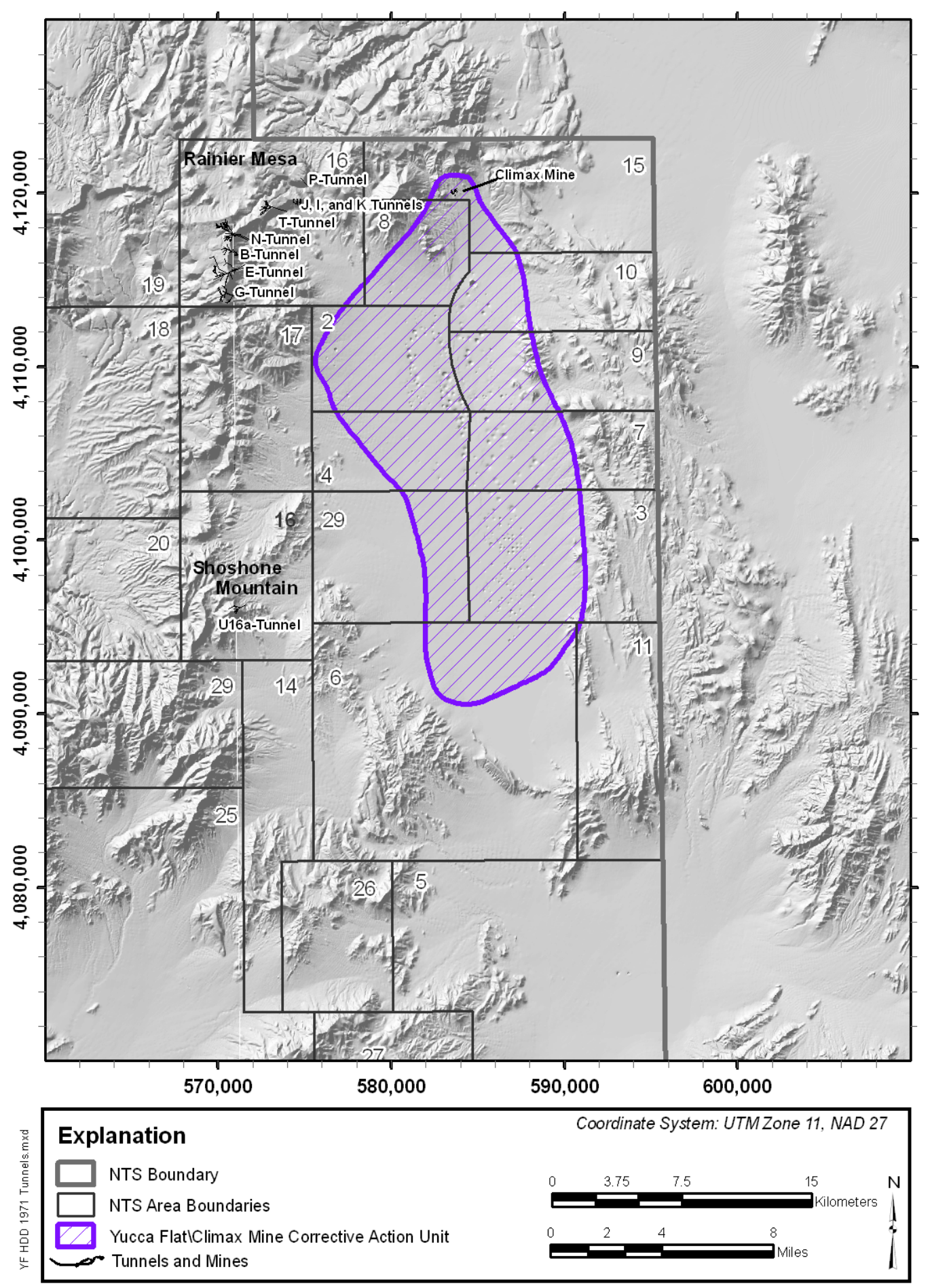

Figure 8-6

\section{Location of Tunnels in the Yucca Flat/Climax Mine Area}


volume due to ET from the surface ponds, to which discharges are routed. This modifies the recharge distribution locally. This information is presented for completeness of documentation for the Yucca Flat/Climax Mine hydrologic system.

\subsubsection{Description of Available Data}

The data available for discharges from the tunnels are varied in quality and completeness.

Information on water discharges from the tunnels has been published in reports on subjects related to the mining of the tunnels and, more recently, discharge from the tunnels. Observations of water discharges can be found in a variety of USGS reports related to the geology and hydrology observed during mining of the tunnels. The $\mathrm{M} \& \mathrm{O}$ contractor collected and compiled information in Annual Site Environmental Reports and predecessors from 1964 to 1995 (DOE/NV, 1997a). Several studies of water quality have been conducted on the discharge water. In 1993, the Defense Threat Reduction Agency (DTRA) assumed responsibility for the tunnels, and information on discharges after this time is contained in informal reports from the ER Contractor to DTRA. In 1996, a permit was issued by the State of Nevada for the continuing discharge from E-Tunnel that requires monthly measurements and reporting. The monitoring information can be accessed at the DTRA office in Mercury or the SNJV Central Files.

There are a variety of miscellaneous reports that contain information on discharges from the tunnels. The most complete is Russell et al. (2003), which reports miscellaneous historical data for discharges of water from N- and T-Tunnels. Groundwater flow through the fractured tuffs at Rainier Mesa were previously investigated and reported in Russell et al. (1987) and Russell et al. (1993). Perched groundwater at Rainier Mesa had been investigated by Thordarson (1965). Other reports containing tunnel discharge information include Clebsch (1960), Davis (1962) on the U16a tunnel, Hoover and Magner (1990), Hansen et al. (1963), and DOE/NV (1996).

A further consideration regarding alteration of groundwater conditions in the area of the tunnels is the fate and effect of water pumped into the tunnels during mining. No data on the quantities of water lost during mining have been identified or compiled. 


\subsubsection{Data Evaluation}

Evaluation of the data for mine and tunnel discharges is based on the standards established for the UGTA project, as defined in Sections 4.3.3.1 and 4.3.3.2. The primary criteria for data quality for discharge data are completeness of records and accuracy of the recorded discharge volumes.

\subsubsection{Data Documentation Evaluation}

The quality level of documentation (DDE_F as defined in Section 4.3.3.1) for most of the tunnel discharge data is 4 . Most of the data were collected by a participating NNSA/NSO ERP organization or other UGTA participating organization using accepted scientific methodology, and the data collection is documented in the cited reports and data sources. However, supporting documentation was not located or evaluated, and the reports were accepted as presented.

\subsubsection{Data Quality Evaluation}

The data (DQE_F as defined in Section 4.3.3.2) are considered to be high quality for measurements made, as qualified in the reports, but the limitations of the availability of tunnel discharge data over the period of interest, 1952 to present, to quantify the yearly discharge should be noted. Only general estimates based on the limited data are possible over this period.

\subsubsection{Tunnel Discharge Data}

Comprehensive compilation of tunnel discharge data has not been conducted for this report.

\subsubsection{Summary of Tunnel Discharge Data}

Historical data from the beginning of tunnel mining until 1993, when a regular program of monitoring discharges from the tunnels was begun, are primarily incidental measurements that do not provide continuous records of changes. The monitoring program only applies to N-, E-, and T-tunnel, which have had sufficient groundwater inflows to result in water discharge from the tunnels. The sealing of T-tunnel in 1993 and N-tunnel in 1994, both of which had substantial groundwater inflows, has eliminated water outflows. However, monitoring of conditions behind the tunnel seals has determined that the tunnel drifts have filled with water, which would distribute groundwater through the open tunnel galleries somewhat differently from the pre mining groundwater condition. The 
effect of the tunnels, similar to the springs, is to modify the local recharge distribution, which would result in only a minor reduction in the total volume, due to ET, while exposed on the ground surface.

\subsubsection{Limitations}

As explained above, the tunnel discharge data have not been compiled and evaluated in detail. The identified data sources do not provide complete, continuous discharge data. Consequently, estimates of the yearly discharge from each tunnel would be highly uncertain. The uncertainty cannot be quantified without a comprehensive data compilation. 


\subsection{Lateral Boundary fluxes}

Inflow and outflow through the lateral boundaries of the Yucca Flat/Climax Mine CAU-scale groundwater flow model constitutes an important portion of the water budget components of the system to be modeled. The other water budget components include CAU-specific precipitation recharge and groundwater system discharge (both natural and well discharge). Precipitation recharge is addressed in Section 7.0 and discharge is addressed in Section 8.0.

There are no practical means of directly measuring groundwater fluxes at the scale and spatial frequency needed to represent the conditions at the CAU flow model boundary. Some estimates were made using hydraulic gradients and hydraulic conductivities to derive the groundwater fluxes similar to the types of estimates made by Blankennagel and Weir (1973). However, the lateral boundary fluxes for the CAU flow model are best estimated indirectly using a regional-scale flow model, which conserves the mass of water over the entire regional flow system and provides better accounting of the flow within the system. A series of alternative regional-scale flow models were developed and calibrated to capture the variability in the boundary fluxes resulting from differences in the conceptualizations of the Yucca Flat/Climax Mine CAU HFM (see Section 5.0) and regional recharge distribution (see Section 7.0).

\subsection{Objectives}

The objective of the regional-scale modeling was to provide a range of lateral boundary fluxes that can be used as calibration guidelines for the Yucca Flat/Climax Mine CAU-scale flow model. Variation in boundary flux was estimated by modifying the DVRFS groundwater flow model (Belcher et al., 2004) and simulating 13 regional-scale flow models using MODFLOW 2000. MODFLOW 2000 is a finite-difference numerical modeling code developed by the USGS (Harbaugh et al., 2000). Calibration for hydraulic properties of selected HSUs was performed using the Yucca Flat/Climax Mine Base HFM and several recharge models. These calibrated hydraulic conductivity values were kept constant for subsequent calculations. The net fluxes into and out of each of the 
CAU-scale model boundaries were then calculated for each model using the MODFLOW utility package ZONEBUDGET (Harbaugh, 1990). The use of 13 regional-flow models allowed for boundary-flux calculations that encompassed the uncertainty associated with several plausible HFMs (see Section 5.0) that honor site data and alternative recharge models developed using different scientific approaches (see Section 7.0).

\subsection{Approach}

Water budgets for the proposed Yucca Flat/Climax Mine CAU flow and transport model domain boundaries, which presently coincide with the Yucca Flat/Climax Mine CAU-specific HFM boundaries (see Figure 1-3), were generated from simulating a series of regional-scale flow models combining alternative HFMs and recharge models. These water budgets are approximate, because the regional-scale flow model MODFLOW cells may not be exactly coincident with the planned Yucca Flat/Climax Mine CAU flow and transport model boundary. The Yucca Flat/Climax Mine CAU flow and transport model will have a considerably finer grid and its boundaries are yet to be determined. The regional model and the procedures described here are expected to provide adequate tools for evaluating the boundary fluxes at the CAU flow model boundaries, because the majority of the flux occurs through the regionally connected LCA.

The steady-state version of the DVRFS flow model (Belcher et al., 2004) was used as the regional model for the analyses. The DVRFS model defines HGUs and the DVRFS HFM in a manner similar to the definition of UGTA CAU-specific HSUs and HFMs. In order to simplify the description of the processes in this section, the abbreviation HSU is used to describe both the HGUs of the DVRFS model and the HSUs for the UGTA CAU-specific models, and the abbreviation HFM refers to both the DVRFS HFM (HDVR) and UGTA CAU-specific HFMs.

The DVRFS model grid (Belcher et al., 2004) served as the base grid for all alternative HFMs. The first of these alternatives is simply the DVRFS HFM (Belcher et al., 2004). The second alternative is referred to as the Yucca Flat/Climax Mine base HFM. This HFM was created by regridding the existing UGTA CAU-scale base HFMs for the Pahute Mesa-Oasis Valley (BN, 2002), Frenchman Flat (BN, 2005) and Yucca Flat/Climax Mine (BN, 2006) areas, and inserting these HFMs into the corresponding DVRFS nodes in the regional model grid. An additional five alternative HFMs resulted from replacing the Yucca Flat/Climax Mine CAU-specific base HFM in the second 
alternative with each of the five Yucca Flat/Climax Mine CAU-specific alternative HFMs (BN, 2006) (see Section 5.0 and Appendix D). Thus, with this procedure, a total of seven DVRFS-Yucca Flat/Climax Mine groundwater flow model alternative HFMs were created (Table 9-1).

Table 9-1

HFM Naming Conventions

\begin{tabular}{|c|l|}
\hline HFM Abbreviation & \multicolumn{1}{|c|}{ HFM Description } \\
\hline \hline HDVR & DVRFS \\
\hline HB & Yucca Flat/Climax Mine Base \\
\hline HPZ & Yucca Flat/Climax Mine Partial Zeolitization \\
\hline HCP & Yucca Flat/Climax Mine Control Point Thrust \\
\hline HHB & Yucca Flat/Climax Mine Hydrologic Barrier \\
\hline HCU & Yucca Flat/Climax Mine Contiguous UCCU \\
\hline HFJ & Yucca Flat/Climax Mine Fault Juxtaposition \\
\hline
\end{tabular}

In addition to considering the uncertainty in the boundary flux conditions introduced by differences in conceptual geologic models (HFMs), the uncertainty associated with approximating recharge was also considered by utilizing alternative recharge models. These alternative recharge models are based on an empirical mass-balance method and its derivatives, a deterministic distributed parameter watershed method, a model calibration method, and a chloride mass-balance method. These recharge models are described in detail in Section 7.0. The seven recharge models are listed in Table 9-2.

Table 9-2

Alternative Recharge Models

\begin{tabular}{|c|l|}
\hline Recharge Model Abbreviation & \multicolumn{1}{c|}{ Recharge Model } \\
\hline \hline RUR & UGTA Revised \\
\hline RUO & UGTA Original \\
\hline RGSNO & USGS Model 1 - with run-on infiltration included in recharge \\
\hline RGSOF & USGS Model 2 - without run-on infiltration included in recharge \\
\hline RDVR & USGS Model 3 - DVRFS calibrated recharge \\
\hline RDRIAI & DRI - Alluvial Mask \\
\hline RDRIAIEI & DRI - Alluvial and Elevation Mask \\
\hline
\end{tabular}


Of the set of 49 possible alternative flow model combinations (seven recharge models and seven HFMs), 13 alternative flow models were selected for lateral boundary flux analyses. These selected alternative flow models included 7 models in which all seven recharge models were applied to the Yucca Flat/Climax Mine base HFM (HB). The other six selected alternative models included each the DVRFS calibrated recharge (RDVR) model applied to all HFMs. This allowed for the comparison of the sensitivity of the regional flow model to HFM variations for a given fixed recharge as well as the sensitivity of the regional flow model to variations in recharge while the HFM was kept constant. Before these simulations, calibration simulations were performed to evaluate a selected best set of hydraulic conductivities representative of the new HFMs. The original DVRFS calibrated hydraulic properties were used as much as possible. Only the most sensitive horizontal hydraulic conductivities, within the Yucca Flat/Climax Mine HFM boundary were calibrated, as discussed in Appendix F. The hydraulic parameters estimated with these calibrations were used for all subsequent lateral boundary flux calculations.

For these calibrations, the parameter estimation and sensitivity analysis capability of the USGS MODFLOW 2000 (Harbaugh et al., 2000) was used to aid in the automation of the calibration process. These results are described in Appendix F.

Lateral boundary fluxes for the Yucca Flat/Climax Mine CAU were calculated for each of the 13 alternative flow models using the utility package ZONEBUDGET (Harbaugh, 1990) that processes the cell-by-cell flow file generated by MODFLOW. The ZONEBUDGET output included inflow and outflow fluxes for lateral boundaries that coincide with the Yucca Flat/Climax Mine CAU HFM boundary.

\subsection{Analysis Results}

The lateral fluxes derived from the regional groundwater flow model simulations using the alternate conceptual models are presented. A comparison of the results and the effects of the hydrostratigraphic framework and recharge models on fluxes are included. The simulation results include a set of files containing the MODFLOW cell-by-cell (in MODFLOW computational volumes are referred to as cells) flow budgets for each of the 13 simulations. The cell-by-cell flow budgets contain the volumetric flow rates across the front, right, and bottom faces of each finite-difference block within the regional-scale flow model. Using the MODFLOW cell-by-cell flow values, the net 
inflow and outflow crossing the lateral boundaries of the CAU-scale model were calculated with ZONEBUDGET.

Table 9-3 summarizes the simulated net inflows and net outflows through each of the lateral boundaries of the Yucca Flat/Climax Mine HFM. All these simulations were run in forward mode (see Appendix F) with identical solver packages and parameters. Table 9-3 shows a stronger groundwater flow through the northern and southern boundaries than through the western and eastern boundaries. This is generally true regardless of the recharge or HSU model. The majority of this flow occurs in the regionally connected LCA with the locally isolated AA contributing very little to the boundary fluxes.

Net flow (Table 9-3) refers to the sum of all the cell-by-cell flow output values along that boundary from the MODFLOW steady-state regional flow simulation. Negative values in Table 9-3 refer to flow out of the specified HFM boundary and positive values refer to flow into the HFM boundary. For example, along the southern boundary for the RUR-HB alternative flow model, a net flow of 21,428 cubic meters per day $\left(\mathrm{m}^{3} / \mathrm{d}\right)$ is flowing south (out of the system) through most of the cells along this boundary. Some of the groundwater may flow southward along some of the HSUs and northward along other HSUs. Similarly, for a particular HSU, groundwater may flow southward from a portion of that HSU and northward along the rest of this boundary. Therefore, the value of $-21,428$ $\mathrm{m}^{3} / \mathrm{d}$ (Table 9-3) represents the net flow rate along this wall, which is southward (out) of the Yucca Flat/Climax Mine CAU system.

The percent difference in water balance closure for the Yucca Flat/Climax Mine HFM area is shown in Table 9-3 and calculated as the difference between total inflow (boundary flux inflow and Yucca Flat/Climax Mine HFM area recharge) and outflow divided by the outflow. Percent difference in DVRFS regional boundary flux, is the MODFLOW calculated value of the percent global mass balance error. Ideally, the mass balance error is less than 0.1 percent (Konikow, 1978). However, an error of 1.0 percent is usually considered acceptable (Anderson and Woessner, 1992). Only global mass balance closure is assessed by MODFLOW, and it is possible, as shown in Table 9-3, to have local errors larger than the total mass balance error.

The larger local mass balance errors are associated with the Maxey-Eakin and chloride mass balance recharge models, which have higher recharge fluxes than the USGS and calibrated DVRFS recharge 
Table 9-3

Total Water Balance for the Alternative Regional Flow Models at the Yucca Flat/Climax Mine HFM

\begin{tabular}{|c|c|c|c|c|c|c|c|c|}
\hline \multicolumn{2}{|c|}{$\begin{array}{c}\text { Alternative Regional } \\
\text { Flow Model }\end{array}$} & \multicolumn{5}{|c|}{ Net Flow } & \multirow{2}{*}{$\begin{array}{c}\text { \% Difference in } \\
\text { CAU-specific } \\
\text { Boundary Flux } \\
\text { ([Inflow + Recharge] } \\
\text { - [Outflow] I } \\
\text { [Outflow]) }\end{array}$} & \multirow{2}{*}{$\begin{array}{l}\text { \% Difference in } \\
\text { DVRFS Regional } \\
\text { Boundary Flux } \\
\text { (MODFLOW } \\
\text { Simulation Output) }\end{array}$} \\
\hline $\begin{array}{l}\text { Recharge } \\
\text { Model }\end{array}$ & HFM & $\begin{array}{c}\text { Northern } \\
\text { Perimeter } \\
\text { Boundary } \\
\left(\mathrm{m}^{3} / \mathrm{d}\right)\end{array}$ & $\begin{array}{l}\text { Southern } \\
\text { Perimeter } \\
\text { Boundary } \\
\left(\mathrm{m}^{3} / \mathrm{d}\right)\end{array}$ & $\begin{array}{c}\text { Eastern } \\
\text { Perimeter } \\
\text { Boundary } \\
\left(\mathrm{m}^{3} / \mathrm{d}\right)\end{array}$ & $\begin{array}{l}\text { Western } \\
\text { Perimeter } \\
\text { Boundary } \\
\left(\mathrm{m}^{3} / \mathrm{d}\right)\end{array}$ & $\begin{array}{c}\text { CAU- } \\
\text { Specific } \\
\text { Recharge } \\
\text { (m²/d) }\end{array}$ & & \\
\hline RUR & $\mathrm{HB}$ & $9,491^{a}$ & $-21,428^{b}$ & 31 & $-1,450$ & 9,942 & -15 & 0.34 \\
\hline RUO & $\mathrm{HB}$ & 9,795 & $-18,229$ & -585 & -852 & 13,507 & 18 & 0.12 \\
\hline RGSOF & $\mathrm{HB}$ & 11,829 & $-15,695$ & -48 & $-2,269$ & 6,325 & 1 & 0.77 \\
\hline RGSNO & $\mathrm{HB}$ & 10,612 & $-16,762$ & -116 & $-1,465$ & 7,805 & 0 & 0.97 \\
\hline RDRIAI & $\mathrm{HB}$ & 7,207 & $-19,317$ & 1,090 & 919 & 11,866 & 9 & 0.59 \\
\hline RDRIAIEI & $\mathrm{HB}$ & 6,814 & $-20,428$ & 828 & 927 & 10,129 & -8 & 0.62 \\
\hline RDVR & $\mathrm{HB}$ & 10,377 & $-16,450$ & 525 & -954 & 6,589 & 1 & 0.87 \\
\hline RDVR & HDVR & 33,681 & $-56,843$ & $-7,594$ & 21,468 & 6,589 & -4 & -0.02 \\
\hline RDVR & $\mathrm{HPZ}$ & 12,980 & $-21,950$ & -100 & 2,480 & 6,589 & 0 & -0.02 \\
\hline RDVR & $\mathrm{HCP}$ & 23,876 & $-36,047$ & $-1,792$ & 7,372 & 6,589 & 0 & -0.02 \\
\hline RDVR & $\mathrm{HHB}$ & 12,934 & $-21,853$ & -96 & 2,425 & 6,589 & 0 & -0.02 \\
\hline RDVR & $\mathrm{HCU}$ & 12,967 & $-21,848$ & -111 & 2,395 & 6,589 & 0 & -0.02 \\
\hline RDVR & $\mathrm{HFJ}$ & 12,978 & $-21,895$ & -101 & 2,423 & 6,589 & 0 & -0.02 \\
\hline
\end{tabular}

${ }^{\mathrm{a}}$ Flow into the HFM area

bFlow out of the HFM boundary 
models. The differences are more noticeable along the edges of Yucca Flat where the topographic gradient is steeper than in the middle of Yucca Flat. However, the base DVRFS model also has one of the greater local mass balance discrepancies in the Yucca Flat area. This is a result of the low permeability rocks surrounding Yucca Flat (the UCCU and LCCU), limiting recharge to the LCA. Therefore, within the Yucca Flat/Climax Mine CAU HFM boundary the uncertainty associated with the fluxes derived from the regional flow model is expected to be larger than the mass balance errors.

As shown in Table 9-3, the southern perimeter boundary outflow for all Yucca Flat HFMs (ranging from 15,695 to $36,047 \mathrm{~m}^{3} / \mathrm{yr}$ ) is less than approximately 60 percent of the DVRFS HFM outflow $\left(56,843 \mathrm{~m}^{3} / \mathrm{yr}\right)$ even when the same recharge model is used; most are less than 50 percent of the DVRFS HFM. Recharge conditions within the Yucca Flat HFMs results in less than approximately 60 percent of the southern outflow, as compared to the DVRFS, even when the same recharge model is used. The highest southern flux UGTA HFM is HCP, the CP Thrust alternative, which places more LCA3 in the northern part of Yucca Flat, and because the LCA3 is assumed to have a higher hydraulic conductivity from fracturing (assumed to be related with overthrusting), this alternative HFM allows more inflow from the regional system to the north into Yucca Flat. Thus, it can be concluded that geologic model uncertainty is exercising the major control on the Yucca Flat water balance. The performance of each model, with respect to calibration targets, is discussed in Appendix F. The HFM model variation has the most significant effect on the western boundary flux of the CAU model. This is mainly due to variations of the UCCU thickness among the alternatives. Recharge model variation has the most significant impact on the northern and southern boundaries.

\subsection{Discussion of Results}

Comparison of the mean, SD, and coefficient of variability (CV) for all 13 simulation results are shown in Table 9-4. This table also shows the mean and SD for recharge over the model area.

Alternative HFMs had significant effects on the calibrated hydraulic heads in the model. This resulted in the residuals (observed minus simulated hydraulic heads) being very sensitive to the HFM alternative. Similarly, the effect of the HFM on the lateral boundary fluxes was also large. The CV for fixed recharge, but varying HFM (RDVR case in Table 9-4), is larger than the fixed HFM, but varying recharge case (HB case in Table 9-4). Therefore, for Yucca Flat/Climax Mine CAU, the HFM has a strong influence on the water balance calculations. The DVRFS HFM has the highest 
north to south flow because of the significant variation in thickness and cross-sectional profiles of the LCA and UCCU between the DVRFS and Yucca Flat alternative HFMs. To demonstrate these differences, three sets of cross-sections were selected along the lines of interest shown in Figure 9-1.

The highest uncertainty occurs on the western and eastern boundaries of the Yucca Flat/Climax Mine HFM, which is generally consistent with the conceptual model of Yucca Flat and the limited data defining the flow system in these areas (compare CV in Table 9-4). Figure 9-2 shows a comparison of the differences in the thicknesses of the HSUs between the DVRFS and Yucca Flat/Climax Mine Base HFM. The Yucca Flat/Climax Mine base HFM has a thicker section of UCCU and a relatively thinner LCA in the center than the DVRFS HFM. The LCCU is raised in the northern parts of the DVRFS model. The differences are more dramatic when the west-to-east cross-sections are compared (Figure 9-3). The LCA in the Yucca Flat/Climax Mine Base HFM is divided into two separate basins by the high in the LCCU. Figure 9-4 shows comparisons of the HSUs in the central portion of the HFMs and also the model block-center nodes. The significant differences in thicknesses of the UCCU and LCA are evident between the two models, especially on the west side.

\subsection{Limitations}

The primary limitation in estimating lateral boundary fluxes used for the CAU flow model stems from the indirect method of deriving the estimates. There are no practical means of directly measuring groundwater fluxes at the scale and spatial frequency needed, or measuring hydraulic gradients and hydraulic conductivities to derive the necessary groundwater fluxes.

The limitations associated with deriving the fluxes from the regional-scale flow model are directly related to the degree to which the model accurately represents the physical system. The flow model representation of the physical system is a function of the: (1) appropriateness of the conceptual model; (2) accuracy of the geologic model used to define parameter heterogeneity; (3) applicability of the recharge model; and (4) degree to which the model can be calibrated. The calibration of the model is dependent on not only how well the model mimics measured data, but how the spatial distribution of target measurements compares to the spatial complexity of the system. Complexity of the physical system or the conceptual model in areas where there are no measurements is inherently uncertain. In addition, the model cannot be calibrated better than the uncertainty associated with the targets. 


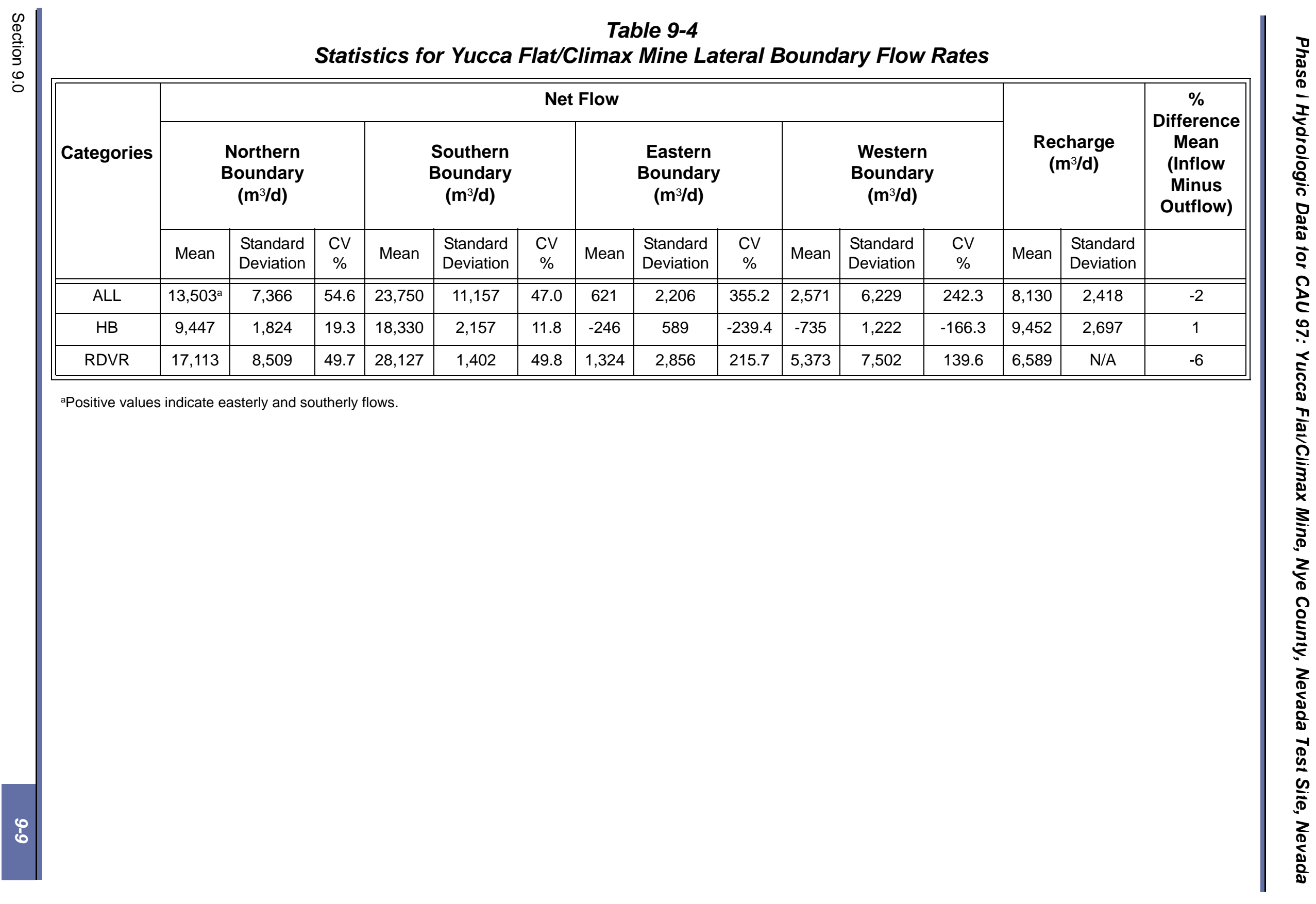




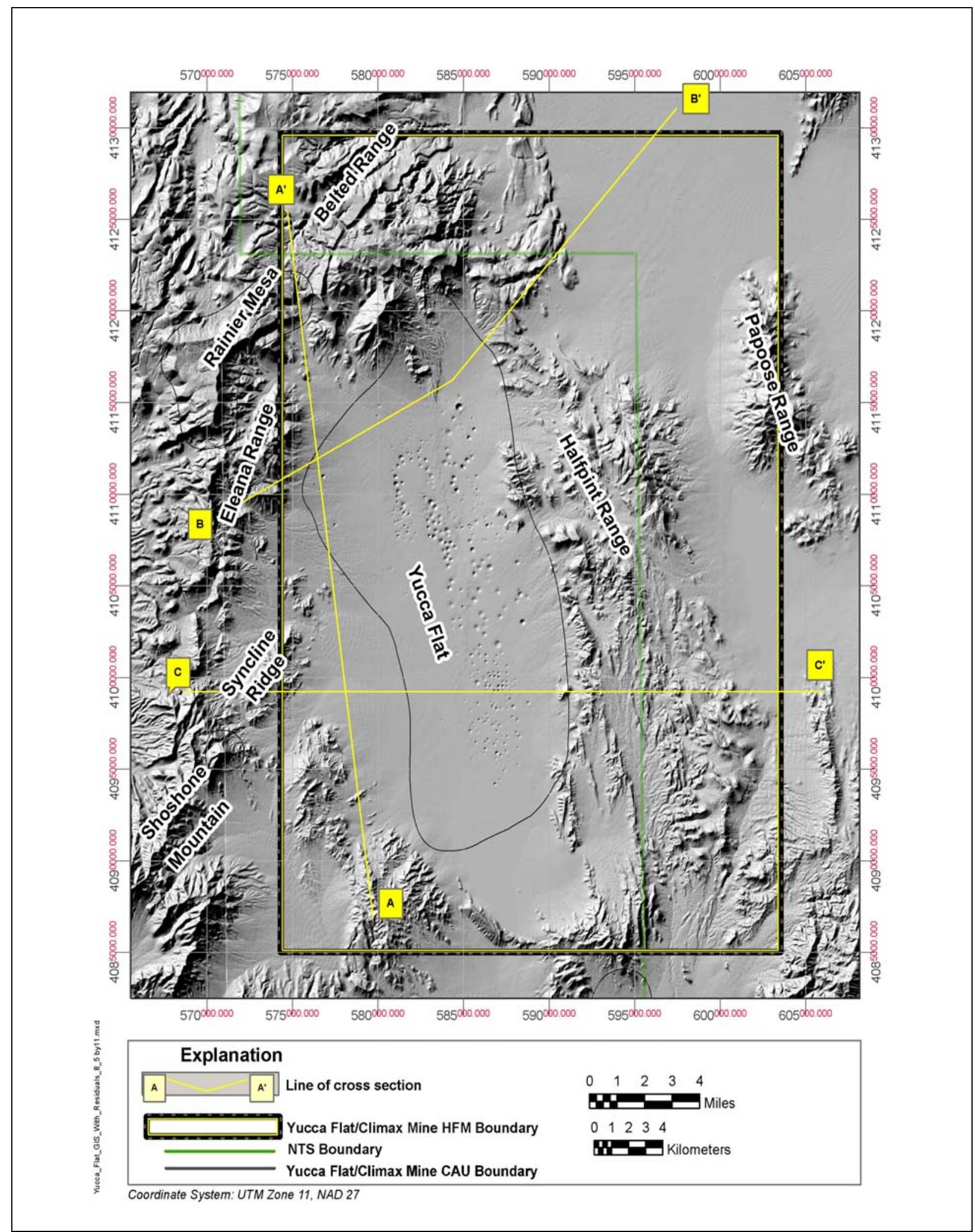

Figure 9-1

Yucca Flat/Climax Mine CAU Area Showing Lines of Cross-Sections 


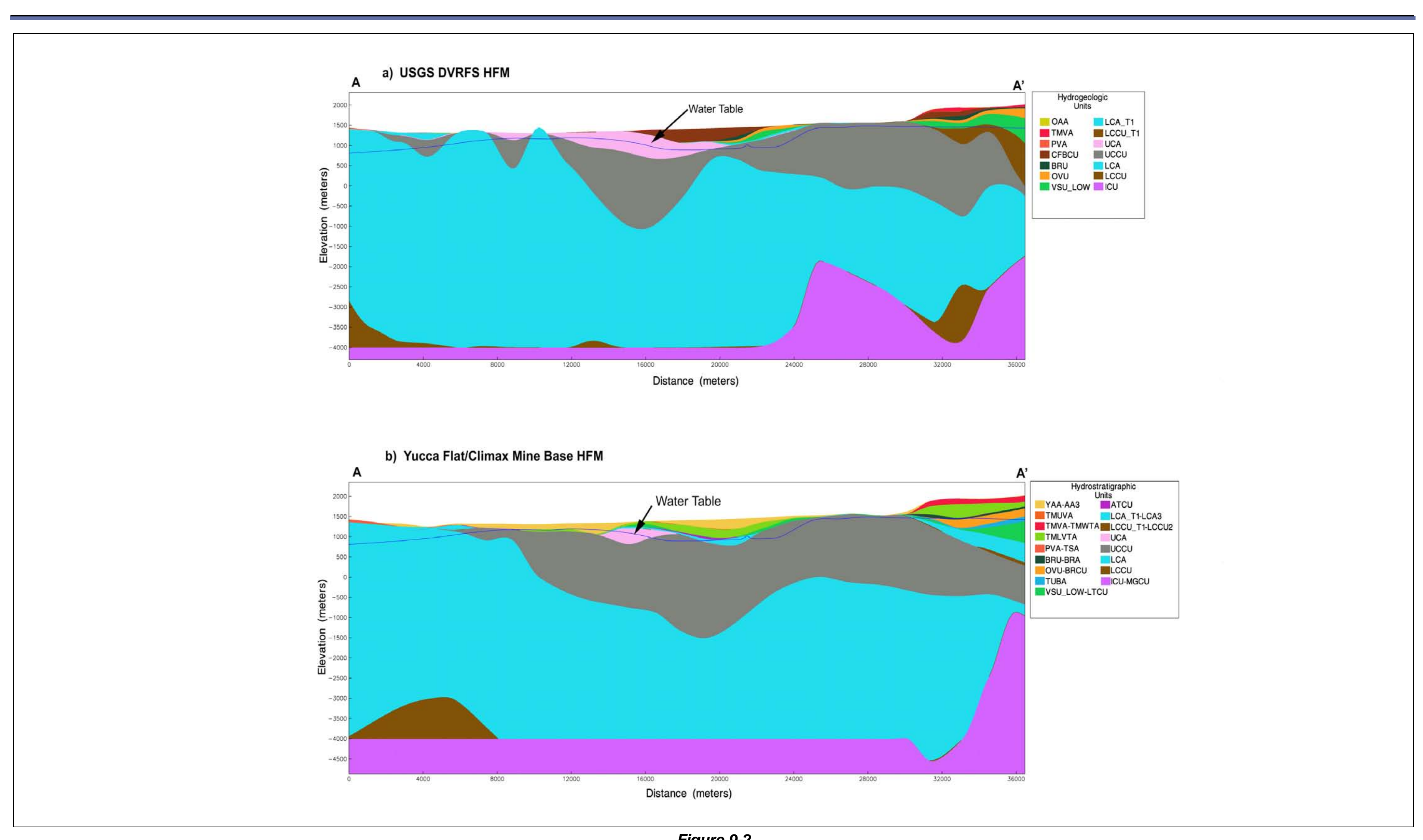

Cross Section A-A' through Yucca Flat/Climax Mine HFM Area 


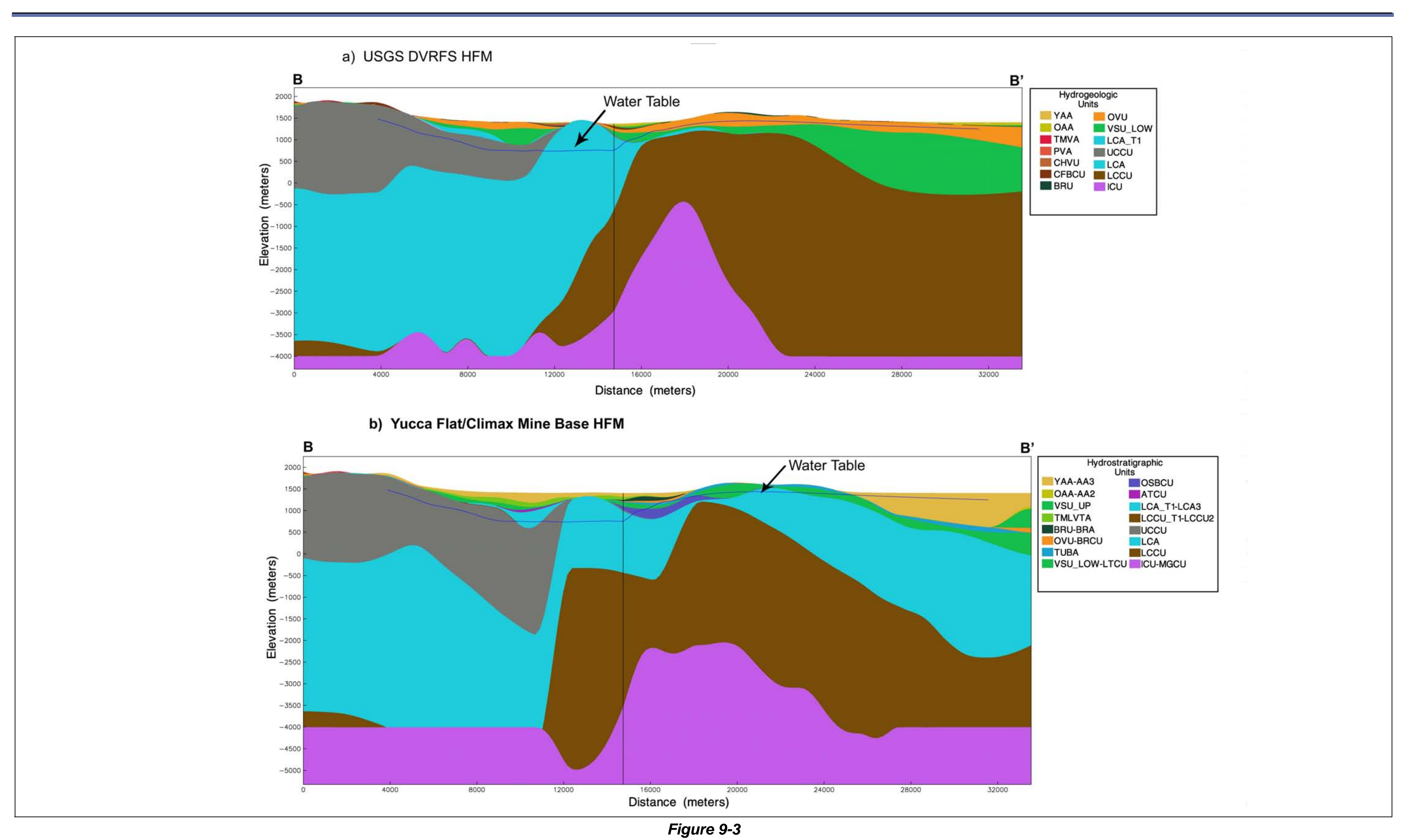

Cross Section B-B' through Yucca Flat/Climax Mine HFM Area 


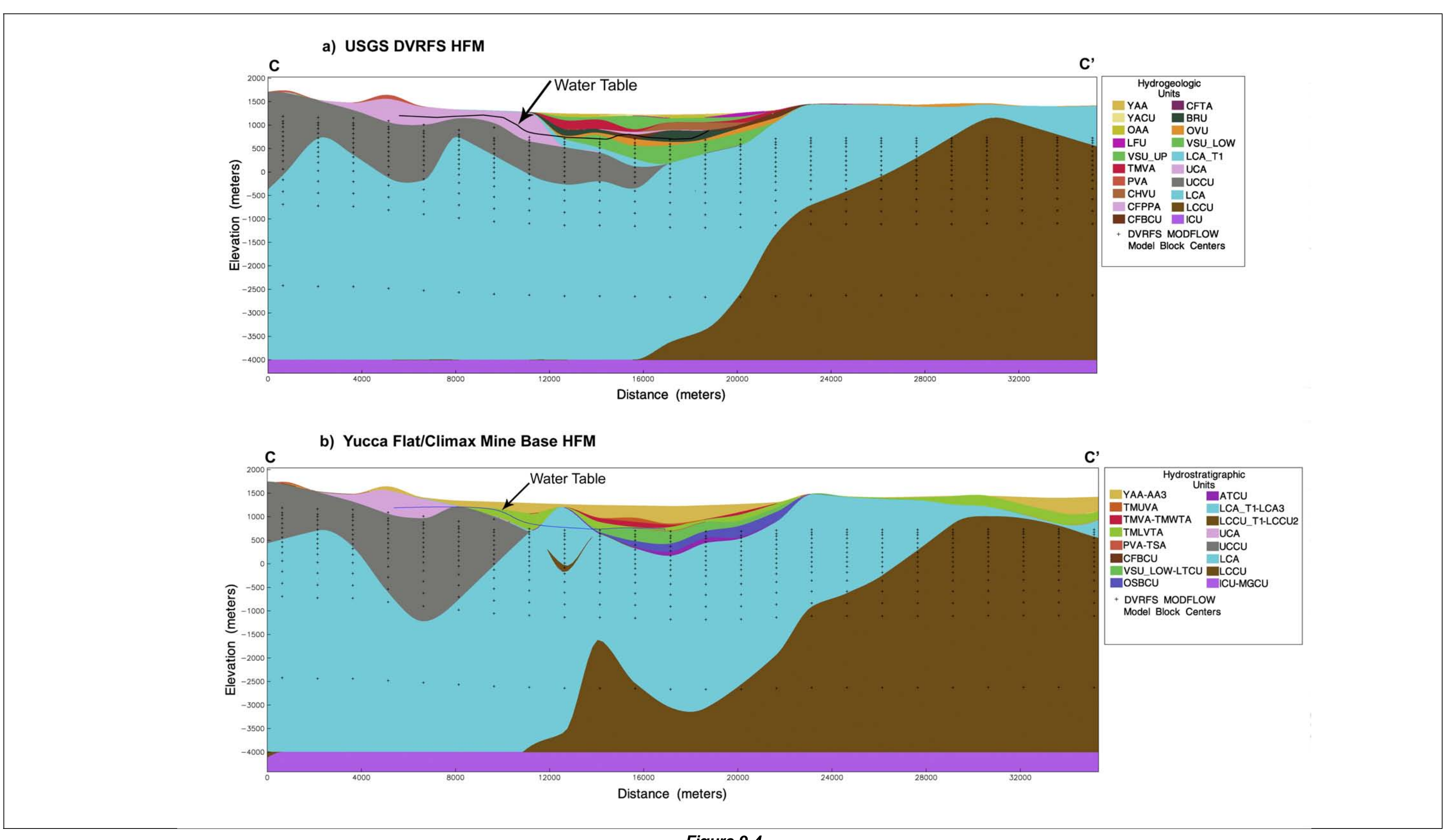

Figure 9-4

Cross Section C-C' through Yucca Flat/Climax Mine HFM Area 
The regional model is applicable to the groundwater flow system at the regional scale with the majority of flow through the LCA and not necessarily representative of the flow within the isolated AA in the Yucca Flat/Climax Mine Flat basin. The lateral boundary fluxes are also dominated by the flow through the LCA and targets in the AA will provide little constraint on these fluxes.

\subsection{Summary}

A set of boundary fluxes to be used with the CAU flow model have been developed based on results generated for 13 regional-scale flow models using MODFLOW 2000. The 13 models represent different HFM conceptual models and recharge models.

The range in net boundary flux across each of the CAU model boundaries (rounded to two significant figures) is summarized in Table 9-5. This approach does not specify the location on the boundary the where flux occurs, rather the bounds on the net inflow or outflow.

Table 9-5

Summary of Net Boundary Flux Ranges for Yucca Flat/Climax Mine HFM Boundaries

\begin{tabular}{|c|c|c|}
\hline Model Boundary & $\begin{array}{l}\text { Range in Net Inflow } \\
\left(\mathrm{m}^{3} / \mathrm{d}\right)\end{array}$ & $\begin{array}{l}\text { Range in Net Outflow } \\
\qquad\left(\mathrm{m}^{3} / \mathrm{d}\right)\end{array}$ \\
\hline Northern & $6,800-33,700$ & 0 \\
\hline Southern & 0 & $15,700-56,800$ \\
\hline Eastern & $30-1,100$ & $50-7,600$ \\
\hline Western & $900-21,500$ & $900-2,300$ \\
\hline
\end{tabular}




\subsection{HYdRaulic HeAD}

Hydraulic head is a fundamental parameter used to constrain groundwater flow modeling. Hydraulic head information for the groundwater flow system in the Yucca Flat/Climax Mine area and vicinity was compiled and analyzed to support CAU-scale groundwater flow modeling. Hydraulic head values were determined primarily from depth-to-water measurements in wells and are associated with the well locations and vertical intervals in the formation (formation access intervals [FAIs]) based on well construction information. The primary objective was to determine representative steady-state hydraulic head values for the flow system that can serve as calibration targets during development of the steady-state flow model. Hydrographs for each water level record were evaluated to identify the representativeness of the head information with respect to measurement reliability, variability, and uncertainty, stability of local groundwater conditions, and long-term trends. Periods of steady-state head were identified, and the mean water level elevation and associated uncertainty during those periods was determined. The vertical interval (FAI) for each steady-state head was identified with respect to the HFM.

The hydraulic head information was evaluated within the context of a simple conceptual model based on the HFM to develop an understanding of groundwater flow in the Yucca Flat/Climax Mine CAU. The conceptual model consisted of an upper potentiometric "horizon," the water table (elevation of the top of saturation for the groundwater flow system), and a lower potentiometric "horizon," head in the LCA. These are designated "horizons," because the head values from wells are not specific to the water table surface, or the top of the LCA, but represent composite heads affected to varying degrees by vertical gradients across completion intervals. There may also be significant local variability in the head distribution for either surface due to local features such as faults and fracturing, which provide local high-transmissivity connection across confining units, and high-pressure areas within the confining units. The available data are not sufficiently specific to resolve the head distribution at the scale of these features. 
The water table and LCA horizons correspond to the uppermost and lowermost heads of the CAU flow system. These horizons are separated by confining units in the middle of the Yucca Flat basin and in the western highlands. Around the perimeter of the Yucca flat basin, the horizons merge due to the structure as presented in detail in Section 5.0. Contours on the discrete head values for the water table and for the LCA would define head potential surfaces that reflect lateral groundwater flow in the uppermost aquifer units (variously the AA, VA, or LFA), and in the lower aquifer (LCA), and vertical flow from the water table to the LCA, where regional groundwater flow occurs.

Interpreted contours for the water table and the LCA have been previously developed and published using the very limited data specific to these contours. The data compiled for this analysis are substantially the same as used for these previous interpretations, and such interpretive contouring was not repeated. These contours do not use the majority of the data or provide locally detailed information. Rather, this data analysis focused on associating the head data with the vertical elevation interval and formation(s), as HSUs, for use in flow modeling. The data, as presented in graphic form for the two potentiometric horizons, are intended to illustrate the complexity of the 3-D head distribution.

Vertical gradients were evaluated based on vertically separated head measurements for wells with successive water level measurements, for different depth intervals; wells with multiple completions, and for wells in close areal proximity with completion intervals at different depths. The generalized vertical gradient distribution can be evaluated by comparing the water table and the LCA potentiometric horizon maps.

There are several areas in Yucca Flat that have been previously investigated for anomalous high-pressure, that is, elevated fluid levels (drilling fluid or water). These areas are loosely defined by the wells with anomalous high fluid levels in Areas 1, 2, 3, 4, 7, and 8, primarily between the Yucca Fault and Carpetbag/Topgallant fault system. The elevated fluid levels are generally attributed to increased pore pressures in the TCUs resulting from underground nuclear testing. The high-pressure in these areas has been persistent over decades and is projected to continue well into the future. Studies indicate that the high pore pressures may be confined to very low conductivity layers of the confining unit HSUs and do not significantly affect adjacent high conductivity HSUs such as the LCA. 


\subsection{Objectives}

There were four objectives for analysis of the hydraulic head information:

1. Determine representative steady-state hydraulic head values assigned to areal locations and vertical elevation intervals, and to HSUs with respect to the HFM, for use as calibration targets for groundwater flow modeling.

2. Evaluate the hydraulic head data and assign with respect to the water table and the LCA, the uppermost and lowermost heads in the groundwater flow system, to determine head distribution for the two potentiometric horizons. Evaluate the variability and features of the head distribution for each horizon.

3. Evaluate the vertical hydraulic head distribution within the context of the head change from the water table to the LCA potentiometric horizons. Also evaluate discrete data on vertical gradient from wells with multiple completion depths or wells in close association with different completion depths.

4. Interpret groundwater flow into, through, and from the Yucca Flat/Climax Mine CAU.

The first objective required identification and compilation of available data relevant to determination of representative, steady-state hydraulic heads. Water level measurements and records were evaluated, well construction data for wells in which there were measurements were evaluated, and the reliability and uncertainty of the data ascertained. Water level hydrographs were used to determine steady-state measurements, a dataset of representative head values for locations and FAIs was compiled, and the FAIs were correlated with the HFM for each well. The steady-state groundwater flow model to be developed for use in predicting contaminant transport will represent the groundwater flow system for the future period of interest, presently 1,000 years. Predevelopment groundwater conditions have been previously considered to be the best guide to determining representative steady-state conditions. However, there is little hydraulic head information predating groundwater development in Yucca Flat, so predevelopment hydraulic head cannot be determined directly. Groundwater production in the Yucca Flat/Climax Mine area started in 1952, became substantial in the early 1960s and continued through the next two decades, declined into the 1990s, and has been fairly constant from the mid 1990s through 2004 at a relatively low rate. The available information was evaluated to determine the best representation of steady-state conditions, considering possible changes from predevelopment to contemporary groundwater conditions, and the uncertainty related to continuing adjustment to changes in groundwater production. The USGS recently 
conducted an Analysis of Ground-Water Levels and Associated Trends in Yucca Flat, Nevada Test Site, Nye County, Nevada, 1951-2003 (Fenelon, 2005), which provides a comprehensive compilation and evaluation of available hydraulic head measurements for Yucca Flat. Additional information was added to the USGS database to complete the dataset for the larger Yucca Flat/Climax Mine Data Compilation Area.

The second objective included determining the representativeness of the steady-state head, based on the FAIs, with respect to the potentiometric horizons. This involved evaluating connections created across different HSUs within each FAI and the conceptual model of the hydraulic head distribution between the water table and the LCA to determine the representativeness of the head for either horizon. The data were sorted according to representativeness for the upper and lower head horizons. The separate datasets were evaluated for contouring, which served as a consistency check for hydraulic head attributions. However, the variability of head values within local areas was too great to be represented by a smooth surface, suggesting that the representativeness of the heads was too complex for detailed contouring. Consequently, a simplified presentation of head values, color-coded according to narrow ranges of head, are presented. These show the same basic, highly generalized head configurations as previous potentiometric maps but directly show the variability. The maps also provide context for evaluating the distribution of information to define the head distribution throughout the area to be modeled.

The third objective was addressed by evaluating the difference between the upper and lower potentiometric horizon maps as well as discrete, paired heads from closely associated wells or heads measured successively with depth of a well. The vertical gradient varies across different HSUs with different hydraulic properties, and also by location, depending on the hydrostratigraphy. With respect to flow modeling, the LCA is the lowest aquifer in the groundwater flow system, as well as the aquifer that conducts regional groundwater flow, and the head in the LCA is the lowest head in the groundwater system. The vertical gradient distribution reflects recharge to the regional aquifer, and is the pathway for contaminant transport from nuclear test cavities to that aquifer.

The fourth objective, evaluation of groundwater flow into, through, and from Yucca Flat, was based on evaluation of the lateral head distribution within the potentiometric horizons and the 3-D head distribution within the context of the HFM and conceptual regional flow model. 
Steady-state is a relative concept in that there is continual long-term change in groundwater conditions due to equilibration to changes in climate, geology, and groundwater use. Interpretations of historical information on groundwater conditions on the NTS suggest that groundwater flow may not be in long-term, steady-state equilibration even before groundwater development activities and underground testing began (Winograd and Thordarson, 1972; Winograd and Doty, 1980). Predevelopment conditions probably reflected near-equilibration to climate changes since the last glacial age. The higher permeability formations equilibrate more rapidly, but are continuously affected by longer-term equilibration in the lower permeability formations. The extent to which this process is occurring in Yucca Flat is not quantified and cannot be determined from analysis of the available hydraulic head measurements.

Groundwater development since the 1950s has since affected local groundwater conditions, and effects of this development are embodied in the data. The predevelopment condition may be directly identified in some wells, depending on the historic data available, and proximity to groundwater production wells. However, in many cases, there is no predevelopment water-level data that can be verified to represent predevelopment steady-state conditions, and representative steady-state heads must be interpreted from the available data (Section 10.5.1). This was primarily based on evaluation of hydrographs with respect to known groundwater production in the area of the well and judgment as to whether production had produced a significant effect.

\subsection{Context for Hydraulic Head Analysis}

The analysis of the hydraulic head data was conducted to provide specific products to meet requirements for developing the Yucca Flat/Climax Mine groundwater flow model. Representative heads were determined within the context of usage for calibration of the groundwater flow model (calibration targets), with representativeness and uncertainties defined to support model calibration. Potentiometric horizons were defined within the context of a hydrologic conceptual model and the HFM to support interpretation of groundwater flow.

\subsubsection{Calibration Target Heads}

The water level in a well is transient, due to several different processes acting over different time scales, resulting in uncertainty in the representative steady-state head value, which can be 
characterized within the context of several categories of uncertainty. Steady-state is defined as the condition in which recharge, discharge, and formation hydraulic characteristics are constant, and the groundwater system is in equilibrium. Background, long-term equilibration to climate changes since the Pleistocene is not well quantified, but any continuing process may be relevant to the time frame over which the steady-state model is meant to apply. Measured water levels since the 1950s are potentially affected by groundwater development within Yucca Flat (see Section 8.0). Due to the distributed development of groundwater production and the inconsistency in collection of most historic water level measurement records, it is not possible to clearly observe the evolution of the effects of groundwater production and estimate the initial state.

Hydrographs can be evaluated to identify periods of apparent steady-state, after accounting for variability caused by short-term water level variations resulting from barometric pressure response and earth tides. Longer-term trends in the hydrographs can be interpreted as equilibration responses to variation in yearly hydrologic conditions, changes in groundwater production, and equilibration to effects of underground nuclear testing. The result of this analysis was a generalized representation of the steady-state condition with qualifiers for both short-term (daily to weekly) and longer-term (yearly to decades) uncertainty, but does not include very long-term (centuries to millenia) trends. The latter two time frames are relevant to groundwater flow modeling, but very long-term trends are undefined from this analysis.

Calibration targets are representative steady-state head values associated with vertical intervals in the HFM. The representative heads are averages of multiple values during time periods, identified based on hydrographs when the well was apparently in equilibrium with the local groundwater system, which presumably was in general equilibrium with natural processes. There is uncertainty in correctly identifying steady-state periods, especially where data are limited, and there is also seasonal and decadal uncertainty due to natural fluctuations in water levels, which may not be incorporated in the standard deviation because of limited periods of available data.

The calibration target values are qualified with the SD of the multiple values, representing variability due to short-period effects such as barometric pressure variation, earth tides (where applicable), and measurement uncertainty. These are treated as random variability even though there are undefined systematic components to these variables due to measurement process factors. There is also a 
systematic uncertainty in the head values due to land surface reference elevation uncertainty and borehole deviation corrections, which is the same for all head values determined for each well, but can vary between wells. There is also a systematic uncertainty resulting from the variation of the temperature profiles for different wells. The variance of the population mean for each dataset was also estimated, which is more appropriate for use in weighting the mean head values during flow model calibration.

The head values, variances, uncertainties, and associated FAIs comprise the dataset developed for flow model calibration. The FAIs associated with head values are often long, and vertical gradients may be present across these intervals. In many cases, the intervals include sections of different HSUs having substantially different hydraulic properties, and consequently, different vertical gradients. The measured heads for the completion intervals are composite values of the gradient across the HSUs within the FAI; weighted by the transmissivity of each HSU interval. These weighted average head values can be used as calibration targets for the flow model by comparing them to equivalent weighted average values from the model. During evaluation of the potentiometric data, it was found that the measured heads for some wells were not representative of the FAI defined from the well drilling and construction information. This is probably due to downhole conditions in the well affecting the connection of the borehole to the formation, typically the result of remnant drilling fluid, fill or bridges in the borehole, or leakage of seals.

\subsubsection{Potentiometric Maps}

Potentiometric maps, either generalized for the water table or for various stratigraphic horizons within the Yucca Flat basin have been previously developed by Winograd and Thordarson (1975) Plates 1 and 2; Doty and Thordarson (1983); Hoover and Trudeau (1987) Figure 2; Hale et al. (1995); Laczniak et al. (1996), and UGTA (IT Corporation, 1996b, Plates 2, 3, 4, and 5; and DOE/NV, 1997b, Plate 3). These maps present conceptualized and generalized head contours. The contouring is based on interpretations of Yucca Flat hydrogeology within the larger structural and hydrologic context, and is smoothed to accommodate variability of the data related to specificity of measurements for the objective head surface, the water table (or generalized ground-water elevation), or the LCA.

The dataset presented in this section includes more wells than are presented on these previous maps to provide greater detail and completeness. The head values for most of these wells generally represent 
composite heads for long intervals across multiple HSUs rather than specific, discrete heads for the water table or the LCA. Consequently, a more complex picture of the 3-D head distribution is embodied in this data, but is difficult to extract. For the purpose of visualizing the potentiometric structure, the representative, steady-state head values for wells were assigned to uppermost and lowermost potentiometric horizons based on the conceptual hydrologic model and hydrostratigraphic considerations. Substantial vertical gradients occur across confining units, and vary across the data compilation area as a result of the hydrogeologic structure.

The uppermost potentiometric horizon, defined as the water table, includes head values representative of the uppermost level of saturation, including both aquifer units and confining units, depending on location. The measured heads are more or less representative of the water table depending upon the depth of the FAI below the level of saturation, and the vertical gradient across the FAI (which is not explicitly known). Formation access intervals extending from near the water table into lower confining units result in composite water levels lower than the actual water table. The lowermost horizon includes heads representative of the LCA. Conceptually, the LCA is the lowest HSU in which there is substantial lateral flow, because it is a transmissive unit that is connected regionally and has the lowest head potential in the vertical. Below the LCA are confining units considered to be the bottom of the flow system, and lateral flow in these units is not thought to be significant. In places where the LCA rises up to or above the water table, the lower potentiometric horizon merges with the water table located within stratigraphically lower HSUs. In places where the LCA is below thick confining units, the head in the LCA is found to be significantly lower than the head in the water table. Formation access intervals extending from overlying confining units into the LCA can result in composite water levels higher than the actual LCA head. Lower carbonate aquifer head data are only available for measurement intervals located high within the LCA, which is projected to have a maximum aggregate thickness of as much as 15,000 ft (Laczniak et al., 1996).

The generalized conceptual model of the hydrostratigraphic structure within the Yucca Flat basin finds the water table within the AA, VA, or TCU HGUs, separated from the LCA (regionally-extensive aquifer unit) by confining units (volcanic and clastic), which is generally thickest in the middle of the basin and pinches out around the perimeter of the basin. Recharge to the basin is primarily from infiltration of precipitation on the surrounding highlands to the water table. 
The difference between the upper and lower potentiometric horizons reflects the vertical gradient across the confining units overlying the LCA and recharge to the LCA.

The assignment of head values for different vertical intervals to these potentiometric horizons was based on evaluation of the representativeness of the head value for the interval relative to the defined objective for each potentiometric horizon. These potentiometric horizons provide the basis for interpreting local groundwater flow directions at each horizon and vertical groundwater movement between horizons. The analysis does not yield head values corrected to each potentiometric horizon, which is typically accommodated by smoothing of contours, resulting in a generalized representation of the potentiometric horizon and an associated uncertainty. This is appropriate because this type of analysis is meant to evaluate groundwater flow on a large rather than local scale. This analysis employs all of the data to evaluate the variability of the potentiometric horizons.

\subsection{Methodology}

Measurements of depth-to-water are the primary data used to determine hydraulic head in conjunction with information about the well in which the measurement was made. Information required to determine hydraulic head includes a reference elevation (land surface-elevation and dimensions with respect to the depth-to-water measurement reference point for the well), and well construction information to identify the vertical FAI associated with the water level in the well. A complete history for the well is evaluated to determine changes in well construction affecting the completion interval at the time of each measurement. The data are qualified with respect to the quality of documentation available for the wells and the measurements, and the accuracy of the methods used to make the measurements. These factors are considered in assigning measurement uncertainty to the resultant head value.

The methodology included the following steps:

- Collect and compile water-level data for the Yucca Flat/Climax Mine area and vicinity, primarily depth-to-water measurements in wells and supporting information on well construction and history. Qualify data for quality of documentation and quality of measurement.

- Correct depth-to-water measurements for true vertical depth as a function of borehole deviation, translate to common reference elevation datums, and compute hydraulic head 
values. In some cases, corrections may also have been made for groundwater temperature out of the normal range.

- Plot head values for each well as hydrographs and evaluate temporal trends to determine the status of the water level record or specific periods of the record. Identify the steady-state condition if present, and determine representative heads for those periods and the uncertainty in the steady-state head values.

- Compile a dataset of representative steady-state heads including the areal location of the measurements, the elevation intervals associated with each measurement, measurement uncertainties, the HSU(s) within the vertical interval, and other qualifying information.

- Determine the applicability of the steady-state heads relative to the water table and the LCA, and also to FAIs intermediate to upper permeable formations, primarily volcanic aquifer units, and the LCA, across lower less-permeable units identified as confining units.

- Evaluate the consistency and adequacy of the head information for defining the potentiometric horizons across the Yucca Flat Data Compilation Area.

- Interpret lateral groundwater flow into, through, and out of the Yucca Flat/Climax Mine CAU based on the potentiometric horizon maps.

- Evaluate vertical gradients from vertically distributed measurement for closely associated wells and using the potentiometric horizon maps.

- Identify and evaluate transient responses to groundwater pumping, based on the hydrograph analysis, in association with groundwater discharge data.

\subsection{Hydraulic Head Data}

A variety of types of data are required to determine hydraulic heads and the associated spatial location assignment for use in the analyses. These data were compiled from a variety of sources of varying quality.

\subsubsection{Data Types}

Wells are the primary source of hydraulic head information. Information has been collected from many wells on the NTS during drilling, and many wells have also been successively modified so that individual water-level data may be representative of different vertical intervals. Some wells include more than one completion interval for which data may be independently acquired. To identify differences between data acquired for different physical configurations or intervals for wells, each 
different configuration or interval is referred to as a site with a unique identifier (common name, which includes depth interval when relevant). Data needed to determine and analyze hydraulic head includes general site information, depth-to-water or pressure measurements and associated measurements, well construction information, and hydrostratigraphic information from the Yucca Flat/Climax Mine HFM.

The data types needed are:

\section{General Site Information}

- Common well name

- Unique site identifier - Borehole Index identification (ID) number

- Site location coordinates (including all surveys)

- Uncertainty in location coordinates

- Land-surface elevation(s) (all surveys)

- Uncertainty in land-surface elevation

\section{Water Level Elevation Data}

- Depth-to-water measurements

- Downhole water pressure measurements

- Reference point/elevation for measurements

- Date of measurement

- Accuracy and uncertainty of the depth-to-water measurement

- Site status at the time of the depth-to-water measurement

- Nearby site status at the time of the depth-to-water measurement

- Other factors that could affect water levels (i.e., underground nuclear tests, earthquakes)

- Barometric pressure at time of measurement

- Groundwater temperature or temperature log

- Continuous monitoring records of water levels and barometric pressure

\section{Well Construction Information}

- Total depth of well

- Well construction diagram

- Screened/slotted/perforated casing interval(s) (top and bottom)

- Open annulus, gravel/sand pack interval(s) (top and bottom)

- Open hole interval(s) (top and bottom)

- Packers (internal, external)/bridge plugs/cement plugs

- Construction flaws/holes in casing

- Well deviation survey 


\section{Stratigraphic/Hydrostratigraphic Data}

- Well lithology log

- Well stratigraphic log

- Completion interval HSU(s)

\subsubsection{Data Sources}

Water-level data historically have been collected in the Yucca Flat area on an ad hoc basis, as wells were drilled or recompleted, and for individual testing programs and projects. Consequently, the historic information generally does not provide complete, continuous records for most wells. A comprehensive water level monitoring program for 41 wells was instituted by the USGS in the early 1990s, and good-quality periodic water level measurements for a distributed selection of wells are available for about the last ten years. These water level measurements provide the best basis for identifying the representative characteristics of current water levels (termed attributes in the database) because of the completeness and consistency of the records. The USGS has recently compiled the historic water-level data and data from their water level monitoring program through calendar year 2003 (Fenelon, 2005). This study is the primary source of water-level data used for this analysis.

\subsection{Data Compilation}

Water level information for surface water, springs and tunnels was excluded from this analysis since these occurrences of surface water were determined to represent perched water conditions at those locations (see Sections 8.4 and 8.5). Only the head distribution within the regional groundwater table and contiguous hydrologic system is of direct interest for groundwater flow modeling, and these data are only available from wells. Well data was also evaluated to ensure that water level information did not represent perched water above the regional water table. In general, this situation does not occur within Yucca Flat but has been observed in wells in the highlands surrounding Yucca Flat.

\subsubsection{Depth-to-Water Data}

The USGS database of water levels and associated information, covering the years 1951 to 2003 (Fenelon, 2005), contains historic water level information compiled from records and literature prior to the advent of the USGS monitoring program, as incorporated in the USGS NWIS database, measurements acquired by the USGS from the ER Contractor, since the advent of the UGTA program, and the measurements made by the USGS since the early 1990s for their comprehensive monitoring 
program. The period of data compilation spans from 1951 (earliest record found) through 2003. The database contains almost 4,000 water level measurements for 216 sites (wells or distinct well completions). This database serves as the primary data source for water-level data and the resultant head values, well location coordinates, land surface elevations and associated accuracies. The USGS evaluated hydrographs of the water levels, and associated historical information, and assigned attributes to each water level measurement designating their interpretation of representativeness with respect to factors affecting water levels. The attributes assigned to water levels by the USGS were adopted and used to identify steady-state water levels for this analysis. The USGS study area was confined to the Yucca Flat basin, while the Yucca Flat/Climax Mine Data Compilation Area was larger, encompassing the basin and surrounding highlands. Additional well and water-level data for the larger area were added to the data from the USGS database.

Information on well construction, well configuration changes, FAIs, and the corresponding HSUs were compiled independently to support specific requirements for the analyses. Data sources for this compilation included historic records and reports.

\subsubsection{General Site Information}

General site information is presented in Appendix C and includes the site common name, unique identifier, site establishment (well completion) date, location coordinates, land-surface elevation, FAI, and the HSUs within the FAI.

\subsubsection{Land-Surface Elevation}

Historically, land-surface elevations at site locations have been determined using a wide variety of methods ranging from estimates using topographic maps, level surveys, to surveys using a Global Positioning System (GPS). Before 1990, most land surface altitude values were determined from standard leveling surveys on a well-by-well basis. These surveys were generally referenced to the nearest benchmark. There are significant discrepancies in some land-surface elevations between historic surveys and subsequent resurveys that may be the result of inaccuracies in benchmark altitudes. Documentation of historical surveys is lacking. The level of documentation (DDE_F [see Section 4.3.3.1]) for historic land-surface elevations is Level 5, due to the lack of standard procedures and documentation for these measurements, unless documentation has been located. 
In support of their recent Yucca Flat water level study, the USGS conducted a differential survey in 2003 to establish consistent reference point elevations for 41 wells in their monitoring network (Fenelon, 2005). The level of documentation (DDE_F [Section 4.3.3.1]) for the 2003 land-surface elevation survey is Level 3 based on standardized procedures and documentation for these measurements. The primary sites used for this analysis were included in this survey.

\subsubsection{Formation Access Interval}

Well construction information was compiled for wells in Yucca Flat and evaluated to identify FAIs and the time period during which each FAI applies. Information sources included the USGS database (Fenelon, 2005), historic records and literature (drilling and completion records, data and completion reports, and miscellaneous data compilation and analysis reports), and ER contractor and $\mathrm{M} \& \mathrm{O}$ contractor drilling and completion reports.

The objective for defining the FAI was to determine the vertical interval of the formation for which the water level in the well was representative. Well construction data of primary interest were the depths to the top and bottom of intervals in the well, which provided pressure/flow communication between the interior of the well and groundwater in the formation. Examples of open intervals include uncased sections of boreholes, perforated intervals of casing (including perforations, slotting, well screens), and unfilled annulus around the casing or gravel packing. There are many variations in the construction of these wells, and the construction of each well was evaluated with regard to the stated objective.

The identified top of the FAI was based on whether the water level was above or below the top of the physical FAI. If the average water level was above the top of the open interval, then the top of the FAI was defined as the top of the open interval, and if the average water level was below the top of the open interval, the top of the FAI was defined as the average depth-to-water. The bottom of the FAI was defined as the lowest point of communication/flow of interior of the well, with the formation through media substantially more permeable than the formation, which allows for the inclusion of filter packs and rubble or fill. 


\subsubsection{Hydrostratigraphic Units in the Formation Access Interval}

Hydrostratigraphic units within the FAI for each site were identified according to the HSU-top elevations for each site in the Yucca Flat/Climax Mine HFM (BN, 2006), which is described in Section 5.0. In a few cases where sites were not in that database, HSU information for the FAIs consistent with the HFM was obtained from BN geologists. The FAIs and the corresponding HSU information are reported in Appendix C that lists the HSUs tops for each site and indicating the vertical length of the FAI interval, in each HSU, and percentage of the total interval. The correlation of the FAI with HSUs is used in evaluation of the representativeness of the steady-state head for the FAI relative to the potentiometric surfaces defined in Section 10.8, allowing consideration of vertical averaging across HSUs in the FAI implicit in the head value. The projected thickness of HSUs below the deepest HSU top encountered by each well, based on the $\mathrm{EV}^{\circledR}$ HFM base model, was used to evaluate the appropriate assignment of steady-state water levels to the different potentiometric horizons.

\subsection{Hydraulic Head Uncertainties}

Hydraulic head is composed of two components: pressure head at the point of measurement and elevation head due to the vertical elevation of the point of measurement. It is necessary to establish both quantities to determine the head. In most cases, the raw data were depth-to-water measurements, which can be referenced to elevation through the land surface elevation survey (or other reference elevation at the measurement location). By definition, the water surface is at zero water pressure head, and the elevation of the water surface provides the head information. There are several sources of uncertainty in the use of depth-to-water measurements to determine the elevation head in addition to the land surface elevation measurement previously discussed. These include uncertainty in the measurement method, due to borehole deviation, and in the representative water surface elevation due to barometric pressure variation and earth tides. There is also uncertainty in the interpretation of the elevation head due to water column density variation. These uncertainties are discussed in the following subsections. 


\subsubsection{Measurement Method Uncertainty}

The uncertainty associated with depth-to-water measurements derives from the method used to measure the water level. The methods most frequently used by the USGS to measure the water level in wells in the Yucca Flat/Climax Mine area and vicinity are calibrated electric cable units (pre-1996), calibrated electric tapes (post-1996), and steel tapes (miscellaneous old measurements). The electric cable units and electric tapes are calibrated annually to a reference steel tape, and calibration factors are determined and applied to the measurements. The accuracy of these devices is given as $0.1 \mathrm{ft}$ $(0.03 \mathrm{~m})$ for the calibrated electric tape and \pm 0.5 to $1 \mathrm{ft}(0.15$ to $0.3 \mathrm{~m})$ for older measurements (Fenelon, 2005). Measurements made by the ER Contractor employ similar equipment with similar uncertainty. Other contractor measurements, primarily prior to 1992, are from fluid density logs and are considered to have an uncertainty of \pm 1 to $2 \mathrm{ft}$.

\subsubsection{Borehole Deviation}

Borehole deviation from true vertical results in groundwater depth measurements that are greater than the true vertical depth to water. Correction of water level measurements for borehole deviation is incorporated in the USGS water level database (Fenelon, 2005). The USGS has determined that the uncertainty of borehole deviation corrections is $0.5 \mathrm{ft}$, and applies corrections for borehole deviation only when the correction is greater than $0.5 \mathrm{ft}$. The method of correction is detailed in Fenelon (2005).

\subsubsection{Barometric Pressure Variation and Earth Tides}

The water level in a well inversely responds to barometric pressure variation, which has historically varied across a wide range. The ratio of the response to the pressure variation is known as barometric efficiency, which is specific for each well and estimated from a long-term, continuous water level/barometric pressure monitoring record. Generally, barometric pressure was not recorded at the time of the water level measurements nor are the necessary long-term monitoring records available; consequently, water level measurements cannot be corrected to a standard barometric pressure. In confined aquifers, earth tides have a daily, periodic effect on water levels. However, direct determination of the magnitude of the earth-tide effect for individual wells also requires individual long-term monitoring records, which generally are not available. Consequently, the water-level data 
have not been corrected for earth tide effects. The USGS has estimated that the combined water level response from barometric pressure and earth-tides is less than $1 \mathrm{ft}$ (Fenelon, 2005).

\subsubsection{Temperature Variation and Temperature Gradients}

The water level in a well reflects the head in the FAI by virtue of the pressure of the water column in the FAI and the height of the water column, as measured by the water surface elevation, is dependent on the density of the water in the water column. Factors affecting the water density are temperature and water composition, specifically dissolved and suspended solids and dissolved and entrained gases. Temperature variation along the water columns in wells is the primary variable affecting the interpretation of head, using the water surface elevation data, and temperature variation between wells is a potentially significant uncertainty affecting the comparison of heads among sites. Generally, changes in the composition of groundwater in wells in Yucca Flat are not enough to significantly affect hydraulic head.

Within Yucca Flat/Climax Mine there is variation in both the temperature profiles within wells and in the temperature ranges of those profiles. To accurately compare heads based on water levels between different wells, the heads must be corrected to a common water density or density profile for the water column. The magnitude of uncertainty resulting from temperature variation is a function of the variation in temperature/temperature profile and the length of the water column. The correction for a linear increase is expressed in the following formula (in consistent units):

$$
n^{\prime}=n\left(\frac{s}{s^{\prime}}\right)
$$

Where:

$n^{\prime}=$ Temperature-corrected length of water column above the point of inflow to the FAI, assumed to be the middle of the FAI

$n=$ Measured water-column length above the point of inflow to the FAI, assumed to be

the middle of the FAI

$s=$ Density of water in the column at the mean measured water temperature

$s^{\prime}=$ Density of water in the column at the reference water temperature

When the temperature variation is not linear, this formula can be applied for every pair of successive water temperature measurements of a temperature log to numerically integrate the temperature effect. 
The USGS evaluated 44 wells in Yucca Flat and determined that water level correction in most wells, relative to a temperature of $30^{\circ} \mathrm{C}$, would be less than $2 \mathrm{ft}$ (Fenelon, 2005). These estimates were based on measured water surface temperatures and an assumed temperature gradient of $0.7^{\circ} \mathrm{C}$ per $100 \mathrm{ft}$. However, the estimated temperature corrections for a few wells ranged up to $-20 \mathrm{ft}$. Generally, there are insufficient data on temperature profiles to calculate an accurate temperature correction or to determine the appropriate temperature gradient. The analysis of the potential magnitude of temperature corrections indicates that there is considerable uncertainty in head associated with temperature variation relative to other uncertainties. Temperature information available for Yucca Flat wells will be evaluated to determine if there is a consistent basis for determining temperature corrections for all of the wells, or the most important ones used for flow model calibration. The application of temperature corrected heads for calibration is also dependent on how temperature is handled for flow modeling. Consequently, any general application of temperature corrections will be determined during flow model development.

\subsection{Steady-State Head Determination}

As discussed in Section 10.2.1, the Yucca Flat/Climax Mine groundwater system is not in true steady-state, nor was it in steady-state before the advent of groundwater development in 1952. This analysis identifies heads that are considered to represent stable flow conditions consistent from historic to contemporary time. These heads were determined by evaluating hydrographs for each site record and supporting information about local groundwater conditions near each site to identify periods of records and/or individual measurements that reflect stability within overall measurement uncertainties, barometric pressure and earth tide-caused variability, and natural fluctuations and trends. Determination of such stability consequently required water level records spanning long periods of time, preferably including the decades of extensive water level production (1960s to 1980s). This evaluation was conducted by the USGS and is documented in the Yucca Flat water level analysis report (Fenelon, 2005). Within the USGS Yucca Flat water level study, attributes were assigned to the individual measurements to identify the interpretation of the representativeness of head values and periods of record (Fenelon, 2005; Table 3).

The attributes of specific interest to the objectives for the head analysis are listed in Table 10-1. Periods of records identified as "Steady State-REGIONAL" with the secondary attribute of 
"Consistent" were selected for estimating steady-state hydraulic heads. Because the objective was a mean water level for the "steady-state" condition, water levels marked as being part of a trend were excluded. The representativeness of steady-state heads was further evaluated by comparing the locations of the "Steady State-Regional," "Consistent" records to those identified as "Transient-REGIONAL," "Declining Trend," and "Rising Trend," and to the distribution of groundwater production. The records marked with those attributes may be correlated with the long-term effects of groundwater development (see Section 8.0) and with natural trends.

Table 10-1

U.S. Geological Survey Water Level Attributes of Interest

\begin{tabular}{|c|c||}
\hline \hline Attribute Name & \multicolumn{1}{|c|}{ Description } \\
\hline \hline \multicolumn{1}{|c|}{ Steady State-REGIONAL } & $\begin{array}{l}\text { General Condition Attribute } \\
\text { in a well that monitors the regional groundwater flow system. }\end{array}$ \\
\hline Transient-REGIONAL & $\begin{array}{l}\text { Water level represents changes from pumping in the regional groundwater } \\
\text { flow system. }\end{array}$ \\
\hline \hline Consistent & \multicolumn{1}{|c|}{ Detailed Condition Attribute } \\
\hline Declining Trend & $\begin{array}{l}\text { Water level appears to be part of a reasonably consistent trend representative } \\
\text { of general water level conditions in the area. }\end{array}$ \\
\hline Rising Trend & $\begin{array}{l}\text { Water level appears to be part of a discernible, overall downward trend. } \\
\text { Possible causes include nearby pumping, decreased recharge, equilibration } \\
\text { following drilling, or depressurization after an underground nuclear test. }\end{array}$ \\
\hline & $\begin{array}{l}\text { Water level appears to be part of a discernible, overall rising trend. Possible } \\
\text { causes include a decrease in nearby pumping, equilibration following drilling, } \\
\text { and above-normal precipitation. }\end{array}$ \\
\hline
\end{tabular}

Source: Fenelon, 2005

One additional well from the USGS database (Fenelon, 2005), UE-2ce, was added to the calibration target list based on review of the hydrograph and after consultation with the USGS. The later record for this well was relatively smooth and consistent, exhibiting a very slow trend. The mean water level for the last 16 years was judged to be of similar representativeness as water level records identified as steady-state. This well is near an underground nuclear test and may have been initially affected; however, the later water level record represents a long-term condition that may be included in flow modeling and is included here. 


\subsubsection{Calibration Target Head Values}

Table 10-2 lists the sites for which stable head values were identified based on the USGS database (Fenelon, 2005) and provides location information, mean of the steady-state water level measurements, SD for the measurements, estimate of the SD for the population, period of the measurements, information on uncertainties of the head values, and FAIs associated with the head values. Appendix $\mathrm{C}$ includes a more complete report on the data for each well, including a hydrograph of the head measurements for each well and information on the HSUs that occur within the FAI, specifying depth intervals, length, and percentage of total length for each HSU. The use of steady-state heads based on different periods of record is justified if they are in fact unaffected by groundwater development. These initial judgments will be evaluated during modeling.

\subsubsection{Explanation of Table 10-2}

The columns headings in Table 10-2 are defined below:

Common name: This is the USGS_local_nm field from Fenelon 2005 and uniquely identifies each water level FAI.

Borehole Index ID: UGTA Borehole Index Database Identifier. This ID is used identify the well in the UGTA Borehole Index.

USGS Site ID: USGS NWIS site identifier. This ID is used by the USGS to identify each unique well configuration.

UTM 11 NAD 27 Coordinates: Coordinates for the well, easting and northing, from the UGTA Borehole Index in the UTM Zone11 NAD 27 coordinate system in meters.

Mean Water Level: Mean of the water level measurements, as elevation, meeting the criteria outlined in Section 10.7 from the USGS Yucca Flat water-level database, in meters. The mean does not include anomalous water level measurements.

Water Level Measurements: Count of the number of water level measurements that were averaged to determine the mean water level. 


\section{Table 10-2}

Yucca Flat/Climax Mine Calibration Target Data

(Page 1 of 4)

\begin{tabular}{|c|c|c|c|c|c|c|c|c|c|c|c|c|c|c|c|}
\hline \multirow{2}{*}{$\begin{array}{l}\text { Common name } \\
\text { (USGS Local Name) }\end{array}$} & \multirow{2}{*}{$\begin{array}{l}\text { Borehole } \\
\text { Index ID }\end{array}$} & \multirow{2}{*}{ USGS Site ID } & \multicolumn{2}{|c|}{$\begin{array}{l}\text { Coordinates UTM Zone } 11 \\
\text { NAD } 27(\mathrm{~m})\end{array}$} & \multirow{2}{*}{$\begin{array}{c}\begin{array}{c}\text { Mean Water } \\
\text { Level } \\
\text { Elevation }\end{array} \\
\text { (m amsl) }\end{array}$} & \multirow{2}{*}{$\begin{array}{l}\text { Water Level } \\
\text { Measurements }\end{array}$} & \multirow{2}{*}{$\begin{array}{c}\begin{array}{c}\text { Water Level } \\
\text { Population } \\
\text { SD }\end{array} \\
\text { (m) }\end{array}$} & \multirow{2}{*}{$\begin{array}{c}\begin{array}{c}\text { Mean Water } \\
\text { Level } \\
\text { Confidence } \\
\text { Interval }\end{array} \\
\text { (m) }\end{array}$} & \multirow{2}{*}{$\begin{array}{c}\begin{array}{c}\text { Surface } \\
\text { Altitude } \\
\text { Accuracy }\end{array} \\
\text { (m) }\end{array}$} & \multirow{2}{*}{$\begin{array}{c}\begin{array}{c}\text { Mean Water } \\
\text { Level } \\
\text { Uncertainty }\end{array} \\
\text { (m) }\end{array}$} & \multicolumn{2}{|c|}{$\begin{array}{l}\text { Period of Steady-State Water } \\
\text { Level Measurements }\end{array}$} & \multirow{2}{*}{\begin{tabular}{|c|}
$\begin{array}{c}\text { Length of } \\
\text { Period }\end{array}$ \\
(years)
\end{tabular}} & \multirow{2}{*}{$\begin{array}{c}\begin{array}{c}\text { FAl Top } \\
\text { Elevation }\end{array} \\
\text { (m amsl) }\end{array}$} & \multirow{2}{*}{$\begin{array}{c}\begin{array}{c}\text { FAl Botton } \\
\text { Elevation }\end{array} \\
\text { (m amsl) }\end{array}$} \\
\hline & & & Easting & Northing & & & & & & & Start Date & End Date & & & \\
\hline ER-3-1-1 (deep) & 550 & 370116115561301 & $594,658.3$ & $4,097,339.0$ & 728.71 & 2 & 0.01 & 2.74 & 0.06 & 2.74 & 9/23/1994 & 6/26/1995 & 0.8 & 570.9 & 550.1 \\
\hline ER-3-1-2 (shallow) & 550 & 370116115561302 & $594,658.3$ & $4,097,339.0$ & 728.83 & 26 & 0.04 & 0.02 & 0.06 & 0.06 & 6/12/1997 & 9/30/2003 & 6.3 & 663.5 & 639.1 \\
\hline ER-3-2-2 (middle) & 551 & 370214116021002 & $585,716.4$ & $4,099,227.8$ & 733.13 & 8 & 0.00 & 0.03 & 0.06 & 0.07 & 3/13/1997 & 12/9/1998 & 1.7 & 429.8 & 418.8 \\
\hline ER- 6-1 (piezometer) & 1939 & 365904115593403 & $589,632.7$ & $4,093,418.7$ & 750.78 & 6 & 0.03 & 0.04 & 0.06 & 0.07 & 3/11/2002 & 9/24/2003 & 1.5 & 755.7 & 730.1 \\
\hline ER- 6-1 main (2129 ft) & 1939 & 365904115593404 & $589,632.7$ & $4,093,418.7$ & 726.98 & 2 & 0.17 & 2.95 & 0.03 & 2.95 & $8 / 5 / 1992$ & $11 / 19 / 1992$ & 0.3 & 644.9 & 550.4 \\
\hline ER- 6-1 main (2243 ft) & 1939 & 365904115593405 & $589,632.7$ & $4,093,418.7$ & 728.57 & 30 & 0.06 & 0.03 & 0.06 & 0.07 & $6 / 7 / 19996$ & 9/24/2003 & 7.3 & 645.6 & 516.4 \\
\hline ER- 6-1-1 & 1940 & 365904115593402 & $589,635.8$ & $4,093,403.8$ & 728.61 & 7 & 0.03 & 0.04 & 0.06 & 0.07 & 7/22/2002 & 9/24/2003 & 1.2 & 636.2 & 574.6 \\
\hline ER- 6-1-2 (1587 ft) & 5203 & 365901115593502 & $589,616.5$ & $4,093,356.9$ & 750.91 & 5 & 0.03 & 0.05 & 0.06 & 0.08 & 2/27/2003 & 9/24/2003 & 0.6 & $1,163.5$ & 715.8 \\
\hline ER- 6-1-2 (3200 ft) & 5203 & 365901115593501 & $589,616.5$ & $4,093,356.9$ & 728.59 & 4 & 0.02 & 0.06 & 0.06 & 0.08 & 1/21/2003 & 9/24/2003 & 0.7 & 658.6 & 224.1 \\
\hline ER- $6-2$ & 1941 & 365740116043501 & $582,235.7$ & $4,090,745.0$ & 745.58 & 39 & 0.28 & 0.10 & 0.06 & 0.11 & 10/12/1994 & $11 / 11 / 2003$ & 9.1 & 757.5 & 250.9 \\
\hline ER-7-1 & 5199 & 370424115594301 & $589,315.1$ & $4,103,275.4$ & 729.38 & 3 & 0.02 & 0.09 & 0.03 & 0.09 & 6/17/2003 & $11 / 17 / 2003$ & 0.4 & 753.2 & 532.2 \\
\hline ER-12-1 (1641-1846 ft) & 2876 & 371106116110401 & $572,411.5$ & $4,115,492.7$ & $1,307.62$ & 23 & 0.18 & 0.08 & 0.03 & 0.08 & 6/16/1998 & $11 / 11 / 2003$ & 5.4 & $1,272.9$ & $1,210.4$ \\
\hline ER-12-1 (3309-3414 ft) & 2876 & 371106116110402 & $572,411.5$ & $4,115,492.7$ & 931.20 & 1 & N/A & N/A & 0.03 & N/A & 9/25/1992 & 9/25/1992 & 0 & 764.5 & 732.5 \\
\hline ER-12-2 (579 ft) & 5201 & 371019116072104 & $577,902.6$ & $4,114,057.7$ & $1,307.70$ & 1 & N/A & N/A & 0.03 & N/A & $11 / 11 / 2003$ & $11 / 11 / 2003$ & 0 & $1,397.7$ & $1,235.9$ \\
\hline TW- 7 & 1747 & 370353116020201 & $585,901.0$ & $4,102,301.1$ & 728.80 & 13 & 0.52 & 0.35 & 0.06 & 0.36 & $2 / 4 / 1958$ & 6/20/1961 & 3.4 & 622.9 & 544.3 \\
\hline$T W-B$ & 1968 & 365849116002101 & $587,779.9$ & $4,092,815.9$ & 739.95 & 95 & 0.09 & 0.04 & 0.06 & 0.07 & $11 / 4 / 1969$ & $11 / 19 / 2003$ & 34 & 729.3 & 687.9 \\
\hline TW- D & 1892 & 370418116044501 & $582,223.9$ & $4,103,327.0$ & 739.87 & 31 & 0.14 & 0.09 & 0.06 & 0.11 & 10/19/1990 & $11 / 18 / 2003$ & 13.1 & 746.9 & 670.7 \\
\hline TW- E (1970 ft) & 1746 & 370321115594201 & $589,361.9$ & $4,101,336.5$ & 748.48 & 4 & 0.03 & 0.49 & 0.31 & 0.57 & $7 / 31 / 1960$ & $11 / 30 / 1960$ & 0.3 & $1,094.8$ & 671.2 \\
\hline TW- E (2430 ft) & 1746 & 370321115594202 & $589,361.9$ & $4,101,336.5$ & 743.70 & 5 & 0.14 & 0.41 & 0.31 & 0.51 & $3 / 10 / 1961$ & 6/20/1961 & 0.3 & $1,094.8$ & 531.0 \\
\hline TW- E (2620 ft) & 1746 & 370321115594203 & $589,361.9$ & $4,101,336.5$ & 729.10 & 7 & 0.34 & 0.40 & 0.31 & 0.51 & $11 / 20 / 1962$ & $9 / 6 / 1963$ & 0.8 & 502.6 & 473.0 \\
\hline$U-2 b s$ & 294 & 370723116033101 & $583,637.6$ & $4,108,733.8$ & 762.84 & 4 & 0.58 & 0.93 & 0.03 & 0.93 & 10/21/1971 & 7/27/1972 & 0.8 & $1,264.1$ & 703.0 \\
\hline U-2dr & 419 & 370802116050301 & $581,340.0$ & $4,109,927.8$ & 748.20 & 13 & 0.29 & 0.25 & 0.03 & 0.25 & $10 / 16 / 1972$ & $5 / 21 / 1974$ & 1.6 & $1,279.0$ & 717.9 \\
\hline U- 2ei & 456 & 370904116040301 & $582,803.6$ & $4,1111,845.1$ & 740.38 & 3 & 0.18 & 0.84 & 0.03 & 0.84 & 4/4/1977 & 4/16/1977 & 0 & $1,283.3$ & 678.9 \\
\hline U - 2ex & 497 & 370826116041901 & $582,414.6$ & $4,110,652.3$ & 752.64 & 2 & 0.00 & 2.74 & 0.03 & 2.74 & 4/29/1983 & 7/22/1983 & 0.2 & $1,278.1$ & 701.7 \\
\hline$U-2 g f$ & 533 & 370728116042001 & $582,427.0$ & $4,108,875.8$ & 754.13 & 3 & 0.17 & 0.83 & 0.03 & 0.83 & 3/30/1987 & 6/24/1987 & 0.2 & $1,259.1$ & 743.3 \\
\hline U-2gh & 539 & 370645116031901 & $583,945.8$ & $4,107,567.1$ & 793.97 & 4 & 0.06 & 0.49 & 0.03 & 0.49 & $5 / 2 / 1989$ & 9/1/1989 & 0.3 & $1,237.5$ & 724.3 \\
\hline U - 3cn 1 & 1011 & 370338116011801 & $586,973.6$ & $4,101,828.2$ & 732.68 & 2 & 0.22 & 3.06 & 0.31 & 3.08 & 6/11/1963 & 6/14/1963 & 0 & 632.2 & 491.9 \\
\hline U - 3cn 3 & 1013 & 370339116011901 & $586,946.3$ & $4,101,855.8$ & 732.59 & 1 & $N / A$ & $N / A$ & 3.05 & $\mathrm{~N} / \mathrm{A}$ & 6/14/1963 & 6/14/1963 & 0 & 630.9 & 492.3 \\
\hline $\mathrm{U}$ - 3cn $4 \mathrm{HTH}$ & 1014 & 370355116013001 & $586,675.8$ & $4,102,350.6$ & 732.71 & 1 & N/A & N/A & 0.03 & N/A & 9/6/1963 & 9/6/1963 & 0 & 628.8 & 545.2 \\
\hline$U-3 c n 5$ & 1015 & 370320116012001 & $586,921.7$ & $4,101,714.5$ & 728.06 & 48 & 0.17 & 0.10 & 0.06 & 0.12 & $11 / 28 / 1973$ & $11 / 17 / 2003$ & 30 & 358.8 & 298.5 \\
\hline
\end{tabular}


Yucca FlattClim Table 10-2

Table 10-2
Mine Calibratior

(Page 2 of 4 )

\begin{tabular}{|c|c|c|c|c|c|c|c|c|c|c|c|c|c|c|c|}
\hline \multirow{2}{*}{$\begin{array}{l}\text { Common name } \\
\text { (USGS Local Name) }\end{array}$} & \multirow{2}{*}{$\begin{array}{l}\text { Borehole } \\
\text { Index ID }\end{array}$} & \multirow{2}{*}{ USGS Site ID } & \multicolumn{2}{|c|}{$\begin{array}{l}\text { Coordinates UTM Zone } 11 \\
\text { NAD } 27 \text { (m) }\end{array}$} & \multirow{2}{*}{$\begin{array}{c}\begin{array}{c}\text { Mean Water } \\
\text { Level } \\
\text { Elevation }\end{array} \\
\text { (m amsl) }\end{array}$} & \multirow{2}{*}{$\begin{array}{l}\text { Water Level } \\
\text { Measurements }\end{array}$} & \multirow{2}{*}{$\begin{array}{c}\begin{array}{c}\text { Water Level } \\
\text { Population } \\
\text { SD }\end{array} \\
\text { (m) }\end{array}$} & \multirow{2}{*}{$\begin{array}{c}\begin{array}{c}\text { Mean Water } \\
\text { Level } \\
\text { Confidence } \\
\text { Interval }\end{array} \\
\text { (m) }\end{array}$} & \multirow{2}{*}{$\begin{array}{c}\begin{array}{c}\text { Surface } \\
\text { Altitude } \\
\text { Accuracy }\end{array} \\
\text { (m) } \\
\end{array}$} & \multirow{2}{*}{$\begin{array}{c}\begin{array}{c}\text { Mean Water } \\
\text { Level } \\
\text { Uncertainty }\end{array} \\
(\mathrm{m}) \\
\end{array}$} & \multicolumn{2}{|c|}{$\begin{array}{l}\text { Period of Steady-State Water } \\
\text { Level Measurements }\end{array}$} & \multirow{2}{*}{\begin{tabular}{|c|}
$\begin{array}{c}\text { Length of } \\
\text { Period }\end{array}$ \\
(years)
\end{tabular}} & \multirow{2}{*}{$\begin{array}{c}\begin{array}{c}\text { FAl Top } \\
\text { Elevation }\end{array} \\
\text { (m amsl) }\end{array}$} & \multirow{2}{*}{$\begin{array}{c}\begin{array}{c}\text { FAl Bottom } \\
\text { Elevation }\end{array} \\
(\mathrm{m} \text { amsl) } \\
\end{array}$} \\
\hline & & & Easting & Northing & & & & & & & Start Date & End Date & & & \\
\hline U- 3jg & 1583 & 370017116014201 & $586,440.9$ & $4,095,646.4$ & 735.32 & 5 & 0.62 & 0.79 & 0.03 & 0.79 & 7/26/1972 & 9/9/1972 & 0.1 & $1,171.5$ & 704.5 \\
\hline$U-\sin 1$ & 1598 & 370326116021101 & $585,667.3$ & $4,101,447.5$ & 731.18 & 3 & 0.88 & 1.94 & 0.03 & 1.94 & $5 / 28 / 1971$ & 7/2/1971 & 0.1 & 820.5 & 623.6 \\
\hline U - 3j, 1 & 1603 & 370353116000601 & $588,764.0$ & $4,102,312.9$ & 750.22 & 6 & 0.18 & 0.36 & 0.03 & 0.37 & 1/19/1972 & 2/3/1972 & 0 & $1,236.4$ & 703.9 \\
\hline U - 3ks & 1654 & 370053116002901 & $588,250.1$ & $4,096,765.0$ & 736.70 & 2 & 0.22 & 3.06 & 0.03 & 3.06 & 6/27/1977 & 10/7/1977 & 0.3 & $1,173.0$ & 718.0 \\
\hline U - 3kv & 1660 & 370020116003701 & $588,070.9$ & $4,095,728.3$ & 738.44 & 24 & 0.15 & 0.14 & 0.03 & 0.15 & 3/4/19886 & 1/28/1991 & 4.9 & $1,170.2$ & 718.2 \\
\hline U - 3mi & 1726 & 370020115593001 & $589,703.9$ & $4,095,777.4$ & 746.08 & 6 & 0.01 & 0.03 & 0.06 & 0.07 & $12 / 11 / 2002$ & $11 / 19 / 2003$ & 0.9 & $1,107.6$ & 674.1 \\
\hline U - 3mt & 1740 & 370348116024301 & $584,879.0$ & $4,102,131.9$ & 771.10 & 6 & 0.07 & 0.33 & 0.03 & 0.33 & $5 / 21 / 1991$ & 6/18/1991 & 0.1 & $1,206.2$ & 767.3 \\
\hline U-7a & 1976 & 370626116015601 & $585,989.4$ & $4,107,000.2$ & 727.41 & 2 & 0.00 & 0.27 & 0.03 & 0.28 & 8/26/1963 & $8 / 26 / 1963$ & 0 & 553.8 & 474.2 \\
\hline U - 7ad (1853 ft) & 2112 & 370613116013601 & $586,483.2$ & $4,106,604.0$ & 751.83 & 2 & 0.02 & 2.74 & 0.03 & 2.74 & 10/27/1972 & 10/28/1972 & 0 & $1,271.8$ & 741.4 \\
\hline$U-7 b c$ & 2167 & 370444116001801 & $588,432.0$ & $4,103,893.8$ & 757.43 & 2 & 0.00 & 2.74 & 0.03 & 2.74 & $11 / 25 / 1981$ & $12 / 1 / 1981$ & 0 & $1,253.3$ & 603.2 \\
\hline U - 7ca & 2214 & 370436116000201 & $588,835.4$ & $4,103,653.9$ & 774.44 & 15 & 0.22 & 0.20 & 0.03 & 0.2 & 12/2/19985 & 10/18/1988 & 2.9 & $1,211.9$ & 744.9 \\
\hline U - 7cb & 2216 & 370514116000601 & $588,718.6$ & $4,104,823.4$ & 761.89 & 11 & 0.16 & 0.23 & 0.03 & 0.23 & 4/7/1987 & 1/24/1989 & 1.8 & $1,215.4$ & 742.6 \\
\hline U - 9 ITS UE-S-25 & 2581 & 370819116022901 & $585,153.6$ & $4,110,463.8$ & 740.16 & 3 & 0.12 & 0.80 & 0.03 & 0.8 & $4 / 1 / 1971$ & $5 / 18 / 1971$ & 0.1 & $1,262.8$ & 668.8 \\
\hline U-10k 1 & 2722 & 370953116030801 & $584,148.2$ & $4,113,350.6$ & 734.30 & 3 & 0.32 & 0.99 & 0.03 & 0.99 & 1/19/1965 & 9/17/1965 & 0.7 & 697.8 & 608.8 \\
\hline$U-10\llcorner 1$ & 2726 & 370917116023701 & $584,922.6$ & $4,112,269.4$ & 733.41 & 3 & 0.42 & 1.14 & 0.03 & 1.15 & 10/29/1971 & 1/14/1980 & 8.2 & 880.7 & 626.8 \\
\hline UE- $1 a$ & 57 & 370254116070601 & $578,394.6$ & $4,100,387.8$ & $1,145.57$ & 45 & 0.15 & 0.07 & 0.06 & 0.1 & $2 / 5 / 1964$ & $11 / 11 / 2003$ & 39.8 & $1,288.0$ & $1,020.0$ \\
\hline UE- $1 \mathrm{~b}$ & 59 & 370254116064201 & $579,004.2$ & $4,100,390.1$ & $1,106.03$ & 46 & 0.12 & 0.06 & 0.06 & 0.09 & 10/15/1964 & 11/18/2003 & 39.1 & $1,279.4$ & 920.3 \\
\hline UE- $1 \mathrm{c}$ & 60 & 370253116055201 & $580,223.0$ & $4,100,394.2$ & 886.79 & 40 & 0.21 & 0.10 & 0.06 & 0.12 & 10/21/1971 & 11/18/2003 & 32.1 & $1,259.6$ & 709.2 \\
\hline UE- $1 \mathrm{~h}$ & 69 & 370005116040301 & $582,983.1$ & $4,095,223.5$ & 743.08 & 10 & 0.10 & 0.22 & 0.06 & 0.23 & 9/17/1991 & $7 / 12 / 1996$ & 4.8 & 567.2 & 194.1 \\
\hline UE- $1 \mathrm{k}$ & 72 & 370218116033101 & $583,731.1$ & $4,099,339.4$ & 745.87 & 5 & 0.29 & 0.50 & 0.31 & 0.58 & 9/14/1969 & 1/21/1973 & 3.4 & $1,201.2$ & 522.1 \\
\hline UE-1L (recompleted) & 73 & 370254116082002 & $576,566.8$ & $4,100,381.8$ & $1,200.22$ & 14 & 0.13 & 0.07 & 0.06 & 0.1 & 9/17/1991 & $11 / 11 / 2003$ & 12.2 & $1,140.3$ & 662.3 \\
\hline UE- 1q $\quad(2437 \mathrm{ft})$ & 22 & 370337116033001 & $583,722.7$ & $4,101,777.7$ & 770.60 & 4 & 0.06 & 0.49 & 0.06 & 0.49 & 4/16/1990 & 9/17/1991 & 1.4 & $1,220.2$ & 501.2 \\
\hline UE- 1q (2600 ft) & 22 & 370337116033002 & $583,722.7$ & $4,101,777.7$ & 739.36 & 9 & 0.04 & 0.04 & 0.06 & 0.07 & 3/21/2001 & 11/18/2003 & 2.7 & 494.5 & 451.5 \\
\hline UE- 2aa (2207 ft) & 156 & 370909116041951 & $582,406.9$ & $4,111,980.8$ & 738.94 & 4 & 0.15 & 0.53 & 0.03 & 0.53 & 8/21/1975 & 8/11/1976 & 1 & $1,301.7$ & 652.5 \\
\hline UE- 2aw & 223 & 370758116040601 & $582,743.7$ & $4,109,794.4$ & 749.35 & 2 & 0.22 & 3.06 & 0.31 & 3.08 & $1 / 21 / 1974$ & 1/29/1974 & 0 & $1,278.6$ & 593.8 \\
\hline UE- $2 \mathrm{ax} 2$ & 231 & 370910116045901 & $581,425.7$ & $4,111,995.4$ & 740.13 & 7 & 0.12 & 0.30 & 0.03 & 0.3 & 2/16/1973 & 2/23/1973 & 0 & $1,318.1$ & 593.3 \\
\hline UE- $2 \mathrm{ce}$ & 319 & 370831116080701 & $576,804.2$ & $4,110,772.7$ & $1,011.07$ & 176 & 0.59 & 0.09 & 0.06 & 0.11 & 8/11/1987 & 11/17/2003 & 16.3 & $1,032.5$ & 949.3 \\
\hline UE- 2dj & 402 & 370823116050001 & $581,406.3$ & $4,110,575.6$ & 745.54 & 4 & 0.35 & 0.69 & 0.03 & 0.69 & 6/18/1971 & $8 / 6 / 1971$ & 0.1 & $1,299.7$ & 623.3 \\
\hline UE- $2 f b$ & 509 & 370736116050301 & $581,365.7$ & $4,109,112.8$ & 763.63 & 8 & 0.56 & 0.51 & 0.03 & 0.51 & $5 / 25 / 1977$ & 10/1/1977 & 0.4 & $1,277.4$ & 452.4 \\
\hline UE- 3e 4-3 (1661 ft) & 561 & 370411116025912 & $584,481.0$ & $4,102,812.6$ & 771.86 & 7 & 0.38 & 0.34 & 0.06 & 0.35 & $5 / 23 / 1990$ & $11 / 18 / 2003$ & 13.5 & 774.6 & 735.6 \\
\hline UE- 4a (2655 ft) & 1766 & 370601116030103 & $584,389.9$ & $4,106,210.5$ & 772.80 & 8 & 0.23 & 0.31 & 0.03 & 0.31 & 6/4/1963 & 12/3/1963 & 0.5 & 801.2 & 484.2 \\
\hline
\end{tabular}


Yucca FlattClima Table 10-2

Table 10-2
Mine Calibratio

(Page 3 of 4)

\begin{tabular}{|c|c|c|c|c|c|c|c|c|c|c|c|c|c|c|c|}
\hline \multirow{2}{*}{$\begin{array}{l}\text { Common name } \\
\text { (USGS Local Name) }\end{array}$} & \multirow{2}{*}{$\begin{array}{l}\text { Borehole e } \\
\text { Index ID }\end{array}$} & \multirow{2}{*}{ USGS Site ID } & \multicolumn{2}{|c|}{$\begin{array}{l}\text { Coordinates UTM Zone } 11 \\
\text { NAD } 27 \text { (m) }\end{array}$} & \multirow{2}{*}{$\begin{array}{c}\begin{array}{c}\text { Mean Water } \\
\text { Level } \\
\text { Elevation }\end{array} \\
\text { (m amsl) } \\
\end{array}$} & \multirow{2}{*}{$\begin{array}{l}\text { Water Level } \\
\text { Measurements }\end{array}$} & \multirow{2}{*}{$\begin{array}{c}\begin{array}{c}\text { Water Level } \\
\text { Population } \\
\text { SD }\end{array} \\
\text { (m) }\end{array}$} & \multirow{2}{*}{$\begin{array}{c}\begin{array}{c}\text { Mean Water } \\
\text { Level } \\
\text { Confidence } \\
\text { Interval }\end{array} \\
\text { (m) }\end{array}$} & \multirow{2}{*}{$\begin{array}{c}\begin{array}{c}\text { Surface } \\
\text { Altitude } \\
\text { Accuracy }\end{array} \\
\text { (m) }\end{array}$} & \multirow{2}{*}{$\begin{array}{c}\begin{array}{c}\text { Mean Water } \\
\text { Level } \\
\text { Uncertainty }\end{array} \\
(\mathbf{m}) \\
\end{array}$} & \multicolumn{2}{|c|}{$\begin{array}{l}\text { Period of Steady-State Water } \\
\text { Level Measurements }\end{array}$} & \multirow{2}{*}{$\begin{array}{l}\text { Length of } \\
\text { Period } \\
\text { (years) } \\
\end{array}$} & \multirow{2}{*}{$\begin{array}{c}\begin{array}{c}\text { FAl Top } \\
\text { Elevation }\end{array} \\
\text { (m amsl) }\end{array}$} & \multirow{2}{*}{$\begin{array}{c}\begin{array}{c}\text { FAl Bottom } \\
\text { Elevation }\end{array} \\
(\mathrm{m} \text { amsl) } \\
\end{array}$} \\
\hline & & & Easting & Northing & & & & & & & Start Date & End Date & & & \\
\hline UE- $4 a(3028 \mathrm{ft})$ & 1766 & 370601116030102 & $584,389.9$ & $4,106,210.5$ & 736.00 & 1 & N/A & N/A & 0.03 & N/A & 11/18/1961 & $11 / 18 / 1961$ & 0 & 386.1 & 343.4 \\
\hline UE- $4 a b$ (2396 ft) & 1843 & 370608116043102 & $582,167.4$ & $4,106,418.8$ & 782.13 & 2 & 0.41 & 3.79 & 0.03 & 3.79 & $8 / 9 / 1974$ & 8/18/1976 & 2 & $1,258.8$ & 550.2 \\
\hline UE- 4ae (2290 ft) & 1851 & 370434116040702 & $582,802.3$ & $4,103,510.9$ & 761.07 & 2 & 0.53 & 4.35 & 0.03 & 4.35 & 6/18/1974 & 8/18/1976 & 2.2 & $1,234.8$ & 560.9 \\
\hline UE- $4 a$ h & 1858 & 370501116041301 & $582,647.0$ & $4,104,363.5$ & 757.70 & 1 & N/A & N/A & 0.03 & N/A & 3/20/1979 & 3/20/1979 & 0 & $1,238.4$ & 393.5 \\
\hline UE- 4av $(1724-2815 \mathrm{ft})$ & 1891 & 370547116041102 & $582,665.5$ & $4,105,777.5$ & 777.57 & 10 & 0.03 & 0.22 & 3.05 & 3.06 & $5 / 9 / 1990$ & 7/11/1990 & 0.2 & 747.7 & 415.1 \\
\hline UE- 4av (1758 ft) & 1891 & 370547116041101 & $582,665.5$ & $4,105,777.5$ & 794.80 & 2 & 0.00 & 2.74 & 3.05 & 4.1 & $7 / 5 / 1989$ & 7/7/1989 & 0 & $1,235.0$ & 737.3 \\
\hline UE- 4av (2815 ft) & 1891 & 370547116041104 & $582,665.5$ & $4,105,777.5$ & 794.55 & 3 & 0.11 & 0.79 & 3.05 & 3.15 & 1/7/1991 & 4/9/1991 & 0.3 & $1,235.0$ & 415.1 \\
\hline UE- $6 d$ & 1954 & 365905116033201 & $583,751.3$ & 4,093,397.3 & 741.42 & 12 & 0.04 & 0.03 & 0.06 & 0.07 & 4/27/19999 & $11 / 19 / 2003$ & 4.6 & 555.3 & 15.5 \\
\hline UE- 6e (2090-2230 ft) & 1960 & 365905116012002 & $587,012.5$ & $4,093,408.8$ & 739.93 & 20 & 0.11 & 0.11 & 0.06 & 0.13 & 2/9/1994 & $3 / 7 / 2000$ & 6.1 & 563.3 & 520.6 \\
\hline UE- 6e (2090-4209 ft) & 1960 & 365905116012001 & $587,012.5$ & $4,093,408.8$ & 740.47 & 15 & 0.27 & 0.22 & 0.06 & 0.23 & 1/10/1980 & $5 / 18 / 1992$ & 12.4 & 563.3 & -82.3 \\
\hline UE-7aa & 2106 & 370412115593601 & $589,492.9$ & $4,102,909.3$ & 729.96 & 5 & 0.61 & 0.77 & 0.03 & 0.77 & $8 / 19 / 1969$ & 10/24/1971 & 2.2 & $1,192.9$ & 641.5 \\
\hline UE-7nS & 2059 & 370556116000901 & $588,643.5$ & $4,106,091.4$ & 730.73 & 145 & 0.21 & 0.06 & 0.06 & 0.08 & $8 / 8 / 1976$ & $11 / 17 / 2003$ & 27.3 & 810.7 & 658.9 \\
\hline UE- $8 \mathrm{e}(2470 \mathrm{ft})$ & 2254 & 371014116051602 & $580,998.1$ & $4,113,987.1$ & 785.72 & 2 & 0.36 & 3.57 & 0.03 & 3.57 & $4 / 11 / 1975$ & 8/16/1976 & 1.3 & $1,346.5$ & 615.2 \\
\hline UE-10 ITS 1 & 2853 & 371154116024601 & $584,643.9$ & $4,117,108.1$ & 997.02 & 4 & 0.27 & 0.61 & 0.03 & 0.61 & 4/27/1971 & 10/28/1972 & 1.5 & $1,342.4$ & 669.7 \\
\hline UE-10 ITS 1 (2040 ft) & 2853 & 371154116024602 & $584,643.9$ & $4,117,108.1$ & 994.91 & 3 & 0.22 & 0.88 & 0.03 & 0.88 & 1/23/1978 & 7/14/1986 & 8.5 & 781.9 & 745.6 \\
\hline UE-10 ITS 3 (1926 ft) & 2855 & 371109116024702 & $584,648.8$ & $4,115,706.7$ & 762.95 & 6 & 0.17 & 0.36 & 0.03 & 0.36 & 3/19/1985 & 9/1/1989 & 4.5 & $1,300.8$ & 739.7 \\
\hline UE-10 ITS 3 (2160 ft) & 2855 & 371109116024701 & $584,648.8$ & $4,115,706.7$ & 756.12 & 5 & 0.86 & 1.03 & 0.03 & 1.03 & $2 / 18 / 1970$ & $12 / 5 / 1970$ & 0.8 & $1,300.8$ & 668.3 \\
\hline UE-10 ITS 5 & 2857 & 371155116031401 & $583,973.5$ & $4,117,105.8$ & 756.96 & 4 & 0.34 & 0.67 & 0.31 & 0.74 & $12 / 5 / 1970$ & $8 / 4 / 1972$ & 1.7 & $1,351.2$ & 666.9 \\
\hline UE-10 ITS 5 (2180 ft) & 2857 & 371155116031402 & $583,973.5$ & $4,117,105.8$ & 772.10 & 3 & 0.53 & 1.31 & 0.31 & 1.34 & 3/16/1973 & $5 / 13 / 1977$ & 4.2 & $1,351.2$ & 713.8 \\
\hline UE-10aa & 2760 & 371131116021501 & $585,438.6$ & $4,116,410.0$ & 993.94 & 4 & 2.30 & 3.20 & 0.03 & 3.2 & $1 / 20 / 1973$ & $1 / 14 / 1980$ & 7 & $1,318.4$ & 920.9 \\
\hline UE-10bf (2144 ft) & 2838 & 371123116025202 & $584,510.1$ & $4,116,147.8$ & 766.27 & 1 & N/A & N/A & 0.03 & N/A & 4/5/1982 & 4/5/1982 & 0 & $1,313.7$ & 683.7 \\
\hline UE-10j (2232-2297 ft) & 2719 & 371108116045303 & $581,526.6$ & $4,115,644.9$ & 736.52 & 25 & 0.07 & 0.03 & 0.06 & 0.07 & $4 / 8 / 1997$ & $11 / 12 / 2003$ & 6.6 & 713.7 & 693.9 \\
\hline UE-10j (2232-2613 ft) & 2719 & 371108116045302 & $581,526.6$ & $4,115,644.9$ & 736.34 & 9 & 0.18 & 0.22 & 0.06 & 0.23 & 2/23/1995 & $11 / 19 / 1996$ & 1.7 & 713.7 & 620.2 \\
\hline UE-10j (2380 ft) & 2719 & 371108116045301 & $581,526.6$ & $4,115,644.9$ & 735.73 & 7 & 0.66 & 0.63 & 0.06 & 0.63 & 6/15/1965 & 6/24/1976 & 11 & $1,377.3$ & 668.6 \\
\hline UE-14a & 3155 & 365550116084201 & $576,155.1$ & $4,087,306.7$ & 820.76 & 3 & 0.18 & 0.84 & 0.03 & 0.84 & $8 / 31 / 1983$ & 9/14/1983 & 0 & $1,298.2$ & 316.7 \\
\hline UE-14b & 3156 & 365550116091101 & $575,427.2$ & $4,087,304.1$ & 819.05 & 40 & 0.17 & 0.09 & 0.03 & 0.1 & $2 / 10 / 1984$ & 11/11/2003 & 19.8 & 701.8 & 205.3 \\
\hline UE-15d WW (1735-6001 ft) & 3186 & 371230116021500 & $585,061.4$ & $4,118,300.8$ & $1,193.49$ & 2 & 0.88 & 6.25 & 0.03 & 6.25 & 3/26/1962 & $3 / 28 / 1962$ & 0 & 869.0 & -356.9 \\
\hline UE-15d WW (5400-6001 ft) & 3186 & 371230116021501 & $585,061.4$ & $4,118,300.8$ & $1,190.48$ & 4 & 3.58 & 4.95 & 0.03 & 4.95 & 10/2/1963 & $1 / 13 / 1983$ & 19.3 & 869.0 & -248.0 \\
\hline UE-15j & 3196 & 371201115573601 & $592,299.1$ & $4,117,406.6$ & $1,316.46$ & 1 & N/A & N/A & 3.05 & N/A & 6/19/1969 & $6 / 19 / 1969$ & 0 & $1,447.2$ & $1,071.4$ \\
\hline UE-15j A-5 & 3198 & 371158115574701 & $592,016.4$ & $4,117,299.8$ & $1,316.77$ & 1 & N/A & N/A & 3.05 & N/A & $9 / 17 / 1969$ & 9/17/1969 & 0 & $1,452.7$ & $1,227.5$ \\
\hline UE-16d WW (2117-2293 ft) & 3235 & 370412116095102 & $574,293.0$ & $4,102,773.4$ & $1,247.53$ & 5 & 0.10 & 0.40 & 0.03 & 0.4 & 7/9/1977 & 7/9/1977 & 0 & 782.5 & 720.3 \\
\hline
\end{tabular}


Phase I Hydrologic Data for CAU 97: Yucca Flat/Climax Mine, Nye County, Nevada Test Site, Nevada

Table 10-2

Mine Calibration Target Data

(Page 4 of 4 )

\begin{tabular}{|c|c|c|c|c|c|c|c|c|c|c|c|c|c|c|c|}
\hline \multirow{2}{*}{$\begin{array}{c}\text { Common name } \\
\text { (USGS Local Name) }\end{array}$} & \multirow{2}{*}{$\begin{array}{l}\text { Borehole } \\
\text { Index ID }\end{array}$} & \multirow{2}{*}{ USGS Site ID } & \multicolumn{2}{|c|}{$\begin{array}{l}\text { Coordinates UTM Zone } 11 \\
\text { NAD } 27(\mathrm{~m})\end{array}$} & \multirow{2}{*}{$\begin{array}{c}\begin{array}{c}\text { Mean Water } \\
\text { Level } \\
\text { Elevation }\end{array} \\
\text { (m amsl) }\end{array}$} & \multirow{2}{*}{$\begin{array}{l}\text { Water Level } \\
\text { Measurements }\end{array}$} & \multirow{2}{*}{$\begin{array}{c}\text { Water Level } \\
\text { Population } \\
\text { SD } \\
\text { (m) }\end{array}$} & \multirow{2}{*}{$\begin{array}{c}\begin{array}{c}\text { Mean Water } \\
\text { Level } \\
\text { confidence } \\
\text { Interval }\end{array} \\
\text { (m) }\end{array}$} & \multirow{2}{*}{$\begin{array}{c}\begin{array}{c}\text { Surface } \\
\text { Altitude } \\
\text { Accuracy }\end{array} \\
\text { (m) }\end{array}$} & \multirow{2}{*}{$\begin{array}{c}\begin{array}{c}\text { Mean Water } \\
\text { Level } \\
\text { Uncertainty }\end{array} \\
\text { (m) }\end{array}$} & \multicolumn{2}{|c|}{$\begin{array}{l}\text { Period of Steady-State Water } \\
\text { Level Measurements }\end{array}$} & \multirow{2}{*}{$\begin{array}{l}\text { Length of } \\
\text { Period } \\
\text { (years) } \\
\end{array}$} & \multirow{2}{*}{$\begin{array}{l}\text { FAl Top } \\
\text { Elevation } \\
\text { (m amsl) }\end{array}$} & \multirow{2}{*}{$\begin{array}{c}\begin{array}{c}\text { FAl Bottom } \\
\text { Elevation }\end{array} \\
\text { (m amsl) } \\
\end{array}$} \\
\hline & & & Easting & Northing & & & & & & & Start Date & End Date & & & \\
\hline UE-16f (1479ft) & 3236 & 370208116092402 & $574,999.7$ & $4,098,960.0$ & $1,305.82$ & 39 & 0.07 & 0.05 & 0.06 & 0.08 & $3 / 5 / 1985$ & $11 / 11 / 2003$ & 18.7 & $1,023.5$ & 976.3 \\
\hline WW- 2 (3422 ft) & 549 & 370958116051512 & $581,005.7$ & 4,113,499.6 & 736.57 & 21 & 0.07 & 0.03 & 0.06 & 0.07 & 3/10/1998 & 11/12/2003 & 5.7 & 581.1 & 319.3 \\
\hline WW- 3 (1800 ft) & 1971 & 365942116032901 & $583,827.5$ & $4,094,554.7$ & 742.84 & 24 & 0.06 & 0.03 & 0.06 & 0.07 & 3/12/1997 & $11 / 19 / 2003$ & 6.7 & 841.3 & 661.1 \\
\hline WW- A (1730 ftt) & 1745 & 370142116021100 & $585,713.5$ & $4,099,194.2$ & 732.41 & 1 & N/A & N/A & 0.06 & N/A & 8/28/1960 & $8 / 28 / 1960$ & 0 & 747.2 & 693.9 \\
\hline WW- A (1870 ft) & 1745 & 370142116021101 & $585,713.5$ & $4,099,194.2$ & 732.90 & 9 & 0.40 & 0.34 & 0.06 & 0.34 & 9/20/1960 & $11 / 19 / 2003$ & 43.2 & 747.2 & 651.2 \\
\hline WW- C (1373-1701 ft) & 1969 & 365508116003501 & $588,214.5$ & $4,086,124.7$ & 726.09 & 7 & 0.81 & 0.75 & 0.00 & 0.75 & 6/20/1961 & 6/16/1962 & 1 & 783.1 & 677.5 \\
\hline WW- c-1 & 1970 & 365500116003901 & $588,235.5$ & $4,086,101.5$ & 726.79 & 1 & 0.21 & 0.20 & 0.00 & 0.2 & 1/25/1963 & 5/11/1998 & 35.3 & 918.6 & 693.0 \\
\hline
\end{tabular}


Water Level Population SD: Standard Deviation of the population of water level measurements used to estimate the mean. The water level population SD is a function of the water level measurements themselves. It is calculated as:

$$
\sigma=\sqrt{\frac{\sum_{1}^{n}\left(x-x_{a v g}\right)^{2}}{(n-1)}}
$$

Where $\mathrm{x}$ is a water level measurement and $\mathrm{n}$ is the total number of water level measurements

Mean Water Level Confidence Interval: 95 percent confidence interval of the mean water level. Incorporates the variance of individual water levels from the mean and the estimated error of water level measurements due to measurement method. The Mean Water Level Confidence interval incorporates the measurement uncertainty of each measurement and is calculated as:

$$
=\sqrt{\frac{\sum_{1}^{\prime \prime}\left(\left(x-x_{\text {avg }}\right)^{2}+x_{\text {meas }}^{2}\right)}{(n-1)} \times t(0.025,(n-1)) \times \frac{1}{\sqrt{n}}}
$$

where $t(0.025,(n-1))$ in the " $t$ value" from Student's distribution with a confidence level of 0.05 and (n-1) degrees of freedom and $x$ means is the estimated uncertainty of the given measurement due to the measurement method.

Surface Altitude Accuracy: Estimate of surface elevation accuracy as included with the USGS water-level data set. The surface elevations are used to calculate the water level elevations.

Mean Water Level Uncertainty: Estimate of the uncertainty for the Mean Water Level based on the Mean Water Confidence Interval and the Surface Altitude Accuracy.

Period of Steady-State Water Level Measurements: First and last date of water level measurements used to estimate mean water level.

Length of Period: The length of the period water levels used to estimate the mean covers (in years). 
FAI Top Elevation: Elevation of the top of the formation access interval for water level measurements used to estimate the mean water level.

FAI Bottom Elevation: Elevation of the bottom of the formation access interval for water level measurements used to estimate the mean water level.

\subsubsection{Additional Representative Head Values}

Table 10-3 lists additional sites, for which head values have been identified, that may be used for calibration of the steady-state flow model. The water level information for wells in Frenchman Flat that are within the Yucca Flat/Climax Mine Data Compilation Area were imported from the Frenchman Flat water level analysis conducted for the Frenchman Flat hydrologic data documentation (SNJV, 2004e). Water level information for several other wells that are within the Yucca Flat/Climax Mine Data Compilation Area but outside of the USGS study area are also provided. The quality of the information for these wells is not as good, but these wells provide information around the data compilation area perimeter where there is sparse or no other information. The lesser quality of the information may be reflected in the greater SD for the mean head elevation and greater uncertainty. Additional information for these wells is provided in Appendix C.

\subsubsection{Variations in Steady-State Head Record Periods}

Table 10-2 shows the periods over which identified steady-state heads vary from short periods of records (days) to long periods (decades) from the early 1960s to the present. The identified steady-state heads represent time periods across the entire range of the periods of record (1950s to present). The different records can be sorted according to the time period: predevelopment of groundwater, during the period of major groundwater production (1960s through 1980s), or after the period of greatest production. No cases are listed where there have been two distinct steady-state head periods. Conglomeration of the mean steady-state head values from all of these records presupposes that there has been no substantial impact of groundwater development on the general state of head in the Yucca Flat basin. This is the apparent situation based on the evaluation of the individual records of available measurements and review of records that cover the overall time period. However, the variability of head values in any area and the lack of well-distributed long-term records makes it difficult to evaluate the consistency of steady-state heads across Yucca Flat at the 
Table 10-3

Additional Water Level Information

(Page 1 of 2)

\begin{tabular}{|c|c|c|c|c|c|c|c|c|c|}
\hline \multirow{2}{*}{$\begin{array}{l}\text { Common Name } \\
\text { (USGS Local } \\
\text { Name) }\end{array}$} & \multirow{2}{*}{$\begin{array}{l}\text { Borehole } \\
\text { Index ID }\end{array}$} & \multirow[t]{2}{*}{ USGS Site ID } & \multicolumn{2}{|c|}{$\begin{array}{c}\text { Coordinates } \\
\text { UTM Zone } 11 \text { NAD } 27 \\
\text { (m) }\end{array}$} & \multirow{2}{*}{$\begin{array}{c}\begin{array}{c}\text { Mean Water } \\
\text { Level } \\
\text { Elevation }\end{array} \\
\text { (m amsl) }\end{array}$} & \multirow{2}{*}{$\begin{array}{c}\begin{array}{c}\text { Standard } \\
\text { Deviation }\end{array} \\
(\mathrm{m})\end{array}$} & \multirow{2}{*}{$\begin{array}{c}\text { Water Level } \\
\text { Measurements }\end{array}$} & \multirow{2}{*}{$\begin{array}{c}\text { FAI Top } \\
\text { Elevation } \\
\text { (m amsl) }\end{array}$} & \multirow{2}{*}{$\begin{array}{c}\begin{array}{c}\text { FAI Bottom } \\
\text { Elevation }\end{array} \\
\text { (m amsl) }\end{array}$} \\
\hline & & & Easting & Northing & & & & & \\
\hline Army-1 WW & 3648 & 363530116021401 & $586,119.8$ & $4,049,799.8$ & 721.87 & 0.24 & 12 & 687.3 & 366.0 \\
\hline $\begin{array}{c}\text { ER 5-3 } \\
\text { (3 in. shallow) }\end{array}$ & 5149 & 365223115561703 & $594,654.8$ & $4,081,116.8$ & 734.57 & 0.06 & 17 & 734.0 & 687.3 \\
\hline ER 5-3 (3 in. deep) & 5149 & 365223115561702 & $594,654.8$ & $4,081,116.8$ & 734.08 & 0.19 & 15 & 408.4 & 335.3 \\
\hline $\begin{array}{c}\text { ER 5-3 } \\
\text { (main/composite) }\end{array}$ & 5149 & 365223115561705 & $594,654.8$ & $4,081,116.8$ & 734.55 & 0.07 & 18 & 575.8 & 239.6 \\
\hline ER 5-3 \#3 & 5197 & 365223115561704 & $594,641.7$ & $4,081,144.0$ & 734.59 & 0.06 & 13 & 586.5 & 467.9 \\
\hline $\begin{array}{c}\text { ER 5-4 } \\
\text { (piezometer) }\end{array}$ & 5198 & 364928115574802 & $592,448.9$ & $4,075,696.3$ & 733.49 & 0.07 & 6 & 732.1 & 705.3 \\
\hline $\begin{array}{c}\text { ER 5-4 } \\
\text { (main/composite) }\end{array}$ & 5198 & 364928115574801 & $592,448.9$ & $4,075,696.3$ & 733.34 & 0.06 & 7 & 430.4 & -184.4 \\
\hline RNM-1 & 1920 & 364928115580101 & $592,142.9$ & $4,075,697.8$ & 731.31 & 0.36 & 6 & 675.6 & 628.0 \\
\hline RNM-2 & 1921 & 364923115575701 & $592,221.5$ & $4,075,527.4$ & 733.58 & NA & 1 & 733.6 & 668.7 \\
\hline RNM-2s & 1922 & 364922115580101 & $592,137.1$ & $4,075,482.9$ & 733.64 & 0.07 & 24 & 734.6 & 601.8 \\
\hline TW-3 & 1928 & 364830115512601 & $601,931.8$ & $4,074,015.8$ & 725.52 & 0.23 & 26 & 696.5 & 495.0 \\
\hline UE-11a & 2861 & 365259115571601 & $593,171.1$ & $4,082,194.8$ & 733.79 & N/A & 1 & 733.9 & 651.9 \\
\hline UE-11b & 2863 & 365315115562701 & $594,393.8$ & $4,082,708.1$ & 743.71 & $\mathrm{~N} / \mathrm{A}$ & 1 & 743.7 & 700.4 \\
\hline UE-5 PW-1 & 1936 & 365105115565801 & $593,655.7$ & $4,078,714.2$ & 733.79 & 0.05 & 71 & 734.3 & 713.5 \\
\hline UE-5 PW-2 & 1937 & 365152115565701 & $593,669.6$ & $4,080,144.3$ & 733.74 & 0.07 & 88 & 734.2 & 709.7 \\
\hline UE-5 PW-3 & 1938 & 365201115581601 & $591,708.1$ & $4,080,410.5$ & 733.75 & 0.07 & 44 & 735.4 & 715.0 \\
\hline UE-5c WW lower & 1901 & 365011115584702 & $590,970.0$ & $4,077,006.9$ & 734.50 & 0.21 & 5 & 645.1 & 162.9 \\
\hline UE-5f & 1905 & 365213115564401 & $593,975.0$ & $4,080,785.4$ & 734.82 & $\mathrm{~N} / \mathrm{A}$ & 1 & 734.9 & 670.9 \\
\hline UE-5n & 1919 & 364915115574101 & $592,627.1$ & $4,075,283.9$ & 733.84 & 0.08 & 15 & 729.5 & 726.5 \\
\hline WW-1 & 3854 & 364844115541301 & $597,789.8$ & $4,074,403.6$ & 727.25 & N/A & 1 & 727.3 & 700.5 \\
\hline
\end{tabular}


Table 10-3

Additional Water Level Information

(Page 2 of 2)

\begin{tabular}{|c|c|c|c|c|c|c|c|c|c|}
\hline \multirow{2}{*}{$\begin{array}{l}\text { Common Name } \\
\text { (USGS Local } \\
\text { Name) }\end{array}$} & \multirow{2}{*}{$\begin{array}{l}\text { Borehole } \\
\text { Index ID }\end{array}$} & \multirow[t]{2}{*}{ USGS Site ID } & \multicolumn{2}{|c|}{$\begin{array}{c}\text { Coordinates } \\
\text { UTM Zone } 11 \text { NAD } 27 \\
(\mathrm{~m})\end{array}$} & \multirow{2}{*}{$\begin{array}{c}\begin{array}{c}\text { Mean Water } \\
\text { Level } \\
\text { Elevation }\end{array} \\
\text { (m amsl) }\end{array}$} & \multirow{2}{*}{$\begin{array}{c}\text { Standard } \\
\text { Deviation } \\
(\mathrm{m})\end{array}$} & \multirow{2}{*}{$\begin{array}{c}\text { Water Level } \\
\text { Measurements }\end{array}$} & \multirow{2}{*}{$\begin{array}{c}\text { FAl Top } \\
\text { Elevation } \\
\text { (m amsl) }\end{array}$} & \multirow{2}{*}{$\begin{array}{c}\text { FAI Bottom } \\
\text { Elevation } \\
\text { (m amsl) }\end{array}$} \\
\hline & & & Easting & Northing & & & & & \\
\hline WW-4 & 1974 & 365418116012601 & $586,951.8$ & $4,084,570.2$ & 844.62 & 0.01 & 2 & 824.9 & 647.8 \\
\hline WW-4A & 1975 & 365412116013901 & $586,649.5$ & $4,084,371.8$ & 844.59 & 0.12 & 6 & 810.9 & 640.8 \\
\hline Watertown-1 & 3855 & 371440115483401 & $605,605.4$ & $4,122,437.2$ & $1,204.20$ & N/A & 1 & $1,182.3$ & $1,149.1$ \\
\hline Watertown-2 & 3856 & 371439115480001 & $606,421.1$ & $4,122,445.0$ & $1,079.30$ & N/A & 1 & $1,246.9$ & $1,019.9$ \\
\hline Watertown-3 & 3857 & 371539115500301 & $603,381.5$ & $4,124,240.7$ & $1,322.50$ & N/A & 1 & $1,306.3$ & $1,243.5$ \\
\hline Watertown-4 & 3858 & 371537115555001 & $603,062.6$ & $4,124,102.5$ & $1,320.70$ & $\mathrm{~N} / \mathrm{A}$ & 1 & $1,319.8$ & $1,190.3$ \\
\hline $\begin{array}{c}\text { ER-12-3 } \\
\text { (piezometer) }\end{array}$ & 5452 & 371142116125101 & $569,748.4$ & $4,116,592.1$ & $1,871.07$ & 0.15 & 3 & $2,251.0$ & $1,580.4$ \\
\hline $\begin{array}{l}\text { ER-12-3 (main } \\
\text { completion) }\end{array}$ & 5452 & 371142116125102 & $569,748.4$ & $4,116,592.1$ & $1,301.68$ & 0.23 & 5 & $1,505.7$ & 755.0 \\
\hline $\begin{array}{c}\text { ER-12-4 } \\
\text { (piezometer) }\end{array}$ & 5453 & 371311116105901 & $572,473.2$ & $4,119,345.6$ & $1,818.38$ & 0.52 & 6 & $2,097.9$ & $1,419.8$ \\
\hline $\begin{array}{l}\text { ER-12-4 (main } \\
\text { completion) }\end{array}$ & 5453 & 371311116105902 & $572,473.2$ & $4,119,345.6$ & $1,313.75$ & 1.91 & 6 & $1,335.6$ & 965.6 \\
\hline ER-16-1 & 5276 & 370031116121102 & $570,900.2$ & $4,095,916.3$ & $<851.92$ & N/A & 1 & $1,297.5$ & 837.9 \\
\hline
\end{tabular}

UTM Zone 11 NAD 27 - Universal Transverse Mercator, Zone 11, North American Datum 1927 
level of uncertainty for the values. The presumption of continuous steady-state will be considered during development of the groundwater flow model, and calibration targets selected to avoid uncertainty related to this assumption.

\subsection{Potentiometric Horizon Maps}

Hale et al. (1995) presents a detailed compilation of Yucca Flat water-level data through 1991, identifying a single representative measurement for each included well, and a contour map of Yucca Flat water table potentiometric contours. These contours are interpreted within a specified hydrogeologic conceptual model and reflect an updated interpretation from an earlier contour map by Doty and Thordarson (1983). This contour map includes delineation of four high-pressure areas believed to have resulted from underground nuclear testing (Section 10.13). The mean steady-state head data compiled in this section were reviewed for development of potentiometric maps specific to two horizons of the HFM model.

Plate 6 shows the location and steady-state head values for all of the wells listed in Tables 10-2 and 10-3. Head values were then plotted on separate maps for wells judged to represent the water table or the head in the LCA. As discussed in Section 10.2.2, these two potentiometric horizons are useful for interpretation of the head structure of the Yucca Flat basin.

The FAIs for the wells were evaluated with respect to the HSUs in the FAI, the stratigraphic position of those HSUs in the vertical structure of the HFM model, a conceptual model of the hydraulic head structure of the Yucca Flat basin, and the vertical position of the measured water level with respect to the FAI to assign the head to the appropriate potentiometric horizon. This evaluation was structured according to the scheme discussed in Appendix $\mathrm{C}$ wherein FAIs were categorized with respect to the conceptual model. These were first assigned as representative for either of the two potentiometric horizons according to a general evaluation the FAI situation. The assignments were then reviewed individually and adjusted based on evaluation within the context of the potentiometric horizon maps. Some wells were eliminated or reassigned due to inconsistencies greater than the general variability within the horizon; judged according to reasonable expectation. These inconsistencies can generally be attributed to non-quantified modifications of the effective FAIs resulting from situations such as drilling fluid in the borehole and fill or bridges subsequent to completion. Such situations generally result in restriction of the effective FAI to the upper part of the borehole due to blockage of the lower 
part of the borehole. There is often anecdotal information (driller reports or other notes) to support the suspicion that the effective FAI is different from the recorded construction.

\subsection{Water Table Potentiometric Horizon}

Plate 7 (a) shows the location and steady-state head values for the wells identified as representative of the water table (Table 10-3). Wells plotted are those with representativeness levels of 1 (very representative) and 2 (less representative), indicated with different symbols. The water levels are binned into elevation intervals, identified by color-coded symbols for the well locations, that are wider than the individual uncertainty and local variability to provide a simplified view of the variation of head with location. This map shows the general elevation distribution of the water table potentiometric horizon within the Yucca Flat basin, which is consistent with previous contour maps of the water table configuration, specifically Winograd and Thordarson (1972), Doty and Thordarson (1983), Hale et al. (1995), Laczniak et al. (1996), DOE/NV (1997b). Those previous maps used information for selected wells that provided information specific to the water table, and interpreted the contour configuration based on a variety of hydrologic considerations. However, most wells do not provide information specific to the water table, and the head information has too much variability to contour without such a large degree of smoothing that the actual water level for each well is poorly-honored. The water table head dataset will be used within the context of a 3-D flow model, which will account for the vertical gradient that is inherent in the head values. Consequently, contours of the water table were not developed, because they would have no specific value for the modeling, and there was no basis for a contour map significantly improved from previous maps.

The color-coded head distribution for the water table shows these features: the water table declines into the center of the basin from the western side and generally declines to the south along the center of the basin. There are two areas in the center of the basin where there appear to be local sinks. These areas closely agree with locations of potential leakage through the TCUs to the LCA that were identified on an alternate HFM model referred to as the "fault juxtaposition model" in which the throw on the Yucca Fault brings near-surface permeable units in direct contact with the LCA. 


\subsection{Lower Carbonate Aquifer Potentiometric Horizon}

Plate 7 (b) shows the location and steady-state head values for the wells identified to represent the LCA, according to the same scheme as for the water table. These are head values for the LCA, but include one well that is completed in underlying confining unit, the LCCU, which defines the lowest head potential in the groundwater system in that location where the LCA is not present.

These head values, when viewed alone and with regard to the uncertainties for the head values, show a very simple configuration with gradient from the west to east and north to the south. Previous generalizations of the LCA head have shown a trough structure with the axis running north to south, down the middle of Yucca Flat, which was an interpretation based on selected heads for the wells and on the geologic structure. Contouring of hydraulic head on the regional scale indicates groundwater flow consistent with those interpretations. However, there is presently no additional data to confirm that interpretation.

\subsection{Vertical Head Differences}

Differences in head between different vertical intervals can be observed in many locations in Yucca Flat. In some cases, wells have been successively modified so that the FAI has changed vertical location. Situations with steady-state head values for different vertical intervals can be identified in Tables 10-2 and 10-3 where there are multiple entries for the same well common name, which has been modified with a depth interval in parentheses. There are also wells in which there are multiple well completions with different depth intervals at the same location. These wells are also found in Tables 10-2 and 10-3 with modifiers for the well common name that specify different depth intervals, or other designations such as deep or shallow, or piezometer. The FAI depth intervals for these different completions are included in Tables 10-2 and 10-3 and also in Appendix C, which provides HSU information. Finally, vertical gradients can also be locally evaluated by identifying wells in close proximity that are completed in different depth intervals. Fourteen locations are listed where this information is available.

Vertical water level differences are addressed in the USGS Yucca Flat water level study (see Fenelon, 2005, Table 9 and Figure 19). Table 9 lists 27 sites where vertical differences in water levels between different vertical intervals can be observed, and these are shown graphically on 
Figure 19. The USGS study includes instances of vertical water level differences based on single or few measurements of the individual water levels, while Tables 10-2 and 10-3 only present instances where sufficient record is available to identify steady-state water levels for the compared well completions. The two different evaluations provide similar information, but the USGS evaluation includes more sites due to the different criteria for representative water levels.

In general, vertical gradients are observed from overlying HSUs downward to the LCA. Head differences of up to $36 \mathrm{~m}$ are observed across substantial thicknesses of TCUs. The water level or head differences are a function of the thickness of the TCUs between the FAI, and the LCA, as well as varying with location in Yucca Flat. There are high-pressure areas where water levels are higher within the TCUs than in the overlying aquifer HSUs or the underlying LCA. However, these areas are a special case and are discussed in Section 10.13. Head differences between different depth intervals within the LCA are small; most clearly observed at the ER-6-1 well site where information on composite heads across different depth intervals is available. There are also instances of vertical gradients upwards from the LCCU to the LCA.

The vertical head difference between the water table and the LCA horizons can be seen by comparing the potentiometric maps (Plate 7 (a), water table, and Plate 7 (b), LCA). The head in the LCA is lower than the water table in the center of the Yucca Flat basin along the north-south axis where TCUs separate these two potentiometric horizons. Around the perimeter of the basin, the LCA rises into the water table and there is no potentiometric gradient across intervening TCUs. Along the western highlands, there is a large vertical head difference between formations overlying the UCCU (volcanics and LCA3) and the LCA beneath the UCCU. This is most clearly seen in ER-12-1 where the head in the uppermost completion interval (nominally UCCU, but in an isolated, embedded section of LCA3) is about $380 \mathrm{~m}$ lower than the head in the LCA (lowest two completion intervals) across a vertical interval separation of about $446 \mathrm{~m}$ of the Eleana Formation. Note the head in the LCA is reported as $\pm 23 \mathrm{~m}$ (see Russell et al., 1996, Table 34), so the exact gradient is uncertain, but substantial.

\subsection{Fiscal Year 2005 Rainier Mesa Wells}

Three wells, ER-12-3, ER-12-4 (both located on Rainier Mesa) and ER-16-1 (on Shoshone Mountain), were drilled and tested in the western highlands during the second half of FY 2005. They 
are located in the Yucca Flat/Climax Mine data compilation area, but were completed after data compilation ended for this document, so data for these wells are not included in the tables. Analysis of the drilling data is not yet complete, and steady-state water levels have not been established. However, initial information from these wells is available and useful for evaluating conditions in the western highlands. Wells ER-12-3 and ER-12-4 are completed in LCA3, and the heads are similar to the uppermost ER-12-1 completion interval at about 1,300 m amsl, which is below the top of the LCA3. These wells include piezometers completed in volcanic tuffs at depths about 75 to $85 \mathrm{~m}$ above the top of the LCA3. The heads in those piezometers are 570 and $505 \mathrm{~m}$ above the LCA3 head, respectively. It is not clear if the heads in the volcanics should be considered water table or perched. These head differences reflect the large vertical gradients that occur across the confining units. The head in ER-16-1, completed in the LCA, is less than $863 \mathrm{~m}$ amsl, which indicates the LCA head to the west of Yucca Flat is substantially below the water table head, and the regional flow in the LCA to the west of Yucca Flat is distinct from the apparent inflow from the west in the upper HSUs. These data also reflect the large vertical gradients that occur across the confining units along the western boundary.

\subsection{High-Pressure Zone}

As mentioned in Section 10.8, Hale et al. (1995) defines four areas of elevated head, where water level measurements made subsequent to underground nuclear testing are substantially higher than the pre-testing map of Doty and Thordarson (1983). The largest area of high-pressure occurs in Areas 1, 2, 3, 4, 7, and 8, between the Yucca Fault and Carpetbag/Topgallant fault system. Hale et al. (1995) also identified three other areas of high-pressure: the first in Areas 8 and 2 centered on U-8n, the second in Areas 7 and 3 centered on U-7ca, and the third in Areas 3 and 6, centered on UE-6e. Some areas on the west side of Yucca Flat identified as high-pressure have high head in the confining units related to the steep gradients, to the west and north, down to Yucca Flat.

Laczniak et al. (1996) presents a brief discussion of the literature for the high-pressure areas. Both documents include references to reports on a variety of sites where comprehensive records are available. Hoover and Trudeau (1987) provided an interim, updated water table contour map that is not as comprehensive as the Hale et al. (1995) map. This map includes an analysis relating the incidence of high-pressure to density of underground nuclear testing. For many of the wells in the 
high-pressure areas, there are some pretesting data to support the interpretation of increased pore pressures after underground nuclear testing. There is also information suggesting anomalous high pressures in a few wells prior to local testing.

Recently, two analyses of groundwater flow in the high-pressure areas have been conducted, culminating in two reports of local ground flow models for specific areas of high-pressure. The USGS study results are reported in Halford et al. (2005). The LANL study is in progress; a report will be published following completion of the study. These reports address the mechanisms for generating high pore pressures and evaluate the persistence of the high-pressures. The LANL study considers the effect on groundwater flow specifically regarding potential transport of contaminants due to the high-pressure areas to the LCA. In general, the reports conclude that the high-pressures occur locally within very low permeability formations, and do not result in substantially increased groundwater flow to the LCA from the high-pressure areas. The high-pressure areas do not appear to represent integral features of the hydrologic system, but rather localized and compartmentalized pore-pressure.

\subsection{Groundwater Flow Interpretation}

The potentiometric horizon maps were used to evaluate horizontal and vertical groundwater flow in the Yucca Flat/Climax Mine area and vicinity. The water table potentiometric map indicates lateral groundwater gradient from the perimeter of the basin on the northeast, north, and west sides toward the center of the basin, and there is a decrease in head to the south along the center axis. Water level elevations are very high to the west in wells that are completed in volcanic HSUs and LCA3 overlying the UCCU or in the UCCU. These high water levels reflect the low permeability of the formations upgradient from Yucca Flat to the west and north. The wells for which there are steady-state data on the east side of the basin were identified by Hale et al. (1995) as affected by the high-pressure phenomenon, and there are no data from the highlands. Consequently, there is no particular lateral gradient clearly evident on the east side of the basin.

There are two interior low spots in the water table potentiometric horizon, one in the north near $\mathrm{U}-10 \mathrm{k} 1$, and a larger area to the south in the vicinity of TW-7 and U-3jn 1. The locations of these two low spots are nearby the postulated traces of the fault juxtaposition alternate HFM, where the throw on the Yucca Fault creates windows through the TCUs from the water table to the LCA. 
The LCA potentiometric map indicates lateral gradient from the west side of the basin toward the east side and from the north to the south. The three lowest head values for the LCA are for U-7a, WW-C, and WW-C-1, which are closely associated with adjoining faults, and could be construed as defining the central axis for groundwater flow to the center of the basin and for flow southward. It should be noted that these wells have been used for water production since the early 1960s, although WW-C has not been pumped since 1995 .

\subsection{Limitations of the Data and Analysis}

Limitations of the hydraulic head data are:

1. The overall period of record for water level measurements is from 1950 through the present. However, the records for many wells are only for short periods within that time span, and those short periods occur throughout the overall period rather than contemporaneously. Groundwater development in Yucca Flat took place during the first several decades starting in the early 1960s, and few records predate the start of substantial pumping. Also, few long-term records are available for wells not directly affected by pumping. Consequently, there is little basis for observing or identifying any long-term, slow water level trends that may be the result of groundwater production.

2. The data are sparse with respect to long period records, regularity of measurements, areal distribution of water level records of similar time periods, areal distribution of wells for both potentiometric horizons, and consistency of FAIs with respect to length and vertical locations. Since 1990, records with more regularly spaced measurements have been collected for a core group of wells providing long-term records that can support characterization of the variability and trends.

Major limitations for analysis of the hydraulic head data for the Yucca Flat/Climax Mine area and vicinity are:

1. The amount of uncertainty in the head for many wells (measurement uncertainty, surface elevation uncertainty, and temperature uncertainty) relative to the range of head values across the central Yucca Flat basin. Uncertainty for many wells is significant relative to the apparent gradients within the central part of the basin. Head values range much higher around the perimeter of the basin, and the relative uncertainty becomes a small factor.

2. Inconsistent representativeness of head values for wells due to the variability of the FAIs. For many wells, the FAIs extend across and cross-connect more than one HSU. The LCA is at substantially lower potential than the water table in many places, reflecting a vertical gradient from the water table down to the LCA. The vertical gradient across the different HSUs is dependent upon the vertical hydraulic conductivity, which differs for the various 
formations. Thus, the water level measured in a well reflects a weighted average of the heads in the different HSUs within an FAI.

3. Difficulty in determining the representativeness of measured water levels with respect to the FAIs identified for each well. Drilling and construction records provide basic information on the FAI of the boreholes. However, borehole conditions such as remnant drilling fluid, fill, or bridges can substantially modify the connection to the formation. These conditions are not always well known or quantified, and are often only recognized by secondary effects such as water levels inconsistent with expectations, based on water levels from other nearby wells with similar FAIs.

4. Apparent complexity of the water table configuration with regard to local (as compared to basin-scale) variability due to changes in the geologic units at the water table (large scale or local) or local structure (i.e., faults), and the high-pressure areas remaining from underground nuclear testing effects. Because of underground widespread nuclear testing within Yucca Flat, the incidence of high-pressure effects may be more widespread and variable than presently identified.

5. Complex hydrogeologic structure around the perimeter of the basin, with laterally changing HSUs, especially to the west, where the HSUs occur as discontinuous, juxtaposed structural blocks.

6. Very sparse data in the area outside the Yucca Flat basin, where the large-scale hydrogeologic complexity is great. There is insufficient data to define the head configuration in the area from the perimeter of the basin to the boundary of the Yucca Flat Data Compilation Area. The Yucca Flat basin head configuration is consistent with the very generalized head configuration that has been interpreted on the regional scale, but there is almost no control for head configuration for inflow and outflow from the basin relative to the detail in the HFM models.

\subsection{Summary}

The primary objective of the water-level data analysis was development of a dataset of hydraulic heads representative of steady-state conditions for use as calibration targets for the steady-state groundwater flow model of the Yucca Flat/Climax Mine CAU. This dataset was prepared through the collection, compilation, and qualification of existing depth-to-water data, analysis of hydrographs to determine periods of steady-state water levels, and computation of the mean head, SD, and uncertainty for each well dataset. The term steady-state is used to refer to periods of stable heads considered to reflect regional head conditions during that period; that is, the local condition in equilibrium with the regional groundwater system. These head values are not represented to reflect a true long-term steady-state condition representative of the future period for modeling. The data are 
not sufficient to determine whether such a steady-state existed during the overall period of the records or how accurately each well record may have reflected such a steady-state. Some hydrologic information for the NTS suggest that the groundwater system in the Yucca Flat/Climax Mine basin was not in true steady-state before the start of human activities in the area.

A secondary objective of this data analysis was to use the head information to characterize the 3-D head structure and interpret groundwater flow based on head gradients. The data was not amenable to simple or straightforward interpretation using standard means such as definition of potentiometric contours. The complex hydrogeologic structure and inconsistency of FAIs precluded accurate assignment of heads to specific potentiometric surfaces. General evaluation of the head data supports previous generalized interpretations of the water table and LCA potentiometric horizons but also made clear the local uncertainties and/or variability of heads. 


\subsection{Subsurface Temperature Data}

Groundwater temperature is controlled by the conductive and advective heat flow in the geologic system. The proximity of the heat source at depth, thermal conductivity of the rocks between the heat source and the groundwater, the advection of heat via groundwater flow, and the complexity of the faults and fracture zones all affect the heat flow and the temperature of groundwater. An overview of existing temperature related data and information, and a compilation and evaluation of a subset of the temperature data for the Yucca Flat/Climax Mine area are presented in this section.

\subsection{Objectives}

The purpose of this data analysis activity was to compile and evaluate existing temperature data for potential use in the CAU-scale groundwater flow model for the Yucca Flat/Climax Mine CAU. Temperature data are used for correcting the hydraulic head data or as a potential field in case non-isothermal groundwater flow modeling is deemed necessary. These data were obtained from geophysical temperature logs and other available information. Groundwater temperature data, collected during well testing, and water-level measurements are necessary to convert the measured columns of water in wells to hydraulic head at the formation access interval. In addition, the spatial temperature variation and temperature gradients for the Yucca Flat/Climax Mine CAU may be used as the basis for specifying the appropriate temperature for use in conversion of hydraulic conductivity values to intrinsic permeability. The selection of the appropriate thermal flow field (isothermal or non-isothermal) will be determined during the development of the groundwater flow model. The conversion of hydraulic conductivity to intrinsic permeability requires temperature data to calculate water density and viscosity (see Section 6.10). Temperature distributions interpreted for the purpose of heat flow and thermal potential evaluation should not be used for hydraulic head or property conversions. The temperature of the groundwater at the time of testing is required for the conversions and is most likely different from the geothermal temperature as a result of disturbances during the testing process. 


\subsection{Temperature Data and Information Relevant to the Yucca Flat/Climax Mine Hydrostratigraphic Framework Model Area}

The specific data types, their sources and prioritization for further evaluation, are discussed in this section. Types of information needed to understand thermal conditions are:

- Previous temperature documents and datasets

- Evaluation of temperature profile data

- Interpretation of heat flow

Table 11-1 identifies the key reports that address temperature data and information for the NTS area.

Table 11-1

Key Reports Providing Temperature Data and Information for the NTS Area

\begin{tabular}{|c|l|}
\hline Report & \multicolumn{1}{|c|}{$\begin{array}{c}\text { Synopsis of Temperature Information Relevant to the } \\
\text { Yucca Flat/Climax Mine Area }\end{array}$} \\
\hline $\begin{array}{c}\text { Preliminary Interpretation of Thermal Data from } \\
\text { the Nevada Test Site } \\
\text { (Sass and Lachenbruch, 1982) }\end{array}$ & Regional heat flow values within and adjacent to the NTS. \\
\hline $\begin{array}{c}\text { Temperature, Thermal Conductivity, and Heat } \\
\text { Flow Near Yucca Mountain, Nevada: Some } \\
\text { Tectonic and Hydrologic Implications, } \\
\text { (Sass et al., 1988) }\end{array}$ & $\begin{array}{l}\text { Laboratory measured thermal conductivity of major volcanic and } \\
\text { dolomite rock types at the NTS. }\end{array}$ \\
$\begin{array}{c}\text { Temperature Data Evaluation (Gillespie, 2003) } \\
\text { and evaluation of temperature log data from 13 boreholes deemed } \\
\text { suitable for the determination of heat flow values. }\end{array}$ \\
\hline $\begin{array}{c}\text { Temperature Profiles and Hydrologic Implications } \\
\text { from the Nevada Test Site Area (Gillespie, 2005) }\end{array}$ & $\begin{array}{l}\text { Compilation of temperature information related to the NTS, the } \\
\text { presentation and analysis of temperature profiles from selected } \\
\text { wells on the NTS, and identification of the thermal conductivity value } \\
\text { for alluvium. }\end{array}$ \\
\hline
\end{tabular}




\subsubsection{Basic Temperature Data Types}

The temperature of groundwater in the subsurface is related to both the conduction of heat from deeper in the subsurface and the advective transport of heat by groundwater flow. In 1-D, heat conduction is defined by the thermal conductivity of the medium and the thermal gradient between two points within that medium using the equation (Gillespie, 2005):

$$
\mathrm{Q}=-\lambda \times \delta \mathrm{T} / \delta \mathrm{z} \times 1000
$$

Where:

$\mathrm{Q}=1$-D heat-flow in milliwatts per square meter $\left(\mathrm{mW} / \mathrm{m}^{2}\right)$

$\lambda=$ Thermal conductivity of the medium in watts per meter degrees Celsius $\left(\mathrm{W} / \mathrm{m}^{\circ} \mathrm{C}\right)$

$\delta \mathrm{T} / \delta \mathrm{z}=$ Thermal gradient $\left({ }^{\circ} \mathrm{C} / \mathrm{m}\right)$

$1000=$ Conversion factor used to convert from watts to milliwatts

Thermal conductivity is a physical property of the medium and is a measure of how easily heat is transmitted through that medium. The thermal conductivity of rock in the subsurface is a function of the composition and volume of the materials making up the rock, and the pore fluid (water) and volume of that pore fluid within the rock.

The thermal gradient is a vector quantity, usually assumed to be vertical. However, the actual direction depends on the distribution of temperature in 3-D. The temperature distribution in the subsurface is obtained within boreholes or wells using temperature logging tools. Interpretation of the resulting temperature profiles identifies the thermal gradient over the profiled interval. Conductive heat flow is also a vector quantity and is conventionally taken to be positive in the direction of decreasing temperature. Like thermal gradient, the actual vector value (magnitude and direction) of conductive heat flow is dependent on the 3-D distribution of temperature.

\subsection{Thermal Conductivity Data and Information}

Laboratory measurements of saturated thermal conductivity for the major volcanic rocks and dolomite in the NTS area are provided in Sass et al. (1988) and summarized in Gillespie (2005). Table 11-2 provides a summary of these saturated thermal conductivity values. Gillespie (2005) provides an estimate of $1.20 \mathrm{~W} / \mathrm{m}{ }^{\circ} \mathrm{C}$ for the saturated thermal conductivity of alluvium at the NTS. 
Table 11-2

Saturated Thermal Conductivity Values for Major Volcanic Rock Units and Dolomite at the NTS

\begin{tabular}{|c|c|c|c|c|c|}
\hline Lithology Type & $\begin{array}{l}\text { Thermal } \\
\text { Conductivity } \\
\text { Minimum } \\
\left(\mathrm{W} / \mathrm{m}^{\circ} \mathrm{C}\right)\end{array}$ & $\begin{array}{c}\text { Thermal } \\
\text { Conductivity } \\
\text { Average } \\
\left(\mathrm{W} / \mathrm{m}^{\circ} \mathrm{C}\right)\end{array}$ & $\begin{array}{l}\text { Thermal } \\
\text { Conductivity } \\
\text { Maximum } \\
\left(\mathrm{W} / \mathrm{m}^{\circ} \mathrm{C}\right)\end{array}$ & $\begin{array}{l}\text { Number of } \\
\text { Samples }\end{array}$ & $\begin{array}{l}\text { Standard } \\
\text { Deviation }\end{array}$ \\
\hline Non-Welded Tuff & 1.06 & 1.42 & 2.10 & 15 & 0.3092 \\
\hline Non- to Partly Welded Tuff & 1.23 & 1.43 & 1.73 & 6 & 0.1936 \\
\hline Tuff & 1.25 & 1.62 & 1.99 & 2 & 0.5232 \\
\hline Partly Welded Tuff & 1.19 & 1.66 & 2.31 & 37 & 0.2931 \\
\hline Bedded Tuff & 1.10 & 1.73 & 2.42 & 8 & 0.4515 \\
\hline $\begin{array}{l}\text { Moderately to Densely } \\
\text { Welded Tuff }\end{array}$ & 1.36 & 1.73 & 1.90 & 4 & 0.2537 \\
\hline $\begin{array}{l}\text { Partly to Moderately } \\
\text { Welded Tuff }\end{array}$ & 1.37 & 1.75 & 2.26 & 20 & 0.2681 \\
\hline Moderately Welded Tuff & 1.37 & 1.78 & 2.21 & 19 & 0.1967 \\
\hline Vitrophyre & 1.67 & 1.82 & 2.00 & 3 & 0.1662 \\
\hline Welded Tuff & 1.80 & 1.86 & 1.92 & 2 & 0.0848 \\
\hline Flow Breccia & 1.43 & 1.89 & 2.46 & 7 & 0.3536 \\
\hline Lithic-Rich Tuff & 1.90 & 1.90 & 1.90 & 1 & N/A \\
\hline Densely Welded Tuff & 1.94 & 2.01 & 2.15 & 4 & 0.0936 \\
\hline Lava & 1.77 & 2.16 & 2.49 & 7 & 0.2360 \\
\hline Dolomite & 4.45 & 4.95 & 5.47 & 13 & 0.2848 \\
\hline
\end{tabular}

Source: Modified from Gillespie, 2005 $\mathrm{N} / \mathrm{A}=$ Not applicable

In addition to these NTS-specific thermal conductivity data, Table 11-3 summarizes typical rock thermal conductivity values reported by Wright and Louden (1989) and Johnston et al. (1981).

The thermal conductivity data and information summarized above have been evaluated to assign saturated thermal conductivity values to the HGUs used in the Yucca Flat/Climax Mine HFM. Table 11-4 identifies and provides ranges of thermal conductivity for these HGUs based on the thermal conductivity data and information in Tables 11-2 and 11-3. 
Table 11-3

Typical Rock Thermal Conductivity Values

\begin{tabular}{||c|c||c|c||}
\hline \multicolumn{2}{||c||}{ Wright and Louden (1989) } & \multicolumn{2}{c|}{ Johnston et al. (1981) } \\
\hline Rock Types & $\begin{array}{c}\text { Thermal } \\
\text { Conductivity } \\
\left.\text { (W/m }{ }^{\circ} \mathbf{C}\right)\end{array}$ & Rock Types & $\begin{array}{c}\text { Thermal } \\
\text { Conductivity } \\
\left.\text { (W/m }{ }^{\circ} \mathbf{C}\right)\end{array}$ \\
\hline \hline All Mudstones & 1.85 & Shale & 1.5 \\
Calcium Mudstones & 1.76 & Evaporites & 5.4 \\
Silty Mudstones & 2.15 & Limestone & $1.3-5.0$ \\
Siltstone & 1.91 & Dolomite & 5.0 \\
Muddy Sandstones & 2.23 & Sandstone & $1.8-4.2$ \\
All Sandstones & 2.92 & Schist & 1.6 \\
Quartz Sandstone & 5.09 & Gneiss & 2.5 \\
All Limestones & 2.51 & Greenstone & 3.3 \\
Dolomite & 4.78 & Slate & 3.8 \\
& & Argillite & 3.3 \\
& & Guartzite & $4.5-7.1$ \\
& & Granite & $1.7-4.0$ \\
& & Diabase & 2.1 \\
& & Gabbro & 2.5 \\
& & & 2.6 \\
\hline
\end{tabular}

Source: Modified from Gillespie, 2005

\subsection{Temperature Logs}

Gillespie (2003) provides a compilation and evaluation of temperature logs from the NTS. In this evaluation, 145 temperature logs from 63 boreholes on or near the NTS were reviewed for both data documentation quality and data evaluation quality. The evaluation of data quality considered various factors that impact the suitability of the data for analysis. Examples of these factors include the identification of logs from wells that had not returned to thermal equilibrium following drilling and the identification of $\log$ s from wells where well construction could contribute to vertical flow within the wellbore. Based on this review, a subset of 13 borehole logs were judged suitable for analysis. Gillespie (2005) extended this analysis by incorporating an additional 36 temperature logs that were obtained in FYs 2003 and 2004. Table 11-5 identifies the 20 wells in the Yucca Flat/Climax Mine area included in this analysis. Figure 11-1 shows the locations of these wells. 
Table 11-4

Saturated Thermal Conductivity for the HGUs Included in the Yucca Flat/Climax Mine Hydrogeologic Framework Model

\begin{tabular}{|c|l|c|}
\hline Hydrogeologic Unit & \multicolumn{1}{|c|}{ Typical Lithologies } & \multicolumn{1}{|c|}{$\begin{array}{c}\text { Thermal } \\
\text { Conductivity } \\
\text { (W/m }{ }^{\circ} \mathbf{C} \text { ) }\end{array}$} \\
\hline \hline PCU & Clayey-silt, sandy-silt & 1.20 \\
\hline AA & $\begin{array}{l}\text { Unconsolidated to partially consolidated gravelly sand, } \\
\text { eolian sand, and colluvium }\end{array}$ & 1.20 \\
\hline WTA & Welded ash-flow tuff, vitric to devitrified & $1.36-2.26$ \\
\hline VTA & Bedded tuff, ash-fall and reworked tuff, vitric & $1.10-2.42$ \\
\hline LFA & $\begin{array}{l}\text { Rhyolite, basalt and dacite lava flows; includes flow breccias } \\
\text { (commonly at base) }\end{array}$ & $1.77-2.49$ \\
\hline TCU & $\begin{array}{l}\text { Zeolitic bedded tuff with interbedded, but less significant, } \\
\text { zeolitic, nonwelded to partially welded ash-flow tuff }\end{array}$ & $1.10-2.42$ \\
\hline GCU & Granodiorite, quartz monzonite & $1.70-4.00$ \\
\hline CCU & Argillite, siltsonte, quartzite & $1.91-7.10$ \\
\hline CA & Dolomite, limestone & $1.30-5.47$ \\
\hline
\end{tabular}

\subsubsection{Temperature Log Data Summary}

Gillespie (2005) used published saturated thermal conductivity values, measured geothermal gradients, and well log temperature profiles to determine conductive heat flow values for NTS area wells. Table 11-6 summarizes temperature and heat flow data for wells in the Yucca Flat/Climax Mine area. Table 11-6 also lists the figure number for temperature profiles that are presented in Appendix A. Figure 11-2 shows the distribution of heat flow for this area.

\subsection{Evaluation of Temperature Profiles to Identify Potential Advective Heat Transport}

Because temperatures increase with depth in response to geothermal heating, groundwater temperature patterns may be useful for identifying vertical flow components. Relatively warm groundwater compared to other areas at the same elevation may indicate upward groundwater flow from depth; conversely, relatively cool groundwater may indicate downward flow. Because aquifer temperature data are sensitive to vertical groundwater movement, temperature data may be helpful in identifying whether groundwater is actually flowing in response to vertical head gradients that have been identified. Alternatively, if the distribution of hydraulic heads with depth is unknown, 
Table 11-5

Wells with Temperature Logs in the Yucca Flat/Climax Mine Area

\begin{tabular}{|c|c|c|c|c|c|c|}
\hline \multirow{2}{*}{ Well Name } & \multicolumn{2}{|c|}{ Well Location } & \multirow{2}{*}{$\begin{array}{c}\text { Date of } \\
\text { Temperature } \\
\text { Log }\end{array}$} & \multirow{2}{*}{$\begin{array}{c}\text { Organization } \\
\text { Providing } \\
\text { Logs }\end{array}$} & \multicolumn{2}{|c|}{$\begin{array}{l}\text { Logged Interval } \\
\text { (m bgs) }\end{array}$} \\
\hline & Easting & Northing & & & Top & Bottom \\
\hline UE-1q & $583,722.7$ & $4,101,777.7$ & $7 / 19 / 1994$ & DRI & 507.52 & 793.46 \\
\hline UE-1q & $583,722.7$ & $4,101,777.7$ & $4 / 22 / 2004$ & DRI & 206.90 & 799.40 \\
\hline UE-1L & $576,566.8$ & $4,100,381.8$ & $1 / 28 / 2002$ & DRI & 160.02 & 237.29 \\
\hline UE-2ce & $576,804.2$ & $4,110,772.7$ & $1 / 28 / 2002$ & DRI & 441.66 & 459.94 \\
\hline $\begin{array}{l}\text { Water Well } 2 \\
\text { (WW-2) }\end{array}$ & $581,005.7$ & $4,113,499.6$ & $4 / 17 / 2003$ & DRI & 609.48 & 864.14 \\
\hline ER-3-1-2 & $594,658.3$ & $4,097,339.0$ & $4 / 17 / 2003$ & DRI & 603.08 & 668.76 \\
\hline ER-3-2-2 & $585,716.4$ & $4,099,227.8$ & $4 / 17 / 2003$ & DRI & 472.32 & 776.81 \\
\hline UE-3e\#4-1 & $584,481.0$ & $4,102,812.6$ & $5 / 13 / 2003$ & DRI & 350.58 & 663.61 \\
\hline TW-7 & $585,901.0$ & $4,102,301.1$ & 3/20/1996 & DRI & 501.03 & 601.80 \\
\hline TW-7 & $585,901.0$ & $4,102,301.1$ & $4 / 22 / 2004$ & DRI & 493.50 & 605.24 \\
\hline TW-D & $582,223.9$ & $4,103,327.0$ & $8 / 29 / 1994$ & DRI & 526.48 & 579.21 \\
\hline TW-D & $582,223.9$ & $4,103,327.0$ & $4 / 22 / 2004$ & DRI & 519.65 & 581.04 \\
\hline ER-6-1 & $589,632.7$ & $4,093,418.7$ & $10 / 16 / 2003$ & DRI & 456.74 & 691.77 \\
\hline UE-6d & $583,751.3$ & $4,093,397.3$ & $6 / 26 / 2003$ & DRI & 456.77 & 853.47 \\
\hline UE-10j & $581,526.6$ & $4,115,644.9$ & $4 / 22 / 2003$ & DRI & 638.74 & 776.66 \\
\hline ER-12-2 & $572,411.5$ & $4,115,492.7$ & $4 / 27 / 2004$ & DRI & 45.35 & $1,569.54$ \\
\hline UE-14b & $575,427.2$ & $4,087,304.1$ & 8/21/1991 & DRI & 509.63 & $1,097.89$ \\
\hline UE-14b & $575,427.2$ & $4,087,304.1$ & 4/16/2003 & DRI & 486.80 & $1,100.36$ \\
\hline U-15k & $583,644.2$ & $4,120,544.4$ & $5 / 18 / 2004$ & DRI & 30.18 & 262.71 \\
\hline UE-16f & $574,999.7$ & $4,098,960.0$ & $5 / 2 / 1994$ & LLNL & 115.13 & 422.30 \\
\hline UE-16f & $574,999.7$ & $4,098,960.0$ & $4 / 16 / 2003$ & DRI & 103.05 & 424.31 \\
\hline UE-17a & $574,116.2$ & $4,103,156.8$ & $5 / 2 / 1994$ & LLNL & 194.33 & 365.07 \\
\hline UE-17a & $574,116.2$ & $4,103,156.8$ & $4 / 17 / 2003$ & DRI & 180.01 & 366.25 \\
\hline UE-4t-1 & $584,575.5$ & $4,106,066.9$ & $5 / 13 / 2003$ & DRI & 91.62 & 602.92 \\
\hline ER-2-1 & $583,334.5$ & $4,108,978.3$ & $4 / 27 / 2004$ & DRI & 502.62 & 765.66 \\
\hline TW-E & $589,361.9$ & $4,101,336.5$ & NR & USGS & $50(\sim)$ & $780(\sim)$ \\
\hline
\end{tabular}

Source: Gillespie 2005

NR $=$ Not Reported

$\sim$ = Approximately 


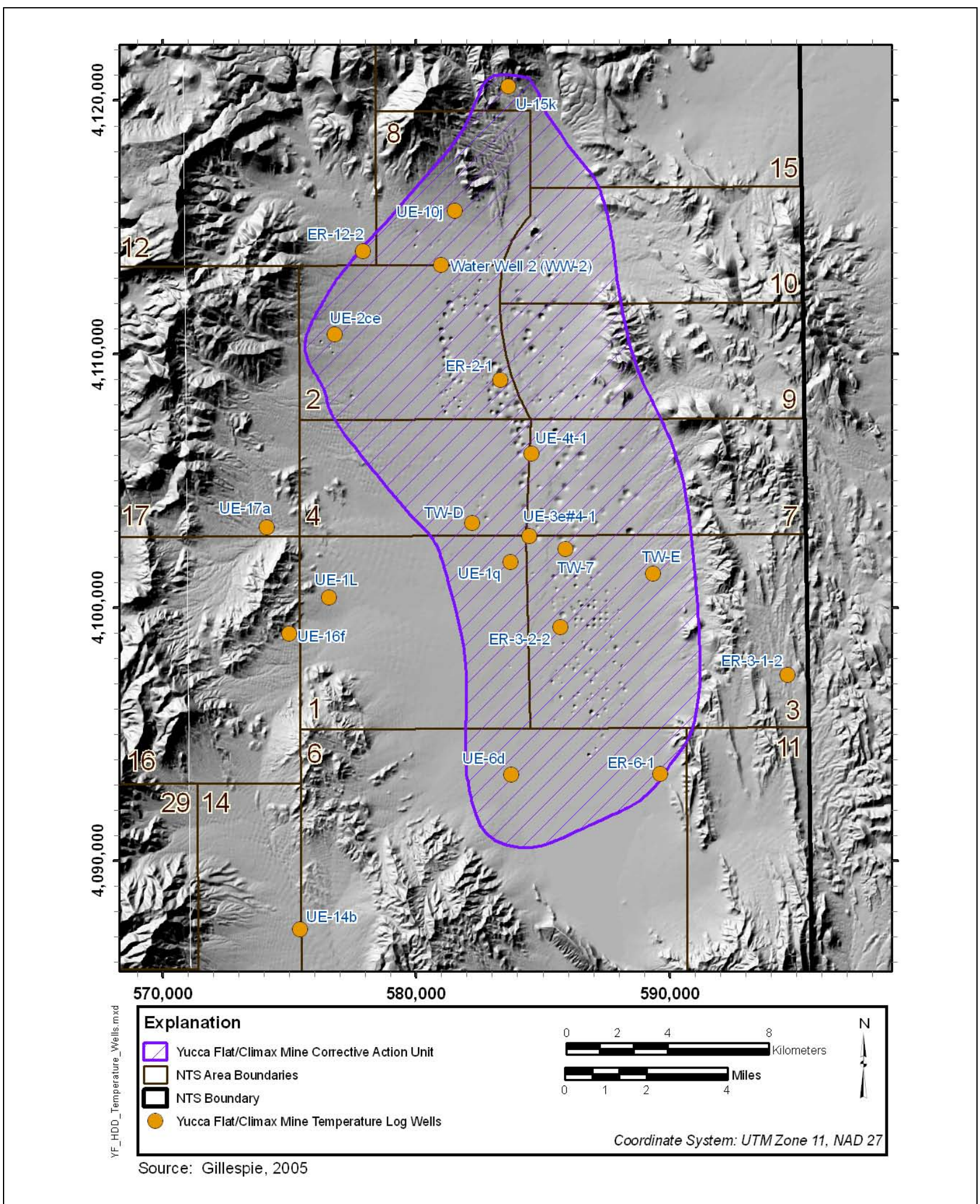

Figure 11-1

Wells in the Yucca Flat/Climax Mine Area with Temperature Logs Evaluated by Gillespie (2005) 
Table 11-6

Temperature and Heat Flow for Wells in the Yucca Flat/Climax Mine Area

\begin{tabular}{|c|c|c|c|c|c|c|}
\hline \multirow{2}{*}{ Well Name } & \multicolumn{2}{|c|}{$\begin{array}{l}\text { Logged Interval } \\
\text { (ft bgs) }\end{array}$} & \multicolumn{2}{|c|}{$\begin{array}{l}\text { Approximate } \\
\text { Temperature Range }\end{array}$} & \multirow{2}{*}{$\begin{array}{l}\text { Heat Flow } \\
\left(\mathrm{mW} / \mathrm{m}^{2}\right)\end{array}$} & \multirow{2}{*}{$\begin{array}{c}\text { Temperature } \\
\text { Log Reference }^{2}\end{array}$} \\
\hline & Top & Bottom & $\begin{array}{l}\text { Minimum } \\
\quad\left({ }^{\circ} \mathrm{C}\right)\end{array}$ & $\begin{array}{l}\text { Maximum } \\
\left({ }^{\circ} \mathrm{C}\right)\end{array}$ & & \\
\hline UE-1q & 507.52 & 793.46 & 23.7 & 28.0 & $28-33$ & Figure G.1-2 \\
\hline UE-1L & 160.02 & 237.29 & 20.2 & 22.3 & 101 & Figure G.1-3 \\
\hline UE-2ce & 441.66 & 459.94 & 31.1 & 32.8 & 8.5 & Figure G.1-4 \\
\hline WW-2 & 609.48 & 864.14 & 22.3 & 29.6 & $34.5-44.5$ & Figure G.1-5 \\
\hline ER-3-1-2 & 603.08 & 668.76 & 45.5 & 50.8 & 57.4 & Figure G.1-6 \\
\hline ER-3-2-2 & 472.32 & 776.81 & 20.7 & 27.7 & 20.4 & Figure G.1-7 \\
\hline UE-3e\#4-1 & 350.58 & 663.61 & 17.6 & 21.2 & 18.4 & Figure G.1-8 \\
\hline TW-7 & 501.03 & 601.80 & $\begin{array}{c}23.0 \\
(3 / 20 / 1996)\end{array}$ & $\begin{array}{c}24.1 \\
(3 / 20 / 1996)\end{array}$ & $\begin{array}{c}19.8 \\
(3 / 20 / 1996)\end{array}$ & Figure G.1-9 \\
\hline TW-7 & 493.50 & 605.24 & $\begin{array}{c}19.8 \\
(4 / 22 / 2004)\end{array}$ & $\begin{array}{c}21.73 \\
(4 / 22 / 2004)\end{array}$ & $\begin{array}{c}18.1 \\
(4 / 22 / 2004)\end{array}$ & Figure G.1-9 \\
\hline TW-D & 526.48 & 579.21 & $\begin{array}{c}26.3 \\
(8 / 29 / 1994)\end{array}$ & $\begin{array}{c}26.7 \\
(8 / 29 / 1994)\end{array}$ & NE & Figure G.1-10 \\
\hline TW-D & 519.65 & 581.04 & $\begin{array}{c}23.7 \\
(4 / 22 / 2004)\end{array}$ & $\begin{array}{c}25.3 \\
(4 / 22 / 2004)\end{array}$ & NE & Figure G.1-10 \\
\hline ER-6-1 & 456.74 & 691.77 & 32.6 & 40.5 & 53.3 & Figure G.1-11 \\
\hline UE-6d & 456.77 & 853.47 & 18.8 & 21.7 & 8.0 & Figure G.1-12 \\
\hline UE-10j & 638.74 & 776.66 & 26.3 & 32.2 & 33.0 & Figure G.1-13 \\
\hline ER-12-2 & 45.35 & $1,569.54$ & 16.6 & 53.7 & 80.5 & Figure G.1-14 \\
\hline UE-14b & 509.63 & $1,097.89$ & 23.2 & 32.3 & 21.9 & Figure G.1-15 \\
\hline U-15k & 30.18 & 262.71 & 19.5 & 20.0 & 54.7 & Figure G.1-16 \\
\hline UE-16f & 115.13 & 422.30 & $\begin{array}{c}21.0 \\
(5 / 2 / 1994)\end{array}$ & $\begin{array}{c}29.9 \\
(5 / 2 / 1994)\end{array}$ & 96.7 & Figure G.1-17 \\
\hline UE-16f & 103.05 & 424.31 & $\begin{array}{c}17.5 \\
(4 / 16 / 2003)\end{array}$ & $\begin{array}{c}25.1 \\
(4 / 16 / 2003)\end{array}$ & 82.5 & Figure G.1-17 \\
\hline UE-17a & 194.33 & 365.07 & $\begin{array}{c}23.9 \\
(5 / 2 / 1994)\end{array}$ & $\begin{array}{c}28.2 \\
(5 / 2 / 1994)\end{array}$ & 105.0 & Figure G.1-18 \\
\hline UE-17a & 180.01 & 366.25 & $\begin{array}{c}14.7 \\
(4 / 17 / 2003)\end{array}$ & $\begin{array}{c}24.3 \\
(4 / 17 / 2003)\end{array}$ & 110.2 & Figure G.1-18 \\
\hline UE-4t-1 & 91.62 & 602.92 & 17.0 & 28.9 & 44.9 & Figure G.1-19 \\
\hline ER-2-1 & 502.62 & 765.66 & 22.3 & 27.3 & 32.7 & Figure G.1-20 \\
\hline TW-E & $\begin{array}{c}50.0 \\
\text { (estimated) }\end{array}$ & $\begin{array}{c}780.0 \\
\text { (estimated) }\end{array}$ & 19.0 & 49.0 & 29.0 & $\begin{array}{c}\text { Sass and } \\
\text { Lachenbruch } \\
\text { (1982), Figure } 6\end{array}$ \\
\hline
\end{tabular}

Source: Gillespie 2005

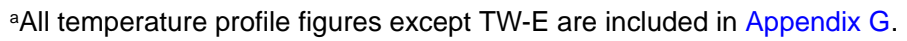

$\mathrm{NE}=$ Not evaluated 

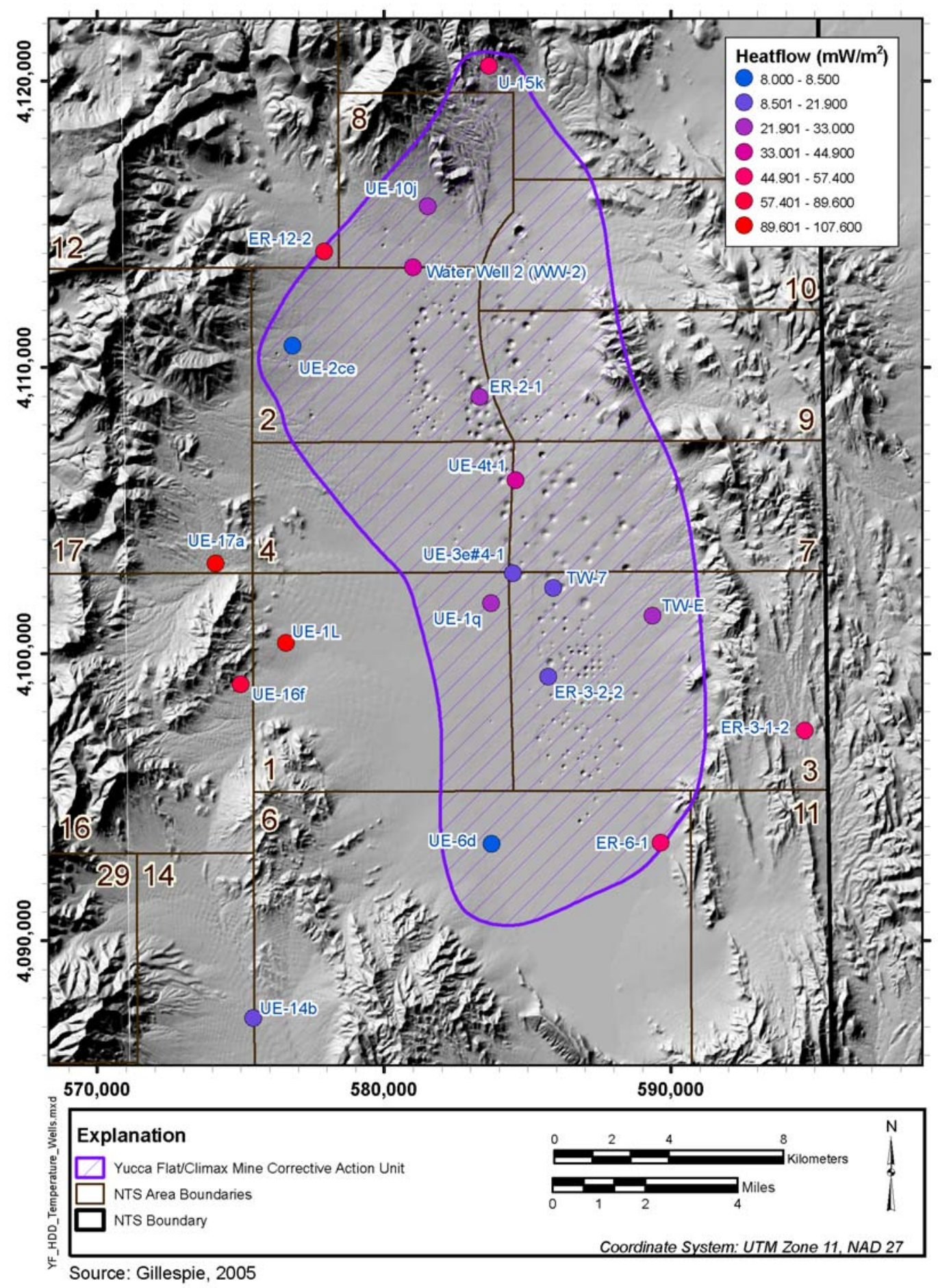

Figure 11-2

Estimated Heat Flow from Gillespie (2005) from Wells in the Yucca Flat/Climax Mine Area 
groundwater temperature data may provide indirect indications of the likely changes of head with depth. In some instances, groundwater temperature at a given elevation varies spatially because of spatial variations in heat flux or the insulating effects associated with variable thickness of the overburden. In these cases, horizontal groundwater flow could alter the heat flux, because the groundwater would warm or cool as it moved from an upgradient area, with a spatially different heat flux downgradient towards an area with a lower or higher heat flux.

\subsubsection{Background}

To provide some context for the evaluation of borehole temperature logs, it is useful to review some simple 1-D heat-transport simulations to illustrate the expected effects of groundwater movement on borehole temperature profiles (Figure 11-3). Although the 1-D nature of these results is somewhat idealized, these simulations help to identify borehole temperature measurements that have been perturbed by the presence of the borehole or by hydraulic tests, and to develop hydrologic interpretations for borehole temperature measurements that appear to reflect actual formation temperatures. The departures from purely conductive heat flow resulting from advective heat flow described here are used to interpret field measurements.

At steady-state in a homogeneous medium, the temperature gradient resulting from purely conductive heat flow processes would be linear (Figure 11-3a) and heat flux would be constant with elevation (Figure 11-3b). A steady, downward groundwater flux would result in cooler temperatures at any elevation compared to the conduction-only profile, resulting in a concave-upwards profile. For downward flux, the concave-upward profile implies a decrease in the geothermal gradient (and, hence, in the heat flux), with elevation. This decrease in heat flux occurs because with increasing elevation, more and more of the heat flux existing at depth has been consumed by warming the downwardly moving groundwater. Conversely, where groundwater flow is upward, rock temperatures at any elevation are warmer than those that would result from heat conduction alone. In this case, the steepening of the temperature profile with elevation implies an increase in the upward heat flux with elevation. This increase occurs because the upward moving groundwater loses heat to the surrounding rock, so that with increasing elevation, more and more heat must be transmitted conductively through the rock. 


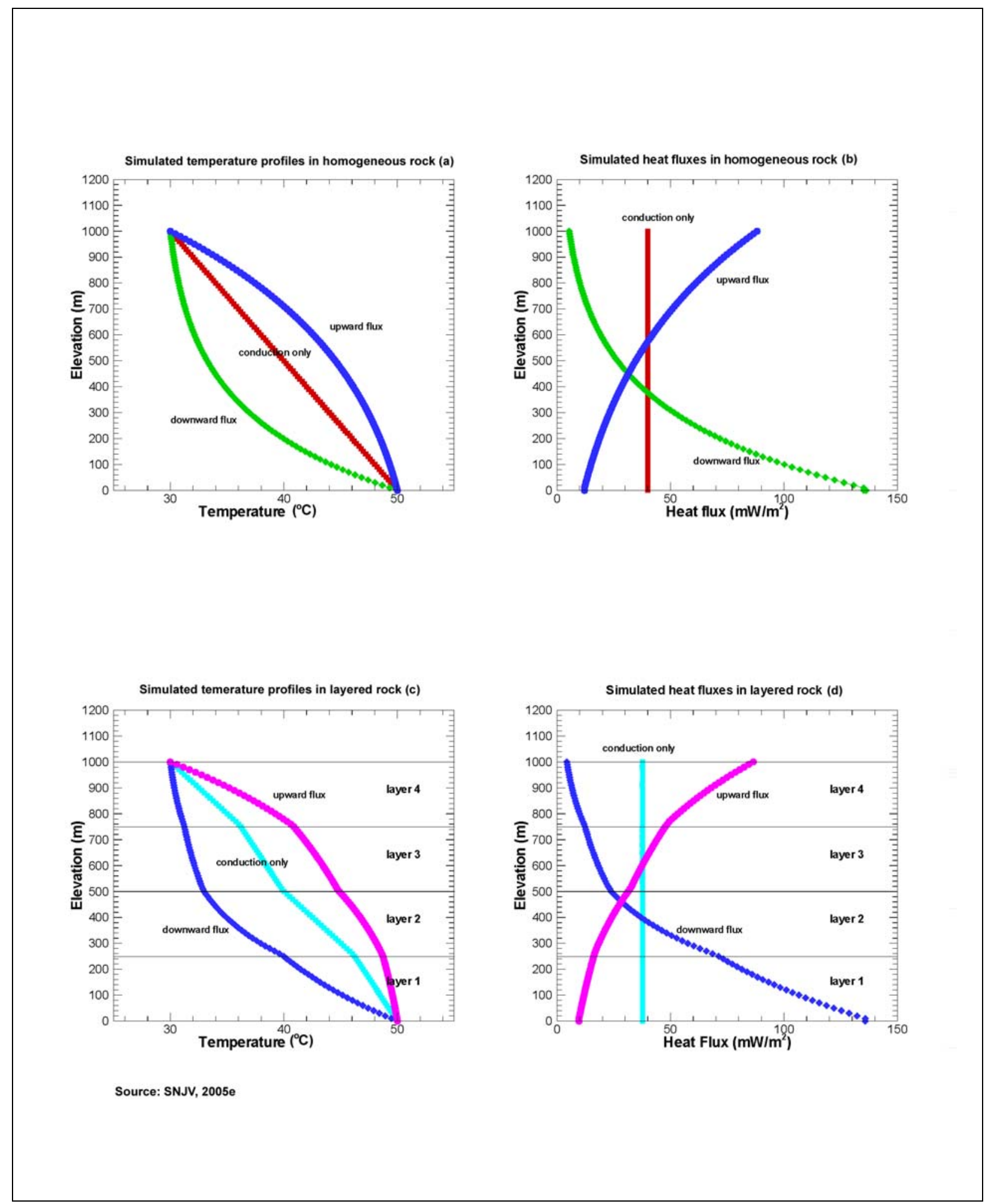

Figure 11-3

Simulated (a) Temperature and (b) Heat Flux Profiles in Homogenous Rock and Simulated (c) Temperature and (d) Heat Flux Profiles in Layered Rock 
At steady-state in a layered medium, the temperature profile resulting from purely conductive heat flow processes would have linear segments within a layer, and the temperature gradient associated with each linear segment would be inversely related to the thermal conductivity of that layer (Figure 11-3c). For pure heat conduction, the thermal conductivity and thermal gradient within each layer result in a constant heat flux with elevation (Figure 11-3d). As in the case of homogeneous rock, a downward groundwater flux results in cooler temperatures at any elevation compared to the pure conduction profiles, with the segments within each layer having an upward concavity. In this case, the heat flux changes with elevation in a way that is similar to that found for a homogenous medium with downward groundwater flow. An upward groundwater flux through a layered medium results in higher temperatures compared to temperatures associated with a pure conduction profile, with each segment in the profile for the layered rock having a downward concavity. The heat flux associated with downward groundwater flow through the layered rock resembles the heat flux profile for downward groundwater flow through a homogeneous medium.

The heat flux $\mathrm{q}_{\mathrm{H}}$ at a given elevation, $\mathrm{z} 2$, can be expressed as a function of $\mathrm{q}_{\mathrm{H}}$ at a lower elevation, $\mathrm{z} 1$, by:

$$
q_{\mathrm{H}}(\mathrm{z} 2)=q_{\mathrm{H}}(\mathrm{z} 1)-q_{\mathrm{l}} C_{\mathrm{l}} \Delta T
$$

Where:

$\mathrm{q}_{\mathrm{H}}(\mathrm{z} 2)=$ Heat flux at upper elevation in Joules per second per square meter $\left(\mathrm{J} / \mathrm{s} \mathrm{m}^{2}\right)$

$\mathrm{q}_{\mathrm{H}}(\mathrm{z} 1)=$ Heat flux at lower elevation $\left(\mathrm{J} / \mathrm{s} \mathrm{m}^{2}\right)$

$\mathrm{q}_{1}=$ Liquid mass flux $\left(\mathrm{kg} / \mathrm{s} \mathrm{m}^{2}\right)$

$\mathrm{C}_{1}=$ Specific heat capacity of water $\left(4,187 \mathrm{~J} / \mathrm{kg}{ }^{\circ} \mathrm{C}\right)$

$\Delta \mathrm{T}=$ Temperature difference between elevation $\mathrm{z} 2$ and $\mathrm{z} 1,[\mathrm{~T}(\mathrm{z} 2)$ minus $\mathrm{T}(\mathrm{z} 1)]\left({ }^{\circ} \mathrm{C}\right)$

Upward fluxes are positive and downward fluxes are negative. As the equation indicates, the heat flux at the higher elevation (z2), depends on the heat flux at the lower elevation (z1), on the direction and magnitude of the liquid flux, and on the change in the temperature the water undergoes as it moves through the rock. The vertical groundwater flux can be calculated from these heat fluxes and corresponding temperature difference between these elevations if heat flux can be estimated at two distinct elevations and assumed to be 1-D. The equation also indicates that heat flux between two elevations would not be changed by horizontal groundwater movement where the temperature of the water did not change. However, as previously mentioned, temperature at a given elevation could vary 
spatially because of spatial variations in heat flux or due to the insulating effects associated with variable thickness of the overburden. In this case, horizontal groundwater flow could alter the heat flux, because the groundwater would warm or cool as it moved from one area to another area at a different temperature.

\subsubsection{Evaluation of Yucca Flat Temperature Profiles}

Gillespie (2005) identified seven temperature profiles in Yucca Flat that could be indicative of advective heat transport. Table 11-7 identifies these wells and the reported profile characteristic that suggests advective heat transport. Figures 11-4 through 11-10 show the temperature profiles for these wells.

Table 11-7

Yucca Flat Wells with Temperature Profiles that Suggest the Potential for Advective Heat Transport

\begin{tabular}{|c|c|}
\hline Well & $\begin{array}{c}\text { Temperature Profile Characteristic Indicative of Potential Advective Heat } \\
\text { Transport }\end{array}$ \\
\hline $\begin{array}{l}\text { UE-1L } \\
\text { (Figure 11-4) }\end{array}$ & $\begin{array}{l}\text { The decrease in thermal gradient below the base of the casing may be indicative of } \\
\text { horizontal flow. Alternatively, there may be downward flow in the borehole or a change in } \\
\text { lithology to an interval with higher thermal conductivity. }\end{array}$ \\
\hline $\begin{array}{l}\text { UE-2ce } \\
\text { (Figure 11-5) }\end{array}$ & $\begin{array}{l}\text { The very low estimated heat flow in this well may indicate that significant horizontal flow } \\
\text { in the CA has effectively increased the apparent thermal conductivity of the aquifer at this } \\
\text { location. }\end{array}$ \\
\hline $\begin{array}{l}\text { Water Well } 2 \\
\quad(\text { WW-2) } \\
\text { (Figure 11-6) }\end{array}$ & $\begin{array}{l}\text { The estimated heat flow for the tuffaceous unit above the Paleozoic dolomite is } \\
44.5 \mathrm{~mW} / \mathrm{m}^{2} \text { and for the Paleozoic dolomite, } 34.5 \mathrm{~mW} / \mathrm{m}^{2} \text {. This difference in estimated } \\
\text { heat flows may indicate horizontal flow or vertical mixing within the CA. Alternatively, the } \\
\text { more likely explanation is that the assigned thermal conductivity for one or both of the } \\
\text { lithologic units is in error. }\end{array}$ \\
\hline $\begin{array}{l}\text { UE-6d } \\
\text { (Figure 11-7) }\end{array}$ & $\begin{array}{l}\text { The temperature profile has a slight concave upward curvature that may indicate } \\
\text { downward fluid flow within the alluvium at this location. Alternatively, this profile may } \\
\text { indicate a gradual decrease in thermal conductivity with depth. }\end{array}$ \\
\hline $\begin{array}{l}\text { UE-10j } \\
\text { (Figure 11-8) }\end{array}$ & $\begin{array}{l}\text { The intervals of near-vertical gradients in the temperature may indicate significant lateral } \\
\text { groundwater flow in the CA at this location. }\end{array}$ \\
\hline $\begin{array}{l}\text { UE-16f } \\
\text { (Figure 11-9) }\end{array}$ & $\begin{array}{l}\text { The decrease in the thermal gradient below the base of the casing may indicate } \\
\text { downward flow within the borehole. Alternatively, this may indicate horizontal flow within } \\
\text { the formation. }\end{array}$ \\
\hline $\begin{array}{l}\text { UE-4t-1 } \\
\text { (Figure 11-10) }\end{array}$ & $\begin{array}{l}\text { This well is located on the southern boundary of the subsidence crater formed by the } \\
\mathrm{U}-4 \mathrm{t} \text { underground nuclear test. The unusual change in the thermal gradient at about } \\
270 \mathrm{~m} \text { bgs may indicate that the temperature profile shows an effect from the heat } \\
\text { produced by the test. }\end{array}$ \\
\hline
\end{tabular}

Source: Modified from Gillespie, 2005 


\subsection{Summary}

Several factors contribute to uncertainties in the interpretation of temperature profiles. The 3-D distribution of temperatures (and heat flux) in a rock mass is a function of the spatial variability in heat flux at depth, topography, and the variability in rock thermal properties, as well as groundwater flow. Model calculations by Rousseau et al. (1999) indicate that in a homogeneous medium, subsurface temperature distributions are a subdued reflection of the topography. Conductive heat flux vectors tend to diverge under ridges and converge toward washes, resulting in decreasing heat fluxes with elevation beneath ridges and increasing heat fluxes with elevation beneath washes. Likewise, the subsurface distribution of rocks with different thermal conductivities can concentrate conductive heat flow toward some areas and away from others. Preliminary analyses of conductive heat flux in the vicinity of the NTS (Gillespie, 2005) have indicated that heat flux tends to be redirected around low thermal conductivity alluvium, in basins like Yucca Flat and Frenchman Flat, and into the higher thermal conductivity rocks beneath ridges bordering the basins. The deflection of conductive heat flux from beneath the alluvium into the surrounding rock is possible, because the insulating properties of the alluvium cause temperatures to be higher beneath the alluvium than in rocks at the same elevation beneath the ridges.

A major difficulty in using temperature measurements as a constraint on hydrologic models is that only after all of these processes and their uncertainties are accounted for can the hydrologic significance of temperatures measurements be reliably identified. The foregoing discussion indicates that borehole temperature profiles should be interpreted with a 3-D model that incorporates all of the relevant processes and their uncertainties. Even then, features of the temperature profiles that cannot be explained by the 3-D conduction model may have hydrologic significance or may simply be the result of an inadequate thermal conduction model.

\subsection{Other Yucca Flat Temperature Data}

The USGS, as part of an on-going program of hydrologic data collection on the NTS, periodically collects temperature data from selected wells. These temperature data include temperature profiles in selected wells with temperature data collected at discrete depths, and single temperature measurements taken at $5 \mathrm{ft}$ and $55 \mathrm{ft}$ below the water level in a well. These data were obtained from 
the USGS website http://nevada.usgs.gov/doe_nv/watertemp (USGS, 2006a). As stated on this website, these data are considered provisional and are subject to revision until formal USGS publication. The USGS temperature data from wells in the Yucca Flat/Climax Mine CAU are summarized in Appendix G. 


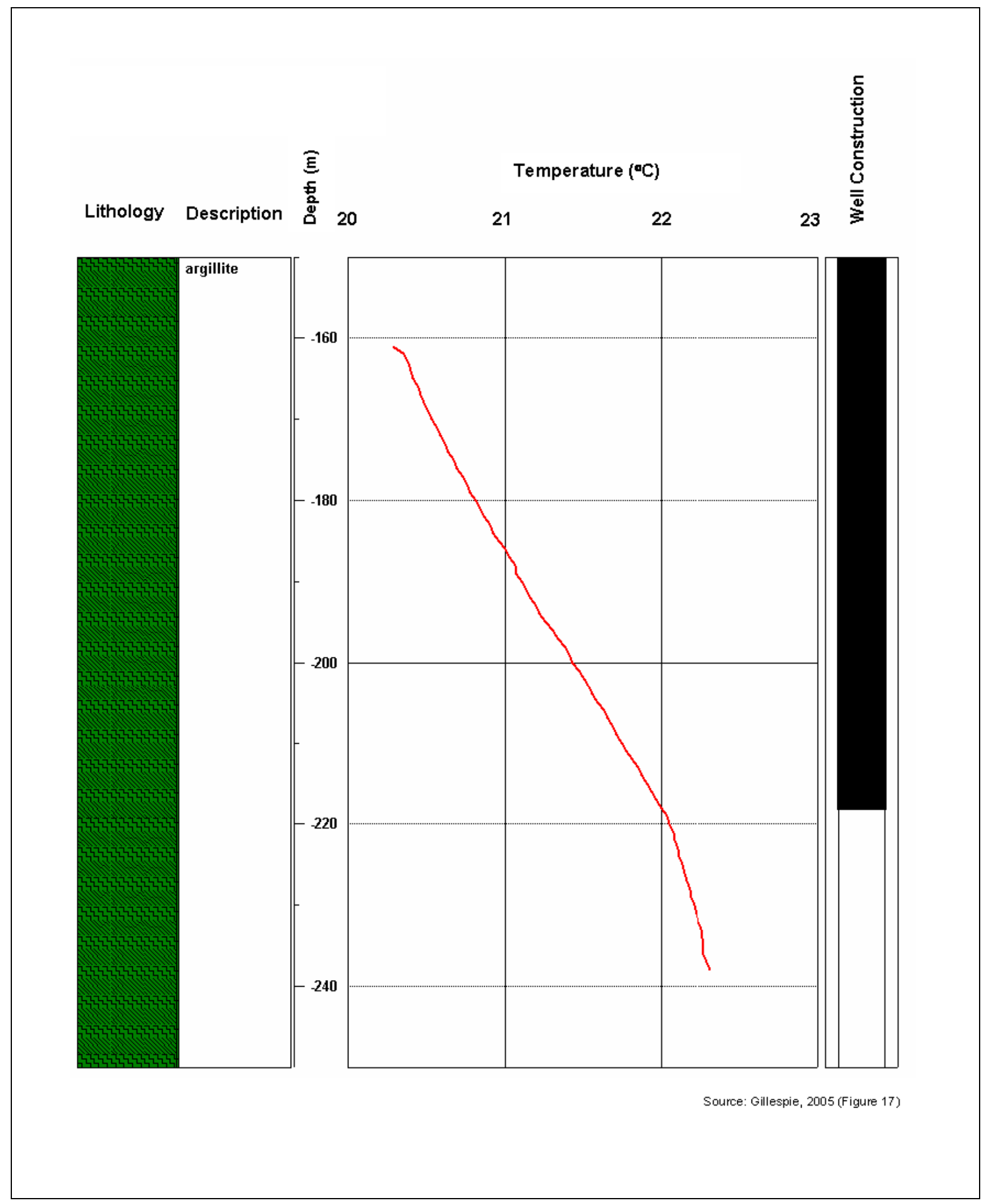

Figure 11-4

Temperature Profile for Well UE-1L 


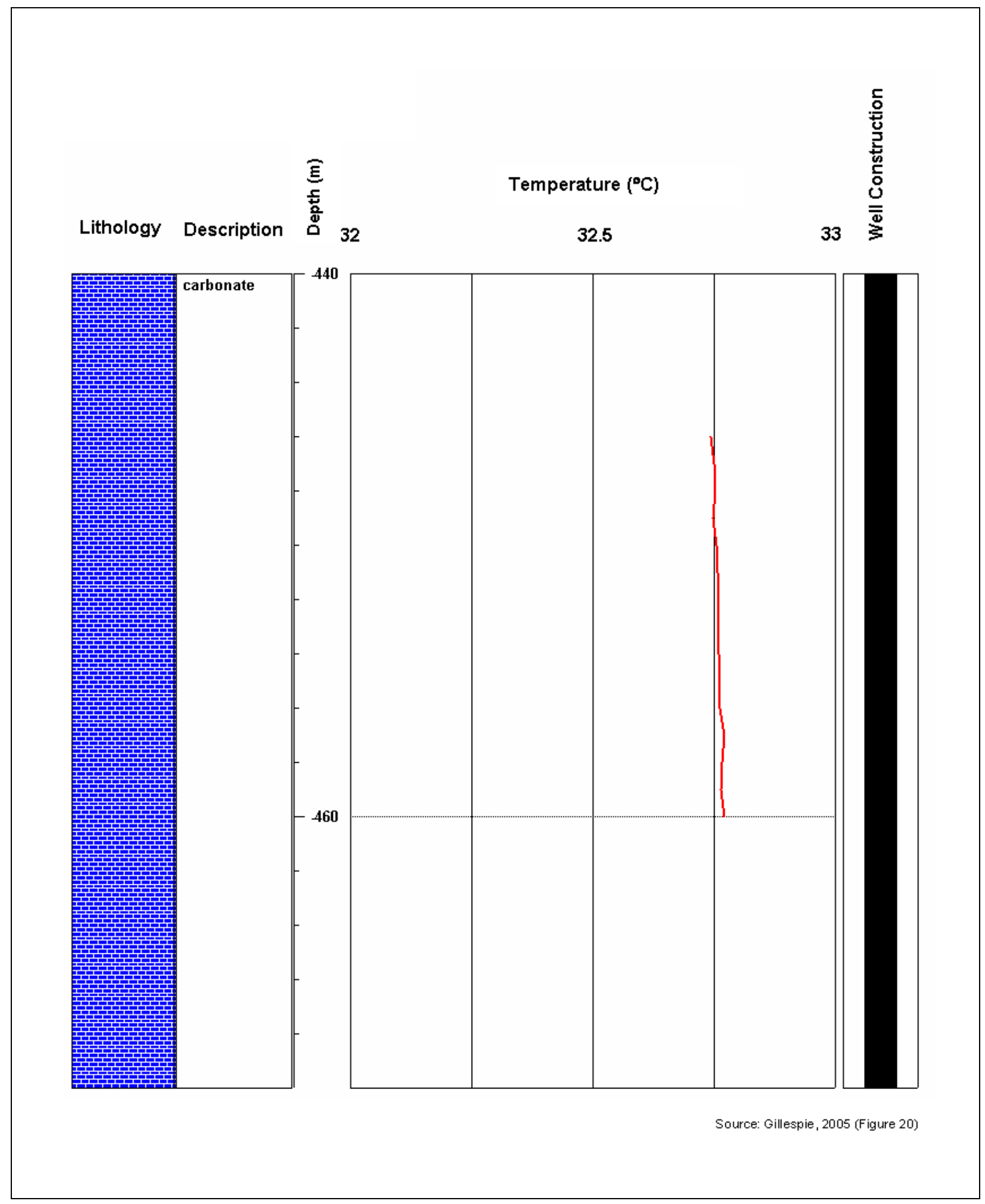

Figure 11-5

Temperature Profile for Well UE-2ce 


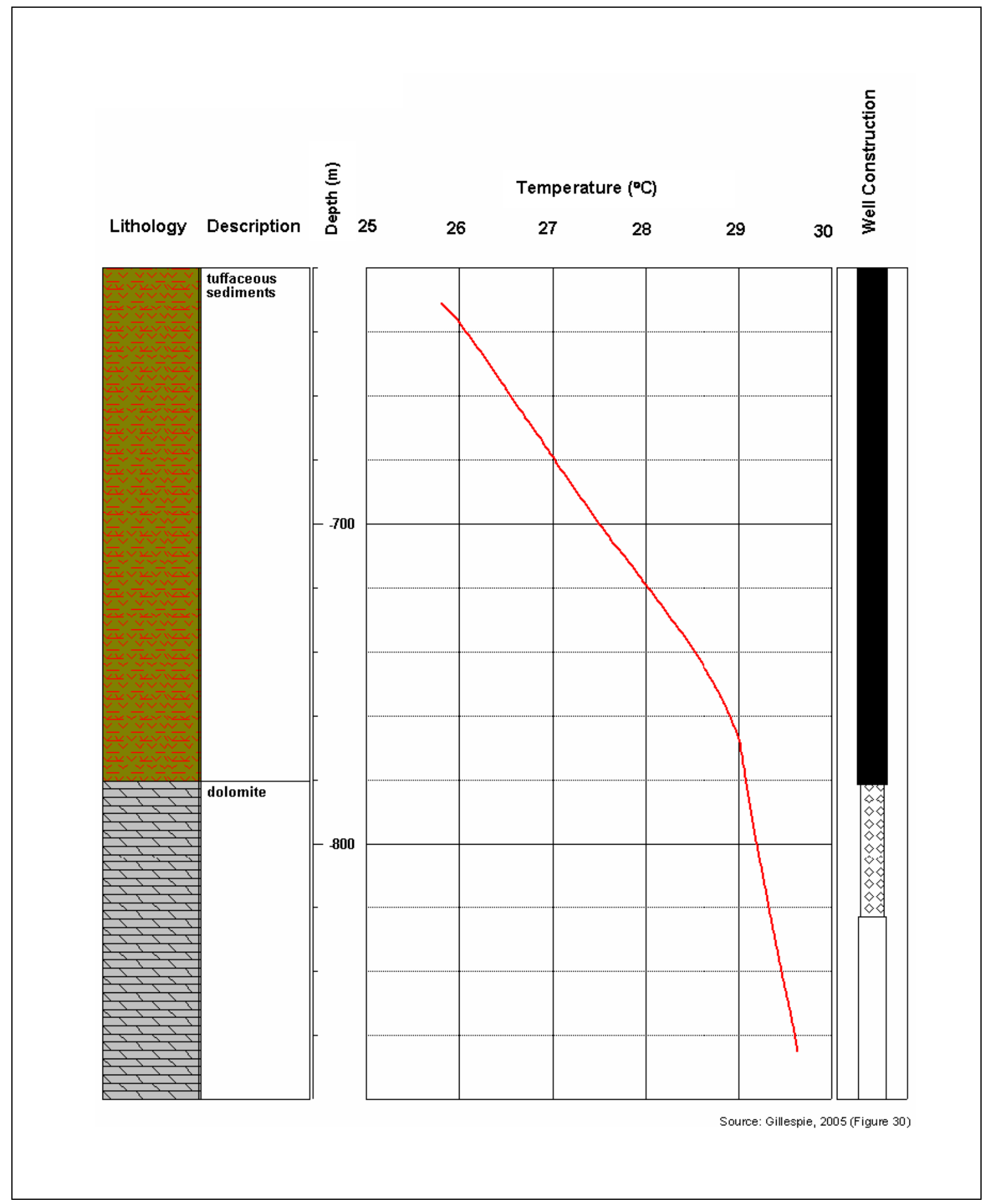

Figure 11-6

Temperature Profile for Water Well 2 (WW-2) 


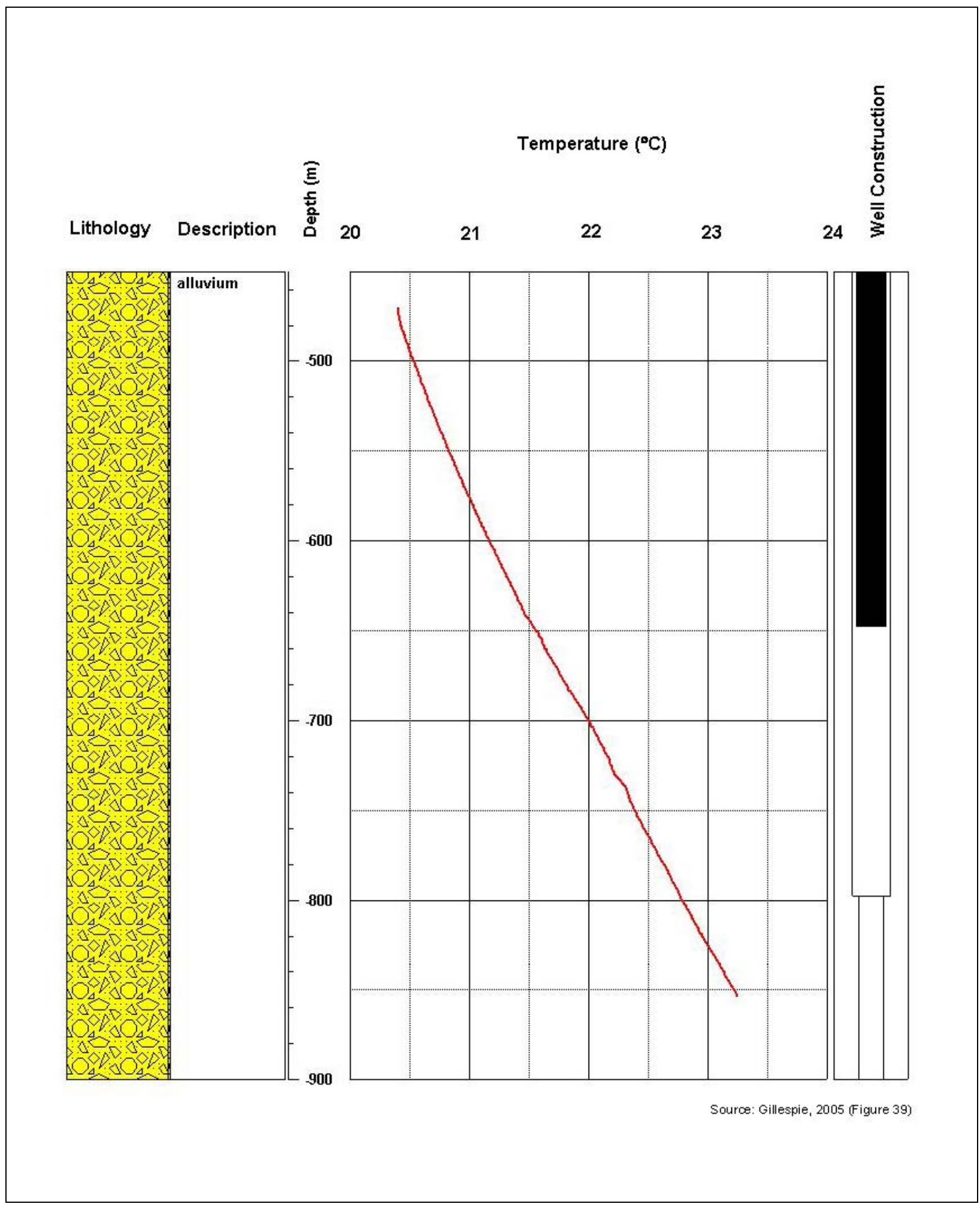

Figure 11-7

Temperature Profile for Well UE-6d 


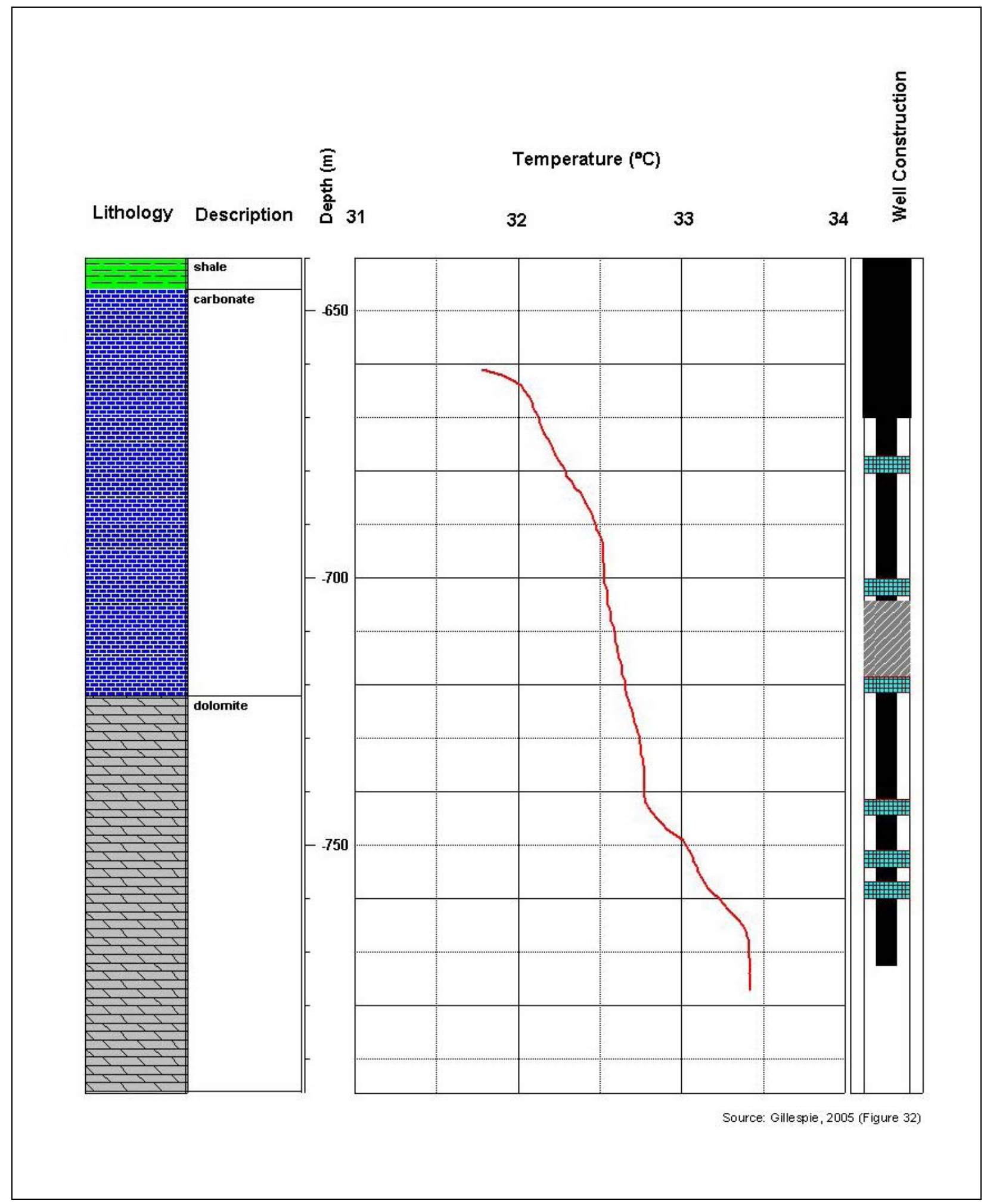

Figure 11-8

Temperature Profile for Well UE-10j 


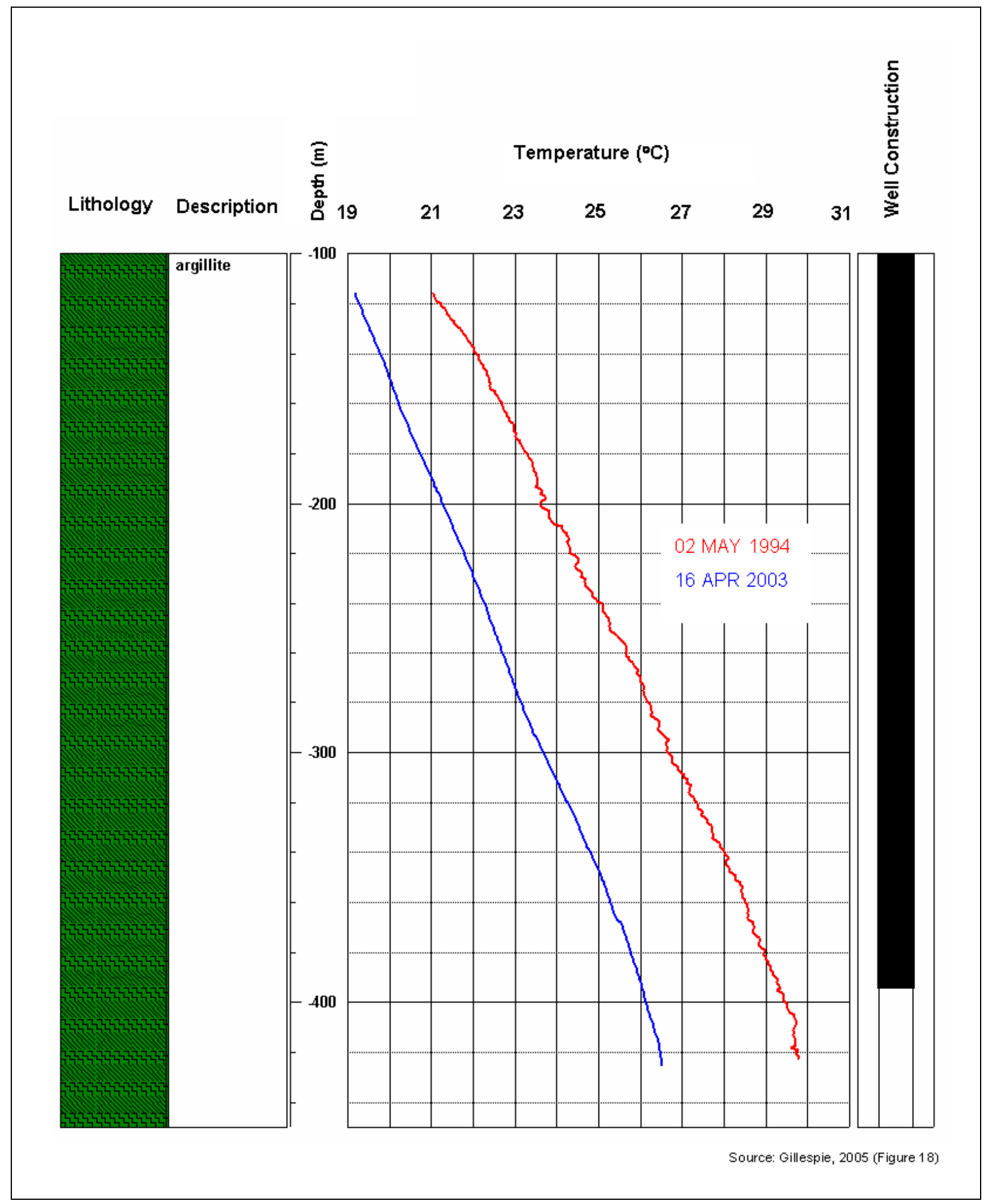

Figure 11-9

Temperature Profile for Well UE-16f 


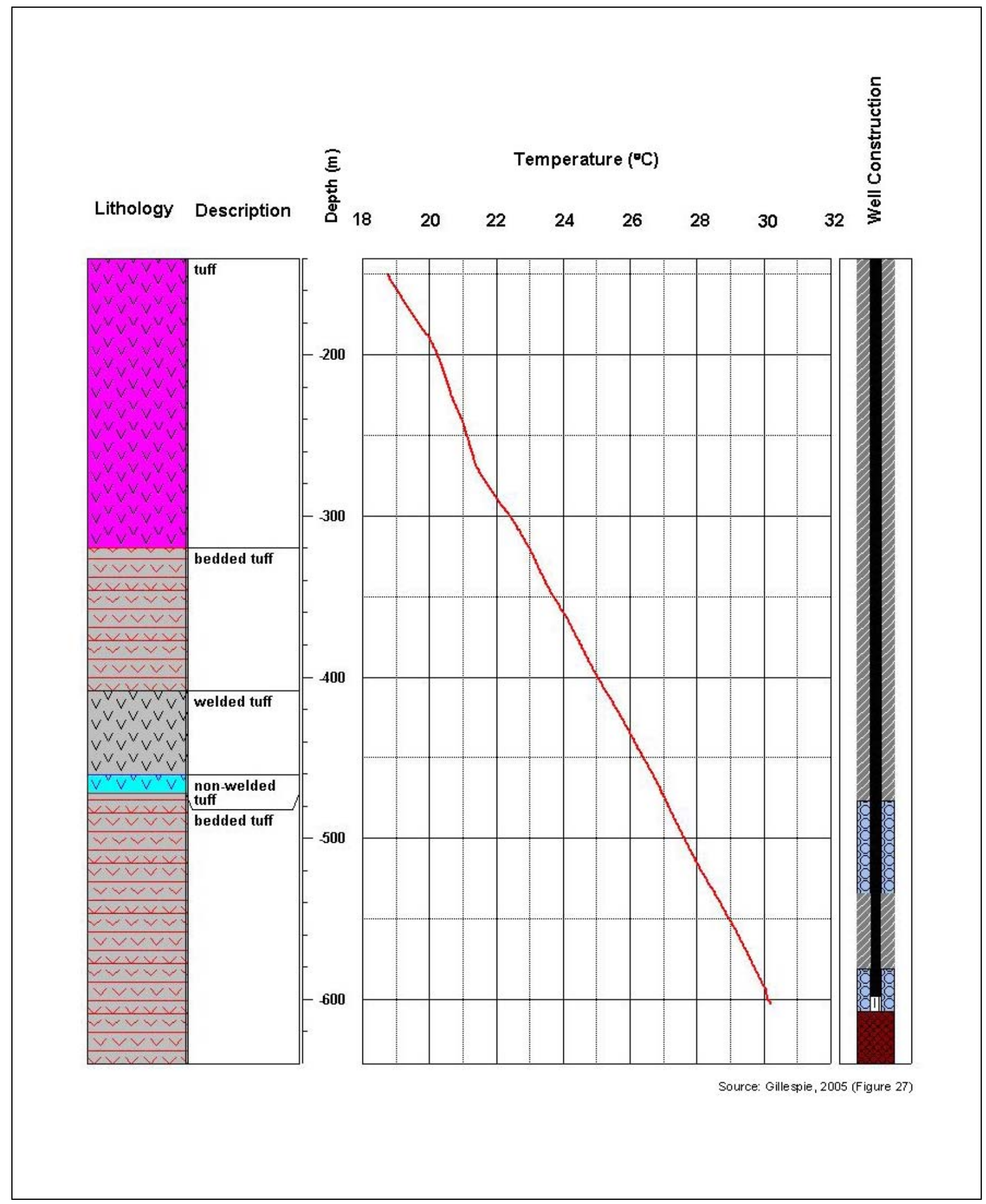

Figure 11-10

Temperature Profile for Well UE-4t-1 


\section{0 groundwater Chemistry}

Groundwater chemistry data are considered during the evaluation of the groundwater flow system, because they provide a means for determining the origin, flow paths, and time scale of groundwater flow that is independent of estimates based on hydraulic flow analysis. Geochemical and hydraulic data reflect distinct but complementary aspects of a groundwater flow system and must be considered in unison to develop a consistent, comprehensive, and defensible flow system assessment. Geochemical data, specifically groundwater chemistry and reactive mineral distribution, are also important constraints on solute transport.

The assessment of groundwater chemistry data for the Yucca Flat/Climax Mine CAU fulfills several project needs. First, the dataset compiled for this task represents the current repository for groundwater geochemical data pertinent to this CAU. Next, these data are used for flow path and travel time evaluations that will provide an independent means to guide and ultimately defend the flow and contaminant transport modeling efforts for the Yucca Flat/Climax Mine CAU. The geochemical evaluation presented in this section is primarily a summary of a collaborative study performed by LLNL, LANL, DRI, USGS, and SNJV. Details of this study are presented in SNJV (2006a).

\subsection{Objectives}

The specific objectives of this groundwater chemistry assessment include the following:

- Describe the groundwater chemistry dataset for the Yucca Flat/Climax Mine CAU and surrounding area.

- Using this dataset, characterize the groundwater chemistry of this area.

- Based on the chemistry characterization, present an evaluation of sources, flow paths, and travel times for groundwater in the Yucca Flat/Climax Mine CAU. 


\subsection{Approach}

The evaluations described in this report are focused on the Yucca Flat/Climax Mine geochemistry study area (Figure 12-1) that corresponds to the data compilation area presented in Figure 1-3. The boundaries of the geochemistry study area were selected so that all wells and springs in the vicinity of the Yucca Flat/Climax Mine CAU with available groundwater chemistry data were included. Data from Pahranagat Valley, Emigrant Valley, the Belted Range, Groom Range, Pintwater Range, and Sheep Range are variously considered as representative source areas for groundwater flowing into the study area (Figure 12-2). Wells within Frenchman Flat are included in this study to evaluate outflow from Yucca Flat within the LCA. A geochemical investigation of the Frenchman Flat CAU was documented in Hershey et al. (2005) and summarized in SNJV (2004e).

The methodology used in this investigation follows the basic format described in the UGTA Geochemistry Technical Basis Document (Benedict et al., 2003) as summarized below:

1. A set of geochemical data from groundwater within the investigation area (Figure 12-2) was compiled from the comprehensive water-quality database, GEOCHEM05.mdb (SNJV, 2005b). A thorough evaluation was then performed to determine representative data for each sampling location. Average values were used to represent the isotopic signature and geochemical composition of each well or spring. These data are described in Section 12.3.

2. Conceptual models for groundwater flow were developed based on conservative tracers $(\mathrm{Cl}$, and stable isotopes of hydrogen $[\delta \mathrm{D}]$ and oxygen $\left[\delta^{18} \mathrm{O}\right]$ ) and previous hydrological studies (Winograd and Thordarson, 1975, Laczniak et al., 1996, SNJV, 2005a).

3. Mixing models were developed for conceptual flow paths using conservative tracers and strontium ( $\mathrm{Sr}$ ) concentrations and ${ }^{87} \mathrm{Sr} /{ }^{86} \mathrm{Sr}$ isotopic ratios. Viable models were then verified using the geochemical modeling programs, NETPATH (Plummer et al., 1994) and PHREEQC (Parkhurst and Appelo, 1999). This flow path analysis is summarized in Section 12.6.

The conceptual flow path evaluation, summarized in Section 12.6, focused on groundwater flow in the LCA. The concern was that radionuclides associated with underground tests in the Yucca Flat/Climax Mine CAU might be transported by groundwater to the LCA where they could then exit the basin. Lateral flow paths in the volcanic and alluvial aquifers are not considered during this study because lateral continuous pathways do not extend beyond the CAU boundaries within these units, and the dataset for permeable alluvial and volcanic units is insufficient to conduct a thorough analysis. 


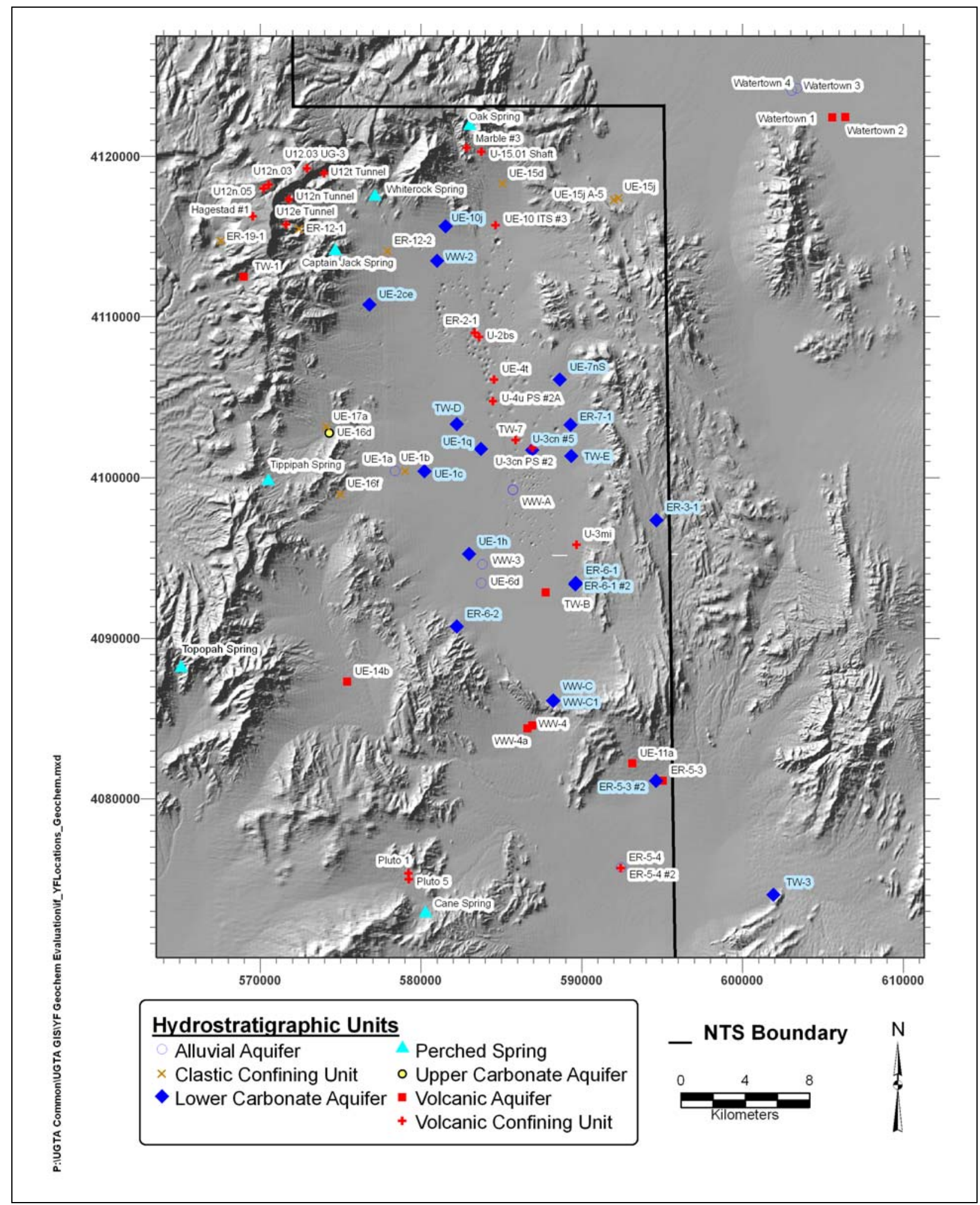

Figure 12-1

\section{Yucca Flat/Climax Mine Geochemistry Study Area}

Note: Blue labels identify wells producing groundwater from the lower carbonate aquifer. 


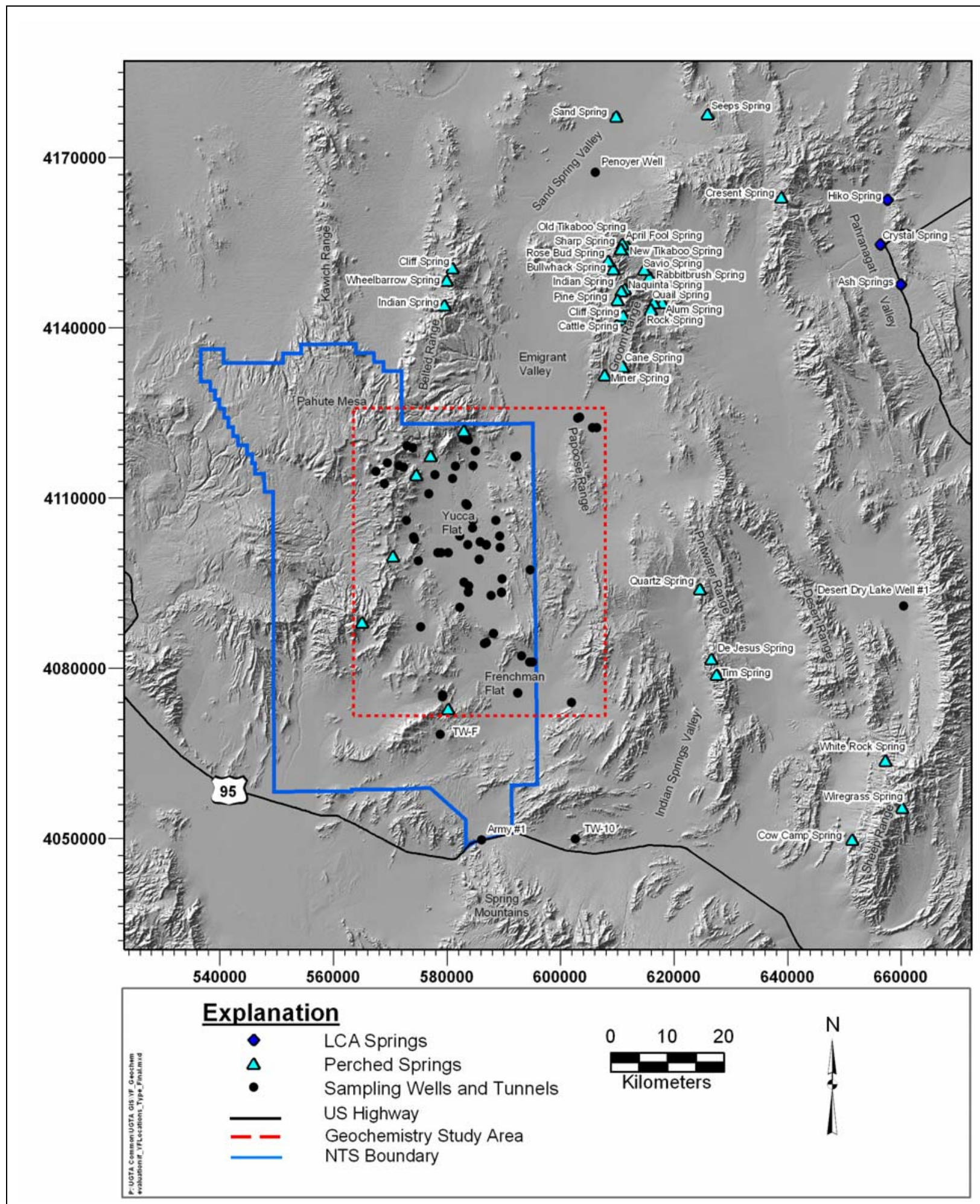

Figure 12-2

Wells and Springs in the Yucca Flat/Climax Mine Geochemical Investigation Area With Geochemical and/or Isotopic Data 


\subsection{Data Description}

The groundwater chemistry dataset for the Yucca Flat/Climax Mine CAU includes data generated during approximately 2,400 sampling events at 85 different wells, springs, or seeps within the area shown in Figure 12-1. A sampling event is defined as a particular date of sampling. The geochemical data are grouped into six parameter groups as follows:

- Minor and Trace Constituents - Elements such as arsenic, lead, or selenium that typically occur at low concentrations in groundwater.

- Environmental Tracers - Stable isotopes such as $\delta \mathrm{D}, \delta^{18} \mathrm{O}$, delta carbon- $13\left(\delta^{13} \mathrm{C}\right)$ and ${ }^{87} \mathrm{Sr} /{ }^{86} \mathrm{Sr}$ isotopic ratios that can be key indicators of water origins.

- Radionuclides - Radioisotopes such as tritium, ${ }^{36} \mathrm{Cl}$, and carbon-14 $\left({ }^{14} \mathrm{C}\right)$.

- Other Parameters - Physical, field, and miscellaneous parameters such as $\mathrm{pH}$, total dissolved solids (TDS), and water temperature.

- Major Constituents - Major cations and anions such as sodium $\left(\mathrm{Na}^{+}\right)$and bicarbonate $\left(\mathrm{HCO}_{3}^{-}\right)$.

- Organic Compounds - Volatile organic compounds, semivolatile organic compounds, and pesticides.

The number of sampling events that have taken place for each parameter group for each sampling location within the Yucca Flat/Climax Mine CAU is summarized in Table 12-1. Although organic compounds are reported in GEOCHEM05.mdb (SNJV, 2005b), these data are not considered representative of the complete dataset available for this study region. For this reason, organic compounds are not listed in Table 12-1.

Several of the wells listed in Table 12-1 are sampled for the Routine Radiological Environmental Monitoring Program (RREMP). These wells are identified by a single asterisk in Table 12-1. Typically, these wells are sampled annually (or biannually) for tritium analysis; biennially for analysis of gross alpha, gross beta, plutonium $(\mathrm{Pu})$, field parameters $(\mathrm{pH}$, specific conductivity, temperature), major ions, TDS, and alkalinity; and every three years for ${ }^{90} \mathrm{Sr},{ }^{14} \mathrm{C}$, and technetium-99 $\left({ }^{99} \mathrm{Tc}\right)$. More detailed information regarding the RREMP is presented in BN (2003). Some wells previously sampled for the RREMP, including ER-3-2 and ER-19-1, are no longer sampled because of poor well development or poor groundwater production from the well. Other 
Table 12-1

Summary of Sampling Events for Groundwater Quality Data Parameters From Wells and Springs in the Yucca Flat/Climax Mine Geochemistry Study Area

(Page 1 of 4)

\begin{tabular}{|c|c|c|c|c|c|c|c|c|c|}
\hline Sampling Location & $\begin{array}{l}\text { Sampling Dates } \\
\text { (Range) }\end{array}$ & $\begin{array}{c}\text { Abbreviated } \\
\text { Name }\end{array}$ & $\begin{array}{c}\text { Primary } \\
\text { HSU }^{\mathrm{a}}\end{array}$ & $\begin{array}{l}\text { HSU } \\
\text { Group }\end{array}$ & $\begin{array}{c}\text { Minor and } \\
\text { Trace } \\
\text { Constituents }\end{array}$ & $\begin{array}{c}\text { Environmental } \\
\text { Tracers }\end{array}$ & Radionuclides & $\begin{array}{c}\text { Other } \\
\text { Parameters }\end{array}$ & $\begin{array}{c}\text { Major } \\
\text { Constituents }\end{array}$ \\
\hline Captain Jack Spring & $5 / 1959-8 / 1997$ & Cap'n Jack & PS & PS & 7 & 8 & 60 & 6 & 6 \\
\hline ER-12-1 & $1 / 1993-12 / 2004$ & $12-1$ & LCA3/UCCU & LCA & 7 & 2 & 6 & 6 & 7 \\
\hline ER-12-2 & $3 / 2003-4 / 2003$ & $12-2$ & UCCU & $\mathrm{CCU}$ & 2 & 1 & 2 & 2 & 2 \\
\hline ER-19-1 & $7 / 1996-5 / 2002$ & $19-1$ & LCCU & $\mathrm{CCU}$ & 1 & 1 & 4 & 1 & 1 \\
\hline ER-2-1 & $9 / 2003$ & $2-1$ & LTCU & TCU & 2 & 1 & 2 & 2 & 2 \\
\hline ER-3-1 (\#1) & 4/1995 - 10/1996 & $3-1$ & LCA & LCA & 4 & 4 & 4 & 3 & 2 \\
\hline ER-3-2 (\#2) & $5 / 1995-6 / 2000$ & $3-2$ & AA & AA & 1 & 0 & 3 & 1 & 0 \\
\hline ER-5-3 & $3 / 2000-7 / 2001$ & $5-3$ & TM-WTA & VA & 6 & 3 & 6 & 6 & 6 \\
\hline ER-5-3 \#2 & $4 / 2001-5 / 2001$ & $5-3 \# 2$ & LCA & LCA & 2 & 1 & 2 & 2 & 2 \\
\hline ER-5-4 & $6 / 2001-7 / 2001$ & $5-4$ & AA & AA & 2 & 1 & 2 & 2 & 2 \\
\hline ER-5-4\#2 & $10 / 2002-11 / 2002$ & $5-4 \# 2$ & LTCU & TCU & 3 & 2 & 3 & 2 & 2 \\
\hline ER-6-1 & $10 / 1992-1 / 2004$ & $6-1$ & LCA & LCA & 7 & 3 & 10 & 7 & 6 \\
\hline ER-6-1 \#2 & $1 / 2003-7 / 2004$ & $6-1 \# 2$ & LCA & LCA & 3 & 2 & 2 & 2 & 2 \\
\hline ER-6-2 & $7 / 2004-8 / 2004$ & $6-2$ & LCA3 & LCA & 2 & 1 & 2 & 2 & 2 \\
\hline ER-7-1 & $7 / 2003$ & $7-1$ & LCA & LCA & 2 & 1 & 2 & 2 & 2 \\
\hline Hagestad \#1 & 9/1957 - 12/1958 & $\mathrm{Hag}$ & LTCU & TCU & 3 & 0 & 3 & 2 & 2 \\
\hline Marble \#3 (ME-3) & $7 / 1959$ & ME-3 & MGCU & GCU & 1 & 0 & 0 & 1 & 1 \\
\hline Oak Spring & $4 / 1958-4 / 1982$ & OakSp & PS & PS & 6 & 5 & 2 & 6 & 10 \\
\hline Pluto 1 & $11 / 1984$ & Pto1 & TCU & TCU & 1 & 0 & 0 & 1 & 1 \\
\hline Pluto 5 & 9/1988 - 9/1988 & Pto5 & $\mathrm{TCU}$ & TCU & 1 & 1 & 0 & 1 & 1 \\
\hline$\star$ *TW-1 & $10 / 1960-3 / 2005$ & TW-1 & PBCRM & VA & 18 & 8 & 23 & 20 & 18 \\
\hline TW-7 & 2/1958 - 1/1994 & TW-7 & LTCU & TCU & 1 & 0 & 2 & 1 & 1 \\
\hline TW-B & $1 / 1963-6 / 1998$ & TW-B & TSA & VA & 8 & 4 & 7 & 90 & 6 \\
\hline${ }^{*} T W-D$ & $1 / 1960-2 / 2005$ & TW-D & LCA & LCA & 9 & 2 & 11 & 28 & 9 \\
\hline
\end{tabular}


Table 12-1

Summary of Sampling Events for Groundwater Quality Data Parameters From Wells and Springs in the Yucca Flat/Climax Mine Geochemistry Study Area

(Page 2 of 4)

\begin{tabular}{|c|c|c|c|c|c|c|c|c|c|}
\hline Sampling Location & $\begin{array}{l}\text { Sampling Dates } \\
\text { (Range) }\end{array}$ & $\begin{array}{c}\text { Abbreviated } \\
\text { Name }\end{array}$ & $\begin{array}{l}\text { Primary } \\
\text { HSUa }^{2}\end{array}$ & $\begin{array}{c}\text { HSU } \\
\text { Group }^{b}\end{array}$ & \begin{tabular}{|c|} 
Minor and \\
Trace \\
Constituents
\end{tabular} & $\begin{array}{c}\text { Environmental } \\
\text { Tracers }\end{array}$ & Radionuclides & $\begin{array}{c}\text { Other } \\
\text { Parameters }\end{array}$ & $\begin{array}{c}\text { Major } \\
\text { Constituents }\end{array}$ \\
\hline TW-E & $7 / 1960-7 / 1991$ & 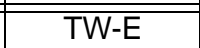 & LCA & $\overline{\mathrm{LCA}}$ & 2 & 1 & $\overline{0}$ & 2 & 2 \\
\hline Tippipah Spring & 9/1957 - 8/1997 & TipSp & PS & PS & 15 & 6 & 76 & 15 & 15 \\
\hline Topopah Spring & $3 / 1958-8 / 1997$ & TopSp & PS & PS & 7 & 7 & 50 & 8 & 6 \\
\hline Tub Spring & $1 / 1989-8 / 1997$ & Tub & PS & PS & 1 & 0 & 16 & 0 & 0 \\
\hline U12.03 UG-3 & $7 / 1974-12 / 1974$ & U12.03 & TCU & TCU & 3 & 0 & 0 & 3 & 3 \\
\hline U-12s Well & $7 / 1993$ & U12s & MGCU & GCU & 1 & 1 & 1 & 1 & 1 \\
\hline U-2bs & 8/1972 - 9/1972 & U2bs & LTCU & TCU & 2 & 0 & 0 & 2 & 2 \\
\hline$\star \star U-2$ bs PS \#1DB & $4 / 1973-6 / 1975$ & U2bsPS\#1 & LTCU & TCU & 14 & 0 & 0 & 13 & 9 \\
\hline **U-2gg PSE \#3a & 9/1993 - 9/1994 & U2ggPSE & TM-LVTA & VA & 1 & 0 & 3 & 1 & 1 \\
\hline$\star \star U-3 c n ~ \# 5$ & $12 / 1965-7 / 2000$ & U-3cn\#5 & LCA & LCA & 22 & 2 & 24 & 96 & 22 \\
\hline **U-3cn PS \#2 & $7 / 1964-12 / 2004$ & U3cn2 & OSBCU & TCU & 50 & 3 & 22 & 52 & 50 \\
\hline U-3mi & Unknown & U3mi & ATCU & TCU & 1 & 0 & 1 & 1 & 1 \\
\hline$\star \star U-4 t$ PS \#3A & $8 / 1993$ & $\mathrm{U} 4 \mathrm{t}$ & LTCU $^{c}$ & $\mathrm{TCU}^{\mathrm{c}}$ & 1 & 0 & 2 & 2 & 1 \\
\hline$\star \star U-4 u$ PS \#2A & $7 / 1992-10 / 2003$ & U4u & LTCU & $\mathrm{TCU}$ & 5 & 4 & 6 & 5 & 5 \\
\hline **U-7ba PS \#1AS & 8/1994 - 7/1995 & U7ba & LTCUC $^{c}$ & $\overline{T C U^{c}}$ & 1 & 0 & 1 & 0 & 1 \\
\hline UE-10 ITS 3 & $8 / 1988$ & UE10-ITS & OSBCU & TCU & 1 & 1 & 0 & 1 & 1 \\
\hline UE-10j & $5 / 1965-4 / 1993$ & UE-10j & LCA & LCA & 2 & 1 & 2 & 2 & 2 \\
\hline UE-10j-1 & $3 / 1997$ & UE10j-1 & LCA & LCA & 1 & 1 & 1 & 1 & 1 \\
\hline UE-10j-2 & $3 / 1997$ & UE10j-2 & LCA & LCA & 1 & 1 & 1 & 1 & 1 \\
\hline UE-10j-3 & 3/1997 & UE10j-3 & LCA & LCA & 1 & 1 & 1 & 1 & 1 \\
\hline UE-11a & 8/1988 & UE11a & TM-WTA & VA & 1 & 1 & 0 & 1 & 1 \\
\hline UE-14b & 9/1988 - 8/1991 & UE14b & TSA & VA & 3 & 3 & 2 & 3 & 3 \\
\hline UE-15d WW & 11/1961 - 7/1991 & UE15d & LCCU & $\mathrm{CCU}$ & 19 & 3 & 34 & 35 & 18 \\
\hline UE-15j & 9/1969 & UE15j & LCCU & $\mathrm{CCU}$ & 1 & 0 & 0 & 1 & 1 \\
\hline
\end{tabular}


Table 12-1

Summary of Sampling Events for Groundwater Quality Data Parameters From Wells and Springs in the Yucca Flat/Climax Mine Geochemistry Study Area

(Page 3 of 4)

\begin{tabular}{|c|c|c|c|c|c|c|c|c|c|}
\hline Sampling Location & $\begin{array}{l}\text { Sampling Dates } \\
\text { (Range) }\end{array}$ & $\begin{array}{c}\text { Abbreviated } \\
\text { Name }\end{array}$ & $\begin{array}{l}\text { Primary } \\
\text { HSU }^{\mathrm{a}}\end{array}$ & $\begin{array}{c}\text { HSU } \\
\text { Group }\end{array}$ & $\begin{array}{c}\text { Minor and } \\
\text { Trace } \\
\text { Constituents }\end{array}$ & $\begin{array}{c}\text { Environmental } \\
\text { Tracers }\end{array}$ & Radionuclides & $\begin{array}{c}\text { Other } \\
\text { Parameters }\end{array}$ & $\begin{array}{c}\text { Major } \\
\text { Constituents }\end{array}$ \\
\hline UE-15j A-5 & $8 / 1969-11 / 1969$ & UE15j-A5 & LCCU & $\mathrm{CCU}$ & 3 & 0 & 0 & 3 & 3 \\
\hline *UE-16d WW & $1 / 1977-7 / 2005$ & UE16d & UCA & UCA & 21 & 6 & 103 & 35 & 20 \\
\hline UE-16f & $8 / 1977-1 / 1995$ & UE16f & UCCU & $\mathrm{CCU}$ & 4 & 3 & 5 & 4 & 4 \\
\hline UE-17a & $9 / 1976-7 / 2002$ & UE17a & UCCU & $\mathrm{CCU}$ & 5 & 1 & 2 & 6 & 2 \\
\hline UE-1a & 8/1988 - 9/1992 & UE1a & AA & AA & 2 & 2 & 1 & 2 & 2 \\
\hline UE-1b & $8 / 1988-9 / 1992$ & UE1b & UCCU & $\mathrm{CCU}$ & 2 & 2 & 1 & 2 & 2 \\
\hline UE-1c & $2 / 1976-7 / 2002$ & UE1c & LCA3 & LCA & 3 & 2 & 3 & 23 & 3 \\
\hline UE-1h & $5 / 1993-6 / 1993$ & UE1h & LCA & LCA & 2 & 2 & 2 & 1 & 2 \\
\hline$\star U E-1 q$ & $8 / 1991-2 / 2005$ & UE1q & LCA & LCA & 6 & 2 & 11 & 8 & 6 \\
\hline 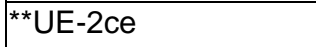 & $1 / 1977-8 / 2001$ & UE2ce & LCA3 & LCA & 5 & 1 & 94 & 9 & 5 \\
\hline 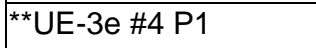 & $3 / 1990-9 / 1998$ & UEЗe\#4P1 & LTCU & TCU & 2 & 1 & 20 & 2 & 2 \\
\hline 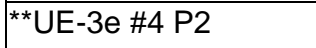 & $3 / 1990-9 / 1998$ & UEЗe\#4P2 & LTCU & TCU & 2 & 1 & 19 & 2 & 2 \\
\hline **UE-3e \#4 P3 & $3 / 1990-9 / 1998$ & UE3e\#4P3 & TM-LVTA & VA & 1 & 0 & 17 & 1 & 1 \\
\hline UE-4t & 8/1990 & UE4t & LTCU & TCU & 1 & 1 & 1 & 0 & 0 \\
\hline **UE-4t 1 & $6 / 1992-6 / 2000$ & UE4t1 & LTCU & TCU & 1 & 1 & 3 & 1 & 1 \\
\hline **UE-4t 2 & $6 / 2000$ & UE4t2 & LTCU & TCU & 0 & 0 & 1 & 0 & 0 \\
\hline UE-6d & $6 / 1986-1 / 1995$ & UE6d & PCU & AA & 1 & 1 & 2 & 1 & 1 \\
\hline UE-6e & 1/1994 - 3/1999 & UE6e & TSA & VA & 0 & 0 & 3 & 0 & 0 \\
\hline *UE-7nS & $7 / 1977-5 / 2005$ & UE7nS & LCA & LCA & 7 & 1 & 18 & 53 & 7 \\
\hline Watertown 1 & 9/1957 - 8/1995 & WT-1 & TUBA & VA & 5 & 1 & 4 & 5 & 5 \\
\hline Watertown 2 & 9/1957 - 9/1969 & WT-2 & TUBA & VA & 2 & 0 & 1 & 2 & 2 \\
\hline Watertown 3 & 11/1959 - 8/1995 & WT-3 & AA & AA & 13 & 2 & 4 & 11 & 11 \\
\hline Watertown 4 & 9/1969 - 8/1995 & WT-4 & AA & AA & 2 & 2 & 1 & 2 & 2 \\
\hline *WW-A & $9 / 1960-2 / 2005$ & WW-A & AA & AA & 32 & 1 & 11 & 167 & 31 \\
\hline
\end{tabular}


Table 12-1

Summary of Sampling Events for Groundwater Quality Data Parameters From Wells and Springs in the Yucca Flat/Climax Mine Geochemistry Study Area

(Page 4 of 4)

\begin{tabular}{|c|c|c|c|c|c|c|c|c|c|}
\hline Sampling Location & $\begin{array}{l}\text { Sampling Dates } \\
\text { (Range) }\end{array}$ & $\begin{array}{c}\text { Abbreviated } \\
\text { Name }\end{array}$ & $\begin{array}{c}\text { Primary } \\
\text { HSU }^{\mathrm{a}}\end{array}$ & $\begin{array}{c}\text { HSU } \\
\text { Group }^{b}\end{array}$ & $\begin{array}{c}\text { Minor and } \\
\text { Trace } \\
\text { Constituents }\end{array}$ & $\begin{array}{c}\text { Environmental } \\
\text { Tracers }\end{array}$ & Radionuclides & $\begin{array}{c}\text { Other } \\
\text { Parameters }\end{array}$ & $\begin{array}{c}\text { Major } \\
\text { Constituents }\end{array}$ \\
\hline WW-1 & $4 / 1966$ & WW-1 & $\mathrm{AA}$ & AA & 1 & 0 & 0 & 1 & 1 \\
\hline *WW-2 & $4 / 1962-2 / 2005$ & WW-2 & LCA & LCA & 22 & 4 & 59 & 130 & 23 \\
\hline${ }^{\star} \mathrm{WW}-4$ & $1 / 1981-7 / 2005$ & WW-4 & TM-WTA & VA & 17 & 2 & 150 & 63 & 16 \\
\hline *WW-4A & $4 / 1992-7 / 2005$ & WW-4a & TM-WTA & VA & 9 & 1 & 45 & 15 & 8 \\
\hline WW-C & 6/1961 - 4/1995 & WW-C & LCA & LCA & 40 & 6 & 269 & 320 & 38 \\
\hline$\star W W-C-1$ & $10 / 1962-7 / 2005$ & WW-C1 & LCA & LCA & 35 & 6 & 102 & 63 & 33 \\
\hline WW-3 & $4 / 1957-4 / 1972$ & WW-3 & AA & AA & 9 & 0 & 6 & 9 & 9 \\
\hline Whiterock Spring & $3 / 1958-10 / 1988$ & Whiterock & PS & PS & 55 & 90 & 13 & 56 & 55 \\
\hline \multicolumn{10}{|c|}{ Climax Stock (U-15.01 Shaft) Samples: } \\
\hline C-30 & Unknown & C30 & MGCU & GCU & 1 & 0 & 0 & 1 & 1 \\
\hline C-36 & Unknown & C36 & MGCU & GCU & 1 & 0 & 0 & 1 & 1 \\
\hline CGW-1 & Unknown & CGW1 & MGCU & GCU & 1 & 1 & 1 & 1 & 1 \\
\hline $\mathrm{NH}-01$ & Unknown & $\mathrm{NHO1}$ & MGCU & GCU & 1 & 0 & 1 & 1 & 1 \\
\hline UG-02 & Unknown & UG02 & MGCU & GCU & 1 & 0 & 1 & 1 & 1 \\
\hline
\end{tabular}

*Periodically sampled for the RREMP (BN, 2003)

**Periodically sampled for the near-field well sampling program.

aPrimary HSU = HSU that comprises the largest section of the open completion interval or the HSU associated with depth-discrete samples.

bHSU Group = HSU group used within the report for evaluation and illustrative purposes.

cHSUs assigned to U-4t PS\#3A and U-7ba PS\#1AS are based on data from U-4t and U-7ba, respectively.

PS $=$ Perched spring 
wells previously monitored as part of the RREMP are now sampled as part of the near-field well (Hot Well) sampling effort initiated in 2001. Near-field wells that are sampled for this program are identified by a double asterisk in Table 12-1. Samples are collected every three to five years by LANL and LLNL and analyzed for a suite of radionuclides (including tritium), major ions, minor and trace constituents, and various field parameters depending on the particular sampling location. The locations and sampling frequency may vary as a function of the accessibility of sampling. Most of the groundwater collected from the near-field wells has been impacted by underground testing.

The sampling events summarized in Table 12-1 have produced the most complete and up-to-date water quality data available for the Yucca Flat/Climax Mine CAU. The completeness of the suite of water quality parameters measured and the associated data quality is largely a function of sample location and collection date. The data have been generated over a significant period of time (1957 to 2005) using various sampling and analytical methods to accomplish a variety of objectives. Some locations have only a single sampling event and a minimal number of measured parameters (e.g., WW-1, UE-11a, U-12s, and UE-15j) while other locations (such as those sampled for the RREMP) have been sampled numerous times for most parameter categories. Although complete datasets have been obtained for many of the wells within the Yucca Flat/Climax Mine CAU, several wells lack critical water quality parameters including environmental isotope data (Table 12-1).

Water quality samples are typically collected as composite samples either from wells with single completions that transect multiple HSU boundaries or from wells with multiple completions that are all pumped simultaneously. Depth-discrete bailer samples were collected from each of the new UGTA wells and analyzed for all parameter groups except environmental isotopes and organic parameters. Depth-discrete sampling provides additional information on the vertical variability in groundwater quality, at multiple completion wells, located in the area of interest. Well UE-10j is the northernmost Yucca Flat well completed in the LCA (Figure 12-1). This well was constructed such that discrete groundwater samples could be collected at three depth intervals: 765.0 to $773.0 \mathrm{~m}$ (UE-10j-1), 732.3 to $740.1 \mathrm{~m}$ (UE-10j-2), and 691.1 to $699.0 \mathrm{~m}$ (UE-10j-3). All three zones are completed within the Banded Mountain Member of the Cambrian Bonanza King Formation (IT, 1995). The primary HSU for each well, the HSU that reflects the largest effective open interval or the HSU associated with the depth-discrete samples, is presented in Table 12-1. 
The Yucca Flat/Climax Mine geochemistry dataset is presented in Appendix H. All sampling locations shown in Figure 12-2 are included in this dataset. Included are the mean values, SDs, and number of independent measurements for each parameter. Outliers that exceeded three SDs of the mean values were removed from the mean calculation. The SD, reported in Figure 12-2, indicates that there is significant variability in some of the measured values for some locations. This variability primarily results from the different methods used for sample collection and analysis over the period of time represented by this dataset (1957 to 2005). In some cases, this variability can be attributed to seasonal differences in groundwater compositions. It is therefore desirable to develop geochemical models that are based on multiple geochemical parameters and that allow for the input of uncertainty such as those developed using the NETPATH and PHREEQC modeling programs (Section 12.6.1.3).

\subsection{Data Evaluation}

The groundwater chemistry data in GEOCHEM05.mdb (SNJV, 2005b) were evaluated with respect to the level of available data documentation and the quality and/or diagnostic utility value of the reported data measurements.

\subsubsection{Data Documentation Evaluation}

The available data documentation for the groundwater chemistry dataset has been evaluated and flags (Levels 1 to 5) were assigned in accordance with the data documentation requirements described in Section 4.3.3.1.

\subsubsection{Data Quality Evaluation}

In addition to the data documentation evaluation flag, a DDF qualifier was assigned to qualitatively rank the reported chemical values in terms of the relative confidence level associated with the data. The following levels of relative confidence have been defined and assigned to the groundwater chemistry data:

- Level C: Consistent - Analytical result is consistent with historical or regional trends for the reported location(s); or, for a given sample, there are no anomalous results within the suite of parameters that would indicate sample contamination due to improper sample collection or erroneous laboratory procedures. 
- Level NC: Not Consistent - Analytical result is not consistent with historical or regional trends for the reported location(s); or, for a given sample, there are data anomalies within the suite of parameters that may indicate sample contamination or laboratory errors.

- Unknown - Data have not been formally evaluated to assess the accuracy and/or consistency of the data; or there is insufficient information (e.g., regionally, temporally, or within the dataset) to determine whether or not the data is consistent with historical or regional trends for the reported location.

Other data quality criteria exist and are commonly applied in the course of conducting evaluations of groundwater geochemical data. For example, the presence of $\mathrm{Br}^{-}$above background levels can be an indication that groundwater samples have been contaminated by residual drilling fluids and are, therefore, not representative of ambient conditions. In addition, evaluation of the major-ion charge balance (Hem, 1985) serves as an indicator of the analytical data quality for the predominant constituents in a given water sample. The charge balances for the Yucca Flat/Climax Mine dataset, calculated as the relative abundance in equivalents of cations $\left(\mathrm{Na}^{+}\right.$, potassium $\left[\mathrm{K}^{+}\right]$, calcium $\left[\mathrm{Ca}^{2+}\right]$, and magnesium $\left.\left[\mathrm{Mg}^{2+}\right]\right)$ and anions $\left(\mathrm{Cl}^{-}, \mathrm{Br}^{-}, \mathrm{HCO}_{3}{ }^{-}\right.$, carbonate $\left[\mathrm{CO}_{3}{ }^{2-}\right]$, fluoride $\left[\mathrm{F}^{-}\right]$, nitrate $\left[\mathrm{NO}_{3}^{-}\right]$, and sulfate $\left[\mathrm{SO}_{4}{ }^{2-}\right]$ ), are presented in Appendix $\mathrm{H}$ (see Table H.1-1).

\subsection{Analysis Process and Results}

The geochemical processes that accompany the movement of groundwater at the NTS include a variety of interactions (e.g., water-rock, solute-solute, and water-atmospheric) that occur in response to changes in the hydrogeologic environment. These geochemical processes, and the changes in the hydrogeologic environment that they are indicative of, are identified through the evaluation of a diverse suite of geochemical parameters. The parameters occur as groups (e.g., major ions, stable isotopes, and radioisotopes) that tend to respond in systematic ways to similar geochemical processes. The following subsections discuss these groups of geochemical parameters in terms of their respective utility as diagnostic hydrogeological indicators for the Yucca Flat/Climax Mine CAU.

\subsubsection{Major-Ion Chemistry}

The dissolved constituents in groundwater provide a record of the minerals encountered as water moves through geologic materials. Accordingly, major-ion chemistry can be used to characterize the interaction and trace the movement of groundwater through aquifer materials. Evaluation of the 
major-ion characteristics of groundwater can provide insight on the source areas and flow directions for groundwater movement.

Piper diagrams illustrating the major-ion data for samples collected within the Yucca Flat/Climax Mine study area are presented in Figures 12-3 through 12-5. A Piper diagram is a graphical tool used to represent the relative concentrations of major ions in a sample and can be used to classify groundwaters into distinct hydrochemical water types (Hem, 1985). Schoff and Moore (1964), Blankennagel and Weir (1973), and Winograd and Thordarson (1975) identified three general water types for the NTS as follows:

- $\quad \mathrm{Na}-\mathrm{K}-\mathrm{HCO}_{3}$ type commonly found in volcanic rock aquifers. The dominant cation is $\mathrm{Na}$ resulting primarily from reaction with volcanic glass and feldspar minerals (White et al., 1980).

- $\mathrm{Ca}-\mathrm{Mg}-\mathrm{HCO}_{3}$ type commonly occurring in carbonate aquifers. Dissolution of calcite and dolomite in the carbonate aquifers results in groundwaters that are dominated by $\mathrm{Ca}$ and $\mathrm{Mg}$.

- $\mathrm{Ca}-\mathrm{Mg}-\mathrm{Na}-\mathrm{HCO}_{3}$ type assumed to be a mixture of the volcanic $\left(\mathrm{Na}-\mathrm{K}-\mathrm{HCO}_{3}\right)$ and carbonate $\left(\mathrm{Ca}-\mathrm{Mg}-\mathrm{HCO}_{3}\right)$ groundwater types.

Bicarbonate is the predominant anionic constituent in the majority of the groundwaters and is derived primarily from the dissolution of soil carbon dioxide $\left(\mathrm{CO}_{2}\right)$ gas and reaction with carbonate minerals.

A Piper diagram illustrating the major-ion data for the AA (represented by red symbols) and the CCUs (represented by blue symbols) is shown in Figure 12-3. The majority of the groundwaters of the AA are the mixed groundwater type, $\mathrm{Ca}-\mathrm{Mg}-\mathrm{Na}-\mathrm{HCO}_{3}$. With the exception of ER-19-1, the groundwaters of the $\mathrm{CCU}$ are either the Na-K-HCO 3 type (UE-16f, ER-12-2, UE-15j, and UE-15j-A5) or the mixed type (UE-1b, UE-15d WW, and UE-17a). Well ER-19-1 groundwater has an anomalously high $\mathrm{pH}(10.7)$, resulting in high concentrations of $\mathrm{CO}_{3}{ }^{2-}$ and no measurable $\mathrm{HCO}_{3}{ }^{-}$ indicating poor development of this well. Samples collected from ER-19-1 will therefore not be considered further in the geochemical analyses.

Major-ion data for groundwater samples from the VAs (represented by blue symbols), TCU (represented by red symbols), Rainier Mesa tunnels (represented using green symbols), and the Climax Stock (represented using black symbols) are presented in the Piper diagram in Figure 12-4. The majority of these groundwaters are the $\mathrm{Na}-\mathrm{K}-\mathrm{HCO}_{3}$ type. The Climax Stock samples are unique 


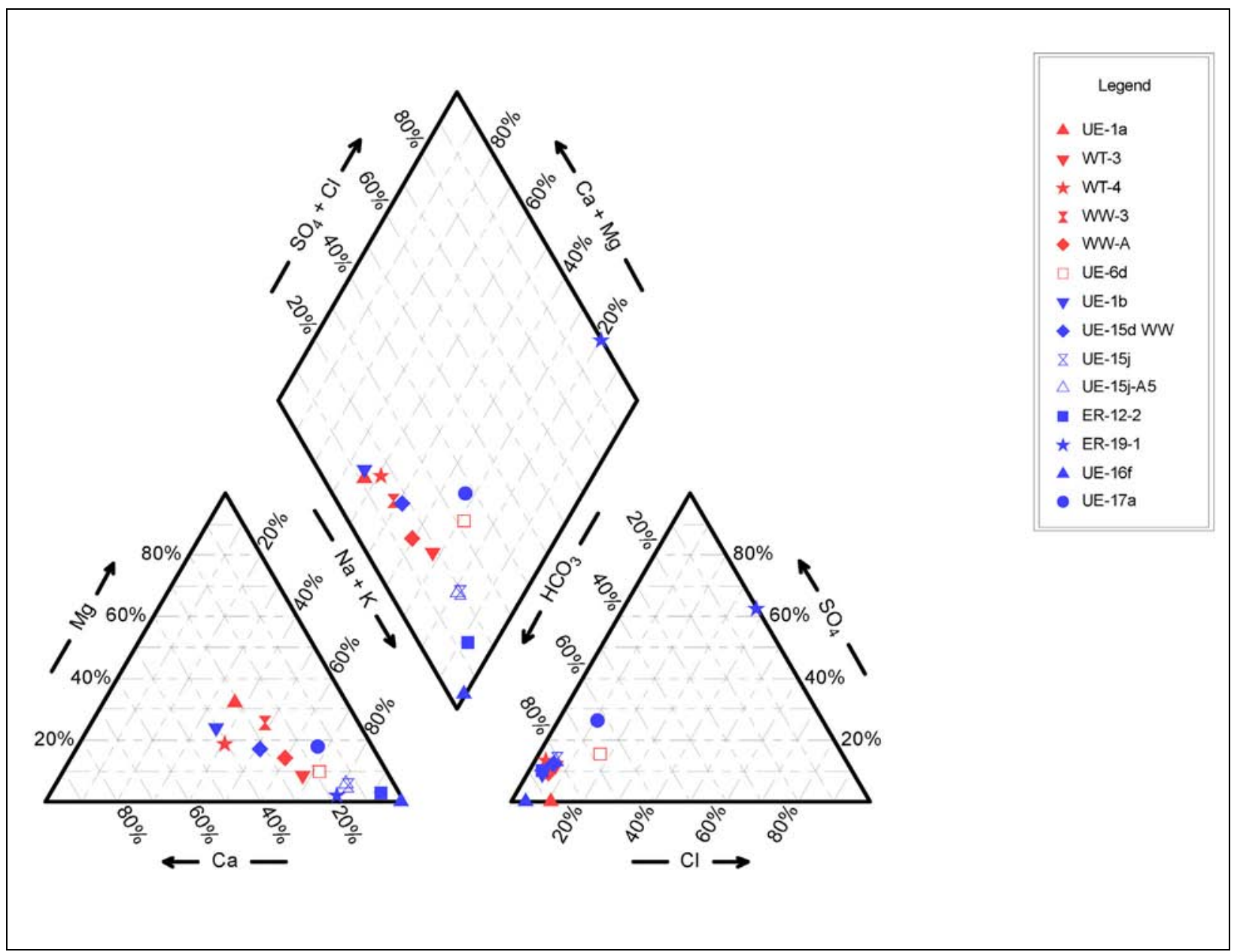

Figure 12-3

Piper Diagram for Groundwater of Alluvial Aquifer and Clastic Confining Units

Note: Samples from the alluvial aquifer and clastic confining units are represented with red and blue symbols, respectively.

when compared to all samples within the study area, in that the total solute concentrations are much higher, and the dominant anion is $\mathrm{SO}_{4}^{2-}$ rather than $\mathrm{HCO}_{3}^{-}$. The high $\mathrm{SO}_{4}{ }^{2-}$ in these samples is inferred to reflect oxidation of the abundant pyrite present along the fractures in the hydrothermally altered granite. One sample from the Climax Stock, C36 is similar to groundwater of ER-12-1 (Figure 12-5) The dominant anion and cation in both samples are $\mathrm{SO}_{4}{ }^{2-}(343 \mathrm{mg} / \mathrm{L}$ in ER-12-1 and $325 \mathrm{mg} / \mathrm{L}$ in C36) and $\mathrm{Ca}^{2+}(94 \mathrm{mg} / \mathrm{L}$ in ER-12-1 and $126 \mathrm{mg} / \mathrm{L}$ in C36), respectively. The TDS of the C36 sample $(1,150 \mathrm{mg} / \mathrm{L})$ is greater than that of the ER-12-1 sample $(760 \mathrm{mg} / \mathrm{L})$ primarily because of the higher relative concentrations of $\mathrm{Cl}^{-}, \mathrm{Ca}^{2+}$, and $\mathrm{Na}^{+}$(see Appendix $\mathrm{H}$ ). 


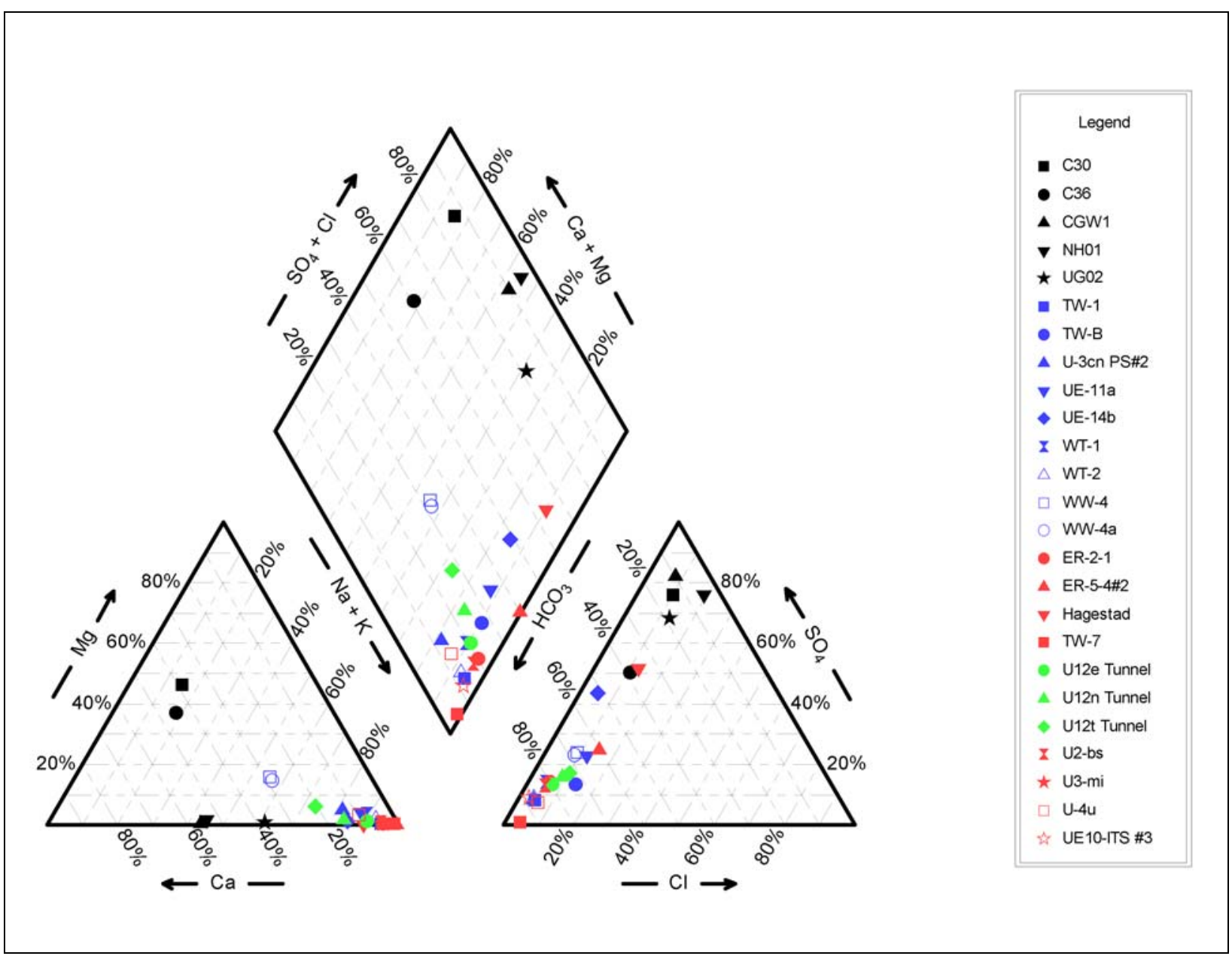

Figure 12-4

Piper Diagram for Groundwater of Volcanic Aquifers and Confining Units

Note: Samples from the Climax Stock, volcanic aquifers, tuff confining units, and the Rainier Mesa tunnels are represented with black, blue, red, and green symbols, respectively.

A Piper diagram illustrating the major-ion data for the LCA is shown in Figure 12-5. With the exception of ER-12-1, the groundwater of the LCA lie along a trend line that ranges from the $\mathrm{Ca}-\mathrm{Mg}-\mathrm{HCO}_{3}$ type (represented by red symbols) to the mixed type (represented by blue symbols), to the $\mathrm{Na}-\mathrm{K}-\mathrm{HCO}_{3}$ type (represented by black symbols). The majority of LCA groundwater samples included in this study are the mixed type. Groundwater of the Pahranagat Valley springs (Crystal, Hiko, and Ash) and all intervals of UE-10j are the $\mathrm{Ca}-\mathrm{Mg}-\mathrm{HCO}_{3}$ type. The $\mathrm{Na}-\mathrm{K}-\mathrm{HCO}_{3}$ type groundwaters of UE-1h, TW-D, and UE-7nS could indicate mixing with groundwater of the overlying units, ion-exchange processes, and/or influence by underground testing (in the case of $\mathrm{UE}-7 \mathrm{nS})$. 


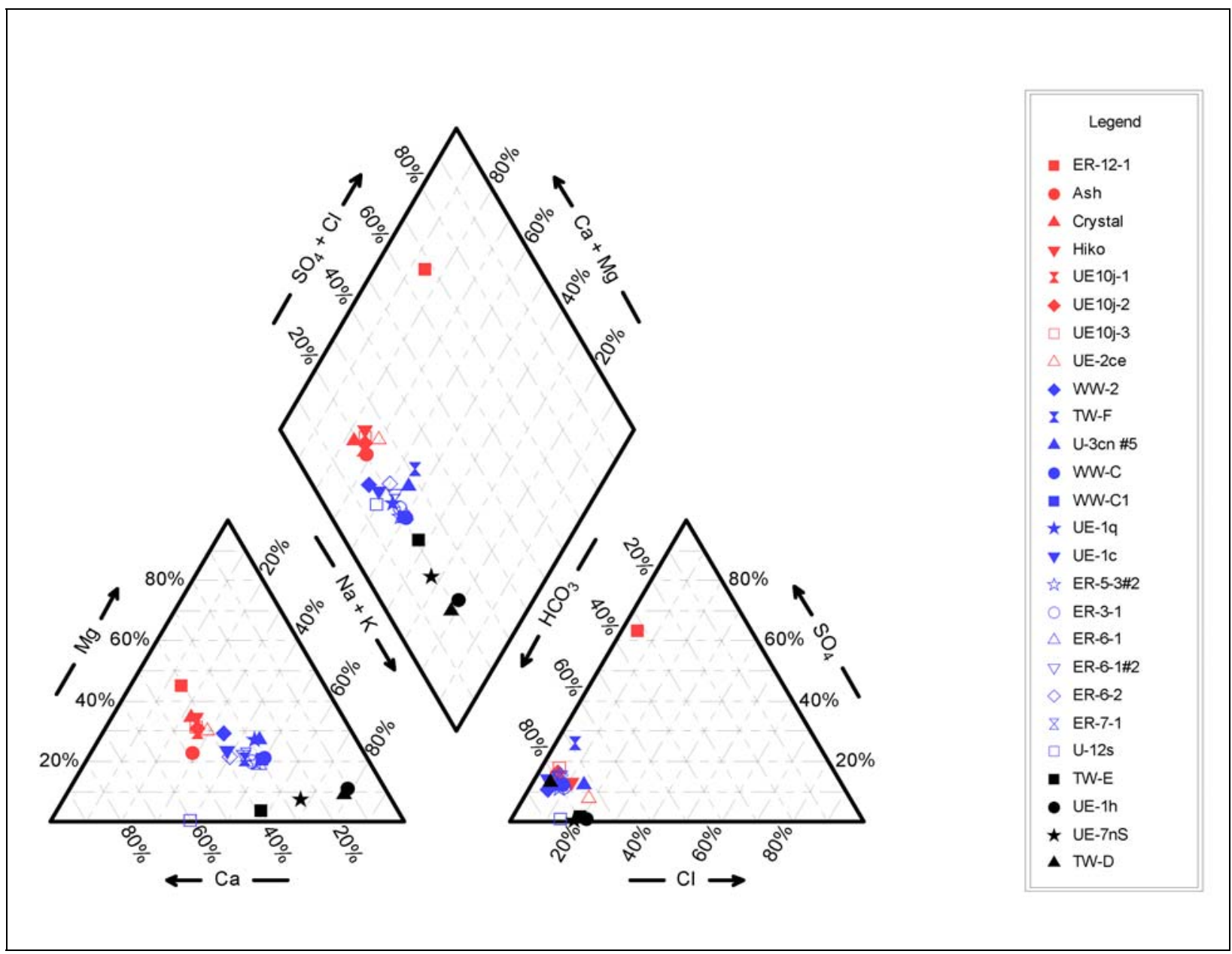

Figure 12-5

Piper Diagram for Groundwater of the Lower Carbonate Aquifer

Note: Samples that are the Ca-Mg- $-\mathrm{HCO}_{3}, \mathrm{Ca}-\mathrm{Mg}-\mathrm{Na}-\mathrm{HCO}_{3}$, and the $\mathrm{Na}-\mathrm{K}-\mathrm{HCO}_{3}$ type are represented by red, blue, and black symbols, respectively.

\subsubsection{Stable and Radioactive Environmental Isotopes}

The stable isotopes of hydrogen and oxygen are perhaps the most conservative of all environmental tracers and can be used to trace the groundwater origin and flow path, and to quantitatively determine mixing ratios of different water masses. Carbon isotopes are strongly influenced by recharge processes and water-rock interaction. The stable isotope of carbon, ${ }^{13} \mathrm{C}$, provides a means to identify the degree of interaction with the available carbon reservoirs along the flow path. 
Stable isotopes are reported as the abundance ratio of the two most common isotopes of a given element relative to a reference standard:

$$
\begin{gathered}
\delta D=\left[\left({ }^{2} \mathrm{H} /{ }^{1} \mathrm{H}\right)_{\text {sample }} /\left({ }^{2} \mathrm{H} /{ }^{1} \mathrm{H}\right)_{\text {VSMOW }}-1.0\right] \cdot 1000 \\
\delta^{18} \mathrm{O}=\left[\left({ }^{18} \mathrm{O} /{ }^{16} \mathrm{O}\right)_{\text {sample }} /\left({ }^{18} \mathrm{O} /{ }^{16} \mathrm{O}\right)_{V S M O W}-1.0\right] \cdot 1000 \\
\delta^{13} \mathrm{C}=\left[\left({ }^{13} \mathrm{C} /{ }^{12} \mathrm{C}\right)_{\text {sample }} /\left({ }^{13} \mathrm{C} /{ }^{12} \mathrm{C}\right)_{P D B}-1.0\right] \cdot 1000
\end{gathered}
$$

The reference standard for $\delta \mathrm{D}$ and $\delta^{18} \mathrm{O}$ is known as the "Vienna Standard Mean Ocean Water" (VSMOW) and the reference standard for groundwater $\delta^{13} \mathrm{C}$ is Pee Dee Belemnite (PDB). Each of these elements is relatively light, and the relative mass differences between the isotopes for a given element are relatively large. This mass difference can result in significant fractionation during physical processes and associated chemical reactions. Fractionation occurring in the natural environment during hydrogeological processes can provide information on the origin and evolution of groundwater.

Radioactive environmental isotopes are also important geochemical indicators. Groundwater residence times can be inferred from the decay of radioactive tracers present in the water if the input concentration of the tracer is reasonably well known and constant over time. Naturally occurring radioisotopes such as ${ }^{14} \mathrm{C},{ }^{36} \mathrm{Cl}$, and ${ }^{3} \mathrm{H}$ can be used to estimate the apparent age or travel time of groundwater.

\subsubsection{Hydrogen and Oxygen Isotopes}

The $\delta \mathrm{D}$ and $\delta^{18} \mathrm{O}$ values of precipitation are strongly dependent on temperature and vary with latitude, elevation, and distance from the ocean (Dansgaard, 1964). The observed variability in groundwater $\delta \mathrm{D}$ and $\delta^{18} \mathrm{O}$ compositions results from fractionation effects that have occurred during evaporation and precipitation before recharge has occurred, or in response to the mixing of groundwaters that have recharged under different conditions. Once precipitation has infiltrated the water table, the stable isotope values are unaffected by water-rock interaction at temperatures below approximately $100^{\circ} \mathrm{C}$ (Criss, 1999). Therefore, an evaluation of the $\delta \mathrm{D}$ and $\delta^{18} \mathrm{O}$ compositions of groundwater can provide information on prevailing environmental conditions at the time of groundwater recharge. 
Long-term variations in the isotopic composition of precipitation and recharge may complicate the interpretation of groundwater isotope signatures in Yucca Flat. Proxy paleoclimate records are consistent with greater effective moisture in the Great Basin during the late Pleistocene. For example, the widespread occurrence of paleospring deposits marks episodes of increased recharge and higher water tables during the late Pleistocene (Quade et al., 1995, 1998). Increased recharge rates imply a significant volume of groundwater was added to the regional aquifers at that time. The extent to which this water persists today is largely a function of groundwater flow velocities and turnover rates for individual sub-basins. Previous isotope hydrology studies in the Oasis Valley-Yucca Mountain-Amargosa Desert region (central DVRFS) concluded that most groundwater in south-central Nevada was probably recharged following the last major cycle of the pluvial period (Claassen, 1986; White and Chuma, 1987; Benson and Klieforth, 1989).

Perched groundwater associated with small springs and seeps can be used as a proxy for the average composition of local recharge if the water has not experienced a large amount of post-discharge evaporation (Rose et al., 2003). Six perched springs with isotopic data are located in or near Yucca Flat (Figure 12-1). Additionally, 19 perched springs with isotopic data are located north of Yucca Flat in the Belted and Groom Ranges (Figure 12-2). The $\delta^{18} \mathrm{O}$ versus the $\delta \mathrm{D}$ composition for these springs and also groundwater of northern Yucca Flat and surrounding areas (Rainier Mesa tunnels, Climax Stock, and Pahranagat Valley) are plotted in Figure 12-6. The plot also includes the weighted average precipitation data from the two precipitation stations, RT 1 and RT 2, on Rainier Mesa. For reference, the global meteoric water line (GMWL) and the local meteoric water line (LMWL) are included in Figure 12-6. The GMWL $\left(\delta \mathrm{D}=8 \delta^{18} \mathrm{O}+10\right)$ represents the observed correlations in $\delta^{18} \mathrm{O}-\delta \mathrm{D}$ values of precipitation samples from around the world (Craig, 1961). The LMWL $\left(\delta \mathrm{D}=6.87 \delta^{18} \mathrm{O}-6.5\right)$ represents the observed correlations in $\delta^{18} \mathrm{O}-\delta \mathrm{D}$ values of precipitation samples collected by DRI at 14 sites at the NTS from 1982 through 1986 (Ingraham et al.,1990; 1991).

Highly evaporated waters plot along a low slope $\delta \mathrm{D}-\delta^{18} \mathrm{O}$ trajectory that lies below the meteoric water lines (an evaporative trend is shown in Figure 12-6). The Climax Stock sample falls along the LMWL. Although there is some variability between the different tunnels (E-, N-, and T-Tunnels), the tunnel waters are not significantly evaporated and also plot close to the LMWL. Several tunnel samples collected in 1999 from impounded water behind the sealed bulkheads are somewhat isotopically lighter than the average isotopic composition of non-evaporated groundwater recharge 


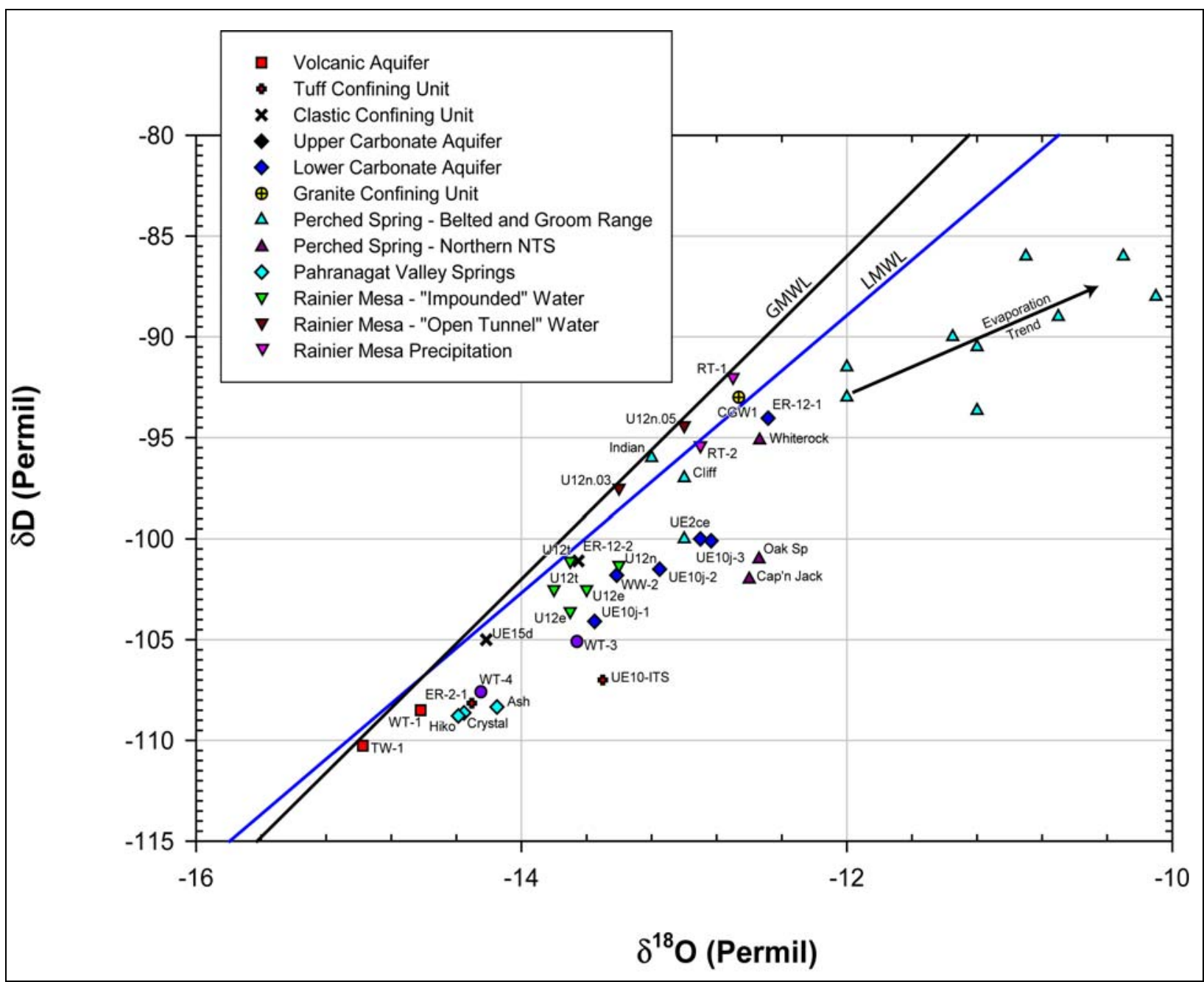

Figure 12-6

Plot of $\delta D$ Versus $\delta^{18} \mathrm{O}$ Values for Regional and Perched Groundwater Samples in Northern Yucca Flat and Surrounding Areas

(open tunnel waters; Figure 12-6). The samples of the perched spring and Rainier Mesa tunnel water show a broad range in $\delta \mathrm{D}$ and $\delta^{18} \mathrm{O}$ values that do not appear to be strongly related to differences in geographic location (Figure 12-6). For this reason, it is difficult to define a single composition that uniquely represents the $\delta \mathrm{D}$ and $\delta^{18} \mathrm{O}$ compositions of local recharge from the Rainier Mesa. Average compositions of individual perched springs are used to represent local recharge in most of the geochemical models identified in SNJV (2006a). These models sometimes require a combination of two perched water sources to accommodate the observed downgradient water composition. 
A comparison of the isotopic signature of groundwaters within the Yucca Flat/Climax Mine study area is presented in Figure 12-7. Groundwater in different geographic areas of the Yucca Flat basin show subtle differences in their isotopic composition. For instance, the lowest LCA $\delta \mathrm{D}$ and $\delta^{18} \mathrm{O}$ values tend to occur in the east-southeast part of the flow system (ER-3-1, ER-5-3\#2, WW-C, WW-C1, and TW-E) or in the center of the basin (TW-D and UE-1q). These values range from -109 to -106 permil $\delta \mathrm{D}$ and -14.5 to -13.9 permil $\delta^{18} \mathrm{O}$. Somewhat higher values of $\delta \mathrm{D}$ and $\delta^{18} \mathrm{O}$ are observed in LCA groundwaters in other parts of the basin (Figure 12-7), which may reflect mixing with local recharge or with groundwater from the overlying volcanic units. The $\delta \mathrm{D}$ and $\delta^{18} \mathrm{O}$ values for the groundwater in the westernmost part of the basin (e.g., UE-16d WW, UE-17a, and UE-1a) range from -103 to -96 permil $\delta \mathrm{D}$ and -13.6 to -12.6 permil $\delta^{18} \mathrm{O}$. The higher $\delta \mathrm{D}$ and $\delta^{18} \mathrm{O}$ values for these waters are consistent with a larger component of local recharge. In general, the major HSUs have non-unique overlapping $\delta \mathrm{D}$ and $\delta^{18} \mathrm{O}$ values. This compositional overlap is a reflection of common source areas for groundwater recharge as well as mixing of the water masses present in the different HSUs.

\subsubsection{Carbon Isotopes}

The geochemical behavior of carbon in groundwater systems is very complex and includes interactions with the atmosphere, biosphere, and geosphere; involving multiple sources and sinks of carbon that can vary in both time and space (Kalin, 2000). Nevertheless, ${ }^{14} \mathrm{C}$ is the tracer most often used to estimate the residence time of groundwaters that are less than approximately 40,000 years in age. By tracking the evolution of the $\delta^{13} \mathrm{C}$ groundwater composition as it interacts with the various carbon reservoirs, it is often possible to develop corrections for carbon mass transfer effects (Mook, 1980).

Groundwaters (as well as pedogenic carbonates) initially have $\delta^{13} \mathrm{C}$ values that reflect soil gas compositions. Once groundwater is isolated from soil zone $\mathrm{CO}_{2}$, its DIC can be modified through dissolution of calcite and dolomite (combined with calcite precipitation) (Clark and Fritz, 1997). These processes tend to drive the dissolved inorganic carbon (DIC) toward higher (less negative) $\delta^{13} \mathrm{C}$ values and lower ${ }^{14} \mathrm{C}$ values (because of the absence of ${ }^{14} \mathrm{C}$ in the calcite). Secondary calcite, present in the alluvial and volcanic HSUs in Yucca Flat, has an average $\delta^{13} \mathrm{C}$ value between about -2.5 and -3.0 permil; whereas carbonate bedrock samples from the NTS have an average $\delta^{13} \mathrm{C}$ value near 


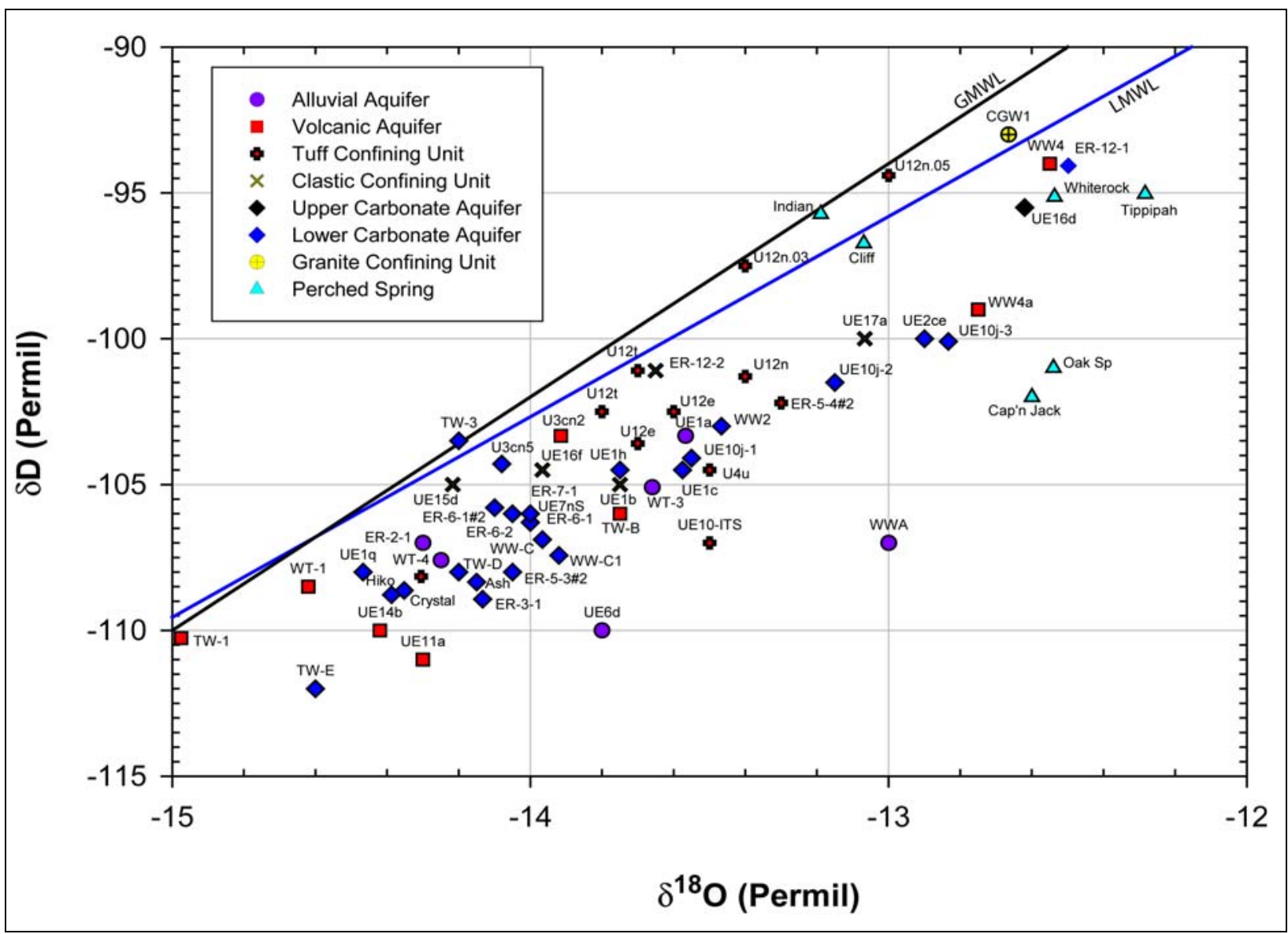

Figure 12-7

Plot of $\delta D$ Versus $\delta^{18} \mathrm{O}$ Values for Groundwater Samples in the Yucca Flat/Climax Mine Study Area

+0.5 permil (see SNJV, 2006a for data summary). In the Great Basin, soil zone $\mathrm{CO}_{2}$ has $\delta^{13} \mathrm{C}$ values that decrease from about -12 permil at a 900 m elevation to about -20 permil at 2,700 m elevation for reasons related to plant type and density and moisture availability (Quade et al., 1989). Soil water and pedogenic carbonates precipitated from infiltrating water have $\delta^{13} \mathrm{C}$ values that are about 8 and 9 permil heavier, respectively, than the soil zone $\mathrm{CO}_{2}$ because of equilibrium isotopic fractionation of carbon between the gas, liquid, and solid phases (Clark and Fritz, 1997).

Carbon isotope values were measured in groundwater samples of the Yucca Flat/Climax Mine study area for both DIC and dissolved organic carbon (DOC) fractions. The DIC isotopic data are used to constrain geochemical mass transfer models (e.g., NETPATH and PHREEQC) whereas the DOC isotopic data provide an estimate of the mean organic carbon residence time in the groundwater. 
Groundwater ${ }^{14} \mathrm{C}$ data for the Yucca Flat/Climax Mine study area are shown as a function of the corresponding $\delta^{13} \mathrm{C}$ data in Figure 12-8. Many of the groundwaters plotted in Figure 12-8 show evidence of reaction with carbonate minerals; the sample from ER-5-4 \#2 being the most extreme example. The data in Figure 12-8 indicate that groundwaters from the volcanic rocks and alluvium generally have higher ${ }^{14} \mathrm{C}$ activities and lighter $\delta^{13} \mathrm{C}$ values than groundwaters from corresponding areas in the LCA. Only a few of the LCA samples along the northern perimeter of Yucca Flat (WW-2 and UE-10j-3) have light $\delta^{13} \mathrm{C}$ values indicating that most of the DIC was obtained by interaction with soil zone $\mathrm{CO}_{2}$ (Figure 12-8). In contrast, most of the groundwater from the volcanic and alluvial aquifers, as well as most of the groundwater from the UCCU in the western part of Yucca Flat, have lighter $\delta^{13} \mathrm{C}$ values indicating that these groundwaters have had less exposure to isotopically heavier calcite. Conversely, groundwater from the UCCU in western Yucca Flat (typified by samples from

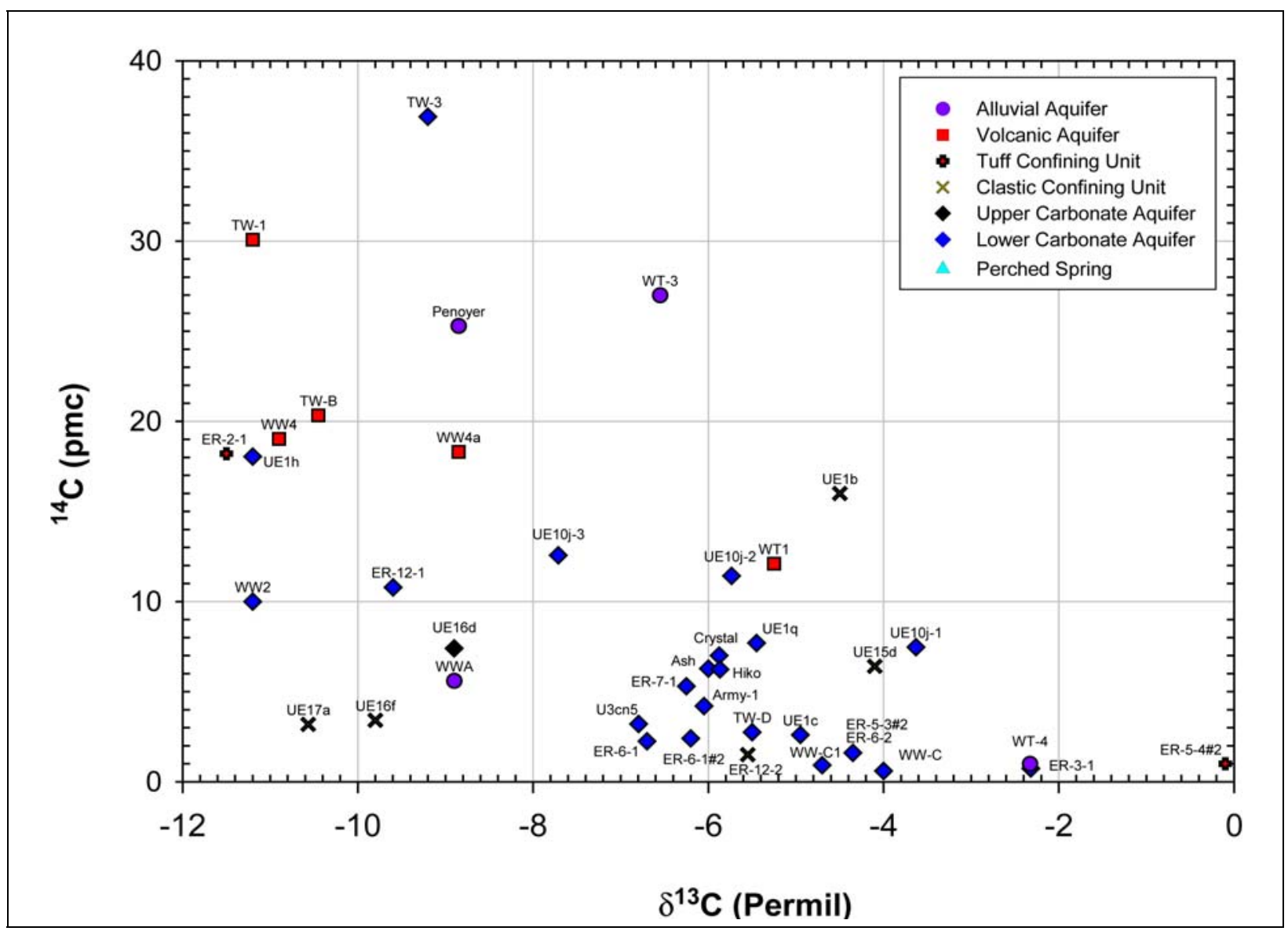

Figure 12-8

Plot of $\delta^{13} \mathrm{C}$ Versus ${ }^{14} \mathrm{C}$ Values for Springs and Wells Within the Yucca Flat/Climax Mine Study Area 
UE-17a and UE-16f) has ${ }^{14} \mathrm{C}$ activities that are as low as those from the LCA but has $\delta^{13} \mathrm{C}$ values that are as light as those from the AA and VAs. These characteristics suggest that the low ${ }^{14} \mathrm{C}$ activities measured in groundwater from the UCCU in western Yucca Flat are not the result of carbonate mineral dissolution, but instead, these groundwaters are quite old.

Dissolved organic carbon, $\mathrm{DO}^{13} \mathrm{C}, \mathrm{DO}^{14} \mathrm{C}$, and calculated DOC ages are presented in Table 12-2. Because $\mathrm{DO}^{14} \mathrm{C}$ estimation of groundwater age is a relatively new technique, very little DOC isotopic data are available for wells and springs within the study area. However, DOC isotopic data do exist for the more recently drilled ER wells (Table $12-2$ ). The $\mathrm{DO}^{14} \mathrm{C}$ ages range from 1,000 to 20,000 years for groundwater in the Yucca Flat area. These ages assume than an initial $\mathrm{DO}^{14} \mathrm{C}$ value during recharge is similar to that measured in UE-29a \#1 and UE-29a \#2 in Fortymile Wash (66 percent modern carbon [pmc]), because no other modern samples are available for the NTS area. The data indicate that groundwater in the recharge area near ER-12-2 is very young, and the groundwater of the LTCU at ER-2-1 is older than recent recharge but younger than most groundwater in the LCA. Groundwater in the LCA in eastern Yucca Flat at ER-6-1 and ER-6-1 \#2 is much older. Improvements in the ability to estimate the initial $\mathrm{DO}^{14} \mathrm{C}$ input to the aquifers in this region will reduce the uncertainty in the interpretation of these data.

Table 12-2

Dissolved Organic Carbon Calculated Groundwater Ages

\begin{tabular}{||c|c|c|c|c||}
\hline Well & $\begin{array}{c}\text { DOC } \\
\text { (mg/L) }\end{array}$ & $\begin{array}{c}\text { DO }^{13} \mathbf{C} \\
\text { (permil) }\end{array}$ & $\begin{array}{c}\text { DO }^{14} \mathbf{C} \\
\text { (pmc) }\end{array}$ & $\begin{array}{c}\text { Age } \\
\text { (years) }\end{array}$ \\
\hline \hline ER-12-2 & 0.2 & -22.7 & 60.7 & 1,000 \\
\hline ER-2-1 & 0.7 & -32.8 & 31.4 & 6,000 \\
\hline ER-7-1 & 0.1 & -24.5 & 31.7 & 6,000 \\
\hline ER-6-1\#2 & 0.7 & -35.0 & 11.1 & 15,000 \\
\hline ER-6-1 & 2.1 & -34.6 & 3.3 & 20,000 \\
\hline
\end{tabular}

\subsubsection{Chlorine-36}

Chlorine has one long-lived radioactive isotope, ${ }^{36} \mathrm{Cl}$, with a half-life of 301,000 years. Chloride concentrations and the available ${ }^{36} \mathrm{Cl} / \mathrm{Cl}$ ratios for groundwater in the Yucca Flat/Climax Mine study area are presented in Figure 12-9. Chloride is a conservative anion in groundwater under most conditions. Changes to the ${ }^{36} \mathrm{Cl} / \mathrm{Cl}$ ratio in groundwater may occur along a flow path by decay of ${ }^{36} \mathrm{Cl}$, subsurface production of ${ }^{36} \mathrm{Cl}$ from neutron capture on ${ }^{35} \mathrm{Cl}$ in water, and water-rock interaction 


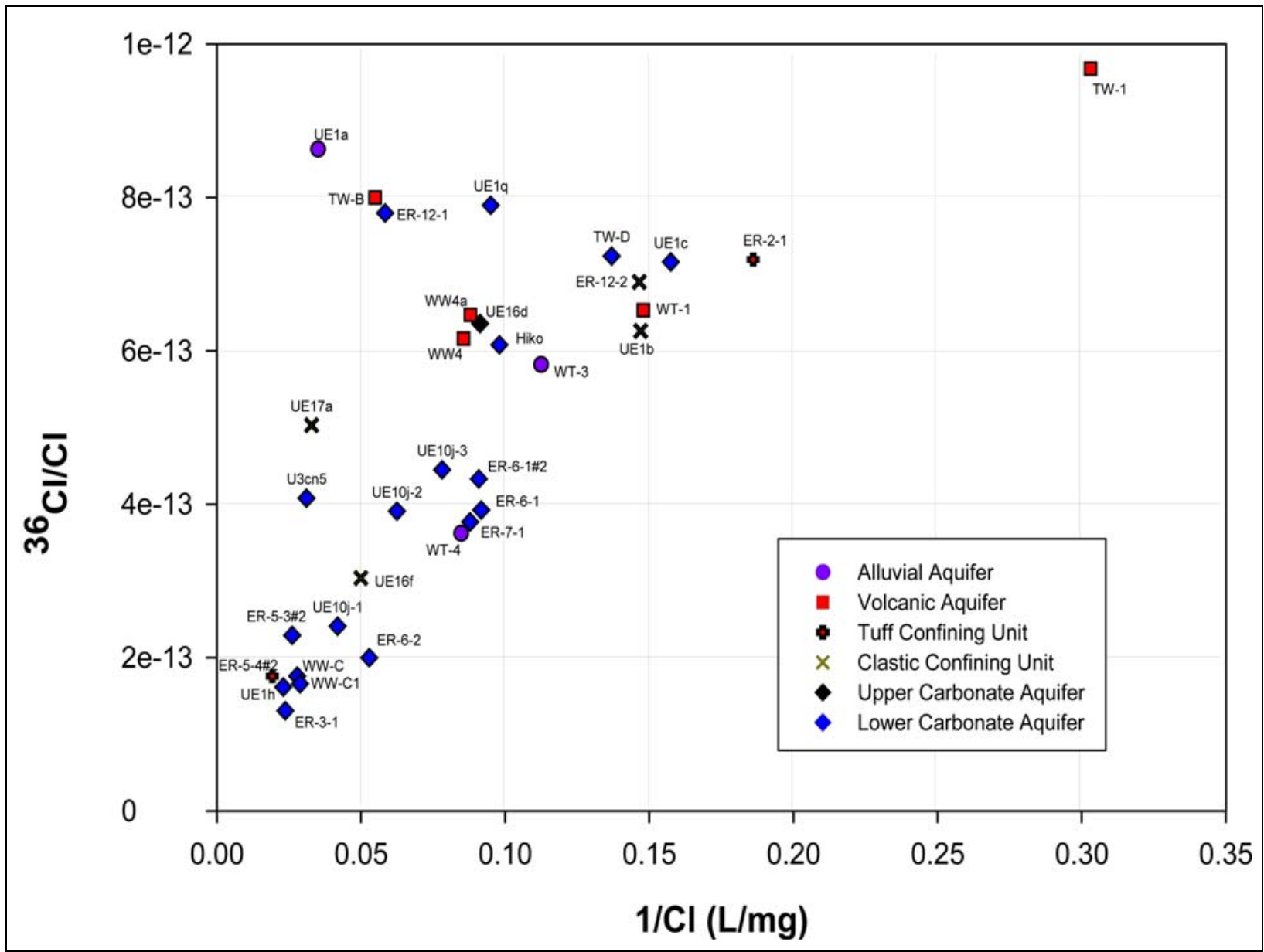

Figure 12-9

Plot of ${ }^{36} \mathrm{Cl} / \mathrm{Cl}$ Ratios Versus Inverse $\mathrm{Cl}$ Values for Wells Within the Yucca Flat/Climax Mine Study Area

(addition of low ${ }^{36} \mathrm{Cl} / \mathrm{Cl}$ chloride from the dissolution of minerals). The low $\mathrm{Cl}$ concentrations, and relatively short subsurface residence times of groundwater in the NTS region, suggest that subsurface production and decay processes are negligible. Hence, the dominant factors controlling the observed ${ }^{36} \mathrm{Cl} / \mathrm{Cl}$ ratios and $\mathrm{Cl}$ concentrations are the initial values inherited during recharge, the progressive dissolution of low ${ }^{36} \mathrm{Cl}$ along groundwater flow paths, and mixing with water of a different ${ }^{36} \mathrm{Cl} / \mathrm{Cl}$ ratio. Mixing processes yield intermediate compositions forming linear trends on a ${ }^{36} \mathrm{Cl} / \mathrm{Cl}$ versus 1/Cl plot (Moran and Rose, 2003).

Typical ${ }^{36} \mathrm{Cl} / \mathrm{Cl}$ ratios of common rocks range from $4 \times 10^{-15}$ for limestone to $50 \times 10^{-15}$ for granite (Andrews et al., 1986; Bentley et al., 1986). Dissolution of carbonate rock material, which is relatively rich in $\mathrm{Cl}$, is likely the most important process controlling the ${ }^{36} \mathrm{Cl} / \mathrm{Cl}$ ratios in the LCA. 
Kenneally (1995) performed leaching experiments on NTS drill core samples and found that carbonate rocks tend to be higher (22 to 93 milligrams per kilogram [mg/kg]) in leachable $\mathrm{Cl}$ than volcanic rocks ( 0.5 to $24 \mathrm{mg} / \mathrm{kg}$ ). Dissolution of $\mathrm{Cl}$ from the carbonate rock will result in progressively lower ${ }^{36} \mathrm{Cl} / \mathrm{Cl}$ ratios and higher $\mathrm{Cl}$ concentrations along a given flow path in the LCA. On a plot of ${ }^{36} \mathrm{Cl} / \mathrm{Cl}$ versus $1 / \mathrm{Cl}$, many of the LCA samples plot along an apparent mixing trend between a high ${ }^{36} \mathrm{Cl} / \mathrm{Cl}$ recharge end-member and a low ${ }^{36} \mathrm{Cl} / \mathrm{Cl}$ carbonate rock end-member (Figure 12-9).

Wells TW-D, UE-1q, and UE-1c have the highest ${ }^{36} \mathrm{Cl} / \mathrm{Cl}$ ratios of any LCA groundwater shown in Figure 12-9. The high ${ }^{36} \mathrm{Cl} / \mathrm{Cl}$ ratios in these waters are likely caused by mixing with high ${ }^{36} \mathrm{Cl} / \mathrm{Cl}$ water from one of the other HSUs. All samples collected from the volcanic HSUs, with the exception of ER-5-4 \#2, are uniformly high in ${ }^{36} \mathrm{Cl} / \mathrm{Cl}$ (ranging from 7.19 to $9.68 \times 10^{-13}$ ). Similarly high ratios are also observed in the AA at UE-1a $\left(8.63 \times 10^{-13}\right)$. These ratios are all considerably higher than the modern atmospheric ratio for southern Nevada (approximately 5 x 10-13; Fabryka-Martin et al., 1993) and may reflect groundwater recharge during the last pluvial period (late Pleistocene), during which time the atmospheric production of ${ }^{36} \mathrm{Cl}$ was greater, because of the reduced strength in the earth's magnetic field (Mazaud et al., 1991). This interpretation was previously used to explain the high ${ }^{36} \mathrm{Cl} / \mathrm{Cl}$ ratios in Frenchman Flat groundwater (Tyler et al., 1996).

\subsubsection{Strontium and ${ }^{87} \mathrm{Sr} /{ }^{86} \mathrm{Sr}$ Values}

Natural Sr comprises four isotopes $\left({ }^{84} \mathrm{Sr},{ }^{86} \mathrm{Sr},{ }^{87} \mathrm{Sr}\right.$, and $\left.{ }^{88} \mathrm{Sr}\right)$; three of which are non-radiogenic and have fixed abundances in terrestrial materials. In contrast, ${ }^{87} \mathrm{Sr}$ is formed by $\beta$ decay of rubidium $\left({ }^{87} \mathrm{Rb}\right)$, which has a half-life of $4.88 \times 10^{10}$ years. The abundance of ${ }^{87} \mathrm{Sr}$, therefore, varies in geologic materials depending on their age, their initial $\mathrm{Sr}$ isotopic composition, and their $\mathrm{Rb} / \mathrm{Sr}$ ratio. Groundwater ${ }^{87} \mathrm{Sr} /{ }^{86} \mathrm{Sr}$ values reflect interactions with soil and rocks during recharge and subsequent flow. Because of the low dissolved Sr content of precipitation, infiltration will rapidly adjust to the ${ }^{87} \mathrm{Sr} /{ }^{86} \mathrm{Sr}$ composition of the most soluble soil components. Like other cations, the $\mathrm{Sr}$ content of groundwater generally increases along a flow path from dissolution of aquifer rocks. The ${ }^{87} \mathrm{Sr} /{ }^{86} \mathrm{Sr}$ composition of the water may change significantly if the aquifer host rock contains large $\mathrm{Sr}$ concentrations in chemically reactive sites. Conversely, the ${ }^{87} \mathrm{Sr} /{ }^{86} \mathrm{Sr}$ composition may be buffered from substantial modification following recharge if the aquifer consists of rocks with low Sr content. 
Values of ${ }^{87} \mathrm{Sr} /{ }^{86} \mathrm{Sr}$ are useful as natural tracers of groundwater flow, because wide variations in $\mathrm{Rb} / \mathrm{Sr}$ ratios in different rock types result in large differences in ${ }^{87} \mathrm{Sr} /{ }^{86} \mathrm{Sr}$ ratios in different aquifers, and fractionation of heavy radiogenic isotopes $\left({ }^{87} \mathrm{Sr}\right.$ from $\left.{ }^{86} \mathrm{Sr}\right)$ is negligible during geologic processes (McNutt, 2000). However, Sr is not necessarily conserved during groundwater flow because of water-rock interactions. Chemical processes resulting in non-conservative behavior of Sr impact concentration data to a greater extent than ${ }^{87} \mathrm{Sr} /{ }^{86} \mathrm{Sr}$ data. Losses of $\mathrm{Sr}$ from solution due to sorption and mineral precipitation will not impact the ${ }^{87} \mathrm{Sr} /{ }^{86} \mathrm{Sr}$ ratio in the remaining fluid. Furthermore, desorption or cation exchange from reactive mineral surfaces along flow paths may not significantly impact ${ }^{87} \mathrm{Sr} /{ }^{86} \mathrm{Sr}$ values if the dynamics of flow and sources of $\mathrm{Sr}$ have remained unchanged over long periods of time (steady-state flow conditions). In contrast, rock dissolution can add Sr containing very different isotopic compositions to the resulting solution; particularly if groundwater that is chemically unsaturated, with respect to calcite or dolomite, flows into the LCA. The resulting impact on ${ }^{87} \mathrm{Sr} /{ }^{86} \mathrm{Sr}$ in solution depends greatly on the concentrations and isotope compositions in both water and solid phases.

Groundwater samples from the Yucca Flat vicinity have a wide range of Sr concentrations that are broadly correlated with aquifer type (Figure 12-10). Compared to water from the AA, volcanic units, and CCUs within the Yucca Flat basin, LCA groundwaters have higher Sr concentrations and ${ }^{87} \mathrm{Sr} /{ }^{86} \mathrm{Sr}$ values. Samples of LCA water on the southeastern side of the Yucca Flat basin (ER-3-1, WW-C, WW-C1, ER-5-3\#2, and TW-3) have high Sr concentrations and ${ }^{87} \mathrm{Sr} /{ }^{86} \mathrm{Sr}$ (Figure 12-10). In contrast, LCA water sampled throughout most of the Yucca Flat basin have lower Sr concentrations and less radiogenic ${ }^{87} \mathrm{Sr} /{ }^{86} \mathrm{Sr}$ values. However, all of these LCA waters have ${ }^{87} \mathrm{Sr} /{ }^{86} \mathrm{Sr}$ values higher than expected from water-rock interaction with unaltered Paleozoic marine limestones (0.707 to 0.709 [Peterman et al., 1970; Burke et al., 1982]). Higher ${ }^{87} \mathrm{Sr} /{ }^{86} \mathrm{Sr}$ values indicate that ${ }^{87} \mathrm{Sr}$ from sources with more radiogenic Sr has been introduced through groundwater mixing or interaction with ${ }^{87} \mathrm{Sr}$-enriched aquifer rock. Samples from two Yucca Flat wells penetrating the LCA in southwestern Yucca Flat (UE-1h and UE-1c) have substantially lower ${ }^{87} \mathrm{Sr} /{ }^{86} \mathrm{Sr}$ than other Yucca Flat LCA wells and are closer to values expected for marine carbonates. Many water samples from other HSUs in the same area of southwestern Yucca Flat have similar non-radiogenic ${ }^{87} \mathrm{Sr} /{ }^{86} \mathrm{Sr}$ values relative to samples further east and north. The groundwaters of the Pahranagat Valley (Hiko, Crystal, and Ash springs) tend to have lower ${ }^{87} \mathrm{Sr} /{ }^{86} \mathrm{Sr}$ values, that are more typical of marine ${ }^{87} \mathrm{Sr} /{ }^{86} \mathrm{Sr}$ values, relative to Yucca Flat LCA samples. 


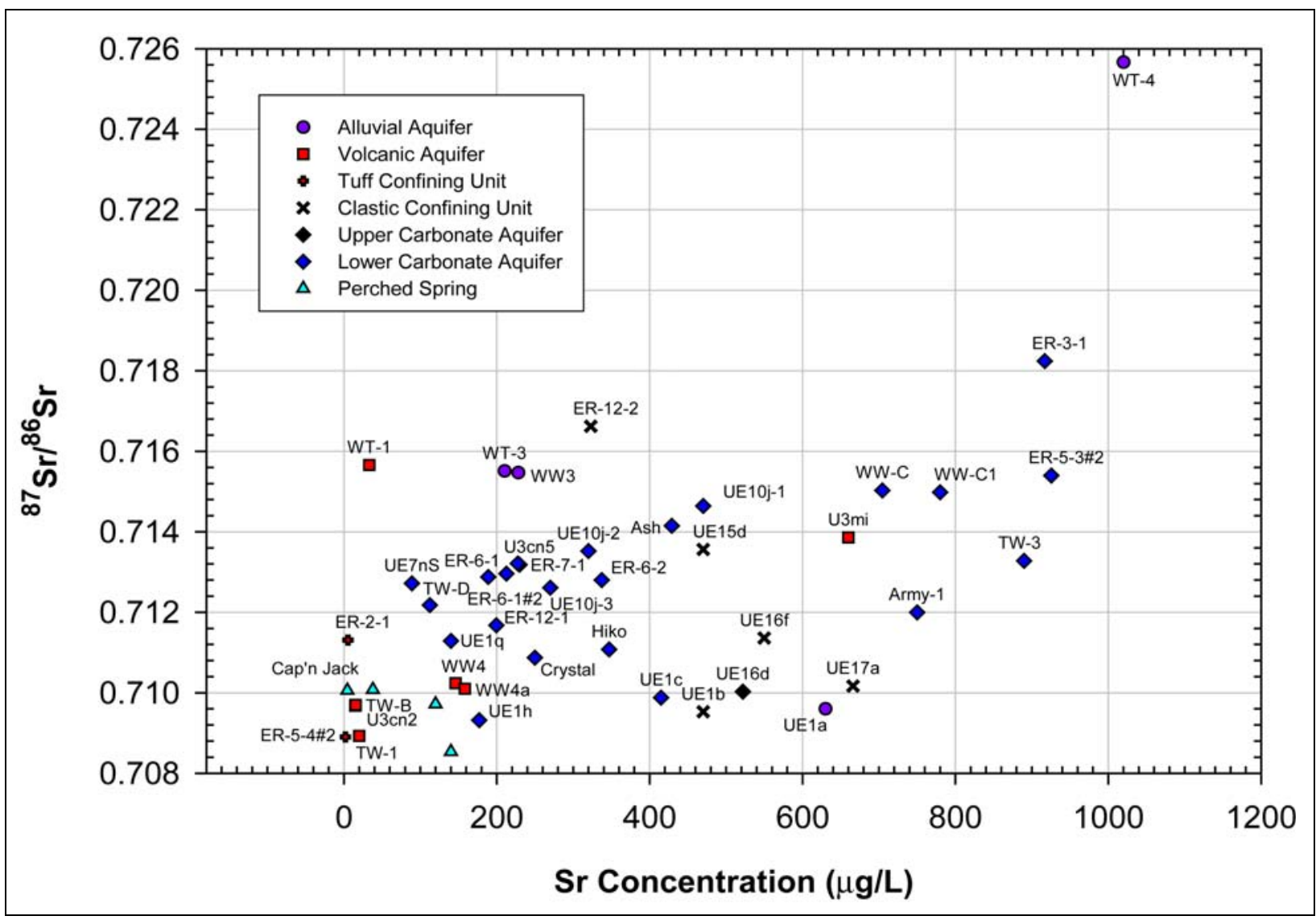

Figure 12-10

${ }^{87} \mathrm{Sr} /{ }^{86} \mathrm{Sr}$ Versus Sr Concentration for Springs and Wells Within the Yucca Flat/Climax Mine Study Area

High Sr concentrations and ${ }^{87} \mathrm{Sr} /{ }^{86} \mathrm{Sr}$ compositions in WT-4 groundwater indicate that water has acquired radiogenic $\mathrm{Sr}$ from an ancient, $\mathrm{Rb}$-rich rock source. Precambrian and Cambrian clastic sediments constituting the LCCU boarder Emigrant Valley on the east, south, and southwest sides (Winograd and Thordarson, 1975, p. 63) and contribute substantial amounts of detritus to the valley fill. Although rock has not been analyzed from this borehole, water ${ }^{87} \mathrm{Sr} /{ }^{86} \mathrm{Sr}$ values are consistent with ${ }^{87} \mathrm{Sr} /{ }^{86} \mathrm{Sr}$ values expected for a Precambrian clastic-rock source. The sample of AA groundwater from WT-3 also has ${ }^{87} \mathrm{Sr} /{ }^{86} \mathrm{Sr}$ values higher than most other sites in Yucca Flat; however, the large ${ }^{87} \mathrm{Sr} /{ }^{86} \mathrm{Sr}$ difference between WT-3 and WT-4 despite their close proximity indicates heterogeneity in the AA sediments or flow dynamics. Elevated ${ }^{87} \mathrm{Sr} /{ }^{86} \mathrm{Sr}$ in WT-1 sampling the VA in Emigrant Valley is substantially higher than most other samples from VA \& TCU sites in Yucca Flat. This is interpreted as recharge of overlying ${ }^{87} \mathrm{Sr} /{ }^{86} \mathrm{Sr}$-rich AA groundwater into the underlying volcanic units. 
The six samples of perched water with ${ }^{87} \mathrm{Sr} /{ }^{86} \mathrm{Sr}$ data, have a narrow range of ${ }^{87} \mathrm{Sr} /{ }^{86} \mathrm{Sr}$ values $(0.70854$ and 0.71097 ) with a mean of 0.70987 . Strontium concentrations for 18 perched-water samples show a much wider range ( 4.4 to $760 \mu \mathrm{g} / \mathrm{L})$ with a mean of 233 and a median of $130 \mu \mathrm{g} / \mathrm{L}$. Assuming that the mean ${ }^{87} \mathrm{Sr} /{ }^{86} \mathrm{Sr}$ value of perched water represents the composition of local recharge, linear relations between ${ }^{87} \mathrm{Sr} /{ }^{86} \mathrm{Sr}$ and $1 / \mathrm{Sr}$ for three UE-10j samples were used to define a local recharge $\mathrm{Sr}$ concentration of about $169 \mu \mathrm{g} / \mathrm{L}$, which falls between the mean and median values measured in perched-water samples (SNJV, 2006a).

\subsubsection{Uranium and ${ }^{234} \mathrm{U} /{ }^{238} \mathrm{U}$ Activity Ratio}

Natural uranium (U) consists of two radioactive isotopes with half lives greater than 700 million years $\left({ }^{235} \mathrm{U}\right.$ and $\left.{ }^{238} \mathrm{U}\right)$ and a minor, short-lived radioactive isotope $\left({ }^{234} \mathrm{U}\right.$, half-life of 0.25 million years) derived from the decay of ${ }^{238} \mathrm{U}$. Although the atomic ${ }^{238} \mathrm{U} / 235 \mathrm{U}$ is constant in rocks and water, ${ }^{234} \mathrm{U} /{ }^{238} \mathrm{U}$ ratios in natural water can vary widely (Osmond and Cowart, 1976; Rosholt, 1983). Alpha-recoil processes associated with decay of ${ }^{238} \mathrm{U}$ result in preferential dissolution of ${ }^{234} \mathrm{U}$ from solid surfaces and ${ }^{234} \mathrm{U} /{ }^{238} \mathrm{U}$ activity ratios in migrating water that are greater than 1.0. Without alpha-recoil processes, the ${ }^{234} \mathrm{U} / 238 \mathrm{U}$ activity ratio would be 1.0. Inputs from rock weathering and recoil processes play a dominant role in the evolution of ${ }^{234} \mathrm{U} / 238 \mathrm{U}$ activity ratios in groundwater systems; however, other factors may also contribute (Porcelli and Swarzenski, 2003). Although these processes lead to spatial variability of ${ }^{234} \mathrm{U} /{ }^{238} \mathrm{U}$ activity ratios in groundwater systems in southern Nevada (1.02 to 8.06 for 177 analyses in Paces et al., 2002), values at a given sampling site likely remain constant over long periods of time (minimal variation in initial ${ }^{234} \mathrm{U} /{ }^{238} \mathrm{U}$ activity ratios for the 600,000-year calcite record at Devils Hole, Nevada; Ludwig et al., 1992).

Uranium concentration and ${ }^{234} \mathrm{U} / 238 \mathrm{U}$ activity ratio data are available from a limited subset of samples (Figure 12-11). Concentrations of dissolved $U$ depend strongly on the oxidation state of the groundwater. Uranium is highly soluble as uranyl carbonate $\left(\mathrm{UO}_{2} \mathrm{CO}_{3}\right)$ complexes in oxidized alkaline groundwater (Langmuir, 1978), typical of southern Nevada. Uranium concentrations in groundwaters in the vicinity of Yucca Flat typically range from about 0.3 to $7 \mu \mathrm{g} / \mathrm{L}$ with a large degree of overlap between different HSUs (Figure 12-11). Only one sample from Yucca Flat (ER-12-2 from the UCCU) has an anomalously low U concentration of $0.017 \mu \mathrm{g} / \mathrm{L}$, implying the presence of reducing conditions at this site. 


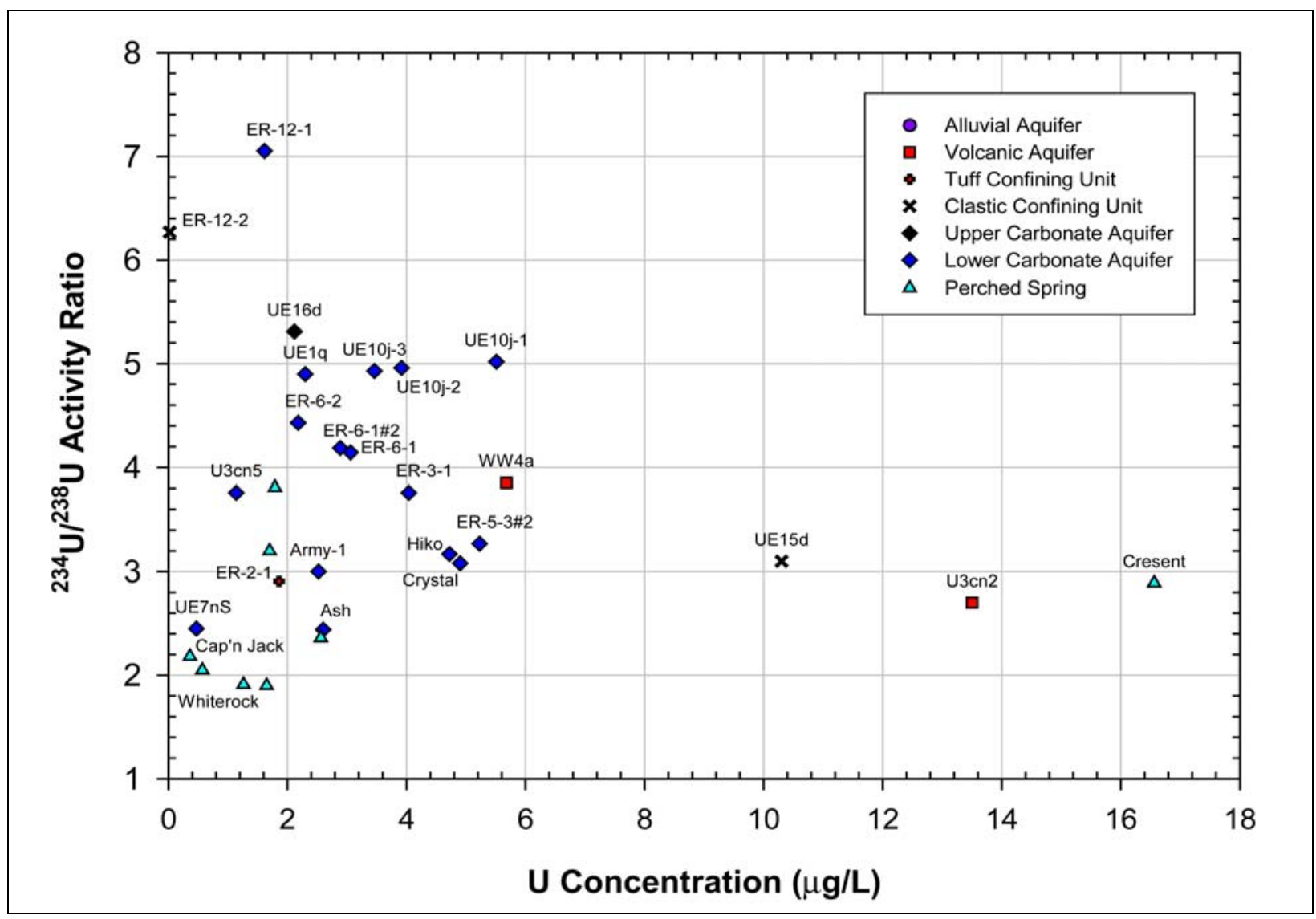

Figure 12-11

${ }^{234} U /{ }^{238} U$ Activity Ratio Versus Uranium Concentration for Springs and Wells Within the Yucca Flat/Climax Mine Study Area

Values of ${ }^{234} \mathrm{U} /{ }^{238} \mathrm{U}$ activity ratio for groundwater samples collected within the study area vary from 1.30 (for ER-5-4\#2; not shown in Figure 12-11) to 7.05. The ER-5-4\#2 sample is not shown in Figure 12-11 because of the high concentration of $U(34.3 \mu \mathrm{g} / \mathrm{L})$ relative to all other groundwaters within the study area. Patterns of $U$ concentration and ${ }^{234} U / 238 U$ activity ratio variation between the different HSUs are not diagnostic of flow paths and mixing processes, although water from the perched springs and VA and TCU wells tends to have higher $\mathrm{U}$ concentrations and lower ${ }^{234} \mathrm{U} /{ }^{238} \mathrm{U}$ activity ratio relative to water from the LCA and CCUs.

\subsection{Groundwater Flow Path Evaluations}

The flow paths evaluated during this investigation, and the specific wells modeled for each flow path, are illustrated in Figure 12-12. This evaluation begins with a geochemical characterization of 


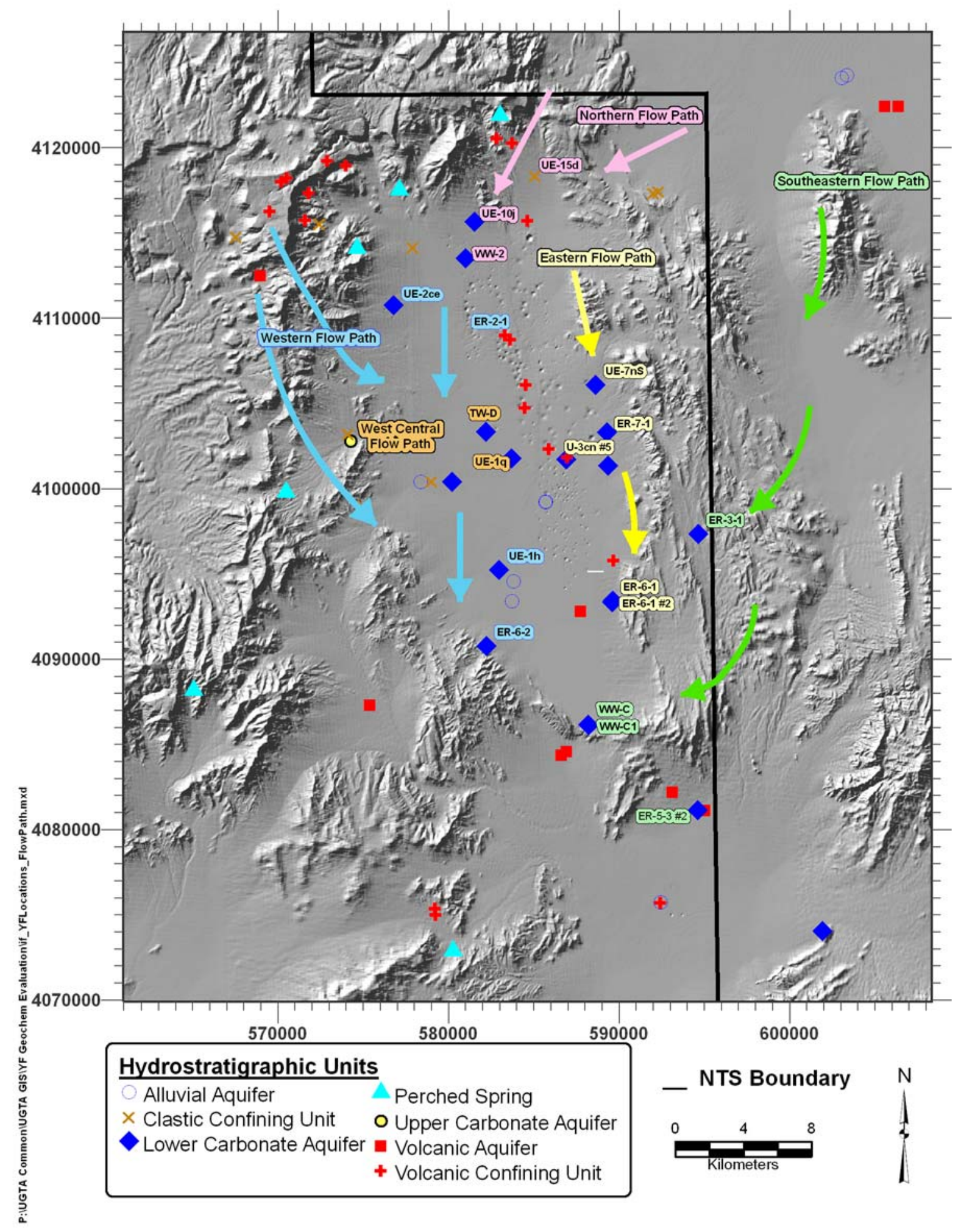

Figure 12-12

Conceptual Flow Paths Evaluated in the Yucca Flat/Climax Mine Geochemical Study 
groundwater in northern Yucca Flat that specifically addresses the proportion of groundwater inflow to Yucca Flat from outlying areas versus local recharge from the surrounding highlands (Northern Flow Path, Section 12.6.2.1). Three generalized conceptual groundwater flow paths through Yucca Flat in the LCA are then evaluated: 1) groundwater moving from northern to southern Yucca Flat along the eastern side of the central fault structures (Eastern Flow Path, Section 12.6.2.2);

2) groundwater moving from north to south along the western side of Yucca Flat (Western Flow Path, Section 12.6.2.3); and 3) groundwater entering Yucca Flat along the southeastern boundary and moving through southern Yucca Flat to Frenchman Flat (Southeastern Flow Path, Section 12.6.2.4). Finally, the nature of groundwater geochemistry in west-central Yucca Flat LCA is evaluated in terms of potential vertical flow from overlying HSUs into the LCA (West Central Flow Path, Section 12.6.2.5).

\subsubsection{Geochemical Modeling Methodology}

Geochemical modeling of Yucca Flat groundwater movement first examined the conservative, or non-reactive, species to identify potential groundwater source areas, flow paths, and mixing relationships. Preliminary conceptual models were developed from a combination of stable isotope and $\mathrm{Cl}$ data. In most cases, a mixture of groundwater from two or three upgradient sources was required to obtain an observed downgradient water composition. Viable models developed using conservative tracers were tested using Sr concentrations and ${ }^{87} \mathrm{Sr} /{ }^{86} \mathrm{Sr}$ isotopic ratios.

In cases where the conservative tracers and $\mathrm{Sr}$ data provide evidence for a possible groundwater flow path, NETPATH and PHREEQC models are used to corroborate those flow paths by modeling changes in reactive species. The NETPATH and PHREEQC models attempt to determine the geochemical evolution of groundwater along a flow path by identifying the net changes in reactive species occurring in the aquifer between the upgradient and downgradient wells. The mixing relationships in these models are determined primarily on the basis of the conservative isotopic tracers $\left(\delta \mathrm{D}\right.$ and $\left.\delta^{18} \mathrm{O}\right)$, while the extent and nature of water-rock reactions are estimated from the changes in dissolved reactive species ( $\mathrm{pH}$, cations, anions, silica, alkalinity, and $\delta^{13} \mathrm{C}$ ).

This section summarizes the general methodology used for the conservative tracer, $\mathrm{Sr}$ and ${ }^{87} \mathrm{Sr} /{ }^{86} \mathrm{Sr}$, and reactive transport (NETPATH and PHREEQC) evaluations. Additional details regarding these evaluations are presented in SNJV (2006a). 


\subsubsection{Conservative Tracers}

Conservative tracers are geochemical species that move with groundwater, exhibiting little or no change in concentration, because of reactive processes. Dissolved $\mathrm{Cl}, \delta \mathrm{D}$, and $\delta^{18} \mathrm{O}$ are considered to be the most conservative geochemical tracers. Chloride is considered conservative in that no significant retardation mechanisms exist that would reduce its concentration along a flow path. The concentration of $\mathrm{Cl}$ may increase along a flow path due to rock water interaction (Section 12.5.2.3). Conservative tracers can provide valuable insight into potential groundwater pathways and mixing processes. Graphical methods are used to identify mixing trends. More precise mixing ratios are then estimated mathematically following the method outlined in Rose et al. (2002) and SNJV (2006a).

\subsubsection{Strontium and Strontium Isotopes $\left({ }^{87} \mathrm{Sr} /{ }^{86} \mathrm{Sr}\right)$}

Strontium concentrations and ratios of ${ }^{87} \mathrm{Sr} /{ }^{86} \mathrm{Sr}$ are treated as a conservative tracer and simple mixing models are developed between two or three end members using mixing equations described elsewhere (Faure, 1986). Because water-rock reactions are not included in these evaluations, mixing proportions derived from $\mathrm{Sr}$ isotope data are considered qualitative rather than quantitative (SNJV, 2006a).

\subsubsection{Geochemical Modeling with NETPATH and PHREEQC}

Geochemical inverse models created with NETPATH and PHREEQC attempt to identify the fractions of groundwaters from different upgradient areas that could be present in groundwater at a downgradient location, taking into account mixing processes as well as water-rock reactions that occur along the groundwater flow path. The geochemical reactions modeled are limited by knowledge of the minerals and gases that are present in the aquifer, and the availability of groundwater chemistry data along potential flow paths. Mineral compositions considered by NETPATH and PHREEQC were measured in discrete rock samples from the Pahute Mesa flow system and then compiled into composite chemical compositions for specific HSUs (SNJV, 2006a). The chemical compositions of the composite volcanic glass, feldspar, clay, and clinoptilolite represent average compositions for these phases as measured for the TM units in the Pahute Mesa CAU. Maps showing the geographic extent of various HSUs for the Yucca Flat flow system (BN, 2006) indicate that the TM units form the uppermost volcanic units found in Yucca Flat. Because downward moving 
water would be expected to react most strongly with the first volcanic units encountered, mineral phases for the TM HSUs were used in the models.

\subsection{NETPATH}

Flow paths successfully identified by conservative tracer mixing models were further evaluated using NETPATH (Plummer et al., 1994). NETPATH is a computer code for geochemical calculations developed by the USGS and is freely available from their website. NETPATH calculates the net mass transfer of major dissolved ions from water-rock reactions along a proposed flow path and the fractionation of carbon isotopes as carbon-containing phases are dissolved or precipitated. By modeling the isotopic evolution of carbon along a flow path, groundwater travel times are calculated.

Mineral dissolution and precipitation reactions used in NETPATH are constrained by thermodynamic calculations, which determine the saturation state of minerals in groundwater. Minerals that have been identified in the aquifer and are undersaturated can only dissolve, whereas those that are supersaturated, can only precipitate or form by incongruent dissolution. The reactive or exchangeable phases used in NETPATH modeling included calcite, dolomite, gypsum, halite, and silica; $\mathrm{Ca}$ and $\mathrm{Mg}$ exchange for $\mathrm{Na}$; and composite glass, feldspar, clay, and clinoptilolite (a composite of the most prevalent zeolites, mordenite and clinoptilolite). Average $\delta^{13} \mathrm{C}$ values for carbonate minerals were calculated from carbonate bedrock samples from wells at the NTS as calcite $=+1.0$ permil, dolomite $=+0.1$ permil $(\mathrm{SNJV}, 2006 \mathrm{a})$.

For a set of geochemical reactions along a proposed flow path to be considered a valid representation of the flow path, the following criteria must be met:

- Net changes in mineral phases must be less than 1 millimole per liter.

- Net changes of mineral phases against their thermodynamic saturation state were limited to less than 0.1 millimole per liter.

- Calculated $\delta \mathrm{D}$ of the final (modeled) water must be within 3 permil of the measured values.

- Calculated $\delta^{18} \mathrm{O}$ of the final (modeled) water must be within 1 permil of the measured values.

- Calculated $\delta^{13} \mathrm{C}$ of the final (modeled) water must be within 1 permil of the measured values. The $\delta^{13} \mathrm{C}$ value of the groundwater at the end of a proposed flow path is calculated using all carbon-containing phases involved in the geochemical reactions and the associated $\delta^{13} \mathrm{C}$ fractionation of each reaction. 
- Calculated $\mathrm{Cl}$ concentration of the final (modeled) water must be equal to, or less than, the measured $\mathrm{Cl}$ concentration.

The mineral saturation states are listed in Table 5-1 of SNJV (2006a). Groundwater travel times calculated by NETPATH for a given flow path were presented when all of the criteria listed above were met. If any of the criteria were not met, or if $\delta^{13} \mathrm{C}$ and/or ${ }^{14} \mathrm{C}$ data were not available for all wells in the model, ${ }^{14} \mathrm{C}$ derived groundwater ages were not calculated.

\subsection{PHREEQC Modeling}

PHREEQC (Parkhurst and Appelo, 1999) is also a public domain software developed by the USGS. PHREEQC version 2.8 accommodates uncertainty in geochemical parameters such as dissolved chemical concentrations, isotope ratios of dissolved species, and isotopic compositions of potentially reactive phases, and propagates these uncertainties through the analysis. The uncertainty in groundwater compositions is expressed in the model results through the identification of multiple possible mixing and reaction models, each involving groundwater from different wells or different water-rock interactions, and uncertainty bounds on the mixing fractions and reactions identified for each particular model. The uncertainty in mixing proportions and reactions associated with multiple possible models generally is considerably greater than the uncertainty bounds provided by PHREEQC for any one particular model. It is also important to note that when multiple plausible models are identified, the true model may be a linear combination of these models.

The uncertainties generally attributed to various groundwater species in the PHREEQC models are:

- $\pm 0.20 \mathrm{pH}$ units for $\mathrm{pH}$ measurements.

- \pm 10 percent for major ions, alkalinity, and silica measurements.

- \pm 1.0 permil for $\delta \mathrm{D}$ values.

- \pm 0.2 permil for $\delta^{18} \mathrm{O}$ and $\delta^{13} \mathrm{C}$ values.

- \pm 20 percent of the measured or estimated value of aluminum (Al) and iron (Fe).

- $\quad \delta^{13} \mathrm{C}$ of dissolving calcite $(0.0 \pm 4.0$ permil $)$ and precipitating calcite $(-4.0 \pm 4.0$ permil $)$.

- $\quad \delta^{13} \mathrm{C}$ of dolomite $(0.0 \pm 2.0$ permil $)$.

These uncertainty ranges were expanded in some cases as described in SNJV (2006a). PHREEQC then adjusts the measured ion concentrations and isotope ratios in each groundwater contained in the model within these uncertainties to satisfy the mass-balance constraints for each element and isotope. Because the PHREEQC models consider uncertainty in the measured groundwater chemical and 
isotopic data, mixing fractions determined with PHREEQC may be different from those calculated from the conservative tracer and NETPATH models. Often, PHREEQC will find models by adjusting reported data within their allowable uncertainty to obtain a fit, rather than by considering additional end-member compositions. These adjustments can result in the models that are substantially different from the conservative tracer and NETPATH models.

PHREEQC performs similar mass-balance calculations as NETPATH but does not account for isotopic fractionation of $\delta^{13} \mathrm{C}$ and ${ }^{14} \mathrm{C}$ and does not calculate groundwater travel times directly. Groundwater travel times are estimated using the results of the PHREEQC mixing, water-rock interaction models, and the groundwater ${ }^{14} \mathrm{C}$ activities measured at the wells involved in the mixture (SNJV, 2006a). A ${ }^{14} \mathrm{C}$ dilution factor, estimated based on DIC data, is used to account for the addition of ${ }^{14} \mathrm{C}$-free carbon to groundwater from water-rock interaction. Although isotope exchange reactions are not explicitly considered, the PHREEQC models are constrained by the groundwater $\delta^{13} \mathrm{C}$ data. In many cases, the geochemical inverse models predicted the simultaneous dissolution of dolomite and precipitation of calcite, reactions that together mimic the isotope exchange process. These composite transit times for the mixture of the upgradient wells to the downgradient well were used to estimate the groundwater travel times from individual wells to the downgradient well (SNJV, 2006a).

Factors other than isotope exchange that may affect the groundwater ${ }^{14} \mathrm{C}$ activities, and thus groundwater travel time estimates, involve the diffusion of ${ }^{14} \mathrm{C}\left(\mathrm{as}^{14} \mathrm{CO}_{3}^{-}\right)$into the relatively stagnant groundwater in the matrix or dead-end fractures of fractured rocks, and the sorption or exchange of $\mathrm{H}^{14} \mathrm{CO}_{3}{ }^{-}$onto fracture-lining calcite (Mozeto et al., 1984; Maloszewski and Zuber, 1991; Sanford, 1997; Sheppard et al., 1998; Hershey et al., 2005; Ware et al., 2005; Reimus et al., 2005). Laboratory experiments have indicated that diffusion of $\mathrm{H}^{14} \mathrm{CO}_{3}{ }^{-}$from fractures into the rock matrix can be expected to occur in Yucca Flat in both nonwelded tuffs and carbonate rocks, with diffusive effects being far more significant in the nonwelded tuffs because of their larger porosity (Ware et al., 2005). Based on these experiments, considerable delay of $\mathrm{H}^{14} \mathrm{CO}_{3}^{-}$breakthrough from the tuff confining units into the LCA and during subsequent flow within the LCA can be expected to occur. Various studies have attempted to correct groundwater ${ }^{14} \mathrm{C}$ ages at the NTS and at other sites to correct for the effects of these diffusive processes (Maloszewski and Zuber, 1991; Sanford, 1997; Hershey et al., 2005). However, because diffusion arising from Brownian motion affects all molecular species including water (as would be evident if tritiated water or "heavy" water had been 
used as tracers in these experiments), the migration of $\mathrm{H}^{14} \mathrm{CO}_{3}^{-}$in Yucca Flat as interpreted through the calculated groundwater ages and velocities in this report provides a useful analog regarding the migration of other dissolved species, provided its sorption and exchange behavior is understood.

Isotopic tracer experiments designed to examine the interaction of $\mathrm{H}^{13} \mathrm{CO}_{3}^{-}$with non-NTS calcites in calcite-saturated water have demonstrated that these interactions consist of an initial period during which the rapid sorption of $\mathrm{H}^{13} \mathrm{CO}_{3}$ - onto high-energy surface sites dominates, followed by a more prolonged period in which $\mathrm{H}^{13} \mathrm{CO}_{3}^{-}$becomes incorporated into the calcite through dissolution and reprecipitation of the calcite surfaces (Mozeto et al., 1984). By analogy, $\mathrm{H}^{14} \mathrm{CO}_{3}{ }^{-}$probably sorbs and undergoes isotopic exchange with calcite through similar processes. The second process is accounted for in this study by modeling the evolution of groundwater $\delta^{13} \mathrm{C}$ as the groundwater interacts with the dolomite and calcite in the LCA. The evolution of groundwater $\delta^{13} \mathrm{C}$ reflects both bulk dissolution of calcite and dolomite, as well as the isotope exchange that results from calcite recrystallization. The modeling approaches used in this study would not account for the sorption of $\mathrm{H}^{14} \mathrm{CO}_{3}{ }^{-}$onto calcite fracture coatings in the LCA if this process were to occur. However, recent batch and column experiments that used natural fracture-lining calcite from the LCA in Yucca Flat have indicated little or no sorption of $\mathrm{H}^{14} \mathrm{CO}_{3}{ }^{-}$onto the calcite (Ware et al., 2005). Based on these results, this study assumes that sorption has not affected the migration of $\mathrm{H}^{14} \mathrm{CO}_{3}^{-}$in the LCA.

\subsubsection{Geochemical Modeling Results}

\subsubsection{Northern Flow Path}

The geochemical evaluation of the northern Yucca Flat groundwater, described in SNJV (2006a), focused on developing models for three wells (UE-10j, UE-15d WW, and WW-2). The first models focused on identifying the origin of groundwater of the shallowest zone of UE-10j (UE-10j-3). In general, all models indicate that UE-10j-3 contains a dominant component of local recharge that has mixed with a much smaller percentage of groundwater inflow through the LCA, as represented by groundwater from the deepest zone of UE-10j (UE-10j-1). Depending on the model, these results suggest that UE-10j-3 contains between 70 and 87 percent of a local recharge component. Local recharge is represented by Whiterock Spring, Oak Spring, Cliff Spring, or Mean Local Recharge (for Sr models). 
The next set of models investigated the possibility that groundwater from Emigrant Valley (represented by the Watertown Wells) enters Yucca Flat from the northeast through the vicinity of UE-15d WW. Although UE-15d WW is located in a block of the LCCU, the areas surrounding this block are thought to be dominantly carbonate rock. Thus, if groundwater from Emigrant Valley enters Yucca Flat along its northeastern margin, it is most likely to do so in the vicinity of UE-15d WW. Models were created to investigate the possible presence of groundwater from WT-1 at UE-15d WW. Models that used Climax Stock Seep groundwater (CGW-1) together with UE10j-1 groundwater found that no more than 1 or 2 percent of Climax Stock Seep water is present at UE-15d WW (based on PHREEQC and NETPATH models). Other models used groundwater from Cliff Spring or ER-12-2, along with UE-10j-1 to produce UE-15d WW groundwater. The relatively high water levels at ER-12-2 and the similarity of its $\delta \mathrm{D}$ and $\delta^{18} \mathrm{O}$ to that of seeps in the tunnels at Rainier Mesa (Figure 12-6) suggest that ER-12-2 can be used to represent local recharge in northern Yucca Flat. These results indicate that UE-15d WW groundwater includes a significant proportion of groundwater like that found at WT-1 (37 to 74 percent), with smaller contributions from the LCA at UE-10j-1 and local recharge. Very similar results were observed for the models developed using Cliff Spring or ER-12-2 as the local recharge component (SNJV, 2006a).

Models for WW-2, located south of UE-10j, involved groundwaters from TW-1, UE-10j-3, and Oak Spring. Because less than 20 percent of the groundwater from UE-10j-3 appears to originate from inflow through the LCA, the model results suggest that only 4 percent or less of the groundwater at WW-2 is derived by inflow through the LCA, as represented by groundwater from UE-10j-1. Hence, these models suggest WW-2 groundwater is principally derived from the mixing of volcanic and local perched water sources in northern Yucca Flat. These findings are also in agreement with some of the conservative tracer models that found it possible to model groundwater at WW-2 using no LCA groundwater components.

The overall conclusion to be drawn from these models is that groundwater in northernmost Yucca Flat is a mixture of water derived from local recharge, underflow in the LCA as represented by UE-10j-1 groundwater, and the inflow of groundwater from the northeast in Emigrant Valley, as represented by WT-1. Thus, local recharge appears to enter the LCA along the northern perimeter of the basin where the LCA intersects the water table. The groundwater from Emigrant Valley does not appear to be present as far west as WW-2 where groundwater appears to be dominated by local recharge. A large 
component of local recharge for both UE-10j and WW-2 is also indicated by a large rise in water levels beginning in late 2005 (USGS, 2006b), which likely result from the significant rainfall during the 2004/2005 winter.

\subsubsection{Eastern Flow Paths}

Hydraulic gradients in eastern Yucca Flat suggest that groundwater in this area flows southwestward toward a potentiometric trough in the center of the basin. However, the recent aquifer test at the ER-6-1 cluster (SNJV, 2005a) indicated that north-south trending faults in this part of Yucca Flat are highly transmissive, creating the possibility that these faults divert groundwater southward along their trend. To evaluate groundwater flow patterns in eastern Yucca Flat, data from a set of wells (UE-7nS, ER-7-1, U-3cn \#5, TW-E, ER-6-1, and ER-6-1 \#2) with a relatively complete suite of chemical and isotopic analyses were examined. Of this initial set of wells, it was found that unusual aspects of the chemical or isotopic composition at two of the wells (TW-E and UE-7nS) ultimately made them unsuitable for developing groundwater mixing models that could help identify their upgradient source areas. Groundwater from TW-E has $\delta \mathrm{D}$ and $\delta^{18} \mathrm{O}$ values that are much lighter than any nearby upgradient groundwaters, making it difficult to identify the source areas for this groundwater. In the case of groundwater from $\mathrm{UE}-7 \mathrm{nS}$, conservative tracer (excluding $\mathrm{Cl}$ ) and $\mathrm{Sr}$ models suggested that this groundwater originates from a mixture of Emigrant Valley water with northern Yucca Flat LCA water. However, inverse geochemical models for UE-7nS were unsuccessful because of the high $\mathrm{Cl}$ concentration, low $\mathrm{SO}_{4}$ concentration, and unusually heavy $\delta^{13} \mathrm{C}$ value of the $\mathrm{UE}-7 \mathrm{nS}$ groundwater relative to upgradient groundwaters. As summarized below, geochemical models developed for other groundwaters in eastern Yucca Flat were more successful.

Models that investigated the origins of groundwater at ER-7-1 considered the potential mixing of local recharge and upgradient groundwater from UE-10j, UE-15d WW, and ER-2-1 in northern Yucca Flat, groundwater from the Watertown Wells (primarily WT-1) in Emigrant Valley, and regional LCA groundwater from the Pahranagat Range. Several distinct sets of potential mixing models were developed from this possible combination of upgradient groundwaters. The primary distinction among these models is that some models allowed the presence of groundwater from Emigrant Valley or the Pahranagat Range in the groundwater at ER-7-1, whereas other models were developed that could explain the composition of ER-7-1 groundwater using only upgradient Yucca Flat 
groundwaters. The models that allowed groundwater from WT-1 in Emigrant Valley to be present at ER-7-1 also required groundwater to interact with LCCU rocks in the Halfpint Range to fully explain the Sr compositions at ER-7-1. The models for ER-7-1 thus allow, but do not require, groundwater to flow from Emigrant Valley through the Halfpint Range into eastern Yucca Flat. Composite travel times to ER-7-1 (from WT-1 and UE-10j) calculated by the NETPATH and PHREEQC models ranged from about 3,900 to 7,200 years. Decomposition of the travel times for one set of PHREEQC models indicated that if groundwater does flow from WT-1 to ER-7-1, beneath the Halfpint Range, groundwater velocities over the roughly $25 \mathrm{~km}$ distance between these wells average between 3.2 and 4.2 meters per year (m/yr). Similarly, the range of travel times of about 5,400 to 7,800 years estimated for flow between wells UE-10j and ER-7-1 results in a groundwater velocity of 1.9 to $2.7 \mathrm{~m} / \mathrm{yr}$ over the $14.6 \mathrm{~km}$ distance between these wells.

Wells ER-6-1 and ER-6-1 \#2 are the southernmost of the LCA wells located along the eastern margin of the basin. A recent aquifer test (SNJV, 2005a) revealed a strong hydraulic connection between the ER-6-1 well cluster and ER-7-1. The flow path continuity between these sites is reflected in their groundwater $\delta \mathrm{D}, \delta^{18} \mathrm{O}$, and $\mathrm{Cl}$ values, which are nearly the same for all three wells. These data indicate that effectively all of the groundwater in the ER-6-1 well cluster originated along a flow path leading southward from ER-7-1. To verify this conclusion, the mixing models developed for ER-7-1 (using Emigrant Valley and northeastern Yucca Flat water compositions) used ER-6-1 \#2 as the new target composition. In general, the models predicted a very similar range in mixing compositions for both wells. On the basis of these results and the observed geochemical similarities between ER-6-1, ER-6-1 \#2, and ER-7-1, it is concluded that all three wells lie along a continuous flow path with a common origin in northeastern Yucca Flat and possibly Emigrant Valley. PHREEQC models for ER-6-1 and ER-6-1 \#2 estimated composite travel times of approximately 5,800 to 7,300 years over the $10 \mathrm{~km}$ distance between ER-7-1 and either ER-6-1 or ER-6-1 \#2. These travel times result in a groundwater velocity in the LCA of between 1.4 to $1.7 \mathrm{~m} / \mathrm{yr}$ between ER-7-1 and ER-6-1 and ER-6-1 \#2. Composite travel times for the successful NETPATH simulations involving several northern Yucca Flat groundwaters and leakage from the volcanic aquifer ranged from 10,500 to 12,500 years.

Well U-3en \#5 is also located downgradient of ER-7-1 but several aspects of its composition distinguish it from groundwater at ER-7-1 and other LCA groundwater in eastern Yucca Flat. 
Because of its high $\mathrm{Cl}$ concentrations, conservative tracer models for $\mathrm{U}-3 \mathrm{cn} \# 5$ could only be developed based on $\delta \mathrm{D}$ and $\delta^{18} \mathrm{O}$. NETPATH models incorporating water-rock reactions were unsuccessful, but PHREEQC models that account for uncertainty in chemical and isotopic measurements found that groundwater at U-3cn \#5 could originate by mixing groundwater from the vicinity of ER-7-1 (80 to 90 percent), with groundwater from northern Yucca Flat at UE-10j-3 (about 15 percent), or from UE-15d WW (0 to 9 percent). Additionally, a small amount (0 to 4 percent) of groundwater from the overlying volcanic units could be present, as represented by the groundwater samples from nearby U-3cn PS \#2. The results of these PHREEQC models are consistent with the fact that groundwater $\mathrm{Sr}$ and ${ }^{87} \mathrm{Sr} /{ }^{86} \mathrm{Sr}$ data at U-3cn \#5 and ER-7-1 are nearly identical. These results indicate that at least some groundwater from the vicinity of ER-7-1 flows southwestward toward the center of the basin, as indicated by southwestward hydraulic gradients for the LCA in this part of the basin, despite the presence of many north-south trending faults. Toward the center of the basin, the groundwater from ER-7-1 mixes with smaller fractions of other groundwaters flowing southward from northern Yucca Flat.

\subsubsection{Western Flow Paths}

The geochemical evaluation of the western Yucca Flat groundwater focused on developing models for four wells (UE-2ce, ER-2-1, UE-1h, and ER-6-2). All of these wells are completed in the LCA, except ER-2-1, which is completed in the LTCU. Models indicate that groundwater in western Yucca Flat may be derived predominantly from underflow through the LCA in northern Yucca Flat (represented by groundwater from UE-10j-1), by local recharge from the north and west of Yucca Flat, and possibly by groundwater flow from upper Fortymile Wash, as represented by groundwater from TW-1. An alternative explanation may be that paleo-recharge in Yucca Flat was considerably lighter in $\delta \mathrm{D}$ and $\delta^{18} \mathrm{O}$ than suggested by modern spring data and the TW-1 groundwater is an isolated remnant of paleo-recharge that was once ubiquitous throughout the NTS area.

Well UE-2ce, completed in the LCA in western Yucca Flat and near the NASH underground nuclear test, was modeled as a mixture of local recharge and groundwater from northern Yucca Flat. Conservative tracers and PHREEQC models were in general agreement that local recharge was a significant component (up to 80 percent) of LCA groundwater at UE-2ce. The large component of local recharge estimated to exist in the LCA groundwater at UE-2ce could indicate that this well is 
located in a structurally isolated block of LCA, with limited regional LCA inflow, or it could reflect the relatively large recharge rates estimated for the high elevation areas at nearby Rainier Mesa.

Mixing models for ER-2-1 met with only partial success. The presence of tritium in the ER-2-1 groundwater is believed to reflect nearby testing in the TCU, and not the presence of modern recharge. The isotopic signature of groundwater at ER-2-1, along with other hydrologic information, suggests that groundwater in the LTCU in the vicinity of ER-2-1 may be composed of groundwater recharge that occurred under paleoclimatic conditions. PHREEQC and conservative tracer models suggest that groundwater at ER-2-1 is composed predominantly of groundwater, similar to that found in the VA at TW-1, mixed with smaller amounts of local modern recharge as characterized by perched spring compositions.

Geochemical models for UE-1h also were only partially successful. Lower carbonate aquifer water at UE-1h in western Yucca Flat has a distinct geochemical signature relative to other LCA groundwater in the rest of Yucca Flat. UE-1h has high $\mathrm{Cl}$ concentrations and extremely light $\delta^{13} \mathrm{C}$ values that, along with other factors, make it difficult to create mixing models. Because of its unique chemical and isotopic composition, mixing models for UE-1h based on conservative tracer could only be developed if $\mathrm{Cl}$ was excluded. No NETPATH models incorporating water-rock reactions were successful. The PHREEQC models required that the very light $\delta^{13} \mathrm{C}$ values at UE-1h be adjusted upward by 2 permil and that the $\mathrm{SO}_{4}{ }^{2-}$ concentration at $\mathrm{UE}-1 \mathrm{~h}$ be adjusted by charge balancing the solution. When these adjustments are made, the PHREEQC models produce mixing models involving TW-1 and UE-16d WW groundwater that are in good agreement with interpretations from Sr data that indicated UE-1h groundwater could originate from a subequal (65:35) mixture of TW-1 groundwater and groundwater from the UCCU in western Yucca Flat. The absence of an LCA component from northern Yucca Flat (UE-10j) or elsewhere at UE-1h indicated that this well may be located in an isolated structural block and not connected to the regional LCA in Yucca Flat. In this case, groundwater leakage from the west through the UCCU, and vertical leakage from the TCU are able to exert a strong local effect on groundwater compositions in the LCA. Unfortunately, meaningful groundwater travel times to UE-1h could not be calculated, possibly because of problems with the ${ }^{14} \mathrm{C}$ data from UE-1h or possibly, because the actual mixing endmembers cannot be identified. 
Well ER-6-2, another LCA well in southwestern Yucca Flat, looks chemically similar to other Yucca Flat LCA groundwater. Several of the geochemical models were in relatively good agreement that groundwater at ER-6-2 can be produced by mixing waters from the LCA in northern Yucca Flat, local paleoclimatic recharge groundwater like TW-1, and UCCU groundwater; although the proportions vary somewhat between the different modeling techniques. Composite groundwater travel times for this mixture average about 15,000 years. Conservative tracer and PHREEQC models suggest that ER-6-2 can also be produced by mixing other southwestern LCA groundwater, but these models are not supported by $\mathrm{Sr}$ data or they lack the necessary Sr data to evaluate these models. Hydraulic gradients and inverse models for WW-C suggest that groundwater from the vicinity of ER-6-2 flows southeast toward the WW-C in the southernmost part of the basin.

\subsubsection{Southeastern Flow Path}

Four wells in southeastern Yucca Flat and northeastern Frenchman Flat (ER-3-1, WW-C, WW-C1, and ER-5-3 \#2) produce LCA groundwater with a distinct set of geochemical characteristics that may indicate an independent flow path in this region. All four waters have similar stable isotope values but exhibit greater solute concentrations and somewhat distinct ${ }^{87} \mathrm{Sr} /{ }^{86} \mathrm{Sr}$ ratios, indicating that they might have evolved from different sources than much of the groundwater in the eastern Yucca Flat group. Possible sources of groundwater at ER-3-1 include groundwater from Emigrant Valley (as represented by WT-4), groundwater from the Pahranagat Valley (as represented by Ash Spring), and more local regional underflow in the LCA (as represented by groundwater from UE-10j-1). Various geochemical models are possible that explain the chemical and isotopic composition of groundwater at WW-C as a mixture of groundwater from different parts of Yucca Flat and groundwater to the east of Yucca Flat. Because hydraulic head contours suggest convergent groundwater flow toward WW-C from the west, north and east, all of these models are hydrologically plausible.

Despite the fact that the models for WW-C are nonunique, the travel times estimated from these inverse models consistently indicate that north-south flow through the LCA in Yucca Flat is very slow. The estimated groundwater travel times of approximately 16,000 to 24,000 years from UE-10j in northern Yucca Flat to WW-C in southern Yucca Flat result in calculated groundwater velocities of approximately 1.3 to $1.9 \mathrm{~m} / \mathrm{yr}$ over this $30 \mathrm{~km}$ distance. Likewise, the travel time analysis indicates that leakage from the volcanic units to the LCA, combined with lateral flow in the LCA to WW-C, 
requires approximately 24,000 to 35,000 years, even for wells much further south than UE-10j (i.e., ER-2-1 and TW- B). Conversely, the estimated travel times indicate the possibility of relatively rapid flow from the vicinity of ER-3-1 to WW-C. Travel times from ER-3-1 to WW-C were estimated to be on the order of 1,000 to 3,000 years for two sets of PHREEQC models that include ER-3-1 as a possible end-member. However, the travel times between ER-3-1 and WW-C are subject to somewhat greater uncertainty because of the small differences and low concentrations of ${ }^{14} \mathrm{C}$ at these wells.

Hydraulic head contours in central Yucca Flat indicate the presence of a potentiometric trough that is aligned with major north-south trending faults in Yucca Flat. The presence of a similar trough extending over $80 \mathrm{~km}$ between Frenchman Flat and Ash Meadows has previously been described by Winograd and Pearson (1976). These authors found that ${ }^{14} \mathrm{C}$ ages of springs at the downgradient end of the trough were younger than the ages at springs adjacent to the trough, suggesting that groundwater flow was channelized and relatively more rapid within the trough. The location of WW-C at the downgradient end of the potentiometric trough in Yucca Flat, and the very long travel time and slow velocities estimated between UE-10j in northern Yucca Flat and WW-C in southernmost Yucca Flat, indicate that groundwater flow in the trough is not especially rapid; hence, this trough does not represent a "megachannel" in the sense hypothesized by Winograd and Pearson (1976).

\subsubsection{West Central Flow Path}

Groundwater from TW-D and UE-1q in west-central Yucca Flat have high ${ }^{36} \mathrm{Cl} / \mathrm{Cl}$ ratios $\left(7 \times 10^{-13}\right.$ to $8 \times 10^{-13}$ ) that are relatively unique for groundwater from the LCA (Figure 12-9) where halite dissolution tends to decrease ${ }^{36} \mathrm{Cl} / \mathrm{Cl}$ ratios below present-day meteoric values of about $5 \times 10^{-13}$. This observation indicates that groundwater in the LCA at TW-D and UE-1q did not originate primarily by flow through the LCA from the north, where groundwater ${ }^{36} \mathrm{Cl} / \mathrm{Cl}$ ratios are generally below $5 \times 10^{-13}$. Alternative groundwater paths include vertical recharge through or around gaps in the TCU created by faulting, or easterly flow through the Eleana Formation in western Yucca Flat, where groundwaters can have similarly elevated ${ }^{36} \mathrm{Cl} / \mathrm{Cl}$ ratios. Strontium data support the presence of a component of groundwater from the UCCU in the western part the basin at UE-1q, but appear to indicate the absence of a UCCU groundwater component at TW-D. 
Both TW-D and UE-1q appear to contain a dominant mixing fraction derived from the volcanic HSUs, with a maximum LCA component of approximately 18 percent at TW-D and approximately 35 percent at UE-1q. The large amount of VA water in TW-D and UE-1q probably accounts for the elevated ${ }^{36} \mathrm{Cl} / \mathrm{Cl}$ ratios of these waters. Whether this component is introduced through vertical leakage or lateral transport cannot be clearly determined with the existing data. The relatively low amounts of LCA groundwater in TW-D and UE-1q could reflect the relatively low rates of LCA inflow into the basin relative to local recharge, possibly coupled with the hydraulic isolation of the LCA block containing TW-D and UE-1q from the regional LCA by block-bounding faults. Composite travel times calculated by NETPATH range from 9,700 to 10,800 years for TW-D models involving wells ER-2-1 and UE-10j-1 as the upgradient wells. Groundwater travel times for the UE-1q models involving wells TW-1, UE-10j-1 and UE-16d WW produced estimated composite travel times of 5,500 to 5,700 years.

\subsection{Limitations}

Geochemical flow path evaluations depend on adequate data coverage, both laterally and vertically, within the study region. The wells with the parameter suite necessary to support geochemical flow path analysis and characterization are irregularly distributed in the Yucca Flat/Climax Mine CAU. This is compounded by a sparse representation of groundwater samples collected from most HSUs, particularly the AA and VAs. Well samples included in the dataset were often collected as composites, from wells either with single completions that transect multiple HSU boundaries or with multiple completions that were pumped simultaneously. Many wells draw from a large vertical cross-section of saturated media, possibly resulting in homogenization of the water composition within the borehole (Fenelon, 2005). This limits the ability to uniquely define the geochemical characteristics of groundwater within a specific HSU, locally or regionally, and may have resulted in some of the groundwater mixing that is inferred to have taken place through hydrodynamic processes.

Groundwater data included in this study represent a period from the late 1950s to 2005 and in many cases data for a given well or spring are limited to samples collected more than 20 years ago. These older datasets are limited and lack some elements of the parameter suite used for the geochemical investigations. In particular, $\mathrm{Sr}$ data for groundwater and aquifer rocks, ${ }^{36} \mathrm{Cl}$ data for groundwater and aquifer rocks, $\mathrm{DI}^{14} \mathrm{C}$ data for groundwater, and $\mathrm{DO}^{14} \mathrm{C}$ data for groundwater are not available for the 
older samples. This lack of a consistent dataset for the available wells in the Yucca Flat/Climax Mine limits the ability to develop unique modeling solutions to possible groundwater flow paths.

Geochemical modeling of groundwater flow into the LCA in northern Yucca Flat was hindered by a lack of data for LCA groundwater upgradient and outside of Yucca Flat. In particular, the origin of deep LCA water at UE-10j-1 could not be determined with the existing dataset. Interpretations of input of local recharge to Yucca Flat are also limited, because most perched springs (and some wells in the upland recharge areas) do not have $\delta^{13} \mathrm{C}$ and ${ }^{14} \mathrm{C}$ data for calculating groundwater travel times. Additionally, limited $\delta \mathrm{D}$ and $\delta^{18} \mathrm{O}$ data for several important perched springs including Oak and Captain Jack Springs have peculiar average isotopic signatures that are substantially different from other perched springs in the area. These average isotopic signatures are calculated on only a handful of analyses, and previous studies have indicated that the isotopic signature of perched springs at the NTS is highly variable (Ingraham et al., 1991). To obtain an adequate average isotopic signature for these perched springs, more sampling and analysis of spring discharge is necessary.

Finally, Sr data, another tool capable of contributing to delineation of groundwater flow or evaluation of water-rock reactions, are available from only a limited number of wells in northern Yucca Flat, and from a small subset of perched springs or other upgradient regional groundwater samples. A better understanding of $\mathrm{Sr}$ concentrations and ${ }^{87} \mathrm{Sr} /{ }^{86} \mathrm{Sr}$ compositions is needed for both groundwater and rock samples. In particular, $\mathrm{Sr}$ data for aquifer rocks would improve the ability to assess the impacts of water-rock reaction in reactive transport models.

\subsection{Summary}

Groundwater chemistry data (major ions, stable isotopes of $\delta \mathrm{D}$ and $\delta^{18} \mathrm{O}$, carbon isotopes $\left[\delta^{13} \mathrm{C}\right.$ and $\left.{ }^{14} \mathrm{C}\right],{ }^{36} \mathrm{Cl}$, and $\mathrm{Sr}$ data including ${ }^{87} \mathrm{Sr} /{ }^{86} \mathrm{Sr}$ ) for the Yucca Flat/Climax Mine CAU were compiled and representative values were identified for each sampling location. These data were used to evaluate groundwater flow within this CAU. Geochemical models using conservative tracers $\left(\delta \mathrm{D}, \delta^{18} \mathrm{O}\right.$, and $\mathrm{Cl}$ ) were first used to identify potential groundwater source areas, flow paths, and mixing processes. Possible flow paths were then evaluated using $\mathrm{Sr}$ and ${ }^{87} \mathrm{Sr} /{ }^{86} \mathrm{Sr}$ data and the geochemical modeling programs PHREEQC and NETPATH. The models developed using PHREEQC and NETPATH attempt to explain the geochemical evolution of groundwater by identifying the 
proportions of groundwater from various upgradient wells that may be present in groundwater at a downgradient well.

The geochemical compositions of perched springs and local precipitation were evaluated in an attempt to establish a composition representative of local recharge. Although perched groundwater associated with small springs and seeps are useful as a proxy for the average composition of local recharge (if the water has not experienced large amounts of post-discharge evaporation), a broad range in $\delta \mathrm{D}$ and $\delta^{18} \mathrm{O}$ values is observed that is not strongly correlated with geographic location. For this reason, a single composition that uniquely represents local recharge in this area could not be determined. Rather than relying on a single inferred "local recharge" composition, models were developed using observed compositions of perched waters in the study area. Models sometimes required a combination of two perched water sources to accommodate the observed downgradient water composition. The composition of mean local recharge for ${ }^{87} \mathrm{Sr} /{ }^{86} \mathrm{Sr}$ and $\mathrm{Sr}$ was approximated based on perched water samples from the NTS.

Conceptual flow models were developed on the basis of observed hydraulic head relationships and broad distinctions in the geochemical character of groundwater in particular areas of the Yucca Flat basin. For this reason, each set of models tends to focus on a particular geographic sub-region within the basin. These include northern Yucca Flat, eastern Yucca Flat, southeastern Yucca Flat, western Yucca Flat, and vertical transport near the center of the basin.

The geochemical models and graphical analyses presented in this report demonstrate that most of the groundwater in Yucca Flat can originate from either paleo- or modern recharge, underflow in the LCA from the north or northeast, and leakage of AA or VA groundwater from Emigrant Valley through the Halfpint Range. In contrast, inflow into Yucca Flat through the granitic rocks of Climax Stock in the northernmost part of the basin appears to be negligible. Paleo-recharge is distinguished from modern recharge by its lighter $\delta^{18} \mathrm{O}$ and $\delta \mathrm{D}$ composition, but both modern and paleo-recharge are characterized by relatively dilute concentrations of major ions and relatively light $\delta^{13} \mathrm{C}$ and high ${ }^{14} \mathrm{C}$ activities compared to groundwater in the LCA. Groundwater originating from either paleo- or modern recharge within the Yucca Flat area is a prominent part of the groundwater system, particularly in northwestern and western Yucca Flat, where high elevation areas at Rainier Mesa, upper Fortymile Wash, the Eleana Range, and Shoshone Mountain are adjacent to the basin. The 
prominence of groundwater that has apparently recharged through volcanic or siliciclastic rocks and flowed into the LCA in Yucca Flat reflects the limited inflow through the LCA into northern Yucca Flat and its subsequent spreading and dilution in the large volume of LCA within the basin. As discussed below, the limited inflow through the LCA into Yucca Flat is also reflected in the extremely long groundwater transit times that have been calculated for the basin. Locally, the presence of a dominant component of VA-like water in the LCA may also reflect the hydraulic isolation of individual blocks of LCA by surrounding faults.

In addition to the aforementioned groundwater sources, there is also some evidence that groundwater from east of Yucca Flat, characterized by groundwater from ER-3-1, becomes a prominent part of the groundwater system in the southernmost part of the Yucca Flat basin near WW-C. Apparently, groundwater with the chemical and isotopic composition of ER-3-1 is prevented from entering the Yucca Flat basin further to the north by the blocking effects of the LCCU, but it sweeps southwestward into the basin toward the southern end of the Halfpint Range where the LCCU is absent. Groundwater flow from ER-3-1 to WW-C in the southeastern part of Yucca Flat appears to preclude the possibility of groundwater leaving Yucca Flat by flowing to the southeast.

Because most of the groundwater within Yucca Flat can be derived from mixing dilute paleo- or modern recharge with groundwater underflow through the LCA or inflow from Emigrant Valley, it is perhaps not surprising that inverse geochemical models are nonunique and that the groundwater composition at a given well can be explained by mixing groundwater from different combinations of wells. One significant finding that emerges from these models is that, despite the many combinations of mixing models that are possible, particularly for WW-C at the southern end of Yucca Flat (where hydraulic head contours indicate convergent groundwater flow along a potentiometric trough), the groundwater transit times are extremely long. The estimated groundwater transit times of approximately 16,000 to 24,000 years from UE-10j in northern Yucca Flat to WW-C in southern Yucca Flat result in estimated linear groundwater velocities of approximately 1.3 to $1.9 \mathrm{~m} / \mathrm{yr}$ over this $30 \mathrm{~km}$ distance. These velocities are consistent with groundwater transit times of approximately 5,800 to 7,200 years, and groundwater velocities of 1.4 to $1.7 \mathrm{~m} / \mathrm{yr}$ estimated for the LCA between ER-7-1 and the wells of the ER-6-1 cluster in eastern Yucca Flat (ER-6-1 and ER-6-1 \#2). Likewise, an analysis of transit times from ER-2-1 and TW-B to WW-C indicates that vertical leakage through the TCU, combined with lateral flow in the LCA to WW-C, requires approximately 24,000 to 35,000 
years. The long transit times, even for flow in the LCA, are attributed to the extremely small inflow of groundwater into the basin from the north, rather than to low hydraulic conductivity in the highly faulted LCA. Only in the southeastern part of Yucca Flat, where groundwater transit times are on the order of 1,000 to 3,000 years between ER-3-1 and WW-C, does the groundwater transit time analysis indicate substantially higher groundwater flow velocities ( 4.3 to $13 \mathrm{~m} / \mathrm{yr}$ ). The possibly rapid flow of groundwater from east of the basin into the southeastern part of Yucca Flat is consistent with the absence of the LCCU in the southeast portion of the basin and the relatively stagnant flow conditions with the upgradient parts of the Yucca Flat basin. 


\subsection{REFERENCES}

ARL/SORD, see Air Resources Laboratory/Special Operations and Research Division.

ASTM, see American Society for Testing and Materials.

Air Resources Laboratory/Special Operations and Research Division. 2004. "Air Resources Laboratory/Special Operations and Research Division Web Site.” As accessed on May 5, 2005 at http://www.sord.nv.gov.

American Society for Testing and Materials. 1993. Standard Guide for Application of a Ground-Water Flow Model to a Site-Specific Problem, ASTM D 5447-93. Philadelphia, PA.

American Society for Testing and Materials. 2002a. Standard Guide for Comparing Ground-Water Flow Model Simulations to Site-Specific Information, ASTM D 5490-93. Philadelphia, PA.

American Society for Testing and Materials. 2002b. Standard Guide for Defining Boundary Conditions in Ground-Water Flow Modeling Designation, ASTM D 5609-94. Philadelphia, PA.

American Society for Testing and Materials. 2002c. Standard Guide for Defining Initial Conditions in Ground-Water Flow Modeling, ASTM D 5610-94. Philadelphia, PA.

American Society for Testing and Materials. 2002d. Standard Guide for Conducting a Sensitivity Analysis for a Ground-Water Flow Model Application, ASTM D 5611-94. Philadelphia, PA.

American Society for Testing and Materials. 2002e. Standard Guide for Documenting a Ground-Water Flow Model Application, ASTM D 5718-95. Philadelphia, PA.

American Society for Testing and Materials. 2002f. Standard for Calibrating a Ground-Water Flow Model Application, ASTM D 5981-96. Philadelphia, PA.

Anderman, E.R., and M.C. Hill. 2003. MODFLOW-2000: The U.S. Geological Survey Modular Ground-Water Model - Three additions to the hydrogeologic-unit flow (HUF) package: Alternative storage for the uppermost active cells (SYTP parameter type), flows in hydrogeologic units, and the hydraulic-conductivity depth-dependence (KDEP) capability, Open-File Report 03-347. Denver, CO: U.S. Geological Survey.

Anderson, M.P., and W.W. Woessner. 1992. Applied Groundwater Modeling. San Diego, CA: Academic Press. 
Andrews, J.N., J. Ch. Fontes, J.L. Michelot, and D. Elmore. 1986. "In-situ Neutron Flux, ${ }^{36} \mathrm{Cl}$ Production and Groundwater Evolution in Crystalline Rocks at Stripa, Sweden." In Earth and Planetary Sciences, Letter 77: 49-59.

Asch, T.A., B.D. Rodriguez, J.A. Sampson, E. Walling, and J.M. Williams. 2005. Deep Resistivity Structures of Yucca Flat, Nevada Test Site, Nevada, Open-File Report. U.S. Geological Survey (in press).

BN, see Bechtel Nevada.

Barnes, H., R.L. Christiansen, and F.M. Byers, Jr. 1965. Geologic Map of the Jangle Ridge Quadrangle, Nye and Lincoln Counties, Nevada, Map GQ-363, Scale 1:24,000. Washington, D.C.: U.S. Geological Survey.

Baugh, R. 2005. Personal communication with Bill Fryer regarding ponds associated with water supply wells in Yucca Flat, 30 November. Las Vegas, NV: Bechtel Nevada.

Bechtel Nevada. 1996. Nevada Test Site Region Image Map, SIGIS-NTS-96038. Las Vegas, NV: Remote Sensing Laboratory.

Bechtel Nevada. 1998a. Hydrogeologic Characterization of the Unsaturated Zone at the Area 3 Radioactive Waste Management Site, DOE/NV/11718-210. Las Vegas, NV.

Bechtel Nevada. 1998b. Recompletion Report for BILBY, DOE/NV-500. Las Vegas, NV.

Bechtel Nevada. 2002. A Hydrostratigraphic Model and Alternatives for the Groundwater Flow and Contaminant Transport Model of Corrective Action Units 101 and 102: Central and Western Pahute Mesa, Nye County, Nevada, DOE/NV/11718-706. Las Vegas, NV.

Bechtel Nevada. 2003. Nevada Test Site Routine Radiological Environmental Monitoring Plan, DOE/NV/11718-804. Las Vegas, NV.

Bechtel Nevada. 2005. A Hydrostratigraphic Model and Alternatives for the Groundwater Flow and Contaminant Transport Model of Corrective Action Unit 98: Frenchman Flat, Clark, Lincoln and Nye Counties, Nevada, DOE/NV/11718--1064. Las Vegas, NV.

Bechtel Nevada. 2006. A Hydrostratigraphic Model and Alternatives for the Groundwater Flow and Contaminant Transport Model of Corrective Action Unit 97: Yucca Flat-Climax Mine, Lincoln and Nye Counties, Nevada, DOE/NV/11718--1119. Las Vegas, NV.

Belcher, W.R., P.E. Elliot, and A.L. Geldon. 2001. Hydraulic-Property Estimates for Use with a Transient Ground-Water Flow Model for the Death Valley Regional Ground-Water Flow System, Nevada and California, Water-Resources Investigations Report 2001-4210. U.S. Geological Survey. 
Belcher, W.R., J.B. Blainey, F.A. D’Agnese, C.C. Faunt, M.C. Hill, R.J. Laczniak, G.M. O’Brien, C.J. Potter, H.M. Putnam, C.A. San Juan, and D.S. Sweetkind. 2004. Death Valley Regional Model Ground-Water Flow System, Nevada and California - Hydrogeologic Framework and Transient Ground-Water Flow Model, Scientific Investigations Report 2004-5205. U.S. Geological Survey.

Belitz, K., and J.D. Bredehoeft. 1988. "Hydrodynamics of the Denver Basin: Explanation of Subnormal Fluid Pressures." In American Association of Petroleum Geologists, Bulletin 72: 1334-1359.

Benedict, Jr. F.C., T.P. Rose, J.M. Thomas, R. Waddell, and R. Jacobson. 2003. Geochemistry Technical Basis Document, DOE/NV/13609-34; Publication No. 45205. Las Vegas, NV: Desert Research Institute.

Benjamin, J.R., and C.A. Cornell. 1970. Probability, Statistics, and Decision for Civil Engineers. New York, NY: McGraw-Hill Book Co.

Benson, L. and H. Klieforth. 1989. "Stable Isotopes in Precipitation and Ground Water in the Yucca Mountain Region, Southern Nevada: Paleoclimatic Implications." In Aspects of Climate Variability in the Pacific and the Western Americas, Geophysical Monograph 55: 41-59 p. Washington, D.C.: American Geophysical Union.

Bentley, H.W., F.M. Phillips, and S.N. Davis. 1986. "Chlorine-36 in the Terrestrial Environment." In Handbook of Environmental Isotope Geochemistry, Volume 2, The Terrestrial Environment, Fritz. P. and J.Ch. Fontes (eds.), 427-480 pp. Amsterdam: Elsevier Science Publishers B.V.

Blankennagel, R.K., and J.E. Weir, Jr. 1973. Geohydrology of the Eastern Part of Pahute Mesa, Nevada Test Site, Nye County, Nevada, Professional Paper 712-B. Washington, D.C.: U.S. Geological Survey.

Budd, D.A. 2001. "Permeability Loss with Depth in the Cenozoic Carbonate Platform of West-Central Florida." In American Association of Petroleum Geologists, Bulletin 85(7): 1253-1272.

Buddemeier, R.W., and D. Isherwood. 1985. Radionuclide Migration Project 1984 Progress Report, UCRL-53628. Livermore, CA: Lawrence Livermore National Laboratory.

Burchfiel, B.C., R.J. Fleck, D.T. Secor, R.R. Vincelette, and G.A. Davis. 1974. "Geology of the Spring Mountains, Nevada." In Geological Society of America, Bulletin 85(7): 1013-1022. Boulder, CO: Geological Society of America, Inc.

Burke, W.H., R.E. Denison, E.A. Hetherington., R.B. Koepnick, N.F. Nelson, and J.B. Otto. 1982. "Variation of Seawater ${ }^{87} \mathrm{Sr} /{ }^{86} \mathrm{Sr}$ throughout Phanerozoic Time." In Geology, v. 10: 516-519. 
Byers, F.M., Jr., and H. Barnes. 1967. Geologic Map of the Paiute Ridge Quadrangle, Nye and Lincoln Counties, Nevada, Quadrangle Map GQ-577, Scale 1:24,000. Washington, D.C.: U.S. Geological Survey.

Carlsson, A. and T. Olsson. 1977. "Hydraulic Properties of Swedish Crystalline Rocks: Hydraulic Conductivity and its Relation to Depth." In Bulletin of the Geological Institutions of the University of Uppsala, 7, 71-84, Uppsala, Sweden

Casadel, M., and W.E. Dietrich, and N.L. Miller. 2003. "Testing a Model for Predicting the Timing and Location of Shallow Landslide Initiation in Soil-Mantled Landscapes." In Earth Surface Processes and Landforms, v. 28: 925-950. John Wiley \& Sons, Ltd.

Caskey, S.J., and R.A. Schweickert. 1992. "Mesozoic Deformation in the Nevada Test Site and Vicinity: Implications for the Structural Framework of the Cordilleran Fold and Thrust Belt and Tertiary Extension North of Las Vegas." In Tectonics, v. 11(6): 1314-1331. Las Vegas, NV.

Claassen, H.C., 1973. Water Quality and Physical Characteristics of Nevada Test Site Water-Supply Wells, NTS-242. Washington, D.C.: U.S. Geological Survey.

Claassen, H.C., 1986. "Late-Wisconsin Paleohydrology of the West-Central Amargosa Desert, Nevada, U.S.A.” In Chemical Geology (Isotope Geoscience Section), v. 58: 311-323.

Clark, I.D., and P. Fritz. 1997. Environmental Isotopes in Hydrogeology. Boca Raton, FL: Lewis Publishers.

Clebsch, A. 1960. Ground Water in the Oak Spring Formation and Hydrologic Effects of Underground Nuclear Explosions at the Nevada Test Site, Trace Elements Investigations Report 759. Washington, D.C.: U.S. Geological Survey.

Cole, J.C. 1997. Major Structural Controls on the Distribution of Pre-Tertiary Rocks, Nevada Test Site Vicinity, Southern Nevada, Open-File Report 97-533. Denver, CO: U.S. Geological Survey.

Cole, J.C., A.G. Harris, and R.R. Wahl. 1997. Subcrop Geologic Map of Pre-Tertiary Rocks in the Yucca Flat and Northern Frenchman Flat Areas, Nevada Test Site, Southern Nevada, Open-File Report 97-678, Scale 1:48,000, 24 pp. Denver, CO: U.S. Geological Survey.

Cole, J.C., and P.H. Cashman. 1999. Structural Relationships of Pre-Tertiary Rocks in the Nevada Test Site Region, Southern Nevada, Professional Paper 1607. Denver, CO: U.S. Geological Survey.

Craig, H. 1961. "Isotopic Variations in Meteoric Waters.” In Science, v. 133: 1702-1703. Washington, DC: American Association for the Advancement of Science.

CRC Press. 1992. CRC Handbook of Chemistry and Physics, 73rd edition. 
Criss, R.E. 1999. Principles of Stable Isotope Distribution. New York: Oxford University Press, $254 \mathrm{p}$.

DOE/NV, see U.S. Department of Energy, Nevada Operations Office.

DOE/OCRWM, see U.S. Department of Energy, Office of Civilian Radioactive Waste Management.

D’Agnese, F.A., C.C. Faunt, A.K. Turner and M.C. Hill. 1997. Hydrogeologic Evaluation and Numerical Simulation of the Death Valley Regional Ground-Water Flow System, Nevada and California, Water-Resources Investigations Report 96-4300. U.S. Geological Survey.

DRI, see Desert Research Institute.

Daley, C., R.P. Nielson, and D.L. Phillips. 1994. “A Statistical-Topographic Model for Mapping Climatological Precipitation over Mountainous Terrain.” In Journal of Applied Meteorology, v. 33: 140-158. Boston, MA: American Meteorological Society.

Dansgaard, W. 1964. “Stable Isotopes in Precipitation.” In Tellus, v. 16: 436-468.

Dash, Z.V. 2000. Validation Test Report (VTR) for the FEHM Application Version 2.10, Yucca Mountain Project Identification Numbers SAN: LANL-1999-046; STN: 10086-2.10-00. Los Alamos, NM: Los Alamos National Laboratory.

Dash, Z.V. 2001. Validation Test Report (VTR) for the FEHM Application Version 2.12, Yucca Mountain Project Identification Numbers SAN: LANL-2001-133; STN: 10086-2.12-00. Los Alamos, NM: Los Alamos National Laboratory.

Dash, Z.V., B.A. Robinson, and G.A. Zyvoloski. 1997. Software Requirements, Design, and Verification and Validation for the FEHM Application - A Finite-Element Heat- and Mass-Transfer Code, LA-13305-MS. Los Alamos, NM: Los Alamos National Laboratory.

Davis, R.E. 1962. Preliminary Report on the Geology of the U16a Tunnel, Nevada Test Site, Technical Letter: Marshmallow-4. Denver, CO: U.S. Geological Survey and U.S. Atomic Energy Commission.

Davis, S.N. and R.J.M. DeWiest. 1966. Hydrogeology. New York, NY. John Wiley, 463 p.

Davis, S.N. and L.J. Turk. 1964. Optimum Depth of Wells in Crystalline Rocks. In Ground Water, 2 (2), p. 6-11. National Water Well Association.

de Marsily, G. 1986. Quantitative Hydrogeology: Groundwater Hydrology for Engineers. Orlando, FL: Academic Press, Inc.

Desert Research Institute. 1992. Data Report, UE-1q Aquifer Test. Las Vegas, NV. 
Dettinger, M.D. 1989. "Reconnaissance Estimates of Natural Recharge to Desert Basins in Nevada, U.S.A., by Using Chloride-Balance Calculations." In Journal of Hydrology, v. 106: 55-78. New York, NY: Elsevier Publishing Co.

Domenico, P.A., and F.W. Schwartz. 1990. Physical and Chemical Hydrogeology. New York, NY: John Wiley \& Sons.

Doty, G. C., and W. Thordarson. 1983. Water Table in Rocks of Cenozoic and Paleozoic Age, 1980, Yucca Flat, Nevada Test Site, Nevada, Water-Resources Investigations Report 83-4067. Lakewood, CO: U.S. Geological Survey.

Doty, G. C. and F.E. Rush. 1985. Inflow to a crack in Playa Deposits of Yucca Lake, Nevada Test Site, Nye County, Nevada. Water-Resources Investigations Report 84-4296. Denver, CO:

U.S. Geological Survey.

Drellack, S.L., Jr., and P.H. Thompson. 1990. Selected Stratigraphic Data for Drill Holes in LANL Use Areas of Yucca Flat, NTS, DOE/NV-10322-39. Las Vegas, NV: Fenix \& Scisson, Inc.

Dynamic Graphics, Inc. 2002. EarthVision 7: Software for 3-D Modeling and Visualization. Alameda, CA.

Eakin, T.E., G.B. Maxey, T.W. Robinson, J.C. Fredericks, and O.J. Loeltz. 1951. "Contributions to the Hydrology of Eastern Nevada." In Water Resources Bulletin, No. 12. Carson City, NV: State of Nevada Office of the State Engineer, U.S. Geological Survey.

Efron, B., and R. Tibshirani. 1998. An Introduction to the Bootstrap. Boca Raton, FL: CRC Press LLC.

Environment Agency. 2002. Enhancements to MODFLOW: User Guide for MODFLOW-VKD - A Modified Version of MODFLOW-96 to Include Variations in Hydraulic Properties with Depth. United Kingdom: National Groundwater \& Contaminated Land Centre Project NC/00/23.

Epstein, B.J. 2004. Development and Uncertainty Analysis of Empirical Recharge Prediction Models for Nevada's Desert Basins. Reno, NV: University of Nevada, Reno, Master of Science Thesis.

Eriksson E., and V. Khunakasem. 1969. "Chloride Concentrations in Groundwater, Recharge Rate and Rate of Deposition of Chloride in the Israel Coastal Plain." In Journal of Hydrology, v. 7:178-197. New York, NY: Elsevier Publishing Company.

FFACO, see Federal Facility Agreement and Consent Order. 
Fabryka-Martin, J., S.J. Wightman, W.J. Murphy, M.P. Wickham, M.W. Caffee, G.J. Nimz,

J.R. Southon, and P. Sharma. 1993. "Distribution of Chlorine-36 in the Unsaturated Zone at Yucca Mountain: An Indicator of Fast Transport Paths." Paper presented at FOCUS '93 Site Characterization and Model Validation. Las Vegas, NV.

Faunt, C.C., F.A. D’Agnese, and A.K. Turner. 1997. A Hydrogeologic Map of the Death Valley Region, Nevada and California, Developed Using GIS Techniques, Water-Resources Investigations Report 95-4016. Denver, CO: U.S. Geological Survey.

Faure, G. 1986. Principles of Isotope Geology, Second Edition. New York, NY: John Wiley \& Sons, 589 p.

Federal Facility Agreement and Consent Order. 1996, as amended. Agreed to by the State of Nevada, the U.S. Department of Energy, and the U.S. Department of Defense. Appendix VI, which contains the Underground Test Area strategy, was last amended December 7, 2000, Revision No. 1.

Fenelon, J.M. 2005. Analysis of Ground-Water Levels and Associated Trends in Yucca Flat, Nevada Test Site, Nye County, Nevada, 1951-2003, Scientific Investigations Report 2005-5175. Carson City, NV: U.S. Geological Survey.

Fenelon, J.M. 2006. Personal communication to SNJV. Nevada ERP Document Review Sheet for Phase I Hydrologic Data for the Groundwater Flow and Contaminant Transport Model of Corrective Action Unit 97; Yucca Flat/Climax Mine, Nye County, Nevada Test Site, Nevada; Draft, 28, April. Las Vegas, NV: U.S. Geological Survey.

Ferguson, J.J., R.N. Felch, C.L. Aiken, J.S. Oldow, and H. Dockery. 1994. “A Geophysical-Geological Transect of the Silent Canyon Caldera Complex, Pahute Mesa, Nevada." In Journal of Geophysical Research, v. 99(33): 4323-4339.

Flint, A.L. and S.W. Childs. 1987. "Calculation of Solar Radiation in Mountainous Terrain." In Journal of Agricultural and Forest Meteorology, v. 40: 233-249.

Fouty, S.C. 1989. Chloride Mass-Balance as a Method for Determining Long-Term Groundwater Recharge Rates and Geomorphic-Surface Stability in Arid and Semi-Arid Regions, Whiskey Flat and Beatty, Nevada. Tucson, AZ: University of Arizona, Master of Science Thesis.

Freeze, R.A., and J.A. Cherry. 1979. Groundwater. Englewood Cliffs, NJ: Prentice Hall.

Freeze, R.A., J. Massmann, L. Smith, T. Sperling, and B.James. 1990. "Hydrogeological Decision Analysis: I.A. Framework." In Groundwater, v. 28(5): 738-766. Columbus, OH: Groundwater Publishing Company.

French, R.H. 1996. Memorandum to E. Jacobson, Desert Research Institute, regarding additional high altitude precipitation data, 21 August. Las Vegas, NV: Desert Research Institute. 
Gangi, A.F. 1978. "Variation of Whole and Fractured Porous Rock Permeability with Confining Pressure." In International Journal of Rock Mechanics and Mining Sciences, v. 15: 249-257. Great Britain: Pergamon Press.

George, D.C. 1997. Unstructured 3D Grid Toolbox for Modeling and Simulation, LA-UR-97-3052. Los Alamos, NM: Los Alamos National Laboratory.

Gibbons, A.B., E.N. Hinrichs, W.R. Hansen, and R.W. Lemke. 1963. Geology of the Rainier Mesa Quadrangle, Nye County, Nevada, Map GQ-215, Scale 1:24,000. Washington, D.C.:

U.S. Geological Survey.

Gillespie, D. 2003. Temperature Data Evaluation, DOE/NV/13609-22; Publication No. 45194. Las Vegas, NV: Desert Research Institute.

Gillespie, D. 2005. Temperature Profiles and Hydrologic Implications from the Nevada Test Site Area, DOE/NV/13609-40; Publication No. 45211. Las Vegas, NV: Desert Research Institute.

Gonzales, J.L., S.L. Drellack, and M.J. Townsend. 1998. Written communication. Subject: Descriptive Narrative for the Hydrogeologic Model of the Yucca Flat Corrective Action Unit: An Interim Report. Las Vegas, NV: Bechtel Nevada.

Grasso, D.N. 2001. GIS Surface Effects Archive of the Underground Nuclear Detonations Conducted at Yucca Flat and Pahute Mesa, Nevada Test Site, Nevada, Open-File Report-2001-272. U.S. Geological Survey.

Grasso, D.N. 2003. Geologic Surface Effects Archive of Underground Nuclear Test, Buckboard Mesa, Climax Stock, Dome Mountain, Frenchman Flat, Rainier/Aqueduct Mesa, and Shoshone Mountain, Nevada Test Site, Nevada, Open-File Report-2003-125. U.S. Geological Survey.

Graves, R.P. 2005. Personal communication to Nathan Bryant (SNJV) that included a spreadsheet containing annual and monthly well-discharge data for Yucca Flat and other areas, 5 April. Las Vegas, NV: U.S. Geological Survey.

Guth, P.L. 1986. Bedrock Geologic Map of the Black Hills, Scale 1:24,000 Quadrangle, Nevada, Open-File Map 86-438. Las Vegas, NV: U.S. Geological Survey.

Hale, G.S., D.A. Trudeau, and C.S. Savard. 1995. Water-Level Data from Wells and Test Holes Through 1991, and Potentiometric Contours as of 1991 for Yucca Flat, Nevada Test Site, Nye County, Nevada, Water-Resources Investigations Report 95-4177. Denver, CO: U.S. Geological Survey.

Halford, K.J., R.J. Laczniak, and D.L. Galloway. 2005. Hydraulic Characterization of Overpressured Tuffs in Central Yucca Flat, Nevada Test Site, Nye County, Nevada, Scientific Investigations Report 2005-5211. U. S. Geological Survey. 
Haneberg. W.C., P. Gomez, A. Gibson, and B. Allred. 1998. "Preliminary Measurements of Stress-Dependent Hydraulic Conductivity of Santa Fe Group Aquifer System Sediments from the $98^{\text {th }}$ St. Core Hole, Albuquerque, New Mexico, 14-20 February." In New Mexico Geology.

Hansen, W.R., R.W. Lemke, J.M. Cattermole, and A.B. Gibbons. 1963. Stratigraphy and Structure of the Rainier Mesa and USGS Tunnel Areas Nevada Test Site, Professional Paper 382-A. U.S. Geological Survey.

Hansen, D.J., P.D. Greger, C.A. Wills, and W.K. Ostler. 1997. Nevada Test Site Wetlands Assessment, DOE/NV/11718-124. Las Vegas, NV: Bechtel Nevada.

Harbaugh, A.W. 1990. A Computer Program for Calculating Subregional Water Budgets Using Results from the U.S. Geological Survey Modular Three-Dimensional Ground-Water Flow Model, Open-File Report 90-392. Reston, VA: U.S. Geological Survey.

Harbaugh, A.W., E.R. Banta, M.C. Hill, and M.G. McDonald. 2000. MODFLOW-2000, the U.S. Geological Survey Modular Ground-Water Model -- User Guide to Modularization Concepts and the Ground-Water Flow Process, Open-File Report 00-92. Reston, VA: U.S. Geological Survey.

Hardman, G. 1936. Nevada Precipitation and Acreages of Land by Rainfall Zones, Bulletin 183. Reno, NV: U.S. Department of Agriculture, University of Nevada Experimental Station.

Hardman, G. 1965. Nevada Precipitation and Acreages of Land by Rainfall Zones. Reno, NV: U.S. Department of Agriculture, University of Nevada Experimental Station.

Harrill, J.R., J.S. Gates, and J.M. Thomas. 1988. "Major Groundwater Flow Systems in the Great Basin Region of Nevada, Utah, and Adjacent States." In U.S. Geological Survey Hydrologic Investigations Atlas, ATLAS-HA-694-C, Scale: 1,000,000. Denver, CO: U.S. Geological Survey.

Hawkins, W.L., D.A. Trudeau, and T.M. Mihevc. 1989. "Hydrologic Testing in Exploratory Drill Hole UE4t, Yucca Flat, the Nevada Test Site." In Fifth Symposium on Containment of Underground Nuclear Explosions, CONF-8909163, v. 2:141-159. Santa Barbara, CA: Mission Research Corporation.

Hem, J.D. 1985. Study and Interpretation of the Chemical Characteristics of Natural Water, Water-Supply Paper 2254, 3rd. ed. Denver, CO: U.S. Geological Survey.

Hershey, R.L., J.M. Thomas, T.P. Rose, J.B. Paces, I.M. Farnham, and F.C. Benedict, Jr. 2005. Evaluation of Groundwater Movement in the Frenchman Flat CAU Using Geochemical and Isotopic Analysis, DOE/NV/13609-36; Publication No. 45207. Las Vegas, NV: Desert Research Institute. 
Hevesi, J.A., A.L. Flint, and L.E. Flint. 2003. Simulation of Net Infiltration and Potential Recharge Using a Distributed Parameter Watershed Model for the Death Valley Region, Nevada and California, Water-Resources Investigations Report 03-4090. Sacramento, CA: U.S. Geological Survey.

Hinrichs, E.N., and E.J. McKay. 1965. Geologic Map of the Plutonium Valley Quadrangle, Nye and Lincoln Counties, Nevada, Map GQ-384, Open-File Report-2003-125. Washington, D.C.:

U.S. Geological Survey and U.S. Atomic Energy Commission.

Hokett, S.L. and D.R. Gillespie. 1996. Preliminary Evaluation of Recharge Potential at Subsidence Crate U5a in Frenchman Flat, Nevada Test Site, DOE/NV/11508-02; Publication No. 45160. Las Vegas, NV: Desert Research Institute.

Hokett, S.L. and R.H. French. 1998. Evaluation of Recharge Potential at Crater U5a (WISHBONE), Nevada Test Site, DOE/NV/11508-32; Publication No. 45160. Las Vegas, NV: Desert Research Institute.

Hokett, S.L., D.R. Gillespie, G.V. Wilson, and R.H. French. 2000. Evaluation of Recharge Potential at Subsidence Crater U10i, Northern Yucca Flat, Nevada Test Site, DOE/NV/11508-53; Publication No. 45174. Las Vegas, NV: Desert Research Institute.

Hoover, D. L., and D.A. Trudeau. 1987. "High Fluid Levels in Drill Holes, Yucca Flat, Nevada Test Site." In Fourth Symposium on Containment of Underground Nuclear Explosions, v. 2: 363 372. Colorado Springs, CO: Sandia National Laboratories.

Hoover, D.L., and J.E. Magner. 1990. Geology of the Rainier Mesa-Aqueduct Mesa Tunnel Areas-U12n Tunnel, Open-File Report 90-623, 49 p. U.S. Geological Survey.

Houser, F.N., and F.G. Poole. 1960. Preliminary Geologic Map of the Climax Stock and Vicinity, Nye County, Nevada, Map I-328, Scale 1:4,800. Washington, D.C.: U.S. Geological Survey.

IT, see IT Corporation.

Ingebritsen, S.E. and C.E. Manning. 1999. "Geological Implications of a Permeability-Depth Curve for the Continental Crust.” In Geology, v. 27(12): 1107-1110.

Ingraham, N.L., R.L. Jacobson, B.F. Lyles, and J.W. Hess. 1990. Stable Isotopic Study of Precipitation and Spring Discharge on the Nevada Test Site, DOE/NV/10845-03; Publication No. 45078. Las Vegas, NV: Desert Research Institute.

Ingraham, N.L., B.F. Lyles, R.L. Jacobson, and J.W. Hess. 1991. "Stable Isotopic Study of Precipitation and Spring Discharge in Southern Nevada." In Journal of Hydrology, v. 125: 243-258. 
IT Corporation. 1995. Written communication. Subject: Pre-Completion Hydrologic Testing Documentation Package for Well UE-10j. Las Vegas, NV.

IT Corporation. 1996a. Groundwater Flow Model Documentation Package (Phase I, Data Analysis Documentation, Volume VI), ITLV/10972--181. Las Vegas, NV.

IT Corporation. 1996b. Groundwater Recharge and Discharge Data Documentation Package (Phase I Data Analysis Documentation, Volume III). Las Vegas, NV.

IT Corporation. 1996c. Hydrologic Parameters Data Documentation Package (Phase I, Data Analysis Documentation, Volume IV), ITLV/10972--181. Las Vegas, NV.

IT Corporation. 1996d. Potentiometric Data Documentation Package (Phase I, Data Analysis Documentation, Volume II), ITLV/10972--181. Las Vegas, NV.

IT Corporation. 1996e. Regional Geologic Model Data Documentation Package (Phase I, Data Analysis Documentation, Volume I, Parts 1 and 2), ITLV/10972--181. Las Vegas, NV.

IT Corporation. 1999. Value of Information Analysis for Corrective Action Unit 97: Yucca Flat, Nevada Test Site, Nevada, Rev. 0, DOE/NV13052-079; IT 13052-079. Las Vegas, NV.

IT Corporation. 2002. Yucca Flat Hydrogeologic Investigation Wells Drilling and Completion Criteria, ITLV/13052--164. Las Vegas, NV.

Jacobson, B. 1996. Personal communication to O. Drici (IT Corporation) regarding Precipitation Data, 20 September. Reno, NV: Desert Research Institute.

James, J.W., T. Hendricks, and K. Sorenson. 1993. Climate of the Death Valley Region, Nevada/California.

Johnston, G.H., B. Ladanyi, N.R. Morgenstern, and E. Penner. 1981. Engineering Characteristics of Frozen and Thawing Soils: Permafrost Engineering Design and Construction. John Wiley \& Sons.

Kalin, R.M. 2000. "Radiocarbon Dating of Groundwater Systems.” In Environmental Tracers in Subsurface Hydrology, Cook, P.G., and A.L. Herczeg (eds.), 111-144 pp. Boston, MA: Kluwer.

Kenneally, J. 1995. Written communication. Subject: Preliminary Report Evaluating the Use of Strontium and Chloride Concentrations and ${ }^{87} \mathrm{Sr} /{ }^{86} \mathrm{Sr}$ Ratios as Analogs for the Dissolution of Inorganic Carbon, 14 p. Livermore, CA: Lawrence Livermore National Laboratory.

Kilroy, K.C. 1992. Aquifer Storage Characteristics of Paleozoic Carbonate Rocks in Southeastern Nevada Estimated from Harmonic Analysis of Water-Level Fluctuations. University of Nevada at Reno, Ph. D. Dissertation. 
Konikow, L.F. 1978. “Calibration of Ground-Water Models.” In Verification of Mathematical and Physical Models in Hydraulic Engineering, 87-93 pp. New York: American Society of Civil Engineering.

Kuiper, L.K. 1994. Nonlinear-Regression Flow Model of the Gulf Coast Aquifer Systems in the South-Central United States, Water-Resources Investigations Report 93-4020. Denver, CO: U.S. Geological Survey.

Laczniak, R.L., J.C. Cole, D.A. Sawyer, and D.A. Trudeau. 1996. Summary of Hydrogeologic Controls on the Movement of Groundwater Flow at the Nevada Test Site, Nye County, Nevada, Water- Resources Investigations Report 96-4109. Carson City, NV: U.S. Geological Survey.

Langmuir, D. 1978. "Uranium Solution-Mineral Equilibria at Low Temperatures with Applications to Sedimentary Ore Deposits." In Geochim Cosmochim Acta, v. 42: 547-569.

Lavenue, A.M., T.L. Cauffman, and J.F. Pickens. 1990. Ground-Water Flow Modeling of the Culebra Dolomite, Volume I Model Calibration, SAND88-7002. Albuquerque, NM: Sandia National Laboratories.

Lee, C-H., B-W. Deng, and J-L. Chang. 1995. "A Continuum Approach for Estimating Permeability in Naturally Fractured Rocks.” In Engineering Geology, v. 39: 71-85. New York, NY: Elsevier Publishing Co.

Loucks, R.G., M.M. Dodge, and W.E. Galloway. 1986. Controls on Porosity and Permeability of Hydrocarbon Reservoirs in Lower Tertiary Sandstones along the Texas Gulf Coast, Report of Investigations No. 149. Austin, TX: Bureau of Economic Geology, The University of Texas at Austin.

Ludwig, K.R., K.R. Simmons, B.J. Szabo, I.J. Winograd, J.M. Landwehr, A.C. Riggs, and R.J. Hoffman. 1992. "Mass-spectrometric ${ }^{230}$ Th- ${ }^{234} \mathrm{U}^{238} \mathrm{U}$ Dating of the Devils Hole Calcite Vein." In Science, v. 258: 284-287.

Lyles, B.F., J. Edkins, R.L. Jacobson, and J.W. Hess. 1990. Time-Series Analysis of Ion and Isotope Geochemistry of Selected Springs of the Nevada Test Site, Nye County, Nevada, Water Resources Center, DOE/NV/10384-27; Publication, No. 45068. Las Vegas, NV: Desert Research Institute.

Mace, R.E. 1998. Ground-Water Flow and Solute Transport in a Fractured Chalk Outcrop, North-Central Texas, May. Ph.D. Dissertation, The University of Texas at Austin.

Mace, R.E. and A.R. Dutton. 1994. "Hydrogeologic Controls on Contaminant Transport in Weathered and Fractured Chalk." In Toxic Substances and the Hydrologic Sciences. American Institute of Hydrology, p. 535-546.

Magara, K. 1978. Compaction and Fluid Migration, Practical Petroleum Geology. Amsterdam: Elsevier Scientific Publishing Company. 
Maidment, D.R. 1993. Handbook of Hydrology. McGraw-Hill, Inc., 889 p.

Maldonado, F. 1977. Summary of the Geology and Physical Properties of the Climax Stock, Nevada Test Site, Open-File Report 77-356. Denver, CO: U.S. Geological Survey.

Malmberg, G.T. 1967. Hydrology of the Valley-Fill and Carbonate-Rock Reservoirs Pahrump Valley, Nevada-California, Water Supply Paper 1832. Denver, CO: U.S. Geological Survey.

Maloszewski, P., and A. Zuber. 1991. "Influence of Matrix Diffusion and Exchange Reactions on Radiocarbon Ages in Fissured Carbonate Aquifers." In Water Resources Research, 27(8): 1937-1945.

Manning, C.E., and S.E. Ingebritsen. 1999. "Permeability of the Continental Crust: Implications of Geothermal Data and Metamorphic Systems." In Reviews of Geophysics, v. 37: 127-150. Washington D.C.: American Geophysical Union.

Maurer, D.K., D.L. Berger, and D.E. Prudic. 1996. Subsurface Flow to Eagle Valley from Vicee, Ash, and Kings Canyons, Carson City, Nevada, Estimated from Darcy's Law and the Chloride-Balance Method, Water-Resources Investigations Report 96-4088, 38 p. Denver, CO: U.S. Geological Survey.

Maxey, G.B., and T.E. Eakin. 1949. "Ground Water in White River Valley, White Pine, Nye, and Lincoln Counties, Nevada.” In Nevada State Engineer Water Resources, Bulletin No. 8, 59 p.

Mazaud, A., C. Laj, E. Bard, M. Arnold, and E. Tric. 1991. "Geomagnetic Field Control of 14C Production Over the Last $80 \mathrm{KY}$ : Implications for the Radiocarbon Time-Scale.” In Geophysical Research Letters, v. 18: 1885-1888.

McNutt, R.H. 2000. "Strontium Isotopes.” In Environmental Tracers in Subsurface Hydrology, Chapter 8: 233-259.

Mook, W.G. 1980. "Carbon-14 in Hydrogeological Studies." In Handbook of Environmental Isotope Geochemistry, The Terrestrial Environment, v. 1: 49-74. Amsterdam, The Netherlands: A. Elsevier.

Moran, J.E., and T.P. Rose. 2003. A Chlorine-36 Study of Regional Groundwater Flow and Vertical Transport in Southern Nevada. In Environmental Geology, v. 43: 592-605.

Moore, J.E. 1961. Records of Wells, Test Holes, and Springs in the Nevada Test Site and Surrounding Area, Trace Elements Investigations-781. Washington, D.C.: U.S. Geological Survey.

Moreo, M.T., K.J. Halford, R.J. La Camera, and R.J. Laczniak. 2003. Estimated Ground-Water Withdrawals from the Death Valley Regional Flow System, Nevada and California, 1913-98, Water-Resources Investigations Report 03-4245. Carson City, NV: U.S. Geological Survey. 
Mozeto, A.A., P. Fritz, and E.J. Reardon. 1984. "Experimental Observations on Carbon Isotope Exchange in Carbonate-Water Systems." In Geochemica et Cosmochimica Acta, 48: 495-504.

NNSA/NSO, see U.S. Department of Energy, National Nuclear Security Administration, Nevada Site Office.

NNSA/NV, see U.S. Department of Energy, National Nuclear Security Administration Nevada Operations Office.

Neglia, S. 1979. "Migration of Fluids in Sedimentary Basins." In American Association of Petroleum Geologists Bulletin 63: 573-597.

Nevada Bureau of Mines and Geology. 1996. County Digital Geologic Mapping Project-Final Report, Open-File Report 97-1, Scale 1:250,000. U.S. Geological Survey.

Orkild, P.P., M.J. Baldwin, and D.R. Townsend. 1983. Geologic and Geophysical Investigations of Climax Stock Intrusive, Nevada: Geologic Investigations, Open-File Report 83-37: 1-24. Denver, CO: U.S. Geological Survey.

Osmond, J.K., and J.B. Cowart. 1976. "The Theory and Uses of Natural Uranium Isotopic Variations in Hydrology.” In Atomic Energy, Rev. 14: 621-679.

Paces, J.B., K.R. Ludwig, Z.E. Peterman, and L.A. Neymark. 2002. “234U/238U Evidence for Local Recharge and Patterns of Ground-Water Flow in the Vicinity of Yucca Mountain, Nevada, USA." In Applied Geochemistry, v. 17: 751-779.

Parkhurst, D.L., and C.A.J. Appelo. 1999. User's Guide to PHREEQC - A Computer Program for Speciation, Batch-Reaction, One-Dimensional Transport, and Inverse Geochemical Calculations, Version 2, Water-Resources Investigations Report 99-4259. Denver, CO: U.S. Geological Survey.

Peterman, Z.E., C.E. Hedge, H.A. Tourtelot. 1970. "Isotopic Composition of Strontium in Sea Water Throughout Phanerozoic Time." In Geochim Cosmochim Acta, v. 34: 105-120.

Peterson, F.F. 1981. "Landforms of the Basin and Range Province Defined for Soil Survey." In Nevada Agricultural, Bulletin No. 28. Reno, NV: Max C. Fleischmann College of Agriculture, University of Nevada Reno.

Phelps, G.A. and E.H. McKee. 1999. High-Angle Faults in the Basement of Yucca Flat, Nevada Test Site, Nevada, Based on the Analysis of a Constrained Gravity Inversion Surface, Open-File Report-99-383. U. S. Geological Survey.

Plummer, L.N., E.C. Prestemon, and D.L. Parkurst. 1994. An Interactive Code (NETPATH) for Modeling Net Geochemical Reactions Along a Flow Path, Version 2.0, Water-Resources Investigations Report 94-4169. Denver, CO: U.S. Geological Survey. 
Porcelli, D., and P.W. Swarzenski. 2003. "The Behavior of U- and Th-series Nuclides in Groundwater, Uranium-Series Geochemistry," B. Bourdon, G.M. Henderson, C.C. Lundstrom, and S.P. Turner (eds.). In Reviews in Mineralogy and Geochemistry, v. 52: 317-361.

Prothro, L.B., and S.L. Drellack. 1997. Nature and Extent of Lava-Flow Aquifers Beneath Pahute Mesa, Nevada Test Site, DOE/NV/11718-156. Las Vegas, NV: Bechtel Nevada.

Prothro, L.B. 1998. Analysis of Fractures in Cores from the Tuff Confining Unit Beneath Yucca Flat, Nevada Test Site. Las Vegas, NV: Bechtel Nevada.

Prothro, L.B. 2005. Written communication via email to P. Cashman and J. Trexler (University of Nevada, Reno [UNR]). Subject: Bechtel Nevada comments (including attached figures) on UNR report, Interpretation of the ER-12-2 Drill Hole: Reducing Stratigraphic and Structural Uncertainty in the Yucca Flat Geologic/Hydrostratigraphic Model. January. Las Vegas, NV: Bechtel Nevada.

Prudic, D.E. 1991. Estimates of Hydraulic Conductivity from Aquifer-Test Analyses and Specific-Capacity Data, Gulf Coast Regional Aquifer Systems, South-Central United States, Water-Resources Investigations Report 90-4121. Denver, CO: U.S. Geological Survey.

Quade, J., T.E. Cerling, and J.R. Bowman. 1989. "Systematic Variations in the Carbon and Oxygen Isotopic Composition of Pedogenic Carbonate Along Elevation Transects in the Southern Great Basin, United States." Geological Society of America Bulletin, v. 101, 464-475.

Quade, J., M.D. Mifflin, W.L. Pratt, and L. Burckle. 1995. "Fossil Spring Deposits in the Southern Great Basin and their Implications for Changes in Water-Table Levels near Yucca Mountain, Nevada, during Quaternary Time." In The Geological Society of America, Bulletin 107: 213-230.

Quade, J., R.M. Forester, W.L. Pratt, and C. Carter. 1998. "Black Mats, Spring-Fed Streams, and Late-Glacial-Age Recharge in the Southern Great Basin.” In Quaternary Research, v. 49: 129-148.

Rasmuson, A., and I. Neretnieks. 1986. "Radionuclide Transport in Fast Channels in Crystalline Rock.” In Water Resources Research, v. 22(8): 1247-1256. Washington D.C.: American Geophysical Union.

Reimus, P.W., R.L. Hershey, D. Decker, S.D. Ware, C. Papelis, S. Earman, A. Abdel-Fattah, M. Haga, D. Counce, S. Chipera, and C. Sedlacek. 2005. Tracer Transport Properties in the Lower Carbonate Aquifer of Yucca Flat. Prepared for the U.S. Department of Energy, Nevada Operations Office. Las Vegas, NV. 
Rose, T.P., F.C. Benedict, Jr., J.M. Thomas, W.S. Sicke, R.L. Hershey, J.B. Paces, I.M. Farnham, and Z.E. Peterman. 2002. Written communication. Subject: Geochemical Data Analysis and Interpretation of the Pahute Mesa-Oasis Valley Groundwater Flow System, Nye County, Nevada. Livermore, CA: Lawrence Livermore National Laboratory. Reno, NV: Desert Research Institute and HSI GeoTrans. Denver, CO: U.S. Geological Survey. Las Vegas, NV: Harry Reid Center for Environmental Studies, University of Nevada.

Rose, T.P., G.F. Eaton, and A.B. Kersting. 2003. Stable Isotope Investigation of Precipitation and Recharge Processes in Central Nevada, UCRL-ID-154357. Livermore, CA: Lawrence Livermore National Laboratory.

Rosholt, J.N. 1983. "Isotopic Composition of Uranium and Thorium in Crystalline Rocks." In Journal of Geophysical Research, v. 88: 7315-7330.

Rousseau, J.P., E.M. Kwicklis, and D.C. Gillies, eds. 1999. Hydrogeology of the Unsaturated Zone, North Ramp Area of the Exploratory Studies Facility, Yucca Mountain, Nevada, Water-Resources Investigations Report 98-4050, 244 p. Denver, CO: U.S. Geological Survey.

Rovey, C.W., and D.S. Cherkauer. 1995. "Scale Dependency of Hydraulic Conductivity Measurements." In Groundwater, v. 33(5): 769-780.

Rubin, Y., and J.J. Gomez-Hernandez. 1990. "A Stochastic Approach to the Problem of Upscaling of Conductivity in Disordered Media: Theory and Unconditional Numerical Simulations." In Water Resources Research, v. 26(4): 691-701. Washington, D.C.: American Geophysical Union.

Rush, F.E. 1970. Regional Ground-Water Systems in the Nevada Test Site Area, Nye, Lincoln, and Clark Counties, Nevada, Water Resources-Reconnaissance Series, Report 54: 21. Carson City, NV: State of Nevada, Department of Conservation and Natural Resources, Division of Water Resources.

Rushton, K.R., E.J. Smith, and L.M. Tomlinson. 1982. “An Improved Understanding of Flow in a Limestone Aquifer Using Field Evidence and Mathematical Models." In Journal of the Institution of Water Engineers and Scientists, v. 36(5): 369-397.

Rushton, K.R., B.J. Connorton, and L.M. Tomlinson. 1989. "Estimation of the Groundwater Resources of the Berkshire Downs Supported by Mathematical Modeling." In Quarterly Journal of Engineering Geology, 22: (4), 329-341.

Russell, C.E., J.W. Hess, and S.W. Tyler. 1987. "Hydrogeologic Investigations of Flow in Fractured Tuffs, Rainier Mesa, Nevada Test Site.” In American Geophysical Union Monograph, v. 42: 43-50.

Russell, C.E., L. Gillespie, and D. Gillespie. 1993. Geochemical and Hydrologic Characterization of the Effluent Draining from U12e, U12n, and U12t Tunnels, Area 12, Nevada Test Site, DOE/NV/10845-21, UC-703; Publication No. 45105. Las Vegas, NV: Desert Research Institute. 
Russell, C.E., D. Gillespie, J.C. Cole, S.L. Drellack, L.B. Prothro, P.H. Thompson, R.L. McCall, G.A. Pawloski, and R. Carlson. 1996. ER-12-1 Completion Report, DOE/NV/10845-36; Publication No. 45120. Las Vegas, NV: Desert Research Institute.

Russell, C.E., and T. Minor. 2002. Reconnaissance Estimates of Recharge Based on an Elevation-Dependent Chloride Mass-Balance Approach, DOE/NV/11508-37; Publication No. 45164. Las Vegas, NV: Desert Research Institute.

Russell, C.E., R.H. French, R.A. Nicholson, J.S. Miller, J.S. Benner, and S. Benner. 2003. Evaluation of Monitoring Data from Impounded Water within U12n and U12t Tunnel - Rainier and Aqueduct Mesas, Nevada Test Site, Letter Report, 30 June. Las Vegas, NV: Desert Research Institute.

Russell, C.E. 2004. Personal communication to Stoller-Navarro Joint Venture regarding "Documentation of Data and Method for Elevation-Dependent Chloride Mass-Balance Extended Analysis," 4 November. Las Vegas, NV: Desert Research Institute.

SNJV, see Stoller-Navarro Joint Venture.

Sanchez-Vila, X., P.M. Meier, and J. Carrera. 1999. "Pumping Tests in Heterogeneous Aquifers: An Analytical Study of What Can Be Obtained from their Interpretation Using Jacob's Method." In Water Resources Research, v. 35(4): 943-952. Washington, D.C.: American Geophysical Union.

Sanford, W.E. 1997. "Correcting for Diffusion in Carbon-14 Dating of Ground Water." In Groundwater, 35(2): 357-361.

Sass, J.H., A.H. Lachenbruch, and C.W. Mase. 1980. Analysis of Thermal Data from Drill Holes UE25a-3 and UE25a-1, Calico Hills and Yucca Mountain, Nevada Test Site, Open-File Report 80-826. U.S. Geological Survey.

Sass, J.H. and A.H. Lachenbruch. 1982. Preliminary Interpretation of Thermal Data from the Nevada Test Site, Open-File Report 82-973. U.S. Geological Survey.

Sass, J.H., A.H. Lachenbruch, W.W. Dudley, S.S. Priest, and R.J. Munroe. 1988. Temperature, Thermal Conductivity, and Heat Flow Near Yucca Mountain, Nevada: Some Tectonic and Hydrologic Implications, Open-File Report 87-649. U.S. Geological Survey.

Savard, C.S. 1994. "Groundwater Recharge in Fortymile Wash Near Yucca Mountain, Nevada, 1992-1993.” In Radioactive Waste Management, v. 4: 1805-1813. Washington, D.C.: American Nuclear Society. 
Sawyer, D.A., R.J. Fleck, M.A. Lanphere, R.G. Warren, and D.E. Broxton. 1994. "Episodic Caldera Volcanism in the Miocene Southwest Nevada Volcanic Field: Revised Stratigraphic Caldera Framework, 40Ar/39Ar Geochronology and Implications for Magnetism and Extension." In Geological Society of America, Bulletin 67(10): 1304-1318.

Schoff, S.L., and J.E. Moore. 1964. Chemistry and Movement of Ground Water; Nevada Test Site, Trace-Elements Investigations-8385. Denver, CO: U.S. Geological Survey.

Scott, R.B., T.J. Smales, R.E. Rush, and A.S. Van Denburgh. 1971. Water for Nevada, Nevada's Water Resources, Report 3. Carson City, NV: State of Nevada Department of Conservation and Natural Resources, Nevada Division of Water Resources.

Shaw, see Shaw Environmental, Inc.

Shaw Environmental, Inc. 2003. Modeling Approach/Strategy for Corrective Action Unit 97, Yucca Flat and Climax Mine, Shaw/13052-305. Las Vegas, NV.

Sheppard, S.C., K.V. Ticknor, and W.G. Evenden. 1998. "Sorption of Inorganic ${ }^{14} \mathrm{C}$ on to Calcite, Montmorillonite and Soil. In Applied Geochemistry." 13: 43-47.

Slate, J.L., M.E. Berry, P.D. Rowley, C.J. Fridrich, K.S. Fridrich, J.B. Morgan, O.D. Workman, G.L. Young,. V.S. Dixon, E.H. Williams, D.A. McKee, T.G. Ponce, W.C. Hildenbrand, S.C. Swadley, E.B. Lundstrom, R.G. Ekren, J.C. Warren, R.J. Cole, M.A. Fleck, D.A. Lanphere, S.A. Sawyer, D.J. Minor, R.J. Grunwald, C.M. Laczniak, J.C. Menges, A.S. Yount, and A.S. Jayko. 1999. Digital Geologic Map of the Nevada Test Site and Vicinity, Nye, Lincoln, and Clark Counties, Nevada, and Inyo County, California, Open-File Report 99-554-A, Scale 1:120,000. Denver, CO: U.S. Geological Survey.

Snyder, R.P. 1977. Geology of the Gold Meadows Stock, Nevada Test Site, USGS-474-179: 10 p. Denver, CO: U.S. Geological Survey.

Snow, D.T. 1968. "Hydraulic Conductivity of Fractured Metamorphic Rocks of the Front Range and Implications to the Rocky Mountain Arsenal." In Quarterly of the Colorado School of Mines, v. 63(1): 201-244.

Stewart, J.H. and J.E. Carlson. 1978. Geologic Map of Nevada, MF-930. U.S. Geological Survey.

Stober, I. 1996. "Researchers Study Conductivity of Crystalline Rock in Proposed Radioactive Waste Site.” In Eos Trans. American Geophysical Union, v. 77(10): 93-94.

Stoller-Navarro Joint Venture. 2004a. Analysis of Well ER-7-1 Testing, Yucca Flat FY 2003 Testing Program, Nevada Test Site, Nevada, Rev. 0, S-N/99205--021. Las Vegas, NV.

Stoller-Navarro Joint Venture. 2004b. Analysis of Well ER-12-2 Testing, Yucca Flat FY 2003 Testing Program, Nevada Test Site, Nevada, Rev. 0, S-N/99205--015. Las Vegas, NV. 
Stoller-Navarro Joint Venture. 2004c. Hydrologic Data for the Groundwater Flow and Contaminant Transport Model of Corrective Action Units 101 and 102: Central and Western Pahute Mesa, Nye County, Nevada, Rev. 0, S-N/99205--002; Shaw/13052-204. Las Vegas, NV.

Stoller-Navarro Joint Venture. 2004d. Letter Report: Analysis of Well ER-2-1 Hydraulic Testing, Yucca Flat FY 2003, Nevada Test Site, Nevada, DOE/NV--992. Las Vegas, NV.

Stoller-Navarro Joint Venture. 2004e Phase II Hydrologic Data for the Groundwater Flow and Contaminant Transport Model of Corrective Action Unit 98: Frenchman Flat, Nye County, Nevada, Rev. 0, S-N/99205--032. Las Vegas, NV.

Stoller-Navarro Joint Venture. 2004f. Transferability of Data Related to the Underground Test Area Project, Nevada Test Site, Nye County, Nevada, Rev. 0, S-N/99205--020. Las Vegas, NV.

Stoller-Navarro Joint Venture. 2004g. Underground Test Area Project, ER-6-1 Multi-Well Aquifer Test - Tracer Test Plan, Rev. 0, S-N/99205--013. Las Vegas, NV.

Stoller-Navarro Joint Venture. 2005a. Analysis of Hydraulic Responses from the ER-6-1 Multiple-Well Aquifer Test, Yucca Flat FY 2004 Testing Program, Nevada Test Site, Nye County, Nevada, Rev. 0, S-N/99205--051. Las Vegas, NV.

Stoller-Navarro Joint Venture. 2005b. Geochem05.mdb and a User's Guide to the Comprehensive Water Quality Database for Groundwater in the Vicinity of the Nevada Test Site, S-N/99205--059. Las Vegas, NV.

Stoller-Navarro Joint Venture. 2005c. Underground Test Area Fracture Analysis Report for Yucca Flat Wells ER-2-1, ER-6-1\#2, ER-7-1, and ER-12-2, Nevada Test Site, Nevada, Rev. 0 S-N/99205--040. Las Vegas, NV.

Stoller-Navarro Joint Venture. 2005d. Written communication. Subject: ER-6-1 Well Cluster Multiple Well Aquifer Test - Tracer Test Data Report Volumes I, II, and III, Rev. 0. Las Vegas, NV.

Stoller-Navarro Joint Venture. 2005e. Written communication. Subject: Groundwater Flow Model of Corrective Action Units 101 and 102: Central and Western Pahute Mesa, Nye County, Nevada, Rev. 0. Las Vegas, NV.

Stoller-Navarro Joint Venture. 2006a. Geochemical and Isotopic Evaluation of Groundwater Movement in Corrective Action Unit 97: Yucca Flat/Climax Mine, Nevada Test Site, Nevada, Rev. 0, S-N/99205--070. Las Vegas, NV.

Stoller-Navarro Joint Venture. 2006b. Phase II Groundwater Flow Model of Corrective Action Unit 98: Frenchman Flat, Nye County, Nevada. Rev. 0, S-N/99205--074. Las Vegas, NV. 
Thordarson, W. 1965. Perched Groundwater in Zeolitized-Bedded Tuff, Rainier Mesa and Vicinity, Nevada Test Site, Trace Elements Investigations-862. U.S. Geological Survey.

Tyler, S.W., W.A. McKay, J.W. Hess, R.L. Jacobson, and K. Taylor. 1986. Effects of Surface Collapse Structures on Infiltration and Moisture Redistribution, DOE/NV/10384-04; Publication. No. 45045. Las Vegas, NV: Desert Research Institute.

Tyler, S.W., W.A. McKay, and T.M. Milhevc. 1992. “Assessment of Soil Moisture Movement in Nuclear Subsidence Craters.” In Journal of Hydrology, v. 139: 159-181.

Tyler, S.W., J.B. Chapman, S.H. Conrad, D.P. Hammermeister, D.O. Blout, J.J. Miller, M.J. Sully, and J.M. Ginanni. 1996. "Soil-Water Flux in the Southern Great Basin, United States: Temporal and Spatial Variations Over the Last 120,000 years. "In Water Resources Research, v. 32 (6): 1481-1499.

USGS, see U.S. Geological Survey.

U.S. Department of Energy, Nevada Operations Office. 1996. Radiological Effluents Released from U.S. Continental Tests: 1961 through 1992, DOE/NV-317 (Rev-1) UC-702.

U.S. Department of Energy, Nevada Operations Office. 1997a. Nevada Test Site Environmental Reports for the Years 1964-1995. Las Vegas, NV: Nevada State Health Division, Bureau of Health Protection Services, and the U.S. Department of Energy.

U.S. Department of Energy, Nevada Operations Office. 1997b. Regional Groundwater Flow and Tritium Transport Modeling and Risk Assessment of the Underground Test Area, Nevada Test Site, Nevada, DOE/NV--477. Las Vegas, NV.

U.S. Department of Energy, Nevada Operations Office. 1998. Routine Radiological Environmental Monitoring Plan, DOE/NV/11718-244. Las Vegas, NV: Bechtel Nevada.

U.S. Department of Energy, Nevada Operations Office. 1999. Corrective Action Investigation Plan for Corrective Action Units 101 and 102: Central and Western Pahute Mesa, Nevada Test Site, Nevada, DOE/NV--516. Las Vegas, NV.

U.S. Department of Energy, Nevada Operations Office. 2000a. Corrective Action Investigation Plan for Corrective Action Unit 97: Yucca Flat/Climax Mine, Nevada Test Site, Nevada, DOE/NV--659. Las Vegas, NV.

U.S. Department of Energy, Nevada Operations Office. 2000b. United States Nuclear Tests, July 1945 through September 1992, DOE/NV--209, Rev. 15. Las Vegas, NV. 
U.S. Department of Energy, National Nuclear Security Administration, Nevada Operations Office. 2001. Addendum to Revision 1 of the Corrective Action Investigation Plan for Corrective Action Unit 98: Frenchman Flat, Nevada Test Site, Nevada, DOE/NV--478 REV. 1-ADD. Las Vegas, NV.

U.S. Department of Energy, National Nuclear Security Administration, Nevada Site Office. 2003. Underground Test Area Quality Assurance Project Plan, Nevada Test Site, Nevada, DOE/NV--341-REV. 4. Las Vegas, NV.

U.S. Department of Energy, Office of Civilian Radioactive Waste Management. 2002. Yucca Mountain Science and Engineering Report, Rev. 1, DOE/RW-0539-1. Las Vegas, NV.

U.S. Department of Energy, Office of Civilian Radioactive Waste Management. 2004. Saturated Zone Site-Scale Flow Model, MDL-NBS-HS-000011, REV. 02. Las Vegas, NV.

U.S. Geological Survey. 2001. Digital Elevation Models: U.S. Geological Survey, National Mapping Program Technical Instructions Data Users Guide 5, p. 38. Denver, CO.

U.S. Geological Survey. 2006a. "USGS/DOE Cooperative Studies in Nevada; Water-Use Wells, Nevada Test Site and Vicinity." As accessed at http://nevada.usgs.gov/dow_nv/ watertemp/temp_map.htm on May 30, 2006.

U.S. Geological Survey. 2006b. "USGS Ground-Water Data for Nevada, National Water Information System: Web Interface.” As accessed at http://nwis.waterdata.usgs.gov/nv/nwis/gw on June 5, 2006.

Vanmarcke, E. 1983. Random Fields: Analysis and Synthesis. Cambridge, MA: The MIT Press.

WRCC, see Western Regional Climate Center.

Wagoner, J.L., and W.Richardson. 1986. Stratigraphic Contacts from Drill Holes at the Nevada Test Site, UCID-20790, 39 pp. Livermore, CA: Lawrence Livermore National Laboratory.

Wahl, R.R., D.A. Sawyer, S.A. Minor, M.D. Carr, J.C. Cole, W.C. Swadley, R.J. Laczniak, R.G. Warren, K.S. Green, and C.M. Engle. 1997. Digital Geologic Map of the Nevada Test Site Area, Nevada, Open-File Report 97-140. Denver, CO: U.S. Geological Survey.

Walker, G.E., and T.E. Eakin. 1963. "Geology and Ground Water of Amargosa Desert, Nevada-California." In Ground-Water Resources - Reconnaissance Series Report 14. Denver, CO: Nevada Department of Conservation and Natural Resources and U.S. Geological Survey.

Walker D.D., and R.M. Roberts. 2003. "Flow Dimension Corresponding to Hydrogeologic Conditions." In Water Resources Research, v. 39(12): 1349-1356. 
Walvoord, M.A., M.A. Plummer, F.M. Phillips, and A.V. Wolfsberg. 2002a. "Deep Arid System Hydrodynamics 1. Equilibrium States and Response Times in Thick Desert Vadose Zones." In Water Resources Research, v. 38(12): 1308.

Walvoord, M.A., F.M. Phillips, S.W. Tyler, and P.C. Hartsough. 2002b. "Deep Arid System Hydrodynamics 2. Application to Paleohydrologic Reconstruction Using Vadose Zone Profiles from the Northern Mojave Desert." In Water Resources Research, v. 38(12): 1291.

Ware, S.D., A. Abdel-Fattah, M. Ding, P.W. Reimus, C. Sedlacek, M.J. Haga, E. Garcia, and S. Chipera. 2005. Radionuclide Sorption and Transport in Fractured Rocks of Yucca Flat, Nevada Test Site. Report LA-UR-05-9279, Los Alamos, NM: Los Alamos National Laboratory.

Warren, R.G., D.A. Sawyer, F.M. Byers, Jr., and J.C. Cole. 2003. A Petrographical, Geochemical and Geophysical Database and Framework for the Southwestern Nevada Volcanic Field, LA-UR-03-1503. Los Alamos National Laboratory: Los Alamos, NM.

Watermark Numerical Computing and Waterloo Hydrogeologic. 2004. Visual PEST User's Manual (Includes PEST2000 \& WinPEST) - Graphical Model-Independent Parameter Estimation. Ontario, Canada, and Tampa, FL.

Western Regional Climate Center. 2004. Western Regional Climate Center Historical Climate Information Website. As accessed on 22 April at http://www.wrcc.dri.edu/CLIMATEDATA. html.

White, A.F., and N.J. Chuma. 1987. "Carbon and Isotopic Mass Balance Models of Oasis Valley-Fortymile Canyon Groundwater Basin, Southern Nevada." In Water Resources Research, v. 23(4): 571-582.

Whittemore, D.O., P.A. Macfarlane, J.H. Doveton, J.J. Butler, Jr., T-M. Chu, R. Bassler, M. Smith, J. Mitchell, and A. Wade. 1993. The Dakota Aquifer Program Annual Report, FY 1992, Open-File Report 93-1. Kansas Geological Survey.

Williams, C.F., and T.N. Narasimhan. 1989. "Hydrogeologic Constraints on Heat Flow along the San Andreas Fault: A Testing of Hypotheses." In Earth and Planetary Sciences Letters, v. 92: 131-143. Amsterdam: Elsevier Science Publishers B.V.

Williamson, A.K., and H.F. Grubb. 2001. Ground-Water Flow in the Gulf Coast Aquifer Systems, South-Central United States, Professional Paper 1416-F. Denver, CO: U.S. Geological Survey.

Wilson, A.M. 2003. "The Occurrence and Chemical Implications of Geothermal Convection of Seawater in Continental Shelves." In Geophysical Research Letters, v. 30(21): 2127, doi:10.1029/2003GL018499. Washington, D.C.: American Geophysical Union.

Wilson, G.V., D.M. Ely, S.L. Hokett, and D.R. Gillespie. 2000. "Recharge from a Subsidence Crater at the Nevada Test Site.” In Soil Science Society of America Journal, v. 64: 1570-1581. 
Wilson, A.M., W. Sanford, F. Whitaker, and P. Smart. 2001. "Spatial Patterns of Diagenesis during Geothermal Circulation in Carbonate Platforms." In American Journal of Science, v. 301: 727-752.

Winograd, I.J. and W. Thordarson. 1975. Hydrogeologic and Hydrochemical Framework, South-Central Great Basin, Nevada-California, with Special Reference to the Nevada Test Site, Professional Paper 712-C. Washington, D.C.: U.S. Geological Survey.

Winograd, I.J. and F.J. Pearson. 1976. "Major Carbon 14 Anomaly in a Regional Carbonate Aquifer: Possible Evidence for MegaScale Channeling, South Central Great Basin." In Water Resources Research, v. 12(6): 1125 - 1142.

Winograd, I.J. and G.C. Doty. 1980. Paleohydrology of the southern Great Basin, with special reference to water table fluctuations beneath the Nevada Test Site during the late Pleistocene, OFR 80-569. Reston, Virginia: U.S. Geological Survey.

Workman, J.B., C. Menges, W.R. Page, E.M. Taylor, E.B. Ekren, P.P. Rowley, G.L. Dixon, R.A. Thompson, and L.A. Wright. 2002. Geologic Map of the Death Valley Groundwater Model Area, Nevada and California, Miscellaneous Map MF-2381-A, Scale 1:250,000. U.S. Geological Survey.

Wright, J.A., and K.E. Louden. 1989. CRC Handbook of Sea Floor Heat Flow, 197 p. Boca Raton, FL: CRC Press, Inc.

Zlotnik, V.A., B.R. Zurburchen, T. Ptak, and G. Teutsch. 2000. "Support Volume and Scale Effect in Hydraulic Conductivity: Experimental Aspects." In Theory, Modeling, and Field Investigation in Hydrogeology: A Special Volume in Honor of Shlomo P. Neuman's 60th Birthday Special Paper, v. 348: 215-231. Boulder, CO: Geological Society of America, Inc.

Zyvoloski, G.A., B.A. Robinson, Z.V. Dash, and L.L. Trease. 1997a. Summary of Models and Methods for the FEHM Application - A Finite-Element Heat- and Mass-Transfer Code, LA-13307-MS. Los Alamos, NM: Los Alamos National Laboratory.

Zyvoloski, G.A., B.A. Robinson, Z.V. Dash, and I.L. Trease. 1997b. User's Manual for the FEHM Application - A Finite-Element Heat- and Mass-Transfer Code, LA-13306-M. Los Alamos, NM: Los Alamos National Laboratory. 
Appendix A

Nuclear Tests in the Yucca Flat/Climax Mine Corrective Action Unit 


\section{A.1.0 nuclear Tests in the Yucca flat/Climax Mine CORRECTIVE ACTION UNIT}

A total of 747 underground nuclear detonations were conducted in shafts and tunnels in the Yucca Flat/Climax Mine CAU. This included 744 detonations in Yucca Flat proper and three detonations in the Climax Mine tunnel complex (DOE/NV, 2000). Underground nuclear tests are designated (either individually or as groups) as CASs in the FFACO (1996). In some cases, multiple detonations were conducted simultaneously in the same emplacement hole and therefore comprise a single CAS (FFACO, 1996). Plate A.1-1 shows the locations of the CASs.

In addition to the UGTA CASs, the locations of three cratering nuclear tests (U-10h, U-10-Ess, and U-10 Uncle), one cratering non-nuclear test (U-10 Scooter), and the UGTA wells are shown in Plate A.1-1. The cratering tests were located in the northeastern area of the Yucca Flat/Climax Mine CAU. A variety of test-related surface effects including collapse craters and associated radial and circumferential surface fractures, along with normal faults within the area (e.g., Yucca, Topgallant, and Carpetbag faults) are also shown (Plate A.1-1).

Unclassified information related to the underground nuclear tests conducted within the Yucca Flat/Climax Mine CAU is compiled primarily in two reports, United States Nuclear Tests, July 1945 through September 1992 (DOE/NV, 2000) and Shaft and Tunnel Nuclear Detonations at the Nevada Test Site: Development of a Primary Database for the Estimation of Potential Interactions with the Regional Groundwater System (DOE/NV, 1997). These data, including the name and date of each detonation, name and location of the emplacement holes, announced yields, depths of burial, estimated depths to the water table, and the HSU associated with the working point, are summarized in Table A.1-1.

The term "yield" refers to the total effective energy released in a nuclear explosion and is usually expressed in terms of equivalent tonnage of trinitrotoluene required to produce the same energy release in an explosion. Announced yield ranges are reported in DOE/NV (2000); the specific yields 
for many tests remain classified. The announced yields for some Yucca Flat tests were termed low, intermediate, or slight (Table A.1-1). Between 1945 and 1963, a less-than-20-kt yield was defined as "low," while a 20-to-200-kt-yield range was referred to as "intermediate." In a few cases, the term "slight" was used without amplification (DOE/NV, 2000). The maximum upper limit of the announced yield range for Yucca Flat is $500 \mathrm{kt}$, whereas that of the Climax Mine tests is $62 \mathrm{kt}$. A zero yield was reported for three tests, SAN JUAN (Operation Hardtack II), COURSER (Operation Whetstone), and TRANSOM (Operation Cresset). The TRANSOM nuclear device did not detonate and was later destroyed, as planned, by the HEARTS detonation (Operation Quicksilver) approximately 16 months later (DOE/NV, 2000).

Nuclear devices were emplaced in one of four types of geologic medium in Yucca Flat and Climax Mine: alluvial deposits, Tertiary volcanics, carbonate rocks, or intrusives. The location of their emplacement is called the working point and the vertical depth to the device primary center line is referred to as the depth of burial (Table A.1-1). An estimate of the depth to the water table is also provided in Table A.1-1. These estimates were determined by interpolating regional and local (Yucca Flat and Pahute Mesa) water table surfaces and were selected as being the most representative estimate of the regional water table based on the data available at the time (DOE/NV, 1997). Never-the-less, these data represent the only published compilation of water table data for the emplacement holes within the Yucca Flat/Climax Mine CAU. A detonation is considered as potentially interacting with the regional groundwater system if the elevation of the working point is $100 \mathrm{~m}$ above the water table or deeper (DOE/NV, 1997). Based on the data in Table A.1-1, less than 25 percent of the detonations (170) are considered to have impacted the water table. The HSUs associated with each working point are also presented in Table A.1-1. Hydrostratigraphic units are described in Section 5.0 and BN (2006). 
Table A.1-1

Shaft and Tunnel Nuclear Detonations in the Yucca Flat/Climax Mine Corrective Action Unit (Page 1 of 24)

\begin{tabular}{|c|c|c|c|c|c|c|c|c|c|c|c|}
\hline Detonation Name & $\begin{array}{c}\text { CAS } \\
\text { Number }\end{array}$ & $\begin{array}{c}\text { Date } \\
\text { Expended }\end{array}$ & $\begin{array}{l}\text { Emplacement } \\
\text { Hole Name }\end{array}$ & $\begin{array}{c}\text { UTM } \\
\text { Easting }\end{array}$ & $\begin{array}{c}\text { UTM } \\
\text { Northing }\end{array}$ & $\begin{array}{c}\text { aLand } \\
\text { Surface } \\
\text { Elevation } \\
\text { (m amsl) }\end{array}$ & $\begin{array}{r}\text { Announced } \\
\text { Yield(kt) }\end{array}$ & $\begin{array}{l}\text { Depth } \\
\text { (m) }\end{array}$ & $\begin{array}{l}\text { Estimated } \\
\text { Depth to } \\
\text { Water (m) }\end{array}$ & $\begin{array}{l}\text { Depth } \\
\text { of } \\
\text { Burial } \\
\text { (m) }\end{array}$ & $\begin{array}{c}\text { Working } \\
\text { Point } \\
\text { HSU }\end{array}$ \\
\hline AARDVARK & $03-57-013$ & $5 / 12 / 1962$ & U-3ams & 586202.6 & 4102340.7 & $1,240.8$ & 40 & 2494 & 503 & 2434 & LTCU \\
\hline ABEYTAS & $03-57-162$ & $11 / 5 / 1970$ & $U-3 g x$ & 587894.0 & 4098394.1 & $1,215.2$ & 20 to 200 & 407 & 481 & 393 & TM-LVTA \\
\hline ABILENE & $03-57-270$ & $4 / 7 / 1988$ & U-3mn & 585020.7 & 4096555.6 & $1,214.6$ & $<20$ & 290 & 481 & 244 & TM-WTA \\
\hline $\mathrm{ABO}$ & $03-57-263$ & $10 / 30 / 1985$ & $\mathrm{U}-3 \mathrm{mc}$ & 585707.0 & 4100717.6 & $1,229.0$ & $<20$ & 213 & 495 & 198 & AA \\
\hline ABSINTHE & $03-57-110$ & $5 / 26 / 1967$ & U-3ep & 587232.8 & 4100113.5 & $1,225.9$ & $<20$ & 244 & 492 & 119 & AA \\
\hline ACE & $02-57-145$ & $6 / 11 / 1964$ & $U-2 n$ & 582057.1 & 4111553.6 & $1,326.8$ & 3 & 271 & 579 & 263 & AA \\
\hline ACUSHI & $03-57-033$ & $2 / 8 / 1963$ & U-3bg & 587049.5 & 4100234.7 & $1,225.9$ & Low & 329 & 492 & 261 & AA \\
\hline ADZE & $03-57-137$ & $5 / 28 / 1968$ & U-3fw & 589379.6 & 4096098.6 & $1,215.2$ & $<20$ & 253 & 475 & 240 & TSA \\
\hline AGILE & $02-57-151$ & $2 / 23 / 1967$ & $\mathrm{U}-2 \mathrm{v}$ & 582934.9 & 4109148.8 & $1,297.2$ & 20 to 200 & 771 & 543 & 733 & TM-LVTA \\
\hline AGOUTI & $03-57-015$ & $1 / 18 / 1962$ & U-3ao & 585868.6 & 4100346.4 & $1,227.4$ & 6.4 & 269 & 494 & 261 & AA \\
\hline AGRINI & $02-57-122$ & $3 / 31 / 1984$ & U-2ev & 581343.1 & 4111306.7 & $1,330.8$ & $<20$ & 429 & 584 & 320 & AA \\
\hline AHTANUM & $02-57-143$ & 9/13/1963 & $\mathrm{U}-2 \mathrm{I}$ & 581628.7 & 4113187.9 & $1,346.9$ & Low & 233 & 604 & 226 & AA \\
\hline AJAX & $09-57-035$ & 11/11/1966 & U-9aL & 584394.3 & 4110007.1 & $1,280.8$ & $<20$ & 245 & 537 & 239 & AA \\
\hline AJO & 03-57-144 & $1 / 30 / 1970$ & U-3gd & 585851.5 & 4098524.0 & $1,218.6$ & $<20$ & 320 & 486 & 304 & AA \\
\hline AKAVI & $02-57-119$ & $12 / 3 / 1981$ & U-2es & 582515.1 & 4111539.4 & $1,320.4$ & 20 to 150 & 518 & 576 & 494 & TM-LVTA \\
\hline AKBAR & $10-57-028$ & $11 / 9 / 1972$ & U-10ax & 585846.5 & 4113082.3 & $1,321.9$ & $<20$ & 305 & 588 & 267 & TM-LVTA \\
\hline ALEMAN & $03-57-240$ & 9/11/1986 & U-3kz & 584481.3 & 4102754.6 & $1,245.1$ & $<20$ & 686 & 475 & 503 & TM-LVTA \\
\hline ALGODONES & $03-57-208$ & $8 / 18 / 1971$ & U-3jn & 585682.5 & 4101447.6 & $1,233.2$ & 20 to 200 & 549 & 497 & 528 & TM-UVTA \\
\hline ALIGOTE & $07-57-028$ & $5 / 29 / 1981$ & U-7bg & 588499.6 & 4106431.8 & $1,337.5$ & $<20$ & 396 & 606 & 320 & LTCU \\
\hline ALIMENT & $03-57-150$ & $5 / 15 / 1969$ & U-3gj & 590293.1 & 4096467.7 & $1,234.1$ & $<20$ & 254 & 503 & 241 & OSBCU \\
\hline ALLEGHENY & $09-57-113$ & 9/29/1962 & $U-9 x$ & 585931.2 & 4108050.1 & $1,297.8$ & Low & 264 & 564 & 211 & TM-WTA \\
\hline ALPACA & $02-57-001$ & $2 / 12 / 1965$ & $\mathrm{U}-2 \mathrm{a}$ & 581991.1 & 4113320.2 & $1,341.7$ & 0.33 & 232 & 604 & 225 & $\mathrm{AA}$ \\
\hline ALUMROOT & $09-57-081$ & $2 / 14 / 1973$ & U-9cj & 584359.2 & 4111408.7 & $1,291.4$ & $<20$ & 206 & 546 & 183 & AA \\
\hline ALVA & $02-57-142$ & $8 / 19 / 1964$ & $\mathrm{U}-2 \mathrm{j}$ & 581415.3 & 4112702.6 & $1,347.2$ & 4.4 & 168 & 602 & 166 & AA \\
\hline ALVISO & 02-57-099 & $6 / 11 / 1975$ & U-2du & 582300.9 & 4107470.5 & $1,287.8$ & $<20$ & 221 & 523 & 183 & AA \\
\hline ANACOSTIA & 09-57-098 & $11 / 27 / 1962$ & U-9i & 586258.2 & 4108733.8 & $1,300.9$ & 5.2 & 296 & 569 & 227 & TM-LVTA \\
\hline ANCHOVY & $03-57-042$ & $11 / 14 / 1963$ & U-3bq & 587295.9 & 4099504.2 & $1,221.3$ & Low & 272 & 488 & 260 & AA \\
\hline ANGUS & $03-57-201$ & $4 / 25 / 1973$ & U-3jg & 586440.9 & 4095646.4 & $1,207.6$ & $<20$ & 503 & 472 & 453 & $\mathrm{AA}$ \\
\hline APODACA & $03-57-158$ & $7 / 21 / 1971$ & U-3gs & 589680.9 & 4096739.6 & $1,221.9$ & $<20$ & 253 & 487 & 241 & LTCU \\
\hline APSHAPA & $09-57-031$ & 6/6/1963 & U-9ai & 585282.1 & 4108928.5 & $1,281.4$ & Low & 96 & 544 & 89 & AA \\
\hline ARABIS-BLUE & 09-57-018 & $3 / 6 / 1970$ & U-9 ITS Z-26 & 586037.8 & 4110591.9 & $1,303.0$ & $<20$ & 116 & 571 & 101 & TM-LVTA \\
\hline
\end{tabular}


Table A.1-1

Shaft and Tunnel Nuclear Detonations in the Yucca Flat/Climax Mine Corrective Action Unit

(Page 2 of 24)

\begin{tabular}{|c|c|c|c|c|c|c|c|c|c|c|c|}
\hline Detonation Name & $\begin{array}{c}\text { CAS } \\
\text { Number }\end{array}$ & $\begin{array}{c}\text { Date } \\
\text { Expended }\end{array}$ & $\begin{array}{c}\text { Emplacement } \\
\text { Hole Name }\end{array}$ & $\begin{array}{c}\text { UTM } \\
\text { Easting }\end{array}$ & $\begin{array}{c}\text { UTM } \\
\text { Northing }\end{array}$ & $\begin{array}{c}\text { aLand } \\
\text { Surface } \\
\text { Elevation } \\
\text { (m amsl) }\end{array}$ & $\begin{array}{l}\text { Announced } \\
\text { Yield(kt) }\end{array}$ & $\begin{array}{l}\text { Depth } \\
\text { (m) }\end{array}$ & $\begin{array}{c}\text { Estimated } \\
\text { Depth to } \\
\text { Water (m) }\end{array}$ & $\begin{array}{l}\text { Depth } \\
\text { of } \\
\text { Burial } \\
\text { (m) }\end{array}$ & $\begin{array}{c}\text { Working } \\
\text { Point } \\
\text { HSU }\end{array}$ \\
\hline ARABIS-GREEN & $09-57-011$ & $3 / 6 / 1970$ & U-9 ITS X-28 & 585793.4 & 4110834.8 & $1,297.2$ & $<<20$ & 264 & 565 & 259 & TM-LVTA \\
\hline ARABIS-RED & $09-57-003$ & $3 / 6 / 1970$ & U-9 iv-26 & 585550.2 & 4110590.2 & $1,291.7$ & $<20$ & 265 & 558 & 250 & TM-LVTA \\
\hline ARIKAREE & $09-57-108$ & $5 / 10 / 1962$ & U-9r & 584540.2 & 4109246.4 & $1,281.4$ & Low & 181 & 538 & 166 & $A A$ \\
\hline ARMADA & 09-57-089 & $4 / 22 / 1983$ & U-9cs & 586856.5 & 4107486.5 & $1,322.5$ & $<20$ & 366 & 590 & 265 & LTCU \\
\hline ARMADILLO & $03-57-018$ & 2/9/1962 & U-3ar & 585464.2 & 4099935.1 & $1,225.0$ & 7.1 & 309 & 492 & 240 & AA \\
\hline ARNICA-VIOLET & $02-57-081$ & $6 / 26 / 1970$ & U-2dd-3 & 581366.4 & 4108055.4 & $1,298.8$ & $<20$ & 279 & 558 & 264 & $\mathrm{AA}$ \\
\hline ARNICA-YELLOW & $02-57-080$ & $6 / 26 / 1970$ & U-2dd-2 & 581193.9 & 4107698.2 & $1,296.9$ & $<20$ & 325 & 554 & 309 & TM-LVTA \\
\hline ARSENATE & $09-57-080$ & 11/9/1972 & U-9ci & 585965.9 & 4108579.5 & $1,295.1$ & $<20$ & 259 & 562 & 250 & TM-LVTA \\
\hline ARTESIA & $07-57-060$ & $12 / 16 / 1970$ & $U-7 x$ & 588155.6 & 4106241.4 & $1,328.9$ & 20 to 200 & 533 & 595 & 485 & LTCU \\
\hline ASCO & $10-57-033$ & $4 / 25 / 1978$ & U-10bc & 585712.3 & 4112251.5 & $1,312.2$ & $<20$ & 292 & 579 & 183 & TM-LVTA \\
\hline ASIAGO & $02-57-016$ & $12 / 21 / 1976$ & U-2ar & 582842.2 & 4108821.8 & $1,292.0$ & $<20$ & 701 & 545 & 331 & AA \\
\hline ATARQUE & $03-57-188$ & $7 / 25 / 1972$ & U-3ht & 587626.0 & 4096508.4 & $1,209.1$ & $<20$ & 309 & 474 & 294 & AA \\
\hline ATRISCO & $07-57-035$ & $8 / 5 / 1982$ & U-7bp & 588299.3 & 4104471.7 & $1,294.8$ & 138 & 686 & 538 & 640 & OSBCU \\
\hline AUGER & $03-57-138$ & 11/15/1968 & $U-3 f x$ & 588938.2 & 4100424.2 & $1,248.8$ & $<20$ & 253 & 507 & 241 & TM-LVTA \\
\hline AUK & $07-57-024$ & $10 / 2 / 1964$ & $U-7 b$ & 588134.1 & 4103773.3 & $1,281.1$ & $<20$ & 471 & 529 & 452 & LTCU \\
\hline AUSTIN & $06-57-003$ & $6 / 21 / 1990$ & $\mathrm{U}-6 \mathrm{e}$ & 588587.7 & 4094337.5 & $1,201.5$ & $<20$ & 457 & 458 & 351 & TM-LVTA \\
\hline AVENS-ALKERMES & $09-57-002$ & $12 / 16 / 1970$ & U-9 ITS U-24 & 585429.5 & 4110346.3 & $1,288.4$ & $<20$ & 326 & 554 & 306 & TM-LVTA \\
\hline AVENS-ANDORRE & $09-57-001$ & $12 / 16 / 1970$ & U-9 ITS T-28 & 585305.9 & 4110833.1 & $1,291.1$ & $<20$ & 395 & 555 & 379 & LTCU \\
\hline AVENS-ASAMLTE & $09-57-006$ & $12 / 16 / 1970$ & U-9 ITS W-21 & 585674.2 & 4109981.4 & $1,290.5$ & $<20$ & 319 & 557 & 306 & LTCU \\
\hline AVENS-CREAM & $09-57-012$ & $12 / 16 / 1970$ & U-9 ITS X-29 & 585793.3 & 4110956.4 & $1,298.4$ & $<20$ & 310 & 566 & 294 & LTCU \\
\hline AZUL & $02-57-113$ & $12 / 14 / 1979$ & U-2em & 583216.9 & 4110319.0 & $1,302.4$ & $<20$ & 221 & 556 & 205 & AA \\
\hline BACCARAT & $07-57-022$ & $1 / 24 / 1979$ & U-7ax & 587818.7 & 4106819.5 & $1,337.8$ & $<20$ & 381 & 606 & 326 & OSBCU \\
\hline BACKGAMMON & $03-57-202$ & $11 / 29 / 1979$ & U-3jh & 586841.3 & 4094444.2 & $1,203.4$ & $<20$ & 434 & 466 & 229 & AA \\
\hline BACKSWING & $09-57-043$ & $5 / 14 / 1964$ & U-9aw & 585382.4 & 4108119.5 & $1,284.1$ & $<20$ & 235 & 547 & 160 & $\mathrm{AA}$ \\
\hline BALTIC & 09-57-099 & $8 / 6 / 1971$ & U-9 ITS S-25 & 585185.3 & 4110467.0 & $1,286.9$ & $<20$ & 504 & 547 & 411 & TM-LVTA \\
\hline BANDICOOT & $03-57-035$ & 10/19/1962 & U-3bj & 587052.7 & 4099503.4 & $1,221.6$ & 12.5 & 247 & 489 & 241 & AA \\
\hline BANEBERRY & $08-57-010$ & $12 / 18 / 1970$ & $\mathrm{U}-8 \mathrm{~d}$ & 580000.4 & 4114255.1 & $1,394.2$ & 10 & 299 & 649 & 278 & TM-LVTA \\
\hline BANON & $02-57-103$ & $8 / 26 / 1976$ & $\mathrm{U}-2 \mathrm{dz}$ & 581549.5 & 4108930.9 & $1,302.4$ & 20 to 150 & 579 & 544 & 536 & $\mathrm{AA}$ \\
\hline BARBEL & 03-57-049 & $10 / 16 / 1964$ & U-3bx & 587539.6 & 4099505.1 & $1,221.3$ & $<20$ & 282 & 488 & 259 & AA \\
\hline BARRACUDA & 03-57-061 & $12 / 4 / 1963$ & $\mathrm{U}-3 \mathrm{cr}$ & 587842.7 & 4099993.7 & $1,228.6$ & Low & 282 & 495 & 263 & $\mathrm{AA}$ \\
\hline BARRANCA & $03-57-168$ & $8 / 4 / 1971$ & U-3he & 587209.7 & 4098010.8 & $1,214.3$ & $<20$ & 290 & 481 & 271 & AA \\
\hline BARSAC & $03-57-143$ & $3 / 20 / 1969$ & $\mathrm{U}-3 \mathrm{gc}$ & 586266.6 & 4097550.4 & $1,213.7$ & $<20$ & 314 & 480 & 304 & AA \\
\hline
\end{tabular}


Table A.1-1

Shaft and Tunnel Nuclear Detonations in the Yucca Flat/Climax Mine Corrective Action Unit

(Page 3 of 24)

\begin{tabular}{|c|c|c|c|c|c|c|c|c|c|c|c|}
\hline Detonation Name & $\begin{array}{c}\text { CAS } \\
\text { Number }\end{array}$ & $\begin{array}{c}\text { Date } \\
\text { Expended }\end{array}$ & $\begin{array}{l}\text { Emplacement } \\
\text { Hole Name }\end{array}$ & $\begin{array}{c}\text { UTM } \\
\text { Easting }\end{array}$ & $\begin{array}{c}\text { UTM } \\
\text { Northing }\end{array}$ & $\begin{array}{c}\text { aLand } \\
\text { Surface } \\
\text { Elevation } \\
\text { (m amsl) }\end{array}$ & $\begin{array}{r}\text { Announced } \\
\text { Yield(kt) }\end{array}$ & $\begin{array}{l}\text { Depth } \\
\text { (m) }\end{array}$ & $\begin{array}{l}\text { Estimated } \\
\text { Depth to } \\
\text { Water (m) }\end{array}$ & $\begin{array}{l}\text { Depth } \\
\text { of } \\
\text { Burial } \\
\text { (m) }\end{array}$ & $\begin{array}{c}\text { Working } \\
\text { Point } \\
\text { HSU }\end{array}$ \\
\hline BASEBALL & $07-57-025$ & $1 / 15 / 1981$ & U-7ba & 584900.6 & 4104756.9 & $1,258.5$ & 20 to 150 & 610 & 458 & 564 & LTCU \\
\hline BAY LEAF & $03-57-156$ & $12 / 12 / 1968$ & $U-3 g q$ & 586238.9 & 4100326.6 & $1,226.2$ & $<20$ & 139 & 493 & 130 & AA \\
\hline BEEBALM & 03-57-131 & $5 / 1 / 1970$ & U-3fn & 586404.5 & 4101679.9 & $1,235.7$ & $<20$ & 411 & 503 & 390 & TM-WTA \\
\hline BELEN & $03-57-043$ & $2 / 4 / 1970$ & $\mathrm{U}-3 \mathrm{br}$ & 585461.5 & 4101204.6 & $1,232.9$ & 20 to 200 & 438 & 497 & 421 & AA \\
\hline BELLOW & $04-57-004$ & $5 / 16 / 1984$ & U-4ac & 580586.7 & 4105316.2 & $1,292.7$ & $<20$ & 244 & 418 & 207 & TM-LVTA \\
\hline BERNAL & $03-57-218$ & $11 / 28 / 1973$ & U-3jy & 586788.9 & 4096333.3 & $1,209.8$ & $<20$ & 308 & 475 & 283 & AA \\
\hline BERNALILLO & $03-57-272$ & 9/17/1958 & $U-3 n$ & 585974.7 & 4100603.9 & $1,227.7$ & 0.015 & 160 & 495 & 140 & AA \\
\hline BEVEL & 03-57-135 & $4 / 4 / 1968$ & U-3fu & 587062.4 & 4100920.4 & $1,232.3$ & $<20$ & 253 & 498 & 241 & AA \\
\hline BIGGIN & $09-57-072$ & $1 / 30 / 1969$ & U-9bz & 585248.2 & 4109887.9 & $1,283.8$ & $<20$ & 251 & 545 & 244 & TM-LVTA \\
\hline BILBY & $03-57-058$ & 9/13/1963 & U-3cn & 586983.0 & 4101819.0 & $1,241.8$ & 249 & 785 & 509 & 714 & OSBCU \\
\hline BILGE & $03-57-221$ & $2 / 19 / 1975$ & U-3kc & 586791.4 & 4095358.2 & $1,206.1$ & $<20$ & 339 & 470 & 319 & $\mathrm{AA}$ \\
\hline BILLET & 07-57-015 & $7 / 27 / 1976$ & U-7an & 584996.6 & 4103457.6 & $1,249.7$ & 20 to 150 & 963 & 487 & 636 & LTCU \\
\hline BIT-A & 03-57-159 & $10 / 31 / 1968$ & U-3gt & 586304.5 & 4100326.9 & $1,225.9$ & $<20$ & 158 & 493 & 148 & $\mathrm{AA}$ \\
\hline BIT-B & 03-57-159 & $10 / 31 / 1968$ & U-3gt & 586304.5 & 4100326.9 & $1,225.9$ & $<20$ & 158 & 493 & 118 & AA \\
\hline BITTERLING & $03-57-063$ & $6 / 12 / 1964$ & U-3cu & 587844.3 & 4099445.5 & $1,231.1$ & $<20$ & 320 & 497 & 193 & AA \\
\hline BLACK & $09-57-106$ & $4 / 27 / 1962$ & $U-9 p$ & 585485.6 & 4108243.2 & $1,285.3$ & Low & 224 & 549 & 218 & AA \\
\hline BLENTON & $07-57-053$ & $4 / 30 / 1969$ & $U-7 p$ & 587645.2 & 4104167.5 & $1,281.7$ & 20 to 200 & 579 & 536 & 558 & LTCU \\
\hline BOBAC & $03-57-037$ & $8 / 24 / 1962$ & U-3bl & 586805.8 & 4100233.5 & $1,225.6$ & Low & 211 & 492 & 206 & AA \\
\hline BOBSTAY & $03-57-196$ & $10 / 26 / 1977$ & U-3jb & 587484.4 & 4095964.3 & $1,207.3$ & $<20$ & 415 & 471 & 381 & TM-WTA \\
\hline BOGEY & $09-57-041$ & $4 / 17 / 1964$ & U-9au & 585828.9 & 4108360.5 & $1,291.7$ & $<20$ & 131 & 557 & 119 & $\mathrm{AA}$ \\
\hline BONARDA & $03-57-161$ & $9 / 25 / 1980$ & U-3gv & 584638.4 & 4101323.3 & $1,236.6$ & 20 to 150 & 450 & 490 & 381 & TM-WTA \\
\hline BONEFISH & $03-57-045$ & $2 / 18 / 1964$ & U-3bt & 585947.4 & 4101693.8 & $1,234.4$ & $<20$ & 483 & 498 & 301 & AA \\
\hline BOOMER & $03-57-001$ & 10/1/1961 & U-3aa & 585854.2 & 4100467.6 & $1,227.7$ & Low & 164 & 495 & 101 & AA \\
\hline BORATE & $02-57-137$ & $10 / 23 / 1987$ & $\mathrm{U}-2 \mathrm{ge}$ & 581824.2 & 4110807.4 & $1,321.3$ & 20 to 150 & 585 & 573 & 543 & AA \\
\hline BORDEAUX & $03-57-086$ & $8 / 18 / 1967$ & U-3dr & 585721.7 & 4096451.4 & $1,210.1$ & $<20$ & 344 & 477 & 332 & AA \\
\hline BORREGO & $07-57-036$ & 9/29/1982 & U-7br & 584883.7 & 4105224.3 & $1,261.0$ & $<150$ & 610 & 493 & 564 & LTCU \\
\hline BOURBON & 07-57-051 & $1 / 20 / 1967$ & U-7n & 588521.7 & 4106212.5 & $1,333.2$ & 20 to 200 & 578 & 601 & 560 & LCA \\
\hline BOUSCHET & $03-57-241$ & $5 / 7 / 1982$ & U-3la & 584857.3 & 4102756.2 & $1,244.5$ & 20 to 150 & 686 & 479 & 564 & LTCU \\
\hline BOWIE & $03-57-268$ & 4/6/1990 & U-3mk & 589600.8 & 4102651.0 & $1,297.5$ & $<20$ & 381 & 568 & 213 & TM-LVTA \\
\hline BOWL-1 & $02-57-041$ & $6 / 26 / 1969$ & U-2bo-1 & 581808.8 & 4113091.3 & $1,343.3$ & $<20$ & 206 & 603 & 198 & $\mathrm{AA}$ \\
\hline BOWL-2 & $02-57-154$ & $6 / 26 / 1969$ & U-2bo-2 & 581763.8 & 4112901.9 & $1,341.7$ & $<20$ & 236 & 600 & 229 & AA \\
\hline
\end{tabular}


Table A.1-1

Shaft and Tunnel Nuclear Detonations in the Yucca Flat/Climax Mine Corrective Action Unit (Page 4 of 24)

\begin{tabular}{|c|c|c|c|c|c|c|c|c|c|c|c|}
\hline Detonation Name & $\begin{array}{c}\text { CAS } \\
\text { Number }\end{array}$ & $\begin{array}{c}\text { Date } \\
\text { Expended }\end{array}$ & $\begin{array}{c}\text { Emplacement } \\
\text { Hole Name }\end{array}$ & $\begin{array}{c}\text { UTM } \\
\text { Easting }\end{array}$ & $\begin{array}{c}\text { UTM } \\
\text { Northing }\end{array}$ & $\begin{array}{c}\text { aLand } \\
\text { Surface } \\
\text { Elevation } \\
\text { (m amsl) }\end{array}$ & $\begin{array}{r}\text { Announced } \\
\text { Yield(kt) }\end{array}$ & $\begin{array}{l}\text { Depth } \\
\text { (m) }\end{array}$ & $\begin{array}{l}\text { Estimated } \\
\text { Depth to } \\
\text { Water (m) }\end{array}$ & $\begin{array}{l}\text { Depth } \\
\text { of } \\
\text { Burial } \\
\text { (m) }\end{array}$ & $\begin{array}{c}\text { Working } \\
\text { Point } \\
\text { HSU }\end{array}$ \\
\hline BRACKEN & $10-57-022$ & $7 / 9 / 1971$ & U-10aq & 585881.2 & 4113350.0 & $1,323.4$ & $<20$ & 336 & 585 & 305 & LTCU \\
\hline BRANCO & $02-57-123$ & 9/21/1983 & U-2ew & 583900.0 & 4108548.8 & $1,282.9$ & $<20$ & 457 & 520 & 293 & $\mathrm{AA}$ \\
\hline BRANCO-HERKIMER & $02-57-123$ & 9/21/1983 & U-2ew & 583900.0 & 4108548.8 & $1,282.9$ & $<20$ & 457 & 520 & 427 & TM-WTA \\
\hline BRAZOS & $09-57-092$ & $3 / 8 / 1962$ & U-9d & 584494.4 & 4108644.4 & $1,280.5$ & 8.4 & 340 & 535 & 256 & $\mathrm{AA}$ \\
\hline BRETON & 04-57-013 & 9/13/1984 & U-4ar & 582552.3 & 4104689.0 & $1,264.6$ & 20 to 150 & 503 & 503 & 483 & TM-LVTA \\
\hline BRIE & $10-57-042$ & $6 / 18 / 1987$ & $\mathrm{U}-10 \mathrm{cc}$ & 585645.9 & 4116576.5 & $1,345.1$ & $<20$ & 230 & 326 & 203 & LTCU \\
\hline BRISTOL & 04-57-017 & $11 / 26 / 1991$ & U-4av & 582680.7 & 4105777.6 & $1,273.1$ & $<20$ & 518 & 482 & 457 & $\overline{L T C U}$ \\
\hline BRONZE & $07-57-044$ & $7 / 23 / 1965$ & $U-7 f$ & 585932.4 & 4105959.3 & $1,284.1$ & 20 to 200 & 576 & 548 & 531 & LTCU \\
\hline BRUSH & $03-57-111$ & $1 / 24 / 1968$ & U-3eq & 587690.7 & 4099871.0 & $1,225.6$ & $<20$ & 221 & 492 & 118 & $\mathrm{AA}$ \\
\hline BUFF & $03-57-077$ & $12 / 16 / 1965$ & U-3dh & 586307.9 & 4103157.5 & $1,250.3$ & 20 to 200 & 507 & 515 & 500 & LTCU \\
\hline BULKHEAD & $07-57-014$ & $4 / 27 / 1977$ & U-7am & 586391.0 & 4105626.1 & $1,286.0$ & 20 to 150 & 625 & 551 & 594 & OSBCU \\
\hline BULLFROG & 04-57-016 & $8 / 30 / 1988$ & U-4au & 582789.3 & 4104607.5 & $1,263.4$ & $<150$ & 533 & 500 & 489 & TM-WTA \\
\hline BUNKER & $09-57-050$ & $2 / 13 / 1964$ & U-9bb & 585952.6 & 4109752.0 & $1,296.6$ & $<20$ & 237 & 564 & 227 & TM-LVTA \\
\hline BURZET & $04-57-007$ & 8/3/1979 & U-4ai & 582669.8 & 4104386.5 & $1,262.5$ & 20 to 150 & 489 & 501 & 450 & $\mathrm{AA}$ \\
\hline BYE & $10-57-048$ & $7 / 16 / 1964$ & $\mathrm{U}-10 \mathrm{i}$ & 584741.3 & 4115308.7 & $1,321.3$ & 20 to 200 & 532 & 566 & 391 & LTCU \\
\hline CABOC & $02-57-067$ & $12 / 16 / 1981$ & U-2cp & 577928.4 & 4107733.7 & $1,374.6$ & $<20$ & 381 & 522 & 335 & TM-LVTA \\
\hline CABRESTO & $07-57-046$ & $5 / 24 / 1973$ & U-7h & 586153.4 & 4103766.4 & $1,255.2$ & $<20$ & 470 & 519 & 198 & AA \\
\hline CABRILLO & $02-57-096$ & $3 / 7 / 1975$ & U-2dr & 581340.0 & 4109927.8 & $1,314.6$ & 20 to 200 & 616 & 566 & 601 & $\overline{A A}$ \\
\hline CALABASH & $02-57-020$ & 10/29/1969 & U-2av & 583141.8 & 4110977.8 & $1,310.0$ & 110 & 668 & 569 & 625 & LTCU \\
\hline CAMPOS & 09-57-086 & $2 / 13 / 1978$ & U-9cp & 586012.8 & 4109098.3 & $1,296.3$ & $<20$ & 335 & 564 & 320 & TM-LVTA \\
\hline CANFIELD & $03-57-238$ & $5 / 2 / 1980$ & U-3kx & 587228.5 & 4101332.3 & $1,237.5$ & $<20$ & 442 & 504 & 351 & TM-LVTA \\
\hline CAN-GREEN & 03-57-072 & $4 / 21 / 1970$ & U-2dd \#1 & 581554.1 & 4107528.9 & $1,293.3$ & 20 to 200 & 290 & 554 & 274 & $\mathrm{AA}$ \\
\hline CANJILON & 03-57-132 & 12/16/1970 & U-3fq & 586673.3 & 4103158.8 & $1,254.6$ & $<20$ & 411 & 522 & 302 & TM-LVTA \\
\hline CANNA-LIMOGES & $09-57-100$ & $11 / 17 / 1972$ & U-9 ITS YZ-26 & 585942.1 & 4110591.5 & $1,300.0$ & $<20$ & 221 & 568 & 213 & TM-LVTA \\
\hline CANNA-UMBRINUS & $09-57-100$ & $11 / 17 / 1972$ & U-9 ITS YZ-26 & 585942.1 & 4110591.5 & $1,300.0$ & $<20$ & 221 & 568 & 183 & TM-LVTA \\
\hline CAN-RED & $03-57-073$ & $4 / 21 / 1970$ & U-2dd \#4 & 581725.0 & 4107886.6 & $1,295.1$ & 20 to 200 & 464 & 554 & 399 & LTCU \\
\hline CANVASBACK & $03-57-060$ & $8 / 22 / 1964$ & U-3cp & 587529.6 & 4102369.5 & $1,253.6$ & $<20$ & 454 & 515 & 448 & LTCU \\
\hline CAPITAN & $03-57-204$ & $6 / 28 / 1972$ & $\mathrm{U}-3 \mathrm{jj}$ & 587017.0 & 4094295.5 & $1,202.7$ & $<20$ & 175 & 465 & 134 & $\mathrm{AA}$ \\
\hline CAPROCK & $04-57-031$ & $5 / 31 / 1984$ & $U-4 q$ & 584589.6 & 4106533.9 & $1,263.7$ & 20 to 150 & 637 & 493 & 600 & LTCU \\
\hline CARMEL & $02-57-141$ & $2 / 21 / 1963$ & $\mathrm{U}-2 \mathrm{~h}$ & 581705.2 & 4112238.6 & $1,338.1$ & Low & 171 & 599 & 164 & $\mathrm{AA}$ \\
\hline CARNELIAN & 04-57-005 & $7 / 28 / 1977$ & U-4af & 580782.8 & 4105880.6 & $1,291.7$ & $<20$ & 305 & 492 & 208 & AA \\
\hline CARP & $03-57-052$ & 9/27/1963 & U-3cb & 587540.2 & 4099261.3 & $1,219.8$ & Low & 344 & 486 & 330 & $\mathrm{AA}$ \\
\hline
\end{tabular}


Table A.1-1

Shaft and Tunnel Nuclear Detonations in the Yucca Flat/Climax Mine Corrective Action Unit (Page 5 of 24)

\begin{tabular}{|c|c|c|c|c|c|c|c|c|c|c|c|}
\hline Detonation Name & $\begin{array}{c}\text { CAS } \\
\text { Number }\end{array}$ & $\begin{array}{c}\text { Date } \\
\text { Expended }\end{array}$ & $\begin{array}{l}\text { Emplacement } \\
\text { Hole Name }\end{array}$ & $\begin{array}{c}\text { UTM } \\
\text { Easting }\end{array}$ & $\begin{array}{c}\text { UTM } \\
\text { Northing }\end{array}$ & $\begin{array}{l}\text { aLand } \\
\text { Surface } \\
\text { Elevation } \\
\text { (m amsl) }\end{array}$ & $\begin{array}{r}\text { Announced } \\
\text { Yield(kt) }\end{array}$ & $\begin{array}{l}\text { Depth } \\
\text { (m) }\end{array}$ & $\begin{array}{l}\text { Estimated } \\
\text { Depth to } \\
\text { Water (m) }\end{array}$ & $\begin{array}{l}\text { Depth } \\
\text { of } \\
\text { Burial } \\
\text { (m) }\end{array}$ & $\begin{array}{c}\text { Working } \\
\text { Point } \\
\text { HSU }\end{array}$ \\
\hline CARPETBAG & $02-57-084$ & $12 / 17 / 1970$ & U-2dg & 581456.2 & 4109387.3 & $1,311.2$ & 220 & 692 & 552 & $\overline{662}$ & TM-LVTA \\
\hline CARRIZOZO & $03-57-186$ & $12 / 3 / 1970$ & U-3hr & 585419.6 & 4095780.0 & $1,210.1$ & $<20$ & 287 & 477 & 279 & TM-WTA \\
\hline CASHMERE & $02-57-004$ & $2 / 4 / 1965$ & U-2ad & 583355.4 & 4109585.1 & $1,297.2$ & $<20$ & 268 & 550 & 233 & AA \\
\hline CASSELMAN & $10-57-047$ & $2 / 8 / 1963$ & U-10g & 584198.8 & 4111604.7 & $1,294.5$ & Low & 309 & 549 & 303 & AA \\
\hline CASSOWARY & 03-57-039 & 12/16/1964 & U-3bn & 586808.3 & 4099502.8 & $1,220.7$ & $<20$ & 161 & 488 & 150 & AA \\
\hline CATHAY & $09-57-079$ & $10 / 8 / 1971$ & U-9ch & 585530.1 & 4107725.7 & $1,288.1$ & $<20$ & 421 & 552 & 378 & TM-LVTA \\
\hline CEBOLLA & $03-57-197$ & $8 / 9 / 1972$ & U-3jc & 587278.0 & 4095916.3 & $1,207.6$ & $<20$ & 309 & 472 & 287 & $\mathrm{AA}$ \\
\hline CEBRERO & 09-57-091 & 8/14/1985 & U-9cw & 587572.4 & 4107446.1 & $1,342.6$ & $<20$ & 213 & 611 & 183 & TM-LVTA \\
\hline CENTAUR & $02-57-009$ & $8 / 27 / 1965$ & U-2ak & 582595.3 & 4110305.5 & $1,310.3$ & $<20$ & 192 & 561 & 173 & $\mathrm{AA}$ \\
\hline CERISE & $03-57-115$ & $11 / 18 / 1966$ & U-3eu & 588010.7 & 4099872.1 & $1,228.6$ & $<20$ & 223 & 494 & 211 & $\overline{A A}$ \\
\hline CERNADA & $03-57-227$ & 9/24/1981 & U-3kk & 586852.1 & 4096059.6 & $1,208.2$ & $<20$ & 442 & 473 & 213 & AA \\
\hline CERRO & $03-57-245$ & 9/2/1982 & U-3lf & 587562.6 & 4097311.1 & $1,211.6$ & $<20$ & 341 & 478 & 229 & $\overline{A A}$ \\
\hline CHAENACTIS & $02-57-090$ & $12 / 14 / 1971$ & $\mathrm{U}-2 \mathrm{dl}$ & 580879.2 & 4108806.6 & $1,307.9$ & 20 to 200 & 347 & 565 & 331 & $\overline{A A}$ \\
\hline CHAMITA & $03-57-261$ & $8 / 17 / 1985$ & U-3lz & 585146.9 & 4095352.4 & $1,208.2$ & $<20$ & 457 & 475 & 335 & TM-UVTA \\
\hline CHANTILLY & $02-57-087$ & 9/29/1971 & U-2di & 581107.5 & 4108868.1 & $1,307.0$ & $<20$ & 366 & 562 & 331 & $\mathrm{AA}$ \\
\hline CHARCOAL & $07-57-045$ & 9/10/1965 & U-7g & 587402.8 & 4103770.5 & $1,271.6$ & 20 to 200 & 471 & 533 & 455 & $\overline{\text { LTCU }}$ \\
\hline CHATTY & $02-57-040$ & $3 / 18 / 1969$ & $\mathrm{U}-2 \mathrm{bn}$ & 582052.4 & 4113070.5 & $1,339.3$ & $<20$ & 212 & 601 & 195 & $\mathrm{AA}$ \\
\hline CHEEDAM & $02-57-120$ & $2 / 17 / 1983$ & U-2et & 583164.7 & 4113141.5 & $1,320.4$ & $<20$ & 427 & 585 & 343 & TM-LVTA \\
\hline CHENILLE & $09-57-055$ & $4 / 22 / 1965$ & U-9bg & 586140.4 & 4107469.1 & $1,303.3$ & $<20$ & 229 & 569 & 141 & TM-WTA \\
\hline CHESS & 07-57-019 & $6 / 20 / 1979$ & U-7at & 587513.1 & 4107062.2 & $1,336.2$ & $<20$ & 460 & 604 & 335 & LTCU \\
\hline CHEVRE & $10-57-029$ & $11 / 23 / 1976$ & U-10ay & 584102.8 & 4114137.0 & $1,304.8$ & $<20$ & 335 & 572 & 317 & $\mathrm{AA}$ \\
\hline CHIBERTA & $02-57-111$ & $12 / 20 / 1975$ & U-2ek & 583361.2 & 4109241.7 & $1,291.4$ & 20 to 200 & 761 & 540 & 716 & $\overline{L T C U}$ \\
\hline CHINCHILLA & $03-57-007$ & $2 / 19 / 1962$ & U-3ag & 586296.4 & 4100551.1 & $1,228.3$ & 1.9 & 166 & 495 & 150 & $\mathrm{AA}$ \\
\hline CHINCHILLA II & 03-57-019 & $3 / 31 / 1962$ & U-3as & 585643.3 & 4100306.6 & $1,227.1$ & Low & 172 & 494 & 137 & $\overline{A A}$ \\
\hline CHIPMUNK & $03-57-025$ & $2 / 15 / 1963$ & U-3ay & 586098.9 & 4100544.6 & $1,227.7$ & Low & 64 & 495 & 59 & $\overline{A A}$ \\
\hline CHOCOLATE & $03-57-113$ & $4 / 21 / 1967$ & U-3es & 585627.5 & 4097243.7 & $1,21,2.8$ & $<20$ & 253 & 480 & 240 & AA \\
\hline CIMARRON & $09-57-096$ & $2 / 23 / 1962$ & U-9h & 584537.9 & 4109387.2 & $1,282.6$ & 11.9 & 370 & 539 & 305 & $\overline{A A}$ \\
\hline CINNAMON & $03-57-082$ & $3 / 7 / 1966$ & U-3dm & 586200.5 & 4098951.9 & $1,219.2$ & $<20$ & 191 & 487 & 120 & $\overline{A A}$ \\
\hline CLAIRETTE & $03-57-232$ & 2/5/1981 & U-3kr & 586103.7 & 4096315.6 & $1,209.4$ & $<20$ & 445 & 475 & 354 & $\mathrm{AA}$ \\
\hline CLARKSMOBILE & $02-57-017$ & $5 / 17 / 1968$ & U-2as & 583612.8 & 4108400.9 & $1,285.6$ & 20 to 200 & 518 & 515 & 472 & TM-LVTA \\
\hline CLUB & $02-57-002$ & $1 / 30 / 1964$ & U-2aa & 582544.6 & 4110183.5 & $1,309.4$ & $<20$ & 190 & 559 & 181 & $\mathrm{AA}$ \\
\hline
\end{tabular}


Table A.1-1

Shaft and Tunnel Nuclear Detonations in the Yucca Flat/Climax Mine Corrective Action Unit

(Page 6 of 24)

\begin{tabular}{|c|c|c|c|c|c|c|c|c|c|c|c|}
\hline Detonation Name & $\begin{array}{c}\text { CAS } \\
\text { Number }\end{array}$ & $\begin{array}{c}\text { Date } \\
\text { Expended }\end{array}$ & $\begin{array}{c}\text { Emplacement } \\
\text { Hole Name }\end{array}$ & $\begin{array}{c}\text { UTM } \\
\text { Easting }\end{array}$ & $\begin{array}{c}\text { UTM } \\
\text { Northing }\end{array}$ & $\begin{array}{c}\text { aLand } \\
\text { Surface } \\
\text { Elevation } \\
\text { (m amsl) }\end{array}$ & $\begin{array}{r}\text { Announced } \\
\text { Yield(kt) }\end{array}$ & $\begin{array}{l}\text { Depth } \\
\text { (m) }\end{array}$ & $\begin{array}{l}\text { Estimated } \\
\text { Depth to } \\
\text { Water }(m)\end{array}$ & $\begin{array}{l}\text { Depth } \\
\text { of } \\
\text { Burial } \\
\text { (m) }\end{array}$ & $\begin{array}{c}\text { Working } \\
\text { Point } \\
\text { HSU }\end{array}$ \\
\hline CLYMER & $09-57-076$ & $3 / 12 / 1966$ & U-9ce & 584147.2 & 4111027.4 & $1,293.0$ & $<20$ & 684 & 546 & 398 & AA \\
\hline COALORA & $03-57-253$ & 2/11/1983 & U-3lo & 584882.1 & 4101324.1 & $1,236.9$ & $<20$ & 305 & 492 & 274 & TM-UVTA \\
\hline COBBLER & $07-57-057$ & $11 / 8 / 1967$ & $\mathrm{U}-7 \mathrm{u}$ & 585690.7 & 4105288.4 & $1,269.2$ & $<20$ & 686 & 531 & 667 & LTCU \\
\hline CODSAW & 09-57-095 & 2/19/1962 & $\mathrm{U}-9 \mathrm{~g}$ & 585533.3 & 4109241.7 & $1,285.3$ & Low & 218 & 550 & 212 & TM-WTA \\
\hline COFFER & $02-57-082$ & 3/21/1969 & U-2de & 581126.4 & 4109837.8 & $1,317.7$ & $<100$ & 479 & 569 & 465 & AA \\
\hline COGNAC & $03-57-130$ & $10 / 25 / 1967$ & $\mathrm{U}-3 \mathrm{fm}$ & 585402.3 & 4100624.5 & $1,229.6$ & $<20$ & 253 & 495 & 240 & AA \\
\hline COLFAX & $03-57-219$ & $10 / 5 / 1958$ & U-3k & 585883.8 & 4100523.5 & $1,228.0$ & 0.0055 & 168 & 495 & 107 & $\overline{A A}$ \\
\hline COLMOR & $03-57-190$ & 4/26/1973 & U-3hv & 587188.9 & 4096465.7 & $1,209.4$ & $<20$ & 260 & 475 & 246 & AA \\
\hline COMMODORE & $02-57-011$ & $5 / 20 / 1967$ & U-2am & 583146.8 & 4109545.6 & $1,297.8$ & 250 & 779 & 549 & 745 & LTCU \\
\hline CONCENTRATION & $03-57-229$ & 12/1/1978 & U-3kn & 586798.4 & 4098405.5 & $1,216.5$ & $<20$ & 274 & 483 & 243 & AA \\
\hline CORAZON & $03-57-164$ & $12 / 3 / 1970$ & U-3ha & 585604.0 & 4095323.5 & $1,207.3$ & $<20$ & 253 & 474 & 241 & AA \\
\hline CORDUROY & $10-57-049$ & $12 / 3 / 1965$ & U-10k & 584139.0 & 4113364.3 & $1,302.4$ & 20 to 200 & 729 & 568 & 679 & OSBCU \\
\hline CORMORANT & $03-57-075$ & $7 / 17 / 1964$ & U-3df & 586329.3 & 4097063.0 & $1,211.6$ & $<20$ & 279 & 478 & 272 & AA \\
\hline CORNICE-GREEN & $10-57-021$ & $5 / 15 / 1970$ & U-10ap-3 & 585340.7 & 4113063.8 & $1,31,2.5$ & 20 to 200 & 457 & 580 & 443 & LTCU \\
\hline CORNICE-YELLOW & $10-57-020$ & $5 / 15 / 1970$ & U-10ap-1 & 585634.7 & 4113511.3 & $1,319.5$ & 20 to 200 & 402 & 584 & 390 & OSBCU \\
\hline CORNUCOPIA & $02-57-135$ & $7 / 24 / 1986$ & U-2ga-S & 582496.6 & 4110908.2 & $1,314.3$ & $<20$ & 548 & 566 & 381 & $\overline{A A}$ \\
\hline CORREO & $03-57-260$ & $8 / 2 / 1984$ & U-3lw & 588279.8 & 4096993.7 & $1,209.1$ & $<20$ & 427 & 475 & 335 & TM-LVTA \\
\hline COSO-BRONZE & $04-57-012$ & 3/8/1991 & U-4an & 582279.4 & 4106647.7 & $1,281.4$ & $<20$ & 488 & 500 & 333 & TM-WTA \\
\hline COSO-GRAY & $04-57-012$ & $3 / 8 / 1991$ & U-4an & 582279.4 & 4106647.7 & $1,281.4$ & $<20$ & 488 & 500 & 442 & LTCU \\
\hline COSO-SILVER & $04-57-012$ & 3/8/1991 & U-4an & 582279.4 & 4106647.7 & $1,281.4$ & $<20$ & 488 & 500 & 475 & LTCU \\
\hline COTTAGE & $08-57-005$ & $3 / 23 / 1985$ & U-8j & 580872.6 & 4115022.7 & $1,388.7$ & 20 to 150 & 610 & 627 & 515 & OSBCU \\
\hline COULOMMIERS & $02-57-110$ & $9 / 27 / 1977$ & U-2ei & 582803.6 & 4111845.1 & $1,318.9$ & 20 to 150 & 640 & 579 & 530 & TM-LVTA \\
\hline COURSER & 03-57-084 & $9 / 25 / 1964$ & U-3do & 587526.8 & 4103161.8 & $1,264.3$ & 0 & 370 & 523 & 359 & LTCU \\
\hline COVE & $03-57-225$ & $2 / 16 / 1977$ & U-3ki & 586180.9 & 4095843.9 & $1,207.9$ & $<20$ & 351 & 474 & 335 & AA \\
\hline COWLES & 03-57-191 & $2 / 3 / 1972$ & U-3hx & 587249.9 & 4095237.9 & $1,205.5$ & $<20$ & 321 & 468 & 302 & $\overline{\mathrm{AA}}$ \\
\hline COYPU & $03-57-006$ & $4 / 10 / 1963$ & U-3af & 586227.0 & 4100523.4 & $1,227.7$ & Low & 81 & 495 & 75 & AA \\
\hline CREMINO & $08-57-004$ & 9/27/1978 & $\mathrm{U}-8 \mathrm{e}$ & 581041.3 & 4114029.9 & $1,367.9$ & $<20$ & 610 & 588 & 210 & AA \\
\hline CREMINO-CAERPHILLY & $08-57-004$ & 9/27/1978 & $\mathrm{U}-8 \mathrm{e}$ & 581041.3 & 4114029.9 & $1,367.9$ & $<20$ & 610 & 588 & 420 & TM-LVTA \\
\hline CREPE & $02-57-147$ & $12 / 5 / 1964$ & $U-2 q$ & 584097.7 & 4107781.6 & $1,278.6$ & 20 to 200 & 415 & 498 & 404 & TM-LVTA \\
\hline CRESTLAKE-BRIAR & $02-57-101$ & $7 / 18 / 1974$ & U-2dw & 581277.2 & 4108289.7 & $1,301.2$ & $<20$ & 381 & 560 & 374 & AA \\
\hline CRESTLAKE-TANSAN & 02-57-101 & $7 / 18 / 1974$ & $\mathrm{U}-2 \mathrm{dw}$ & 581277.2 & 4108289.7 & $1,301.2$ & $<20$ & 381 & 560 & 272 & AA \\
\hline CREW & $02-57-073$ & $11 / 4 / 1968$ & $\mathrm{U}-2 \mathrm{db}$ & 581142.7 & 4109533.4 & $1,314.3$ & 20 to 200 & 632 & 561 & 359 & AA \\
\hline
\end{tabular}


Table A.1-1

Shaft and Tunnel Nuclear Detonations in the Yucca Flat/Climax Mine Corrective Action Unit (Page 7 of 24)

\begin{tabular}{|c|c|c|c|c|c|c|c|c|c|c|c|}
\hline Detonation Name & $\begin{array}{c}\text { CAS } \\
\text { Number }\end{array}$ & $\begin{array}{c}\text { Date } \\
\text { Expended }\end{array}$ & $\begin{array}{l}\text { Emplacement } \\
\text { Hole Name }\end{array}$ & $\begin{array}{c}\text { UTM } \\
\text { Easting }\end{array}$ & $\begin{array}{c}\text { UTM } \\
\text { Northing }\end{array}$ & $\begin{array}{c}\text { aLand } \\
\text { Surface } \\
\text { Elevation } \\
\text { (m amsl) }\end{array}$ & $\begin{array}{r}\text { Announced } \\
\text { Yield(kt) }\end{array}$ & $\begin{array}{l}\text { Depth } \\
\text { (m) }\end{array}$ & $\begin{array}{l}\text { Estimated } \\
\text { Depth to } \\
\text { Water (m) }\end{array}$ & $\begin{array}{l}\text { Depth } \\
\text { of } \\
\text { Burial } \\
\text { (m) }\end{array}$ & $\begin{array}{c}\text { Working } \\
\text { Point } \\
\text { HSU }\end{array}$ \\
\hline CREW-2ND & $02-57-073$ & $11 / 4 / 1968$ & U-2db & 581142.7 & 4109533.4 & $1,314.3$ & $2<20$ & 632 & 561 & 360 & $\overline{\mathrm{AA}}$ \\
\hline CREW-3RD & $02-57-073$ & $11 / 4 / 1968$ & $\mathrm{U}-2 \mathrm{db}$ & 581142.7 & 4109533.4 & $1,314.3$ & $<20$ & 632 & 561 & 604 & TM-LVTA \\
\hline CREWLINE & $07-57-017$ & $5 / 25 / 1977$ & U-7ap & 584882.5 & 4105559.8 & $1,264.3$ & 20 to 150 & 625 & 498 & 564 & LTCU \\
\hline CROCK & $10-57-014$ & $5 / 8 / 1968$ & U-10ak & 585695.3 & 4112557.4 & $1,315.8$ & $<20$ & 207 & 583 & 182 & AA \\
\hline CROWDIE & $02-57-132$ & $5 / 5 / 1983$ & U-2fe & 580886.0 & 4111213.7 & $1,335.9$ & $<20$ & 450 & 590 & 390 & AA \\
\hline \begin{tabular}{|l|} 
CRUET \\
\end{tabular} & $02-57-065$ & $10 / 29 / 1969$ & U-2cn & 577488.7 & 4108504.9 & $1,398.7$ & 11 & 472 & 523 & 264 & TM-WTA \\
\hline CUCHILLO & $03-57-213$ & $8 / 9 / 1972$ & U-3jt & 587279.6 & 4095535.1 & $1,206.1$ & $<20$ & 223 & 469 & 198 & AA \\
\hline CULANTRO-A & $03-57-172$ & 12/10/1969 & U-3hi-a & 588707.2 & 4096766.6 & $1,208.2$ & $<20$ & 143 & 472 & 134 & AA \\
\hline CULANTRO-B & $03-57-173$ & $12 / 10 / 1969$ & U-3hi-b & 588859.5 & 4096789.7 & $1,209.1$ & $<20$ & 158 & 473 & 149 & AA \\
\hline CUMARIN & $03-57-163$ & $2 / 25 / 1970$ & $U-3 g z$ & 588972.9 & 4099205.4 & $1,232.9$ & 20 to 200 & 422 & 498 & 409 & LTCU \\
\hline CUMBERLAND & $02-57-104$ & 4/11/1963 & $\mathrm{U}-2 \mathrm{e}$ & 582495.2 & 4112453.8 & $1,326.5$ & Low & 248 & 588 & 226 & $\mathrm{AA}$ \\
\hline CUP & $09-57-074$ & $3 / 26 / 1965$ & U-9cb & 584998.0 & 4111471.6 & $1,293.9$ & 20 to 200 & 558 & 554 & 538 & LTCU \\
\hline CYATHUS & $08-57-002$ & $3 / 6 / 1970$ & $\mathrm{U}-8 \mathrm{~b}$ & 580631.5 & 4114259.8 & $1,379.8$ & 8.7 & 314 & 611 & 294 & TM-LVTA \\
\hline CYCLAMEN & $03-57-065$ & $5 / 5 / 1966$ & $U-3 c x$ & 585554.7 & 4100717.3 & $1,230.2$ & 12 & 343 & 496 & 305 & $\mathrm{AA}$ \\
\hline DAIQUIRI & $07-57-052$ & 9/23/1966 & U-7o & 585686.5 & 4106568.5 & $1,287.2$ & $<20$ & 579 & 550 & 561 & LTCU \\
\hline \begin{tabular}{|l} 
DALHART \\
\end{tabular} & $04-57-035$ & $10 / 13 / 1988$ & $\mathrm{U}-4 \mathrm{u}$ & 584497.3 & 4104964.6 & $1,255.8$ & $<150$ & 671 & 477 & 640 & LTCU \\
\hline DAMAN I & $03-57-031$ & $6 / 21 / 1962$ & U-3be & 586238.7 & 4099886.0 & $1,224.1$ & Low & 268 & 491 & 260 & AA \\
\hline DANABLU & $02-57-121$ & 6/9/1983 & U-2eu & 580872.2 & 4112542.3 & $1,353.6$ & $<20$ & 432 & 607 & 320 & $\mathrm{AA}$ \\
\hline DAUPHIN & $09-57-087$ & $11 / 14 / 1980$ & U-9cq & 587191.7 & 4107487.7 & $1,332.6$ & $<20$ & 336 & 600 & 320 & LTCU \\
\hline DEAD & $09-57-102$ & $4 / 21 / 1962$ & U-9k & 586040.0 & 4108309.5 & $1,298.8$ & Low & 238 & 566 & 194 & AA \\
\hline DECK & $03-57-222$ & 11/18/1975 & U-3kd & 587120.5 & 4097370.5 & $1,206.4$ & $<20$ & 399 & 472 & 326 & $\mathrm{AA}$ \\
\hline DELPHINIUM & $02-57-094$ & 9/26/1972 & $\mathrm{U}-2 \mathrm{dp}$ & 581221.5 & 4108524.1 & $1,303.3$ & 15 & 335 & 562 & 296 & AA \\
\hline DEXTER & $03-57-187$ & $6 / 23 / 1971$ & U-3hs & 587503.6 & 4096587.2 & $1,209.4$ & $<20$ & 130 & 475 & 120 & AA \\
\hline DIANTHUS & $10-57-025$ & $2 / 17 / 1972$ & U-10at & 583792.8 & 4113467.9 & $1,306.1$ & $<20$ & 335 & 572 & 305 & AA \\
\hline DISCUS THROWER & $08-57-001$ & $5 / 27 / 1966$ & $\mathrm{U}-8 \mathrm{a}$ & 580092.9 & 4114839.3 & $1,406.7$ & 22 & 360 & 661 & 337 & TM-LVTA \\
\hline DIVIDER & $03-57-269$ & 9/23/1992 & $\mathrm{U}-3 \mathrm{ml}$ & 590030.7 & 4097442.0 & $1,234.7$ & $<20$ & 396 & 503 & 340 & LTCU \\
\hline DOFINO & $10-57-031$ & $3 / 8 / 1977$ & U-10ba & 584072.7 & 4114634.8 & $1,309.4$ & $<20$ & 290 & 575 & 183 & $\mathrm{AA}$ \\
\hline DOFINO-LAWTON & $10-57-031$ & $3 / 8 / 1977$ & U-10ba & 584072.7 & 4114634.8 & $1,309.4$ & $<20$ & 290 & 575 & 282 & $\mathrm{AA}$ \\
\hline DOLCETTO & $07-57-030$ & 8/30/1984 & U-7bi & 588930.9 & 4105098.7 & $1,318.0$ & $<20$ & 457 & 568 & 366 & LTCU \\
\hline DORMOUSE & $03-57-017$ & $1 / 30 / 1962$ & U-3aq & 585413.8 & 4100297.2 & $1,227.1$ & Low & 370 & 493 & 363 & AA \\
\hline DORMOUSE PRIME & $03-57-026$ & $4 / 5 / 1962$ & U-3az & 586834.7 & 4100052.0 & $1,224.1$ & 10.6 & 269 & 490 & 261 & AA \\
\hline
\end{tabular}


Table A.1-1

Shaft and Tunnel Nuclear Detonations in the Yucca Flat/Climax Mine Corrective Action Unit

(Page 8 of 24)

\begin{tabular}{|c|c|c|c|c|c|c|c|c|c|c|c|}
\hline Detonation Name & $\begin{array}{c}\text { CAS } \\
\text { Number }\end{array}$ & $\begin{array}{c}\text { Date } \\
\text { Expended }\end{array}$ & $\begin{array}{l}\text { Emplacement } \\
\text { Hole Name }\end{array}$ & $\begin{array}{c}\text { UTM } \\
\text { Easting }\end{array}$ & $\begin{array}{c}\text { UTM } \\
\text { Northing }\end{array}$ & $\begin{array}{c}\text { aLand } \\
\text { Surface } \\
\text { Elevation } \\
\text { (m amsl) }\end{array}$ & $\begin{array}{r}\text { Announced } \\
\text { Yield(kt) }\end{array}$ & $\begin{array}{l}\text { Depth } \\
\text { (m) }\end{array}$ & $\begin{array}{l}\text { Estimated } \\
\text { Depth to } \\
\text { Water (m) }\end{array}$ & $\begin{array}{l}\text { Depth } \\
\text { of } \\
\text { Burial } \\
\text { (m) }\end{array}$ & $\begin{array}{c}\text { Working } \\
\text { Point } \\
\text { HSU }\end{array}$ \\
\hline DOVEKIE & $03-57-053$ & $1 / 21 / 1966$ & U-3cd & 587542.6 & 4098651.5 & $1,216.5$ & $<20$ & 345 & 483 & 333 & AA \\
\hline DRAUGHTS & $07-57-013$ & 9/27/1978 & U-7al & 587130.2 & 4103312.7 & $1,261.6$ & 20 to 150 & 460 & 526 & 442 & OSBCU \\
\hline DRILL (SOURCE-LOWER) & $02-57-008$ & $12 / 5 / 1964$ & U-2ai & 582627.0 & 4109970.4 & $1,306.4$ & 3.4 & 226 & 557 & 219 & AA \\
\hline DRILL (TARGET-UPPER) & $02-57-008$ & $12 / 5 / 1964$ & U-2ai & 582627.0 & 4109970.4 & $1,306.4$ & $<20$ & 226 & 557 & 188 & AA \\
\hline DRIVER & $09-57-039$ & $5 / 7 / 1964$ & U-9ar & 585259.1 & 4108440.8 & $1,280.2$ & $<20$ & 160 & 543 & 150 & AA \\
\hline DUB & $10-57-001$ & $6 / 30 / 1964$ & $\mathrm{U}-10 \mathrm{a}$ & 583769.3 & 4114435.6 & $1,308.5$ & 11.7 & 430 & 575 & 259 & AA \\
\hline DUFFER & $10-57-043$ & 6/18/1964 & U-10ds & 585375.1 & 4113516.1 & $1,314.3$ & $<20$ & 455 & 580 & 447 & LTCU \\
\hline DUMONT & $02-57-149$ & $5 / 19 / 1966$ & $\mathrm{U}-2 \mathrm{t}$ & 583702.8 & 4107414.5 & $1,278.6$ & 20 to 200 & 696 & 486 & 671 & LTCU \\
\hline DUORO & $03-57-259$ & $6 / 20 / 1984$ & U-3lv & 585147.6 & 4095139.1 & $1,207.3$ & 20 to 150 & 457 & 474 & 381 & TM-UVTA \\
\hline DUTCHESS & $07-57-033$ & $10 / 24 / 1980$ & U-7bm & 588957.9 & 4103410.3 & $1,291.7$ & $<20$ & 472 & 534 & 427 & LTCU \\
\hline EAGLE & $09-57-042$ & 12/12/1963 & U-9av & 584928.9 & 4109631.1 & $1,281.1$ & 5.3 & 174 & 541 & 165 & AA \\
\hline EBBTIDE & $03-57-234$ & 9/15/1977 & U-3kt & 585104.5 & 4098734.7 & $1,220.7$ & $<20$ & 460 & 487 & 381 & AA \\
\hline EDAM & $02-57-102$ & $4 / 24 / 1975$ & U-2dy & 581080.2 & 4107892.3 & $1,299.4$ & 20 to 200 & 427 & 556 & 412 & TM-LVTA \\
\hline EEL & $09-57-104$ & $5 / 19 / 1962$ & U-9m & 584642.4 & 4108698.3 & $1,280.2$ & 4.5 & 224 & 536 & 218 & AA \\
\hline EFFENDI & 02-57-015 & $4 / 27 / 1967$ & U-2ap & 583203.9 & 4110475.3 & $1,305.8$ & $<20$ & 235 & 560 & 221 & $A A$ \\
\hline ELIDA & 03-57-192 & $12 / 19 / 1973$ & U-3hy & 586183.3 & 4095234.1 & $1,205.5$ & $<20$ & 399 & 471 & 381 & AA \\
\hline ELKHART & 09-57-066 & 9/17/1965 & U-9bs & 585774.9 & 4107421.8 & $1,293.9$ & $<20$ & 340 & 558 & 220 & TM-WTA \\
\hline EMBUDO & $03-57-167$ & $6 / 16 / 1971$ & U-3hd & 587724.9 & 4098804.8 & $1,218.0$ & $<20$ & 312 & 484 & 303 & AA \\
\hline EMERSON & $02-57-010$ & $12 / 16 / 1965$ & U-2al & 583203.7 & 4110703.5 & $1,307.3$ & $<20$ & 294 & 564 & 261 & AA \\
\hline ERMINE & $03-57-002$ & $3 / 6 / 1962$ & U-3ab & 585930.0 & 4100474.6 & $1,227.7$ & Low & 81 & 495 & 73 & AA \\
\hline ESCABOSA & $07-57-004$ & $7 / 10 / 1974$ & U-7ac & 586063.2 & 4103430.9 & $1,250.3$ & 20 to 200 & 675 & 513 & 640 & LTCU \\
\hline ESROM & 07-57-012 & $2 / 4 / 1976$ & U-7ak & 585529.5 & 4106927.3 & $1,285.0$ & 20 to 200 & 686 & 548 & 655 & LTCU \\
\hline ESTACA & 03-57-195 & 10/17/1974 & U-3ja & 587650.3 & 4095832.9 & $1,206.7$ & $<20$ & 341 & 470 & 320 & TM-UVTA \\
\hline FADE & $09-57-053$ & $6 / 25 / 1964$ & U-9be & 586292.9 & 4107438.8 & $1,307.0$ & $<20$ & 235 & 574 & 205 & TM-LVTA \\
\hline FAHADA & 07-57-029 & $5 / 26 / 1983$ & U-7bh & 588352.9 & 4106547.1 & $1,338.7$ & $<20$ & 396 & 606 & 384 & OSBCU \\
\hline FAJY & $02-57-130$ & $6 / 28 / 1979$ & $\mathrm{U}-2 \mathrm{fc}$ & 581039.6 & 4110940.3 & $1,330.1$ & 20 to 150 & 571 & 584 & 536 & AA \\
\hline FALLON & $02-57-100$ & $5 / 23 / 1974$ & $\mathrm{U}-2 \mathrm{dV}$ & 581826.7 & 4108876.7 & $1,302.7$ & 20 to 200 & 488 & 548 & 466 & $\overline{A A}$ \\
\hline FARALLONES & $02-57-128$ & $12 / 14 / 1977$ & $U-2 f a$ & 581179.6 & 4110132.3 & $1,317.3$ & 20 to 150 & 732 & 570 & 668 & $\overline{A A}$ \\
\hline FAWN & 03-57-109 & $4 / 7 / 1967$ & $\mathrm{U}-3 \mathrm{eo}$ & 586939.7 & 4101148.2 & $1,233.5$ & $<20$ & 282 & 500 & 271 & AA \\
\hline FENTON & $02-57-144$ & $4 / 23 / 1966$ & $\mathrm{U}-2 \mathrm{~m}-1$ & 581433.6 & 4112871.8 & $1,348.1$ & 1.4 & 169 & 601 & 167 & AA \\
\hline FERRET & $03-57-032$ & $2 / 8 / 1963$ & U-3bf & 586309.5 & 4101581.4 & $1,235.0$ & Low & 370 & 502 & 326 & TM-UVTA \\
\hline FERRET PRIME & $03-57-050$ & $4 / 5 / 1963$ & U-3by & 586809.2 & 4099258.7 & $1,219.8$ & Low & 256 & 487 & 242 & AA \\
\hline
\end{tabular}


Table A.1-1

Shaft and Tunnel Nuclear Detonations in the Yucca Flat/Climax Mine Corrective Action Unit (Page 9 of 24)

\begin{tabular}{|c|c|c|c|c|c|c|c|c|c|c|c|}
\hline Detonation Name & $\begin{array}{c}\text { CAS } \\
\text { Number }\end{array}$ & $\begin{array}{c}\text { Date } \\
\text { Expended }\end{array}$ & $\begin{array}{l}\text { Emplacement } \\
\text { Hole Name }\end{array}$ & $\begin{array}{c}\text { UTM } \\
\text { Easting }\end{array}$ & $\begin{array}{c}\text { UTM } \\
\text { Northing }\end{array}$ & $\begin{array}{c}\text { aLand } \\
\text { Surface } \\
\text { Elevation } \\
\text { (m amsl) }\end{array}$ & $\begin{array}{r}\text { Announced } \\
\text { Yield(kt) }\end{array}$ & $\begin{array}{l}\text { Depth } \\
\text { (m) }\end{array}$ & $\begin{array}{l}\text { Estimated } \\
\text { Depth to } \\
\text { Water (m) }\end{array}$ & $\begin{array}{l}\text { Depth } \\
\text { of } \\
\text { Burial } \\
\text { (m) }\end{array}$ & $\begin{array}{c}\text { Working } \\
\text { Point } \\
\text { HSU }\end{array}$ \\
\hline FILE & $03-57-142$ & $10 / 31 / 1968$ & $\overline{U-3 g b}$ & 585781.0 & 4097000.1 & $1,212.2$ & $2<20$ & 253 & 479 & 229 & $\overline{\mathrm{AA}}$ \\
\hline FINFOOT & 03-57-089 & $3 / 7 / 1966$ & U-3du & 586321.6 & 4099257.0 & $1,220.4$ & $<20$ & 221 & 488 & 196 & AA \\
\hline FISHER & $03-57-008$ & $12 / 3 / 1961$ & U-3ah & 586464.9 & 4100198.2 & $1,225.3$ & 13.4 & 370 & 492 & 364 & AA \\
\hline FIZZ & $03-57-133$ & $3 / 10 / 1967$ & U-3fr & 586277.2 & 4100363.0 & $1,225.9$ & $<20$ & 130 & 493 & 118 & AA \\
\hline FLASK-GREEN & $02-57-026$ & $5 / 26 / 1970$ & U-2az-1 & 583308.9 & 4107656.6 & $1,277.7$ & 105 & 555 & 497 & 529 & TM-UVTA \\
\hline FLASK-RED & $02-57-028$ & $5 / 26 / 1970$ & U-2az-3 & 582917.7 & 4107966.4 & $1,286.3$ & 0.035 & 168 & 518 & 152 & AA \\
\hline FLASK-YELLOW & $02-57-027$ & $5 / 26 / 1970$ & U-2az-2 & 583194.3 & 4108184.0 & $1,286.3$ & 0.09 & 351 & 516 & 335 & AA \\
\hline FLAX-BACKUP & $02-57-088$ & $12 / 21 / 1972$ & U-2dj & 581421.8 & 4110588.1 & $1,323.1$ & $<20$ & 723 & 577 & 445 & AA \\
\hline FLAX-SOURCE & $02-57-088$ & $12 / 21 / 1972$ & U-2dj & 581421.8 & 4110588.1 & $1,323.1$ & $<20$ & 723 & 577 & 688 & TM-LVTA \\
\hline FLAX-TEST & $02-57-088$ & $12 / 21 / 1972$ & U-2dj & 581421.8 & 4110588.1 & $1,323.1$ & 20 to 200 & 723 & 577 & 436 & $\mathrm{AA}$ \\
\hline FLORA & $03-57-246$ & $5 / 22 / 1980$ & U-3lg & 586182.6 & 4095447.4 & $1,206.4$ & $<20$ & 396 & 472 & 335 & AA \\
\hline FLOTOST & $02-57-014$ & $8 / 16 / 1977$ & U-2ao & 583203.2 & 4111355.9 & $1,310.9$ & $<20$ & 290 & 569 & 275 & AA \\
\hline FLOYDADA & $07-57-042$ & 8/15/1991 & $\mathrm{U}-7 \mathrm{cb}$ & 588718.6 & 4104823.3 & $1,306.7$ & $<20$ & 564 & 545 & 503 & OSBCU \\
\hline FOB-BLUE & $09-57-013$ & $1 / 23 / 1970$ & U-9 ITS Y-27 & 585916.0 & 4110713.0 & $1,299.7$ & $<20$ & 112 & 567 & 101 & TM-LVTA \\
\hline FOB-GREEN & $09-57-005$ & $1 / 23 / 1970$ & U-9 iv-27 & 585549.8 & 4110712.0 & $1,293.0$ & $<20$ & 264 & 560 & 244 & TM-LVTA \\
\hline FOB-RED & $09-57-004$ & $1 / 23 / 1970$ & U-9 iv-24 & 585551.0 & 4110346.7 & $1,289.9$ & $<20$ & 282 & 556 & 266 & TM-LVTA \\
\hline FORE & $09-57-036$ & $1 / 16 / 1964$ & U-9ao & 584452.2 & 4110875.8 & $1,289.6$ & 20 to 200 & 504 & 545 & 491 & TM-LVTA \\
\hline FOREFOOT & $03-57-223$ & $6 / 2 / 1977$ & U-3kf & 586695.7 & 4101208.6 & $1,233.5$ & $<20$ & 201 & 500 & 194 & AA \\
\hline FOREST & $07-57-001$ & $10 / 31 / 1964$ & $\mathrm{U}-7 \mathrm{a}$ & 585989.4 & 4107000.2 & $1,296.9$ & $<20$ & 823 & 562 & 387 & LTCU \\
\hline FREEZEOUT & $03-57-237$ & $5 / 11 / 1979$ & U-3kw & 587403.4 & 4094918.5 & $1,204.3$ & $<20$ & 415 & 466 & 335 & AA \\
\hline FRIJOLES-DEMING & $03-57-216$ & 9/22/1971 & U-3jw & 587513.1 & 4097518.2 & $1,212.2$ & $<20$ & 169 & 478 & 150 & $\mathrm{AA}$ \\
\hline FRIJOLES-ESPUELA & $03-57-214$ & 9/22/1971 & U-3ju & 587500.5 & 4097640.0 & $1,212.8$ & $<20$ & 169 & 479 & 149 & AA \\
\hline FRIJOLES-GUAJE & $03-57-169$ & 9/22/1971 & U-3hf & 587591.2 & 4097829.3 & $1,213.1$ & $<20$ & 274 & 479 & 257 & AA \\
\hline FRIJOLES-PETACA & $03-57-193$ & 9/22/1971 & U-3hz & 587272.2 & 4097553.9 & $1,213.1$ & $<20$ & 396 & 479 & 229 & AA \\
\hline FRISCO & $08-57-008$ & 9/23/1982 & U-8m & 580981.3 & 4114444.1 & $1,373.7$ & 20 to 150 & 518 & 583 & 451 & OSBCU \\
\hline FUNNEL & $03-57-141$ & $6 / 25 / 1968$ & U-3ga & 586239.2 & 4100250.4 & $1,226.2$ & $<20$ & 131 & 493 & 119 & AA \\
\hline FUTTOCK & $03-57-102$ & $6 / 18 / 1975$ & U-3eh & 586950.5 & 4102397.9 & $1,247.9$ & $<20$ & 472 & 514 & 186 & $\mathrm{AA}$ \\
\hline GALENA-GREEN & $09-57-090$ & $6 / 23 / 1992$ & $\mathrm{U}-9 \mathrm{cV}$ & 586059.4 & 4108855.0 & $1,295.7$ & $<20$ & 457 & 563 & 401 & OSBCU \\
\hline GALENA-ORANGE & $09-57-090$ & 6/23/1992 & U-9cv & 586059.4 & 4108855.0 & $1,295.7$ & $<20$ & 457 & 563 & 381 & OSBCU \\
\hline GALENA-YELLOW & $09-57-090$ & $6 / 23 / 1992$ & U-9cv & 586059.4 & 4108855.0 & $1,295.7$ & $<20$ & 457 & 563 & 290 & LTCU \\
\hline GARDEN & $09-57-032$ & $10 / 23 / 1964$ & U-9aj & 586075.5 & 4108091.1 & $1,301.2$ & $<20$ & 158 & 568 & 150 & TM-LVTA \\
\hline
\end{tabular}


Table A.1-1

Shaft and Tunnel Nuclear Detonations in the Yucca Flat/Climax Mine Corrective Action Unit (Page 10 of 24)

\begin{tabular}{|c|c|c|c|c|c|c|c|c|c|c|c|}
\hline Detonation Name & $\begin{array}{c}\text { CAS } \\
\text { Number }\end{array}$ & $\begin{array}{c}\text { Date } \\
\text { Expended }\end{array}$ & $\begin{array}{c}\text { Emplacement } \\
\text { Hole Name }\end{array}$ & $\begin{array}{l}\text { UTM } \\
\text { Easting }\end{array}$ & $\begin{array}{c}\text { UTM } \\
\text { Northing }\end{array}$ & $\begin{array}{c}\text { aLand } \\
\text { Surface } \\
\text { Elevation } \\
\text { (m amsl) }\end{array}$ & $\begin{array}{r}\text { Announced } \\
\text { Yield(kt) }\end{array}$ & $\begin{array}{l}\text { Depth } \\
\text { (m) }\end{array}$ & $\begin{array}{c}\text { Estimated } \\
\text { Depth to } \\
\text { Water }(\mathrm{m})\end{array}$ & 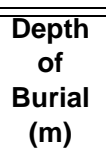 & $\begin{array}{c}\text { Working } \\
\text { Point } \\
\text { HSU }\end{array}$ \\
\hline GASCON & $04-57-034$ & $11 / 14 / 1986$ & $\mathrm{U}-4 \mathrm{t}$ & 584590.7 & 4106233.8 & $1,263.1$ & 20 to 150 & 2616 & 490 & 593 & LTCU \\
\hline GAZOOK & $02-57-093$ & $3 / 23 / 1973$ & U-2do & 581110.4 & 4108068.2 & $1,300.9$ & $<20$ & 343 & 558 & 326 & $\mathrm{AA}$ \\
\hline GERBIL & $03-57-041$ & $3 / 29 / 1963$ & U-3bp & 587294.7 & 4099748.0 & $1,222.9$ & Low & 291 & 489 & 280 & AA \\
\hline GIBSON & $03-57-117$ & $8 / 4 / 1967$ & U-3ew & 587850.6 & 4097830.2 & $1,213.1$ & $<20$ & 253 & 479 & 241 & AA \\
\hline GILROY & $03-57-118$ & $9 / 15 / 1967$ & U-3ex & 587084.7 & 4098985.4 & $1,218.6$ & $<20$ & 253 & 485 & 241 & AA \\
\hline GLENCOE & $04-57-025$ & $3 / 22 / 1986$ & $\mathrm{U}-4 \mathrm{i}$ & 583012.9 & 4104285.0 & $1,260.7$ & 29 & 671 & 493 & 610 & OSBCU \\
\hline GORBEA & $02-57-068$ & $1 / 31 / 1984$ & U-2cq & 578034.8 & 4107531.7 & $1,371.3$ & 20 to 150 & 442 & 521 & 388 & TM-LVTA \\
\hline GOUDA & $02-57-107$ & $10 / 6 / 1976$ & U-2ef & 583290.9 & 4110007.8 & $1,298.4$ & $<20$ & 335 & 552 & 200 & AA \\
\hline GOURD-AMBER & $02-57-033$ & $4 / 24 / 1969$ & $\mathrm{U}-2 \mathrm{bf}$ & 581716.8 & 4113255.2 & $1,346.6$ & $<20$ & 187 & 606 & 181 & $\overline{A A}$ \\
\hline GOURD-BROWN & $02-57-038$ & $4 / 24 / 1969$ & $\mathrm{U}-2 \mathrm{bl}$ & 581611.7 & 4112809.7 & $1,343.9$ & $<20$ & 238 & 600 & 227 & AA \\
\hline GRAPE A & 07-57-055 & 12/17/1969 & U-7s & 588741.4 & 4104384.9 & $1,300.9$ & 20 to 200 & 579 & 539 & 551 & OSBCU \\
\hline GRAPE B & $07-57-058$ & $2 / 4 / 1970$ & U-7v & 586511.3 & 4105992.2 & $1,296.3$ & 20 to 200 & 579 & 563 & 554 & LTCU \\
\hline GREYS & $09-57-044$ & $11 / 22 / 1963$ & U-9ax & 584827.1 & 4108332.3 & $1,274.7$ & Intermediate & 328 & 533 & 301 & $\mathrm{AA}$ \\
\hline GROVE & $02-57-097$ & $5 / 22 / 1974$ & U-2ds & 582208.3 & 4107805.4 & $1,291.1$ & $<20$ & 379 & 537 & 314 & TM-LVTA \\
\hline GRUNION & $03-57-051$ & 10/11/1963 & U-3bz & 587052.9 & 4099259.6 & $1,219.8$ & Low & 284 & 487 & 261 & AA \\
\hline GRUYERE & 09-57-078 & $8 / 16 / 1977$ & U-9cg & 584451.4 & 4111195.7 & $1,289.9$ & $<20$ & 335 & 545 & 207 & $\mathrm{AA}$ \\
\hline GRUYERE-GRADINO & $09-57-078$ & $8 / 16 / 1977$ & U-9cg & 584451.4 & 4111195.7 & $1,289.9$ & $<20$ & 335 & 545 & 320 & AA \\
\hline GUANAY & $03-57-078$ & $9 / 4 / 1964$ & U-3di & 586939.0 & 4097065.2 & $1,211.6$ & $<20$ & 268 & 478 & 261 & $\overline{A A}$ \\
\hline GUNDI & $03-57-038$ & $11 / 15 / 1962$ & U-3bm & 586807.8 & 4099746.3 & $1,222.2$ & Low & 248 & 489 & 241 & AA \\
\hline GUNDI PRIME & $03-57-070$ & $5 / 9 / 1963$ & U-3db & 587535.8 & 4100602.1 & $1,232.3$ & Low & 282 & 498 & 272 & AA \\
\hline HADDOCK & $03-57-081$ & $8 / 28 / 1964$ & U-3dL & 586920.1 & 4102550.5 & $1,248.8$ & $<20$ & 370 & 515 & 364 & LTCU \\
\hline HANDCAR & $10-57-030$ & $11 / 5 / 1964$ & U-10b & 582825.0 & 4114420.1 & $1,333.5$ & 12 & 458 & 598 & 403 & LCA \\
\hline HANDICAP & $09-57-049$ & $3 / 12 / 1964$ & U-9ba & 585600.0 & 4109517.7 & $1,287.8$ & $<20$ & 189 & 554 & 144 & $\mathrm{AA}$ \\
\hline HAPLOPAPPUS & $09-57-021$ & $6 / 28 / 1972$ & U-9 ITS W-22 & 585689.3 & 4110103.1 & $1,291.4$ & $<20$ & 223 & 558 & 184 & TM-LVTA \\
\hline HARD HAT & $15-57-001$ & $2 / 15 / 1962$ & $\mathrm{U}-15 \mathrm{a}$ & 583452.9 & 4120183.5 & $1,558.7$ & 5.7 & 294 & 222 & 287 & MGCU \\
\hline HAREBELL & $02-57-046$ & $6 / 24 / 1971$ & $\mathrm{U}-2 \mathrm{br}$ & 582872.3 & 4111349.9 & $1,314.3$ & 20 to 200 & 557 & 572 & 519 & TM-LVTA \\
\hline HARKEE & $03-57-047$ & $5 / 17 / 1963$ & U-3bv & 587537.9 & 4099992.9 & $1,225.9$ & Low & 256 & 492 & 241 & $\mathrm{AA}$ \\
\hline HARLINGEN-A & $06-57-004$ & $8 / 23 / 1988$ & $\mathrm{U}-6 \mathrm{~g}$ & 587387.5 & 4094141.3 & $1,202.4$ & $<20$ & 320 & 463 & 290 & $\overline{A A}$ \\
\hline HARLINGEN-B & $06-57-005$ & $8 / 23 / 1988$ & U-6h & 587388.8 & 4093867.1 & $1,201.8$ & $<20$ & 320 & 462 & 290 & $\mathrm{AA}$ \\
\hline HATCHET & $03-57-140$ & $5 / 3 / 1968$ & U-3fz & 587178.3 & 4098284.9 & $1,215.2$ & $<20$ & 253 & 482 & 241 & AA \\
\hline HATCHIE & 09-57-093 & $2 / 8 / 1963$ & $\mathrm{U}-9 \mathrm{e}$ & 585399.2 & 4109074.5 & $1,282.6$ & Low & 66 & 546 & 61 & AA \\
\hline HAVARTI & $10-57-037$ & 8/5/1981 & U-10bg & 585685.2 & 4112160.0 & $1,310.0$ & $<20$ & 221 & 578 & 200 & TM-LVTA \\
\hline
\end{tabular}


Table A.1-1

Shaft and Tunnel Nuclear Detonations in the Yucca Flat/Climax Mine Corrective Action Unit (Page 11 of 24)

\begin{tabular}{|c|c|c|c|c|c|c|c|c|c|c|c|}
\hline Detonation Name & $\begin{array}{c}\text { CAS } \\
\text { Number }\end{array}$ & $\begin{array}{c}\text { Date } \\
\text { Expended }\end{array}$ & $\begin{array}{l}\text { Emplacement } \\
\text { Hole Name }\end{array}$ & $\begin{array}{c}\text { UTM } \\
\text { Easting }\end{array}$ & $\begin{array}{c}\text { UTM } \\
\text { Northing }\end{array}$ & $\begin{array}{c}\text { aLand } \\
\text { Surface } \\
\text { Elevation } \\
\text { (m amsl) }\end{array}$ & $\begin{array}{r}\text { Announced } \\
\text { Yield(kt) }\end{array}$ & $\begin{array}{l}\text { Depth } \\
\text { (m) }\end{array}$ & $\begin{array}{l}\text { Estimated } \\
\text { Depth to } \\
\text { Water (m) }\end{array}$ & $\begin{array}{l}\text { Depth } \\
\text { of } \\
\text { Burial } \\
\text { (m) }\end{array}$ & $\begin{array}{c}\text { Working } \\
\text { Point } \\
\text { HSU }\end{array}$ \\
\hline HAYMAKER & $03-57-021$ & $6 / 27 / 1962$ & U-3au(s) & 586022.4 & 4099759.4 & $1,223.5$ & 67 & 463 & 491 & 408 & $\overline{\mathrm{AA}}$ \\
\hline HAZEBROOK-APRICOT & $10-57-038$ & 2/3/1987 & U-10bh & 584467.8 & 4115187.7 & $1,317.3$ & $<20$ & 297 & 571 & 262 & AA \\
\hline HAZEBROOK-CHECKERBERRY & $10-57-038$ & $2 / 3 / 1987$ & U-10bh & 584467.8 & 4115187.7 & $1,317.3$ & $<20$ & 297 & 571 & 226 & AA \\
\hline HAZEBROOK-EMERALD & $10-57-038$ & $2 / 3 / 1987$ & U-10bh & 584467.8 & 4115187.7 & $1,317.3$ & $<20$ & 297 & 571 & 186 & AA \\
\hline HEARTS & $04-57-028$ & 9/6/1979 & $U-4 n$ & 584185.3 & 4104863.2 & $1,258.8$ & 140 & 671 & 473 & 640 & LTCU \\
\hline HEILMAN & $02-57-059$ & $4 / 6 / 1967$ & $\mathrm{U}-2 \mathrm{cg}$ & 577034.6 & 4110254.9 & 1432.3 & $<20$ & 190 & 531 & 153 & AA \\
\hline HERMOSA & $07-57-037$ & $4 / 2 / 1985$ & U-7bs & 585994.6 & 4105624.7 & $1,277.7$ & 20 to 150 & 677 & 541 & 640 & LTCU \\
\hline HOD-A (GREEN) & $09-57-008$ & $5 / 1 / 1970$ & U-9 ITS X-23 & 585795.6 & 4110225.6 & $1,294.8$ & $<20$ & 256 & 562 & 241 & TM-LVTA \\
\hline HOD-B (RED) & $09-57-007$ & $5 / 1 / 1970$ & U-9 ITS X-20 & 585797.2 & 4109859.7 & $1,293.0$ & $<20$ & 280 & 560 & 265 & TM-LVTA \\
\hline HOD-C (BLUE) & $09-57-017$ & $5 / 1 / 1970$ & U-9 iz-25 & 586038.5 & 4110470.0 & $1,302.4$ & $<20$ & 116 & 570 & 101 & TM-LVTA \\
\hline HOGNOSE & 03-57-009 & $3 / 15 / 1962$ & U-3ai & 586168.2 & 4099984.8 & $1,225.0$ & Low & 370 & 492 & 240 & AA \\
\hline HOOK & $09-57-051$ & $4 / 14 / 1964$ & U-9bc & 586179.3 & 4109411.5 & $1,302.7$ & $<20$ & 233 & 571 & 204 & TM-LVTA \\
\hline HOOPOE & 03-57-054 & $12 / 16 / 1964$ & U-3cf & 585968.1 & 4100478.0 & $1,227.1$ & $<20$ & 81 & 494 & 70 & $\mathrm{AA}$ \\
\hline HOOSIC & 09-57-101 & $3 / 28 / 1962$ & U-9j & 585824.9 & 4108896.8 & $1,290.8$ & 3.4 & 202 & 557 & 187 & TM-LVTA \\
\hline HOREHOUND & $03-57-153$ & $8 / 27 / 1969$ & U-3gm & 589385.8 & 4094331.2 & $1,201.5$ & $<20$ & 351 & 460 & 332 & LTCU \\
\hline HOSPAH & $03-57-199$ & $12 / 14 / 1971$ & U-3je & 586356.6 & 4097977.3 & $1,215.2$ & $<20$ & 321 & 482 & 302 & $\mathrm{AA}$ \\
\hline HUDSON & 09-57-105 & $4 / 12 / 1962$ & U-9n & 584845.4 & 4109204.2 & $1,280.2$ & Low & 181 & 539 & 151 & AA \\
\hline HULA & $09-57-068$ & $10 / 29 / 1968$ & U-9bu & 585210.3 & 4107663.6 & $1,280.8$ & $<20$ & 375 & 543 & 200 & AA \\
\hline HULSEA & $02-57-051$ & $3 / 14 / 1974$ & $\mathrm{U}-2 \mathrm{bx}$ & 583106.7 & 4112288.0 & $1,316.4$ & $<20$ & 229 & 577 & 195 & $\mathrm{AA}$ \\
\hline HUPMOBILE & $02-57-153$ & $1 / 18 / 1968$ & $\mathrm{U}-2 \mathrm{y}$ & 582976.7 & 4111227.4 & $1,313.7$ & 7.4 & 280 & 573 & 247 & $\mathrm{AA}$ \\
\hline HURON KING & $03-57-239$ & $6 / 24 / 1980$ & U-3ky & 585915.7 & 4097689.3 & $1,214.6$ & $<20$ & 354 & 481 & 320 & $\overline{A A}$ \\
\hline $\mathrm{HUTCH}$ & $02-57-083$ & $7 / 16 / 1969$ & U-2df & 581050.2 & 4110535.3 & $1,327.1$ & 20 to 200 & 568 & 581 & 549 & AA \\
\hline HUTIA & $03-57-029$ & 6/6/1963 & U-3bc & 585694.3 & 4100015.7 & $1,225.0$ & Low & 142 & 492 & 135 & AA \\
\hline HYRAX & 03-57-034 & 9/14/1962 & U-3bh & 587050.7 & 4099990.9 & $1,224.4$ & Low & 329 & 491 & 217 & AA \\
\hline ICEBERG & $04-57-023$ & $3 / 23 / 1978$ & $\mathrm{U}-4 \mathrm{~g}$ & 584315.6 & 4106380.6 & $1,265.5$ & 20 to 150 & 744 & 485 & 640 & LTCU \\
\hline ILDRIM & $02-57-019$ & $7 / 16 / 1969$ & U-2au & 583943.4 & 4108335.6 & $1,282.9$ & 20 to 200 & 428 & 514 & 410 & TM-WTA \\
\hline IMP & $02-57-037$ & $8 / 9 / 1968$ & U-2bj & 581937.1 & 4113015.3 & $1,340.8$ & $<20$ & 187 & 602 & 182 & AA \\
\hline INGOT & $02-57-139$ & $3 / 9 / 1989$ & $\mathrm{U}-2 \mathrm{gg}$ & 582867.7 & 4110922.0 & $1,307.3$ & 20 to 150 & 555 & 564 & 500 & TM-WTA \\
\hline IPECAC-A & $03-57-175$ & $5 / 27 / 1969$ & U-3hk-a & 588768.4 & 4096797.3 & $1,208.5$ & $<20$ & 134 & 472 & 124 & AA \\
\hline IPECAC-B & $03-57-176$ & $5 / 27 / 1969$ & U-3hk-b & 588950.9 & 4096782.7 & $1,209.4$ & $<20$ & 134 & 473 & 124 & AA \\
\hline ISLAY & $02-57-118$ & 8/27/1981 & U-2er & 582885.3 & 4112872.3 & $1,323.4$ & $<20$ & 335 & 587 & 294 & TM-LVTA \\
\hline
\end{tabular}


Table A.1-1

Shaft and Tunnel Nuclear Detonations in the Yucca Flat/Climax Mine Corrective Action Unit (Page 12 of 24)

\begin{tabular}{|c|c|c|c|c|c|c|c|c|c|c|c|}
\hline Detonation Name & $\begin{array}{c}\text { CAS } \\
\text { Number }\end{array}$ & $\begin{array}{c}\text { Date } \\
\text { Expended }\end{array}$ & $\begin{array}{c}\text { Emplacement } \\
\text { Hole Name }\end{array}$ & $\begin{array}{c}\text { UTM } \\
\text { Easting }\end{array}$ & $\begin{array}{c}\text { UTM } \\
\text { Northing }\end{array}$ & $\begin{array}{c}\text { aLand } \\
\text { Surface } \\
\text { Elevation } \\
\text { (m amsl) }\end{array}$ & $\begin{array}{r}\text { Announced } \\
\text { Yield(kt) }\end{array}$ & $\begin{array}{l}\text { Depth } \\
\text { (m) }\end{array}$ & $\begin{array}{l}\text { Estimated } \\
\text { Depth to } \\
\text { Water (m) }\end{array}$ & $\begin{array}{l}\text { Depth } \\
\text { of } \\
\text { Burial } \\
\text { (m) }\end{array}$ & $\begin{array}{c}\text { Working } \\
\text { Point } \\
\text { HSU }\end{array}$ \\
\hline IZZER & $09-57-064$ & $7 / 16 / 1965$ & U-9bp & 585682.0 & 4107863.3 & $1,299.7$ & $<<20$ & 239 & 565 & 164 & $\overline{\mathrm{AA}}$ \\
\hline JACKPOTS & $03-57-226$ & $6 / 1 / 1978$ & U-3kj & 586113.6 & 4097397.5 & $1,212.8$ & $<20$ & 351 & 479 & 305 & AA \\
\hline $\mathrm{JAL}$ & 03-57-171 & $3 / 19 / 1970$ & U-3hh & 586945.1 & 4095236.8 & $1,205.5$ & $<20$ & 311 & 469 & 301 & AA \\
\hline JARA & $03-57-099$ & $6 / 6 / 1974$ & U-3hp & 586883.1 & 4095541.3 & $1,207.0$ & $<20$ & 396 & 471 & 378 & AA \\
\hline JARLSBERG & $10-57-040$ & $8 / 27 / 1983$ & U-10ca & 585732.9 & 4116509.2 & $1,344.5$ & $<20$ & 265 & 325 & 200 & TM--LVTA \\
\hline JERBOA & $03-57-020$ & $3 / 1 / 1963$ & U-3at & 586571.4 & 4100049.9 & $1,224.1$ & Low & 309 & 491 & 301 & $\mathrm{AA}$ \\
\hline JIB & $03-57-165$ & $5 / 8 / 1974$ & U-3hb & 588834.1 & 4095243.7 & $1,204.3$ & $<20$ & 253 & 463 & 180 & TM-UVTA \\
\hline JICARILLA & $03-57-207$ & 4/19/1972 & U-3jm & 587494.2 & 4095854.9 & $1,207.0$ & $<20$ & 168 & 470 & 148 & AA \\
\hline JORNADA & $04-57-026$ & $1 / 28 / 1982$ & $\mathrm{U}-4 \mathrm{j}$ & 584319.7 & 4105223.0 & $1,260.0$ & 139 & 686 & 477 & 640 & LTCU \\
\hline KANKAKEE & $10-57-052$ & $6 / 15 / 1966$ & U-10p & 584440.2 & 4114121.4 & $1,308.2$ & 20 to 200 & 462 & 575 & 455 & LCA \\
\hline KARA & $02-57-086$ & $5 / 11 / 1972$ & U-2dh-3 & 581340.7 & 4107540.3 & $1,294.5$ & $<20$ & 290 & 554 & 259 & $\mathrm{AA}$ \\
\hline KARAB & $04-57-006$ & $3 / 16 / 1978$ & U-4ah & 581625.6 & 4104512.0 & $1,274.7$ & $<20$ & 351 & 525 & 331 & LTCU \\
\hline KASHAN & $10-57-026$ & $5 / 24 / 1973$ & U-10av & 583820.0 & 4113082.8 & $1,303.9$ & $<20$ & 320 & 567 & 265 & $\mathrm{AA}$ \\
\hline KAWEAH & $09-57-025$ & $2 / 21 / 1963$ & U-9ab & 584777.9 & 4108442.2 & $1,276.2$ & 3 & 233 & 534 & 227 & AA \\
\hline KAWICH A-BLUE & 08-57-009 & $12 / 9 / 1988$ & $U-8 n$ & 580630.7 & 4114503.8 & $1,384.4$ & $<20$ & 577 & 540 & 384 & OSBCU \\
\hline KAWICH A-WHITE & $08-57-009$ & $12 / 9 / 1988$ & U-8n & 580630.7 & 4114503.8 & $1,384.4$ & $<20$ & 577 & 540 & 369 & LTCU \\
\hline KAWICH-BLACK & $02-57-072$ & $2 / 24 / 1989$ & $\mathrm{U}-2 \mathrm{cu}$ & 577996.1 & 4109283.8 & $1,379.5$ & $<20$ & 462 & 551 & 431 & TM-LVTA \\
\hline KAWICH-RED & $02-57-072$ & $2 / 24 / 1989$ & $\mathrm{U}-2 \mathrm{cu}$ & 577996.1 & 4109283.8 & $1,379.5$ & $<20$ & 462 & 551 & 370 & TM-LVTA \\
\hline KEEL & $03-57-189$ & $12 / 16 / 1974$ & U-3hu & 587398.0 & 4096373.8 & $1,208.8$ & $<20$ & 329 & 473 & 305 & $\mathrm{AA}$ \\
\hline KEELSON & 07-57-010 & $2 / 4 / 1976$ & U-7ai & 586217.5 & 4102791.8 & $1,244.8$ & 20 to 200 & 664 & 508 & 640 & LTCU \\
\hline KENNEBEC & $02-57-005$ & $6 / 25 / 1963$ & U-2af & 582780.2 & 4109651.9 & $1,303.0$ & Low & 238 & 554 & 226 & $\mathrm{AA}$ \\
\hline KERMET & $02-57-054$ & $11 / 23 / 1965$ & $\mathrm{U}-2 \mathrm{c}$ & 582493.4 & 4113032.5 & $1,331.4$ & $<20$ & 233 & 594 & 196 & AA \\
\hline KESTI & 09-57-085 & 6/16/1982 & U-9cn & 587373.1 & 4107793.1 & $1,338.4$ & $<20$ & 336 & 606 & 289 & LTCU \\
\hline KESTREL & $03-57-071$ & $4 / 5 / 1965$ & U-3dd & 586935.2 & 4097979.3 & $1,214.6$ & $<20$ & 454 & 481 & 447 & AA \\
\hline KHAKI & $03-57-114$ & $10 / 15 / 1966$ & U-3et & 587414.8 & 4100342.9 & $1,228.6$ & $<20$ & 244 & 495 & 233 & $\mathrm{AA}$ \\
\hline KINIBITO & $03-57-264$ & $12 / 5 / 1985$ & U-3me & 584883.3 & 4101004.2 & $1,235.0$ & 20 to 150 & 686 & 496 & 579 & LTCU \\
\hline KLICKITAT & $10-57-045$ & $2 / 20 / 1964$ & $\mathrm{U}-10 \mathrm{e}$ & 585241.1 & 4111838.4 & $1,300.3$ & 70 & 511 & 568 & 493 & LTCU \\
\hline KLOSTER & $02-57-115$ & $2 / 15 / 1979$ & U-2eo & 582422.6 & 4111935.2 & $1,324.1$ & 20 to 150 & 558 & 584 & 536 & TM-LVTA \\
\hline KNIFE A & $03-57-122$ & 9/12/1968 & U-3fb & 587908.0 & 4098653.1 & $1,217.4$ & $<20$ & 344 & 483 & 332 & TM-LVTA \\
\hline KNIFE B & $03-57-093$ & $11 / 15 / 1968$ & U-3dz & 585990.5 & 4098006.5 & $1,215.2$ & $<20$ & 375 & 482 & 363 & AA \\
\hline KNIFE C & $03-57-112$ & $10 / 3 / 1968$ & U-3er & 589586.5 & 4098019.1 & $1,228.3$ & $<20$ & 314 & 495 & 301 & LTCU \\
\hline KNOX & $02-57-018$ & $2 / 21 / 1968$ & U-2at & 584072.8 & 4108017.9 & $1,279.9$ & 20 to 200 & 669 & 504 & 645 & LTCU \\
\hline
\end{tabular}


Table A.1-1

Shaft and Tunnel Nuclear Detonations in the Yucca Flat/Climax Mine Corrective Action Unit (Page 13 of 24)

\begin{tabular}{|c|c|c|c|c|c|c|c|c|c|c|c|}
\hline Detonation Name & $\begin{array}{c}\text { CAS } \\
\text { Number }\end{array}$ & $\begin{array}{c}\text { Date } \\
\text { Expended }\end{array}$ & $\begin{array}{l}\text { Emplacement } \\
\text { Hole Name }\end{array}$ & $\begin{array}{c}\text { UTM } \\
\text { Easting }\end{array}$ & $\begin{array}{c}\text { UTM } \\
\text { Northing }\end{array}$ & $\begin{array}{c}\text { aLand } \\
\text { Surface } \\
\text { Elevation } \\
\text { (m amsl) }\end{array}$ & $\begin{array}{r}\text { Announced } \\
\text { Yield(kt) }\end{array}$ & $\begin{array}{c}\text { Depth } \\
\text { (m) }\end{array}$ & $\begin{array}{l}\text { Estimated } \\
\text { Depth to } \\
\text { Water (m) }\end{array}$ & $\begin{array}{l}\text { Depth } \\
\text { of } \\
\text { Burial } \\
\text { (m) }\end{array}$ & $\begin{array}{c}\text { Working } \\
\text { Point } \\
\text { HSU }\end{array}$ \\
\hline KOHOCTON & $09-57-034$ & $8 / 23 / 1963$ & U-9ak & 585690.0 & 4108966.8 & $1,300.6$ & Low & 262 & 566 & 255 & TM-LVTA \\
\hline KOOTANAI & 09-57-111 & $4 / 24 / 1963$ & U-9w & 585615.8 & 4108481.7 & $1,287.8$ & Low & 186 & 552 & 182 & AA \\
\hline KRYDDOST & $02-57-066$ & $5 / 6 / 1982$ & $\mathrm{U}-2 \mathrm{co}$ & 577568.2 & 4107987.2 & $1,390.5$ & $<20$ & 357 & 516 & 335 & TM-LVTA \\
\hline KYACK-A & $02-57-044$ & 9/20/1969 & U-2bq-1 & 582780.2 & 4112686.1 & $1,323.4$ & $<20$ & 199 & 586 & 185 & $\mathrm{AA}$ \\
\hline KYACK-B & $02-57-045$ & 9/20/1969 & $\mathrm{U}-2 \mathrm{bq}-2$ & 582920.0 & 4112540.3 & $1,320.1$ & $<20$ & 206 & 582 & 192 & AA \\
\hline LABAN & $02-57-133$ & $8 / 3 / 1983$ & U-2ff & 580942.1 & 4108258.1 & $1,303.0$ & $<20$ & 366 & 561 & 326 & AA \\
\hline LABIS & $10-57-019$ & $2 / 5 / 1970$ & U-10an & 585340.2 & 4113290.2 & $1,313.1$ & 25 & 480 & 580 & 442 & LTCU \\
\hline LAGOON & $10-57-023$ & 10/14/1971 & U-10ar & 584056.7 & 4115032.4 & $1,312.8$ & $<20$ & 369 & 575 & 305 & AA \\
\hline LAGUNA & $03-57-124$ & $6 / 23 / 1971$ & U-3fd & 586937.0 & 4097552.4 & $1,213.4$ & 20 to 200 & 469 & 480 & 455 & TM-WTA \\
\hline LAMPBLACK & $07-57-049$ & $1 / 18 / 1966$ & $\mathrm{U}-7 \mathrm{i}$ & 587212.2 & 4105292.2 & $1,294.2$ & 20 to 200 & 579 & 560 & 561 & OSBCU \\
\hline LANPHER & $02-57-152$ & $10 / 18 / 1967$ & $U-2 x$ & 583723.9 & 4107906.7 & $1,282.0$ & 20 to 200 & 782 & 498 & 715 & LTCU \\
\hline \begin{tabular}{|l|} 
LAREDO \\
\end{tabular} & $03-57-267$ & $5 / 21 / 1988$ & U-3mh & 590070.9 & 4098752.1 & $1,247.2$ & $<150$ & 531 & 515 & 351 & LTCU \\
\hline LATIR & $04-57-020$ & $2 / 27 / 1974$ & U-4d & 584162.6 & 4106654.3 & $1,270.1$ & 20 to 200 & 686 & 486 & 641 & LTCU \\
\hline LEDOUX & 01-57-001 & 9/27/1990 & U-1a.01 & 583791.1 & 4095876.4 & $1,217.7$ & $<20$ & NA & 479 & 291 & AA \\
\hline LEXINGTON & $02-57-039$ & $8 / 24 / 1967$ & $\mathrm{U}-2 \mathrm{bm}$ & 582204.5 & 4113122.6 & $1,336.9$ & $<20$ & 233 & 599 & 226 & AA \\
\hline LEYDEN & 09-57-084 & $11 / 26 / 1975$ & U-9cm & 587165.1 & 4108127.5 & $1,329.8$ & $<20$ & 355 & 597 & 326 & LTCU \\
\hline LIME & $07-57-047$ & 4/1/1966 & $\mathrm{U}-7 \mathrm{j}$ & 587088.1 & 4106511.9 & $1,318.6$ & $<20$ & 578 & 585 & 561 & OSBCU \\
\hline \begin{tabular}{|l|} 
LINKS \\
\end{tabular} & $09-57-054$ & $7 / 23 / 1964$ & U-9bf & 586002.4 & 4107727.0 & $1,300.0$ & $<20$ & 127 & 566 & 120 & $\mathrm{AA}$ \\
\hline LIPTAUER & $02-57-109$ & $4 / 3 / 1980$ & U-2eh & 581499.3 & 4111689.4 & $1,331.4$ & 20 to 150 & 686 & 585 & 417 & $\mathrm{AA}$ \\
\hline LONGCHAMPS & 02-57-091 & 4/19/1972 & $\mathrm{U}-2 \mathrm{dm}$ & 581388.9 & 4108588.7 & $1,303.0$ & $<20$ & 344 & 560 & 326 & AA \\
\hline LOVAGE & $03-57-125$ & $12 / 17 / 1969$ & U-3fe & 586942.7 & 4095846.3 & $1,207.9$ & $<20$ & 396 & 472 & 378 & AA \\
\hline LOWBALL & $07-57-021$ & $7 / 12 / 1978$ & U-7av & 584995.6 & 4103823.6 & $1,252.4$ & 20 to 150 & 591 & 490 & 564 & LTCU \\
\hline LUBBOCK & 03-57-271 & 10/18/1991 & U-3mt & 584879.0 & 4102131.9 & $1,239.6$ & 20 to 150 & 472 & 468 & 457 & LTCU \\
\hline LUNA & $03-57-262$ & 9/21/1958 & $\mathrm{U}-3 \mathrm{~m}$ & 585925.1 & 4100568.1 & $1,227.7$ & 0.0015 & 160 & 495 & 148 & AA \\
\hline MACKEREL & 04-57-018 & $2 / 18 / 1964$ & $\mathrm{U}-4 \mathrm{~b}$ & 584360.3 & 4105698.8 & $1,263.4$ & $<20$ & 500 & 484 & 334 & TM-LVTA \\
\hline MAD & $09-57-023$ & $12 / 13 / 1961$ & U-9a & 584500.3 & 4109136.9 & $1,281.4$ & 0.5 & 187 & 537 & 182 & AA \\
\hline MALLET & $03-57-136$ & $1 / 31 / 1968$ & U-3fv & 588164.0 & 4095241.4 & $1,204.3$ & $<20$ & 253 & 465 & 240 & AA \\
\hline MANATEE & 09-57-029 & $12 / 14 / 1962$ & U-9af & 585284.7 & 4108882.8 & $1,280.8$ & Low & 67 & 543 & 60 & $\mathrm{AA}$ \\
\hline MANTECA & 04-57-010 & $12 / 10 / 1982$ & U-4al & 582496.0 & 4103966.9 & $1,263.1$ & 20 to 150 & 488 & 505 & 413 & AA \\
\hline MANZANAS & 03-57-157 & $5 / 21 / 1970$ & U-3gr & 589681.8 & 4096496.1 & $1,221.6$ & $<20$ & 253 & 485 & 241 & TSA \\
\hline MARIBO & $02-57-070$ & $6 / 26 / 1985$ & $\mathrm{U}-2 \mathrm{cs}$ & 577997.8 & 4108796.2 & $1,379.5$ & $<20$ & 457 & 547 & 381 & TM-LVTA \\
\hline
\end{tabular}


Table A.1-1

Shaft and Tunnel Nuclear Detonations in the Yucca Flat/Climax Mine Corrective Action Unit (Page 14 of 24)

\begin{tabular}{|c|c|c|c|c|c|c|c|c|c|c|c|}
\hline Detonation Name & $\begin{array}{c}\text { CAS } \\
\text { Number }\end{array}$ & $\begin{array}{c}\text { Date } \\
\text { Expended }\end{array}$ & $\begin{array}{c}\text { Emplacement } \\
\text { Hole Name }\end{array}$ & $\begin{array}{c}\text { UTM } \\
\text { Easting }\end{array}$ & $\begin{array}{c}\text { UTM } \\
\text { Northing }\end{array}$ & $\begin{array}{c}\text { aLand } \\
\text { Surface } \\
\text { Elevation } \\
\text { (m amsl) }\end{array}$ & $\begin{array}{l}\text { Announced } \\
\text { Yield(kt) }\end{array}$ & $\begin{array}{l}\text { Depth } \\
\text { (m) }\end{array}$ & $\begin{array}{l}\text { Estimated } \\
\text { Depth to } \\
\text { Water (m) }\end{array}$ & $\begin{array}{l}\text { Depth } \\
\text { of } \\
\text { Burial } \\
(\mathrm{m})\end{array}$ & $\begin{array}{c}\text { Working } \\
\text { Point } \\
\text { HSU }\end{array}$ \\
\hline MARSH & $03-57-220$ & $9 / 6 / 1975$ & U-3kb & 586433.6 & 4097734.1 & $1,214.0$ & $<<20$ & 460 & 480 & 427 & $\overline{A A}$ \\
\hline MARSILLY & $02-57-112$ & $4 / 5 / 1977$ & $\mathrm{U}-2 \mathrm{eL}$ & 583306.2 & 4108418.4 & $1,286.3$ & 20 to 150 & 732 & 520 & 690 & LTCU \\
\hline MARVEL & $10-57-044$ & 9/21/1967 & U-10ds-1 & 585381.5 & 4113496.4 & $1,314.3$ & 2.2 & 626 & 580 & 176 & $\mathrm{AA}$ \\
\hline MATACO & $03-57-036$ & $6 / 14 / 1963$ & U-3bk & 587293.9 & 4100235.9 & $1,227.1$ & Low & 201 & 493 & 196 & AA \\
\hline MAUVE & 03-57-085 & 8/6/1965 & U-3dp & 585415.1 & 4097059.5 & $1,21,2.5$ & $<20$ & 348 & 479 & 321 & AA \\
\hline MAXWELL & $09-57-065$ & $1 / 13 / 1966$ & U-9br & 586397.6 & 4108003.3 & $1,310.0$ & $<20$ & 308 & 578 & 183 & TM-LVTA \\
\hline MEMORY & $03-57-231$ & $3 / 14 / 1979$ & U-3kq & 585411.2 & 4098187.3 & $1,217.7$ & $<20$ & 443 & 485 & 366 & AA \\
\hline MERIDA & $02-57-092$ & 6/7/1972 & U-2dn & 581263.2 & 4107916.4 & $1,297.8$ & $<20$ & 232 & 556 & 204 & AA \\
\hline MERLIN & $03-57-062$ & $2 / 16 / 1965$ & U-3ct & 586803.3 & 4100843.3 & $1,230.8$ & 10.1 & 317 & 497 & 296 & AA \\
\hline MERRIMAC & $03-57-030$ & $7 / 13 / 1962$ & U-3bd & 585946.0 & 4101214.5 & $1,231.7$ & Intermediate & 422 & 498 & 413 & $\overline{A A}$ \\
\hline MESCALERO & $03-57-160$ & 1/5/1972 & U-3gu & 586298.9 & 4100174.2 & $1,225.3$ & $<20$ & 128 & 492 & 120 & AA \\
\hline MESITA & $03-57-198$ & $5 / 9 / 1973$ & U-3jd & 587541.9 & 4095817.0 & $1,207.0$ & $<20$ & 162 & 470 & 149 & AA \\
\hline METROPOLIS & $02-57-140$ & $3 / 10 / 1990$ & U-2gh & 583945.8 & 4107567.1 & $1,273.1$ & 20 to 150 & 549 & 479 & 469 & TM-LVTA \\
\hline MICKEY & $07-57-050$ & $5 / 10 / 1967$ & $\mathrm{U}-7 \mathrm{~m}$ & 589307.3 & 4103777.5 & $1,304.5$ & 20 to 200 & 518 & 573 & 500 & LTCU \\
\hline MIDLAND & $07-57-040$ & $7 / 16 / 1987$ & U-7by & 586783.4 & 4106602.6 & $1,310.6$ & 20 to 150 & 549 & 577 & 488 & OSBCU \\
\hline MIERA & $07-57-005$ & $3 / 8 / 1973$ & U-7ad & 586483.2 & 4106603.9 & $1,306.1$ & 20 to 200 & 599 & 573 & 569 & OSBCU \\
\hline MINERO & $03-57-257$ & $12 / 20 / 1984$ & U-3It & 584988.3 & 4096420.8 & $1,214.6$ & $<20$ & 274 & 481 & 244 & TM-UVTA \\
\hline MINIATA & $02-57-048$ & $7 / 8 / 1971$ & $\mathrm{U}-2 \mathrm{bu}$ & 584282.2 & 4107306.5 & $1,273.8$ & 83 & 564 & 494 & 529 & LTCU \\
\hline MINK & $03-57-005$ & $10 / 29 / 1961$ & U-3ae & 586157.6 & 4100495.8 & $1,227.7$ & Low & 210 & 495 & 192 & AA \\
\hline MINNOW & $03-57-064$ & $5 / 15 / 1964$ & U-3cv & 587843.5 & 4099749.6 & $1,225.9$ & $<20$ & 274 & 492 & 241 & AA \\
\hline MISSISSIPPI & $09-57-027$ & $10 / 5 / 1962$ & U-9ad & 584347.0 & 4110555.5 & $1,290.5$ & 115 & 553 & 546 & 494 & TM-LVTA \\
\hline MIZZEN & 07-57-009 & $6 / 3 / 1975$ & U-7ah & 585660.0 & 4105623.5 & $1,274.1$ & 20 to 200 & 978 & 536 & 637 & LTCU \\
\hline MOA & 03-57-097 & 9/1/1965 & U-3ed & 587692.9 & 4099261.8 & $1,220.7$ & $<20$ & 206 & 487 & 194 & AA \\
\hline MOGOLLON & $03-57-248$ & $4 / 20 / 1986$ & U-3li & 584869.0 & 4096387.5 & $1,214.6$ & $<20$ & 274 & 481 & 259 & TM-UVTA \\
\hline MONAHANS-A & $03-57-250$ & $11 / 9 / 1988$ & U-3lk & 587113.8 & 4094139.8 & $1,202.1$ & $<20$ & 396 & 463 & 290 & $\mathrm{AA}$ \\
\hline MONAHANS-B & $06-57-006$ & 11/9/1988 & $\mathrm{U}-6 \mathrm{i}$ & 587114.5 & 4093866.1 & $1,201.5$ & $<20$ & 320 & 462 & 290 & AA \\
\hline MONERO & $03-57-210$ & $5 / 19 / 1972$ & U-3jq & 588748.7 & 4102312.8 & $1,272.5$ & $<20$ & 580 & 522 & 537 & OSBCU \\
\hline MONTEREY & $04-57-008$ & $7 / 29 / 1982$ & U-4aj & 582197.9 & 4106418.6 & $1,280.2$ & 20 to 150 & 488 & 495 & 400 & TM-LVTA \\
\hline MORRONES & $03-57-103$ & $5 / 21 / 1970$ & U-3ei & 587740.8 & 4102979.7 & $1,264.3$ & 20 to 200 & 533 & 518 & 483 & LTCU \\
\hline MUDPACK & $10-57-051$ & $12 / 16 / 1964$ & U-10n & 582823.3 & 4114801.0 & $1,336.9$ & 2.7 & 160 & 602 & 152 & TM-LVTA \\
\hline MUGGINS & $03-57-256$ & $12 / 9 / 1983$ & U-3ls & 584899.0 & 4096509.5 & $1,215.2$ & $<20$ & 305 & 482 & 244 & TM-UVTA \\
\hline MULESHOE & 07-57-031 & 11/15/1989 & U-7bk & 587666.5 & 4106940.6 & $1,338.4$ & $<20$ & 376 & 606 & 244 & LTCU \\
\hline
\end{tabular}


Table A.1-1

Shaft and Tunnel Nuclear Detonations in the Yucca Flat/Climax Mine Corrective Action Unit (Page 15 of 24)

\begin{tabular}{|c|c|c|c|c|c|c|c|c|c|c|c|}
\hline Detonation Name & $\begin{array}{c}\text { CAS } \\
\text { Number }\end{array}$ & $\begin{array}{c}\text { Date } \\
\text { Expended }\end{array}$ & $\begin{array}{l}\text { Emplacement } \\
\text { Hole Name }\end{array}$ & $\begin{array}{c}\text { UTM } \\
\text { Easting }\end{array}$ & $\begin{array}{c}\text { UTM } \\
\text { Northing }\end{array}$ & $\begin{array}{c}\text { aLand } \\
\text { Surface } \\
\text { Elevation } \\
\text { (m amsl) }\end{array}$ & $\begin{array}{r}\text { Announced } \\
\text { Yield(kt) }\end{array}$ & $\begin{array}{l}\text { Depth } \\
\text { (m) }\end{array}$ & $\begin{array}{l}\text { Estimated } \\
\text { Depth to } \\
\text { Water (m) }\end{array}$ & $\begin{array}{l}\text { Depth } \\
\text { of } \\
\text { Burial } \\
\text { (m) }\end{array}$ & $\begin{array}{c}\text { Working } \\
\text { Point } \\
\text { HSU }\end{array}$ \\
\hline MULLET & $02-57-006$ & $10 / 17 / 1963$ & U-2ag & 582878.8 & 4109587.4 & $1,301.5$ & Low & 63 & 552 & $\overline{600}$ & $\overline{\mathrm{AA}}$ \\
\hline MUNDO & $07-57-034$ & $5 / 1 / 1984$ & U-7bo & 586866.8 & 4106899.7 & $1,319.2$ & 20 to 150 & 610 & 586 & 567 & OSBCU \\
\hline MUSCOVY & $03-57-091$ & $4 / 23 / 1965$ & $U-3 d x$ & 589376.5 & 4097073.4 & $1,216.5$ & $<20$ & 191 & 482 & 180 & TM-WTA \\
\hline MUSHROOM & $03-57-100$ & $3 / 3 / 1967$ & U-3ef & 588026.9 & 4099506.8 & $1,225.0$ & $<20$ & 191 & 491 & 180 & AA \\
\hline MUSTANG & $09-57-040$ & $11 / 15 / 1963$ & U-9at & 584660.2 & 4109770.1 & $1,283.8$ & Low & 174 & 542 & 166 & AA \\
\hline NAMA-AMARYLIS & $09-57-020$ & $8 / 5 / 1971$ & U-9 ITS XY-31 & 585853.1 & 4111200.7 & $1,300.3$ & $<20$ & 305 & 568 & 273 & LTCU \\
\hline NAMA-MEPHISTO & 09-57-019 & $8 / 5 / 1971$ & U-9 ITS Z-27 & 586037.6 & 4110713.8 & $1,303.0$ & $<20$ & 264 & 571 & 244 & TM-LVTA \\
\hline NARRAGUAGUS & $02-57-127$ & 9/27/1963 & $U-2 f$ & 582284.4 & 4112241.0 & $1,328.9$ & Low & 156 & 589 & 150 & AA \\
\hline NASH & $02-57-058$ & $1 / 19 / 1967$ & U-2ce & 576803.9 & 4110955.3 & $1,452.1$ & 39 & 370 & 527 & 365 & LCA3 \\
\hline NATCHES & $09-57-033$ & $8 / 23 / 1963$ & U-9ak \#1 & 585702.2 & 4108966.8 & $1,288.4$ & Low & 64 & 554 & 59 & $\mathrm{AA}$ \\
\hline NATOMA & $10-57-027$ & $4 / 5 / 1973$ & U-10aw & 583987.3 & 4114820.4 & $1,309.7$ & $<20$ & 416 & 574 & 244 & AA \\
\hline NAVATA & $03-57-242$ & 9/29/1983 & U-3lb & 587107.3 & 4101042.4 & $1,233.8$ & $<20$ & 244 & 500 & 183 & AA \\
\hline NESSEL & $02-57-116$ & $8 / 29 / 1979$ & U-2ep & 582922.5 & 4108524.0 & $1,286.6$ & 20 to 150 & 543 & 532 & 464 & AA \\
\hline NEWARK & $10-57-057$ & 9/29/1966 & U-10u & 584694.2 & 4113804.8 & $1,306.1$ & $<20$ & 233 & 573 & 229 & AA \\
\hline NIGHTINGALE & $02-57-125$ & $6 / 22 / 1988$ & U-2ey & 582371.1 & 4113504.4 & $1,336.2$ & $<150$ & 279 & 600 & 238 & AA \\
\hline NIPPER & 03-57-152 & $2 / 4 / 1969$ & $U-3 g L$ & 588163.4 & 4095423.9 & $1,204.9$ & $<20$ & 253 & 466 & 241 & AA \\
\hline NIZA & $09-57-088$ & 7/10/1981 & U-9cr & 585829.0 & 4109372.2 & $1,293.0$ & $<20$ & 369 & 560 & 341 & LTCU \\
\hline NOGGIN & $09-57-070$ & 9/6/1968 & U-9bx & 584631.9 & 4110188.0 & $1,286.3$ & 20 to 200 & 640 & 543 & 582 & TM-LVTA \\
\hline NOOR & $02-57-032$ & $4 / 10 / 1968$ & U-2be & 581797.0 & 4112191.7 & $1,336.5$ & 20 to 200 & 399 & 596 & 381 & $\mathrm{AA}$ \\
\hline NORBO & $08-57-003$ & $3 / 8 / 1980$ & U-8c & 581390.6 & 4115024.5 & $1,376.2$ & $<20$ & 279 & 639 & 271 & OSBCU \\
\hline NORMANNA & $10-57-041$ & $7 / 12 / 1984$ & U-10cb & 585704.1 & 4116403.1 & $1,342.3$ & $<20$ & 230 & 350 & 200 & LTCU \\
\hline NUMBAT & $03-57-046$ & $12 / 12 / 1962$ & U-3bu & 587537.7 & 4100236.7 & $1,228.3$ & Low & 256 & 494 & 232 & AA \\
\hline OAKLAND & $02-57-036$ & $4 / 4 / 1967$ & $\mathrm{U}-2 \mathrm{bi}$ & 581489.4 & 4113032.0 & $1,348.1$ & $<20$ & 171 & 601 & 166 & AA \\
\hline OARLOCK & $03-57-228$ & $2 / 16 / 1977$ & U-3km & 586422.3 & 4096606.3 & $1,210.1$ & $<20$ & 343 & 476 & 320 & $\mathrm{AA}$ \\
\hline OBAR & $07-57-008$ & $4 / 30 / 1975$ & U-7ag & 586293.8 & 4107185.6 & $1,306.4$ & 20 to 200 & 602 & 573 & 569 & OSBCU \\
\hline OCATE & $03-57-209$ & $3 / 30 / 1972$ & U-3jp & 587651.1 & 4095621.1 & $1,206.4$ & $<20$ & 229 & 469 & 210 & $\mathrm{AA}$ \\
\hline OCHRE & 03-57-096 & $4 / 29 / 1966$ & $\mathrm{U}-3 \mathrm{ec}$ & 586928.6 & 4099960.0 & $1,223.2$ & $<20$ & 136 & 490 & 126 & $A A$ \\
\hline OCONTO & $09-57-045$ & $1 / 23 / 1964$ & U-9ay & 585607.7 & 4109127.7 & $1,286.6$ & 10.5 & 277 & 552 & 265 & TM-LVTA \\
\hline OFFSHORE & $03-57-233$ & 8/8/1979 & U-3ks & 588250.1 & 4096765.0 & $1,208.8$ & 20 to 150 & 492 & 472 & 396 & LTCU \\
\hline ONAJA & $03-57-212$ & $3 / 30 / 1972$ & U-3js & 587187.2 & 4095725.2 & $1,207.0$ & $<20$ & 321 & 471 & 279 & $\mathrm{AA}$ \\
\hline ORGANDY & $09-57-063$ & $6 / 11 / 1965$ & U-9bo & 586778.3 & 4107958.6 & $1,320.4$ & $<20$ & 191 & 588 & 168 & TM-LVTA \\
\hline
\end{tabular}


Table A.1-1

Shaft and Tunnel Nuclear Detonations in the Yucca Flat/Climax Mine Corrective Action Unit (Page 16 of 24)

\begin{tabular}{|c|c|c|c|c|c|c|c|c|c|c|c|}
\hline Detonation Name & $\begin{array}{c}\text { CAS } \\
\text { Number }\end{array}$ & $\begin{array}{c}\text { Date } \\
\text { Expended }\end{array}$ & $\begin{array}{l}\text { Emplacement } \\
\text { Hole Name }\end{array}$ & $\begin{array}{c}\text { UTM } \\
\text { Easting }\end{array}$ & $\begin{array}{c}\text { UTM } \\
\text { Northing }\end{array}$ & $\begin{array}{c}\text { aLand } \\
\text { Surface } \\
\text { Elevation } \\
\text { (m amsl) }\end{array}$ & $\begin{array}{r}\text { Announced } \\
\text { Yield(kt) }\end{array}$ & $\begin{array}{l}\text { Depth } \\
\text { (m) }\end{array}$ & $\begin{array}{c}\text { Estimated } \\
\text { Depth to } \\
\text { Water (m) }\end{array}$ & 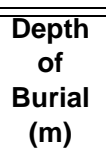 & $\begin{array}{c}\text { Working } \\
\text { Point } \\
\text { HSU }\end{array}$ \\
\hline ORKNEY & $10-57-035$ & $5 / 2 / 1984$ & U-10be & 583958.3 & 4117105.7 & $1,378.3$ & $<<20$ & 229 & 2606 & 210 & $\overline{\mathrm{AA}}$ \\
\hline OSCURO & $07-57-062$ & 9/21/1972 & $\mathrm{U}-7 \mathrm{z}$ & 585633.6 & 4104206.1 & $1,252.1$ & 20 to 200 & 581 & 513 & 560 & LTCU \\
\hline OTERO & $03-57-274$ & 9/12/1958 & $U-3 q$ & 586089.4 & 4100642.4 & $1,229.0$ & 0.038 & 157 & 496 & 146 & $\mathrm{AA}$ \\
\hline PACA & $03-57-024$ & $5 / 7 / 1962$ & U-3ax & 586701.4 & 4100279.2 & $1,225.6$ & Low & 267 & 492 & 258 & AA \\
\hline PACKARD & $02-57-150$ & $1 / 15 / 1969$ & $\mathrm{U}-2 \mathrm{u}$ & 582975.8 & 4111486.5 & $1,315.2$ & 10 & 311 & 575 & 247 & AA \\
\hline PACKRAT & $03-57-023$ & $6 / 6 / 1962$ & U-3aw & 585432.6 & 4100172.0 & $1,225.9$ & Low & 270 & 492 & 262 & AA \\
\hline PAISANO & $09-57-112$ & $4 / 24 / 1963$ & U-9w-1 & 585625.0 & 4108474.1 & $1,287.8$ & Low & 62 & 553 & 57 & AA \\
\hline PAJARA & $03-57-203$ & $12 / 12 / 1973$ & $\mathrm{U}-3 \mathrm{ji}$ & 586842.2 & 4094169.9 & $1,202.4$ & $<20$ & 297 & 465 & 278 & AA \\
\hline PALISADE-1 & $04-57-015$ & $5 / 15 / 1989$ & U-4at & 578112.7 & 4106968.3 & $1,365.2$ & $<20$ & 464 & 490 & 335 & TM-LVTA \\
\hline PALISADE-2 & $04-57-015$ & $5 / 15 / 1989$ & U-4at & 578112.7 & 4106968.3 & $1,365.2$ & $<20$ & 464 & 490 & 390 & TM-LVTA \\
\hline PALISADE-3 & 04-57-015 & 5/15/1989 & U-4at & 578112.7 & 4106968.3 & $1,365.2$ & $<20$ & 464 & 490 & 404 & TM-LVTA \\
\hline PALIZA & $07-57-026$ & $10 / 1 / 1981$ & U-7bd & 588106.2 & 4104182.8 & $1,287.5$ & 20 to 150 & 610 & 533 & 472 & LTCU \\
\hline PAMPAS & $03-57-012$ & $3 / 1 / 1962$ & U-3aL & 586380.7 & 4099687.8 & $1,222.9$ & 9.5 & 370 & 490 & 363 & AA \\
\hline PANAMINT & $02-57-136$ & $5 / 21 / 1986$ & $\mathrm{U}-2 \mathrm{gb}$ & 583468.9 & 4108952.6 & $1,286.0$ & $<20$ & 573 & 529 & 480 & TM-WTA \\
\hline PANCHUELA & $03-57-266$ & 6/30/1987 & U-3mg & 585148.3 & 4094941.0 & $1,206.1$ & $<20$ & 457 & 473 & 320 & AA \\
\hline PAR & $02-57-146$ & $10 / 9 / 1964$ & $U-2 p$ & 581965.5 & 4111857.4 & $1,331.4$ & 38 & 416 & 586 & 406 & AA \\
\hline PARNASSIA & $02-57-030$ & $11 / 30 / 1971$ & $U-2 b c$ & 582555.9 & 4112872.7 & $1,328.9$ & $<20$ & 346 & 592 & 331 & TM-LVTA \\
\hline PARROT & $03-57-080$ & $12 / 16 / 1964$ & U-3dk & 587846.5 & 4098988.1 & $1,219.5$ & 1.3 & 187 & 486 & 180 & AA \\
\hline PASCAL-A & $03-57-194$ & $7 / 26 / 1957$ & U-3j & 585947.3 & 4100848.8 & $1,229.3$ & Slight & 152 & 496 & 152 & AA \\
\hline PASCAL-B & $03-57-068$ & 8/27/1957 & $U-3 d$ & 585902.7 & 4100547.6 & $1,227.7$ & Slight & 152 & 495 & 152 & AA \\
\hline PASCAL-C & $03-57-094$ & $12 / 6 / 1957$ & $U-3 e$ & 586176.6 & 4100648.5 & $1,228.6$ & Slight & 158 & 496 & 76 & AA \\
\hline PASSAIC & $09-57-103$ & $4 / 6 / 1962$ & U-9L & 584931.9 & 4108150.8 & $1,275.0$ & Low & 270 & 536 & 233 & AA \\
\hline PEBA & $03-57-028$ & 9/20/1962 & U-3bb & 586311.4 & 4101215.8 & $1,232.3$ & Low & 283 & 499 & 241 & AA \\
\hline PEDERNAL & $03-57-170$ & 9/29/1971 & U-3hg & 588312.5 & 4096353.9 & $1,207.3$ & $<20$ & 396 & 470 & 379 & TM-LVTA \\
\hline PEKAN & $03-57-048$ & $8 / 12 / 1963$ & U-3bw & 587539.1 & 4099748.9 & $1,223.8$ & Low & 311 & 490 & 302 & $\mathrm{AA}$ \\
\hline PENASCO & $03-57-181$ & 11/19/1970 & U-3hL & 587549.3 & 4096762.6 & $1,209.8$ & $<20$ & 282 & 475 & 271 & AA \\
\hline PERA & $10-57-034$ & 9/8/1979 & U-10bd & 585407.4 & 4112296.1 & $1,307.3$ & $<20$ & 335 & 575 & 200 & TM-LVTA \\
\hline PERSIMMON & $03-57-083$ & $2 / 23 / 1967$ & U-3dn & 587548.2 & 4097067.6 & $1,210.7$ & $<20$ & 309 & 476 & 299 & $\mathrm{AA}$ \\
\hline PETREL & 03-57-092 & 6/11/1965 & U-3dy & 587416.2 & 4099870.0 & $1,224.1$ & 1.3 & 192 & 490 & 181 & AA \\
\hline PICCALILLI & $03-57-123$ & $11 / 21 / 1969$ & U-3fc & 588761.4 & 4098595.2 & $1,222.2$ & 20 to 200 & 407 & 489 & 394 & LTCU \\
\hline PIKE & $03-57-066$ & $3 / 13 / 1964$ & U-3cy & 587901.4 & 4100724.6 & $1,237.5$ & $<20$ & 289 & 501 & 115 & AA \\
\hline PILE DRIVER & $15-57-002$ & $6 / 2 / 1966$ & U-15.01 & 583511.6 & 4119950.0 & $1,551.4$ & 62 & NA & 185 & 463 & MGCU \\
\hline
\end{tabular}


Table A.1-1

Shaft and Tunnel Nuclear Detonations in the Yucca Flat/Climax Mine Corrective Action Unit (Page 17 of 24)

\begin{tabular}{|c|c|c|c|c|c|c|c|c|c|c|c|}
\hline Detonation Name & $\begin{array}{c}\text { CAS } \\
\text { Number }\end{array}$ & $\begin{array}{c}\text { Date } \\
\text { Expended }\end{array}$ & $\begin{array}{l}\text { Emplacement } \\
\text { Hole Name }\end{array}$ & $\begin{array}{c}\text { UTM } \\
\text { Easting }\end{array}$ & $\begin{array}{c}\text { UTM } \\
\text { Northing }\end{array}$ & $\begin{array}{c}\text { aLand } \\
\text { Surface } \\
\text { Elevation } \\
\text { (m amsl) }\end{array}$ & $\begin{array}{r}\text { Announced } \\
\text { Yield(kt) }\end{array}$ & $\begin{array}{l}\text { Depth } \\
\text { (m) }\end{array}$ & $\begin{array}{l}\text { Estimated } \\
\text { Depth to } \\
\text { Water (m) }\end{array}$ & $\begin{array}{l}\text { Depth } \\
\text { of } \\
\text { Burial } \\
\text { (m) }\end{array}$ & $\begin{array}{c}\text { Working } \\
\text { Point } \\
\text { HSU }\end{array}$ \\
\hline PINEAU & $07-57-016$ & $7 / 16 / 1981$ & U-7ao & 587154.5 & 4104958.3 & $1,286.3$ & $2<20$ & 460 & 552 & 204 & TM-UVTA \\
\hline PINEDROPS-BAYOU & $10-57-024$ & $1 / 10 / 1974$ & U-10as & 584266.4 & 4114406.9 & $1,310.0$ & $<20$ & 366 & 576 & 343 & TM-LVTA \\
\hline PINEDROPS-SLOAT & $10-57-024$ & $1 / 10 / 1974$ & U-10as & 584266.4 & 4114406.9 & $1,310.0$ & $<20$ & 366 & 576 & 213 & $\mathrm{AA}$ \\
\hline PINEDROPS-TAWNY & $10-57-024$ & $1 / 10 / 1974$ & U-10as & 584266.4 & 4114406.9 & $1,310.0$ & $<20$ & 366 & 576 & 282 & TM-LVTA \\
\hline PIPEFISH & 03-57-059 & $4 / 29 / 1964$ & $\mathrm{U}-3 \mathrm{co}$ & 586564.5 & 4099501.4 & $1,221.0$ & $<20$ & 274 & 488 & 262 & $\mathrm{AA}$ \\
\hline PIRANHA & $07-57-043$ & $5 / 13 / 1966$ & U-7e & 585905.9 & 4104740.6 & $1,263.7$ & 20 to 200 & 587 & 526 & 549 & LTCU \\
\hline PITON-A & $09-57-014$ & $5 / 28 / 1970$ & U-9 ITS Y-30 & 585914.5 & 4111079.0 & $1,300.9$ & $<20$ & 251 & 568 & 236 & TM-LVTA \\
\hline PITON-B & 09-57-010 & $5 / 28 / 1970$ & U-9 ITS X-27 & 585794.5 & 4110712.6 & $1,296.9$ & $<20$ & 244 & 564 & 229 & TM-LVTA \\
\hline PITON-C & $09-57-116$ & $5 / 28 / 1970$ & U-9 ITS AA-25 & 586160.7 & 4110470.4 & $1,305.8$ & $<20$ & 122 & 573 & 101 & TM-LVTA \\
\hline PLAID II & $02-57-148$ & $2 / 3 / 1966$ & $\mathrm{U}-2 \mathrm{r}$ & 582660.9 & 4109086.8 & $1,298.4$ & $<20$ & 500 & 546 & 269 & AA \\
\hline PLANER & 03-57-106 & $11 / 21 / 1969$ & U-3el & 586939.8 & 4096760.4 & $1,210.4$ & $<20$ & 396 & 476 & 378 & AA \\
\hline PLATYPUS & $03-57-004$ & $2 / 24 / 1962$ & U-3ad & 586086.1 & 4100469.3 & $1,227.1$ & Low & 66 & 494 & 58 & AA \\
\hline PLAYER & $09-57-075$ & $8 / 27 / 1964$ & U-9cc & 585230.1 & 4108118.6 & $1,280.5$ & $<20$ & 94 & 543 & 90 & $\overline{A A}$ \\
\hline PLEASANT & $09-57-030$ & $5 / 29 / 1963$ & U-9ah & 584973.0 & 4109304.9 & $1,279.6$ & Low & 219 & 540 & 211 & AA \\
\hline PLIERS & $03-57-154$ & $8 / 27 / 1969$ & U-3gn & 585566.0 & 4097487.0 & $1,214.3$ & $<20$ & 253 & 481 & 239 & $\mathrm{AA}$ \\
\hline PLOMO & $03-57-126$ & 5/1/1974 & U-3ff & 590224.1 & 4098600.6 & $1,253.9$ & $<20$ & 283 & 522 & 149 & TM-LVTA \\
\hline POD-A & $02-57-063$ & $10 / 29 / 1969$ & U-2ck & 577225.1 & 4110576.5 & $1,424.0$ & \multirow{4}{*}{16.7} & 285 & 540 & 267 & TM-LVTA \\
\hline POD-B & $02-57-060$ & $10 / 29 / 1969$ & U-2ch & 576218.3 & 4110593.9 & $1,491.7$ & & 267 & 444 & 249 & TM-LVTA \\
\hline POD-C & $02-57-061$ & $10 / 29 / 1969$ & U-2ci & 576388.4 & 4110138.7 & $1,474.9$ & & 265 & 466 & 171 & $\mathrm{AA}$ \\
\hline POD-D & $02-57-062$ & 10/29/1969 & U-2cj & 576745.9 & 4110032.1 & $1,451.2$ & & 334 & 512 & 312 & TM-LVTA \\
\hline POLKA & $10-57-008$ & $12 / 6 / 1967$ & U-10ai & 584091.8 & 4112756.8 & $1,299.4$ & $<20$ & 207 & 558 & 190 & $\mathrm{AA}$ \\
\hline POLYGONUM & $02-57-052$ & $10 / 2 / 1973$ & U-2by & 582313.0 & 4112686.0 & $1,330.8$ & $<20$ & 244 & 592 & 213 & AA \\
\hline POMMARD & $03-57-098$ & $3 / 14 / 1968$ & U-3ee & 587962.8 & 4100420.7 & $1,235.4$ & 1.5 & 223 & 501 & 209 & AA \\
\hline PONGEE & $02-57-007$ & $7 / 22 / 1965$ & U-2ah & 582887.3 & 4109696.8 & $1,301.5$ & $<20$ & 142 & 553 & 135 & AA \\
\hline PONIL & $07-57-039$ & 9/27/1985 & U-7bv & 588717.6 & 4105097.9 & $1,310.6$ & $<20$ & 396 & 556 & 366 & LTCU \\
\hline PORTMANTEAU & $02-57-022$ & $8 / 30 / 1974$ & $\mathrm{U}-2 \mathrm{ax}$ & 581401.3 & 4111977.3 & $1,340.2$ & 20 to 200 & 701 & 600 & 655 & TM-LVTA \\
\hline PORTOLA & $10-57-032$ & $2 / 6 / 1975$ & U-10bb & 584194.6 & 4114881.4 & $1,31,2.2$ & $<20$ & 290 & 575 & 198 & AA \\
\hline PORTOLA-LARKIN & $10-57-032$ & $2 / 6 / 1975$ & U-10bb & 584194.6 & 4114881.4 & $1,312.2$ & $<20$ & 290 & 575 & 274 & AA \\
\hline PORTULACA & $02-57-049$ & $6 / 28 / 1973$ & $\mathrm{U}-2 \mathrm{bv}$ & 581181.7 & 4111525.2 & $1,337.5$ & 20 to 200 & 518 & 591 & 466 & AA \\
\hline POTRERO & $02-57-106$ & $4 / 23 / 1974$ & U-2eb & 582007.9 & 4112814.4 & $1,337.2$ & $<20$ & 274 & 597 & 210 & $\overline{A A}$ \\
\hline POTRILLO & $07-57-007$ & $6 / 21 / 1973$ & U-7af & 586452.7 & 4105321.5 & $1,282.3$ & 20 to 200 & 606 & 548 & 568 & OSBCU \\
\hline
\end{tabular}


Table A.1-1

Shaft and Tunnel Nuclear Detonations in the Yucca Flat/Climax Mine Corrective Action Unit (Page 18 of 24)

\begin{tabular}{|c|c|c|c|c|c|c|c|c|c|c|c|}
\hline Detonation Name & $\begin{array}{c}\text { CAS } \\
\text { Number }\end{array}$ & $\begin{array}{c}\text { Date } \\
\text { Expended }\end{array}$ & $\begin{array}{c}\text { Emplacement } \\
\text { Hole Name }\end{array}$ & $\begin{array}{l}\text { UTM } \\
\text { Easting }\end{array}$ & $\begin{array}{c}\text { UTM } \\
\text { Northing }\end{array}$ & $\begin{array}{c}\text { aLand } \\
\text { Surface } \\
\text { Elevation } \\
\text { (m amsl) }\end{array}$ & $\begin{array}{r}\text { Announced } \\
\text { Yield(kt) }\end{array}$ & $\begin{array}{l}\text { Depth } \\
\text { (m) }\end{array}$ & $\begin{array}{c}\text { Estimated } \\
\text { Depth to } \\
\text { Water }(\mathrm{m})\end{array}$ & $\begin{array}{l}\text { Depth } \\
\text { of } \\
\text { Burial } \\
\text { (m) }\end{array}$ & $\begin{array}{c}\text { Working } \\
\text { Point } \\
\text { HSU }\end{array}$ \\
\hline PRATT & $03-57-185$ & $9 / 25 / 1974$ & U-3hq & 586270.5 & 4096453.4 & $1,210.1$ & $<20$ & 335 & 476 & 313 & $\overline{A A}$ \\
\hline PRESIDIO & $06-57-002$ & $4 / 22 / 1987$ & U-6d & 588591.5 & 4093261.8 & $1,198.5$ & $<20$ & 396 & 458 & 320 & TM-LVTA \\
\hline PUCE & $03-57-044$ & $6 / 10 / 1966$ & U-3bs & 585459.2 & 4101692.1 & $1,235.4$ & $<20$ & 492 & 493 & 486 & AA \\
\hline PUDDLE & $03-57-224$ & $11 / 26 / 1974$ & U-3kg & 587981.2 & 4095240.4 & $1,219.8$ & $<20$ & 203 & 481 & 183 & AA \\
\hline PURPLE & $03-57-087$ & $3 / 18 / 1966$ & U-3ds & 588160.5 & 4096154.9 & $1,206.7$ & $<20$ & 346 & 469 & 333 & TM-WTA \\
\hline PUYE & $03-57-206$ & $8 / 14 / 1974$ & U-3jl & 585717.6 & 4097700.5 & $1,215.2$ & $<20$ & 460 & 482 & 430 & AA \\
\hline PYRAMID & $07-57-027$ & $4 / 16 / 1980$ & U-7be & 586148.4 & 4106326.1 & $1,292.7$ & 20 to 150 & 610 & 557 & 579 & OSBCU \\
\hline QUARGEL & $02-57-129$ & $11 / 18 / 1978$ & $\mathrm{U}-2 \mathrm{fb}$ & 581380.9 & 4109135.7 & $1,301.8$ & 20 to 150 & 567 & 539 & 542 & TM-LVTA \\
\hline QUESO & $10-57-036$ & $8 / 11 / 1982$ & U-10bf & 584525.4 & 4116147.8 & $1,337.2$ & $<20$ & 555 & 571 & 216 & $\mathrm{AA}$ \\
\hline QUINELLA & $04-57-027$ & $2 / 8 / 1979$ & U-4I & 583986.5 & 4106455.6 & $1,267.7$ & 20 to 150 & 710 & 484 & 579 & LTCU \\
\hline RACCOON & $03-57-010$ & 6/1/1962 & U-3ajS & 585861.6 & 4100165.0 & $1,225.6$ & Low & 172 & 493 & 164 & $\mathrm{AA}$ \\
\hline RACK & $09-57-037$ & $8 / 15 / 1968$ & U-9ap & 584551.1 & 4108818.9 & $1,280.5$ & $<20$ & 236 & 536 & 200 & AA \\
\hline RARITAN & 09-57-109 & 9/6/1962 & U-9u & 584853.6 & 4109551.9 & $1,281.4$ & Low & 181 & 540 & 157 & $\overline{A A}$ \\
\hline REBLOCHON & $02-57-114$ & $2 / 23 / 1978$ & U-2en & 583164.7 & 4108799.1 & $1,288.1$ & 20 to 150 & 747 & 534 & 658 & LTCU \\
\hline REDMUD & $07-57-003$ & $12 / 8 / 1976$ & U-7ab & 588743.0 & 4103928.1 & $1,295.7$ & $<20$ & 519 & 533 & 427 & LTCU \\
\hline REO & $10-57-050$ & $1 / 22 / 1966$ & $\mathrm{U}-10 \mathrm{~m}$ & 585360.5 & 4112541.0 & $1,309.4$ & $<20$ & 328 & 577 & 208 & AA \\
\hline RHYOLITE & $02-57-126$ & $6 / 22 / 1988$ & U-2ey & 582371.1 & 4113504.4 & $1,336.2$ & $<150$ & 279 & 600 & 207 & $\mathrm{AA}$ \\
\hline RIB & $03-57-215$ & $12 / 14 / 1977$ & U-3jv & 587365.7 & 4097067.0 & $1,211.0$ & $<20$ & 232 & 477 & 213 & $\overline{A A}$ \\
\hline RINGTAIL & $03-57-011$ & $12 / 17 / 1961$ & U-3ak & 586678.0 & 4099901.2 & $1,223.5$ & Low & 370 & 490 & 363 & AA \\
\hline RIOLA & $02-57-117$ & 9/25/1980 & U-2eq & 583107.7 & 4107931.4 & $1,281.1$ & 1.07 & 520 & 508 & 424 & AA \\
\hline RIVET I & $10-57-002$ & $1 / 18 / 1967$ & U-10aa & 584653.8 & 4113411.8 & $1,302.4$ & $<20$ & 206 & 567 & 152 & AA \\
\hline RIVET II & $10-57-061$ & $1 / 26 / 1967$ & $\mathrm{U}-10 \mathrm{z}$ & 584519.9 & 4113374.8 & $1,300.6$ & $<20$ & 223 & 563 & 198 & AA \\
\hline RIVET III & $10-57-060$ & $3 / 2 / 1967$ & U-10y & 584461.9 & 4113493.1 & $1,301.5$ & $<20$ & 308 & 567 & 274 & $\mathrm{AA}$ \\
\hline RIVOLI & $02-57-108$ & $5 / 20 / 1976$ & U-2eg & 582905.9 & 4110296.9 & $1,305.8$ & $<20$ & 297 & 559 & 200 & $\overline{A A}$ \\
\hline ROANOKE & $09-57-107$ & $10 / 12 / 1962$ & $\mathrm{U}-9 \mathrm{q}$ & 584322.4 & 4108706.0 & $1,279.6$ & Low & 218 & 530 & 177 & $\mathrm{AA}$ \\
\hline ROMANO & $02-57-124$ & $12 / 16 / 1983$ & U-2ex & 582414.6 & 4110652.3 & $1,314.0$ & 20 to 150 & 612 & 561 & 515 & TM-UVTA \\
\hline ROQUEFORT & $04-57-014$ & 10/16/1985 & U-4as & 578066.1 & 4107227.1 & $1,367.9$ & 20 to 150 & 442 & 508 & 415 & TM-LVTA \\
\hline ROUSANNE & $04-57-030$ & $11 / 12 / 1981$ & $U-4 p$ & 584501.4 & 4107089.7 & $1,269.8$ & 20 to 150 & 564 & 499 & 518 & LTCU \\
\hline ROVENA & $10-57-055$ & $8 / 10 / 1966$ & U-10s & 584541.8 & 4113804.2 & $1,304.8$ & $<20$ & 198 & 572 & 195 & $\mathrm{AA}$ \\
\hline RUDDER & $07-57-011$ & 12/28/1976 & U-7aj-s & 585622.1 & 4106251.4 & $1,281.7$ & 20 to 150 & 698 & 544 & 640 & OSBCU \\
\hline RUMMY & $07-57-020$ & 9/27/1978 & U-7au & 584324.5 & 4103942.8 & $1,253.0$ & 20 to 150 & 744 & 489 & 640 & LTCU \\
\hline RUSSET & $06-57-001$ & $3 / 5 / 1968$ & U-6a & 584046.3 & 4091762.8 & $1,197.9$ & $<20$ & 130 & 459 & 120 & PCUT \\
\hline
\end{tabular}


Table A.1-1

Shaft and Tunnel Nuclear Detonations in the Yucca Flat/Climax Mine Corrective Action Unit (Page 19 of 24)

\begin{tabular}{|c|c|c|c|c|c|c|c|c|c|c|c|}
\hline Detonation Name & $\begin{array}{c}\text { CAS } \\
\text { Number }\end{array}$ & $\begin{array}{c}\text { Date } \\
\text { Expended }\end{array}$ & $\begin{array}{l}\text { Emplacement } \\
\text { Hole Name }\end{array}$ & $\begin{array}{c}\text { UTM } \\
\text { Easting }\end{array}$ & $\begin{array}{c}\text { UTM } \\
\text { Northing }\end{array}$ & $\begin{array}{c}\text { aLand } \\
\text { Surface } \\
\text { Elevation } \\
\text { (m amsl) }\end{array}$ & $\begin{array}{r}\text { Announced } \\
\text { Yield(kt) }\end{array}$ & $\begin{array}{l}\text { Depth } \\
\text { (m) }\end{array}$ & $\begin{array}{l}\text { Estimated } \\
\text { Depth to } \\
\text { Water (m) }\end{array}$ & $\begin{array}{l}\text { Depth } \\
\text { of } \\
\text { Burial } \\
\text { (m) }\end{array}$ & $\begin{array}{c}\text { Working } \\
\text { Point } \\
\text { HSU }\end{array}$ \\
\hline SABADO & $03-57-243$ & $8 / 11 / 1983$ & U-3ाc & 588744.6 & 4094877.4 & $1,202.7$ & $2<20$ & 335 & 461 & 320 & UTCU \\
\hline SACRAMENTO & $09-57-110$ & 6/30/1962 & U-9v & 584629.8 & 4108118.6 & $1,273.1$ & Low & 267 & 527 & 149 & AA \\
\hline SAN JUAN & $03-57-273$ & $10 / 20 / 1958$ & U-3p & 586030.1 & 4100629.1 & $1,228.0$ & Zero & 160 & 495 & 71 & AA \\
\hline SANDREEF & 07-57-018 & $11 / 9 / 1977$ & $\mathrm{U}-7 \mathrm{aq}$ & 584449.6 & 4103090.0 & $1,247.9$ & 20 to 150 & 1103 & 479 & 701 & LTCU \\
\hline SANTEE & $10-57-046$ & $10 / 27 / 1962$ & U-10f & 584053.6 & 4111651.4 & $1,296.6$ & Low & 323 & 551 & 319 & $\mathrm{AA}$ \\
\hline SAPELLO & $03-57-145$ & $4 / 12 / 1974$ & U-3ge & 585035.3 & 4096753.8 & $1,215.8$ & $<20$ & 283 & 482 & 181 & AA \\
\hline SAPPHO & $02-57-085$ & $3 / 23 / 1972$ & U-2dh-2 & 581666.9 & 4107605.1 & $1,292.7$ & $<20$ & 282 & 552 & 198 & AA \\
\hline SARDINE & $03-57-056$ & $12 / 4 / 1963$ & U-3ch & 586320.5 & 4099500.8 & $1,221.3$ & Low & 273 & 489 & 262 & AA \\
\hline SATSOP & $02-57-134$ & $8 / 15 / 1963$ & $\mathrm{U}-2 \mathrm{~g}$ & 581994.9 & 4112161.9 & $1,332.9$ & Low & 232 & 590 & 226 & AA \\
\hline SATZ & $02-57-095$ & 7/7/1978 & $\mathrm{U}-2 \mathrm{dq}$ & 581995.9 & 4107469.5 & $1,289.9$ & $<20$ & 404 & 536 & 315 & TM-LVTA \\
\hline SAXON & $02-57-056$ & $7 / 28 / 1966$ & $U-2 c c$ & 576988.3 & 4110605.5 & $1,438.4$ & 1.2 & 189 & 536 & 154 & TM-LVTA \\
\hline SAZERAC & $03-57-121$ & $10 / 25 / 1967$ & U-3fa & 586598.4 & 4098618.4 & $1,217.7$ & $<20$ & 314 & 485 & 301 & AA \\
\hline SCANTLING & $04-57-024$ & $8 / 19 / 1977$ & $\mathrm{U}-4 \mathrm{~h}$ & 584008.0 & 4107293.7 & $1,272.5$ & 20 to 150 & 732 & 482 & 701 & OSBCU \\
\hline SCAUP & 03-57-069 & $5 / 14 / 1965$ & U-3da-S & 587973.7 & 4101654.6 & $1,249.1$ & $<20$ & 454 & 507 & 427 & LTCU \\
\hline SCHELLBOURNE & $02-57-138$ & $5 / 13 / 1988$ & U-2gf & 582427.0 & 4108875.8 & $1,295.1$ & $<150$ & 552 & 541 & 463 & AA \\
\hline SCISSORS & $03-57-148$ & $12 / 12 / 1968$ & U-3gh & 585481.1 & 4095536.4 & $1,208.5$ & $<20$ & 253 & 475 & 241 & AA \\
\hline SCREAMER & $03-57-076$ & 9/1/1965 & U-3dg & 588155.5 & 4097678.9 & $1,211.6$ & $<20$ & 309 & 478 & 302 & TM-WTA \\
\hline SCREE-ACAJOU & $09-57-009$ & $10 / 13 / 1970$ & U-9 ITS X-24 & 585795.1 & 4110353.3 & $1,296.0$ & $<20$ & 268 & 563 & 250 & TM-LVTA \\
\hline SCREE-ALHAMBRA & $09-57-015$ & $10 / 13 / 1970$ & U-9 ITS Z-21 & 586040.2 & 4109982.7 & $1,300.0$ & $<20$ & 211 & 568 & 192 & TM-LVTA \\
\hline SCREE-CHAMOIS & $09-57-016$ & $10 / 13 / 1970$ & U-9 ITS Z-24 & 586038.9 & 4110344.7 & $1,301.8$ & $<20$ & 207 & 569 & 101 & TM-LVTA \\
\hline SCUPPER & $03-57-174$ & $8 / 19 / 1977$ & U-3hj & 586146.5 & 4097062.4 & $1,211.9$ & $<20$ & 477 & 478 & 450 & $\mathrm{AA}$ \\
\hline SCUTTLE & $02-57-035$ & $11 / 13 / 1969$ & $\mathrm{U}-2 \mathrm{bh}$ & 582143.2 & 4113332.6 & $1,339.3$ & 1.7 & 183 & 602 & 165 & AA \\
\hline SEAFOAM & $02-57-105$ & $12 / 13 / 1973$ & U-2ea & 582304.4 & 4112975.4 & $1,333.2$ & $<20$ & 229 & 595 & 198 & AA \\
\hline SEAMOUNT & $03-57-230$ & $11 / 17 / 1977$ & U-3kp & 586724.9 & 4097399.0 & $1,212.8$ & $<20$ & 430 & 479 & 371 & AA \\
\hline SEAWEED B & $03-57-177$ & $10 / 16 / 1969$ & U-3hk-d & 589119.4 & 4096533.4 & $1,211.9$ & $<20$ & 128 & 474 & 119 & AA \\
\hline SEAWEED-C & $03-57-179$ & $10 / 1 / 1969$ & U-3hk-e & 589089.1 & 4096405.3 & $1,211.6$ & $<20$ & 128 & 473 & 119 & AA \\
\hline SEAWEED-D & $03-57-180$ & $10 / 1 / 1969$ & U-3hk-f & 589005.6 & 4096302.6 & $1,210.4$ & $<20$ & 128 & 472 & 118 & AA \\
\hline SEAWEED-E & $03-57-178$ & $10 / 1 / 1969$ & U-3hk-c & 589088.2 & 4096661.3 & $1,211.3$ & $<20$ & 134 & 474 & 124 & AA \\
\hline SECO & $08-57-007$ & $2 / 25 / 1981$ & $\mathrm{U}-8 \mathrm{~L}$ & 581288.4 & 4115240.2 & $1,383.2$ & $<20$ & 233 & 646 & 200 & OSBCU \\
\hline SEERSUCKER & $09-57-061$ & $2 / 19 / 1965$ & U-9bm & 586089.7 & 4108118.3 & $1,301.2$ & $<20$ & 152 & 568 & 144 & TM-LVTA \\
\hline SEPIA & 03-57-108 & 11/12/1965 & U-3en & 586956.6 & 4100661.0 & $1,229.3$ & $<20$ & 253 & 496 & 241 & AA \\
\hline
\end{tabular}


Table A.1-1

Shaft and Tunnel Nuclear Detonations in the Yucca Flat/Climax Mine Corrective Action Unit (Page 20 of 24)

\begin{tabular}{|c|c|c|c|c|c|c|c|c|c|c|c|}
\hline Detonation Name & $\begin{array}{c}\text { CAS } \\
\text { Number }\end{array}$ & $\begin{array}{c}\text { Date } \\
\text { Expended }\end{array}$ & $\begin{array}{c}\text { Emplacement } \\
\text { Hole Name }\end{array}$ & $\begin{array}{c}\text { UTM } \\
\text { Easting }\end{array}$ & $\begin{array}{c}\text { UTM } \\
\text { Northing }\end{array}$ & $\begin{array}{c}\text { aLand } \\
\text { Surface } \\
\text { Elevation } \\
\text { (m amsl) }\end{array}$ & $\begin{array}{l}\text { Announced } \\
\text { Yield(kt) }\end{array}$ & $\begin{array}{l}\text { Depth } \\
\text { (m) }\end{array}$ & $\begin{array}{l}\text { Estimated } \\
\text { Depth to } \\
\text { Water (m) }\end{array}$ & $\begin{array}{l}\text { Depth } \\
\text { of } \\
\text { Burial } \\
(\mathrm{m})\end{array}$ & $\begin{array}{c}\text { Working } \\
\text { Point } \\
\text { HSU }\end{array}$ \\
\hline SEVILLA & 03-57-129 & 6/25/1968 & U-3fk & 589611.2 & 4099756.1 & $1,253.0$ & $<<20$ & 411 & 516 & 359 & TM-LVTA \\
\hline SEYVAL & $03-57-252$ & 11/12/1982 & U-3Im & 586098.4 & 4097732.6 & $1,214.3$ & $<20$ & 427 & 481 & 366 & AA \\
\hline SHALLOWS & $03-57-200$ & $2 / 26 / 1976$ & U-3jf & 587543.9 & 4098286.2 & $1,215.2$ & $<20$ & 260 & 481 & 244 & AA \\
\hline SHAPER & $07-57-054$ & $3 / 23 / 1970$ & $U-7 r$ & 587003.8 & 4104683.3 & $1,278.6$ & 20 to 200 & 579 & 545 & 560 & OSBCU \\
\hline SHAVE & 03-57-151 & $1 / 22 / 1969$ & U-3gk & 589468.7 & 4096860.4 & $1,218.0$ & $<20$ & 254 & 483 & 241 & UTCU \\
\hline SHREW & $03-57-003$ & 9/16/1961 & U-3ac & 586005.9 & 4100481.8 & $1,227.4$ & Low & 162 & 494 & 98 & $\mathrm{AA}$ \\
\hline SHUFFLE & $10-57-056$ & $4 / 18 / 1968$ & $\mathrm{U}-10 \mathrm{t}$ & 585514.7 & 4112021.9 & $1,306.1$ & 20 to 200 & 543 & 574 & 493 & ATCU \\
\hline SIDECAR & $03-57-120$ & $12 / 13 / 1966$ & U-3ez & 588334.1 & 4098989.5 & $1,222.2$ & $<20$ & 253 & 489 & 240 & TM-WTA \\
\hline SIENNA & $03-57-057$ & $1 / 18 / 1966$ & U-3cj & 587296.4 & 4099260.1 & $1,220.1$ & $<20$ & 310 & 487 & 275 & $\mathrm{AA}$ \\
\hline SILENE & $09-57-082$ & $6 / 28 / 1973$ & U-9ck & 585209.7 & 4107846.4 & $1,280.8$ & $<20$ & 336 & 543 & 198 & $\overline{A A}$ \\
\hline SIMMS & $10-57-058$ & $11 / 5 / 1966$ & U-10w & 584589.5 & 4113947.6 & $1,306.4$ & 2.3 & 201 & 573 & 199 & AA \\
\hline SNUBBER & $03-57-116$ & $4 / 21 / 1970$ & U-3ev-2s & 589971.4 & 4101236.8 & $1,279.9$ & 12.7 & 358 & 551 & 344 & LTCU \\
\hline SOLANO & $03-57-217$ & $8 / 9 / 1972$ & U-3jx & 587489.8 & 4095476.1 & $1,206.1$ & $<20$ & 153 & 468 & 134 & $\mathrm{AA}$ \\
\hline SOLANUM & $09-57-022$ & $12 / 14 / 1972$ & U-9 ITS W-24.5 & 585733.9 & 4110423.2 & $1,294.2$ & $<20$ & 221 & 561 & 201 & TM-LVTA \\
\hline SOLENDON & $03-57-067$ & $2 / 12 / 1964$ & $\mathrm{U}-3 \mathrm{cz}$ & 586313.5 & 4101389.8 & $1,233.2$ & $<20$ & 161 & 500 & 150 & $\mathrm{AA}$ \\
\hline SPAR & $03-57-211$ & $12 / 19 / 1973$ & U-3jr & 587291.6 & 4095759.1 & $1,207.0$ & $<20$ & 163 & 471 & 149 & AA \\
\hline SPIDER-A & $02-57-042$ & $8 / 14 / 1969$ & U-2bp-1 & 583144.6 & 4112855.9 & $1,318.6$ & $<20$ & 221 & 582 & 213 & AA \\
\hline SPIDER-B & $02-57-043$ & $8 / 14 / 1969$ & U-2bp-2 & 583130.8 & 4112627.6 & $1,318.3$ & $<20$ & 236 & 581 & 228 & AA \\
\hline SPOON & $09-57-052$ & 9/11/1964 & U-9bd & 586581.4 & 4107729.0 & $1,315.5$ & $<20$ & 189 & 583 & 180 & TM-LVTA \\
\hline SPRIT & $03-57-166$ & 11/10/1976 & U-3hc & 587388.7 & 4099108.4 & $1,219.2$ & $<20$ & 202 & 486 & 183 & AA \\
\hline SPUD & $03-57-139$ & $7 / 17 / 1968$ & U-3fy & 589078.2 & 4095244.0 & $1,205.8$ & $<20$ & 253 & 464 & 240 & TM-LVTA \\
\hline ST. LAWRENCE & $02-57-029$ & $11 / 9 / 1962$ & $\mathrm{U}-2 \mathrm{~b}$ & 582280.6 & 4113243.5 & $1,336.2$ & Low & 171 & 599 & 167 & AA \\
\hline STACCATO & $10-57-007$ & $1 / 19 / 1968$ & U-10ah & 584012.5 & 4112436.3 & $1,298.8$ & 20 to 200 & 462 & 559 & 443 & AA \\
\hline STANLEY & $10-57-053$ & $7 / 27 / 1967$ & $\mathrm{U}-10 \mathrm{q}$ & 584495.7 & 4111592.0 & $1,291.4$ & 20 to 200 & 512 & 547 & 484 & TM-LVTA \\
\hline STANYAN & $02-57-021$ & 9/26/1974 & U-2aw & 582749.8 & 4109788.0 & $1,301.8$ & 20 to 200 & 660 & 554 & 573 & TM-WTA \\
\hline STARWORT & $02-57-047$ & $4 / 26 / 1973$ & $\mathrm{U}-2 \mathrm{bs}$ & 583637.5 & 4108733.7 & $1,288.1$ & 90 & 610 & 525 & 564 & LTCU \\
\hline STILLWATER & $09-57-073$ & $2 / 8 / 1962$ & U-9c & 584153.6 & 4109205.1 & $1,282.9$ & 3.07 & 194 & 537 & 181 & AA \\
\hline STILT & $03-57-127$ & $12 / 15 / 1967$ & U-3fh & 588759.6 & 4099204.6 & $1,230.8$ & $<20$ & 344 & 497 & 333 & TM-LVTA \\
\hline STOAT & 03-57-016 & $1 / 9 / 1962$ & U-3ap & 585809.3 & 4100056.4 & $1,225.6$ & 5.1 & 309 & 493 & 302 & AA \\
\hline STODDARD & $02-57-064$ & 9/17/1968 & $\mathrm{U}-2 \mathrm{cms}$ & 577514.9 & 4108322.2 & $1,396.9$ & 31 & 480 & 522 & 468 & TM-LVTA \\
\hline STONES & $09-57-028$ & $5 / 22 / 1963$ & U-9ae & 585378.8 & 4107420.1 & $1,284.1$ & Intermediate & 403 & 547 & 393 & TM-LVTA \\
\hline STRAIT & 04-57-001 & $3 / 17 / 1976$ & $\mathrm{U}-4 \mathrm{a}$ & 584191.6 & 4106990.5 & $1,270.7$ & 200 to 500 & 961 & 484 & 780 & OSBCU \\
\hline
\end{tabular}


Table A.1-1

Shaft and Tunnel Nuclear Detonations in the Yucca Flat/Climax Mine Corrective Action Unit (Page 21 of 24)

\begin{tabular}{|c|c|c|c|c|c|c|c|c|c|c|c|}
\hline Detonation Name & $\begin{array}{c}\text { CAS } \\
\text { Number }\end{array}$ & $\begin{array}{c}\text { Date } \\
\text { Expended }\end{array}$ & $\begin{array}{l}\text { Emplacement } \\
\text { Hole Name }\end{array}$ & $\begin{array}{c}\text { UTM } \\
\text { Easting }\end{array}$ & $\begin{array}{c}\text { UTM } \\
\text { Northing }\end{array}$ & $\begin{array}{c}\text { aLand } \\
\text { Surface } \\
\text { Elevation } \\
\text { (m amsl) }\end{array}$ & $\begin{array}{r}\text { Announced } \\
\text { Yield(kt) }\end{array}$ & $\begin{array}{l}\text { Depth } \\
\text { (m) }\end{array}$ & $\begin{array}{l}\text { Estimated } \\
\text { Depth to } \\
\text { Water (m) }\end{array}$ & $\begin{array}{l}\text { Depth } \\
\text { of } \\
\text { Burial } \\
\text { (m) }\end{array}$ & $\begin{array}{c}\text { Working } \\
\text { Point } \\
\text { HSU }\end{array}$ \\
\hline STRAKE & $07-57-006$ & $8 / 4 / 1977$ & U-7ae & 588267.9 & 4104733.7 & $1,300.3$ & 20 to 150 & 870 & 546 & 518 & LTCU \\
\hline STURGEON & $03-57-040$ & $4 / 15 / 1964$ & U-3bo & 587294.8 & 4099991.8 & $1,225.0$ & $<20$ & 156 & 491 & 150 & AA \\
\hline STUTZ & $02-57-055$ & $4 / 6 / 1966$ & U-2ca & 576304.6 & 4110491.9 & $1,485.0$ & $<20$ & 233 & 466 & 226 & TM-LVTA \\
\hline SUEDE & $09-57-060$ & $3 / 20 / 1965$ & U-9bk & 586490.8 & 4107916.7 & $1,312.8$ & $<20$ & 152 & 581 & 143 & TM-LVTA \\
\hline SUNDOWN-A & $01-57-003$ & 9/20/1990 & U-1d & 583883.6 & 4099324.7 & $1,233.5$ & $<20$ & 457 & 495 & 270 & AA \\
\hline SUNDOWN-B & $01-57-003$ & $9 / 20 / 1990$ & U-1d & 583883.6 & 4099324.7 & $1,233.5$ & $<20$ & 457 & 495 & 256 & AA \\
\hline SUTTER & $02-57-050$ & $12 / 21 / 1976$ & U-2bw & 583168.9 & 4111930.2 & $1,314.3$ & $<20$ & 229 & 573 & 200 & AA \\
\hline SWITCH & 09-57-069 & $6 / 22 / 1967$ & U-9bv & 586287.3 & 4109038.6 & $1,303.6$ & 3.1 & 312 & 572 & 302 & LTCU \\
\hline TAHOKA & $03-57-265$ & $8 / 13 / 1987$ & $\mathrm{U}-3 \mathrm{mf}$ & 584880.3 & 4101857.7 & $1,239.6$ & 20 to 150 & 671 & 487 & 640 & LTCU \\
\hline TAJIQUE & $07-57-002$ & $6 / 28 / 1972$ & U-7aa & 589600.0 & 4102864.3 & $1,300.6$ & $<20$ & 587 & 571 & 332 & LTCU \\
\hline TAJO & $07-57-032$ & $6 / 5 / 1986$ & U-7bi & 587486.3 & 4106026.0 & $1,315.8$ & 20 to 150 & 552 & 582 & 518 & LTCU \\
\hline TAN & $07-57-048$ & $6 / 3 / 1966$ & U-7k & 585761.0 & 4102698.5 & $1,240.5$ & 20 to 200 & 579 & 499 & 561 & TM-LVTA \\
\hline TANGERINE & 03-57-095 & $8 / 12 / 1966$ & U-3eb & 586318.1 & 4100247.1 & $1,225.6$ & $<20$ & 95 & 492 & 88 & $\mathrm{AA}$ \\
\hline TANYA & $02-57-098$ & $7 / 30 / 1968$ & $\mathrm{U}-2 \mathrm{dt}$ & 581536.8 & 4108016.4 & $1,297.5$ & 20 to 200 & 559 & 558 & 381 & AA \\
\hline TAPESTRY & $02-57-013$ & $5 / 12 / 1966$ & U-2an & 582505.7 & 4109969.7 & $1,307.9$ & $<20$ & 279 & 557 & 249 & AA \\
\hline TAPPER & $03-57-155$ & $6 / 12 / 1969$ & U-3go & 586271.8 & 4096087.7 & $1,208.5$ & $<20$ & 319 & 475 & 303 & AA \\
\hline TARKO & $02-57-131$ & $2 / 28 / 1980$ & $\mathrm{U}-2 \mathrm{fd}$ & 580969.6 & 4109096.1 & $1,306.7$ & $<20$ & 465 & 561 & 369 & AA \\
\hline TAUNTON & $09-57-024$ & $12 / 4 / 1962$ & U-9aa & 584387.9 & 4109300.1 & $1,282.9$ & Low & 232 & 539 & 227 & $\mathrm{AA}$ \\
\hline TECHADO & $04-57-029$ & 9/22/1983 & $\mathrm{U}-40$ & 584466.8 & 4106807.4 & $1,267.7$ & $<150$ & 579 & 493 & 533 & LTCU \\
\hline TEE & $02-57-003$ & $5 / 7 / 1965$ & $\mathrm{U}-2 \mathrm{ab}$ & 582895.8 & 4110647.9 & $1,309.7$ & 7 & 233 & 564 & 184 & $\mathrm{AA}$ \\
\hline TEJON & $03-57-055$ & $5 / 17 / 1963$ & U-3cg & 586045.8 & 4100469.2 & $1,227.1$ & Low & 79 & 494 & 75 & AA \\
\hline TELEME & $09-57-083$ & $2 / 6 / 1975$ & U-9cL & 586977.4 & 4107776.4 & $1,327.1$ & $<20$ & 355 & 594 & 305 & LTCU \\
\hline TEMESCAL & $04-57-003$ & $11 / 2 / 1974$ & U-4ab & 580723.6 & 4105392.9 & $1,290.5$ & $<20$ & 299 & 445 & 263 & $\mathrm{AA}$ \\
\hline TEMPLAR & $09-57-067$ & $3 / 24 / 1966$ & U-9bt & 586061.7 & 4107680.9 & $1,301.8$ & 0.37 & 233 & 568 & 150 & TM-WTA \\
\hline TENAJA & $03-57-247$ & $4 / 17 / 1982$ & U-3lh & 588082.0 & 4096993.0 & $1,204.6$ & $<20$ & 427 & 470 & 357 & TM-LVTA \\
\hline TENDRAC & $03-57-027$ & $12 / 7 / 1962$ & U-3ba & 586313.0 & 4100849.8 & $1,229.3$ & Low & 337 & 496 & 303 & $\mathrm{AA}$ \\
\hline TERN & $03-57-090$ & $1 / 29 / 1965$ & U-3dw & 587750.8 & 4100115.3 & $1,229.0$ & $<20$ & 225 & 495 & 211 & AA \\
\hline TERRINE-WHITE & $09-57-057$ & $12 / 18 / 1969$ & U-9bi-1 & 585749.6 & 4108470.0 & $1,290.8$ & 20 to 200 & 480 & 556 & 457 & TM-LVTA \\
\hline TERRINE-YELLOW & $09-57-058$ & $12 / 18 / 1969$ & U-9bi-2 & 586297.1 & 4108498.7 & $1,303.9$ & 20 to 200 & 442 & 572 & 418 & LTCU \\
\hline TEXARKANA & $07-57-041$ & $2 / 10 / 1989$ & U-7ca & 588835.4 & 4103653.9 & $1,293.6$ & 20 to 150 & 549 & 519 & 503 & OSBCU \\
\hline THISTLE & $07-57-056$ & $4 / 30 / 1969$ & $\mathrm{U}-7 \mathrm{t}$ & 588372.8 & 4105145.1 & $1,307.9$ & 20 to 200 & 579 & 556 & 560 & OSBCU \\
\hline
\end{tabular}


Table A.1-1

Shaft and Tunnel Nuclear Detonations in the Yucca Flat/Climax Mine Corrective Action Unit (Page 22 of 24)

\begin{tabular}{|c|c|c|c|c|c|c|c|c|c|c|c|}
\hline Detonation Name & $\begin{array}{c}\text { CAS } \\
\text { Number }\end{array}$ & $\begin{array}{c}\text { Date } \\
\text { Expended }\end{array}$ & $\begin{array}{c}\text { Emplacement } \\
\text { Hole Name }\end{array}$ & $\begin{array}{c}\text { UTM } \\
\text { Easting }\end{array}$ & $\begin{array}{c}\text { UTM } \\
\text { Northing }\end{array}$ & $\begin{array}{c}\text { aLand } \\
\text { Surface } \\
\text { Elevation } \\
\text { (m amsl) }\end{array}$ & $\begin{array}{l}\text { Announced } \\
\text { Yield(kt) }\end{array}$ & $\begin{array}{l}\text { Depth } \\
\text { (m) }\end{array}$ & $\begin{array}{l}\text { Estimated } \\
\text { Depth to } \\
\text { Water (m) }\end{array}$ & $\begin{array}{l}\text { Depth } \\
\text { of } \\
\text { Burial } \\
(\mathrm{m})\end{array}$ & $\begin{array}{c}\text { Working } \\
\text { Point } \\
\text { HSU }\end{array}$ \\
\hline THROW & $02-57-034$ & $4 / 10 / 1968$ & U-2bg & 581491.1 & 4112444.2 & $1,343.6$ & $<<20$ & 236 & 601 & 228 & $\overline{A A}$ \\
\hline TICKING & 09-57-059 & $8 / 21 / 1965$ & U-9bj & 586536.1 & 4107607.3 & $1,314.9$ & $<20$ & 236 & 582 & 208 & TM-LVTA \\
\hline TIJERAS & $07-57-061$ & $10 / 14 / 1970$ & U-7y & 588441.4 & 4102969.9 & $1,276.2$ & 20 to 200 & 579 & 523 & 561 & OSBCU \\
\hline $\mathrm{TILCl}$ & $04-57-009$ & 11/11/1981 & U-4ak & 582802.2 & 4103541.3 & $1,259.1$ & 20 to 150 & 497 & 492 & 445 & AA \\
\hline TINDERBOX & $09-57-046$ & $11 / 22 / 1968$ & U-9az & 585062.8 & 4110618.9 & $1,287.8$ & $<20$ & 472 & 547 & 442 & LTCU \\
\hline TINY TOT & $15-57-003$ & 6/17/1965 & $\mathrm{U}-15 \mathrm{e}$ & 583635.8 & 4119815.4 & $1,530.7$ & $<20$ & NA & 228 & 111 & MGCU \\
\hline TIOGA & $09-57-094$ & $10 / 18 / 1962$ & U-9f & 585254.4 & 4109360.5 & $1,281.1$ & Low & 66 & 543 & 59 & AA \\
\hline TOMATO & $03-57-105$ & $4 / 7 / 1966$ & U-3ek & 589650.8 & 4097075.0 & $1,222.2$ & $<20$ & 236 & 489 & 226 & TM-LVTA \\
\hline TOPGALLANT & $04-57-021$ & $2 / 28 / 1975$ & $\mathrm{U}-4 \mathrm{e}$ & 583857.1 & 4106866.9 & $1,271.9$ & 20 to 200 & 1022 & 483 & 713 & LTCU \\
\hline TOPMAST & $07-57-023$ & $3 / 23 / 1978$ & U-7ay & 587120.4 & 4106085.7 & $1,309.4$ & $<20$ & 488 & 576 & 457 & OSBCU \\
\hline TORCH & $03-57-128$ & $2 / 21 / 1968$ & U-3fj & 588757.4 & 4099753.1 & $1,237.2$ & $<20$ & 253 & 501 & 241 & TM-WTA \\
\hline TORNERO & $03-57-251$ & $2 / 11 / 1987$ & U-3II & 584991.2 & 4096281.3 & $1,213.4$ & $<20$ & 396 & 480 & 298 & TM-WTA \\
\hline TORNILLO & $09-57-038$ & 10/11/1963 & U-9aq & 585832.6 & 4108278.0 & $1,293.6$ & 0.38 & 157 & 559 & 150 & $\mathrm{AA}$ \\
\hline TORRIDO & $07-57-059$ & $5 / 27 / 1969$ & U-7w & 589308.4 & 4103472.4 & $1,297.2$ & 20 to 200 & 533 & 566 & 515 & OSBCU \\
\hline TORTUGAS & $03-57-147$ & $3 / 1 / 1984$ & U-3gg & 584787.0 & 4102390.0 & $1,243.3$ & 20 to 150 & 686 & 474 & 640 & LTCU \\
\hline TOYAH & $09-57-026$ & $3 / 15 / 1963$ & U-9ac & 584855.0 & 4109054.6 & $1,279.2$ & Low & 137 & 538 & 130 & AA \\
\hline TRANSOM & $04-57-022$ & $5 / 10 / 1978$ & $\mathrm{U}-4 \mathrm{f}$ & 584199.5 & 4104826.1 & $1,258.5$ & Zero & 713 & 472 & 640 & LTCU \\
\hline TRAVELER & $02-57-057$ & $5 / 4 / 1966$ & $\mathrm{U}-2 \mathrm{~cd}$ & 576639.2 & 4110223.7 & $1,457.2$ & $<20$ & 233 & 497 & 198 & $\mathrm{AA}$ \\
\hline TREBBIANO & $03-57-249$ & 9/4/1981 & U-3lj & 584637.3 & 4101536.6 & $1,238.1$ & $<20$ & 335 & 486 & 305 & TM-UVTA \\
\hline TROGON & $03-57-079$ & $7 / 24 / 1964$ & U-3dj & 587842.1 & 4100237.5 & $1,231.1$ & $<20$ & 200 & 497 & 193 & AA \\
\hline TRUCHAS-CHACON & $03-57-184$ & $10 / 28 / 1970$ & U-3hn & 587366.7 & 4096674.8 & $1,209.4$ & $<20$ & 128 & 475 & 118 & AA \\
\hline TRUCHAS-CHAMISAL & $03-57-182$ & $10 / 28 / 1970$ & U-3ho & 587427.7 & 4096675.3 & $1,209.4$ & $<20$ & 130 & 475 & 118 & AA \\
\hline TRUCHAS-RODARTE & $03-57-183$ & $10 / 28 / 1970$ & U-3hm & 587244.5 & 4096761.5 & $1,210.1$ & $<20$ & 282 & 476 & 266 & AA \\
\hline TRUMBULL & $04-57-002$ & 9/26/1974 & U-4aa & 580449.3 & 4105391.9 & $1,295.7$ & $<20$ & 299 & 400 & 263 & TM-LVTA \\
\hline TUB-A & $10-57-011$ & 6/6/1968 & U-10aj-C & 585011.6 & 4113677.3 & $1,308.8$ & $<20$ & 207 & 575 & 189 & $\mathrm{AA}$ \\
\hline TUB-B & $10-57-010$ & $6 / 6 / 1968$ & U-10aj-B & 584929.5 & 4113446.3 & $1,306.1$ & $<20$ & 200 & 573 & 189 & AA \\
\hline TUB-C & $10-57-013$ & $6 / 6 / 1968$ & U-10aj-F & 585174.5 & 4113447.5 & $1,310.0$ & $<20$ & 198 & 577 & 189 & AA \\
\hline TUB-D & $10-57-012$ & $6 / 6 / 1968$ & U-10aj-D & 584806.4 & 4113620.2 & $1,305.2$ & $<20$ & 286 & 572 & 273 & TM-LVTA \\
\hline TUB-F & $10-57-009$ & 6/6/1968 & U-10aj-A & 585051.1 & 4113621.3 & $1,308.8$ & $<20$ & 209 & 575 & 189 & AA \\
\hline TULIA & $04-57-033$ & $5 / 26 / 1989$ & $\mathrm{U}-4 \mathrm{~s}$ & 583979.3 & 4104612.0 & $1,257.3$ & $<20$ & 610 & 471 & 396 & TM-UVTA \\
\hline TULOSO & $03-57-149$ & $12 / 12 / 1972$ & U-3gi & 587055.0 & 4098589.2 & $1,216.5$ & $<20$ & 285 & 483 & 271 & AA \\
\hline TUNA & $03-57-074$ & $12 / 20 / 1963$ & U-3de & 585950.0 & 4100962.2 & $1,229.9$ & Low & 427 & 497 & 414 & AA \\
\hline
\end{tabular}


Table A.1-1

Shaft and Tunnel Nuclear Detonations in the Yucca Flat/Climax Mine Corrective Action Unit (Page 23 of 24)

\begin{tabular}{|c|c|c|c|c|c|c|c|c|c|c|c|}
\hline Detonation Name & $\begin{array}{c}\text { CAS } \\
\text { Number }\end{array}$ & $\begin{array}{c}\text { Date } \\
\text { Expended }\end{array}$ & $\begin{array}{l}\text { Emplacement } \\
\text { Hole Name }\end{array}$ & $\begin{array}{c}\text { UTM } \\
\text { Easting }\end{array}$ & $\begin{array}{c}\text { UTM } \\
\text { Northing }\end{array}$ & $\begin{array}{c}\text { aLand } \\
\text { Surface } \\
\text { Elevation } \\
\text { (m amsl) }\end{array}$ & $\begin{array}{r}\text { Announced } \\
\text { Yield(kt) }\end{array}$ & $\begin{array}{l}\text { Depth } \\
\text { (m) }\end{array}$ & $\begin{array}{l}\text { Estimated } \\
\text { Depth to } \\
\text { Water (m) }\end{array}$ & $\begin{array}{l}\text { Depth } \\
\text { of } \\
\text { Burial } \\
\text { (m) }\end{array}$ & $\begin{array}{c}\text { Working } \\
\text { Point } \\
\text { HSU }\end{array}$ \\
\hline TUN-A & $10-57-015$ & $12 / 10 / 1969$ & U-10am-1 & 581745.5 & 4113669.8 & $1,350.0$ & $2<20$ & 213 & 611 & 200 & $\overline{\mathrm{AA}}$ \\
\hline TUN-B & $10-57-016$ & $12 / 10 / 1969$ & U-10am-2 & 581744.8 & 4113867.8 & $1,351.5$ & $<20$ & 206 & 613 & 194 & AA \\
\hline TUN-C & $10-57-017$ & $12 / 10 / 1969$ & U-10am-3 & 581943.6 & 4113670.1 & $1,345.7$ & $<20$ & 214 & 608 & 194 & TM-LVTA \\
\hline TUN-D & $10-57-018$ & $12 / 10 / 1969$ & U-10am-4 & 581943.5 & 4113868.2 & $1,347.2$ & $<20$ & 275 & 610 & 256 & OSBCU \\
\hline TURF & $10-57-039$ & $4 / 24 / 1964$ & $\mathrm{U}-10 \mathrm{c}$ & 583885.9 & 4111681.3 & $1,298.4$ & 20 to 200 & 588 & 553 & 506 & TM-LVTA \\
\hline TURNSTONE & $03-57-088$ & $10 / 16 / 1964$ & $\mathrm{U}-3 \mathrm{dt}$ & 586734.5 & 4098831.9 & $1,218.0$ & $<20$ & 136 & 485 & 126 & AA \\
\hline TURQUOISE & $07-57-038$ & $4 / 14 / 1983$ & U-7bu & 584809.2 & 4103174.8 & $1,246.0$ & $<150$ & 610 & 480 & 533 & LTCU \\
\hline TWEED & $09-57-062$ & $5 / 21 / 1965$ & U-9bn & 586381.4 & 4108261.9 & $1,308.2$ & $<20$ & 322 & 576 & 284 & TM-LVTA \\
\hline TYG-A & $02-57-074$ & $12 / 12 / 1968$ & $\mathrm{U}-2 \mathrm{dc}-4$ & 581681.5 & 4108467.9 & $1,300.0$ & $<20$ & 244 & 556 & 228 & AA \\
\hline TYG-B & $02-57-075$ & $12 / 12 / 1968$ & U-2dc-5 & 581773.6 & 4108110.1 & $1,296.6$ & $<20$ & 270 & 555 & 251 & AA \\
\hline TYG-C & $02-57-076$ & $12 / 12 / 1968$ & $U-2 d c-3$ & 581980.0 & 4108163.0 & $1,295.1$ & $<20$ & 244 & 551 & 228 & AA \\
\hline TYG-D & $02-57-077$ & $12 / 12 / 1968$ & U-2dc-2 & 581887.9 & 4108520.7 & $1,298.8$ & $<20$ & 223 & 553 & 207 & AA \\
\hline TYG-E & $02-57-078$ & $12 / 12 / 1968$ & U-2dc-1 & 582037.2 & 4108368.6 & $1,296.6$ & $<20$ & 213 & 551 & 198 & $\mathrm{AA}$ \\
\hline TYG-F & $02-57-079$ & $12 / 12 / 1968$ & $\mathrm{U}-2 \mathrm{dc}-6$ & 581579.9 & 4108250.8 & $1,299.7$ & $<20$ & 282 & 559 & 265 & AA \\
\hline UMBER & $03-57-107$ & $6 / 29 / 1967$ & U-3em & 586934.2 & 4098284.7 & $1,215.5$ & 10 & 344 & 482 & 310 & AA \\
\hline VALENCIA & $03-57-275$ & 9/26/1958 & $U-3 r$ & 586269.3 & 4100609.8 & $1,228.0$ & 0.002 & 160 & 495 & 148 & AA \\
\hline VALISE & 09-57-071 & $3 / 18 / 1969$ & U-9by & 585189.3 & 4110534.6 & $1,287.8$ & $<20$ & 107 & 548 & 91 & AA \\
\hline VAT & $09-57-077$ & $10 / 10 / 1968$ & U-9cf & 585065.4 & 4109887.0 & $1,282.6$ & $<20$ & 213 & 543 & 192 & $\mathrm{AA}$ \\
\hline VAUGHN & $03-57-255$ & $3 / 15 / 1985$ & U-3Ir & 584881.4 & 4101537.4 & $1,238.1$ & 20 to 150 & 457 & 489 & 427 & TM-LVTA \\
\hline VELARDE & $03-57-205$ & $4 / 25 / 1973$ & U-3jk & 587114.1 & 4094413.1 & $1,203.4$ & $<20$ & 297 & 465 & 277 & $\mathrm{AA}$ \\
\hline VERDELLO & $03-57-235$ & $7 / 31 / 1980$ & U-3ku & 586940.5 & 4096562.4 & $1,210.1$ & $<20$ & 411 & 476 & 366 & AA \\
\hline VERMEJO & $04-57-032$ & $10 / 2 / 1984$ & $\mathrm{U}-4 \mathrm{r}$ & 584186.7 & 4104543.2 & $1,255.5$ & $<20$ & 686 & 467 & 351 & TM-UVTA \\
\hline VICTORIA & $03-57-236$ & 6/19/1992 & U-3kv & 588070.9 & 4095728.3 & $1,205.8$ & $<20$ & 488 & 468 & 244 & AA \\
\hline VIDE & $08-57-006$ & $4 / 30 / 1981$ & U-8k & 581247.8 & 4114733.3 & $1,373.4$ & $<20$ & 367 & 635 & 323 & OSBCU \\
\hline VIGIL & $10-57-004$ & $11 / 22 / 1966$ & U-10ad & 584492.2 & 4113883.3 & $1,304.8$ & $<20$ & 96 & 572 & 91 & AA \\
\hline VILLE & $04-57-011$ & $6 / 12 / 1985$ & U-4am & 581416.3 & 4104858.4 & $1,276.8$ & $<20$ & 335 & 520 & 293 & TM-LVTA \\
\hline VILLITA & $03-57-244$ & $11 / 10 / 1984$ & U-3ld & 587433.1 & 4095131.9 & $1,204.6$ & $<20$ & 457 & 467 & 373 & AA \\
\hline VISE & $03-57-104$ & $1 / 30 / 1969$ & U-3ej & 586315.4 & 4101024.4 & $1,230.8$ & 20 to 200 & 472 & 498 & 454 & TM-LVTA \\
\hline VITO & $10-57-003$ & $7 / 14 / 1967$ & U-10ab & 584797.3 & 4113427.6 & $1,304.5$ & $<20$ & 98 & 571 & 97 & AA \\
\hline VULCAN & $02-57-031$ & $6 / 25 / 1966$ & $\mathrm{U}-2 \mathrm{bd}$ & 582390.6 & 4112300.5 & $1,327.1$ & 25 & 370 & 588 & 323 & $\overline{A A}$ \\
\hline WACO & $03-57-258$ & $12 / 1 / 1987$ & U-3lu & 588586.3 & 4094734.0 & $1,202.7$ & $<20$ & 335 & 461 & 183 & AA \\
\hline
\end{tabular}


Table A.1-1

Shaft and Tunnel Nuclear Detonations in the Yucca Flat/Climax Mine Corrective Action Unit (Page 24 of 24)

\begin{tabular}{|c|c|c|c|c|c|c|c|c|c|c|c|}
\hline Detonation Name & $\begin{array}{c}\text { CAS } \\
\text { Number }\end{array}$ & $\begin{array}{c}\text { Date } \\
\text { Expended }\end{array}$ & $\begin{array}{c}\text { Emplacement } \\
\text { Hole Name }\end{array}$ & $\begin{array}{c}\text { UTM } \\
\text { Easting }\end{array}$ & $\begin{array}{c}\text { UTM } \\
\text { Northing }\end{array}$ & $\begin{array}{c}\text { aLand } \\
\text { Surface } \\
\text { Elevation } \\
\text { (m amsl) }\end{array}$ & $\begin{array}{r}\text { Announced } \\
\text { Yield(kt) }\end{array}$ & $\begin{array}{l}\text { Depth } \\
\text { (m) }\end{array}$ & $\begin{array}{l}\text { Estimated } \\
\text { Depth to } \\
\text { Water (m) }\end{array}$ & $\begin{array}{l}\text { Depth } \\
\text { of } \\
\text { Burial } \\
\text { (m) }\end{array}$ & $\begin{array}{c}\text { Working } \\
\text { Point } \\
\text { HSU }\end{array}$ \\
\hline WAGTAIL & $03-57-014$ & $3 / 3 / 1965$ & U-3an & 585598.6 & 4102259.1 & $1,237.5$ & 20 to 200 & 767 & 492 & 750 & LTCU \\
\hline WALLER & $02-57-053$ & $10 / 2 / 1973$ & $\mathrm{U}-2 \mathrm{bz}$ & 582787.2 & 4112149.8 & $1,320.7$ & $<20$ & 408 & 582 & 311 & AA \\
\hline WARD & $10-57-059$ & $2 / 8 / 1967$ & $\mathrm{U}-10 \mathrm{x}$ & 584599.3 & 4113678.0 & $1,303.9$ & $<20$ & 265 & 571 & 260 & AA \\
\hline WASHER & $10-57-054$ & $8 / 10 / 1967$ & U-10r & 584598.9 & 4112476.1 & $1,297.5$ & $<20$ & 509 & 553 & 466 & LTCU \\
\hline WELDER & $03-57-134$ & $10 / 3 / 1968$ & U-3fs & 586280.6 & 4100270.4 & $1,225.9$ & $<20$ & 131 & 493 & 118 & AA \\
\hline WEMBLEY & $03-57-119$ & $6 / 5 / 1968$ & U-3ey & 587511.0 & 4098986.9 & $1,218.6$ & $<20$ & 253 & 485 & 238 & AA \\
\hline WEXFORD & $02-57-069$ & $8 / 30 / 1984$ & $\mathrm{U}-2 \mathrm{cr}$ & 577687.2 & 4110989.1 & $1,403.3$ & $<20$ & 417 & 558 & 314 & TM-LVTA \\
\hline WHITE & $09-57-048$ & $5 / 25 / 1962$ & $\mathrm{U}-9 \mathrm{~b}$ & 584215.2 & 4108940.6 & $1,280.5$ & Low & 200 & 534 & 193 & $\mathrm{AA}$ \\
\hline WHITEFACE-A & $03-57-254$ & $12 / 20 / 1989$ & U-3lp & 586173.7 & 4097976.7 & $1,214.6$ & $<20$ & 411 & 481 & 197 & AA \\
\hline WHITEFACE-B & $03-57-254$ & $12 / 20 / 1989$ & U-3/p & 586173.7 & 4097976.7 & $1,214.6$ & $<20$ & 411 & 481 & 183 & $\overline{A A}$ \\
\hline WICHITA & $09-57-114$ & $7 / 27 / 1962$ & U-9y & 583810.8 & 4109475.1 & $1,292.0$ & Low & 224 & 547 & 150 & AA \\
\hline $\mathrm{WINCH}$ & $03-57-146$ & $2 / 4 / 1969$ & U-3gf & 585205.0 & 4096144.9 & $1,212.2$ & $<20$ & 254 & 479 & 241 & TM-WTA \\
\hline WOLVERINE & $03-57-022$ & $10 / 12 / 1962$ & U-3av & 586027.4 & 4100518.2 & $1,227.4$ & Low & 81 & 494 & 73 & AA \\
\hline WOOL & 09-57-056 & $1 / 14 / 1965$ & U-9bh & 586640.0 & 4108317.7 & $1,313.7$ & $<20$ & 304 & 582 & 216 & TM-LVTA \\
\hline WORTH & $10-57-006$ & $10 / 25 / 1967$ & U-10ag & 584481.7 & 4112435.8 & $1,295.7$ & $<20$ & 206 & 548 & 187 & $\mathrm{AA}$ \\
\hline YANNIGAN-BLUE & $02-57-025$ & $2 / 26 / 1970$ & U-2ay-3 & 583000.6 & 4107701.8 & $1,284.4$ & 20 to 200 & 366 & 510 & 364 & AA \\
\hline YANNIGAN-RED & $02-57-023$ & $2 / 26 / 1970$ & U-2ay-1 & 583384.8 & 4107989.6 & $1,284.4$ & 20 to 200 & 402 & 508 & 392 & AA \\
\hline YANNIGAN-WHITE & $02-57-024$ & $2 / 26 / 1970$ & U-2ay-2 & 582938.3 & 4108172.4 & $1,288.4$ & 20 to 200 & 397 & 523 & 395 & $\mathrm{AA}$ \\
\hline YARD & $10-57-005$ & 9/7/1967 & U-10af & 584113.4 & 4112079.2 & $1,297.5$ & 20 to 200 & 533 & 555 & 521 & TM-LVTA \\
\hline YERBA & $01-57-002$ & $12 / 14 / 1971$ & $\mathrm{U}-1 \mathrm{c}$ & 583737.0 & 4097663.4 & $1,228.6$ & $<20$ & 335 & 490 & 332 & $\mathrm{AA}$ \\
\hline YORK & $09-57-115$ & $8 / 24 / 1962$ & $\mathrm{U}-9 \mathrm{z}$ & 585333.2 & 4108261.3 & $1,282.6$ & Low & 233 & 546 & 226 & AA \\
\hline ZAZA & $04-57-019$ & $9 / 27 / 1967$ & $\mathrm{U}-4 \mathrm{c}$ & 584134.2 & 4106044.8 & $1,267.4$ & 20 to 200 & 686 & 488 & 667 & LTCU \\
\hline ZINNIA & $02-57-089$ & $5 / 17 / 1972$ & U-2dk & 581030.2 & 4108432.1 & $1,304.2$ & $<20$ & 366 & 563 & 323 & AA \\
\hline
\end{tabular}

Source: DOE/NV, 1997; DOE/NV, 2000; FFACO, 1996; BN, 2006

aModified from information in DOE/NV, 2000

$\mathrm{AA}=$ Alluvial Aquifer

ATCU = Argillic Tuff Confining Unit

$\mathrm{HSU}=$ Hydrostratigraphic Unit

$\mathrm{kt}=$ Kiloton

LCA = Lower Carbonate Aquifer $\mathrm{LTCU}=$ Lower Tuff Confining Unit

LCA3 $=$ Lower Carbonate Aquifer - Yucca Flat Upper Plate

MGCU = Mesozoic Granite Confining Unit $\mathrm{NA}=$ Not available

$\mathrm{m}$ amsl $=$ Meters above mean sea leve

OSBCU = Oak Spring Butte Confining Unit

PBRCM = Pre-Belted Range Composite Unit

PCUT = Playa Confining Unit

TM-WTA = Timber Mountain-Welded Tuff Aquifer

TSA = Topopah Spring Aquifer
TUBA = Tub Spring Aquifer

UCCU = Upper Clastic Confining Unit

UTCU = Upper Tuff Confining Unit 


\section{A.2.0 RefERENCES}

BN, see Bechtel Nevada.

Bechtel Nevada. 2006. A Hydrostratigraphic Model and Alternatives for the Groundwater Flow and Contaminant Transport Model of Corrective Action Unit 97: Yucca Flat-Climax Mine, Lincoln and Nye Counties, Nevada, Report DOE/NV/11718-1119. Las Vegas, NV.

DOE/NV, see U.S. Department of Energy, Nevada Operations Office.

FFACO, see Federal Facility Agreement and Consent Order.

Federal Facility Agreement and Consent Order. 1996, as amended. Agreed to by the State of Nevada, the U.S. Department of Energy, and the U.S. Department of Defense. Appendix III, which contains the Corrective Action Investigations/Corrective Actions as last amended in January 2005, Revision No. 19.

Grasso, D.N. 2001. GIS Surface Effects Archive of Underground Nuclear Detonations Conducted at Yucca Flat and Pahute Mesa, Nevada Test Site, Nevada, Open-File Report 01-272. Denver, CO: U.S. Geological Survey.

U.S. Department of Energy, Nevada Operations Office. 1997. Shaft and Tunnel Nuclear Detonations at the Nevada Test Site: Development of a Primary Database for the Estimation of Potential Interactions with the Regional Groundwater System, DOE/NV-464. Las Vegas, NV.

U.S. Department of Energy, Nevada Operations Office. 2000. United States Nuclear Tests, July 1945 through September 1992, DOE/NV--209, Rev. 15. Las Vegas, NV. 
Appendix B

Data Collection Activities 


\section{B.1.0 Summary of Data Collection for the Yucca FLAT/Climax Mine CorRective ACtION UNIT}

Data collection is defined to encompass all characterization and analysis activities that have been conducted to characterize groundwater contamination that may have resulted from underground nuclear testing. The characterization program was initially known as the Groundwater Characterization Project (GCP) in 1989, which became the UGTA Project in 1992. The Yucca Flat/Climax Mine CAIP (DOE/NV, 2000) discussed in detail the notable data collection developed during the GCP and the UGTA Project before calendar year 2000 and specified the Yucca Flat/Climax Mine CAU-specific Phase I CAIP to address identified data gaps. This appendix identifies UGTA Project wells drilled in the Yucca Flat/Climax Mine CAU for geological and hydrologic characterization, and summarizes key data collection documentation that were provided by the Yucca Flat/Climax Mine Phase I CAIs. 


\section{B.2.0 Yucca Flat/Climax Mine CaU-Specific Well DRILLING AND TESTING}

A total of eleven UGTA Project wells have been drilled, completed, and tested within the Yucca Flat/Climax Mine CAU for geologic and hydrologic characterization. Table B.2-1 lists the wells and their coordinates, and identifies the data documentation associated with these wells. The locations for these wells are shown in Figure B.2-1. In addition, several other wells were recompleted and tested, and a cavity re-entry was fitted with a pump for sampling. These are listed in Table B.3-1, and the limited available documentation is identified. The UGTA wells included in the Hot Well Program are not included in this appendix because they are not used to support the hydrologic characterization discussed in this document. 
Table B.2-1

Yucca Flat/Climax Mine Phase I Well Drilling and Testing

(Page 1 of 2)

\begin{tabular}{|c|c|c|c|c|c|c|}
\hline \multirow{2}{*}{$\begin{array}{l}\text { Well } \\
\text { Name }\end{array}$} & \multirow{2}{*}{ Criteria Document } & \multicolumn{2}{|c|}{$\begin{array}{l}\text { Location } \\
\text { UTM, NAD 27, Zone } 11 \text { (m) }\end{array}$} & \multirow{2}{*}{$\begin{array}{l}\text { Completion } \\
\text { Date }\end{array}$} & \multirow{2}{*}{ Completion Report } & \multirow{2}{*}{ Testing/Analysis Report } \\
\hline & & Easting & Northing & & & \\
\hline ER-2-1 & $\begin{array}{c}\text { Yucca Flat Hydrogeologic } \\
\text { Investigation Wells Drilling } \\
\text { and Completion Criteria } \\
\text { (IT, 2002) }\end{array}$ & $583,334.49$ & $4,108,978.33$ & $3 / 07 / 2003$ & $\begin{array}{c}\text { Completion Report for } \\
\text { Well ER-2-1 } \\
\text { (NNSA/NSO, 2004b) }\end{array}$ & $\begin{array}{l}\text { Letter Report: Analysis of Well } \\
\text { ER-2-1 Hydraulic Testing, } \\
\text { Yucca Flat FY 2003, Nevada } \\
\text { Test Site, Nevada } \\
\text { (SNJV, 2004d) }\end{array}$ \\
\hline ER-3-1 & N/A & $594,658.28$ & $4,097,338.98$ & $5 / 20 / 1994$ & $\begin{array}{l}\text { Completion Report for Well } \\
\text { ER-3-1 (DOE/NV, 1995a) }\end{array}$ & N/A \\
\hline ER-3-2 & N/A & $585,716.38$ & $4,099,227.75$ & 2/18/1994 & $\begin{array}{l}\text { Completion Report for Well } \\
\text { ER-3-2 (DOE/NV, 1995b) }\end{array}$ & N/A \\
\hline ER-6-1 & N/A & $589,632.69$ & $4,093,418.70$ & $5 / 25 / 1995$ & \multirow[b]{3}{*}{$\begin{array}{c}\text { Completion Report for Well } \\
\text { Cluster ER-6-1 } \\
\text { (NNSA/NSO, 2004a) }\end{array}$} & \multirow{3}{*}{$\begin{array}{c}\text { Analysis of Hydraulic } \\
\text { Responses from the ER-6-1 } \\
\text { Multiple-Well Aquifer Test, } \\
\text { Yucca Flat FY } 2004 \text { Testing } \\
\text { program, Nevada Test Site, } \\
\text { Nye County, Nevada } \\
\text { (SNJV, 2005a) }\end{array}$} \\
\hline ER-6-1\#1 & N/A & $589,635.80$ & $4,093,403.75$ & $7 / 16 / 1993$ & & \\
\hline ER-6-1\#2 & $\begin{array}{l}\text { Underground Test Area } \\
\text { Project, ER-6-1 Multi-Well } \\
\text { Aquifer Test - Tracer } \\
\text { Test Plan, Rev. 0 } \\
\text { (SNJV, 2004f) }\end{array}$ & $589,616.49$ & $4,093,356.86$ & $10 / 05 / 2002$ & & \\
\hline ER-6-2 & N/A & $582,235.73$ & $4,090,745,00$ & $7 / 21 / 1994$ & $\begin{array}{l}\text { Completion Report for Well } \\
\text { ER-6-2, (DOE/NV, 1997) }\end{array}$ & $\begin{array}{c}\text { Analysis of Well ER-6-2 } \\
\text { Testing, Yucca Flat FY } 2004 \\
\text { Testing Program, Nevada Test } \\
\text { Site, Nye County, Nevada } \\
\text { (SNJV, 2005b) }\end{array}$ \\
\hline ER-7-1 & $\begin{array}{c}\text { Yucca Flat Hydrogeologic } \\
\text { Investigation Wells Drilling } \\
\text { and Completion Criteria } \\
\text { (IT, 2002) }\end{array}$ & $589,315.09$ & $4,103,275.35$ & $2 / 09 / 2003$ & $\begin{array}{l}\text { Completion Report for Well } \\
\text { ER-7-1 (NNSA/NSO 2004c) }\end{array}$ & $\begin{array}{c}\text { Analysis of Well ER-7-1 } \\
\text { Testing, Yucca Flat FY } 2003 \\
\text { Testing Program, Nevada Test } \\
\text { Site, Nevada (SNJV, 2004a) }\end{array}$ \\
\hline
\end{tabular}


Table B.2-1

Yucca Flat/Climax Mine Phase I Well Drilling and Testing

(Page 2 of 2)

\begin{tabular}{|c|c|c|c|c|c|c|}
\hline \multirow{2}{*}{$\begin{array}{l}\text { Well } \\
\text { Name }\end{array}$} & \multirow{2}{*}{ Criteria Document } & \multicolumn{2}{|c|}{$\begin{array}{l}\text { Location } \\
\text { UTM, NAD 27, Zone } 11 \text { (m) }\end{array}$} & \multirow{2}{*}{$\begin{array}{l}\text { Completion } \\
\text { Date }\end{array}$} & \multirow{2}{*}{ Completion Report } & \multirow{2}{*}{ Testing/Analysis Report } \\
\hline & & Easting & Northing & & & \\
\hline ER-8-1 & $\begin{array}{c}\text { Yucca Flat Hydrogeologic } \\
\text { Investigation Wells Drilling } \\
\text { and Completion Criteria } \\
\text { (IT, 2002) }\end{array}$ & $583,790.62$ & $4,118,738.19$ & $11 / 17 / 2002$ & $\begin{array}{c}\text { Completion Report for } \\
\text { Well ER-8-1 } \\
\text { (NNSA/NSO, 2004d) }\end{array}$ & N/A \\
\hline ER-12-1 & $\mathrm{N} / \mathrm{A}$ & $572,411.49$ & $4,115,492.72$ & 11/24/1992 & $\begin{array}{l}\text { ER-12-1 Completion Report } \\
\quad \text { (Russell et al., 1996) }\end{array}$ & $\begin{array}{l}\text { ER-12-1 Completion Report } \\
\quad \text { (Russell et al., 1996) }\end{array}$ \\
\hline ER-12-2 & $\begin{array}{c}\text { Yucca Flat Hydrogeologic } \\
\text { Investigation Wells Drilling } \\
\text { and Completion Criteria } \\
\text { (IT, 2002) }\end{array}$ & $577,902.59$ & $4,114,057.67$ & $4 / 17 / 2003$ & $\begin{array}{c}\text { Completion Report for Well } \\
\text { ER-12-2 } \\
\text { (NNSA/NSO, 2004e) }\end{array}$ & $\begin{array}{l}\text { Analysis of Well ER-12-2 } \\
\text { Testing, Yucca Flat FY } 2003 \\
\text { Testing Program, Nevada Test } \\
\text { Site, Nevada (SNJV, 2004b) }\end{array}$ \\
\hline
\end{tabular}




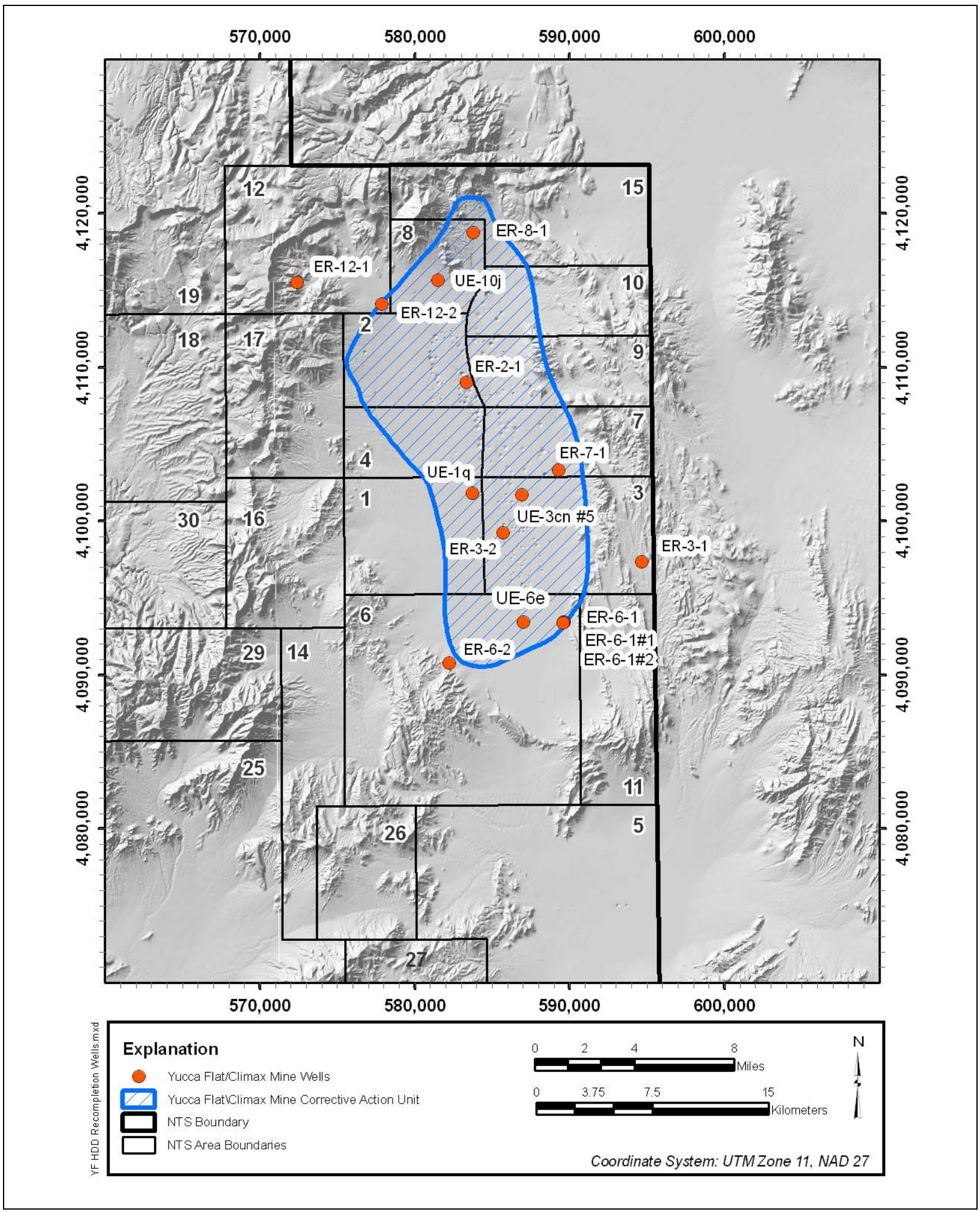

Figure B.2-1

Yucca Flat/Climax Mine CAU-Specific Investigation and Recompletion Well Locations 


\section{B.3.0 Yucca Flat/CLIMAX Mine CAIP-IDENTIFIED CHARACTERIZATION ACTIVITIES}

Nine specific characterization activities were identified in the Yucca Flat/Climax Mine CAIP

(DOE/NV, 2000). These characterization activities included:

- Mineralogy studies of the TCU

- Geophysical interpretation of the Paleozoic framework

- Analysis of existing seismic data

- Hydrologic investigation of ER-6-1 and ER-6-2

- Isotope/geochemistry mass-balance studies

- Analysis of existing tracer test data

- Laboratory radionuclide transport studies

- Rainier Mesa colloid transport studies

- Analysis of data for phenomenological models

The following subsections discuss the studies that have been conducted as part of these CAIP-specified data collection activities. A full discussion of these investigation areas is documented in the Yucca Flat/Climax Mine CAIP (DOE/NV, 2000).

\section{B.3.1 Tuff Confining Unit Mineralogical Studies}

The TCU may partition the LCA from the overlying contaminated volcanic tuff aquifers because of its position between the underground nuclear tests and the LCA. Knowledge of the lateral continuity and hydraulic characteristics of the TCU will be important in modeling groundwater movement from underground nuclear tests through the TCU to the LCA. Also of importance are the type and distribution of alteration minerals in the composition of the TCU. The alteration minerals, which can retard contaminant transport within the TCU, possess a significant range in sorption capacity for radionuclides, which will be important to transport modeling. 
Table B.3-1

Yucca Flat/Climax Mine Phase I Well Recompletions and Testing

\begin{tabular}{|c|c|c|c|c|c|}
\hline \multirow{2}{*}{$\begin{array}{l}\text { Well } \\
\text { Name }\end{array}$} & \multicolumn{2}{|c|}{$\begin{array}{l}\text { Location } \\
\text { UTM, NAD 27, Zone } 11(\mathrm{~m})\end{array}$} & \multirow{2}{*}{$\begin{array}{l}\text { Recompletion } \\
\text { Date }\end{array}$} & \multirow{2}{*}{$\begin{array}{l}\text { Recompletion } \\
\text { Report }\end{array}$} & \multirow{2}{*}{$\begin{array}{c}\text { Testing/Analysis } \\
\text { Report }\end{array}$} \\
\hline & Easting & Northing & & & \\
\hline UE-10j & $581,526.63$ & $4,115,644.86$ & 2/24/1993 & $\begin{array}{c}\text { Recompletion Report for } \\
\text { Well UE-10j, } \\
\text { (DOE/NV, 1995c) }\end{array}$ & $\begin{array}{c}\text { Pre-Completion } \\
\text { Hydrologic Testing } \\
\text { Documentation } \\
\text { Package for Well } \\
\text { UE-10j (IT, 1995) }\end{array}$ \\
\hline UE-1q & $583,722.73$ & $4,101,777.68$ & $5 / 22 / 1992$ & $\begin{array}{l}\text { Recompletion Report and } \\
\text { Summary of Well History for } \\
\text { Well UE-1q (IT, 1996b) }\end{array}$ & $\begin{array}{c}\text { Data Report, UE-1q } \\
\text { Aquifer Test } \\
\text { (DRI, 1992) }\end{array}$ \\
\hline UE-6e & $587,012.48$ & $4,093,408.77$ & 11/11/1992 & $\begin{array}{l}\text { Recompletion Report and } \\
\text { Summary of Well History for } \\
\text { Well UE-6e (IT, 1996c) }\end{array}$ & $\mathrm{N} / \mathrm{A}$ \\
\hline U-3 cn \#5 & $586,921.72$ & $4,101,714.46$ & $\mathrm{~N} / \mathrm{A}$ & $\begin{array}{l}\text { Recompletion Report for } \\
\text { BILBY (BN, 1998) }\end{array}$ & $\begin{array}{c}\text { Environmental } \\
\text { Restoration Program } \\
\text { Underground Test } \\
\text { Area Project Data } \\
\text { Analysis, Hydrologic } \\
\text { Testing } \\
\text { Documentation } \\
\text { Package for Bilby } \\
\text { (U-3cn) Hydrologic } \\
\text { Test Hole U-3cn \#5 } \\
\text { and Postshot Hole } \\
\text { U-3cn PS \#2 (IT, 1997) }\end{array}$ \\
\hline
\end{tabular}

The study of the TCU has been in progress for several years, embodied in a number of tasks for BN, SNJV, LANL, and LLNL. Table B.3-2 contains a list of major reports that have been published reporting on these studies. The most recent document Mineralogic Zonation Within the Tuff Confining Unit, Yucca Flat, Nevada Test Site (Prothro, 2005) reports the analysis of the variation of alteration mineral assemblages in the TCU based on mineralogic data from 17 holes and stratigraphic data, lithologic descriptions, and geophysical logs from approximately 500 drill holes in Yucca Flat. A three-layer mineralogic model was developed to aid in the development of the HFM for the Yucca Flat/Climax Mine CAU. This model will further support transport modeling for the Yucca Flat/Climax Mine CAU. 
Table B.3-2

Reports of TCU Studies

\begin{tabular}{||l|c|}
\hline \multicolumn{1}{|c|}{ Document Title } & Reference \\
\hline \hline $\begin{array}{l}\text { Examples of Textural and Mineralogical Alteration at the Interface of Vitric and } \\
\text { Zeolitic Tuff, Yucca, Flat, Nevada Test Site }\end{array}$ & Krier, 1991 \\
\hline $\begin{array}{l}\text { Analysis of Fractures in Cores from the Tuff Confining Unit beneath Yucca Flat, } \\
\text { Nevada Test Site }\end{array}$ & Prothro, 1998 \\
\hline $\begin{array}{l}\text { Letter Report: Underground Test Area Project, Mineralogical and Isotopic Analysis of } \\
\text { Fracture-Coating and Alteration Minerals in the Yucca Flat Tuff Confining Unit, } \\
\text { Nevada Test Site }\end{array}$ & Dickerson et al., 2004 \\
\hline Mineralogic Zonation Within the Tuff Confining Unit, Yucca Flat, Nevada Test Site & Prothro, 2005 \\
\hline
\end{tabular}

\section{B.3.2 Geophysical Interpretation of the Paleozoic Framework}

A variety of geophysical data-based investigations have been conducted in Yucca Flat in support of determining the geologic structure of the basin. These activities are identified in the following subsections and reports. The results of these investigations were used for development of the Yucca Flat/Climax Mine HFM and are discussed in A Hydrostratigraphic Model and Alternatives for the Groundwater Flow and Contaminant Transport Model of Corrective Action Unit 97: Yucca Flat-Climax Mine, Lincoln and Nye Counties, Nevada (BN, 2006).

\section{B.3.2.1 Natural-Source Magnetotelluric Survey}

An MT survey was conducted by the USGS in Yucca Flat in 2003 to provide data on the pre-Tertiary stratigraphy and structure for use in development of the HFM. The survey included 51 stations variably spaced 2 to $3 \mathrm{~km}$ apart along seven east-west oriented lines across the basin. The results of the MT survey are published in Deep Resistivity Structures of Yucca Flat, Nevada Test Site, Nevada (Asch et al., 2005) and discussed in Appendix D of BN (2006). The MT method was very successful in providing constraints on the thickness and lateral extent of the CCU in the western portion of the Yucca Flat basin (BN, 2006).

\section{B.3.2.2 Gravity and Aeromagnetic Data Interpretation}

A variety of work in support of development of the Yucca Flat/Climax Mine HFM has been based on many aeromagnetic surveys in support of the weapons testing program, and additional data collected by the USGS in 2003 (Phelps et al., 2005). Reports of geophysical interpretation studies related to the Yucca Flat/Climax Mine CAU area are listed in Table B.3-3. 
Table B.3-3

Reports of Gravity and Aeromagnetic Studies

\begin{tabular}{||l|c||}
\hline \multicolumn{1}{|c|}{ Document Title } & Reference \\
\hline \hline $\begin{array}{l}\text { Thickness of Cenozoic Deposits of Yucca Flat Inferred from Gravity Data, } \\
\text { Nevada Test Site, Nevada }\end{array}$ & $\begin{array}{c}\text { Phelps et al., } \\
1999\end{array}$ \\
\hline $\begin{array}{l}\text { High-Angle Faults in the Basement of Yucca Flat, Nevada Test Site, Nevada, } \\
\text { Based on the Analysis of a Constrained Gravity Inversion Surface }\end{array}$ & $\begin{array}{c}\text { Phelps and } \\
\text { McKee, } 1999\end{array}$ \\
\hline $\begin{array}{l}\text { Preliminary Model of the Pre-Tertiary Basement Rocks Beneath Yucca Flat, } \\
\text { Nevada Test Site, Nevada, Based on Analysis of Gravity and Magnetic Data }\end{array}$ & $\begin{array}{c}\text { Phelps et al., } \\
2000\end{array}$ \\
\hline $\begin{array}{l}\text { Modeling of the Climax Stock and Related Plutons Based on the Inversion of } \\
\text { Magnetic Data, Southwest Nevada }\end{array}$ & $\begin{array}{c}\text { Phelps et al., } \\
2004\end{array}$ \\
\hline $\begin{array}{l}\text { A Preliminary Investigation of the Structure of Southern Yucca Flat, } \\
\text { Massachusetts Mountain, and CP Basin, Nevada Test Site, Nevada, Based on } \\
\text { Geophysical Modeling }\end{array}$ & $\begin{array}{c}\text { Phelps et al., } \\
2005\end{array}$ \\
\hline
\end{tabular}

\section{B.3.2.3 Analysis of Existing Seismic Data}

Extensive seismic reflection and refraction investigations have been previously conducted in Yucca Flat by LLNL and LANL in support of weapons testing and site-characterization activities. The existing seismic data have not been evaluated comprehensively for possible contribution to the interpretation of the geologic structure and stratigraphy of Yucca Flat. The objective of this activity is to conduct a comprehensive reinterpretation of existing 2-D seismic data incorporating current structural understanding to provide, at basin-wide scale, an investigation of key features such as fault locations and HSU pinchouts or juxtapositions that may influence flow and transport. Analysis would also allow for imaging to depths below those previously considered. In addition, the use of seismic data obtained from local arrays, and from regional seismological stations during underground nuclear tests, was evaluated for its contribution to the understanding of geologic structure in Yucca Flat. This work is documented in Evaluation of Seismic Data Acquired in Yucca Flat, NTS (Pawloski and Wagoner, 2003).

\section{B.3.3 Hydrologic Investigation of Wells ER-6-1 and ER-6-2}

In FY 2004, a large-scale MWAT-TT was conducted at the ER-6-1 Well Cluster located in southwestern Yucca Flat to characterize the hydraulic and transport properties of the LCA in Yucca Flat. The plan for this test was documented in Underground Test Area Project, ER-6-1 Multi-Well Aquifer Test - Tracer Test Plan (SNJV, 2004f). 
The test involved pumping of ER-6-1 \#2 for a period of 90 days. A suite of tracers were injected into two wells at the ER-6-1 well site; ER-6-1 and ER-6-1 \#1, shortly after pumping began. Tracer breakthrough curves for ER-6-1 \#2 were determined from analysis of water samples collected from the pump discharge and from downhole discrete sampling. Water level response was continuously monitored in all three ER-6-1 wells, in three other wells completed in the LCA located up to $11.7 \mathrm{~km}$ from the ER-6-1 well cluster, and in two nearby wells completed in the overlying volcanics.

The hydraulic analysis of the test data is documented in Analysis of Hydraulic Responses from the ER-6-1 Multiple-Well Aquifer Test, Yucca Flat FY 2004 Testing Program, Nevada Test Site, Nye County, Nevada (SNJV, 2005a). The tracer test analysis is in progress and will be documented in a future report to provide information on the transport properties of the LCA in Yucca Flat.

\section{B.3.4 Isotope/Geochemistry Mass-Balance Study}

The isotope/geochemistry mass-balance studies include field and laboratory activities, compilation of existing geochemistry data, and data interpretation including geochemical modeling. The purpose of these studies is to independently verify the origin and groundwater flow paths through the Yucca Flat/Climax Mine groundwater flow system, and to provide estimates of the age and travel time for groundwater flow. The data and information from these studies is combined and assessed in the report Geochemical and Isotopic Evaluation of Groundwater Movement in Corrective Action Unit 97: Yucca Flat/Climax Mine, Nevada Test Site, Nevada (SNJV, 2006a) and summarized in Section 12.0 of this report.

\section{B.3.5 Analysis of Existing Tracer Test Data}

Three two-well recirculating tracer tests were previously conducted in the Bonanza King dolomite, which is one member of the group of formations included in the LCA HSU, at the Amargosa tracer calibration site in the Amargosa Desert, approximately $24 \mathrm{~km}$ southwest of Mercury, Nevada. This site was initially developed to study the velocity of groundwater movement through carbonate rocks underlying the NTS and the Amargosa Desert (Johnston, 1968). Further tests were run to determine the effective porosity and apparent longitudinal dispersivity in the carbonate aquifer (Leap and Belmonte, 1992). During the development of the Yucca Flat/Climax Mine CAIP (DOE/NV, 2000), data from these tracer tests were identified for reanalyses using newer techniques to estimate 
transport parameters. However, in lieu of the older tracer test data reanalyses, a new multiple-well tracer test was conducted at the ER-6-1 Well Cluster in Yucca Flat. These data were deemed to be more appropriate for use in transport modeling for the Yucca Flat/Climax Mine CAU. This ER-6-1 MWAT-TT is described in Section B.3.3.

\section{B.3.6 Laboratory Radionuclide Transport Studies}

Laboratory transport studies: diffusion cell experiments, fractured-core column experiments, and colloid transport experiments, will help estimate parameters describing solute transport, including colloid and colloid-facilitated transport. Results will be laboratory estimates of radionuclide transport parameters (e.g., matrix diffusion, dispersion, and sorption), and the uncertainty associated with these parameters. This information will provide experimental insight into colloid transport processes and the parameters describing those processes. The information will be used in the CAU-scale transport model. These activities do not address hydrologic data needs and are not discussed in this document. The results of these studies will be presented in the transport parameter data documentation report.

\section{B.3.7 Rainier Mesa Colloid Transport Studies}

Horizontal tunnels bored into Rainier Mesa were used to conduct more than 60 underground nuclear weapons effects tests for the Defense Nuclear Agency from 1957 to 1992. These tunnel tests were conducted above the water table in tuffs and lavas variably fractured by inelastic failure adjacent to the tests. The resulting fracture system allows groundwater recharge from the surface of Rainier Mesa to infiltrate and interact with residual radionuclides from the tests. The tunnels provide access to an evolved hydrologic source term of radionuclides transported by groundwater through volcanic tuffs under variably saturated flow conditions. Data from Rainier Mesa tuffs should be applicable to tuff units in Yucca Flat since the tuffs at Rainier Mesa and older tuffs deposited in deeper portions of Yucca Flat are stratigraphically similar. Results may also be extrapolated to younger tuffs that overlie the older tuffs at Yucca Flat. The objective of this activity is to investigate the geochemical and radiochemical controls on the movement of actinides introduced from underground nuclear testing under ambient flow conditions such as those found in the tunnel complexes. This study will provide information on transport of radionuclides under variably saturated conditions and will help to define the range of colloid-facilitated transport that may be expected under various groundwater conditions. 
Rainier Mesa colloid transport studies do not support the general hydrologic characterization, and will be discussed in a future report as well as the transport parameters data documentation report.

\section{B.3.8 Analysis of Data for Phenomenological Models}

Phenomenology describes the effects of the nuclear explosion on the surrounding medium during and immediately following the explosion of an underground nuclear test. Phenomenological models that are representative of reality are essential to understanding the sources of groundwater contamination present at the underground nuclear test locations. Therefore, they are essential to the modeling of groundwater flow and contaminant transport away from underground nuclear test locations. Under this CAI activity, existing data from drill backs and mine backs, pre-test, post-test, and calculational data will be analyzed to develop phenomenological models of the near-field environment of underground nuclear tests in the Yucca Flat/Climax Mine CAU.

This characterization activity has been pursued, and results will be reported in a future report on classification of underground nuclear tests in Yucca Flat, as well as a future report on the hydrologic source term for the Yucca Flat/Climax Mine CAU. The analysis of phenomenological data does not support the general hydrologic characterization and is not discussed in this report. 


\section{B.4.0 OTHER STUDIES}

Other studies have been conducted that support the Yucca Flat/Climax Mine CAU characterization. Major reports on these studies are summarized in Table B.4-1.

\section{Table B.4-1 \\ Reports of Other Studies Conducted for the Yucca Flat/Climax Mine Phase I Characterization (Page 1 of 2)}

\begin{tabular}{|c|c|}
\hline Report & Report Synopsis \\
\hline $\begin{array}{l}\text { Potential for Infiltration Through Fractured } \\
\text { Alluvium in Yucca Flat of the Nevada Test } \\
\text { Site: Preliminary Field Investigation } \\
\text { (McKinnis and Kao, 1993) }\end{array}$ & Evaluation of recharge through alluvium and volcanics in Yucca Flat. \\
\hline $\begin{array}{c}\text { New Observations of Infiltration through } \\
\text { Fractured Alluvium in Yucca Flat, Nevada } \\
\text { Test Site: A Preliminary Field Investigation } \\
\text { (Kao et al., 1994) }\end{array}$ & Evaluation of recharge through alluvium and volcanics in Yucca Flat. \\
\hline $\begin{array}{c}\text { ER-6-1 and ER-6-2 Core Fracture } \\
\text { Analyses and Geophysical Log } \\
\text { Comparisons (IT, 1996a) }\end{array}$ & $\begin{array}{l}\text { Characterization of fracturing of core samples obtained in wells ER-6-1 } \\
\text { and ER-6-2. }\end{array}$ \\
\hline $\begin{array}{l}\text { Estimation of Groundwater Velocities from } \\
\text { Yucca Flat to the Amargosa Desert } \\
\text { Using Geochemistry and } \\
\text { Environmental Isotopes } \\
\text { (Hershey and Acheampong, 1997) }\end{array}$ & $\begin{array}{l}\text { This report presents the evaluation of groundwater mixing models and } \\
\text { geochemical evolution models to potential flow from Yucca Flat to } \\
\text { Amargosa Desert. The results provide perspective for large-scale flow } \\
\text { patterns and travel times from Yucca Flat. }\end{array}$ \\
\hline $\begin{array}{c}\text { Evaluation of Recharge Potential at } \\
\text { Subsidence Crater U10i, Northern Yucca } \\
\text { Flat, Nevada Test Site } \\
\text { (Hokett et al., 2000) }\end{array}$ & Evaluation of recharge in a crater area in Yucca Flat. \\
\hline $\begin{array}{l}\text { Temperature Data Evaluation } \\
\quad \text { (Gillespie, 2003) }\end{array}$ & $\begin{array}{l}\text { The thermal gradient and associated heat flow is determined for } 13 \text { wells } \\
\text { on the NTS, of which } 8 \text { are in the Yucca Flat/Climax Mine data } \\
\text { compilation area. These wells were selected after evaluation of } \\
145 \text { temperature logs for } 63 \text { wells. }\end{array}$ \\
\hline $\begin{array}{c}\text { Final Report: Depth-Specific Hydraulic } \\
\text { Testing of Yucca Flat and Frenchman Flat } \\
\text { Environmental Restoration Wells, } \\
\text { FY } 2003 \text { (Oberlander and Russell, 2003). }\end{array}$ & $\begin{array}{l}\text { Evaluation of flow logging data for wells in Yucca Flat and Frenchman } \\
\text { Flat. }\end{array}$ \\
\hline
\end{tabular}


Table B.4-1

\section{Reports of Other Studies Conducted for the Yucca Flat/Climax Mine Phase I Characterization \\ (Page 2 of 2)}

\begin{tabular}{|c|c|}
\hline Report & Report Synopsis \\
\hline $\begin{array}{l}\text { Hydrologic Data for the Groundwater Flow } \\
\text { and Contaminant Transport Model of } \\
\text { Corrective Action Units } 101 \text { and 102: } \\
\text { Central and Western Pahute Mesa, } \\
\text { Nye County, Nevada (SNJV, 2004c) }\end{array}$ & $\begin{array}{l}\text { This report documents Pahute Mesa hydrologic data and provides } \\
\text { peripheral information related to the Yucca Flat/Climax Mine CAU. }\end{array}$ \\
\hline $\begin{array}{c}\text { Phase II Hydrologic Data for the } \\
\text { Groundwater Flow and Contaminant } \\
\text { Transport Model of Corrective Action } \\
\text { Unit 98: Frenchman Flat, Nye County, } \\
\text { Nevada (SNJV, 2004e) }\end{array}$ & $\begin{array}{l}\text { This report documents the Frenchman Flat hydrologic data and provides } \\
\text { peripheral information related to the Yucca Flat/Climax Mine CAU. }\end{array}$ \\
\hline $\begin{array}{c}\text { Analysis of Ground-Water Levels and } \\
\text { Associated Trends in Yucca Flat, Nevada } \\
\text { Test Site, Nye County, Nevada, } \\
\text { 1951-2003 (Fenelon, 2005) }\end{array}$ & $\begin{array}{l}\text { This report provides a broad overview of water level information for } \\
\text { Yucca Flat, a compilation of historic records, and an analysis of trends in } \\
\text { water levels over the historic time period. }\end{array}$ \\
\hline $\begin{array}{c}\text { Written Communication. Subject: } \\
\text { Analysis and Evaluation of Pore-Fluid } \\
\text { Overpressure and their Impact on } \\
\text { Groundwater Flow and Solute Transport } \\
\text { in Areas 3, 4, and } 7 \text { at the Nevada Test } \\
\text { Site, Nye County, Nevada } \\
\text { (Wolfsburg et al., 2006) }\end{array}$ & $\begin{array}{l}\text { Water levels within bedded tuffs in central Yucca Flat were elevated } \\
\text { hundreds of meters in response to nuclear testing in the tuffs. This } \\
\text { report documents the LANL analysis of anomalous high pore pressures } \\
\text { in the Yucca Flat Tuff Pile area. A groundwater flow and transport model } \\
\text { was developed for this area to investigate the relationship between the } \\
\text { overpressured formation, rock properties, and head observations. }\end{array}$ \\
\hline $\begin{array}{l}\text { Hydraulic Characterization of } \\
\text { Overpressured Tuffs in Central Yucca } \\
\text { Flat, Nevada Test Site, Nye County, } \\
\text { Nevada (Halford et al., 2005) }\end{array}$ & $\begin{array}{l}\text { Water levels within bedded tuffs in central Yucca Flat were elevated } \\
\text { hundreds of meters in response to nuclear testing in the tuffs. This } \\
\text { report documents the USGS analysis of anomalous high pore pressures } \\
\text { in the Yucca Flat Tuff Pile area. Calibration of cross-sections and 3-D } \\
\text { groundwater flow models to land subsidence rates yields hydraulic } \\
\text { conductivity estimates for the tuff units. }\end{array}$ \\
\hline $\begin{array}{l}\text { Temperature Profiles and Hydrologic } \\
\text { Implications from the Nevada Test Site } \\
\text { Area (Gillespie, 2005) }\end{array}$ & $\begin{array}{l}\text { This study follows the Gillespie, 2002, study determining the thermal } \\
\text { gradient and associated heat flow for an additional } 39 \text { wells on the NTS, } \\
\text { of which } 20 \text { are in the Yucca Flat/Climax Mine data compilation area. }\end{array}$ \\
\hline $\begin{array}{l}\text { Underground Test Area Fracture Analysis } \\
\text { Report for Yucca Flat Wells ER-2-1, } \\
\text { ER-6-1\#2, ER-7-1, and ER-12-2, Nevada } \\
\text { Test Site, Nevada (SNJV, 2005c) }\end{array}$ & $\begin{array}{l}\text { Fracture characterization analyses from borehole logs obtained in Yucca } \\
\text { Flat Wells ER-2-1, ER-6-1 \#2, ER-7-1, and ER-12-2. }\end{array}$ \\
\hline
\end{tabular}




\section{B.5.0 REFERENCES}

Asch, T.A., B.D. Rodriguez, J.A. Sampson, E. Walling, and J.M. Williams. 2005. Deep Resistivity Structures of Yucca Flat, Nevada Test Site, Nevada. U.S. Geological Survey Open-File Report (in press). U.S. Geological Survey.

BN, see Bechtel Nevada.

Bechtel Nevada. 1998. Recompletion Report for BILBY. U.S. Department of Energy, Nevada Operations Office, DOE/NV-500. Las Vegas, NV.

Bechtel Nevada. 2006. A Hydrostratigraphic Model and Alternatives for the Groundwater Flow and Contaminant Transport Model of Corrective Action Unit 97: Yucca Flat-Climax Mine, Lincoln and Nye Counties, Nevada, DOE/NV/11718-210. Las Vegas, NV.

DOE/NV, see U.S. Department of Energy, Nevada Operations Office.

DRI, see Desert Research Institute.

Desert Research Institute. 1992. Data Report, UE-1q Aquifer Test. Las Vegas, NV: Water Resources Center.

Dickerson, R., and T.P. Rose, and G. Eaton. 2004. Written communication. Subject: Letter Report: Underground Test Area Project, Mineralogical and Isotopic Analysis of Fracture-Coating and Alteration Minerals in the Yucca Flat Tuff Confining Unit, Nevada Test Site. Lafayette, CO: Stoller-Navarro Joint Venture. Livermore, CA: Lawrence Livermore National Laboratory.

Fenelon, J.M. 2005. Analysis of Ground-Water Levels and Associated Trends in Yucca Flat, Nevada Test Site, Nye County, Nevada, 1951-2003, Scientific Investigations Report 2005-5175: 87. Carson City, NV: U.S. Geological Survey.

Gillespie, D. 2003. Temperature Data Evaluation. U.S. Department of Energy, National Nuclear Security Administration Nevada Site Office, DOE/NV/13609-22; Publication No. 45194. Reno, NV: Desert Research Institute.

Gillespie, D. 2005. Temperature Profiles and Hydrologic Implications from the Nevada Test Site Area, DOE/NV--3609-40; Publication No. 45211. Las Vegas, NV: Desert Research Institute. 
Halford, K.J., R.J. Laczniak, and D.L. Galloway. 2005. Hydraulic Characterization of Overpressured Tuffs in Central Yucca Flat, Nevada Test Site, Nye County, Nevada, ScientificInvestigations Report 2005-5211. U.S. Geological Survey.

Hershey, R.L., and S.Y. Acheampong. 1997. Estimation of Groundwater Velocities from Yucca Flat to the Amargosa Desert Using Geochemistry and Environmental Isotopes. DOE/NV/11508-26; Publication No. 45157. Desert Research Institute.

Hokett, S.L., D.R. Gillespie, G.V. Wilson, and R.H. French. 2000. Evaluation of Recharge Potential at Subsidence Crater U10i, Northern Yucca Flat, Nevada Test Site, DOE/NV/11508-53; Publication No. 45174. Reno, NV: Desert Research Institute.

IT, see IT Corporation.

IT Corporation. 1995. Pre-Completion Hydrologic Testing Documentation Package for Well UE-10j. Las Vegas, NV.

IT Corporation. 1996a. ER-6-1 and ER-6-2 Core Fracture Analyses and Geophysical Log Comparisons. Las Vegas, NV.

IT Corporation. 1996b. Recompletion Report and Summary of Well History for Well UE-1q, DOE/NV--444. Las Vegas, NV.

IT Corporation. 1996c. Recompletion Report and Summary of Well History for Well UE-6e, DOE/NV--434. Las Vegas, NV.

IT Corporation. 1997. Environmental Restoration Program Underground Test Area Project Data Analysis, Hydrologic Testing Documentation Package for Bilby (U-3cn) Hydrologic Test Hole U-3cn \#5 and Postshot Hole U-3cn PS \#2. Las Vegas, NV.

IT Corporation. 2002. Yucca Flat Hydrogeologic Investigation Wells Drilling and Completion Criteria, Rev. 0, ITLV/13052-164. Las Vegas, NV.

Johnston, R.H. 1968. U.S. Geological Survey Tracer Study Amargosa Desert, Nye County, Nevada Part 1: Exploratory Drilling, Tracer Well Construction and Testing, and Preliminary Findings, Open File Report-474-98. Denver, CO: U.S. Geological Survey.

Kao, C.S., D.K. Smith, and W.B. McKinnis. 1994. New Observations of Infiltration through Fractured Alluvium in Yucca Flat, Nevada Test Site: A Preliminary Field Investigation.

U.S. Department of Energy, UCRL-ID-116129. Livermore, CA: Lawrence Livermore National Laboratory.

Krier, D.J. 1991. "Examples of Textural and Mineralogical Alteration at the Interface of Vitric and Zeolitic Tuff, Yucca, Flat, Nevada Test Site, Sixth Symposium on Containment of Underground Nuclear Explosions," Reno, NV. Livermore, CA: Lawrence Livermore National Laboratory. 
Leap, D.I., and P.M. Belmonte. 1992. "Influence of Pore Pressure on Apparent Dispersivity of a Fissured MITIC Dolomitic Aquifer.” In Groundwater, v. 30(1): 87-95. Washington, D.C.: American Geophysical Union.

McKinnis, W.B., and C.S. Kao. 1993. Potential for Infiltration Through Fractured Alluvium in Yucca Flat of the Nevada Test Site: Preliminary Field Investigation. Lawrence Livermore National Laboratory and University of California at Berkeley.

NNSA/NV, see U.S. Department of Energy, National Nuclear Security Administration, Nevada Operations Office.

NNSA/NSO, see U.S. Department of Energy, National Nuclear Security Administration, Nevada Site Office.

Oberlander, P.L., and C.E. Russell. 2003. Final Report: Depth-Specific Hydraulic Testing of Yucca Flat and Frenchman Flat Environmental Restoration Wells, FY 2003, DOE/NV/13609-28; Publication No. 45199. Reno, NV: Desert Research Institute.

Pawloski, G.A., and J.L. Wagoner. 2003. Evaluation of Seismic Data Acquired in Yucca Flat, NTS, by the Lawrence Livermore National Laboratory. Livermore, CA: Lawrence Livermore National Laboratory.

Phelps, G.A., V.E. Langenheim, and R.C. Jachens. 1999. Thickness of Cenozoic Deposits of Yucca Flat Inferred from Gravity Data, Nevada Test Site, Nevada, Open-File Report-99-310. U.S. Geological Survey.

Phelps, G.A., and E.H. McKee. 1999. High-Angle Faults in the Basement of Yucca Flat, Nevada Test Site, Nevada, Based on the Analysis of a Constrained Gravity Inversion Surface, Open-File Report-99-383. U.S. Geological Survey.

Phelps, G.A., E.H. McKee, D.S. Sweetkind, and V.E. Langenheim. 2000. Preliminary Model of the Pre-Tertiary Basement Rocks Beneath Yucca Flat, Nevada Test Site, Nevada, Based on Analysis of Gravity and Magnetic Data, Open-File Report-2000-134. U.S. Geological Survey.

Phelps, G.A., R.C. Jachens, B.C. Moring, and C.W. Roberts. 2004. Modeling of the Climax Stock and Related Plutons Based on the Inversion of Magnetic Data, Southwest Nevada, Open-File Report-2004-1345.

Phelps, G.A., A.L. Justet, B.C. Moring, and C.W. Roberts. 2005. A Preliminary Investigation of the Structure of Southern Yucca Flat, Massachusetts Mountain, and CP Basin, Nevada Test Site, Nevada, Based on Geophysical Modeling, Open-File Report-2005-1367. U.S. Geological Survey.

Prothro, L.B 1998. Analysis of Fractures in Cores from the Tuff Confining Unit Beneath Yucca Flat, Nevada Test Site. Las Vegas, NV: Bechtel Nevada. 
Prothro, L.B. 2005. Mineralogic Zonation Within the Tuff Confining Unit, Yucca Flat, Nevada Test Site. DOE/NV/11718--995. Las Vegas, NV: Bechtel Nevada.

Russell, C.E., D. Gillespie, J.C. Cole, S.L. Drellack, L.B. Prothro, P.H. Thompson, R.L. McCall, G.A. Pawloski, and R. Carlson. 1996. Completion Report for ER-12-1, DOE/NV/10845-36; Publication No. 45120. Las Vegas, NV: Desert Research Institute.

SNJV, see Stoller-Navarro Joint Venture.

Smith, D.K. 1995. Phenomenology of Underground Nuclear Explosions Conducted at the Nevada Test Site with Emphasis on Recent Experience at BASEBALL (U7ba) and INGOT (U2gg). Livermore, CA: Lawrence Livermore National Laboratory.

Stoller-Navarro Joint Venture. 2004a. Analysis of Well ER-7-1 Testing, Yucca Flat FY 2003 Testing Program, Nevada Test Site, Nevada, S-N/99205--021. Las Vegas, NV.

Stoller-Navarro Joint Venture. 2004b. Analysis of Well ER-12-2 Testing, Yucca Flat FY 2003 Testing Program, Nevada Test Site, Nevada, Rev. 0, S-N/99205--015. Las Vegas, NV.

Stoller-Navarro Joint Venture. 2004c. Hydrologic Data for the Groundwater Flow and Contaminant Transport Model of Corrective Action Units 101 and 102: Central and Western Pahute Mesa, Nye County, Nevada, S-N/99205--002; Shaw/13052-204. Las Vegas, NV.

Stoller-Navarro Joint Venture. 2004d. Letter Report: Analysis of Well ER-2-1 Hydraulic Testing, Yucca Flat FY 2003, Nevada Test Site, Nevada, DOE/NV--992. Las Vegas, NV.

Stoller-Navarro Joint Venture. 2004e. Phase II Hydrologic Data for the Groundwater Flow and Contaminant Transport Model of Corrective Action Unit 98: Frenchman Flat, Nye County, Nevada, S-N/99205--032. Las Vegas, NV.

Stoller-Navarro Joint Venture. 2004f. Underground Test Area Project, ER-6-1 Multi-Well Aquifer Test - Tracer Test Plan, Rev. 0, S-N/99205--013. Las Vegas, NV.

Stoller-Navarro Joint Venture. 2005a. Analysis of Hydraulic Responses from the ER-6-1 Multiple-Well Aquifer Test, Yucca Flat FY 2004 Testing Program, Nevada Test Site, Nye County, Nevada, S-N/99205--051. Las Vegas, NV.

Stoller-Navarro Joint Venture. 2005b. Analysis of Well ER-6-2 Testing, Yucca Flat FY 2004 Testing Program, Nevada Test Site, Nevada, S-N/99205--053. Las Vegas, NV.

Stoller-Navarro Joint Venture. 2005c. Underground Test Area Fracture Analysis Report for Yucca Flat Wells ER-2-1, ER-6-1\#2, ER-7-1, and ER-12-2, Nevada Test Site, Nevada, S-N/99205--040. Las Vegas, NV. 
Stoller-Navarro Joint Venture. 2006. Geochemical and Isotopic Evaluation of Groundwater Movement in Corrective Action Unit 97: Yucca Flat/Climax Mine, Nevada Test Site, Nevada S-N/99205--070. Las Vegas, NV.

U.S. Department of Energy, Nevada Operations Office. 1995a. Completion Report for Well ER-3-1, DOE/NV-396, UC-700. Las Vegas, NV.

U.S. Department of Energy, Nevada Operations Office. 1995b. Completion Report for Well ER-3-2, DOE/NV-408, UC-700. Las Vegas, NV.

U.S. Department of Energy, Nevada Operations Office. 1995c. Written communication. Subject: Recompletion Report for Well UE-10j. Las Vegas, NV.

U.S. Department of Energy, Nevada Operations Office. 1997. Written communication. Subject: Completion Report for Well ER-6-2. Las Vegas, NV.

U.S. Department of Energy, Nevada Operations Office. 2000. Corrective Action Investigation Plan for Corrective Action Unit 97: Yucca Flat/Climax Mine, Nevada Test Site, Nevada, DOE/NV--659. Las Vegas, NV.

U.S. Department of Energy, National Nuclear Security Administration, Nevada Site Office. 2004a. Completion Report for Well Cluster ER-6-1, DOE/NV/11718-862. Las Vegas, NV.

U.S. Department of Energy, National Nuclear Security Administration, Nevada Site Office. 2004b. Completion Report for Well ER-2-1, DOE/NV/11718-893. Las Vegas, NV.

U.S. Department of Energy, National Nuclear Security Administration, Nevada Site Office. 2004c. Completion Report for Well ER-7-1, DOE/NV/11718-865. Las Vegas, NV.

U.S. Department of Energy, National Nuclear Security Administration, Nevada Site Office. 2004 d. Completion Report for Well ER-8-1, DOE/NV/11718-854. Las Vegas, NV.

U.S. Department of Energy, National Nuclear Security Administration, Nevada Site Office. 2004e. Completion Report for Well ER-12-2, DOE/NV/11718-846. Las Vegas, NV.

Wolfsburg, A., J. Boryta, P. Stauffer, S. Kelkar, Z. Dash, R. Warren, and C. Gable. 2006. Written communication. Subject: Analysis and Evaluation of Pore-Fluid Overpressures and their Impact on Groundwater Flow and Solute Transport in Areas 3, 4, and 7 at the Nevada Test Site, Nye County, Nevada. Los Alamos, New NM: Los Alamos National Laboratory. 
Appendix C

Hydraulic Head Supplementary Information 


\section{C.1.0 Hydraulic Head Supplementary INFORMation}

This appendix contains supplementary information for Section 10.0, Hydraulic Head. Section C.1.1 presents supporting information for the supplementary report Formation Access Interval and Hydrograph included on the compact disc (CD) version of this document and also for the data presented in Tables 10-2 and 10-3. Section C.1.2 presents a discussion of the system used to screen the FAIs to determine the representativeness of FAI/water levels for assignment to potentiometric horizons.

\section{C.1.1 Well Formation Access Interval and Hydrograph Report}

An Adobe Acrobat file entitled "Formation Access Interval and Hydrograph Report" is provided on the $\mathrm{CD}$ version of this document. The report contains an entry for each of the wells listed in Table 10-2. The report combines data from a number of sources (primarily BN, 2006 and Fenelon, 2005) and provides location information, a summary of water level data, FAI information, HSU information at the well, and a hydrograph of available water levels.

\section{C.1.1.1 Hydraulic Head Formation Access Interval and Hydrograph Report Field Descriptions}

- USGS ID: USGS NWIS site identifier. This ID is used by the USGS to identify each unique well configuration.

- UGTA Borehole ID: UGTA Borehole Index Database Identifier. This ID is used to identify the well in the UGTA Borehole Index.

- UTM 11 NAD 27 Coordinates: Coordinates for the well, easting and northing, from the UGTA Borehole Index in the UTM Zone 11 NAD 27 coordinate system in meters.

- USGS Surface Elevation: Surface elevation datum for the well, in meters amsl from the USGS Yucca Flat water-level database using NAD 27. The surface elevations are consistent with the UGTA Borehole Index. 
- Estimated Accuracy: Estimated accuracy of the surface elevation from the USGS Yucca Flat water-level database, in meters.

- Survey Method: Method used to determine the surface elevation from the USGS Yucca Flat water-level database.

- Mean Water Level: Mean of the steady state water-level measurements, as elevation, identified as steady-state in the USGS Yucca Flat water-level database in meters. The mean does not include anomalous water-level measurements.

- Count: Count of the number of water-level measurements averaged to determine the mean water level.

- WL meas. SD: SD of the population of water-level measurements averaged to determine the mean water level in meters.

- Minimum: Lowest elevation of the water-level measurements averaged to determine the mean water level in meters amsl.

- Maximum: Highest elevation of the water-level measurements averaged to determine the mean water level in meters amsl.

- Start Date: Earliest date of the water-level measurements averaged to determine the mean water level.

- End Date: Latest date of the water-level measurements averaged to determine the mean water level.

- Sample Mean Confidence Interval: 95 percent confidence interval of the mean water level. This incorporates the variance of individual water levels from the mean and the estimated error of water level measurements due to measurement method.

- Total WL Uncertainty: Estimate of the uncertainty for the Mean Water Level based on Sample Mean Confidence Interval and the Surface Elevation Estimated Accuracy

- Open Interval Top: Highest elevation of the FAI, in meters amsl. The open interval top may be above the mean water level, in which case a correction is made.

- Water-Level-Corrected-Top: Highest elevation of the FAI or the mean water, in meters amsl, whichever is lower. If the mean water-level is below the open interval top, the water-levelcorrected-top is the mean water level; otherwise, it is the open interval top.

- Open Interval Bottom: Lowest elevation of the FAI in meters amsl.

- Effective Thickness: The water-level-corrected-top minus the open interval bottom in meters. 
- Hydrostratigraphic Units: HSUs identified in the well from Yucca Flat/Climax Mine HFM database.

- HSU Top Elevation: Elevation of the top of the HSU in the well in meters amsl.

- Effective FAI HSU Thickness: Thickness of the HSU within the FAI, below the water-levelcorrected-top, in meters.

- Effective FAI HSU Percent: Percentage of the FAI effective thickness for the HSU.

\section{C.1.1.2 Significant Figures}

The FAI and HSU information in the report Formation Access Interval and Hydrograph for well construction is shown to one decimal place, which is considered appropriate accuracy for these values. The surface elevation measurements and water-level measurements are generally made to $0.01 \mathrm{ft}$, and two decimal places are carried through conversions (to meters) and calculations involving these elevations. The accuracy and uncertainty values reported conform to these conventions for significant figures. Values reported as 0.00 indicate that calculated values were less than this level of significance.

\section{C.1.1.3 Hydrographs}

The hydrograph presents all of the water-level measurements for the site with the measurements color-coded to indicate those that were identified as steady-state. A standard legend for the hydrograph is provided at the beginning of the file. The steady-state measurements were used to compute a mean steady-state water-level elevation in meters amsl. The uncertainty of the mean water level is also shown on the hydrograph.

\section{C.1.2 Assignment of Formation Access Intervals to Potentiometric Horizons}

The FAIs for each site in Tables 10-2 and 10-3 were evaluated to determine whether the mean water level was applicable to the water table or to the LCA potentiometric horizon based on a conceptual model of the hydrology (HSU structure in terms of HGUs, and the general vertical gradient configuration in Yucca Flat) and consideration of the position of the FAI with respect to the water level and within the HGU structure. Because many of the FAIs span multiple HGUs across which vertical gradients exist, the water levels measured in these FAIs do not necessarily closely represent 
the head at all levels within the FAI. The measured water levels reflect the transmissivity-weighted average head for the range of heads across the FAI, if viewed as HGU intervals with different heads, or as the depth-integrated head versus hydraulic conductivity across the FAI. For HGUs with high vertical hydraulic conductivity, vertical gradients are generally low and the average head across the HGU may be representative of the entire HGU interval. However, for confining unit HGUs with low vertical hydraulic conductivity, vertical gradients can be high and measured water levels in FAIs across confining unit HGUs would be intermediate relative to the actual head at the top and at the bottom of the FAI. For FAIs that cross multiple HGUs, the measured water level would reflect a transmissivity-weighted average of the heads in each HGU interval. Because the available data do not support quantification of these effects, a generalized scheme for evaluating these effects was developed and is presented here.

\section{C.1.2.1 Conceptual Model and Considerations}

The conceptual model of the hydrology used for evaluation was generalized (using HGUs) from the HFM model, consisting of uppermost permeable formations (AA, VAs) overlying confining units (TCUs, UCCU), overlying a permeable unit (LCA) with an underlying confining unit (LCCU, MGCU). To the extent that there is a vertical gradient, it is downward from the upper units to the LCA. Vertical gradients are low across permeable HGUs and large across confining HGUs.

The location of the water level with respect to the FAI was specifically considered when assigning representativeness qualifiers. If the water level was within the FAI, it was considered to represent the water table, modified by consideration of head averaging if the FAI extended downwards across units of lower head. If the water level was above the top of the FAI, the effect of averaging on the potential higher head in the formation above the FAI top was considered in assessing the representativeness. The relative proportions of different kinds of HGUs in the FAI were also taken into consideration. If there was a long proportion of confining unit within an FAI, the effect of the head gradient within the confining unit was weighted according to the proportion.

\section{C.1.2.2 Qualification Scheme}

Table C.1-1 shows the levels of representativeness used to qualify the mean water levels with respect to the specific potentiometric horizons. The FAIs were reviewed regarding different situations that 
Table C.1-1

Qualification Levels

\begin{tabular}{|c|c|}
\hline Qualifiers & Representativeness Level \\
\hline \hline 1 & Representative \\
\hline 2 & Less Representative \\
\hline 3 & Indeterminate Representativity \\
\hline 4 & Not Applicable \\
\hline
\end{tabular}

occurred in spanning multiple HGUs and categorized with respect to the implications regarding averaging heads of different HGUs. With respect to the water table, FAIs wholly in the uppermost aquifer units, with top elevations above or near the measured water level, were considered as representative of the water table. Formation access intervals with top elevations a substantial distance below the measured water level and within upper aquifer units were considered to be less representative. Formation access intervals that spanned from the upper aquifer units into confining units were considered less representative or of indeterminate representivity depending upon the depth of the top of the FAI below the measured water level and the depth of penetration into the confining units. With respect to the LCA, the logic was inverted. Water levels for FAIs wholly within the LCA were considered representative of the LCA. Water levels were considered less representative due to FAIs that extended up to confining units. The different FAI situations are listed in Table C.1-2 and matrixed with the two different situations regarding the relationship of the water level in the well to the FAI. This table provides the matrix of the FAI situations and the water level situations, and the qualification levels assigned to the different possibilities.

\section{C.1.2.3 Assignment Methodology}

Table C.1-3 lists all of the sites, and presents the assignment of qualifiers for the representativeness of the mean water level. In cases where a range of qualifiers are listed in Table C.1-2, the assignment was based on judgement of the relative thicknesses of the HSUs in the FAI, and the potential vertical gradient across the HSUs at the site location. Review of the water levels within the spatial context, as shown in Plate 7, may identify apparent inconsistencies. This may be due to unrecognized local features, or the mean water level may not be representative due to well conditions not accounted for in this qualification scheme. Such factors include remnant drilling fluid, fill, or bridges in the borehole that restrict the effective FAI to an upper interval; different from that identified from the 
Table C.1-2

Representativity Matrix

\begin{tabular}{|c|c|c|c|}
\hline FAl situations & Water Level Situations & $\begin{array}{l}\text { Water Table } \\
\text { Qualifier }\end{array}$ & $\begin{array}{l}\text { LCA } \\
\text { Qualifier }\end{array}$ \\
\hline \multirow{2}{*}{$\begin{array}{l}\text { 1) Corrected FAl totally within upper permeable } \\
\text { formation. }\end{array}$} & 1) Below top of FAI & $1-2$ & N/A \\
\hline & 2) Above top of FAI & $1-2$ & $N / A$ \\
\hline \multirow{2}{*}{$\begin{array}{l}\text { 2a) Corrected FAI crosses upper permeable formation } \\
\text { into confining formation. }\end{array}$} & 1) Below top of FAI & $1-2$ & $\mathrm{~N} / \mathrm{A}$ \\
\hline & 2) Above top of FAl & $1-2$ & N/A \\
\hline \multirow{2}{*}{$\begin{array}{l}\text { 2b) Corrected FAI crosses two units of upper permeable } \\
\text { formation separated by a confining formation. }\end{array}$} & 1) Below top of FAI & 2 & N/A \\
\hline & 2) Above top of FAl & 2 & N/A \\
\hline \multirow{2}{*}{ Corrected FAI totally within confining formation. } & 1) Below top of FAI & 1 & $\mathrm{~N} / \mathrm{A}$ \\
\hline & 2) Above top of FAl & $1-3$ & N/A \\
\hline \multirow{2}{*}{$\begin{array}{l}\text { 4a) Corrected FAI crosses confining formation into lower } \\
\text { permeable formation - large proportion of FAI within } \\
\text { confining formation. }\end{array}$} & 1) Below top of FAl & $1-4$ & 3 \\
\hline & 2) Above top of FAI & $3-4$ & 3 \\
\hline \multirow{2}{*}{$\begin{array}{l}\text { 4b) Corrected FAI crosses confining formation into lower } \\
\text { permeable formation - low proportion of FAI in } \\
\text { confining formation. }\end{array}$} & 1) Below top of FAI & 1 & 1 \\
\hline & 2) Above top of FAl & 3 & 1 \\
\hline \multirow{2}{*}{ Corrected FAI totally in lower permeable formation. } & 1) Below top of FAI & 1 & 1 \\
\hline & 2) Above top of FAl & $1-4$ & 1 \\
\hline \multirow{2}{*}{$\begin{array}{l}\text { Corrected FAl crosses upper permeable formation } \\
\text { across confining formation into lower permeable } \\
\text { formation. }\end{array}$} & 1) Below top of FAl & 3 & $3-4$ \\
\hline & 2) Above top of FAl & 3 & 4 \\
\hline
\end{tabular}

construction information presented in Section 10.0 tables and this appendix. These instances must be judged individually. This categorization effort was meant to establish a first approximation of representativeness for potentiometric horizons and is not presented as definitive. 
Table C.1-3

Formation Access Interval Assignment to Potentiometric Horizons

(Page 1 of 3)

\begin{tabular}{|c|c|c|c|c|c|c|c|c|c|c|c|c|c|c|c|c|c|c|c|c|c|c|c|}
\hline \multirow{2}{*}{$\begin{array}{l}\text { Common Name } \\
\text { (USGS Local Name) }\end{array}$} & \multirow{2}{*}{$\begin{array}{c}\text { FAl } \\
\text { Situation }^{\mathrm{a}}\end{array}$} & \multirow{2}{*}{$\begin{array}{l}\text { Water Level } \\
\text { Situation }\end{array}$} & \multicolumn{2}{|c|}{ Representativeness $^{\mathrm{C}}$} & \multirow{2}{*}{$\begin{array}{c}\begin{array}{c}\text { Mean Water } \\
\text { Level }\end{array} \\
m \text { amsl }\end{array}$} & \multirow{2}{*}{$\begin{array}{c}\begin{array}{c}\text { FAl Top } \\
\text { Elevation }\end{array} \\
m \text { amsl }\end{array}$} & \multirow{2}{*}{$\begin{array}{c}\begin{array}{c}\text { FAl Bottom } \\
\text { Elevation }\end{array} \\
m \text { amsl }\end{array}$} & \multirow{2}{*}{$\begin{array}{c}\begin{array}{c}\text { Water Level } \\
\text { Corrected Top }\end{array} \\
\mathrm{m} \text { amsl }\end{array}$} & \multirow{2}{*}{ HSU1 } & \multicolumn{2}{|c|}{ Length } & \multirow{2}{*}{ HSU2 } & \multicolumn{2}{|c|}{ Length } & \multirow{2}{*}{ HSU3 } & \multicolumn{2}{|c|}{ Length } & \multirow{2}{*}{ HSU4 } & \multicolumn{2}{|c|}{ Length } & \multirow{2}{*}{ HSU5 } & \multicolumn{2}{|c|}{ Length } \\
\hline & & & Water Table & LCA & & & & & & $\mathrm{m}$ & $\%$ & & m & $\%$ & & m & $\%$ & & $\mathrm{~m}$ & $\%$ & & $\mathrm{~m}$ & $\%$ \\
\hline ER-3-1-1 (deep) & 5 & 2 & 4 & 1 & 728.71 & 570.87 & 550.07 & 570.87 & LCA & 20.80 & $100 \%$ & & & & & & & & & & & & \\
\hline ER-3-1-2 (shallow) & 5 & 2 & 4 & 1 & 728.83 & 663.47 & 639.07 & 663.47 & LCA & 24.40 & $100 \%$ & & & & & & & & & & & & \\
\hline ER- 3-2-2 (middle) & 1 & 2 & 1 & & 733.13 & 429.78 & 418.78 & 429.78 & AA & 10.08 & $92 \%$ & TMUVTA & 0.92 & $8 \%$ & & & & & & & & & \\
\hline ER- 6-1 (piezometer) & 3 & 1 & 1 & & 750.78 & 755.67 & 730.07 & 750.78 & OSBCU & 20.71 & $100 \%$ & & & & & & & & & & & & \\
\hline ER- 6-1 main (2129 ft) & 5 & 2 & 4 & 1 & 726.98 & 644.87 & 550.38 & 644.87 & LCA & 94.49 & $100 \%$ & & & & & & & & & & & & \\
\hline ER- 6-1 main (2243 ft) & 5 & 2 & 4 & 1 & 728.57 & 645.64 & 516.41 & 645.64 & LCA & 129.24 & $100 \%$ & & & & & & & & & & & & \\
\hline ER- 6-1-1 & 5 & 2 & 4 & 1 & 728.61 & 636.16 & 574.59 & 636.16 & LCA & 61.57 & $100 \%$ & & & & & & & & & & & & \\
\hline ER- 6-1-2 (1587 ft) & 1 & 1 & 1 & & 750.91 & 1163.52 & 715.77 & 750.91 & TSA & 35.14 & $100 \%$ & & & & & & & & & & & & \\
\hline ER- 6-1-2 (3200 ft) & 5 & 2 & 4 & 1 & 728.59 & 658.60 & 224.13 & 658.60 & LCA & 434.47 & $100 \%$ & & & & & & & & & & & & \\
\hline ER- 6-2 & 2 & 1 & 2 & 2 & 745.58 & 757.51 & 250.93 & 745.58 & LCA3 & 334.58 & $68 \%$ & uccu & 160.07 & $32 \%$ & & & & & & & & & \\
\hline ER- 7-1 & 5 & 1 & 1 & 1 & 729.38 & 753.22 & 532.24 & 729.38 & LCA & 197.14 & $100 \%$ & & & & & & & & & & & & \\
\hline ER-12-1 (1641-1846 ft) & 3 & 2 & 3 & & 1307.62 & 1273.13 & 1210.63 & 1273.13 & uccu & 62.50 & $100 \%$ & & & & & & & & & & & & \\
\hline ER-12-2 (579 ft) & $2 a$ & 1 & 2 & & 1307.70 & $1,397.68$ & $1,235.88$ & $1,307.70$ & $\mathrm{AA}$ & 10.70 & $15 \%$ & LTCU & 48.80 & $68 \%$ & uccu & 12.32 & $17 \%$ & & & & & & \\
\hline TW- 7 & 3 & 2 & 3 & & 728.80 & 622.91 & 544.31 & 622.91 & LTCU & 78.60 & $100 \%$ & & & & & & & & & & & & \\
\hline TW- B & 1 & 2 & 1 & & 739.95 & 729.33 & 687.88 & 729.33 & TSA & 41.45 & $100 \%$ & & & & & & & & & & & & \\
\hline TW- D & $4 \mathrm{~b}$ & 1 & 1 & 1 & 739.87 & 746.86 & 670.66 & 739.87 & ATCU & 1.37 & $2 \%$ & LCA & 67.80 & $98 \%$ & & & & & & & & & \\
\hline TW- E (1970 ft) & 3 & 1 & 1 & & 748.48 & 1094.85 & 671.17 & 748.48 & LTCU & 77.31 & $100 \%$ & & & & & & & & & & & & \\
\hline TW- E (2620 ft) & 5 & 2 & 4 & 1 & 729.10 & 502.62 & 473.05 & 502.62 & LCA & 29.57 & $100 \%$ & & & & & & & & & & & & \\
\hline U- 2bs & $2 a$ & 1 & 2 & & 762.84 & 1264.00 & 702.86 & 762.84 & TMLVTA & 1.74 & $3 \%$ & LTCU & 58.24 & $97 \%$ & & & & & & & & & \\
\hline U- $2 \mathrm{dr}$ & 1 & 1 & 1 & & 748.20 & 1278.94 & 717.80 & 748.20 & $\mathrm{AA}$ & 30.40 & $100 \%$ & & & & & & & & & & & & \\
\hline U - 2ei & 3 & 1 & 1 & & 740.38 & 1283.21 & 678.79 & 740.38 & LTCU & 61.59 & $100 \%$ & & & & & & & & & & & & \\
\hline U- 2ex & $2 a$ & 1 & 2 & & 752.64 & 1278.02 & 701.65 & 752.64 & TMWTA & 36.04 & $71 \%$ & TMLVTA & 2.50 & $5 \%$ & LTCU & 12.45 & $24 \%$ & & & & & & \\
\hline U- $2 g f$ & 1 & 1 & 1 & & 754.13 & 1259.13 & 743.41 & 754.13 & TMWTA & 10.72 & $100 \%$ & & & & & & & & & & & & \\
\hline U-2gh & 3 & 1 & 1 & & 793.97 & 1237.49 & 724.21 & 793.97 & LTCU & 69.72 & $100 \%$ & & & & & & & & & & & & \\
\hline U - 3cn 5 & 5 & 2 & 4 & 1 & 728.06 & 358.82 & 298.47 & 358.82 & LCA & 60.35 & $100 \%$ & & & & & & & & & & & & \\
\hline U - 3jg & 1 & 1 & 1 & & 735.32 & 1171.65 & 704.70 & 735.32 & $\mathrm{AA}$ & 30.62 & $100 \%$ & & & & & & & & & & & & \\
\hline$U-3 j n 1$ & 1 & 1 & 1 & & 731.18 & 820.83 & 623.93 & 731.18 & $\mathrm{AA}$ & 107.25 & $100 \%$ & & & & & & & & & & & & \\
\hline U - 3jq 1 & 3 & 1 & 1 & & 750.22 & 1236.57 & 704.09 & 750.22 & OSBCU & 46.13 & $100 \%$ & & & & & & & & & & & & \\
\hline U - 3ks & 3 & 1 & 1 & & 736.70 & 1173.18 & 718.11 & 736.70 & LTCU & 18.59 & $100 \%$ & & & & & & & & & & & & \\
\hline U-3kv & $2 \mathrm{~b}$ & 1 & 2 & & 738.44 & 1170.13 & 718.11 & 738.44 & UTCU & 8.14 & $40 \%$ & TSA & 12.19 & $60 \%$ & & & & & & & & & \\
\hline
\end{tabular}


Formation Access Interval Assignment to Potentiometric Horizons

(Page 2 of 3 )
(Pssignent to

\begin{tabular}{|c|c|c|c|c|c|c|c|c|c|c|c|c|c|c|c|c|c|c|c|c|c|c|c|}
\hline \multirow{2}{*}{$\begin{array}{l}\text { Common Name } \\
\text { (USGS Local Name) }\end{array}$} & \multirow{2}{*}{$\begin{array}{c}\text { FAl } \\
\text { Situation }\end{array}$} & \multirow{2}{*}{$\begin{array}{l}\text { Water Level } \\
\text { Situation }^{b}\end{array}$} & \multicolumn{2}{|c|}{ Representativeness $^{\mathrm{C}}$} & \multirow{2}{*}{$\begin{array}{c}\begin{array}{c}\text { Mean Water } \\
\text { Level }\end{array} \\
\mathrm{m} \text { amsl }\end{array}$} & \multirow{2}{*}{$\begin{array}{c}\begin{array}{c}\text { FAl Top } \\
\text { Elevation }\end{array} \\
\mathrm{m} \text { amsl }\end{array}$} & \multirow{2}{*}{$\begin{array}{c}\begin{array}{c}\text { FAl Bottom } \\
\text { Elevation }\end{array} \\
\mathrm{m} \text { amsl }\end{array}$} & \multirow{2}{*}{$\begin{array}{c}\begin{array}{c}\text { Water Level } \\
\text { Corrected Top }\end{array} \\
\mathrm{m} \text { amsl }\end{array}$} & \multirow{2}{*}{ HSU1 } & \multicolumn{2}{|c|}{ Length } & \multirow{2}{*}{ HSU2 } & \multicolumn{2}{|c|}{ Length } & \multirow{2}{*}{ HSU3 } & \multicolumn{2}{|c|}{ Length } & \multirow{2}{*}{ HSU4 } & \multicolumn{2}{|c|}{ Length } & \multirow{2}{*}{ HSU5 } & \multicolumn{2}{|c|}{ Length } \\
\hline & & & Water Table & LCA & & & & & & $\mathrm{m}$ & $\%$ & & $\mathrm{~m}$ & $\%$ & & $\mathrm{~m}$ & $\%$ & & $\mathrm{~m}$ & $\%$ & & $\mathrm{~m}$ & $\%$ \\
\hline$U-3 \mathrm{mi}$ & $4 a$ & 1 & 3 & 3 & 746.08 & 1107.57 & 674.15 & 746.08 & LTCU & 27.08 & $38 \%$ & ATCU & 40.80 & $57 \%$ & LCA & 4.05 & $6 \%$ & & & & & & \\
\hline U - 3mt & 3 & 1 & 1 & & 771.10 & 1206.09 & 767.18 & 771.10 & LTCU & 3.92 & $100 \%$ & & & & & & & & & & & & \\
\hline U - 7a & $4 a$ & 2 & 3 & 3 & 727.41 & 553.79 & 474.24 & 553.79 & LTCU & 57.29 & $72 \%$ & ATCU & 15.20 & $19 \%$ & LCA & 7.03 & $9 \%$ & & & & & & \\
\hline U - 7ad (1853 ft) & 3 & 1 & 1 & & 751.83 & 1271.63 & 741.28 & 751.83 & LTCU & 0.53 & $5 \%$ & OSBCU & 10.02 & $95 \%$ & & & & & & & & & \\
\hline$U-7 b c$ & 3 & 1 & 1 & & 757.43 & 1253.34 & 603.20 & 757.43 & OSBCU & 154.23 & $100 \%$ & & & & & & & & & & & & \\
\hline U - 7ca & 3 & 1 & 1 & & 774.44 & 1211.88 & 744.93 & 774.44 & OSBCU & 29.51 & $100 \%$ & & & & & & & & & & & & \\
\hline U - 7cb & 3 & 1 & 1 & & 761.89 & 1215.54 & 742.80 & 761.89 & OSBCU & 19.09 & $100 \%$ & & & & & & & & & & & & \\
\hline U - 9 ITS UE-S-25 & $4 a$ & 1 & 2 & 2 & 740.16 & 1262.79 & 668.74 & 740.16 & LTCU & 50.36 & $71 \%$ & LCA & 21.06 & $29 \%$ & & & & & & & & & \\
\hline U-10k 1 & 1 & 2 & 1 & & 734.30 & 697.69 & 608.69 & 697.69 & AA & 89.00 & $100 \%$ & & & & & & & & & & & & \\
\hline$U-10<1$ & 4b & 1 & 2 & 2 & 733.41 & 880.57 & 626.67 & 733.41 & LTCU & 40.61 & $38 \%$ & LCA & 66.13 & $62 \%$ & & & & & & & & & \\
\hline UE- $1 a$ & $2 a$ & 1 & 2 & & 1145.57 & 1287.96 & 1020.04 & 1145.57 & AA & 108.37 & $86 \%$ & uccu & 17.16 & $14 \%$ & & & & & & & & & \\
\hline UE-1b & $2 a$ & 1 & 2 & & 1106.03 & 1279.36 & 920.30 & 1106.03 & AA & 35.53 & $19 \%$ & uccu & 150.20 & $81 \%$ & & & & & & & & & \\
\hline UE-1c & $2 \mathrm{~b}$ & 1 & 2 & & 886.79 & 1259.59 & 709.17 & 886.79 & TMLVTA & 140.59 & $79 \%$ & ATCU & 4.20 & $2 \%$ & LCA3 & 32.83 & $18 \%$ & & & & & & \\
\hline UE-1h & 5 & 2 & 4 & 1 & 743.08 & 567.21 & 194.13 & 567.21 & LCA & 373.08 & $100 \%$ & & & & & & & & & & & & \\
\hline UE- $1 \mathrm{k}$ & 1 & 1 & 1 & & 745.87 & 1277.11 & 598.02 & 745.87 & AA & 147.85 & $100 \%$ & & & & & & & & & & & & \\
\hline UE- 1L (recompleted) & 3 & 2 & 3 & & 1200.22 & 1140.25 & 662.33 & 1140.25 & uccu & 477.93 & $100 \%$ & & & & & & & & & & & & \\
\hline UE- 1q $(2437 \mathrm{ft})$ & 6 & 1 & 3 & 4 & 770.60 & $1,220.15$ & 501.22 & 770.60 & TMWTA & 30.90 & $11 \%$ & TMLVTA & 44.10 & $16 \%$ & LTCU & 161.60 & $60 \%$ & ATCU & 6.10 & $2 \%$ & LCA & 26.68 & $10 \%$ \\
\hline UE- 1q (2600 ft) & 5 & 2 & 4 & 1 & 739.36 & 494.51 & 451.54 & 494.51 & LCA & 42.98 & $100 \%$ & & & & & & & & & & & & \\
\hline UE- 2aa (2207 ft) & $2 a$ & 1 & 2 & & 738.94 & 1301.80 & 652.58 & 738.94 & TMLVTA & 72.14 & $84 \%$ & LTCU & 14.22 & $16 \%$ & & & & & & & & & \\
\hline UE-2aw & $2 a$ & 1 & 2 & & 749.35 & 1278.64 & 593.75 & 749.35 & TMWTA & 31.35 & $20 \%$ & TMLVTA & 76.10 & $49 \%$ & LTCU & 48.15 & $31 \%$ & & & & & & \\
\hline UE- $2 a \times 2$ & $2 a$ & 1 & 2 & & 740.13 & 1317.95 & 593.14 & 740.13 & AA & 30.63 & $21 \%$ & TMLVTA & 82.50 & $56 \%$ & LTCU & 33.86 & $23 \%$ & & & & & & \\
\hline UE- $2 \mathrm{dj}$ & 1 & 1 & 2 & & 745.54 & 1299.67 & 623.32 & 745.54 & AA & 80.44 & $66 \%$ & TMLVTA & 41.78 & $34 \%$ & & & & & & & & & \\
\hline UE- 2fb & 6 & 1 & 3 & 3 & 763.63 & 1277.42 & 452.33 & 763.63 & TMLVTA & 240.93 & $77 \%$ & LTCU & 11.90 & $4 \%$ & LCA & 58.47 & $19 \%$ & & & & & & \\
\hline UE- 3e 4-3 (1661 ft) & $2 a$ & 1 & 1 & & 771.86 & 774.60 & 735.58 & 771.86 & TMWTA & 10.46 & $29 \%$ & TMLVTA & 13.70 & $38 \%$ & LTCU & 12.12 & $33 \%$ & & & & & & \\
\hline UE- $4 a(2655 \mathrm{ft})$ & 3 & 2 & 3 & & 772.80 & 386.79 & 343.51 & 386.79 & OSBCU & 10.99 & $25 \%$ & ATCU & 32.29 & $75 \%$ & & & & & & & & & \\
\hline UE- 4ab (2396 ft) & 3 & 1 & 1 & & 782.13 & $1,258.82$ & 550.16 & 782.13 & LTCU & 141.73 & $61 \%$ & OSBCU & 90.24 & $39 \%$ & & & & & & & & & \\
\hline UE- 4ae (2290 ft) & $2 a$ & 1 & 3 & & 761.07 & 1234.74 & 560.83 & 761.07 & TMLVTA & 50.78 & $25 \%$ & LTCU & 149.46 & $75 \%$ & & & & & & & & & \\
\hline UE- $4 a h$ & 6 & 1 & 3 & 4 & 757.70 & $1,238.37$ & 393.47 & 757.70 & TMUVTA & 25.20 & $7 \%$ & TMWTA & 58.30 & $16 \%$ & TMLVTA & 13.40 & $4 \%$ & LTCU & 247.20 & $68 \%$ & LCA & 20.12 & $6 \%$ \\
\hline UE- 4av (1724-2815 ft) & $4 a$ & 2 & 4 & 3 & 777.57 & 747.67 & 415.14 & 747.67 & LTCU & 68.57 & $21 \%$ & OSBCU & 182.90 & $55 \%$ & ATCU & 34.70 & $10 \%$ & LCA & 46.35 & $14 \%$ & & & \\
\hline UE- 4av (1758 ft) & 3 & 1 & 1 & & 794.80 & 1235.05 & 737.31 & 794.80 & LTCU & 57.49 & $100 \%$ & & & & & & & & & & & & \\
\hline UE- 4av (2815 ft) & $4 a$ & 1 & 4 & 3 & 794.55 & $1,235.05$ & 415.14 & 794.55 & LTCU & 115.45 & $30 \%$ & OSBCU & 182.90 & $48 \%$ & ATCU & 34.70 & $9 \%$ & LCA & 46.35 & $12 \%$ & & & \\
\hline UE- $6 \mathrm{~d}$ & 1 & 2 & 2 & & 741.42 & 555.33 & 15.53 & 555.33 & PCUT & 513.53 & $95 \%$ & TMLVTA & 26.27 & $5 \%$ & & & & & & & & & \\
\hline
\end{tabular}


Formation Access Interval Assignment to Potentiometric Horizons

(Page 3 of 3 )
(Pssignent to

\begin{tabular}{|c|c|c|c|c|c|c|c|c|c|c|c|c|c|c|c|c|c|c|c|c|c|c|c|}
\hline \multirow{2}{*}{$\begin{array}{c}\text { Common Name } \\
\text { (USGS Local Name) }\end{array}$} & \multirow{2}{*}{$\begin{array}{c}\text { FAl } \\
\text { Situation }\end{array}$} & \multirow{2}{*}{$\begin{array}{l}\text { Water Level } \\
\text { Situation }^{b}\end{array}$} & \multicolumn{2}{|c|}{ Representativeness $\mathrm{s}^{\mathrm{C}}$} & \multirow{2}{*}{$\begin{array}{c}\begin{array}{c}\text { Mean Water } \\
\text { Level }\end{array} \\
\mathrm{m} \text { amsl }\end{array}$} & \multirow{2}{*}{$\begin{array}{c}\begin{array}{c}\text { FAl Top } \\
\text { Elevation }\end{array} \\
m \text { amsl }\end{array}$} & \multirow{2}{*}{$\begin{array}{c}\begin{array}{c}\text { FAl Bottom } \\
\text { Elevation }\end{array} \\
\mathrm{m} \text { amsl }\end{array}$} & \multirow{2}{*}{$\begin{array}{c}\begin{array}{c}\text { Water Level } \\
\text { Corrected Top }\end{array} \\
\mathrm{m} \text { amsl } \\
\end{array}$} & \multirow{2}{*}{ HSU1 } & \multicolumn{2}{|c|}{ Length } & \multirow{2}{*}{ HSU2 } & \multicolumn{2}{|c|}{ Length } & \multirow{2}{*}{ HSU3 } & \multicolumn{2}{|c|}{ Length } & \multirow{2}{*}{ HSU4 } & \multicolumn{2}{|c|}{ Length } & \multirow{2}{*}{ HSU5 } & \multicolumn{2}{|c|}{ Length } \\
\hline & & & Water Table & LCA & & & & & & $\mathrm{m}$ & $\%$ & & $\mathrm{~m}$ & $\%$ & & m & $\%$ & & $\mathrm{~m}$ & $\%$ & & $\mathrm{~m}$ & $\%$ \\
\hline UE- 6e (2090-2230 ft) & $2 a$ & 2 & 2 & & 739.93 & 563.32 & 520.65 & 563.32 & TSA & 37.22 & $87 \%$ & LTCU & 5.45 & $13 \%$ & & & & & & & & & \\
\hline UE- 6e (2090-4209 ft) & 6 & 2 & 3 & 4 & 740.47 & 563.31 & -82.25 & 563.31 & TSA & 37.21 & $6 \%$ & LTCU & 216.40 & $34 \%$ & OSBCU & 313.30 & $49 \%$ & ATCU & 11.30 & $2 \%$ & LCA & 67.35 & $10 \%$ \\
\hline UE- 7aa & 5 & 1 & 1 & 1 & 729.96 & 1192.98 & 641.60 & 729.96 & LCA & 88.36 & $100 \%$ & & & & & & & & & & & & \\
\hline UE-7nS & 5 & 1 & 1 & 1 & 730.73 & 810.68 & 658.89 & 730.73 & LCA & 71.84 & $100 \%$ & & & & & & & & & & & & \\
\hline UE- 8e (2470 ft) & $4 a$ & 1 & 4 & 3 & 785.72 & $1,346.45$ & 615.24 & 785.72 & OSBCU & 121.62 & $71 \%$ & ATCU & 32.30 & $19 \%$ & LCA & 16.45 & $10 \%$ & & & & & & \\
\hline UE-10 ITS 1 & 6 & 1 & 3 & 4 & 997.02 & $1,342.40$ & 669.71 & 997.02 & TMLVTA & 14.02 & $4 \%$ & LTCU & 109.50 & $33 \%$ & OSBCU & 175.20 & $54 \%$ & LCA & 28.59 & $9 \%$ & & & \\
\hline UE-10 ITS 1 (2040 ft) & 3 & 2 & 3 & & 994.91 & 781.81 & 745.54 & 781.81 & OSBCU & 36.27 & $100 \%$ & & & & & & & & & & & & \\
\hline UE-10 ITS 3 (1926 ft) & 3 & 1 & 1 & & 762.95 & 1300.88 & 739.75 & 762.95 & LTCU & 1.55 & $7 \%$ & OSBCU & 21.65 & $93 \%$ & & & & & & & & & \\
\hline UE-10 ITS 3 (2160 ft) & $4 a$ & 1 & 4 & 2 & 756.12 & $1,300.79$ & 668.33 & 756.12 & OSBCU & 60.22 & $69 \%$ & LCA & 27.51 & $31 \%$ & & & & & & & & & \\
\hline UE-10 ITS 5 & $4 a$ & 1 & 3 & 3 & 756.96 & 1351.18 & 666.91 & 756.96 & OSBCU & 89.96 & $100 \%$ & LCA & 0.09 & $0 \%$ & & & & & & & & & \\
\hline UE-10 ITS 5 (2180 ft) & 3 & 1 & 1 & & 772.10 & 1351.18 & 713.85 & 772.10 & OSBCU & 58.25 & $100 \%$ & & & & & & & & & & & & \\
\hline UE-10j (2232-2297 ft) & 5 & 2 & 3 & 1 & 736.52 & 713.74 & 693.92 & 713.74 & LCA & 19.81 & $100 \%$ & & & & & & & & & & & & \\
\hline UE-10j (2232-2613 ft) & 5 & 2 & 3 & 1 & 736.34 & 713.74 & 620.16 & 713.74 & LCA & 93.57 & $100 \%$ & & & & & & & & & & & & \\
\hline UE-10j (2380 ft) & 5 & 1 & 1 & 1 & 735.73 & 1377.29 & 668.63 & 735.73 & LCA & 67.10 & $100 \%$ & & & & & & & & & & & & \\
\hline UE-14a & $2 b$ & 1 & 3 & & 820.76 & 1298.15 & 316.69 & 820.76 & TMWTA & 73.16 & $15 \%$ & UTCU & 66.10 & $13 \%$ & TSA & 364.81 & $72 \%$ & & & & & & \\
\hline UE-14b & $2 b$ & 2 & 3 & & 819.05 & 701.65 & 205.13 & 701.65 & TMWTA & 27.15 & $5 \%$ & UTCU & 62.80 & $13 \%$ & TSA & 406.57 & $82 \%$ & & & & & & \\
\hline UE-16d WW (2117-2293 ft) & 3 & 2 & 3 & & 1247.53 & 782.42 & 720.24 & 782.42 & uccu & 62.18 & $100 \%$ & & & & & & & & & & & & \\
\hline UE-16f (1479 ft) & 3 & 2 & 3 & & 1305.82 & 1023.51 & 976.27 & 1023.51 & UCCU & 47.24 & $100 \%$ & & & & & & & & & & & & \\
\hline WW- 2 (3422 ft) & 5 & 2 & 4 & 1 & 736.57 & 581.14 & 319.32 & 581.14 & LCA & 261.80 & $100 \%$ & & & & & & & & & & & & \\
\hline WW- 3 (1800 ft) & 1 & 1 & 1 & & 742.84 & 841.27 & 661.13 & 742.84 & AA & 81.71 & $100 \%$ & & & & & & & & & & & & \\
\hline WW- A (1730 ft) & 1 & 1 & 1 & & 732.41 & 747.19 & 693.85 & 732.41 & AA & 38.56 & $100 \%$ & & & & & & & & & & & & \\
\hline WW- A (1870 ft) & 1 & 1 & 1 & & 732.90 & 747.20 & 651.18 & 732.90 & $\mathrm{AA}$ & 81.72 & $100 \%$ & & & & & & & & & & & & \\
\hline WW- C (1373-1701 ft) & 5 & 1 & 1 & 1 & 726.09 & 782.12 & 676.54 & 726.09 & LCA & 49.43 & $100 \%$ & & & & & & & & & & & & \\
\hline ww- C-1 & 5 & 1 & 1 & 1 & 726.79 & 917.75 & 692.20 & 726.79 & LCA & 34.59 & $100 \%$ & & & & & & & & & & & & \\
\hline ER-3-1-1 (deep) & 5 & 2 & 4 & 1 & 728.71 & 570.87 & 550.07 & 570.87 & LCA & 20.80 & $100 \%$ & & & & & & & & & & & & \\
\hline TW- E (2430 ft) & $4 a$ & 1 & 4 & 3 & 743.70 & 1094.85 & 530.97 & 743.70 & LTCU & 170.10 & $80 \%$ & ATCU & 21.00 & $10 \%$ & LCA & 21.63 & $10 \%$ & & & & & & \\
\hline UE-15d WW (1735-6001 ft) & 5 & 2 & 4 & 2 & 1194.11 & 868.98 & -356.92 & 868.98 & OSBCU & 11.98 & $1 \%$ & LCCU & $\begin{array}{r}1213.9 \\
2\end{array}$ & $99 \%$ & & & & & & & & & \\
\hline UE-15d WW (5400-6001 ft) & 5 & 2 & 4 & 2 & 1193.37 & 868.98 & -248.11 & 868.98 & OSBCU & 11.98 & $1 \%$ & LCCU & $\begin{array}{c}1105.1 \\
1\end{array}$ & $99 \%$ & & & & & & & & & \\
\hline
\end{tabular}

asee Table C.1-2
bSee Table $.1-2$
cSee Table C.1-1 


\section{C.2.0 RefERENCES}

BN, see Bechtel Nevada.

Bechtel Nevada. 2006. A Hydrostratigraphic Model and Alternatives for the Groundwater Flow and Contaminant Transport Model of Corrective Action Unit 97: Yucca Flat-Climax Mine, Lincoln and Nye Counties, Nevada, DOE/NV/11718--1119. Las Vegas, NV.

Fenelon, J.M. 2005. Analysis of Ground-Water Levels and Associated Trends in Yucca Flat, Nevada Test Site, Nye County, Nevada, 1951-2003, Scientific Investigations Report 2005-5175. Carson City, NV: U.S. Geological Survey. 
Appendix D

Alternative Hydrostratigraphic Framework Models 


\section{D.1.0 Alternative Hydrostratigraphic FRAMEWORK MODELS}

The complexity of the model area and the non-uniqueness of some of the interpretations incorporated into the base hydrostratigraphic framework model (HFM) made it necessary to formulate alternative interpretations for some of the major features in the model. Five of these alternatives were developed so they could be modeled in the same fashion as the base HFM. Each of the alternative HFMs honors the data available, with differences between the HFMs representing differences in interpretations of various features described by the data. Thus, each alternative HFM can be considered a possible representation of reality. Brief descriptions of the five alternative HFMs developed for the Yucca Flat/Climax Mine model are provided below and the corresponding figures are located at the end of this appendix. Additional details can be found in the framework model documentation report: $A$ Hydrostratigraphic Model and Alternatives for the Groundwater Flow and Contaminant Transport Model of Corrective Action Unit 97: Yucca Flat/Climax Mine, Lincoln and Nye Counties, Nevada (BN, 2006).

\section{D.1.1 Alternative 1 - CP Thrust}

Based on MT data and regional structural analysis, Mississippian siliciclastic rocks that compose the UCCU occur within the footwall of the CP thrust fault which is modeled as steepening rapidly eastward and forming a ramp structure beneath central Yucca Flat coincident with the Carpetbag-Topgallant fault system (Plate 3, Profile C-C'). As a result, the base HFM limits the UCCU to the western portion of the model area west of the Carpetbag-Topgallant fault system. However, MT data are sparse in northern Yucca Flat east of the Carpetbag fault due to the presence of power lines that interfere with MT recordings. The eastern limit of the UCCU is, therefore, poorly constrained east of the Carpetbag fault in northern Yucca Flat.

The $\mathrm{CP}$ thrust alternative scenario models the $\mathrm{CP}$ thrust ramp as being coincident with the Carpetbag-Topgallant fault system in the southern and central portions of Yucca Flat, but shifting to 
the east in northern Yucca Flat to become coincident with the Yucca fault (Figure D.1-1 through Figure D.1-4). In this scenario, the UCCU within the footwall rocks of the CP thrust fault extends eastward to the Yucca fault and thus underlies northern Yucca Flat between the Carpetbag and Yucca faults. More extensive UCCU in the subsurface of northern Yucca Flat could have significant hydrologic effects, particularly with regard to influx of groundwater into Yucca Flat from the north.

\section{D.1.2 Alternative 2 - Hydrologic Barrier in Northern Yucca Flat}

The intent of this alternative is to limit inter-basin groundwater flow from the north, southward into Yucca Flat. The LCCU, UCCU and MGCU form a hydrologic barrier immediately north of Yucca Flat (see map of HSUs at the water table, Plate 2). If this barrier is too low, the HFM may allow too much water to flow into Yucca Flat; if it is too high, the HFM will not allow enough lateral flow to occur. This alternative restricts inflow, while the base HFM allows for some flow on the east side over the LCCU anticline. Flow on the west side of Climax is limited to deeper flow under the UCCU in both cases.

To restrict flow on the east side of the Climax stock, the "nose" of the Halfpint Range anticline (mostly LCCU at that location) is raised up to the water table (Figure D.1-5 and Figure D.1-6). The west side was only slightly modified by warping the UCCU downward at the Tippinip fault. Groundwater flow on the west side of the Climax stock is forced deep under the UCCU and consequently flow is reduced due to a natural decrease in conductivity with depth.

\section{D.1.3 Alternative 3 - Contiguous UCCU in Southwestern Yucca Flat}

Magnetollurgic data suggest that the UCCU is not continuous within the southwest portion of the model area, such as beneath the CP Hills and Mid Valley (Plate 2). The data seem to indicate that much of the area is underlain by thick, highly resistive carbonate, and that the more electrically conductive Mississippian siliciclastic rocks that compose the UCCU are structurally broken up in this area and thus do not form a thick continuous sheet of clastic confining unit. This interpretation was incorporated into the base HFM. However, interpretation of the MT data in this area is difficult due to sparse drill hole data, (Plate 3) and the possible presence of abundant higher resistance quartzite-rich units within the UCCU that may make it difficult to distinguish Mississippian siliciclastic rocks (i.e., UCCU) from older carbonate rocks (i.e., LCA and LCA3). In addition, 
foreland imbrication related to the Belted Range thrust fault likely produced complex structural geometries in the area, further complicating interpretation of the MT data.

Because of the uncertainty with regard to the occurrence of the UCCU beneath the southwest portion of the HFM area and the potential significance to groundwater flow, particularly flow out of the basin to the southwest, an alternative HFM was created that modeled UCCU as a continuous sheet within the subsurface in the southwest portion of the model area (Figure D.1-7 and Figure D.1-8).

\section{D.1.4 Alternative 4 - Fault Juxtaposition}

Because basin-forming faults typically have large vertical displacements, the juxtaposition of shallow aquifers against deeper aquifers could occur and may be significant with regard to flow-and-transport modeling in the Yucca Flat area. In the base HFM, aquifers may be juxtaposed slightly in some places due to faulting along the main basin-forming faults. However, the locations, orientations and amounts of displacements associated with these faults are not precisely constrained. Therefore, an alternative HFM was developed that juxtaposed shallow volcanic aquifer HSUs with the LCA along the major basin-forming faults (Figure D.1-9).

For this alternative, a volcanic aquifer (typically the TM-WTA or TM-LVTA) is positioned against the LCA. This is accomplished by either increasing fault displacements or thinning underlying confining units (but still conforming to any existing nearby data). The target areas for this manipulation were the testing areas in central Yucca Flat and below the water table. Most commonly, the larger basin-forming faults are involved (e.g., the Carpetbag, Topgallant, and Yucca faults). The base HFM does contain such geometries, but this alternative provides more such situations, particularly in the testing areas.

\section{D.1.5 Alternative 5 - Partial Zeolitization}

Geologists have recognized a zone of partial zeolitization above the level of pervasive zeolitization in north-central Yucca Flat (Areas 2 and 9). The zone of partial zeolitization is defined to include areas of partial (less than 30 percent) zeolitization, as well as areas of sporadic zeolitization (more than 30 percent) alternating with weakly to non-zeolitized rocks. This has consequences for vertical and horizontal conductivity and transport of radionuclides. 
This "partial zeolitization" zone was defined for all strata below the water table down to the top of the LTCU in Area 2, Area 9, and the very northeast corner of Area 4 (Figure D.1-10). This zone may exist above the water table. However, above the water table it will not have an effect on radionuclide transport (because the unsaturated zone will not be modeled). Therefore, it will not be modeled in the alternative. 


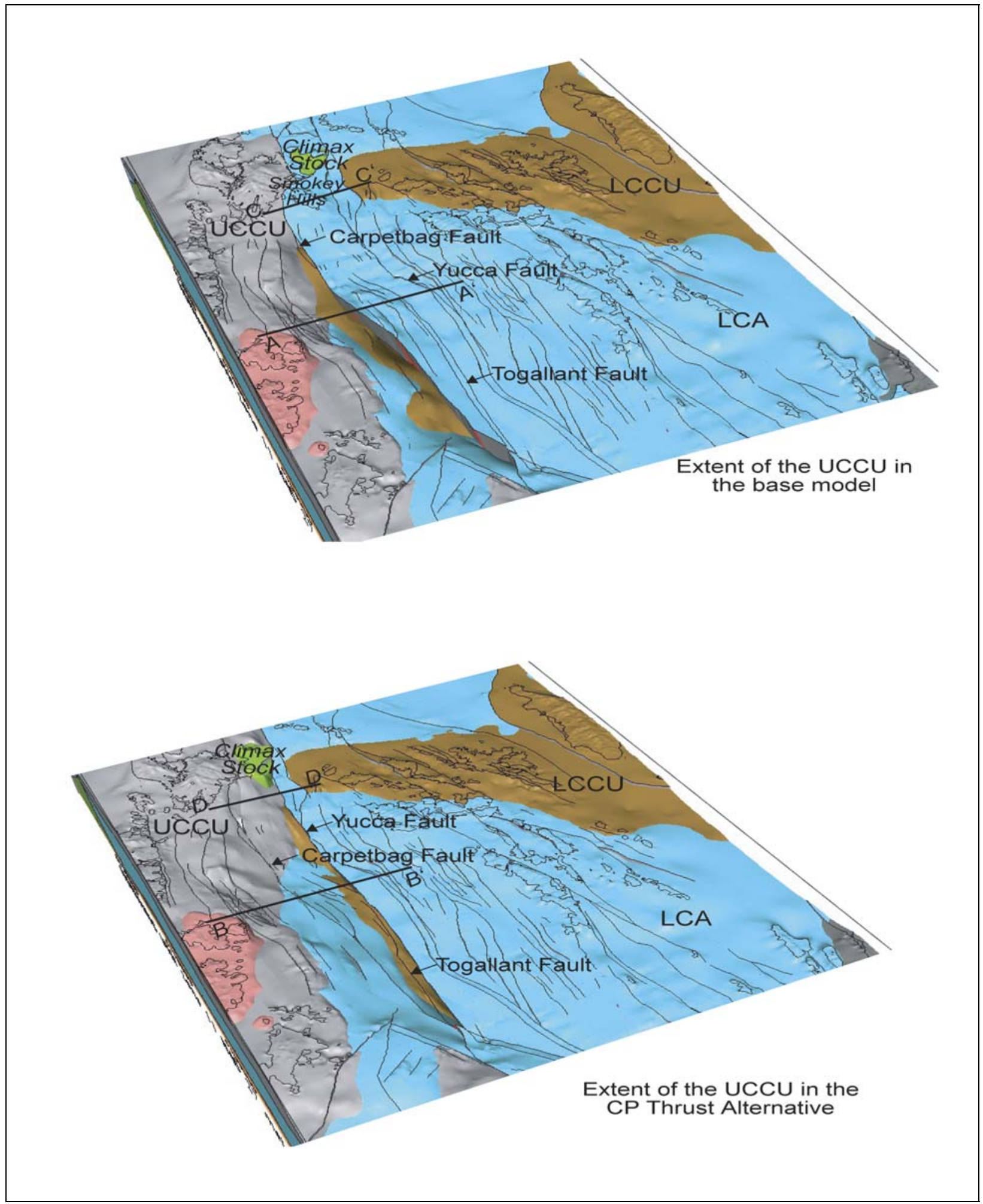

Figure D.1-1

Comparison of the UCCU Extent and CP Thrust Location in the Base Model with the CP Thrust Alternative 


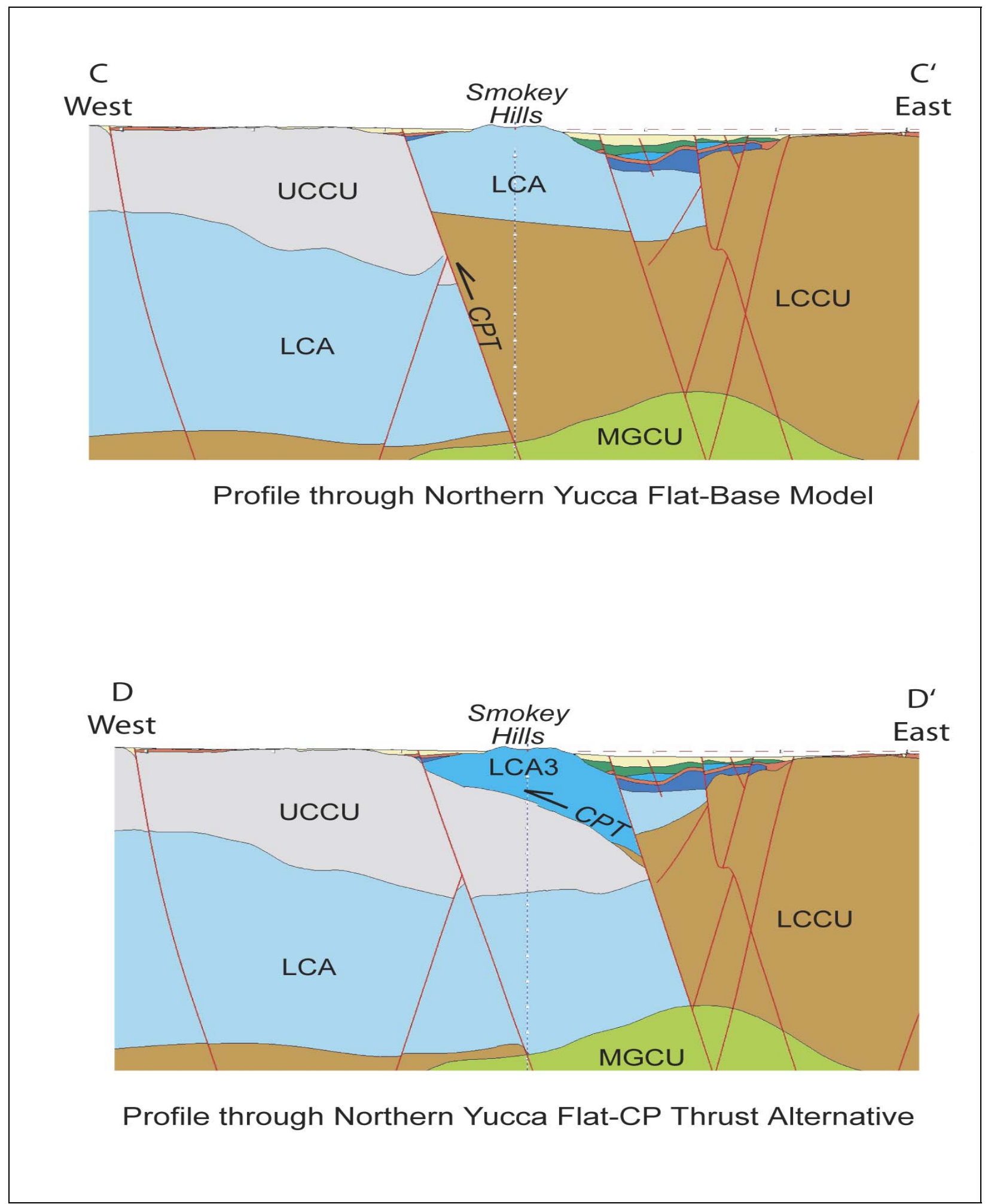

Figure D.1-2

West-East Profiles through Northern Yucca Flat Comparing the UCCU Extent and CP Thrust Location in the Base Model with the CP Thrust Alternative 


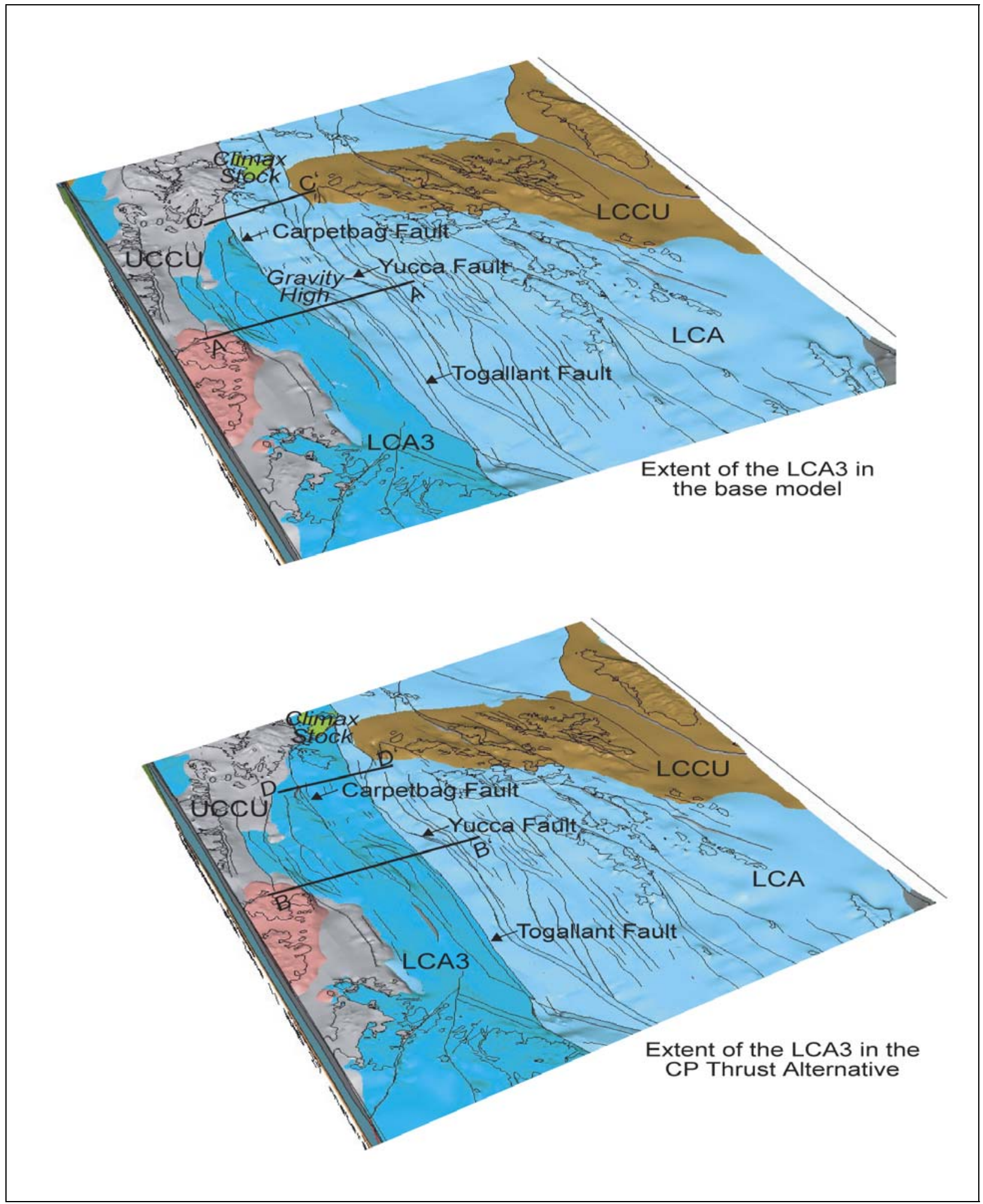

Figure D.1-3

Comparison of the LCA3 Extent and CP Thrust Location in the Base Model with the CP Thrust Alternative 
A

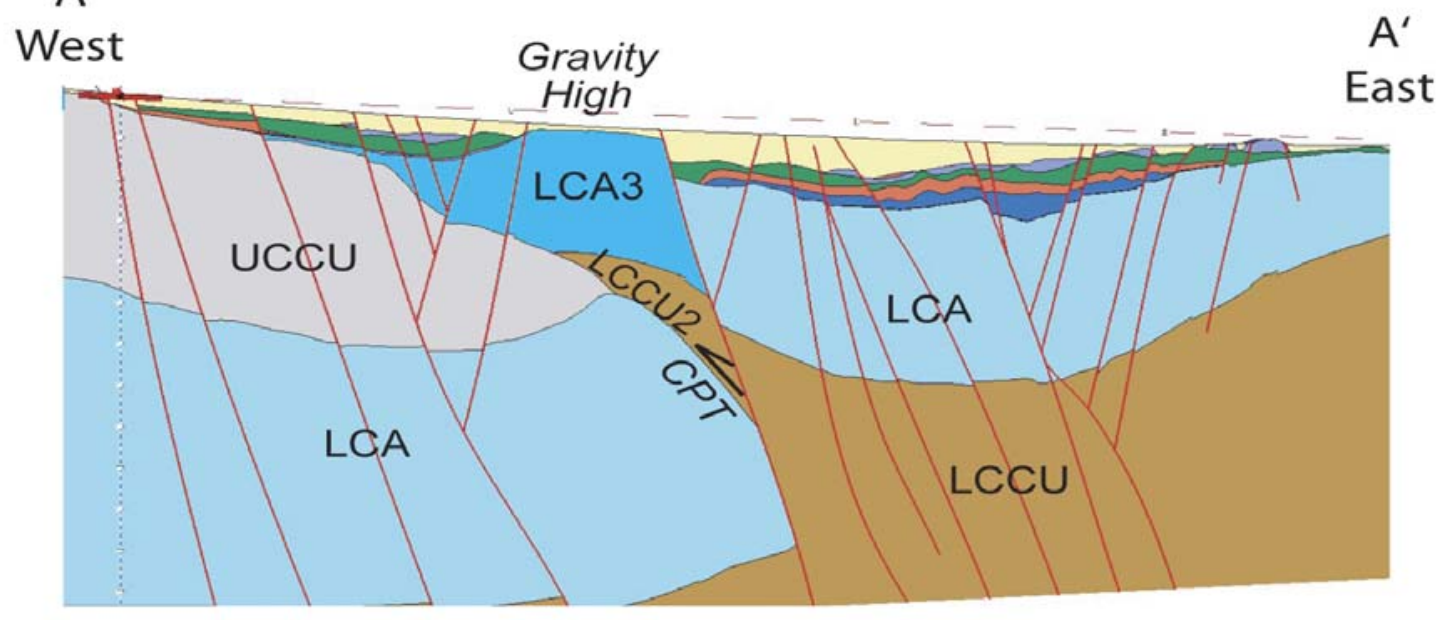

Profile through Central Yucca Flat-Base Model

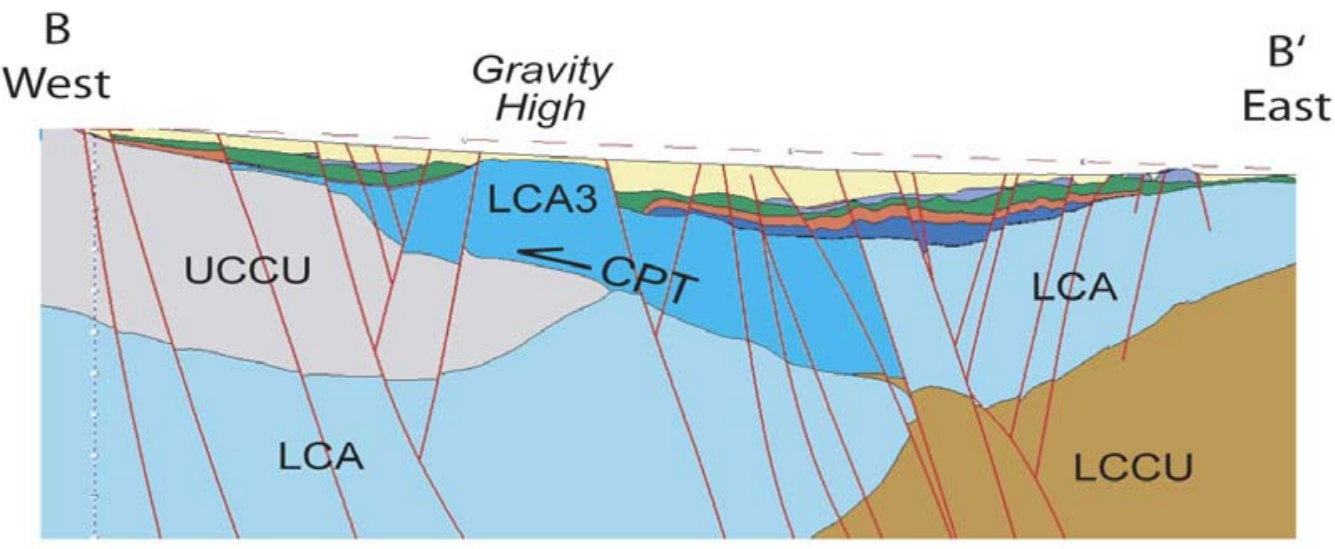

Profile through Central Yucca Flat-CP Thrust Alternative Showing a more eastern extent for the LCA3

Figure D.1-4

West-East Profiles through Northern Yucca Flat Comparing the LCA3 Extent and CP Thrust Location in the Base Model with the CP Thrust Alternative 

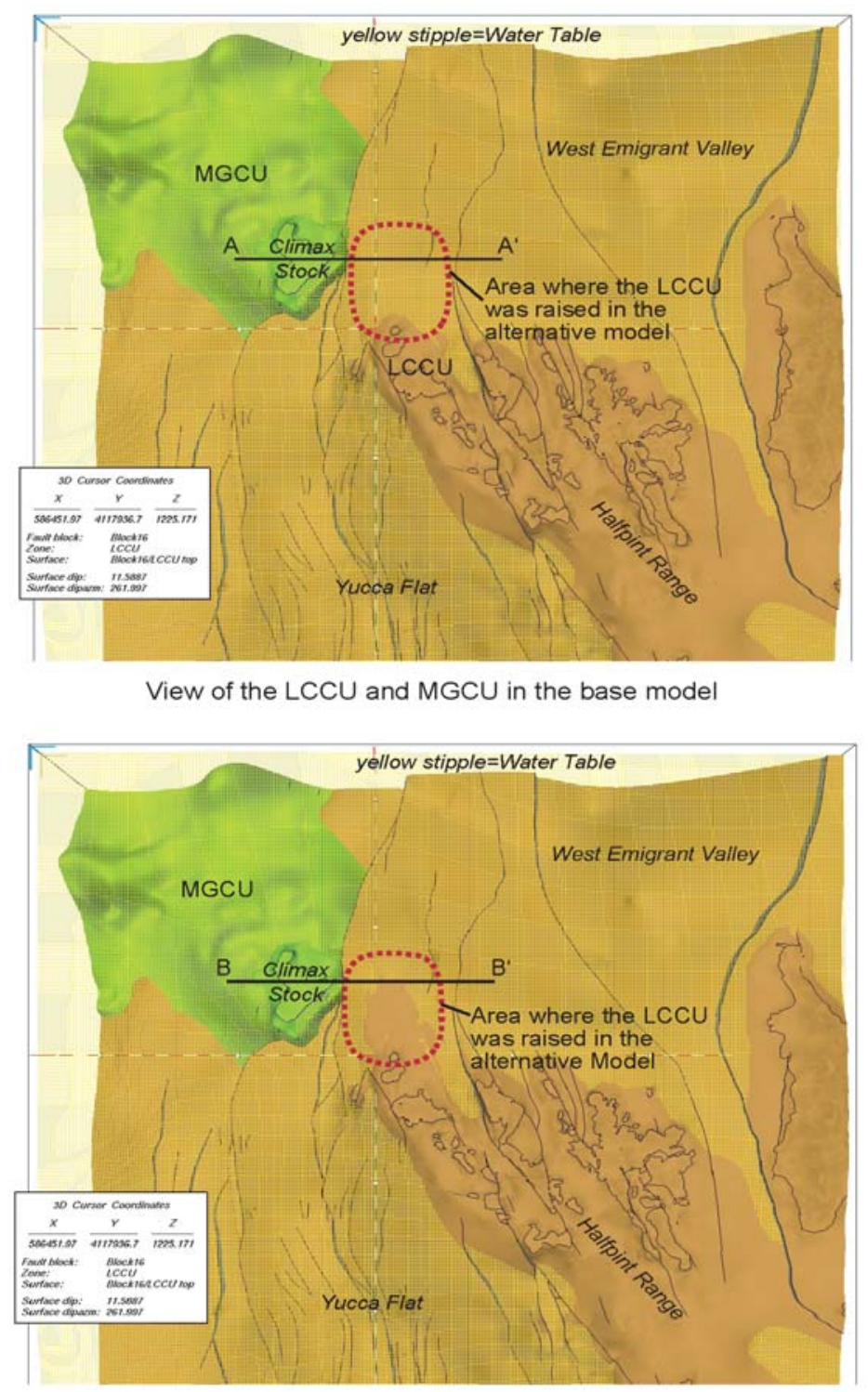

View of the LCCU and MGCU in the alternative model

Figure D.1-5

Comparison of the LCCU Geometry in the Base Model with the Hydrologic Barrier Alternative 


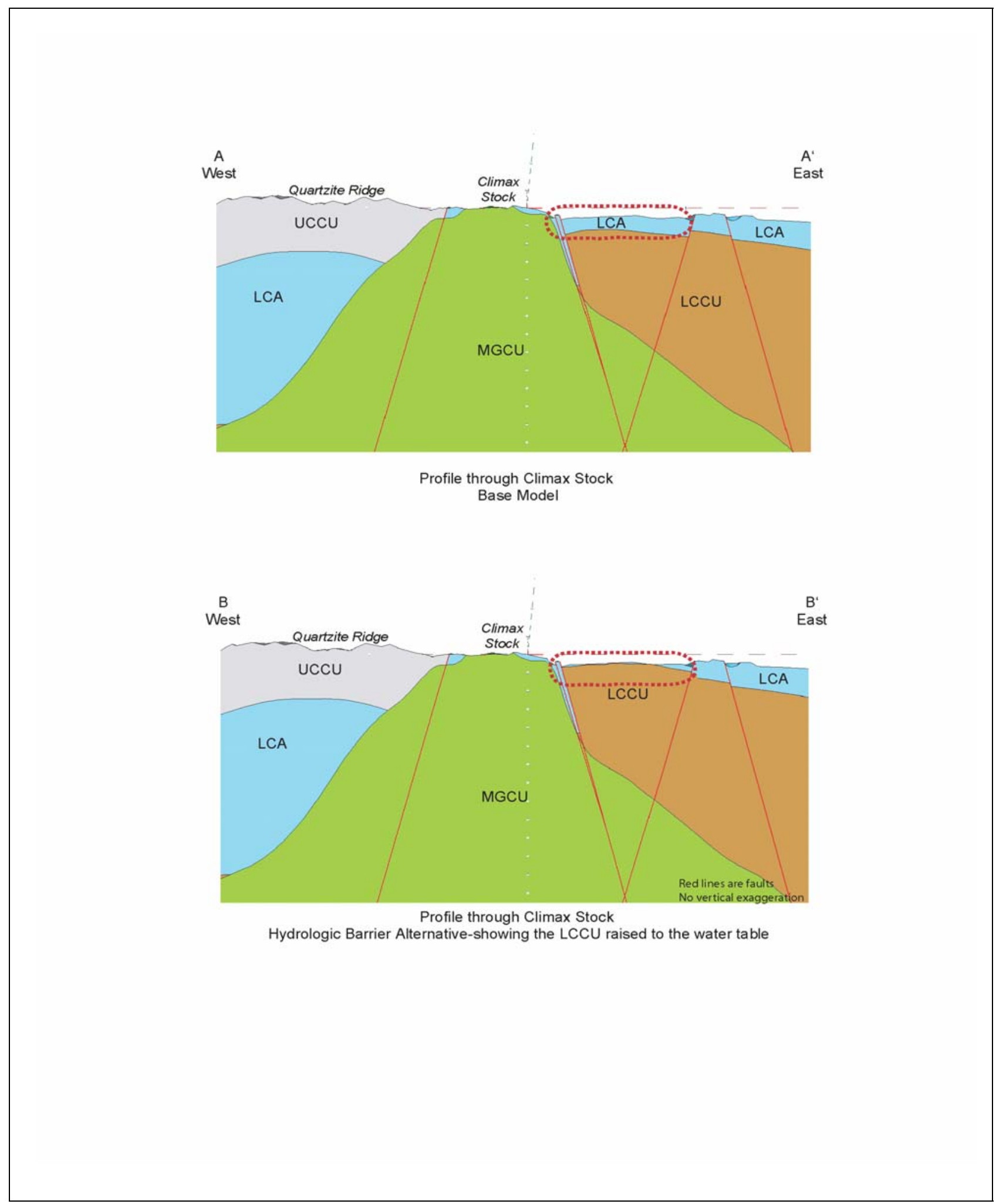

Figure D.1-6

West-East Profiles through Climax Stock Comparing the Base Model with the Hydrologic Barrier Alternative 


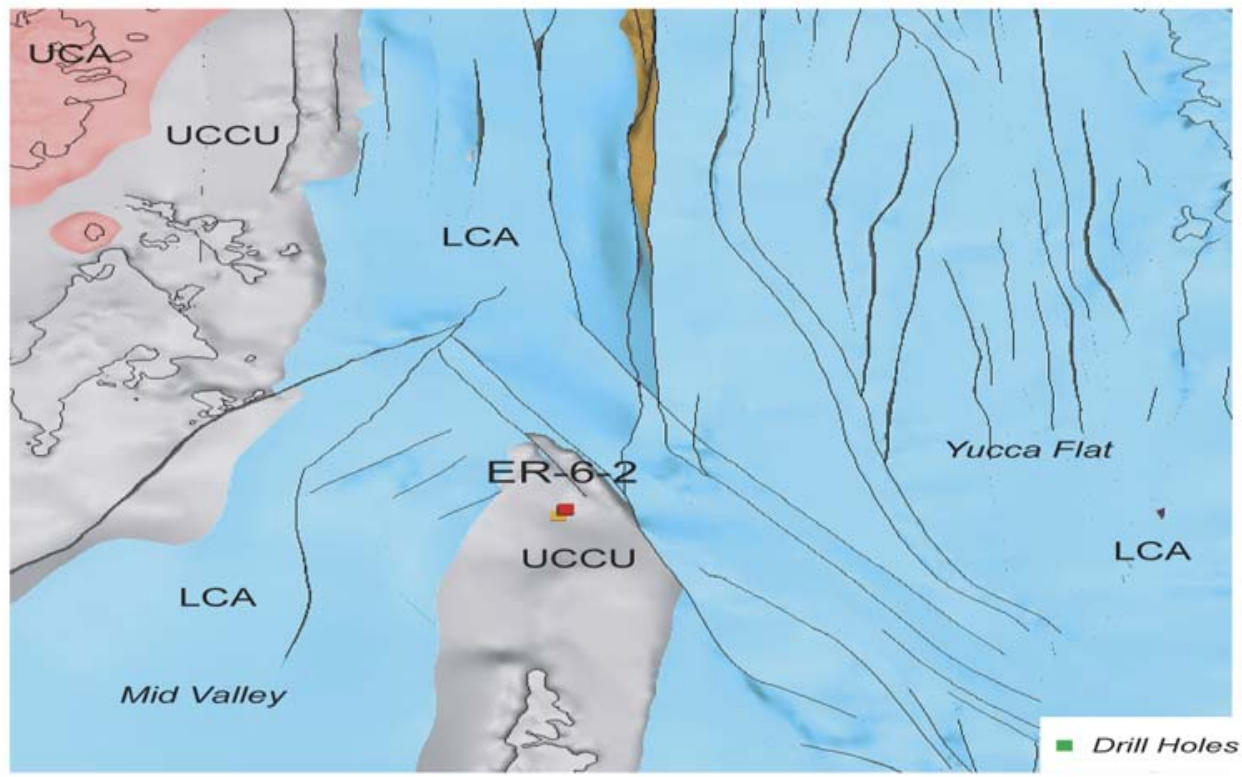

Extent of the UCCU in the Southwestern Corner of the Yucca Flat/Climax Mine Base Model

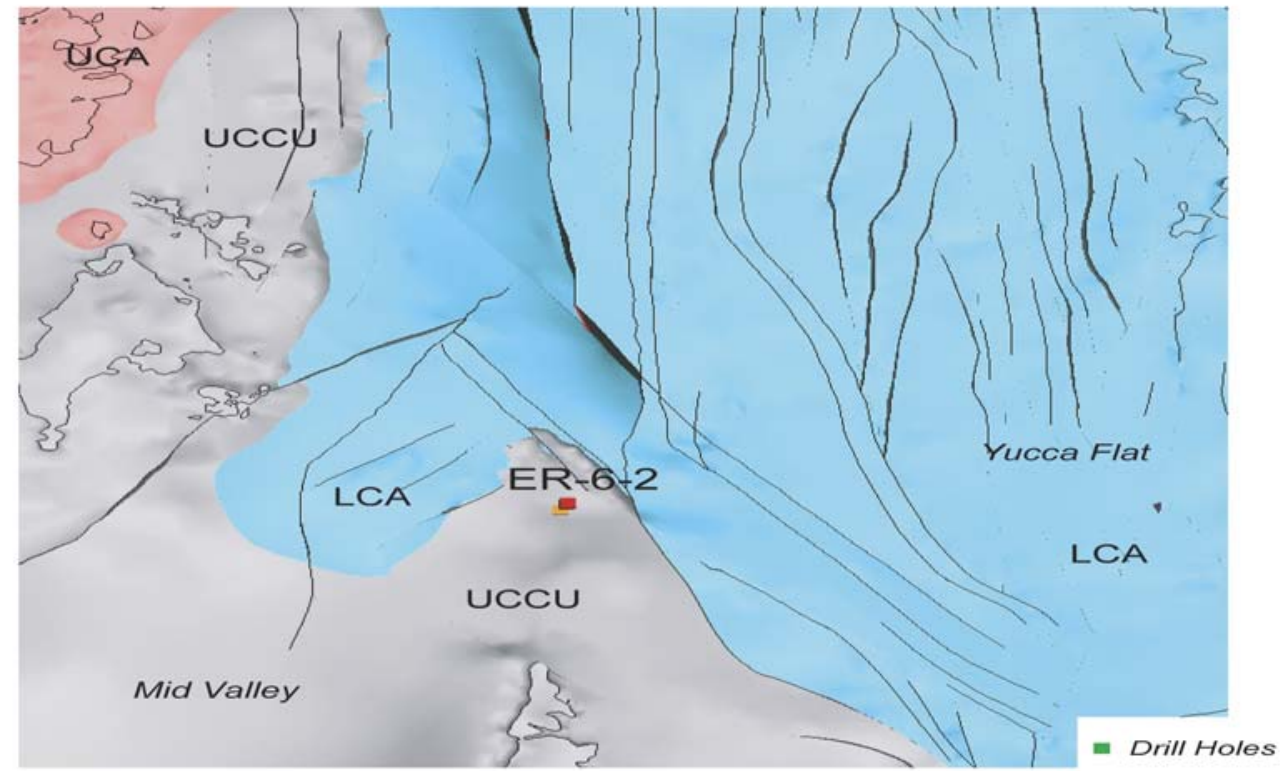

Extent of the UCCU in the Southwestern Corner of the Contiguous UCCU Alternative

Figure D.1-7

Comparison of the UCCU Extent in the Base Model with the Contiguous UCCU Alternative 


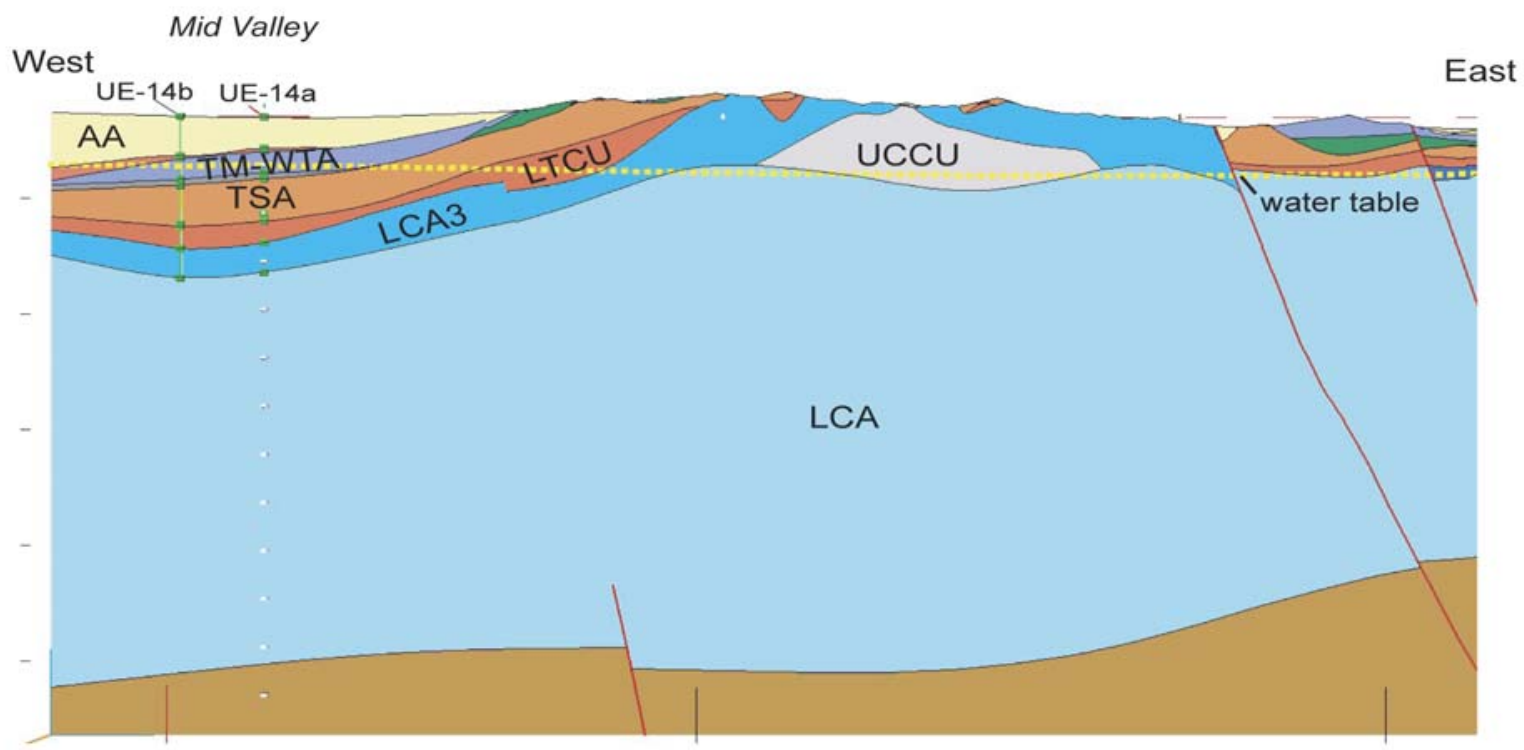

Profile through Southwest Corner of the Base Model Showing Limited Extent of the UCCU

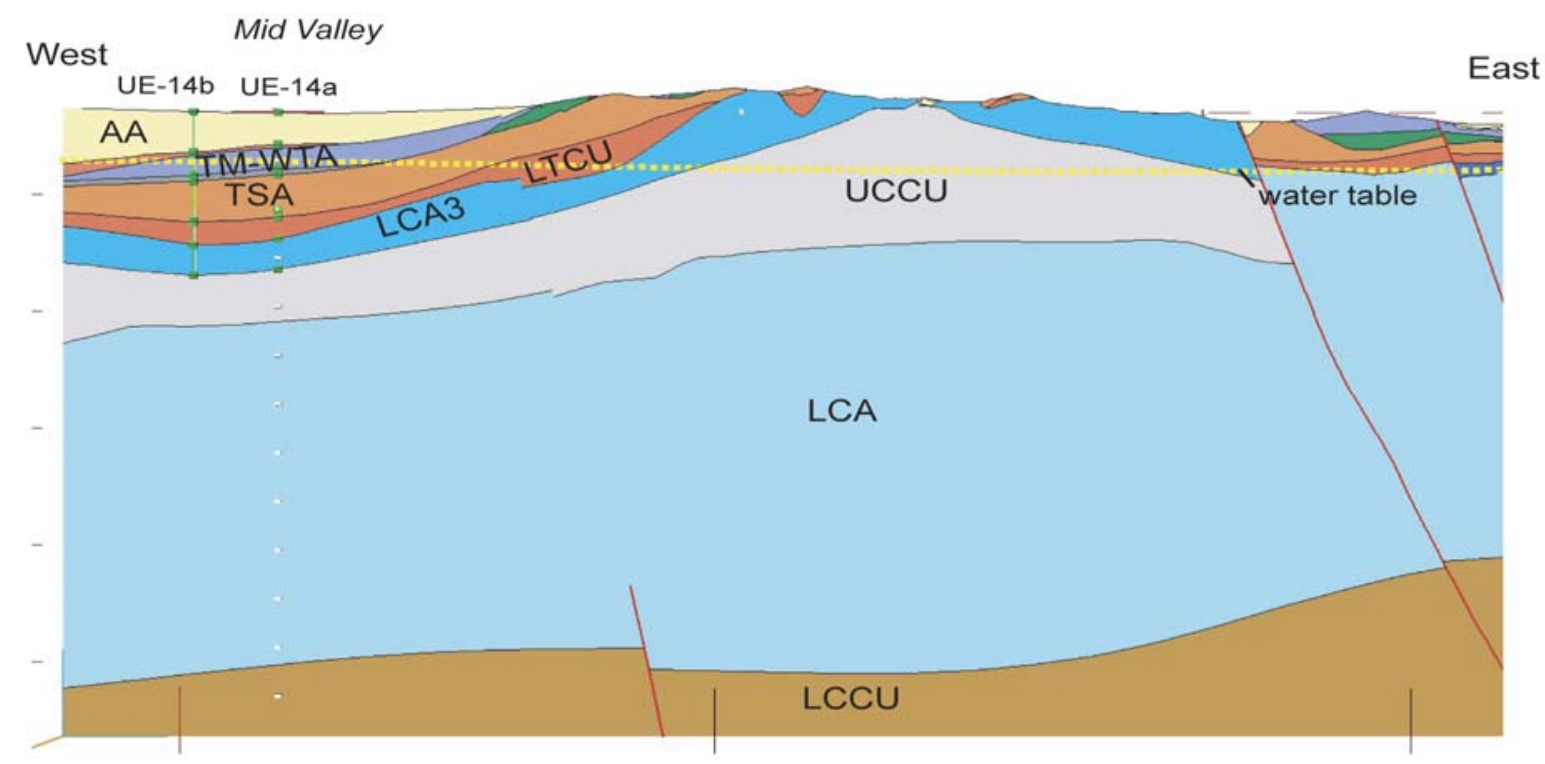

Profile through Contiguous UCCU Alternative Model Showing Extension of UCCU Beneath Mid Valley

Figure D.1-8

West-East Profile through the Southwestern Corner of the Yucca Flat Model Comparing the Base Model with the Contiguous UCCU Alternative 


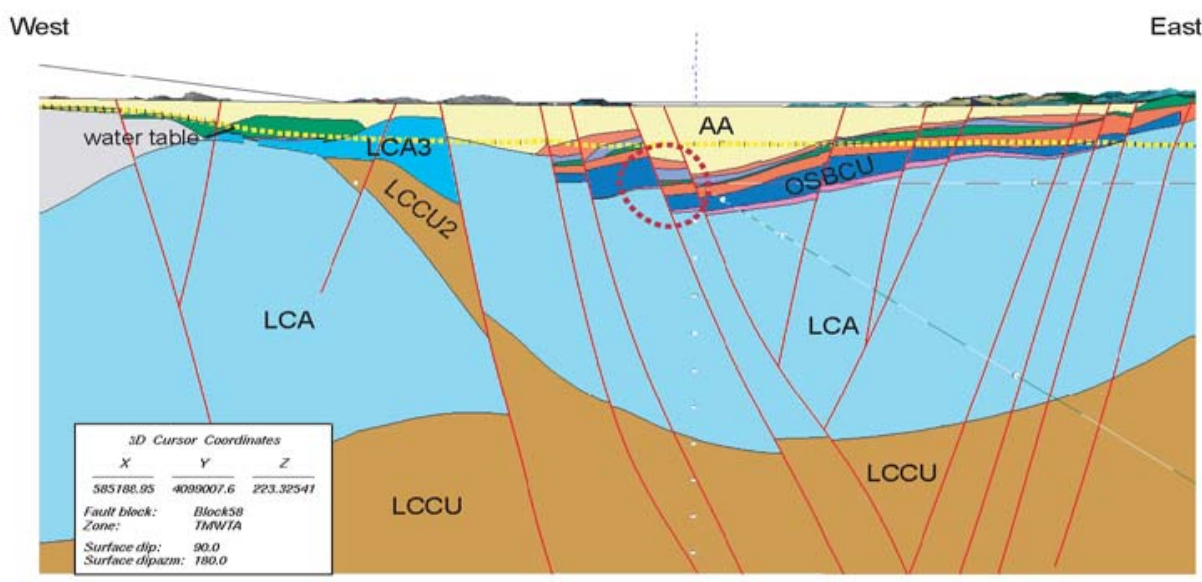

Profile through base model

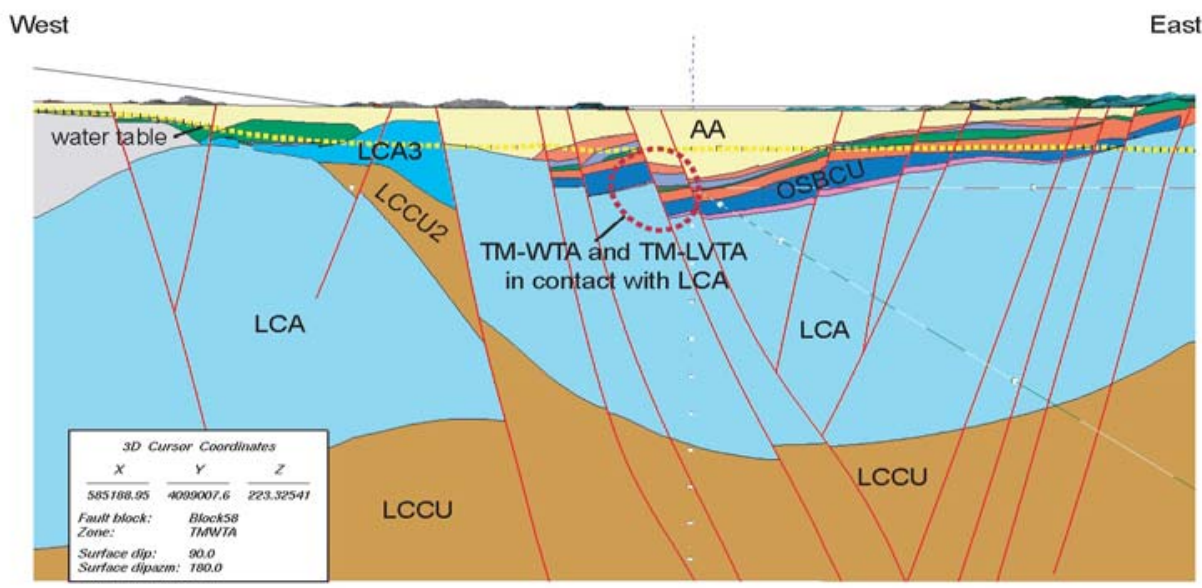

Profile through alternative model-

Showing juxtaposition of volcanic aquifers against LCA

Figure D.1-9

West-East Profiles through Central Yucca Flat Comparing the Base Model with the Fault Juxtaposition Alternative 

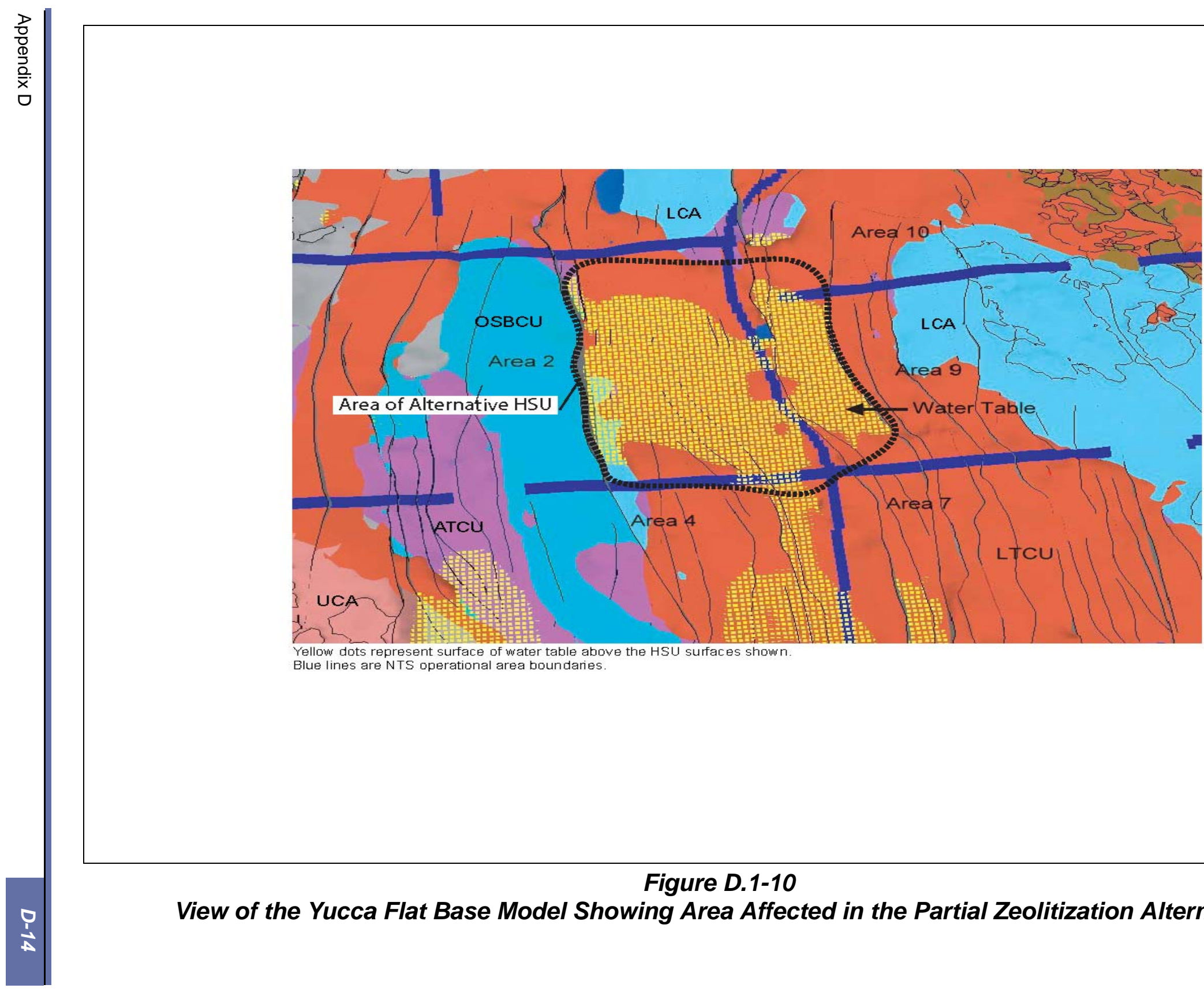

Yellow dots represent surface of water tabe above the HSU surfaces shown. Blue lines are NTS operational area boundaries.

Figure D.1-10

View of the Yucca Flat Base Model Showing Area Affected in the Partial Zeolitization Alternative 


\section{D.2.0 REFERENCES}

Bechtel Nevada. 2006. A Hydrostratigraphic Model and Alternatives for the Groundwater Flow and Contaminant Transport Model of Corrective Action Unit 97: Yucca Flat/Climax Mine, Lincoln, and Nye Counties, Nevada. DOE/NV/11718--1119. Las Vegas, NV. 
Appendix E

Literature Review and Technical Basis for Permeability Depth-Decay 


\section{E.1.0 Literature ReVIeW AND TECHNICAL Basis for PERMEABILITY DEPTH-DECAY}

Since the 1960s, many authors have presented data and evaluations to identify and utilize a relationship that shows decreasing permeability or hydraulic conductivity with increasing depth in geologic and hydrogeologic investigations. This reduction in permeability with depth is discussed generally in the context of porosity reduction (and correlated permeability reduction), with depth as a consequence of compaction and/or geochemical processes for unfractured formations, and as a consequence of fewer fractures present and fracture closure at higher in situ stresses for fractured formations. The literature presented in Table E.1-1 indicates that permeability depth-decay has been recognized by investigators in many geologic environments for decades and has been routinely employed in groundwater modeling studies. In addition, permeability depth-decay has been incorporated as a standard capability in MODFLOW (the most-widely distributed and used groundwater flow model in the world) code versions in recent years.

The most common types of permeability or hydraulic conductivity versus depth relationships use an exponential function of the form:

$$
k=a 10^{-\lambda D}
$$

or

$$
k=b e^{-\gamma D}
$$

Where:

$\mathrm{k}=$ Permeability or hydraulic conductivity

$\mathrm{a}, \mathrm{b}, \lambda$, and $\gamma=$ Constants (fitting parameters estimated generally from site-specific data) $\mathrm{D}=$ Depth

Examples of studies from the literature that address depth dependence of permeability or hydraulic conductivity are summarized in Table E.1-1 and discussed subsequently. 
Table E.1-1

Investigations Addressing Depth Dependence

of Permeability or Hydraulic Conductivity

(Page 1 of 2)

\begin{tabular}{|c|c|c|}
\hline Reference & $\begin{array}{l}\text { Permeability or } \\
\text { Hydraulic Conductivity } \\
\text { Depth-Dependence } \\
\text { Investigation }\end{array}$ & $\begin{array}{c}\text { Inclusion of Permeability } \\
\text { or Hydraulic } \\
\text { Conductivity } \\
\text { Depth-Dependence in } \\
\text { Groundwater Modeling }\end{array}$ \\
\hline Davis and Turk (1964) & $x$ & \\
\hline Davis and DeWiest (1966) & $x$ & \\
\hline Snow (1968) & $x$ & \\
\hline Carlsson and Olsson (1977) & $X^{*}$ & \\
\hline Magara (1978) & $x$ & \\
\hline Gangi (1978) & $x$ & \\
\hline Freeze and Cherry (1979) & $x$ & \\
\hline Neglia (1979) & $X^{*}$ & \\
\hline Rushton et al. (1982) & $x$ & $x$ \\
\hline de Marsily (1986) & $x^{*}$ & \\
\hline Rasmuson and Neretnieks (1986) & $x$ & \\
\hline Loucks et al. (1986) & $X^{*}$ & \\
\hline Belitz and Bredehoeft (1988) & $x$ & $x$ \\
\hline Williams and Narasimhan (1989) & $X^{*}$ & $x$ \\
\hline Rushton et al. (1989) & $x$ & $x$ \\
\hline Lavenue et al. (1990) & $x$ & $x$ \\
\hline Domenico and Schwartz (1990) & $x$ & \\
\hline Prudic (1991) & $X^{*}$ & \\
\hline Whittemore et al. (1993) & $X^{*}$ & $x$ \\
\hline Kuiper (1994) & $X^{*}$ & $X^{*}$ \\
\hline Mace and Dutton (1994) & $x$ & \\
\hline Lee et al. (1995) & $x$ & \\
\hline Stober (1996) & $x$ & \\
\hline DOE/NV (1997) & $X^{*}$ & $X^{*}$ \\
\hline Haneberg et al. (1998) & $x$ & \\
\hline Mace (1998) & $x^{*}$ & \\
\hline
\end{tabular}


Table E.1-1

Investigations Addressing Depth Dependence of Permeability or Hydraulic Conductivity (Page 2 of 2)

\begin{tabular}{|c|c|c|}
\hline Reference & $\begin{array}{l}\text { Permeability or } \\
\text { Hydraulic Conductivity } \\
\text { Depth-Dependence } \\
\text { Investigation }\end{array}$ & $\begin{array}{c}\text { Inclusion of Permeability } \\
\text { or Hydraulic } \\
\text { Conductivity } \\
\text { Depth-Dependence in } \\
\text { Groundwater Modeling }\end{array}$ \\
\hline Manning and Ingebritsen (1999) & $x$ & \\
\hline Ingebritsen and Manning (1999) & $x$ & \\
\hline Williamson and Grubb (2001) & $X^{*}$ & $X^{*}$ \\
\hline Budd (2001) & $X^{\star}$ & \\
\hline Wilson et al. (2001) & $x$ & $x$ \\
\hline Belcher et al. (2001) & $X^{*}$ & \\
\hline Wilson (2003) & $x$ & $x$ \\
\hline Casadel et al. (2003) & $X^{\star}$ & $X^{*}$ \\
\hline Anderman and Hill (2003) & $X^{*}$ & $x^{*}$ \\
\hline Environment Agency (2003) & $X^{*}$ & $x^{*}$ \\
\hline Belcher et al. (2004) & $X^{*}$ & $X^{*}$ \\
\hline SNJV (2005) & $X^{*}$ & $X^{\star}$ \\
\hline
\end{tabular}

*Denotes investigations that use an exponential function to describe decreasing permeability or hydraulic conductivity with increasing depth.

Davis and Turk (1964) conducted an evaluation of well yields in crystalline rocks. They presented plots of log well yield versus log depth for several data groupings including 2,336 wells in granite and schist in the eastern United States (depths to about 600 feet [ft]) and 239 wells in crystalline rocks of the Sierra Nevada, California (depths to about $350 \mathrm{ft}$ ), and a plot of log water-injection rate versus log depth for water-injection tests in granitic rocks of California (depths to about $300 \mathrm{ft}$ ). All of these plots showed an approximate linear relationship indicative of a logarithmic decrease in hydraulic conductivity with increasing depth. They discuss the dependence of hydraulic properties on the occurrence of joints and faults and the extent of weathering.

Davis and DeWiest (1966) present a book section titled "Permeability as a Function of Depth." They discuss that average permeability of metamorphic and igneous plutonic rocks decreases rapidly with 
depth. They present a plot of decrease in well yield with depths (to $500 \mathrm{ft}$ ) for crystalline rocks in the Statesville area of North Carolina that demonstrate an approximate exponential rate of decrease with depth. The decrease in permeability with depth was hypothesized to be the combined effect of the increasing weight of overlying rock and the tendency of surface disturbances to penetrate to limited depths; it is noted that fractures and faults have a tendency to close at depth because of the weight of the overlying material.

Snow (1968) investigated the fractured metamorphic rocks of the front range of Colorado from pressure-test data from four dam sites and well-performance data from residential areas. Presented is a plot of the data with log permeability versus log depth and a linear relationship found that was fit to the relationship:

$$
\log k=-8.9-1.67 \log d
$$

Where:

$\mathrm{k}=$ Permeability $\left(\mathrm{ft}^{2}\right)$

$\mathrm{d}=$ Depth (ft bgs) or overburden

The data showed relatively little scatter about the best-fit straight line. Permeabilities varied by three orders of magnitude over the depth range to $300 \mathrm{ft}$ and were more dependent on depth than rock type or site location.

Hydraulic conductivity reduction as a function of depth in crystalline rocks was investigated by Carlsson and Ohlsson (1977) for various sites in Sweden. They used a relationship to estimate hydraulic conductivity based on water loss in packer-isolated intervals of drill holes. From a study of 55 drill holes at five sites, they determined functions for dependency of hydraulic conductivity with depth to about $75 \mathrm{~m}$ depth of the form:

$$
k=10^{-(0.04 \mathrm{D}+5.6)} \text { (with coefficient of determination of 0.62) }
$$

and

$$
k=10^{-(1.65 \log \mathrm{D}+4.5)} \text { (with coefficient of determination of } 0.65 \text { ) }
$$


Where:

$\mathrm{k}=$ Hydraulic conductivity $(\mathrm{m} / \mathrm{s})$

$\mathrm{D}=$ Depth below the rock surface $(\mathrm{m})$

Shale porosity-depth relationships for a variety of settings are discussed by Magara (1978), who cites Rubey and Hubbert (1959), who proposes an exponential relationship between porosity and depth of the form:

$$
\varphi=\varphi_{o} e^{-c Z}
$$

Where:

$\varphi=$ Value of shale porosity at depth $\mathrm{Z}$

$\varphi_{\mathrm{o}}=$ Porosity at the surface $(\mathrm{Z}=0)$

$\mathrm{e}=$ Base of the Naperian logarithms

$\mathrm{c}=$ Constant

Magara (1978) presented data for shales that show decreasing porosity and permeability with increasing depth.

Freeze and Cherry (1979) suggest (Chapter 4 on groundwater geology), an interpretive framework for the distribution of permeability that is based on an understanding of the depositional environment. References are cited that show porosity of sandstones systematically decreases with depth as a result of compaction and from cementation during groundwater circulation. A figure (from Chilinger et al., 1963) shows sand and sandstone are grouped according to grain size categories (i.e., coarseand very coarse-grained, coarse- and medium-grained, fine-grained, silty, and clayey) with log permeability versus porosity. The figure demonstrates well-defined trends of decreasing permeability with decreasing porosity for each grain-size category. In conjunction with the correlation of decreasing porosity with depth, the figure further illustrates that permeability shows a decrease with depth.

Neglia (1979) conducted an evaluation of migration of water and hydrocarbons in sedimentary basins that found substantial decreases in porosity as burial depth increases and sediments are compacted. Data on a log-permeability versus linear-depth plot was presented and linear lines representing an 
exponential relationship between permeability and depth bracketed the plotted data for the younger shales to depths of about $3,500 \mathrm{~m}$.

The observation that hydraulic conductivity generally decreases with depth in fractured rocks has been discussed by a numerous authors. This correlation is discussed by de Marsily (1986) as to the result from the increase in mechanical stress with depth causing the fractures to close. Reported are empirical relations for crystalline rocks from the literature as follows:

$$
\begin{gathered}
K(z)=\left(K_{s}\right)\left(10^{-z / m}\right) \\
K(z)=\left(K_{s}\right)\left(z^{-2.5}\right) \\
K(z)=\left(K_{s}\right)\left(z^{-1.6}\right)
\end{gathered}
$$

Where:

$\mathrm{K}(\mathrm{z})=$ Hydraulic conductivity at depth $\mathrm{z}$ below ground surface

$\mathrm{K}_{\mathrm{s}}=$ Hydraulic conductivity at ground surface

$\mathrm{m}=\operatorname{Depth}(100$ to $500 \mathrm{~m})$

It is noted that these relations may apply under average conditions, but higher hydraulic conductivities may be encountered in a given borehole. Gangi (1978) provides theoretical arguments and relations for permeability reduction of whole or fractured porous rock, with increasing confining pressure, which will occur with increasing depth. Decrease in permeability in the fractured rock is related to the effective modulus of the asperities, the distribution function of the asperity lengths, and effective pressure. Rasmuson and Neretnieks (1986) present a figure that shows a correlation of decreasing hydraulic conductivity with increasing depth (with total depth investigated to about $700 \mathrm{~m}$ ) in crystalline rock for the Kamlunge site in Sweden. The data showed a relatively large amount of scatter about the approximated exponential curve through the data, on the log hydraulic conductivity versus linear depth plot. Lee et al. (1995) used fracture data from fractured andesite rock on the Taiwan Lan-Yu site in conjunction with hydromechanical coupling, geostatic stresses, and fracture geometry to demonstrate decreasing permeability with increasing depth. Empirical relations to estimate fracture closure with depth are presented, and graphical representations of permeability-depth curves based on assumptions for the underlying fracture model (i.e., single fracture set, three fracture sets, or random disc model). Stober (1996) presented data and a linear fit 
of $\log$ hydraulic conductivity versus log depth for gneiss rocks, demonstrating a decrease in hydraulic conductivity with depth. The data showed a relatively large amount of data scatter.

An investigation of the controls on porosity and permeability of the sedimentary formations along the Texas Gulf Coast is presented by Loucks et al. (1986), who provide both porosity-depth and core permeability-depth plots, based on several thousand data points, showing both porosity and permeability decreasing with increasing depth. The data showed a trend but also a large scatter. A straight-line approximation on the log-permeability/linear-depth plot (representative of an exponential relationship) showed up to about 4 to 5 orders of magnitude decrease in permeability to depths of about $17,000 \mathrm{ft}$.

A quasi 3-D groundwater model of the Denver basin and adjacent Mid-Continent region was developed by Belitz and Bredehoeft (1988) that found a regional trend of east-to-west decreasing permeability with east-to-west increasing depth for the Dakota and basal sandstones. In the first modeling phase, which included the Dakota and basal Cretaceous sandstone layer, three different permeability-depth relationships (log-permeability versus depth, log-permeability versus log-depth, and log-permeability versus depth) were used. The best model results were obtained using the log log-permeability versus depth relationship:

$$
\log \log -k \sim \text { depth }
$$

Belitz and Bredehoeft (1988) originally proposed the log log-permeability versus depth relationship and noted that many researchers find a correlation between log-permeability and porosity and $\log$-porosity and depth. Three functional relationships were illustrated graphically to depths of about $13,000 \mathrm{ft}$ with permeability decreasing by about 3 orders of magnitude over the depth range. Also, depth-dependent hydraulic conductivity was incorporated into the groundwater model for the overlying Cretaceous shales using a log-permeability versus depth relationship. In the final modeling phase, which included the Dakota and basal sandstones overlying Cretaceous shales and underlying Paleozoic and Mesozoic sedimentary strata, the best match was obtained between observed and simulated potentiometric surfaces when the hydraulic conductivities of all lithologic units in the model were made dependent on depth. The same log log-permeability versus depth function was used for all lithologies, which resulted in a 3 orders of magnitude decrease in permeability for depths up to about $10,000 \mathrm{ft}$. 
Williams and Narasimhan (1989) developed a mathematical model to study the effects of hydrothermal circulation on heat flow along the San Andreas Fault and its effect on the state of stress on the fault for three cases (San Francisco peninsula Cholame Hills, and San Gabriel Mountains/Mojave Desert) designed to investigate the effects of topography on the regional groundwater flow system and heat flow, they chose an exponential relationship for permeability versus depth over $15 \mathrm{~km}$ of the form:

$$
K=10^{-(0.20 \mathrm{Z}+15)}
$$

Where:

$\mathrm{k}=$ Permeability $\left(\mathrm{m}^{2}\right)$

$\mathrm{Z}=\operatorname{Depth}(\mathrm{km})$

They included fault zone permeabilities of either $7.5 \times 10^{-17} \mathrm{~m}^{2}$ or $4 \times 10^{-17} \mathrm{~m}^{2}$ for the upper $5 \mathrm{~km}$ and decreasing exponentially with depth below $5 \mathrm{~km}$. Simulation results for these cases that included the topographic effects on regional groundwater flow provided fair to reasonable matches to regional heat flow measurement profiles normal to the fault.

A calibrated regional-scale groundwater flow model for the Culebra dolomite at the Waste Isolation Pilot Plant site in southeastern New Mexico was developed by Lavenue et al. (1990). The depth of the Culebra dolomite, varying from about 8 to $420 \mathrm{~m}$ at well locations, exhibits a trend of increasing from west to east across the modeled region. The initial kriged and the final calibrated transmissivity (or hydraulic conductivity) fields show a pronounced decrease in transmissivity (about 7 orders of magnitude) from west to east. The reduction in transmissivity is the result of increased burial depth and reduction in fracturing that results when halite layers are removed by post-depositional dissolution from either above or below the Culebra dolomite layer. Regional dissolution is greatest in the west and decreases eastward as shown by an increase in the number and thickness of the halite beds.

Domenico and Schwartz (1990) discuss the physical and chemical changes that sediments undergo because of increases in overburden pressure and temperature, and chemical interaction between minerals and migrating porewater subsequent to the progressive burial of sediments in depositional environments. It was indicated that there is a reduction in porosity from compaction and pressure 
solution (grain dissolution at grain-to-grain contacts), and deformation from pressure solution to accompany basin loading in depositional environments and to be driven by the same stress that causes closer grain packing is expected. A figure is presented that shows a relationship of porosity reduction as a function of increasing depth for shales and sandstones, and notes, "Whatever the mechanism, the reduction of porosity causes a rather large reduction in permeability."

An evaluation of hydraulic conductivities from 1,500 aquifer-test analyses and more than 5,000 specific-capacity data is presented by Prudic (1991) from wells in sediments of the Gulf Coast region in the south-central United States. Additionally, the hydraulic conductivity of an unconsolidated sediment should decrease with depth because of sediment compaction from increasing overburden pressure. The depths of the middle of the screened test intervals varied down to depths below 3,000 ft. Analyses were performed to evaluate correlation between geographic areas, geologic layer, and depth to screen midpoint, and functional relationships were developed exhibiting decreasing hydraulic conductivity with depth for 31 of 42 area-layer combinations. The functional relation was of the form:

$$
K=C / 10^{\lambda D}
$$

Where:

$\mathrm{K}=$ Hydraulic conductivity

$\mathrm{C}$ and $\lambda=$ Constants

$\mathrm{D}=$ Depth

The sediments of the Gulf Coast region in the south-central United States were also studied by Kuiper (1994) who found that the hydraulic conductivity of the coarse-grained sediments decreased with depth due to decreasing porosity and increased due to decreased viscosity resulting from higher temperatures; with a net effect of decreasing hydraulic conductivity with depth. A functional relationship was provided that represented decreasing sand hydraulic conductivity with depth based on the data from Loucks et al. (1986) of the form:

$$
K=C_{1} 10^{-0.8 d d}
$$


Where:

$\mathrm{C}_{1}=$ Constant

$\mathrm{dd}=\operatorname{depth}(\mathrm{km})$

Kuiper (1994) stated that the hydraulic conductivity of the fine-grained sediments or clays tended to decrease with increasing depth as a consequence of compaction and provided a clay hydraulic conductivity-depth relationship:

$$
\mathrm{K}=\mathrm{C}_{2} 10^{\left(-1.167 \mathrm{dd}+0.0833 \mathrm{dd}^{2}\right)}
$$

Where $\mathrm{C}_{2}$ is a constant.

Plots of the data (which showed a large amount of scatter about the trend line) were provided and the functional relations for the coarse- and fine-grained sediments, with hydraulic conductivity variations of about 5 and 3 orders of magnitude, respectively, for depths up to about 17,000 ft. A multiple-regression methodology was used to calibrate several groundwater flow models of the regional Gulf Coast aquifer system.

A groundwater investigation of the Austin chalk of North-Central Texas was conducted by Mace and Dutton (1994), who found that groundwater flow is controlled by fractures that decline in intensity with depth. A data plot of log hydraulic conductivity versus linear depth that showed a corresponding decline in hydraulic conductivity with depth (data to about $380 \mathrm{~m}$ depth), and additional data and evaluations from the same study area to a depth of about $150 \mathrm{~m}$ for weathered and unweathered chalk. A data plot provided a log hydraulic conductivity versus linear depth fitted with the exponential functional relation:

$$
K=10^{-4.35 \log (\mathrm{d} / 3.28)}
$$

Where:

$\mathrm{K}=$ Hydraulic conductivity ( $\mathrm{m} /$ day)

$\mathrm{d}=$ Depth $(\mathrm{m})$

Hydraulic conductivity data varied over about 8 orders of magnitude in both the Mace and Dutton (1994) and Mace (1998) investigations. The larger hydraulic conductivities at shallower depths were attributed to unloading and weathering resulting in increased fracturing. 
A calibrated regional groundwater flow model of the NTS and vicinity was developed by DOE/NV (1997), in which site-specific data was used to develop relationships between hydraulic conductivity and depth for each of the three rock types that form the major aquifers (alluvial, volcanic, and carbonate). A linear trend in the logarithm of hydraulic conductivity, with increased depth, was expressed as:

$$
K_{\text {depth }}=K_{h} 10^{-\lambda d}
$$

Where:

$\mathrm{K}_{\text {depth }}=$ Horizontal hydraulic conductivity at a specified depth

$\mathrm{K}_{\mathrm{h}}=$ Horizontal hydraulic conductivity at land surface

$\lambda=$ Hydraulic conductivity decay coefficient

$\mathrm{d}=$ Depth from land surface

This hydraulic conductivity depth-decay functional relation is the same type as that previously adopted by Prudic (1991) and Kuiper (1994). The site hydraulic conductivity versus depth data showed a large amount of scatter about the functional line used to describe the relationship. Depth-dependent conductivity relationships were used for the entire model.

Haneberg et al. (1998) conducted laboratory measurements on core samples from a site in Albuquerque, New Mexico to investigate the impact of effective stress on hydraulic conductivity. The investigation found that "the hydraulic conductivities of consolidated, undisturbed, and typically fine-grained sediments, decreased two to three orders of magnitude between vertical effective stresses of about 50 and 1,000 kPa." A series of plots were shown with a linear relationship of log-hydraulic conductivity versus log-vertical effective stress for data from nine samples. Those data demonstrated the relationship of decreasing hydraulic conductivity that would be expected from increasing depth or effective stress.

A permeability-depth relationship for the continental crust based on geothermal and metamorphic data was evaluated by Manning and Ingebritsen (1999), and based on a variety of geologic settings in the United States and worldwide with depths to about $30 \mathrm{~km}$, a relationship developed of decaying permeability with depth of the form:

$$
\log k=-3.2 \log z-14
$$


Where:

$\mathrm{k}=$ Permeability $\left(\mathrm{m}^{2}\right)$

$\mathrm{z}=$ Depth $(\mathrm{km})$

The constant in the equation provides $\mathrm{k}$ at a depth of $1 \mathrm{~km}$. Fault zones were noted, but not addressed in the analysis, which may locally yield higher permeability values. The above relationship was presented based on geothermal and metamorphic data and also data from direct hydraulic measurements from two investigations (sedimentary facies in Uinta basin in Utah and the Pierre Shale) that showed decreasing permeability with increasing depth. The direct hydraulic measurement permeability data plotted, as log permeability versus linear depth, showed about 7 orders of magnitude variation over $4.5 \mathrm{~km}$ depth for the Uinta basin and about 4.5 orders of magnitude variation over $3.2 \mathrm{~km}$ depth for the Pierre Shale. The direct hydraulic measurement permeability data were fairly scattered. It was found that "the crustal-scale k-z relation from geothermal and metamorphic data to be at least as coherent as typical k-z data relations determined from direct hydraulic measurements of the upper crust."

Williamson and Grubb (2001) studied the sediments of the Gulf Coast region in the south-central United States, and used the equations of Kuiper (1994) for hydraulic conductivity as a function of depth for the coarse-grained sediments expressed as:

$$
\mathrm{K}=3010^{-0.000243 \mathrm{D}}
$$

and for the clays expressed as:

$$
\mathrm{K}=\mathrm{C} 10^{-0.000356 \mathrm{D}+0.0000254 \mathrm{D}^{-2}}
$$

Where:

$\mathrm{D}=$ Depth $(\mathrm{ft})$

$\mathrm{C}=$ Constant

For the coarse-grained sediments, Williamson and Grubb (2001) presented a plot of log-hydraulic-conductivity versus linear-depth with a straight-line approximation representing the hydraulic conductivity relation. The data showed a large amount of scatter about the best-fit line. Therefore, a regional groundwater flow model was developed consisting of 10 aquifers and 5 regional confining units. 
An investigation of the relationship between permeability and depth ( 0 to $470 \mathrm{~m})$ in the Cenozoic platform of west-central Florida was conducted by Budd (2001). Permeability-depth relationships were developed based on more than 12,000 minipermeameter measurements on 1,210 m of core from limestones in Florida. It was found that the dolostones and low-permeability limestones did not exhibit permeability-with-depth trends, but the high-permeability limestones (high-mud packstones, low-mud packstones, very low-mud packstones, and grainstones) exhibited a systematic reduction in their mean and maximum permeabilities with increasing burial depth. For the high-permeability limestones, permeability decreased by about one order of magnitude over the $470 \mathrm{~m}$ depth. Petrographic observations on grainstones revealed mechanical and chemical (i.e., pressure solution) compaction features. There was no evidence of burial cementation. Permeability reduction with depth was interpreted to result from observed compaction phenomena including grain repacking and reorientation, grain breakage, grain interpenetrations, and grain-to-grain pressure solution. Budd (2001) developed least-squared exponential regressions between permeability and depth for the high-permeability limestones being investigated:

$$
\begin{gathered}
k=145 e^{(-\mathrm{z} / 220)} \text { for silty packstone } \\
k=151 e^{(-\mathrm{z} / 270)} \text { for high-mud packstone } \\
k=295 e^{(-\mathrm{z} / 236)} \text { for low-mud packstone } \\
k=427 e^{(-\mathrm{z} / 236)} \text { for very low-mud packstone }
\end{gathered}
$$

Where:

$\mathrm{k}=$ Permeability (millidarcy)

$\mathrm{z}=$ Depth (m)

The $\mathrm{R}^{2}$ values ranged from 22 to 31 percent. The data showed decreasing permeability with depth but also a relatively large amount of scatter.

Geothermal convection of seawater in carbonate platforms and geochemical reactions related to dolomitization were investigated by Wilson et al. (2001), who adopted exponential relationships for porosity decreasing with depth of the form:

$$
\varphi=0.4173 \exp (-\mathrm{z} / 2498) \text { for medium- and coarse-grained sediments }
$$


and

$$
\varphi=0.4 \exp (-\mathrm{z} / 125)+0.4 \exp (-\mathrm{z} / 6500) \text { for fine-grained sediments }
$$

where $\varphi$ is porosity and $\mathrm{z}$ is depth below sea level $(\mathrm{m})$. Then, the calculated permeability was used as a function of porosity using the relation:

$$
k=a \varphi^{b}
$$

Where:

$\mathrm{k}=$ Permeability in millidarcies in the direction of maximum permeability (assumed to be horizontal) $\mathrm{a}$ and $\mathrm{b}=$ Fit parameters for coarse-, medium-, and fine-grained sediments.

Calculated permeabilities ranged 7 orders of magnitude. Wilson et al. (2001) chose a horizontal to vertical permeability ratio of 1,000 and presented log-permeability versus linear-depth plots for the coarse-, medium-, and fine-grained sediments that were used in modeling studies of groundwater flow and geothermal circulation. In later modeling studies of geothermal convection in continental shelves, Wilson (2003) adopted similar permeability-depth relations for coarse-, medium-, and fine-grained carbonates and added relations for coarse- and fine-grained clastics.

Belcher et al. (2001) prepared hydraulic property estimates for use in developing a transient groundwater flow model of the Death Valley Regional Groundwater Flow System. The relationship between hydraulic conductivity and depth for $10 \mathrm{HGUs}$ was examined and presented a log-hydraulic conductivity versus linear-depth plot for data for the units in the Death Valley region. It was noted that there is a trend as well as a relatively high data scatter. The hydraulic-conductivity data spanned 9 orders of magnitude variation over about 2,500 $\mathrm{m}$ depth. The linear regression analysis obtained the greatest correlation to depth with the $\log _{10}$ transform of the hydraulic-conductivity estimates (coefficient of determination is 0.296 ). The hydraulic conductivity depth-decay functional relationship is the same form as that adopted by Prudic (1991), Kuiper (1994), and DOE/NV (1997).

A spatially distributed runoff model was used by Casadel et al. (2003) in a study to predict landslides. The model assumed an exponential decay of hydraulic conductivity with depth for the colluvium and the underlying rock expressed as:

$$
K=K_{1} e^{-f z a}
$$




$$
K=K_{2} e^{-g z b}
$$

Where:

$\mathrm{K}=$ Hydraulic conductivity

$\mathrm{K}_{1}, \mathrm{~K}_{2}$, $\mathrm{f}$, and $\mathrm{g}=$ Parameters varied during model calibration

$\mathrm{za}=$ Depth in the colluvium measured from ground surface

$\mathrm{zb}=$ Depth in the rock measured from the soil-rock interface

Anderman and Hill (2003) published an update to the USGS groundwater flow model

MODFLOW-2000, which included the addition of the capability to handle hydraulic-conductivity depth-dependence. The update discusses that hydraulic conductivity can decline systematically with depth and cite a field example in Whittemore et al. (1993). Whittemore et al. (1993) used a log-log vertical hydraulic-conductivity versus depth relationship to represent decreasing hydraulic conductivity, with depth for the aquitard in the regional-scale groundwater flow model of the Dakota aquifer system. Anderman and Hill (2003) include the hydraulic conductivity decrease with depth in MODFLOW-2000 using the function:

$$
K_{\text {Depth }}=K_{\text {Surface }} 10^{-\lambda d}
$$

Where:

$\mathrm{K}_{\text {Depth }}=$ Hydraulic conductivity at depth

$\mathrm{K}_{\text {Surface }}=$ Hydraulic conductivity projected to a reference surface

$\lambda=$ Depth-dependence coefficient

$\mathrm{d}=$ Depth below the reference surface

The depth-dependent coefficient can be defined separately for different HGUs or for different regions in each HGU. The hydraulic conductivity depth-decay functional relation is the same form as adopted by Prudic (1991), Kuiper (1994), and DOE/NV (1997).

An enhancement to MODFLOW-96 that includes a variation of hydraulic conductivity with depth option (code called MODFLOW-VKD) was published by the Environment Agency (2003). The agency noted that hydraulic conductivity is a function of depth for many aquifers. The revised code package introduced two new layer types to represent aquifers where hydraulic conductivity reduces with depth within the layer. The conceptualization for varying hydraulic conductivity with depth is based on Rushton et al. (1982 and 1989) where hydraulic conductivity decreases continuously until 
reaching a reference level and is then constant below the reference level. This hydraulic conductivity variation with depth was developed from an investigation in a chalk aquifer in the United Kingdom and was incorporated into their mathematical model of the groundwater flow system.

The USGS has developed a transient groundwater flow model (with 16 layers) of the Death Valley region that includes the NTS and vicinity (Belcher et al., 2004). Belcher et al. (2004) discussed that hydraulic conductivity is expected to decrease with depth as "geostatic load increases, compressing favorably oriented fractures, faults, and sedimentary units." Depth-decay of hydraulic conductivity is included in the model through use of the HUF package in MODFLOW-2000 (Anderman and Hill, 2003). The hydraulic conductivity depth-decay functional relation is the same form as adopted by Prudic (1991), Kuiper (1994), and DOE/NV (1997). Initial parameter estimates for hydraulic-conductivity decay with depth were based on the previous estimates in IT (1996) (these initial estimates were also used in the model by DOE/NV, 1997). Belcher et al. (2004) found that depth-decay was important in all volcanic-rock and basin-fill units, and was of somewhat less importance in the carbonate-rock aquifer. It was also found that including depth-decay in selected confining units improved the model. Belcher et al. (2004) provide comparison of the initial and calibrated depth-decay parameter for $10 \mathrm{HGUs}$, and a plot showing hydraulic conductivity relative to surface-hydraulic conductivity versus depth (to $3 \mathrm{~km}$ ) for the calibrated depth-decay parameters for the 10 HGUs.

A regional-scale groundwater flow model was developed for the Pahute Mesa CAU at the NTS by SNJV (2005). The area of interest for the Pahute Mesa CAU is defined by the potentially affected portion of the regional groundwater flow system, which includes a region stretching from the northern side of Pahute Mesa south and southwestward to Oasis Valley. The hydraulic conductivity data with plots of log hydraulic conductivity versus depth for selected hydrostratigraphic units is presented in SNJV (2004), which found that there is considerable scatter in the data at any particular depth. The model calibration approaches for parameterizing the hydrostratigraphic units as discussed in SNJV (2005) included no depth-decay, no anisotropy; depth-decay and anisotropy in selected units; and depth-decay and anisotropy in all units. The no depth-decay, no anisotropy case was rejected as reasonable because of permeabilities and flow paths judged to be unrealistic. The calibration approaches with depth-decay resulted in successful calibrations judged to be representative of the flow system based on matching head and flow calibration targets and 
examination of flow paths. The hydraulic conductivity depth-decay functional relation is the same form as that adopted by Prudic (1991), Kuiper (1994), DOE/NV (1997), and Belcher (2004).

The plots of measured hydraulic conductivities versus depth that are reported in the literature tend to show a relatively large amount of scatter, and thus a large amount of spread about any best-fit line, representing the functional relationship of decreasing permeability or hydraulic conductivity versus increasing depth (e.g., Rasmuson and Neretnieks, 1986; Loucks et al, 1986; Lavenue et al., 1990; Prudic, 1991; Kuiper, 1994; Mace and Dutton, 1994; Stober, 1996; DOE/NV, 1997; Mace, 1998; Williamson and Grubb, 2001; Budd, 2001; Belcher et al., 2001; Belcher et al., 2004; SNJV, 2005). However, utilizing these depth-dependent relationships is a useful approach to assist in parameterizing groundwater flow models because often there are limited data available to characterize the full depth and lateral extent of all HSUs in large regional groundwater flow models. Initial depth-decay relationships based on site-specific data are valuable starting points for model parameterization that can then be modified during model calibration.

The technical basis for permeability to decrease with depth is reasonable (e.g., decreasing porosity with increased burial depth and overburden pressure due to compaction, pressure solution, and/or cementation; reduction in fracture frequency and aperture with depth in fractured formations) and is well supported by published data studies from many different geologic environments. The above literature review illustrates there is a solid foundation of scientific works that document reduction in permeability, with depth as a reasonable approximation to represent hydraulic properties, in regional-scale groundwater flow models. 


\section{E.2.0 REFERENCES}

Anderman, E.R., and M.C. Hill. 2003. MODFLOW-2000, The U.S. Geological Survey Modular Ground-Water Model - Three additions to the hydrogeologic-unit flow (HUF) package: Alternative storage for the uppermost active cells (SYTP parameter type), flows in hydrogeologic units, and the hydraulic-conductivity depth-dependence (KDEP) capability, USGS Open-File Report 03-347. Denver, CO: U.S. Geological Survey.

Belcher, W.R., ed. 2004. Death Valley Regional Ground-Water Flow System, Nevada and California-Hydrogeologic Framework and Transient Ground-Water Flow Model, Scientific Investigations Report 2004-5205, 408 p. U.S. Geological Survey

Belcher, W.R., P.E. Elliot, and A.L. Geldon. 2001. Hydraulic-Property Estimates for Use With a Transient Ground-Water Flow Model for the Death Valley Regional Ground-Water Flow System, Nevada and California, USGS Water-Resources Investigations Report 2001-4210, 28 p. U.S. Geological Survey.

Belcher, W.R., J.B. Blainey, F.A. D’Agnese, C.C. Faunt, M.C. Hill, R.J. Laczniak, G.M. O’Brien, C.J. Potter, H.M. Putnam, C.A. San Juan, and D.S. Sweetkind. 2004. Death Valley Regional Model Ground-Water Flow System, Nevada and California - Hydrogeologic Framework and Transient Ground-Water Flow Model, Scientific Investigations Report 2004-5205.

U.S. Geological Survey.

Belitz, K., and J.D. Bredehoeft. 1988. "Hydrodynamics of the Denver Basin: Explanation of Subnormal Fluid Pressures." In American Association of Petroleum Geologists. Bulletin v. 72: 1334-1359.

Budd, D.A. 2001. "Permeability Loss With depth in the Cenozoic Carbonate Platform of West-Central Florida." In American Association of Petroleum Geologists. Bulletin v. 85: (7): 1253-1272.

Carlsson, A. and T. Olsson. 1977. "Hydraulic Properties of Swedish Crystalline Rocks: Hydraulic Conductivity and its Relation to Depth." In Bulletin of the Geological Institutions of the University of Uppsala, 7, 71-84, Uppsala, Sweden

Casadel, M., and W.E. Dietrich, and N.L. Miller. 2003. "Testing a Model for Predicting the Timing and Location of Shallow Landslide Initiation in Soil-Mantled Landscapes." In Earth Surf. Process. Landforms, v. 28: 925-950. NY: John Wiley \& Sons, Ltd. 
Chilinger, G.V. 1963. "Relationship Between Porosity, Permeability, and Grain-Size Distribution of Sands and Sandstones.” Proc. Intern. Sedimentol. Congr., Amsterdam, Antwerp.

Davis, S.N. and R.J.M. DeWiest. 1966. Hydrogeology. New York, NY. John Wiley, 463 p.

Davis, S.N. and L.J. Turk. 1964. Optimum Depth of Wells in Crystalline Rocks. In Ground Water, 2 (2), p. 6-11. National Water Well Association.

de Marsily, G. 1986. Quantitative Hydrogeology, Groundwater Hydrology for Engineers. Orlando, FL: Academic Press, Inc.

Domenico, P.A., and F.W. Schwartz. 1990. Physical and Chemical Hydrogeology. New York, NY: John Wiley \& Sons.

Environment Agency. 2003. Enhancements to MODFLOW, User Guide for MODFLOW-VKD - A Modified Version of MODFLOW-96 to Include Variations in Hydraulic Conductivity with Depth, Water Management Consultants Ltd. Prepared for National Groundwater \& Contaminated Land Centre, UKEA, Project NC/00/23.

Freeze, R.A., and J.A. Cherry. 1979. Groundwater. Englewood Cliffs, NJ: Prentice-Hall, Inc.

Gangi, A.F. 1978. "Variation of Whole and Fractured Porous Rock Permeability with Confining Pressure.” In Int. J. Rock Mech. Min. Sci. Geomech. Abstr., v. 15: 249-257. Great Britain: Pergamon Press.

Haneberg. W.C., P. Gomez, A. Gibson, and B. Allred. 1998. "Preliminary Measurements of Stress-Dependent Hydraulic Conductivity of Santa Fe Group Aquifer System Sediments from the $98^{\text {th }}$ St Core Hole, Albuquerque, New Mexico, 14-20 February." In New Mexico Geology.

Ingebritsen, S.E. and C.E. Manning. 1999. “Geological Implications of a Permeability-Depth Curve for the Continental Crust.” In Geology, v. 27(12): 1107-1110.

IT Corporation. 1996. Hydrologic Parameter Data Documentation Package (Phase I Data Analysis Documentation, Volume IV), ITLV/10972-181. Las Vegas, NV.

Kuiper, L.K. 1994. Nonlinear-Regression Flow Model of the Gulf Coast Aquifer Systems in the South-Central United States, Water-Resources Investigations Report 93-4020. Denver, CO: U.S. Geological Survey.

Lavenue, A.M., T.L. Cauffman, and J.F. Pickens. 1990. Ground-Water Flow Modeling of the Culebra Dolomite, Volume I Model Calibation, SAND88-7002. Albuquerque, NM: Sandia National Laboratories. 
Lee, C-H., B-W. Deng, J-L. Chang. 1995. “A Continuum Approach for Estimating Permeability in Naturally Fractured Rocks.” In Engineering Geology, v. 39: 71-85. New York, NY: Elsevier Publishing Co.

Loucks, R.G., M.M. Dodge, and W.E. Galloway. 1986. Controls on Porosity and Permeability of Hydrocarbon Reservoirs in Lower Tertiary Sandstones along the Texas Gulf Coast, Report of Investigations No. 149. Austin, TX: Bureau of Economic Geology, The University of Texas at Austin.

Mace, R.E. 1998. Ground-Water Flow and Solute Transport in a Fractured Chalk Outcrop, North-Central Texas. Ph.D. Dissertation, The University of Texas at Austin.

Mace, R.E. and A.R. Dutton. 1994. "Hydrogeologic Controls on Contaminant Transport in Weathered and Fractured Chalk." Toxic Substances and the Hydrologic Sciences, American Institute of Hydrology, p. 535-546.

Magara, K. 1978. Compaction and Fluid Migration, Practical Petroleum Geology. Amsterdam: Elsevier Scientific Publishing Company.

Manning, C.E., and S.E. Ingebritsen. 1999. "Permeability of the Continental Crust: Implications of Geothermal Data and Metamorphic Systems.” In Reviews of Geophysics, v. 37: 127-150. Washington D.C. American Geophysical Union.

Neglia, S. 1979. "Migration of Fluids in Sedimentary Basins." In American Association of Petroleum Geologists. Bulletin, v. 63: 573-597.

Prudic, D.E. 1991. Estimates of Hydraulic Conductivity from Aquifer-Test Analyses and Specific-Capacity Data, Gulf Coast Regional Aquifer Systems, South-Central United States, Water-Resources Investigations Report 90-4121. Denver, CO: U.S. Geological Survey.

Rasmuson, A., and I. Neretnieks. 1986. "Radionuclide Transport in Fast Channels in Crystalline Rock." In Water Resources Research, v. 22: (8), 1247-1256. Washington DC: American Geophysical Union.

Rubey, W.W. and M.K. Hubbert. 1959. "Role of Fluid Pressure in Mechanics of Overthrust Faulting”, In Geol. Soc. Am. Bulletin, 70, 167-206.

Rushton, K.R., E.J. Smith, and L.M. Tomlinson. 1982. “An Improved Understanding of Flow in a Limestone Aquifer Using Field Evidence and Mathematical Models." In Journal of the Insitution of Water Engineers and Scientists, v. 36 (5): 369-397.

Rushton, K.R., B.J. Connorton, and L.M. Tomlinson. 1989. "Estimation of the Groundwater Resources of the Berkshire Downs Supported by Mathematical Modeling." In Quarterly Journal of Engineering Geology, v. 22 (4): 329-341. 
Snow, D.T. 1968. “Hydraulic Conductivity of Fractured Metamorphic Rocks of the Front Range and Implications to the Rocky Mountain Arsenal." In Quarterly of the Colorado School of Mines, v. 63 (1): 201-244.

Stober, I. 1996. "Researchers Study Conductivity of Crystalline Rock in Proposed Radioactive Waste Site." In Eos Trans. Am. Geophys. Union, v. 77 (10): 93-94.

Stoller-Navarro Joint Venture. 2004. Hydrologic Data for the Groundwater Flow and Contaminant Transport Model of Corrective Action Units 101 and 102: Central and Western Pahute Mesa, Nye County, Nevada, Rev. 0, S-N 199205--002; Shaw/13052-204. Prepared for the U.S. Department of Energy, Nevada Operations Office. Las Vegas, NV. February 2004.

U.S. Department of Energy, Nevada Operations Office. 1997. Regional Groundwater Flow and Tritium Transport Modeling and Risk Assessment of the Underground Test Area, Nevada Test Site, Nevada, DOE/NV--477, UC-700. Las Vegas, NV.

Whittemore, D.O., P.A. Macfarlane, J.H. Doveton, J.J. Butler, Jr., T-M. Chu, R. Bassler, M. Smith, J. Mitchell, and A. Wade. 1993. The Dakota Aquifer Program Annual Report, FY92. Kansas Geological Survey.

Williams, C.F., and T.N. Narasimhan. 1989. "Hydrogeologic Constraints on Heat Flow Along the San Andreas Fault: A Testing of Hypotheses.” In Earth Planet. Sci. Lett., v. 92: 131-143. Amsterdam: Elsevier Science Publishers B.V.

Williamson, A.K., and H.F. Grubb. 2001 Ground-Water Flow in the Gulf Coast Aquifer Systems, South-Central United States, Professional Paper 1416-F. Denver, CO: U.S. Geological Survey.

Wilson, A.M. 2003. "The Occurrence and Chemical Implications of Geothermal Convection of Seawater in Continental Shelves." In Geophysical Research Letters, v. 30 (21): 2127, doi:10.1029/2003GL018499. Washington D.C.: American Geophysical Union.

Wilson, A.M., W. Sanford, F. Whitaker, and P. Smart. 2001. "Spatial Patterns of Diagenesis during Geothermal Circulation in Carbonate Platforms." In American Journal of Science, v. 301: 727-752. 
Appendix F

Boundary Flux Calculations 


\section{F.1.0 Boundary flux Calculations}

\section{F.1.1 Introduction}

This section provides details of the data compilation, calculations, and simulations presented in Section 9.0. Calculations were performed in several stages. First, recharge data were compiled, revised, and analyzed to obtain a set of six alternative recharge models. Next, six HFM alternatives were merged into the DVRFS HFM to create seven alternative HFMs, including the HFM used in the original DVRFS model (Belcher et al., 2004). The recharge models were then applied to the DVRFS model modified with the HFM alternatives. Calibration was achieved using the base alternative HFM and the original DVRFS recharge model. Finally, a series of simulations were performed, using the estimated parameter values obtained from the calibration process, to calculate the boundary flux rates and capture the uncertainties associated with recharge and the HFMs.

\section{F.1.2 Recharge}

The original regional groundwater flow model (DOE/NV, 1997) used for the UGTA project was based on MODFLOW (McDonald and Harbaugh, 1988). The mesh for this model had variable grid spacing that was coarse at the edges and became finer within the NTS area (toward the center of the mesh). The UGTA recharge distributions (see Section 7.0) were calculated on a $1 \mathrm{~km}$ grid, using precipitation data (Hardman, 1965) with the same grid spacing. The DRI recharge distributions were provided on a $1 \mathrm{~km}$ grid spacing and did not require regridding. The recharge distributions were then converted to accommodate the variable grid spacing of the original UGTA regional model.

The USGS net infiltration recharge models 1 and 2 were provided on approximately $278.5 \mathrm{~m}$ grid spacing (Hevesi et al., 2003). These data were re-sampled to produce data that corresponded to the $1 \mathrm{~km}$ grid used for the UGTA and DRI recharge/precipitation models. The location of the UGTA and DRI $1 \mathrm{~km}$ spaced locations were found on the USGS grid (Hevesi et al., 2003), and the exact value of recharge at that point was used. This point-based approach does not honor the data exactly as an area 
averaged approach would, but the difference (approximately 5 percent) was deemed insignificant compared to the errors introduced by other assumptions made during recharge calculations.

\section{F.1.2.1 Preparation of Recharge Data for Lateral Boundary Flux Calculations}

The current regional model selected for use in the UGTA project is the DVRFS model (Belcher, et al., 2004), which has a grid spacing of $1.5 \mathrm{~km}$. Previous recharge models do not extend to the boundaries of the DVRFS model, as they were designed for the smaller area covered by the 1997 UGTA regional model area (see Figure 1-2). Furthermore, because the nodes of the UGTA regional model mesh do not coincide with the nodes of the DVRFS model, values of recharge from the alternative recharge models needed to be re-sampled. This was accomplished by using an inverse-distance weighted averaging method (Isaaks and Srivastava, 1989). The data at the nodes of the alternative recharge models (either at $1 \mathrm{~km}$ or $278.5 \mathrm{~m}$ grid spacing), that fell within the $1.5 \mathrm{~km}$ spacing of the DVRFS model nodes, were inverse-distance weighted and the average of the recharge was assigned to the DVRFS model nodes. This was accomplished so that the grid spacing was $1.5 \mathrm{~km}$ for all alternative recharge models.

Because of the larger extent of the DVRFS model relative to the extent of the alternative recharge models (Figure 1-2), the alternative recharge models were merged into the DVRFS recharge model. To accomplish this, the recharge values in the interior (active) nodes of the DVRFS model (within the boundaries common to both models) were replaced with the inverse-distance averaged values; representing the values at the nodes $(1.5 \mathrm{~km}$ grid $)$ of the alternative recharge models. Outside this boundary, the DVRFS calibrated recharge values were used.

\section{F.1.3 Lateral Boundary Flux Evaluation and Analysis}

Analysis of the lateral boundary flux entailed comparing the results of the original DVRFS steady-state model with the results of the alternative models developed using the six alternative HFMs for Yucca Flat/Climax Mine. The Yucca Flat/Climax Mine HFM alternative models are listed in Table F.1-1. Descriptions of these alternative HFMs are provided in Section 5.0 and Appendix D. 
Table F.1-1

Alternative Hydrologic Framework Models

\begin{tabular}{|c|l|}
\hline HFM Abbreviations & \multicolumn{1}{c|}{ Description } \\
\hline \hline HDVR & DVRFS \\
\hline HB & Yucca Flat/Climax Mine Base \\
\hline HPZ & Yucca Flat/Climax Mine Partial Zeolitization \\
\hline HCP & Yucca Flat/Climax Mine Control Point Thrust \\
\hline HHB & Yucca Flat/Climax Mine Hydrologic Barrier \\
\hline HCU & Yucca Flat/Climax Mine Contiguous UCCU \\
\hline HFJ & Yucca Flat/Climax Mine Fault Juxtaposition \\
\hline
\end{tabular}

The recharge models used for simulations included two UGTA models (UGTA Original and UGTA Revised), three USGS models (USGS with run-on infiltration included in recharge, USGS without run-on infiltration included in recharge, and calibrated DVRFS recharge), and two DRI models (DRI alluvial mask and DRI alluvial and elevation mask). These recharge models are listed in Table F.1-2. Descriptions of these alternative recharge models are provided in Section 7.0.

Table F.1-2

Alternative Recharge Models

\begin{tabular}{|c|l|}
\hline Recharge Model Abbreviation & \multicolumn{1}{|c|}{ Recharge Model } \\
\hline \hline RUR & UGTA Revised \\
\hline RUO & UGTA Original \\
\hline RGSNO & $\begin{array}{l}\text { USGS Model 1 - with run-on infiltration } \\
\text { included in recharge }\end{array}$ \\
\hline RGSOF & $\begin{array}{l}\text { USGS Model 2 - without run-on infiltration } \\
\text { included in recharge }\end{array}$ \\
\hline RDVR & USGS Model 3 - DVRFS calibrated recharge \\
\hline RDRIAI & DRI - Alluvial Mask \\
\hline RDRIAIEI & DRI - Alluvial and Elevation Mask \\
\hline & \\
\hline
\end{tabular}

Table F.1-3 provides a matrix of the 13 simulation cases that will be described briefly in the following section. 
Table F.1-3

Simulation Cases Presented in this Report

\begin{tabular}{|c|c|c|c|c|c|c|c||}
\hline \multirow{2}{*}{$\begin{array}{c}\text { Recharge } \\
\text { Models }\end{array}$} & \multicolumn{7}{|c|}{ Alternative HFM } \\
\cline { 2 - 8 } & HB & HPZ & HCP & HHB & HCU & HFJ & HDVR \\
\hline \hline RUR & & & & & & & $X$ \\
\hline RUO & & & & & & & $X$ \\
\hline RGSNO & & & & & & & $X$ \\
\hline RGSOF & & & & & & $X$ \\
\hline RDVR & (Figure F.1-3) & (Figure F.1-4) & (Figure F.1-5) & (Figure F.1-6) & (Figure F.1-7) & (Figure F.1-8) & (Figure F.1-2) \\
\hline RDRIAl & & & & & & & $X$ \\
\hline RDRIAIEl & & & & & & & $X$ \\
\hline
\end{tabular}

$\mathrm{X}=$ Simulation cases

\section{F.1.4 Application of Recharge Models}

The recharge models described above were applied to the original DVRFS model (Belcher, et al., 2004) and the six alternatives generated by inserting the six HFMs as described previously (see Section 5.0 for details). For the original DVRFS HFM, all recharge models were applied. Application of the original calibrated DVRFS recharge to all the alternatives produced similar ranges of the residual hydraulic heads.

\section{F.1.5 Procedures for Simulations and Calibrations}

A selected set of horizontal hydraulic conductivity parameters, within the area affected by the insertion of the Yucca Flat/Climax Mine HFMs into the DVRFS HFM, were calibrated using the parameter estimation method of MODFLOW-2000 (Hill, et al., 2000 and Harbaugh, et al., 2000). The parameter estimation method of MODFLOW-2000 is a statistical technique by which simulation of a selected number of parameters (such as hydraulic head, recharge, and/or discharge) are fitted to measured (observed) values of the same parameters. The goodness of fit is then evaluated using the sum of squared weighted residuals (measured minus simulated values). The measured values of the parameters are referred to as calibration targets. Simulations are run until an acceptable closure criteria for the error is reached (Hill, et al., 2000 and Harbaugh, et al., 2000). 
During model calibration, horizontal hydraulic conductivity parameters within the NTS area were selected as the primary parameters of interest for model calibration (Table F.1-4). The location and extent of these parameters are shown in Belcher et al. (2004). The remaining parameters were fixed as calibrated by Belcher et al. (2004). The initial values for hydraulic conductivity were set to the calibrated values of the original DVRFS steady-state model. The minimum and maximum values prescribed for horizontal hydraulic conductivity are shown in Table F.1-4. This table also compares the results of the original DVRFS with the calibration simulation using DVRFS recharge and HB HFM. Figure F.1-1 shows the calibration targets for head values in Yucca Flat/Climax Mine CAU. Only values for the top layer are presented in this figure. The results of this case were used for all lateral boundary flux calculations.

Table F.1-4

Calibrated Horizontal Hydraulic Conductivity (in $\mathrm{m} / \mathrm{d}$ )

(Page 1 of 2)

\begin{tabular}{|c|c|c|c|c||}
\hline $\begin{array}{c}\text { Parameter } \\
\text { Names }\end{array}$ & $\begin{array}{c}\text { Lower Limit } \\
\text { (Minimum) }\end{array}$ & $\begin{array}{c}\text { Upper Limit } \\
\text { (Maximum) }\end{array}$ & $\begin{array}{c}\text { Original DVRFS } \\
\text { (RDVR+HDVR) }\end{array}$ & $\begin{array}{c}\text { Yucca Flat/Climax } \\
\text { Mine HFM } \\
\text { (RDVR+HB) }\end{array}$ \\
\hline \hline \multicolumn{5}{|c|}{ Confining Units } \\
\hline \hline K11_ICU & $6.00 \mathrm{E}-04$ & 1.4 & $2.64 \mathrm{E}-03$ & $2.76 \mathrm{E}-03$ \\
\hline K11C_XILCU & $3.00 \mathrm{E}-08$ & 5 & $1.94 \mathrm{E}-03$ & $1.07 \mathrm{E}-02$ \\
\hline K1LCCU_XCU & $3.00 \mathrm{E}-08$ & 5 & $4.08 \mathrm{E}-03$ & $1.06 \mathrm{E}-03$ \\
\hline K12223LCCU & $3.00 \mathrm{E}-08$ & 5 & $1.57 \mathrm{E}-03$ & $1.65 \mathrm{E}-03$ \\
\hline K122fgLCCU & $3.00 \mathrm{E}-08$ & 5 & $6.00 \mathrm{E}-05$ & $2.19 \mathrm{E}-05$ \\
\hline K1221UCCU & $2.00 \mathrm{E}-04$ & 0.4 & $3.88 \mathrm{E}-02$ & $8.82 \mathrm{E}-03$ \\
\hline \hline & & Carbonate Rock Aquifers & $7.28 \mathrm{E}-09$ \\
\hline \hline K221_LCA & N/A & N/A & $6.09 \mathrm{E}+00$ & $1.11 \mathrm{E}-01$ \\
\hline K232_LCA & N/A & N/A & $1.00 \mathrm{E}-03$ & $1.37 \mathrm{E}-02$ \\
\hline K2412_LCA & N/A & N/A & $8.06 \mathrm{E}-02$ & $5.17 \mathrm{E}+02$ \\
\hline K242G_LCA & N/A & N/A & $6.46 \mathrm{E}-02$ & $3.31 \mathrm{E}-01$ \\
\hline K2YMLCA & N/A & N/A & $4.23 \mathrm{E}-01$ & $5.26 \mathrm{E}-02$ \\
\hline K242A_LCA & N/A & N/A & $3.39 \mathrm{E}+00$ & $3.30 \mathrm{E}+00$ \\
\hline K243_LCA & N/A & N/A & $2.19 \mathrm{E}+00$ & $1.97 \mathrm{E}-03$ \\
\hline K241SM_LCA & N/A & N/A & $1.51 \mathrm{E}-03$ & \\
\hline
\end{tabular}


Table F.1-4

Calibrated Horizontal Hydraulic Conductivity (in $\mathrm{m} / \mathrm{d}$ )

(Page 2 of 2)

\begin{tabular}{|c|c|c|c|c||}
\hline $\begin{array}{c}\text { Parameter } \\
\text { Names }\end{array}$ & $\begin{array}{c}\text { Lower Limit } \\
\text { (Minimum) }\end{array}$ & $\begin{array}{c}\text { Upper Limit } \\
\text { (Maximum) }\end{array}$ & $\begin{array}{c}\text { Original DVRFS } \\
\text { (RDVR+HDV) }\end{array}$ & $\begin{array}{c}\text { Yucca Flat/Climax } \\
\text { Mine HFM } \\
\text { (RDVR+HB) }\end{array}$ \\
\hline \hline \multicolumn{5}{|c|}{ Volcanic Rock Units } \\
\hline \hline K3C_TM & $2.00 \mathrm{E}-04$ & 20 & $8.44 \mathrm{E}+00$ & $6.77 \mathrm{E}+00$ \\
\hline K3211TMVA & $2.00 \mathrm{E}-04$ & 20 & $5.66 \mathrm{E}-01$ & $1.02 \mathrm{E}+00$ \\
\hline K3BRU123 & 0.01 & 4 & $1.89 \mathrm{E}+00$ & $1.70 \mathrm{E}+00$ \\
\hline K32CH24LF & 0.002 & 4 & $1.60 \mathrm{E}-03$ & $1.20 \mathrm{E}-05$ \\
\hline K32BR4CH13 & 0.008 & 4 & $1.60 \mathrm{E}-01$ & $4.47 \mathrm{E}+00$ \\
\hline K3215BCU1 & 0.001 & 180 & $1.00 \mathrm{E}-02$ & $5.35 \mathrm{E}-03$ \\
\hline K3215BCU34 & 0.0003 & 55 & $1.24 \mathrm{E}+00$ & $6.91 \mathrm{E}+01$ \\
\hline \hline & & 6.00 & $3.83 \mathrm{E}+00$ \\
\hline \hline K4UP_VSUC & 0.00004 & 6 & $9.40 \mathrm{E}-01$ & $7.52 \mathrm{E}+00$ \\
\hline K42UP_VSU & 0.00004 & $6.06 \mathrm{E}+00$ & \\
\hline
\end{tabular}

$\mathrm{N} / \mathrm{A}=$ Not applicable

\section{F.1.6 Forward Simulations with Fixed (Unperturbed) Hydraulic Parameters}

The main objective of the 13 selected simulation cases was to evaluate the sensitivity of the boundary flux calculations to varying alternative HFMs and alternative recharge models. Forward simulations were performed for 13 combinations of recharge model and HFM alternatives as shown in Table F.1-3 matrix. Parameters shown in Table F.1-4 for Yucca Flat/Climax Mine HFM case were used for all simulations. Graphical presentation of the residuals for the cases involving DVRFS original recharge are shown in Figures 1-2 through F.1-8. Residuals for all cases, including the original USGS results showed a consistent problem in residual heads west of Yucca Flat/Climax Mine area. In both Syncline Ridge and Rainier Mesa, simulations under-predicted water levels by over 200 m. While in Eleana Range, simulations over-predicted hydraulic head values by more than $100 \mathrm{~m}$. 


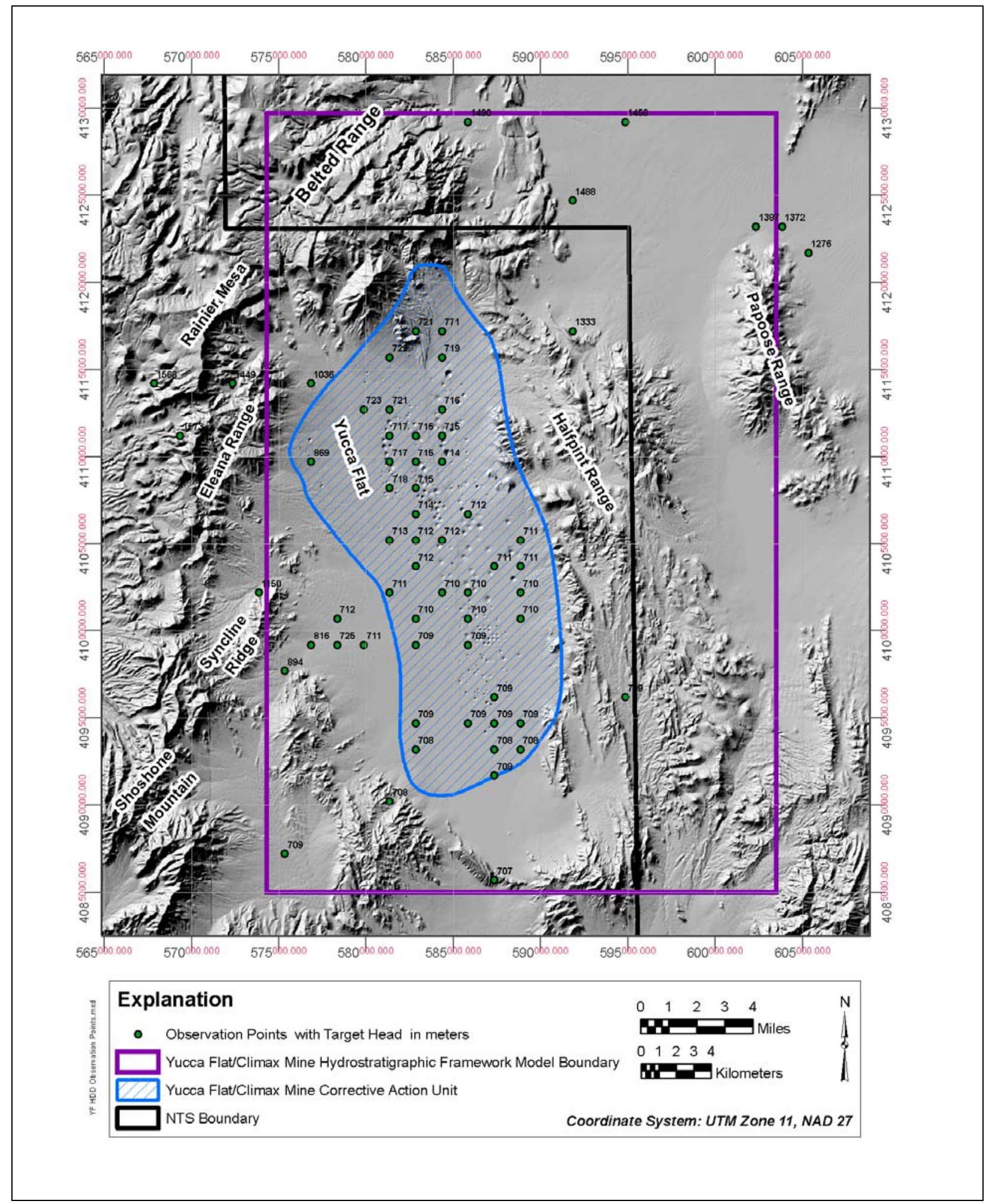

Figure F.1-1

Observation Points and Calibration Targets Used for the Original and Modified (merged) Calibrations in the Vicinity of the Yucca Flat/Climax Mine HFM 


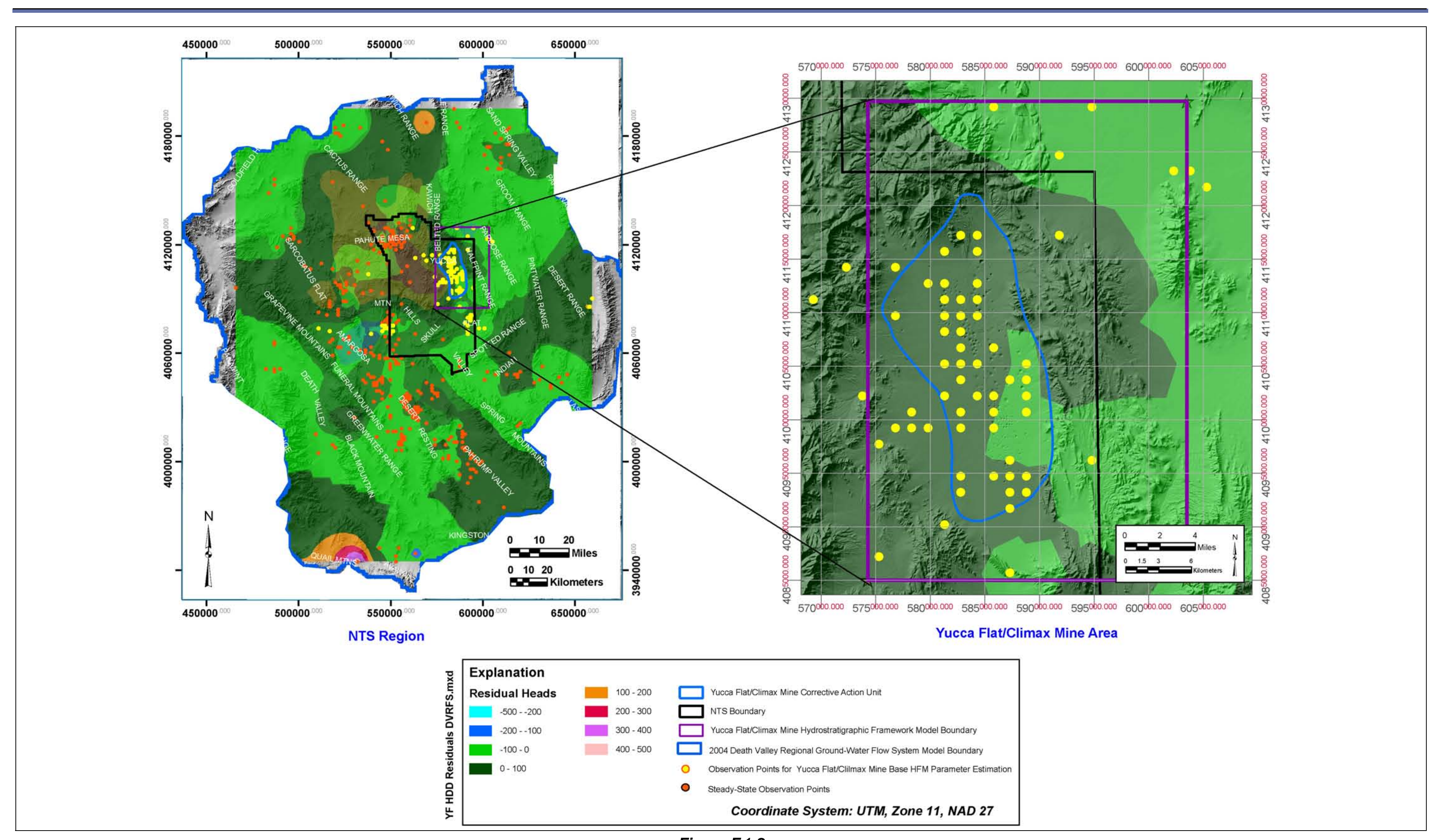

Residual Heads (Observed-Simulated) Distribution for Simulation Case Using the Original DVRFS Steady-State Calibrated Recharge Model and the Original DVRFS HFM 


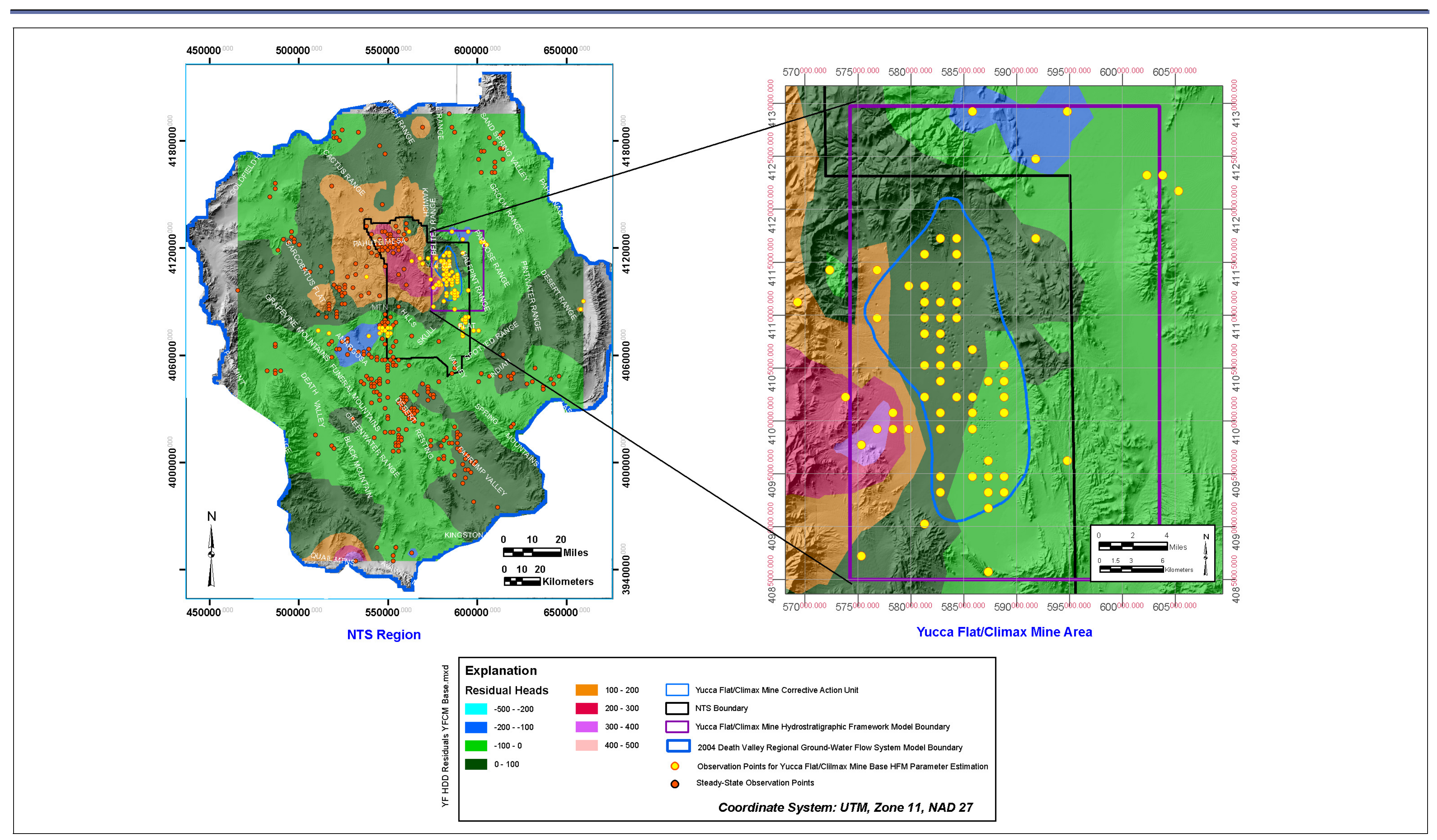

Residual Heads (Observed-Simulated) Distribution for Simulation Case Using the USGS DVRFS Recharge Model and the Yucca Flat/Climax Mine Base HFM (merged) 


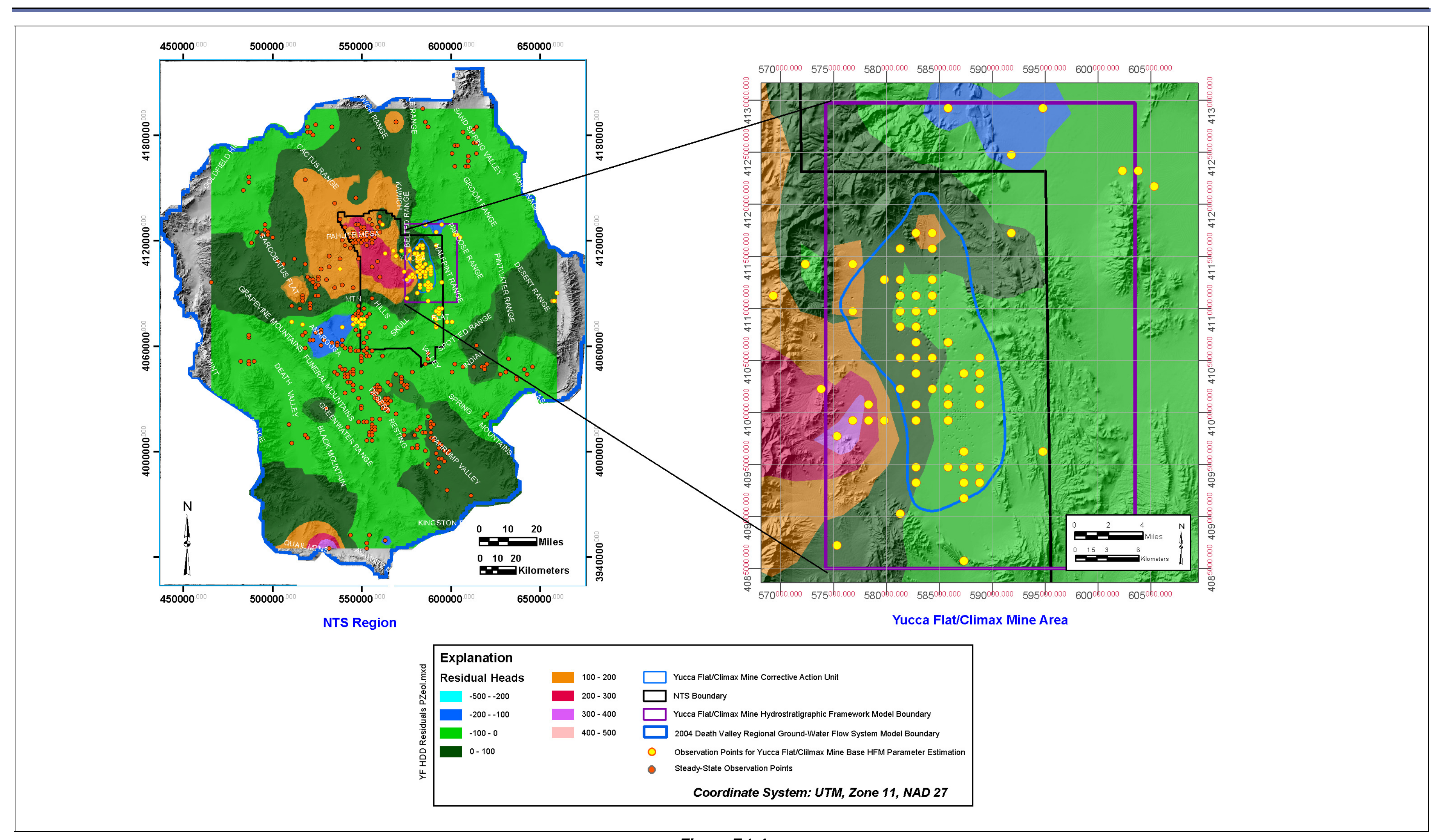

Figure F.1-4

Residual Heads (Observed-Simulated) Distribution for Simulation Case Using the Original DVRFS Steady-State Callibrated Recharge Model and the Yucca Flat/Climax Mine Partial Zeolitization HFM (merged) 


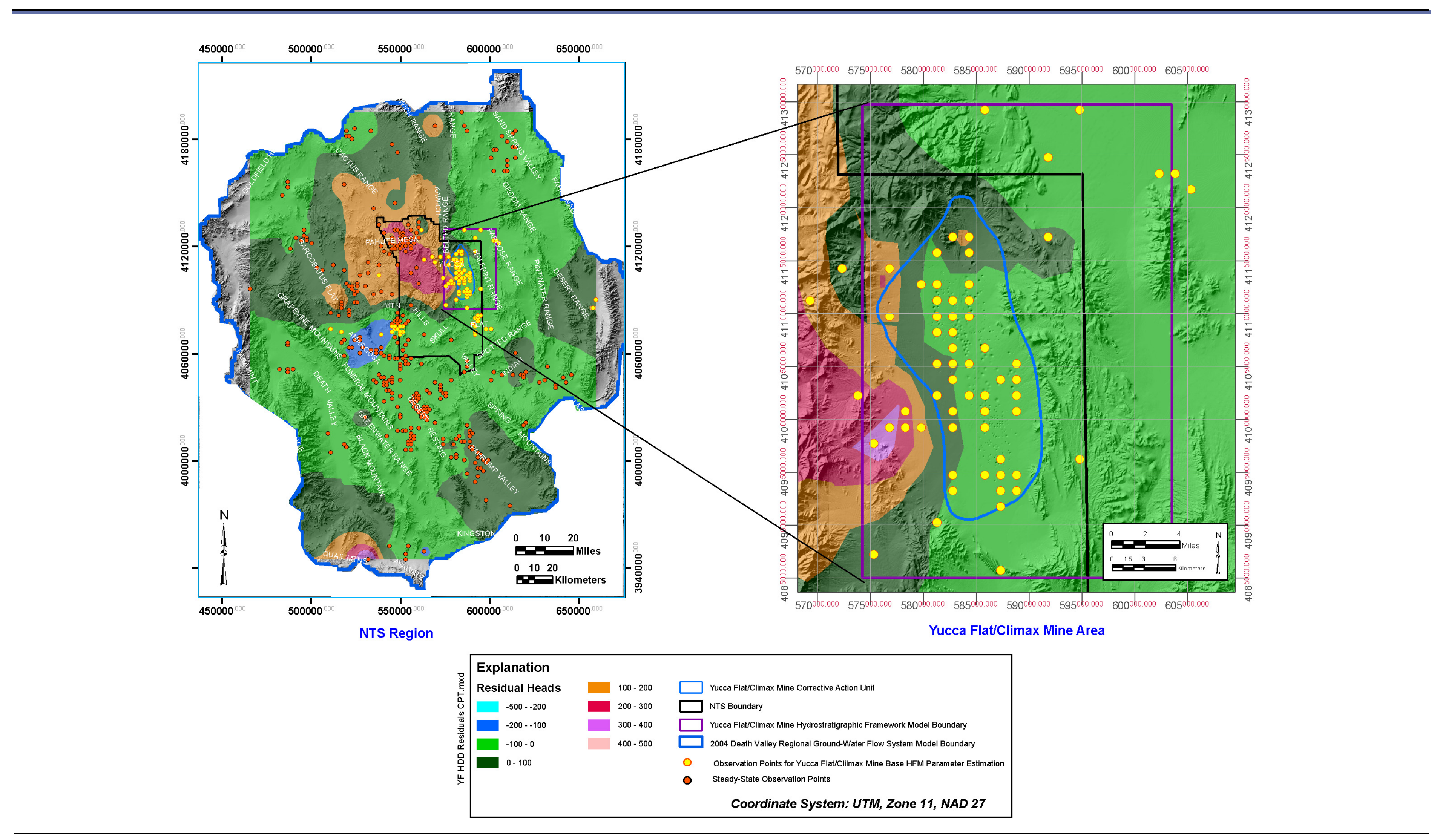

Figure F.1-5

Residual Heads (Observed-Simulated) Distribution for Simulation Case Using the Original DVRFS Steady-State Calibrated Recharge Model and the Yucca Flat/Climax Mine Control Point Thrust HFM (merged) 


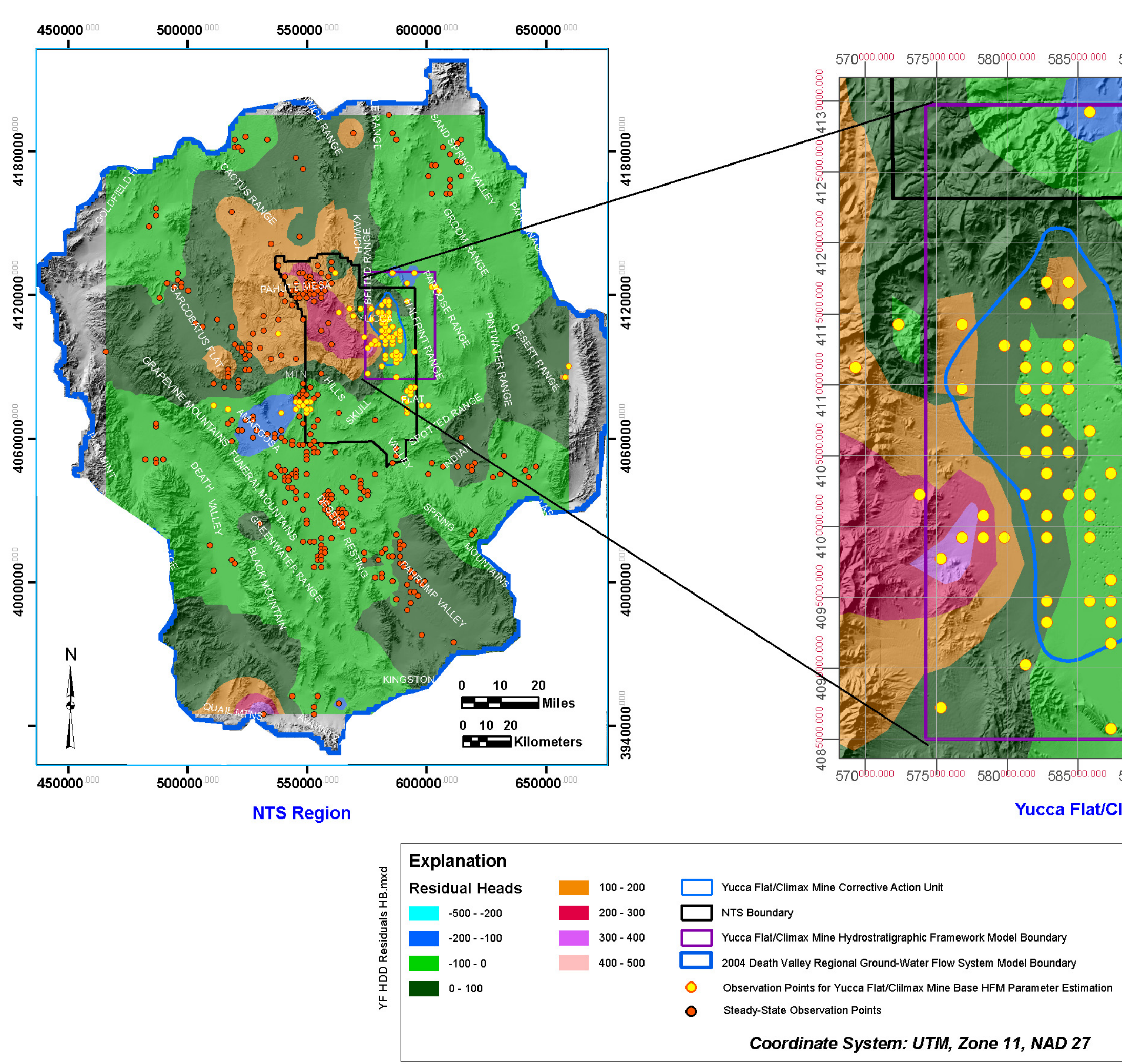

Figure F.1-6

Residual Heads (Observed-Simulated) Distribution for Simulation Case Using the Original DVRFS Steady-State Calibrated Recharge Model and the Yucca Flat/Climax Mine Hydrologic Barrier HFM (merged) 


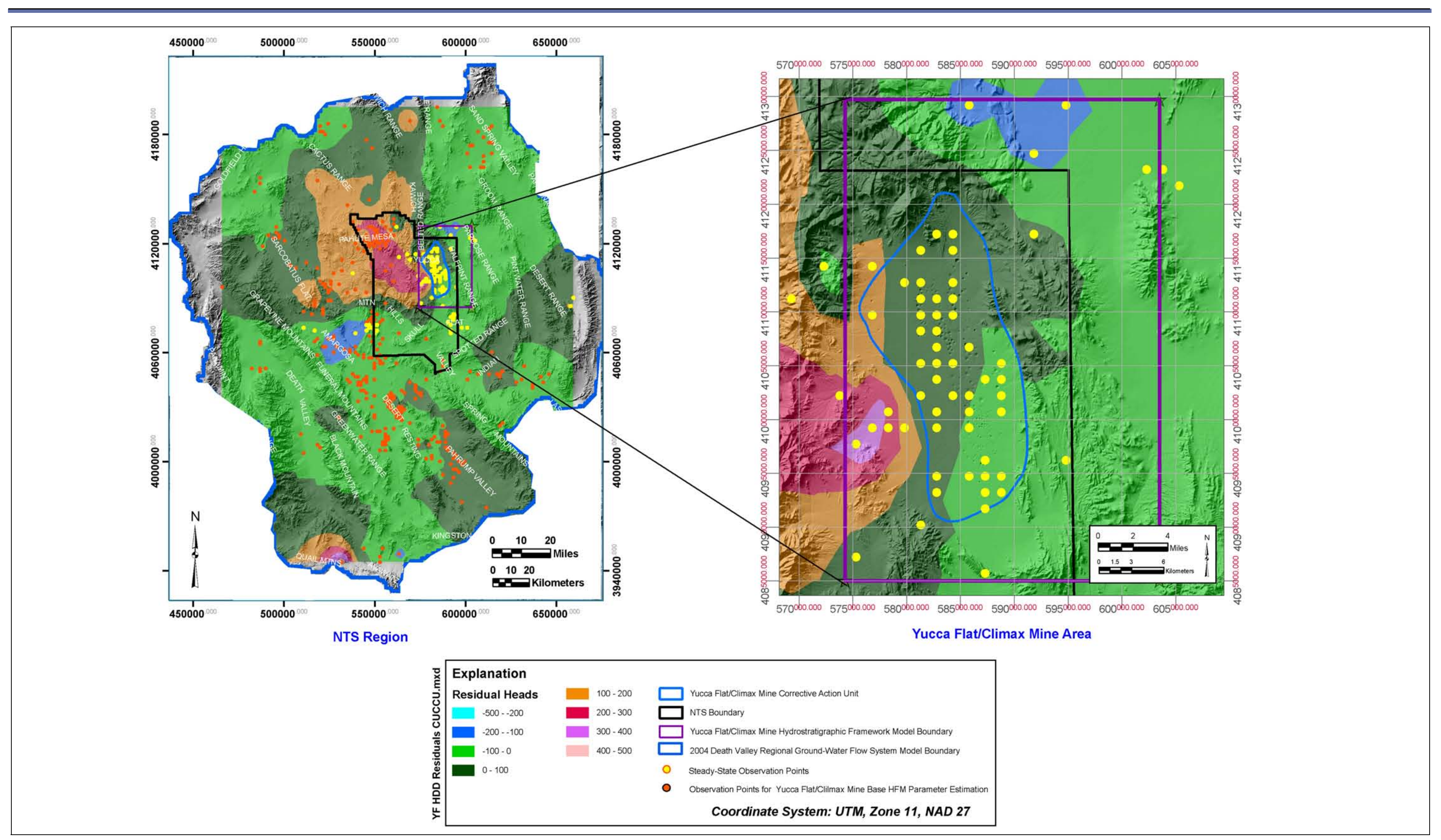

Residual Heads (Observed-Simulated) Distribution for Simulation Case Using the Original DVRFS Steady-State Calibrated Recharge Model and the Yucca Flat/Climax Mine Contiguous UCCU HFM (merged) 


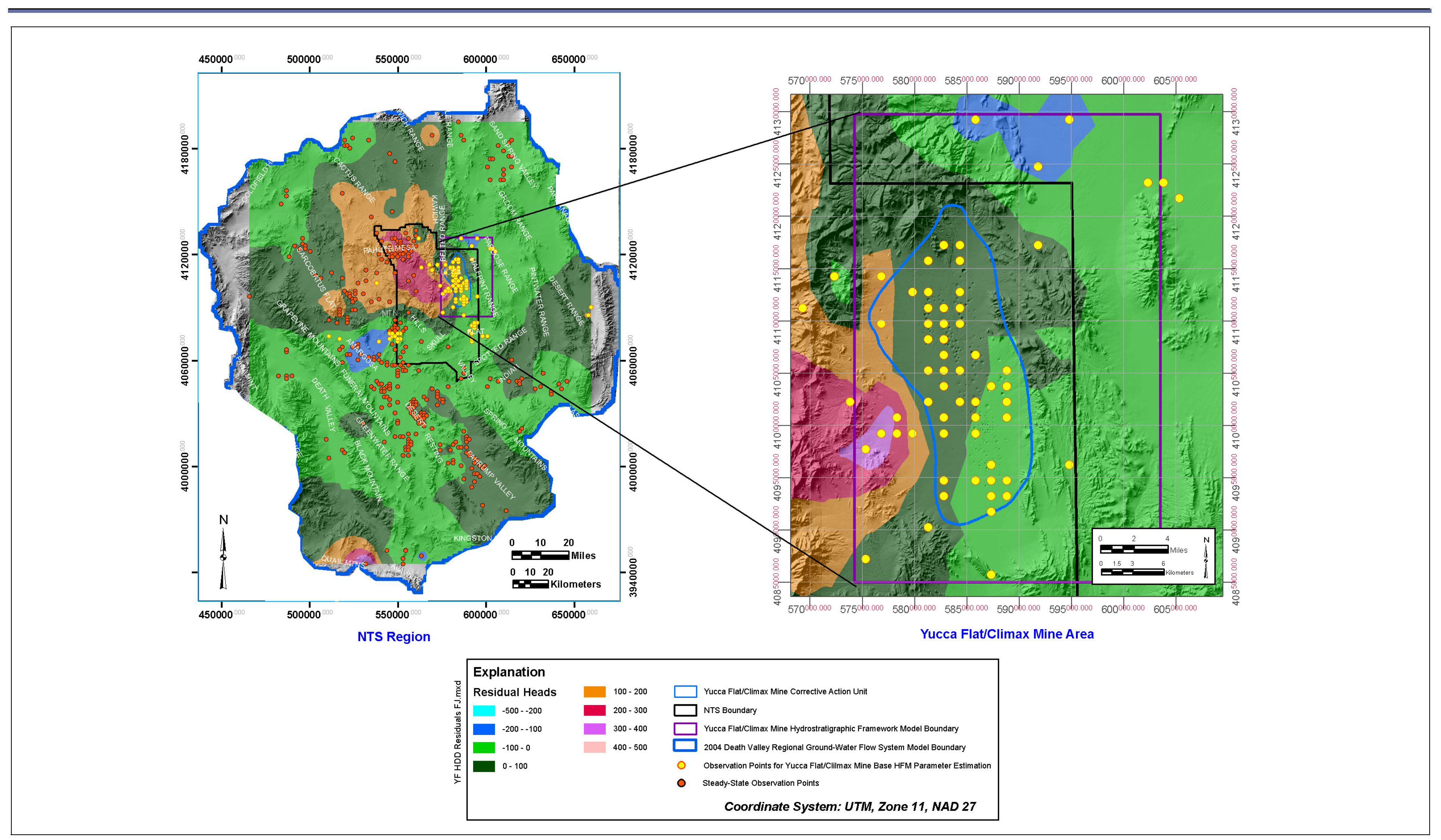

Figure F.1-8

Residual Heads (Observed-Simulated) Distribution for Simulation Case Using the Original DVRFS Steady-State Calibrated Recharge Model and the Yucca Flat/Climax Mine Fault Juxtaposition HFM (merged) 


\section{F.2.0 References}

Belcher, W.R., J.B. Blainey, F.A. D’Agnese, C.C. Faunt, M.C. Hill, R.J. Laczniak, G.M. O’Brien, C.J. Potter, H.M. Putnam, C.A. San Juan, and D.S. Sweetkind. 2004. Death Valley Regional Model Ground-Water Flow System, Nevada and California - Hydrogeologic Framework and Transient Ground-Water Flow Model, Scientific Investigations Report 2004-5205. U.S. Geological Survey.

DOE/NV, see U.S. Department of Energy, Nevada Operations Office.

Harbaugh, A.W., Banta, E.R., Hill, M.C., and McDonald, M.G. 2000. MODFOW-2000, The U.S. Geological Survey Modular Ground-Water Model -- User Guide to Modularization Concepts and the Ground-water Flow Process, USGS Open-File Report 00-92. Reston, VA: U.S. Geological Survey.

Hardman, G. 1965. Nevada Precipitation and Acreages of Land by Rainfall Zones. Reno, NV: U.S. Department of Agriculture, University of Nevada Experimental Station.

Hevesi, J.A., A.L. Flint, and L.E. Flint. 2003. Simulation of Net Infiltration Using a Distributed Parameter Watershed Model for the Death Valley Regional Flow System, Nevada and California. Sacramento, CA.

Hill, E.C., E.R. Banta, A.W. Harbaugh, and A.R. Anderman. 2000, MODFLOW-2000, The U.S. Geological Survey Modular Ground-Water Model - User Guide to the Observation, Sensitivity, and Parameter-Estimation Processes and Three Postprocessing Programs, Open-File Report 00-184. Denver, Colorado: U.S. Geological Survey.

Isaaks, E.H., and R.M. Srivastava. 1989. An Introduction to Applied Geostatistics. Oxford University Press, New York, NY, 561 p.

McDonald, M.G., and A.W. Harbaugh. 1988. "A Modular Three-Dimensional Finite-Difference Ground-Water Flow Model,” In U.S. Geological Survey Techniques of Water-Resources Investigations, Book 6, Chap. A1, 586 p. U.S. Geological Survey.

U.S. Department of Energy, Nevada Operations Office. 1997. Regional Groundwater Flow and Tritium Transport Modeling and Risk Assessment of the Underground Test Area, Nevada Test Site, Nevada, DOE/NV--477. Las Vegas, NV. 
Appendix G

Temperature Profile Data 


\section{G.1.0 yucca Flat/Climax Mine AREa temperature DATA}

The Yucca Flat/Climax Mine area temperature data provided in this appendix includes temperature data, temperature data analysis documented in Gillespie (2005), and provisional temperature data from the USGS obtained from the USGS website. The website address is included in Section G.2.0. As stated on the website, these USGS temperature data are considered provisional and are subject to revision until formal USGS publication.

\section{G.1.1 Temperature Data From Gillespie (2005)}

Temperature data in the form of vertical profiles obtained from temperature logs from wells evaluated in Gillespie (2005) for the Yucca Flat/Climax Mine area are provided in this section. Temperature log data including the date the log was obtained, organization that provided the log, and intervals of the well logged are provided in Table G.1-1. Figure G.1-1 shows the location of the wells. Table G.1-2 is a list of temperature profile figures for these wells (Figures G.1-5 through G.1-20). 
Table G.1-1

Wells with Temperature Logs from Gillespie (2005) in the Yucca Flat/Climax Mine Area

\begin{tabular}{|c|c|c|c|c|c|c|}
\hline \multirow{2}{*}{ Well Name } & \multicolumn{2}{|c|}{ Well Location } & \multirow{2}{*}{$\begin{array}{c}\text { Date of } \\
\text { Temperature } \\
\text { Log }\end{array}$} & \multirow{2}{*}{$\begin{array}{c}\text { Organization } \\
\text { Providing } \\
\text { Log }\end{array}$} & \multicolumn{2}{|c|}{$\begin{array}{l}\text { Logged Interval } \\
\text { (m bgs) }\end{array}$} \\
\hline & Easting & Northing & & & Top & Bottom \\
\hline UE-1q & $583,722.7$ & $4,101,777.7$ & $7 / 19 / 1994$ & DRI & 507.52 & 793.46 \\
\hline UE-1q & $583,722.7$ & $4,101,777.7$ & $4 / 22 / 2004$ & DRI & 206.90 & 799.40 \\
\hline UE-1L & $576,566.8$ & $4,100,381.8$ & $1 / 28 / 2002$ & DRI & 160.02 & 237.29 \\
\hline UE-2ce & $576,804.2$ & $4,110,772.7$ & $1 / 28 / 2002$ & DRI & 441.66 & 459.94 \\
\hline Water Well 2 (WW-2) & $581,005.7$ & $4,113,499.6$ & $4 / 17 / 2003$ & DRI & 609.48 & 864.14 \\
\hline ER-3-1-2 & $594,658.3$ & $4,097,339.0$ & $4 / 17 / 2003$ & DRI & 603.08 & 668.76 \\
\hline ER-3-2-2 & $585,716.4$ & $4,099,227.8$ & $4 / 17 / 2003$ & DRI & 472.32 & 776.81 \\
\hline UE-3e\#4-1 & $584,481.0$ & $4,102,812.6$ & $5 / 13 / 2003$ & DRI & 350.58 & 663.61 \\
\hline TW-7 & $585,901.0$ & $4,102,301.1$ & $3 / 20 / 1996$ & DRI & 501.03 & 601.80 \\
\hline TW-7 & $585,901.0$ & $4,102,301.1$ & $4 / 22 / 2004$ & DRI & 493.50 & 605.24 \\
\hline TW-D & $582,223.9$ & $4,103,327.0$ & $8 / 29 / 1994$ & DRI & 526.48 & 579.21 \\
\hline TW-D & $582,223.9$ & $4,103,327.0$ & $4 / 22 / 2004$ & DRI & 519.65 & 581.04 \\
\hline ER-6-1 & $589,632.7$ & $4,093,418.7$ & $10 / 16 / 2003$ & DRI & 456.74 & 691.77 \\
\hline UE-6d & $583,751.3$ & $4,093,397.3$ & $6 / 26 / 2003$ & DRI & 456.77 & 853.47 \\
\hline UE-10j & $581,526.6$ & $4,115,644.9$ & $4 / 22 / 2003$ & DRI & 638.74 & 776.66 \\
\hline ER-12-2 & $572,411.5$ & $4,115,492.7$ & $4 / 27 / 2004$ & DRI & 45.35 & $1,569.54$ \\
\hline UE-14b & $575,427.2$ & $4,087,304.1$ & $8 / 21 / 1991$ & DRI & 509.63 & $1,097.89$ \\
\hline UE-14b & $575,427.2$ & $4,087,304.1$ & $4 / 16 / 2003$ & DRI & 486.80 & $1,100.36$ \\
\hline U-15k & $583,644.2$ & $4,120,544.4$ & $5 / 18 / 2004$ & DRI & 30.18 & 262.71 \\
\hline UE-16f & $574,999.7$ & $4,098,960.0$ & $5 / 2 / 1994$ & LLNL & 115.13 & 422.30 \\
\hline UE-16f & $574,999.7$ & $4,098,960.0$ & $4 / 16 / 2003$ & DRI & 103.05 & 424.31 \\
\hline UE-17a & $574,116.2$ & $4,103,156.8$ & $5 / 2 / 1994$ & LLNL & 194.33 & 365.07 \\
\hline UE-17a & $574,116.2$ & $4,103,156.8$ & $4 / 17 / 2003$ & DRI & 180.01 & 366.25 \\
\hline UE-4t-1 & $584,575.5$ & $4,106,066.9$ & $5 / 13 / 2003$ & DRI & 91.62 & 602.92 \\
\hline ER-2-1 & $583,334.5$ & $4,108,978.3$ & $4 / 27 / 2004$ & DRI & 502.62 & 765.66 \\
\hline TW-E & $589,361.9$ & $4,101,336.5$ & Not reported & USGS & $50(\sim)$ & $780(\sim)$ \\
\hline
\end{tabular}

NR $=$ Not reported

$\sim$ Approximately 


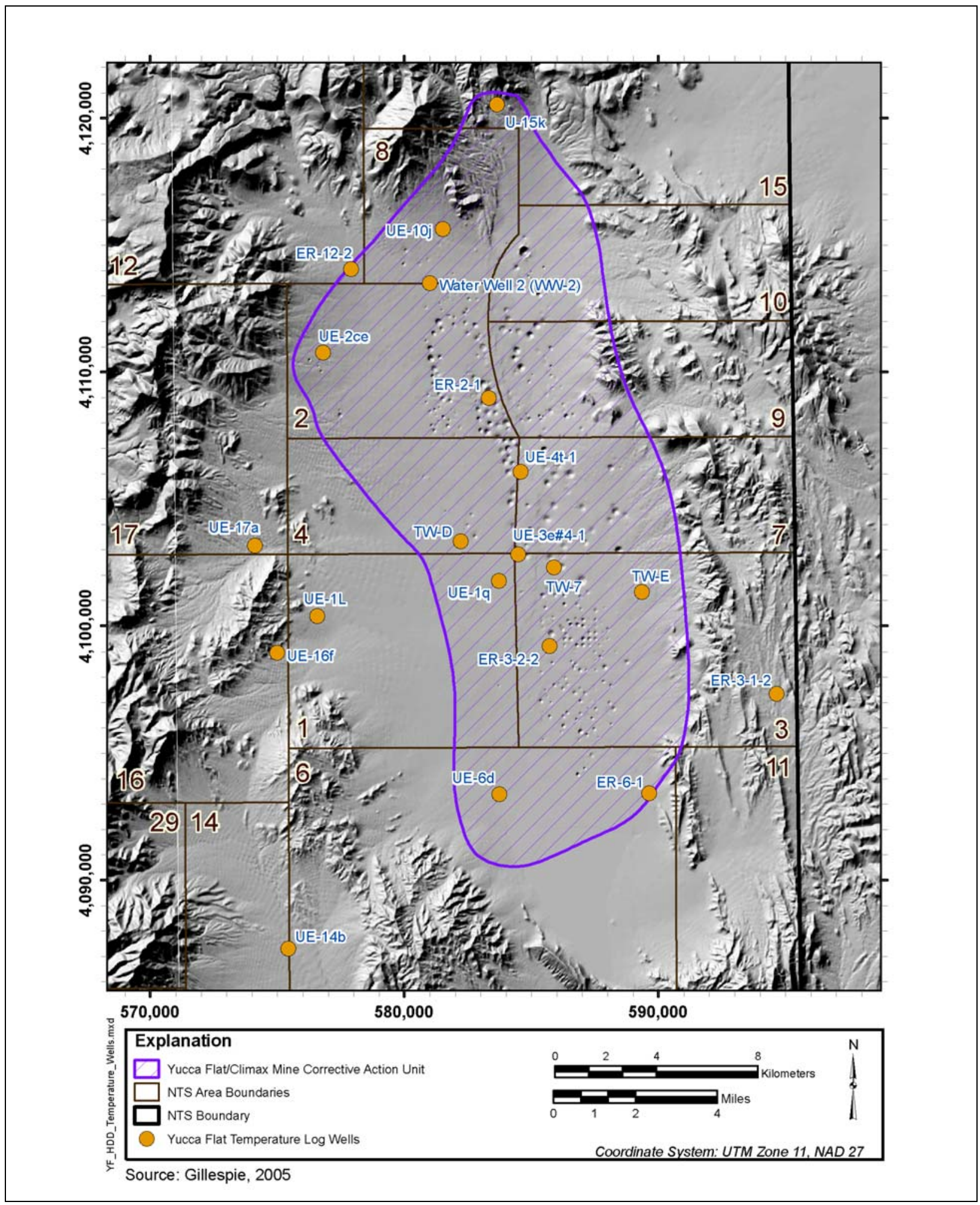

Figure G.1-1

Location of Wells in the Yucca Flat/Climax Mine Area with Temperature Log Profiles 
Table G.1-2

List of Temperature Profile Figures from Gillespie (2005) for the Yucca Flat/Climax Mine Area

\begin{tabular}{|c|c|}
\hline Figure Number & Well Identifier \\
\hline \hline G.1-2 & UE-1q \\
\hline G.1-3 & UE-1L \\
\hline G.1-4 & UE-2ce \\
\hline G.1-5 & Water Well 2 (WW-2) \\
\hline G.1-6 & ER-3-1-2 \\
\hline G.1-7 & ER-3-2-2 \\
\hline G.1-8 & UE-3e\#4-1 \\
\hline G.1-9 & TW-7 \\
\hline G.1-10 & TW-D \\
\hline G.1-11 & ER-6-1 \\
\hline G.1-12 & UE-6d \\
\hline G.1-13 & UE-10j \\
\hline G.1-14 & ER-12-2 \\
\hline G.1-15 & UE-14b \\
\hline G.1-16 & U-15k \\
\hline G.1-17 & UE-16f \\
\hline G.1-18 & UE-17a \\
\hline G.1-19 & UE-4t-1 \\
\hline G.1-20 & ER-2-1 \\
\hline
\end{tabular}




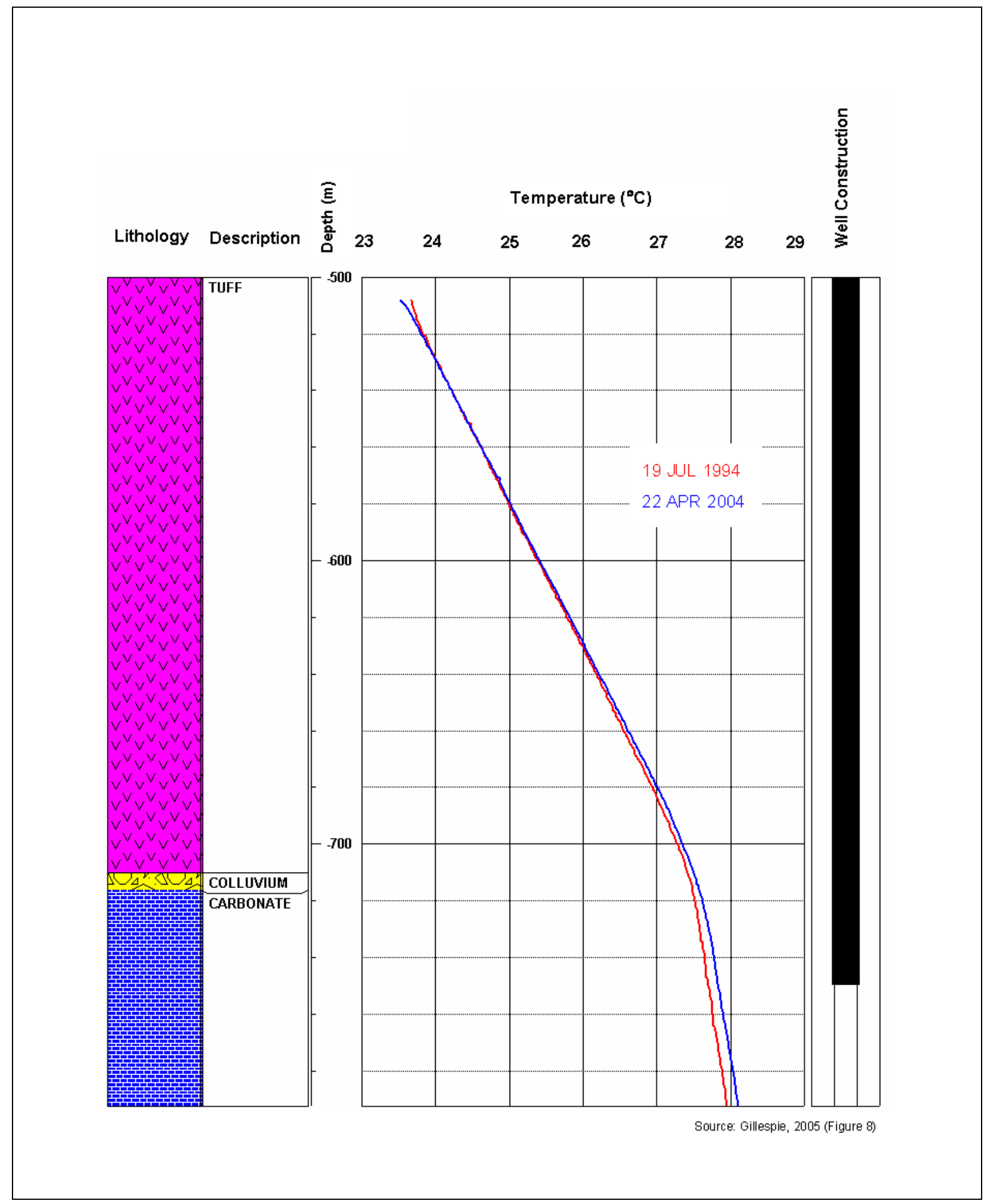

Figure G.1-2

Temperature Profile for Yucca Flat Well UE-1q 


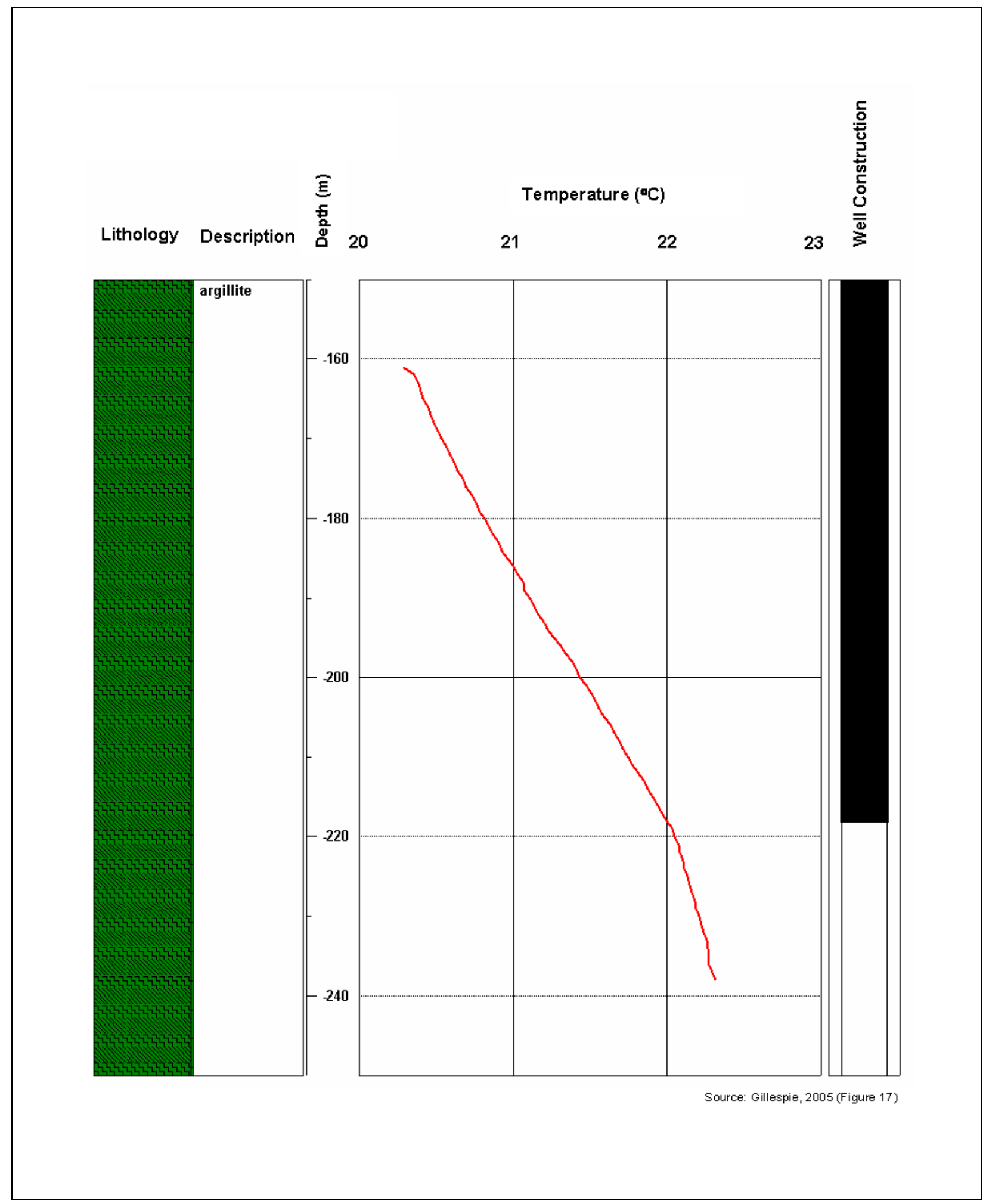

Figure G.1-3

Temperature Profile for Yucca Flat Well UE-1L 


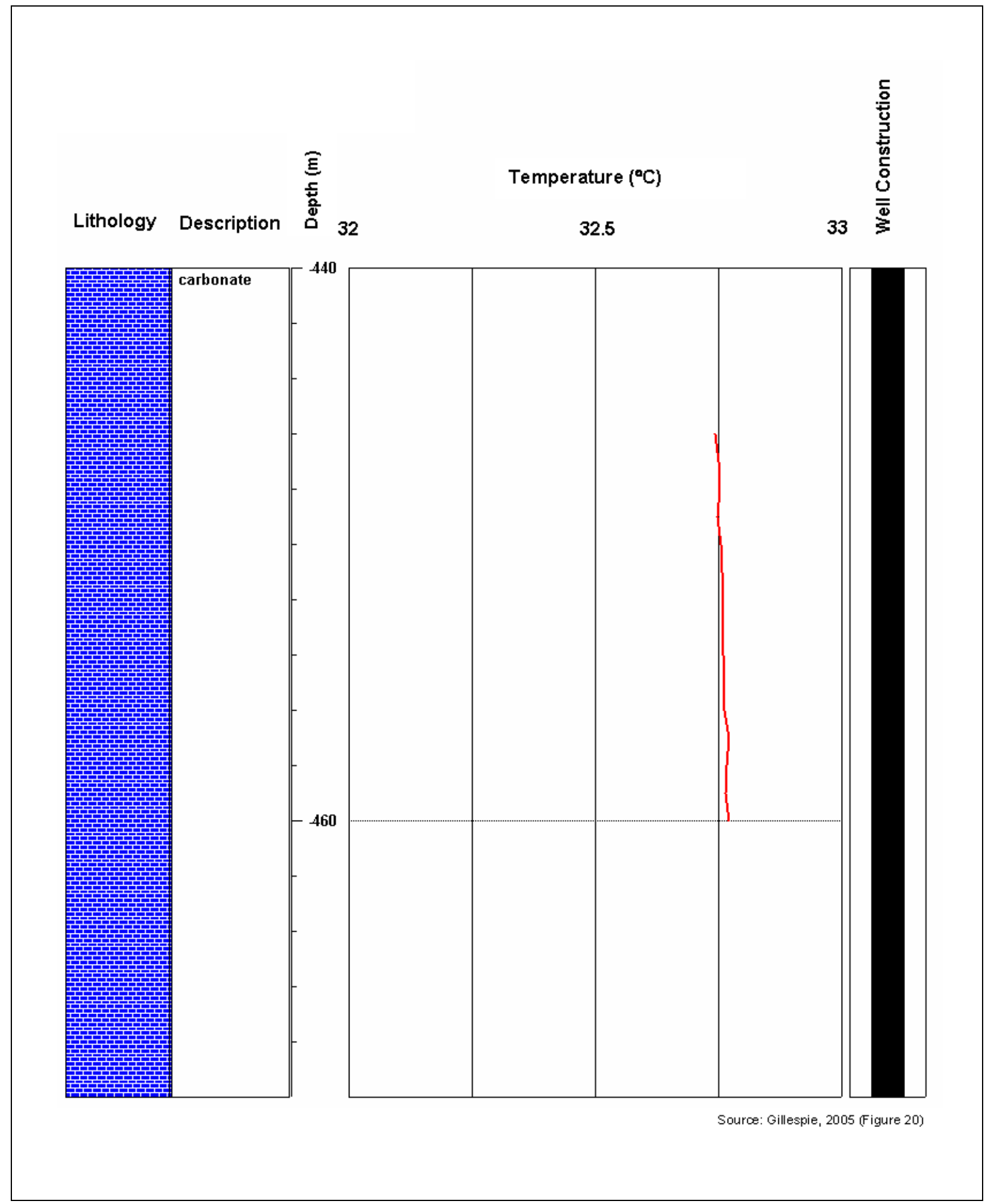

Figure G.1-4

Temperature Profile for Yucca Flat Well UE-2ce 


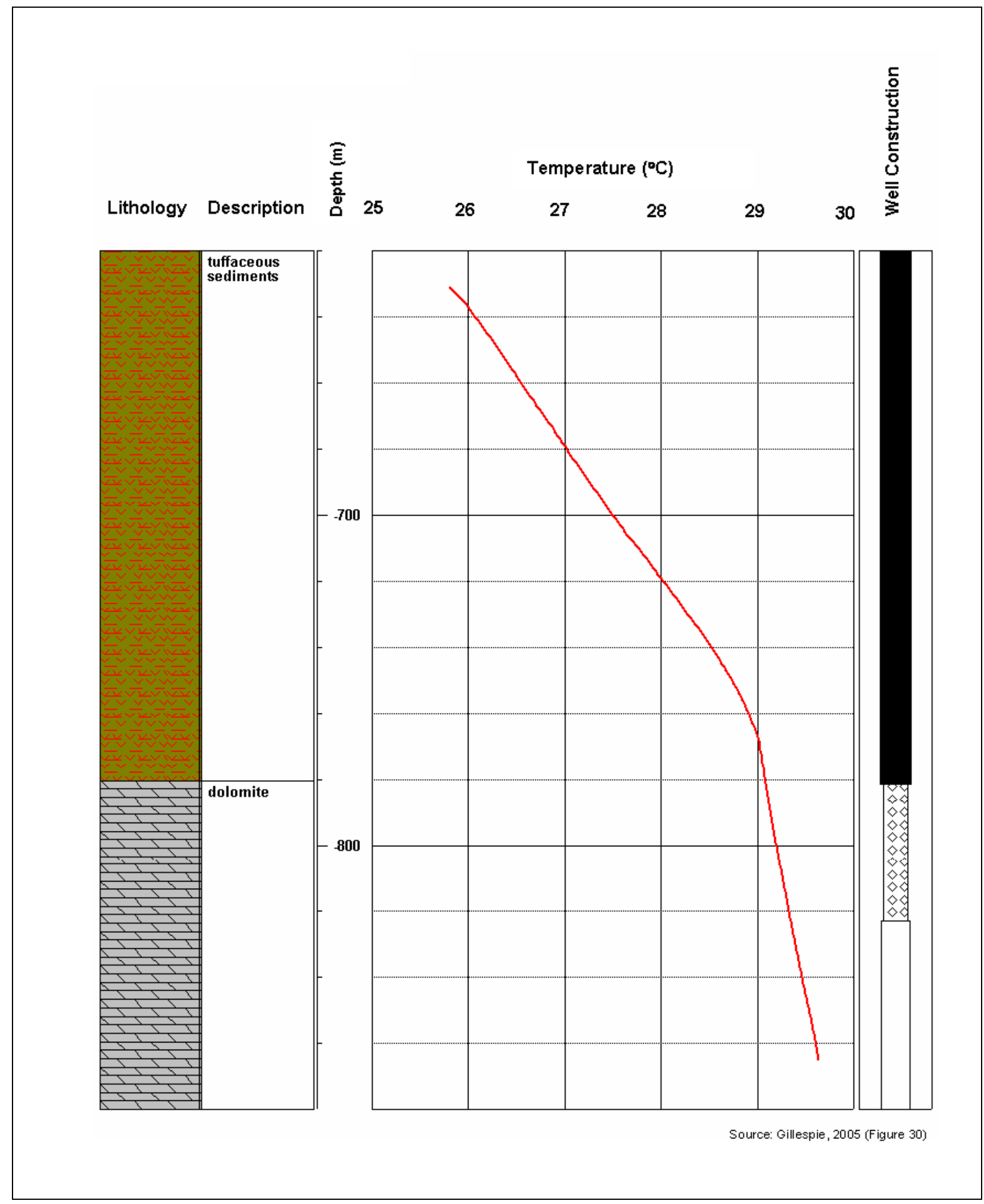

Figure G.1-5

Temperature Profile for Yucca Flat Well WW-2 


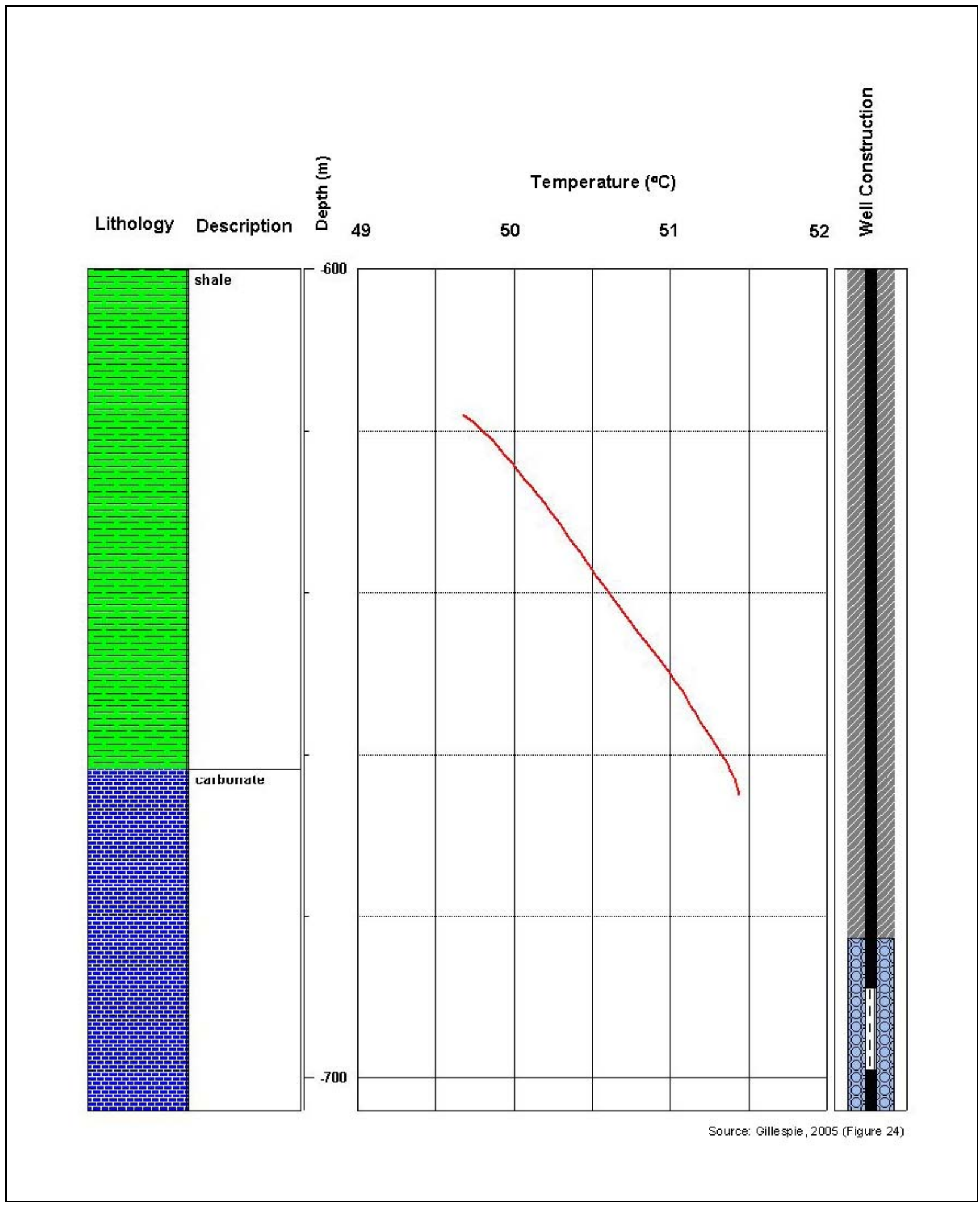

Figure G.1-6

Temperature Profile for Yucca Flat Well ER-3-1-2 


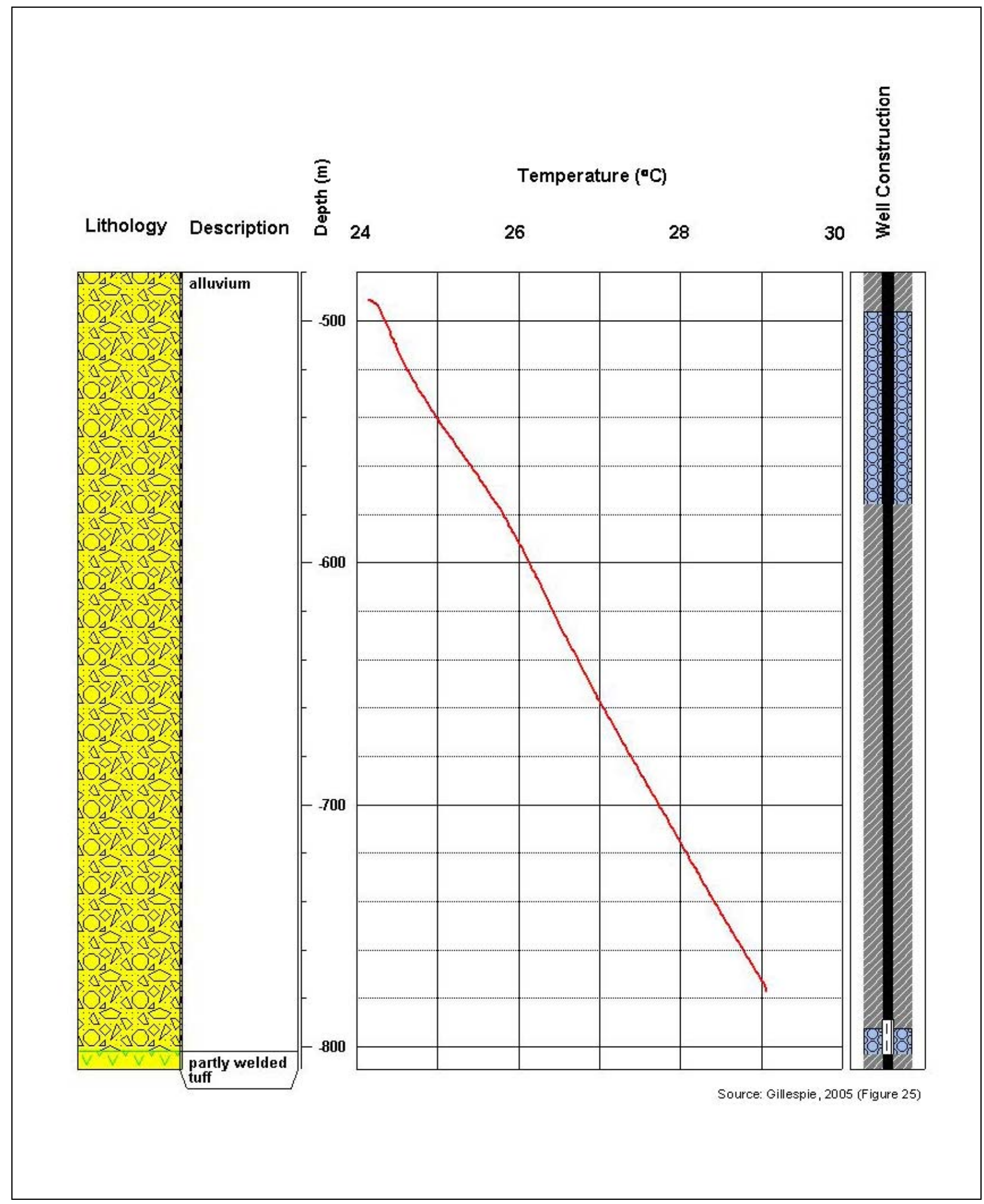

Figure G.1-7

Temperature Profile for Yucca Flat Well ER-3-2-2 


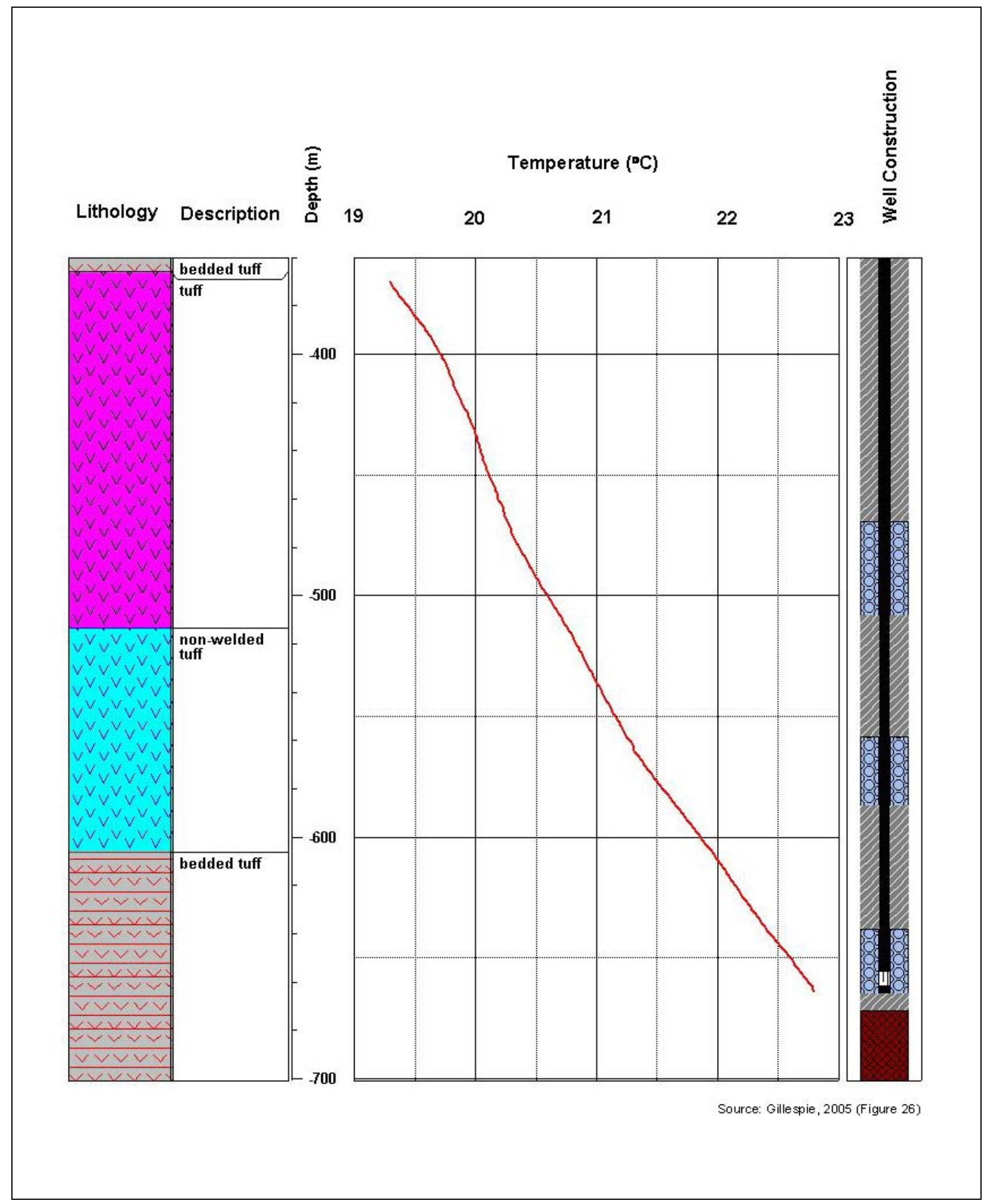

Figure G.1-8

Temperature Profile for Yucca Flat Well UE-3e\#4-1 


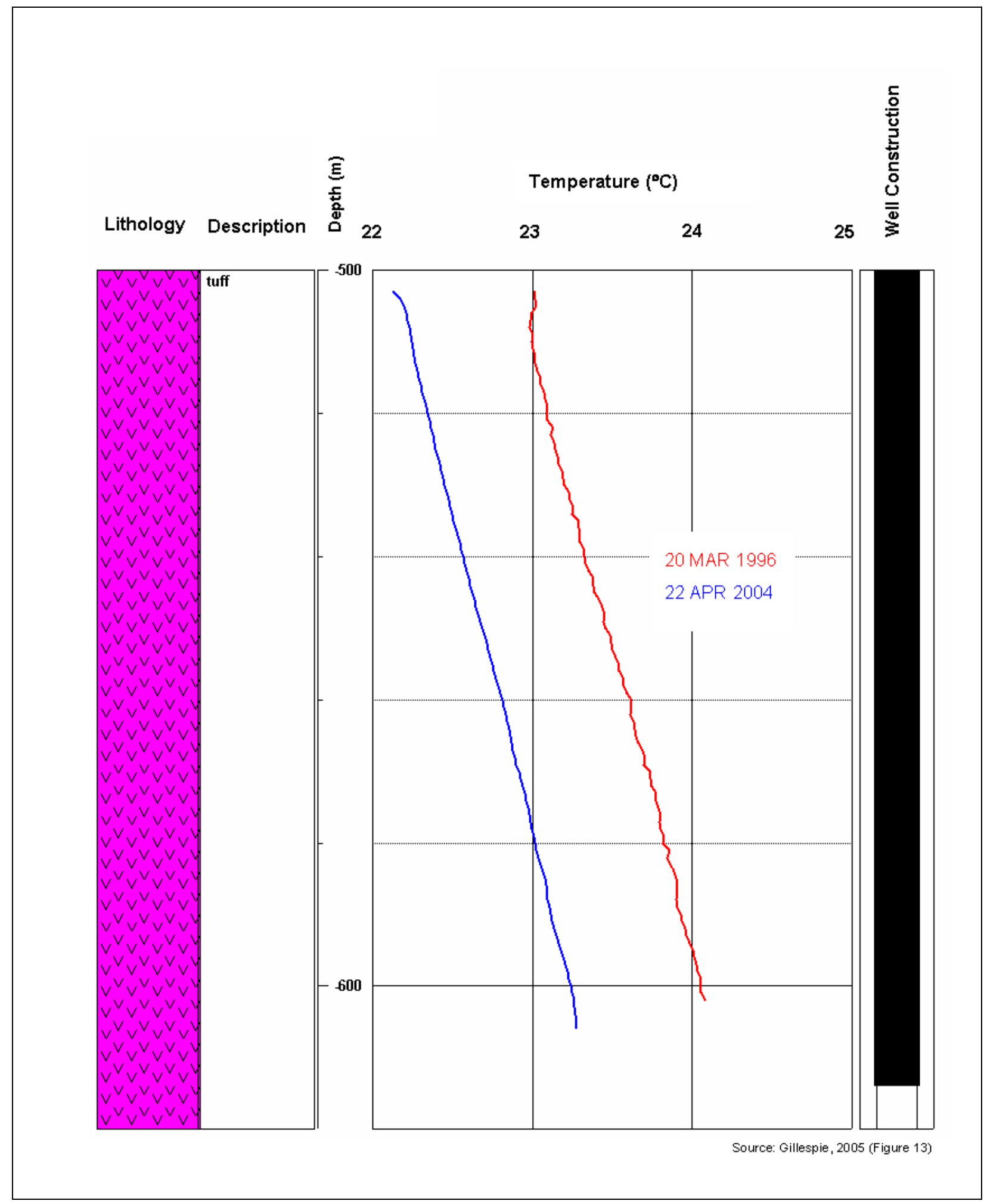

Figure G.1-9

Temperature Profile for Yucca Flat Well TW-7 


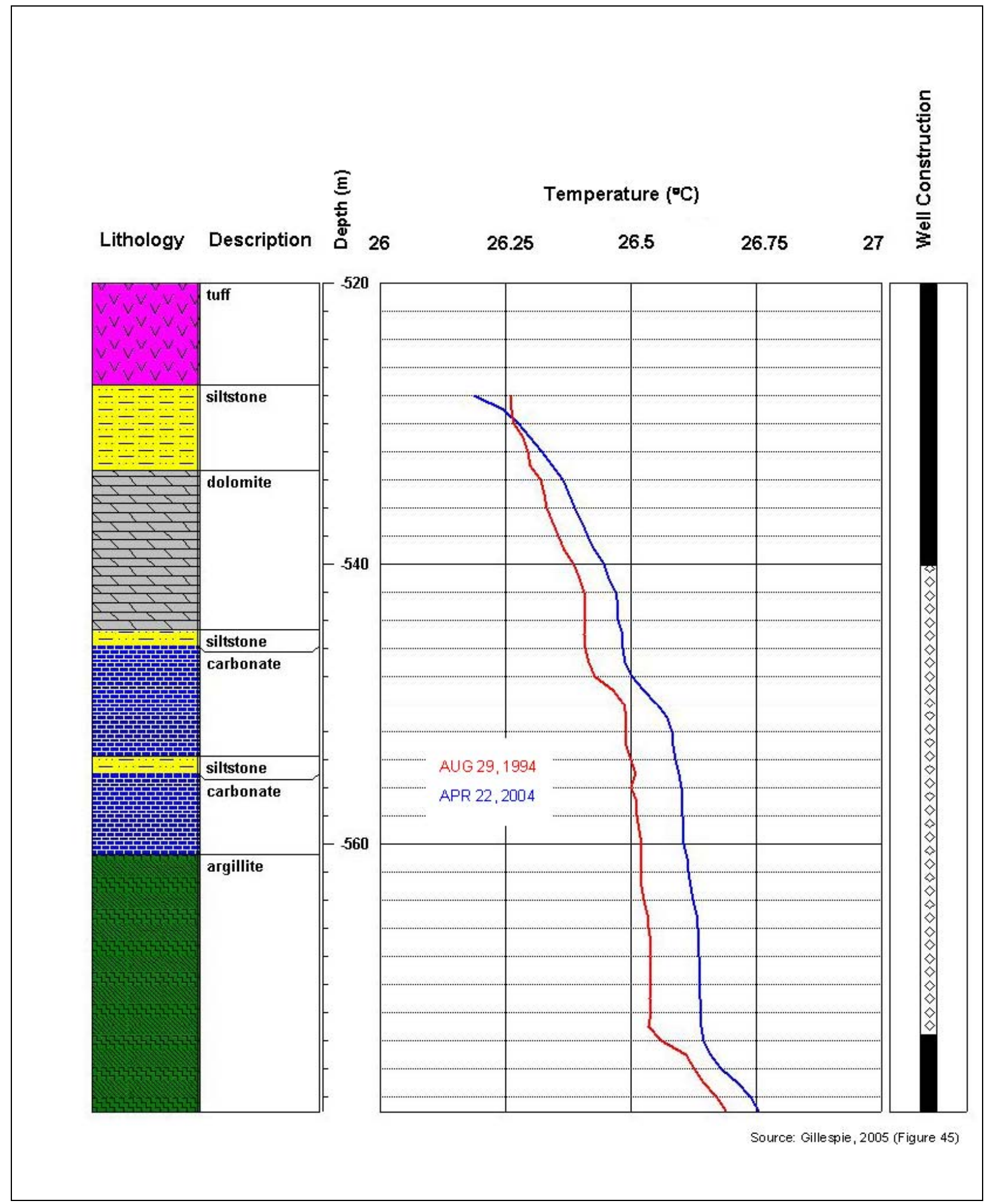

Figure G.1-10

Temperature Profile for Yucca Flat Well TW-D 


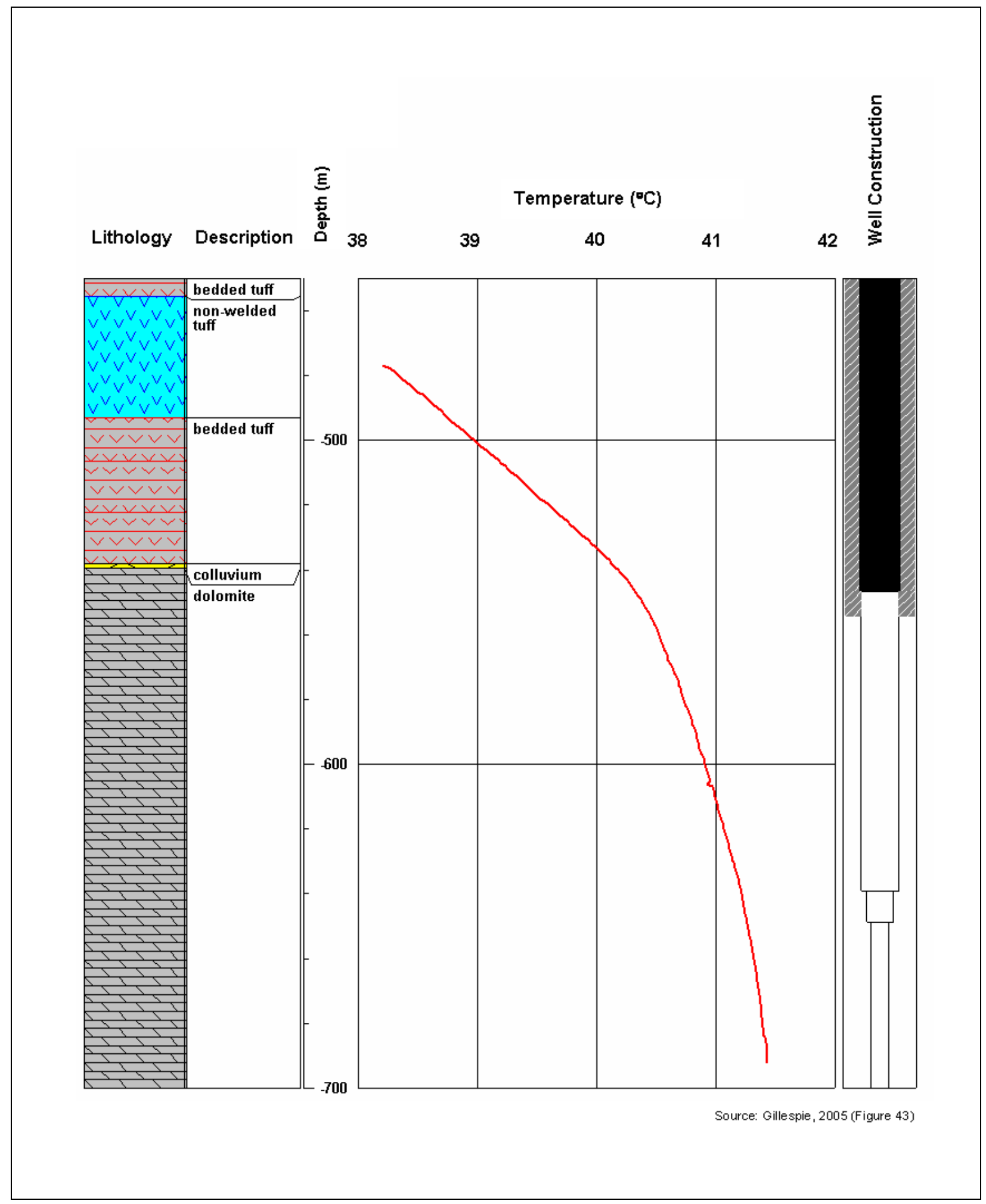

Figure G.1-11

Temperature Profile for Yucca Flat Well ER-6-1 


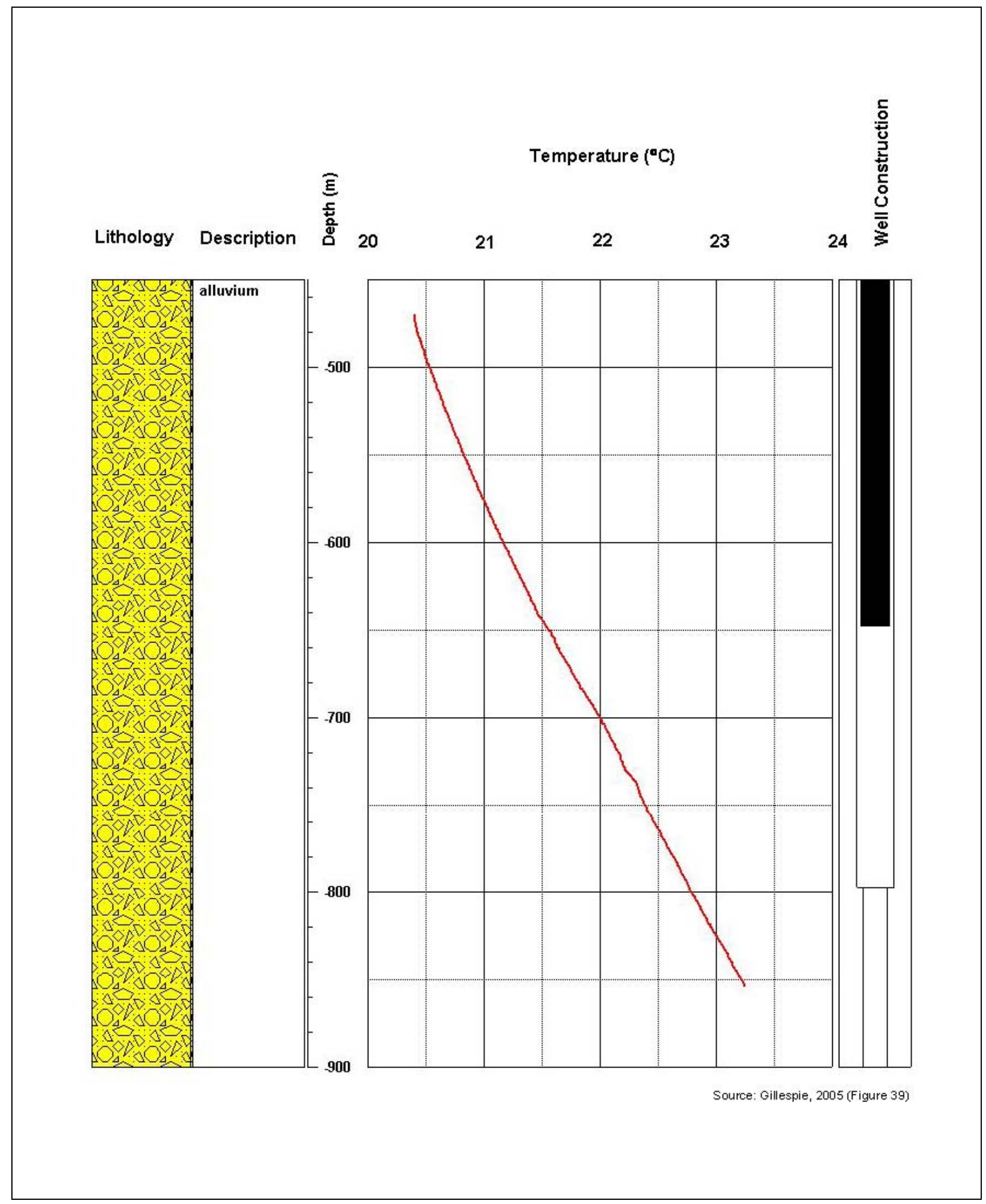

Figure G.1-12

Temperature Profile for Yucca Flat Well UE-6d 


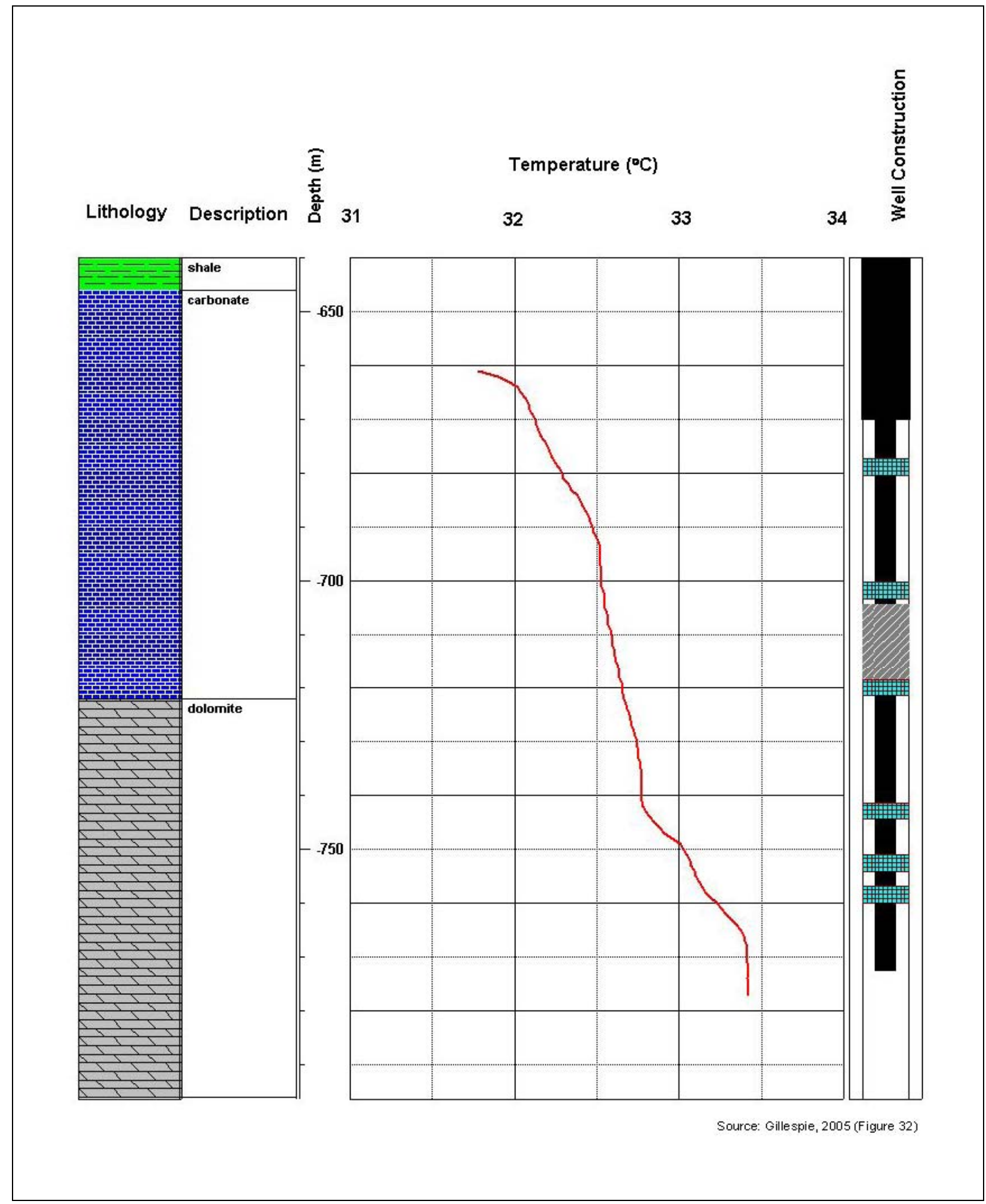

Figure G.1-13

Temperature Profile for Yucca Flat Well UE-10j 


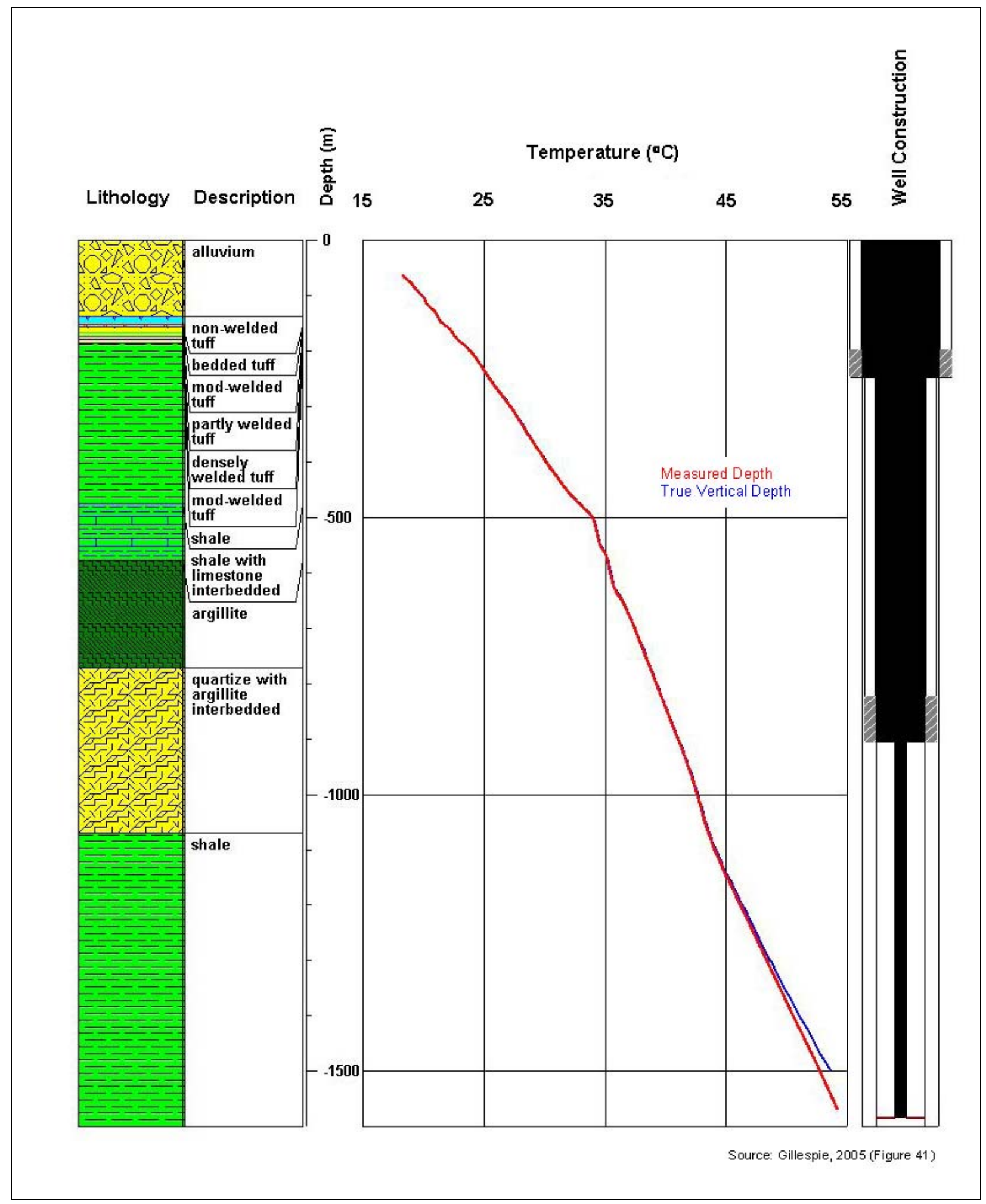

Figure G.1-14

Temperature Profile for Yucca Flat Well ER-12-2 


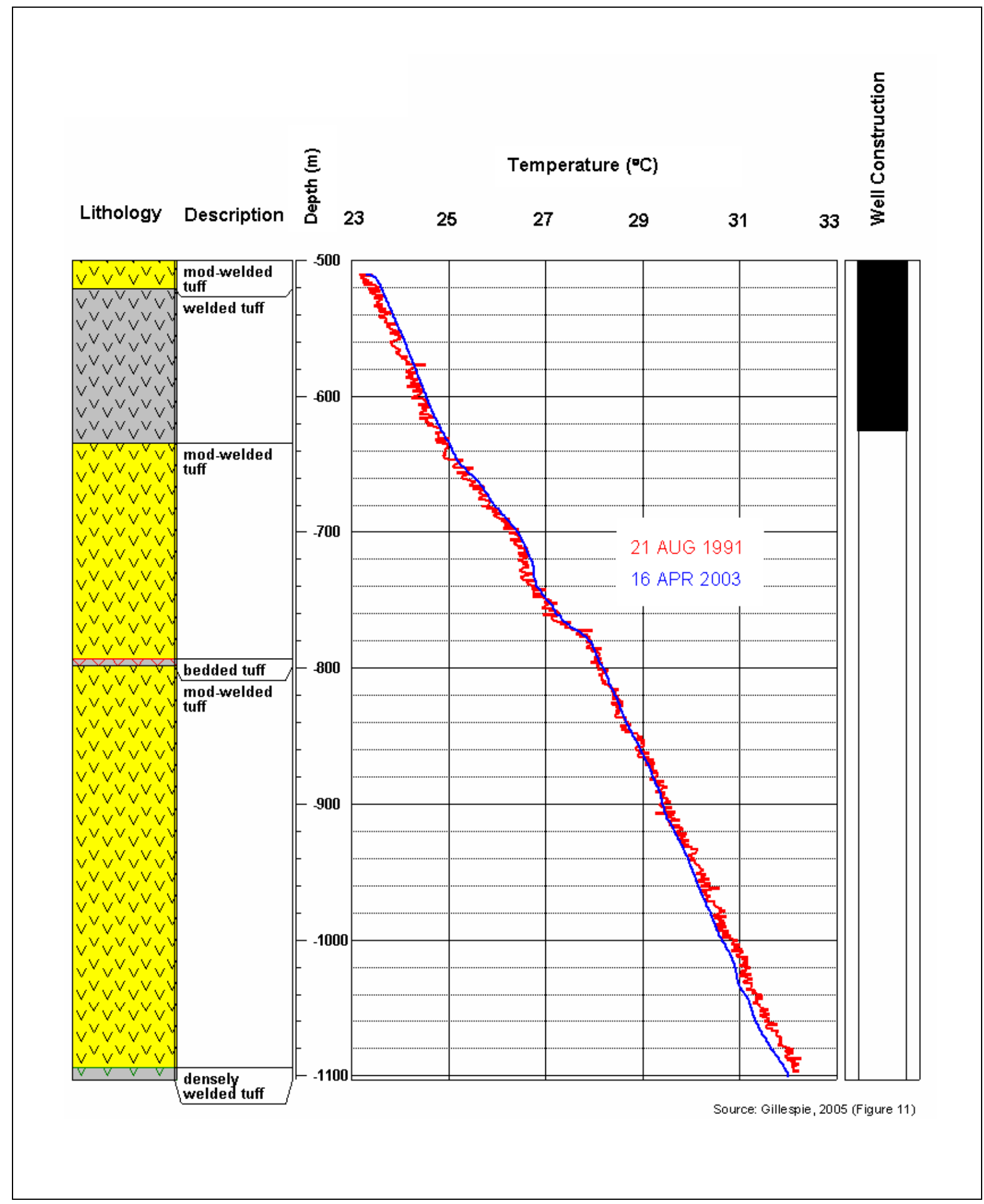

Figure G.1-15

Temperature Profile for Yucca Flat Well UE-14b 


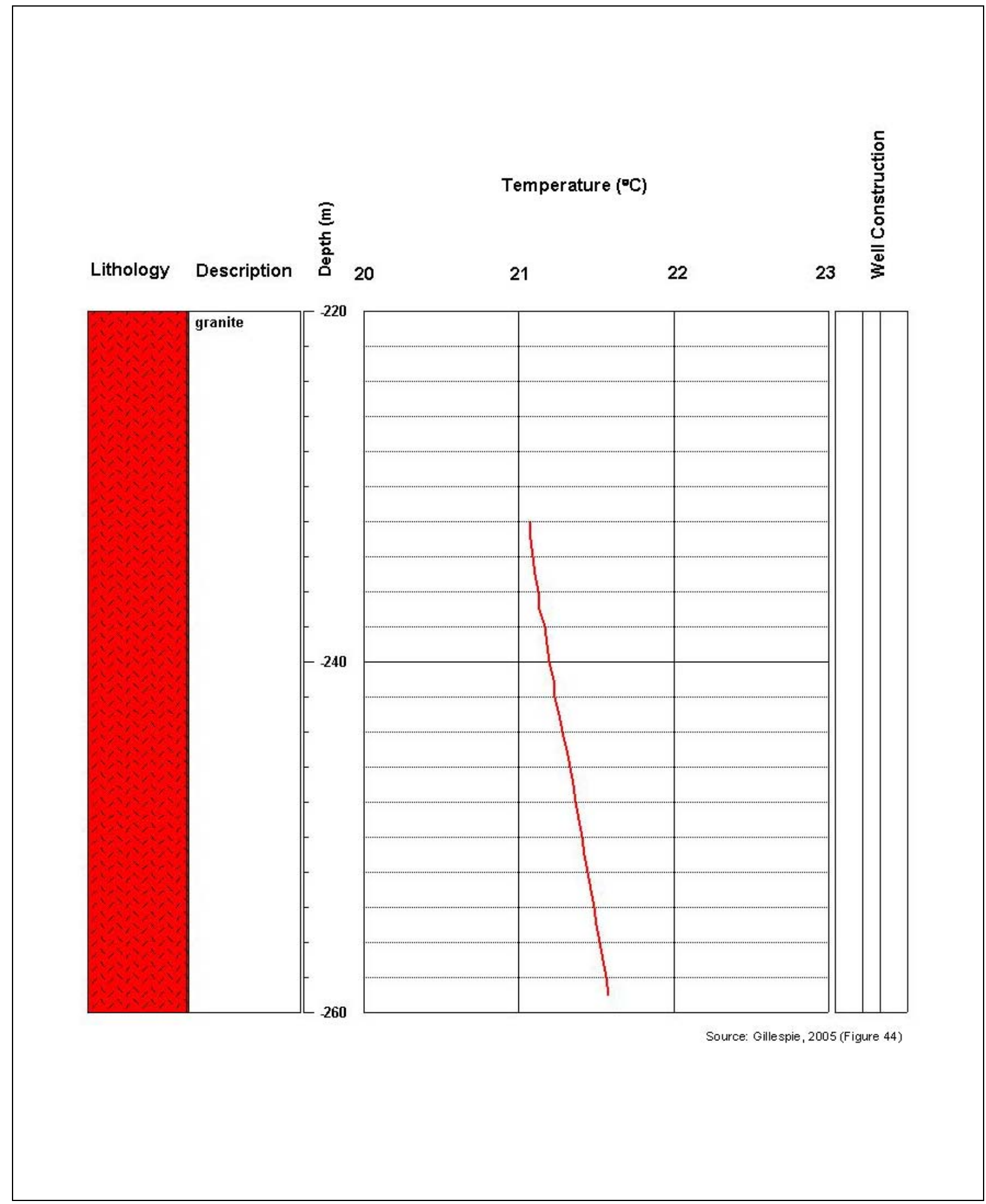

Figure G.1-16

Temperature Profile for Yucca Flat Well U-15k 


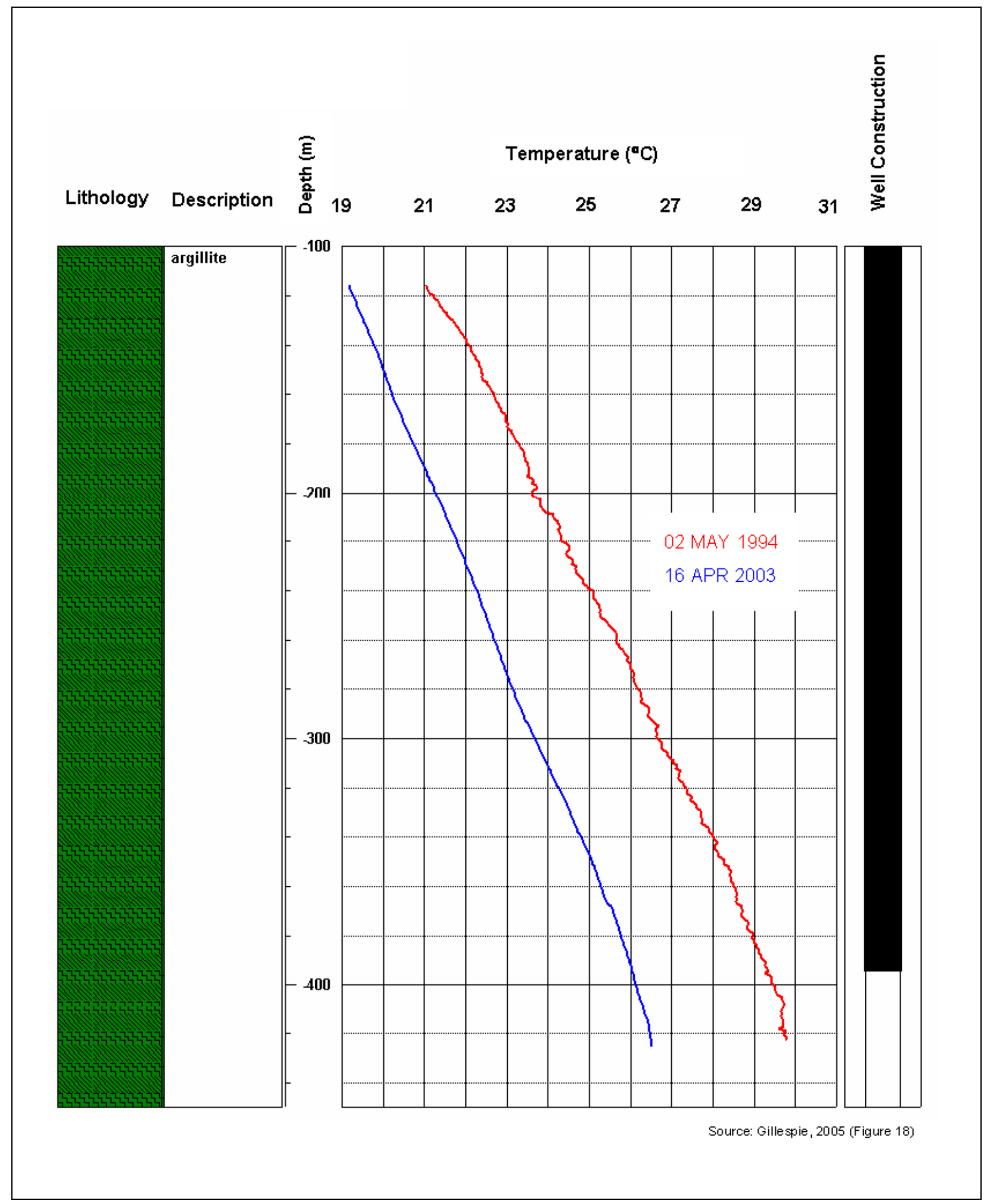

Figure G.1-17

Temperature Profile for Yucca Flat Well UE-16f 


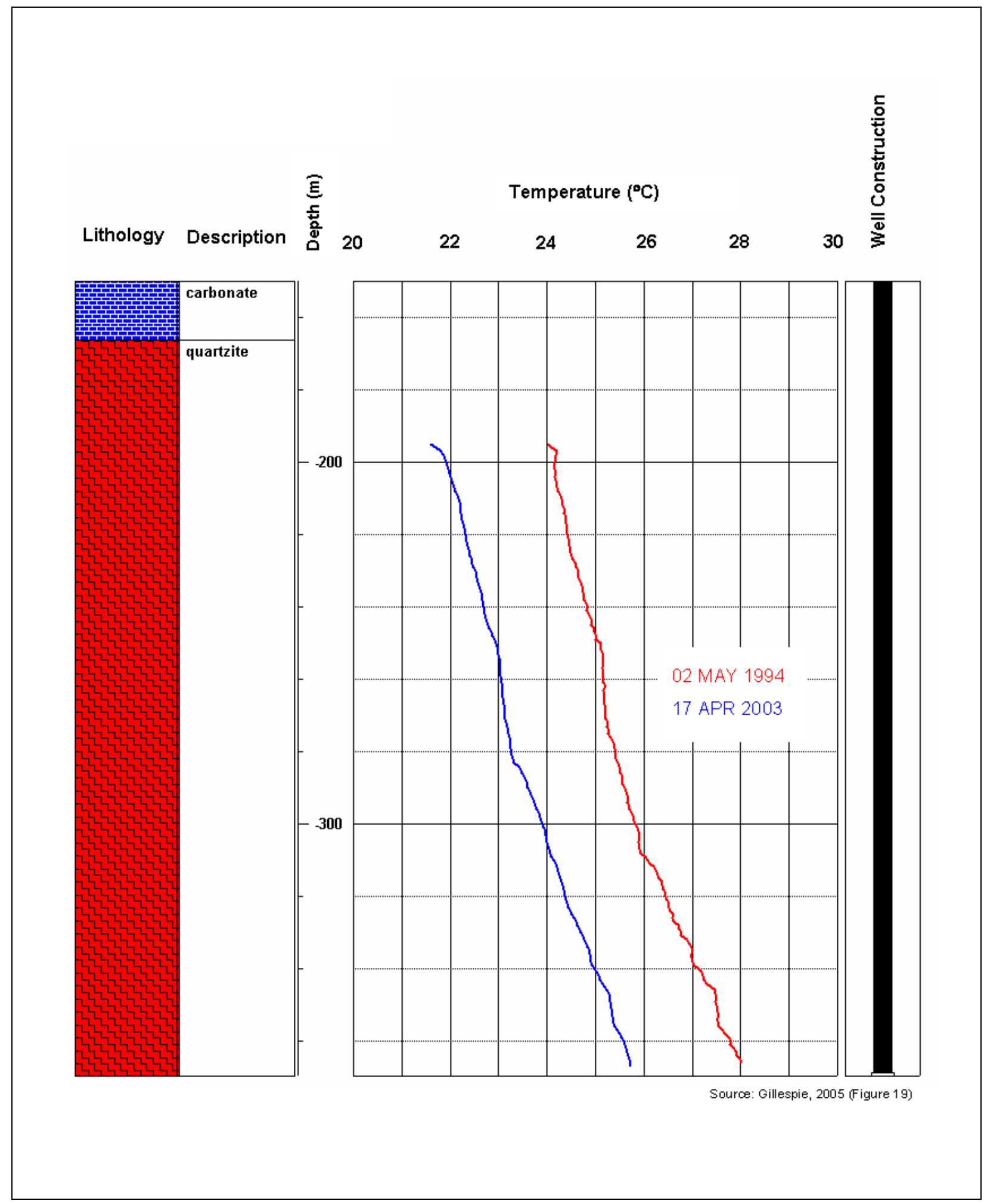

Figure G.1-18

Temperature Profile for Yucca Flat Well UE-17a 


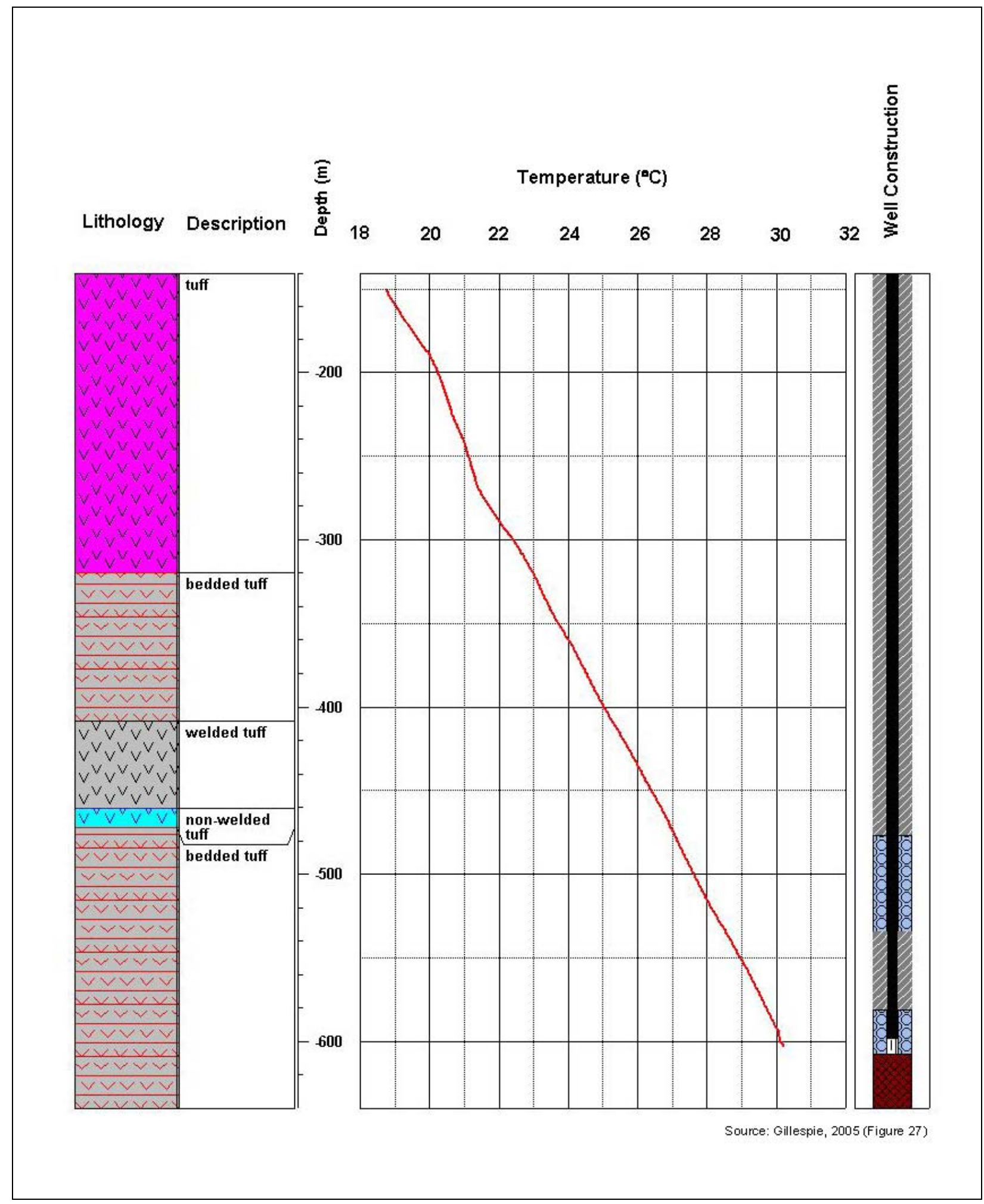

Figure G.1-19

Temperature Profile for Yucca Flat Well UE-4t-1 


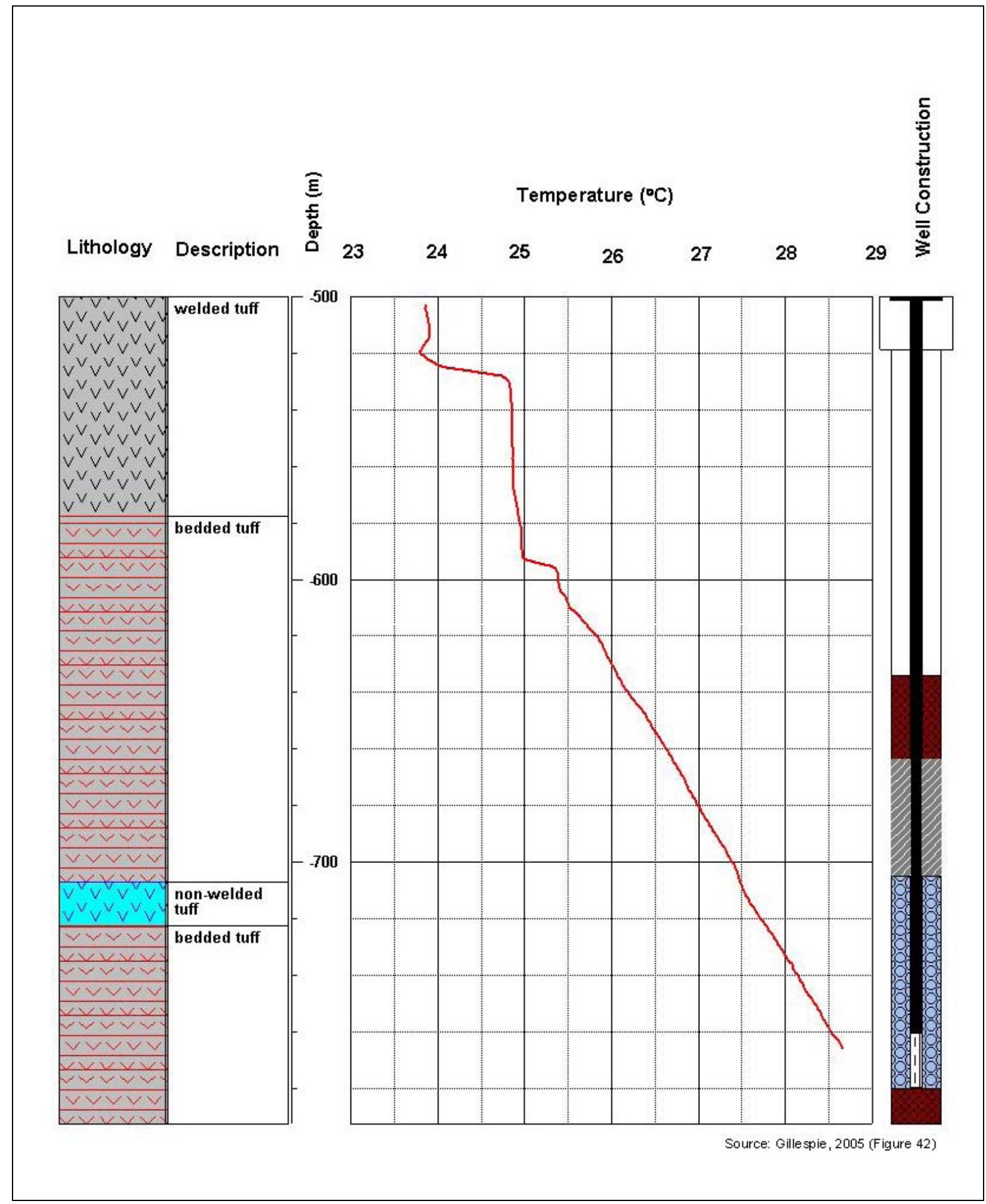

Figure G.1-20

Temperature Profile for Yucca Flat Well ER-2-1 


\section{G.1.2 USGS Temperature Data}

Temperature data from the USGS for the Yucca Flat/Climax Mine area are provided in this section. Table G.1-3 provides a summary of the Yucca Flat/Climax Mine area wells with USGS temperature profile data and includes the well location, date temperature profile was obtained, and depth intervals for the temperature profiles. Figure G.1-21 shows the location of these wells. Table G.1-4 provides a summary of Yucca Flat/Climax Mine area wells with single temperature measurements taken at 5 and $55 \mathrm{ft}$ below the water level in the well and includes the well location, date the temperature measurements were started, and average temperature for all measurements. Figure G.1-22 shows the location of these wells. Table G.1-5 is a list of the USGS temperature profile figures for the Yucca Flat/Climax Mine area (Figures G.1-23 through G.1-53). 
Table G.1-3

Wells with USGS Temperature Logs in the Yucca Flat/Climax Mine Area

\begin{tabular}{|c|c|c|c|c|c|c|}
\hline \multirow{2}{*}{ Well Name } & \multicolumn{2}{|c|}{ Well Location } & \multirow{2}{*}{$\begin{array}{c}\text { Date of } \\
\text { Temperature } \\
\text { Log }\end{array}$} & \multirow{2}{*}{$\begin{array}{l}\text { Organization } \\
\text { Providing } \\
\text { Log }\end{array}$} & \multicolumn{2}{|c|}{$\begin{array}{l}\text { Logged Interval } \\
\text { (m bgs) }\end{array}$} \\
\hline & Easting & Northing & & & Top & Bottom \\
\hline ER- 2-1 main (shallow) & $583,334.5$ & $4,108,978.3$ & $2 / 12 / 2004$ & USGS & 527.2 & 614.7 \\
\hline ER- 2-1 piezometer (deep) & $583,334.5$ & $4,108,978.3$ & $2 / 12 / 2004$ & USGS & 185.8 & 761.0 \\
\hline ER-3-2-2 (middle) & $585,716.4$ & $4,099,227.8$ & $3 / 31 / 2004$ & USGS & 490.8 & 772.1 \\
\hline ER- 6-1 main (3206 ft) & $589,632.7$ & $4,093,418.7$ & $10 / 19 / 2004$ & USGS & 473.1 & 649.8 \\
\hline ER- 6-1-1 & $589,635.8$ & $4,093,403.8$ & $10 / 19 / 2004$ & USGS & 472.9 & 611.6 \\
\hline ER- 6-1-2 main & $589,616.5$ & $4,093,356.9$ & $10 / 19 / 2004$ & USGS & 472.4 & 649.2 \\
\hline ER- 6-1-2 piezometer & $589,616.5$ & $4,093,356.9$ & $11 / 1 / 2004$ & USGS & 450.2 & 477.7 \\
\hline ER- 6-2 & $582,235.7$ & $4,090,745.0$ & $2 / 5 / 2004$ & USGS & 545.4 & 813.6 \\
\hline ER-12-1 (1641-1846 ft) & $572,411.5$ & $4,115,492.7$ & $6 / 24 / 2004$ & USGS & 466.8 & 524.4 \\
\hline ER-12-2 main (lower zone) & $577,902.6$ & $4,114,057.7$ & $6 / 29 / 2004$ & USGS & 63.6 & 370.9 \\
\hline ER-12-2 main (upper zone) & $577,902.6$ & $4,114,057.7$ & $6 / 29 / 2004$ & USGS & 57.6 & $1,213.7$ \\
\hline ER-12-2 piezometer & $577,902.6$ & $4,114,057.7$ & $6 / 25 / 2004$ & USGS & 126.2 & 141.2 \\
\hline TW- 7 & $585,901.0$ & $4,102,301.1$ & $11 / 2 / 2004$ & USGS & 502.8 & 599.7 \\
\hline TW- B & $587,779.9$ & $4,092,815.9$ & $11 / 1 / 2004$ & USGS & 459.5 & 502.2 \\
\hline TW- D & $582,223.9$ & $4,103,327.0$ & $11 / 2 / 2004$ & USGS & 527.0 & 575.7 \\
\hline$U-3 c n 5$ & $586,921.7$ & $4,101,714.5$ & $11 / 2 / 2004$ & USGS & 495.6 & 705.9 \\
\hline$U-3 m i$ & $589,703.9$ & $4,095,777.4$ & $11 / 1 / 2004$ & USGS & 476.4 & 500.8 \\
\hline U -15k Test Hole & $583,644.2$ & $4,120,544.4$ & $2 / 1 / 2005$ & USGS & 228.3 & 258.8 \\
\hline UE- $1 \mathrm{~h}$ & $582,983.1$ & $4,095,223.5$ & $10 / 14 / 2004$ & USGS & 475.4 & 971.6 \\
\hline UE- $1 q(2600 \mathrm{ft})$ & $583,722.7$ & $4,101,777.7$ & $2 / 2 / 2004$ & USGS & 506.2 & 791.2 \\
\hline UE- 3e 4-2 (1919 ft) & $584,481.0$ & $4,102,812.6$ & $11 / 1 / 2004$ & USGS & 436.0 & 573.8 \\
\hline UE- 4t 1 (1906-2010 ft) & $584,576.0$ & $4,106,066.1$ & $3 / 29 / 2004$ & USGS & 153.9 & 598.3 \\
\hline UE- 4t 2 (1564-1754 ft) & $584,576.0$ & $4,106,066.1$ & $3 / 29 / 2004$ & USGS & 365.9 & 507.6 \\
\hline UE- 6d & $583,751.3$ & $4,093,397.3$ & $10 / 18 / 2004$ & USGS & 463.0 & $1,004.0$ \\
\hline UE- $6 e$ (2090-2230 ft) & $587,012.5$ & $4,093,408.8$ & $10 / 18 / 2004$ & USGS & 461.5 & 624.9 \\
\hline UE-10j (2232-2297 ft) & $581,526.6$ & $4,115,644.9$ & $3 / 29 / 2004$ & USGS & 659.3 & 769.9 \\
\hline UE-14b & $575,427.2$ & $4,087,304.1$ & $2 / 2 / 2005$ & USGS & 509.5 & $1,113.0$ \\
\hline UE-16f (1479 ft) & $574,999.7$ & $4,098,960.0$ & $2 / 7 / 2005$ & USGS & 113.1 & 420.3 \\
\hline UE-17a & $574,116.2$ & $4,103,156.8$ & $10 / 13 / 2004$ & USGS & 193.0 & 362.2 \\
\hline WW- $2(3422 \mathrm{ft})$ & $581,005.7$ & $4,113,499.6$ & $6 / 25 / 2004$ & USGS & 627.4 & 857.9 \\
\hline WW- $3(1800 \mathrm{ft})$ & $583,827.5$ & $4,094,554.7$ & $2 / 2 / 2004$ & USGS & 468.4 & 544.0 \\
\hline
\end{tabular}




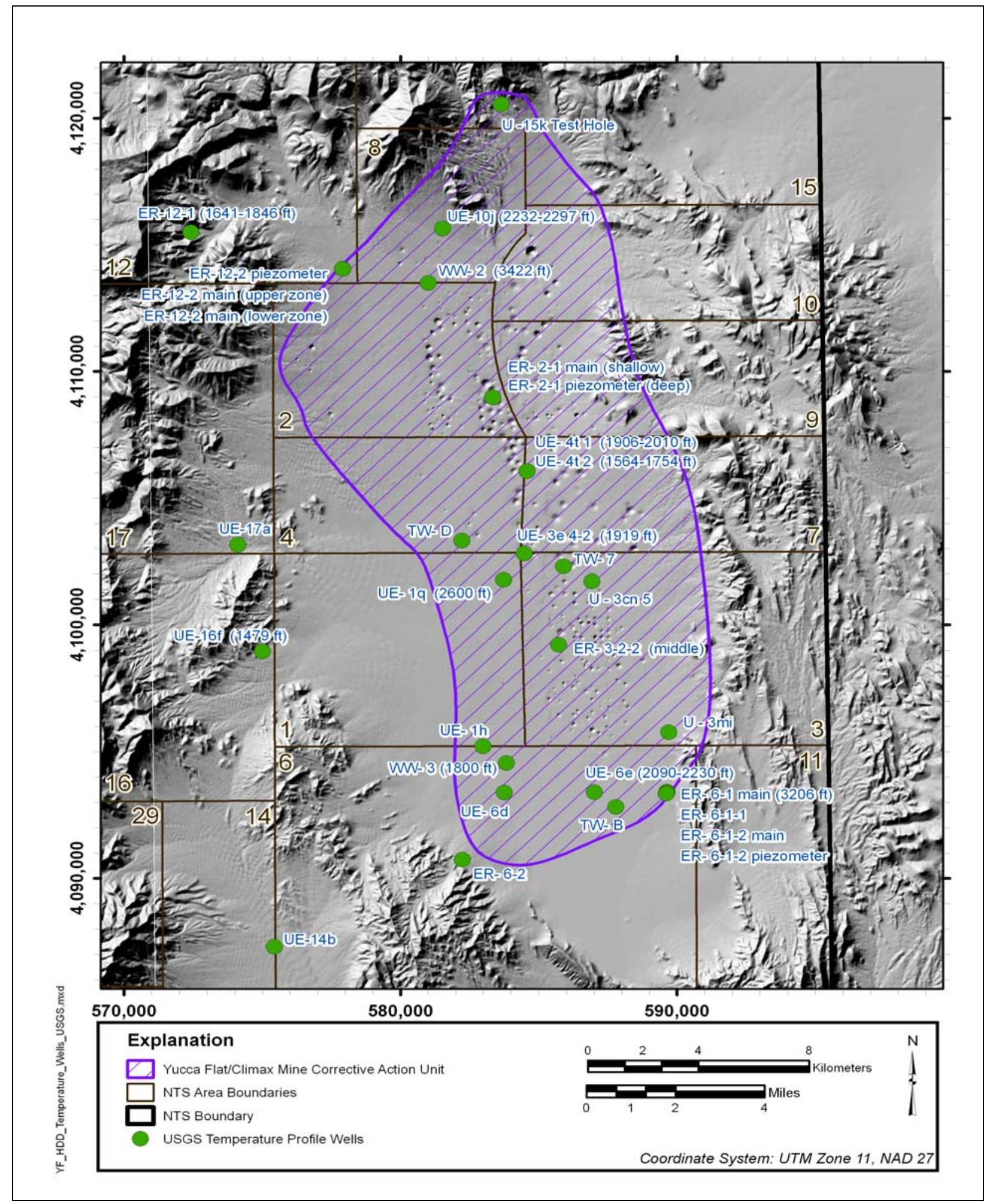

Figure G.1-21

Location of Wells in the Yucca Flat/Climax Mine Area with USGS Temperature Log Profiles 
Table G.1-4

Yucca Flat/Climax Mine Area Wells with USGS Temperature Measurements made at 5 and 55 feet below the Static Water Level

(Page 1 of 2)

\begin{tabular}{|c|c|c|c|c|c|c|c|}
\hline \multirow{2}{*}{ Well Name } & \multicolumn{2}{|c|}{ Well Location } & \multirow{2}{*}{$\begin{array}{c}\text { Temperature } \\
\text { Monitoring } \\
\text { Start Date }\end{array}$} & \multicolumn{2}{|c|}{ Monitoring Interval } & \multirow{2}{*}{$\begin{array}{c}\text { Primary } \\
\text { HSUa }^{\circ}\end{array}$} & \multirow{2}{*}{$\begin{array}{c}\text { Average } \\
\text { Temperature }^{\mathrm{b}} \\
\left({ }^{\circ} \mathrm{C}\right)\end{array}$} \\
\hline & Easting & Northing & & $\begin{array}{l}\text { Uppermost } \\
\text { (m, bgs) }\end{array}$ & $\begin{array}{l}\text { Lowermost } \\
\text { (m, bgs) }\end{array}$ & & \\
\hline UE-1q (2600 ft) & $583,722.7$ & $\overline{4} 4,101,777.7$ & $3 / 6 / 2000$ & 749.7 & 792.7 & LCA & 23.8 \\
\hline UE- 1a & $578,394.6$ & $4,100,387.8$ & $2 / 22 / 2000$ & 23.8 & 291.8 & AA & 22.6 \\
\hline UE- 1-b & $579,004.2$ & $4,100,390.1$ & $2 / 22 / 2000$ & 23.2 & 382.3 & UCCU & 23.6 \\
\hline UE- 1c & $580,223.0$ & $4,100,394.2$ & $2 / 22 / 2000$ & 22.6 & 573.2 & LCA & 26.1 \\
\hline UE- $1 \mathrm{~h}$ & $582,983.1$ & $4,095,223.5$ & $2 / 24 / 2000$ & 650.6 & 1023.8 & LCA & 22.2 \\
\hline UE- 1L (recompleted) & $576,566.8$ & $4,100,381.8$ & $2 / 22 / 2000$ & 218.3 & 696.3 & UCCU & 21.3 \\
\hline $\mathrm{U}-2 \mathrm{gk}$ & $582,510.4$ & $4,108,645.6$ & $2 / 28 / 2000$ & 35.4 & 551.5 & AA & 27.8 \\
\hline WW- $2(3422 \mathrm{ft})$ & $581,005.7$ & $4,113,499.6$ & $3 / 9 / 2000$ & 823.2 & 1040.2 & LCA & 27.4 \\
\hline ER- 3-1-2 (shallow) & $594,658.3$ & $4,097,339.0$ & $3 / 23 / 2000$ & 673.2 & 704.3 & LCA & 49.0 \\
\hline ER- 3-2-2 (middle) & $585,716.4$ & $4,099,227.8$ & $3 / 6 / 2000$ & 789.0 & 803.7 & AA & 24.4 \\
\hline UE- 3e 4-1 (2181 ft) & $584,481.0$ & $4,102,812.6$ & $2 / 28 / 2000$ & 638.4 & 668.3 & LTCU & 19.3 \\
\hline UE- 3e 4-2 (1919 ft) & $584,481.0$ & $4,102,812.6$ & $2 / 28 / 2000$ & 558.5 & 587.2 & LTCU & 20.1 \\
\hline UE- 3e 4-3 (1661 ft) & $584,481.0$ & $4,102,812.6$ & $2 / 28 / 2000$ & 469.5 & 508.5 & TM-LVTA & 20.4 \\
\hline$U-3 \operatorname{cn} 5$ & $586,921.7$ & $4,101,714.5$ & $2 / 28 / 2000$ & 863.4 & 923.8 & LCA & 33.5 \\
\hline$U-3 m i$ & $589,703.9$ & $4,095,777.4$ & $2 / 17 / 2000$ & 113.4 & 547.0 & ATCU & 41.4 \\
\hline WW- A (1870 ft) & $585,713.5$ & $4,099,194.2$ & $3 / 9 / 2000$ & 474.1 & 570.1 & AA & 24.3 \\
\hline TW- 7 & $585,901.0$ & $4,102,301.1$ & $2 / 28 / 2000$ & 0.0 & 692.7 & LTCU & 22.4 \\
\hline UE- 4t 1 (1906-2010 ft) & $584,576.0$ & $4,106,066.1$ & $3 / 6 / 2000$ & 581.1 & 612.8 & LTCU & 18.9 \\
\hline UE- 4t 2 (1564-1754 ft) & $584,576.0$ & $4,106,066.1$ & $3 / 6 / 2000$ & 476.8 & 534.8 & LTCU & 24.1 \\
\hline TW- D & $582,223.9$ & $4,103,327.0$ & $2 / 28 / 2000$ & 518.3 & 594.5 & LCA & 26.4 \\
\hline ER- 6-1 (piezometer) & $589,632.7$ & $4,093,418.7$ & $3 / 7 / 2000$ & 437.5 & 470.1 & OSBCU & 37.0 \\
\hline ER- 6-1 main (3206 ft) & $589,632.7$ & $4,093,418.7$ & $3 / 7 / 2000$ & 554.6 & 977.4 & LCA & 38.3 \\
\hline ER- 6-1-1 & $589,635.8$ & $4,093,403.8$ & $7 / 22 / 2002$ & 559.5 & 625.6 & LCA & 38.2 \\
\hline ER- 6-2 & $582,235.7$ & $4,090,745.0$ & $2 / 17 / 2000$ & 532.3 & 1045.7 & LCA3 & 33.8 \\
\hline UE- 6d & $583,751.3$ & $4,093,397.3$ & $2 / 24 / 2000$ & 647.9 & 1187.8 & PCU & 20.4 \\
\hline
\end{tabular}


Table G.1-4

Yucca Flat/Climax Mine Area Wells with USGS Temperature Measurements made at 5 and 55 feet below the Static Water Level

(Page 2 of 2)

\begin{tabular}{|c|c|c|c|c|c|c|c|}
\hline \multirow[b]{2}{*}{ Well Name } & \multicolumn{2}{|c|}{ Well Location } & \multirow{2}{*}{$\begin{array}{l}\text { Temperature } \\
\text { Monitoring } \\
\text { Start Date }\end{array}$} & \multicolumn{2}{|c|}{ Monitoring Interval } & \multirow{2}{*}{$\begin{array}{l}\text { Primary } \\
\text { HSUa }^{a}\end{array}$} & \multirow{2}{*}{$\begin{array}{c}\text { Average } \\
\text { Temperature } \\
\left({ }^{\circ} \mathrm{C}\right)\end{array}$} \\
\hline & Easting & Northing & & $\begin{array}{l}\text { Uppermost } \\
\text { (m, bgs) }\end{array}$ & $\begin{array}{l}\text { Lowermost } \\
\text { (m, bgs) }\end{array}$ & & \\
\hline UE- 6e (2090-2230 ft) & $587,012.5$ & $4,093,408.8$ & $3 / 7 / 2000$ & 637.2 & 679.9 & TSA & 22.2 \\
\hline TW- B & $587,779.9$ & $4,092,815.9$ & $2 / 24 / 2000$ & 436.6 & 510.7 & TSA & 24.9 \\
\hline WW- 3 (1800 ft) & $583,827.5$ & $4.094,554.7$ & $3 / 9 / 2000$ & 368.6 & 548.8 & AA & 19.6 \\
\hline UE- 7nS & $588,643.5$ & $4,106,091.4$ & $2 / 28 / 2000$ & 520.4 & 672.3 & $\mathrm{LCA}$ & 41.5 \\
\hline U- 7cd & $584,903.0$ & $4,104,066.7$ & $7 / 14 / 2003$ & 35.7 & 495.4 & OSBCU & 23.1 \\
\hline UE-10j (2232-2297 ft) & $581,526.6$ & $4115,644.9$ & $3 / 13 / 2000$ & 680.5 & 700.3 & LCA & 32.0 \\
\hline ER-12-1 (1641-1846 ft) & $572,411.5$ & $4,115,492.7$ & $3 / 13 / 2000$ & 500.3 & 562.8 & UCCU/LCA3 & 23.0 \\
\hline UE-14b & $575,427.2$ & $4,087,304.1$ & $7 / 6 / 2000$ & 625.3 & 1122.0 & TSA & 23.8 \\
\hline U -15k Test Hole & $583,644.2$ & $4,120,544.4$ & $4 / 25 / 2000$ & 123.2 & 261.3 & MGCU & 21.3 \\
\hline UE-16f (1479 ft) & $574,999.7$ & $4,098,960.0$ & $2 / 22 / 2000$ & 394.2 & 450.9 & UCCU & 19.5 \\
\hline UE-17a & $574,116.2$ & $4,103,156.8$ & $2 / 22 / 2000$ & 227.1 & 370.1 & UCCU & 22.2 \\
\hline UE-2ce & $576,804.1$ & $4,110,773.3$ & $2 / 22 / 2000$ & 419.8 & 503.0 & LCA3 & 32.9 \\
\hline ER- 7-1 & $589,315.1$ & $4,103,275.4$ & $6 / 17 / 2003$ & 541.2 & 762.2 & LCA & 45.5 \\
\hline $\begin{array}{c}\text { ER-12-2 main (upper } \\
\text { zone) }\end{array}$ & $577,902.6$ & $4,114,057.7$ & $6 / 24 / 2003$ & 903.7 & 1586.3 & UCCU & 19.2 \\
\hline $\begin{array}{c}\text { ER-12-2 main (lower } \\
\text { zone) }\end{array}$ & $577,902.6$ & $4,114,057.7$ & $6 / 24 / 2003$ & 1586.3 & 2098.5 & UCCU & 19.6 \\
\hline ER- 6-1-2 (piezometer) & $589,616.5$ & $4,093,356.9$ & $6 / 24 / 2003$ & 36.6 & 483.8 & TSA & 37.9 \\
\hline ER- 6-1-2 (main) & $589,616.5$ & $4,093,356.9$ & $6 / 24 / 2003$ & 541.2 & 975.6 & LCA & 38.3 \\
\hline ER- 2-1 main (shallow) & $583,334.5$ & $4,108,978.3$ & $6 / 16 / 2003$ & 500.6 & 663.7 & TCU & 25.0 \\
\hline $\begin{array}{c}\text { ER- 2-1 piezometer } \\
\text { (deep) }\end{array}$ & $583,334.5$ & $4,108,978.3$ & $6 / 16 / 2003$ & 705.2 & 792.7 & LTCU & 19.2 \\
\hline
\end{tabular}

aprimary HSU is the HSU that comprises the largest section of the monitoring interval.

${ }^{\text {b} A v e r a g e ~ t e m p e r a t u r e ~ o f ~ a l l ~ m e a s u r e m e n t s ~ m a d e ~ a t ~} 5$ and $55 \mathrm{ft}$ below the surface of the water. 


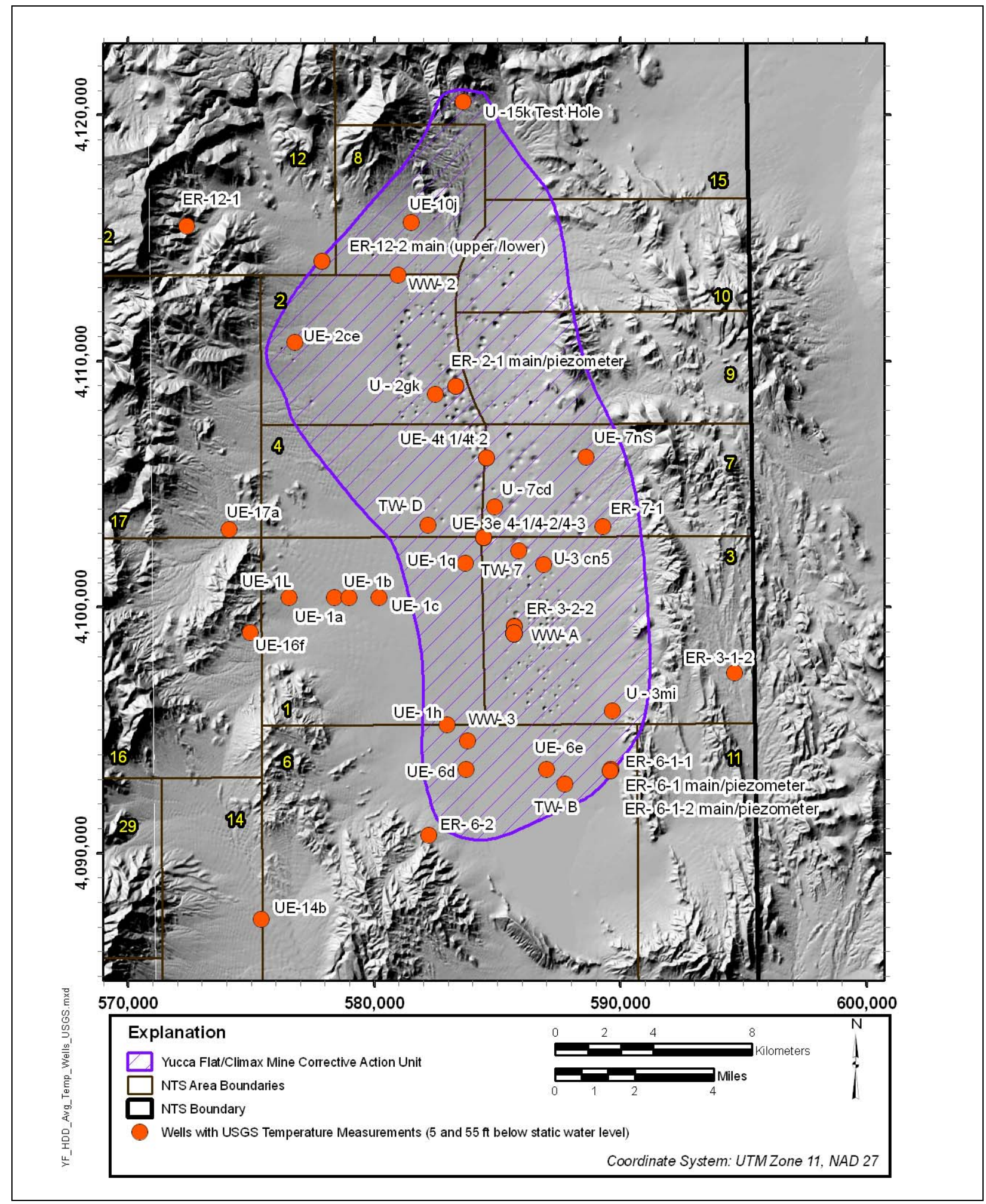

Figure G.1-22

Location of Wells in the Yucca Flat/Climax Mine Area with USGS Temperature Measurements in the Upper Part of the Water Column (5 and 55 feet below static water level) 
Table G.1-5

\section{List of USGS Temperature Profile Figures for the Yucca Flat/Climax Mine Area}

\begin{tabular}{|c|c|}
\hline Figure Number & Well Identifier \\
\hline G.1-23 & ER- 2-1 main (shallow) \\
\hline G.1-24 & ER- 2-1 piezometer (deep) \\
\hline G.1-25 & ER- 3-2-2 (middle) \\
\hline G.1-26 & ER- $6-1$ main $(3,206 \mathrm{ft})$ \\
\hline G.1-27 & ER- 6-1-1 \\
\hline G.1-28 & ER- 6-1-2 main \\
\hline G.1-29 & ER- 6-1-2 piezometer \\
\hline G.1-30 & ER- 6-2 \\
\hline G.1-31 & ER-12-1 (1,641-1,846 ft) \\
\hline G.1-32 & ER-12-2 main (lower zone) \\
\hline G.1-33 & ER-12-2 main (upper zone) \\
\hline G.1-34 & ER-12-2 piezometer \\
\hline G.1-35 & TW- 7 \\
\hline G.1-36 & TW- B \\
\hline G.1-37 & TW- D \\
\hline G.1-38 & $U-3 \operatorname{cn} 5$ \\
\hline G.1-39 & $U-3 m i$ \\
\hline G.1-40 & U -15k Test Hole \\
\hline G.1-41 & UE- $1 \mathrm{~h}$ \\
\hline G.1-42 & UE- 1q (2600 ft) \\
\hline G.1-43 & UE- 3e 4-2 (1919 ft) \\
\hline G.1-44 & UE- 4t 1 (1906-2010 ft) \\
\hline G.1-45 & UE- 4t 2 (1564-1754 ft) \\
\hline G.1-46 & UE- 6d \\
\hline G.1-47 & UE- $6 e$ (2090-2230 ft) \\
\hline G.1-48 & UE-10j (2232-2297 ft) \\
\hline G.1-49 & UE-14b \\
\hline G.1-50 & UE- $16 f(1479 \mathrm{ft})$ \\
\hline G.1-51 & UE- 17a \\
\hline G.1-52 & WW- 2 (3422 ft) \\
\hline G.1-53 & WW- 3 (1800 ft) \\
\hline
\end{tabular}




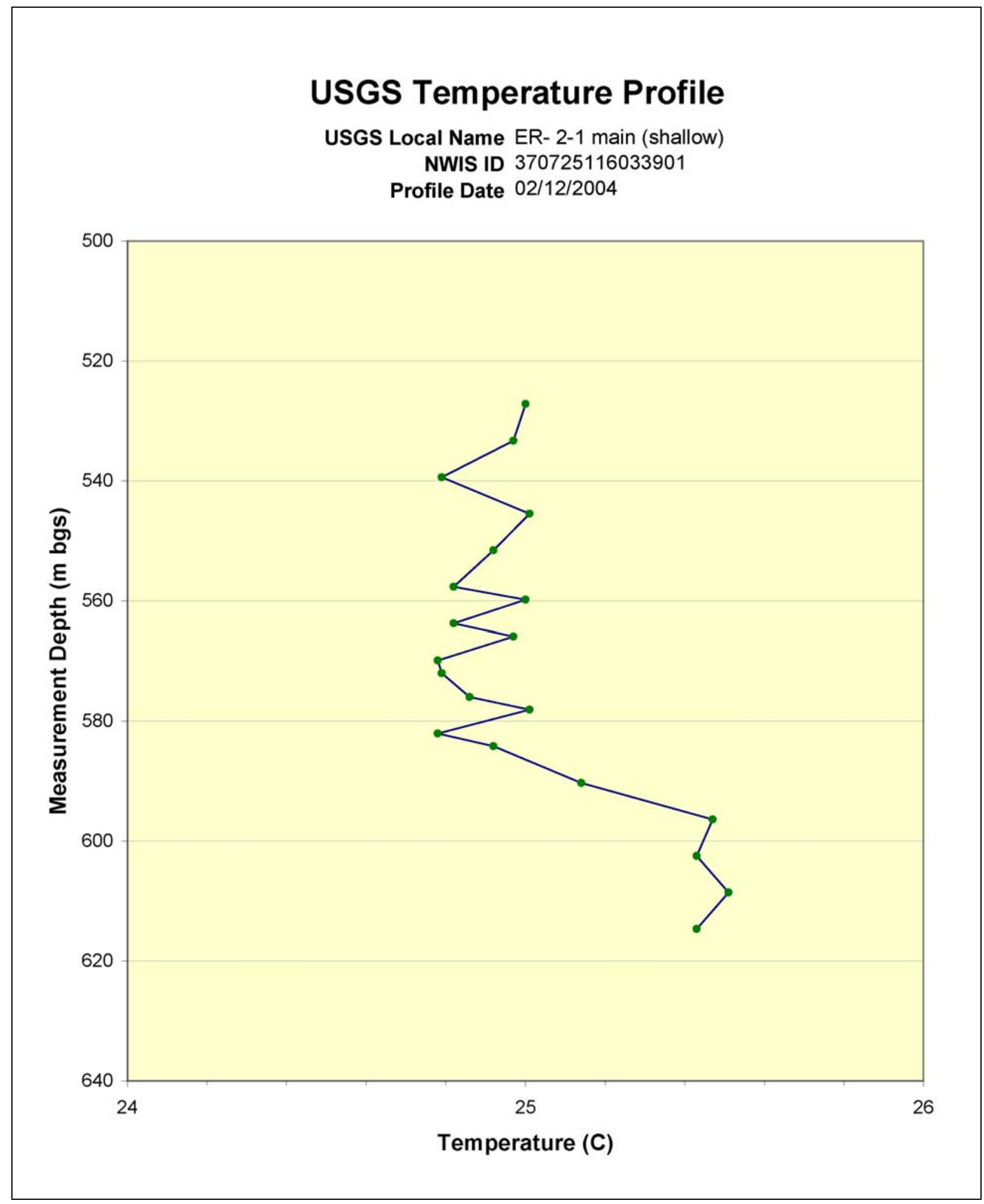

Figure G.1-23

USGS Temperature Profile for Yucca Flat Well ER- 2-1 main (shallow) 


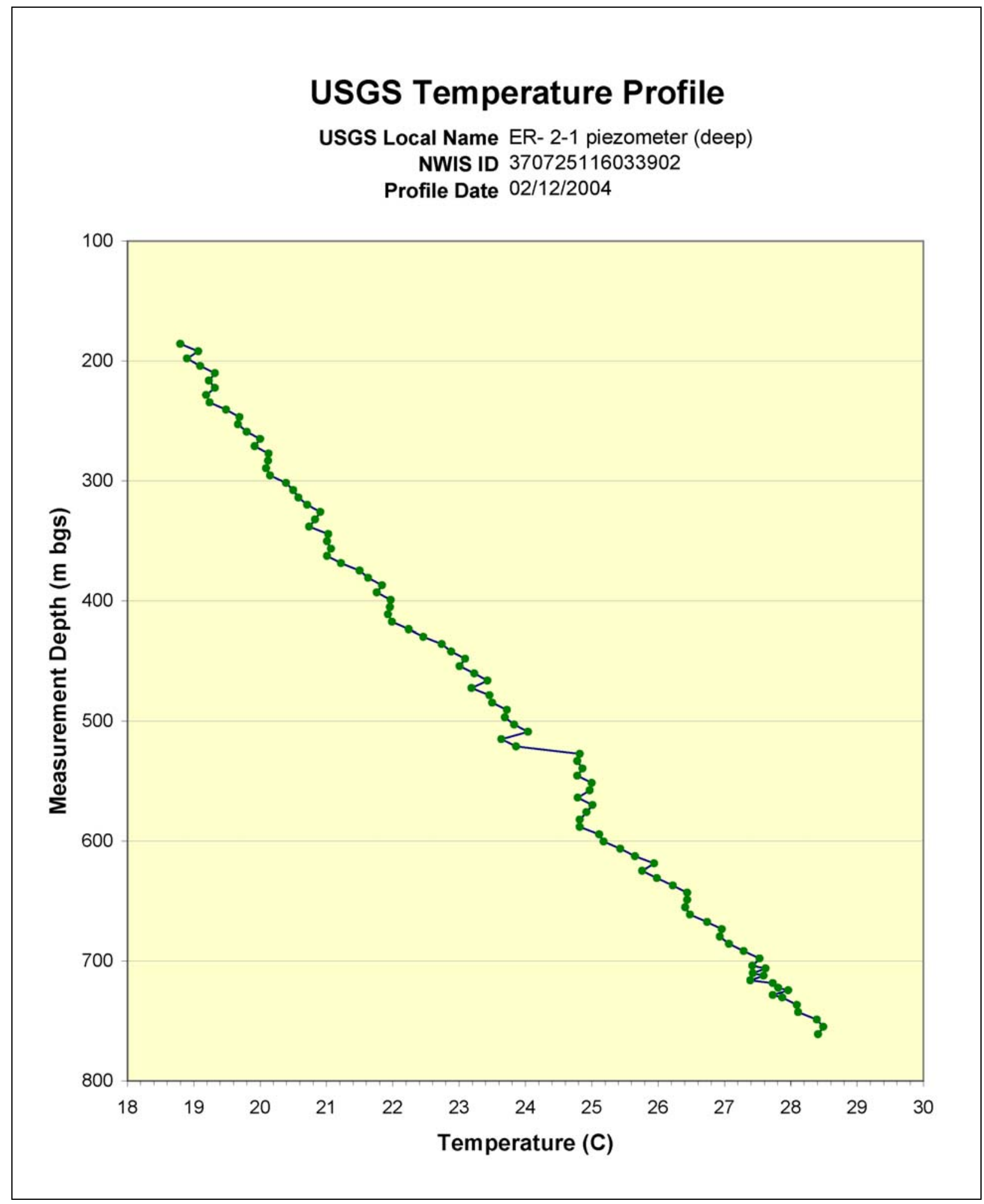

Figure G.1-24

USGS Temperature Profile for Yucca Flat Well ER- 2-1 piezometer (deep) 


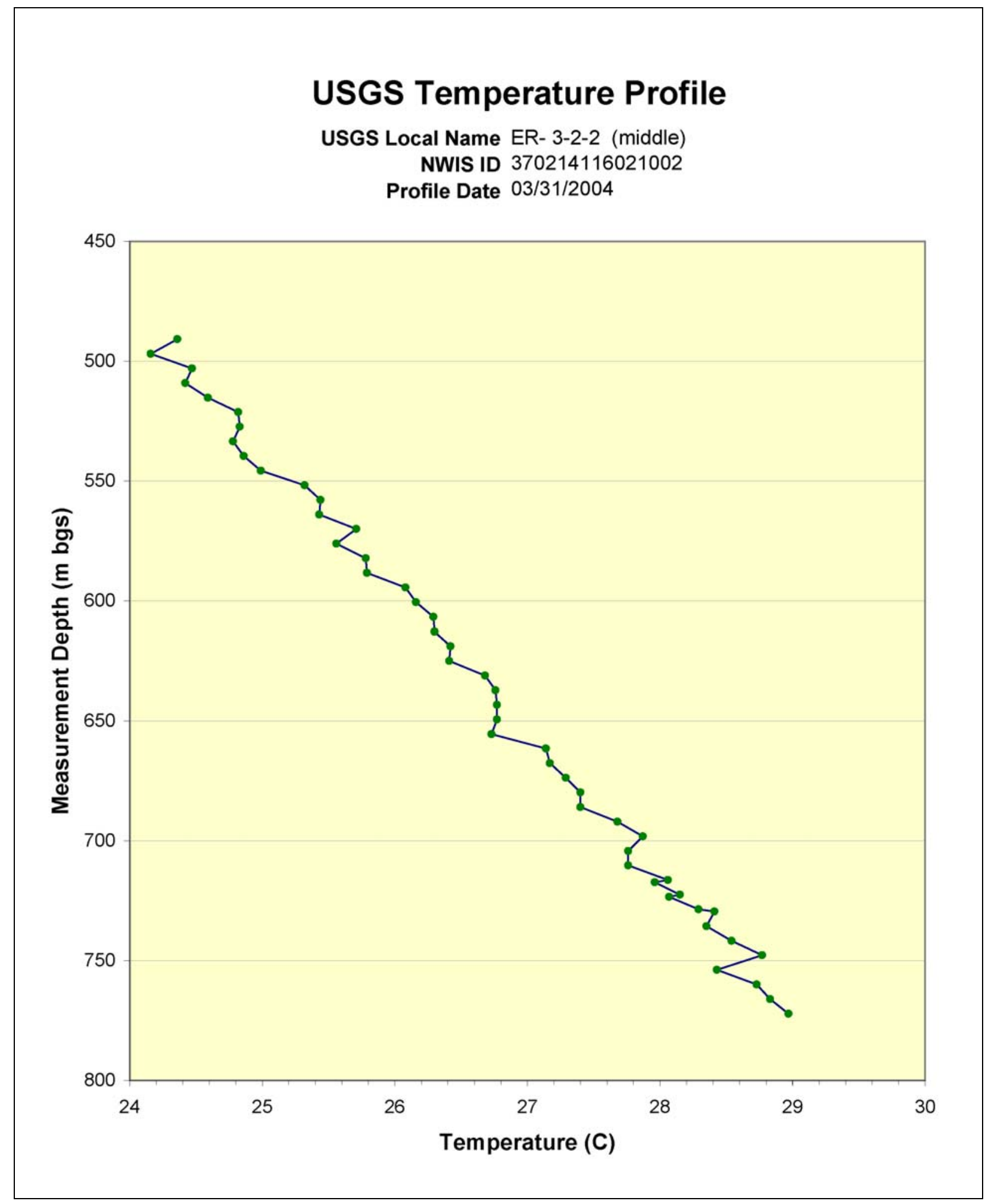

Figure G.1-25

USGS Temperature Profile for Yucca Flat Well ER- 3-2-2 (middle) 


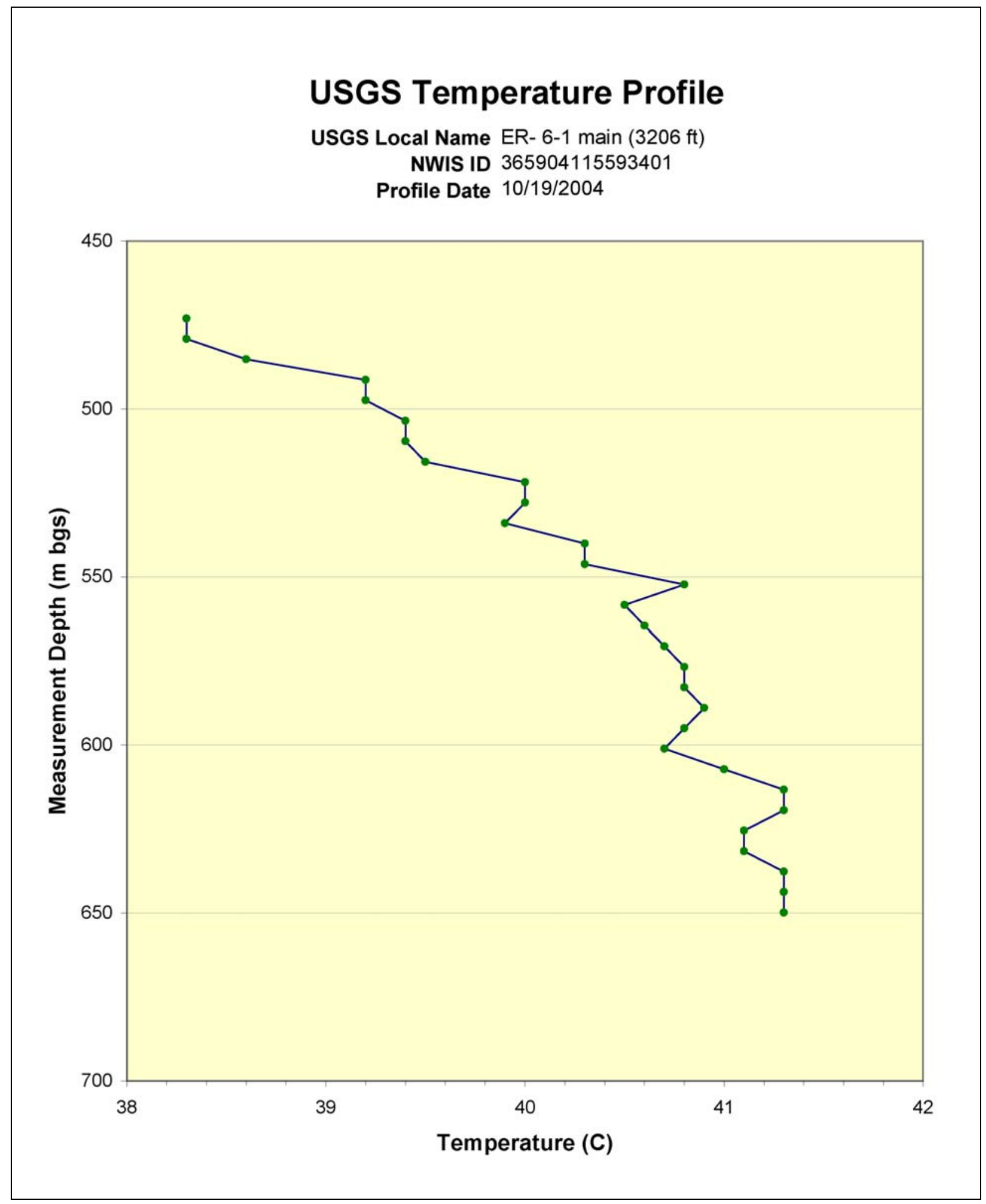

Figure G.1-26

USGS Temperature Profile for Yucca Flat Well ER- 6-1 main (3206 ft) 


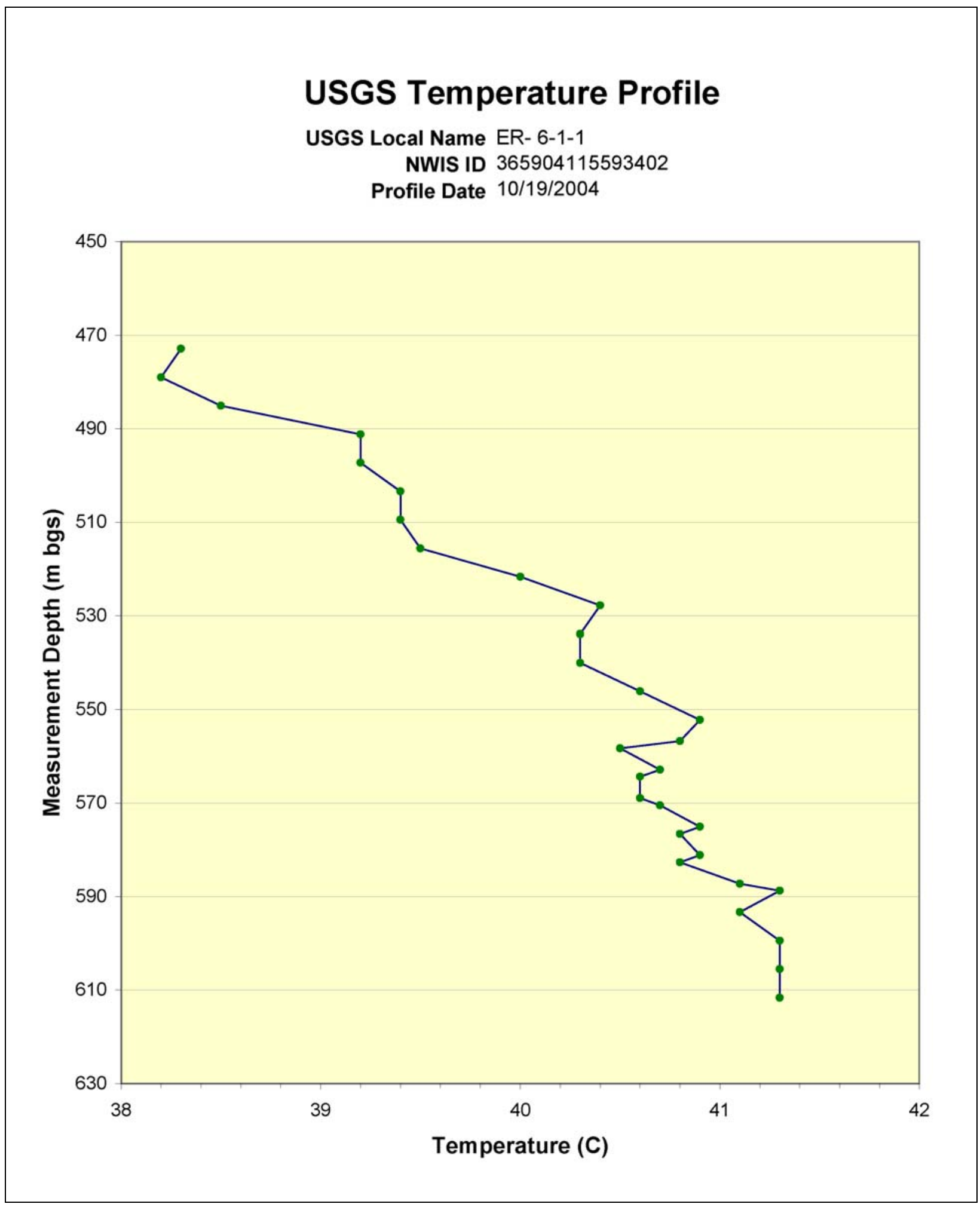

Figure G.1-27

USGS Temperature Profile for Yucca Flat Well ER- 6-1-1 


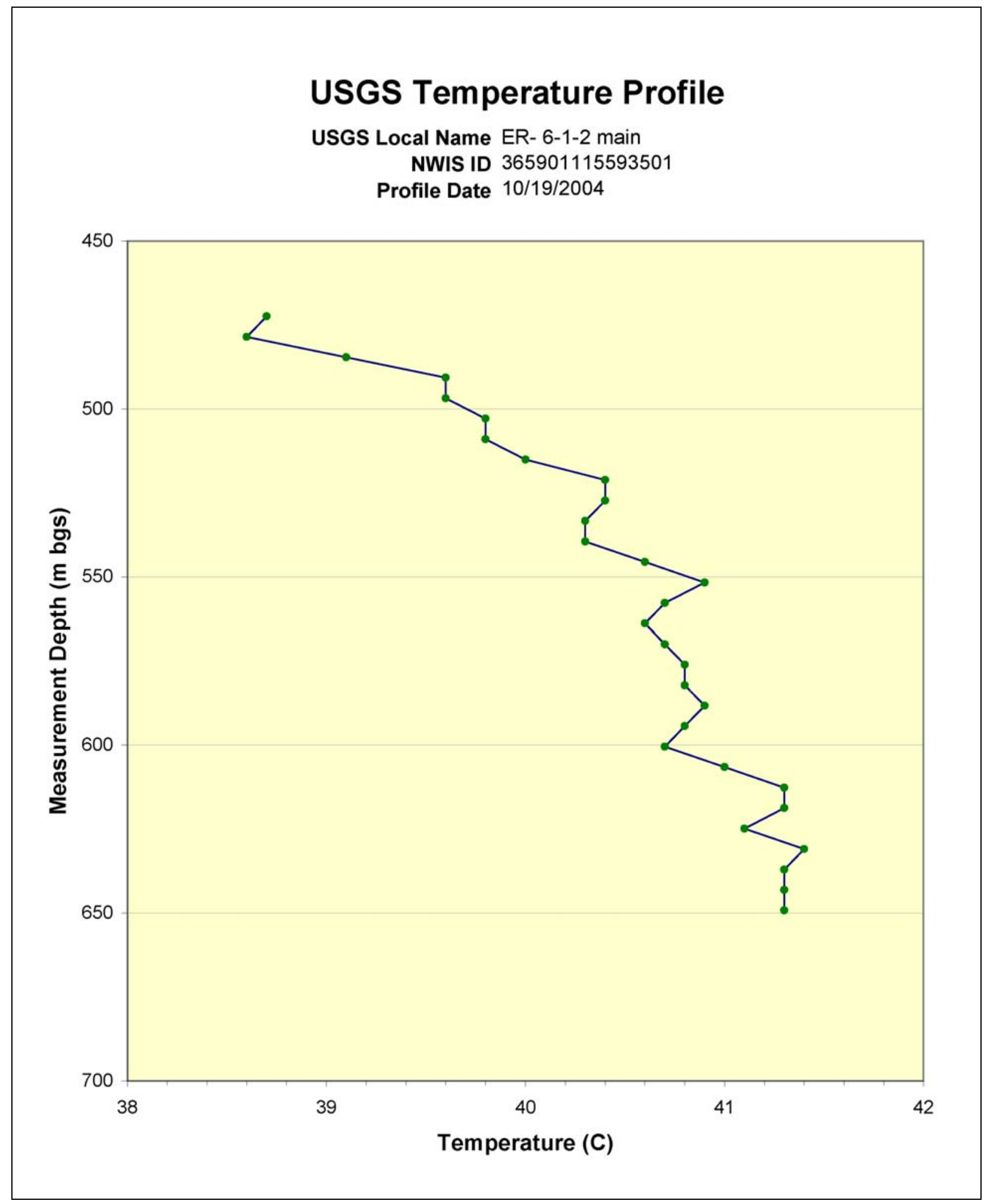

Figure G.1-28

USGS Temperature Profile for Yucca Flat Well ER- 6-1-2 main 


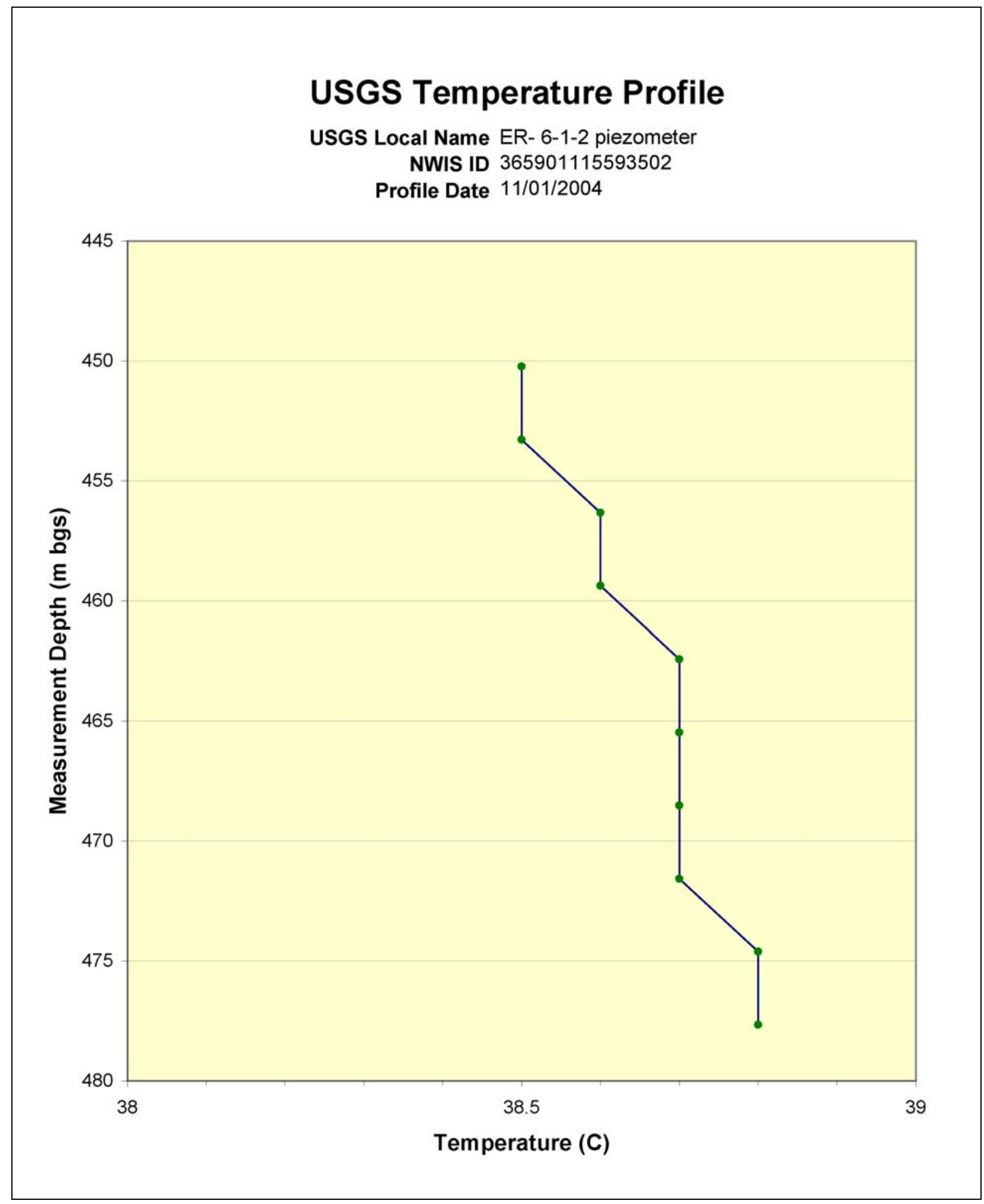

Figure G.1-29

USGS Temperature Profile for Yucca Flat Well ER- 6-1-2 piezometer 


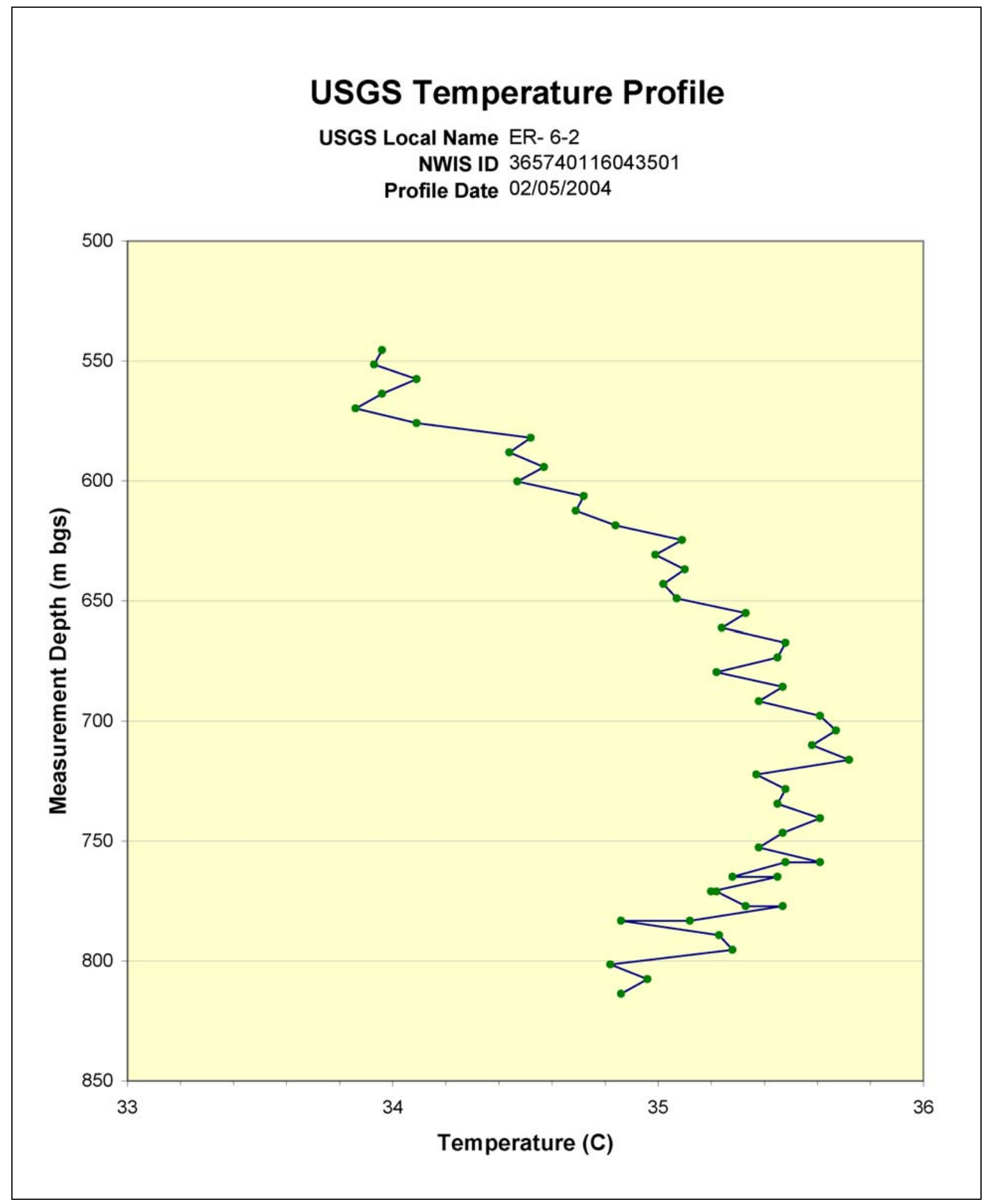

Figure G.1-30

USGS Temperature Profile for Yucca Flat Well ER- 6-2 


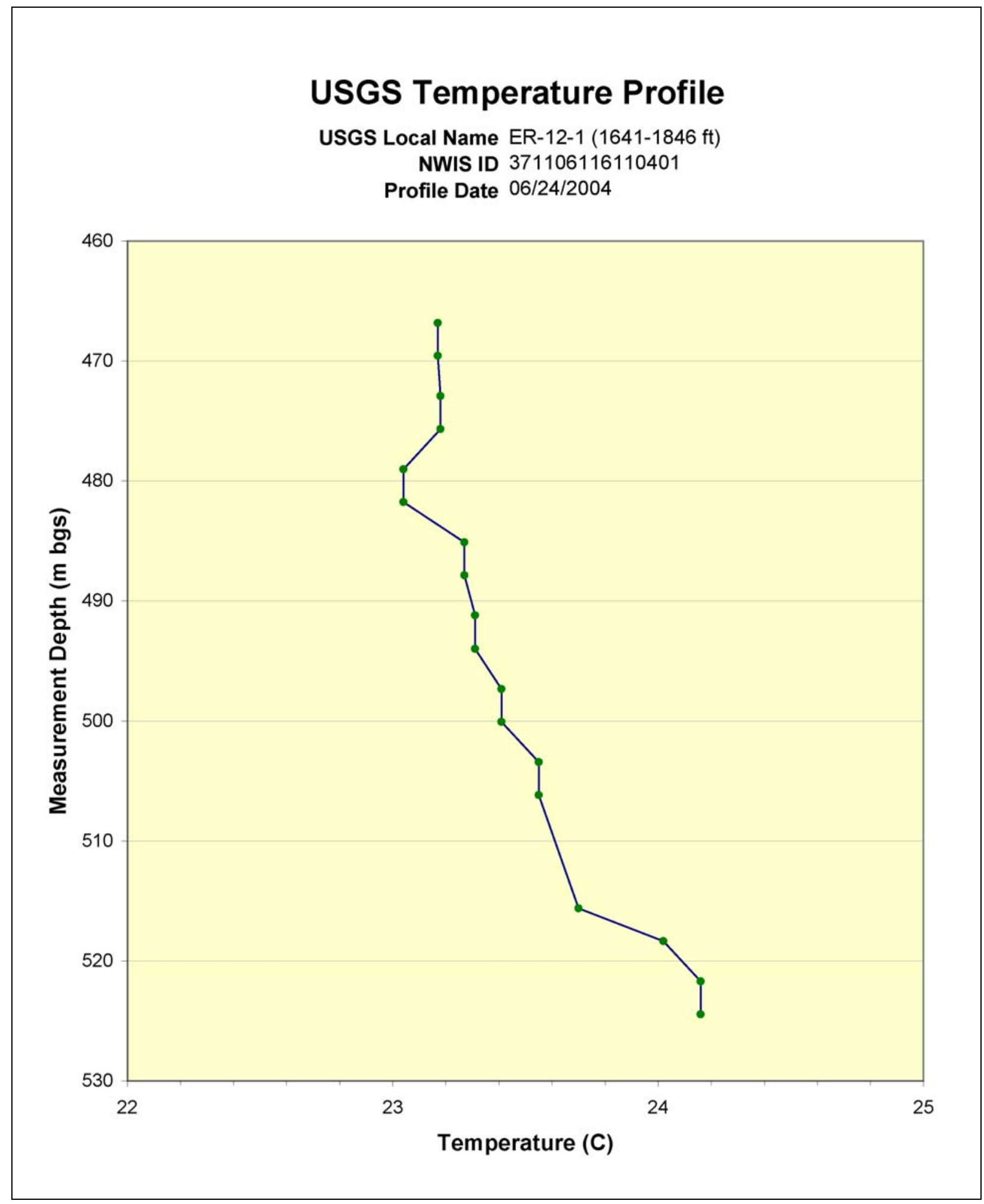

Figure G.1-31

USGS Temperature Profile for Yucca Flat Well ER-12-1 (1641-1846 ft) 


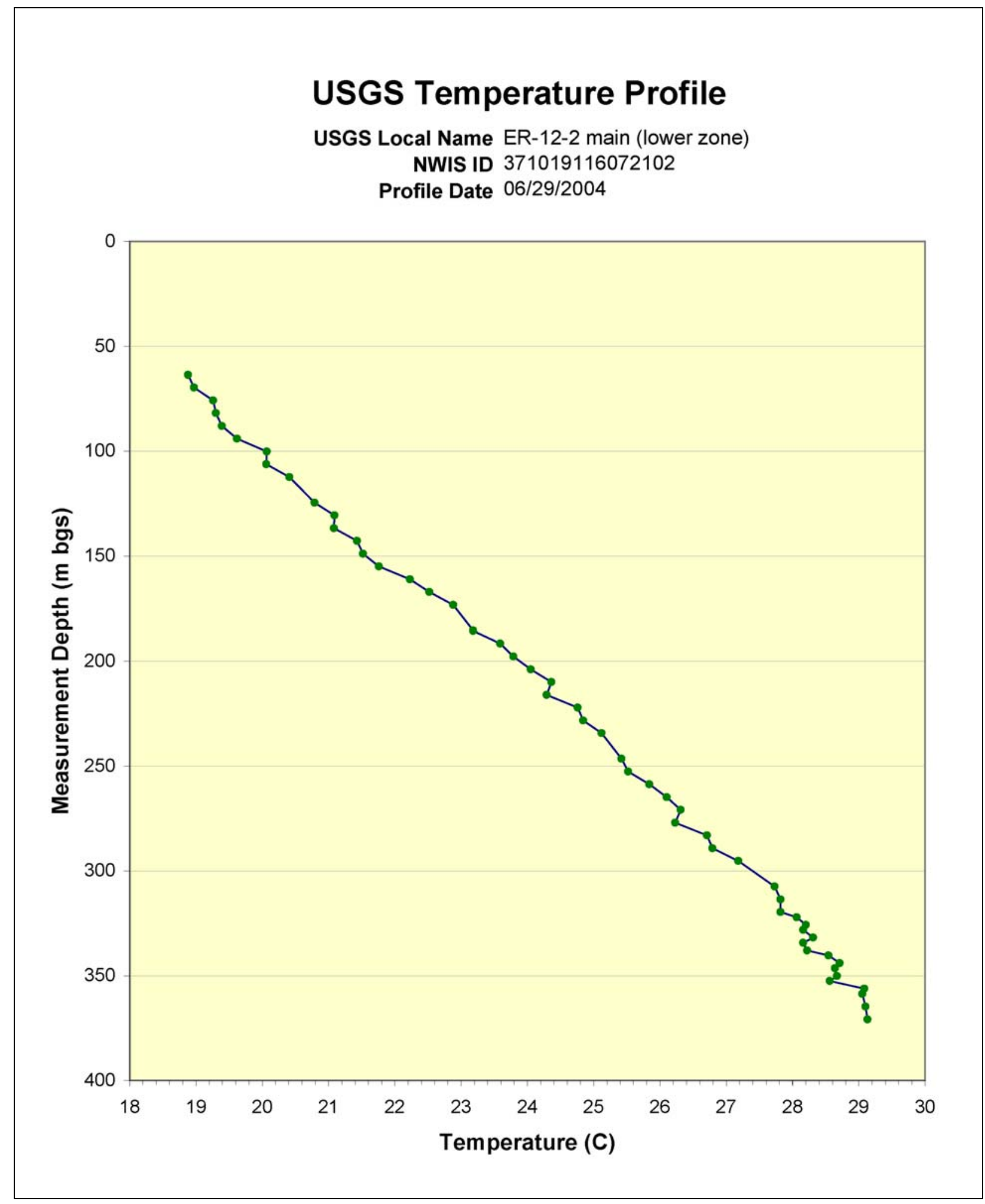

Figure G.1-32

USGS Temperature Profile for Yucca Flat Well ER-12-2 main (lower zone) 


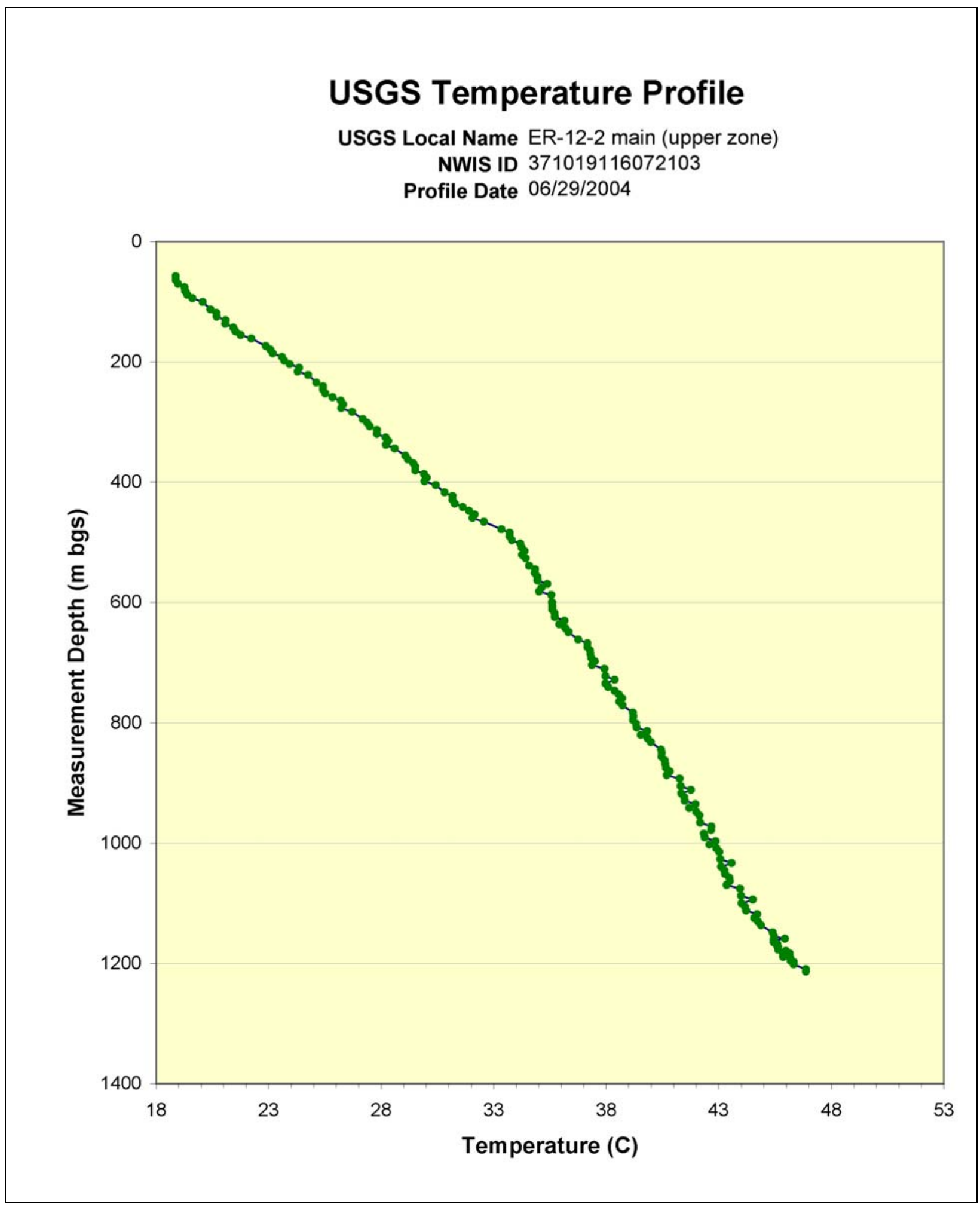

Figure G.1-33

USGS Temperature Profile for Yucca Flat Well ER-12-2 main (upper zone) 


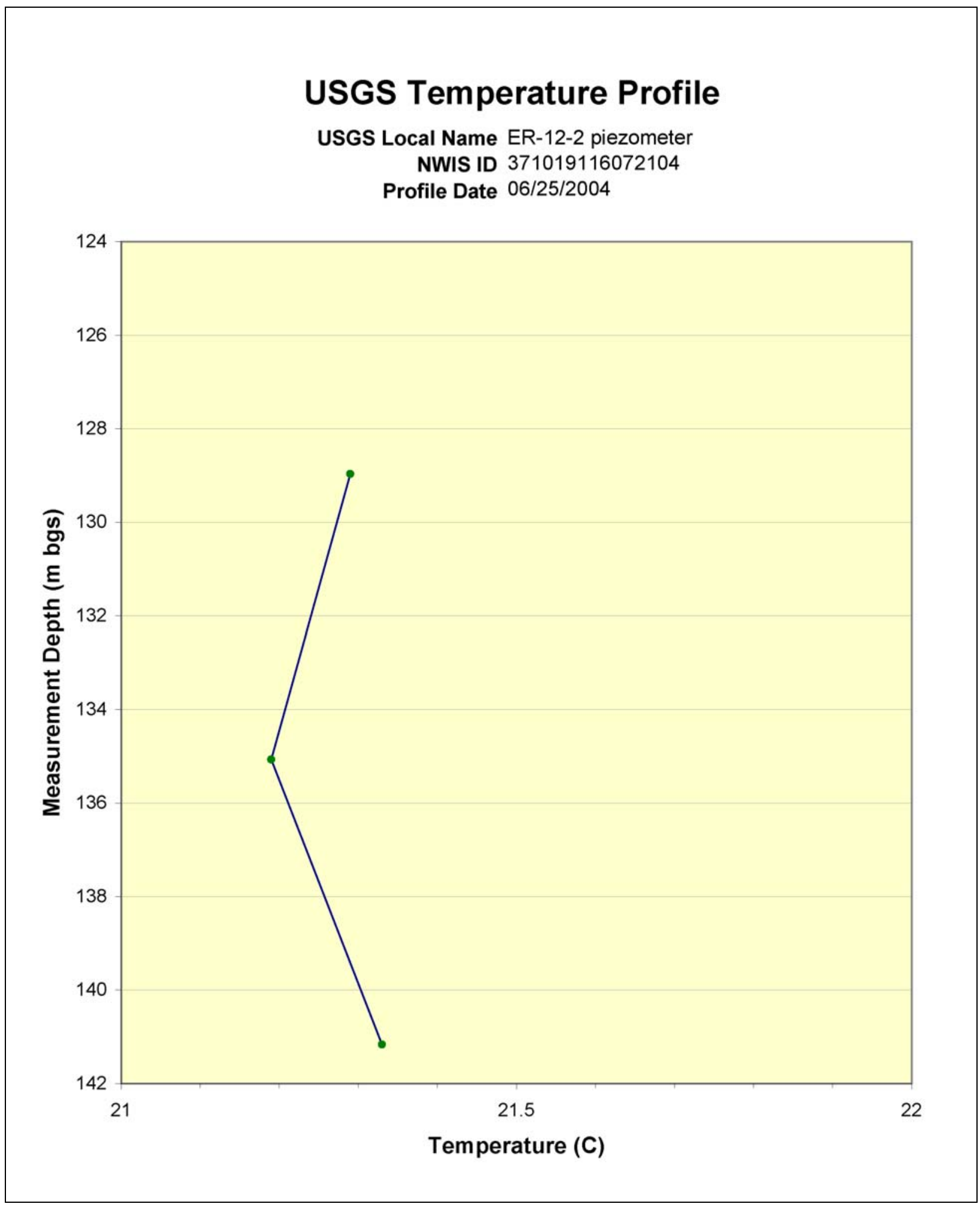

Figure G.1-34

USGS Temperature Profile for Yucca Flat Well ER-12-2 piezometer 


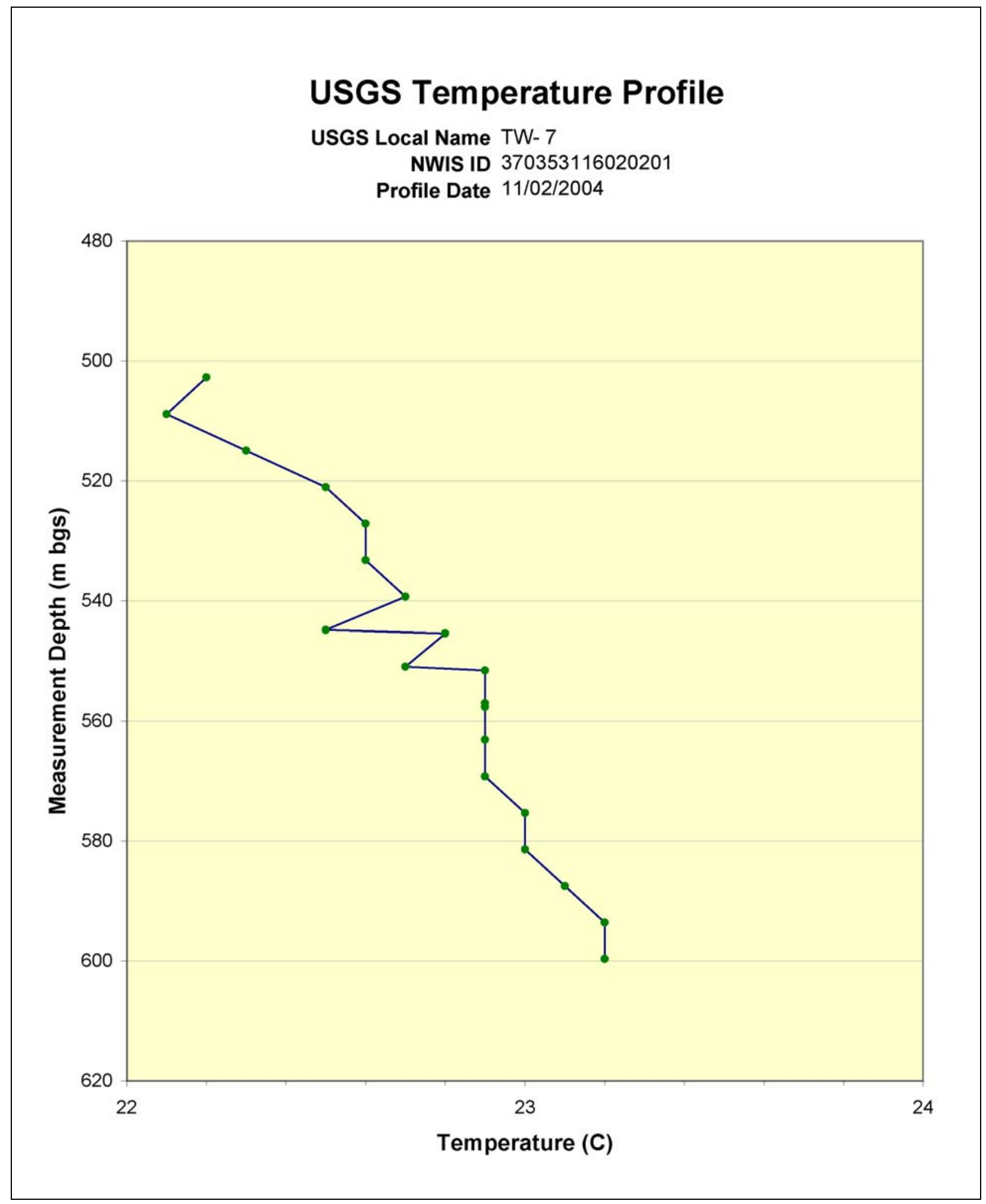

Figure G.1-35

USGS Temperature Profile for Yucca Flat Well TW- 7 


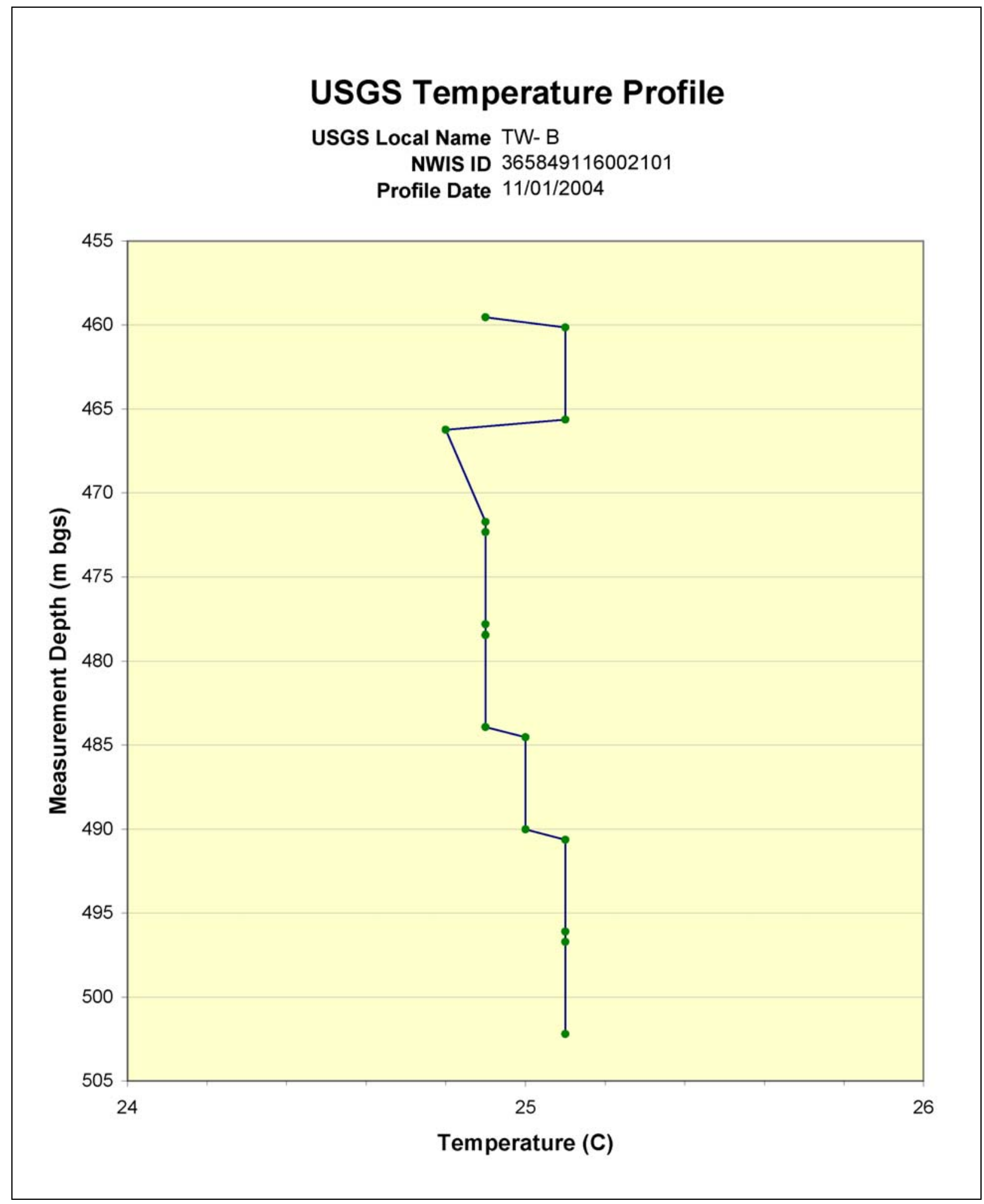

Figure G.1-36

USGS Temperature Profile for Yucca Flat Well TW- B 


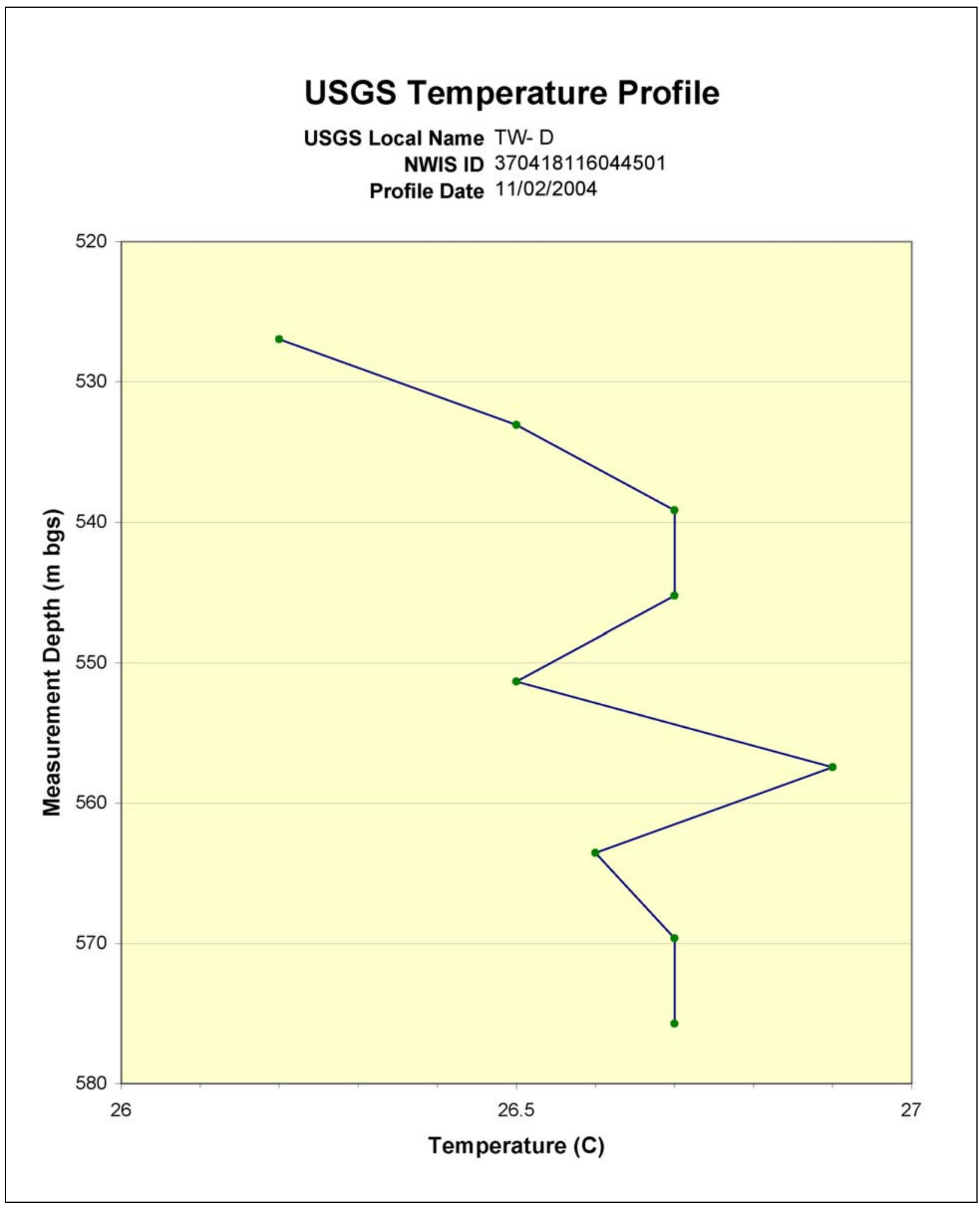

Figure G.1-37

USGS Temperature Profile for Yucca Flat Well TW- D 


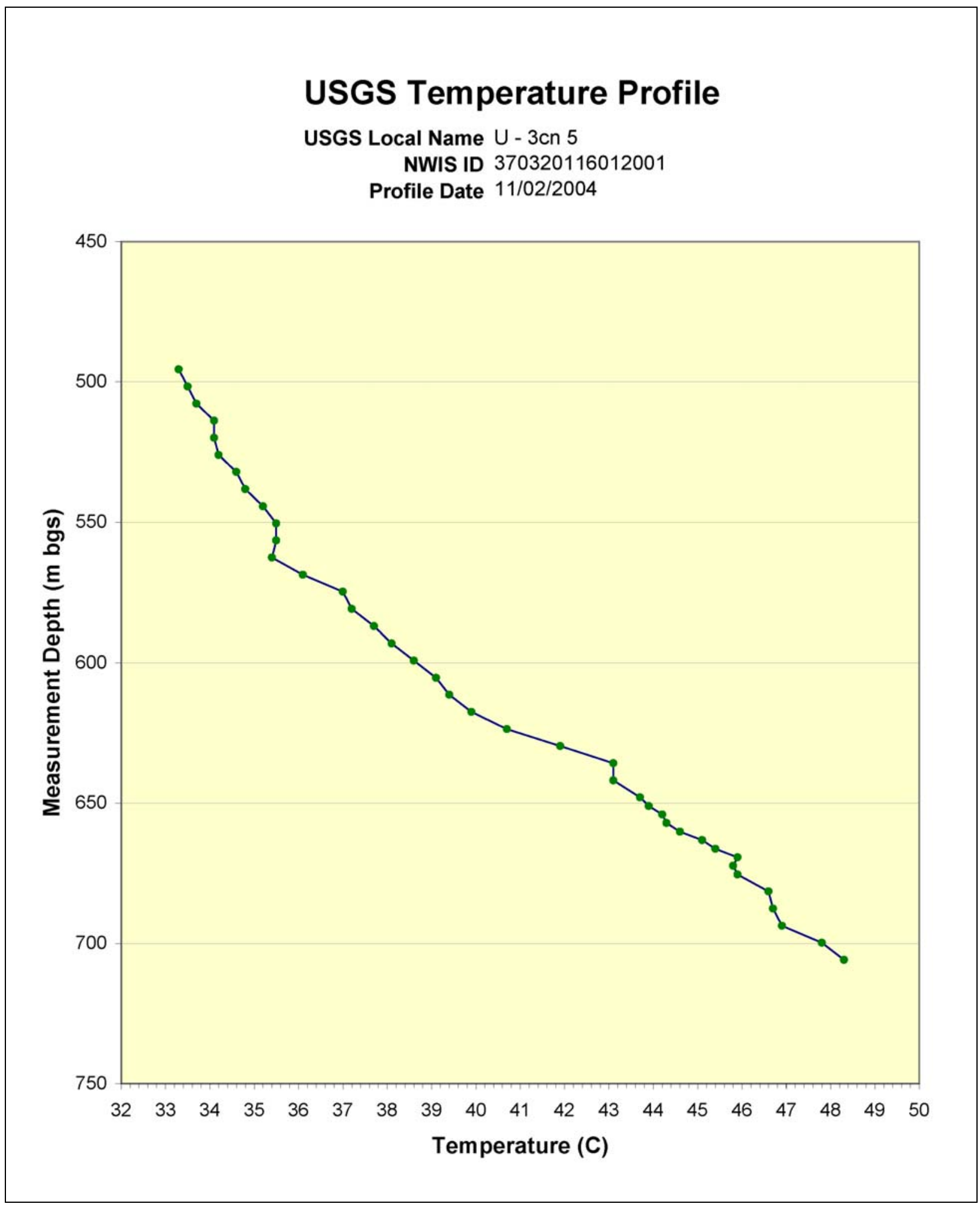

Figure G.1-38

USGS Temperature Profile for Yucca Flat Well U - 3cn 5 


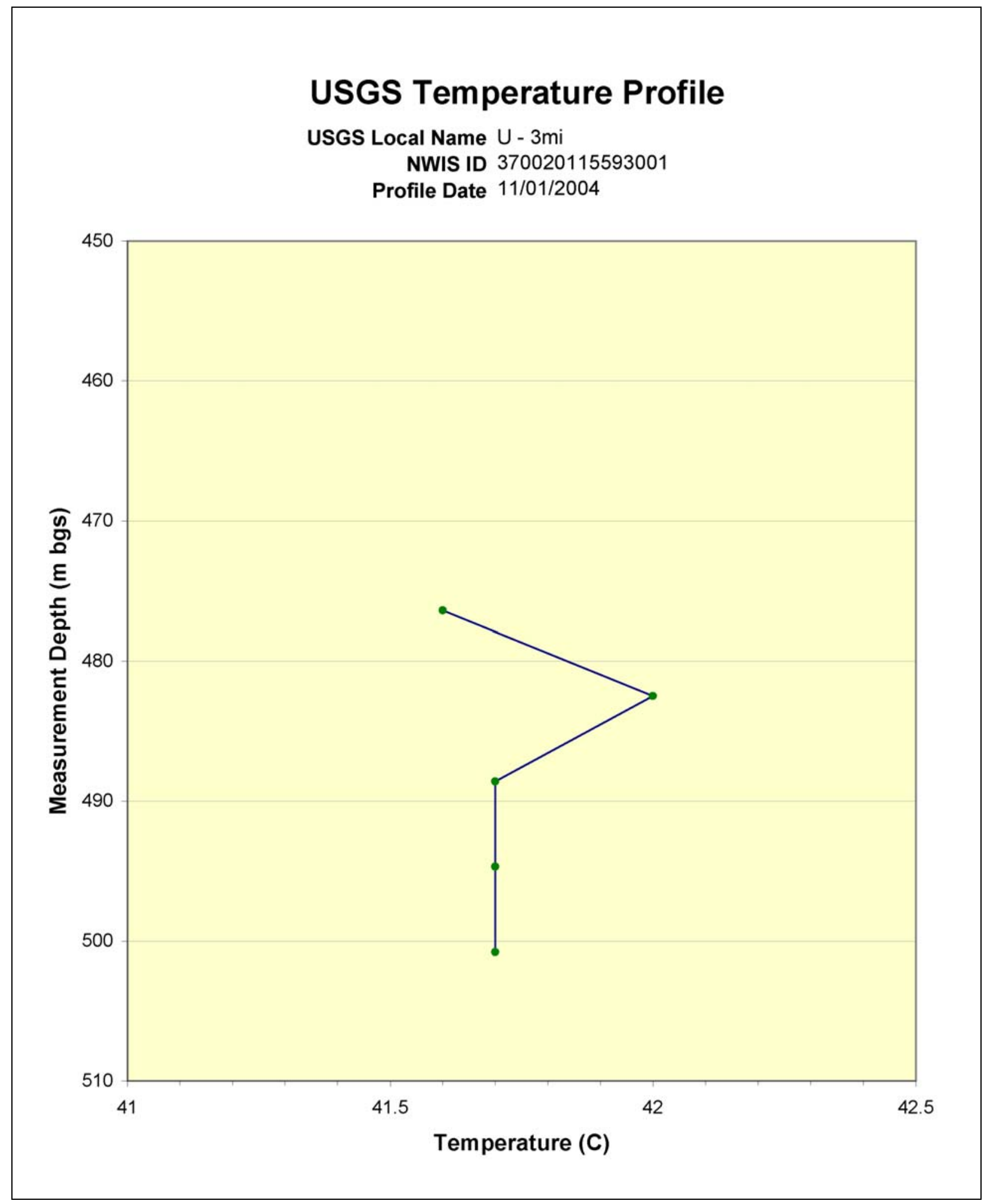

Figure G.1-39

USGS Temperature Profile for Yucca Flat Well U - 3mi 


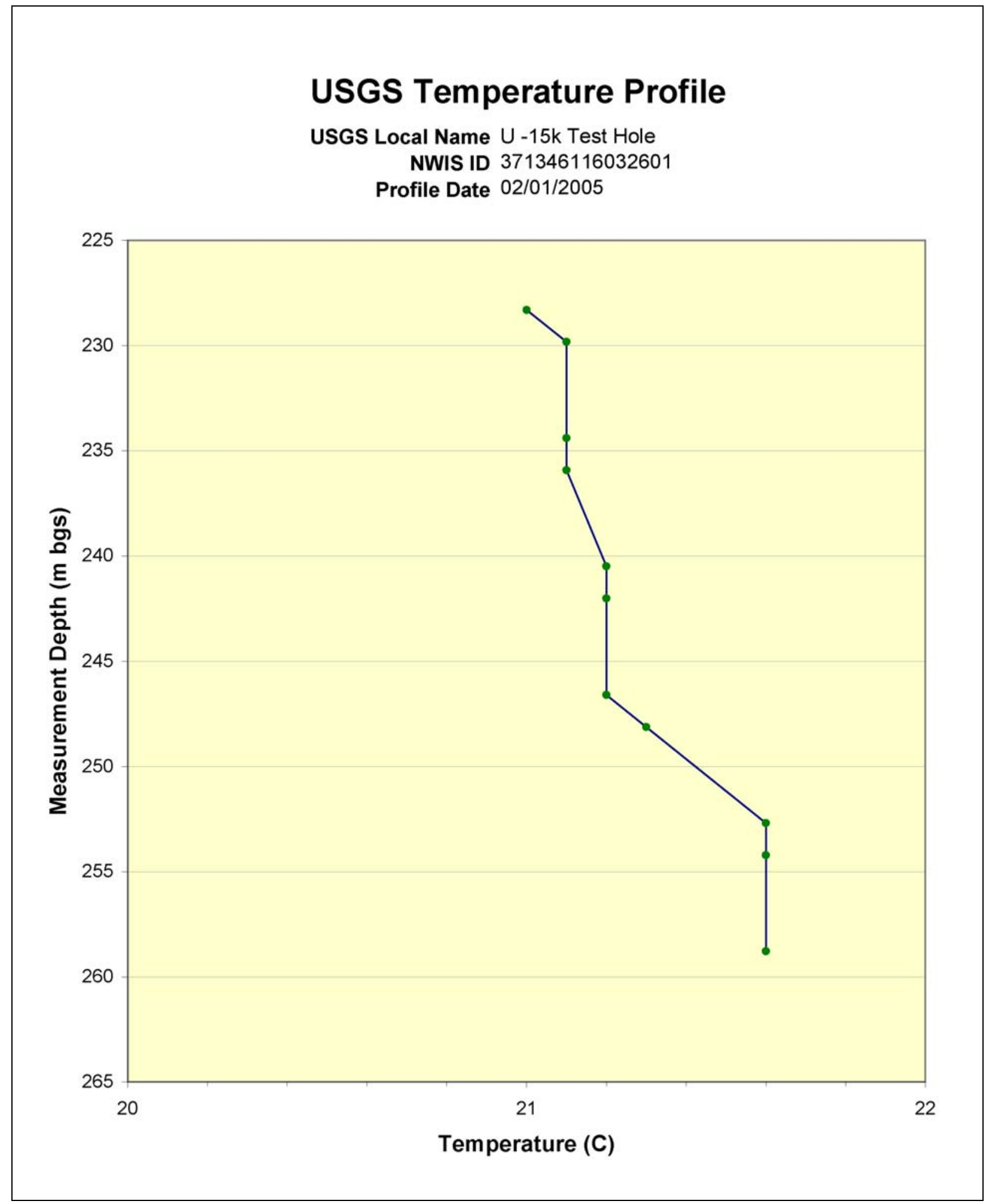

Figure G.1-40

USGS Temperature Profile for Yucca Flat Well U -15k Test Hole 


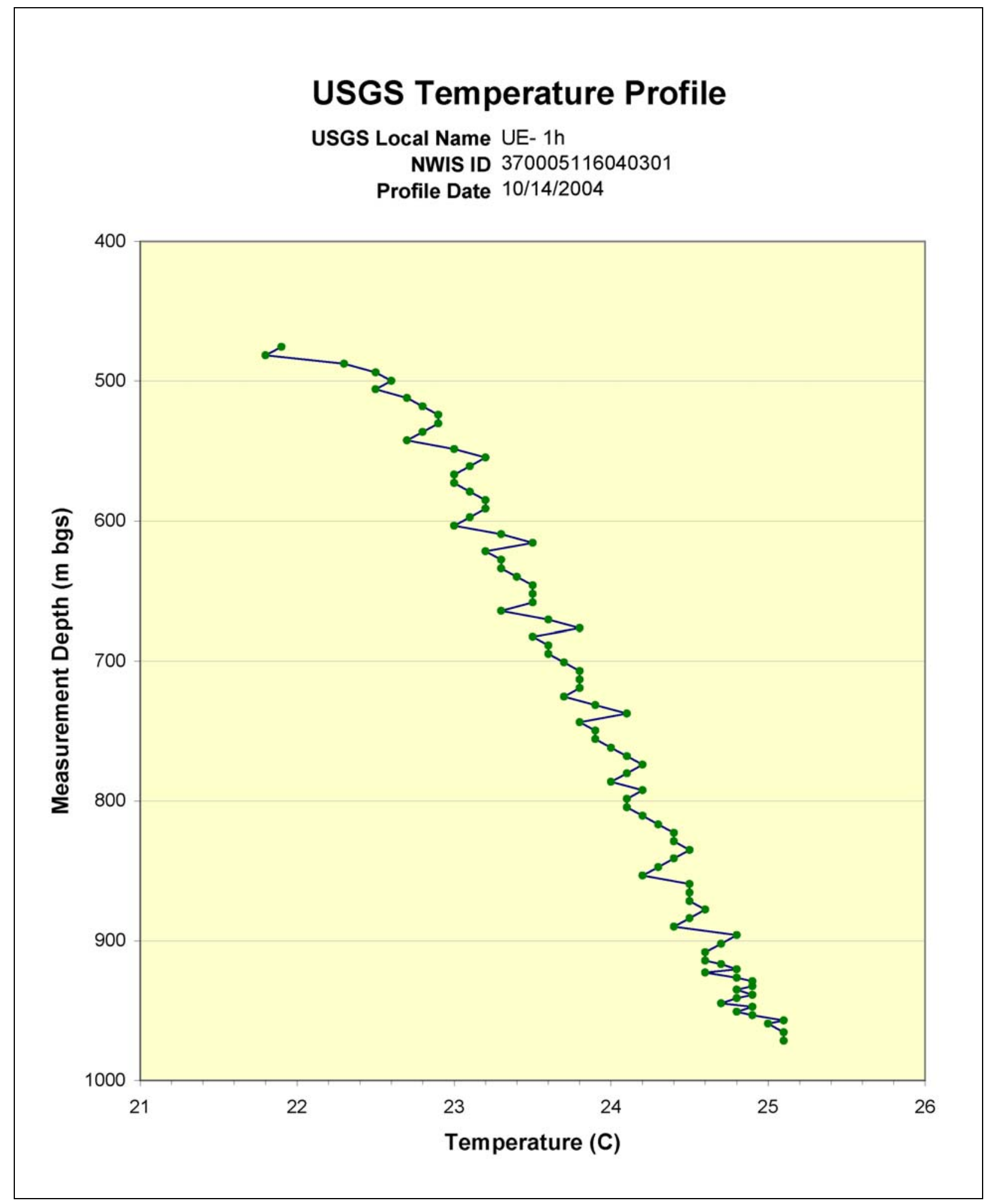

Figure G.1-41

USGS Temperature Profile for Yucca Flat Well UE- $1 \mathrm{~h}$ 


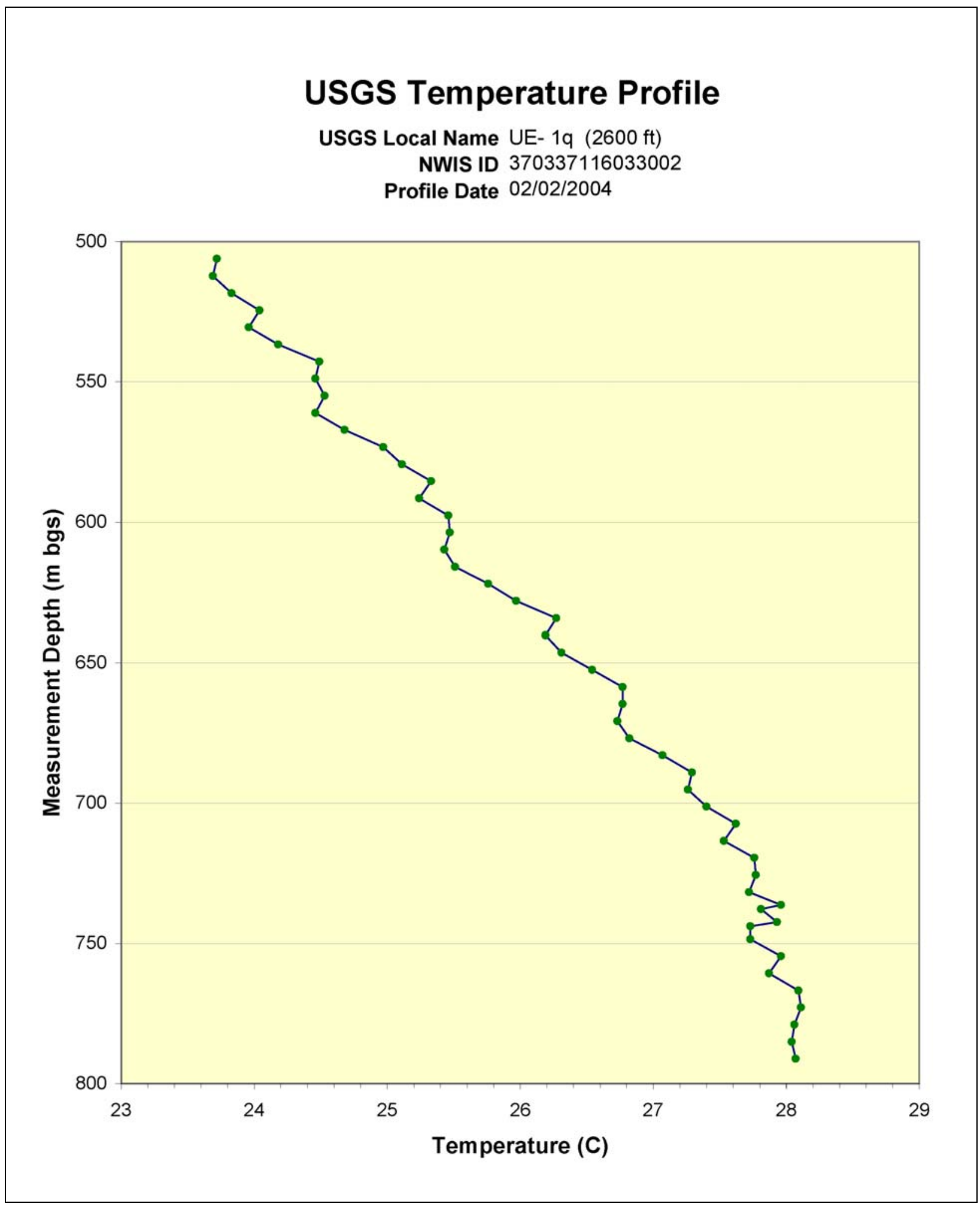

Figure G.1-42

USGS Temperature Profile for Yucca Flat Well UE- 1q (2600 ft) 


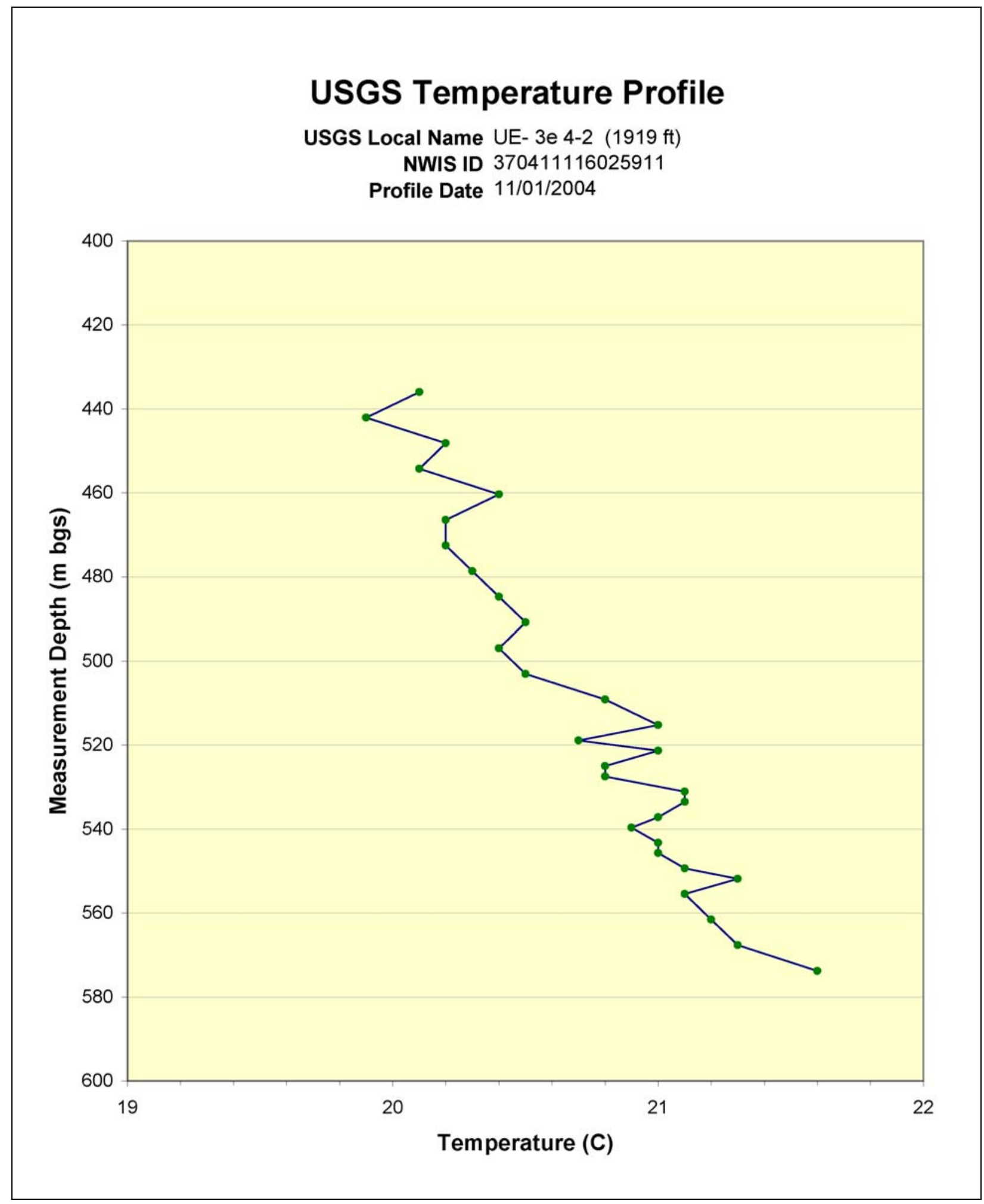

Figure G.1-43

USGS Temperature Profile for Yucca Flat Well UE- 3e 4-2 (1919 ft) 


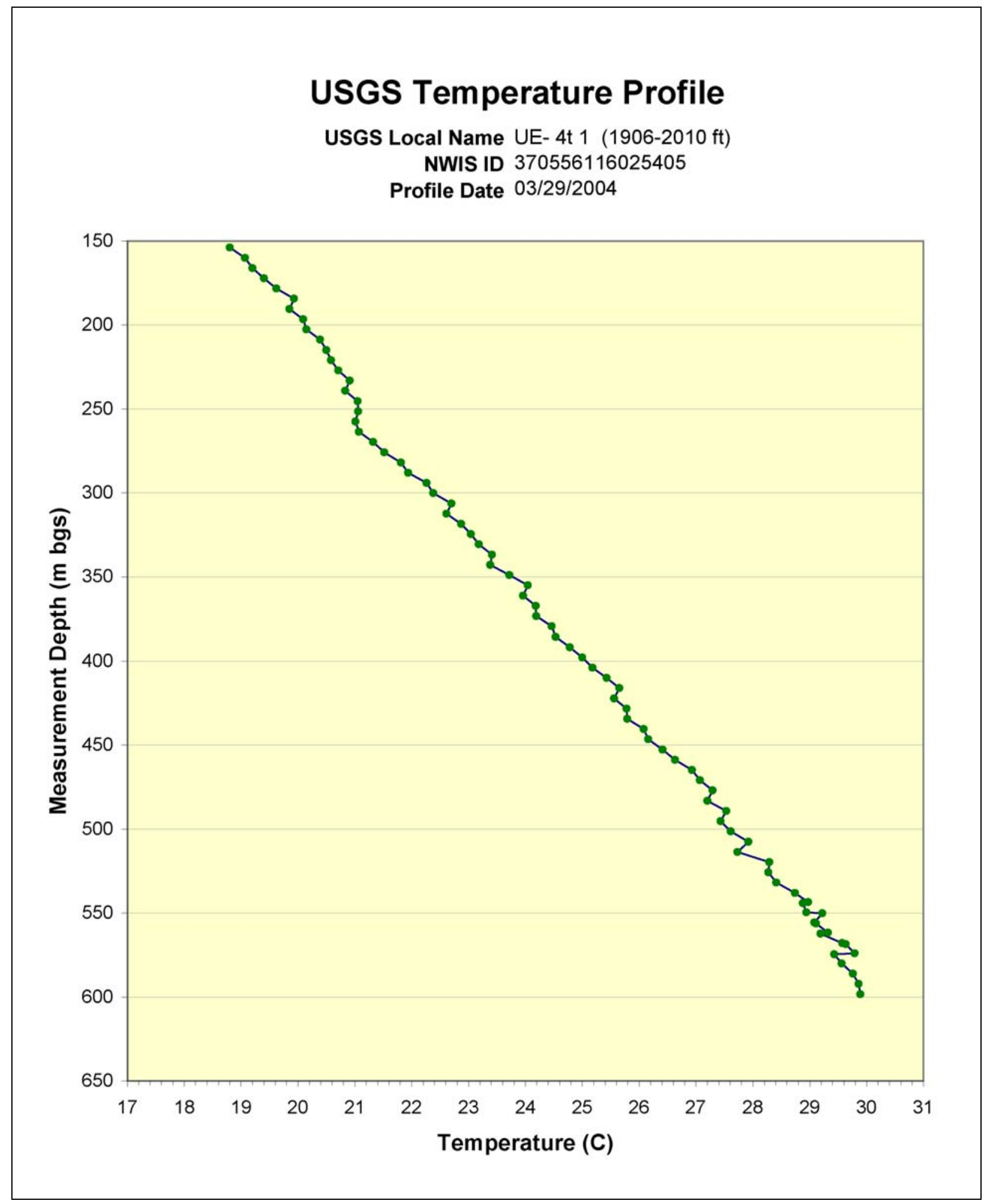

Figure G.1-44

USGS Temperature Profile for Yucca Flat Well UE- $4 t 1$ (1906-2010 ft) 


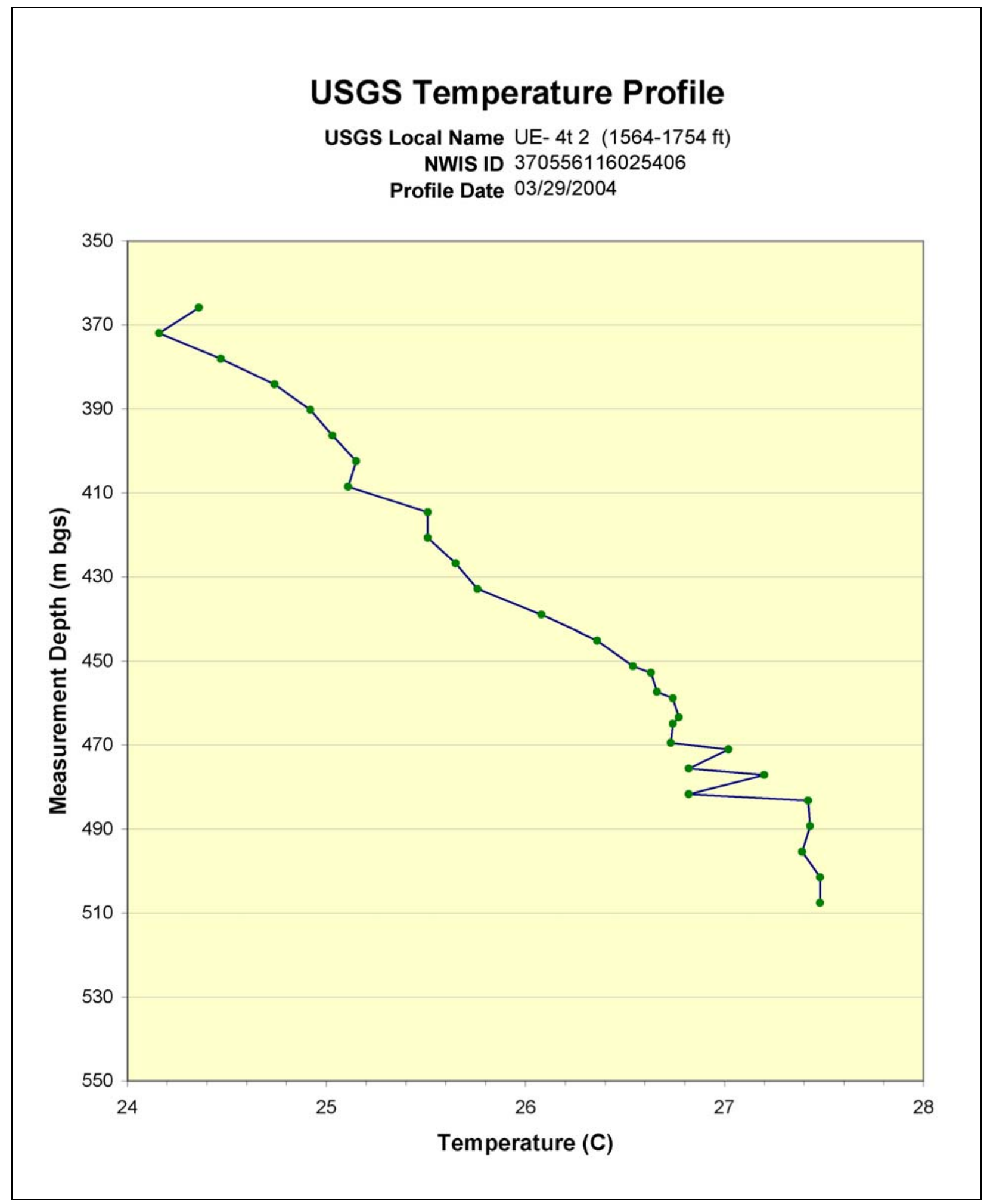

Figure G.1-45

USGS Temperature Profile for Yucca Flat Well UE- $4 t 2$ (1564-1754 ft) 


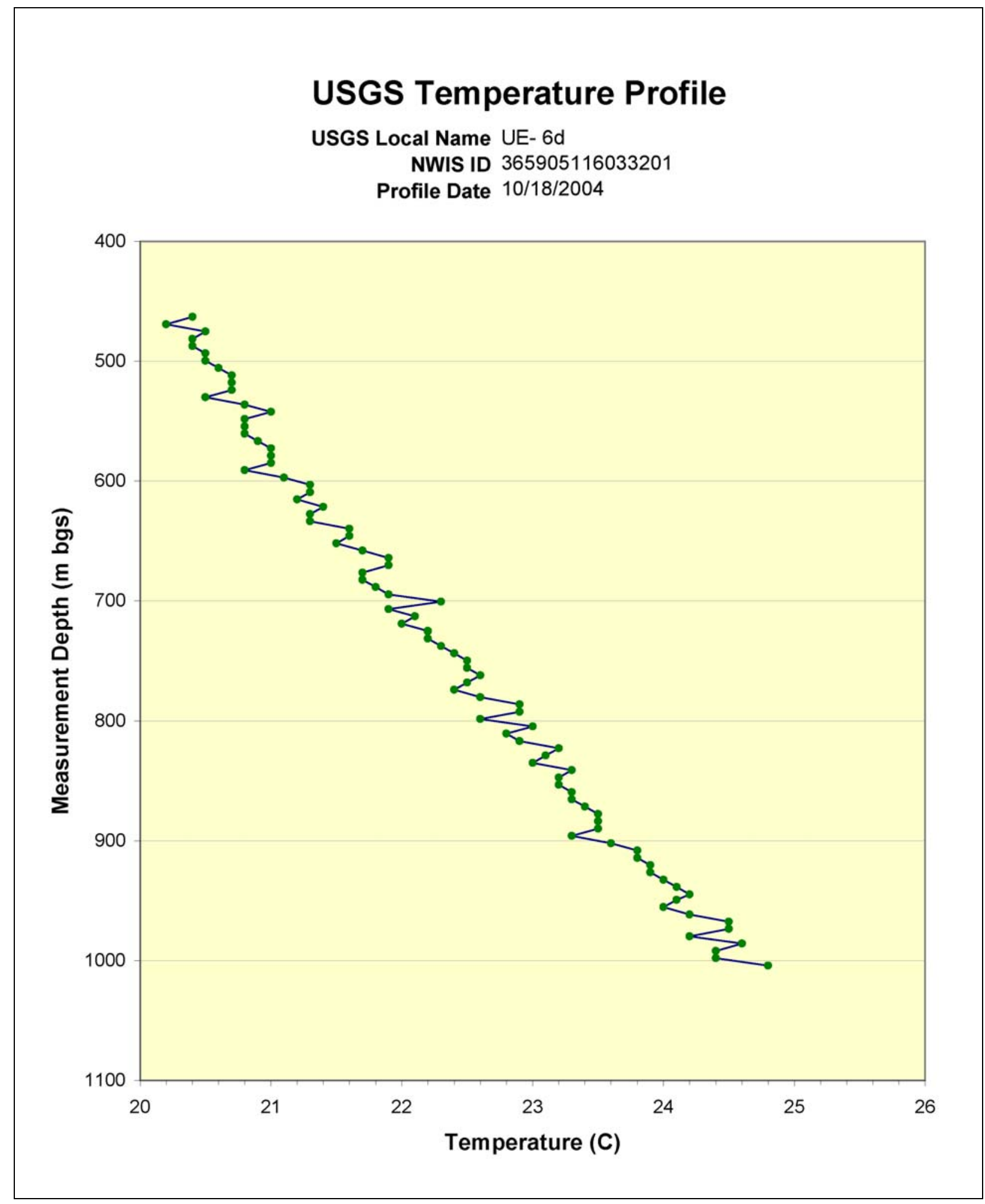

Figure G.1-46

USGS Temperature Profile for Yucca Flat Well UE- 6d 


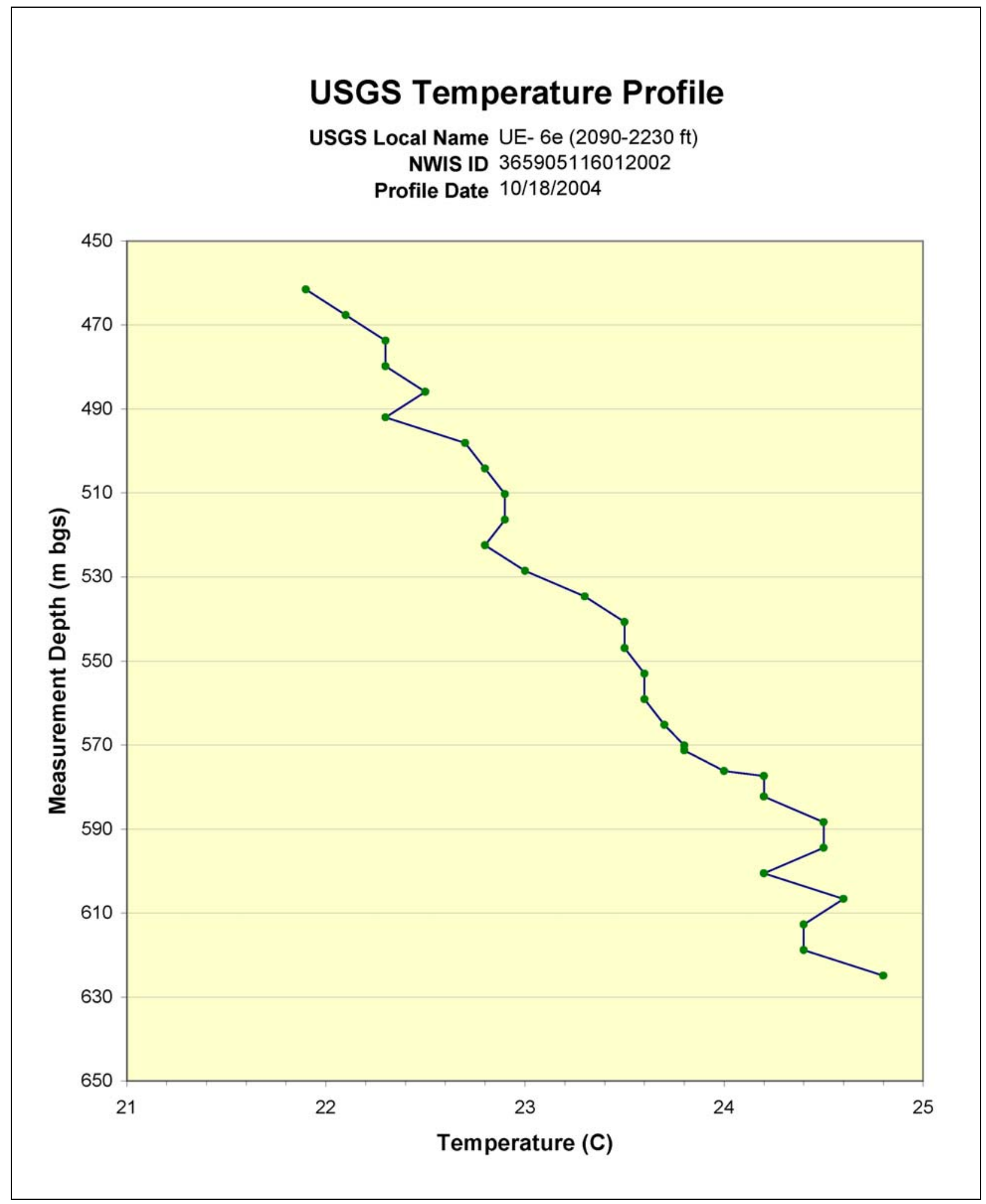

Figure G.1-47

USGS Temperature Profile for Yucca Flat Well UE- 6e (2090-2230 ft) 


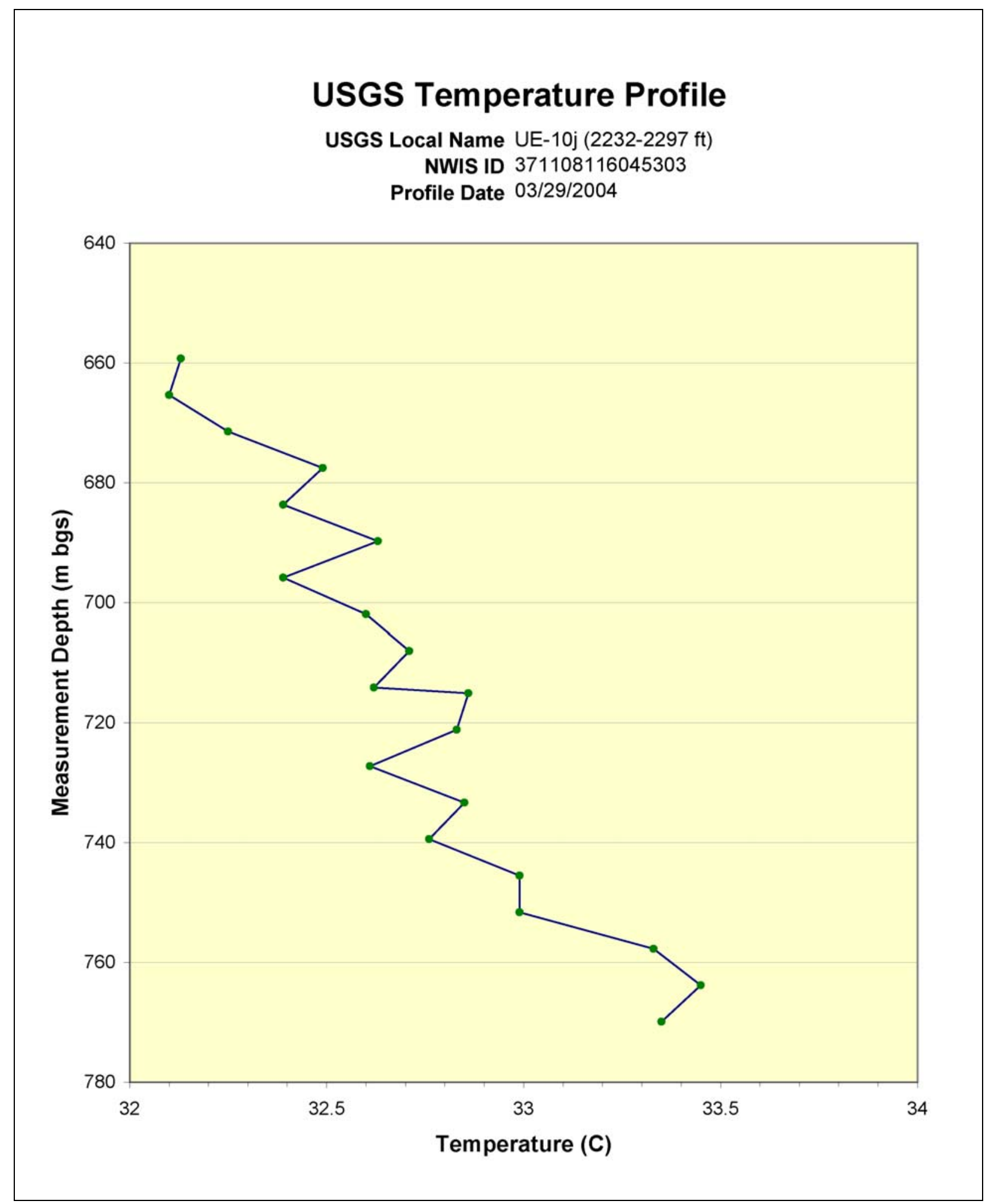

Figure G.1-48

USGS Temperature Profile for Yucca Flat Well UE-10j (2232-2297 ft) 


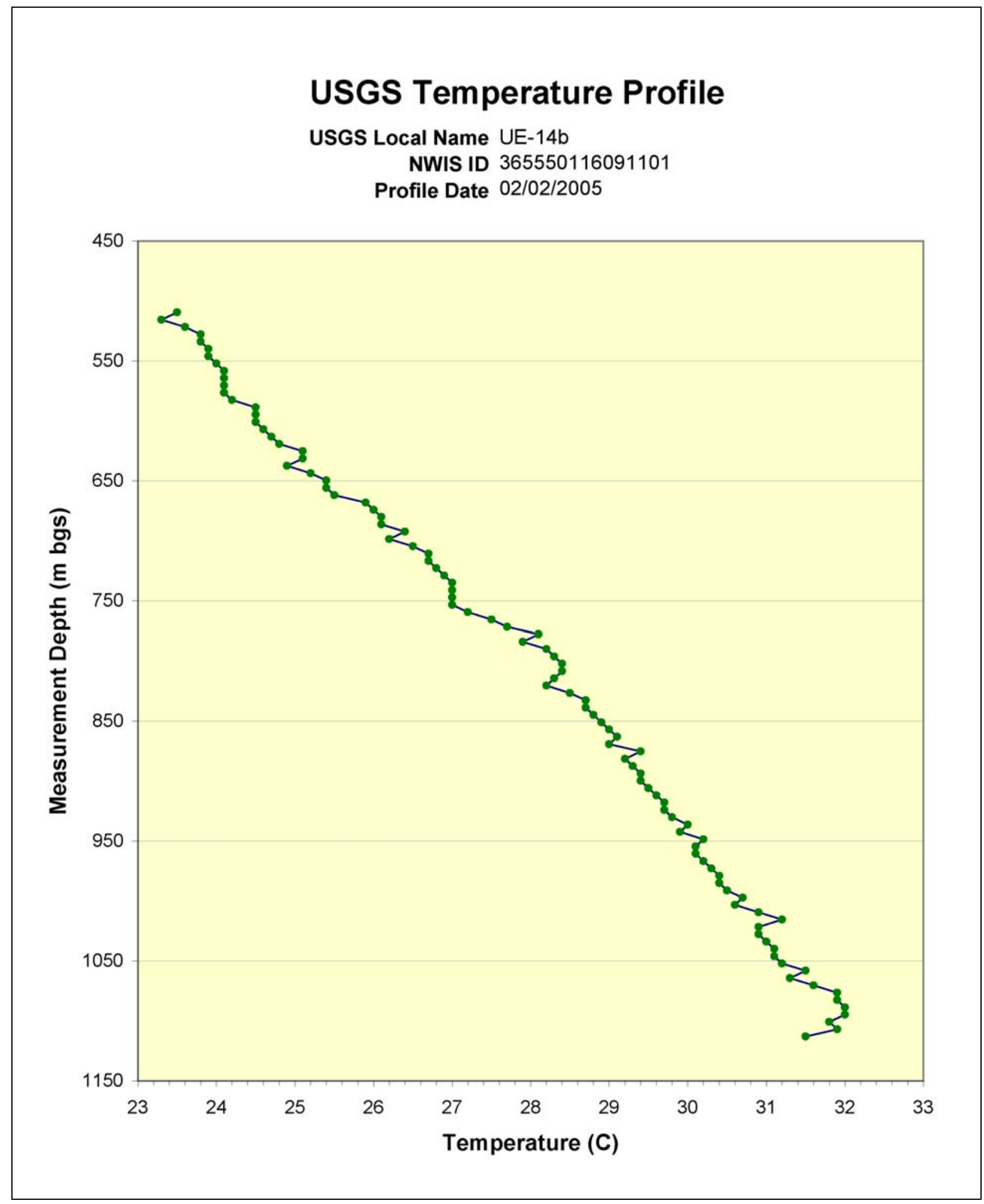

Figure G.1-49

USGS Temperature Profile for Yucca Flat Well UE-14b 


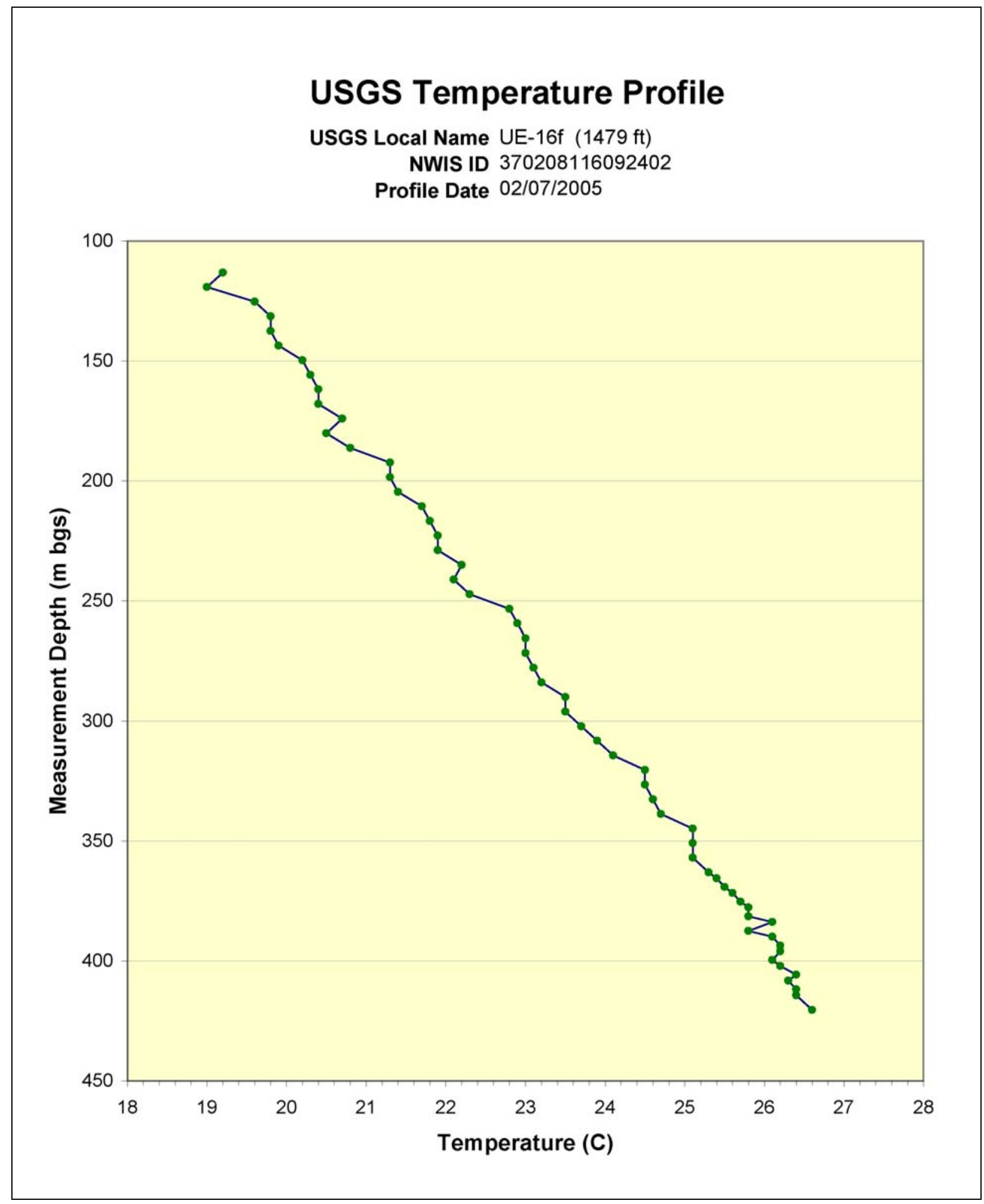

Figure G.1-50

USGS Temperature Profile for Yucca Flat Well UE-16f (1479 ft) 


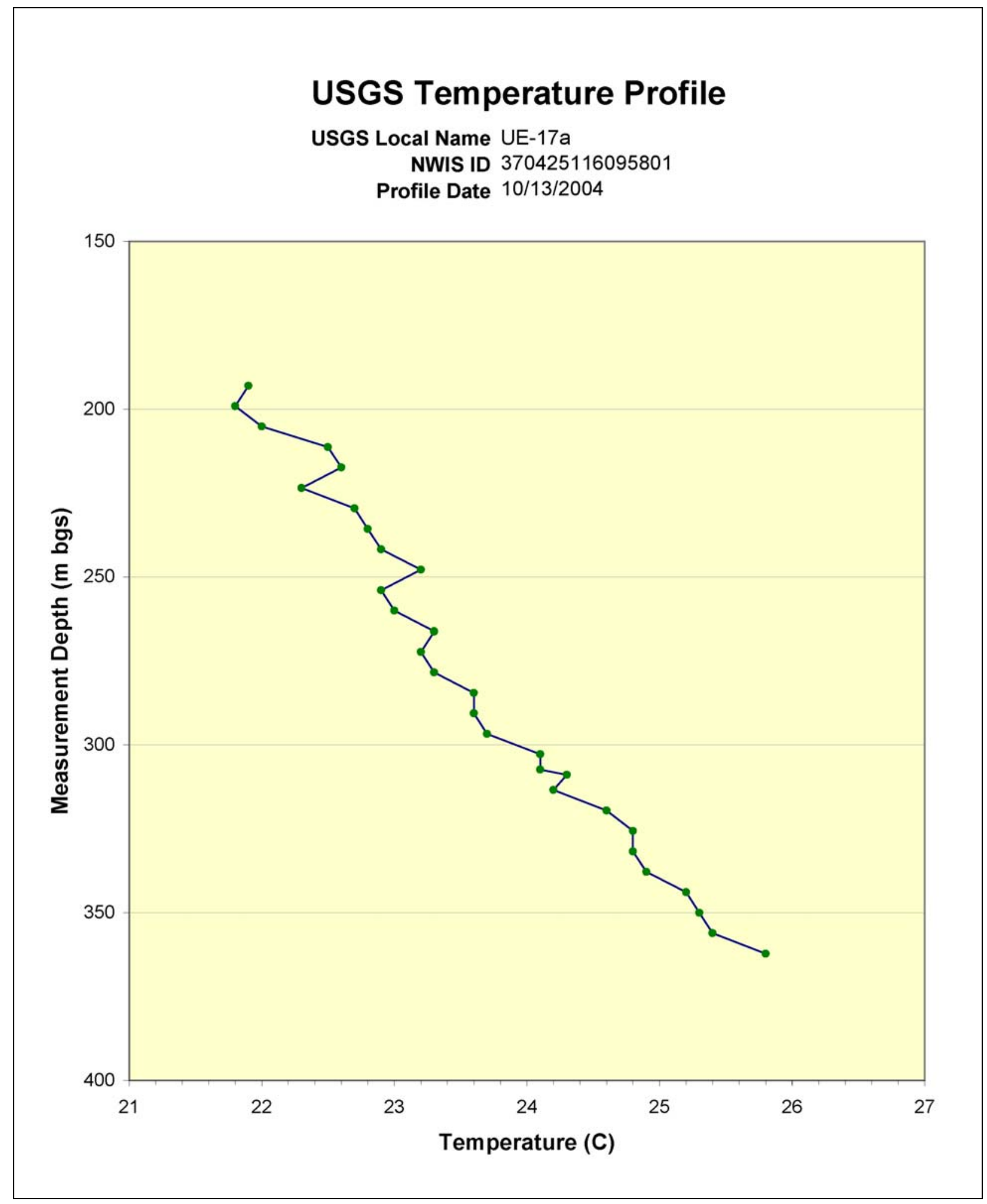

Figure G.1-51

USGS Temperature Profile for Yucca Flat Well UE-17a 


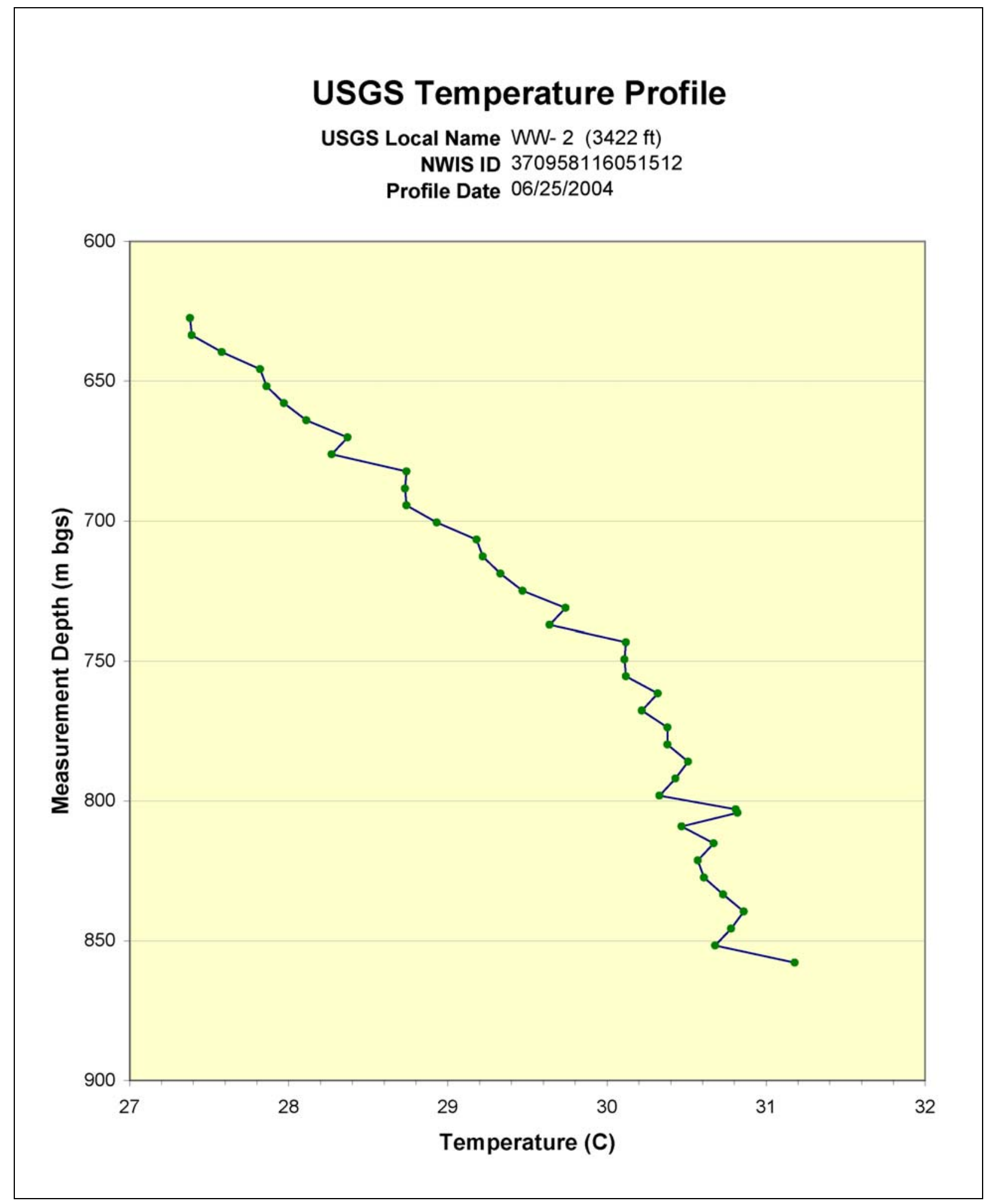

Figure G.1-52

USGS Temperature Profile for Yucca Flat Well WW- 2 (3422 ft) 


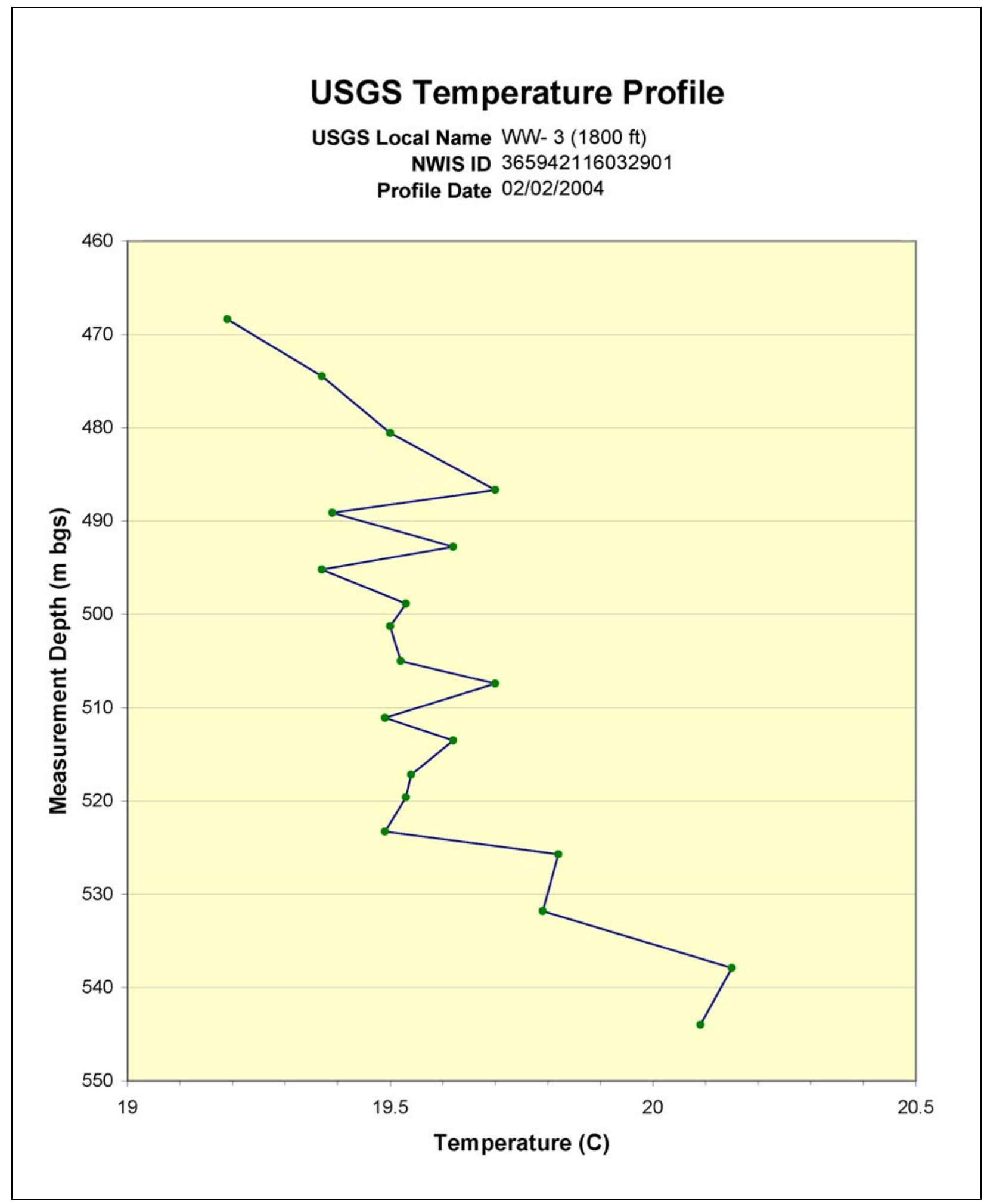

Figure G.1-53

USGS Temperature Profile for Yucca Flat Well WW- 3 (1800 ft) 


\section{G.2.0 REFERENCES}

Gillespie, D. 2005. Temperature Profiles and Hydrologic Implications from the Nevada Test Site Area, DOE/NV/13609-40; Publication No. 45211. Las Vegas, NV: Desert Research Institute.

USGS, see U.S. Geological Survey

U.S. Geological Survey. 2006. "USGS/DOE Cooperative Studies in Nevada; Water-Use Wells, Nevada Test Site and Vicinity." As accessed at http://nevada.usgs.gov/doe_nv/ watertemp/temp_map.htm on May 30, 2006. 
Appendix $\mathrm{H}$

Groundwater Chemistry Data 


\section{H.1.0 GROUNDWATER CHEMISTRY}

The datasets used for the geochemical evaluations described in Section 12.0 are provided in this appendix. The datasets include the mean, standard deviation, and the number of independent measurements for each well, spring, and seep identified in Figures 12-1 and 12-2. Included in this appendix are the major-ion (Table H.1-1), isotope (Table H.1-2), field measurement (Table H.1-3), strontium and uranium (Table H.1-4), and selected trace and minor element (Table H.1-5) data. 
Table H.1-1

Major-Ion Data for Yucca Flat/Climax Mine Geochemical Evaluation

(Page 1 of 5)

\begin{tabular}{|c|c|c|c|c|c|c|c|c|c|c|c|c|c|c|c|c|c|c|c|c|c|c|c|c|c|c|c|c|c|c|c|c|}
\hline \multirow{2}{*}{ Site Identification } & \multicolumn{3}{|c|}{$\begin{array}{c}\mathrm{HCO}_{3}, \mathrm{Lab} \\
(\mathrm{mg} / \mathrm{L})\end{array}$} & \multicolumn{3}{|c|}{$\begin{array}{c}\mathrm{CO}_{3}, \mathrm{Lab} \\
\text { (mg/L) }\end{array}$} & \multicolumn{3}{|c|}{$\begin{array}{c}\mathrm{HCO}_{3}, \text { Field } \\
(\mathrm{mg} / \mathrm{L})\end{array}$} & \multicolumn{3}{|c|}{$\begin{array}{c}\mathrm{CO}_{3}, \text { Field } \\
(\mathrm{mg} / \mathrm{L})\end{array}$} & \multicolumn{3}{|c|}{$\begin{array}{c}\mathrm{SO}_{4} \\
\text { (mg/L) }\end{array}$} & \multicolumn{3}{|c|}{$\begin{array}{c}\mathrm{Cl} \\
(\mathrm{mg} / \mathrm{L})\end{array}$} & \multicolumn{3}{|c|}{$\begin{array}{c}\mathrm{Mg} \\
(\mathrm{mg} / \mathrm{L})\end{array}$} & \multicolumn{3}{|c|}{$\begin{array}{c}\mathrm{Na} \\
(\mathrm{mg} / \mathrm{L})\end{array}$} & \multicolumn{3}{|c|}{$\begin{array}{c}\mathrm{K} \\
(\mathrm{mg} / \mathrm{L})\end{array}$} & \multicolumn{3}{|c|}{$\begin{array}{c}\mathrm{Ca} \\
(\mathrm{mg} / \mathrm{L})\end{array}$} & \multirow{2}{*}{$\begin{array}{l}\text { C/B } \\
\mathrm{Lab}\end{array}$} & \multirow{2}{*}{$\begin{array}{l}\text { C/B } \\
\text { Field }\end{array}$} \\
\hline & Avg & SD & $\mathbf{n}$ & Avg & SD & $\mathbf{n}$ & Avg & SD & $\mathbf{n}$ & Avg & SD & $n$ & Avg & SD & $\mathbf{n}$ & Avg & SD & $\mathbf{n}$ & Avg & SD & $\mathbf{n}$ & Avg & SD & $\mathbf{n}$ & Avg & SD & $\mathbf{n}$ & Avg & SD & $\mathbf{n}$ & & \\
\hline \multicolumn{33}{|l|}{ Alum Spring } \\
\hline April Fool Spring & 406 & & & & & & 417 & & & & & & 110 & & & 16 & & & 51 & & & 28 & & & 3.7 & & & 79 & & & \begin{tabular}{|l|}
-0.1 \\
\end{tabular} & 0.8 \\
\hline Army \#1 WW & 255 & 21 & 36 & 0.3 & & & 253 & 5 & 3 & & & & 52 & 2 & 36 & 17 & 3 & 33 & 23 & 2 & 37 & 38 & 3 & 36 & 5.6 & 0.9 & 37 & 42 & 5 & 36 & 0.4 & 0.1 \\
\hline Ash Spring & 253 & 20 & 3 & 0.3 & & & 250 & & & & & & 34.5 & 0.6 & 4 & 12 & 6 & 4 & 14.3 & 0.7 & 4 & 30 & 3 & 4 & 6.8 & 1.0 & 3 & 50 & 7 & 4 & 1.0 & 0.4 \\
\hline Bullwhack Spring & 398 & & & & & & & & & & & & 151 & & & 11 & & & 60 & & & 18 & & & 2.0 & & & 89 & & & -1 & \\
\hline Cane Spring, FF & 189 & 10 & 29 & & & & & & & & & & 34 & 9 & 28 & 22 & 4 & 28 & 10.4 & 0.9 & 28 & 42 & 3 & 28 & 6.4 & 0.5 & 29 & 36 & 3 & 28 & 0.1 & \\
\hline Cane Spring, GR & 360 & & & & & & & & & & & & 136 & & & 18 & & & 48 & & & 24 & & & 2.4 & & & 84 & & & 0.0 & \\
\hline Captain Jack Spring & 78 & 30 & 7 & & & & & & & & & & 12 & 4 & 7 & 6.1 & 0.9 & 7 & 0.9 & 0.5 & 7 & 32 & 9 & 7 & 2.5 & 0.9 & 7 & 4 & 1 & 7 & $\mid-0.4$ & \\
\hline Cattle Spring & 261 & & & & & & & & & & & & 39 & & & 16 & & & 11 & & & 41 & & & 5.3 & & & 56 & & & -1 & \\
\hline Cliff Spring, BR & 110 & & & & & & & & & & & & 20 & & & 14 & & & 1.2 & & & 44 & & & 0.6 & & & 10 & & & 2 & \\
\hline Cliff Spring, GR & 271 & & & & & & & & & & & & 51 & & & 6.5 & & & 11 & & & 18 & & & 0.9 & & & 76 & & & 1 & \\
\hline Cow Camp Spring & & & & & & & 290 & 14 & 2 & & & & 19 & 14 & 2 & 29 & 1 & 2 & 33 & 3 & 2 & 23 & 3 & 2 & 0.7 & 0.1 & 2 & 49 & 1 & 2 & & -2 \\
\hline Cresent Spring & 373 & & & & & & 368 & & & & & & 15 & & & 11 & & & 11 & & & 21 & & & 2.9 & & & 94 & & & 2 & 1 \\
\hline Crystal Spring & 251 & 9 & 3 & 0.7 & & & 253 & 5 & 5 & & & & 35 & 4 & 7 & 9.0 & 0.6 & 7 & 22 & 2 & 7 & 24 & 3 & 7 & 5.1 & 0.4 & 7 & 44 & 1 & 7 & -0.4 & -0.2 \\
\hline De Jesus Spring & 261 & 37 & 2 & & & & & & & & & & 52 & 16 & 2 & 13 & 1 & 2 & 32 & 18 & 2 & 19 & 1 & 2 & 3.1 & 0.8 & 2 & 46 & 8 & 2 & 1 & \\
\hline Desert Dry Lake Well \#1 & 206 & & & & & & 218 & 15 & 2 & & & & 46 & 2 & 2 & 8.6 & 0.4 & 2 & 27 & 0.5 & 2 & 34 & 2 & 2 & 5.8 & 0.2 & 2 & 21 & 1 & 2 & 2 & 4 \\
\hline ER-12-1 & 221 & 13 & 4 & 0.3 & & & & & & & & & 343 & 9 & 7 & 17 & 0.4 & 7 & 64 & 4 & 7 & 37 & 2 & 7 & 3.6 & 0.5 & 7 & 94 & 6 & 7 & -2 & \\
\hline ER-12-2 & 300 & 12 & 4 & 5 & 3 & 4 & 286 & & & & & & 27.3 & 0.5 & 4 & 6.8 & 0.2 & 4 & 1.8 & 0.3 & 4 & 114 & 5 & 4 & 3.1 & 0.7 & 4 & 5.5 & 0.9 & 4 & 4 & 1 \\
\hline ER-19-1 & & & & 96 & & & & & & & & & 44 & & & 19 & & & 1.2 & & & 82 & & & 3.9 & & & 16 & & & 2 & \\
\hline ER-2-1 & 144 & 22 & 4 & 24 & 10 & 4 & 118 & & & 28 & & & 16.5 & 0.6 & 4 & 5.4 & 0.6 & 4 & 0.3 & 0.2 & 4 & 75 & 3 & 4 & 4.9 & 0.7 & 4 & 2.8 & \begin{tabular}{|l|}
0.7 \\
\end{tabular} & 4 & 3 & -1 \\
\hline ER-3-1 & \begin{tabular}{|l|}
584 \\
\end{tabular} & 106 & 4 & 0.2 & 0.1 & 2 & & & & & & & 67 & 2 & 4 & 42 & 1 & 4 & 34 & 1 & 4 & 139 & 4 & 3 & 18.3 & 0.8 & 4 & 91 & 3 & 4 & -6 & \\
\hline ER-5-3 & 176 & 24 & 6 & 7.3 & 8 & 2 & & & & & & & 39 & 4 & 6 & 14 & 1 & 6 & 3.4 & 0.3 & 5 & 64 & 10 & 4 & 5.0 & 0.9 & 7 & 12 & 2 & 5 & 9 & \\
\hline ER-5-3 \#2 & 626 & 50 & 4 & 0.1 & & & & & & & & & 69 & 3 & 4 & 38.3 & 0.5 & 4 & 30 & 2 & 4 & 129 & 14 & 4 & 17.0 & 0.9 & 4 & 80 & 4 & 4 & 2 & \\
\hline ER-5-4 & 268 & 32 & 3 & 25 & 15 & 3 & & & & & & & 120 & 0 & 3 & 27 & 1 & 3 & 0.1 & 0.1 & 3 & 161 & 32 & 3 & 10 & 2 & 4 & 2.0 & 0.2 & 4 & 9.2 & \\
\hline ER-5-4 \#2 & 360 & 17 & 4 & 22 & 8 & 4 & 275 & & & 11 & & & 117 & 5 & 4 & 52.0 & 0.1 & 4 & 0.2 & 0.1 & 2 & 319 & 11 & 4 & 6 & 1 & 4 & 0.6 & 0.1 & 2 & $\mid-1.2$ & -8.0 \\
\hline ER-6-1 & 238 & 26 & 6 & 0.1 & & & 228 & 27 & 3 & & & & 33.4 & 0.8 & 5 & 11 & 1 & 6 & 12 & 1 & 8 & 46 & 3 & 6 & 7.8 & 0.5 & 6 & 33 & 1 & 8 & 2 & -0.1 \\
\hline ER-6-1 \#2 & 244 & 0.2 & 4 & 0.6 & & & 219 & & & & & & 34.3 & 0.5 & 4 & 11 & 1 & 4 & 13.3 & 0.5 & 4 & 44 & 3 & 4 & 7.5 & 0.8 & 4 & 33 & 1 & 4 & 3 & -2 \\
\hline ER-6-2 & 373 & 19 & 5 & 0.7 & & & 261 & & & & & & 58 & 4 & 5 & 19 & 3 & 5 & 20 & 1 & 5 & 63 & 7 & 5 & 10.8 & 0.4 & 5 & 58 & 5 & 5 & 3 & -11 \\
\hline ER-7-1 & 241 & 6 & 4 & 0.6 & & & 209 & & & & & & 34.1 & \begin{tabular}{|l|}
0.2 \\
\end{tabular} & 4 & 11 & 1 & 4 & 14 & 0.5 & 4 & 47 & 4 & 4 & 7 & 1 & 4 & 34 & 5 & 4 & 0.2 & -5 \\
\hline Hagestad \#1 & 32 & 8 & 2 & 59 & 25 & 2 & & & & & & & 36 & 17 & 2 & 7 & 2 & 2 & & & & 79 & & & 4.2 & 0.3 & 2 & 1.6 & & & -2 & \\
\hline Hiko Spring & 263 & 13 & 3 & 1 & & & 272 & 14 & 2 & & & & 36 & 2 & 3 & 10 & 1 & 2 & 23.2 & 0.2 & 3 & 27 & 2 & 3 & 7.1 & 0.5 & 3 & 46 & 2 & 3 & -1 & 0.1 \\
\hline
\end{tabular}


Table H.1-1

Major-Ion Data for Yucca Flat/Climax Mine Geochemical Evaluation

(Page 2 of 5)

\begin{tabular}{|c|c|c|c|c|c|c|c|c|c|c|c|c|c|c|c|c|c|c|c|c|c|c|c|c|c|c|c|c|c|c|c|c|}
\hline \multirow{2}{*}{ Site Identification } & \multicolumn{3}{|c|}{$\begin{array}{c}\mathrm{HCO}_{3}, \mathrm{Lab} \\
\text { (mg/L) }\end{array}$} & \multicolumn{3}{|c|}{$\begin{array}{c}\mathrm{CO}_{3}, \mathrm{Lab} \\
(\mathrm{mg} / \mathrm{L})\end{array}$} & \multicolumn{3}{|c|}{$\begin{array}{c}\mathrm{HCO}_{3}, \text { Field } \\
(\mathrm{mg} / \mathrm{L})\end{array}$} & \multicolumn{3}{|c|}{$\begin{array}{c}\mathrm{CO}_{3} \text {, Field } \\
(\mathrm{mg} / \mathrm{L})\end{array}$} & \multicolumn{3}{|c|}{$\begin{array}{c}\mathrm{SO}_{4} \\
(\mathrm{mg} / \mathrm{L})\end{array}$} & \multicolumn{3}{|c|}{$\begin{array}{c}\mathrm{Cl} \\
(\mathrm{mg} / \mathrm{L})\end{array}$} & \multicolumn{3}{|c|}{$\begin{array}{c}\mathrm{Mg} \\
(\mathrm{mg} / \mathrm{L})\end{array}$} & \multicolumn{3}{|c|}{$\begin{array}{c}\mathrm{Na} \\
(\mathrm{mg} / \mathrm{L})\end{array}$} & \multicolumn{3}{|c|}{$\begin{array}{c}\mathrm{K} \\
(\mathrm{mg} / \mathrm{L})\end{array}$} & \multicolumn{3}{|c|}{$\begin{array}{c}\mathrm{Ca} \\
(\mathrm{mg} / \mathrm{L})\end{array}$} & \multirow{2}{*}{$\begin{array}{l}\text { C/B } \\
\text { Lab }\end{array}$} & \multirow{2}{*}{$\begin{array}{l}\text { C/B } \\
\text { Field }\end{array}$} \\
\hline & Avg & SD & $\mathbf{n}$ & Avg & SD & $n$ & Avg & SD & $\mathbf{n}$ & Avg & SD & $\mathbf{n}$ & Avg & SD & $\mathbf{n}$ & Avg & SD & $\mathbf{n}$ & Avg & SD & $\mathbf{n}$ & Avg & SD & $\mathbf{n}$ & Avg & SD & $\mathbf{n}$ & Avg & SD & $\mathbf{n}$ & & \\
\hline Indian Spring, BR & 160 & & & & & & & & & & & & 19.8 & & & 8.3 & & & 6.4 & & & 19 & & & 4.9 & & & 37 & & & -0.2 & \\
\hline Indian Spring, GR & 173 & & & & & & & & & & & & 31 & & & 9.4 & & & 7.1 & & & 39 & & & 0.9 & & & 30 & & & -1 & \\
\hline Marble \#3 & 310 & & & & & & & & & & & & 24 & & & 5.0 & & & 47 & & & 15 & & & 3.8 & & & 25 & & & -1 & \\
\hline Miner Spring & 485 & & & & & & & & & & & & 585 & & & 53 & & & 153 & & & 97 & & & 12 & & & 97 & & & -1 & \\
\hline MX Coal Valley Well & & & & & & & 239 & 20 & 2 & & & & 24 & 3 & 2 & 5.8 & 0.2 & 2 & 19.1 & 0.2 & 2 & 19 & 2 & 2 & 4.5 & 0.1 & 2 & 38 & 1 & 2 & & 4 \\
\hline Naquinta Spring & 180 & & & & & & & & & & & & 12 & & & 5.7 & & & \begin{tabular}{l|l}
11 \\
\end{tabular} & & & 25 & & & 1.1 & & & 32 & & & -2 & \\
\hline \multicolumn{33}{|l|}{ New Tikaboo Spring } \\
\hline Oak Spring & 113 & 2 & 5 & & & & & & & & & & 11 & 1 & 5 & 9.2 & 0.7 & 5 & 4.4 & 0.2 & 5 & 20.6 & 0.8 & 5 & 6.2 & 0.1 & 5 & 17.8 & 0.6 & 5 & 1 & \\
\hline \multicolumn{33}{|l|}{ Old Tikaboo Spring } \\
\hline Penoyer Well & 157 & & & 0.1 & & & & & & & & & 40.8 & & & 40 & & & 3.3 & & & 31 & & & 12.3 & & & 50 & & & 2 & \\
\hline Pine Spring, GR & 222 & & & 5 & & & & & & & & & 23.7 & & & 12 & & & 8.2 & & & 54 & & & \begin{tabular}{|l|}
2.5 \\
\end{tabular} & & & 32 & & & -0.5 & \\
\hline Pluto 1 & 150 & & & & & & & & & & & & 46.9 & & & 24 & & & 10 & & & 36 & & & 7.7 & & & 41 & & & 0.1 & \\
\hline Pluto 5 & 218 & & & & & & & & & & & & 54 & & & 12 & & & 22 & & & 26 & & & 4.3 & & & 55 & & & -0.1 & \\
\hline Quail Spring, GR & 166 & & & & & & & & & & & & 206 & & & 11 & & & 19 & & & 29 & & & 1.9 & & & 86 & & & \begin{tabular}{|l|}
1 \\
\end{tabular} & \\
\hline Quartz Spring & 420 & 35 & 3 & & & & & & & & & & 85 & 22 & 3 & 31 & 7 & 3 & 40 & 2 & 3 & 62 & 14 & 3 & 2.9 & 0.8 & 3 & 72 & 5 & 3 & 1 & \\
\hline Rabbitbrush Spring & 197 & & & & & & & & & & & & 27 & & & 9.0 & & & 9 & & & 25 & & & 3.5 & & & 42 & & & 0.5 & \\
\hline Rock Spring & 348 & & & & & & & & & & & & 35 & & & 5.8 & & & 19 & & & 13 & & & 1.7 & & & 87 & & & 1 & \\
\hline Rose Bud Spring & 400 & & & & & & & & & & & & 150 & & & 11 & & & 60 & & & 18 & & & 2.0 & & & 89 & & & -1 & \\
\hline Sand Spring, PW & 263 & 37 & 3 & 5 & 9 & 3 & & & & & & & 36 & 24 & 3 & 14 & 2 & 3 & 42 & 4 & 3 & 18 & 1 & 3 & 4.3 & 0.6 & 3 & 31 & 11 & 3 & 0.3 & \\
\hline Sand Spring, SSV & 111 & & & 33 & & & 126 & & & 37 & & & 22 & & & 3.6 & & & 11 & & & 37 & & & 11.4 & & & 16 & & & 0.1 & 5 \\
\hline Savio Spring & 268 & & & & & & & & & & & & 26 & & & 10 & & & 14 & & & 24 & & & 6.2 & & & 55 & & & 1 & \\
\hline \multicolumn{33}{|l|}{ Sharp Spring } \\
\hline \multicolumn{33}{|l|}{ The Seeps Spring } \\
\hline Tim Spring & 143 & 4 & 2 & & & & & & & & & & 38 & 1 & 2 & 11 & 0.0 & 2 & 27 & 1 & 2 & 13.2 & 0.2 & 2 & 2.92 & 0.02 & 2 & 18.8 & 0.4 & 2 & -1 & \\
\hline Tippipah Spring & 86 & 6 & 9 & & & & 90 & 7 & 6 & & & & 18 & 3 & 15 & 7.4 & 0.8 & 15 & 0.4 & 0.2 & 14 & 39.8 & 3 & 15 & 2.9 & 0.3 & 15 & 5.0 & 0.8 & 15 & 1 & 2 \\
\hline Topopah Spring & 52 & 9 & 6 & & & & & & & & & & 7.6 & 0.9 & 5 & 2.9 & 1.2 & 6 & 1.4 & 0.1 & \begin{tabular}{|l|}
6 \\
\end{tabular} & 11 & 1 & 6 & 6.0 & 0.9 & 6 & 6.7 & 0.4 & \begin{tabular}{|l|}
6 \\
\end{tabular} & 1 & \\
\hline TW-1 & 97 & 15 & 24 & 15 & 5 & 22 & 113 & 15 & 7 & & & & 7 & 2 & 20 & 3.3 & 0.3 & 23 & 0.2 & 0.1 & 22 & 50.4 & 2 & 24 & 0.6 & 0.3 & 21 & 2.1 & 2 & 23 & 2 & -4 \\
\hline TW-10 & 198 & 4 & 3 & & & & & & & & & & 14.3 & 0.6 & 3 & 5.7 & 0.9 & 3 & 18.0 & 1 & \begin{tabular}{|l|}
3 \\
\end{tabular} & \begin{tabular}{|l|}
7.2 \\
\end{tabular} & 0.4 & 3 & 1.9 & 1.2 & 2 & 38 & 2 & 3 & 0.1 & \\
\hline TW-3 & 336 & 11 & 2 & & & & 323 & & & & & & 75 & 12 & 2 & 23 & 0.1 & 2 & 20.4 & 0.9 & 2 & 81.3 & 2 & 2 & 8.4 & 1.1 & 2 & 50 & 2 & 2 & -1 & -2 \\
\hline TW-4 & 197 & & & & & & & & & & & & 17 & & & 6.1 & & & 17 & & & \begin{tabular}{|l|}
13 \\
\end{tabular} & & & 2.5 & & & 34 & & & 0.4 & \\
\hline
\end{tabular}


Table H.1-1

Major-Ion Data for Yucca Flat/Climax Mine Geochemical Evaluation

(Page 3 of 5)

\begin{tabular}{|c|c|c|c|c|c|c|c|c|c|c|c|c|c|c|c|c|c|c|c|c|c|c|c|c|c|c|c|c|c|c|c|c|}
\hline \multirow{2}{*}{ Site Identification } & \multicolumn{3}{|c|}{$\begin{array}{c}\mathrm{HCO}_{3}, \mathrm{Lab} \\
(\mathrm{mg} / \mathrm{L})\end{array}$} & \multicolumn{3}{|c|}{$\begin{array}{c}\mathrm{CO}_{3}, \mathrm{Lab} \\
(\mathrm{mg} / \mathrm{L})\end{array}$} & \multicolumn{3}{|c|}{$\begin{array}{c}\mathrm{HCO}_{3}, \text { Field } \\
(\mathrm{mg} / \mathrm{L})\end{array}$} & \multicolumn{3}{|c|}{$\begin{array}{c}\mathrm{CO}_{3}, \text { Field } \\
(\mathrm{mg} / \mathrm{L})\end{array}$} & \multicolumn{3}{|c|}{$\begin{array}{c}\mathrm{SO}_{4} \\
(\mathrm{mg} / \mathrm{L})\end{array}$} & \multicolumn{3}{|c|}{$\begin{array}{c}\mathrm{Cl} \\
(\mathrm{mg} / \mathrm{L})\end{array}$} & \multicolumn{3}{|c|}{$\begin{array}{c}\mathrm{Mg} \\
(\mathrm{mg} / \mathrm{L})\end{array}$} & \multicolumn{3}{|c|}{$\begin{array}{c}\mathrm{Na} \\
(\mathrm{mg} / \mathrm{L})\end{array}$} & \multicolumn{3}{|c|}{$\begin{array}{c}\mathrm{K} \\
(\mathrm{mg} / \mathrm{L})\end{array}$} & \multicolumn{3}{|c|}{$\begin{array}{c}\mathrm{Ca} \\
(\mathrm{mg} / \mathrm{L})\end{array}$} & \multirow{2}{*}{$\begin{array}{l}\text { C/B } \\
\text { Lab }\end{array}$} & \multirow{2}{*}{$\begin{array}{l}\text { C/B } \\
\text { Field }\end{array}$} \\
\hline & Avg & SD & $\mathbf{n}$ & Avg & SD & $n$ & Avg & SD & $\mathbf{n}$ & Avg & SD & $\mathbf{n}$ & Avg & SD & $\mathbf{n}$ & Avg & SD & $\mathbf{n}$ & Avg & SD & $\mathbf{n}$ & Avg & SD & $\mathbf{n}$ & Avg & SD & $\mathbf{n}$ & Avg & SD & $\mathbf{n}$ & & \\
\hline TW-7 & 286 & & & & & & & & & & & & 2 & & & 8.0 & & & 0.2 & & & \begin{tabular}{|l|l}
113 \\
\end{tabular} & & & 4.6 & & & 1 & & & -0.2 & \\
\hline TW-B & 163 & 16 & 4 & 0.7 & 0.5 & 3 & 122 & & & & & & 24 & 4 & 4 & 18 & 3 & 4 & 0.59 & 0.03 & 3 & 75 & 4 & 4 & 3.5 & 0.4 & 4 & 6 & 0.6 & 4 & 0.4 & -10 \\
\hline TW-D & 238 & 24 & 7 & 2 & 1 & 3 & & & & & & & 30 & 8 & 5 & 7.3 & 1.1 & 7 & 5.0 & 0.5 & 7 & 84 & 4 & 7 & 8.3 & 0.5 & 7 & 12 & 1 & 7 & -0.1 & \\
\hline TW-E & 58 & & & 1.8 & & & & & & & & & 1.1 & & & 8.2 & & & 0.6 & & & 17 & & & 1.7 & & & 10 & & & -2.1 & \\
\hline TW-F & 264 & & & & & & 254 & 15 & 2 & & & & 79 & 8 & 3 & 13 & 6 & 3 & 16.7 & 0.6 & 3 & 63 & 3 & 3 & 9.1 & 0.7 & 3 & 46 & 2 & 3 & -1 & -2 \\
\hline U12.03 UG-3 & 134 & 3 & 4 & & & & & & & & & & 14 & 2 & 4 & 10.5 & 0.9 & 4 & 4.6 & 0.5 & 4 & 25 & 1 & 3 & 4.9 & 0.9 & 3 & 23 & 6 & 4 & 2 & \\
\hline U-12e Tunnel & 171 & 6 & 17 & 3 & 2 & 14 & & & & & & & 23 & 5 & 19 & 9.2 & 1.0 & 19 & 0.53 & 0.04 & 18 & 74 & 1 & 17 & 3.5 & 1.2 & 19 & 5.9 & 0.8 & 18 & 1 & \\
\hline U-12n Tunnel & 146 & 29 & 33 & 9 & 7 & 27 & & & & & & & 24 & 11 & 33 & 10 & 3 & 35 & 0.7 & 0.4 & 34 & 63 & 8 & 34 & 7.3 & 1.3 & 34 & 10.2 & 3 & 34 & 1 & \\
\hline U-12s & & & & & & & 146 & & & & & & $<1$ & & & 14 & & & 0.13 & & & 24 & & & 5.0 & & & & 36 & & & -2 \\
\hline U-12t Tunnel & 122 & 22 & 24 & 5 & & & & & & & & & 22 & 6 & 23 & 10.4 & 0.9 & 24 & 2.1 & 1 & 23 & 43 & 12 & 23 & 6 & 1 & 23 & 11.2 & 5 & 24 & 5 & \\
\hline U-15.01 Shaft, C-30 & 167 & & & & & & & & & & & & 750 & & & 77 & & & 118 & & & 72 & & & 5.5 & & & 161 & & & -1 & \\
\hline U-15.01 Shaft, C-36 & 316 & & & & & & & & & & & & 325 & & & 52 & & & 63 & & & 56 & & & 4.8 & & & 126 & & & -2 & \\
\hline U-15.01 Shaft, CGW-1 & 163 & & & & & & & & & & & & 1,060 & & & 77 & & & 0.9 & & & 250 & & & 3.4 & & & 283 & & & 3 & \\
\hline U-15.01 Shaft, NH-01 & 65 & & & & & & & & & & & & 850 & & & 160 & & & 4.8 & & & 229 & & & 3.8 & & & 240 & & & 2 & \\
\hline U-15.01 Shaft, UG-02 & 165 & & & & & & & & & & & & 480 & & & 70 & & & 1.5 & & & 214 & & & 4.7 & & & 114 & & & -2 & \\
\hline $\mathrm{U}-2 \mathrm{bs}$ & 198 & 13 & 2 & & & & & & & & & & 25 & 5 & 2 & 7.5 & 2.6 & 2 & 0.5 & 0.3 & 2 & 79 & 0.0 & 2 & 6.0 & 0.6 & 2 & 3.1 & 0.9 & 2 & 3 & \\
\hline U-3cn \#5 & 263 & 46 & 13 & 7 & & & 271 & & & & & & 36 & 3 & 15 & 32 & 7 & 14 & 19 & 3 & 15 & 56 & 4 & 14 & 9 & 1 & 15 & 32 & 7 & 15 & 3 & 2 \\
\hline U-3cn PS \#2 & 272 & 23 & 4 & 0.6 & & & & & & & & & 21 & 2 & 4 & 8.0 & 0.8 & 4 & 3.4 & 0.1 & 4 & 92 & 6 & 4 & 19.3 & 1.5 & 4 & 14.5 & 0.4 & 4 & -2 & \\
\hline U-3mi & & & & & & & & & & & & & & & & & & & 3.7 & & & 122 & & & 8.0 & & & 19 & & & & \\
\hline U-4u PS \#2A & 155 & 13 & 3 & 0.4 & 0.3 & 2 & & & & & & & 11 & 1 & 3 & 6.0 & 0.8 & 3 & 5 & 5 & 3 & 73 & 6 & 3 & 20 & 11 & 3 & 12 & 5 & 3 & -16 & \\
\hline UE-10 ITS \#3 & 543 & & & 2 & & & & & & & & & 43 & & & 10 & & & 0.4 & & & 209 & & & 21.5 & & & 8 & & & 1 & \\
\hline UE-10j & 363 & 60 & 2 & 0.1 & & & & & & & & & 60 & & & 19 & 4 & 2 & 33 & 11 & 2 & 51 & 11 & 2 & 9 & 4 & 2 & 81 & 38 & 2 & -8 & \\
\hline UE-10j-1 & 552 & 68 & 2 & 0.1 & & & & & & & & & 79 & 5 & 2 & 23.9 & 0.2 & 2 & 45 & 3 & 2 & 68 & 6 & 2 & 13 & 1 & 2 & 107 & 8 & 2 & -4 & \\
\hline UE-10j-2 & 403 & & & 0.1 & & & & & & & & & 67 & & & 16 & & & 30 & & & 43 & & & 8.3 & & & 68 & & & 3 & \\
\hline UE-10j-3 & 322 & 38 & 2 & 0.2 & & & & & & & & & 59 & 3 & 2 & 12.8 & 0.4 & 2 & 27 & 2 & 2 & 37 & 3 & 2 & 7.3 & 0.6 & 2 & 60 & 6 & 2 & -1 & \\
\hline UE-11a & 217 & & & & & & & & & & & & 60 & & & 25 & & & 2.7 & & & 106 & & & 4.7 & & & 9.1 & & & 1 & \\
\hline UE-14b & 118 & 5 & 4 & 2.4 & 2 & 4 & & & & & & & 79 & 10 & 5 & 7.1 & 0.4 & 5 & 0.7 & 0.6 & 5 & 77 & 7 & 5 & 1.4 & 0.5 & 5 & 11 & 4 & 5 & 0.4 & \\
\hline UE-15d WW & 368 & 31 & 13 & & & & & & & & & & 44 & 10 & 15 & 15 & 2 & 15 & 16 & 2 & 15 & 81 & 16 & 14 & 16 & 1 & 14 & 48 & 8 & 15 & -1 & \\
\hline UE-15j & 908 & & & & & & & & & & & & 123 & & & 39 & & & 12 & & & 310 & & & 56 & & & 46 & & & 1 & \\
\hline UE-15j A-5 & 882 & 21 & 3 & & & & & & & & & & 112 & 2 & 3 & 37.7 & 0.6 & 3 & 12 & 0.0 & 3 & 297 & 20 & 3 & 51 & 3 & 3 & 47 & 0.6 & 3 & 1 & \\
\hline UE-16d WW & 340 & 40 & 13 & & & & 269 & 12 & 3 & & & & 59 & 1 & 13 & 11 & 2 & 16 & 24 & 2 & 16 & 31 & 4 & 15 & 6.7 & 0.5 & 15 & 76 & 6 & 16 & -1 & -10 \\
\hline
\end{tabular}


Table H.1-1

Major-Ion Data for Yucca Flat/Climax Mine Geochemical Evaluation

(Page 4 of 5)

\begin{tabular}{|c|c|c|c|c|c|c|c|c|c|c|c|c|c|c|c|c|c|c|c|c|c|c|c|c|c|c|c|c|c|c|c|c|}
\hline \multirow{2}{*}{ Site Identification } & \multicolumn{3}{|c|}{$\begin{array}{c}\mathrm{HCO}_{3}, \mathrm{Lab} \\
(\mathrm{mg} / \mathrm{L})\end{array}$} & \multicolumn{3}{|c|}{$\begin{array}{c}\mathrm{CO}_{3}, \mathrm{Lab} \\
(\mathrm{mg} / \mathrm{L})\end{array}$} & \multicolumn{3}{|c|}{$\begin{array}{c}\mathrm{HCO}_{3}, \text { Field } \\
(\mathrm{mg} / \mathrm{L})\end{array}$} & \multicolumn{3}{|c|}{$\begin{array}{c}\mathrm{CO}_{3}, \text { Field } \\
(\mathrm{mg} / \mathrm{L})\end{array}$} & \multicolumn{3}{|c|}{$\begin{array}{c}\mathrm{SO}_{4} \\
(\mathrm{mg} / \mathrm{L})\end{array}$} & \multicolumn{3}{|c|}{$\begin{array}{c}\mathrm{Cl} \\
(\mathrm{mg} / \mathrm{L})\end{array}$} & \multicolumn{3}{|c|}{$\begin{array}{c}\mathrm{Mg} \\
(\mathrm{mg} / \mathrm{L})\end{array}$} & \multicolumn{3}{|c|}{$\begin{array}{c}\mathrm{Na} \\
(\mathrm{mg} / \mathrm{L})\end{array}$} & \multicolumn{3}{|c|}{$\begin{array}{c}\mathrm{K} \\
(\mathrm{mg} / \mathrm{L})\end{array}$} & \multicolumn{3}{|c|}{$\begin{array}{c}\mathrm{Ca} \\
(\mathrm{mg} / \mathrm{L})\end{array}$} & \multirow{2}{*}{$\begin{array}{l}\text { C/B } \\
\text { Lab }\end{array}$} & \multirow{2}{*}{$\begin{array}{c}\text { C/B } \\
\text { Field }\end{array}$} \\
\hline & Avg & SD & $\mathbf{n}$ & Avg & SD & $\mathbf{n}$ & Avg & SD & $\mathbf{n}$ & Avg & SD & $\mathbf{n}$ & Avg & SD & $\mathbf{n}$ & Avg & SD & $\mathbf{n}$ & Avg & SD & $\mathbf{n}$ & Avg & SD & $\mathbf{n}$ & Avg & SD & $\mathbf{n}$ & Avg & SD & $\mathbf{n}$ & & \\
\hline UE-16f & 799 & & & 132 & & & & & & & & & 1.7 & & & 20 & & & 0.4 & & & 412 & & & 1.41 & & & 1.5 & & & 0.1 & \\
\hline UE-17a & 301 & 160 & 4 & 2 & 2 & 3 & & & & & & & 99 & 47 & 4 & 30 & 9 & 4 & 21 & 12 & 4 & 147 & 104 & 4 & 5 & 3 & 4 & 29 & 16 & 4 & -9 & \\
\hline UE-1a & 386 & 87 & 2 & 0.3 & & & & & & & & & 1 & & & 29 & 3 & 2 & 28 & 6 & 2 & 55 & 6 & 2 & 10.5 & 2.6 & 2 & 45 & 5 & 2 & \begin{tabular}{|l|}
-0.3 \\
\end{tabular} & \\
\hline UE-1b & 248 & & & & & & & & & & & & 20 & & & 6.8 & 1.3 & 2 & 13.6 & 0.1 & 2 & 31.4 & \begin{tabular}{|l|}
0.2 \\
\end{tabular} & 2 & 11.1 & 0.6 & 2 & 37.7 & \begin{tabular}{|l|}
0.4 \\
\end{tabular} & 2 & 1 & \\
\hline UE-1c & 241 & 4 & 2 & & & & & & & & & & 33 & 1 & 2 & 6.3 & 1.0 & 4 & 13.6 & 0.3 & 4 & 34 & 1 & 4 & 12.6 & 0.3 & 4 & 36 & 2 & 4 & 1 & \\
\hline UE-1h & 270 & & & 2 & & & & & & & & & 3 & & & 43.4 & 0.3 & 2 & 9 & 2 & 2 & 101 & 1 & 2 & 24 & 1 & 2 & 13 & 3 & 2 & -5 & \\
\hline UE-1q & 197 & 12 & 3 & 1 & & & 195 & & & & & & 24 & 3 & 2 & 11 & 6 & 4 & 14 & 1 & 4 & 39 & 11 & 4 & 7 & 3 & 4 & 24 & 6 & 4 & -3 & -3 \\
\hline UE-2ce & 405 & 31 & 3 & 0.09 & & & 402 & & & & & & 11 & 19 & 4 & 17 & 50 & 3 & 25 & 8 & 5 & 40 & 10 & 5 & 21 & 6 & 5 & 53 & 22 & 5 & 2 & 2 \\
\hline \multicolumn{33}{|l|}{ UE-4t } \\
\hline UE-4t 1 & 224 & & & 17.1 & & & & & & & & & 25.8 & & & \begin{tabular}{|l|}
19.7 \\
\end{tabular} & & & 0.12 & & & 154 & & & 6.8 & & & 1.1 & & & 3 & \\
\hline UE-5 PW-1 & 154 & 10 & 5 & 2 & 1 & 2 & 125 & 4 & 2 & & & & 35 & 2 & 17 & 10 & 1 & 17 & 5 & 0.4 & 7 & 56 & 3 & 20 & 6.2 & 0.3 & 7 & 14.3 & 1.6 & 7 & 5 & -2.4 \\
\hline UE-5 PW-2 & 157 & 9 & 6 & 6 & 4 & 2 & 122 & & & & & & 28 & 1 & 14 & 9.1 & 1.8 & 15 & 6.2 & 0.7 & 6 & 50 & 3 & 15 & 5.4 & 0.3 & 6 & 16.6 & \begin{tabular}{|l|}
1.3 \\
\end{tabular} & 6 & 4 & -6.2 \\
\hline UE-5 PW-3 & 150 & 21 & 8 & 3 & 5 & 3 & 116 & 22 & 3 & & & & 31 & 2 & 16 & \begin{tabular}{|l|}
9.0 \\
\end{tabular} & 0.9 & 17 & 5.6 & 0.8 & 8 & 54 & 3 & 18 & 5 & 1 & 8 & 16.2 & \begin{tabular}{|l|}
1.1 \\
\end{tabular} & 8 & 6 & -3.1 \\
\hline UE-5c WW & 172 & 15 & 13 & 6 & 4 & 6 & 160 & 33 & 2 & 7 & & & 44 & 8 & 13 & 12 & 8 & 13 & 1.8 & 0.5 & 13 & 86 & 6 & 12 & 6.2 & 0.7 & 12 & 8.1 & \begin{tabular}{|l|}
0.9 \\
\end{tabular} & 8 & 0.4 & -1.4 \\
\hline UE-5n & 162 & 13 & 5 & 10 & 9 & 5 & 172 & & & 9 & & & 32 & 6 & 6 & 14 & 3 & 6 & 1.8 & \begin{tabular}{|l|}
0.4 \\
\end{tabular} & 7 & 81 & 5 & 6 & 8.4 & 0.5 & 7 & 7.1 & \begin{tabular}{|l|}
1.5 \\
\end{tabular} & 7 & \begin{tabular}{|l|}
-0.5 \\
\end{tabular} & \begin{tabular}{|l|}
0.9 \\
\end{tabular} \\
\hline UE-6d & 245 & & & 0.5 & & & & & & & & & 19 & & & 8.2 & & & 10 & & & 58 & & & 11.6 & & & 21 & & & 1 & \\
\hline UE-7nS & 167 & 47 & 4 & 0.4 & & & 207 & & & & & & 0.8 & 0.7 & 3 & 27 & 6 & 3 & 3.5 & 0.4 & 5 & 58 & 6 & 5 & 4.6 & 0.4 & 4 & 20 & 1 & 5 & -5 & 4 \\
\hline Watertown 1 & 176 & 16 & 5 & 0.2 & 0.2 & 2 & & & & & & & 24 & 9 & 4 & 6.8 & 1.3 & 5 & 1.7 & 0.5 & 5 & 71 & 4 & 5 & 8.6 & 0.4 & 4 & 5 & 1 & 5 & 0.4 & \\
\hline Watertown 2 & 211 & 6 & 2 & 2 & & & & & & & & & 17 & 3 & 2 & 6.3 & 0.5 & 2 & 1.1 & 0.1 & 2 & 85 & 2 & 2 & 9.6 & 0.6 & 2 & 4 & 2 & 2 & -0.1 & \\
\hline Watertown 3 & 188 & 15 & 12 & 0.1 & 0.3 & 6 & & & & & & & 22 & 10 & 11 & 8.9 & 2.1 & 12 & 4.1 & 2 & 12 & 56 & 4 & 12 & 6.9 & 0.6 & 7 & 18 & 3 & 12 & 1 & \\
\hline Watertown 4 & 533 & 66 & 2 & 0.2 & & & 507 & & & & & & 69 & 1 & 2 & 12 & 1 & 2 & 23 & 2 & 2 & 82.5 & \begin{tabular}{|l|}
0.7 \\
\end{tabular} & 2 & 23.9 & 1.3 & 2 & 83.0 & 0.04 & 2 & 2 & -0.5 \\
\hline Wheelbarrow Spring & 164 & & & & & & & & & & & & 22 & & & 15 & & & 6.0 & & & 42 & & & 3.6 & & & 24 & & & -1 & \\
\hline White Rock Spring, SR & & & & & & & 275 & 21 & 2 & & & & 12 & & & 10 & 1 & 2 & 30 & 1 & 2 & 14.5 & 0.7 & 2 & 7.2 & 0.3 & 2 & 37.5 & 0.7 & 2 & & -1 \\
\hline Whiterock Spring, YF & 80 & 5 & 53 & & & & 57 & 25 & 3 & & & & 31 & 5 & 55 & 10 & 2 & 56 & 0.7 & 0.4 & 54 & 43 & 5 & 56 & 6 & 0.9 & 56 & 6 & 1 & 56 & 1 & -8 \\
\hline Wiregrass Spring & 386 & & & & & & 367 & 13 & 8 & & & & 7 & 1 & 10 & 3.0 & 0.4 & 10 & 34 & 1 & 11 & 2.9 & 0.2 & 10 & 1.6 & 1.5 & 10 & 70 & 2 & 10 & 2 & -1 \\
\hline WW-1 & 165 & & & & & & & & & & & & 38 & & & 5.9 & & & 1.6 & & & 73 & & & 9 & & & 5.5 & & & -1 & \\
\hline WW-2 & 202 & 28 & 18 & & & & & & & & & & 20 & 6 & 18 & \begin{tabular}{|l|}
7.4 \\
\end{tabular} & 1.9 & 17 & 15 & 3 & 18 & 28 & 2 & 17 & 6.6 & 0.6 & 17 & 30 & 8 & 12 & $|-0.5|$ & \\
\hline WW-3 & 194 & 3 & 8 & & & & & & & & & & 21 & 1 & 8 & 5.8 & 1.2 & 8 & 12 & 1 & 8 & 39 & 1 & 8 & 7.6 & 0.4 & 8 & 20 & 1 & 8 & \begin{tabular}{|l|}
0.4 \\
\end{tabular} & \\
\hline WW-4 & 150 & 15 & 12 & 8 & 7 & 3 & & & & & & & 42 & 2 & 12 & 12 & 2 & 13 & 8.0 & 0.9 & 13 & 50 & 1 & 11 & 5.0 & 0.2 & 11 & 23 & 1 & 12 & \begin{tabular}{|l|}
1 \\
\end{tabular} & \\
\hline WW-4A & 150 & 12 & 7 & 2 & 3 & 3 & 145 & & & & & & 40 & 3 & 7 & 11 & 1 & 7 & 7.5 & 0.7 & 7 & 52 & 3 & 7 & 5.6 & 0.4 & 7 & 24 & 2 & 7 & -3 & -5 \\
\hline
\end{tabular}


Table H.1-1

Major-Ion Data for Yucca Flat/Climax Mine Geochemical Evaluation

(Page 5 of 5)

\begin{tabular}{|c|c|c|c|c|c|c|c|c|c|c|c|c|c|c|c|c|c|c|c|c|c|c|c|c|c|c|c|c|c|c|c|c|}
\hline \multirow{2}{*}{ Site Identification } & \multicolumn{3}{|c|}{$\begin{array}{c}\mathrm{HCO}_{3}, \mathrm{Lab} \\
\text { (mg/L) }\end{array}$} & \multicolumn{3}{|c|}{$\begin{array}{c}\mathrm{CO}_{3}, \mathrm{Lab} \\
(\mathrm{mg} / \mathrm{L})\end{array}$} & \multicolumn{3}{|c|}{$\begin{array}{c}\mathrm{HCO}_{3}, \text { Field } \\
(\mathrm{mg} / \mathrm{L})\end{array}$} & \multicolumn{3}{|c|}{$\begin{array}{c}\mathrm{CO}_{3} \text {, Field } \\
(\mathrm{mg} / \mathrm{L})\end{array}$} & \multicolumn{3}{|c|}{$\begin{array}{c}\mathrm{SO}_{4} \\
\text { (mg/L) }\end{array}$} & \multicolumn{3}{|c|}{$\begin{array}{c}\mathrm{Cl} \\
(\mathrm{mg} / \mathrm{L})\end{array}$} & \multicolumn{3}{|c|}{$\begin{array}{c}\mathrm{Mg} \\
(\mathrm{mg} / \mathrm{L})\end{array}$} & \multicolumn{3}{|c|}{$\begin{array}{c}\mathrm{Na} \\
(\mathrm{mg} / \mathrm{L})\end{array}$} & \multicolumn{3}{|c|}{$\begin{array}{c}\mathrm{K} \\
(\mathrm{mg} / \mathrm{L})\end{array}$} & \multicolumn{3}{|c|}{$\begin{array}{c}\mathrm{Ca} \\
\text { (mg/L) }\end{array}$} & \multirow{2}{*}{$\begin{array}{l}\text { C/B } \\
\text { Lab }\end{array}$} & \multirow{2}{*}{$\begin{array}{c}\text { C/B } \\
\text { Field }\end{array}$} \\
\hline & Avg & SD & $\mathbf{n}$ & Avg & SD & $\mathbf{n}$ & Avg & SD & $\mathbf{n}$ & Avg & SD & $n$ & Avg & SD & $\mathbf{n}$ & Avg & SD & $\mathbf{n}$ & Avg & SD & $\mathbf{n}$ & Avg & SD & $\mathbf{n}$ & Avg & SD & $\mathbf{n}$ & Avg & SD & $n$ & & \\
\hline WW-5A & 332 & 28 & 10 & 22 & 10 & 10 & 229 & & & 22 & & & 26 & 6 & 10 & 11 & 2 & 10 & 0.7 & 0.2 & 8 & 158 & 9 & 10 & 5.9 & 0.5 & 8 & 2.2 & 0.5 & 9 & 0.1 & -13 \\
\hline WW-5B & 166 & 19 & 29 & 10 & 7 & 14 & 102 & & & 7 & & & 55 & 7 & 29 & 23 & 2 & 28 & 2 & 0.7 & 28 & 98 & 17 & 28 & 11.3 & 1.3 & 26 & 7 & 3 & 29 & $\mid-0.1$ & -13 \\
\hline WW-5C & 281 & 54 & 37 & 20 & 9 & 21 & 244 & 121 & 2 & 7 & & & 26 & 4 & 38 & 10 & 2 & 38 & 0.8 & 0.9 & 34 & 138 & 42 & 37 & 6.7 & 1.2 & 35 & 2 & 2 & 38 & $|-0.7|$ & -9.7 \\
\hline WW-A & 212 & 8 & 23 & & & & & & & & & & 19 & 3 & 25 & 9 & 6 & 25 & 7 & 1 & 25 & 52 & 3 & 25 & 9.0 & 1.6 & 25 & 22 & 3 & 15 & 1 & \\
\hline WW-C & 544 & 85 & 37 & 0.2 & & & & & & & & & 66 & 5 & 36 & 36 & 6 & 39 & 30 & 4 & 38 & 127 & 7 & 35 & 15.0 & 3.3 & 34 & 67 & 10 & 37 & -1 & \\
\hline WW-C-1 & 548 & 94 & 27 & 3 & 4 & 2 & 580 & & & & & & 66 & 2 & 26 & 35 & 3 & 28 & 30 & 2 & 26 & 124 & 5 & 27 & 14 & 1 & 26 & 69 & 10 & 27 & $|-0.7|$ & -1.1 \\
\hline
\end{tabular}

Avg $=$ Average

$\mathrm{BR}=$ Belted Range

$\mathrm{C} / \mathrm{B}$ Field $=$ Charge balance calculated using $\mathrm{HCO}_{3}$ and $\mathrm{CO}_{3}$ measured in the field

$\mathrm{C} / \mathrm{B} \mathrm{Lab}=$ Charge balance calculated using $\mathrm{HCO}_{3}$ and $\mathrm{CO}_{3}$ measured in the lab

$\mathrm{FF}=$ Frenchman Flat

$\mathrm{GR}=$ Groom Range

$\mathrm{n}=$ Number of independent measurements

$\mathrm{PW}=$ Pintwater Range

SR = Sheep Range

SSV = Sandy Spring Valley

YF = Yucca Flat 
Table H.1-2

Isotope Data for Yucca Flat/Climax Mine Geochemical Evaluation

(Page 1 of 5)

\begin{tabular}{|c|c|c|c|c|c|c|c|c|c|c|c|c|c|c|c|}
\hline \multirow[t]{2}{*}{ Site Identification } & \multicolumn{3}{|c|}{$\begin{array}{c}\delta D \\
\text { (permil) }\end{array}$} & \multicolumn{3}{|c|}{$\begin{array}{c}\delta^{18} \mathrm{O} \\
\text { (permil) }\end{array}$} & \multicolumn{3}{|c|}{$\begin{array}{c}\delta^{13} \mathrm{C} \\
\text { (permil) }\end{array}$} & \multicolumn{3}{|c|}{$\begin{array}{c}{ }^{14} \mathrm{C} \\
(\mathrm{pmc})\end{array}$} & \multicolumn{3}{|c|}{$\begin{array}{c}{ }^{36} \mathrm{Cl} / \mathrm{Cl} \\
\text { (ratio) }\end{array}$} \\
\hline & Avg & SD & $\mathbf{n}$ & Avg & SD & $\mathbf{n}$ & Avg & SD & $\mathbf{n}$ & Avg & SD & $\mathbf{n}$ & Avg & SD & $\mathbf{n}$ \\
\hline Alum Spring & -87 & & & -9.6 & & & -9.6 & & & & & & & & \\
\hline April Fool Spring & -94 & 5 & 3 & -11.2 & 1.3 & 3 & -8.2 & 0.4 & 2 & & & & & & \\
\hline Army \#1 WW & -101 & 2 & 8 & -13.5 & 0.3 & 6 & -6.0 & 0.7 & 4 & 4 & 1.3 & 3 & $4.25 \mathrm{E}-13$ & 3.7E-15 & 2 \\
\hline Ash Spring & -109 & 2 & 5 & -14.2 & 0.1 & 2 & -6.0 & 1.2 & 3 & 6.3 & 0.5 & 3 & $6.51 \mathrm{E}-13$ & & \\
\hline Bullwhack Spring & -90 & 3 & 2 & -9.3 & 1.3 & 2 & -6.4 & & & & & & & & \\
\hline Cane Spring, FF & -90 & 2 & 25 & -11.0 & 0.5 & 35 & -9.6 & 0.9 & 10 & 86 & 9.3 & 2 & & & \\
\hline Cane Spring, GR & -90 & 3 & 2 & -11.3 & 2.6 & 2 & -7.6 & & & & & & & & \\
\hline Captain Jack Spring & -102 & 1 & 2 & -12.6 & 0.8 & 7 & & & & & & & & & \\
\hline Cattle Spring & -88 & 4 & 2 & -8.8 & 0.8 & 2 & -11.4 & & & & & & & & \\
\hline Cliff Spring, BR & -97 & & & -13.0 & & & & & & & & & & & \\
\hline Cliff Spring, GR & -92 & 6 & 2 & -12.0 & 1.6 & 2 & -10.9 & 0.6 & 2 & & & & & & \\
\hline Cow Camp Spring & -93 & 2 & 3 & -12.7 & 0.2 & 3 & & & & & & & & & \\
\hline Cresent Spring & -95 & & & -12.6 & & & -8.5 & & & & & & & & \\
\hline Crystal Spring & -108.6 & 0.9 & 9 & -14.35 & 0.05 & 4 & -5.9 & 0.9 & 5 & 7.0 & 1.1 & 2 & & & \\
\hline De Jesus Spring & -96 & 6 & 2 & -12.6 & 0.8 & 2 & -10.3 & 2.5 & 2 & & & & & & \\
\hline Desert Dry Lake Well \#1 & -98.5 & 0.7 & 2 & -13.0 & 0.1 & 2 & -5.3 & & & 1 & & & & & \\
\hline ER-12-1 & -94 & & & -12.5 & 0.1 & 3 & -9.6 & 0.6 & 2 & 11 & 0.1 & 2 & $7.80 \mathrm{E}-13$ & & \\
\hline ER-12-2 & -101.1 & 0.1 & 2 & -13.7 & 0.2 & 2 & -5.5 & 0.9 & 2 & 2 & & & $6.90 \mathrm{E}-13$ & & \\
\hline ER-19-1 & -105 & & & -13.9 & & & -14.3 & & & & & & & & \\
\hline ER-2-1 & -108 & 2 & 2 & -14.3 & 0.1 & 2 & -11.5 & 0.8 & 2 & 18 & & & $7.19 \mathrm{E}-13$ & & \\
\hline ER-3-1 & -109 & 3 & 3 & -14.1 & 0.1 & 3 & -2.3 & 0.9 & 3 & 1 & 0.1 & 3 & $1.31 \mathrm{E}-13$ & 3.7E-15 & 2 \\
\hline ER-5-3 & -108 & 1 & 2 & -14.0 & 0.1 & 2 & -7.9 & 0.1 & 2 & 9 & & & $8.42 \mathrm{E}-13$ & & \\
\hline ER-5-3 \#2 & -108 & 3 & 2 & -14.1 & 0.1 & 2 & -4.4 & 0.1 & 2 & 2 & & & $2.29 \mathrm{E}-13$ & & \\
\hline ER-5-4 & -108 & 2 & 2 & -13.7 & 0.1 & 2 & -4.6 & 0.1 & 2 & 1.5 & & & 3.94E-13 & & \\
\hline ER-5-4 \#2 & -102 & 2 & 2 & -13.3 & 0.0 & 2 & -0.1 & 0.4 & 2 & 1 & & & $1.76 \mathrm{E}-13$ & & \\
\hline ER-6-1 & -106 & 2 & 2 & -14.0 & 0.0 & 3 & -6.7 & 0.6 & 2 & 2.2 & 0.2 & 2 & $3.92 \mathrm{E}-13$ & & \\
\hline ER-6-1 \#2 & -106 & 1 & 2 & -14.1 & 0.1 & 2 & -6.2 & 0.4 & 2 & 2.4 & & & 4.33E-13 & & \\
\hline
\end{tabular}


Table H.1-2

Isotope Data for Yucca Flat/Climax Mine Geochemical Evaluation

(Page 2 of 5 )

\begin{tabular}{|c|c|c|c|c|c|c|c|c|c|c|c|c|c|c|c|}
\hline \multirow[t]{2}{*}{ Site Identification } & \multicolumn{3}{|c|}{$\begin{array}{c}\delta D \\
\text { (permil) }\end{array}$} & \multicolumn{3}{|c|}{$\begin{array}{c}\delta^{18} O \\
\text { (permil) }\end{array}$} & \multicolumn{3}{|c|}{$\begin{array}{c}\delta^{13} \mathbf{C} \\
\text { (permil) }\end{array}$} & \multicolumn{3}{|c|}{$\begin{array}{c}{ }^{14} \mathrm{C} \\
(\mathrm{pmc})\end{array}$} & \multicolumn{3}{|c|}{$\begin{array}{l}{ }^{36} \mathrm{Cl} / \mathrm{Cl} \\
\text { (ratio) }\end{array}$} \\
\hline & Avg & SD & $\mathbf{n}$ & Avg & SD & $\mathbf{n}$ & Avg & SD & $\mathbf{n}$ & Avg & SD & $\mathbf{n}$ & Avg & SD & $\mathbf{n}$ \\
\hline ER-6-2 & -106 & & & -14.1 & 0.1 & 2 & -4.3 & 0.4 & 2 & & & & $2.00 \mathrm{E}-13$ & & \\
\hline ER-7-1 & -106 & 0.0 & 2 & -14.0 & 0.1 & 2 & -6.3 & 0.6 & 2 & 5.3 & & & 3.77E-13 & & \\
\hline \multicolumn{16}{|l|}{ Hagestad \#1 } \\
\hline Hiko Spring & -109 & 2 & 7 & -14.4 & 0.7 & 4 & -5.9 & 1.0 & 3 & 6.2 & 0.4 & 2 & $6.08 \mathrm{E}-13$ & & \\
\hline Indian Spring, BR & -96 & & & -13.2 & & & & & & & & & & & \\
\hline Indian Spring, GR & -83 & 8 & 2 & -9.3 & 1.5 & 2 & -5.5 & & & & & & & & \\
\hline \multicolumn{16}{|l|}{ Marble \#3 } \\
\hline Miner Spring & -82 & & & -8.9 & & & & & & & & & & & \\
\hline Naquinta Spring & -89 & & & -10.7 & & & -7.7 & & & 62 & & & & & \\
\hline New Tikaboo Spring & -86 & & & -10.3 & & & -8.2 & & & & & & & & \\
\hline Oak Spring & -101 & 7 & 2 & -12.5 & 0.3 & 5 & & & & & & & & & \\
\hline Old Tikaboo Spring & -84 & & & -8.5 & & & -5.2 & & & & & & & & \\
\hline Penoyer Well & -118 & & & -15.1 & & & -8.9 & & & 25 & & & & & \\
\hline Pine Spring, GR & -80 & & & -8.9 & & & -7.6 & & & & & & & & \\
\hline \multicolumn{16}{|l|}{ Pluto 1} \\
\hline Pluto 5 & -76 & & & -7.1 & & & & & & & & & & & \\
\hline Quail Spring, GR & -91 & 2 & 2 & -11.2 & 1.0 & 2 & -10.6 & & & & & & & & \\
\hline Quartz Spring & -86 & 2 & 3 & -11.1 & 0.5 & 3 & -10.3 & 1.7 & 3 & 98 & & & & & \\
\hline Rabbitbrush Spring & -88 & 1 & 2 & -10.1 & 1.6 & 2 & -11.5 & & & & & & & & \\
\hline Rock Spring & -86 & & & -10.9 & & & $\begin{array}{l}-9.8 \\
\end{array}$ & & & 81 & & & & & \\
\hline \multicolumn{16}{|l|}{ Rose Bud Spring } \\
\hline Sand Spring, PW & -88 & & & -11.9 & & & -5.3 & & & & & & & & \\
\hline Sand Spring, SSV & -107 & & & 14.3 & & & 3.2 & & & & & & & & \\
\hline \multicolumn{16}{|l|}{ Savio Spring } \\
\hline Sharp Spring & -86 & & & -9.5 & & & -9.0 & & & & & & & & \\
\hline The Seeps Spring & -98 & & & -13.3 & & & & & & & & & & & \\
\hline Tim Spring & -99 & 1 & 2 & -13.1 & 0.1 & 2 & -8.5 & 0.6 & 2 & & & & & & \\
\hline Tippipah Spring & $\begin{array}{l}-95 \\
\end{array}$ & 5 & 2 & -12.3 & 1.0 & 6 & & & & & & & & & \\
\hline
\end{tabular}


Table H.1-2

Isotope Data for Yucca Flat/Climax Mine Geochemical Evaluation

(Page 3 of 5)

\begin{tabular}{|c|c|c|c|c|c|c|c|c|c|c|c|c|c|c|c|}
\hline \multirow{2}{*}{ Site Identification } & \multicolumn{3}{|c|}{$\begin{array}{c}\delta D \\
\text { (permil) }\end{array}$} & \multicolumn{3}{|c|}{$\begin{array}{c}\delta^{18} O \\
\text { (permil) }\end{array}$} & \multicolumn{3}{|c|}{$\begin{array}{c}\delta^{13} \mathrm{C} \\
\text { (permil) }\end{array}$} & \multicolumn{3}{|c|}{$\begin{array}{c}{ }^{14} \mathrm{C} \\
(\mathrm{pmc})\end{array}$} & \multicolumn{3}{|c|}{$\begin{array}{c}{ }^{36} \mathrm{Cl} / \mathrm{Cl} \\
\text { (ratio) }\end{array}$} \\
\hline & Avg & SD & $\mathbf{n}$ & Avg & SD & $\mathbf{n}$ & Avg & SD & $\mathbf{n}$ & Avg & SD & $\mathbf{n}$ & Avg & SD & $\mathbf{n}$ \\
\hline Topopah Spring & -88 & & & -12.3 & 0.6 & 7 & & & & & & & & & \\
\hline TW-1 & -110 & 1 & 15 & -15.0 & 0.2 & 16 & -11.2 & 1.0 & 3 & 30 & & & $9.68 \mathrm{E}-13$ & & \\
\hline \multicolumn{16}{|l|}{ TW-10 } \\
\hline TW-3 & -103.5 & 0.7 & 2 & -14.2 & 0.0 & 2 & -9.2 & & & 37 & & & & & \\
\hline \multicolumn{16}{|l|}{ TW-4 } \\
\hline \multicolumn{16}{|l|}{ TW-7 } \\
\hline TW-B & -106.0 & 0.8 & 4 & -13.8 & 0.3 & 4 & -10.4 & 0.4 & 2 & 20 & & & 8.00E-13 & & \\
\hline TW-D & -108 & 4 & 2 & -14.2 & 0.1 & 2 & -5.5 & & & 3 & & & & & \\
\hline TW-E & -112 & & & -14.6 & & & & & & & & & & & \\
\hline \multicolumn{16}{|l|}{ TW-F } \\
\hline \multicolumn{16}{|l|}{ U12.03 UG-3 } \\
\hline U12n.03 Tunnel & -97.5 & 1.9 & 47 & -13.4 & 0.3 & 47 & & & & & & & & & \\
\hline U12n.05 Tunnel & -94.4 & 1.6 & 44 & -13.0 & 0.3 & 44 & & & & & & & & & \\
\hline *U-12e main (0+100' bulkhead) & -103.6 & & & -13.7 & & & & & & & & & & & \\
\hline *U-12e south (0+1350' bulkhead) & -102.5 & & & -13.6 & & & & & & & & & & & \\
\hline *U-12n (0+1940' bulkhead) & -101.3 & & & -13.4 & & & & & & & & & & & \\
\hline *U-12t (0+1700’ bulkhead) & -102.5 & & & -13.8 & & & & & & & & & & & \\
\hline *U-12t (0+2100’ bulkhead) & -101.1 & & & -13.7 & & & & & & & & & & & \\
\hline$U-12 s$ & -94 & & & -12.6 & & & & & & 100 & & & 3.35E-13 & & \\
\hline \multicolumn{16}{|l|}{ U-15.01 Shaft, C-30 } \\
\hline \multicolumn{16}{|l|}{ U-15.01 Shaft, C-36 } \\
\hline U-15.01 Shaft, CGW-1 & -93 & & & -12.7 & & & -4.1 & & & & & & & & \\
\hline \multicolumn{16}{|l|}{ U-15.01 Shaft, NH-01 } \\
\hline \multicolumn{16}{|l|}{ U-15.01 Shaft, UG-02 } \\
\hline \multicolumn{16}{|l|}{$\mathrm{U}-2 \mathrm{bs}$} \\
\hline U-3cn \#5 & -104 & 2 & 2 & -14.1 & 0.03 & 2 & -6.8 & 1.0 & 2 & 3 & & & $4.08 \mathrm{E}-13$ & & \\
\hline U-3cn PS \#2 & -103.3 & 0.6 & 3 & -13.9 & 0.1 & 4 & -6.8 & 1.2 & 3 & & & & 1.24E-09 & & \\
\hline
\end{tabular}


Table H.1-2

Isotope Data for Yucca Flat/Climax Mine Geochemical Evaluation

(Page 4 of 5)

\begin{tabular}{|c|c|c|c|c|c|c|c|c|c|c|c|c|c|c|c|}
\hline \multirow{2}{*}{ Site Identification } & \multicolumn{3}{|c|}{$\begin{array}{c}\delta D \\
\text { (permil) }\end{array}$} & \multicolumn{3}{|c|}{$\begin{array}{c}\delta^{18} O \\
\text { (permil) }\end{array}$} & \multicolumn{3}{|c|}{$\begin{array}{c}\delta^{13} \mathrm{C} \\
\text { (permil) }\end{array}$} & \multicolumn{3}{|c|}{$\begin{array}{c}{ }^{14} \mathrm{C} \\
(\mathrm{pmc})\end{array}$} & \multicolumn{3}{|c|}{$\begin{array}{c}{ }^{36} \mathrm{Cl} / \mathrm{Cl} \\
\text { (ratio) }\end{array}$} \\
\hline & Avg & SD & $\mathbf{n}$ & Avg & SD & $\mathbf{n}$ & Avg & SD & $\mathbf{n}$ & Avg & SD & $\mathbf{n}$ & Avg & SD & $\mathbf{n}$ \\
\hline \multicolumn{16}{|l|}{ U-3mi } \\
\hline U-4u PS \#2A & -101.5 & 0.1 & 2 & -13.0 & 0.1 & 3 & -9.1 & 0.5 & 3 & & & & $4.45 \mathrm{E}-08$ & & \\
\hline UE-10 ITS \#3 & -107 & & & -13.5 & & & & & & & & & & & \\
\hline UE-10j & -104 & & & -13.3 & 0.2 & 2 & -5.0 & & & 7 & 5.3 & 2 & $2.76 \mathrm{E}-13$ & & \\
\hline UE-10j-1 & -104 & 4 & 2 & -13.6 & 0.1 & 2 & -3.6 & 1.3 & 2 & 7 & 0.0 & 2 & $2.41 \mathrm{E}-13$ & & \\
\hline UE-10j-2 & -102 & 5 & 2 & -13.2 & 0.1 & 2 & -5.7 & 0.9 & 2 & 11 & & & 3.91E-13 & & \\
\hline UE-10j-3 & -100 & 4 & 2 & -12.8 & 0.1 & 3 & -7.7 & 0.3 & 3 & 13 & 0.0 & 2 & $4.45 \mathrm{E}-13$ & & \\
\hline UE-11a & -111 & & & -14.3 & & & & & & & & & & & \\
\hline UE-14b & -110 & 2 & 5 & -14.4 & 0.04 & 5 & -9.9 & 0.1 & 2 & & & & & & \\
\hline UE-15d WW & -105 & 5 & 3 & -14.2 & 0.1 & 3 & -4.1 & & & 6 & & & & & \\
\hline \multicolumn{16}{|l|}{ UE-15j } \\
\hline \multicolumn{16}{|l|}{ UE-15j A-5 } \\
\hline UE-16d WW & -95.5 & 0.7 & 2 & -12.6 & 0.2 & 5 & -8.9 & 1.3 & 5 & 7 & 0.8 & 2 & 6.36E-13 & & \\
\hline UE-16f & -104.5 & 0.7 & 2 & -14.0 & 0.8 & 3 & -9.8 & 2.0 & 3 & 3 & & & $3.12 E-13$ & & \\
\hline UE-17a & -100 & 0.0 & 2 & -13.1 & 0.4 & 3 & -10.6 & 0.8 & 3 & 3 & 2 & 3 & 5.03E-13 & $1.3 \mathrm{E}-13$ & 3 \\
\hline UE-1a & -103.3 & 0.6 & 3 & -13.6 & 0.1 & 3 & -8.6 & & & 61 & & & $8.63 E-13$ & & \\
\hline UE-1b & -105 & 0.0 & 3 & -13.8 & 0.1 & 2 & -4.5 & & & 16 & & & $6.26 \mathrm{E}-13$ & & \\
\hline UE-1c & -105 & 1 & 4 & -13.6 & 0.5 & 4 & -5.0 & 0.5 & 2 & 3 & 0.0 & 2 & $7.18 \mathrm{E}-13$ & $5.9 \mathrm{E}-15$ & 2 \\
\hline UE-1h & -104.5 & 0.7 & 2 & -13.8 & 0.1 & 2 & -11.2 & 1.3 & 2 & 18 & 8 & 2 & $1.61 \mathrm{E}-13$ & $1.4 \mathrm{E}-14$ & 2 \\
\hline UE-1q & -108 & 1 & 2 & -14.5 & 0.4 & 3 & -5.5 & 4.3 & 2 & 8 & & & $7.90 \mathrm{E}-13$ & & \\
\hline UE-2ce & -100 & & & -12.9 & & & -5.3 & & & & & & & & \\
\hline UE-4t & -101 & & & -13.8 & & & & & & & & & & & \\
\hline UE-4t 1 & -104 & & & -13.6 & & & & & & & & & & & \\
\hline UE-5 PW-1 & -107 & 1 & 2 & -13.7 & 0.1 & 2 & -8.0 & 0.7 & 5 & 20 & 6 & 4 & $8.42 \mathrm{E}-13$ & & \\
\hline UE-5 PW-2 & -106 & & & -13.8 & & & -8.6 & 0.6 & 2 & 30.4 & 4.7 & 2 & $5.27 \mathrm{E}-13$ & & \\
\hline UE-5 PW-3 & -104 & 1 & 4 & -13.5 & 0.1 & 4 & -7.6 & 0.3 & 5 & 18.0 & 2.6 & 3 & $6.78 \mathrm{E}-13$ & & \\
\hline UE-5c WW & -106 & 1 & 3 & -13.8 & 0.1 & 3 & -7.5 & 0.3 & 3 & 6.6 & 0.1 & 2 & $6.13 \mathrm{E}-13$ & & \\
\hline UE-5n & -106 & 3 & 9 & -13.3 & 0.2 & 9 & -8.0 & 1.2 & 3 & 18.8 & & & $5.96 \mathrm{E}-10$ & 5.57E-11 & 3 \\
\hline
\end{tabular}


Table H.1-2

Isotope Data for Yucca Flat/Climax Mine Geochemical Evaluation

(Page 5 of 5)

\begin{tabular}{|c|c|c|c|c|c|c|c|c|c|c|c|c|c|c|c|}
\hline \multirow[t]{2}{*}{ Site Identification } & \multicolumn{3}{|c|}{$\begin{array}{c}\delta D \\
\text { (permil) }\end{array}$} & \multicolumn{3}{|c|}{$\begin{array}{c}\delta^{18} O \\
\text { (permil) }\end{array}$} & \multicolumn{3}{|c|}{$\begin{array}{c}\delta^{13} \mathrm{C} \\
\text { (permil) }\end{array}$} & \multicolumn{3}{|c|}{$\begin{array}{c}{ }^{14} \mathrm{C} \\
(\mathrm{pmc})\end{array}$} & \multicolumn{3}{|c|}{$\begin{array}{l}{ }^{36} \mathrm{Cl} / \mathrm{Cl} \\
\text { (ratio) }\end{array}$} \\
\hline & Avg & SD & $\mathbf{n}$ & Avg & SD & $\mathbf{n}$ & Avg & SD & $\mathbf{n}$ & Avg & SD & $\mathbf{n}$ & Avg & SD & $\mathbf{n}$ \\
\hline UE-6d & -110 & & & -13.8 & & & & & & & & & & & \\
\hline UE-7nS & -106 & & & -14.0 & & & -2.0 & & & & & & & & \\
\hline Watertown 1 & -109 & & & -14.6 & & & -5.3 & & & 12 & & & $6.53 \mathrm{E}-13$ & & \\
\hline \multicolumn{16}{|l|}{ Watertown 2} \\
\hline Watertown 3 & -105 & & & -13.7 & & & -6.5 & 0.8 & 2 & 27 & & & $5.82 \mathrm{E}-13$ & & \\
\hline Watertown 4 & -108 & & & -14.3 & & & -2.3 & & & 1 & & & $3.62 \mathrm{E}-13$ & & \\
\hline Wheelbarrow Spring & -93 & & & -12.0 & & & & & & & & & & & \\
\hline White Rock Spring, SR & -84 & 2 & 2 & -9.8 & 0.1 & 2 & -8.3 & & & & & & & & \\
\hline Whiterock Spring, YF & -95 & 2 & 65 & -12.5 & 0.5 & 85 & -11.4 & 1.8 & 20 & 91 & & & & & \\
\hline Wiregrass Spring & -94 & 2 & 10 & -12.8 & 0.1 & 11 & -10.4 & 0.4 & 2 & 97 & & & & & \\
\hline \multicolumn{16}{|l|}{ WW-1 } \\
\hline WW-2 & -103 & 1 & 3 & -13.5 & 0.6 & 3 & -11.2 & & & 10 & & & & & \\
\hline \multicolumn{16}{|l|}{ WW-3 } \\
\hline WW-4 & -94 & & & -12.6 & 0.1 & 2 & -10.9 & & & 19 & 1.1 & 2 & $6.16 \mathrm{E}-13$ & & \\
\hline WW-4A & -99 & 3 & 2 & -12.8 & 0.1 & 2 & -8.8 & 0.6 & 2 & 18 & & & 6.47E-13 & & \\
\hline WW-5A & -108 & 4 & 2 & -13.6 & 0.3 & 2 & -4.6 & 0.4 & 2 & 2.6 & & & 8.43E-13 & & \\
\hline WW-5B & -107 & 3 & 4 & -13.5 & 0.5 & 3 & -10.4 & 1.2 & 3 & 13.1 & & & 7.83E-13 & & \\
\hline WW-5C & -108 & 2 & 4 & -13.9 & 0.4 & 4 & -6.0 & 0.1 & 3 & 3.3 & 0.2 & 2 & $6.96 \mathrm{E}-13$ & & \\
\hline WW-A & -107 & & & -13.0 & & & -8.9 & & & 6 & & & & & \\
\hline WW-C & -107 & 2 & 9 & -14.0 & 0.6 & 9 & -4.0 & 0.3 & 2 & 1 & & & $1.76 \mathrm{E}-13$ & & \\
\hline WW-C-1 & -107 & 3 & 6 & -13.9 & 0.7 & 5 & -4.7 & 1.2 & 2 & 1 & 0.2 & 2 & $1.66 \mathrm{E}-13$ & & \\
\hline
\end{tabular}

*Empounded tunnel water samples were collected on 8/23/99 (U-12e), 8/24/99 (U-12t), and 8/25/99 (U-12n). 
Table H.1-3

Field Measurement Data for Yucca Flat/Climax Mine Geochemical Evaluation

(Page 1 of 5)

\begin{tabular}{|c|c|c|c|c|c|c|c|c|c|c|c|c|c|c|c|}
\hline \multirow[t]{2}{*}{ Site Identification } & \multicolumn{3}{|c|}{$\begin{array}{c}\text { Water } \\
\text { Temperature } \\
\left({ }^{\circ} \mathrm{C}\right)\end{array}$} & \multicolumn{3}{|c|}{ pH } & \multicolumn{3}{|c|}{ pH, Field } & \multicolumn{3}{|c|}{$\begin{array}{c}\text { Specific } \\
\text { Conductance } \\
(\mu \mathrm{S} / \mathrm{cm})\end{array}$} & \multicolumn{3}{|c|}{$\begin{array}{c}\text { Total } \\
\text { Dissolved Solids } \\
\text { (mg/L) }\end{array}$} \\
\hline & Avg & SD & $\mathbf{n}$ & Avg & SD & $\mathbf{n}$ & Avg & SD & $\mathbf{n}$ & Avg & SD & $\mathbf{n}$ & Avg & SD & $\mathbf{n}$ \\
\hline \multicolumn{16}{|l|}{ Alum Spring } \\
\hline April Fool Spring & 12.5 & & & 8.0 & & & 7.3 & & & 777 & & & & & \\
\hline Army \#1 WW & 31 & 1 & 13 & 7.3 & 0.3 & 155 & 7.3 & 0.1 & 5 & 533 & 76 & 152 & 327 & 26 & 27 \\
\hline Ash Spring & 35.1 & 2.2 & 7 & 7.6 & 0.2 & 4 & 7.0 & & & 475 & 19 & 3 & 347 & 66 & 3 \\
\hline Bullwhack Spring & & & & 7.3 & & & & & & 845 & & & & & \\
\hline Cane Spring, FF & 13 & 2 & 18 & 7.7 & 0.2 & 29 & 7.0 & 0.6 & 5 & 452 & 33 & 28 & & & \\
\hline Cane Spring, GR & 13.0 & & & 7.6 & & & 7.6 & & & 809 & 2 & 2 & & & \\
\hline Captain Jack Spring & 11 & 6 & 6 & 7.4 & 0.2 & 7.0 & 7.3 & 0.3 & 3 & 160 & 39 & 7 & & & \\
\hline Cattle Spring & 16.5 & & & 8.0 & & & 8.0 & & & 528 & 3 & 2 & & & \\
\hline Cliff Spring, BR & & & & 7.9 & & & & & & 244 & & & & & \\
\hline Cliff Spring, GR & 13.0 & & & 7.7 & & & & & & 508 & & & & & \\
\hline Cow Camp Spring & 12 & 3 & 2 & 8.1 & 0.1 & 2 & 7.6 & 0.0 & 2 & 568 & 46 & 2 & 312 & 28 & 2 \\
\hline Cresent Spring & 11.7 & & & 8.0 & & & 7.3 & & & 489 & & & & & \\
\hline Crystal Spring & 27.6 & 0.5 & 10 & 7.8 & 0.4 & 6 & 7.41 & 0.07 & 4 & 480 & 20 & 5 & 314 & 57 & 4 \\
\hline De Jesus Spring & 13 & 3 & 2 & 7.9 & 0.5 & 2 & 7.9 & 0.2 & 2 & 536 & 69 & 2 & 345 & & \\
\hline Desert Dry Lake Well \#1 & 19.4 & 0.5 & 2 & 8.1 & 0.3 & 2 & 8.0 & 0.1 & 2 & 447 & 7 & 2 & 310 & & \\
\hline ER-12-1 & 25 & & & 7.7 & 0.2 & 3 & & & & 987 & 12 & 3 & 758 & 42 & 2 \\
\hline ER-12-2 & 35.2 & & & 8.2 & 0.1 & 4 & 7.6 & & & 557 & 30 & 4 & 347 & 21 & 3 \\
\hline ER-19-1 & & & & 10.7 & & & & & & 504 & & & 271 & & \\
\hline ER-2-1 & 21.3 & & & 9.1 & 0.3 & 4 & 9.2 & & & 360 & 14 & 4 & 337 & 32 & 3 \\
\hline ER-3-1 & 41 & 5 & 2 & 6.7 & 0.1 & 3 & & & & 1,216 & 23 & 4 & 730 & 56 & 3 \\
\hline ER-5-3 & 30.0 & & & 8.4 & 0.5 & 6 & & & & 363 & 73 & 6 & 306 & 15 & 5 \\
\hline ER-5-3 \#2 & 33.8 & & & 7.1 & 0.3 & 4 & & & & 1,115 & 29 & 4 & 687 & 6 & 3 \\
\hline ER-5-4 & 30.2 & & & 8.9 & 0.2 & 3 & & & & 885 & 5 & 3 & 570 & 14 & 2 \\
\hline ER-5-4\#2 & 38.1 & & & 8.68 & 0.05 & 4 & 8.57 & & & 1,362 & 76 & 4 & 847 & 12 & 3 \\
\hline ER-6-1 & 41 & 3 & 2 & 7.8 & 0.4 & 5 & 7.27 & 0.05 & 2 & 485 & 23 & 6 & 331 & 87 & 6 \\
\hline ER-6-1 \#2 & 39.9 & & & 7.7 & 0.1 & 3 & 7.2 & & & 467 & 41 & 4 & 303 & 12 & 3 \\
\hline
\end{tabular}


Table H.1-3

Field Measurement Data for Yucca Flat/Climax Mine Geochemical Evaluation (Page 2 of 5)

\begin{tabular}{|c|c|c|c|c|c|c|c|c|c|c|c|c|c|c|c|}
\hline \multirow[t]{2}{*}{ Site Identification } & \multicolumn{3}{|c|}{$\begin{array}{c}\text { Water } \\
\text { Temperature } \\
\left({ }^{\circ} \mathrm{C}\right)\end{array}$} & \multicolumn{3}{|c|}{$\mathrm{pH}$} & \multicolumn{3}{|c|}{ pH, Field } & \multicolumn{3}{|c|}{$\begin{array}{c}\text { Specific } \\
\text { Conductance } \\
(\mu \mathrm{S} / \mathrm{cm})\end{array}$} & \multicolumn{3}{|c|}{$\begin{array}{c}\text { Total } \\
\text { Dissolved Solids } \\
\text { (mg/L) }\end{array}$} \\
\hline & Avg & SD & $\mathbf{n}$ & Avg & SD & $\mathbf{n}$ & Avg & SD & $\mathbf{n}$ & Avg & SD & $\mathbf{n}$ & Avg & SD & $\mathbf{n}$ \\
\hline ER-6-2 & 34.9 & & & 7.6 & 0.1 & 5 & 7.0 & & & 642 & 63 & 5 & 436 & 25 & 4 \\
\hline ER-7-1 & 49.4 & & & 7.7 & 0.1 & 4 & 7.4 & & & 492 & 13 & 4 & 307 & 6 & 23 \\
\hline Hagestad \#1 & 15.6 & & & 10.7 & 0.6 & 2 & & & & 497 & 181 & 2 & 277 & 30 & 2 \\
\hline Hiko Spring & 26.7 & 0.2 & 4 & 8.0 & 0.2 & 3 & 7.4 & 0.0 & 2 & 514 & 40 & 2 & 445 & & \\
\hline Indian Spring, BR & 10.3 & & & 7.5 & & & & & & 299 & & & & & \\
\hline Indian Spring, GR & 14.4 & & & 8.1 & & & 8.1 & & & 358 & 2.8 & 2 & & & \\
\hline Marble \#3 & 21.7 & & & 7.9 & & & & & & 522 & & & 323 & & \\
\hline Miner Spring & & & & 7.9 & & & & & & 1,710 & & & & & \\
\hline Naquinta Spring & 16.5 & & & 8.2 & & & & & & 308 & & & & & \\
\hline \multicolumn{16}{|l|}{ New Tikaboo Spring } \\
\hline Oak Spring & 14 & 3 & 5 & 7.3 & 0.2 & 5 & 7.0 & 0.6 & 4 & 228 & 5.6 & 5 & & & \\
\hline \multicolumn{16}{|l|}{ Old Tikaboo Spring } \\
\hline Penoyer Well & 13.1 & & & 7.3 & & & & & & 450 & & & & & \\
\hline Pine Spring, GR & 20.2 & & & 8.5 & & & & & & 424 & & & & & \\
\hline Pluto 1 & & & & 8.0 & & & & & & 459 & & & & & \\
\hline Pluto 5 & & & & 7.9 & & & & & & 558 & & & 386 & & \\
\hline Quail Spring, GR & 15 & 0.0 & 2 & 7.8 & & & 7.8 & & & 669 & 1.4 & 2 & & & \\
\hline Quartz Spring & 15 & 5 & 3 & 8.0 & 0.2 & 3 & 7.7 & 0.5 & 2 & 828 & 85 & 4 & & & \\
\hline Rabbitbrush Spring & 14 & & & 7.9 & & & 7.9 & & & 378 & 4 & 2 & & & \\
\hline Rock Spring & 16 & & & 7.8 & & & & & & 580 & & & & & \\
\hline Rose Bud Spring & 10.3 & & & 7.3 & & & & & & 850 & & & & & \\
\hline Sand Spring, PW & & & & 8.3 & 0.5 & 3 & & & & 513 & 62 & 3 & & & \\
\hline Sand Spring, SSV & 18.5 & & & 9.3 & & & 9.3 & & & 332 & & & & & \\
\hline Savio Spring & & & & 8.3 & & & & & & 470 & & & & & \\
\hline \multicolumn{16}{|l|}{ Sharp Spring } \\
\hline TW-7 & 20.6 & & & 7.3 & & & & & & 466 & & & 289 & & \\
\hline The Seeps Spring & & & & & & & & & & & & & & & \\
\hline
\end{tabular}


Table H.1-3

Field Measurement Data for Yucca Flat/Climax Mine Geochemical Evaluation

(Page 3 of 5)

\begin{tabular}{|c|c|c|c|c|c|c|c|c|c|c|c|c|c|c|c|}
\hline \multirow[t]{2}{*}{ Site Identification } & \multicolumn{3}{|c|}{$\begin{array}{c}\text { Water } \\
\text { Temperature } \\
\left({ }^{\circ} \mathrm{C}\right)\end{array}$} & \multicolumn{3}{|c|}{$\mathrm{pH}$} & \multicolumn{3}{|c|}{ pH, Field } & \multicolumn{3}{|c|}{$\begin{array}{c}\text { Specific } \\
\text { Conductance } \\
(\mu \mathrm{S} / \mathrm{cm})\end{array}$} & \multicolumn{3}{|c|}{$\begin{array}{c}\text { Total } \\
\text { Dissolved Solids } \\
\text { (mg/L) }\end{array}$} \\
\hline & Avg & SD & $\mathbf{n}$ & Avg & SD & $\mathbf{n}$ & Avg & SD & $\mathbf{n}$ & Avg & SD & $\mathbf{n}$ & Avg & SD & $\mathbf{n}$ \\
\hline Tim Spring & 15 & 1 & 2 & 8.1 & 0.1 & 2 & 8.1 & 0.4 & 2 & 361 & 1 & 2 & & & \\
\hline Tippipah Spring & 11 & 3 & 12 & 7.4 & 0.2 & 10 & 7.0 & 0.2 & 8 & 192 & 25 & 15 & 175 & 29 & 10 \\
\hline Topopah Spring & 15 & 9 & 8 & 7.1 & 0.3 & 6 & 6.91 & 0.04 & 2 & 103 & 16. & 7 & & & \\
\hline U12.03 UG-3 & & & & 7.5 & 0.1 & 3 & 7.4 & & & 270 & 5 & 4 & 203 & 8 & 4 \\
\hline U-12s & 26.1 & & & & & & 10.5 & & & 632 & & & & & \\
\hline U12e Tunnel & 16 & 4 & 2 & 8.2 & 0.6 & 19 & 8.11 & 0.01 & 2 & 331 & 57 & 19 & 277 & 111 & 18 \\
\hline U12n Tunnel & 17 & 4 & 3 & 8.4 & 0.5 & 36 & 7.8 & 0.5 & 3 & 347 & 61.7 & 34 & 250 & 50 & 26 \\
\hline U12t Tunnel & 16 & & & 7.7 & 0.4 & 23 & 7.7 & 0.4 & 4 & 268 & 19 & 23 & 220 & 53 & 23 \\
\hline U-15.01 Shaft, C-30 & & & & 8.1 & & & & & & & & & 1,910 & & \\
\hline U-15.01 Shaft, C-36 & & & & 7.8 & & & & & & & & & 1,150 & & \\
\hline U-15.01 Shaft, CGW-1 & & & & 7.3 & & & & & & & & & 1,900 & & \\
\hline U-15.01 Shaft, NH-01 & & & & 8.2 & & & & & & & & & 1,770 & & \\
\hline U-15.01 Shaft, UG-02 & & & & 7.5 & & & & & & & & & 1,110 & & \\
\hline $\mathrm{U}-2 \mathrm{bs}$ & 26 & 0.4 & 2 & 7.1 & 0.4 & 2 & & & & 389 & 0.0 & 2 & 275 & 4.2 & 2 \\
\hline U-3cn \#5 & 45 & & & 7.3 & 0.4 & 89 & & & & 550 & 126 & 90 & 343 & 62 & 12 \\
\hline U-3cn PS \#2 & 34.6 & 0.8 & 2 & 7.8 & 0.2 & 4 & 7.6 & & & 678 & 72 & 76 & 462 & 122 & 76 \\
\hline U-3mi & 33 & & & 8.1 & & & & & & & & & & & \\
\hline U-4u PS \#2A & 28 & & & 7.8 & 0.6 & 2 & 7.4 & 0.4 & 3 & 372 & 38 & 4 & 209 & & \\
\hline UE-10 ITS \#3 & & & & 8.3 & & & & & & 927 & & & 621 & & \\
\hline UE-10j & 28.9 & 4.7 & 2 & 7.0 & 0.4 & 2 & & & & 862 & 309 & 2 & 398 & & \\
\hline UE-10j-1 & 32.7 & & & 6.4 & & & & & & 1,079 & 12 & 2 & 627 & & \\
\hline UE-10j-2 & 32.3 & & & 6.7 & & & & & & 725 & & & & & \\
\hline UE-10j-3 & 32.1 & & & 7.1 & 0.2 & 2 & & & & 625 & 51 & 2 & 394 & & \\
\hline UE-11a & & & & 8.1 & & & & & & 536 & & & 365 & & \\
\hline UE-14b & & & & 8.5 & 0.3 & 5 & & & & 401 & 35 & 5 & 296 & & \\
\hline UE-15d WW & 34 & 2 & 5 & 7.1 & 0.5 & 32 & 7.6 & 0.4 & 2 & 686 & 66 & 29 & 381 & 76 & 8 \\
\hline UE-15j & 45 & & & 6.8 & & & 6.6 & & & 2,530 & & & 1,090 & & \\
\hline
\end{tabular}


Table H.1-3

Field Measurement Data for Yucca Flat/Climax Mine Geochemical Evaluation (Page 4 of 5)

\begin{tabular}{|c|c|c|c|c|c|c|c|c|c|c|c|c|c|c|c|}
\hline \multirow[t]{2}{*}{ Site Identification } & \multicolumn{3}{|c|}{$\begin{array}{c}\text { Water } \\
\text { Temperature } \\
\left({ }^{\circ} \mathrm{C}\right)\end{array}$} & \multicolumn{3}{|c|}{ pH } & \multicolumn{3}{|c|}{ pH, Field } & \multicolumn{3}{|c|}{$\begin{array}{c}\text { Specific } \\
\text { Conductance } \\
(\mu \mathrm{S} / \mathrm{cm})\end{array}$} & \multicolumn{3}{|c|}{$\begin{array}{c}\text { Total } \\
\text { Dissolved Solids } \\
\text { (mg/L) }\end{array}$} \\
\hline & Avg & SD & $\mathbf{n}$ & Avg & SD & $\mathbf{n}$ & Avg & SD & $n$ & Avg & SD & $\mathbf{n}$ & Avg & SD & $\mathbf{n}$ \\
\hline UE-15j A-5 & 44.6 & 0.5 & 2 & 6.9 & 0.3 & 3 & & & & 2,110 & 528 & 3 & 1,030 & 10 & 3 \\
\hline UE-16d WW & 20.8 & 3.6 & 3 & 7.4 & 0.4 & 14 & 7.5 & 0.3 & 3 & 690 & 46 & 14 & 380 & 28 & 15 \\
\hline UE-16f & 24.8 & 3.1 & 4 & 8.9 & 0.5 & 3 & 8.4 & 0.3 & 2 & 1,483 & 260 & 5 & 1,032 & 54 & 3 \\
\hline UE-17a & 22.3 & 3.0 & 14 & 7.8 & 0.4 & 3 & 7.8 & 0.2 & 7 & 1,042 & 409 & 14 & 597 & 332 & 4 \\
\hline UE-1a & 25.4 & & & 7.7 & 0.5 & 2 & & & & 760 & 96 & 2 & 392 & 62 & 2 \\
\hline UE-1b & 27.4 & & & 7.7 & 0.5 & 2 & & & & 440 & 11 & 2 & 262 & 63 & 2 \\
\hline UE-1c & 26.7 & 0.7 & 10 & 7.5 & 0.7 & 23 & 7.3 & 0.1 & 8 & 460 & 66 & 31 & 284 & 63 & 4 \\
\hline UE-1h & 25.3 & & & 8.2 & & & & & & 1,029 & & & 515 & & \\
\hline UE-1q & 27.7 & 4.5 & 5 & 7.9 & 0.1 & 2 & 8.2 & 0.2 & 4 & 424 & 35 & 4 & 227 & & \\
\hline UE-2ce & 32.9 & 0.5 & 2 & 7.9 & 0.7 & 3 & 7.0 & 0.5 & 3 & 552 & 165 & 2 & 336 & 100 & 8 \\
\hline \multicolumn{16}{|l|}{ UE-4t } \\
\hline UE-4t 1 & & & & 8.9 & & & & & & 694 & & & & & \\
\hline UE-5 PW-1 & 20.3 & 3.2 & 2 & 8.5 & 0.2 & 2 & 8.2 & 0.2 & 13 & 374 & 23 & 14 & 275 & 54 & 10 \\
\hline UE-5 PW-2 & 23.3 & & & 8.5 & & & 8.3 & 0.3 & 13 & 364 & 37 & 14 & 243 & 51 & 10 \\
\hline UE-5 PW-3 & 20.9 & 3.6 & 3 & 8.5 & 0.5 & 4 & 8.4 & 0.2 & 16 & 359 & 23 & 18 & 247 & 50 & 10 \\
\hline UE-5c WW & 25.2 & 1.0 & 31 & 8.1 & 0.4 & 34 & 8.5 & 0.03 & 2 & 468 & 181 & 34 & 308 & 44 & 8 \\
\hline UE-5n & 25.7 & 2.8 & 3 & 8.8 & 0.1 & 5 & 8.7 & 0.00 & 2 & 419 & 35 & 6 & 214 & & \\
\hline UE-6d & & & & 8.3 & & & & & & 440 & & & & & \\
\hline Ue-7nS & 34.7 & 1.9 & 4 & 7.6 & 0.7 & 47 & 7.6 & 0.1 & 2 & 567 & 114 & 49 & 261 & 49 & 4 \\
\hline TW-1 & 23 & 3 & 17 & 9.0 & 0.3 & 20 & 9.1 & 0.2 & 16 & 232 & 15 & 36 & 143 & 14.2 & 5 \\
\hline TW-10 & 27.7 & 0.7 & 2 & 7.5 & 0.3 & 3 & & & & 384 & 59 & 3 & 192 & 13 & 3 \\
\hline TW-3 & 36 & 2 & 2 & 7.3 & & & 7.4 & & & 710 & & & 444 & & \\
\hline TW-4 & & & & & & & 7.5 & & & & & & 212 & & \\
\hline TW-E & & & & 8.4 & & & & & & 130 & & & & & \\
\hline TW-F & 64.5 & 0.7 & 5 & 6.9 & 0.5 & 11 & 7.3 & & & 577 & 177 & 10 & 367 & 25 & 3 \\
\hline TW-B & 20.1 & & & 8.2 & 0.4 & 88 & & & & 369 & 62 & 87 & 209 & 29 & 2 \\
\hline TW-D & 23.9 & & & 7.9 & 0.5 & 24 & & & & 480 & 95 & 24 & 286 & 36 & 5 \\
\hline
\end{tabular}


Table H.1-3

Field Measurement Data for Yucca Flat/Climax Mine Geochemical Evaluation

(Page 5 of 5)

\begin{tabular}{|c|c|c|c|c|c|c|c|c|c|c|c|c|c|c|c|}
\hline \multirow[t]{2}{*}{ Site Identification } & \multicolumn{3}{|c|}{$\begin{array}{c}\text { Water } \\
\text { Temperature } \\
\left({ }^{\circ} \mathrm{C}\right)\end{array}$} & \multicolumn{3}{|c|}{$\mathrm{pH}$} & \multicolumn{3}{|c|}{ pH, Field } & \multicolumn{3}{|c|}{$\begin{array}{c}\text { Specific } \\
\text { Conductance } \\
(\mu S / c m)\end{array}$} & \multicolumn{3}{|c|}{$\begin{array}{c}\text { Total } \\
\text { Dissolved Solids } \\
\text { (mg/L) }\end{array}$} \\
\hline & Avg & SD & $n$ & Avg & SD & $n$ & Avg & SD & $\mathbf{n}$ & Avg & SD & $\mathbf{n}$ & Avg & SD & $\mathbf{n}$ \\
\hline WW-A & 26.5 & 0.5 & 9 & 7.5 & 0.3 & 157 & 7.9 & 0.2 & 3 & 397 & 52 & 154 & 285 & 39 & 18 \\
\hline WW-C & 34.7 & 3.0 & 213 & 7.0 & 0.4 & 223 & 7.1 & 0.3 & 6 & 1,020 & 148 & 218 & 632 & 69 & 53 \\
\hline WW-1 & 24.4 & & & 7.8 & & & & & & 338 & & & 272 & & \\
\hline WW-2 & 34.6 & 0.2 & 3 & 7.4 & 0.3 & 119 & 7.5 & 0.1 & 2 & 408 & 65 & 118 & 218 & 52 & 10 \\
\hline WW-4 & 28.2 & 5.4 & 40 & 7.6 & 0.3 & 48 & & & & 635 & 202 & 45 & 280 & 26 & 11 \\
\hline WW-4A & 26.5 & & & 8.1 & 0.2 & 3 & 7.9 & & & 395 & 13 & 3 & 285 & 11 & 6 \\
\hline WW-5A & 22.9 & 0.5 & 3 & 8.7 & 0.2 & 10 & 8.8 & 0.1 & 3 & 651 & 39 & 10 & 475 & 74 & 10 \\
\hline WW-5B & 24.9 & 1.1 & 40 & 8.1 & 0.4 & 45 & 8.4 & 0.3 & 7 & 507 & 63 & 45 & 340 & 25 & 25 \\
\hline WW-5C & 24.6 & 1.4 & 176 & 8.4 & 0.5 & 186 & 8.7 & 0.1 & 7 & 579 & 118 & 188 & 386 & 36 & 28 \\
\hline WW-C-1 & 36.2 & 1.6 & 8 & 7.2 & 0.5 & 43 & 6.9 & 0.2 & 3 & 1,020 & 112 & 42 & 609 & 55 & 19 \\
\hline Watertown 1 & 23.9 & 1.0 & 4 & 7.9 & 0.2 & 5 & & & & 336 & 6 & 3 & 278 & 8 & 3 \\
\hline Watertown 2 & 28.0 & 2.3 & 2 & 8.3 & & & & & & 396 & 23 & 2 & 307 & 16 & 2 \\
\hline Watertown 3 & 23.0 & 0.8 & 6 & 7.8 & 0.2 & 12 & & & & 360 & 34 & 7 & 280 & 5 & 5 \\
\hline Watertown 4 & 30.4 & 7.6 & 2 & 6.9 & 0.01 & 2 & & & & 1,003 & 138 & 2 & 565 & & \\
\hline WW-3 & 22.4 & 1.1 & 6 & 7.8 & 0.2 & 8 & 7.9 & 0.1 & 2 & 378 & 20 & 8 & 273 & 10 & 8 \\
\hline Wheelbarrow Spring & 13.8 & & & 8.1 & & & & & & 324 & & & & & \\
\hline White Rock Spring, SR & 12.5 & 3.5 & 2 & 7.8 & 0.2 & 2 & 7.5 & 0.1 & 2 & 473 & 27 & 2 & 302 & & \\
\hline Whiterock Spring, YF & 13 & 2.7 & 35 & 7.4 & 0.3 & 53 & 7 & 0.6 & 10 & 214 & 36 & 57 & 195 & 37 & 8 \\
\hline Wiregrass Spring & 8.4 & 3.5 & 9 & 7.7 & 0.2 & 10 & 7.32 & 0.04 & 8 & 580 & 61 & 10 & 315 & 11 & 8 \\
\hline
\end{tabular}

$\mu \mathrm{S} / \mathrm{cm}=$ Microsiemens per centimeter 
Table H.1-4

Strontium and Uranium Data for Yucca Flat/Climax Mine Geochemical Evaluation

(Page 1 of 5)

\begin{tabular}{|c|c|c|c|c|}
\hline Site Identification & $\begin{array}{l}\text { Strontium } \\
(\mu g / L)\end{array}$ & ${ }^{87} \mathrm{Sr} /{ }^{86} \mathrm{Sr}$ & $\begin{array}{l}\text { Uranium } \\
(\mu g / L)\end{array}$ & $\begin{array}{c}{ }^{234} \mathrm{U} /{ }^{238} \mathrm{U} \\
\text { Activity Ratio }\end{array}$ \\
\hline \multicolumn{5}{|l|}{ Alluvial Aquifer } \\
\hline Desert Dry Lake Well \#1 & 463 & & 2.6 & 2.46 \\
\hline Sand Spring, SSV & 294 & & & \\
\hline WW-A & 223 & & 5.2 & \\
\hline Watertown 3 & 210 & 0.71551 & 3.2 & \\
\hline Watertown 4 & 1,020 & 0.72567 & 4.0 & \\
\hline WW-3 & 228 & 0.71547 & 3.5 & \\
\hline \multicolumn{5}{|l|}{ Clastic Confining Unit } \\
\hline ER-12-1 & 199 & 0.71169 & 1.61 & 7.05 \\
\hline ER-12-2 & 323 & 0.71662 & 0.02 & 6.27 \\
\hline ER-19-1 & 67 & & & \\
\hline UE-15d WW & 470 & 0.71356 & 10.3 & 3.10 \\
\hline UE-15j & 1,250 & & & \\
\hline UE-15j A-5 & 1,120 & & & \\
\hline UE-16f & 550 & 0.71136 & & \\
\hline UE-17a & 666 & 0.71017 & 0.6 & \\
\hline UE-1b & 470 & 0.70953 & 4.3 & \\
\hline \multicolumn{5}{|c|}{ Lower Carbonate Aquifer and Lower Carbonate Aquifer- Yucca Flat Upper Plate } \\
\hline Army \#1 WW & 750 & 0.71200 & 2.52 & 3.00 \\
\hline Army 6 & 90 & 0.71117 & 0.3 & \\
\hline Ash Springs & 429 & 0.71415 & 2.60 & 2.44 \\
\hline Crystal Spring & 250 & 0.71087 & 4.9 & 3.08 \\
\hline
\end{tabular}


Table H.1-4

Strontium and Uranium Data for Yucca Flat/Climax Mine Geochemical Evaluation

(Page 2 of 5)

\begin{tabular}{|c|c|c|c|c|}
\hline Site Identification & $\begin{array}{c}\text { Strontium } \\
(\mu \mathrm{g} / \mathrm{L})\end{array}$ & ${ }^{87} \mathrm{Sr} /{ }^{86} \mathrm{Sr}$ & $\begin{array}{c}\text { Uranium } \\
(\mu g / L)\end{array}$ & $\begin{array}{c}{ }^{234} \mathrm{U} /{ }^{238} \mathrm{U} \\
\text { Activity Ratio }\end{array}$ \\
\hline ER-3-1 & 917 & 0.71824 & 4.04 & 3.76 \\
\hline ER-5-3 \#2 & 926 & 0.71540 & 5.23 & 3.27 \\
\hline ER-6-1 & 189 & 0.71288 & 3.06 & 4.14 \\
\hline ER-6-1 \#2 & 213 & 0.71296 & 2.89 & 4.19 \\
\hline ER-6-2 & 337 & 0.71280 & 2.18 & 4.43 \\
\hline ER-7-1 & 230 & 0.71318 & 4.72 & \\
\hline Hiko Spring & 347 & 0.71108 & 4.72 & 3.17 \\
\hline U-3cn \#5 & 227 & 0.71321 & 1.14 & 3.76 \\
\hline UE-10j & 432 & 0.71451 & 5.92 & 5.01 \\
\hline UE-10j-1 & 470 & 0.71464 & 5.51 & 5.02 \\
\hline UE-10j-2 & 320 & 0.71352 & 3.92 & 4.96 \\
\hline UE-10j-3 & 270 & 0.71261 & 3.46 & 4.93 \\
\hline UE-1c & 415 & 0.70988 & 4.2 & \\
\hline UE-1h & 177 & 0.70932 & 0.1 & \\
\hline UE-1q & 140 & 0.71129 & 2.3 & 4.90 \\
\hline UE-7nS & 89 & 0.71272 & 0.47 & 2.45 \\
\hline TW-10 & & & 0.6 & \\
\hline TW-3 & 890 & 0.71328 & 2.8 & \\
\hline TW-E & & & 2.5 & \\
\hline TW-F & 545 & & 4 & \\
\hline TW-D & 112 & 0.71218 & 0.7 & \\
\hline WW-C & 704 & 0.71503 & 6.7 & \\
\hline WW-2 & 79 & & 1.1 & \\
\hline
\end{tabular}


Table H.1-4

Strontium and Uranium Data for Yucca Flat/Climax Mine Geochemical Evaluation

(Page 3 of 5)

\begin{tabular}{|c|c|c|c|c|}
\hline Site Identification & $\begin{array}{c}\text { Strontium } \\
(\mu \mathrm{g} / \mathrm{L})\end{array}$ & ${ }^{87} \mathrm{Sr} /{ }^{86} \mathrm{Sr}$ & $\begin{array}{l}\text { Uranium } \\
(\mu \mathrm{g} / \mathrm{L})\end{array}$ & $\begin{array}{l}{ }^{234} \mathrm{U} /{ }^{238} \mathrm{U} \\
\text { Activity Ratio }\end{array}$ \\
\hline WW-C-1 & 780 & 0.71498 & 6.9 & \\
\hline UE-2ce & 188 & & 0.4 & \\
\hline \multicolumn{5}{|l|}{ Perched Spring } \\
\hline April Fool Spring & 465 & & 2.6 & 2.36 \\
\hline Cane Spring, FF & 120 & 0.70972 & 1.79 & 3.81 \\
\hline Cane Spring, GR & & & 2.3 & \\
\hline Captain Jack Spring & 4.4 & 0.71006 & 0.36 & 2.18 \\
\hline Cliff Spring, GR & 38 & 0.71008 & & \\
\hline Cow Camp Spring & 280 & & 1.7 & 3.2 \\
\hline Cresent Spring & 321 & & 16.6 & 2.89 \\
\hline De Jesus Spring & 305 & & 5.9 & \\
\hline Indian Spring, BR & & & 5.2 & \\
\hline Indian Spring, GR & & 0.71097 & & \\
\hline Oak Spring & & & 0.4 & \\
\hline Pyramid Spring & 700 & & & \\
\hline Quartz Spring & 470 & & & \\
\hline Sand Spring, PW & 240 & & & \\
\hline Tim Spring & 90 & & & \\
\hline Tippipah Spring & 24.1 & & 0.9 & \\
\hline Topopah Spring & 23.5 & & & \\
\hline White Rock Spring, SR & 140 & 0.70854 & 1.65 & 1.90 \\
\hline Whiterock Spring, YF & 28 & & 1.26 & 1.91 \\
\hline
\end{tabular}


Table H.1-4

Strontium and Uranium Data for Yucca Flat/Climax Mine Geochemical Evaluation

(Page 4 of 5)

\begin{tabular}{|c|c|c|c|c|}
\hline Site Identification & $\begin{array}{c}\text { Strontium } \\
(\mu \mathrm{g} / \mathrm{L})\end{array}$ & ${ }^{87} \mathrm{Sr} /{ }^{86} \mathrm{Sr}$ & $\begin{array}{l}\text { Uranium } \\
(\mu \mathrm{g} / \mathrm{L})\end{array}$ & $\begin{array}{c}{ }^{234} \mathrm{U} /{ }^{238} \mathrm{U} \\
\text { Activity Ratio }\end{array}$ \\
\hline Wiregrass Spring & 73 & 0.70987 & 0.57 & 2.05 \\
\hline \multicolumn{5}{|l|}{ Upper Carbonate Aquifer } \\
\hline UE-16d WW & 522 & 0.71003 & 2.12 & 5.31 \\
\hline \multicolumn{5}{|l|}{ Volcanic Aquifer } \\
\hline ER-5-3 & 70 & 0.71025 & 9.1 & 3.40 \\
\hline UE-14b & 35 & & & \\
\hline TW-1 & 20 & 0.70893 & 1.1 & \\
\hline TW-4 & & & 0.5 & \\
\hline TW-B & 15 & 0.70968 & 0.9 & \\
\hline WW-4 & 146 & 0.71024 & 5.36 & \\
\hline WW-4A & 158 & 0.71010 & 5.7 & 3.85 \\
\hline Watertown 1 & 33 & 0.71566 & 0.3 & \\
\hline Watertown 2 & 60 & & 1.0 & \\
\hline \multicolumn{5}{|l|}{ Tuff Confining Unit } \\
\hline ER-2-1 & 5 & 0.71131 & 1.86 & 2.91 \\
\hline ER-5-4 \#2 & 2 & 0.70890 & 34.3 & 1.30 \\
\hline Hagestad \#1 & 0.2 & & 0.4 & \\
\hline TW-7 & $<100$ & & 0.5 & \\
\hline U12.03 UG-3 & 20 & & & \\
\hline U12e Tunnel & 42 & & 4.4 & \\
\hline U12n Tunnel & 27 & & & \\
\hline U12t Tunnel & 28 & & & \\
\hline U-2bs & 64 & & & \\
\hline
\end{tabular}


Table H.1-4

Strontium and Uranium Data for Yucca Flat/Climax Mine Geochemical Evaluation

(Page 5 of 5)

\begin{tabular}{|l|c|c|c|c||}
\hline \multicolumn{1}{|c|}{ Site Identification } & $\begin{array}{c}\text { Strontium } \\
(\mu \mathrm{g} / \mathrm{L})\end{array}$ & ${ }^{87} \mathbf{S r} /{ }^{86} \mathbf{S r}$ & $\begin{array}{c}\text { Uranium } \\
(\mu \mathrm{g} / \mathrm{L})\end{array}$ & $\begin{array}{c}{ }^{234} \mathbf{U} /{ }^{238} \mathbf{U} \\
\text { Activity Ratio }\end{array}$ \\
\hline \hline U-3cn PS \#2 & 15.4 & 0.70970 & 13.5 & 2.70 \\
\hline U-3mi & 660 & 0.71386 & 18.6 & \\
\hline U-4u PS \#2A & 46 & & 5.0 & \\
\hline \hline Granite Confining Unit & $<200$ & & \multicolumn{3}{|c|}{} \\
\hline \hline Marble \#3 & 2060 & 0.70555 & ND & \\
\hline U-12s & &
\end{tabular}

$\mathrm{ND}=$ Not detected 
Table H.1-5

Select Trace and Minor Element Data for Yucca Flat/Climax Mine Geochemical Evaluation

(Page 1 of 5)

\begin{tabular}{|c|c|c|c|c|c|c|c|c|c|c|c|c|c|c|c|}
\hline \multirow{2}{*}{ Site Identification } & \multicolumn{3}{|c|}{$\begin{array}{c}\mathrm{SiO}_{2}, \text { Dissolved } \\
\text { (mg/L) }\end{array}$} & \multicolumn{3}{|c|}{$\begin{array}{l}\mathrm{SiO}_{2}, \text { Total } \\
\text { (mg/L) }\end{array}$} & \multicolumn{3}{|c|}{$\begin{array}{c}\mathrm{NO}_{3} \\
(\mathrm{mg} / \mathrm{L})\end{array}$} & \multicolumn{3}{|c|}{$\begin{array}{c}\mathrm{Br} \\
(\mathrm{mg} / \mathrm{L})\end{array}$} & \multicolumn{3}{|c|}{$\begin{array}{c}F \\
(\mathrm{mg} / \mathrm{L})\end{array}$} \\
\hline & Avg & SD & $\mathbf{n}$ & Avg & SD & $\mathbf{n}$ & Avg & SD & $\mathbf{n}$ & Avg & SD & $\mathbf{n}$ & Avg & SD & $\mathbf{n}$ \\
\hline \multicolumn{16}{|l|}{ Alum Spring } \\
\hline April Fool Spring & 28 & & & & & & 0.3 & & & & & & 0.6 & & \\
\hline Army \#1 WW & 20 & 3 & 27 & 20 & 1 & 4 & 1.3 & 0.4 & 15 & 0.10 & 0.04 & 4 & 1.0 & 0.1 & 34 \\
\hline Ash Spring & 30 & 1 & 3 & & & & 3.1 & & & & & & 0.8 & 0.0 & 2 \\
\hline Bullwhack Spring & 25 & & & & & & & & & & & & & & \\
\hline Cane Spring, FF & 64 & 2 & 29 & & & & 15 & 2 & 27 & & & & & & \\
\hline Cane Spring, GR & 21 & & & & & & & & & & & & & & \\
\hline Captain Jack Spring & 35 & 8 & 7 & & & & 1.8 & 1.4 & 5 & & & & & & \\
\hline Cattle Spring & 33 & & & & & & & & & & & & & & \\
\hline Cliff Spring, BR & 35 & & & & & & 0.3 & & & & & & & & \\
\hline Cliff Spring, GR & 28 & & & & & & & & & & & & & & \\
\hline Cow Camp Spring & 16 & 1 & 2 & & & & & & & & & & 0.20 & 0.00 & 2 \\
\hline Cresent Spring & 61 & & & & & & 1.5 & & & & & & 0.2 & & \\
\hline Crystal Spring & 24 & 1 & 6 & & & & 1.2 & & & 0.09 & 0.0 & 2 & 0.35 & 0.04 & 6 \\
\hline De Jesus Spring & 15.8 & 0.3 & 2 & & & & 20 & 14 & 2 & & & & & & \\
\hline Desert Dry Lake Well \#1 & 48.8 & 0.4 & 2 & & & & 30 & 27 & 2 & & & & 0.58 & 0.04 & 2 \\
\hline ER-12-1 & 20 & 3 & 3 & 19 & 1 & 5 & 0.12 & 0.03 & 2 & 0.42 & 0.03 & 2 & 0.25 & 0.05 & 5 \\
\hline ER-12-2 & 22 & 4 & 6 & 22 & 1 & 3 & $<0.2$ & & & $<0.2$ & & & 2.3 & 0.3 & 4 \\
\hline ER-19-1 & 71 & & & & & & & & & 1.6 & & & 2.2 & & \\
\hline ER-2-1 & 59 & 11 & 5 & 111 & 28 & 3 & 2.4 & & & & & & 1.9 & 0.2 & 4 \\
\hline ER-3-1 & 35 & 2 & 4 & & & & & & & & & & 1.2 & 0.4 & 6 \\
\hline ER-5-3 & 55 & 5 & 5 & 53 & 2 & 3 & 7.0 & & & 0.2 & 0.1 & 3 & 2.6 & 0.4 & 5 \\
\hline ER-5-3 \#2 & 29 & 1 & 3 & 30 & 0.0 & 3 & & & & 0.17 & 0.02 & 3 & 1.2 & 0.1 & 4 \\
\hline ER-5-4 & 77 & 3 & 2 & 78 & 2 & 2 & 4 & & & 0.22 & & & 6.4 & 0.3 & 2 \\
\hline ER-5-4\#2 & 75 & 5 & 5 & 82 & 9 & 3 & & & & $<0.2$ & & & 61 & 2 & 4 \\
\hline ER-6-1 & 29 & 6 & 10 & 27 & 6 & 5 & 0.5 & 0.2 & 2 & 0.7 & 0.1 & 5 & 0.75 & 0.05 & 8 \\
\hline ER-6-1 \#2 & 33 & 2 & 7 & 32 & 0.0 & 3 & 1.1 & & & 0.4 & 0.3 & 4 & 0.77 & 0.03 & 4 \\
\hline
\end{tabular}


Table H.1-5

Select Trace and Minor Element Data for Yucca Flat/Climax Mine Geochemical Evaluation (Page 2 of 5)

\begin{tabular}{|c|c|c|c|c|c|c|c|c|c|c|c|c|c|c|c|}
\hline \multirow{2}{*}{ Site Identification } & \multicolumn{3}{|c|}{$\begin{array}{c}\mathrm{SiO}_{2} \text {, Dissolved } \\
\text { (mg/L) }\end{array}$} & \multicolumn{3}{|c|}{$\begin{array}{l}\mathrm{SiO}_{2}, \text { Total } \\
\text { (mg/L) }\end{array}$} & \multicolumn{3}{|c|}{$\begin{array}{c}\mathrm{NO}_{3} \\
(\mathrm{mg} / \mathrm{L})\end{array}$} & \multicolumn{3}{|c|}{$\begin{array}{c}\mathrm{Br} \\
(\mathrm{mg} / \mathrm{L})\end{array}$} & \multicolumn{3}{|c|}{$\begin{array}{c}F \\
(\mathrm{mg} / \mathrm{L})\end{array}$} \\
\hline & Avg & SD & $\mathbf{n}$ & Avg & SD & $\mathbf{n}$ & Avg & SD & $\mathbf{n}$ & Avg & SD & $\mathbf{n}$ & Avg & SD & $\mathbf{n}$ \\
\hline ER-6-2 & 31 & 2 & 5 & 30 & 0.0 & 3 & 0.8 & 0.8 & 2 & 0.4 & 0.4 & 2 & 1.40 & 0.07 & 5 \\
\hline ER-7-1 & 33 & 6 & 6 & 37 & 1 & 3 & 0.07 & & & 0.05 & & & 0.81 & 0.01 & 4 \\
\hline Hagestad \#1 & 58 & 8 & 2 & & & & 0.3 & & & & & & 0.90 & 0.14 & 2 \\
\hline Hiko Spring & 32.7 & 0.5 & 2 & & & & 1.3 & & & & & & 0.57 & 0.04 & 2 \\
\hline Indian Spring, BR & 62 & & & & & & 0.8 & & & & & & & & \\
\hline \multicolumn{16}{|l|}{ Indian Spring, GR } \\
\hline Marble \#3 & 46 & & & & & & 2.9 & & & & & & 0.7 & & \\
\hline \multicolumn{16}{|l|}{ Miner Spring } \\
\hline \multicolumn{16}{|l|}{ Naquinta Spring } \\
\hline \multicolumn{16}{|l|}{ New Tikaboo Spring } \\
\hline Oak Spring & 57 & 1 & 5 & & & & 2 & 3 & 3 & & & & & & \\
\hline \multicolumn{16}{|l|}{ Old Tikaboo Spring } \\
\hline Penoyer Well & 83 & & & & & & & & & & & & 0.3 & & \\
\hline \multicolumn{16}{|l|}{ Pine Spring, GR } \\
\hline Pluto 1 & 54 & & & & & & 31.2 & & & & & & & & \\
\hline Pluto 5 & 58 & & & & & & 46 & & & & & & & & \\
\hline \multicolumn{16}{|l|}{ Quail Spring, GR } \\
\hline Quartz Spring & 51 & 8 & 3 & & & & 13 & 6 & 3 & & & & 0.56 & 0.06 & 2 \\
\hline \multicolumn{16}{|l|}{ Rabbitbrush Spring } \\
\hline \multicolumn{16}{|l|}{ Rock Spring } \\
\hline \multicolumn{16}{|l|}{ Rose Bud Spring } \\
\hline Sand Spring, PW & 16 & 2 & 3 & & & & 14 & 4 & 3 & & & & 0.3 & 0.1 & 2 \\
\hline Sand Spring, SSV & 35 & & & & & & 0.2 & & & & & & 1.7 & & \\
\hline \multicolumn{16}{|l|}{ Savio Spring } \\
\hline \multicolumn{16}{|l|}{ Sharp Spring } \\
\hline The Seeps Spring & & & & & & & & & & & & & & & \\
\hline
\end{tabular}


Table H.1-5

Select Trace and Minor Element Data for Yucca Flat/Climax Mine Geochemical Evaluation

(Page 3 of 5)

\begin{tabular}{|c|c|c|c|c|c|c|c|c|c|c|c|c|c|c|c|}
\hline \multirow{2}{*}{ Site Identification } & \multicolumn{3}{|c|}{$\begin{array}{c}\mathrm{SiO}_{2}, \text { Dissolved } \\
(\mathrm{mg} / \mathrm{L})\end{array}$} & \multicolumn{3}{|c|}{$\begin{array}{l}\mathrm{SiO}_{2}, \text { Total } \\
\text { (mg/L) }\end{array}$} & \multicolumn{3}{|c|}{$\begin{array}{c}\mathrm{NO}_{3} \\
(\mathrm{mg} / \mathrm{L})\end{array}$} & \multicolumn{3}{|c|}{$\begin{array}{c}\mathrm{Br} \\
(\mathrm{mg} / \mathrm{L})\end{array}$} & \multicolumn{3}{|c|}{$\begin{array}{c}F \\
(\mathrm{mg} / \mathrm{L})\end{array}$} \\
\hline & Avg & SD & $\mathbf{n}$ & Avg & SD & $\mathbf{n}$ & Avg & SD & $\mathbf{n}$ & Avg & SD & $\mathbf{n}$ & Avg & SD & $\mathbf{n}$ \\
\hline Tim Spring & 24 & 18 & 2 & & & & 20 & & & & & & 0.2 & & \\
\hline Tippipah Spring & 47 & 12 & 14 & & & & 6 & 2 & 9 & 0.1 & & & 0.24 & 0.09 & 10 \\
\hline Topopah Spring & 49 & 13 & 6 & & & & 2 & 2 & 4 & & & & & & \\
\hline TW-1 & 19 & 4 & 22 & 23 & 1 & 4 & 0.04 & 0.01 & 8 & & & & 1.20 & 0.00 & 4 \\
\hline TW-10 & 15 & 1 & 3 & & & & 2.3 & 0.8 & 3 & & & & 0.20 & 0.00 & 2 \\
\hline TW-3 & 21 & 5 & 2 & & & & 0.9 & & & & & & 1.5 & & \\
\hline TW-4 & 43 & & & & & & & & & & & & & & \\
\hline TW-7 & 1.4 & & & & & & & & & & & & 2.4 & & \\
\hline TW-B & 17 & 1 & 4 & & & & 0.1 & 0.1 & 3 & & & & 0.9 & & \\
\hline TW-D & 44 & 2 & 5 & 50.8 & 0.2 & 2 & 0.20 & 0.03 & 2 & & & & 1.33 & 0.05 & 5 \\
\hline TW-F & 36 & 2 & 3 & & & & 1.2 & 0.6 & 2 & & & & 3.2 & 0.2 & 3 \\
\hline U12.03 UG-3 & 66 & 1 & 4 & & & & 0.47 & 0.03 & 4 & & & & 0.2 & 0.1 & 4 \\
\hline U12e Tunnel & 42 & 5 & 19 & & & & 2.2 & 0.4 & 18 & 0.08 & 0.01 & 16 & 0.3 & 0.1 & 19 \\
\hline U12n Tunnel & 52 & 5 & 36 & & & & 2.5 & 1.5 & 34 & 0.08 & 0.02 & 31 & 0.2 & 0.1 & 27 \\
\hline U-12s & 22 & & & & & & & & & & & & $<1$ & & \\
\hline U12t Tunnel & 54 & 7 & 23 & & & & 3.4 & 1.9 & 23 & 0.14 & 0.05 & 16 & 0.1 & 0.1 & 24 \\
\hline \multicolumn{16}{|l|}{ U-15.01 Shaft, C-30 } \\
\hline \multicolumn{16}{|l|}{ U-15.01 Shaft, C-36 } \\
\hline U-15.01 Shaft, CGW-1 & & & & & & & & & & & & & 0.9 & & \\
\hline \multicolumn{16}{|l|}{ U-15.01 Shaft, NH-01 } \\
\hline U-15.01 Shaft, UG-02 & & & & & & & & & & & & & 1.4 & & \\
\hline $\mathrm{U}-2 \mathrm{bs}$ & 53 & 1 & 2 & & & & 0.6 & 0.3 & 2 & & & & 1.30 & 0.00 & 2 \\
\hline U-3cn \#5 & 56 & 24 & 15 & & & & 0.3 & 0.1 & 5 & & & & 0.8 & 0.3 & 15 \\
\hline U-3cn PS \#2 & 55 & 6 & 75 & & & & 5.4 & 0.7 & 3 & 0.4 & 0.2 & 2 & 0.76 & 0.04 & 4 \\
\hline U-3mi & 117 & & & & & & & & & & & & & & \\
\hline U-4u PS \#2A & 60 & 17 & 3 & & & & 18.9 & 0.6 & 2 & & & & 0.9 & 0.2 & 3 \\
\hline UE-10 ITS \#3 & 62 & & & & & & 5.5 & & & & & & & & \\
\hline
\end{tabular}


Table H.1-5

Select Trace and Minor Element Data for Yucca Flat/Climax Mine Geochemical Evaluation (Page 4 of 5)

\begin{tabular}{|c|c|c|c|c|c|c|c|c|c|c|c|c|c|c|c|}
\hline \multirow{2}{*}{ Site Identification } & \multicolumn{3}{|c|}{$\begin{array}{c}\mathrm{SiO}_{2}, \text { Dissolved } \\
(\mathrm{mg} / \mathrm{L})\end{array}$} & \multicolumn{3}{|c|}{$\begin{array}{l}\mathrm{SiO}_{2}, \text { Total } \\
\text { (mg/L) }\end{array}$} & \multicolumn{3}{|c|}{$\begin{array}{c}\mathrm{NO}_{3} \\
(\mathrm{mg} / \mathrm{L})\end{array}$} & \multicolumn{3}{|c|}{$\begin{array}{c}\mathrm{Br} \\
(\mathrm{mg} / \mathrm{L})\end{array}$} & \multicolumn{3}{|c|}{$\begin{array}{c}F \\
(\mathrm{mg} / \mathrm{L})\end{array}$} \\
\hline & Avg & SD & $\mathbf{n}$ & Avg & SD & $\mathbf{n}$ & Avg & SD & $\mathbf{n}$ & Avg & SD & $\mathbf{n}$ & Avg & SD & $\mathbf{n}$ \\
\hline UE-10j & 34 & 9 & 2 & & & & 4.0 & & & & & & 0.30 & & \\
\hline UE-10j-1 & 41 & 3 & 2 & & & & & & & 0.1 & & & 0.33 & & \\
\hline UE-10j-2 & 36 & & & & & & & & & & & & 0.33 & & \\
\hline UE-10j--3 & 32 & 3 & 2 & & & & & & & 0.1 & & & 0.35 & 0.04 & 2 \\
\hline UE-11a & 58 & & & & & & 1.0 & & & & & & & & \\
\hline UE-14b & 43.8 & 0.3 & 4 & & & & 9.4 & 0.5 & 4 & & & & & & \\
\hline UE-15d WW & 36 & 20 & 14 & & & & 1.4 & 0.6 & 4 & & & & 1.5 & 0.4 & 10 \\
\hline UE-15j & 36 & & & & & & & & & & & & 3.3 & & \\
\hline UE-15j A-5 & 33 & 1 & 3 & & & & 1.6 & 2.1 & 2 & & & & 3.1 & 0.2 & 3 \\
\hline UE-16d WW & 30 & 4 & 13 & 29.7 & 0.3 & 4 & 0.2 & 0.1 & 2 & & & & 0.5 & 0.1 & 12 \\
\hline UE-16f & 5 & 2 & 5 & & & & 0.01 & & & & & & & & \\
\hline UE-17a & 12 & 1 & 3 & & & & & & & & & & 2.2 & 1.7 & 7 \\
\hline UE-1a & 19.1 & 0.2 & 2 & & & & 0.04 & & & & & & & & \\
\hline UE-1b & 83 & 3 & 2 & & & & 2.7 & & & & & & & & \\
\hline UE-1c & 93 & 5 & 4 & & & & 2.4 & & & & & & 0.5 & & \\
\hline UE-1h & 11 & 1 & 2 & & & & & & & & & & & & \\
\hline UE-1q & 51 & & & 25 & 25 & 2 & & & & & & & 0.4 & 0.1 & 2 \\
\hline UE-2ce & 47 & & & & & & & & & & & & 0.3 & 0.3 & 4 \\
\hline UE-4t & & & & & & & & & & 0.06 & & & & & \\
\hline UE-4t 1 & & & & 24 & & & 1.02 & & & 3.9 & & & 38 & & \\
\hline UE-5 PW-1 & 51 & 3 & 2 & 58 & 4 & 5 & 27 & 23 & 8 & & & & 1.2 & 0.2 & 13 \\
\hline UE-5 PW-2 & 31 & & & 60 & 1 & 5 & 21 & 17 & 6 & & & & 1.0 & 0.2 & 11 \\
\hline UE-5 PW-3 & 49 & 14 & 3 & 59 & 1 & 4 & 42 & 25 & 7 & & & & 1.1 & 0.2 & 13 \\
\hline UE-5c WW & 67 & 11 & 10 & 71 & & & 7.0 & 2.3 & 4 & & & & 1.9 & 0.2 & 12 \\
\hline UE-5n & 51 & 8 & 5 & & & & 7.1 & 4.1 & 5 & & & & 0.75 & 0.04 & 3 \\
\hline UE-6d & 53 & & & & & & 7.6 & & & & & & & & \\
\hline
\end{tabular}


Table H.1-5

Select Trace and Minor Element Data for Yucca Flat/Climax Mine Geochemical Evaluation (Page 5 of 5)

\begin{tabular}{|c|c|c|c|c|c|c|c|c|c|c|c|c|c|c|c|}
\hline \multirow{2}{*}{ Site Identification } & \multicolumn{3}{|c|}{$\begin{array}{c}\mathrm{SiO}_{2} \text {, Dissolved } \\
\text { (mg/L) }\end{array}$} & \multicolumn{3}{|c|}{$\begin{array}{l}\mathrm{SiO}_{2}, \text { Total } \\
\text { (mg/L) }\end{array}$} & \multicolumn{3}{|c|}{$\begin{array}{c}\mathrm{NO}_{3} \\
(\mathrm{mg} / \mathrm{L})\end{array}$} & \multicolumn{3}{|c|}{$\begin{array}{c}\mathrm{Br} \\
(\mathrm{mg} / \mathrm{L})\end{array}$} & \multicolumn{3}{|c|}{$\begin{array}{c}F \\
(\mathrm{mg} / \mathrm{L})\end{array}$} \\
\hline & Avg & SD & $\mathbf{n}$ & Avg & SD & $\mathbf{n}$ & Avg & SD & $\mathbf{n}$ & Avg & SD & $\mathbf{n}$ & Avg & SD & $\mathbf{n}$ \\
\hline Ue-7nS & 21 & & & 21 & & & & & & & & & 0.9 & 0.1 & $\overline{4}$ \\
\hline Watertown 1 & 79 & 7 & 4 & & & & 1.7 & 0.2 & 3 & & & & 2.1 & 0.2 & 4 \\
\hline Watertown 2 & 75 & 22 & 2 & & & & 1.9 & 0.3 & 2 & & & & 2.1 & 0.1 & 2 \\
\hline Watertown 3 & 78 & 2 & 7 & & & & 3.9 & 1.4 & 7 & & & & 1.0 & 0.3 & 10 \\
\hline Watertown 4 & 22 & 1 & 2 & & & & & & & & & & 1.4 & 0.1 & 2 \\
\hline Wheelbarrow Spring & 29 & & & & & & & & & & & & & & \\
\hline White Rock Spring, SR & 46 & 2 & 2 & & & & & & & & & & 0.20 & 0.00 & 2 \\
\hline Whiterock Spring, YF & 47 & 10 & 56 & & & & 6 & 1.7 & 50 & & & & 0.41 & 0.14 & 8 \\
\hline Wiregrass Spring & 11.9 & 0.3 & 10 & & & & 4.1 & 1.6 & 5 & 0.02 & 0.01 & 2 & 0.17 & 0.07 & 10 \\
\hline WW-1 & 71 & & & & & & 1.8 & & & & & & 2.1 & & \\
\hline WW-2 & 56 & 16 & 9 & 12 & 5 & 2 & 5 & 1 & 8 & 0.1 & & & 0.41 & 0.06 & 11 \\
\hline WW-3 & 65 & 16 & 8 & & & & 6.4 & 0.7 & 7 & & & & 0.92 & 0.07 & 8 \\
\hline WW-4 & 63 & 3 & 7 & 62 & 2 & 4 & 15 & 6 & 6 & 1.1 & & & 0.75 & 0.09 & 12 \\
\hline WW-4A & 67 & 3 & 2 & 64 & 2 & 4 & 16 & 3 & 2 & & & & 0.8 & 0.2 & 7 \\
\hline WW-5A & 52 & 9 & 10 & & & & 5 & 1 & 7 & & & & 1.6 & 0.6 & 10 \\
\hline WW-5B & 64 & 38 & 15 & 59 & 2 & 4 & 10 & 5 & 17 & & & & 0.8 & 0.1 & 28 \\
\hline WW-5C & 53 & 7 & 18 & 54 & 3 & 4 & 6 & 2 & 16 & & & & 0.9 & 0.2 & 35 \\
\hline WW-A & 75 & 7 & 11 & 23 & 1 & 3 & 5.5 & 2.4 & 11 & & & & 0.7 & 0.3 & 24 \\
\hline WW-C & 35 & 12 & 24 & & & & 0.3 & 0.3 & 13 & 1.6 & 0.0 & 2 & 1.1 & 0.2 & 29 \\
\hline WW-C-1 & 30 & 2 & 17 & 30.4 & 0.4 & 4 & 0.3 & 0.1 & 11 & 0.2 & & & 1.10 & 0.09 & 22 \\
\hline
\end{tabular}


Plates 

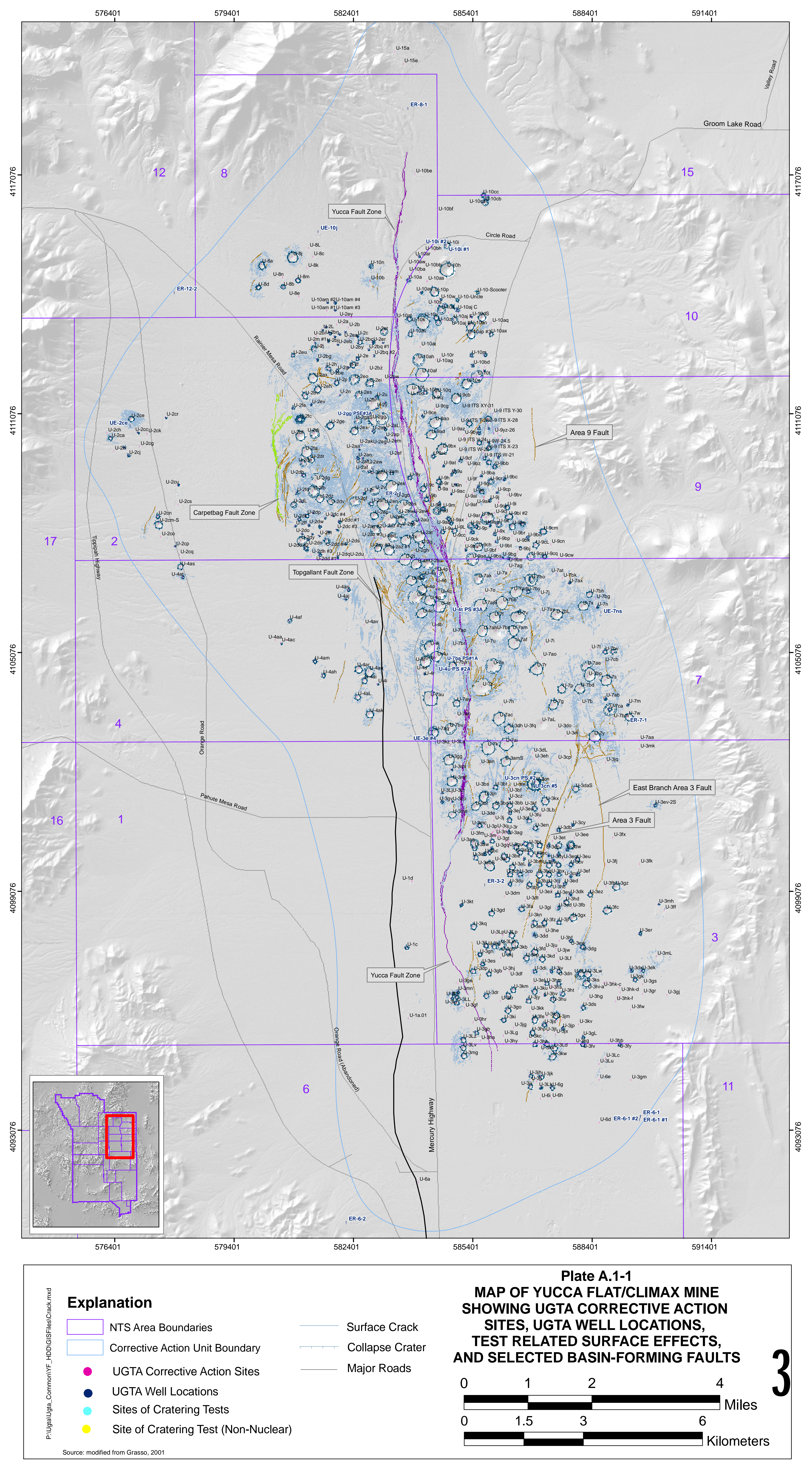


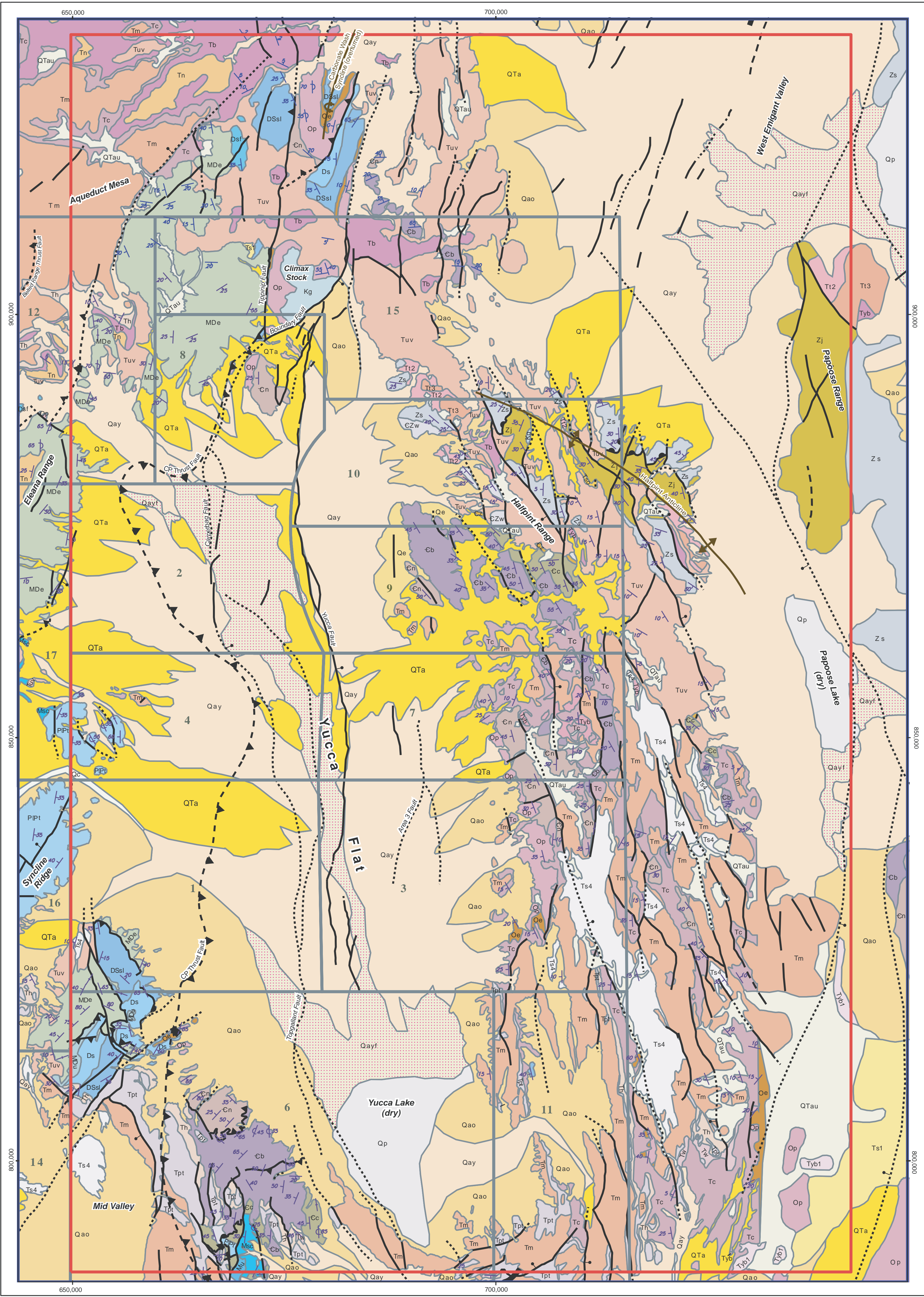

\begin{tabular}{|c|c|c|c|c|}
\hline 鹤 & \multicolumn{3}{|c|}{$\begin{array}{c}\text { Plate 1 } \\
\text { Geologic Map of the Yucca Flat/Climax Mine Model Area }\end{array}$} & Source: BN, 2006 \\
\hline 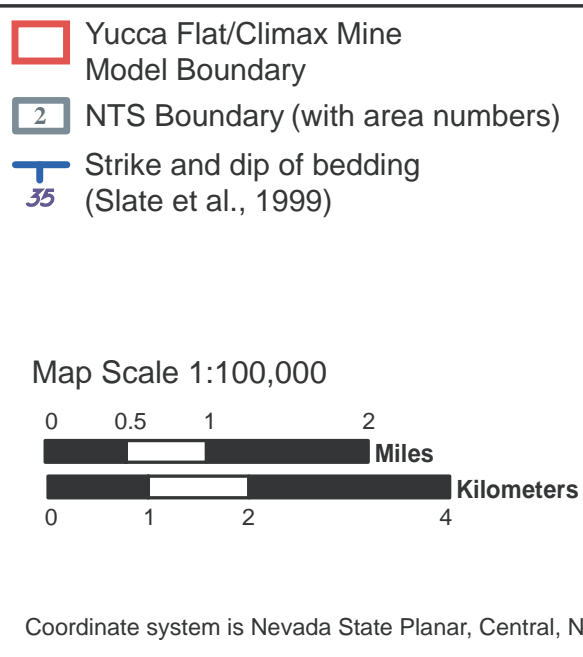 & 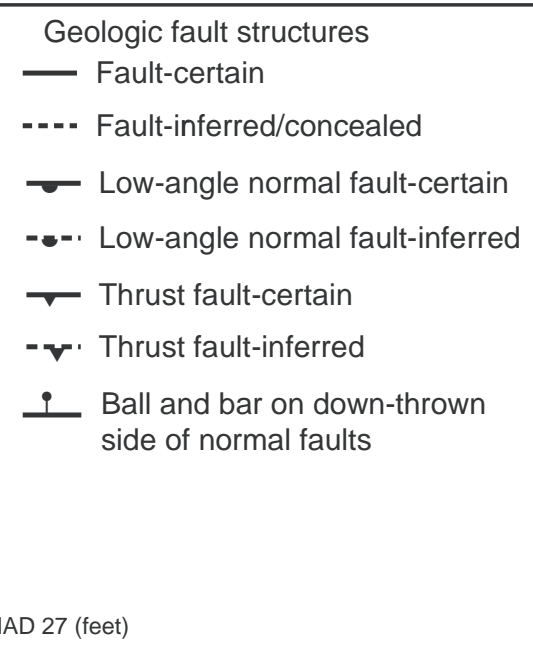 & 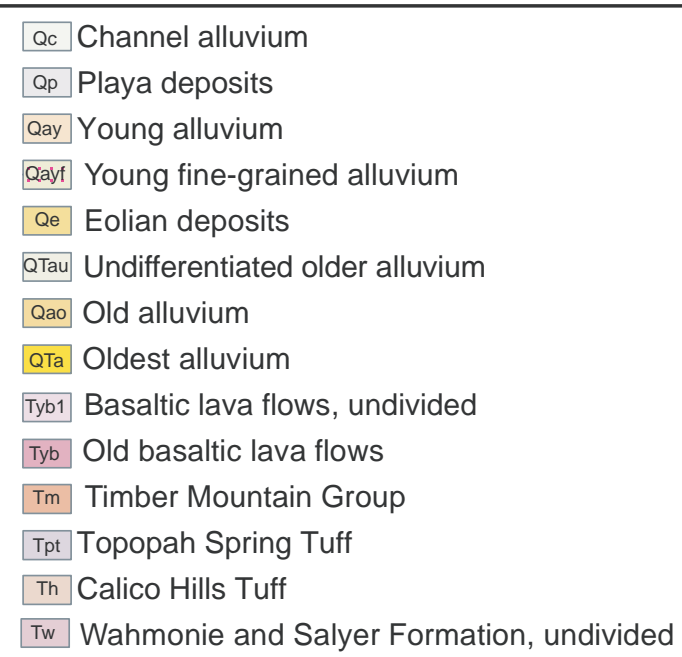 & 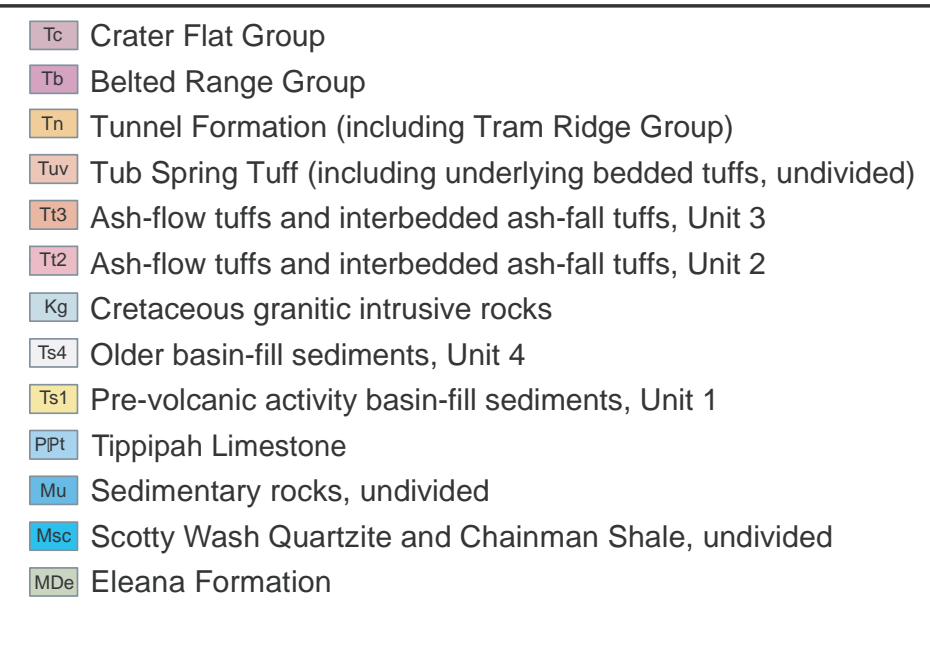 & 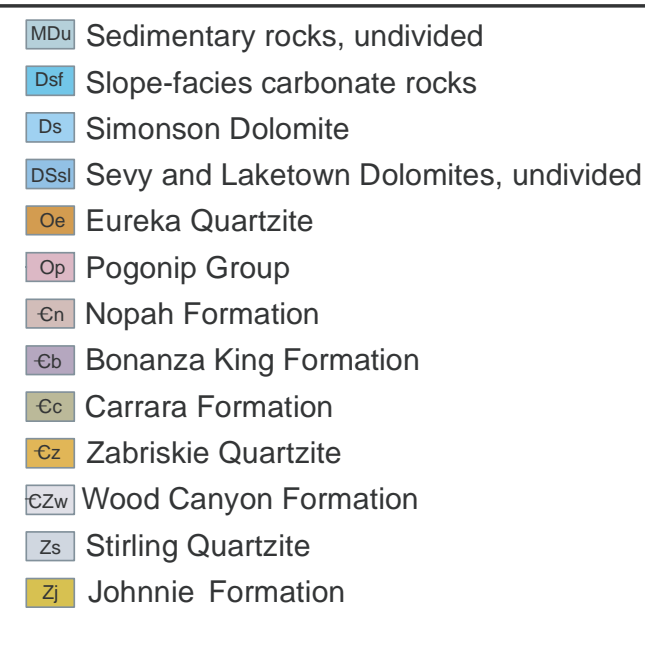 \\
\hline
\end{tabular}




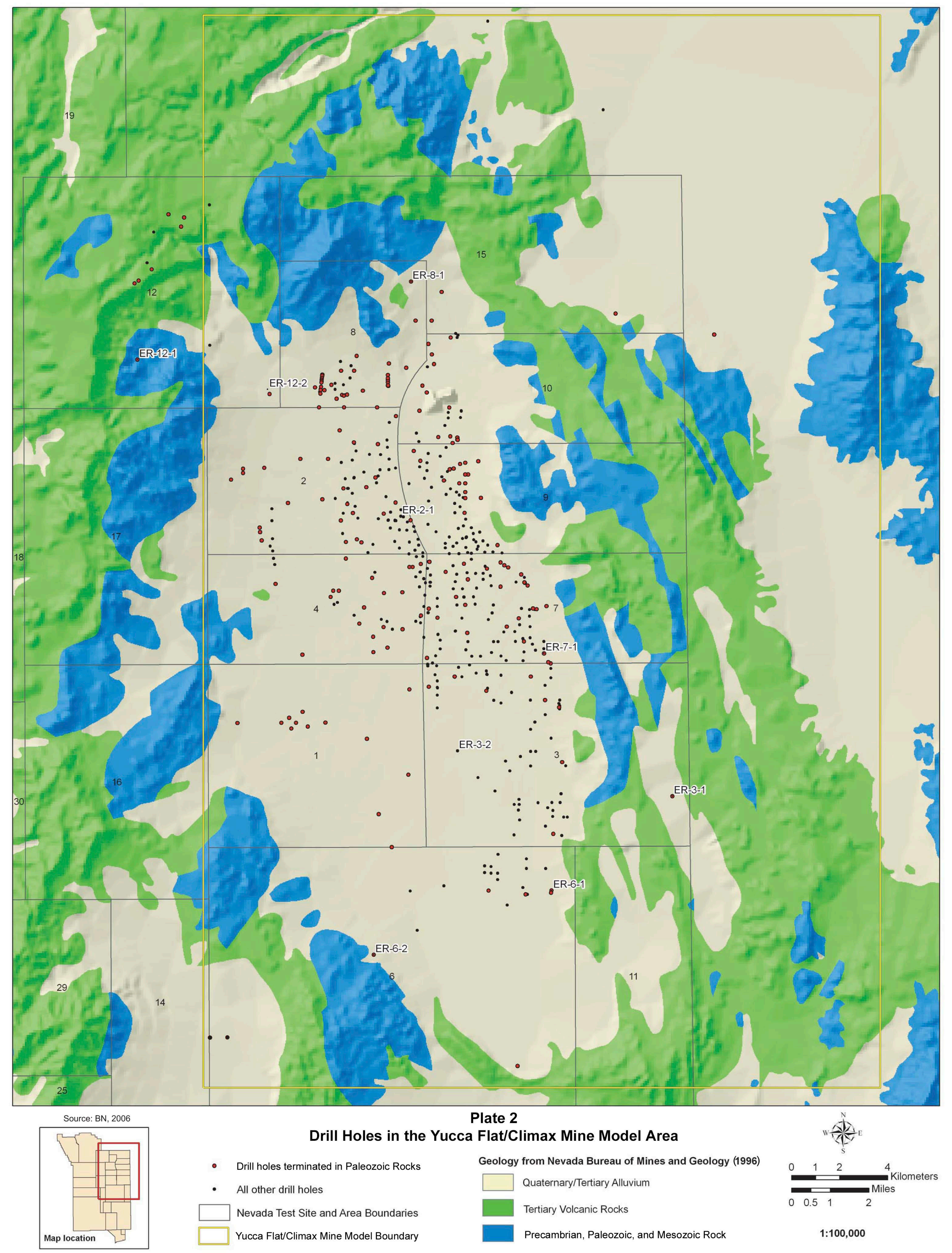




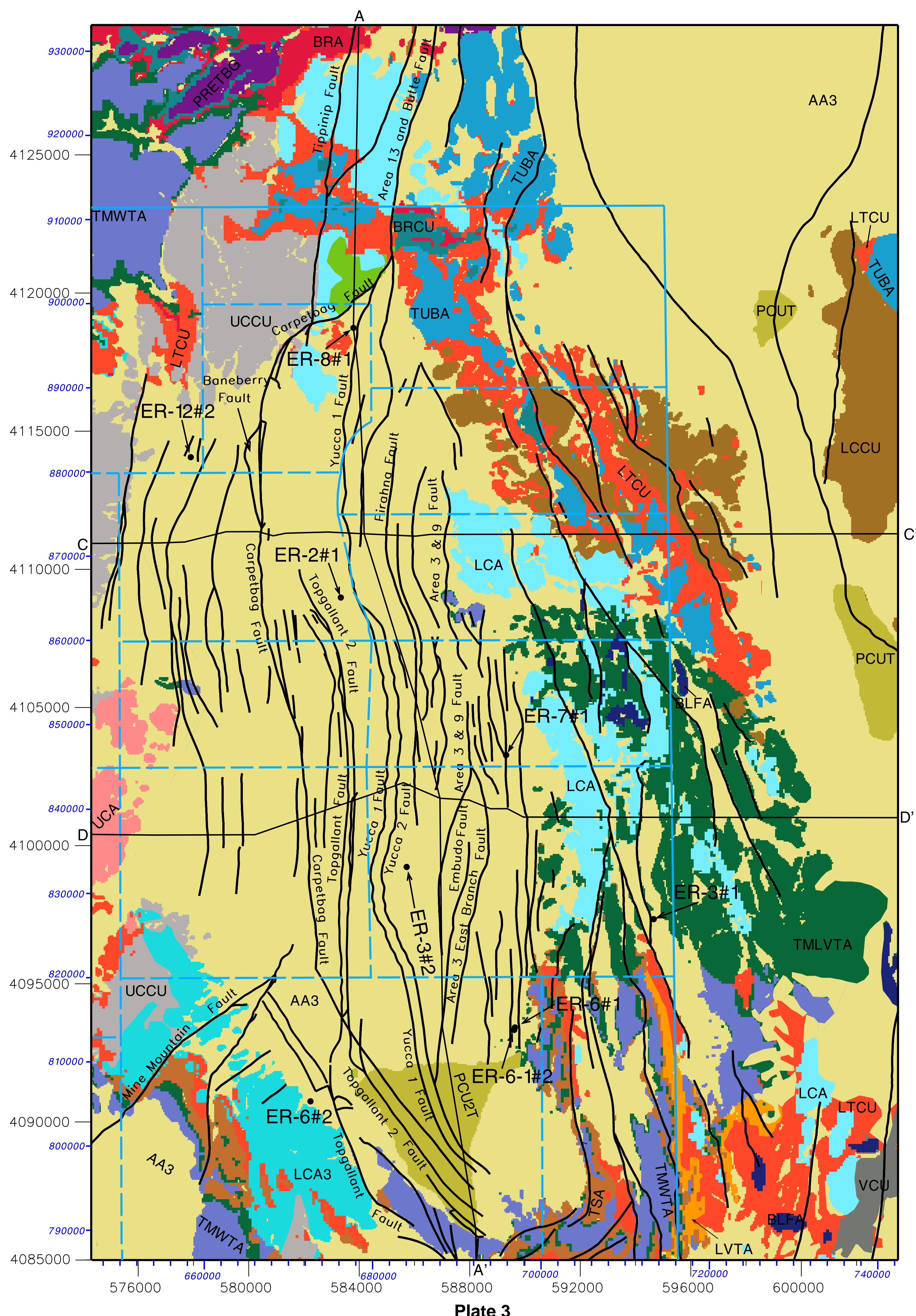

Distribution of Hydrostratigraphic Units at the Surface for the Yucca Flat/Climax Mine Model Area

\begin{tabular}{|c|c|c|c|c|c|c|}
\hline ER-6\#2 & $\begin{array}{l}\text { Drill Hole Name } \\
\text { Drill Hole I ocation }\end{array}$ & Legend & $\mathrm{HSUs}^{+}$at $\mathrm{Gro}$ & d Surface & & \\
\hline & Drill Hole Location & Scale: $\quad 1: 100,000$ & $\square$ AА3 & $\square$ TSA & $\square$ & LCA3 \\
\hline---- & NTS Area Boundary & $\begin{array}{lllll}0 & 1 & 2 & 3 & 4 \\
& 1 & \end{array}$ & $\square$ PCUT & $\square$ LVTA & $\square$ & UCA \\
\hline & NTS Boundary & $\begin{array}{l}\mathrm{KM} \\
2\end{array}$ & $\begin{array}{l}\square \text { PCU2T } \\
\text { BLFA }\end{array}$ & $\square$ BRA & $\square$ & UCCU \\
\hline A $\quad A^{\prime}$ & Cross Section & MLLES & $\square \quad$ TMWTA & $\begin{array}{ll}\square & \text { BRCU } \\
\square & \text { PRETBG }\end{array}$ & $\square$ & LCA \\
\hline$\underbrace{\text { rucca }}$ & $\begin{array}{l}\text { Fault Name } \\
\text { Major Basin Forming } \\
\text { Faults* (Certain \& Inferred) }\end{array}$ & $\begin{array}{l}\text { UTM Zone } 11 \text { NAD } 27 \text { (meters) } \\
\text { Nevada State Plane (2702) (feet) }\end{array}$ & $\square$ TMLVTA & $\begin{array}{ll}\square & \text { TUBA } \\
\square \quad \text { LTCU }\end{array}$ & $\begin{array}{l}\square \\
\square\end{array}$ & $\begin{array}{l}\text { LCCU } \\
\text { MGCU }\end{array}$ \\
\hline * See Plate 1 for & nore detailed structural information & & \multicolumn{4}{|c|}{${ }^{+}$See report for definitions for HSUs } \\
\hline
\end{tabular}




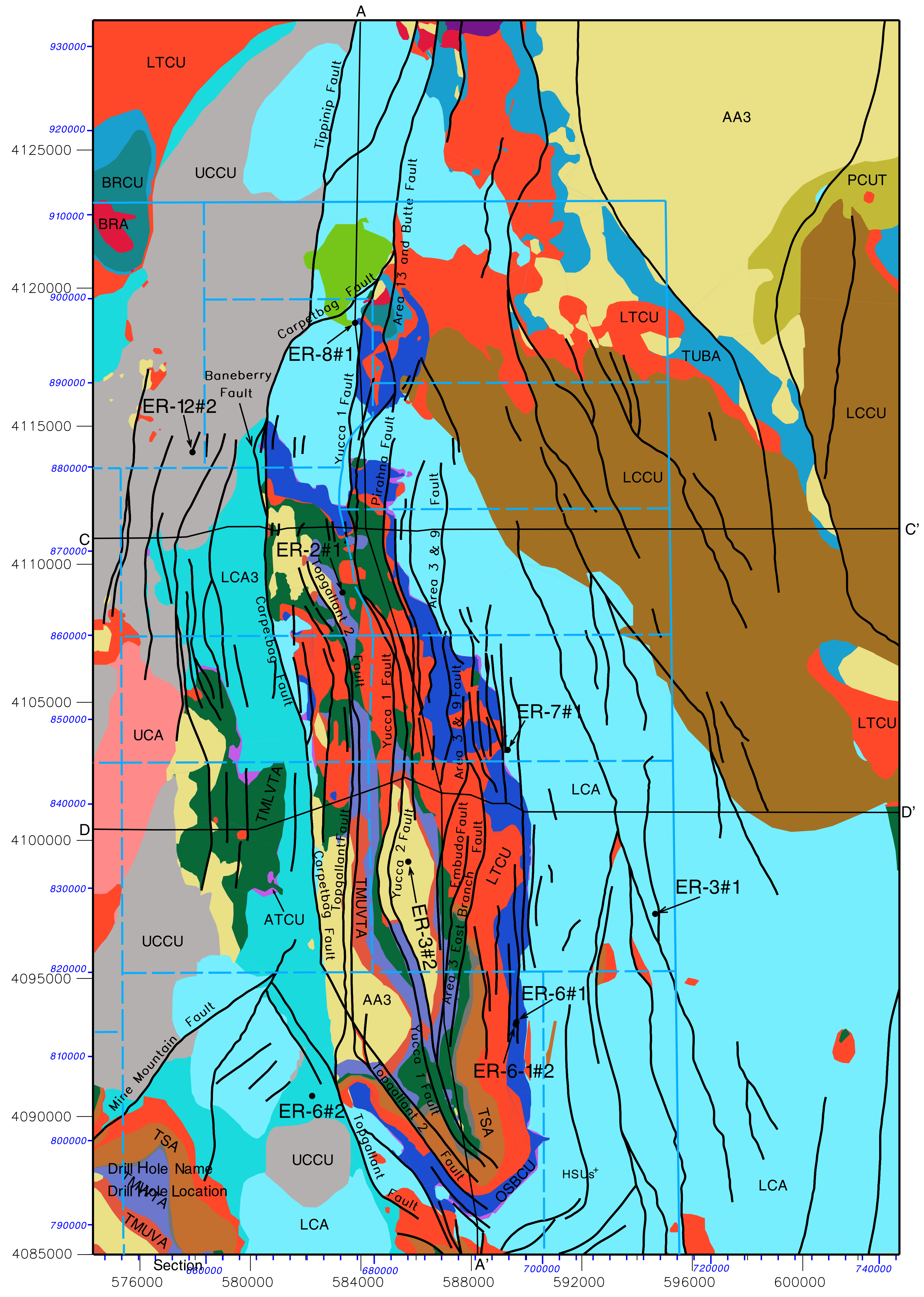

Plate 4

Distribution of Hydrostratigraphic Units at the Water Table for the Yucca Flat/Climax Mine Model Area

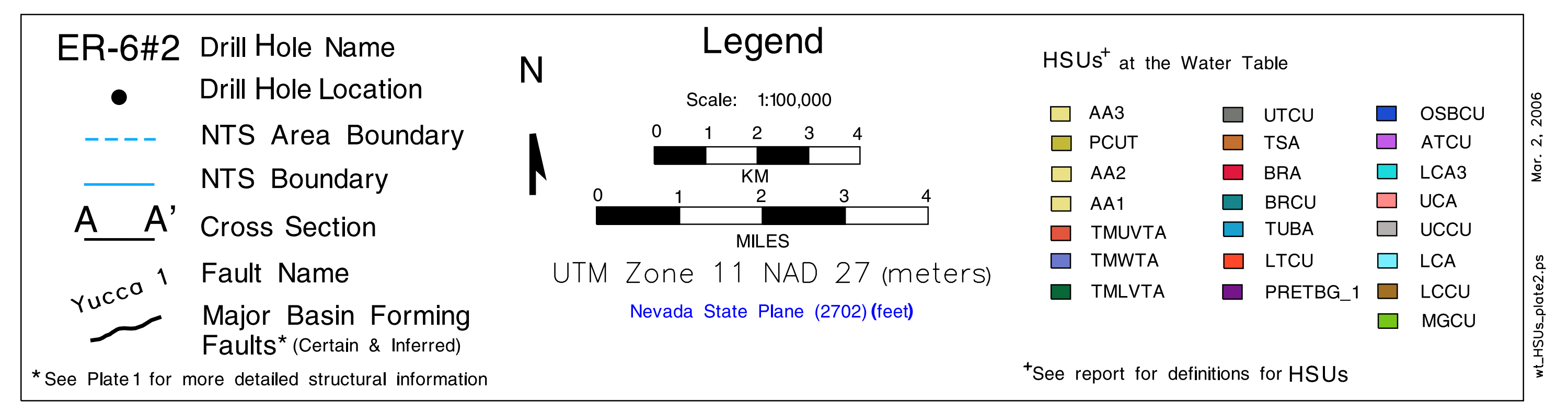



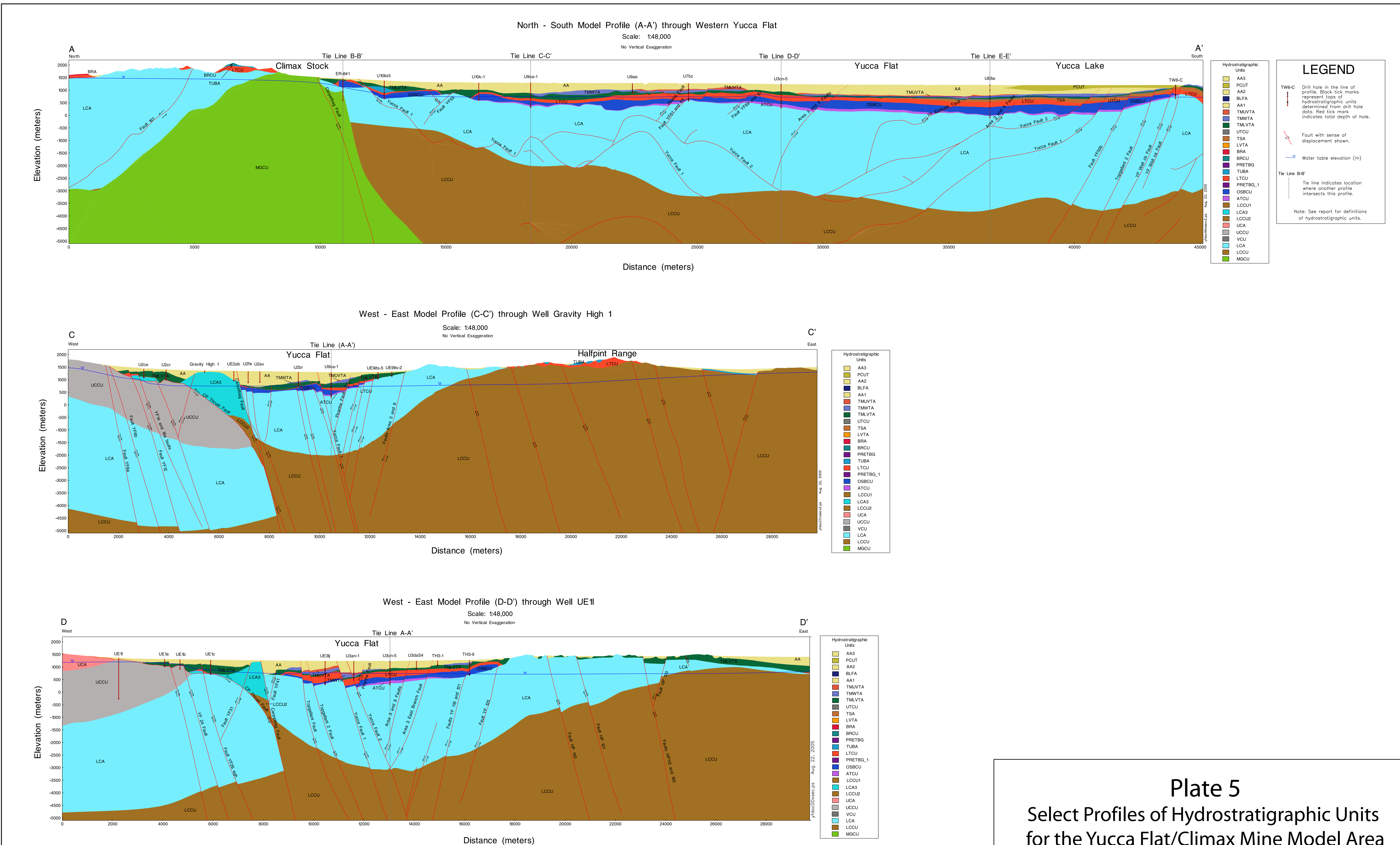

Plate 5

Select Profiles of Hydrostratigraphic Units for the Yucca Flat/Climax Mine Model Area 


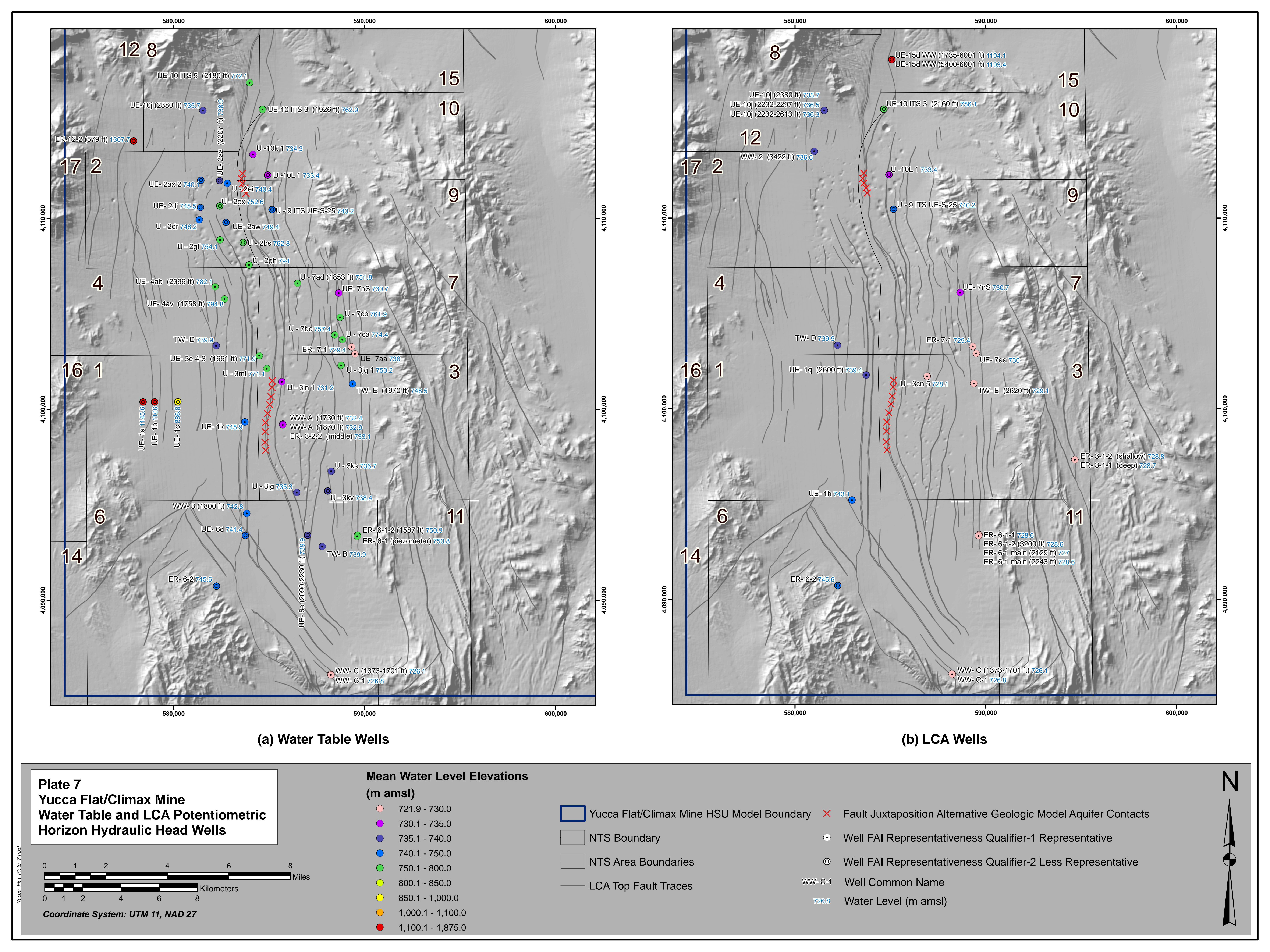




\section{DISTRIBUTION}

Tim Murphy

$2 \mathrm{HC} / 2 \mathrm{CD}$

State of Nevada

Division of Environmental Protection

1771 E. Flamingo Road, Suite 121A

Las Vegas, NV 89119

Bill R. Wilborn

$2 \mathrm{HC} / 2 \mathrm{CD}$

Environmental Restoration Project

U.S. Department of Energy

National Nuclear Security Administration

Nevada Site Office

P.O. Box 98518, MS/505

Las Vegas, NV 89193-8518

Alicia Tauber

$1 \mathrm{CD}$

Environmental Management Records

U.S. Department of Energy

National Nuclear Security Administration

Nevada Site Office

P.O. Box 98518, MS/505

Las Vegas, NV 89193-8518

U.S. Department of Energy

$1 \mathrm{HC}$

National Nuclear Security Administration

Nevada Site Office

Technical Library

P.O. Box 98518, M/S 505

Las Vegas, NV 89193-8518

U.S. Department of Energy

$1 \mathrm{CD}$

Office of Scientific and Technical Information

P.O. Box 62

Oak Ridge, TN 37831-0062

Southern Nevada Public Reading Facility

$1 \mathrm{HC}$

c/o Nuclear Testing Archive

P.O. Box 98521, M/S 400

Las Vegas, NV 89193-8521 
Manager, Northern Nevada FFACO

$1 \mathrm{HC}$

Public Reading Facility

c/o Nevada State Library \& Archives

100 N Stewart Street

Carson City, NV 89701-4285

Naomi Becker

$1 \mathrm{CD}$

Los Alamos National Laboratory, M/S F665

Bikini Atoll Rd., SM30

Los Alamos, NM 87545

Gayle Pawloski

$1 \mathrm{CD}$

Lawrence Livermore National Laboratory

7000 East Avenue, L-221

Livermore, CA 94550-9234

Mavrik Zavarin

$1 \mathrm{CD}$

Lawrence Livermore National Laboratory

7000 East Avenue, L-221

Livermore, CA 94550-9234

Bonnie Thompson

$1 \mathrm{CD}$

USGS WRD

160 North Stephanie Street

Henderson, NV 89074

Chuck E. Russell

$1 \mathrm{CD}$

Desert Research Institute

755 E. Flamingo

Las Vegas, NV 89119

Ken Ortego

$1 \mathrm{CD}$

Bechtel Nevada

P.O. Box 98521, M/S NLV 082

Las Vegas, NV 89193-8521

John P. McCord

$1 \mathrm{CD}$

Stoller-Navarro Joint Venture

7710 W. Cheyenne, Bldg. 3

Las Vegas, NV 89129

Greg Ruskauff

$1 \mathrm{CD}$

Stoller-Navarro Joint Venture

7710 W. Cheyenne, Bldg. 3

Las Vegas, NV 89129 
Stoller-Navarro Joint Venture

$1 \mathrm{HC} / 1 \mathrm{CD}$

FFACO Support Office

7710 W. Cheyenne Ave., Bldg. 3

Las Vegas, NV 89129

Stoller-Navarro Joint Venture

$1 \mathrm{HC} / 1 \mathrm{CD}$

Central Files

7710 W. Cheyenne, Bldg. 3

Las Vegas, NV 89129 